\title{
Ontstaan en ontwikkeling van het nieuwe Burgerlijk Wetboek
}

Citation for published version (APA):

Florijn, E. O. H. P. (1994). Ontstaan en ontwikkeling van het nieuwe Burgerlijk Wetboek. [Doctoral Thesis, Maastricht University]. Datawyse / Universitaire Pers Maastricht. https://doi.org/10.26481/dis.19941117ef

Document status and date:

Published: 01/01/1994

DOI:

10.26481/dis.19941117ef

Document Version:

Publisher's PDF, also known as Version of record

\section{Please check the document version of this publication:}

- A submitted manuscript is the version of the article upon submission and before peer-review. There can be important differences between the submitted version and the official published version of record.

People interested in the research are advised to contact the author for the final version of the publication, or visit the DOI to the publisher's website.

- The final author version and the galley proof are versions of the publication after peer review.

- The final published version features the final layout of the paper including the volume, issue and page numbers.

Link to publication

\footnotetext{
General rights rights.

- You may freely distribute the URL identifying the publication in the public portal. please follow below link for the End User Agreement:

www.umlib.nl/taverne-license

Take down policy

If you believe that this document breaches copyright please contact us at:

repository@maastrichtuniversity.nl

providing details and we will investigate your claim.
}

Copyright and moral rights for the publications made accessible in the public portal are retained by the authors and/or other copyright owners and it is a condition of accessing publications that users recognise and abide by the legal requirements associated with these

- Users may download and print one copy of any publication from the public portal for the purpose of private study or research.

- You may not further distribute the material or use it for any profit-making activity or commercial gain

If the publication is distributed under the terms of Article $25 \mathrm{fa}$ of the Dutch Copyright Act, indicated by the "Taverne" license above, 


\title{
ONTSTAAN EN ONTWIKKELING
}

\author{
VAN HET
}

NIEUWE BURGERLIJK WETBOEK 
(C) E.O.H.P. Florijn, Berkenwoude 1994

p/a Universitaire Pers Maastricht, Postbus 2945, 6201 NA Maastricht

CIP-GEGEVENS KONINKLIJKE BLBLIOTHEEK, DEN HAAG

Florijn Evert Otto Hendrik Peter

Ontstaan en ontwikkeling van het nieuwe Burgerlijk Wetboek

/ Evert Otto Hendrik Peter Florijn. - Maastricht :

Universitaire Pers Maastricht

Proefschrift Maastricht. - Met reg. - Met

samenvatting in het Engels.

ISBN 90-5278-164-8

Trefw.: Nieuw Burgerlijk Wetboek / codificatie :

geschiedenis 


\section{ONTSTAAN EN ONTWIKKELING VAN HET NIEUWE BURGERLIJK WETBOEK}

\section{PROEFSCHRIFT}

ter verkrijging van de graad van doctor

aan de Rijksuniversiteit Limburg te Maastricht, op gezag van de Rector Magnificus, Prof.dr. H. Philipsen, volgens het besluit van het College van Dekanen, in het openbaar te verdedigen op donderdag 17 november 1994 om 16.00 uur

$$
\text { door }
$$

Evert Otto Hendrik Peter Florijn

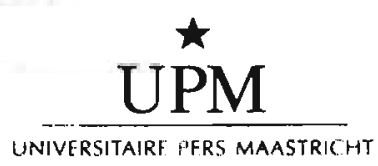


Promotoren:

Prof.mr. G.E. van Maanen

Prof.mr. N.H.M. Roos

Beoordelingscommissie:

Prof.mr. A.Fl. Gehlen (voorzitter)

Prof.mr. G.R. de Groot

Prof.mr. A.S. Hartkamp (RUU)

Prof.mr. E.H. Hondius (RUU) 


\section{Hoofdstuk 1}

\section{OPZET EN VERANTWOORDING}

1 Inleiding

2 Doel van het onderzoek

3 Afbakening

$4 \quad$ Wijze van behandeling

a archiefonderzoek

b vraaggesprekken

c detailonderzoek

d literatuuronderzoek

5 Opbouw van dit boek

\section{Hoofdstuk 2}

\section{DE CODIFICATIEGEDACHTE TUSSEN 1838 EN 1938}

1 Inleiding

$2 \quad$ Een terechte waardering?

3 De codificatiegedachte na 1813

4 Andere opinies

5 De teloorgang van het Ontwerp-1820 17

$6 \quad \mathrm{Na} 1821$

7 De "Bijdragen" opgericht

8 Van Hall krijgt weinig respons $\quad 21$

9 Na $1830 \quad 23$

10 Lipmans gelijk 26

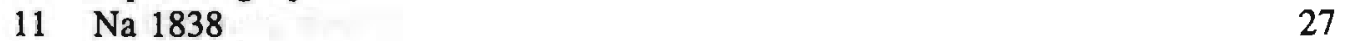

12 Roep om algehele herziening $\quad 29$

13 Een doortastend minister 31

14 Een eerste partiële herziening toegelaten 33

15 De meningen in de literatuur 36

16 De positie van de rechtspraak 37

17 De rol van de wetenschap 39

18 Staatsrechtelijke belemmeringen voor het proces van wetgeving 41

19 De Nederlandse Juristen-Vereniging in $1870 \quad 48$

20 Partiële herziening als beginsel van wetgeving erkend 51

21 Tóch algehele herziening van B.W. en W.v.K. 53 
22 De taakopvatting van de Staatscommissie - Van Meerbeke I

23 Ondanks goede waardering bijgezet in archief

24 Minister en Kamer

25 Andere oorzaken ter verklaring van de geringe wetgevingsactiviteit

26 Wetgever of rechter?

27 De Nederlandse Juristen-Vereniging in 1912

28 Een pragmatische beslissing

29 De Staatscommissie-Wetgeving (in de wandeling

(Staatscommissie-Limburg) opgericht

30 De taakomschrijving van de Staatscommissie: kritieken

31 Het falen van de Staatscommissie

32 Meijers' oppositie

33 Samenvatting en conclusie

Hoofdstuk 3

DE HERCODIFICATIE VAN HET BURGERLIJK WETBOEK (1947-1954)

1 De opdracht aan Meijers

2 Achtergronden

3 De werkwijze van Meijers

4 De Staatscommissie

5 De vraagpuntenprocedure

6 Minister Donker treedt aan

7 Het interdepartementaal overleg

8 Het vooroverleg; criteria voor voorlegging

9 De vaste Commissie

10 De procedure

11 Het debat in de Kamer

12 De betekenis van de vraagpuntenprocedure

13 Mei 1954: Het eerste deel van het Ontwerp-Meijers gepubliceerd

1425 juni 1954: Meijers overlijdt

\section{HET DRIEMANSCHAP (1954-1961)}

1 De opvolging van Meijers: Drion, Eggens en De Jong

2 Het werk aan Boek 5 O.M.

b oorzaken voor vertraging 
a perfectionisme versus impressionisme

b lager tempo; méér rechtsvergelijking en grotere invloed 140 van het Departement

c gebrek aan samenwerking

d gezag en onderlinge verhoudingen

e moeilijkheidsgraad stof

5 Het Driemanschap en de rol van de Ministers

a Donker

b Van Oven

c Samkalden

d Beerman

$6 \quad$ Het Driemanschap en de rechtsvergelijking

7 Het Driemanschap en de consultatie van de praktijk

8 Gevolgen van lange duur

a dalende belangstelling buitenwereld

b afnemende interesse Kamer

c stagnatie andere boeken

Bijlage I

Bijlage II

Hoofdstuk 5

DRION EN VAN EWIJK (1961-1964)

1 Organisatie van het werk

2 Het Voorlopig Verslag over Boek 4

3 Rapport I van de Commissie Erfrecht

4 Naar een Gewijzigd Ontwerp

5 Voortgang Boeken 1, 3 en 6

6 Andere maatregelen

7 Het tweede rapport van de Commissie Erfrecht

81 maart 1964: Drion overlijdt

9 De opvolging van Drion

10 Andere maatregelen

a indiening Boek 6

b oprichting Stafafdeling Wetgeving NBW

\section{BOEK 4: ERFRECHT}


4 Boek 4 door de Tweede Kamer aanvaard

5 Boek 4 bij de Eerste Kamer

308

6 De Memorie van Antwoord

311

7 Boek 4 aanvaard

314

8 De voortrein-Van Agt

315

9 De totstandkoming van w.o. 12863

10 Kritiek

318

11 De jaarvergadering van 1974

321

12 Nog méér kritiek

13 Een nieuwe koers wordt ingeslagen

14 Wetsontwerp 17141

15 Opnieuw bedenkingen

1624 september 1982

17 Wetsontwerp 17141 ontkoppeld

18 Een nieuw geluid?

19 Het "tweede" vruchtgebruikontwerp

20 Een "rondje ringen"

21 Van Mourik slaat terug

228 April 1992

23 Het voorstel-Luijten

24 De laatste wending?

25 Pro en contra

a Een oud probleem

b De ouderlijke boedelverdeling

c De rol van de traditie

d Hertrouwen

e Het sop is de kool niet waard

26 Het wenselijke systeem

a vruchtgebruik

b ouderlijke boedelverdeling

27 De praktijk van het erfrecht

28 Tenslotte

Hoofdstuk 7

HET WERK AAN DE BOEKEN 3, 5 EN 6 (1964-1980)

Inleiding

I Het werk aan Boek 3

1 Boek 3 vóór Boek 6

2 Snijders en Ten Kate

3 Het eerste begin

$4 \quad$ Voortgang en vertraging

5 Exit Langemeijer (en Fischer-Keuls)

6 De laatste loodjes 
7 Oorzaken voor vertraging

8 Besluit

II Het werk aan Boek 5

1 Beekhuis en Franken

384

2 Werkwijze

385

3 Voortgang en vertraging

386

4 Oorzaken voor vertraging

389

5 Gevolgen

392

6 De laatste loodjes

394

7 Besluit

III Het werk aan Boek $6 \quad 397$

A De voorbereiding voor het Voorlopig Verslag: kantje boord 397

1 Verwachtingen

397

$2 \quad$ De begrotingsbehandeling 1968

399

3 Vraagpunten "nieuwe stijl"

400

4 1971: Eerste deel Voorlopig Verslag gepubliceerd 404

5 Hoe verder? 406

6 De nota "Algemeen beleid Nieuw B.W." gepresenteerd 407

7 Een vruchtbaar overleg $\quad 409$

8 Een nieuw incident 311

9 De "Nota voortgang NBW" 413

10 De dreiging afgewend 415

B De voorbereiding van M.v.A. en G.O. Boek $6 \quad 416$

1 De "zwoegers in het vooronder" 1716

$\begin{array}{ll}\text { a Literatuurkritiek } & 418\end{array}$

b Rechtsvergelijking $\quad 421$

c Overleg met de praktijk $\quad 422$

2 Boek 6 G.O. voltooid; verdere procedure 426

3 Conclusie $\quad 429$

Bijlage I $\quad 432$

$\begin{array}{lr}\text { Bijlage II } & 434\end{array}$

Hoofdstuk 8

BOEK 7: BIJZONDERE OVEREENKOMSTEN (1954-1972)

1 Inleiding

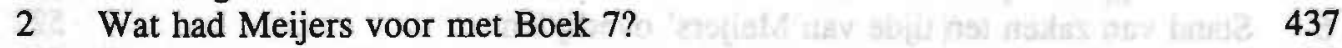

3 Opzet en werkwijze

$4 \quad$ Stand van zaken in juni '54

5 Het Driemanschap en Boek 7 O.M.

6 December 1954: Boek 7 bijna voor de helft gereed

8 De herverkaveling 
9 Wijze van bewerking 459

10 Oorzaken voor vertraging 462

11 Redactie- en afstemmingsproblemen 469

12 De Jongs aandeel in Boek 7; besluit 471

Bijlage

\section{Hoofdstuk 9}

BOEK 8: VERKEERSMIDDELEN EN VERVOER (1954-1992)

1 Inleiding

2 Meijers' opzet voor Boek 8

3 Juni 1954; Boek 8 O.M. is vrijwel gereed

4 1954-1961: Een periode van stilstand

5 1961: Een nieuwe aanpak?

6 Oktober 1964: Boek 8 voor tweederde gereed

7 Wat nu?

8 De opdracht aan Swart beëindigd

9 Boek 8 uitgebreid met hoofdstuk voor wegvervoer

10 Zee- en luchtrecht vervroegd publiceren?

11 1967: het binnenvaartrecht in eerste concept gereed

12 Splitsing publicatie Boek 8

13 Boek 8 O.M. (eerste stuk) gepubliceerd 500

14 Boek 8 (eerste stuk) ook invoeren? $\quad 504$

15 Boek 8II gereed; Boek 8I ingediend bij Kamer 505

16 Intermezzo 506

17 Na $1976 \quad 508$

18 Samenvatting en conclusie 509

Hoofdstuk 10

BOEK 9: RECHTEN OP VOORTBRENGSELEN VAN DE GEEST (1954-1992)

1 Inleiding

2 De inhoud van Boek 9

3 Wijze van bewerking

4 Kritiek

5 De vraagpuntenprocedure

6 Stand van zaken ten tijde van Meijers' overlijden

$7 \quad 1954-1956$

8 Na 1956

9 De nota

10 De discussie in 1971

11 En nu...? 


\section{Hoofdstuk 11}

INVOERINGSPERIKELEN (1980-1992)

1 Inleiding

535

2 Verhuizen kost bedstro

3 Problemen

$4 \quad$ Notitie invoering nieuw B.W.

543

5 Reacties en stellingname

6 De Hoorzitting van de vaste Commissie

7 Korthals Altes reageert; de operatie-Stofkam aangekondigd

8 Mondeling Overleg

9 Opnieuw tegenslag

10 Een zuur werk

11 Een onzedelijk voorstel

12 Een meesterzet

561

13 Tenslotte

Hoofdstuk 12

CONCLUSIE

SUMMARY

REGISTER 
viii 


\section{VOORWOORD}

Velen zijn bij de totstandkoming van dit werkstuk behulpzaam geweest. Ik wil hen hiervoor van harte danken.

In het bijzonder wil ik noemen prof.mr. N.H.M. Roos, die gedurende mijn onderzoek en bij de afronding daarvan mij tot grote steun is geweest. Zijn stimulerende begeleiding en zijn niet-aflatende bemoeienis van dichtbij én op afstand heb ik bijzonder gewaardeerd.

Ik ben eveneens dank verschuldigd aan prof.mr. G.E. van Maanen voor zijn bereidheid mijn manuscript te lezen en de mogelijkheid om over de daarin verdedigde standpunten met hem in discussie te treden.

De Juridische Faculteit van de Rijksuniversiteit Limburg wil ik danken voor het feit dat zij mij in staat heeft gesteld dit onderzoek te verrichten.

Speciaal wil ik Elly Peters bedanken voor het geduld en de toewijding waarmee zij dit manuscript heeft getypt en vele malen heeft herzien en aangepast. Joke Oud dank ik voor de secretariële inspanningen.

Mijn ouders ben ik zeer erkentelijk voor de hulp en steun van diverse aard, die zij mij hebben geboden.

De leden van de Stafafdeling Nieuw Burgerlijk Wetboek dank ik voor de waardevolle informatie die zij mij hebben verschaft met betrekking tot het wetgevingsproces, de medewerkers van de bibliotheek van het Ministerie van Justitie voor hun gastvrijheid en behulpzaamheid tijdens mijn bezoeken aldaar.

Mijn collega's bij de Raad van State ben ik erkentelijk voor hun bereidheid de drukproeven te corrigeren.

Tenslotte wil ik alle geïnterviewden bedanken voor hun grote mate van bereidheid om informatie te verschaffen over het werk aan het nieuwe Burgerlijk Wetboek.

Berkenwoude, 4 oktober 1994 
Hoofdstuk 1

OPZET EN VERANTWOORDING

\section{Inleiding}

Op 25 april 1947 ontving de Leidse hoogleraar Eduard Maurits Meijers (1880-1954) bij Koninklijk Besluit de opdracht een "nieuw burgerlijk wetboek" te ontwerpen. Daarmee werd het sein gegeven voor het grootste en meest ambitieuze Nederlandse wetgevingsproject van de twintigste eeuw.

Eén van de belangrijkste overwegingen om Meijers de opdracht te verlenen, was de verwachting dat hij het grote werk binnen een jaar of tien zou kunnen volbrengen. Het is evenwel anders gelopen. De totstandkoming van het nieuwe Burgerlijk Wetboek, waarin ook de stof van het Wetboek van Koophandel is opgenomen, is een werk van zeer lange adem geweest en heeft generaties van ontwerpers, juristen en soms ook Kamerleden in de ban gehouden. Nu pas, bijna vijftig jaar later, is de herziening van het uit 1838 stammende Burgerlijk Wetboek nagenoeg voltooid. Op 1 januari 1992 zijn de Boeken 3, 5 en 6 in werking getreden, alsmede een aantal belangrijke titels van Boek 7. Zij werden voorafgegaan door Boek 1 (Personen- en familierecht) en Boek 2 (Rechtspersonen), die respectievelijk op 1 januari 1970 en 26 juli 1976 geldend recht werden. Boek 8, dat het zee-, binnenvaart- en wegvervoersrecht omvat, is stukje bij beetje ingevoerd; op 1 april 1991 werd het laatste deel daarvan geldend recht. Boek 4 (Erfrecht) rust echter nog steeds bij de Tweede Kamer, terwijl het Departement met het werk aan het Negende en laatste boek (Rechten op voortbrengselen van de geest) pas onlangs een begin heeft gemaakt.

Hoe heeft het zo lang kunnen duren en waarom is er, toen de voorspellingen steeds maar niet uitkwamen, nooit een punt achter gezet?

\section{Doel van het onderzoek}

Bij dit onderzoek naar de ontwikkeling en de totstandkoming van het nieuwe B.W. stonden twee doelstellingen voorop. De eerste doelstelling was de beschrijving van de wordingsgeschiedenis van het nieuwe Burgerlijk Wetboek. De hercodificatie van het privaatrecht is de grootste en langdurigste wetgevingsoperatie in de Nederlandse rechtsgeschiedenis geweest, een operatie waaraan een groot deel van de privaatrechtselite van deze eeuw heeft deelgenomen. De laatste jaren geven een groeiende belangstelling te zien voor de moderne, dat wil zeggen negentiende en twintigste-eeuwse rechtsgeschiedenis, waarvan bijvoorbeeld de NJB-jubileumuitgave "Zestig juristen" getuigt.

De tweede doelstelling betrof een specifiek aspect van de wordingsgeschiedenis, het vaststellen van de oorzaken van voortgang en vertraging bij de hercodificatie van het privaatrecht. Het bijzondere van de geschiedenis van het nieuwe Burgerlijk Wetboek is de grote mate van variatie die zich in de organisatie, werkstijlen en de mate van aard en betrokkenheid van belangengroepen, wetenschap en politiek hebben voorgedaan. Meer in detail laten zich in de codificatiegeschiedenis voor- en nadelen analyseren van oplossingstrategieën voor min of meer structurele problemen van wetge- 
ving, volledigheid tegenover overzichtelijkheid, praktische tegenover dogmatische oplossingen, ideale tegenover aanvaardbare regelingen, algemeenheid tegenover casuïstiek, keuze tussen formuleren in de vorm van rechtsregels dan wel opdrachten tot rechtsontwikkeling in de vorm van vage normen. Op de achtergrond van deze dilemma's spelen steeds voorstellingen ten aanzien van de werking van de wetsregel en de verhouding van wetgeving en rechtspraak.

Naast deze twee hoofddoelstellingen, die tezamen het grondthema van dit proefschrift vormen, was er een nevengeschikte doelstelling, de aanvulling van de bronnen van het nieuwe Burgerlijk Wetboek met gegevens uit de departementale archieven. Vele teksten van het nieuwe B.W. hebben vaak een zeer lange en kronkelige wordingsgeschiedenis achter zich en geven daarom soms nog steeds aanleiding tot controverses. Het archief maakt het mogelijk de tekst van een regel te zien als de uitkomst van een probleemgeschiedenis, doordat het gegevens bevat die veelal een wat ander beeld werpen op de betekenis van rechtsregels en de officiële toelichting.

\section{Afbakening}

Uiteraard kon, gelet op de omvang van het onderwerp, slechts een klein deel van het archief worden bewerkt. Dat neemt niet weg, dat getracht is het omvangrijke archiefmateriaal zoveel mogelijk te inventariseren, omdat het anders welhaast onmogelijk was de weg terug te vinden, in verband met de doorgaans weinig schematische opbouw van de archieven.

De archiefstukken die betrekking hebben op de Boeken 1 en 2, alsmede die over Boek 8, zijn niet in het onderzoek betrokken. De beide eerste Boeken zijn reeds geruime tijd geleden in werking getreden en sindsdien al weer verschillende malen gewijzigd. Te vrezen viel dat het onderzoek op deze wijze wel heel erg sterk achter de feiten aan zou lopen. Ten aanzien van Boek 8 geldt, dat op het moment dat de basis werd gelegd voor dit onderzoek, nog niet kon worden beschikt over het archief van Regeringscommissaris Schadee.

\section{Wijze van behandeling}

\section{a. archiefonderzoek}

Omdat bij het begin van het onderzoek (1986) slechts een gering inzicht bestond in de concrete onderzoeksmogelijkheden, is allereerst getracht de voorhanden bronnen te inventariseren en zonodig aan te vullen. Dit betrof vooral de verschillende op Justitie aanwezig zijnde archieven. Daarnaast werd een begin gemaakt met de inventarisatie van de persoonlijke archieven van J. Drion en J.H. Beekhuis, die naar aanleiding van dit onderzoek aan het Ministerie van Justitie ter beschikking werden gesteld. Tenslotte zijn de bruikbaarheid en toegankelijkheid van de diverse archieven onderzocht, door verschillende proefstudies te verrichten. 
Dit werk heeft weliswaar ongeveer een jaar in beslag genomen, maar is niettemin onmisbaar geweest voor het verdere verloop van het onderzoek. ${ }^{1}$ Niet alleen werd het daardoor aanzienlijk eenvoudiger om de weg te vinden in de verschillende dossiers en verbanden te leggen tussen de rijstebrijberg aan nota's, concepten en brieven, maar bovendien kon zo een stevige ondergrond worden ontwikkeld voor de beschrijving van de codificatiegeschiedenis in het algemeen. Onderzocht zijn het NBWarchief (380 archiefbanden), het Dossier-Drion (53 archiefbanden), het DossierBeekhuis (12 archiefbanden), het Dossier-Belinfante (109 archiefbanden), het DossierDe Jong (12 archiefbanden), het Centraal Archief (15 archiefbanden), het Semi-statisch archief (45 archiefbanden); de gezamenlijke lengte bedraagt \pm 100 meter. $^{2}$ Daarnaast zijn enkele archieven en dossiers onderzocht die weliswaar geen direct verband hielden met het werk aan de hercodificatie, maar die niettemin toch van belang konden zijn voor het onderzoek. Genoemd worden: Dossier A 55/50 (archief mr. De Meijere), Wetten 441 (1936-1938) eerste enquête-Meijers eigendomsoverdracht tot zekerheid, Wetten 496 (1947-1950) tweede enquête-Meijers eigendomsoverdracht tot zekerheid, Archief van de Raad van Ministers 1823-1964 en het Geheim Archief div. Ministers van Justitie.

Tenslotte zijn, in verband met de rijkdom aan materiaal, de parlementaire stukken met betrekking tot de Justitiebegroting van 1947 tot en met 1993 doorgenomen.

\section{b. vraaggesprekken}

Gedurende met name het eerste en het tweede jaar van het onderzoek is door professor Roos en mijzelf een groot aantal gesprekken gevoerd met huidige en voormalige medewerkers van het Ministerie van Justitie, alsmede met een aantal direct-betrokkenen. Ter voorbereiding op deze vraaggesprekken zijn twee dossiers aangelegd van 400 bladzijden elk, inhoudende externe publicaties over het nieuwe B.W.

De periode waarin de geïnterviewden nauw betrokken waren bij het werk aan het nieuwe B.W. verschilt zeer. Gesproken is met medewerkers van het eerste uur, zoals Franken en Belinfante, die Meijers en het Driemanschap nog hebben meegemaakt, maar ook met de werkers van het laatste uur, zoals Snijders, Hartkamp en De Die. Ook de reden van hun betrokkenheid bij het werk loopt sterk uiteen: sommigen hebben een familieband met de ontwerpers, anderen zijn daarbij beroepsmatig betrokken geweest, weer anderen behoorden tot critici van het project. Kortom, als er

\footnotetext{
1. Soms was dat niet eenvoudig. Het archief van Drion had bijvoorbeeld bijna dertig jaar staan te verstoffen, zodat de schoonmaakdienst van het Ministerie driemaal moest uitrukken, eer mijn kamer weer enigszins toonbaar was. Het dossier met betrekking tot wetsontwerp 1430 (opheffing handelingsonbekwaamheid gehuwde vrouw) was per abuis naar het Rijksarchief gezonden, waar het niet in de collectie bleek te zijn opgenomen omdat het een wet van na W.O.II betrof.

2. Een beschrijving van de NBW-archieven, die tien bladzijden telt, is ter beschikking gesteld van het Ministerie van Justitie. Daaraan zijn toegevoegd negen bijlagen, waarin de belangrijkste kenmerken van elk archief of dossier zijn vermeld, alsmede een inhoudsopgave van stukken, nota's etc. Beide zijn zeer geschikt als aanknopingspunt voor nadere bestudering van de archieven, of als hulpmiddel bij toekomstige bronnenuitgaven. Bij de officiële viering van đe invoering van het nieuwe vermogensrecht is door de Minister van Justitie inmiddels een publicatie van de "Meijers-stukken" toegezegd. (Zie Trema 1992, p. 51 e.v.)
} 
al wat over deze interviews kan worden gezegd, is het dat zij zeer verschillend zijn en in weinig op elkaar lijken. Voorafgaand aan elk interview is dan ook een aparte vragenlijst opgesteld, waarvan alleen de meest voor de handliggende vragen overeenstemmen met die op de andere lijsten. Overigens zijn deze vragenlijsten slechts zelden tot het einde toe gevolgd. Dikwijls nam de geïnterviewde zelf het heft in handen of was men zo uitvoerig met informatie, dat geen vraag meer overbleef. Incidenteel hebben, op uitnodiging van de geïnterviewden, ook vervolggesprekken plaatsgevonden.

De kwaliteit van de aangeboden informatie verschilde nogal. De één herinnerde zich vooral de anekdotes, een ander legde de nadruk op de menselijke verhoudingen of juist op dingen van heel praktische aard. In elk geval is, voor zover maar enigszins mogelijk was, de hierdoor verkregen informatie, in totaal 450 pagina's gesproken tekst, getoetst aan de hand van de in de archieven beschikbare dossiers. Vanzelfsprekend is ieder in de gelegenheid gesteld verbeteringen of aanvullingen in de tekst aan te brengen. Van een publicatie van de interviews is vooralsnog afgezien. ${ }^{3}$

Gesproken is met J.H. Beekhuis, W.G. Belinfante, H. Cohen Jehoram, A.A. Creutzberg, C.C. van Dam, H. Drion, E.C. Drion-van Rooijen, B.C. de Die, E.J.A. Fischer-Keuls, D.C. Fokkema, R. Franken, W.C.L. van der Grinten, A.S. Hartkamp, W. Heuff, J.B. in 't Hout, Th.B. ten Kate, G.E. Langemeijer, E.E.A. Luijten, C. Meijers, J.M.A. van Mourik, P. Neleman. P.W. van der Ploeg, J.M. Polak, M. Rood-de Boer, K.T.M. van Rijckevorsel, I. Samkalden, H. Schadee, M.W. Scheltema, H.C.F. Schoordijk, W. Slagter, A.L.M. Soons, W. Snijders, P.J. Swart, J. Vermeulen, L. de Vries, K.W. Wiersma, D. Wolf, C.J. van Zeben, R. Zegering Hadders ${ }^{4}$.

\section{c. detailonderzoek}

Teneinde de bruikbaarheid van de archieven te verifiëren zijn allereerst drie detailstudies verricht, betrekking hebbend op de Boeken 3, 5 en 6, die samen het corpus van het nieuwe B.W. vormen en elk hun eigen geschiedenis hebben doorgemaakt. Onderzocht zijn afdeling 3.1.1 (algemene bepalingen), titel 5.2 (eigendom van onroerende zaken) en titel 6.3 (onrechtmatige daad, waarvan in het bijzonder de aansprakelijkheid voor zaken). De omvang van deze onderzoeken ( \pm 250 pagina's) liet een publicatie in extenso niet toe, althans niet in het kader van dit proefschrift. Wel is bij de beschrijving van de ontwikkeling van deze boeken regelmatig teruggegrepen op deze bronnen; de resultaten van de studie naar de algemene bepalingen van het vermogensrecht zijn weergegeven in Hoofdstuk 7; de studie over de ontwikkeling van de gedachten ten aanzien van de eigendomsverkrijging van roerende zaken vormt de achtergrond waartegen Hoofdstuk 4 is geschreven en heeft tevens een plaats gevonden in bijlage I; het onderzoek naar de aansprakelijkheid voor gebrekkige en

3. Met één uitzondering. Op verzoek van mr. H. Beekhuis is het met zijn vader gehouden interview gepubliceerd (zie Kwartaalbericht Nieuw BW 1989, p. 65-71). In ieder geval zullen de interviews aan andere onderzoekers ter beschikking staan.

4. Daarnaast ben ik veel dank verschuldigd aan notaris J.A. de Bruyn (Nieuwegein) en aan oudnotaris M.A. van Dorp (Gouda) bij wie ik ter voorbereiding op de interviews met betrekking tot het erfrecht informatie heb ingewonnen ten aanzien van de praktijk van het erfrecht. 
gevaarlijke zaken is gebruikt ter illustratie van de werkwijze van het Driemanschap (Hoofdstuk 4, bijlage III), alsmede om de betekenis aan te geven van de literatuur en de rechtsvergelijking voor het nieuwe B.W. (Hoofdstuk 7).

Omdat het archief met name ten aanzien van de Boeken 3 en 5 een aantal leemten vertoonde en de getrokken conclusies derhalve slechts beperkt geldig konden zijn, is voor het vervolg van het onderzoek het accent gelegd op Boek 6, titel 4 (verbintenissen uit andere bron dan onrechtmatige daad of overeenkomst). Ook deze studie is niet in dit proefschrift opgenomen, omdat zij vanwege haar overwegend juridisch-dogmatisch karakter in het kader van de beschouwingen over de historische ontwikkeling van de hercodificatie het effect van een stijlbreuk zou hebben. Wel is een uittreksel van de onderzoeksresultaten opgenomen in Hoofdstuk 4, bijlage III.

Eén en ander heeft ertoe geleid dat de nevengeschikte doelstelling wat minder uit de verf is gekomen, zij het dat deze detailstudies mijns inziens mijn vermoeden betreffende de waarde van het archiefmateriaal voor juridisch-dogmatisch onderzoek genoegzaam heeft bevestigd.

\section{d. literatuuronderzoek}

Vanzelfsprekend is zoveel mogelijk kennis genomen van alle op het nieuwe Burgerlijk Wetboek betrekking hebbende literatuur. Om de naoorlogse hercodificatie in een adequaat rechtshistorisch perspectief te plaatsen, is ook de geschiedenis van de hercodificatie vanaf 1838 tot aan de Tweede Wereldoorlog onderzocht. Deze is niet alleen van belang om de meningsvorming over de wenselijkheid van de hercodificatie nader te analyseren, maar ook omdat Meijers, die deze geschiedenis vrij goed kende, daaruit organisatorische lessen heeft getrokken; bovendien heeft hij veelvuldig gebruik gemaakt van eerdere ontwerpen voor hercodificatie.

Omdat bij de beschrijving van de geschiedenis van de vroegere pogingen tot herziening nauwelijks sprake kon zijn van aansluiting op reeds door anderen verricht onderzoek ${ }^{5}$, is daarbij de volgende werkwijze gehanteerd. Allereerst is, aan de hand van een aantal trefwoorden, de inhoudsopgave van de belangrijkste juridische tijdschriften uit deze en de vorige eeuw doorgenomen. In aansluiting daarop zijn vanaf \pm 1870 de begrotingen van het Ministerie van Justitie bestudeerd. Tenslotte zijn de wetgevingsdossiers van enkele voor het privaatrecht bij uitstek belangrijke wetsontwerpen doorgenomen, alsmede de complete notulen en stukken van de vier Staatscommissies die sinds de tweede helft van de vorige eeuw op het terrein van het burgerlijk recht actief zijn geweest.

Tot de onderzochte tijdschriften behoren het Magazijn voor Handelsrecht (18591920), De Regtzaal (1850-1861), Bijdragen tot Regtsgeleerdheid en Wetgeving (18261894), Juridische correspondent (Vraagal en opmerker) (1854-1864), Opmerkingen en Mededelingen betreffende het Ned. Regt (1845-1863), Tijdschrift voor Recht (1868-

5. "Eine erschöpfende Darstellung der Revisionsgeschichte des Burgerlijk Wetboek von 1838 (..) fehlt bisher", aldus Holthöfer (H. Coing. Handbuch der Quellen und Literatur der neueren europäischen Privatrechtsgeschichte, Band III. Das 19. Jahrhundert. Erster Teilband. Gesetzgebung zum allgemeinen Privatrecht, München 1982, p. 1284). Zie vooral de bijdragen van Scholten en Meijers in het Gedenkboek Burgerlijk Wetboek 1838-1938, Zwolle 1938; J.Th. de Smidt, Codificatieperikelen, Deventer 1966; H. Cohen Jehoram, Over codificatie van vóór Portalis tot na Meijers, Deventer 1970. 
1875), Vragen des Tijds (1875-1923), Themis (1838-1938), Rechtsgeleerd Magazijn (1882-1938), Rechtsgeleerd Magazijn Themis (1938-1993), Nederlands Juristenblad (1925-1993), Advocatenblad (1920-1993), Handelingen van de Nederlandse Juristen Vereniging (1913-1992) Weekblad voor Privaatrecht, Notariaat en Registratie (18701993) en het Weekblad van het Regt (1839-1940). Van de wettendossiers zijn op het rijksarchief (Archief Ministerie van Justitie) geraadpleegd; Wetten 61, Dossier 246 "1907-1941", Ontwerp tot herziening wettelijke bepalingen ter invoering eerste 6 titels Boek 4 B.W.; Wetten 15, Dossier 265 "1908-1920", Ontwerp van Wet tot wijziging en aanvulling van de bepalingen van het Burgerlijk Wetboek omtrent de verbintenis uit onrechtmatige daad enz.; Wetten 150, Herziening B.W. Staatscommissie-Van Meerbeke (1880-1900). Tenslotte is kennisgenomen van de notulen van de Staatscommissie voor de Nederlandse Burgerlijke Wetgeving (1919-1947, 1200 pagina's) en de notulen van de subcommissie Burgerlijk Recht (1938-1954, 800 pagina's).

\section{Opbouw van dit boek}

Bij de opbouw van dit boek zijn drie uitgangspunten gehanteerd. Allereerst is naar chronologie gestreefd. In de tweede plaats is getracht een overzicht te geven van de organisatie van de hercodificatie. Tenslotte worden in de diverse hoofdstukken één of meer aspecten van het werk aan het nieuwe B.W. in verband met de onderzoeksvraag belicht.

Hoofdstuk 2 beschrijft de codificatiegeschiedenis van het Nederlands burgerlijk recht tussen 1838 en 1938. In de daaropvolgende hoofdstukken wordt het verloop van de codificatiegeschiedenis na 1938 geschetst. Duidelijk blijkt dat tussen beide een onlosmakelijk verband bestaat, met name wat betreft de relatie wetgeving en politiek.

Hoofdstuk 3 beschrijft en analyseert de rol van Meijers bij de hercodificatie. Dit hoofdstuk, dat eindigt bij het overlijden van Meijers in 1954, gaat uitgebreid in op de werkwijze van Meijers, zijn taakopvatting, zijn voorzitterschap van de Staatscommissie voor de Burgerlijke Wetgeving, zijn verhouding met het Departement en de verschillende Ministers van Justitie, de vormgeving en betekenis van de vraagpuntenprocedure en de rol van de Tweede Kamer.

In hoofdstuk 4 wordt deze beschrijving en analyse voortgezet met betrekking tot het Driemanschap dat Meijers in 1954 opvolgde. Gewezen wordt op de steeds verder uitdijende organisatie van het werk, verschillen in taakopvatting, het verminderde gezag van de ontwerpers, alsmede de persoonlijke verhoudingen. Daarnaast wordt aandacht besteed aan de vraag in welk opzicht de door het Driemanschap voor de Boeken 5 en 6 afgescheiden teksten nog als die van Meijers zijn te beschouwen. Als eindpunt van dit hoofdstuk is 1961 gekozen, toen het Driemanschap uiteenviel.

In hoofdstuk 5 wordt het accent gelegd op de belangrijkste opvolger van Meijers, Jan Drion, die samen met Justitieambtenaar Van Ewijk tussen 1961 en 1964 werkte aan de Memorie van Antwoord voor het nieuwe Erfrecht. Daarnaast wordt aandacht geschonken aan de opvolging van Drion, die in 1964 overleed en waardoor het werk over drie andere Regeringscommissarissen werd verdeeld: Wiersma (Boek 4), Beekhuis (Boek 5) en Langemeijer (Boeken 3 en 6).

Hoofdstuk 6 behandelt de lotgevallen van het nieuwe erfrecht. Nadruk wordt gelegd op de rol van het notariaat als belangengroep en zijn voornaamste woordvoer- 
ders, alsmede op die van de ontwerpers en hun gezag. Dit gebeurt vanuit het perspectief van de emancipatie van de langstlevende echtgenoot in het testamentair erfrecht en de ondeskundigheid en ongeïnteresseerdheid van het parlement, dat deze kwestie al meer dan een halve eeuw voor zich uitschuift.

Hoofdstuk 7 beschrijft de ontwikkeling van de Boeken 3, 5 en 6 na 1964. Voor de beschrijving van het wetgevingsproces van Boek 3 wordt inspiratie geput uit een studie naar de ontwikkeling van afdeling 3.1.1. Het accent ligt daarbij op de taakopvatting van de ontwerpers en op de organisatie van het werk. Ten aanzien van Boek 5 wordt vooral de verhouding tussen Regeringscommissaris en Departement belicht, in het bijzonder het ontbreken van voldoende toezicht en begeleiding. In de studie naar Boek 6 wordt het werk van Regeringscommissaris Snijders vergeleken met dat van het Driemanschap, met betrekking tot de rechtsvergelijking, de verwerking van kritiek en het overleg met de praktijk. Afzonderlijk aandacht wordt besteed aan de wetgevingsprocedure na 1976, toen de Kamer voor de taak stond de tekst van deze boeken vast te stellen.

Hoofdstuk 8 behandelt de totstandkoming van het voorontwerp voor Boek 7, betreffende Bijzondere Overeenkomsten. Uiteengezet worden de bedoelingen van Meijers, de rol van het Driemanschap en de inbreng van de verschillende medewerkers, die na 1961 opdracht kregen dit onderdeel te voltooien. Het hoofdstuk sluit af met een globale vergelijking tussen enkele titels van het concept-Meijers en het uiteindelijk gepubliceerde ontwerp.

Hoofdstuk 9 beschrijft de totstandkoming van het nieuwe verkeersmiddelen- en vervoersrecht. Gewezen wordt op de samenhang tussen deze rechtsgebieden en de consequentie daarvan voor het wetgevende werk. Verder wordt de rol van Regeringscommissaris Schadee belicht en de betekenis van het door hem consequent en met groot doorzettingsvermogen toegepaste overleg met de praktijk.

In hoofdstuk 10 komen de rechten op de voortbrengselen van de menselijke geest aan de orde, een onderdeel van het nieuwe Burgerlijk Wetboek dat het nooit tot een voorontwerp heeft gebracht. Belangrijk daarbij is de afhankelijkheid van een Minister ten opzichte van zijn ambtenaren, alsook de overladen wetgevingsagenda van de Tweede Kamer en de plaats van het nieuwe B.W. daarin.

In hoofdstuk 11 tenslotte worden de invoeringsperikelen betreffende de Boeken 3-6 van het nieuwe Burgerlijk Wetboek in de periode 1980-1992 belicht. Aandacht wordt in dat verband besteed aan de rol van de vaste Commissie voor Justitie, die ernaar snakte van deze arbeid verlost te zijn, de huiver van de praktijk voor de veelheid aan veranderingen die zij op zich zag afkomen, de steeds wassende invloed van de rechtswetenschap op het wetgevingsproces, alsmede de betrekkelijkheid van het feit dat reeksen van Kabinetten en Regeringsfracties het werk aan het nieuwe wetboek gesteund, althans niet hadden tegengewerkt. 
Hoofdstuk 2

DE CODIFICATIEGEDACHTE TUSSEN 1838 EN 1938

\section{Inleiding}

Sinds de Staatsregeling van 1798 treffen wij, met een enkele onderbreking, in de Grondwet een zogenaamd "codificatie-artikel" aan. ${ }^{1}$ Daarin wordt met zoveel woorden voorgeschreven dat de wetgever bepaalde delen van het recht dient te regelen in algemene wetboeken. Zo bepaalt artikel 107 lid 1 Grondwet sinds de laatste grondwetswijziging (1983):

"De wet regelt het burgerlijk recht, het strafrecht en het burgerlijk en strafprocesrecht in algemene wetboeken, behoudens de bevoegdheid tot regeling van bepaalde onderwerpen in afzonderlijke wetten."

Over de vraag wat het begrip "codificatie" inhoudt, bestaat in de Nederlandse privaatrechtsliteratuur geen verschil van mening. Bellefroid ${ }^{2}$ definieert codificatie als "de systematische samenvatting van het recht in wetboeken", codificeren "noemt men het in wetboeken samenvatten van de gehele rechtsstof", volgens Pitlo ${ }^{3}$, Molengraaff ${ }^{4}$ vindt het een "geven van een samenstel van samenhangende en onderling harmonierende rechtsregels", terwijl Scholten ${ }^{5}$ noteert "ons burgerlijk recht is gecodificeerd, d.w.z., de gehele stof is in één wetboek samengevat." ${ }^{16}$

De codificatiegedachte, het woord spreekt voor zich, duidt op de binnen een samenleving heersende opvatting over de wenselijkheid van codificatie. Scholten memoreert in zijn bijdrage in het "Gedenkboek Burgerlijk Wetboek 1838-1938" dat deze gedachte na de invoering van de Franse wetboeken in 1811 vanuit politiek oogpunt nooit meer onderwerp van discussie is geweest: "De noodzakelijkheid van codificeeren was iets vanzelfsprekends, zij werd niet bestreden, maar behoefde ook niet te worden betoogd; emoties wekte het denkbeeld niet, allerminst politieke. ${ }^{77}$

In het denken over codificatie is sindsdien weinig veranderd. Natuurlijk, er zijn in het verleden wel stemmen opgegaan om de codificatie-opdracht uit de Grondwet te

1. Zie W.J.C. van Hasselt, Verzameling van Nederlandse staatsregelingen en grondwetten, 17e druk, Alphen aan den Rijn 1987, p. 17 e.v. In de Staatsregeling van 1805 ontbrak een dergelijk voorschrift, wellicht omdat de federalisten meer invloed hadden gekregen dan de unitarissen.

2. J.H.P. Bellefroid, Inleiding tot de rechtswetenschap in Nederland, derde druk, Nijmegen-Utrecht 1943, p. 90.

3. A. Pitlo, Het systeem van het Nederlandse Privaatrecht, zevende druk, Arnhem 1978, p. 14.

4. Rechtsgeleerd Magazijn, 1882, p. 221 e.v.

5. P. Scholten, Algemeen Deel, derde druk, Zwolle 1974, p. 169.

6. Vergelijk ook J.H.A. Lokin en W.J. Zwalve, Hoofdstukken uit de Europese Codificatiegeschiedenis, Groningen 1992, p. 2: "Codificatie is geschreven recht, waaraan de overheid een aan haar gezag ontleende, uitsluitende gelding toekent; deze exclusiviteit maakt de rechtsoptekening tot een volledige."

7. P. Scholten, Gedenkboek Burgerlijk Wetboek 1838-1938, Zwolle 1938, p. 2. Zie ook Csaba Varga, Codification as a socio-historical phenomenon, Budapest 1991, p. 16. 
schrappen $^{8}$ en iemand als Gerbrandy, onze Londense Minister-President, noemde tijdens een discussie over het nieuwe Burgerlijk Wetboek de codificatiegedachte "fout", want heidens ${ }^{9}$, maar veel invloed is daarvan niet uitgegaan. De codificatiegedachte is springlevend, zoals nog onlangs werd opgemerkt. Noch vanuit de theorie, noch vanuit de praktijk wordt serieus bepleit de idee van algemene wetboeken te verlaten. ${ }^{10}$

Dit is echter slechts één aspect van de codificatiegedachte. Het andere is dat een codificatie ook regelmatig moet worden bijgewerkt en aangepast aan de eisen van de tijd. Gebeurt dat niet, of slechts sporadisch en gebrekkig, dan wint het buitenwettelijk recht steeds meer terrein, met als gevolg dat de voordelen van codificatie, eenvoud van het recht, overzichtelijkheid en rechtszekerheid, langzaam maar zeker verloren gaan.

In dit hoofdstuk worden de totstandkoming, aanpassing en herziening van het Nederlands Burgerlijk Wetboek belicht tegen de achtergrond van dit aspect van de codificatiegedachte. Zoals zal blijken, heeft dit onderwerp nooit onderdeel uitgemaakt van een zuiver theoretische beschouwing. Er is in de periode voorafgaande aan de totstandkoming van het Burgerlijk Wetboek wel veel gediscussieerd over codificatie, maar niet over hercodificatie. En toen het Burgerlijk Wetboek in 1838 eenmaal was ingevoerd, bleek het direct al zoveel gebreken te tellen, dat daartegen slechts repressief kon worden opgetreden. Er was daardoor geen tijd om zich te bezinnen over de bij een herziening te volgen methode, geen gelegenheid om diepgaand van gedachten te wisselen over de verhouding tussen wet en rechter, in feite de kern van dit probleem. ${ }^{11}$

\section{Een terechte waardering?}

Opvallend aan het "Gedenkboek" van 1938 is dat vrijwel iedere schrijver - met uitzondering van Meijers - zeer ingenomen leek met het honderdjarige Burgerlijk Wetboek. De kritiek, die er terloops op werd uitgeoefend, had weinig te betekenen.

Recensent Van Oven, die er kort tevoren nog op had gewezen dat sommige juristen wel wat al te gemakkelijk voorbijgingen aan de gebreken van het Burgerlijk Wetboek ${ }^{12}$, schreef dan ook met een nauwelijks verholen verbazing: "Alles bijeengenomen komt ons oude B.W. er in dit boek lang niet kwaad af. Een blijvende kern van in verstaanbare, niet mooi, niet al te scherp, niet altijd duidelijke, maar toch nog niet zoo kwade bepalingen neergelegde rechtvaardigheid, blijkt het naar de meening van hen, die het hier bekeken, toch zeer zeker te bezitten ...." ${ }^{13}$ Van Apeldoorn oordeelde in Themis: "De indruk, dien de lezing van het Gedenkboek ons gaf, is deze,

8. Zowel de staatscommissie-Van Schaik, die in 1954 eindrapport uitbracht, als de staatscommissieCals-Donner, die in 1971 haar bevindingen rapporteerde, adviseerden het codificatie-artikel te schrappen. Zie J. de Boer, Grondwettelijke codificatie-opdracht en risico-aansprakelijkheid: Paard van Troje in het ontwerp-Wet Bodembescherming, Ars Aequi 1987, p. 472.

9. Handelingen Tweede Kamer 1953-1954. p. 2103.

10. Zie N.A. Florijn, De symbolische waarde van codificatie, in: Wat maakt de wet symbolisch?, Zwolle 1991, p. 199.

11. Vergelijk J.P. Fockema Andreae, Moderne Praetuur? Beschouwingen over het jongste verleden en de naaste toekomst van wetstoepassing en rechtshervorming, Haarlem 1907, p. 147 e.v.

12. NJB 1938, p. 595 e.v.: p. 763 e.v.

13. NJB 1938, p. 771 
dat het rechtsgeleerde Nederland in het algemeen onze wetgeving op het gebied van het burgerlijke recht bevredigend acht. Scholten heeft, naar het schijnt, weer niet alleen zijn eigen, maar de heerschende meening uitgesproken, toen hij het B.W. qualificeerde als een "bruikbare copie van een meesterwerk"."14

$\mathrm{Nu}$ is zo'n welwillende houding wellicht te verklaren door te bedenken dat zij paste in de sfeer van het eerbiedwaardig gedenken. ${ }^{15}$ En het kan ook daarmee te maken hebben, dat men van oordeel was dat rechtspraak en wetenschap de voornaamste gebreken van het wetboek hadden geheeld. Maar hoe dit ook zij. in ieder geval had Van Apeldoorn gelijk toen hij in het vervolg van zijn bespreking "deze algemene tevredenheid" als "zeer opmerkelijk" bestempelde, mede gezien het feit dat "vroeger herhaaldelijk een scherpe kritiek op ons wetboek is uitgeoefend. ${ }^{16}$

Hoewel Van Apeldoorn daarbij in het bijzonder het oog had op Opzoomer en Land, kost het weinig moeite om nog vroegere critici voor het voetlicht te brengen. Zo maakte reeds in 1840 , dus amper twee jaar na de invoering van de nationale wetgeving, S.P. Lipman, een bekend publicist op het gebied van het burgerlijk recht die later tot raadsheer in de Hoge Raad zou worden benoemd ${ }^{17}$, zich de woordvoerder van "vele bevoegde beoordeelaars" 18 door "a priori reeds de waarde onzer wetboeken te beslissen, en daaruit de noodzakelijkheid af te leiden eener algehele herziening. ${ }^{19} \mathrm{Hij}$ besloot zijn ingezonden bijdrage met de verzuchting: "Een blik op de resultaten verheft ons beweren boven twijfel en tegenspraak, en leidt op nieuw tot de zekere gevolgtrekking, dat, welke aanspraak ook de Regering, sedert het herstel der onafhankelijkheid van Nederland, tot de troonsbeklimming van den tweeden Koning, moge hebben op den dank der tijdgenooten en de bewondering van de nakomelingschap, die aanspraak geenszins kan berusten op wetgevende voortreffelijkheid." 20

14. Rechtsgeleerd Magazijn, 1939, p. 80.

15. Vergelijk J.H. Beekhuis, Meijers en de vernieuwing van onze codificatie, Rechtsgeleerd Magazijn Themis, 1950, p. 258.

16. Rechtsgeleerd Magazijn, 1939 , p. $80-81$.

17. Volgens het "Nieuw Nederlands Biografisch Woordenboek", Amsterdam 1974, deel V, p. 319 , was Lipman een "verdienstelijk rechtsgeleerde en Staatsman."

18. Aldus C.J. François, Themis, 1844, p. 101.

19. W 142 (1840). Zie ook W 127, 130-132 (1840). Daarin schreef Lipman, met instemming van M. Wiardi Beckman, de latere rechter (en enige civilist) in het Hof van Noord-Holland, dat het gelukkig is "dat de aansprakelijkheid, waaraan de wetgever den bouwmeester onderwierp, niet wederkeerig op den wetgever rust, voor de duurzaamheid en deugdzaamheid van het ontworpen en opgetrokken gebouw. Want men heeft zich gevleid, wetten te maken voor de eeuwen, doch er zijn nauwelijks twee jaren verstreken, sedert de invoering onzer nieuwe wetgeving, en in dit korte tijdvak, heeft zich de behoefte van herziening en verbetering allerwege levendig doen gevoelen, en hebben zich tallooze gebreken, treurige misbruiken en schier onoverkomelijke moeijelijkheden vertoond, in het burgerlijke regt, in de regtspleging, in het handelsregt, in de regterlijke organisatie, in de lijfstraffelijke regtsvordering."

20. W 143 (1840). 


\section{De codificatiegedachte na $\mathbf{1 8 1 3}$}

Om te kunnen begrijpen waarom dit pleidooi zo kort na 1838 te beluisteren viel, is enig inzicht vereist in de betrokkenheid van de juridische wereld bij de voorbereiding van de nieuwe codificatie.

Uit de "Briefwisseling van eenige regtsgeleerden over de aanstaande Nederlandsche Wetgeving" die in de jaren 1814-1819 werd uitgegeven om "die belangstelling, en dien geest van onderzoek en discussie, en deszelfs aanwending op onze nieuwe Wetgeving, op te wekken en vruchtbaar te doen zijn", kan worden opgemaakt dat de codificatiegedachte als zodanig volledig was geaccepteerd, de vooroordelen tegen al wat Frans of nieuw was ten spijt. Weliswaar leefde de wens om tot een algemene nationale wetgeving te komen al geruime tijd voordien - men vergelijke de uit het laatste kwart van de $18 \mathrm{e}$ eeuw daterende pennevruchten van Schorer, Vitringa en Thorbecke - maar pas met de komst van de Fransen kon men voor het eerst de waarde beoordelen van een bepaalde en vaste wetgeving. Die driejarige kennismaking was volgens de briefschrijvers voldoende om de "onverschilligheid en het mistrouwen (...) jegens de groote ontwerpen en beloften der Batafsche Revolutie" ${ }^{21}$ geheel te doen vergeten: "Welke ook de inhoud van de nieuwe wetten zijn moge; het is de wensch van geheel Nederland, de bepaling van de Grondwet, de wil van den Vorst, dat er eene vaste en algemeene Wetgeving zij over het geheele land. "22

Vanzelfsprekend waren er destijds ook critici, "sommigen (die men) aan deze zijde raaskallende hoort wenschen, om, hangende de vervaardiging der nieuwe algemeene Wetboeken, inmiddels het oude, dat vóór de Fransche overheersching bestond, terug te roepen en weêr in kracht te stellen"23, maar ook uit die reactie kan worden opgemaakt dat men althans de idee van algemene wetboeken niet verwierp. Het denkbeeld om bepaalde delen van het recht te codificeren vond bij iedereen ingang. De discussie over de wenselijkheid van een algemeen wetboek, zoals deze omstreeks 1814 in Duitsland werd gevoerd tussen Savigny en Thibaut, ging dan ook vrijwel aan ons land voorbij, "omdat wij alreeds eene algemeene en stellige wetgeving bezaten" $^{24}$ in de vorm van de Code Civil, "en er (...) geen voornemen (is) om dezelve

21. J.D. Meyer, H.W. Tydeman, Briefwisseling van eenige regtsgeleerden over de aanstaande Nederlandsche Wetgeving. Leiden 1819, p. 308. Zie ook H.M.A.J. Van Asch van Wijck, die in zijn voorrede bij Voorduin, Geschiedenis en beginselen der Nederlandsche Wetboeken, Utrecht 1837, deel 1 , eerste stuk, p. XI-XII, schreef dat "reeds (..) de invoering van het wetboek Napoleon, ingerigt voor het Koningrijk Holland, het heilzame (had) doen ondervinden van eene algemeene wetgeving in burgerlijke zaken, waardoor die ontallijke verscheidenheden ophielden, welke tusschen de provinciën en landschappen, ja zelfs tusschen onderscheidene steden van dezelfde provincie voormaals bestonden, en het was die zelfde algemeenheid van wetgeving, welke de invoering van de onderscheidene Fransche wetboeken. hoezeer voortbrengselen van eenen vreemden bodem, en minder geschikt voor Nederland, echter als eene weldaad deed beschouwen, daar de voordeelen eener gelijkmatige regtsbedeeling, daaruit ontsproten, de oorsprong van die invoering zelve van lieverlede deden uit het oog verliezen."

22. Briefwisseling, p. 9 e.v.

23. H.W. Tydeman, Verhandeling over de wetenschappelijke beoefening van het regt in Nederland, na het uitvaardigen van nieuwe wetboeken in de taal des lands, Leiden 1819, p. 29.

24. J. de Bosch Kemper, Gedachten over de beoefening en toepassing der aanstaande Nederiandsche Wetgeving, Amsterdam 1838, p. 3. 
eenvoudiglijk af te schaffen en den oude staat van zaken te herstellen; maar om ze door andere, meer nationale, te doen vervangen. "2s

Slechts met betrekking tot de vraag of het nieuwe wetboek zich zou moeten bepalen tot het geven van algemene beginselen, danwel tot in bijzonderheden zou moeten afdalen, zodat de wetgever "zoo veel doenelijk, alle de bestaande of mogelijke gevallen in zijn Wetboek moet opnemen, en daarop uitspraak doen" ${ }^{26}$, weerklonk iets van het Duitse standpunt. J.A. Weiland, een Rotterdams advocaat die later tot rechter in het Hof te Den Haag zou worden benoemd, had zich in zijn opstel "Proeve over eenige belangrijke onderwerpen uit de wetenschap der wetgeving" uitgesproken voor een wetboek dat, daargelaten de onvermijdelijke onvolledigheid van elk wetboek, de volledigheid zoveel mogelijk zou moeten benaderen.

De op dat moment nog onbekende rechtsgeleerde in de "Briefwisseling" was het daarmee echter bepaald niet eens en zijn reactie verklaart mede waarom de weerstand tegen de als leerstellig ervaren ontwerpen van 1816 en 1820 niet uitsluitend in de schoenen van de Zuidelijken kan worden geschoven. Hij schreef: "Hoe schoonschijnend deze redenering ook zijn moge, komt mij dezelve geheel onvoldoende voor. Immers het is niet zoo zeer het gebrekkige der bestaande Wetboeken, dat mij het denkbeeld doet omhelzen, om alleen algemeene regels in eene wet optenemen; maar de onmogelijkheid der volledigheid van een gedetailleerd Wetboek brengt mij tot de gedachte, dat de Wetgever, die tot deze volledigheid zoekt te naderen, zich zelven bedriegt." 27

Geen twijfel bestond ook over de vraag uit welke rechtsbronnen de nieuwe wetgeving zou moeten worden samengesteld. De voormalige Nederlandse wetgeving kwam daarvoor in ieder geval niet in aanmerking. Zo zei H.W. Tydeman, de Leidse hoogleraar die als één van de weinigen de colleges in het vaderlandse recht van Van der Keesel had bezocht en dus wist waarover hij sprak, deze oud-vaderlandse bronnen slechts in zijn betoog te betrekken "zoo ver die doolhof mij bekend is, en ik in dien bajert licht zie." ${ }^{28}$ Iets later oordeelde hij dat de keuze tussen de Franse wetboeken en "den ouden doolhof van regten en wetten" voor geen enkel "kundig en verstandig en onbevooroordeeld Regtsgeleerde" een probleem zou betekenen, aangezien deze, "zoodra hij zich Nederlander gevoelde, zonder beraad het eerste zoude kiezen." 29 Deze verzameling van wetten, keuren en verordeningen was naar zijn mening onvatbaar voor wetenschappelijke beoefening, omdat zij uit tal van heterogene en strijdige bestanddelen was samengesteld en door de menigte van wetten en wetboeken en de gebrekkige uitgave in druk door niemand in haar geheel kon worden gekend: "Wie kon deze massa overzien, wie kon ze schiften, ordenen, beginselen en zamenhang daarin zoeken? Welke er, trouwens volstrekt niet in te vinden waren." ${ }^{30}$

\footnotetext{
25. H.W. Tydeman, a.w., p. 49.

26. Briefwisseling, p. 159

27. Briefwisseling, p. 162

28. H.W. Tydeman, a.w., p. 16.

29. H.W. Tydeman, a.w., p. 50.

30. H.W. Tydeman, a.w., p. 29. Zie ook A.J. Duymaer van Twist in Gratama's Rechtsgeleerd Magazijn, 1809, p. 375: "... hoe die moeielijkheid (om het recht van een bepaalde streek of stad te leren kennen) daardoor nog aanzienlijk vergroot werd, dat die kennis moest worden verkregen uit wetten, die dikwijls zeer verspreid, door den druk niet gemeen gemaakt, of door eenige weinigen, gelijk een kostbare schat in hunne boekerijen verborgen en weggesloten waren."
} 
Niet minder scherp was de kritiek op het "Wetboek Napoleon, ingerigt voor het Koningrijk Holland" (WNH), dat van 1 mei 1809 tot 1 maart 1811 in grote delen van Nederland van kracht is geweest. Zo wenste Tydeman "dat basterd-kind van den Code Napoleon, het Wetboek van Lodewijk Napoleon, 't welk eigenlijk nooit regt geboren is geweest"31 zelfs niet in zijn beschouwingen te betrekken en werd in de "Briefwisseling" opgemerkt dat een snelle vorming van de nationale wetgeving zelfs de voorkeur zou verdienen boven de invoering van een herzien WNH, waarvan men de gebreken als gevolg van de beperkte periode gedurende welke het van kracht was geweest, nog niet kende. ${ }^{32}$ Daarnaast zou het WNH te weinig nationaal zijn omdat het eerste Boek voornamelijk op Provinciaal Hollands recht was gebaseerd, en gebrekkig en onvolledig - uit menige bepaling sprak de haast waarmee het wetboek moest worden samengesteld, alsmede het vooroordeel tegen nieuwe Franse instellingen. Ook was het ontwerp onvoldoende becommentarieerd, omdat het nooit in druk was uitgegeven. Bovendien waren er geen prijsvragen ter beoordeling van het ontwerp uitgeschreven, een in die dagen geliefde manier om kritiek op te wekken (of lof te oogsten), hadden de rechtbanken geen inzage gekregen en had de Staatsraad er slechts weinige woorden aan besteed. ${ }^{33}$

Kortom, het WNH illustreerde "dat op die wijze en in dien tijd geen Wetboek te maken was" ${ }^{34}$, zodat het ook niet als basis voor de nieuwe wetgeving mocht worden gebruikt: "dit denkbeeld (wordt) niet alleen algemeen (...), maar ook van alle zijden openlijk aan den dag gelegd. " ${ }^{35}$

Nu mag in deze scherpe afwijzing van het oud-vaderlandse recht en het wetboek van 1809 geen onvoorwaardelijke bereidverklaring worden gelezen om de Code Civil te behouden. Uit de hierboven weergegeven citaten blijkt slechts, dat men zich er tegen verzette om de oude rechtsbronnen als enige bouwstof voor het Burgerlijk Wetboek te gebruiken of te volstaan met een partiële herziening van het WNH; "men (werpe) niet doldriftig de Fransche soubise (weg), om slechts een onpassend buis, voor twee-derde uit Fransche lappen zaamgestikt, aan te schieten. ${ }^{36}$ Zeer wel werd beseft dat een volledig nationale of geheel nieuwe wetgeving tot de onmogelijkheden behoorde. Het oud-vaderlandse recht was immers als gevolg van de beoefening van het nieuwe Franse recht al voor een groot deel vergeten ${ }^{37}$, en bovendien te zeer

31. H.W. Tydeman, a.w., p. 27.

32. Briefwisseling. p. 28-29.

33. Briefwisseling, p. 33-70.

34. Briefwisseling, p. 73.

35. Briefwisseling, p. 155. Deze kritiek was uiteraard koren op de molen van Kemper, die, in zijn streven om tot een oorspronkelijk Nederlands wetboek te komen, op weerstand stuitte van de andere leden van de wetgevingscommissie uit 1814, die een beperkte wijziging van het WNH voldoende achtten. Zie daarover H.W. Heijman, Kemper's strijd tegen de Code Civil. Kanttekeningen bij een vertrouwd beeld, Rechtsgeleerd Magazijn Themis, 1975, p. 420 e.v.; E. Holthöfer, in: H. Coing, Handbuch der Quellen und Literatur der neueren europäischen Privatrechtsgeschichte, Band III, Das 19. Jahrhundert. Erster Teilband. Gesetzgebung zum allgemeinen Privatrecht, München 1982, p. 1255.

36. Briefwisseling, p. 32; Zie ook H.W. Tydeman, a.w., p. 35.

37. H.W. Tydeman, a.w., p. 29. Zie ook Voorduin, a.w., deel 1, eerste stuk, p. 175, die erop wijst dat sinds 1811 "velen in het Oud-Hollandsch regt, vreemdelingen geworden waren, of hetzelve nimmer hadden beoefend, en dus zelfs eene gedeeltelijke wederinvoering daarvan, op geenen zoo hoogen prijs stelden, als bij de opstellers van het ontwerp van 1816 het geval was." 
versplinterd om als bouwstof te kunnen dienen voor een binnen een redelijke termijn te ontwerpen wetgeving.

In het grondwettelijk voorschrift dat er een nationale wetgeving zou moeten komen, zag men dan ook geen andere aanwijzing dan dat de nieuwe wetgeving een nationaler karakter diende te krijgen dan het wetboek van 1809. Daarvoor zou dan (in de visie van de briefschrijvers) gebruik kunnen worden gemaakt van de ontwerpen van 1798 "ofschoon wat te veel op leerstelligen trant ingerigt" - Vaderlandse Land- en Stadsrechten, Costumen en Keuren "welke van overoude zeden, of bedaarde wijsheid en schrander beleid onzer voorvaderen afkomstig sedert lange jaren, en veelal sedert eeuwen, onder ons als wet geëerbiedigd (zijn)", het Oostenrijkse B.W., de Code Civil met de daarbij behorende jurisprudentie en de nieuwste Russische wetgevingsvoorstellen. ${ }^{38}$ Bovendien zou het in het belang van de verbroedering zijn, indien de Belgen in de nieuwe wetgeving "hier en daar de beschikkingen hunner oude Wetten en Gewoonten wedervonden. "39

De briefschrijvers wekten de wetgever op om niet te overhaast te werk te gaan, want in ieder geval moest de wetenschap in staat worden gesteld zich over de ontwerpen uit te spreken. Veel commentaar werd overigens niet verwacht: "Men beve niet te rug voor dien ballast van aanmerkingen welke langs alle deze opgenoemde wegen zouden aangevoerd worden, en de Ontwerpen van Wetgeving wel eens geheel kunnen overstelpen en versmoren. (...) Deze vrees is ijdel; (indien dezc.'ve al opregt, en geen dekmantel van andere vreesachtigheid of onwilligheid is). Er zouden toch uit dit kleine land, en bij de tegenwoordige gesteldheid van den publieken geest, wel niet meerdere aanmerkingen komen, dan, bij voorbeeld, op het Projet de Code Civil François. ${ }^{40}$ Bovendien was enige vertraging geen bezwaar, want "men is aan alle de nieuwe inrigtingen genoegzaam gewend, en ziet er zeker veel meer tegen op, om, pas bekomen van den schok, zoo dra weer een' nieuwen, naar de tegenovergestelde rigting te moeten ondergaan. ${ }^{41}$

\section{Andere opinies}

Het is de vraag in hoeverre deze "Briefwisseling" als representatief kan worden aangemerkt, met name met betrekking tot het punt in hoeverre de Code Civil als voorbeeld zou moeten dienen voor de te ontwerpen nationale wetgeving.

Het lijkt mij, maar dat is weinig meer dan een veronderstelling, dat de briefschrijvers in het begin op weinig instemming konden rekenen. Vele Nederlanders waren, hetgeen begrijpelijk is, aanvankelijk sterk gekant tegen elke Franse invloed, of deze nu een weldadige werking had of niet. Menige, door de omwenteling ingevoerde instelling, zoals de jury-rechtspraak, had dan ook na 1813 het veld moeten ruimen.

Het ligt voor de hand dat met betrekking tot de Code Civil geen ander standpunt werd gehuldigd. De codificatie, uitgegroeid tot hét teken van nationale eenheid en identiteit, bestond uit vreemd, aan ons opgedrongen recht. Een gruwel ongetwijfeld voor Koning, Parlement en volk. En de wetenschap dat Napoleon er ooit zijn naam 
aan had verbonden, was, dunkt me, een reden temeer om het belang van een eigen, op nationale leest geschoeide wetgeving te benadrukken. ${ }^{42}$

In de briefwisseling zijn enige passages aan te wijzen die deze voorstelling van zaken lijken te bevestigen. Zo neemt reeds in 1814, zelfs nog voordat het befaamde conflict tussen Kemper en de overige leden van de codificatiecommissie zich openbaarde, één van de auteurs stelling tegen de opvatting, dat al wat Frans is, dient te verdwijnen: "dat (...) geen vooroordeel (ons) misleide, en alles doe verwerpen, wat van eene Natie komt, voor welke wij in meer dan één opzigt achting moeten hebben, hoe groot nok onze redenen van klagen over hare behandeling moge zijn." ${ }^{43}$ En uit de reacties die deze opmerking losmaakte, kan worden afgeleid dat lang niet iedereen de juistheid van dit standpunt wenste te onderschrijven: Nog in hetzelfde jaar moest één van de schrijvers zich verweren tegen de opmerking dat hij "eenen bijzonderen en te hoogen prijs stelde op de Fransche Wetgeving, en dezelve veel te gunstig beschouwde." 44

Tenslotte zij vermeld een interessante opmerking uit een in 1815 geschreven brief. Daarin wordt namelijk geconcludeerd dat "onkunde, vooroordeel, en, bij velen, kwade trouw" de enige oorzaken zijn dat men het Franse wisselrecht "als verderfelijk (heeft) uitgekreten." 45 Deze critici hadden, in hun ijver het wetboek van de gehate overheerser als een wanprodukt af te schilderen, namelijk over het hoofd gezien dat de Franse tekst qua strekking nagenoeg geheel overeenkwam met het Oud-Hollandse recht. Het kon daarom volgens de briefschrijver "weinig ten nadeele der Fransche Wetgeving verstrekken, dat in de meeste plaatsen de lieden tegen dezelve zijn opgezet geworden; wanneer men de sprekendste bewijzen van zoodanige vooringenomenheid bij de voornaamste Regtsgeleerden en Regtbanken vindt, dat zelfs, alleenlijk omdat de Fransche wet de oude Hollandsche beginselen bevestigde, men gemeend heeft, dezelve mede te moeten verwerpen, en uitspraak doen, zoo als zich niemand te voren zoude hebben laten in den zin komen. "46 47

En daarna? Wel, na enige jaren sleet de ergste weerstand tegen het Franse recht. Men kan immers niet altijd verontwaardigd blijven. De burgerij raakte na verloop van tijd vertrouwd met de Code Civil, werd van een krachtig voorstander van nationale wetgeving tot een onverschillig beschouwer. En de rechterlijke macht zag natuurlijk al helemaal geen bezwaren. Daarbij kwam, dat ook diegenen, die fel tegenstander waren van de Code Civil, er niet de ogen voor konden sluiten dat een codificatie van Oud-Hollands recht, zo niet zeer moeilijk te verwezenlijken, toch in ieder geval tot onoverkomelijke bezwaren bij de Zuidelijke Nederlanden zou leiden. Bovendien werd

42. Zie E. Holthöfer, a.w., p. 1241 .

43. Briefwisseling, p. 157; Zie ook H.W. Tydeman, a.w., p. 3.

44. Briefwisseling, p. 241.

45. Briefwisseling, p. 371 .

46. Briefwisseling, p. 372. Een aardig detail hierbij is dat Joannes van der Linden, die in de jaren 1807-1808 een ontwerp voor een Burgerlijk Wetboek opstelde, op dit punt ook voor het OudHollandse recht had gekozen.

47. De vooringenomenheid tegen de Code Civil ging zelfs zover, dat Meyer en Tydeman, de auteurs van de "Briefwisseling", aanvankelijk anoniem waren gebleven en pas in 1819 hun ware identiteit onthulden. Daarmee wilden zij namelijk voorkomen (zie Briefwisseling. p. 54l) dat alleen vanwege hun naam de door hen ontvouwde denkbeelden verworpen zouden worden - met name Meijer kon vanwege zijn goede verhouding met Lodewijk Napoleon op weinig sympathie rekenen. 
men volstrekt in het onzekere gelaten over de voortgang van de codificatiearbeid, een voortgang die aanzienlijk minder snel verliep dan menigeen in zijn enthousiasme had gedroomd.

Deze factoren maakten dat de interesse voor de te ontwerpen wetgeving vrijwel geheel verliep. Illustratief hiervoor is dat de "Briefwisseling" tussen 1815 en 1819 volledig werd gestaakt. De schrijvers weten dit niet alleen aan een gebrek aan belangstelling bij het publiek, maar vooral aan "de toestand der Wetgeving zelve, de doodslaap, waarin de nieuw beraamde Wetgeving scheen gezonken te zijn" aangezien "niets van de reeds in 1814 gevormde nieuwe ontwerpen (werd) publiek gemaakt. "48

Van het kleine aantal ijveraars voor een echt nationale wetgeving dat er dan tenslotte nog over is, moesten Meyer en Tydeman dan ook niets hebben. Op een opmerking van Meyer, als zouden er in 1819 twee scholen van rechtsgeleerdheid bestaan, een Franse en een Hollandse, reageerde Tydeman furieus: "Aan hen, daarentegen, die nimmer iets hebben geleerd, en niets meer kunnen en willen leeren, dan eenige begrippen van het oude provinciaal-Hollandsche regt; die, met echten provinciäaltrots, van te voren overtuigd zijn, dat niets daarbij in aanmerking verdient te komen; die dus al het nieuwe schuwen, haten en vlieden, en op alle wijze het zalige oude weder zoeken in te dringen, - aan zulken kan toch wel geen naam van School gegeven worden; als welke naam nog eenig denkbeeld van wetenschappelijke redenering en zamenhangend leerstelsel opwekt. Secte of cligue mogten ze heeten: maar ik wilde liever die lieden, al waren er duizend, met geen' collectiven naam verwaardigen, welke slechts den partijgeest opwekt en nieuwe sterkte geeft." ${ }^{149}$

\section{De teloorgang van het Ontwerp-1820}

De betrokkenheid bij de codificatiepogingen zou in de volgende jaren eerder verminderen dan vermeerderen. Het is niet zo moeilijk daarvoor een aantal redenen aan te dragen, wél om te beoordelen welke daarvan het meeste gewicht in de schaal legde.

Een belangrijke verklaring voor de afnemende interesse in het wetgevingsproces ligt naar mijn mening in de eerste plaats in de aanvankelijk volstrekte onmogelijkheid een goed beeld van het Ontwerp-1820 te krijgen. In de Staatscourant, die uiteraard niet in ieders bezit kwam, werden in eerste instantie slechts de eerste elf titels van Boek 1 gepubliceerd. Deze werkwijze, waaruit niet veel eerbied voor publiek en wetenschap sprak, wekte zozeer het misnoegen op, zowel in als buiten de Karner Donker Curtius brak de staf over deze "digten sluijer van geheimhouding", waarvoor hij geen andere verklaring kon bedenken "dan die zo onteerend voor het volk zoowel, als voor de hooge Regering zouden zijn"50 - dat de Regering het verstandiger achtte de ontwerpen maar in te trekken.

\footnotetext{
48. Briefwisseling, p. 543. Inderdaad is dit ontwerp, en het "Ontwerp-1816" dat reeds op 12 December 1815 gereed was, maar pas op 5 Maart 1816 door de voltallige commissie kon worden aangeboden, nooit openbaar verkrijgbaar gesteld. De raad van Tydeman en Meyer om het ontwerp voor openlijke becommentariëring vrij te geven, werd dus in de wind geslagen.

49. Briefwisseling, p. 577 e.v.

50. W.B. Donker Curtius, Vrijmoedige aanmerkingen op het ontwerp van Burgerlijk Wetboek zoo verre hetzelve aan de Staten Generaal is voorgedragen, Dordrecht 1819, p. 4-5.
} 
Het spreekt vanzelf dat deze gang van zaken niet bevorderlijk was om de belangstelling voor de codificatiepoging, die zich al een paar jaar in het diepste geheim voortsleepte, nieuw leven in te blazen.

Intussen beloofde de inhoudelijke kritiek die Donker Curtius had uitgeoefend op de eerste elf titels van Boek 1 niet veel goeds voor de ontvangst van de resterende gedeelten. Naar de mening van Donker Curtius werd de geringe belangstelling voor dit "elftal" dan ook vooral veroorzaakt doordat allen, "zelfs zij die het vurigst verlangen naar nieuwe wetgeving, en diepe afkeer hebben van het bestaande" erop vertrouwden dat de ontwerpen vanwege hun "noodeloze omslag, herhalingen en langwijligheid" ook zonder verder commentaar wel zouden worden verworpen: "bij eene zoo algemeene afkeuring van het ontwerp, heeft men, meestal, zich de verwerping daarvan zoo zeker voorgesteld, dat men gemeend heeft, veilig te kunnen zwijgen, en dat het schier noodeloos was, de gebreken aan te wijzen. ${ }^{51}$

Het is uiteraard de vraag of dit stilzwijgen - Donker Curtius was de enige die vóór 1820 een commentaar schreef - op deze wijze geheel is verklaard. Neemt men de reactie van de Kamer in ogenschouw, die in 1821 de eerste 73 artikelen van het ontwerp vanwege hun leerstelligheid één voor één afstemde, dan lijkt Donker Curtius met zijn "vrijmoedige aanmerkingen" de plank echter niet ver mis te hebben geslagen.

Als derde factor ter verklaring van de geringe belangstelling voor het werk aan het Burgerlijk Wetboek zou ik erop willen wijzen dat de belangstelling voor de codificatiepoging in het algemeen tanende was. Aan de dringende oproep van Donker Curtius, om de adhesie met zijn denkbeelden ook publiekelijk te uiten ${ }^{52}$, omdat hij er niet gerust op was dat "allen, die in dezen moeten oordelen, daartoe volkomen in staat zijn", werd bijvoorbeeld door niemand gehoor gegeven.

Ook dit verklaart niet alles. In die dagen was het namelijk nog een twistpunt of het geoorloofd, en met het oog op een goede maatschappelijke carrière, verstandig was om zich over onderwerpen van staatszorg openlijk uit te laten. Zo maakt Meijers ${ }^{53}$ melding van het bestaan van de uit 1810 daterende verhandeling van Weiland, luidende "Proeve over het al of niet geoorloofde eener wetenschappelijke beoordeling der bestaande wetten", terwijl ook uit de "Briefwisseling" (zie bijvoorbeeld p. 580) en zelfs bij Donker Curtius nog enige schroom op dit punt valt waar te nemen. Want ofschoon de laatste zei het "ongenoegen van hen, die in reegeringsposten (zijn) gesteld" niet te vrezen, maakte hij zijn identiteit pas bekend nadat hij zich van voldoende zijden van steun had verzekerd..$^{54}$

Alles bijeen genomen waren er dus genoeg redenen om de ontwerpen links te laten liggen.

Op 22 november 1820 diende de Regering het gehele ontwerp in, vergezeld van een uitgebreide "ophelderende" memorie, inhoudende de uitgangspunten die bij het

51. W.B. Donker Curtius, a.w., p. 376. Zie ook p. 88, 246 en 366.

52. W.B. Donker Curtius, a.w., p. 249.

53. E.M. Meijers, De honderdjarige burgerlijke wetgeving, V.P.O. I, Leiden 1954, p. 137.

54. W.B. Donker Curtius, a.w., p. 60-61 en 67. Het leveren van openlijke kritiek was trouwens een "familietrekje". De broer van W.B., Dirk Donker Curtius, bestreed in de Standaard, één van de weinige Belgische kranten die niet door Van Maanens stromannen werd volgeschreven, de conservatieve politiek van de Regering ten opzichte van de zuidelijke Nederlanden. Daardoor kwam hij herhaaldelijk in conflict met genoemde Minister van Justitie. 
ontwerp van het B.W. in acht waren genomen. Tegelijkertijd verscheen het ontwerp in boekvorm om ieder gelegenheid te geven van het ontwerp kennis te nemen.

Veel resultaat leverde dit gebaar niet op. Na 1820 verscheen slechts één commentaar, dat evenals bij de "vrijmoedige aanmerkingen" het geval was, niet verder ging dan het eerste Boek. ${ }^{55}$ Hoewel het nu wel mogelijk was het gehele ontwerp te bestuderen, zweeg de rechtsgeleerde wereld in alle talen. Zelfs zij, die in het ontwerp hun voorliefde voor het Oud-Hollandse recht belichaamd zagen, lieten niets van zich horen.

Vermoedelijk zal de factor tijd hierbij een belangrijke rol hebben gespeeld. De openbare beraadslagingen zouden namelijk binnen twee maanden na het in druk verschijnen van het ontwerp beginnen. En die periode was, zo stel ik mij voor, zelfs nog te kort om het ontwerp open te snijden en de 3631 artikelen één voor één door te nemen. Want, en daar mag geen misverstand over bestaan, er was wél alle reden om met kritiek te komen: de Regering had in de "ophelderende memorie" namelijk met zoveel woorden te kennen gegeven niet overtuigd te zijn van het bezwaar inzake de leerstelligheid van het ontwerp, volgens Donker Curtius een algemene klacht.

Het is uiteraard eveneens begrijpelijk dat na afloop van het debat geen commentaar meer verscheen. Aangezien de uitslag daarvan weinig bemoedigend was voor de levensvatbaarheid van de overige gedeelten van het ontwerp - zoals vermeld werd er van de eerste 73 artikelen niet één gespaard - en daarenboven binnen een maand het besluit werd genomen de redactie van het ontwerp geheel te herzien, is het duidelijk dat elke lust tot becommentariëring (zo die er al ooit was geweest) verdween. Een dergelijke arbeid zou een vrij zinloze bezigheid zijn geweest in verband met de grote tekstaanpassingen die het ontwerp waarschijnlijk zou moeten ondergaan.

\section{Na 1821}

$\mathrm{Na} 1821$ werd de belangstelling voor de nieuwe wetgeving er niet beter op. Vanzelfsprekend had het voorlopige echec van de nationale poging tot codificatie de Franse codes meer glans gegeven, maar dat is vermoedelijk niet de belangrijkste reden voor de grote mate van desinteresse. Het proces van wetgeving - de Regering had een commissie uit de Kamer opdracht gegeven het Ontwerp-1820 om te werken - was in die dagen nu eenmaal uiterst moeilijk te volgen. Het enige waarover een geïnteresseerde kon beschikken was de vrijwel waardeloos geworden tekst van het Ontwerp1820 en een klein aantal, meestal breedsprakige redevoeringen van Kamerleden die deze, ter eigene meerdere eer en glorie, af en toe lieten verschijnen in een willekeurig dagblad.

Daar kwam nog bij, dat de vastgestelde wetsteksten, die uitsluitend in het Staatsblad werden gepubliceerd, met vrij grote tussenpozen verschenen. Van een nauwlettend volgen van het wetgevingsproces kon derhalve geen sprake zijn. Weliswaar probeerde het K.B. van 12 Juni 1822 , no. 8 , enige duidelijkheid in deze situatie te scheppen door te bepalen dat "aan ieder nommer van het staatsblad, bevattende een gedeelte van het B.W., behalve het gewoon, nog een buitengewoon en doorlopend

55. Naast het hierboven gememoreerde werk van Donker Curtius verscheen in 1821 een geschrift van W.Y. van Hamelsveld, getiteld: "Het ontwerp voor het Burgerlijk Wetboek voor het Koningrijk der Nederlanden, vergeleken met het vorig, bij ons in gebruik geweest zijnde regt." 
nommer zal worden gegeven, en dat wijders, laatstgemelde staatsbladen afzonderlijk zullen worden verkrijgbaar gesteld", maar succesrijk lijkt die poging niet te zijn geweest. In 1842 werd er, ter verklaring van de geringe betrokkenheid bij de totstandkoming van de codificatie, namelijk nog op gewezen dat de moeilijkheid bleef bestaan "om de eindelijk vastgestelde bepalingen, in Staats- en Nieuwsbladen verspreid, in derzelver zamenhang te leeren kennen." 56

De omstandigheid, dat er grote onzekerheid bestond over de uiteindelijke redactie van de wetten, bracht velen ertoe de nog bestaande belangstelling voor wetgeving te concentreren op de Franse wetboeken, waarmee men sinds 1811 vertrouwd was geraakt. Het feit dat Latijn nog de internationale taal was van juristen en ook de Franse taal in Nederland nog in aanzien stond - zij werd aanvankelijk wel gepropageerd als de enig juiste taal voor de nieuwe wetgeving - gaf aan deze beweging nog meer kracht. Ook daardoor bleef de interesse in het werk van de herzieningscommissie gering. Men wachtte gelaten af wat komen zou, afkeuring noch instemming werden vernomen.

Terugblikkend op deze periode schreef De Bosch Kemper in 1838: "Geachte lieden toch heb ik reeds meermalen hooren verklaren, dat het lange bezit van het Fransche regt in alle opzigten niet even voordeelig voor ons Vaderland geweest is, en dat de herhaalde teleurstelling in eene spoedige verkrijging der Nationale Wetgeving (...), de belangstelling bij velen minder heeft gemaakt, dan vroeger toen de afschudding van het Fransche juk algemeen met den wensch gepaard ging, om ook van de vreemde wetgeving verlost te worden. ${ }^{57}$

56. Regtsgeleerd Bijblad, 1842, p. 13.

57. J. de Bosch Kemper, a.w., p. IV. Zie ook Frets" verhandeling "Over het verval van de Judiciëele Praktijk", Bijdragen 1829, p. 210 e.v. en de redevoering van het Kamerlid Luzac bij de discussie over het Wetboek van Strafvordering, opgenomen in het Bijvoegsel tot de Staatscourant van 24 Maart 1830 , no. 71 , p. 7 : "De voortduring van dien provisionelen staat, in welken wij, sedert de afschudding van het Fransche juk hebben voortgeleefd, houde ik, en voor de Regters, en voor de uitoefenaars der praktijk, - en voor de geheele studie der Regten - hoogst nadelig. Voor de Regters, omdat de aanhoudende onzekerheid, zóbwel omtrent den post, welken men verkrijgen of behouden zal, als omtrent de wetten zelve, welke men zal blijven toepassen, eene onbestemdheid veroorzaken, en zekere lusteloosheid geeft, tot het voortzetten van regtsgeleerde onderzoekingen, welke hun ten allen tijde zoo zeer te passe komen kunnen, en algemeen nuttig zijn. - Voor de beoefenaars des regts zelve, omdat deze dagelijks eene geheele nieuwe wetgeving verwachtende, zich alleen bij de dagelijksche behoeften veelal bepalen, tevreden, met zich, naar gelang de zaken zich voordoen, au fait der regtsdecisiën gemaakt te hebben; zij vreezen daarenboven door vooruitloopende studiën, dikwijls verschillende principes te vermengen, en willen zich niet overgeven aan de wetenschappelijke beoefening der vigerende wetten, omdat zij op het punt staan van afgeschaft te zullen worden. Uit dit oogpunt vooral geloof $i k$, dat de zeer en bovenmatig langdurige provisionele staat, een allerwezenlijkst nadeel aan de grondige regtskennis gedaan heeft. Dat in het algemeen de studie groot nadeel hierdoor geleden heeft, kan de zeldzaamheid van belangrijke regtsgeleerde oorspronkelijke werken getuigen. Vele vertalingen, handleidingen en dergelijke boeken, hebben wij zien te voorschijn komen, daar de behoefte aan dezelve dadelijk was, en een zeker debiet verzekerde." 


\section{De "Bijdragen" opgericht}

De oprichting in 1826 van het eerste grote tijdschrift voor burgerlijk recht in Nederland, "Bijdragen tot Regtsgeleerdheid en wetgeving", bracht maar weinig verandering in deze situatie. En dat ondanks dat zij die de moeite namen om het werk van de herzieningscommissie te beoordelen, meestal uiterst kritisch gestemd waren.

$\mathrm{Zo}$ verweet bijvoorbeeld redacteur $\mathrm{J}$. van Hall in een breed opgezet artikel, opgenomen in de jaargang van 1827 , de Commissie van redactie voor de Nationale Wetgeving dat zij zich teveel zou richten op de Franse rechtsgeleerden en onvoldoende aandacht besteedde aan de jongste ontwikkelingen in het recht. Naar zijn mening werd deze houding veroorzaakt doordat men langzamerhand gewend was geraakt aan het Franse recht en men zich in feite die wetgeving niet wilde laten ontnemen, omdat men haar niet elke verdienste kon ontzeggen. ${ }^{58}$ Van Hall besloot zijn kritiek met de constatering, dat het Nederlandse Ontwerp in veel opzichten een verbetering betekende ten opzichte van de Code Civil, maar dat er nog vele gebreken aan kleefden "waarvoor men nog zoo gaarne eene algemeene herziening van het Wetboek zou verlangen." 59

Nog in hetzelfde jaar richtte F.A. van Hall, de oudere broer van J. van Hall en de latere Minister van Justitie, zich tot zijn "Mede-Regtsgeleerden", met het verzoek de nieuwe wetgeving kritisch te doorvorsen op 'fouten, onhelderheden en tegenspraak, die ongetwijfeld aan haar kleven, aangezien zij haar wortels heeft in het Franse Wetboek, dat ook niet van fouten vrij te pleiten is. ${ }^{60}$ In 1827 lanceerde F.A. van Hall vijf vragen over het hypotheekrecht. Een jaar later, in 1828, verschenen zijn volgens Opzoomer zo bekend geworden "Dertig vragen omtrent Bezit en bezitregt. "61 Daarnaast publiceerde François Frets, een vooraanstaand en invloedrijk lid van de Tweede Kamer ${ }^{62}$, in 1828 een aantal "Bedenkingen" over de wettelijke regeling van de borgtocht. ${ }^{63}$

De teneur van deze publicaties was dezelfde: Aan het ontwerp voor het Burgerlijk Wetboek kleven nog vele gebreken.

\section{Van Hall krijgt weinig respons}

Van Hall stond in zijn kritiek echter vrijwel alleen. Hoewel er in de "Bijdragen" nog een aantal kritische commentaren werd gepubliceerd, verzameld uit reacties van lezers, constateerde de redactie diverse keren met een enigszins spijtige ondertoon dat de nieuwe wetgeving, en vooral het B.W., "nog geenszins die algemeene belang-

58. Bijdragen, 1827 , p. 448 . Bij deze kritiek moet men wel bedenken dat Van Hall een oud-leerling was van de natuurrechtsgeleerde Cras, en wellicht in navolging van zijn leermeester uitsluitend prijs stelde op een oorspronkelijk, dat is, natuurrechtelijk geïnspireerd wetboek. Zie echter Bijdragen $1831 / 32$, p. 294 e.v. en 1834 , p. 335.

59. Bijdragen, 1827 , p. 479.

60. Bijdragen, 1827 , p. 636 e.v.

61. Bijdragen, 1828 , p. 118 e.v.

62. Zie het "Nieuw Nederlands Biografisch Woordenboek", Amsterdam 1974, deel IX, p. 262. Frets had een grote belangstelling voor de codificatie, hetgeen onder meer blijkt uit zijn beoordeling van Tydemans "Beoefening van het Regt".

63. Bijdragen, 1828, p. 97 e.v. 
stelling en dien ijver der Regtsgeleerden heeft opgewekt, welke het gewigt der zake ongetwijfeld verdient. "64

Dit blijkt ook wanneer de inhoud van dit tijdschrift wordt vergeleken met het in 1839 opgerichte "Themis". Meijers ${ }^{65}$ heeft er in dit verband op gewezen dat, ofschoon beide periodieken dezelfde rubrieken kenden, in de Bijdragen vóór 1838 de Algemene rechtsgeleerdheid zowel in plaats als in betekenis vooraan stond, terwijl Themis daarentegen het Nederlandse recht de ereplaats gaf.

Een verklaring voor deze geringe bijval ligt, behalve in wat er hierboven al over is gezegd, ook in het feit dat de Regering - met als hoofdrolspeler de autoritaire Van Maa-nen $^{66}$ - absoluut niet van zins was zich iets gelegen te laten liggen aan de kritiek van anderen dan de "officieel geroepenen". Zo had F.A. van Hall in 1828 een uitgebreide lijst met "zeer gewigtige aanmerkingen" over het Wetboek van Koophandel ter kennis van de Regering gebracht. De Minister keurde zijn opmerkingen echter geen blik waardig en nam zelfs niet de moeite hem te bedanken.

Vanzelfsprekend maakte die gevoelige afwijzing Van Halls oordeel er niet milder op. Als hij een jaar later die uitvoerige en zeer bekend geworden lijst publiceert, komt hij dan ook tot de slotsom dat de burgerlijke wetgeving geheel moet worden herzien. In vrijwel elk artikel is, volgens Van Hall, de Nederlandse taal geweld aan gedaan, worden de belangen van de rechtspraktijk geheel over het hoofd gezien, is onvoldoende rekening gehouden met de vorderingen van de rechtswetenschap. ${ }^{67}$

Dat er voor Van Halls opmerkingen zeker wat te zeggen viel, blijkt uit de twee volgende voorbeelden, ontleend aan zijn commentaar op het ontwerp-Wetboek van Koophandel.

Met betrekking tot het ontwerp voor artikel 1 W.v.K., "Het Burgerlijk Wetboek is op zaken van Koophandel toepasselijk, voor zoo verre daarvan bij het Wetboek van Koophandel niet bijzonderlijk is afgeweken", merkt Van Hall op:

"Behoort deze bepaling wel in het Wetboek van koophandel? Zij loopt over de kracht en den invloed van het Burgerlijk Wetboek, en had waarlijk hare plaats beter gevonden onder de algemeene bepalingen daarvan, waar dit Artikel zeker meer voegzaam geweest ware, dan de daarin gelezen wordende 9e en 10e Artikelen.

Is de plaatsing van het Artikel min gunstig, ook de redactie schijnt niet zoo gelukkig uitgevallen te zijn, als te wenschen ware geweest, vooral bij het begin van een Wetboek.

64. Bijdragen, 1829, p. 243; Zie ook Bijdragen, 1829, voorrede; 1828, p. 225.

65. E.M. Meijers, De honderdjarige burgerlijke wetgeving. V.P.O. I, Leiden 1954, p. 138.

66. In W 270 (1842) werd naar aanleiding van diens aftreden opgemerkt: "In den persoon van den heer Van Maanen zag men het systema der vorige regering vertegenwoordigd. Bedenkingen, met ernst en waardigheid voorgedragen, vonden geen' ingang: mannen die, wars van vleijerij, en alleen gedreven door de liefde voor hun land, de stem verhieven tegen de hand over hand toenemende misbruiken, werden niet gehoord; hunne verwijdering uit betrekkingen, waarin zij der algemeene zaak de uitstekendste diensten konden bewijzen, werd bewerkt. Daarentegen bediende men zich of van gelukzoekers, of van onhandige en onbekwame dienaren: personen, door alle partijen gehaat, waren niet zelden de werktuigen, met welke men zich in de meest onhoudbare stelling wilde handhaven en bevestigen."

67. Bijdragen, 1829, p. 59 e.v.; Zie ook Bijdragen, 1829, p. 210; 1830, p. 86 en 209. 
'Het Burgerlijk Wetboek is op zaken van koophandel toepasselijk, voor zoo verre daarvan niet is afgeweken'. Slaat daarvan op het Wetboek of op zaken van koophandel? De bedoeling is op het eerste, doch de aard der taal doet dit woord op het laatst voorafgaande, "zaken van koophandel", betrekkelijk zijn. Wil men dus al de woorden van dit Artikel behouden, zoo zou men moeten zeggen: "Het Burgerlijk Wetboek is, voor zoo verre daarvan bij het Wetboek van koophandel niet bijzonderlijk is afgeweken, ook op zaken van koophandel toepasselijk. ${ }^{168}$

Inderdaad volgt artikel 1 van het Wetboek van Koophandel 1838 letterlijk de redactie van Van Hall. Het ontwerp van 1830 hield echter woordelijk aan de door hem bestreden formulering vast.

lets dergelijks geldt ook met betrekking tot artikel 90, lid 1 van het Wetboek van Koophandel. De redactie daarvan is afkomstig van Van Hall, die zijn kritiek op de oorspronkelijke tekst (art. 11 Ontwerp-1830) niet gehonoreerd zag. In dit artikel werd onder meer bepaald dat de vrachtbrief "Den aard en het gewigt of de maat der te vervoeren goederen, benevens derzelver merken en getallen" moest bevatten.

Van Hall tekent aan: "den aard, dit is het woord niet. De wet bedoelt hier, dat uit den vrachtbrief blijke, wat het voor goederen zijn; bijvoorbeeld of het koffij of katoen is, niet welke eigenschap de goederen hebben; of van welke natuurlijke gesteldheid zij zijn; in dezen laatsten zin alleen kan het woord aard gebruikt worden. Men zie Weiland, Taalkundig Woordb. op dit woord. Zoo zou men, wanneer men deze bepaling woordelijk volgt, op een' vrachtbrief van suiker moeten zeggen, dat zij melasseerde, van olie, dat zij vet was, of van katoen, dat zij broeijig was; want dit toont den aard van die goederen aan. Soort of naam is het woord, dat men had moeten gebruiken. Onze Wetgever gebruikt in Art. 9, Art. $120.3^{\circ}$ en $5^{\circ}$ in Art. 125, van de algemeene wet voor de heffing der regten van in-, uit- en doorvoer van 26 augustus 1822 (Staatsbl. $\mathrm{N}^{0} 38$ ) en nog duidelijker is Art. 213, 214 en 215 dier wet, het woord benaming; hetgeen welligt hier kan gaan. In Art. 56 van den $5^{\circ} n$ Titel des II $^{\text {en }}$ Boeks van dit Wetboek heeft men al deze woorden bijeengevoegd. Ik weet niet, of zulks is om hetzelfde, of om een verschillend denkbeeld uit te drukken. ${ }^{169}$

Samenvattend kan dus worden gezegd, dat de belangstelling voor de nieuwe wetgeving uiterst gering was, ondanks dat er - gemeten naar de stand van de wetenschap in die dagen - scherpe kritiek op mogelijk was.

\section{Na 1830}

Na 1830 trad er geen wezenlijke verandering op in deze situatie. Hoewel Van Hall kort na het uitbreken van de Belgische opstand constateerde dat deze "de hoop op het verkrijgen van eene goede Nationale Wetgeving weder levendig heeft gemaakt ${ }^{\text {"70 }}$ en Tammo Sypkens, de voorzitter van de herzieningscommissie, er naderhand op zou wijzen dat het wel "duizend maal" was herhaald, dat het B.W. moest worden gezuiverd "van inmengselen, die in andere tijden en onder verschillende omstandighe-

68. Bijdragen, 1829, p. 61.

69. Bijdragen, 1829 , p. 113 e.v.

70. Bijdragen, 1830 , p. 713. 
den, waren teweeggebracht"71, bleef de belangstelling voor de codificatie in wezen tot deze woorden beperkt. ${ }^{72}$ Daarin werd ook geen verandering gebracht doordat de Regering de ontwerpen nu wel vrij snel en met een grotere samenhang dan voorheen in de Staatscourant publiceerde en bij K.B. van 24 februari 1831, no. 6 bekend maakte dat de reeds gedrukte wetboeken, die bedoeld waren om op 1 februari 1831 in werking te treden, via de Staatsdrukkerij algemeen verkrijgbaar zouden worden gesteld.

Het is uiteraard mogelijk, dat de rechtsgeleerde wereld veel vertrouwen had in de commissie die de herzieningsarbeid op zich nam, - zij werd onder andere versterkt met Frets en Donker Curtius, de laatste zoals bekend een verklaard tegenstander van het Ontwerp-1820 - maar waarschijnlijk moeten we de verklaring voor dit totale gebrek aan belangstelling in een andere richting zoeken.

In de eerste plaats bestond er onzekerheid over de taak van de commissie. Zo vroeg de redactie van de "Bijdragen" zich bijvoorbeeld af "in hoeverre de bevolen taalkundige herziening der voorloopig reeds aangenomen Wetboeken, welke wij mede reeds vroeger hebben vermeld, eenig gevolg zal hebben", daarmee ongewild illustrerend dat zij niet wist dat de wetsteksten reeds lang met de resultaten van die herziening in overeenstemming waren gebracht. Even later schreef zij, dat het "volstrekt onzeker schijnt, of aan de telkens op nieuw van alle zijden geuite wenschen, tot eene algeheele nieuwe bearbeiding dier Wetten, nog zal gehoor gegeven worden", een opmerking die nu ook niet direct een stimulans vormt om pen en papier te pakken en in een fraaie verhandeling de voor- en de nadelen van een bepaald wetsartikel uiteen te zetten. ${ }^{73}$

Een tweede, niet minder belangrijke verklaring voor het gebrek aan commentaar van de rechtsgeleerde wereld is vermoedelijk dat men murw was geraakt door het aantal malen dat de invoering was uitgesteld. Het steeds weer opnieuw omwerken van een tekst is nu eenmaal niet erg bevorderlijk voor de schrijfzin. ${ }^{74}$ Daarbij kwam, dat

71. Voorduin, a.w., deel 1, le stuk, p. 366 e.v. Ofschoon deze redevoering ongewoon fel op ons overkomt, past zij in het tijdsbeeld. Zij viel zelfs zo in de smaak van de Kamerleden dat zij op besluit van de Kamer werd gedrukt (Staatscourant d.d. 7 Juni 1832, n. 135).

72. In de "Bijdragen" verschijnt alleen een aantal commentaren met betrekking tot Boek $1 \mathrm{~B} . \mathrm{W}$. en enkele titels van het W.v.K.

73. Bijdragen, 1830 , p. 146 e.v. Zie ook Bijdragen 1829, p. 607 . De taalkundige herziening was opgedragen aan Van Lennep, die daartoe overigens nooit een formele benoeming heeft ontvangen. Waarschijnlijk zijn de resultaten van zijn arbeid onopgemerkt gebleven doordat de door hem gecorrigeerde titels volstrekt willekeurig in het Staatsblad verschenen. Zie Voorduin, a.w., deel 1, 1e stuk, p. $346-349$.

74. "De onzekere staat, waarin zich het Regt in ons Vaderland sedert een aantal jaren bevindt, door het vooruitzigt, dat de bestaande Wetboeken afgeschaft zullen worden, en eene Nationale Wetgeving dezelfde zal vervangen, heeft op de beoefening van het hedendaagsch Burgerlijk Regt eenen hoogst nadeeligen invloed, en het is aan deze omstandigheid ongetwijfeld toe te schrijven, dat schriften, tot dat regt betrekkelijk, zoo men sommige inwijdingsverhandelingen uitzondert, bijna eene zeldzaamheid worden. En inderdaad, met welke onderwerpen zal men zijne lezers bij voorkeur bezighouden? Zal men dezelve ontleenen uit het bestaande Regt? Maar dit staat opgeheven te worden. Zal men over de ontwerpen der nieuwe Wetgeving spreken? Maar morgen misschien ondergaan zij eene verandering, die al de waarde van uw geschrijf nutteloos maakt. Ik weet wel, dat het er verre af is, dat deze redenen eene volledige verdediging der Nederlandsche Regtsgeleerden, tegen de beschuldiging van eene te groote spaarzaamheid in de openbare medeedeling hunner 
het oogmerk van de herziening, alle Franse invloeden te weren, nog slechts een enkeling kon overtuigen. Het oude recht had afgedaan, men was inmiddels vertrouwd geraakt met de Code Civil.

Tekenend voor dit laatste is, dat de inhoud van het nog steeds kleine aantal juridische tijdschriften, nog meer dan voorheen, voornamelijk was samengesteld uit beschouwingen over het Franse en Romeinse recht. Daarbij werd, ondanks dat dat wel voor de hand zou liggen, slechts zelden een uitstapje gewaagd naar het komende recht of een uitspraak gedaan over het wenselijke recht. Eenzijdigheid was troef.

Eveneens veelzeggend is, dat het handjevol juristen dat wél kritiek levert, over het algemeen zuiver technische verbeteringen voorstelt, die zelden of nooit gerechtvaardigd worden met een beroep op een nationaal gebruik of wet. Zo werd in de "Bijdragen" een aantal malen een commentaar van "eenige Amsterdamsche regtsgeleerden" geplaatst over de herziene ontwerpen. Door hen werd de bespreking van Boek I, titel V, een toch bij uitstek nationale materie, zonder dat maar ook een keer over het "nationale element" werd gesproken, afgesloten met een pleidooi voor een zuiver technische verbetering: "Over het geheel hebben wij in deze afdeeling ons over de menigte van nietig-verklaringen verwonderd, en wij kunnen niet nalaten nogmaals in bedenking te geven (...) hoe omzigtig men dus behoort te zijn, om de vorderingen tot nietigverklaring niet al te wijd uit te breiden. ${ }^{\text {"75 }}$

Een factor tenslotte die mogelijk ook een rol heeft gespeeld bij het al dan niet inzenden van kritieken, is de geringe tijd die daarvoor beschikbaar was. De eerste ontwerpen voor de herziening van het B.W. werden op 22 februari 1832 ingediend. Reeds op 13 juni 1833 waren de laatste titels van het vierde Boek aangenomen. Slechts drie titels - van bevoorregte schulden, pand en hypotheek - zouden daarna nog volgen. ${ }^{76}$ En ofschoon deze vaststelling naar tegenwoordige begrippen zeer snel verliep, spraken de debatten daarover niet tot de verbeelding van de rechtsgeleerde wereld. De uitgebreide beraadslagingen in de Staten-Generaal dienden in wezen ook niet om verbeteringen in de ontwerpen aan te brengen, maar waren (volgens Lipman) bedoeld om de aandacht af te leiden van de ongelukkige en moeizaam verlopende

\begin{abstract}
74. $\rightarrow$
gevoelens over gewigtige onderwerpen, opleveren; maar ik geloof toch, in goeden ernst, dat zij het verschijnsel verklaren, vooral als men daarbij in aanmerking neemt, dat het vooruitzigt, dat, ondanks onze pogingen, de Nederlandsche Wetgeving, naar den zin onzer voormalige broeders, zou verwrongen en verfranscht worden, weinig bemoediging geven kon. Mogt de zekerheid, dat deze vrees althans voortaan vervalt, onzen Regtsgeleerden ten prikkel wezen, om zich van nu af meer aan de Wetgeving te laten gelegen zijn", aldus J. van Hall in Bijdragen $1831 / 32$, p. 283 e.v.

75. Bijdragen, $1831 / 32$, p. 710 . De enkele keer dat de Commissie een beroep doet op een vermeend nationaal element, vindt ook geen genade in de ogen van de beoordelaars: "De benaming van echte en onechte of natuurlijke kinderen, ofschoon ook in oude Costumen en regtsgeleerde schriften voorkomende, is evenwel geenszins nationaal, zoo min van oorsprong als van gebruik; Echt is het Hoogduitsche Ehe, als zelfstandig naamwoord, waarvan het bijvoeglijk naamwoord zoude moeten zijn echtelijk (ehelich). In allen gevalle heeft het bijvoeglijk naamwoord Echt bij ons eene andere betekenis, namelijk van wezenlijk, niet schijnbaar. De benaming van natuurlijke kinderen is geheel vreemd aan onze zeden, en oorspronkelijk uit de Romeinsche tegenstelling van liberi naturalis en legitimi, (...). Wij zouden liever met Art. 88 tot 90 alleen spreken van wettige en onwettige kinderen, als zijnde eene juistere, meer algemeen verstaanbare en gebruikelijke benaming." Bijdragen, $1831 / 32$, p. 686-687.
\end{abstract}

76. Voorduin, a.w., deel 1, le stuk, p. 410. 
onderhandelingen met België: "De Regering (vond) in die herziening der wetboeken een gelukkig middel, om den ijver en de bedrijvigheid met onschadelijke onderwerpen bezig te houden. Aldus werd menige zitting der Tweede Kamer op eene nuttige en aangename wijze aan dat langgerekt werk in eindelooze beraadslagingen toegewijd. "77

\section{Lipmans gelijk}

De situatie waarin de rechtswetenschap tot 1838 verkeerde, was weinig florissant. Meijers vermeldt dat tussen 1820 en 1830 in Leiden nog wekelijks 22 uur college in het Romeinse recht werd gegeven, tegen 5 à 6 uur in het Franse recht: "Het werd in dien tijd als een soort heiligschennis aangemerkt om in twijfel te trekken, dat ook na de invoering van een nationale wetgeving het Romeinsche recht als een geopenbaarde rede, een ratio scripta, moest aangemerkt worden. ${ }^{78} \mathrm{Geen}$ wonder dus, dat de bestudering van het Nederlandse Burgerlijk Wetboek buiten vrijwel ieders gezichtsveld bleef.

Het meest kenmerkend hiervoor is wellicht dat - hoewel de tekst van het B.W. in 1834 was vastgesteld en in 1836 in druk werd uitgegeven - pas in 1837 het eerste commentaar, deel I van De Pinto's "Handleiding tot het Burgerlijk Wetboek", verscheen.

Om aan de geringe bekendheid met het B.W. een einde te maken, voelde de Kroon zich, volgens De Pinto, dan ook verplicht om allen die een rechtsgeleerd werk wilden schrijven over de nieuwe wetgeving een onderscheiding in het vooruitzicht te stellen. ${ }^{79}$ Dat betekende een groot verschil met de situatie vóór 1838 , toen ieder commentaar als ongepast werd ervaren.

Werkelijk resultaat schijnt deze premie overigens niet te hebben gehad. De Pinto merkt bij het verschijnen van de tweede druk (1839) van zijn "Handleiding" op: "Veel echter van belang is er, wat de wetenschappelijke uitlegging van het wetboek betreft, in dien tusschentijd (vanaf 1 oct. 1838), niet uitgekomen. De schrijflust is zoo spoedig weder uitgedoofd, als hij voor een oogenblik aangewakkerd scheen; groote werken zijn aangevangen, maar niet voltooid; bijgekomen is er weinig of niets. Voor een oogenblik scheen aan den horizont der regtswetenschap de aloude heldere zon te herrijzen; dan, helaas! de zon is verdwenen, en de vonken, welke zij achterliet, waren weinig in getal. ${ }^{180}$

77. W 142-143 (1840). Zie ook E. Holthöfer, a.w., p. 1267.

78. E.M. Meijers, De honderdjarige burgerlijke wetgeving, V.P.O. I, Leiden 1954, p. 138. Vergelijk ook H. Kooiker, De overlevingskanalen van het Romeinse recht na de hercodificatie, in: Twaalf bijdragen tot de studie van de rechtsgeschiedenis in de negentiende eeuw, Amsterdam 1993, p. 118 e.v.; C.J.H. Jansen, Natuurrecht of Romeins recht. Enkele twisten uit de eerste decennia van de $19 \mathrm{e}$ eeuw over de inrichting van het academisch onderwijs, Tijdschrift voor rechtsgeschiedenis, 1989 , p. 135 e.v.

79. Zie W 2517 (1863). Vermoedelijk werd deze "lintjesregen" gebaseerd op het Besluit van 19 Juni 1822, no. 92 "houdende instelling van Medailles voor edele en menschlievende daden", waaronder sinds 1830 (Besluit van 28 Juni 1830, no. 57) ook het schrijven van boeken of het maken van kunstwerken was begrepen.

80. Voorrede bij de tweede druk, (deel 1), Zwolle 1885, p. IX-X. 
In deze situatie was Lipmans pleidooi om a priori de noodzaak van algehele herziening te bewijzen, hoewel voorbarig, niet onbegrijpelijk. In zijn betoog komen de reeds hierboven aangeduide factoren naar voren. De onzekere en lange provisionele toestand betekende de doodsteek voor de wetenschappelijke beoefening van het recht. $^{81}$ De Franse wet werd, alhoewel de haat daartegen was gesleten, niet geestdriftig toegepast en daardoor vulden wetenschap en praktijk elkaar niet goed aan. Bovendien was er weinig animo om het geldende recht te verbeteren, nu het toch slechts "tijdelijk" zou gelden. Voeg daarbij het feit dat de Belgen, anders dan de Nederlanders, volstrekt geen behoefte hadden aan nationale wetboeken, en het is duidelijk, volgens Lipman, dat het tijdvak $1815-1838$ volstrekt ongeschikt was voor het werk van de codificatie.

\section{Na 1838}

Hoewel, zoals hierboven is opgemerkt, sommige critici herhaaldelijk hadden betoogd dat de wetboeken in deze vorm niet konden worden ingevoerd, zou het overgrote deel van de wetsuitleggers en -toepassers, voor wie de nieuwe wetgeving als gevolg van een gebrek aan belangstelling onbekend was gebleven, pas na de invoering ${ }^{82}$ geleidelijk aan de feilen ontdekken. ${ }^{83}$

Ook dat proces verliep niet bijzonder voorspoedig. Onverschilligheid, lauwheid en onkunde beheersten rechtspraak en wetenschap. Zo werden de "enige honderden drukfouten", die in de eerste officiële editie van de wetboeken voorkwamen, niet ontdekt door de juridische faculteiten of op het Ministerie, maar door enkele "Groninger Couranten." 84 De verwarring werd nog groter, toen de Staatsdrukkerij, na op de fouten te zijn gewezen, in de onverkochte exemplaren nieuwe en verbeterde bladen invoegde, zodat twee officiële edities ontstonden. ${ }^{85}$ Ook de constatering, dat de Nederlandse rechtsgeleerde literatuur sinds 1838 een opmerkelijke bloei doormaakte, in 1844 werd verheugd opgemerkt dat er in die zes jaar al meer was gepubliceerd dan in de vijfentwintig jaar daarvoor -, dient met enige scepsis te worden bekeken, want zij zegt meer over de kwantiteit dan over de kwaliteit van de geschriften. ${ }^{86}$ Aan een werkelijk doorknede behandeling van de wetboeken, een onderzoek naar de beginselen waarop de artikelen waren gebaseerd, een antwoord op de vraag of de door de wetgever verkozen oplossing ook redelijk en wenselijk was, kwam men niet toe.

81. Zie hierover met name J. de Bosch Kemper, a.w., p. 74 en de daar genoemde literatuur.

82. De invoering was ook niet van fouten vrij te pleiten. De Wet van 2 Augustus 1822, S. 33 schreef afkondiging voor en invoering bij wet. De Nederlandse wetboeken zijn echter bij K.B. van 10 april 1838, S. 12 , zonder dat afkondiging plaatsvond, ingevoerd.

83. Zie Regtsgeleerd Bijblad, 1842, p. 12 e.v.

84. Zie Themis, 1840 , p. 371 .

85. Particuliere drukkers konden hiervan niet profiteren, want de Wet van 25 Januari 1817 , S. 5 en de K.B.'s van 2 en 30 Juli 1822 (S. 16 en S. 22) verboden de nadruk van officiële stukken, geplaatst in Staatscourant of Staatsblad. Bovendien was bij K.B. van 18 Juni 1829 , S. 48 , het recht op de eerste druk van de nieuwe wetboeken aan de Staatsdrukkerij tot 6 maanden na de invoering van het B.W. voorbehouden.

86. Nederlandsche Jaarboeken voor regtsgeleerdheid en wetgeving, 1844, p. 746. Zie ook Themis, 1844 , p. 309. Dav. H. Levyssohn merkt daarin 0.a. op: "De afzonderlijke bepalingen der wetboeken zijn en worden nog voortdurend behandeld vooral in de tijdschriften, verzamelingen en woordenboeken, als tot de letterkunde des regts behoorende." 
Handboeken als die van Vernède, Pliester en De Pinto waren in hoofdzaak een parafrase van de wet en in die eerste jaren na de invoering hadden de verklaringen van de afzonderlijke bepalingen meer het karakter van woordenboeken dan van commentaren, met als meest beruchte voorbeeld de talloze "registers" die als een soort concordantie naast het wetboek fungeerden.

Dientengevolge waren, volgens Meijers ${ }^{87}$, de gevaren niet te ontgaan waartegen De Bosch Kemper in 1838 had gewaarschuwd: "Hoe verderfelijk de overbrenging van den geest der Fransche Codes op de Nationale wetgeving ook moge zijn, de omstandigheden, waarin wij verkeeren, en de inrigting van de nieuwe wetboeken zelve doen hiervoor echter wel eenige vrees ontstaan. Ons Vaderland is met Fransche regtsgeleerde werken opgevuld; bij gebrek aan vaderlandsche uitleggers, zal men steeds tot hen, die men over de vroegere wetgeving raadpleegde, zijne toevlugt nemen; de menigvuldige overeenkomst, welke tusschen beide wetgevingen bestaat, zal te weeg brengen, dat men dit met eenigen schijnbaren grond zal achten te kunnen doen; vooringenomenheid met oudere begrippen zal overal het oude meenen terug te vinden; gemakkelijkheid zal deze meening versterken; oppervlakkige schrijvers zullen welligt, om spoedig en goed debiet te erlangen, Fransche uitleggers tot commentaristen op de Nederlandsche wetgeving hervormen. In dezen stand van zaken zijn de herhaalde waarschuwingen tegen eene onvoorwaardelijke verklaring van het Nederlandsche regt uit het Fransche niet overbodig. " 88

Anderzijds ontleenden vele vragen over "merkwaardige bepalingen" hun oorsprong vooral hieraan dat de ijverige commentator "volstrekt in ieder Art. der Wetboeken iets nieuws en iets anders dan het oude en afgeschafte wil(de) zien. "89 Zo deed zich volgens De Pinto in de beginjaren soms ook het opmerkelijke verschijnsel voor, dat wat door velen onder het Franse recht voor een axioma werd gehouden, nu al spoedig in twijfel werd getrokken. ${ }^{90}$ Het was dus, om het met Opzoomer te zeggen "niet altijd eene fout der wet $(. .$.$) wanneer er vele twistvragen tusschen de uitleggers ont-$ staan." 91

Zoals te verwachten was, lag de nadruk van die eerste kritieken vooral op de taalkundige en systematische onvolkomenheden van het B.W. Een paar voorbeelden.

"Meermalen heb ik met nadruk op de feilen gewezen die ik gemeend heb aan slordigheid, en vooral aan onverschilligheid omtrent de taal te moeten toeschrijven, en ik ga zelfs zoo ver, van te beweren, dat de meeste quaestiën daaruit worden geboren", zo schreef Levyssohn, "tot wiens uitspanningen het behoorde, de voorbeelden van slordige redactie onzer wetboeken op te teekenen. ${ }^{12}$ Kappeyne, één van de redac-

87. E.M. Meijers, De honderdjarige burgerlijke wetgeving, V.P.O. I, Leiden 1954, p. 138.

88. J. de Bosch Kemper, a.w., p. 14 e.v.; Frets had in zijn advies met betrekking tot Tydemans opstel (p. 120 e.v.) er zelfs voor gepleit om alleen practici commentaren te laten schrijven, "om alzoo de vrees weg te nemen, alsof dit Wetboek door het toelaten van iedereen tot deszelfs uitlegging en toepassing, het geheele karakter en aanzien van de regtsgeleerdheid zoude vernietigen (...). Ik houde het er voor, dat wetenschappelijke beoefening, zonder aanmoediging en ondersteuning van hooger hand, vooral bij den tegenwoordigen zedelijken toestand onzer maatschappij, veel grooter gevaar loopt, dan men doorgaans aan eene Akademie gelooft."

89. Themis, 1839 , p. 135.

90. Themis, 1852 , p. 647.

91. Geciteerd door Dav. H. Levyssohn, Themis, 1849, p. 513.

92. Themis, 1849 , p. 513. 
teuren van Themis, was in zijn oordeel nog strenger en verweet de wetgever de Franse wetboeken onkundig vertaald te hebben, "bloot uit zucht tot afwisseling. ${ }^{193}$ In 1852 publiceerde Themis veertig pagina's voorbeelden van onjuiste redactie in het B.W., zuiver taalkundig bezien ${ }^{94}$, een jaar later werd weinig vleiend opgemerkt: "de commissie van redactie der Nationale Wetgeving heeft schrikbarend uit het oog verloren, dat men in een wetboek behoort toe te zien, om aan hetzelfde woord steeds dezelfde betekenis te hechten (...) Het is, als had men eene proeve willen geven van den rijkdom onzer taal; maar men doe het elders dan in de wet. ${ }^{95}$

Instructief tenslotte is ook de kritiek die werd geuit naar aanleiding van de invoering van de nieuwe wetgeving in Nederlands-Indië: "Hij was overbrenging van de Nederlandse wetboeken zonder onderzoek naar de deugdelijkheid dier wetgeving; naschrijving zonder aanvulling der leemten, zonder wegname der overtolligheden, zonder verhelping der gebreken, die reeds ontdekt, onderzocht en algemeen erkend waren (...). Alleen waar Indië verandering vorderde, zou verandering geschieden. Waarom heeft men dan verbetering van stijl en taal nagelaten? (...). Het belang van Nederland, zoowel als van Indië, vorderde, dat de wetten van het moederland in minder slordigen toestand ginds in onze overzeesche gewesten aanlandden, dan zij hier voor een tiental jaren officieel den volke werden voorgelegd (...). Het is echter nagelaten. Er werd beter gevonden, willens en wetens de overtolligheden, de duisterheden, de tegenstrijdigheden der Nederlande wetten na te schrijven, om Indië ook dien zegen des moederlands niet te doen missen! "96

\section{Roep om algehele herziening}

Er is vanzelfsprekend geen uitsluitsel te geven over de vraag in welke mate deze oppervlakkige literatuur, waardoor het aantal misslagen dat aan de nieuwe wetgeving werd toegedicht op een nog hoger getal uitkwam dan dat zij aan werkelijke gebreken telde, stimulerend heeft gewerkt op de vraag om een herziening van de wetboeken. Zeker is, dat zij het enthousiasme voor de nieuwe wetgeving bepaald niet bevorderde. Zo vond C.J. François het al in 1844 nodig om op te roepen tot een grotere verdraagzaamheid ten opzichte van de gebreken van de wetgeving, want "niets is nadeeliger voor de regtsstudie, dan die kreet om eene algeheele herziening, welke door zoo vele bevoegde beoordeelaars zoo luide wordt aangeheven; wij worden daardoor gehouden in dien provisionelen toestand, waaronder de studie, zoo lang de Fransche Codes golden, zoo veel geleden heeft: men leert de ingevoerde Wetboeken al weder als voorloopige bepalingen te beschouwen, welker aanwezen van korten duur zijn zal om weder door andere te worden vervangen. Zoo ligt wordt bij veler oefening als hoofddoel gesteld om bij twijfelachtige uitdrukking of bedoeling aan den wetgever de

93. Themis, 1870 , p. 352 e.v. (i.h.b. p. 367 ).

94. Themis, 1852 , p. 566 e.v. Zie ook Themis, 1851, p. 104 e.v.

95. Themis, 1853 , p. 376 . Zie ook Themis, 1852 , p. $442 ; 1844$, p. 327 e.v.

96. Themis, 1848 , p. 509 e.v. De methode die werd gevolgd bij het ontwerpen van deze wetten bepaalde zich tot het aanpassen van de Nederlandse wetboeken aan de aldaar geldende wetten en gewoonten. De herschrijving kwam voornamelijk neer op het aanpassen van diverse termijnen. Meer principieel (?) was de verandering van artikel $556 \mathrm{~B}$.W.; door bestemming onroerend zijn niet meer de vaderlandse hangoren in de konijnenwarande, maar de "eetbare vogelnestjes, zolang ze nog niet ingezameld zijn." 
ongerijmdste bepaling toe te dichten; men leert twijfelingen opperen, waar eigenlijk geen twijfel bestaat." 97

De geduchtste kritiek kwam echter van de kant van de praktijk, die bepaalde afdelingen van met name het B.W. scherp hekelde op grond van hun "rampzalige" uitwerking op het rechtsleven. Reeds spoedig werd ingezien, dat in het bijzonder de titel van boedelscheiding (art. 1112-1131 B.W.) - een letterlijke vertaling van de Code Civil - uiterst gebrekkig was. Het kwam namelijk dikwijls voor dat de in deze artikelen voorgeschreven procedure tot vereffening van de boedel kostbaarder was dan de boedel zelf, hetgeen het nut van dit instituut hoogst twijfelachtig maakte. Daarnaast schreef de wet voor dat de boedel in gelijke kavels moest worden verdeeld, die dan door middel van loting aan de partijen zouden moeten worden toegewezen. Dit leidde regelmatig tot ingewikkelde kwesties, die zelfs met de wet in de hand niet altijd tot een goed einde waren te brengen. Wanneer men dan niet het geluk had een notaris te vinden die bereid was een oogje toe te knijpen, dan bleef er niets anders over dan óf een proces aan te spannen tegen de mede-erfgenamen óf voort te leven in de onverdeelde boedel. Deze narigheid leidde ertoe dat al snel tal van verzoekschriften de Staten-Generaal bereikten tot afschaffing van deze bepalingen, waarvan in het Wetboek van 1809 en bij Wet 12 juni 1816, S. 26 met reden was afgeweken. ${ }^{98}$

De eerste kritieken stelden, afgezien van de titel inzake de boedelscheiding, vrijwel uitsluitend de taal van het wetboek ter discussie. Dat dit kennelijk voldoende reden werd geacht voor de wens tot algehele herziening, wijst op een zeer legistische houding, of op een meer algemeen ongenoegen met betrekking tot het B.W. Taalkundige fouten vielen vanzelfsprekend het eerste op, zo kort na de inwerkingtreding van het Burgerlijk Wetboek. Daarentegen zien we dat de literatuur van een tiental jaren later de noodzaak van een algehele herziening afwees, in de overtuiging dat slechts een periode van langdurige ondervinding en toepassing de meeste leemten en fouten aan het licht kon brengen. ${ }^{99}$ Een taalkundige herziening werd toen vermoedelijk niet meer zo belangrijk gevonden, want met die gebreken viel wel te leven.

Hierbij dient echter te worden opgemerkt, dat voor de hedendaagse toeschouwer het zicht op deze materie enigszins wordt belemmerd doordat de rechtsgeleerde wereld tot ongeveer 1860 vrij algemeen de wenselijkheid van wetswijziging door middel van partiële herzieningen heeft bestreden, en zich aldus veroordeelde met niet minder genoegen te nemen dan met een algehele herziening. Anders gezegd, "herziening" stond zo tot het midden van de vorige eeuw gelijk aan "algehele herziening", ook al woog de beoogde omvang daarvan wellicht niet op tegen sommige van de sinds 1870 toegepaste partiële herzieningen.

Het Departement wilde aanvankelijk echter niets weten van een algehele herziening. ${ }^{100}$ Dit hield in de eerste plaats verband met een argument dat ook werd aangevoerd tegen de idee van partiële wetswijziging, namelijk het gezag van de wet. Hoewel de wetgever zelf ook niet bepaald overtuigd was van de "voltreffelijkheid,

97. Themis, 1844 , p. 101.

98. Zie Themis, 1841, p. 263; W 387 (1843); Regtsgeleerd Bijblad, 1842, p. 12 e.v.; 1843, p. 225 e.v.

99. Zie Themis, 1847 , p. 202; 1848, p. 151; Zie ook W 359 (1843).

100. Zie daarover S. Katz, Partiëele herziening onzer wetboeken. Historisch-staatsrechtelijk beschouwd, Haarlem 1875, p. 35 e.v.; Vergelijk ook W 279, 282 (1842). 
volledigheid en volkomenheid" van de burgerlijke wetgeving, zou, zo werd geredeneerd, de mogelijkheid om de zojuist in werking getreden wetboeken ieder moment te veranderen, de kracht van de wet, haar aanzien doen verminderen. De wet gold als onaantastbaar en werd met een quasi-sacrale, holistische eerbied benaderd. ${ }^{101}$ In het begin van de 19e eeuw was dit een algemeen aanvaard denkbeeld: "Het Gouvernement, eens eene Wetgeving bezorgd hebbende, vertrouwt, daarmede van die zaak af te zijn; en het is ook waar, dat, zoowel het wederom veranderen der geheele Wetgeving, als het gedurig uitvaardigen van suppletoire wetten en reglementen, lastig en schadelijk voor de regtsgeleerden niet alleen, maar voor alle ingezetenen zoude zijn." 102

Wat ook een rol gespeeld kan hebben, is dat het gezag van de burgerlijke wetgeving in de veertiger jaren toch al wankel was. Elke verandering, hoe gewenst ook, zou de roep om een meer ingrijpende herziening voeden, de hang naar het Franse recht, zoals deze in rechtspraak en wetenschap tot uiting kwam, versterken.

Een andere voor de hand liggende reden waarom de wetgever de eerste tien, vijftien jaar niet van een algehele herziening wilde weten, was de grondwettelijke codificatie-opdracht tot het maken van een Wetboek van Strafrecht, die alle aandacht voor zich zou gaan opeisen. Daarbij kwam, dat het wetgevende werk vrijwel geheel op de schouders van de Minister lag, hoewel de wetgeving in die dagen één van de belangrijkste onderdelen van Justitie was. Het Departement kende dan ook geruime tijd geen afdeling voor de wetgeving en toen Van Hall in 1842 daarin verandering wilde brengen en twee ambtenaren aantrok voor het wetgevende werk, leidde dat tot een verhitte discussie in de Kamer. ${ }^{103}$

Tenslotte speelde het in de literatuur levend wordend besef, dat men er beter aan deed te wachten met zo'n ingrijpende herziening, aangezien er onder de juristen nog geen algemene mening bestond welke punten dienden te worden verbeterd. Een algehele herziening, zo kort na de invoering, zou ondoelmatig zijn, zo oordeelde de redactie van het Weekblad van het Regt in paginagroot hoofdartikel: "Men kent nog niet alles wat verbetering behoeft; men weet nog niet, waar aanvulling of verklaring noodig is; de wet is nog te kort in werking geweest, om te bepalen, waarin door de jurisprudentie zal worden voorzien, wat aan de toepassing kan worden overgelaten, waar de wetgevende tusschenkomst noodig is. "104

\section{Een doortastend Minister}

Was aldus een algehele herziening van de wetboeken gedurende een tiental jaren onbespreekbaar en tot 1879 onbereikbaar (zie hieronder), uit het voorgaande bleek dat het stelsel van partiële wetswijziging aanvankelijk eveneens werd afgewezen. Niet alleen speelde de problematiek van het gezag van de wet enige tijd een rol, ook koesterde men de gedachte dat een wetboek als een gesloten geheel diende te worden beschouwd. Bij velen bestond namelijk het schrikbeeld dat een "bajert van verwar-

101. Dit gegeven werpt ook een enigszins ander licht op het legisme waarin de magie van het sacrale woord naar voren komt.

102. Briefwisseling, p. 28.

103. Zie HNJV 1870 , p. $71-72$.

104. W 359 (1843); W 2517 (1863). 
ring" zou ontstaan als men zonder eenheid, zonder verband, dan eens hier, dan eens daar, enige artikelen zou vervangen of veranderen. Een wetboek kon, zo geloofde men, alleen worden verbeterd door er een geheel nieuw voor in de plaats te stellen.

Natuurlijk kon dit zuiver doctrinaire standpunt, door Meijers ooit als een "bakerpraatje" afgedaan, niet lang worden volgehouden. Vooral de praktijk - getuige de "Wenschen en verwachtingen van een (niet-regtsgeleerde) kantonregter ten platten lande"105 - drong al snel aan op herziening van die delen van de wetboeken die dringend en ogenblikkelijk verbeterd dienden te worden. Dit streven werd spoedig kracht bijgezet door verschillende artikelen in de juridische pers. Zo schreef de redactie van het Weekblad, na uitvoerig te hebben betoogd dat het ogenblik voor een algehele herziening nog niet was aangebroken:

"Moet daaruit nu volgen, dat men niets zal mogen veranderen, niets verbeteren, niets verklaren? Moet daaruit nu volgen, dat men ook zal moeten behouden alles, wat nu reeds met zekerheid, naar het oordeel van allen, slecht en onbruikbaar is bevonden? Dit gelooven wij evenmin.

Inderdaad, wij weten hiervoor niet eene reden te bedenken; het is zoo, wij hebben meermalen hooren verkondigen de magtspreuk, dat, onze wetboeken éénmaal ingevoerd zijnde, men die ongeschonden moest bewaren, zonder daarin eene letter of jota te veranderen; doch het waarom dezer zonderlinge stelling hebben wij altijd vruchteloos gezocht.

Wanneer gij een splinternieuw kleed hebt, en het blijkt, dat één der panden scheef of averechts is, hebt gij dan de keus om uw kleed weg te werpen, of het te dragen met het gebrek, dat hetzelve ontsiert, en onbruikbaar maakt?

Als gij een nieuw huis gebouwd hebt, en er vertoont zich in den kelder, op den zolder, of in één der vertrekken eene grove fout van constructie, moogt gij dan die fout niet doen herstellen, indien gij niet het geheele huis omverre werpt?" 106107

En van de hand van J. van Hall verschenen in het Regtsgeleerd Bijblad twee niet minder strijdbare artikelen, met als conclusie dat aan een herziening op beperkte schaal niet viel te ontkomen: "Indien het zeker is, dat men, aan de eene zijde, niet telkens den regtstoestand eener Natie weder op nieuw als op losse schroeven stellen mag, en toch, aan de andere zijde, er voor moet waken, dat geschreven Algemeene Wetboeken niet eenen onoverkomelijken hinderpaal aan de ontwikkeling en trapsgewijze

105. Zie Themis, 1841 , p. 263.

106. W 359 (1843); zie ook W 387 (1843).

107. Het is opvallend hoezeer metaforen als deze steeds zijn gebruikt om de wenselijkheid of de overbodigheid van herziening van het B.W. aan te tonen. Meijers (Uitlegging en toepassing in Nederland van aan de Code Civil ontleende wetsvoorschriften, VPO I, p. 61 e.v.) vergeleek het B.W. ooit met "een lappendeken, wellicht wel geschikt om daaronder behagelijk in te slapen, maar geenszins om de bewondering en de navolging van anderen te wekken." Scholten (Gedenkboek Burgerlijk Wetboek 1838-1938, p. 30) plaatste daartegenover het beeld van een oud, groot huis: "Hier en daar is het vervallen, er is afgebroken en in anderen stijl bijgebouwd, er zijn gemoderniseerde vertrekken naast oude ruimten, het wordt minder bewoond en is heel wat minder waard dan vroeger." Maar, zo vervolgt Scholten, "Bij alle bezwaren behoudt het behagelijkheid, het is er vertrouwd, men is er thuis." Zie ook HNJV 1988, p. 4, alwaar een uitgebreide opsomming wordt gegeven. 
volmaking der Wetgeving tegenwerpen, dan moet de Regering zich zonder twijfel eene partiëele verbetering der Wetgeving, als een blijvend doel, voor oogen stellen." ${ }^{108}$ De Regering wilde echter naar deze goede raad niet luisteren, boog niet voor deze van gezaghebbende zijde geuitte kritiek, totdat F.A. van Hall in 1842 Minister van Justitie werd. Van Hall makte zijn reputatie als praktisch man en voorvechter voor een goede codificatie al direkt waar. Eén van zijn eerste daden bestond uit het versturen van een "rondgaande brief", gericht aan de Procureurs-Generaal bij de Gerechtshoven. ${ }^{109}$ De Minister vroeg daarin aandacht voor de nationale wetgeving, waarin leemten zouden voorkomen die niet door middel van jurisprudentie konden worden opgelost. Aan alle ambtenaren bij de Hoven werd daarom verzocht iedere zes maanden een lijst met opmerkingen over de wetgeving in te sturen en daarbij tevens aan te geven op welke wijze de gebreken zouden kunnen worden opgeheven. ${ }^{110}$

Het Weekblad vond het een loffelijk voornemen: "Niemand kan ontkennen, dat eene ondervinding van drie jaren reeds menigvuldige gebreken en gapingen heeft aangewezen, welke eene spoedige voorziening vorderen; De stelling, die men het vorige ministerie toeschreef, dat er in de wetboeken niets moest veranderd worden, was juist daarom eene ongerijmdheid, die niet lang kon worden volgehouden. "111

Dit initiatief van Van Hall, dat een eerste schrede was op de weg van de erkenning van de partiële herziening als beginsel van wetgeving, mislukte echter als gevolg van gebrek aan voldoende respons. Slechts enkele ambtenaren namen de moeite aan de oproep gehoor te geven. ${ }^{112}$

\section{Een eerste partiële herziening toegelaten}

Meer succes had Van Hall met het "Ontwerp van Wet op de boedelscheiding"113, dat strekte tot vervanging van de eerste afdeling van de $16 \mathrm{e}$ titel van het tweede Boek

108. Regtsgeleerd Bijblad, 1843, p. 193 e.v.; p. 321 e.v. Zie ook W 393 (1843), waarin een zekere $\mathrm{K}$. fulmineert tegen de "ijdele schrikbeelden, en niets afdoende magtspreuken" waarmee de wens om tot partiële herziening te komen bestreden wordt: "Of is het geen ijdel schrikbeeld te zeggen, dat, als men zonder eenheid, zonder verband, dan eens hier, dan weder daar, eenige artikelen uitneemt en verandert, en steeds evenveel artikelen moet teruggeven, men een bajert van verwarring te gemoet gaat! (...) Is het niet eene niets afdoende magtspreuk te zeggen: dat de ingevoerde Wetboeken niet ieder oogenblik moeten worden veranderd, dat de kracht der wetten ondermijnd wordt, door gedurige verandering, dan eens hier, dan weder daar, aangebragt?"

109. Circulaire van 9 april 1842 , no. 87 . Zie W 279 (1842).

110. Ook tegenwoordig leven deze ideeën nog voort. Zie C.H.F. Polak, Hulp voor de Wetgever, NJB 1976, p. 909 e.v.; H. Drion, Stellingen (over wetgeving en rechtspraak) bij het 60-jarig bestaan van de Nederlandse Jurisprudentie, NJB 1975, p. 1035-1036; M. Scheltema, HNJV 1979, p. 122 e.v. (pre-advies). Zie echter Trema, 1978, p. 42.

111. W 282 (1842). Veel vertrouwen in de onderneming had het Weekblad overigens niet. Menig lid van het parket zou "niet weinig verlegen (...) zijn met al dat geleerde werk, dat men nu van hem vergen komt."

112. Zie S.A. Vening Meinesz, Geschiedenis der Staatsrechtelijke Bepalingen betrekkelijk tot het vervaardigen van wetten en algemene beginselen, Amsterdam 1856, p. 127-128; Nederlandsche Jaarboeken voor regtsgeleerheid en wetgeving, 1843, p. 542; de Tijdgenoot, 1842, deel II, p. 165; 1843 , deel III, p. 174 e.v.

113. Wet van 31 mei 1843 , S. $22,23$. 
van het Burgerlijk Wetboek. Vanuit politiek oogpunt ontmoette de voorgestelde regeling geen bezwaren, omdat zowel Kamer als Kabinet door talrijke verzoekschriften van notarissen van de "ondoelmatigheid en onuitvoerlijkheid" van de oude regeling overtuigd waren geraakt. Niettemin had het wel enige voeten in aarde voordat de Kamer de wetsvoordracht aanvaardde. Zij stond namelijk op het standpunt dat de gewenste verbeteringen in een afzonderlijke wet zouden moeten worden neergelegd, zodat het B.W. onveranderd zou kunnen blijven. Door partieel te wijzigen zou, volgens het Voorlopig Verslag, de eenheid in stijl, in wetenschappelijke uitdrukking en in algemene beginselen geheel verloren gaan. Bovendien zou de noodzaak, om een gelijk aantal artikelen terug te geven, de wetgever voor onoplosbare problemen kunnen stellen, terwijl de regel "lex posterior derogat legi priori" de beoefening van het recht zou bemoeilijken, omdat steeds - bij strijdigheid tussen verschillende regels - zou moeten worden nagegaan welke regel de oudste was. ${ }^{114}$

Nadat de Minister in de Memorie van Antwoord deze bezwaren op betrekkelijk overtuigende wijze had weten te weerleggen - hij wees er bijvoorbeeld op dat het bestaan van afzonderlijke wetten, zoals de geschiedenis na 1813 had geleerd, het bestaan van wetboeken "zonder doel" maakt en de "goede en nuttige zijde van codificatie geheel verloren (doet) gaan" -, kwam het gewichtigste bezwaar van de Kamer aan de orde, namelijk het argument dat het toepassen van partiële herzieningen nooit zou kunnen voorkomen dat de wetboeken na verloop van tijd geheel zouden moeten worden herzien. Met andere woorden, het argument van in de naaste toekomst onafwendbare herzieningen werd gebruikt om partiële verbeteringen tegen te gaan, een motief dat ook in later jaren nog herhaaldelijk zou opduiken.

Van Hall bestreed deze visie bijzonder heftig, en stelde onder meer:

"Wil men slechts eene geheele herziening der bestaande wetgeving toelaten, dan zal men ò geheele titels en afdeelingen, te welker juiste beoordeeling eene ondervinding van nog geen vijf jaren, weinig of geene gelegenheid heeft gegeven, en waaromtrent geen bijzonder onderzoek van regtsgeleerden nieuwe denkbeelden heeft ontwikkeld, onverbeterd laten liggen, of nog zeer langen tijd die herziening moeten uitstellen, ten einde, met de vereischte kennis toegerust, iedere wetsbepaling behoorlijk aan de uitkomsten der ondervinding en wetenschap te kunnen toetsen.

In het eerste geval zou de herziening voor een groot gedeelte zonder nut en doelloos zijn, en het is daarom, dat de Regering het thans nog geenszins de geschikte tijd rekent, om tot dezelve over te gaan. Eene geheele herziening na verloop van tijd, wil zij niet afkeuren, mits de voorkeur daaraan niet in die mate worde geschonken, dat men dien ten gevolge alle gedeeltelijke verbeteringen, hoe dringend ook gevorderd, tegenhoudt, en alzoo de natie bij voortduring doe gebukt blijven onder een last, welken men nu reeds in staat is van hare schouders te nemen." 115

114. Voor een uitgebreide weergave van de gebruikte argumenten, S. Katz, a.w., p. 35-53.

115. S. Katz, a.w., p. 44 e.v. De Memorie van Antwoord is in haar geheel gepubliceerd in W 393 (1843). 
Met deze uiteenzetting waren de bezwaren over de vorm van de herziening bepaald niet weggenomen. Uit het algemeen verslag van de Centrale Afdeling bleek dat "vele der leden, die het tegenovergesteld gevoelen aankleven, hebben te kennen gegeven door de ontvangene oplossingen niet bevredigd te zijn, zonder dat het evenwel noodig is geoordeeld, tot eene nadere uiteenzetting der wederzijdsche meeningen over te gaan, of aan bedenkingen omtrent den vorm bij eene wets-voordragt, die als eene wezenlijke behoefte kan worden beschouwd, een overwigtig bezwaar te hechten. "116 Niettemin accepteerde de Kamer uiteindelijk toch de wetsvoordracht, omdat een verwerping tot een wel zeer sterke reactie van de praktijk zou leiden.

Slechts het Leidse Kamerlid en rechter Luzac liet de vorm boven de inhoud prevaleren en stemde alleen om dit motief tegen, hoewel hij de wet op zichzelf een verbetering vond. Naar zijn oordeel zou het wetsvoorstel in deze vorm niet alleen verwarring in de hand werken - volgens Luzac beschouwde de Regering het wetboek als een "corps soldaten, waaruit men degenen die invalide worden, verwijdert, om er andere manschappen voor in de plaats te stellen"117 -, maar zou daardoor tevens "de gebiedende noodzakelijkheid minder (...) worden gevoeld, om onze Wetboeken, waarin, ten gevolge van de ongelukkige wijze, waarop zij in de wereld zijn gekomen, zooveel defecten aan te wijzen zijn, geheel te herzien." ${ }^{118}$ Zijn mede-lid Van Dam van Isselt gaf daarop te kennen dat het debat waarin een zo levendige strijd was gevoerd "enkel over den vorm" van een wetsontwerp, dat de belangen van een zo groot aantal gezinnen verzekerde en waarnaar de rechterlijke ambtenaren met zoveel verlangen uitzagen, op hem, als niet-rechtsgeleerde, een onaangename indruk had achtergelaten. ${ }^{119}$

Aangezien vrijwel elke spreker zich bij de behandeling van dit wetsvoorstel uitdrukkelijk tegen de gekozen vorm had verklaard ${ }^{120}$, en bovendien eerder in hetzelfde zittingsjaar zowel een wetsontwerp tot herziening van art. 12 R.O. als ook één ter vervanging van de zesde titel van het tweede Boek van Rechtsvordering alleen vanwege de vorm waren gestrand, duurde het geruime tijd - tot 1855 - alvorens de Regering het aandurfde opnieuw wijzigingswetten in te dienen.

Ook nu ging het om een wetsvoorstel dat de Kamer eigenlijk met goed fatsoen niet kon verwerpen. In het wetsvoorstel, dat leidde tot de wet van 9 juli $1855, \mathrm{~S}$. 67, werden de wachttermijnen van de artt. 523, 526 en 549 B.W. voor hertrouwen na afwezigheid aanmerkelijk verkort. De voornaamste reden daarvoor was, dat er tal van klachten waren omdat de vrouw van een vermiste zeeman elf jaar moest wachten alvorens het rechtsvermoeden van overlijden kon worden uitgesproken. Het gevolg daarvan was dat de meeste weduwen armlastig werden en een zware druk betekenden op de plaatselijke diaconieën, of dat "de jonge levenslustige vrouwtjes (...) overgingen tot een "vrij huwelijk" - een samenwonen "in strijd met de goede zeden, en soms weer afgebroken, nadat kinderen, in overspel gewonnen, daaruit geboren waren." Toen dan ook nog in 1854 kort voor de kust een schip (de "Hendrika") met

116. Zie J. van den Honert, Geschiedenis en Beginselen der Wetten van den 31 Mei 1843, Den Haag 1845, p. 19. Het verslag van de Centrale Afdeling is ook te vinden in W 393 (1843).

117. Handelingen Tweede Kamer 1842-1843, p. 263.

118. Van den Honert, a.w., p. 32.

119. S. Katz, a.w., p. 51.

120. Zie Van den Honert, a.w., p. 24, 27, 29, 35-37 en 41. 
man en muis verging, kon de Regering niet langer talmen met haar wetsvoordracht. Deze werd dan ook prompt door de Kamer aangenomen, zonder dat men zich bekommerde over vormproblemen. Geen enkel Kamerlid realiseerde zich dat gebroken was met de na 1843 zo sterk gepropageerde voorkeur voor algehele herzieningen. Van een trendbreuk was evenwel geen sprake.

\section{De meningen in de literatuur}

Hield de Kamer zich met de kwestie van de herziening van de wetboeken in feite tot het eind van de zestiger jaren van de vorige eeuw niet meer bezig - wel werd elk jaar het debat over de Justitiebegroting traditioneel geopend met een beschrijving van de voor- en nadelen van partiële herzieningen in het algemeen - in de literatuur was men vrij algemeen de mening toegedaan dat alleen een algehele herziening uitkomst zou kunnen bieden. De volgende citaten spreken voor zich.

In 1847 schrijft Levyssohn: "De tijd is nog niet geboren, waarop de Nederlandsche wetgeving zal moeten worden herzien. Eene veeljarige beoefening, toepassing, behandeling van een ingevoerd regt kan eerst de leemten en gebreken van hetzelve doen kennen." ${ }^{121}$ Een jaar later ijvert hij voor authentieke interpretaties, in plaats van een algehele herziening waarop "velen" hebben aangedrongen: "Die thans verbeide en achtereenvolgens te herhalen authentieke uitlegging vermag eene algeheele herziening der wetboeken te vervangen, waarvan enkele regtsgeleerden voortdurend droomen." 122 In 1868 vat De Pinto zijn "verzoek aan de Tweede Kamer" om een begin te maken met de "door elk als noodzakelijk erkende verbetering onzer wetgeving" als volgt samen:

"Wij hebben (..) sedert een tal van jaren telkens en telkens aangedrongen op herziening onzer wetgeving. Vruchteloos. Wij hebben eerst verlangd algemeene herziening, théoretisch zeker het beste, het meest afdoende middel van herstel. Maar toen allerlei practische bezwaren zich tegen de vervulling van dien overigens regtmatigen wensch kwamen verzetten, toen moesten wij buigen, niet voor onwil, maar voor onmagt bij onze wetgevende magt: toen wij begrepen dat dit van onzen parlementairen omslag toch niet te verkrijgen zou zijn; - hebben wij water in onzen wijn gegoten, en hebben wij met anderen gezegd: - wel nu, het zij zoo, wij willen het onmogelijke niet vergen, beter iets dan niets, en wij zullen tevreden zijn met gedeeltelijke hervorming en verbetering; wij zijn toegetreden tot het stelsel der partiële wijziging. ${ }^{123}$

En in 1869 verweert de redactie van het Weekblad zich tegen de opmerking dat een partiële herziening wetten bederft, door te stellen dat elke verbetering er éen is:

"Zij, die door de ondervinding geleerd hebben, dat men algemeene herzieningen, waarom dan ook, wel wenschen, maar niet verkrijgen kan, stellen zich, faute de mieux, met partiële wijziging tevreden, niet omdat zij daarin het summum bonum,

121. Themis, 1847, p. 202.

122. Themis, 1848 , p. 151.

123. W 3050 (1868). 
maar omdat zij daarin het eenig bereikbare zien, omdat zij liever iets dan niets hebben." 124

Kortom, algehele herziening was het ideaal, partiële het surrogaat. Dat een ideaal soms moet wijken voor de werkelijkheid, de citaten gaven er reeds blijk van, is een punt dat in één van de volgende paragrafen aan de orde komt. Hier wil ik er slechts op wijzen, dat het opmerkelijk is dat de vraag om herziening in die eerste jaren na de invoering van de nationale wetgeving vrijwel uitsluitend door theoretici werd gesteld en beantwoord. Slechts zelden werd zij in verband gebracht met een wetstekst waaraan een verlammende werking op het rechtsleven kon worden toegeschreven. Kennelijk had de praktijk zich allengs verzoend met de gebreken van de wetboeken, of was zij afkerig van een herziening die weer andere eisen zou gaan stellen aan de uitleg en toepassing. Van Boneval Faure, sprekend over het Wetboek van Burgerlijke Rechtsvordering, geeft trouwens nog een plausibele verklaring voor het zwijgen van de praktijk: "Ik geloof bovendien, dat er juist op dit gebied der wetgeving, tot welker toepassing nagenoeg uitsluitend de rechtsgeleerden van beroep geroepen worden, steeds eene machtige en juist door haar stilzwijgen krachtige partij gevonden wordt, die, zoo zij al gebreken erkent, evenwel nog afkeeriger is van herziening en wie juist haar dagelijksche taak van toepassing en uitlegging der bestaande wet uitermate conservatief stemt. ${ }^{125}$

\section{De positie van de rechtspraak}

Terzijde zij opgemerkt dat het niet toevallig was dat men bij de verbetering van het recht steeds oog had voor de taak van de wetgever. De rechtspraak en de wetenschap dachten zichzelf daarbij slechts een ondergeschikte rol toe. $\mathrm{Zij}$ waren er primair om de wetgever behulpzaam te zijn bij het signaleren van gebreken, of zoals Van Boneval Faure het uitdrukte: "Wel kan derhalve de jurisprudentie of de toepassing der Wet in het algemeen de gebreken te voorschijn brengen, en doen gevoelen, hetgeen verouderd of verkeerd door de Wet is bekrachtigd, maar eene wettige verandering zal er niet kunnen plaats grijpen, voordat die gebreken als uitvloeisel van de algemeene rechtsovertuiging, door het gezag der wetenschap ondersteund, wederom door stellige wetsbepalingen zullen zijn verholpen of uit den weg geruimd." 126

$\mathrm{Nu}$ kon van een verbetering van het recht door middel van de rechtspraak, zeker in de eerste jaren na de invoering van de nationale wetgeving, maar weinig worden verwacht. Zo trok de rechterlijke macht zich aanvankelijk weinig aan van de diverse termijnen die in het Wetboek van Burgerlijke Rechtsvordering voorkwamen en ook kwam het geregeld voor, dat een uitspraak gebaseerd was op een Nederlandse wetstekst, maar dat de motivering geheel afkomstig was van een commentaar op een Franse tekst.

Onwil en onmacht gingen daarbij hand in hand. Onwil, omdat men opzag tegen de moeite die het zou kosten kennis te verwerven van het nieuwe recht, onmacht, omdat

\footnotetext{
124. W 3141 (1869). Vergelijk ook Nieuwe Bijdragen, 1866, p. 859 e.v.; 1868, p. 228 e.v.; p. 694 e.v.

125. Nieuwe Bijdragen, 1866, p. 207 e.v.

126. Nederlandsche Jaarboeken voor regtsgeleerheid en wetgeving, 1848, p. 88.
} 
men ook vaak de capaciteiten daartoe miste. Zo bestond in 1841 het gehele Maastrichtse kantongerecht uit ongegradueerden en werden er in Limburg in dat jaar tien kantonrechters benoemd, waarvan twee gegradueerd, tien griffiers en twintig plaatsvervangers, waarvan één gegradueerd. ${ }^{127}$ In 1899 was die situatie, ondanks dat sinds 1877 het bezit van een juridische opleiding verplicht werd gesteld, maar weinig verbeterd, want "zoowel bij de aanbevelingen als bij de benoemingen trekt het niet zelden de aandacht dat op het vereischte van eenige wetenschappelijke ontwikkeling en practische geoefendheid niet altijd in de eerste plaats gekeken wordt en dat tot de uitoefening van het gewichtig ambt des rechters wel eens geroepen worden personen die misschien (...) goede en voortreffelijke eigenschappen als rentenier hebben, maar toch niet geacht mogen worden een zelfstandig oordeel te kunnen vellen over de netelige vraagstukken die vaak den rechter voorgelegd worden." ${ }^{128}$ Het was in die dagen alleen mogelijk het rechtersambt in waardigheid te bekleden indien men het karige loon wist aan te vullen met inkomsten uit eigen vermogen. De rechter die dat laatste moest ontberen, was dikwijls door de nood gedwongen tot op hoge leeftijd in functie te blijven, ook al omdat een pensioenvoorziening ontbrak. Dit gegeven, en het feit dat een rechter alleen ontslagen mocht worden wanneer zijn ongeschiktheid voor het ambt als gevolg van ouderdom duidelijk zichtbaar werd, leidde ertoe dat het niet ongebruikelijk was een afgeleefd en ziekelijk of zelfs krankzinnig magistraat op de stoel van de rechter aan te treffen. ${ }^{129}$

Het schortte in die beginjaren niet alleen aan de deskundigheid van de leden van de rechterlijke macht. Ook de rechtsleer was in die fase nog weinig ontwikkeld, juist omdat velen hun vertrouwen op de wetgever hadden gesteld. Zo had de opvatting nog geen opgang gemaakt, dat, naarmate een wet ouder wordt, de rechter een grotere vrijheid dient te hebben bij het uitleggen van de wet, omdat de bestaansreden van een wetstekst niet meer, of niet meer in dezelfde vorm bestaat.

Zelfs de Hoge Raad speelde, althans volgens Levyssohn, een weinig belangrijke rol in de rechtsvorming. De rechtsgeleerde wereld was het zijns inziens er over eens dat de veelvuldige wisselingen in de personele samenstelling de eenvormigheid van de wetsuitleg niet zeer bevorderden. De minnelijke schikking werd daardoor hét alternatief voor een dure, tijdrovende en onzekere procedure. ${ }^{130}$

Een andere factor was dat de Hoge Raad zich - een kleine uitzondering daargelaten - niet mocht uitlaten over de feiten maar slechts over schending van de wet. Het

127. Themis, 1841, p. 144. Dit hangt ook daarmee samen dat vele Limburgse rechtsgeleerden na 1830 de zijde van de Belgen kozen en van Maastricht vertrokken naar het op een steenworp afstand gelegen Tongeren. Het "Mr"-vereiste werd voor kantonrechters pas in 1877 verplicht gesteld (Wet van 9 April 1877, S. 73). Voordien gold als eis dat zij uit de "kundigste, bekwaamdste, gegoedste en meest geachte ingezetenenen, doch bij voorkeur uit meesters of licenciaten in de regten" zouden worden gekozen (art. 35 W.R.O). Tot het aftreden van Van Maanen werd deze eis aldus verstaan dat er slechts "vrienden" van hem voor benoeming in aanmerking kwamen. Kennis van het recht was wel een pré, maar beslist geen voorwaarde. Zie W 196, 234 (1841) en 284 (1842).

128. Themis, 1899 , p. 86.

129. Nieuwe Bijdragen, 1870 , p. $460 ; 1880$, p. 421 e.v. De leeftijdsgrens werd in 1932 in de wet opgenomen (Wet van 3 december 1932, S. 576), nadat reeds bij Wet van 27 september 1909, S. 324 aan oudere leden was toegezegd dat zij ingeval van vrijwillig vertrek hun volle wedde als pensioen zouden behouden.

130. Themis 1848 , p. $151-152$. 
gevolg daarvan was, dat de vele, ook onderling rivaliserende Hoven, hun uitspraken zo inrichtten, dat de rechtsvraag verpakt werd in een samenstel van feitelijke beslissingen en dus niet in cassatie aan de orde kon komen. ${ }^{131}$

De rechterlijke macht kon dus niet voldoende tegenwicht bieden in het verlangen naar herziening, was daarvoor geen volwaardig alternatief. De volgende uitspraak van Van Boneval Faure illustreert dat nog eens:

"Wanneer men (..) bedenkt dat de Hooge Raad uiterst voorzichtig pleegt te zijn met het aannemen van eene schending der wet, en meer dan één arrest er op wijzen, dat, zoolang de letter der wet de aangevallen interpretatie toelaat, de Hooge Raad deze eerder pleegt te handhaven dan te veroordeelen, (...) dat dan ook wel eens de klacht gehoord wordt, als zoude de Hooge Raad al te angstvallig te werk gaan, en niet altijd die breede rechtsopvatting huldigen (..) zodat het gevaar van de onweerstaanbare macht van de rechtsregel sprekend wordt. "132

\section{De rol van de wetenschap}

Ook de wetenschap was geen ontwikkeld element van het rechtsleven. Aanvankelijk werd de wetstekst zelfs in blind vertrouwen op de alwijze wetgever verklaard: "De Wetgever toch is dáár, om te bepalen wat regt zal zijn, de uitleggers moeten met zijne bepalingen, zoo als die geschreven staan, te vrede zijn. Het moet voor rekening van den Wetgever, en van dezen alleen, blijven, of de Wet goed of slecht is; daar mag men bij het interpreteren niet naar vragen; dat was de vraag, die, bij het vaststellen der Wet, een punt van onderzoek moest uitmaken, en - wij moeten het vertrouwen - ook waarlijk heeft uitgemaakt; en bewijst desniettegenstaande de uitkomst, dat de Wetgever zich bedrogen heeft, dat zijne bepaling niet deugt, dat zij althans beter geweest ware, indien hij een ander woord, eene andere uitdrukking had gebezigd; ja al blijkt het ook dat de Wetgever een ander woord had willen gebruiken, welnu, dan bedroeve men zich over den Wetgever, maar miskenne zijn gezag niet, en stelle zich niet in zijne plaats, door eigendunkelijk de woorden der Wet te veranderen." 133

En wie kent niet de uitspraken van Opzoomer, dat wanneer hij zijn eigen aantekeningen over het Burgerlijk Wetboek herleest, hij zich er steeds aan moet ergeren "dat hij den regter uitspraken voorschrijft, die hij zelf als regtsgeleerde niet anders dan ongerijmd kan noemen", en die, wanneer hij bedenkt hoeveel jaren van rijke ondervinding er liggen tussen de totstandkoming van de Code Civil en het B.W., zich met "schaamte afkeert" van de vaderlandse arbeid. ${ }^{134}$

De Pinto, weliswaar één van de meer bekende legisten, belijdt in 1863: "Hoe gegrond vele dezer beschuldigingen (tegen gebreken van het W.v.K.) ook zijn mogen, bij de uitlegging der wet moet men zich houden aan hare theorie, hoe verkeerd en hoe

131. Zie HNJV 1870 , p. 166.

132. Regtsgeleerd Bijblad, 1874 , p. 306 . Vergelijk ook Themis, 1874, p. 72 : "De rechtspraak is geen ontwikkeld element van ons rechtsleven. De bekrompen opvatting van de Hoge Raad leidt tot een vormendienst, die de inhoud niet acht."

133. Regtsgeleerd Bijblad, 1845, p. 837 e.v. Deze uitspraak staat op naam van S.M.J. Modderman.

134. C.W. Opzoomer, Het Burgerlijke Wetboek verklaard, Amsterdam 1865, voorrede p. VI-VII, eerste deel. 
valsch die ook zijn moge; en er zich vooral voor wachten, om uit vooringenomenheid met andere, al zijn het betere theoriën, die niet zijn die der wet, haar op te dringen, eene leer, die zij, het zij niet gekend, het zij niet gewild, in ieder geval, niet verkondigd heeft." 135 Tenslotte nog een reactie van Van Hall op een schrijver die de duidelijke woorden van een wetsbepaling wil omzeilen, omdat zij voor de praktijk een grote belemmering inhouden: "Waarom de Wetgever het endossement na den vervaltijd verboden heeft, is eene vraag waarin wij niet te treden hebben, doch dat het verboden is, lezen we in art. 133 W.v.K. en dit is voldoende. De Wetgever kan voor dat verbod geldige redenen gehad hebben, of het uit loutere willekeur, of waarom dan ook, gedaan hebben, maar het is nu eenmaal zoo." Wat het belang van de handel betreft, "dit kan zeer waar zijn, doch daarom mogen wij nog niet eigenmagtig de Wet verbeteren; dit doet ook tot de quaestie niets af, maar behoort, zoo als de schrijver te regt zegt, tot het jus constituendum, en niet tot het jus constitutum. " 136

De meerderheid van de Nederlandse juristen kon zich eenvoudig geen andere remedie voorstellen dan een optreden van de wetgever. En aangezien deze maar moeilijk in beweging te krijgen was, riep een enkeling zelfs op tot een stricte toepassing van de wet, ook al zou dit tot zeer onbillijke resultaten leiden. ${ }^{137}$

Uit de toon van deze reacties blijkt echter tevens, dat er ook juristen zijn geweest die aanmerkelijk minder vertrouwen hadden in een mogelijke tussenkomst van de wetgever, of, zo men wil, minder aan wetsverafgoding deden. Maar ook zij voelden zich sterk aan de tekst van de wet gebonden en gingen in hun interpretatie niet verder dan wat de wordingsgeschiedenis van een bepaling leerde of zij probeerden aan de hand van een uitspraak, afkomstig van de één of andere volksvertegenwoordiger, te bewijzen wat de wetgever had willen zeggen of, belangrijker nog, had moeten zeggen.

Dat deze onschuldige excercitie de uitlegger vaak nog voor de nodige problemen plaatste, blijkt wel uit de verzuchting wanneer na lang zoeken een artikel werd aangetroffen waarbij 'de wetgever werkelijk de bedoeling heeft gehad welke hij volgens de tekst van de wet had moeten hebben.'

Zelfs wanneer de commentaren aan diepgang winnen - men denke daarbij vooral aan het verschijnen van de handboeken van Diephuis (13 delen, 1869-1890) en Opzoomer (16 delen, 1865-1887) die overigens beide door eenvoudiger werken waren voorafgegaan (men denke aan Opzoomers eersteling "Aanteekeningen op de artikelen, die nog verklaring behoeven") - en meer inzicht verkregen wordt in doel en wezen van de codificatie, vindt geen relativering van haar betekenis plaats. In de gevallen waarin de bedoeling van de wetgever onduidelijk is, put men zich in de meest starre en minutieuze interpretaties, waarbij de ongerijmdheid van de uitkomst "nauwelijks meer een bezwaar tegen de uitlegging oplevert, maar liever als een verwijt tegen de

135. A. de Pinto, Handleiding tot het Wetboek van Koophandel, deel II, Den Haag 1854, derde druk, p. 106.

136. Nieuwe Bijdragen, 1858 , p. 323.

137. Men denke in het bijzonder aan de leer van Goudsmit in zijn uit 1871 daterende "Oratio de variis causis quibus fit, ut populorum leges ab eorum moribus discrepent" (over de verschillende oorzaken waardoor het komt dat de wetten van de volkeren op hun gewoonten gaan verschillen), p. 29, waarin hij verdedigde dat de wetgever wel tot grotere werkzaamheid zou worden verleid, indien men zich zo streng mogelijk zou houden aan verouderde of slechte wetsbepalingen. 
wet gekeerd wordt"138, een "bekend gebrek" van Opzoomer, aldus één van zijn critici. ${ }^{139}$

Slechts een enkele theoreticus, zoals de Leidse hoogleraar Van Boneval Faure zet, na lang aarzelen, enige vraagtekens bij deze denkwijze en schuift de schuld af op het misbruik dat wordt gemaakt van de "goede Voorduin" of op de "achterlijkheid in de kunst van uitlegging" (een ondubbelzinnige kritiek op Opzoomers' brochure "Over de achterlijkheid in de kunst van wetgeving"): "Zelfs bij de blijkbare en veelvuldige onnauwkeurigheden, welke men in de redactie der wet aantreft, onjuiste uitdrukkingen, slechte vertaling, verkeerde woordvoeging, en wat men meer van dien aard wil, zal de billijkheid de beoordelaar rekening doen houden met deze omstandigheid, dat het wetgevend werk een nieuw werk voor onze rechtsgeleerden was, dat de taal zich nog niet voegde in dien wetgevenden vorm, of wil men liever, dat de rechtsgeleerden in het algemeen niet die heerschappij over de taal voerden, welke vereist wordt om haar aan eenen behoorlijken stijl dienstbaar te maken. De uitlegger, daarop indachtig, zal aan de taal der wet niet den maatstaf aanleggen van die regels van taal en stijl, welke men later eerst begon in acht te nemen, doch met recht zich bevoegd en zelfs verplicht achten om tegenover de letter meer ruimte te geven aan eene, op zich zelve min juist uitgedrukte, bedoeling des wetgevers." ${ }^{140}$

De schaarse pogingen die worden aangewend om te ontsnappen aan de legalistische benadering van de wetstekst zoeken het in een verruiming van de uitlegging. Aan vernieuwing van het recht wordt niet gedacht en opvallend is dat er weinig oog is voor de toepassing van het recht op het concrete geval. De theorie vervreemdt van de praktijk; "Het is meermalen opgemerkt, dat bij de wetenschappelijke bewerking van het positieve regt op de jurisprudentie luttel acht wordt gegeven, dat zij zelfs met eenigszins minachtend stilzwijgen pleegt behandeld te worden; terwijl de jurisprudentie zich met al die nieuwigheden, welke in het studeervertrek worden uitgedacht, niet meent te kunnen ophouden en zich liever aan hare bekende autoriteiten pleegt vast te houden." ${ }^{141}$ Kappeyne, één van de redacteuren van Themis klaagt: "Velen zien laag neder op het regt der arresten en zij hebben tot zekere hoogte gelijk. De beste juristen zitten niet altoos op de zetels der magistratuur; de beslissing van een bepaald geval ontleent schier immer iets aan de omstandigheden, waaronder het geval zich voordeed, en wordt er door gekleurd." Maar, zo besluit hij, "de jurisprudentie moet niet verwaarloosd worden, in de praktijk zal niemand dit stelselmatig durven doen. ${ }^{142} 143$

\section{Staatsrechtelijke belemmeringen voor het proces van wetgeving}

De veroudering van de wetboeken, de - in onze ogen - bekrompen opvatting over de taak van de rechtspraak en de weinig inspirerende letterknechterij van de wetenschap.

138. Nieuwe Bijdragen, 1866 , p. 207.

139. Nieuwe Bijdragen, 1867 , p. 352.

140. Nieuwe Bijdragen, 1873 , p. 593-594.

141. Regtsgeleerd Bijblad, 1864 , p. 139 e.v.

142. Themis, 1863, p. 242; zie ook H.L. Drucker die spreekt over de afstand tussen wetenschap en praktijk als "de grootste kanker" van het recht; Rechtsgeleerd Magazijn, 1882, p. 517 e.v.

143. De uitspraken, zoals gepubliceerd in het Weekblad van het Regt, werden vaak uitgeknipt en tot een kaartsysteem verwerkt. 
het zijn factoren die verklaren dat de wens om een herziening binnen de wetenschap levend bleef. Tot de eerste helft van de zestiger jaren waren - ik heb daar reeds op gewezen - de voorstanders van een algehele herziening veruit in de meerderheid. ${ }^{144}$ Algehele herziening bleef het ideaal, ofschoon wel werd ingezien dat aan een beperkte partiële herziening soms niet viel te ontkomen.

Deze voorkeur voor een grootschalige bewerking werd gemotiveerd met het argument dat een reeks van partiële herzieningen onvermijdelijk afbreuk zou doen aan de conceptuele eenheid van het Burgerlijk Wetboek. Daarnaast wees men dikwijls op de inspanning die het Minister Van Hall in 1843 had gekost om de Kamer van de noodzaak van een partiële herziening te overtuigen.

Vanzelfsprekend had deze stroming, die, zoals gezegd, het B.W. vanaf de geboorte heeft vergezeld, aanvankelijk het tij mee. Als gevolg van het toenemende inzicht in de codificatie van 1838 raakte men er steeds meer van overtuigd dat slechts een algehele herziening toereikend zou zijn om alle gebreken op te heffen. En ofschoon daarbij nog voornamelijk werd gedacht aan een verbetering van de terminologie en systematiek van het B.W., die door het in deze periode op zijn hoogtepunt verkerende legisme niet hoog werden aangeslagen, had men wel oog voor de maatschappelijke bezwaren die aan het gebruik van het oude wetboek waren verbonden. Kritiek was er op de wel zeer beknopte regeling van het arbeidscontract, het ontbreken van een behoorlijke verzuimregeling, de scheve verhouding tussen de rechten en plichten van koper en verkoper en de positie van de gehuwde vrouw in het familie- en erfrecht.

Het eigenaardige was echter, dat hoewel met het verstrijken van de tijd die herziening steeds meer juristen als gewenst voorkwam, ditzelfde tijdsverloop er mede de oorzaak van werd dat een algehele herziening zo goed als onbereikbaar werd. Het aantal wijzigingen dat moest worden aangebracht werd na verloop van tijd namelijk dermate groot, dat een herziening op grote schaal, gegeven de parlementaire vormen en gewoonten (zie hieronder), niet anders dan op een fiasco kon uitlopen. Daardoor moest men langzamerhand wel tot de overtuiging komen dat een algehele herziening een onvervulbaar ideaal was. Partiële herziening werd noodgedwongen als beginsel van wetgeving geaccepteerd:

"De ondervinding heeft geleerd, dat voor ons ten minste eene algeheele herziening van eenige van onze wetboeken, daaronder begrepen de regterlijke organisatie, een onbereikbaar ideaal is; en al ware het daarom alleen, moet men zich tevreden stellen met partieele wijziging, met, zoo als men het onlangs in de Tweede Kamer noemde, hier en daar een lap te zetten op onze wetboeken. Men heeft te kiezen tusschen haar en tusschen stilstand. De keuze kan dus niet moeijelijk zijn. ${ }^{145}$

Daarmee is niet gezegd dat men ingenomen was met deze oplossing: "Partieele herziening nu is eene Staatsrechtelijke noodhulp. Tot stelsel verheven, staat zij met een brevet van blijvend onvermogen gelijk. Zij brengt de noodzakelijke eenheid der codificatie in gevaar. Zij verbreekt de onderlinge verhouding en bemoeilijkt het recht verstand der wetgeving. Verkieslijk is zij slechts boven volstrekten stilstand. Daaren-

144. Aldus ook G. de Vries Azn. in Themis 1875, p. 58 e.v.

145. W 3926 (1876). Zie ook W 3141 (1869), W 3050 (1868) en S. Katz, a.w., p. 304, i.h.b. de noten $1 \mathrm{t} / \mathrm{m} 13$. 
boven verliest zij aan bruikbaarheid naarmate zij vaker wordt gebezigd. Het oudste fragment is van het jongste niet slechts door tijdsruimte, maar ook door verschil van beginsel gescheiden. De gedeeltelijke herziening schept zelfstandige deelen, buiten machte om elkander aan te vullen, even ongeschikt om elkander te verklaren." ${ }^{14 h}$ Maar, zo besloot de redactie van het WPNR, na haar instemming te hebben betoond met deze woorden van J. Kappeyne van de Coppello, "met het oog op den eigenaardigen toestand van ons politiek, of - indien men wil - van ons parlementair leven, meenen wij den bestrijders eener dergelijke herziening te moeten toeroepen "le mieux est souvent l'ennemi du bien. "147

Wat moet nu worden verstaan onder "den eigenaardigen toestand van ons politiek leven"?

In de eerste plaats kan daartoe het omslachtige "afdelingenonderzoek" worden gerekend. Van 1815 tot 1887 kende de Grondwet namelijk een voorschrift dat inhield dat de Kamer pas met de openbare behandeling van een wetsvoorstel kon beginnen nadat zij het desbetreffende voorstel in haar afdelingen had onderzocht. ${ }^{148} \mathrm{De}$ loting, die de samenstelling van de afdelingen bepaalde, rekende weliswaar af met het provincialisme ${ }^{149}$ dat de Kamer voor 1815 had beheerst, maar had als negatief effect, dat zij geen enkele garantie gaf voor de deskundigheid van de leden in een bepaalde afdeling, nog daargelaten de vraag of de samenstelling van de gehele Kamer, die naast juristen bestond uit medici, theologen en geschiedkundigen, een voldoende waarborg bood voor kwaliteit op het gebied van de burgerlijke wetgeving. ${ }^{150}$

Tot 1848 bepaalde de Grondwet dat de rapportages van de - aanvankelijk zeven afdelingen tot een algemeen verslag moesten worden verwerkt. Tot groot ongenoegen van onder andere Thorbecke beperkte men zich echter tot het verzamelen van alle opmerkingen die in de afdelingen waren gemaakt, zodat het voor de Regering vaak volkomen onduidelijk bleef welk standpunt de Kamer als geheel zou innemen tijdens het gemeen overleg. En juist de Regering had belang bij een duidelijk standpunt van

146. J.A. Levy, De moderne levensbeschouwing van mr. J. Kappeyne van de Coppello, Den Haag 1875.

147. WPNR 268, 270 (1875).

148. Art. 106 Grondwet (1848): "Over eenig ingekomen voorstel des Konings wordt door de volle Kamer niet beraadslaagd, dan nadat het is overwogen in de onderscheidene afdeelingen, waarin al de leden der Kamer zich verdelen en welke op gezette tijden bij loting vernieuwd worden."

149. Artikel 17 van het Reglement van Orde van 3 Mei 1814 schreef voor dat ieder wetsvoorstel zou worden onderzocht in de "besogne" die op dat beleidsonderdeel betrekking had. Aangezien iedere provincie in ieder besogne een aantal vertegenwoordigers had en bovendien de afgevaardigden onderling beslisten wie in welke besogne zitting zou nemen, wordt gesproken van "provincialisme". Zie P.J. Oud, Het constitutioneel recht van het Koninkrijk der Nederlanden, deel II, Zwolle 1967/1970, p. 105 e.v.

150. Tot 1888 bestond zo'n 80 à $85 \%$ van het totale bestand aan Tweede Kamerleden uit academici, waarvan het overgrote deel ( 85 à $90 \%$ ) was afgestudeerd aan een juridische faculteit. Enige concurrentie werd geboden door de natuurwetenschappen en de medici, beiden goed voor zo'n $6 \%$. Na 1879 nam het percentage theologen in de Kamer toe tot zo'n $12 \%$, met als uitschieten $19 \%$, in 1929. Deze gegevens zijn ontleend aan J.Th.J. van den Berg, in: "De toegang tot het Binnenhof", Weesp 1983, p. 133 e.v.; Zie ook C.H.F. Polak in: Handelingen der Nederlandse Juristen-Vereniging 1976, deel 2, p. 8-10. 
de Kamer waarop zij haar wetsvoordracht kon afstemmen, wilde zij niet het risico lopen dat de Kamer, die het recht van amendement pas na de Grondwetswijziging van $1848 \mathrm{kreeg}$, de gehele voordracht zou verwerpen:

"En was, met deze verslagen in de hand, de Regeering er toe overgegaan in hare voordracht de wijzigingen aan te brengen, die zij meende dat door de Kamer werden gewenscht, dan bleek het later herhaalde malen bij de algemeene beraadslaging, dat over deze wijzigingen geen woord werd gerept of juist die deelen van het ontwerp door de Vergadering hevig werden bestreden, die oorspronkelijk door de Regeering ook niet gewenscht waren, en zij nu gedwongen was te verdedigen, hetgeen zij van den aanvang zelve niet in haar ontwerp had willen opnemen. ${ }^{151}$

Dit soort vertoningen werd nog in de hand gewerkt doordat vele leden ofwel de afdelingsvergaderingen meden - in 1872 werd zelfs een disciplinaire maatregel getroffen om dit verzuim terug te dringen - ofwel zich beperkten tot het doen van vage mededelingen. Daardoor bereikte men dat de beste argumenten voor de openbare behandeling bewaard bleven, want alleen daar was de volledige aandacht op hun persoon gericht en lag - in verband met de parlementaire berichtgeving - de mogelijkheid het electoraat uit het kiesdistrict dat zij vertegenwoordigden, te imponeren.

Het duidelijkst kwam deze "publiciteitsgezindheid", te vergelijken met het tegenwoordige gebruik van de motie, naar voren, toen in 1851 werd voorgesteld een proef te nemen met zelfstandige rapporteurs, die wél een beredeneerd verslag konden leveren. De proefneming, die maar drie maanden heeft geduurd als gevolg van de "stille" oppositie onder de Kamerleden, mislukte doordat het afdelingenbezoek nog geringer werd dan het was geweest. Zoals de Kamerleden zelf verklaarden, werd nu niet meer elke opmerking, in de afdeling losgelaten, in het verslag opgenomen, waardoor "aan de eigenliefde niet meer de hulde werd gebracht van vroeger. "152 ${ }^{153}$ Bovendien werd de naam van het Kamerlid niet meer vermeld, maar verdween zijn opmerking onder de pseudoniemen "enige", "vele", "sommige" enzovoort, en bestond bij de Kamerleden de vrees dat de rapporteurs het in de afdelingen opgemerkte als eigen denkbeelden zouden presenteren. ${ }^{154}$

Dat vele opmerkingen die in de afdelingen werden gemaakt, meestal zeer onbelangrijk waren, meldt, eigenaardig genoeg, het algemeen verslag dat het zelfstandig rapporteursstelsel moest beoordelen, zelf: "Alles toch wat in de afdeelingen is overwogen in strijd met het gevoelen der rapporteurs, het moge over het behandelde

151. F.H.M. van Lilaar, De wijze van beraadslaging in wetgevende vergaderingen, Leiden 1879, p. 137. Zie ook p. 148 en 155 e.v.

152. J.H. Telders, Het onderzoek van wetsvoorstellen in wetgevende vergaderingen, Leiden 1900, p. 121; Van Lilaar, a.w., p. 147.

153. Een onbekend gebleven Kamerlid verklaarde, geciteerd bij Van Lilaar, a.w., p. 193: "Aan die gewone garnizoensdiensten doe ik niet mede, ik kom alleen bij parades."

154. HNJV 1870 , p. 90 e.v.: "De Kamer is niet gesteld op die zelfstandige rapporteurs. Ik weet, dat sommige leden der Kamer nog al gevoelig zijn, als zij door anderen worden overschaduwd"; zie ook p. 120 . 
onderwerp licht aanbrengen al dan niet, dat alles zal door de rapporteurs, die hun verslag naar eigen oordeel inrigten, meestentijds niet worden opgenomen. "155

$\mathrm{Na}$ het "mislukken" van de proef kregen de rapporteurs wel de mogelijkheid om in het eindverslag van een zelfstandig oordeel blijk te geven, maar niet in het Voorlopig Verslag. Kennelijk vonden zij dat te weinig eer, en zo kwam het dat de eindverslagen bijna zonder uitzondering de stereotype formule kregen "dat de rapporteurs zich van het uitbrengen van een eigen oordeel onthouden". De rapporteurs kwamen na 1850 zelden of nooit bijeen om het eindverslag vast te stellen "omdat dit stuk door de practijk geworden is een in den regel voor alle gevallen passend eenvoudig formulier."156 Het werk aan het Voorlopig Verslag werd eenvoudig uitbesteed aan de daardoor overbelaste griffier.

Is het verwonderlijk dat de Regering langzamerhand tot de overtuiging kwam dat zij met evenveel reden weinig doordachte wetsontwerpen kon indienen, aangezien de reactie van de Kamer toch onvoorspelbaar was? Het afdelingsonderzoek werd in die dagen eerder gezien als een methode om door middel van een gedachtenwisseling de Kamerleden enigszins op de hoogte te brengen van de aanhangige wetsontwerpen, dan als een middel om de Regering over het standpunt van de Kamer voor te lichten.

Hoewel na 1849 nog een aantal pogingen is gedaan om het voorbereidende onderzoek een reëlere betekenis te geven en bij de grondwetsherziening van 1887 het verplichte afdelingsonderzoek zelfs geheel werd afgeschaft, duurde het tot 1925 voordat in het Reglement van Orde voor de Tweede Kamer het voorschrift verviel dat elk wetsontwerp aan een onderzoek in de afdelingen moest worden onderworpen. Toen werd namelijk bepaald dat ontwerpen, die in de handen van een "vaste commissie" werden gesteld, niet in de afdelingen behoefden te worden overwogen. Veel verschil maakte dat overigens niet, want het zou nog 1966 duren voordat het afdelingenonderzoek voorgoed uit het Reglement van Orde zou worden geschrapt.

Voor dat het zover was had het afdelingenonderzoek door een andere oorzaak wel een opwaardering ondergaan. De partijvorming, die in 1879 aanving met de oprichting van de ARP en in 1926 haar voorlopig einde kende met de vorming van de Rooms-Katholieke Staatspartij, maakte een einde aan de individuele vertegenwoordiging en dwong de fracties tot het bepalen van hun verhouding tot partijen en Kabinet. Dit kwam het voorbereidend onderzoek vanzelfsprekend zeer ten goede. Toch kan worden gesteld dat tot kort voor de eeuwwisseling het afdelingenonderzoek een negatieve invloed had op het wetgevingsproces, zodat aan grotere wetsvoorstellen alleen viel te denken indien het afdelingenonderzoek kon worden vermeden. Dit is ook de reden geweest dat de voorbereiding van de parlementaire behandeling van het Ontwerp voor een Wetboek van Strafrecht in handen is gelegd van een speciale

155. Geciteerd bij Van Lilaar, a.w., p. 147, noot 2. Deze opmerking werpt bovendien een duidelijk licht op het zelfstandige optreden van de rapporteurs.

156. Bijzonder illustratief voor de houding van Kamerleden én rapporteurs is de volgende uitlating, gedaan naar aanleiding van het wegstemmen van de invoeringswet van de Wet op de Rechterlijke Organisatie, waarover weinig eensgezindheid bestond: "Deze is de reden geweest", zo vertelde een rapporteur, "waarom de commissie van rapporteurs niet in het voorlopig verslag heeft melding gemaakt van de verschillende gevoelens over eene mogelijke rechterlijke organisatie en van de gronden waarop deze zou moeten rusten. In de sectiën, waarvan ik de eer had lid en rapporteur te zijn, was zelfs de afspraak gemaakt dat men die zaak niet zou bespreken; zoo ook in andere sectiên." Regtsgeleerd Bijblad, 1870, p. 416. 
commissie. Om dezelfde reden kwam de Nederlandse Juristenvereniging in 1870 tot het voorstel om voor de behandeling van grotere wetsvoorstellen een speciale commissie met verstrekkende bevoegdheden in te stellen.

Een tweede factor die de trage werkwijze van de Kamer kan verklaren, spreekt ook nu nog tot verbeelding; het recht van amendement. Durfde de Tweede Kamer aanvankelijk dit in 1848 verkregen recht slechts zelden te gebruiken en bepaalde zij zich tot de mogelijkheden die het onderzoek in de afdelingen bood, zo rond het einde van de vijftiger jaren barstte een ware amendementenwoede los, omdat men de publiciteitswaarde ervan begon in te zien.

Hoewel de rapporteurs van 1852 tot 1872 de bevoegdheid hadden om de voorgestelde amendementen vooraf te overwegen, is daarvan, met het oog op deze publiciteitswaarde, nooit gebruik gemaakt. ${ }^{157}$ Als gevolg daarvan kwamen bij de openbare behandeling vele slecht geformuleerde of innerlijk tegenstrijdige amendementen ter tafel, waardoor zeer veel wetsontwerpen of werden ingetrokken of zwaar gehavend in het Staatsblad verschenen. Dit is dan ook één van de bezwaren tegen omvangrijke herzieningsvoorstellen die De Vries, als pre-adviseur voor de NJV uit 1870, in kleurrijke bewoordingen zou schilderen. De lotgevallen van de herziening van de Wet op de Rechterlijke Organisatie spreken in dit opzicht het meest tot de verbeelding. Nadat in 1873 voor de achtste maal een herzieningsvoorstel door de Kamer was verworpen, richtte De Pinto zich over de hoofden van de lezers van het Weekblad van het Recht heen tot de leden van de Kamer en gaf hen op ondubbelzinnige wijze te verstaan dat een algehele herziening van deze wet onmogelijk was, zolang men zich niet verplicht voelde van het recht van amendement een zinnig gebruik te maken: "Men heeft het ontwerp letterlijk doodgemarteld, bij stukken en brokken vernield; en nadat men het had bedorven, verknoeid en onbruikbaar gemaakt, heeft men het eindelijk geheel weggeworpen. - De Kamer heeft vermoord, en daarna begraven wat zij vermoord had." 158

Een derde oorzaak die oponthoud veroorzaakte in de behandeling van wetsontwerpen betrof de sluiting (en ontbinding) van de Kamer, een onderwerp dat de NJV uit 1870 eveneens aanleiding gaf tot een oproep aan de Kamer.

Zoals ook nu nog gebruikelijk is, werd in de periode 1815-1848 de zitting elk jaar gesloten. Daaraan werd echter de consequentie verbonden, dat de volgende vergadering de wetsontwerpen die in de vorige zitting onafgedaan waren gebleven, niet meer in behandeling kon nemen. Nu was dit tot 1848 niet zo'n groot probleem, omdat de Kamer meestal aan vier maanden per jaar genoeg had om alle wetsontwerpen te behandelen. Niet alleen was destijds de wetgevende produktie geringer dan nu, maar tevens moet worden bedacht dat de Kamer tot 1848 het recht van amendement miste en zich daardoor niet geroepen voelde om elk artikel van een wetsontwerp uitgebreid te bespreken. ${ }^{159}$ Sluiting bracht dus stuiting en wilde de Kamer zich opnieuw kunnen buigen over de wetsontwerpen, dan moest de Regering het ontwerp nog maar eens indienen, waarop de behandeling van voor af aan begon.

157. Zie F.H.M. van Lilaar, a.w., p. 138 e.v

158. W 3586 (1873).

159. A.H. Philipse. De sluiting van de vergadering der Staten-Generaal in hare regtsgevolgen, Den Haag 1867, p. 17. 
De achtergrond van deze procedure was dat tot 1848 elk jaar eenderde van de Kamerleden aftrad ${ }^{160}$, met als gevolg dat de ingrijpend vernieuwde Kamer na de opening niet noodzakelijkerwijs dezelfde denkbeelden hoefde aan te hangen als haar voorganger. Het eigenaardige was echter, dat ook toen de Kamer langer bijeen bleef en de leden van de Tweede Kamer om de twee jaar voor de helft aftraden, men bleef vasthouden aan de oude, ongeschreven regel. ${ }^{161}$

Aangezien de Grondwet van 1848 niets bepaalde met betrekking tot de gevolgen van sluiting, besloot de Kamer dit punt ter gelegenheid van de herziening van het Reglement van Orde in 1852 aan de orde te stellen. Daarbij is door het vaststellen van artikel 129 R.v.O. ${ }^{162}$ beslist dat de Kamer die na een sluiting aantreedt, zich niet mag bezighouden met door de vorige Kamer niet afgehandelde wetsvoorstellen. Een argument daarvoor achtte men gelegen in artikel 106 Grondwet 1848, waarin werd bepaald dat een wetsvoorstel van de Regering voorafgaande aan de openbare behandeling in de afdelingen moest worden onderzocht. Het leed volgens de meeste sprekers geen twijfel dat zowel vooronderzoek als openbare beraadslaging door dezelfde Kamer moest geschieden, want anders zou het doel van het vooronderzoek, "te zorgen dat geen voorstel als bij acclamatie worde verworpen of aangenomen," niet worden bereikt. ${ }^{163}$

Deze opvatting werd ook door de Regering gedeeld, waarbij zij bovendien nog aanvoerde dat indien de beraadslagingen na een "sluiting" door een volgende Vergadering zouden kunnen worden voortgezet, deze er wellicht snel toe geneigd zou zijn de wetsontwerpen vooruit te schuiven. Het onderzoek in de afdelingen zou, om het geheel samen te vatten, in dat geval van zijn betekenis zijn beroofd en de sluiting zou een krachteloze vorm zijn. ${ }^{164}$

Het hoeft geen betoog dat de elkaar opeenvolgende Regeringen, naarmate de lijst van onafgedane wetsontwerpen groeide, zich ertoe beperkten om of geen enkel wetsontwerp in te dienen, óf zeer eenvoudige, die de kans boden in een jaar te worden afgedaan. Hoewel de Kamer vanaf 1874 haar standpunt "sluiting brengt stuiting" liet varen en de noodzaak van een doorlopende behandeling inzag, betekende dit slechts een geringe verbetering. Gering, omdat, zoals in 1852 reeds was voorzien, politiek weinig interessante wetsontwerpen werden vooruitgeschoven, maar ook omdat "beginselen van hogere politiek" de levenskansen van grote wetsontwerpen aanzienlijk

160. Artt. 80, 82, 97 en 100 Grondwet 1815 .

161. Tot welke merkwaardige situaties dit kon leiden, illustreert het volgende voorbeeld: Op 10 en 11 september 1851 was de Tweede Kamer bijeengeroepen om een "adres" naar de Koningin te zenden ter gelegenheid van de geboorte van haar zoon, maar omdat er onvoldoende leden aanwezig waren - vaak kwam het voor dat drie maanden voordat de zitting gesloten zou worden de meeste leden al vertrokken waren -, kon aan dit voornemen geen gevolg worden gegeven. Na de opening van de volgende zitting werd alsnog een poging ondernomen, maar de gelukwens bleef uit omdat "een 'adres', in het vorig zittingjaar in eene onvoltallige Kamer ingekomen, thans niet moest worden opgenomen; daarbij gaf het antwoord op de Troonrede de gelegenheid om daarin van de deelneming der Kamer te doen blijken". A.H. Philipse, a.w., p. 52 e.v.

162. Dit artikel luidt: "Alle werkzaamheden der Kamer of van door haar, den voorzitter of de afdeelingen benoemde commissiën, die bij de sluiting eener zitting onafgedaan zijn gebleven, worden, zoo verre zij niet de behandeling van voorstellen des Konings betreffen, in een volgende zitting hervat, ten zij de Kamer anders beslisse."

163. Themis, 1852 , p. 539.

164. Themis, 1852 , p. 541 e.v. 
deden verminderen. Bij diverse Kabinetten ontstond namelijk de gewoonte om bij de aanvang van een vierjarig tijdvak alle wetsvoorstellen van haar voorganger in te trekken. Dat dit gebruik ergerlijke vormen aannam en meer uit gewoonte dan uit overtuiging werd toegepast, bewijst wel het feit dat nog in 1897 een nieuw aangetreden Kabinet begon met alle aanhangige wetsontwerpen in te trekken, met daaronder zelfs een aantal, dat zij kort te voren zelf had ingediend. Het Kabinet dat hierop volgde, week in zoverre af van het voorbeeld van haar voorganger, dat zij niet alle aanhangige wetsontwerpen introk, maar er één spaarde. ${ }^{165}$ De Kamer wilde hierin na verloop van tijd uiteraard niet achterblijven en anticipeerde op de Ministerswisselingen ${ }^{166}$ door ruim voor de verkiezingen de beraadslagingen te stoppen wanneer het duidelijk werd dat een wetsontwerp in die periode niet kon worden afgedaan.

\section{De Nederlandse Juristen-Vereniging in $\mathbf{1 8 7 0}$}

Al met al is het dus niet zo verwonderlijk dat in 1870 door een aantal juristen onder leiding van $\mathrm{mr}$ G. de Vries het initiatief werd genomen om de Nederlandse JuristenVereniging op te richten om een einde te maken aan "den in menig opzicht achterlijke toestand van het Nederlandsche rechtswezen" en "het gemis, ook in de rechtsgeleerde wereld, van een gemeenschappelijke overtuiging over de hoofdbeginselen der hervormingen, welker noodzakelijkheid toch ieder beaamt."167 De respons was enorm: binnen twee maanden na het verschijnen van deze oproep telde de vereniging al 300 leden. P.R. Feith schreef in de Gids van juli 1873 dat dit succes verklaard kon worden "uit de algemeen erkende behoefte aan herziening en verbetering der wetgeving op elk gebied, en de overtuiging dat daaraan sedert 1838 geen bevrediging was gegeven."

Evenmin verbazingwekkend is het dat het prae-advies van De Vries over welke methode behoorde te worden gevolgd bij de herziening van de wetboeken, in afwijking van de oorspronkelijk vastgelegde volgorde (het zou behandeld worden wanneer de tijd dat toeliet) als eerste besproken werd, omdat het "zóó zeer alles beheerscht en beheerschen moet." 168 De behoefte naar wetshervorming, de wens om daadwerkelijk invloed uit te kunnen oefenen op het wetgevingsproces, was niet te stuiten.

De taak van De Vries was, gegeven deze geestesgesteldheid, betrekkelijk eenvoudig. Hij moest alle vooroordelen uit de weg ruimen die er nog bestonden ten aanzien van partiële herzieningen. Daarmee zou een krachtige impuls worden gegeven aan een gemeenschappelijke overtuiging ten aanzien van de meest bruikbare methode van herziening, wat tevens een signaal voor de wetgever zou zijn. Want dat een algehele herziening een onbereikbaar ideaal bleef als gevolg van de werkwijze van de Kamer -

165. Rechtsgeleerd Magazijn, 1901, p. 545; zie ook p. 335.

166. In de periode $1848-1870$ waren er 18 verschillende Ministers van Justitie.

167. W 3211 (1870). Deze zinsneden kwamen voor in de oproep tot oprichting van de NJV. Aangezien sommigen meenden dat slechts plaats zou zijn voor geleerden, werd enige tijd later nog bericht dat de vereniging alleen wenste mee te werken tot verbetering van de wetgeving, daarbij voornamelijk rekenend op de hulp van "practische regtsgeleerden, in welken werkkring ook geplaatst. Hoe algemeener de toetreding is, hoe grooter de kans zal zijn om in het nuttig doel, dat men zich voorstelt, te slagen." W 3213 (1870).

168. HNJV 1870, p. 23. 
het ontwerp tot wijziging van de rechterlijke organisatie was inmiddels voor de zesde maal verworpen -, was nu wel duidelijk: "Ik moet het zeggen", zo sprak één van de ter vergadering aanwezigen, "(..) wij weten het allen, het kwaad ligt bij den wetgever zelven. ${ }^{169}$

De Vries noemde twee bezwaren tegen de methode van partiële herzieningen. Het eerste bezwaar, "het gevaar, dat het verband van het geheel door gedeeltelijke wijzigingen zal worden verbroken"170, weerlegde hij door erop te wijzen dat ook bij een algehele herziening dit gevaar allerminst denkbeeldig was:

"Gesteld eens men ging bij de herziening zoo ver, dat men een geheel nieuw wetboek ontwierp, door één man, naar een vast stelsel opgemaakt en in alle onderdeelen uitgewerkt, zou men daardoor verzekerd zijn, dat bij de plaatsing in het Staatsblad het verband tusschen alle deelen van zulk een volkomen geheel ongeschonden zou zijn bewaard? Immers neen. Eerst moet de Minister zich met den voor hem verrichten arbeid vereenigen; de Raad van State moet worden gehoord; aan het voorloopig verslag van het onderzoek in de afdeelingen der Tweede Kamer moet gehoor worden gegeven. Bij de openbare beraadslagingen worden amendementen aangenomen. Met de behandeling van een geheel wetboek zijn zeer vele dagen gemoeid. Is het bijna mogelijk dat nooit het onderling verband der deelen zal worden uit het oog verloren, of dat de Minister op elk oogenblik het geheel en alle zijne bijzondere deelen zoo levendig voor den geest zal hebben, dat hij de gevolgen van elke voorgestelde of aangenomen wijziging, van elke verwerping van een artikel dadelijk overziet; is het schier denkbaar dat gedurende de geheele behandeling geene beslissing zal worden genomen, die op eenig punt de zoo noodige harmonie van het geheel verstoort?" 171

Het tweede bezwaar dat de Vries naar voren bracht, was dat men, door voor de methode van partiële herzieningen te kiezen, steeds alle wijzigingswetten, en daardoor alle Staatsbladen, zou moeten "doorsukkelen" om na te gaan of de bepaling die men wilde gebruiken niet door latere wetten was gewijzigd. Dat dit een reëel bezwaar was - het is nu haast niet meer voor te stellen - bleek uit een mededeling ter vergadering, die erop neer kwam dat het letterlijk onmogelijk was om uit de officiële editie van de Postwet te leren wat er nog als werkelijk geldend recht van over was.

Volgens De Vries zou aan dit bezwaar grotendeels kunnen worden ontkomen door na verloop van tijd de bij partiële wijzigingswetten aangenomen verbeteringen in het wetboek over te nemen, en vervolgens dit wetboek door de Kamer te laten aannemen, zodat de bedoelde uitgave een officieel karakter zou krijgen. ${ }^{172}$

Laat dit voorstel al enigszins zien hoezeer men nog gehecht was aan de "eenheid" van de wetboeken, uit de discussie kwam dit nog duidelijker naar voren. Coninck Liefsting, rechter in Leiden, vroeg zich namelijk af of het niet verstandiger zou zijn om de oude artikelen direct te vervangen door nieuwe, wat tot dusverre in 1843 voor

169. Aldus G. Belinfante (advocaat), HNJV 1870, p. 116.

170. HNJV 1870 , p. 88 (pre-advies).

171. HNJV 1870 , p. 89 e.v. (pre-advies).

172. HNJV 1870, p. 91 e.v. (pre-advies). De Vries nam derhalve het standpunt in dat Luzac reeds in 1843 had verdedigd. 
het laatst was gebeurd. Naar zijn mening zou daarbij getracht moeten worden de nummering van de artikelen zoveel mogelijk te behouden. T.M.C. Asser was het met dit laatste eens, want "er zijn van die classieke artikelen, aan welker nummer men gewend is." Toch waren voor hem de bezwaren groter dan de voordelen: "Als dit geschiedt, dan onstaat door de inlassching der partieele herzieningswetten in de wetboeken, eene andere zwarigheid. Het zal dan daarmede gaan zooals bv. met de nieuwe straten van Amsterdam, waar dikwijls alle woningen hetzelfde nummer hebben, terwijl ter aanduiding van ieder huis, bij het cijfer een kleine letter of ander teken gevoegd wordt. Daardoor zou het gebruik van de wetboeken zeer moeilijk worden." ${ }^{173}$

Hoewel nog het voorstel werd gedaan om met onderscheidingstekens te gaan werken $^{174}$ zodat, wanneer er meer artikelen moeten worden ingevoegd, dan afgeschaft worden, daarin kan worden voorzien door deze in paragrafen onder te verdelen, werd Liefstings suggestie met grote meerderheid verworpen.

Vermeldenswaard is verder dat de vergadering eenstemmig de wens uitsprak dat de Kamer ten aanzien van herzieningswetten de regels "sluiting brengt stuiting" niet zou moeten toepassen, niettegenstaande het voorschrift van artikel 106 Grondwet. Bovendien beval zij aan - met 83 stemmen vóór en 53 tegen - "dat elk wetsontwerp tot geheele of gedeeltelijke herziening van een der wetboeken van wege de Tweede Kamer der Staten-Generaal door eene speciale commissie worde onderzocht. "175

De bedoeling van dit laatste voorstel was om het stelsel van zelfstandige rapporteurs ten aanzien van dit soort wetsontwerpen, ter welker beoordeling specialistische kennis is vereist, te (her-)introduceren. En ofschoon sommige sprekers ervoor vreesden, "dat de aanneming van het voorstel meer kwaad dan goed zal doen, omdat de Tweede Kamer er allicht in zien zal het willen uitoefenen door deze Vergadering van een zedelijken dwang om haar reglement van orde in dien geest te veranderen"176, lieten de meeste leden zich niet terughouden om deze conclusie aan te nemen. "Dit besluit van de NJV is", zo betoogde Belinfante, een "uiting van de publieke opinie (...), welke niemand kan miskennen en waarnaar de Tweede Kamer ook ondanks zich zelve zal moeten luisteren. "177

Dat de kwestie van de herziening der wetboeken niet alleen de Juristen-Vereniging bezighield, maar rond 1870 algemeen leefde, blijkt doordat zij in de vergadering van het Provinciaal Utrechts Genootschap "ex improvisio" aan de orde werd gesteld. ${ }^{178}$ Ook in de daarop volgende discussie werd tot uiting gebracht dat een algehele herziening van het B.W. en W.v.K. dringend gewenst zou zijn, maar dat deze "bij den tragen gang onzer legislatieven arbeid (...) niet licht denkbaar is", zodat "wie op een geheele herziening wachten, wel eens lang en vergeefs kunnen wachten." 179 180

173. HNJV 1870 , p. 41.

174. HNJV 1870 , p. 50.

175. Besluit E, zie de gedachtenwisseling, p. 111-121.

176. HNJV 1870 , p. 115.

177. HNJV 1870 , p. 117.

178. Aantekeningen PUG, d.d. 27 juni 1870, p. 7.

179. Aantekeningen PUG, p. 8 en 10.

180. Vergelijk ook T.M.C. Asser, Wetgeving-Studiën I, Herziening der wetboeken, Amsterdam 1871. 


\section{Partiële herziening als beginsel van wetgeving erkend}

Kort nadat de Nederlandse Juristen-Vereniging met overgrote meerderheid voor het stelsel van partiële herzieningen had gekozen, diende het Ministerie van Justitie een aantal wetsontwerpen in die alle van dit stelsel uitgingen. ${ }^{181}$ Verwonderlijk was dit niet, want het "signaal" van de Juristen-Vereniging had het Departement bereikt in niemand minder dan de persoon van prae-adviseur De Vries, die op 6 juli 1872 was aangetreden als Minister van Justitie. Men herkent de parallel met de situatie in 1842, toen Van Hall, een voorstander van herziening, brak met het dogma van zijn voorganger dat er in de wetboeken niets mocht worden gewijzigd.

De discussie in de Kamer omtrent de wenselijkheid van partiële herzieningen concentreerde zich vooral op de voorgestelde wijziging van de regeling van de beperkte handlichting. Want hoewel de commissie van rapporteurs zich haastte te verklaren dat zij in het algemeen geenszins tegen partiële wetswijziging was, voldeed het wetsvoorstel naar haar oordeel op twee punten niet. In de eerste plaats werd de vorm discutabel gevonden. De Vries had namelijk artikel voor artikel veranderd en telkens het oude artikel door een nieuw vervangen. De commissie echter wenste de afgeschafte of veranderde artikelen te behouden, en de nieuwe, van een onderscheidingsteken voorzien, achter de "vervangen" artikelen te laten volgen. ${ }^{182}$ Met andere woorden, het wetboek moest, volgens de beste Justiniaanse tradities, intact blijven.

De Vries verweerde zich krachtig tegen deze gedachte, hoewel hij zich in de vergadering van de NJV nog achter dit denkbeeld had geschaard. ${ }^{183}$ Hij stelde nu dat hij niet anders had gedaan dan de vorm uit 1843 te kiezen. In het geval echter, dat er een verandering zou worden aangebracht in een beginsel of regel, niet in een bepaald artikel omschreven, maar slechts uit een samenstel daarvan af te leiden, zou hij iets voor de suggestie van de Kamer voelen: na verloop van tijd zou dan een nieuwe, officiële uitgave van het op deze wijze herziene wetboek dienen te verschijnen, waarin de veranderingen, die niet tot een nieuwe tekst hadden geleid, zouden kunnen worden

181. K.B.'s van 11 januari 1873 met betrekking tot

a. wijziging van de bepalingen van het Burgerlijk Wetboek over de beperkte handlichting;

b. overbrenging van enkele bevoegdheden van de arrondissementsrechtbanken bij de kantonrechters;

c. aanvulling van art. 96 van het Wetboek van Strafvordering;

d. intrekking van de wet van 26 Ventose jaar IV, en van art. 471 , lid 8, Wetboek van Strafrecht.

$\mathrm{Zij}$ werden weldra gevolgd door vier andere, betrekking hebbend op:

e. het pandrecht (25 januari 1873$)$;

f. het zegelrecht wegens de acten van belening (17 november 1873);

g. de rechterlijke tucht (17 november 1873);

h. het wettelijk voorrecht van de commissionairs (18 februari 1874).

182. Zie S. Katz, a.w., p. 213. De door de Kamer voorgestelde methode had De Vries wel gevolgd bij het wetsvoorstel, hiervoor genoemd onder b. De tekst van de artikelen van het B.W. waarin een wijziging werd aangebracht, bleef dus (Wet van 18 april 1874, S. 68) onveranderd.

183. HNJV 1870 , p. 42. 
opgenomen. Tevens zouden dan de afgeschafte artikelen in noten aan de voet van de bladzijden kunnen worden vermeld. ${ }^{184}$

Deze toezegging, die natuurlijk geen enkele Minister of Kamerlid zich later nog zou herinneren, was kennelijk voldoende om de Kamer over de streep te trekken, want zij liet zich bij de verdere behandeling van dit wetsvoorstel niet meer over deze materie uit. ${ }^{185}$

Het andere punt van kritiek betrof de te "wijde strekking" van het wetsvoorstel, waardoor het inbreuk zou maken op de beginselen van het wetboek. Het ontwerp, dat het misbruik dat door ouders van de beperkte handlichting werd gemaakt, trachtte te keren - na de verkregen handlichting zetten dezen de minderjarige onder druk om ten behoeve van hen de beschikking over effecten en grootboekinschrijvingen af te staan zou, volgens de commissie van rapporteurs, de beginselen der ouderlijke macht in de "hartader" aantasten, "en ondermijnt zoodoende het familierecht, waarvan, volgens onze wetgeving, de ouderlijke macht de grondzuil is. " ${ }^{186}$

De Vries wilde zich echter niet gewonnen geven, zodat de Tweede Kamer uiteindelijk niets anders restte dan met het wetsvoorstel akkoord te gaan. En daarmee was de partiële herziening als beginsel van wetgeving erkend.

Het middel bleek echter erger te zijn dan de kwaal. Hoewel de voorstanders van partiële herziening zich aanvankelijk verheugd toonden, "omdat op die wijze de kans bestaat, dat er tenminste iets van het gebrekkige verbeterd zal worden"187, kwam men toch al snel in het geweer tegen de vele partiële wijzigingen die de opeenvolgende Ministers van Justitie voorstelden: "De ééne partieele wijziging volgt de andere met zooveel snelheid op, dat men goede beenen moet hebben om niet omver te vallen als men wil medeloopen." ${ }^{188}$

Daarbij werd met name gedoeld op het grote aantal keren (vier maal in drie jaar) dat Van Lynden van Sandenburg een wijziging in de Wet op de Rechterlijke Organisatie wist aan te brengen, terwijl zijn argumenten om tot een wetswijziging over te gaan niet altijd even sterk waren. Zo motiveerde hij de verlaging van de meerderjarigheidsgrens, met als enige grond, dat er "geen overwegende reden bestaat om de bestaande wet te handhaven." Het Weekblad merkte daarop terecht op, dat er op die

184. S. Katz, a.w., 216-217. Gelijk Meijers (Wijzigingen en aanvullingen van het Burgerlijk Wetboek na 1838 , V.P.O. I, p. 124) vermeldt, is deze vorm van wijziging slechts zelden toegepast en hebben particuliere drukkers, met de gedachte achter dit beleid onbekend, eigenmachtig de veranderingen in het B.W. aangebracht. Iets dergelijks doet zich nu nog voor bij het Wetboek van Koophandel. De officiële wetstekst en de wijzigingswetten bevatten artikelen zonder "leden". In de commerciële uitgaven is dat niet het geval.

185. Bij de behandeling van het wetsvoorstel, genoemd onder noot 181 onder e bleek de Kamer zelfs volledig voor het stelsel van 1843 gewonnen te zijn. De wetsvoordracht van De Vries, die slechts enkele wijzigingen in het B.W. tengevolge zou hebben, werd aanvankelijk afgekeurd omdat de Commissie van Rapporteurs het wenselijk vond dat de gehele materie werd herzien. Uiteindelijk werd zij, na ingrijpend veranderd en uitgebreid te zijn, met algemene stemmen aangenomen zonder dat iemand bezwaar maakte tegen de gekozen vorm (Wet van 8 juli 1874, S. 95).

186. S. Katz, a.w., p. 214.

187. Themis, 1876, p. 168 . Zie ook Themis, 1875 , p. 85 . De Vries schrijft daar: "De ervaring op wetgevend gebied sedert vele jaren schijnt partieële verbetering zeer aanbevelenswaardig te maken. Wetsontwerpen van dien aard en zoo beperkten omvang, dat zij in één zittingsjaar kunnen worden aangeboden, onderzocht en aangenomen, hebben de meeste kans van het Staatsblad te bereiken."

188. W 4076 (1877). 
wijze nog maar weinig wetten veilig zouden zijn tegen het "snoeimes van de partieele wijziging." 189

Bovendien bleek veelvuldig, dat de voorgestelde verbetering én eenvoudiger kon worden bereikt én dat de wetgever alles behalve volledig was geweest in zijn invoeringswetgeving. Om een voorbeeld van het laatste te noemen, bij het wetsvoorstel tot verlaging van het tijdstip waarop men meerderjarig wordt, was nagelaten het nieuwe criterium in de bepalingen omtrent handlichting, testament, ouderlijke toestemming bij huwelijk en huwbare leeftijd te verwerken. In 1877 constateerde een schrijver van een ingezonden brief dan ook niet zonder wrevel dat "er (..) nog haast geen maatregel van dien aard (was) genomen, of men heeft er de schadelijke gevolgen van ondervonden. Het afbreken en op nieuw invoegen aan den eenen hoek van het gebouw geeft spleten en scheuren aan een anderen hoek, waarop men niet gerekend had." 190

\section{Tóch algehele herziening van B.W. en W.v.K.}

Of deze bezwaren tegen partiële herzieningen voor Minister Modderman een doorslaggevende reden zijn geweest om kort na zijn aantreden een Staatscommissie in te stellen tot algehele herziening van het Wetboek van Koophandel, mag worden betwijfeld. ${ }^{191}$ Reeds in 1863 had hij in zijn beroemd geworden proefschrift "De Hervorming onzer Strafwetgeving", de algehele herziening, bij voorkeur op te dragen aan een Staatscommissie, aanbevolen als de enig wenselijke methode van herziening, aangezien partiële aanpassingen tot stelselloosheid zouden leiden ${ }^{192}$, een standpunt dat hij altijd trouw zou blijven. ${ }^{193}$

Deze voorkeur bleek ook duidelijk uit de argumenten die de Minister aanvoerde om tot een herziening van het Wetboek van Koophandel over te gaan. Want ofschoon het wetboek in de veertig jaar van zijn bestaan geen noemenswaardige wijzigingen had ondergaan ${ }^{194}$ en op slechts bepaalde punten sterk was verouderd, zoals op het punt van het faillissements- en vennootschapsrecht, werd de taak van de Staatscommissie niet tot die punten beperkt. Het ging, volgens Modderman, niet uitsluitend om het herzien van de afdelingen van het Wetboek van Koophandel waarin die onderwerpen geregeld waren en waardoor de herziening, hoewel ingrijpend, toch een partieel karakter zou dragen, maar ook om "zorgvuldige toetsing van het geheele Wetboek aan de lessen der ondervinding, zoowel hier als elders verkregen."

De herziening van het Wetboek van Koophandel was slechts één van de vele pijlen die Modderman op z'n boog had. Niet lang na de instelling van deze commissie, werd, mede ${ }^{195}$ naar aanleiding van een voorstel van het liberale Eerste Kamerlid

\section{W 4089 (1877).}

190. W 4090 (1877).

191. De Staatscommissie werd ingesteld bij K.B. van 22 november 1879, no. 26.

192. Zie de recensie in Themis, 1864 , p. 116 e.v. (i.h.b. p. 127 e.v.).

193. Zie bijvoorbeeld Themis, 1876 , p. 261.

194. Slechts artikel 302 (Wet van 1 juni 1875 , S. 81), de bepalingen inzake het voorrecht van de commissionairs (Wet van 4 juli 1874, S. 89) en de bepalingen omtrent het pandrecht (Wet van 8 juli 1874, S. 95) waren gewijzigd of aangevuld.

195. In W 4438 (1879) werd aangetekend dat de opdracht tot herziening van het W.v.K. in feite te eng was, omdat een herziening van het B.W. niet werd genoemd en het kunstmatige onderscheid tussen deze twee wetboeken diende te vervallen. 
Van Eck - in 1870 ter vergadering van de NJV al een verklaard voorstander van algehele herziening - de "Staatscommissie tot herziening van het Burgerlijk Wetboek" ingesteld. ${ }^{196}$ Als motief voor de instelling van deze commissie wees Modderman op de gebreken van het Burgerlijk Wetboek, de leemten, de verouderde rechtsinzichten en de talrijke vragen die het wetboek zou oproepen. Ter illustratie werd door hem een twintigtal onderwerpen genoemd, welker regeling dringend herzien diende te worden. "Bleef herziening uitgesteld," zo viel in het instellings-K.B. te lezen, "Nederland zou na verloop van andermaal 40 jaren, aan zijn Burgerlijk Wetboek ontgroeid zijn en zich, als noodzakelijk kwaad, een geheel nieuw Wetboek hebben te getroosten. Daardoor zou aan het rechtsleven een gevaarlijke schok, aan het volk een onmetelijk nadeel worden toegebracht, waartegen zij thans, door tijdige maatregelen nog behoed kunnen worden."

Over het algemeen werd de instelling van de commissie met instemming begroet. Zo stelde het Weekblad dat de motieven, die werden aangevoerd voor de instelling, "onwedersprekelijk" juist waren; "op vele en op nog veel meerdere punten dan in dit rapport zijn aangewezen, eischt ons Burgerlijk Wetboek aanvulling, verbetering, herziening." 197

Wel ontmoette de grootte en de samenstelling van de commissie enige kritiek. Zo vroeg de Nieuwe Amsterdamsche Courant zich af welke criteria de Minister had gehanteerd bij het benoemen van de zestien leden tellende commissie: "Men ontmoet in eene commissie, die toch wel uit de bekwaamsten behoort te bestaan, met verbazing namen, die velen in dit verband voor het eerst uit het koninklijk besluit zullen hebben vernomen. De Minister schijnt, als gold het een bedeeling van aalmoezen, aan elke provincie haar eigen lid te willen geven." ${ }^{198}$ Het Weekblad verbond aan een soortgelijke constatering de achteraf juist gebleken voorspelling dat na verloop van een paar jaren, een kleinere commissie uit deze zou voortkomen, die puttend uit de stukken van haar voorganger, een goede basis zou kunnen leggen voor een systematische herziening. ${ }^{199}$

Een zekere N.F. van Nooten was zo mogelijk nog pessimistischer: "Het blijkt alzoo dat degenen, aan wie de herziening van het Burgerlijk Wetboek is toevertrouwd, handen vol werks zullen hebben, door één man beter en stelselmatiger tot stand te brengen dan door vijftien personen, die in hunne maatschappelijke betrekkingen veel arbeid hebben, die in de verst verwijderde deelen des lands woonachtig zijn, zoodat, zelfs bij de versnelde middelen van correspondentie en van verkeer, de samenkomsten moeielijk te regelen zullen zijn; ik houd het voor zeker dat de

196. K.B. van 28 februari 1880 , no. 8. Tot de leden behoorden onder andere P.R. Feith, Van Boneval Faure, C. Asser, Eyssell en Opzoomer. De laatste was overigens niet op voorhand overtuigd van het welslagen van de onderneming. Op 1 februari 1880 ontving Modderman een schrijven waarin het volgende viel te lezen: "Waar Gij, trouw aan Uw woord, met zoo kloeken ijver den weg eener volledige rechtshervorming betoonde, daar acht ik tot meegaan door $\mathrm{U}$ geroepen, het plicht mij niet te onttrekken. Zoo toone het idealisme zijn macht ook over de practijk. "

197. W 4470,4475 (1880). Naar aanleiding van de discussie over de begroting had het Weekblad ook al haar instemming met dit denkbeeld betuigd. Zij noemde het "eene blijde boodschap, eene der aangenaamste verrassingen. Eene flinke herziening van het Burgerlijk Wetboek lacht ons meer toe dan eene miniatuurverbetering in de acten van den burgerlijken stand." W 4442 (1879).

198. NAC van 2 maart 1880 , p. 3.

199. W 4475 (1880). 
Commissie jaren noodig zal hebben voor hetgeen één man in een half jaar tijds in staat is met goed gevolg te volbrengen. Het is te vreezen dat eene op dergelijke wijze samengestelde, uit heterogene bestanddeelen samengestelde, Commissie niet in staat zal zijn hare taak te volbrengen, en dat zij, na eenige jaren gearbeid te hebben, deze zal moeten opgeven. ${ }^{200}$

\section{De taakopvatting van de Staatscommissie - Van Meerbeke I}

Inderdaad is de grootte en met name de omslachtige werkwijze ${ }^{201}$ een verklaring voor het feit dat het codificatiewerk slecht vorderde, ofschoon ter bespoediging van het werk op aandrang van voorzitter Van Meerbeke zelf een aantal procedurevoorschriften was opgesteld. Hij schreef aan Modderman: "Vergeef mij, dat ik nog eens op mijn wensen terugkom, om waarborgen te zien vastgesteld voor de eenheid van redactie. Welligt is het voldoende, dat het Besluit ons oplegt, maatregelen te nemen; Ik kan mij niet voorstellen, dat 16 juristen, hoe bekwaam de meeste hunner ook zijn, de gaaf zouden bezitten, om in denzelfden trant en stijl wetsbepalingen scherp te formuleren. Het is bekend, hoe groote juristen juist dat talent kunnen missen. Bestaat er nu een voorschrift, dan krenkt men de minder geschikten niet door hun dit gedeelte van de arbeid uit de hand te nemen. ${ }^{202}$ Deze voorschriften leidden echter niet tot het beoogde doel. Uiteindelijk waren nog negen vergaderingen van een daartoe speciaal ingestelde commissie vereist om de gewenste gelijkheid in redactie te krijgen, een werk dat, zoals de commissie zelf schreef "is gebleken veel omslachtiger en tijdroovender te zijn dan aanvankelijk scheen." 203

Daarnaast was een factor van betekenis dat men vanaf 1883 de krachtige steun van Modderman moest missen en zich moest behelpen met de uiterst welwillende Du Tour van Belinchave, die echter geen enkele moeite deed om de commissie tot meer spoed te bewegen. Men stond er vanaf dat ogenblik in feite geheel alleen voor: het contact met het Departement bleek beperkt tot het leveren van gegevens voor de begroting.

De Kamer had, hoe kan het ook anders, aanvankelijk ook geen enkel probleem met dit trage tempo. De commissie van rapporteurs merkte in 1883 bij de behandeling van de begroting zelfs op, dat zij "zich met deze langzaamheid van werken bijzonder tevreden vertoonde." 204 Hoewel deze uitlating kennelijk de achterliggende gedachte had dat in het langzame het bewijs van het zorgvuldige was besloten, moet worden

200. N.F. van Nooten, "De voorgenomen herziening van het Burgerlijk Wetboek", in: Recht en Wet, maart 1880 , p. 236 e.v.

201. Art. 7 van het K.B. van 20 maart 1880 , no. 20 , bepaalt dat de voorstellen van de drie afdelingen (Zwolle, Utrecht en 's-Gravenhage) eerst een subcommissie moeten passeren, die toetst aan "eenheid van beginselen en eenvormigheid van redactie", alvorens zij behandeld - en zo mogelijk vastgesteld kunnen worden in de algemeene Vergadering.

Art. 8 luidt: "Alle eindbesluiten, betreffende wijziging of aanvulling der wetgeving, worden genomen in de algemeene Vergadering. Ingeval de besluiten der afdeelingen in de algemeene Vergadering wijziging of aanvulling ondergaan, beslist de algemeene Voorzitter, in overleg met de afdeelingsvoorzitters of een nader onderzoek in eene of meer afdeelingen raadzaam is."

202. Brief van 14 maart 1880.

203. Zie de aanbiedingsbrief, behorend bij het ontwerp voor Boek 1, d.d. 30 november 1886, p. III. 204. W 4939 (1883). Zie echter het voorstel tot afschaffing van de Staatscommissie van het Kamerlid Huber, besproken in W 5219 (1885). 
bedacht dat in die dagen meer de nadruk lag op vraagstukken van beleid dan van wetgeving: "Ook in Nederland komen zittingen voor, "qui se passent à rien faire, dont il ne reste du moins aucune trace': (...) Het is een bedenkelijk, maar tevens onloochenbaar verschijnsel, dat de staatkundige toestand, de zoogenaamde hooge politiek, meer en meer als een hinderpaal in den weg staat aan de bevrediging van zoovele nooden en behoeften der maatschappij. " ${ }^{205}$

Onder dit ongelukkig gesternte deed het ontwerp van Boek 1 van de inmiddels tot 11 leden afgeslankte commissie op 30 november 1886 zijn intrede in de rechtsgeleerde wereld. Opmerkelijk daarbij was, dat de vorm waarin het ontwerp gegoten was een doorlopende, nieuwe tekst van alle titels - afweek van de oorspronkelijke opdracht, namelijk voorstellen in de vorm van afzonderlijke wetten. Dit verschil werd, volgens de commissie, veroorzaakt doordat het

"haar echter reeds dadelijk in den aanvang van hare taak (is) gebleken, dat herziening van het Burgerlijk Wetboek onmogelijk was tot stand te brengen bij wege van verandering van sommige artikelen en tusschenschuiving van nieuwe bepalingen. Dit zou een groot gevaar voor allerlei misstellingen hebben opgeleverd, en vrij zeker in hooge mate het dagelijksch gebruik hebben bemoeielijkt van die wet, die het meest van alle in het leven van elken burger ingrijpt, en zijne rechten en verplichtingen in de meest gewone rechtsbetrekkingen van het maatschappelijk leven regelt. Dat gevaar mocht de Commissie niet doen ontstaan. Evenmin konde zij het oog sluiten voor de rijke bron van kritiek, die omtrent het thans geldend wetboek bestaat in de geschriften der beste commentatoren. Dat wetenschappelijk oordeel behoorde in aanmerking genomen en, waar het gegrond werd bevonden, opgevolgd te worden. Wordt dit in het oog gehouden, dan zal het duidelijk zijn, dat alleen eene geheel nieuwe bewerking van den tekst de eenig mogelijke vrucht van elke ernstige herziening moest zijn."

Volgens de Commissie was niet aan een "doorgaande vernieuwing van den inhoud van het wetboek (...) gedacht." Slechts waar het maatschappelijk verkeer om nieuwe regels vroeg waren deze in het ontwerp opgenomen. Daarbij was men echter bewust terughoudend te werk gegaan, want "doordrongen van de waarheid, dat nagenoeg elke verandering eene storende werking uitoefent, en dat zoo licht eenig verband kan worden verbroken, waardoor soms elders groote schade wordt toegebracht, hebben wij weerstand geboden aan de verleiding om telkens, wanneer ons iets juister voorkwam, het voor hetgeen thans rechtens is in de plaats te stellen, maar zijn daartoe slechts overgegaan, wanneer zwaarwichtige redenen er als het ware toe drongen. " 206

\section{Ondanks goede waardering bijgezet in archief}

In de literatuur kreeg het ontwerp een behoorlijke ontvangst. De goede en korte redactie van de artikelen, de keuzen die waren gemaakt bij het beslechten van allerlei twistvragen, de aanmerkelijke vereenvoudiging van processuele voorschriften en de

206. Aanbiedingsbrief Ontwerp Staatscommissie Burgerlijk Wetboek, Boek 1, Den Haag 1886, p. IV. 
weinig behoudende geest die uit het ontwerp sprak, vonden in de rechtsgeleerde wereld zonder uitzondering waardering. ${ }^{207}$

Niet echter bij de Regering. Tot de niet geringe verbazing van velen vond $\mathrm{zij}$ in deze goede kritieken onvoldoende aanleiding om het ontwerp in wetsvoorstellen om te zetten, met als enig argument dat dit ontwerp, als deel van een groter geheel, pas op zijn waarde kon worden getoetst, zodra alle ontwerpen waren ontvangen. ${ }^{208}$

Dit standpunt was, merkwaardig genoeg, lijnrecht in strijd met de opvattingen van de Commissie, die ter vereenvoudiging van het werk het ontwerp in een vorm had gegoten - zij sprak zelf van "een vrij zelfstandig geheel"209 - waardoor het mogelijk zou zijn het zonder veel omhaal in te voeren. De dieperliggende reden voor deze weigerachtige houding ligt dan ook vermoedelijk elders.

In 1888 was het Kabinet-Mackay aangetreden en men mag veronderstellen dat deze coalitie van anti-revolutionairen en rooms-katholieken er weinig voor voelde om het van een nogal liberale geest getuigende ontwerp tot wetsvoorstel te verheffen. De in het ontwerp voorgestelde verruiming van de gronden voor echtscheiding (art. 230), de gecreëerde mogelijkheid om een huwelijk te ontbinden ook tegen de wil van de ene echtgenoot (art. 264) en de bescheiden verbetering van de positie van de gehuwde vrouw konden, zo stel ik mij voor, in deze kringen op weinig instemming rekenen. Bovendien zou, aangezien men in beide Regeringspartijen verschillend dacht over deze punten, ook zelfs maar het discussiëren over dit ontwerp de moeizaam verkregen onderlinge eensgezindheid weer verloren kunnen doen gaan, waardoor het gemeenschappelijk streven, de gelijkstelling van openbaar en bijzonder onderwijs, in gevaar zou kunnen worden gebracht. Kortom, men liet het ontwerp liever rusten en nam het gevaar op de koop toe dat het weer verouderd zou zijn wanneer de andere delen zouden verschijnen.

In dit licht bezien is het dan ook weinig verwonderlijk dat de Regering ook niet wenste in te gaan op het door tegenstanders van dit beleid veelvuldig herhaalde verzoek om aan dit ontwerp dan maar ideeën te ontlenen voor urgente partiële wijzigingen. ${ }^{210}$ Dat die keuze voor partiële herzieningen meer uit nood dan uit overtuiging werd geboren, blijkt duidelijk uit de volgende reactie van Land: "Met gepaste bescheidenheid hebben wij optezien tot onzen wetgever, en ook over partieele herzieningen zouden wij ons nog verheugen. Grootschere plannen zouden zeker te verkiezen zijn, en wie gelooven, haasten niet; maar wie heeft zijn geloof behouden?

207. Zie bijvoorbeeld Land, Themis, 1887, p. 251 e.v., 504 e.v.; 1888 , p. 242 e.v. Hij noemt het een "welkom kerstgeschenk."

208. Hetzelfde argument werd overigens ook gehanteerd in 1820 . Zie Voorduin, deel I, eerste stuk, p. 189.

209. Zie de aanbiedingsbrief, p. VII.

210. Themis, 1887, p. 251 e.v.; Zie ook W 5542, 5608 (1888), 6130 (1892): "Nu eindelijk na verloop van vele jaren goed voorbereide en met zorg geredigeerde wetsontwerpen tot vervanging van sommige onderdeelen van het Burgerlijk Wetboek en het Wetboek van Koophandel door geheel nieuwe titels sedert korter of langer tijd gereed liggen, komt het ons, behoudens beter oordeel, voor, toch warlijk niet onmogelijk te zijn, met gebruikmaking van dat kostbaar materiaal, verder stelselmatig voort te gaan op den sedert 1879 zoo goed als verlaten weg der partieele herziening van ons materieel privaatrecht." 
De partieele herziening heeft ook naast haar gebrek aan quantiteit dikwijls een gebrek in qualiteit; doch juist hier is voor dit laatste minder gevaar." 211

De verkiezingen van 1891 brachten de rechterzijde de nederlaag, met als gevolg dat het Kabinet-Mackay plaats moest maken voor een liberaal bewind. Daardoor ontstond weer enige hoop dat het ontwerp alsnog zou worden gebruikt voor een herziening van het Burgerlijk Wetboek, ondanks dat het al weer zes jaar geleden was verschenen. De in 1891 aangetreden Minister Smidt had namelijk de aandacht op zich gevestigd door een wetsontwerp in te dienen dat voorzag in een bescheiden partiële wijziging in het B.W. ${ }^{212}$ - het eerste sinds die methode na de instelling van de Staatscommissie tot herziening van het Wetboek van Koophandel in 1879 in de ban was gedaan -, terwijl hij zich tijdens het debat over de begroting van 1893 een warm voorstander van een "krachtig aangevatte partiëele herziening onzer wetgeving" betoonde, volgens Molengraaff. ${ }^{213}$

Veel werk heeft Smidt echter niet kunnen verzetten, want het kabinet waarvan hij deel uitmaakte, viel reeds in 1894. Daarmee werd het doodvonnis van het ontwerp voor Boek 1 B.W. getekend en, indirect, tevens van het in 1899 te verschijnen ontwerp voor Boek 2 B.W. Want hoewel de opeenvolgende Ministers "de uitnemende kwaliteiten van de ontwerpen" volmondig erkenden, vermeden zij zorgvuldig zich ermee in te laten.

In wezen deed zich in die jaren een herhaling voor van de situatie die tot 1870 had bestaan. De wens van destijds, om slechts algehele herzieningen toe te laten, waaruit door de wetgever werd afgeleid dat werkeloosheid op het gebied van partiële herziening geboden was, werd nu in zoverre door de wetgever geëerbiedigd, dat hij, onder verwijzing naar de opdracht van de Staatscommissies, sinds 1879 de weg van partiële wetswijziging niet meer wilde bewandelen. Een ergerlijke situatie, temeer indien wordt bedacht dat voor Boek 3 zelfs nooit een commissie werd ingesteld. Wanneer dan ook in 1900 door de Regering tijdens de begrotingsbehandeling op een vraag om met gebruikmaking van de ontwerpen der Staatscommissies voorstellen tot partiële herziening in te dienen, voor de zoveelste maal wordt geantwoord, dat deze niet kunnen worden behandeld alvorens alle delen gereed zijn, merkt de redactie van het Weekblad, haast buiten zichzelf van woede, op: "Meent men door deze zuiver doctrinaire opmerking, al heeft zij, indien het werk der partieele verbetering met oordeel des onderscheids en kennis van zaken wordt verricht, slechts eene betrekkelijke waarde, den aandrang tot verbetering van die onderdelen van ons privaat recht, welke daaraan het meest behoefte hebben opnieuw te kunnen stuiten gelijk in de eerste decennia na de invoering der wetboeken van $1838 ?^{\text {"214 }}$

211. Themis, 1888, p. 291.

212. Dit voorstel heeft geleid tot de Wet van 18 juni 1892, S.146, ter aanvulling van de artikelen 980 en 988 van het B.W.

213. Rechtsgeleerd Magazijn, 1893, p. 322. De denkbeelden van Smidt vonden, volgens Molengraaff, aan weerszijden van het Binnenhof toejuiching: "Zonder overigens op het werkplan des Ministers vooruit te willen loopen, wees men in de Tweede Kamer 'op het in vele opzichten gebrekkige onzer handelswetgeving; op het dienst- en werkbodencontract...; op de rechten van de gehuwde vrouw, die in onze wetgeving niet genoegzaam zijn gewaarborgd; op de vele leemten, die in het Wetb. v. Burg. Rechtsvord. bestaan; ook op het erfrecht van den langstlevenden echtgenoot ab intestato.'"

214. W $7381(1900)$. 
De Regering bleef echter doof voor deze kritiek. De desillusie hierover werd het treffendst geillustreerd door de Staatscommissie van 1887, die als een van de verklaringen waarom het werk aan het ontwerp voor het tweede Boek elf jaar in beslag moest nemen, wees op "de tot hare teleurstelling waargenomen omstandigheid, dat de Regeering gedurende velen jaren blijk gaf in het werk der vorige Staatscommissie geene aanleiding te vinden tot het indienen van wetsvoorstellen. "215

Interessant is overigens dat de Staatscommissie uitdrukkelijk aangaf in partiële herzieningen van met name het verbintenissenrecht geen heil te zien. Ofschoon een herziening van de bepalingen omtrent "de huur en verhuur van diensten" met het oog op de veranderende arbeidsverhoudingen dringend gewenst was, kwam het de commissie "toch niet gewenscht voor een greep te doen in het verbintenissenrecht en regelen vast te stellen voor een onderdeel van de overeenkomsten van huur en verhuur, terwijl noch van het vaststellen van beginselen omtrent deze overeenkomsten in het algemeen en nog veel minder van algemeene beginselen omtrent de overeenkomsten sprake had kunnen zijn." 216 Uiteindelijk kwam het daar zeven jaar later toch van, omdat de regeling van de arbeidsverhoudingen niet langer uitstel kon lijden. ${ }^{217} \mathrm{Om}$ dezelfde reden ging de commissie ook voorbij aan een wenk, gedaan in het Voorlopig Verslag bij de begroting van 1891, om in de eerste plaats aandacht te besteden aan een herziening van artikel 1638 van het Burgerlijk Wetboek.

\section{Minister en Kamer}

Vanzelfsprekend betekende de forse kritiek van de Staatscommissie, Kamerleden en hoogleraren - Land schreef een 236 pagina's tellende monografie over het Ontwerp voor Boek 2 - dat een Minister naar andere wegen moest zoeken om zijn geringe inspanningen op wetgevend gebied te rechtvaardigen. Die argumenten waren echter in ruime mate voorhanden.

Aangezien vrijwel elk jaar bij de behandeling van de begroting het denkbeeld werd bepleit om met gebruikmaking van de ontwerpen althans in de voornaamste leemten en gebreken van het B.W. te voorzien, is het vrij eenvoudig de verschillende argumenten te bestuderen. Zij zijn in twee groepen te scheiden. Het ene soort argumenten komt erop neer dat één en ander niet binnen het werkplan valt, een eufemistische uitdrukking die moet verhullen dat men het werk van de ambtsvoorganger niet wil voortzetten, hetzij omdat het onderwerp in strijd is met de politieke uitgangspunten van de nieuw aangetreden Minister, hetzij omdat het buiten zijn interessesfeer of intellectuele capaciteiten valt. De andere categorie argumenten heeft betrekking op de omslachtige werkwijze van de Kamer en komt erop neer dat de Minister niet het nut inziet van het indienen van uitgebreide wetsontwerpen, wanneer op voorhand vaststaat dat bij de Kamer óf de tijd óf de wil ontbreekt de ontwerpen in behandeling te nemen. 215. Aanbiedingsbrief Ontwerp Staatscommissie Burgerlijk Wetboek, Boek II, Den Haag 1899, p. IV
en V.

216. Aanbiedingsbrief Ontwerp Staatscommissie Burgerlijk Wetboek Boek II, p. I e.v.

217. Wet van 13 juli 1907, S. 193 . Daaruit blijkt tevens, dat wanneer de politieke wil er is, de weg snel gevonden wordt. 
Een voorbeeld van het eerste argument vindt men in de Memorie van Antwoord voor het begrotingsjaar 1901, waarbij mijns inziens duidelijk sprake is van onwil van de zijde van het Ministerie. In het Voorlopig Verslag hadden enkele leden aangedrongen op herziening van het eerste en het tweede Boek van het B.W. Zij wezen er daarbij op dat bij deze herzieningen dankbaar gebruik zou kunnen worden gemaakt van de "uitnemende" ontwerpen van de Staatscommissies. De behandeling daarvan zou, volgens deze Kamerleden, niet zoveel tijd en de toepassing niet zoveel moeite kosten als van de ontwerpen van het Ministerie zelf, "die, wat de redactie betreft, bijna alle schromelijk ingewikkeld en moeilijk verstaanbaar zijn. "218

De Minister wond er in de Memorie van Antwoord geen doekjes om. In de eerste plaats werd zonder opgaaf van redenen geconstateerd, dat de tijd voor een dergelijke herziening nog niet was aangebroken. Dat De Vries en Modderman, tal van hoogleraren en de NJV er anders over dachten, was kennelijk niet in tel. In de tweede plaats liet de Minister weten dat een dergelijke herziening veel meer tijd zou kosten dan door de Kamerleden werd voorgesteld, daargelaten de uitnemende kwaliteit van de voorontwerpen en de nadelen, verbonden aan partiële herzieningen: "Of de wijze van behandeling gunstig afsteekt bij de ontwerpen die in den laatste tijd het Departement van Justitie verlaten, mag de Minister niet beoordelen. Waar men er echter over klaagt dat deze ontwerpen, wat de redactie betreft, bijna alle schromelijk ingewikkeld en moeilijk verstaanbaar zijn, veroorlooft hij zich de vraag of men zich voldoende rekenschap heeft gegeven van het feit dat deze ontwerpen wijzigingen betreffen die moesten worden ingevoegd in en aangepast aan wettelijke bepalingen die veelal noch in zichzelf noch in haar verband door helderheid uitmunten." 219 Men begrijpt, deze Minister was nog met geen tien paarden in beweging te krijgen.

Een goed voorbeeld van de tweede soort argumenten levert een discussie tussen Minister Regout en de Tweede Kamer in 1912. De aanzet daarvoor was een passage in het Voorlopig Verslag, waarin, overigens in uiterst gematigde bewoordingen, het beleid van de Minister op wetgevend gebied aan de kaak werd gesteld. Regout had volgens enkele leden op justitieel gebied nog weinig belangrijks tot stand gebracht. Voorts werd hem kortzichtigheid verweten, omdat hij bij zijn werkplan slechts aandacht had voor het werk dat hij dacht te verrichten binnen zijn ambtsperiode, maar geen acht gaf op hetgeen hij aan zijn opvolger zou kunnen overdoen. Tenslotte werd door een aantal leden tot hun spijt geconstateerd, dat de reeds jaren geoefende aandrang om partiële wijzigingen, van betrekkelijk eenvoudige aard in het B.W. aan te brengen, tot dusverre weinig resultaat had gehad:

"In de laatste jaren is bij de behandeling van de begrooting herhaaldelijk het denkbeeld bepleit om door partieele wijzigingen, van nauw begrensde strekking, in verschillende erkende leemten en gebreken van het Burgerlijk Wetboek te voorzien. De Minister bleek daarvoor niet veel sympathie te gevoelen en voerde o.a. in de Memorie van Antwoord betreffende de begrooting voor 1912 aan, dat naar zijn meening de herziening van de wetsbepalingen, welke door de voorstanders van het denkbeeld vaak in de eerste plaats plegen te worden genoemd, zou blijken niet van zoo eenvoudigen aard te zijn als het gewoonlijk wordt voorgesteld. 
Verschillende leden verklaarden het te betreuren, dat de Minister heeft gemeend dit standpunt te moeten innemen en dat, dientengevolge, de ontwikkeling van ons burgerlijk recht zoo goed als geheel stil ligt (...). Op sommige punten van burgerlijk recht kan de rechtspraak ten deze baat brengen, door de interpretatie der wet te doen aansluiten aan de nieuwe maatschappelijke behoeften, maar - daargelaten nog de vraag, of zulk een wijze van rechtsontwikkeling wel geoorloofd of gewenscht mag heeten - het is duidelijk, dat ten aanzien van verreweg de meeste onderwerpen, welke aan gewijzigde rechtsregelen dringend behoefte hebben, de rechtspraak geen hulp kan bieden.

Erop wijzende, dat in de jongste vergadering van de Nederlandsche Juristenvereeniging de groote meerderheid zich ook heeft verklaard voor het stelsel van partieele herziening van het Burgerlijk Wetboek, wenschten bovenbedoelde leden daarom nogmaals het voormelde denkbeeld in 's Ministers overweging aan te bevelen. "220

Regout kon deze opmerkingen vanzelfsprekend niet over zijn kant laten gaan en antwoordde "met groote felheid" dat de kritiek op zijn beleid geheel misplaatst was:

"Deze opmerking, die blijkens het opschrift van dien passus niet een klacht bedoelt over beweerden tragen loop der parlementaire werkzaamheden op dit gebied, doch de strekking heeft van kritiek op het beleid van den Minister, houdt inderdaad zóó weinig rekening met de feiten, dat de ondergeteekende niet had kunnen verwachten, dat deze leden, indien zij zich de moeite hadden willen getroosten na te gaan, welke beloften door den ondergeteekende zijn afgelegd en hoe die zijn vervuld, daaruit stof zouden putten voor een min gunstig oordeel. "221

Voor de afdoening van reeds voorbereide wetsontwerpen voelde hij niet, aangezien

"de toevoeging van zoodanig nieuw ontwerp thans aan de lange lijst, die op afdoening door de Tweede Kamer wacht, een doelloos, zelfs schadelijk stelsel zoude zijn. Of gevoelt men niet, dat een al te groote overlading van den legislatieven disch, waarvan verreweg het grootste deel nog in verre toekomst schijnt niet te kunnen worden aangeroerd, er toe moet leiden, dat tal van wetsontwerpen hunne frischheid verliezen en reeds sporen van veroudering vertoonen, voordat zij het zelfs gebracht hebben tot een volledig onderzoek?"222

Geïrriteerd merkte hij vervolgens op, dat hij wel degelijk rekening hield met zijn opvolger. Dat hij gedurende dit laatste jaar van zijn parlementaire leven geen nieuwe plannen ontwikkelde, kwam omdat

"hetgeen reeds nu gereed is en wordt voorbereid, indien de Kamer dit inderdaad in behandeling wenschte te nemen, reeds meer dan genoeg zou zijn, om nog ten 
minste gedurende twee nieuwe parlementaire perioden de gansche openbare werkzaamheid van een Minister van Justitie te vullen. ${ }^{223}$

Met betrekking tot de wens tot herziening van het Burgerlijk Wetboek deelde de Minister mee, dat hij

"vooralsnog geene aanleiding kan vinden stappen te doen tot het instellen van eene commissie tot voorbereiding van de herziening van het geheele Burgerlijk Wetboek of van bepaalde gedeelten daarvan. Waar de voorraadschuur der wetgevende macht thans reeds zoo overvol is, zou de arbeid eener nieuwe commissie ernstig gevaar loopen het lot te deelen der ontwerpen van vorige staatscommissiën tot herziening van gedeelten van het Burgerlijk Wetboek en te verouderen, voordat hij door den wetgever kon worden ter hand genomen. "224

In wezen komen alle argumenten van Regout erop neer dat het geen zin heeft om aan herziening te denken alvorens de Kamer zich niet eerst verplicht zou voelen om voortvarender te werken, een klacht die door R.A. Fockema eens als volgt onder woorden werd gebracht: "Voor eenige jaren had ik over dit onderwerp een gesprek met een vroegeren Minister van Justitie, mede in verband met de vraag in hoever het wenschelijk was, dat uit de rechterlijke macht gegevens zouden worden verschaft, welke stof konden leveren tot wetsherziening. Zijne Excellentie verklaarde, dat aan dergelijke stof allerminst behoefte bestond, dat het hem groote moeite kostte om van de Tweede Kamer eenige dagen in het jaar te krijgen tot behandeling van justitieele onderwerpen. Zijn aanbod was dus altijd te groot. Behoefte aan stof tot vermeerdering van aanbod was derhalve buitengesloten." ${ }^{225}$ Zou Fockema met Regout hebben gesproken?

Tijdens de mondelinge behandeling was Regout zo mogelijk nog scherper en gaf hij uitdrukkelijk te kennen niet met een dergelijk wetsontwerp te komen, voordat de Kamer zich verplicht zou voelen het Reglement van Orde een belangrijke wijziging te laten ondergaan.

Het Weekblad wist geen redelijke verklaring voor Regouts uitval te geven en weet zijn prikkelbaarheid aan de geringe medewerking van de Kamer bij de behandeling van wetsvoorstellen, die zodra een Ministerwisseling plaatsgrijpt, wellicht weer worden ingetrokken: "Reeds verleden jaar beklaagde hij zich over de geringe medewerking van de Kamer (...). Mochten de aanstaande verkiezingen aan de ministerieele loopbaan van den Minister een einde maken, dan zal het hem dus wel niet gegeven zijn ontwerp zelf voor de Kamer te verdedigen en wat zijn opvolger er meê doen zal, is zeker in hooge mate twijfelachtig. Dat zoo iets onaangenaam is voor een bewindsman, die hart heeft voor zijne zaak, (...) is begrijpelijk. "226

223. W 9389 (1912). Het citaat vervolgt: "De bewering, door sommige leden uitgesproken, als zouden verscheidene ontwerpen, die dringend voorziening eischen, nog steeds niet zijn aangevat, mist niet slechts allen grond, maar spreekt een oordeel uit over den wetgevenden arbeid binnen zijn Departement, waartoe die leden alle recht en wetenschap missen."

224. W 9390 (1912).

225. R.A. Fockema, Varia, Haarlem 1915, p. 11.

226. W 9396 (1912). 


\section{Andere oorzaken ter verklaring van de geringe wetgevingsactiviteit}

Het is achteraf moeilijk vast te stellen welke factor het meest bepalend is geweest voor de "nagenoeg volkomen stilstand van onze burgerlijke wetgeving. "227 Voor een Minister die meer lette op het "beleid" dan op de wetgeving, was de werkwijze van de Kamer in ieder geval een voldoende alibi om zich te onthouden van serieuze pogingen op wetgevend gebied: "De staatkundige debatten, de algemene gedachtenwisseling over groote hervormingen, de critische bespreking van bestuursmaatregelen nemen meer en meer de tijd van Regeering en Staten-Generaal in beslag. Bij Ministeries en Departementen dreigt zelfs een gevoel van berusting post te vatten; waarom zouden wij ons afsloven, uitgebreide wetsontwerpen voor te bereiden en in te dienen, wanneer de Staten-Generaal blijkbaar toch niet ertoe komen, ze af te doen?"228 Bovendien, de wetenschap, dat wat men als Minister ook voorstelt, "men altijd veel blaam en weinig dank oogst, moet de animo bij menig lid der Regeering wel eens doen verslappen. Is het een zaak van eenig gewicht, dan weet de Minister haast wel vooruit, dat het ontwerp een deel van de Kamerleden te ver, een ander deel niet ver genoeg gaat. En wat men vooral begrijpen kan dat hem tureluursch maakt is de met tergende regelmatigheid terugkeerende grief, dat de Minister niet in plaats van de meer algemeene een partieele en niet in plaats van de partieele later een meer algemeene regeling of herziening heeft voorgedragen, m.a.w. dat hij òf te veel heeft gedaan òf te vlug is geweest!" 229

Tevens moet men bedenken dat de produktie van wetten in hoofdzaak voor rekening van de Minister zelf kwam, tenzij hij het geluk had een ontwerp te kunnen uitbesteden aan een bevriende hoogleraar. ${ }^{230}$ De toelichting bij de begroting voor het jaar 1896 vermeldt bijvoorbeeld dat $\mathrm{f} 4.000,--$ zal worden uitgetrokken voor het in dienst nemen van een jurist, die uitsluitend zal worden belast met wetgevende arbeid, iets waarvoor - gelet op de vele andere taken van de eerste afdeling ${ }^{231}$ - weinig tijd was.

227. Aldus Molengraaff, Rechtsgeleerd Magazijn, 1903, p. 226.

228. Rechtsgeleerd Magazijn, 1910, p. 151.

229. J.P. Fockema Andreae, De kunst van wetgeven op en om het Binnenhof, Utrecht 1913, p. 6263.

230. Wellicht vormt het feit, dat de wetgevingsambtenaren met een zekere beweterigheid neerkijken op produkten van buitenstaanders, ook een verklaring voor de traagheid van het wetgevingsproces. Meijers, maar ook Molengraaff heeft met dit probleem te maken gehad. Men vergelijke verder de beschouwingen van J.H. Beekhuis, "Herinneringen aan mijn werk voor het nieuwe B.W.", Zwolle 1984, p. 325 e.v. en de uitlating van de Savornin Lohman naar aanleiding van Molengraaffs harde woorden aan het Departement van Justitie; "Voor een niet gering deel schrijf ik dit (de laksheid van Justitie) toe aan de ambtenaren die de departementen samenstellen. Van allerlei kanten hoort men klachten dat zij niet of verkeerd meewerken, het altijd beter weten en de incarnatie zijn van ..... zij lieten de zaak zoals het was." Geciteerd uit: Rechtsgeleerd Utrecht, Zutphen 1986, p. 118.

231. De taak van de - in 1895 uit zes man bestaande - Eerste Afdeling bestond uit: Burgerlijk en Handelsrecht; Rechterlijke organisatie; Verenigingen en naamloze vennootschappen; Verzoeken om dispensatie, meerderjarigverklaring, wettiging, naamsaanneming; Naturalisaties; Consulaire wetgeving; Wetgeving op het notariaat; Uitvoering van de wet tot regeling van het auteursrecht en beheer van de drukwerken, ingevolge die wet ingezonden; Rogatoire commissies; Buitenlandse dagvaardingen; Adelszaken; Zaken betreffende de erediensten, voor zover de behandeling daarvan ingevolge het K.B. van 29 oktober 1870 (S. 173) bij het Departement van Justitie behoorde. 
Ook de figuur van de Regeringscommissaris (art. 110 Grondwet) bood in dit opzicht geen werkelijke verlichting, waarschijnlijk als gevolg van een gebrek aan "zedelijke moed" van de achtereenvolgende Ministers. De vrees bestond dat de Kamer, maar ook het grote publiek, het inschakelen van een dergelijk figuur als een gemis aan zelfvertrouwen zou beschouwen.

De belangrijkste factor voor de trage voortgang van de wetgeving lag mogelijk toch echter bij de Kamer. Drucker schreef in 1907: "Ook elders klaagt men, doch zoo ernstig als in Nederland is de kwaal in weinige staten." En ofschoon in het begin van de twintigste eeuw op sommige terreinen belangrijke wijzigingen tot stand kwamen (faillissementsrecht, arbeidsovereenkomstenrecht), stuitte zelfs de meest wilskrachtige Minister vaak op haar onverwrikbare werkeloosheid, veroorzaakt door de naar huidige maatstaven onontwikkelde parlementaire vormen.

Zo stelde nog in 1917 het Kamerlid J. Limburg dat 'eene stervende Kamer niet meer aan zou kunnen dringen op maatregelen van wetgeving, die zij toch niet kon helpen vaststellen. ${ }^{232}$ Verder kan worden gewezen op het gebrek aan wetgevingstraditie en vooral, de afwezigheid van belangstelling voor wetgeving die buiten de politieke belangstelling lag, zoals grote delen van het vermogensrecht. Want zonodig bleek de Kamer in die gevallen wel snel te kunnen werken, zoals met betrekking tot de Kinderwetten, die in één dag de Eerste Kamer passeerden. ${ }^{233}$

\section{Wetgever of rechter?}

Hadden we derhalve in het begin van de twintigste eeuw te maken met 'eene zeer langzaam, omslachtig en onvoldoende functioneerende wetgevende machine', ook de wetenschap, 'weinig practisch getint, enigszins lusteloos' en de rechterlijke macht 'zich om rechtsovertuiging en behoeften, die in de maatschappij opdoemen, nauwelijks bekommerend', vormden nog steeds geen gezonde loten aan de juridische boom. ${ }^{234}$

Wellicht doet dit oordeel, opgetekend in Fockema Andreae's boekje "Moderne Preatuur?" hard aan, feit is dat het geen enkel protest opriep, ja alleen bijval oogstte. Zo schreef de recensent in het Weekblad: "Er moet een middel gevonden worden, om tot hervorming te komen van het steeds meer verouderende recht." ${ }^{235}$ In het Rechtsgeleerd Magazijn tekende Drucker aan: "Doch, helaas, wie zal durven beweren, dat ze (deze karaktertekening) onjuist is? Wie zal durven ontkennen, dat zich inderdaad in Nederland de symptomen voordoen, die Schrijver (..) aanwijst?"236 Kortom, rond 1900 was men vrij algemeen van mening dat er een middel

232. Zie W 10047 (1917).

233. Vergelijk ook WPNR 2511 (1918): "De groote meerderheid van onze juristen van de eersten rang, zal ons kunnen vertellen dat een vertoog, welsprekend, vleiend, dreigend, niet helpt. Men moet aan de zaak een politiek tintje geven. Zie de wordingsgeschiedenis van de Wet op het Handelsregister. Het had er in geen jaren kunnen komen, wanneer niet ontdekt ware, dat met dit register politieke oogmerken konden worden bereikt."

234. Ontleend aan J.P. Fockema Andreae, Moderne Praetuur? Beschouwingen over het jongste verleden en de naaste toekomst van wetstoepassing en rechtshervorming, Haarlem 1907, p. 138.

235. W 8613 (1907).

236. Rechtsgeleerd Magazijn 1908, p. 309 e.v. Zie ook Themis, 1908, p. 386 e.v. 
diende te worden gevonden om het recht te hervormen, en dat noch de wetgever, noch de rechtspraak daarvoor afzonderlijk voldoende waren gekwalificeerd.

Hoewel het legisme rond 1870 zijn hoogtepunt had bereikt met het verschijnen van de commentaren van Diephuis en Opzoomer en alle kwesties die mogelijk zouden rijzen bij de interpretatie van het B.W. hun plaats gekregen hadden in deze standaardwerken, betekende dit dus niet dat deze wijze van benadering van het recht snel verdween. Wat wel verdween, was het zelfstandige bronnenonderzoek, nu het oplossen van een probleem kon worden beperkt tot het zorgvuldig bestuderen van de diverse opinies die de grote uitleggers erop na hielden.

Vanzelfsprekend had men meestal geen vrede met de op deze wijze verkregen oplossingen. Hingst, lid van de Hoge Raad, schreef in 1885: "De ongeoorloofde dwang der wetboeken is ongehoord (...). Men leert onzuiver denken, omdat de wet aan hetzelfde woord meer dan eene en zelfs tegenstrijdige betèkenis toekent, en men genoodzaakt is taal en voorstelling der wet te volgen. Men wordt soms genoodzaakt onrecht te spreken, omdat de wet bij het detaillèren de beginselen zoodanig uit het oog verliest, dat ze verkregen rechten schendt. ${ }^{\text {"237 }}$ Opvallend is echter, en wellicht is dat wel één van de belangrijkste kenmerken van het legisme, dat men tegen beter weten in zijn hoop bleef stellen op de wetgever.

Zo verwachtte de omstreeks 1884 aangetreden lichting van zes nieuwe hoogleraren in het Recht (Moltzer, Molengraaff, Cort van der Linden, D'Ablaing, Drucker en Hamaker) nog alles van ingrijpende herzieningen - wegnemen van fouten in redactie, gebreken en het aanbrengen van de hoogst noodzakelijke aanvullingen en het ontwikkelen van een goede, ondubbelzinnige terminologie - . Het enige wat men van de afgelopen vijftig jaar had geleerd, was, zo lijkt het, dat de wetgever niet te zeer in details moet treden: "Om het in onnatuurlijke banden kluisteren van het recht te ontgaan en de moeiten van revisies te vermijden (is) vereenvoudiging der wettelijke bepalingen het beste $(\ldots)$, terwijl de goede uitwerking verder aan eene theoretisch en praktisch ontwikkelde magistratuur veilig kan worden overgelaten. "238

De grammaticale en wetshistorische interpretatie bleef dus centraal $\operatorname{staan}^{239}$ en voor jurisprudentiële rechtsvorming was over het algemeen weinig oog. Aanvankelijk besteedde de wetenschap vrijwel geen aandacht aan de lagere jurisprudentie, waardoor de ontwikkeling binnen de lagere rechtspraak om wel rechtsvormend op te treden,

\footnotetext{
237. Rechtsgeleerde Bijdragen en Bijblad, 1885, p. 30 e.v. (i.h.b. p. 48).

238. Rechtsgeleerde Bijdragen en Bijblad, 1885 , p. 75 e.v.

239. P.R. Feith, één van de leden van de Staatscommissie - Van Meerbeke en lid van de Hoge Raad, verwoordde dit standpunt als volgt: "Kritiek is uitstekend als middel om tot verbetering van onjuiste of verouderde voorschriften te komen; maar, als men zich te veel daarmede bezighoudt, vergeet men zoo licht, dat die verbetering zelve zich nog wel wat zal laten wachten, en, als zij komt, zeker de een evenzeer mishagen zal als zij door den ander zal worden toegejuicht. Inmiddels is onze taak het bestaande recht zoo goed mogelijk toe te passen, en dit kan het best bevorderd worden, als men zich onbevangen afvraagt, niet, wat naar de bijzondere meening van dezen of genen billijk of rechtmatig wezen zou, maar wat de wetgever heeft gewild. Leveren zijne woorden aanvankelijk zwarigheden op, dan is het beter moeite te doen om ons te verplaatsen in de voorstellingen en opvattingen, die bij onze oude juristen golden, en allicht eene oplossing zullen geven, dan terstond gereed staan om den staf te breken over hetgeen ons minder duidelijk voorkomt." (Themis, 1891, p. 180).
} 
haar volkomen ontging. ${ }^{240}$ Zo beperkte het tijdschrift "Bijdragen" zich hoofdzakelijk tot het opnemen van een verkorte weergave van uitspraken, die bovendien meestal afkomstig waren van praktijkjuristen die reageerden op de keer op keer herhaalde oproepen om "opmerkelijke" arresten toe te sturen. ${ }^{241}$ Pas in 1876 ging het Bijblad ertoe over korte "annotaties" te verzorgen, die niet meer dan enkele regels telden en zich voornamelijk beperkten tot opmerkingen in de trant van "een aantal keren is reeds een soortgelijke uitspraak gegeven."

Hoewel deze "annotaties" waren bedoeld "als middel om het kwaad eener tegenstrijdige en weifelende Jurisprudentie zooveel mogelijk tegen te gaan, (door) de vrijmoedige beoordeling en onderlinge vergelijking der rechterlijke uitspraken en hare toetsing aan de resultaten der wetenschap ${ }^{1242}$, heb ik de indruk dat én rechtspraak én wetenschap er zich maar weinig aan gelegen lieten liggen. In ieder geval klaagde Molengraaff tot op het einde van de negentiende eeuw keer op keer dat

"niets (..) meer moeite (kostte) dan medewerking te vinden bij het streven om de resultaten der rechtspraak aan eene wetenschappelijke kritiek en onpartijdige bespreking te onderwerpen, en toch, welke practicus zal het niet beamen, bestaat daaraan ten onzent groote behoefte. Aan eene zoo belangrijke factor voor de rechtsontwikkeling als de rechtspraak wordt tot heden nog altijd niet die belangstelling gewijd, welke zij zoo ruimschoots verdient. "243

Illustratief is ook, dat in de handboeken van die dagen vrijwel geen jurisprudentie was verwerkt. Meijers schreef daarover: "Opzoomer vermeldt in zijn 992 bladzijden, die aan de algemeene leer der verbintenissen en overeenkomsten zijn gewijd, slechts één arrest van den Hoogen Raad, beslissend, dat de zaakwaarnemer geen retentierecht heeft. Diephuis geeft in zijn twee deelen, die zich met dit gedeelte van het recht bezighouden, iets meer, maar toch volgens tegenwoordige begrippen uiterst weinig rechtspraak; 20 arresten van den Hoogen Raad, 12 van Hoven en 43 vonnissen van rechtbanken - waarvan 10 uit Groningen - worden aangehaald." 244

Vanzelfsprekend kon deze toestand niet altoos voortduren. De onvrede over de trage voortgang van de wetgeving, de niet aflatende pleidooien van Molengraaff, de schrikbarende veroudering van onze wetboeken, zij leidden er uiteindelijk toe dat er omstreeks de eeuwwisseling in de wetenschap een stroming ontstond die zich meer ging interesseren voor ontwikkelingen in de rechtspraak. ${ }^{245}$ Aanvankelijk was het

240. Men moet van deze ontwikkeling geen overdreven voorstelling hebben. Nog in 1908 verklaarde de president van de Rechtbank te Groningen dat artikel 13 Wet Algemene Bepalingen de rechter zou verbieden de verouderde Burgerlijke Wetgeving buiten toepassing te laten, zodat de klacht dat de rechter de wet toepast, maar niet het recht ongegrond is, en alleen als verwijt tegen de wetgever gekeerd mag worden.' Themis, 1908, p. 392.

241. De rechterlijke macht had vroeger kennelijk minder reden om "ijdel" te zijn. Zie NJB 1988, p. 1003 e.v.

242. Voorbericht Regtsgeleerd Bijblad 1877.

243. Rechtsgeleerd Magazijn, 1887 , p. $00 ; 1889$, p. 37. Sinds \pm 1918 is sprake van een systematische becommentariëring.

244. E.M. Meijers, De honderdjarige burgerlijke wetgeving, V.P.O. I, p. 143.

245. Men zie de discussie tussen Treub, De Pinto, Hamaker en Land in het WPNR in de jaren 18941897. Vergelijk ook P.C. Kop, Legisme en Privaatrechtswetenschap, Deventer 1992, p. 54 e.v. 
echter, volgens Fockema Andreae, een wat ondergrondse beweging, aangezien de Hoge Raad duidelijk liet blijken vast te willen houden aan het primaat van de wet. ${ }^{246}$ In 1904 gaf bijvoorbeeld Coninck Liefsting, president van de Hoge Raad, nog onomwonden te kennen dat het zijn taak was om "zoowel met de zuivere logische deductie uit de woorden der wet, als met hare beginselen, uit het algemeen rechtsstelsel en uit de historische vorming af te leiden, ten einde voor elke wetsbepaling haar ware betekenis en tegelijk haar juiste begrenzing nauwkeurig vast te stellen. "247 In 1910 werd dat standpunt nog eens onderschreven door het geruchtmakende arrest van de Hoge Raad inzake de Zuthpense Juffrouw. ${ }^{248}$

\section{De Nederlandse Juristen-Vereniging in 1912}

Zoals hierboven al ter sprake kwam, boog de NJV zich in 1912, voor de tweede maal in haar bestaan, over de vraag "welke methode behoort te worden gevolgd bij de herziening van ons Burgerlijk Recht". Ofschoon reeds uit deze vraagstelling kon worden opgemaakt dat niet de wenselijkheid van een algehele herziening, doch slechts de daarbij te volgen methode centraal stond, beperkte het debat zich hoofdzakelijk tot het eerste aspect.

De eerste prae-adviseur, J.P. Fockema Andreae, verdedigde het standpunt dat een algehele herziening, gelet op de vele fouten, leemten en gebreken die aan het B.W. kleefden, noodzakelijk, maar onbereikbaar was. De wetgevingstechniek zou nog te weinig ontwikkeld zijn en bovendien zou er onvoldoende zijn gedaan aan een kritische en systematische bewerking van de bouwmaterialen voor het nieuwe wetboek, waarbij hij met name doelde op het onderzoek naar de voortbrengselen van de rechtspraak. Naar zijn mening zou de wetgever bovendien nog onvoldoende inzicht hebben in het "levende" recht, terwijl dit als gevolg van de snelle maatschappelijke ontwikkelingen nog niet rijp zou zijn voor optekening. Wanneer na verloop van tijd deze bezwaren uit de weg geruimd zouden zijn, kon met de algehele herziening worden begonnen. In de tussentijd zou de rechter corrigerend kunnen optreden door middel van een vrije wetsinterpretatie, en waar deze tekort zou schieten, zouden partiële verbeteringen van beperkte strekking of afzonderlijke wetten de noodzakelijke verbeteringen en aanvullingen in het bestaande recht dienen aan te brengen. Kortom, Fockema Andreae ontkende de noodzakelijkheid van een algehele herziening niet, maar vond dat juridisch Nederland er eigenlijk nog niet voldoende op was voorbereid.

E.E. van Raalte, de tweede prae-adviseur, ging er, mede gelet op de vraagstelling van het bestuur, vanuit dat de noodzaak tot een algehele herziening niet behoefde te worden betoogd. Hij bepaalde zich daarom tot de vraag welke methode daarvoor het meest geschikt was. Met in zijn achterhoofd de wetenschap dat eenmansarbeid verre viel te verkiezen boven het werk van Staatscommissies of Departement - kort na zijn aantreden als Minister van Justitie in 1905 had deze van origine Rotterdamse advocaat

246. Beeldend is ook de volgende uitspraak van Gerbrandy, gedaan tijdens de vraagpuntenprocedure in 1952-1953: "Ik herinner mij nog de uitlating van een van mijn leermeesters, toen hij het had over de "Moderne Praetuur?" van Fockema Andreae: 'En nu zijn er blijkbaar ook nog mensen, die de stelling verdedigen, dat de rechter toch wel enigszins van de wet kan afwijken.'” (Handelingen Tweede Kamer 1952-1953, p. 2867).

247. W 8047 (1904).

248. HR 10 juni 1910 , W 9038 (1910). 
aan Molengraaff de opdracht gegeven om de herziening van het Zeerecht voor te bereiden, een opdracht aan welke deze binnen twee jaar voldeed - kwam hij tot de volgende aanbeveling: "Aan één rechtsgeleerde worde de samenstelling opgedragen van een voor-ontwerp. Nadat dit voltooid en openbaar gemaakt is, worde het ter fine van advies in handen gesteld van eene, door den Minister benoemde uitgebreide deskundigen-commissie (niet uitsluitend uit juristen bestaande en waarin ook de verschillende richtingen vertegenwoordigd zijn) die het, in samenwerking met den ontwerper nader in behandeling neemt. Met de eindredactie der, ingevolge het overleg met de commissie noodig geachte, veranderingen, blijve de ontwerper belast. Ook het gewijzigd ontwerp, eventueel met het verslag der commissie, worde onverwijld publiek gemaakt." 249

In de discussie, die hierop volgde, bleef deze kwestie vrijwel geheel buiten beschouwing en ging het in eerste instantie vooral om de vraag of het, gelet op de parlementaire gebruiken en gewoonten, reëel was om op een algehele herziening te blijven aansturen. Want dat een algehele herziening hoogst wenselijk was, werd slechts door een enkele spreker betwist.

Terzijde merk ik op, dat de argumenten van Fockema, als zou de geringe ervaring met het grotere wetgevende werk en het gebrek aan goede juristen een voorname hinderpaal vormen voor een algehele herziening, in de discussie geen rol speelden. Dat is ook niet zo verwonderlijk, want de prae-adviseur had nog enkele jaren daarvoor beklemtoond dat de kloof tussen wet en recht in hoofdzaak viel toe te schrijven aan de lakse houding van de Tweede Kamer. "Geen wetgevend lichaam ook," zo schreef Fockema in 1907, "bleek minder geschikt voor omvangrijken, zuiver legislatieven arbeid dan een hedendaagsch parlement. ${ }^{n 250}$ En dat standpunt zou hij een jaar na het verdedigen van zijn prea-advies nog eens herhalen, door in zijn brochure "De kunst van wetgeven" van harte in te stemmen met een opmerking van Minister Heemskerk over het tempo van de wetgeving: "Dat bij al wat zorg eischt in ons openbaar leven, er niets is wat hem persoonlijk met zooveel zorg vervult als de ontzettende langzaamheid bij het tot stand komen van wetten, waaraan eigenlijk een ieder gevoelt, dat behoefte bestaat. "251

Niet voor niets richtte de kritiek van de meeste sprekers zich juist ten aanzien van dit punt op het prae-advies van Van Raalte, die geheel aan het probleem van de onwillige Kamer was voorbijgegaan. Loder, lid van de Hoge Raad, sprak er bijvoorbeeld zijn verwondering over uit, dat Van Raalte "er niet aan twijfelt dat zelfs met onze tegenwoordige volksvertegenwoordiging, zonder verandering van werkwijze een nieuw Wetboek ware tot stand te brengen. Ik breng een eeresaluut aan een zóó ongeschokt vertrouwen." ${ }^{\text {252; }}$ Van Geuns, Officier van Justitie, zei tot zijn spijt er de aandacht op te moeten vestigen "hoe juist in deze dagen een zekere angst bij ons allen opkomt over de vraag of het parlement wel berekend zal blijken te zijn voor de groote wetgevende taak, welke het in de volgende jaren te wachten staat. ${ }^{253}$ Focke-

249. HNJV 1912, p. 283 (pre-advies).

250. J.P. Fockema Andreae, Moderne Praetuur? a.w., p. 140.

251. J.P. Fockema Andreae, De kunst van wetgeven op en om het Binnenhof, a.w., p. 47. De uitspraak van Heemskerk is van 2 februari 1911 (Handelingen Eerste Kamer 1910-1911, p. 308).

252. HNJV 1912, p. 110.

253. HNJV 1912, p. 125. Zie voor soortgelijke uitlatingen, p. 116, 133, 139 en 148. 
ma tenslotte, merkte op, dat "de langzaamheid, waarmede de wetgevende machine werkt een zoo algemeen, sterk sprekend en tegelijk chronisch karakter" (had) aangenomen, dat het een illusie was om op korte termijn een algehele herziening te verwachten. ${ }^{254}$

Kortom, iedereen was er van overtuigd dat dat de mogelijkheid om op binnen afzienbare tijd een nieuw Burgerlijk Wetboek vast te stellen primair afhankelijk was de houding van de Kamer. Zou zij bereid zijn absolute prioriteit te verlenen aan de ontwerpen voor een nieuw wetboek, zou zij de herziening niet gebruiken om politiek te bedrijven, zou zij het recht van amendement spaarzaam gebruiken, zou zij de Minister in bescherming nemen tegen de kritiek uit wetenschappelijke hoek, die ongetwijfeld zou losbarsten? De ervaring, opgedaan met de ontwerpen van de Commissie-Van Meerbeke, maakte het antwoord op die vraag niet twijfelachtig.

Dit betekende dat het debat zich al snel verplaatste naar het thema dat door Fockema Andreae was aangesneden, namelijk de vraag of de rechterlijke macht, tot het moment dat de wetgever eindelijk in actie zou komen, bereid en in staat zou zijn de zekerheid te geven die het wetboek niet meer bieden kon. Bij de beantwoording van deze vraag deed zich het opmerkelijke verschijnsel voor, dat - en dit blijkt ook uit de uitslagen van de stemming - alle sprekers deze vraag positief beantwoordden, met uitzondering van degenen waarvan deze wijze van taakvervulling werd verwacht.

Zo wilde Loder, raadsheer in het arrest van de "Zutphense Juffrouw", van vrije wetsinterpretatie niets weten; "Als men op die manier door den rechter wil laten doen wat des wetgevers taak is; en als men dan meent daarvoor den Nederlandschen rechter te kunnen vinden en op die wijze een herziening te kunnen voorbereiden, dan geloof ik vooralsnog dat men zich bedriegt. Als de wet den rechter niet meer tot wet is, waartoe dient ze dan?" ${ }^{255}$ Van Geuns zei: "Het (staat) voor mij vast, dat wij met de vrije rechtspraak het Burgerlijk Wetboek niet geheel in orde kunnen brengen en dat er grote leemten en gebreken over blijven." ${ }^{256} \mathrm{Rh}$. Feith, rechter en raadsheer in het nog te wijzen arrest Lindenbaum-Cohen, erkende dat de rechter een taak had op het gebied van de rechtsvorming, "maar wat onze rechters tot dusver nog niet hebben kunnen doen en ook in de toekomst niet zullen doen, dat is: met de gemakkelijkheid van hunne Fransche collega's heenstappen over bepaalde, positieve wetsbepalingen en te gaan noemen zwart, wat de wet als wit aanduidt (...). Hier is herziening de eenige oplossing." ${ }^{257} \mathrm{~S}$. Gratama, mede-verantwoordelijk voor de "Zutphense Juffrouw", meende "men zal er enkel langs den weg van jurisprudentie niet kunnen komen." 258 Du Mosch, rechter en daarvoor advocaat, zei, sprekend vanuit zijn ervaring als advocaat: "Wanneer men, zooals ik, de droevige gevolgen van dergelijke rechtsonzekerheid gezien heeft, daar zeg ik, nu hier wordt gepleit om zooveel mogelijk aan den rechter over te laten: laat liever alles zoveel mogelijk van te voren

254. HNJV 1912, p. 193 (prea-advies).

255. HNJV 1912, p. 114 e.v.

256. HNJV 1912 , p. 124.

257. HNJV 1912, p. 137. Feith vervolgde zijn betoog met de opmerking: "En nu kome men niet aan met partieele herziening, want daarvoor zijn de fouten te groot en te veel en zijn er ook te veel onvolkomenheden. Hier kan (...) alleen een generale herziening uitkomst geven. En komt het daarvan, dan ben ik overtuigd, dat onze rechters, (..) zich meer dan wie dan ook daarover zullen verheugen."

258. HNJV 1912, p. 146. 
geregeld zijn, dan weet men waar men aan toe is, anders wordt het dagelijksch leven onhoudbaar. "259

Kortom, van de rechterlijke macht en - meer in het bijzonder: de Hoge Raad -, mocht geen medewerking worden verwacht op rechtsvormend terrein. Die taak was uitsluitend aan de wetgever voorbehouden. ${ }^{260}$

Een laatste punt dat opvalt, is dat velen heil verwachtten van eenmanswerk, aangevuld met een kleine commissie. Fockema Andreae: "Ik blijf er dus bij, dat het maken van het ontwerp voor een verjongd Burgerlijk Wetboek moet worden opgedragen aan eene kleine commissie of liever nog aan één man, die den bijstand aanvaardt van deskundigen en het oor leent aan critiek. "261 Loder: "Neen, als men wil herzien, totaal en in eens, dan volgt men het advies van den heer Van Raalte: opdracht aan éénen man en behandeling van diens arbeid op de wijze zooals hij die in zijn prae-advies beschreef." 262 Gratama wilde een kleine commissie het levende recht laten onderzoeken, door grotere beginselen te laten vaststellen en lijnen aan te geven die het ontwerp moet volgen, waarna "de nadere redactie moet worden overgelaten hetzij aan één man, hetzij aan enkelen." 263 Van Raalte tenslotte zei: "Wanneer nu eerst een jurist van beteekenis benoemd is, die belast wordt met het ontwerpen van een nieuw Burgerlijk Wetboek, dan is daarmede reeds een gewichtige stap op den weg der herziening gedaan. "264

\section{Een pragmatische beslissing}

De conclusie waartoe de NJV kwam, is duidelijk. Het eerste vraagpunt "Behoort thans tot eene algemeene herziening van ons Burgerlijk Wetboek te worden overgegaan" werd met 57 tegen 28 stemmen ontkennend beantwoord. Daarmee won, althans voorlopig, de opportuniteit het van het principe. Want hoewel de gebreken van het B.W., maar ook van het wetboek van Koophandel en van Strafvordering niet meer ter discussie stonden, zag iedereen wel in dat een uitgebreide herziening, voor te bereiden door een Staatscommissie, voorlopig geen schijn van kans had. Weliswaar zou eenmansarbeid op dit punt uitkomst kunnen bieden, maar de ervaring die van Van Raalte met het "Ontwerp-Zeerecht" had gehad - zijn ambtsopvolger had geen interesse voor het wetsontwerp - zou toch ook tot nadenken moeten stemmen. ${ }^{265}$

\section{HNJV 1912, p. 154.}

260. Wanneer men de uitlatingen van de leden van de Hoge Raad achter elkaar zet, dan lijkt het mij onwaarschijnlijk dat, zoals G.E. Van Maanen (Onrechtmatige Daad, Aspekten van de ontwikkeling en struktuur van een omstreden leerstuk, Deventer 1986, p. 146) stelt, het arrest de Zutphense Juffrouw "kan worden begrepen als het testament van de oude president van de Hoge Raad Eyssell, die hier nog eenmaal ten strijde trekt tegen de steeds meer terrein winnende opvatting van Molengraaff." Zie ook F.C.J. Ketelaar, De schepping van het arrest Lindenbaum-Cohen, in: Kabaal in Holland, Arnhem 1993, p. 15-23.

261. HNJV 1912, p. 230 (pre-advies).

262. HNJV 1912, p. 112.

263. HNJV 1912, p. 149.

264. HNJV 1912, p. 178.

265. Van Raalte schreef naar aanleiding van die ervaring aan Molengraaff: "Men kan niet weten wat de heeren rechts onderling brouwen." Molengraaff zelf oordeelde later in zijn afscheidsrede: "Zijn opvolgers in het ambt wisten echter niet beter te doen, dan dit ontwerp bij te zetten in de archieven 
Het besluit om nog even te wachten met een algehele herziening, betekende dat de methode van partiële herziening in de visie van de NJV uitsluitend zou moeten worden bestemd om aanvullingen aan te brengen, opgedrongen door de actualiteit van het ogenblik, een afgerond geheel betreffend, niet om oude fouten uit de weg te ruimen. Want daarvoor werd de methode van herzieningen op beperkte schaal ten enen male ongeschikt geacht. Daarnaast zou de rechter een belangrijke rol moeten spelen bij het op de hoogte van de tijd houden van het wetboek. Hij mocht nu, overeenkomstig het votum van een meerderheid van de NJV, tonen wat hij kon. Dit vertrouwen op de vormende kracht van de rechtspraak was overigens weinig gegrond. Niet alleen waren de rechters er zelf weinig gelukkig mee, maar tevens doet deze, door Fockema Andreae uitgelokte uitspraak vreemd aan, indien men haar vergelijkt met zijn van slechts enkele jaren daarvoor daterende en onweersproken gebleven negatieve oordeel over diezelfde rechtspraak.

Achteraf bekeken, en de wijsheid achteraf schijnt bij dit soort zaken de enige wijsheid te zijn, gaven de uitkomsten van het debat in 1912 een goede voorspelling van wat er op wetgevend gebied zou gaan gebeuren. Zeer snel werd duidelijk dat een min of meer ingrijpende herziening van een van de wetboeken tot de absolute onmogelijkheden behoorde. Tussen 1913 en 1919 lag, mede als gevolg van de oorlog, de wetgeving op het gebied van het burgerlijk recht zelfs volledig stil en wie de vierjaarlijkse overzichten van de Nederlandse Wetgeving in het Rechtsgeleerd Magazijn opslaat, kan Molengraaffs klacht begrijpen, dat "het tijd (zal) worden te peinzen op andere middelen dan tot dusver werden aangewend, om die herziening (wie de gedeelten van het B.W. en W.v.K. wilde opsommen, welke dringend om herziening roepen, zou wel weten waar te beginnen, niet waar te eindigen) aan den gang te brengen en te doen slagen." 266

Opmerkelijk is dat zelfs de Kamer, de hoofdschuldige, deze mening was toegedaan. In het Voorlopig Verslag bij de begroting voor 1914 werd namelijk de instelling van een kleine commissie ter herstelling van kleine, maar ernstige gebreken, met klem aangeprezen "onder opmerking, dat een algemeene herziening van het Burgerlijk Wetboek in afzienbare tijd toch niet te verwachten is. "267 Hoewel de Minister zijn instemming betuigde met dit denkbeeld en zelfs de aspirant-leden in 1914 benaderde, kwam, als gevolg van de oorlogsdreiging, deze "Commissie tot voorbereiding van wetgevende arbeid" niet van de grond. De Eerste Wereldoorlog had zelfs een zo verstorende invloed op het functioneren van de Kamer, dat de Minister haar uitdrukkelijk moest opwekken "om de wetgevende arbeid toch niet geheel en al te sta$\mathrm{ken}^{\prime 268}$, terwijl in het Voorlopig Verslag van 1917 werd opgemerkt, dat hoewel er wensen bestonden op wetgevend gebied, geen nieuwe wetsontwerpen door de Kamer

265.

van het Departement. De zorg voor goed recht schijnt te onzent nooit haast te hebben." Ontleend aan: Rechtsgeleerd Utrecht, p. 123. Gelet op deze ervaringen is het dan ook begrijpelijk dat Molengraaff, wanneer hij een tiental jaren later door Heemskerk wordt uitgegenodigd om een ontwerp-antwoord op te stellen naar aanleiding van het uit 1910 daterende advies van de Raad van State betreffende het nieuwe Zeerecht, van de Minister de toezegging verlangt dat deze ook werkelijk tot indiening bereid is.

266. Rechtsgeleerd Magazijn, 1914, p. 216.

267. W 9543 (1913).

268. W 9716, (1914) 
in behandeling zouden worden genomen, teneinde de behandeling van de lange lijst van onafgedane wetsontwerpen niet verder te vertragen. ${ }^{269}$

Volgens het Weekblad was de codificatie tot stilstand gekomen: "De feiten spreken duidelijk ten bewijze van het onvermogen onzer wetgevende macht om eene hervorming op groote schaal van onze codificatie tot stand te brengen"270, een opvatting waarbij J.C. Frederiks zich in Themis aansloot: "Vrijwel algemeen is de opvatting, dat bij een codificatie er iets gedaan moet worden om het recht op de hoogte van zijn tijd te houden (..)." De richting waarbij men heil zoekt bij de wetgever, is volgens hem "voor de naaste toekomst althans feitelijk, in ons land de minst belangrijke, zoowel in den vorm van een gedeeltelijke als in de vorm van een algehele herziening. "271

Deze "ontzettende achterstand op justitieel wetgevend terrein", werd in hoge mate veroorzaakt door de Kamer, die duidelijk liet blijken geen belangstelling te hebben in wetgeving, omdat onderwerpen van politieke aard "ongemeene krachtsinspanning" vorderden. ${ }^{272}$ Keer op keer werd de begroting van Justitie in een avondzitting afgejakkerd, eenmaal tot zulk een duidelijk ongenoegen van Minister Heemskerk, dat deze sarcastisch verklaarde de Kamer niet te zeer te willen vermoeien met wetgevende arbeid. De Kamer zou dan meer tijd hebben om over belangrijker zaken te kunnen praten, zoals Financiën en Werkgelegenheid. ${ }^{273}$

Het is duidelijk dat onder deze omstandigheden de verbetering van het recht alleen door middel van de rechter kon geschieden. Een theorie stak daar niet achter. Het was eenvoudig een bittere noodzaak.

269. W 10015 (1916).

270. W 10001 (1916). Het 10000 e nummer was vrijwel geheel gevuld met klachten op dit terrein, waaronder Molengraaffs bekend geworden boutade over de rechtspraak met betrekking tot het zeerecht. Daarin sprak hij de hoop uit dat het verouderde wetboek in de nabije toekomst niet langer een gevaar voor de rechtsontwikkeling zou zijn, "omdat het niet langer als geldend recht zal worden beschouwd, maar als een eerbiedwaardige antikwiteit worden behandeld."

271. Themis, 1917, p. 391 e.v. Zie ook Themis, 1914, p. 325; W 10352 (1919). J.P. Cau noemt daar een viertal oorzaken voor het trage totstandkomen van wetten en wetswijzigingen. Zijn conclusie is dat de traagheid voornamelijk een gevolg van twee factoren: de voortdurende wisseling van ministers en het feit dat degenen die het ontwerp hebben opgesteld na de aanbieding daarvan meestal van hun taak worden ontheven: "De Minister, die de benoeming der commissie heeft uitgelokt en dus van de noodzakelijkheid der herziening doordrongen was, is bij de aanbieding van het ontwerp meestal afgetreden. Zijn opvolger voelt minder voor die herziening, meer voor eene andere herziening en benoemt daarvoor eene nieuwe commissie, welke verslag uitbrengt aan zijn opvolger, die ook dat ontwerp weer laat liggen." Cau stelt daarom voor én of meer leden van de commissie te belasten met de verdediging van haar ontwerp: "De taak van den Minister zal daardoor zeer worden vergemakkelijkt. Hij behoeft dan alleen te beoordelen, of hij zich met de strekking en de hoofdbeginselen van het ontwerp kan vereenigen, en kan verder de verdediging aan den regeerings-commissaris overlaten. Zoo noodig kan de regeerings-commissaris tijdelijk als raadadviseur aan het Departement worden toegevoegd om den Minister bij de voorbereiding van het wetsontwerp behulpzaam te zijn, waardoor de ambtenaren van het Departement niet aan hunne gewone werkzaamheden behoeven te worden onttrokken." Een voorstel dat later door Meijers en Donker in praktijk zou worden gebracht. 272. W 10366 (1919). Zie ook W 10066, 10067, 10159, 10173 (1917); W 10232 (1918); W 10345 , 10366 (1919).

273. W 10653 (1920). 


\section{De Staatscommissie-Wetgeving (in de wandeling Staatscommissie-Limburg) opgericht}

Geheel tegen de verwachtingen in vond er in 1919 een belangrijke gebeurtenis op wetgevend gebied plaats: de Staatscommissie tot wegneming van onjuistheden en aanvulling van leemten in de Nederlandsche burgerlijke wetgeving werd ingesteld.

Het denkbeeld tot oprichting van "de Staatscommissie met de lange naam" was afkomstig van de Amsterdamse advocaat mr. J. Kappeyne van de Coppello, een liberaal Eerste Kamerlid, kort na de Eerste Wereldoorlog. Zijn voorstel luidde als volgt: "Dat de Kamer besluite den heer Minister van Justitie uit te noodigen te willen bevorderen de benoeming van een Staatscommissie met opdracht aan te geven in en door de praktijk algemeen erkende onjuistheden en leemten in de huidige Nederlandsche burgerlijke wetgeving (het Burgerlijk Wetboek, het Wetboek van Koophandel en het Wetboek van Burgerlijke Rechtsvordering), die aan een goede rechtsbedeeling in de weg staan, en door eenvoudige partieele wetswijziging verbeterd en aangevuld kunnen worden. "274

In een pleidooi dat nog steeds de moeite van het lezen waard is, lichtte Kappeyne zijn voorstel toe door erop te wijzen dat het geen betoog hoeft "dat schier onze geheele burgerlijke wetgeving verouderd is", met alle bedenkelijke gevolgen van dien, "bedenkelijke gevolgen, waarover in alle klassen der maatschappij wordt gejammerd, en te recht gejammerd."

Ter illustratie verwees hij naar een circulaire van de vereniging "Handelsrecht" die gericht was "tot alle belangstellenden en belanghebbenden in den lande." In die circulaire, ondertekend door een aantal prominenten zoals Molengraaff ${ }^{275}$, Loder en oudMinister van Justitie Van Raalte, viel te lezen dat

"algemeen wordt toegegeven, dat ons Wetboek van Koophandel onherstelbaar verouderd is (...). Samengesteld met het oog op de verkeerstoestanden uit het begin der vorige eeuw en sindsdien nagenoeg ongewijzigd gebleven weet (het) nog niets van de moderne naamloze vennootschappen, van de tegenwoordige organisatie van den tusschenhandel, van het credietwezen van dezen tijd.(..) Het spreekt van vuurhouten zeilschepen voor de grote vaart, reederijen en mede-eigenaars in schepen, het aanleggen op stukgoederen, bodemerijen en andere afgestorven instituten."

Kappeyne, die deze circulaire als akte van beschuldiging kwalificeerde, stelde vervolgens "ik mag echter zonder vrees voor tegenspraak verklaren, dat het met het Burgerlijk Wetboek en het Wetboek van Burgerlijke Rechtsvordering even slecht is gesteld."

Een tweede factor die er zijns inziens voor zou pleiten een Staatscommissie in te stellen was de nadelige invloed die de gebrekkige wetgeving zou hebben op de procesgang. Hoewel die trage gang ook te wijten was aan de "sleur van de balie" en aan de zeer slechte bezetting van sommige rechtscolleges, "ik heb hierbij uit den aard der zaak allereerst het oog op de rechtbank te Amsterdam, die zeer hard werkt tegen

274. Voor deze en andere citaten: Handelingen Eerste Kamer 1919, 36e vergadering d.d. 6 juni 1919 , p. $526-530$.

275. Molengraaff was de oprichter van deze "pressiegroep". Zie W 10195 (1918). 
karig loon, die niet op hedendaagsche wijze "georganiseerd" is, een groot gevoel van waardigheid bezit en zich deswege niet wendt tot de wetgevende macht", werd die trage gang in hoofdzaak veroorzaakt door de zeer gebrekkige wetgeving, volgens Kappeyne.

Een derde "zeer bedenkelijk gevolg van die achterlijkheid (is) dat de rechter zich geroepen, ja verplicht acht, de wet uit te leggen en toe te passen niet zooals zij luidt, maar zooals zij, naar zijn mening, luiden moest." Daarbij wees Kappeyne op het bekende arrest van de Hoge Raad van 31 januari 1919 (Lindenbaum/Cohen) waarin de rechter de wetgever vooruitging: de rechtsoverwegingen van dit arrest zijn namelijk vrijwel gelijk aan de tekst van het wetsvoorstel tot aanpassing van artikel 1401 e.v. Burgerlijk Wetboek, zoals in januari 1911 ingediend bij de Tweede Kamer.

Kappeyne was geen voorstander van deze rechtstoepassing, omdat de justitiabele zijns inziens zou moeten kunnen weten wat recht is en niet afhankelijk mag zijn van het wisselende billijkheids- en rechtsgevoel van de rechter. Vervolgens gaf hij aan waarom in het verleden noodzakelijke wetswijzingen op het gebied van het burgerlijk recht zijn achterwege gebleven: belangrijke onderwerpen van politieke aard leggen zozeer beslag op de tijd van de Kamers, dat zij aan wijziging van de wetboeken niet meer toekomt.

In dit verband is het duidelijk dat de door hem voorgestelde commissie een praktische, en daardoor beperkte taak moet krijgen: "Zij moet de fouten opsporen, die bekend zijn aan een ieder die onze wetboeken als dagelijksch gereedschap bij zijn arbeid hanteert, die direct verbeterd en aangevuld kunnen worden, zodat debat overbodig is." In wezen volgde hij daarmee het voorbeeld van Van Hall uit 1842, een idee dat in 1912 door Scholten in de NJV opnieuw werd verwoord, eveneens met het argument dat deze voorstellen, "omdat zij klein zijn en bijna altijd van technische aard, gemakkelijk de Kamers kunnen passeeren en tot wet worden verheven."

Minister Heemskerk was niet zo bijster enthousiast, maar maakte toch geen bezwaar. Zijn indruk van Staatscommissies in het algemeen was, dat zij zich verloren in wijdlopige, lijvige rapporten waarvan de hoofdzaken zijn verstopt in een omhaal van woorden; "Het (rapport) is een vondeling, die bij hem (de Minister van Justitie) thuis wordt gebracht (...) heel groot en dik, en dat maakt het in de praktijk zoo bij uitstek moeilijk om te zeggen: nu kan ik dat voor mijn rekening nemen."

Nadat de motie zonder hoofdelijke stemming was aangenomen, ontving Kappeyne op 19 juni 1919 het vererende verzoek om voorzitter te worden van de in te stellen Staatscommissie, hetwelk hij als "een groot voorrecht" beschouwde. Tevens werd hem gevraagd een de Minister niet bindende voordracht op te stellen van personen die zijns inziens voor het lidmaatschap in aanmerking zouden moeten komen. Daarop selecteerde Minister Heemskerk persoonlijk de leden, waarbij hij in het bijzonder lette op de functie in het maatschappelijk leven van de betrokkenen (Hoge Raad, Hoogleraarschap, Advocatuur), gelijkmatige geografische spreiding (het Noorden en het Zuiden moeten ook vertegenwoordigd zijn) en zijn of haar vermeende politieke voorkeur. ${ }^{276}$

276. Dat deze toetsing hem ernst was, niet in het minst met betrekking tot het laatste aspect, moge blijken uit een briefwisseling van 4 en 11 oktober 1919 tussen Kappeyne en mevrouw SchönfeldPolano, ambtenaar bij het Ministerie van Justitie en als vertegenwoordiger daarvan gedurende meer 


\section{De taakomschrijving van de Staatscommissie: kritieken}

De Commissie werd ingesteld bij Koninklijk Besluit van 13 september 1919, nr 51. Haar taak luidde:

a. te overwegen, hoe in het belang eener goede rechtsbedeeling ware te geraken tot wegneming van onjuistheden en aanvulling van leemten, waarvan in en door de practijk algemeen erkend wordt, dat zij als zoodanig voorkomen in de Nederlandsche burgerlijke wetgeving (Burgerlijk Wetboek, Wetboek van Koophandel en Faillissementswet, en Wetboek van Burgerlijke Rechtsvordering);

b. na overweging van onderwerpen, naarmate zij rijp bevonden worden voor regeling in vooromschreven zin, een plan in ruwe schets en hoofdtrekken schriftelijk of mondeling aan het oordeel van Onzen Minister van Justitie te onderwerpen, ten einde, indien ook dezen regeling wenschelijk voorkomt, met inachtneming van diens eventueele aanwijzingen haar in den vorm van een of meer ontwerpen van wet met toelichtende memorie aan voornoemden Minister te doen geworden.

Zowel uit de taakomschrijving als uit de samenstelling van de Commissie - zij telde hoofdzakelijk mensen uit de praktijk ${ }^{277}$ - blijkt dat de nadruk lag op een praktische aanpak van een aantal kleine gebreken in de Nederlandse burgerlijke wetgeving. Een algehele herziening was niet haar doel, behoorde ook tot de politieke onmogelijkheden.

276. $\rightarrow$

dan 42 jaar lid van de Staatscommissie.

Nadat de commissie officieel was geïstalleerd, diende men zich te beraden over de aanstelling van een drietal adjunct-secretarissen ten behoeve van de drie subcommissies, te weten Rechtsvordering, Handels- en faillietenrecht en Burgerlijk recht. De Minister had daarbij de wens te kennen gegeven dat hij het op prijs zou stellen indien daarbij ook iemand van anti-revolutionairen huize zou zijn. De subcommissies hadden echter geen geschikte kandidaat van die richting gevonden, zodat het de vraag was of Heemskerk de voordracht, waarop slechts één rechtse kandidaat voorkwam - C.P.M. Romme, later voorman van de KVP - zou accepteren. Kappeyne was hier zeer verbolgen over, aangezien hij niet begreep "wat religie of politieke richting bij deze benoeming ter zake afdoet (..). Misschien is ... wel fel christelijk, doch het kan mij absoluut niet schelen, daar wij niet den Bijbel maar de wetboeken gaan herzien. Ik ben te zeer bevriend met den Minister om niet zooveel mogelijk aan zijn verlangens tegemoet te komen, maar niet bereid, aan een der sub-commissies in overweging te geven, haar aanbeveling te wijzigen, alleen omdat de man harer keuze niet van rechtschen huize is." Uiteindelijk zou Kappeijne aan het langste eind trekken.

277. Naast Kappeijne (voorzitter) en mevrouw Schönfeld-Polano (algemeen secretaresse) waren lid: F.J. Bolsius, President van de rechtbank te Roermond; P. Coninck Westenberg, President van de rechtbank te Amsterdam; P. Dieleman, lid G.S. van Zeeland, advocaat en procureur te Middelburg; J. Limburg, lid G.S. van Zuid-Holland, oud-lid van de Tweede Kamer, advocaat en procureur te 'sGravenhage; P.H. Loeff, President van de rechtbank te 's-Hertogenbosch; M. Mendels, lid van de Eerste Kamer, advocaat en procureur te Amsterdam; W.L.P.A. Molengraaff, oud-hoogleraar R.U. Utrecht; P.I. du Pui, kantonrechter te Zwolle; J.Ph. Suijling, hoogleraar R.U. Utrecht; H. van der Vegte, rechter-plaatsvervanger in de Rechtbank, advocaat en procureur te Zwolle; L.E. Visser, raadsheer in de Hoge Raad. 
Snel na het verschijnen van het K.B. volgde de plechtige installatievergadering $^{278}$, waarin Heemskerk nog eens duidelijk te kennen gaf, dat het niet tot de taak van de commissie behoorde fundamentele herzieningsvoorstellen in behandeling te nemen: Deze opdracht "laat algeheele herziening, fundamenteele omwerking van de Wetboeken ongemoeid, en bedoelt geenszins in de plaats daarvan te treden. Zij strekt tot wegneming van gebreken, niet om een nieuw stelsel aan de wetgeving ten grondslag te leggen, maar om te voldoen aan op bepaalde punten gevoelde eischen der practijk. Zij beoogt stuksgewijze te voorzien in wat naar algemeen erkende ondervinding verandering en aanvulling behoeft in onze burgerlijke codificatie, met de hoop, dat dit spoedig kunne geschieden."

Dit werd volmondig beaamd door haar voorzitter. Kappeyne antwoordde: "Algemeene herziening, fundamenteele omwerking van de Nederlandsche Wetboeken zal onze taak niet wezen. Gelukkig. Immers, van onze werkzaamheid wordt spoedig practisch resultaat verwacht, en die verwachting zou, gelijk de ervaring leerde, allicht beschaamd kunnen worden, wanneer wij, van zoodanig weidsch mandaat voorzien, aan den arbeid togen."

Gelet op de beperkte taak van de Staatscommissie is het begrijpelijk dat de overtuiging bestond dat het werk snel kon worden volbracht. Immers, Kappeyne had in de Eerste Kamer toch ook gesproken over "enige maanden"? Iets geheel nieuws maken was niet aan de orde. "Wij toch zetten", aldus drukte het lid Coninck Westenberg het uit, slechts "nieuwe lappen op een oud pak." Slechts mevrouw Schönfeld voorzag reeds in de openingsvergadering dat de Staatscommissie "veeleer" een permanent karakter zou dragen, al dacht zij hierbij aan het feit "dat er geen bepaald getal van die leemten en onjuistheden bestaat; haar inziens zal men niet op zeker tijdstip kunnen constateren, dat men nu op alle de vinger heeft gelegd. "279

De instelling van de Staatscommissie werd door de volksvertegenwoordiging en de rechtsgeleerde wereld over het algemeen met instemming begroet, enerzijds omdat de Minister uitdrukkelijk had toegezegd aan de algehele herziening niet minder aandacht te besteden ${ }^{280}$, anderzijds omdat Heemskerk hiermee aangaf een voorstander te zijn partiële herzieningen, een weg die sinds het instellen van de Staatscommissie-Van Meerbeke vrijwel geheel was verlaten: "Wij behoeven niet te zeggen", zo schreef de redactie van het Weekblad van het Recht, "dat wij al de pogingen om eindelijk beweging te brengen in de stilstaande machine met ingenomenheid begroeten. Wij hebben reeds zo dikwijls op den plicht van den wetgever gewezen, dat herhaling overbodig lijkt. "281

Slechts één kritisch - maar achteraf gezien, zeer juist - commentaar begeleidde de nieuwe Staatscommissie. Een zekere Van Slooten (hij heeft het biografisch woordenboek niet gehaald) merkte op: "In de commissie voor onjuistheden en leemten bespeurt natuurlijk iedereen leemten. Misschien ook wel onjuistheden, doch daarover spreekt men thans nog niet (...). Er zijn twee punten in de omschrijving van den taak der commissie, waarop de aandacht onmiddellijk valt. Vooreerst dat haar arbeidsveld

278. De teksten van de gehouden voordrachten zijn gepubliceerd in W 10465 (1919).

279. Notulen van de eerste plenaire vergadering van de Staatscommissie voor de burgerlijke wetgeving van 4 oktober 1919 , p. 13-14.

280. W 10492 (1919).

281. W 10413 (1919). Zie ook W 10482 (1919). 
wordt beperkt door de grenzen van de communis opinio. Terecht mag men vragen of de leemten en onjuistheden, waarover men 't algemeen ééns is (het zijn er heel wat minder dan gij zoo oppervlakkig zoudt meenen), nog aan den Minister van Justitie behoeven te worden gerapporteerd, en met behulp van een zoo geweldig apparaat moeten worden aangevuld of doorgehaald. Het heeft er wel wat van, alsof hij, die de zinsnede stelde, waarin aan de commissie deze toovercirkel om de beenen wordt getrokken, daarbij, met een mephistophelischen glimlach, heel goed geweten heeft wat hij deed. In de tweede plaats valt op te merken, dat een onjuistheid of leemte, waaromtrent de bovenvermelde communis-opinie bestaat, en die ook als zoodanig aan den speurzin der commissie niet is ontsnapt, toch nog niet mag worden aangemerkt als voorwerp voor haar streven naar verbetering. Aan de allerwege gevestigde meening in de praktijk moet zich het - waarschijnlijk - met eenparige stemmen opgemaakt oordeel der commissie aansluiten, maar dan moet ook nog de Minister zelf van meening zijn, dat een regeling hem wenschelijk voorkomt. Zoodat, alles tezamen genomen, er veel kans bestaat, dat, indien zij maar tijd van leven hebben, alle gepasseerden nog in de commissie zullen komen. ${ }^{282}$

\section{Het falen van de Staatscommissie}

Reeds in de eerste plenaire vergadering na de installatie constateerde de nieuwe voorzitter, mr. J. Limburg, (Kappeyne was al ongeneeslijk ziek ten tijde van de openingsvergadering en overleed op 6 februari 1920) dat "onze Staatscommissie dienstbaar wordt gemaakt aan het tot stand brengen van een herziening op breederen grondslag", herzieningen van groter belang dan haar beperkte taakomschrijving had doen vermoeden. De Minister had namelijk spoedshalve rechtstreeks advies gevraagd over zijn Ontwerp-Erfrecht, terwijl het hem ook welkom zou zijn voorstellen te ontvangen over diverse punten van huwelijksgoederenrecht.

Het bleef echter niet bij dit enkele verzoek en mede daarom kan worden gezegd dat reeds in de jaren ' 20 de normale werkwijze van de Staatscommissie was, dat zij vrijwel zonder uitzondering werkte in opdracht van het Departement. Dan eens ging het om het opstellen van een wetsontwerp, dan weer diende de Staatscommissie advies uit te brengen met betrekking tot een door de Minister zelf ontworpen wetsvoorstel. Het eigenlijke werk van de commissie kwam daardoor natuurlijk aardig in de verdrukking.

Toch was dit niet de enige reden waarom de resultaten van de commissie achterbleven bij de verwachtingen. Wanneer men de notulen van de eerste paar jaren doorbladert, dan valt het namelijk op dat het opsporen van "kennelijke leemten" in de praktijk minder eenvoudig was dan aanvankelijk werd gedacht. Er waren weliswaar naar ieders oordeel leemten en onjuistheden, maar die constatering liet nog voldoende ruimte over voor de vraag of deze "algemeen als zodanig erkend" werden. Zo openbaarde zich bijvoorbeeld een principieel verschil van mening tussen de plenaire vergadering en de subcommissie Handelsrecht over de vraag of na artikel $1374 \mathrm{~B}$.W.

282. WPNR 2601 (1919). Ofschoon het mij niet duidelijk is geworden of de schrijver bij het noemen van de "gepasseerden" zekere personen op het oog had, is het op z'n minst verwonderlijk dat noch Paul Scholten, noch Meijers zitting mochten nemen in deze commissie. Beiden genoten immers reeds toen een groot gezag. Wilde de Minister wellicht teveel "wetenschap" vermijden? 
een bepaling zou moeten worden ingevoegd die het de rechter mogelijk zou maken een overeenkomst te wijzigen of te ontbinden op grond van onvoorziene omstandigheden. De voorstanders beriepen zich daarbij op het eenparig votum van de NJV in 1918, de tegenstanders achtten een dergelijke regel alleen in het kader van oorlogswetgeving zinvol, beriepen zich op de aanvullende werking van de goede trouw en waarschuwden tegen een overschatting van het oordeel van de NJV, waar tal van leden stemmen, "die geen diepgaande studie van de zaak hebben gemaakt. "283

Een andere factor die voor de nodige problemen zorgde, was dat het niet altijd eenvoudig was om overeenstemming te bereiken omtrent de wijze waarop een verbetering zou moeten plaatsvinden. Men stuitte daarbij soms op het probleem, dat de voorgestelde herziening óf te weinig belangrijk was om de aandacht van Kamer en Regering te vragen, of dat deze juist te principieel van aard was, zodat men moest vrezen dat één van beide met de voorgestelde wijziging niet akkoord zou gaan. Dat deze kwestie diep zat, blijkt hieruit dat Molengraaff, in zijn hoedanigheid van voorzitter van de subcommissie Handelsrecht, eens weigerde een ontwerp op te stellen tot herziening van de Faillissementswet, met als argument "dat de subcommissie daarin weinig lust heeft, gezien de vele door haar reeds ingediende ontwerpen en de geringe resultaten daarvan. "284

De Staatscommissie werd ook met dit probleem geconfronteerd naar aanleiding van het arrest Lindenbaum/Cohen, waaraan zij nota bene voor een belangrijk deel haar bestaan had te danken. ${ }^{285}$ Toen de Hoge Raad in 1919 de omschrijving van het begrip "onrechtmatig" in artikel 1401 B.W. rechtstreeks ontleende aan een terzake ingediend wetsontwerp, rees bij de Minister de vraag of het nog zinvol was dit voorstel te handhaven, nu het verder niets nieuws bracht dan een aantal weinig belangrijke wijzigingen in de artikelen 1402, 1406 en 1409 B.W., wijzigingen die bovendien voor een groot deel voortbouwden op jurisprudentie.

Hoewel de grootst mogelijke meerderheid van de subcommissie Burgerlijk Recht van oordeel was dat het wenselijk zou zijn het ontwerp te handhaven, adviseerde zij uiteindelijk, na sterke aandrang van het oud-Kamerlid Limburg, het ontwerp toch maar in te trekken en, zoals men zei, de door de Hoge Raad niet aangeroerde punten mee te nemen bij een algehele herziening van het B.W.: "Het hoofdpunt is beslist conform het ontwerp. De andere aangeroerde punten zijn van niet veel gewicht, al zijn het zaken, die bij een algeheele herziening behooren te worden opgelost in den zin van het ontwerp." De reden hiervoor was dat Limburg, één van de opstellers van het reeds uit 1912 daterende Voorlopig Verslag, van mening was dat het ontwerp of door de Kamer zou worden verworpen óf door middel van amendementen tot een "beperkter" 1401 zou leiden. "Er zijn", zo waarschuwde hij, "tal van civilisten wien het ontwerp te ver gaat." Bovendien, zo voegde hij eraan toe, "de Hoge Raad zal ten aanzien van de definitie van de term "onrechtmatig" niet omgaan." ${ }^{286}$ Het feit dat

283. Notulen 10e plenaire vergadering Staatscommissie 1919, d.d. 22 januari 1921, p. 196 e.v.

284. Notulen 26e plenaire vergadering Staatsconmissie 1919, d.d. 18 maart 1922, p. 439.

285. N.J. 1919, p. 161; W 10365 (1919). Zie het derde argument van Kappeynes pleidooi voor het instellen van een wetgevingscommissie.

286. Notulen 19e vergadering subcommissie Burgerlijk Recht d.d. 15 december 1921, p. 255 e.v. Een pikant detail is nog dat Limburg tevens als raadsman optrad voor Cohen, de onrechtmatig handelende drukker. 
L.E. Visser, raadsheer in de bewuste zaak, lid was van de Staatscommissie, zal aan die overtuiging zeker kracht hebben gegeven.

Een andere, eveneens belangrijke oorzaak voor de geringe produktiviteit van de Staatscommissie was dat sommige voorstellen tot verbetering dermate ingrijpende consequenties bleken te hebben voor andere delen van het recht, dat de commissie na ampele overweging toch maar besloot van een voorstel tot herziening af te zien. De formele reden luidde dan, dat de veronderstelde leemte niet kon worden opgeheven, omdat niet gesproken kon worden van een binnen het raam van haar opdracht vallende leemte of onjuistheid. De werkelijke verklaring was echter dat deze methode van herzien op beperkte schaal alleen daar doeltreffend kon werken waar voor het verbreken van het verband met andere bepalingen niet behoefde te worden gevreesd. Veelzeggend is dat de Staatscommissie slechts driemaal in haar bestaan de mogelijkheid heeft overwogen een wijziging voor te stellen in het algemene deel van het verbintenissenrecht ${ }^{287}$ en dat zij haar werkzaamheden, het B.W. betreffend, bijna uitsluitend heeft beperkt tot het personen- en familierecht, dat zelfs niet tot haar taken behoorde. ${ }^{288}$

Het meest duidelijk kwam dit probleem naar voren toen zij op uitnodiging van de Minister van Justitie gevraagd werd een voorstel te doen tot verbetering van een essentieel onderdeel van het verbintenissenrecht, namelijk de regeling betreffende de ontbinding van overeenkomsten (1302 B.W.). Ofschoon de subcommissie Burgerlijk Recht enige voorstellen tot wetswijziging deed, kwam de plenaire vergadering, zeer tegen de zin van de subcommissie, tot de slotsom dat op dit punt geen enkele wetswijziging noodzakelijk of zelfs maar wenselijk was te achten.

De oorzaak voor dit negatieve oordeel berustte niet op het vertrouwen in de tussenkomst van de rechter - omstreeks dat tijdstip verscheen het 184 pagina's tellende boekje van de NJ met jurisprudentie en literatuur omtrent artikel 1302 B.W. - maar op de inmiddels ervaren onmogelijkheid incidentele verbeteringen aan te brengen zonder acht te slaan op het groter geheel.

287. Dit betrof de imprévision, artikel 1302 B.W. en artikel 1416 B.W.

288. Een analyse van de 250 maal dat de plenaire vergadering voor 1940 bijeenkwam, levert het volgende beeld op:

Rechtsvordering: 75 bijeenkomsten, met als voornaamste onderwerpen de verzoekschriftprocedures, de unus judex, gijzeling, lijfsdwang, beslag en bijstand aan on- en minvermogenden.

Wetboek van Koophandel: 60 bijeenkomsten, waarin besproken werd de wettelijke regeling inzake makelaars, handelsreizigers, levensverzekering, wisselrecht, stichtingen en de Faillissementswet.

Burgerlijk Wetboek Boek 1: 80 bijeenkomsten, met als belangrijkste onderwerpen de rechtspositie van de gehuwde vrouw, het natuurlijke kind, echtscheiding, vaderschapsactie, alimentatie, droit de visité, hertrouwverbod, voogdij, adoptie, verklaring van vermoedelijk overlijden en Registers van de Burgerlijke Stand.

Burgerlijk Wetboek (anders dan Boek 1): 35 bijeenkomsten, inzake het Erfrecht (5), artikel 1302 B.W. (4), hypotheek (10), eigendomsoverdracht tot zekerheid (2), cessie (2), onvoorziene omstandigheden (2) en de (collectieve) arbeidsovereenkomst (15).

Dit betekent dat het vermogensrecht slechts $14 \%$ van de besprekingen uitmaakte. De subcommissie Burgerlijk Recht ( 64 bijeenkomsten) besteedde $23 \%$ van haar tijd aan de wat meer algemene leerstukken, zoals de arbeidsovereenkomst, artikel 1302 B.W., het erfrecht en de eigendomsoverdracht tot zekerheid. 
Zo werd bijvoorbeeld een regeling van de exceptio non adimpleti contractus afgewezen, ofschoon men van het wenselijke van een regeling overtuigd was, alleen op grond van het argument dat dan ook de bepalingen inzake de nakoming zou moeten worden herzien. En ten aanzien van een voorstel tot regeling van de zuivering van het verzuim werd, naast het feit dat een minderheid van de commissie er op materiële gronden tegen was, ook nog het argument gebruikt dat het een algemener vraagstuk was, dat niet alleen voor de wederkerige overeenkomsten diende te worden geregeld. De onmacht van de Staatscommissie om voorstellen te doen tot principiële verbeteringen te doen in het algemeen deel van het verbintenissenrecht werd wel het treffendst uitgedrukt door Limburg die, na afloop van de beraadslagingen over de herziening van artikel 1302 B.W., naar hij zei, voor het eerst sinds zijn voorzitterschap moest constateren dat de Commissie "niets in staat van wijzen heeft. ${ }^{289} \mathrm{Het}$ was ook de eerste en enige keer dat de Commissie een dergelijk algemeen leerstuk behandelde! Het failliet van de methode van partiële herzieningen van dit gedeelte van het B.W. werd daarmee overtuigend en ondubbelzinnig aangetoond. Tekenend is ook dat van al de wetsontwerpen waaraan de Commissie-Limburg voor de oorlog op de een of andere wijze heeft meegewerkt - in totaal 14 in getal - er slechts één was die tot doel had een leemte of onjuistheid weg te nemen in het vermogensrecht, te weten de Wet van 23 mei 1935, S. 307, tot intrekking van art. 1416 lid 2 B.W. Dit artikel bepaalde dat de vordering tot schadevergoeding wegens doodslag of verwonding (artt. 1406 en 1407 B.W.) verjaarde conform de termijnen die in Strafvordering waren gesteld.

Een laatste verklaring voor het feit dat de Staatscommissie aan haar eigenlijke taak niet meer toekwam, hiervoor is dit punt reeds aangestipt, vormen de talloze aanvragen voor advies die via de Minister van Justitie de commissie bereikten. Aangezien het veelal zeer uiteenlopende zaken betrof en zij liefst bij voorrang afgedaan moesten worden, is het duidelijk dat de commissie aan haar oorspronkelijke opzet vrijwel niet meer toekwam. Vooral onder Heemskerk dijde deze adviestaak steeds verder uit, waardoor de Kamer, vermoedelijk niet ten onrechte, de indruk kreeg, dat de Minister ieder politiek controversieel onderwerp in de Staatscommissie bracht. Aldus verzekerde hij zich van een innerlijk tegenstrijdig advies, waarop het bovendien lang wachten was en waarmee hij op aannemelijke wijze kon betogen dat de kwestie nog niet rijp was voor een wettelijke regeling.

Vanzelfsprekend was de oppositie met deze gang van zaken niet zeer tevreden. In het Voorlopig Verslag voor de begroting voor 1924 werd door de Eerste Kamer opgemerkt: "Op civielrechtelijk gebied blijkt de Minister alles bijna zonder uitzondering op de schouders te leggen van de Staatscommissie-Limburg" (...) zodat zij de betekenis heeft of krijgt "dat zij het departement ontheft van eigen zelfstandige werkzaamheid. "290

Het antwoord van de Minister was veelzeggend. Hij stelde voor de taak van de commissie uit te breiden ${ }^{291}$, hoewel dit niet zou insluiten, dat geen wetgevende

289. Notulen 15le plenaire vergadering Staatscommissie 1919, d.d. 9 januari 1932, p. 1952.

290. W 11170 (1924). Zie ook W 10993, 11004, 11145 (1924).

291. W 11179 (1924). Dit is ook gebeurd. Het K.B. van 22 mei 1924 no. 31 geeft als eerste taak: "te overwegen, hoe in het belang eener goede rechtsbedeeling ware te geraken tot wijziging of aan- 
arbeid op dit gebied zou mogen worden ondernomen zonder advies van de Staatscommissie. Daarmee werd de praktijk niettemin tot regel werd verheven. Toen Heemskerk voor de zoveelste maal een wetsontwerp op het terrein van het personen- en familierecht naar de Staatscommissie had verwezen voor advies, tekende het Weekblad sarcastisch aan: "Als het advies van de Commissie-Limburg inkomt, - het bestaan van dergelijke commissies is toch voor een Minister een buitengewoon voordeel - zal de Minister nader de mogelijkheid overwegen van eenige, niet al te ver strekkende wijziging op dit stuk. Wie nu nog mocht meenen, dat er van dezen Minister eenige verruiming van rechten van het natuurlijk kind zal worden verkregen, is wel een onverbeterlijke utopist. "292

In wezen fungeerde de Staatscommissie op het gebied van het personen- en familierecht - en dan met name ten aanzien van het huwelijksgoederenrecht - als fopspeen voor de Kamer. ${ }^{293}$ Dit blijkt ook wel doordat Heemskerk, hoewel hij een verbazingwekkend groot aantal wetsontwerpen op het terrein van het burgerlijk recht op zijn naam had $\operatorname{staan}^{294}$, en er niet tegen op zag om naast omvangrijke wijzigingen met zeer kleine veranderingen te komen, geen enkele principiële herziening toeliet in Boek 1 B.W.

\section{Meijers' oppositie}

Zoals Levenbach overtuigend heeft aangetoond, betroffen de wijzigingen die het B.W. na 1930 heeft ondergaan, nagenoeg alle een reactie van de wetgever op "nieuwe toestanden en verschuivingen in de maatschappij" en hadden zij geen betrekking op legislatief- of rechtstechnische gebreken, waarvoor de Staatscommissie in eerste instantie was bedoeld. ${ }^{295}$ Van de zesentwintig onderwerpen, die Modderman in 1880 noemde als voorbeelden van "hoogst gewigtige onderwerpen" en waarvan het merendeel betrekking had op het vermogensrecht, was er na de Tweede Wereldoorlog slechts één, het arbeidscontract, geregeld.

291. $\rightarrow$

vulling van de Nederlandsche burgerlijke wetgeving". Bovendien werd een alinea toegevoegd, luidende: "Onzen voornoemden Minister desverlangd van advies te dienen, omtrent onderwerpen van privaatrechtelijken aard." Het valt op dat Meijers in zijn bekende WPNR-artikel "Het feillooze deel van ons burgerlijk Wetboek" de wijziging in taakomschrijving ontgaan is. Indien dat niet het geval zou zijn geweest dan zou zijn kritiek wellicht nog minder aangenaam zijn geweest.

292. W 11274 (1924).

293. De Commissie getuigt daar overigens zelf van. Wanneer voorzitter Limburg voorstelt het onderwerp "de maritale macht en de vermogensrechtelijke positie der getrouwde vrouw" te bespreken, wordt opgemerkt dat het weinig zin heeft tot behandeling over te gaan, aangezien de Minister hieromtrent toch geen wijzigingsvoorstellen zal willen doen. Ondanks dat Limburg antwoordt dat Heemskerk hem heeft toegezegd enkele leemten op dit punt te willen aanvullen, vindt de subcommissie deze toezegging niet voldoende en dringt zij er op aan de Minister na de bespreking van de hoofdvraagpunten te polsen omtrent zijn standpunt ten aanzien van de voornaamste onderdelen van het vraagstuk. (Notulen 9e vergadering subcommissie Burgerlijk Recht, d.d. 13 februari 1920, p. 148).

294. De belangrijkste daarvan betreffen het Erfrecht (wet van 17 februari 1923, S. 40), de makelaardij (wet van 5 mei 1922, S. 247) en de Faillissementswet (wet van 16 mei 1925, S. 191).

295. M.G. Levenbach, Gedenkboek Burgerlijk Wetboek 1838-1938, Zwolle 1938, p. 129 e.v. Zie i.h.b. p. $159-160$. 
Dit gebrek aan aandacht voor een zuiver technische herziening - hoe klein dan ook - valt vooral te verklaren door de houding van de Kamer, die zich slechts met "op den nagel brandende kwesties" wenste onledig te houden, het onvermogen van de Staatscommissie om principiële verbeteringen in het vermogensrecht aan te brengen en de door dit alles opgetreden verplaatsing van het zwaartepunt in de rechtsvorming van wetgever naar rechtspraak. Het arrest van 1919, dat materieel gezien misschien niet eens zoveel nieuws bracht ${ }^{296}$, rekende af met de gedachte dat de rechter zich onder de wetgever diende te stellen. Eindelijk durfde de Hoge Raad de ruimte te gebruiken die de wetgever had laten ontstaan. ${ }^{297}$ Bovendien stak hij de lagere colleges, die de wet al veel langer vrijmoedig tegemoet traden, een hart onder de riem, door bij wijze van provocatie de ook vanuit terminologisch oogpunt sterk bekritiseerde redactie van het wetsontwerp vrijwel letterlijk over te nemen.

De strijd om de rechtspraak als kenbron van recht erkend te krijgen, was hiermee beslecht. Het gebrek aan vertrouwen in het rechtsvormende karakter van de jurisprudentie, waar Meijers in 1918 nog tegen te strijden had toen hij zich moest verdedigen tegen de opvatting dat een wettelijke regeling van de imprévision verkieslijker zou zijn dan de door hem bepleite aanvullende werking van de goede trouw ${ }^{298}$, was met dit arrest geheel verdwenen. Vóór 1919 stond bij de wetsinterpretatie de bedoeling van de wetgever centraal. Het arrest van 1919 ging verder; het zocht het recht naast de wet. De vraag "wet of rechter?" verdween gedurende een aantal jaren geheel van het tapijt, vervuld als iedereen ervan was dat de rechter die zekerheid gaf die het wetboek niet meer kon geven. ${ }^{299}$ De wrevel over het trage werken van de wetgever was algemeen.

296. Zie daarover G.E. van Maanen, De mythe rond het arrest Lindenbaum-Cohen ( 31 januari 1919), in: Recht en kritiek 1983, p. 51-87.

297. Vergelijk in dit verband ook de gewijzigde opstelling van Loder. In 1910 raadsheer in het arrest Zutphense Juffrouw; in 1912, ter vergadering van de NJV, nog hopend op rechtsvorming door de wetgever; in 1918 ondertekenaar van het manifest van Molengraaff; in 1919 tenslotte, met L.E. Visser (eveneens behorend tot de groep-Molengraaff), de belangrijkste auteur van het arrest Lindenbaum-Cohen. Zie verder F.C.J. Ketelaar, De schepping van het arrest Lindenbaum-Cohen, in: Kabaal in Holland, Arnhem 1993, p. 15.

298. HNJV 1918, p. 70 e.v. Meijers zei letterlijk: "Nu schijnt men ook geen vertrouwen meer te schenken aan den rechter, niettegenstaande eenige jaren geleden onze Vergadering zich heeft uitgesproken tegen een wijziging van het Burgerlijk Wetboek in zijn geheel in de hoop en in de verwachting, dat de noodige verbeteringen wel zouden komen van den rechter (...). Wanneer de rechterlijke macht - wat zij gelukkig niet meer zooveel doet als vroeger - principieele quaesties niet omzeilt, maar de waarde begrijpt welke aan hare beginseluitspraken is te hechten, dan zullen wij veel verder komen. Laat ons derhalve liever dien kant uitgaan, want mijn vertrouwen in den wetgever is weg. Slechts door het oplossen van principieele quaesties door de rechterlijke macht zullen wij, wat de rechtszekerheid betreft, gediend zijn."

299. Vergelijk ook de verwachtingsvolle reacties die het arrest losmaakte. Molengraaff schreef in W 10365 (1919): "Wie inziet, dat de mogelijkheid eener volledige beschrijving van het recht een waan is, omdat niemand, 6́6k niet de wetgever, de geheele rechtsstof kan beheerschen en alle mogelijkheden kan overzien, (...) moet er zich in verheugen, dat de Hoge Raad de opvatting van art. 1401 heeft aanvaard, die het den rechter mogelijk maakt, het gedrag van eenen mensch tegenover den anderen te toetsen ook aan de onbeschreven regels (...). Er is door ons hoogste rechtscollege zelden een arrest gewezen, waarvan zoo heilzame invloed op ons rechtsleven mag worden verwacht. "Meijers tekende in WPNR 2564 (1919) aan: "Het is een beslissing, die in belangrijkheid tegen de invoering van een geheel nieuw boek in het Burgerlijk Wetboek opweegt." 
Maar, zoals elke reactie een tegenreactie opwerpt, kon ook nu een reactie niet uitblijven. Door het stilzitten van de wetgever dreigde het gevaar dat de rechtspraak als exclusieve rechtsbron zou gaan functioneren, met alle bezwaren vandien. Reeds in 1917 had Molengraaff - de onvermoeibare strijder voor codificatie - mismoedig opgemerkt dat het Wetboek van Koophandel zoveel leemten en gebreken kende, dat zij geen regeling meer mocht heten en dientengevolge minder hinderde "dan bij een volledige regeling stellig het geval zou wezen" 300 , terwijl Drucker vijf jaar later schreef dat "zich vele rechtsregels (...) buiten de wet om" vormen, waardoor het van betrekkelijk gering belang is "of men het voor de gelding dier regels noodig vindt een wettelijke bepaling te zoeken, die als geldingsbron voor die regel kan dienen. Een zoodanige wettelijke regel is toch altijd wel te vinden." ${ }^{301}$

De vraag die dus in alle ernst diende te worden gesteld, was of op deze weg moest worden doorgegaan, of de wetgever alleen nog daar mocht optreden waar een snelle interventie vereist was of op terreinen waar de rechter niet kon komen.

Het was deze - rechtspolitieke - vraag die Meijers in 1922 als voorzitter van de NJV aan de orde stelde en ontkennend beantwoordde: wet en rechtspraak hebben ieder een eigen taak bij de rechtsvorming, die bepaald wordt door de wet, het persoonlijk inzicht van de rechter, maar ook door grenzen, "door den aard der rechtspraak zelf gegeven. ${ }^{n 302}$ Te vaak is, volgens Meijers, de wet een obstakel om tot een redelijke beslissing te komen, te vaak ook heeft een beslissing alleen waarde voor de bij het proces betrokken partijen. Meijers besloot zijn pleidooi met de opmerking "dat groote rechtshervormingen het best te verwezenlijken zijn (...) door invloed uit te oefenen op een hervorming van de Nederlandsche wetgeving. " ${ }^{303}$

Gaf Meijers hiermee al duidelijk te kennen hoe hij tegenover de codificatiegedachte stond, in 1928 volgt dan zijn befaamde artikel "Het feillooze deel van ons Burgerlijk Wetboek. " 304 Het artikel begon met te constateren dat de Commissie-Limburg in de bijkans negen jaar van haar bestaan nooit voorstellen had gedaan voor het vermogensrecht. "Vóór alles", zo schreef Meijers, "heeft (...) de Commissie de verdienste ons bevrijd te hebben van een gevaarlijken waan, den waan, dat er in ons Burgerlijk Wetboek en in het bijzonder in het meest toegepaste deel, in het vermogensrecht, leemten of onjuistheden van enige beteekenis zouden voorkomen." Hij, Meijers, had daarentegen altijd in de veronderstelling verkeerd dat juist dat deel rijk aan onduidelijkheden en onjuistheden was en dat de wetgever deze gebreken diende te verhelpen: "Waar de studeerende jeugd door de bestaande studieboeken voortdurend nog in de overtuiging opgevoed wordt, dat ons ons gansche vermogensrecht niet veel anders is dan een onafgebroken reeks van artikelen, waarin de wetgever zich minder juist heeft uitgedrukt en van kwesties, waaromtrent de deskundigen van meening verschillen, daar zou de Commissie een kolossaal nut stichten, indien zij het resultaat van haar negenjarige studie op papier mocht vastleggen en in een handboek voor iedereen luce clarius mocht aantoonen, dat ons vermogensrecht geen enkele onduidelijkheid of leemte, die aanvulling behoeft, bevat." Toch zegt Meijers niet geheel te overtuigd te

300. Rechtsgeleerd Magazijn, 1917, p. 283 e.v., i.h.b. p. 286.

301. Rechtsgeleerd Magazijn, 1922, p. 163.

302. HNJV 1922, p. 4 e.v.

303. HNJV 1922, p. 8-9.

304. WPNR 3031 (1928). 
zijn van het oordeel van de Commissie: "Nog steeds kost het mij weinig moeite voor de hand weg een honderdtal punten te noemen, waarbij ik vroeger meende, dat algemeen leemten erkend werden en een betere wettelijke regeling ook de rechtspraak ten goede zou komen." Nadat hij die lijst gegeven heeft, geeft hij, heel in het kort, een verklaring voor het feit dat de Commissie nog geen enkel voorstel heeft gedaan tot wijziging van het $2 \mathrm{e}$ en $3 \mathrm{e}$ Boek: "Hangen de rechtsregelen, die het vermogensrecht vormen, niet zoozeer samen, dat het niet aan te raden is incidenteel op verschillende plekken verbeteringen aan te brengen? Loopt men anders niet het gevaar met het oplossen van één moeilijkheid, twee nieuwe te scheppen en het systematische van ons Wetboek geheel te loor te doen gaan? Is een wijze van herziening, waarbij men al springend van schots tot schots vooruitgaat wel geschikt om ons snel vooruit te helpen? Zou men niet beginnen met de wijze van herziening te herzien?" ${ }^{\text {"305 }}$

Hoewel Meijers' stem doorklonk tot in de Eerste Kamer - met name de laatste alinea had de instemming van enkele Kamerleden ${ }^{306}$ - kreeg hij het Departement - en ik denk ook niet dat Meijers anders had verwacht - niet mee. Minister Donner erkende dat het denkbeeld zijn bekoring had, maar oordeelde dat het niet praktisch was, omdat een volledige herziening de krachten van Minister en Parlement te boven zou gaan: "De ervaring hier te lande opgedaan op het terrein van herziening van het geldende Burgerlijk Wetboek geeft de volgende uitkomst: plannen tot herziening zelfs van een enkel Boek hebben het nimmer tot het Staatsblad gebracht. Juist deze uitkomst heeft den weg van de partieele herzieningen doen inslaan." 307

Toch bleef Meijers' oproep niet geheel zonder gevolg. De Staatscommissie kwam, na een lange periode van werkloosheid, weer bijeen ${ }^{308}$, en Ribbius, de redacteur van het Weekblad, schreef een hoofdartikel met de kop "Niet verslappen", waarin hij opriep tot een principiële herziening van het verbintenissenrecht. Enkele citaten daaruit.

"Wanneer men een nieuw gebouwd huis betrekt, is het raadzaam reeds spoedig te beginnen met onderhoud en noodige vernieuwingen, herstellingen en verbeteringen, wil men zich niet spoedig voor het feit gesteld zien, dat wat men nog steeds als een nieuwe fraaie woning beschouwde, reeds bedenkelijke teekenen van verval begint te vertoonen en oud is geworden voor zijn tijd. Dan komt de vraag of, in plaats van nu de herstellingen ter hand te nemen, niet liever naar een nieuwe woning zal

305. Vergelijk ook Meijers in WPNR 3395 (1935): "Het wordt hoog tijd, dat onze wetgever inziet, dat voor het burgerlijk recht het stelsel van partieele herzieningen niet het meest gelukkige is. Men moge met deze wijze van herziening voortgaan in het Wetboek van Koophandel, dat niets meer is dan een verzameling van bijzondere contracten, voor het Burgerlijk Wetboek en het Wetboek van Burgerlijke Rechtsvordering hebben wij noodig, dat op gezette tijden b.v. eens om de tien jaren een technische herziening van het geheel plaats vindt. (..) Wat ten aanzien van het burgerlijk recht in de eerste plaats herziening behoeft, dat is het stelsel der herzieningen zelf."

306. W 12086 (1930).

307. W 12095 (1930).

308. De opvolgers van Heemskerk stelden kennelijk minder belang in de kwaliteiten van de Staatscommissie. Het gevolg was dan ook dat de Staatscommissie na diens aftreden nog slechts één of twee keer per jaar bijeenkwam. Ook hieruit blijkt dat zij een herziening van het B.W. in wezen niet aandurfde. 
worden gezocht, maar wanneer men zoekt en niet kan vinden of andere redenen daarvan doen afzien, heeft de achteruitgang en het verval verderen voortgang gehad en blijft er niets over, dan thans met grootere moeite en kosten te halen, wat men lang heeft verzuimd en wat men makkelijker goedkooper vroeger had kunnen bereiken. (...)

Met zulk een huis, waarvan de herstellingen te lang zijn uitgesteld, kan onze burgerlijke wetgeving worden vergeleken. Toen het oogenblik kwam, dat men zich van de veroudering in allerlei opzichten rekenschap gaf, verkoos men verbouwing boven verbetering en toen na jaren bleek, dat vernieuwing binnen afzienbare tijd niet was te verkrijgen, was de veroudering begrijpelijkerwijze in toenemende mate voortgegaan."

Nadat Ribbius erop heeft gewezen dat de partielle herziening in het verleden zeker vruchten heeft afgeworpen, schrijft hij dat er met name op het terrein van het verbintenissenrecht nog veel valt te verbeteren:

"Maar ook ten aanzien van het vermogenrecht is genoeg te doen; vele van de honderd wenschen van Meijers hebben daarop betrekking. Hoevele twistvragen zijn er niet, hoevele onzekerheden, hoe dikwijls is er niet tegenspraak tusschen de uitspraken van verschillende colleges, zonder dat de kwestie in jaren bij de Hoge Raad komt. Met een enkele verduidelijking of aanvulling zou de zaak beslist zijn. Een mooie kwestie om te debatteeren zou uit de wereld zijn, maar de rechtszekerheid was bevorderd."

Ribbius' conclusie is duidelijk: de bestaande grote achterstand op het gebied van het burgerlijk recht moet worden ingehaald:

"Het moet de constante taak zijn van elken Minister van Justitie en het Departement moet geregeld hiermede bezig zijn.(...) Dikwijls is het niet van het allereerste belang, welke oplossing gegeven wordt bij twijfel, maar dat er een oplossing is. ${ }^{309}$

Ook deze oproep bleef zonder gevolg. Ofschoon een aantal jaren later in de Kamer nog eens werd bepleit grotere voortvarendheid te betrachten met "de dringend noodzakelijke herziening van onze burgerlijke wetgeving", door partiële wijzigingen aan te brengen in bijvoorbeeld het verbintenissenrecht en de regels met betrekking tot de verjaring, omdat met betrekking tot deze onderwerpen in ieder geval geen aanleiding zal zijn tot "het toespitsen van politieke en geestelijke tegenstellingen" ${ }^{\text {"310 }}$, werd door Minister Van Schaik nietszeggend geantwoord dat bij het opstellen van bijzondere wetten mede rekening wordt gehouden met het B.W., voorzover het die wetten "raakt". Tussen 1930 en 1934 kwam er zelfs geen enkele wet op het terrein van het burgerlijk recht tot stand.

Uit een enkele regel van "Het juridische jaar 1934" blijkt waarom men in de periode voor de Tweede Wereldoorlog aan hercodificatie, op welke manier dan ook te 
bereiken, niet meer hoefde te denken: "Voor den jurist is het een droeve tijd. Hij kan zoo weinig scheppend werk leveren. Immers in deze wanhopige vertrouwenscrisis heeft de rechtsgeleerde haast geen kans om nieuw groot opbouwend werk te verrichten. De eenige plaats, waar nog naar hem gevraagd wordt, en waar dan ook tal van jonge juristen meer of minder tijdelijk een onderkomen vinden en iets verdienen, is bij de voorbereiding en de uitvoering der crisiswetten. "311

In 1938 liet Meijers zich het meest duidelijk uit over de noodzaak om tot hercodificatie over te gaan. Het eeuwfeest van het B.W. bood voor hem een welkom aanknopingspunt om zich op de toekomst te beraden. Nadat hij in zijn bijdrage in het "Gedenkboek" een overzicht heeft gegeven van de aard van de wijzigingen en aanvullingen van het B.W. sinds 1838 , waaruit duidelijk blijkt dat de wetgever de codificatiegedachte heeft losgelaten, volgt een beschrijving van de pogingen die zijn ondernomen om die ontwikkeling een halt toe te roepen.

Uit zijn uitstekend gedocumenteerd betoog blijkt dat Meijers als geen ander op de hoogte is van de oorzaken die tot het falen van die pogingen hebben geleid. Het onvermogen van de Staatscommissies om anders dan partieel te herzien wordt geschetst, de gemakzucht van de wetgever om slechts op actuele ontwikkelingen te reageren komt aan bod en tevens wordt het problematische van politiek gevoelige onderwerpen aan de orde gesteld.

Daarbij gebruikt Meijers het inzicht in de oorzaken van het falen van deze en eerdere commissies voor het formuleren van voorwaarden die dienen te worden vervuld, wil een toekomstige poging tot herziening meer succes opleveren. Zo kan zijn advies om bij het voorbereiden van een herziening van het B.W. een onderscheid te maken tussen wijzigingen van sociaal-politieke aard, waarover het parlement zich vooraf expliciet dient uit te spreken, en wijzigingen van zuiver technische aard, waarbij die inspraak niet gewenst is, alleen worden begrepen indien men zich de ervaringen, opgedaan met Heemskerk en Donner en de totstandkoming van het B.W. weet te herinneren. En zijn voorkeur voor een uit zo weinig mogelijk leden samengestelde Staatscommissie wijst duidelijk op de trieste ervaringen met de traagwerkende Staatscommissie-Van Meerbeke.

Het advies van Meijers is eenvoudig: geef aan één of enkele vooraanstaande juristen de opdracht tot herziening van het politiek weinig interessante vermogensrecht en zet de organisatie verder zo op, dat het werk aan een nieuw wetboek nooit een hinderpaal zal kunnen vormen voor andere wetgeving.

Ook dit pleidooi liet de wetgever echter onaangedaan. Minister Goseling zei een technische herziening van het B.W. niet het meest urgent te vinden omdat hij niet de overtuiging had dat de wetgever, in verband met de gebeurtenissen in Duitsland, op korte termijn voldoende tijd zou kunnen vinden de ontwerpen ter hand te nemen. ${ }^{312}$

In vele tegenwoordige geschriften wordt dit stilzwijgen van de wetgever verklaard doordat men weliswaar flinke kritiek had op het B.W., maar dat er buiten Meijers niemand overtuigd was van de noodzaak van ingrijpende herzieningen. Die opvatting is, om het in de woorden van Kemper te zeggen, een tot walgens toe herhaald beeld. Ongetwijfeld was men in 1938 van oordeel dat het B.W. als gevolg van het beleid 
van de rechter lang niet slecht functioneerde. Het feit dat het B.W. door zijn gebrekkige en onvolledige redactie de rechter die ruimte liet, leidde zelfs tot de gedachte dat de codificatie zo slecht nog niet was. In het beeld van het recht, zoals de rechtspraak dit weerspiegelt, zijn de meeste gebreken bovendien niet zichtbaar.

Deze tevredenheid nam echter niet weg, dat men besefte, dat de door de rechter veroverde ruimte zijn oorsprong vond in de feilen van het wetboek. Heel duidelijk blijkt dit, wanneer men de reacties op Meijers' geruchtmakende opstel nagaat. Zo is de waardering van Scholten voor het B.W. in zijn academische redevoering uit 1938 aanmerkelijk gedaald en heet het B.W. als veel, wat uit zijn tijd stamt, wat "onbeduidend en armelijk", en geeft hij aan Meijers toe dat "een slap berusten in het bestaande, omdat het bestaat (..) altijd gevaarlijk (is). "313 En Van Apeldoorn verwijt Scholten dat deze de codificatiegedachte nog slechts in naam belijdt, en de vernieuwing bestrijdt van iets dat in werkelijkheid geen codificatie meer mag heten. Scholten zou naar zijn mening in het wetboek nauwelijks méér zien dan een historisch uitgangspunt voor de beoordeling van concrete gevallen, door de rechtspraak aan de hand gedaan. ${ }^{314} \mathrm{Hij}$ besloot zijn recensie van het gedenkboek met de opmerking dat de tijd in Nederland rijp was voor een algehele herziening, en dat er op dit ogenblik zeker meer dan één rechtsgeleerde zou zijn, die deze taak tot een goed einde zou weten te brengen. ${ }^{315} \mathrm{Hij}$ voegde daaraan toe, dat er niet de minste zekerheid bestond dat dit laatste over twintig jaar ook nog het geval zou zijn: "Daarom moet, indien het eenigszins mogelijk is, van de thans aanwezige krachten gebruik gemaakt worden om dit werk ten behoeve van de komende generatie te volbrengen."

Uit geheel onverdachte hoek ${ }^{316}$ klonk eenzelfde geluid. F.G. Scheltema, schrijvend over de toekomst van het Burgerlijk Recht, stelde voorop, dat het

"van het hoogste belang is, een rechtsstelsel te hebben, waarin het geldend recht zo volledig mogelijk in wet of wetboek is "geschreven". Het is misschien wel goed, hierop te wijzen, omdat de hoge waarde van een deugdelijk "geschreven" recht,

313. Gedenkboek Burgerlijk Wetboek 1838-1938 (Redevoeringen), Zwolle 1939, p. 101 e.v.; zie ook p. 47 e.v., waar D.G. Rengers Hora Siccama Scholtens uitspraak "Ons Burgerlijk Wetboek is een rustig bezit", afzwakt door haar te betrekken op de legislatieve stand van zaken: "Dat het in een oud, groot huis rustig is (..), daar is inderdaad alle kans op; doch dat het een rustig bezit is, schijnt mij betwistbaar: oude grote huizen zijn geen aantrekkelijk beleggingsobject meer."

314. In 1923 schreef Scholten in zijn personenrecht (Asser-Scholten, eerste deel, Zwolle 1923, p. 26): "Dat het Burgerlijk Wetboek daaraan (algehele herziening) behoefte heeft, is een sinds jaren vaststaande overtuiging onzer juristenwereld - hoe verschillend overigens over de waarde van het wetboek uit technisch oogpunt wordt geoordeeld. Toch bleef een herziening tot nog toe uit en gelooft niemand meer dat zij in een afzienbaar tijdsverloop tot stand zal komen. Alleen van partiëele herziening is er nog iets te verwachten (..)." Zie ook G.J. Scholten in WPNR 6039 (1992): "Hij heeft in 1938 niet geschreven dat het (nieuwe BW) er niet mocht komen, maar dat het er niet zou komen."

315. Rechtsgeleerd Magazijn, 1939, p. 84 e.v.

316. Volgens Limburg, de voorzitter van de Staatscommissie-1919, bestond er als gevolg van de echtscheiding van Scheltema tussen deze en Meijers "een hoge graad van vijandschap", die er bijvoorbeeld toe heeft geleid dat Meijers, die al ruim vóór 1930 op de nominatie stond, in 1930 door Scholten werd voorbijgestreefd en pas na het overlijden van Scheltema op 4 mei 1939 kon worden benoemd in deze commissie. Zie ook J.H. Beekhuis, Kwartaalbericht NBW, 1989, p. 65-71, die vermeldt dat deze controverse zo diep ging, dat Scheltema Meijers niet eens wenste te citeren. 
naar wij menen, hier en daar wel eens wordt onderschat. Een onderschatting, die schijnt samen te hangen met de opkomst van de gedachte, dat naast geschreven ook ongeschreven recht als geldend moet worden erkend." 317

Net zoals Meijers in 1922 deed, wees Scheltema erop dat de strijd om het ongeschreven recht als rechtsbron erkend te krijgen, tot een overschatting van dat ongeschreven recht heeft geleid. Daaraan zou nog kunnen worden toegevoegd dat deze tendens ook wel te verwachten was, gezien de volkomen stilstand van de wetgeving. Scheltema beklemtoonde voorts dan dat men niet mag vergeten dat in de trits "geen recht ongeschreven recht - geschreven recht" de laatste categorie stellig de beste is. Vervolgens koos hij voor een frontale aanval met Scholten:

"Zij die, met verwijzing naar hetgeen in de afgelopen tijd zonder wetswijziging door rechtspraak en wetenschap werd bereikt, betogen, dat men ook in de toekomst alles gerust aan deze rechtsvormende krachten kan overlaten, miskennen deze waarheid. Rechtspraak en wetenschap hebben, als rechtsvormende factoren, stellig veel bereikt; doch de vraag, zoals men haar stellen moet, is, of niet veel meer had kunnen worden bereikt, wanneer de eigenlijke wetgever actiever ware geweest. Die vraag moet, naar onze stellige overtuiging, bevestigend worden beantwoord: de methode der wetgeving biedt o.i. betere waarborgen voor een deugdelijk rechtsstelsel dan die der vorming van ongeschreven recht."

De rechtszekerheid, de overzichtelijkheid van het recht zouden daarmee ten zeerste gediend zijn, volgens Scheltema. Aangezien het B.W. volstrekt verouderd is en deze voordelen niet biedt, komt de vraag naar de meest wenselijke methode van herziening naar voren. Scheltema prefereert de totale herziening ver boven de partiële, maar acht deze onbereikbaar:

"Gesteld al, men vond een staatscommissie, die, na jaren arbeids, er in zou slagen, een ontwerp gereed te maken, waar vindt men den minister, die bereid is, het te verdedigen, waar het parlement, bereid het te behandelen? Een opzet als deze zou er toe dwingen, alle problemen, ook die van de meest "politieke" aard, opnieuw, en grotendeels zonder noodzaak, in discussie te brengen; de kans, dat de daaraan te besteden arbeid enig resultaat zal opleveren, schijnt zo uitermate gering, dat tot het doen der poging o.i. niet kan worden geraden."

De conclusie was duidelijk. Slechts een doorlopende technische herziening van het vermogensrecht is doelmatig en uitvoerbaar. De Staatscommissie-Limburg, waarvan Scheltema zelf deel uitmaakt, was daartoe niet geschikt. Niet alleen was het voor haar, gelet op de grote herzieningsachterstand, praktisch onmogelijk om deze taak aan te vatten, maar ook ontbrak het volgens Scheltema bij de leden aan beheersing van de te codificeren rechtsmaterie. Met een verwijzing naar de opdracht van Van Raalte aan Molengraaff om een ontwerp Zeerecht te vervaardigen stelde hij voor de herziening aan één of enige vooraanstaande juristen op te dragen. Een duidelijker erkenning van het redelijke van zijn legislatieve wensen kon Meijers toch moeilijk verlangen.

317. Rechtsgeleerd Magazijn, 1938, p. 569; Zie ook Van Oven, NJB 1938, p. 601 en p. 763. 


\section{Samenvatting en conclusie}

Uit het voorgaande is gebleken, dat het B.W. reeds kort na de inwerkingtreding in 1838 veel kritiek te verduren kreeg. Dat de wetgever er aanvankelijk weinig voor voelde om tot herziening over te gaan, is zeker te begrijpen. Er is moed voor nodig om te erkennen dat een twintigjarige arbeid van velen tot een minder resultaat leidde dan het werk dat door enkele mannen in Frankrijk in vier maanden tot stand werd gebracht, ook al konden zij profiteren van veel voorwerk. Bovendien was de kritiek anvankelijk wat al te scherp, omdat men de vorm boven de inhoud stelde en pas langzamerhand vertrouwd raakte met grondbeginselen van het burgerlijk recht.

Na verloop van tijd echter traden, deels als gevolg van een grondige studie, deels als gevolg van maatschappelijke ontwikkelingen, nieuwe, veelal meer ernstige gebreken aan het licht. Wellicht was een enkele Minister van Justitie nog wel te vinden voor een beperkte herziening, men denke aan Van Hall, De Vries, Smidt, Modderman en Van Raalte, maar al snel leerde de ervaring dat deze pogingen of strandden na het vertrek van de Minister óf vastliepen op de houding van de Kamer. Ook bleek het werken aan wetgeving in commissoriaal verband niet erg effectief.

Dit leidde ertoe dat er steeds vaker toe werd overgegaan nieuwe wetgeving buiten het B.W. te plaatsen, met als gevolg dat de ontwikkeling van de algemene leerstukken, verwoord in de niet-herziene gedeelten van het B.W., achterbleef of zelfs ongunstig werd beïnvloed. Aangezien de wetgever zich daarvan zo min mogelijk rekenschap wenste te geven en de gevolgen voor de justitiabelen steeds ernstiger werden, deed zich, na lang aarzelen, een reactie voor; men vroeg de rechter om een billijker rechtssysteem te beproeven. De uitspraak van de NJV uit 1912 betekende een aarzelende eerste schrede op deze weg. Zij hield tevens de constatering in dat de gehele Burgerlijke Wetgeving volstrekt verouderd was.

Het arrest van 1919 was het antwoord op deze roep, het fungeerde als katalysator, markeerde het begin van een nieuw tijdperk. Het gemak waarmee de rechter een aantal gebreken kon verhelpen, stemde zeer hoopvol. Het vertrouwen in het optreden van de rechter werd zo groot, dat de roep om herziening geruime tijd bijna niet meer werd gehoord. Ook kreeg de waardering voor het B.W. een ander karakter. Ofschoon men de vele gebreken van het wetboek niet kon ontkennen, waren juist die lacunes, weinig precieze bepalingen en met elkaar conflicterende voorschriften er de oorzaak van dat de rechter weinig dwingende en knellende regels tegenover zich zag.

Toch moest men al spoedig ervaren dat de rechter niet het gehele terrein kon bestrijken dat de wetgever haar door zijn indolentie had gelaten. Soms stonden de woorden van de wet een acceptabele beslissing in de weg, soms ook durfde de rechter terwille van de rechtszekerheid niet op zijn oude uitspraken terug te komen. De mate van verantwoordelijkheid die op zijn schouders gelegd was, werd immers nog elke dag vergroot. Zijn beslissing gold niet meer alleen het concrete geval, maar kreeg een veel wijdere strekking, niet in het minst veroorzaakt door de indringende annotaties die verschenen.

Meijers was één van de eersten die op dit probleem de aandacht vestigde. Net zoals Molengraaff vond hij dat wetgever en rechter beiden een taak hadden op het gebied van de rechtsvorming. Naar zijn overtuiging zou terwille van de rechtszekerheid het evenwicht tussen de wet en de rechter moeten worden hersteld en niet afhankelijk 
moeten zijn van de proceslust van partijen. Voor de wetgever betekende dat concreet een herschikking en herformulering van de algemene leerstukken. De rechter zou zich weer met zijn eigenlijke taak bezig kunnen houden, namelijk het zoeken naar een acceptabele vertaling van deze regels voor elk concreet geval. Zou de beslissing dan onbillijk zijn, dan kon dat in ieder geval niet als verwijt tegen de wetgever worden gekeerd. 
Hoofdstuk 3

DE HERCODIFICATIE VAN HET BURGERLIJK WETBOEK (1947-1954)

\section{De opdracht aan Meijers}

Op 5 maart 1947, bij de behandeling van de Justitiebegroting, zei het liberale Eerste Kamerlid Zegering Hadders, na enkele kanttekeningen te hebben geplaatst bij het feit dat de Minister bij de vervulling van vacatures bij de rechterlijke macht uitsluitend een beroep deed op mannen, het volgende:

"Mijnheer de Voorzitter! Ik zal vandaag niet in den breede ingaan op de plaats, die de vrouw krachtens ons Burgerlijk Wetboek in het huwelijk inneemt; ik zal niet spreken over het huwelijksgoederenrecht of over de toegezegde wijziging van de wetgeving betreffende de echtscheiding. Ik volsta met te zeggen, dat naar onze meening ons Burgerlijk Wetboek in hooge mate verouderd is. Op tal van gebieden van het civiele recht zijn volkomen nieuwe denkbeelden naar voren gekomen, terwijl de maatschappelijke verhoudingen sedert 1839 een geweldige verandering hebben ondergaan.

Ik zou den Minister daarom ernstig in overweging willen geven het initiatief te nemen tot een algemeene herziening van het Burgerlijk Wetboek, waarbij met het resultaat der wetenschappelijke studiën uit de laatste decennia kan worden rekening gehouden. Het is wel teekenend, dat b.v. het nieuwe regime in Italië er niet aan denkt het Burgerlijk Wetboek, dat van 1942 dateert, in te trekken.

Zouden wij den Minister bereid mogen vinden ten aanzien van het Burgerlijk Wetboek een nieuwen weg in te slaan en naar het voorbeeld van wat met stukken van het Wetboek van Koophandel geschiedde thans aan een rechtsgeleerde van den eersten rang, ik denk aan prof. Meijers, te verzoeken een geheel nieuw Burgerlijk Wetboek samen te stellen, een ontwerp dat, omdat het door eén man wordt ontworpen, van één geest kan zijn vervuld en daardoor tevens een logisch sluitend geheel zal vormen?"

Minister Van Maarseveen antwoordde de volgende dag:

"De geachte afgevaardigde de heer Zegering Hadders heeft mij gevraagd of het niet aanbeveling zou verdienen aan een bekwaam jurist als prof. Meijers op te dragen een nieuw Burgerlijk Wetboek samen te stellen. Op zich zelf verdient dit denkbeeld alle overweging. $\mathrm{Nu}$ wij het geluk hebben in onze samenleving zoo'n voortreffelijk jurist als prof. Meijers is te hebben, zouden wij hem kunnen verzoeken om, indien hij daartoe bereid is, een herziening van het Burgerlijk Wetboek ter hand te nemen. Ik wil op dit punt nog geen beslissing nemen. Men moet nooit onvoorbereid beslissingen nemen, ook al is men nog zoo besluitvaardig. Wel zal ik dit denkbeeld gaarne overwegen." ${ }^{2}$ 
Twee weken later, op 19 maart 1947, schreef Van Maarseveen een brief aan Meijers met de uitnodiging voor een gesprek. De tekst van deze brief, die in de nalatenschap van Jan Drion, van 1947 tot 1950 secretaris van Meijers, werd aangetroffen, luidde als volgt:

"In de Eerste Kamer der Staten-Generaal is het denkbeeld geopperd aan U Hooggeleerde - zoo U daartoe bereid zoudt zijn - de opdracht te verleenen een nieuw Burgerlijk Wetboek samen te stellen. Ik heb dadelijk verklaard, dat dit denkbeeld zeer veel aantrekkelijks heeft. Indien $U$ het met dit laatste eens zijt, zou ik U mogen verzoeken met mij ter zake een bespreking te willen hebben. Misschien wilt $\mathrm{U}$ over dag en uur wel even telefonisch overleg plegen met mij of met mijn secretaresse.

Tevens wilde ik bij deze gelegenheid met $U$ van gedachten wisselen over het weder op gang brengen van de Staatscommissie Limburg."

De datum voor deze bespreking, waarbij naast de Minister ook Secretaris-Generaal Tenkink, mevrouw Schönfeld-Polano en de heren Eijssen en De Meijere aanwezig zouden zijn, werd vastgesteld op 15 april $1947 .{ }^{3}$ Kort daarvoor, op 12 april, vond een ambtelijke voorbespreking plaats. Het verslag van deze bespreking, waarbij de Secretaris-Generaal ontbrak, begint aldus:

"De M.v.J. deelt mede, dat het in het voornemen ligt aan prof. Meijers opdracht te geven, een nieuw B.W. samen te stellen.

Teneinde voor deze taak in de juristenwereld belangstelling te wekken, zal over de vraag of vernieuwing en meer in het bijzonder de voorgenomen methode van vernieuwing wenschelijk wordt geacht, het oordeel worden ingewonnen van den Hoogen Raad, Procureur-Generaal, alle Hoven en Rechtbanken, de juridische faculteiten, de Advocaten Vereeniging, de Ned. Juristen Ver., Broederschap der Notarissen en die der Cand.-notarissen.

Wellicht is er ook een modus te vinden, om vooraf de vaste commissie voor Privaat- en Strafrecht te polsen. Misschien ook de Eerste Kamer, die zich het eerst over een dergelijke opdracht heeft uitgesproken.

Raadpleging van een nog uitgebreider kring is ongewenscht, omdat het Ministerie niet den schijn moet wekken zichzelf incompetent te achten. ${ }^{\prime 4}$

Uit het vervolg van het verslag wordt duidelijk dat Van Maarseveen inmiddels zijn gedachten heeft laten gaan over de bij de herziening van het Burgerlijk Wetboek te volgen procedure. De drie volgende suggesties, alle erop gericht het gehele proces zo doelmatig mogelijk te laten verlopen, stammen uit zijn koker;

3. Uit de stukken blijkt althans niet dat Meijers vóór 15 april met Van Maarseveen van gedachten heeft gewisseld.

4. Een kanttekening vermeldt dat het van "het grootste belang is dat de Juristenwereld meeleeft." Raadpleging van "sociale" faculteiten is niet aan de orde, omdat de Minister "geen infiltratie" wenst. 
- om de opdracht aan Meijers onafhankelijk te maken van Ministers-wisseling, dient deze bij Koninklijk Besluit te worden verleend;

- Meijers dient te worden benoemd tot voorzitter van de Staatscommissie ter herziening van de Nederlandse Burgerlijke Wetgeving. Deze commissie, waarin het Ministerie vertegenwoordigd is in de persoon van mevrouw Schönfeld-Polano, krijgt als taak de door Meijers opgestelde ontwerpen te behandelen;

- op voetspoor van de in 1820 opgestelde "vraagpunten van stellig recht" zou Meijers omtrent bepaalde punten vooraf een uitspraak van Regering of Kamer kunnen vragen. ${ }^{5}$

In het ambtelijk vooroverleg werd ook aandacht besteed aan de richtlijnen de ontwerper bij zijn herzieningsarbeid in het oog zou dienen te houden. Zo liet Van Maarseveen er geen twijfel over bestaan dat er van zijn kant geen principiële wijzigingen in het personen- en familierecht waren te verwachten: in de gronden van echtscheiding mag "niets, of althans niet veel" worden gewijzigd, het beginsel, dat de man het hoofd van de echtvereniging is "behoort niet te worden aangetast" en met betrekking tot het wettelijk huwelijksgoederenrecht moet worden vastgehouden aan de algehele gemeenschap van goederen. Het kinderrecht tenslotte, zou evenmin belangrijk mogen worden gewijzigd. De reden daarvoor was niet een partij-politiek bezwaar, maar de omstandigheid dat reeds een ontwerp tot herziening van het kinderrecht bij de Kamer aanhangig was. ${ }^{6}$

Met betrekking tot de wijzigingen die in het vermogensrecht zouden kunnen worden aangebracht, had Van Maarseveen minder uitgesproken denkbeelden. Hij beperkte zich tot het noemen van een aantal punten waaraan Meijers aandacht zou moeten besteden (o.a. de positie van de langstlevende echtgenoot in het erfrecht, de vraag of toerekeningsvatbaarheid een voorwaarde is voor het aannemen van aansprakelijkheid en of de aansprakelijkheid in het algemeen moet berusten op schuld of op gevaarzetting). Het verslag besloot met de opmerking dat de ontwerper "in het algemeen het midden (zal) moeten houden tusschen nieuwe denkbeelden en traditie."

Van het gesprek met Meijers, drie dagen later, is eveneens een verslag gemaakt. Ik licht er een aantal interessante punten uit.

Iets wat onmiddellijk opvalt, is dat Van Maarseveen en Meijers kennelijk kort daarvoor tot overeenstemming waren gekomen over de voorwaarden waaronder Meijers aan het werk kon gaan. ${ }^{7}$ Het verslag begint namelijk met de mededeling dat

5. In de marge van dit verslag was aangetekend "dit geeft fundament."

6. Dit ontwerp leidde tot de wet van 10 juli 1947, Staatsblad H 232 (in werking getreden 1 september 1948, Staatsblad I 343).

7. Meijers zelf had slechts drie voorwaarden gesteld: het voorontwerp zou pas mogen worden gepubliceerd als het geheel gereed zou zijn; het Departement zou de kosten, verbonden aan het aantrekken van een jurist ter zijner ondersteuning, moeten vergoeden; het Departement zou zorg moeten dragen voor het vervoer van en naar Den Haag voor overleg met de Minister en de Staatscommissie (vergelijk art. 9 van de Justitiebegroting 1948).

Overigens zou Meijers met ingang van september 1950, toen hij ontslag had genomen als hoogleraar in verband met het bereiken van de pensioengerechtigde leeftijd, een kleine maandelijkse toelage krijgen, gelijk aan het verschil tussen zijn salaris en het hem toegekende pensioen (Vergelijk art. 11 van de Justitiebegroting 1950). 
Meijers de opdracht zal aanvaarden. Als motief voor het verlenen van de opdracht wijst Van Maarseveen erop dat "de wet teveel een doode letter wordt en de jurisprudentie te los van de wet komt te staan." Meijers zelf brengt naar voren dat het Burgerlijk Wetboek niet alleen oud maar ook zeer verouderd is: het dreigt daardoor slechts leerboek te worden.

Een andere, eveneens interessante passage uit het verslag is die waarin wordt ingegaan op de vraag of er naast instemming met wellicht ook sprake zal zijn van kritiek op de voorgenomen methode van herziening. Het resultaat van de bespreking is dat de Minister afstapt van zijn aanvankelijk voornemen de juridische wereld vooraf te polsen. In het verslag wordt deze standpuntwijziging als volgt onder woorden gebracht:

"Desgevraagd zegt E.M.M., dat als men het oordeel gaat inwinnen van colleges en vereenigingen, er wellicht ook van oppositie zal blijken. \pm 15 jaar geleden ${ }^{8}$ heeft de Ned. Jur. Ver. zich voor partieele herziening uitgesproken.

M.v.J. wenscht eventueele oppositie te negeeren; de Koningin zal met het denkbeeld instemmen. Secr. Gen. stelt voor: eerst opdracht verleenen, daarna kennisgeven en uitnoodigen om bij E.M.M. suggesties naar voren te brengen. E.M.M. gaat hiermede accoord en zou dan willen toevoegen, dat suggesties op prijs worden gesteld.

Zoo kan men er achter komen, of er bepaalde artt. zijn, die door de rechterlijke macht als hinderlijke slagboomen worden gevoeld."

Vanzelfsprekend maakte ook de te volgen procedure voor de totstandkoming van het nieuwe wetboek onderwerp van bespreking uit. Zo werd besloten Boek voor Boek bij de Kamer in te dienen, teneinde haar niet met werk te overvoeren. Tevens viel het besluit het secretariaat van de Staatscommissie-Limburg tijdelijk met twee wetgevingsjuristen te versterken, een maatregel die er blijkens de circulaire van 14 mei 1947, waarin de opdracht aan Meijers werd bekendgemaakt, op gericht was te bereiken "dat de ontwerpen welke van de hand van prof. Meijers zullen komen, onverwijld bij de Staten-Generaal (kunnen) worden ingediend." 9 Het Regeringsontwerp zou dus in beginsel identiek zijn aan het voorontwerp.

In het laatste gedeelte van het verslag kwamen aard en omvang van het nieuwe wetboek aan de orde. Daarover leest men onder andere:

"Om te voorkomen dat het werk vastloopt op groote verscheidenheid van meeningen moet er de voorkeur aan worden gegeven om niet Boek 1 maar het technische gedeelte van het B.W. voorop te stellen.

8. Vermoedelijk moet hier worden gelezen " \pm 35 jaar geleden". In 1912 was er binnen de Nederlandse Juristen Vereniging voor het laatst gedebatteerd over de wenselijkheid van een algehele herziening.

9. In het verslag zelf wordt deze maatregel niet toegelicht. Vermeld wordt slechts dat "bestudering door het Ministerie kan worden gecombineerd met de behandeling door de Commissie-Limburg. waarin het Ministerie vertegenwoordigd is en waaraan ad hoc voor deze speciale taak kan worden toegevoegd $\mathrm{mr}$. Eijssen als eerste secretaris en $\mathrm{mr}$. De Meijere als tweede secretaris." Eijssen zou overigens nooit fungeren als algemeen secretaris. Zijn plaats zou worden ingenomen door mr. W.G. Belinfante. 
Het bewijsrecht moet opnieuw worden geregeld, en overgebracht naar het procesrecht.

Het zou gewenst zijn om de tegenstelling tusschen B.W. en W.v.K. te doen verdwijnen (..). Overigens moet het wetboek niet te uitgebreid worden."

Zoals de Minister al in het gesprek met Meijers had aangekondigd, werd onmiddellijk een nota voorbereid, bestemd om in de Ministerraad te worden behandeld. In dit stuk, gedateerd 16 april 1947, wordt onder andere opgemerkt:

"Het Burgerlijk Wetboek, dat sinds 1 October 1838 van kracht is, en mitsdien een hoogen leeftijd heeft bereikt is behalve oud, ook verouderd.

De sporen van den ouderdom zijn ondanks de partieele herzieningen, diep in het wetboek gegroefd. De ontwikkeling van het burgerlijk recht, voor zoover dit in het wetboek is neergelegd, is buiten het wetboek getreden, doordat de rechtspraak over het burgerlijk recht een ontwikkeling te zien geeft, die buiten het wetboek óm gaat en die bovendien tegen beginselen van het wetboek indruischt.

Dit dubbele aspect van de ontwikkeling van het burgerlijk recht doet het wettenrecht wijken voor een jurisprudentierecht, welk recht - veel minder dan wettenrecht en met name wanneer jurisprudentierecht tot ontwikkeling moet komen naast en tegen een bestaand wetboek in - in staat is het gecompliceerde maatschappelijke leven te omvatten.

De tijd is daarom aangebroken voor de samenstelling van een nieuw Burgerlijk Wetboek. In Frankrijk heeft een Staatscommissie bereids een aanvang gemaakt met de bewerking van een nieuwen Code Civil. (..)

Prof. Meijers streeft naar: korte formuleeringen, waardoor wijdlopigheid wordt vermeden en het nieuwe wetboek niet langer, doch korter wordt dan het oude (..). Het nieuwe burgerlijke wetboek zal, wil het een evenwichtig stuk worden en in de wet worden verwezenlijkt, het midden moeten bewaren tusschen hetgeen bereids gemeen goed van de rechtswetenschap is geworden en de rechtsontwikkeling van de toekomst. Het zal daarom niet te ver mogen vooruitloopen op de resultaten, die de wetenschap heeft bereikt. Het nieuwe wetboek zal daarom geen belangrijke verandering kunnen brengen in onderwerpen, die kort geleden bij de wet zijn vastgesteld en voorts t.a.v. principieele punten zich conformeeren aan het beleid van het ogenblikkelijke Hoofd van het Ministerie van Justitie (geen uitbreiding van de gronden voor echtscheiding; de man geldt als hoofd van de echtvereeniging onder voorbehoud van belangrijke maatregelen tegen misbruik van de macht van den man; geen algeheele wijziging van het erfrecht).

Prof. Meijers zal in verband met den aan de samenstelling van een nieuw burgerlijk wetboek te besteden tijd voor een aanmerkelijk deel van zijn werkzaamheden als hoogleraar moeten worden ontlast. De in uitzicht zijnde benoeming van een tweeden hoogleeraar in het burgerlijk recht aan de Rijksuniversiteit te Leiden zal daartoe kunnen bijdragen en dient daarom te worden bevorderd.

Prof. Meijers verlangt naast het honorarium, dat hij als hoogleraar geniet, geen honorarium voor zijn nieuwe taak. Hij moet wel kunnen beschikken over een zoodanige vergoeding van te maken kosten, dat hij ruime bewegingsvrijheid geniet om op deugdelijke wijze te kunnen arbeiden, met name wat betreft het contact dat Prof. Meijers heeft met de kringen van de Fransche juristenwereld, die een nieu- 
wen Code Civil samenstelt. Ook alle andere kosten, ook van personeelen aard, moeten hem worden vergoed."

Vermoedelijk heeft deze nota de Ministerraad, die op 21 april zou bijeenkomen, nooit bereikt, want drie dagen daarvoor zond Minister Van Maarseveen "in overeenstemming met het gevoelen van den Minister-President" een nota naar de Koningin met daarin het verzoek aan Meijers opdracht te verlenen tot het ontwerpen van een nieuw Burgerlijk Wetboek. ${ }^{10}$ Dit stuk is, afgezien van verschillen in woordkeus en formulering, vrijwel gelijk aan de nota die voor de Raad van Ministers was bestemd. Er is echter één belangrijk verschil: naast de hierboven uiteengezette beweegredenen om tot hercodificatie over te gaan wordt bovendien aangevoerd dat een nieuw Burgerlijk Wetboek "met name voor de jongere generatie een machtige impuls (zou) kunnen zijn, om zich met vernieuwden ijver aan de studie van het burgerlijk recht te wijden."11

Enkele dagen later, op 25 april 1947, tekende Koningin Wilheimina het benoemings-K.B. ${ }^{12}$ Op 14 mei tenslotte, verscheen de door Van Maarseveen toegezegde circulaire, met daarin de oproep aan alle Nederlandse juristen om een bijdrage te leveren aan het welslagen van de onderneming. Tot zover de onmiddellijke aanleiding tot de opdracht.

\section{Achtergronden}

Met betrekking tot het antwoord op de vraag waarom Minister Van Maarseveen direct zo positief reageerde op de suggestie van Zegering Hadders, een suggestie die min of meer toevallig werd geopperd ${ }^{13}$, bestaan vele hypothesen.

Zo heeft Langemeijer ${ }^{14}$ het totstandkomen van het K.B. grotendeels toegeschreven aan de vreugde over Meijers' terugkeer uit gevangenschap en aan het feit dat hij reeds

10. Deze veronderstelling wint nog aan betekenis, doordat uit de notulen van de Ministerraad niet blijkt dat het verlenen van de opdracht onderwerp van behandeling is geweest. Het zou ook hoogst zonderling zijn om, vooruitlopend op het besluit van de Ministerraad, het benoemings-K.B. aan de Koningin voor te leggen.

11. Vergelijk ook R.L. Drilsma, Een vraag en een antwoord, NJB 1947, p. 283 e.v. In dit artikel, geschreven ter ondersteuning van het initiatief van Zegering Hadders, wijst Drilsma erop dat de wenselijkheid van een algehele herziening vooral een eis is van juridische pedagogiek.

12. Het besluit werd gepubliceerd in de Staatscourant van 6 mei 1947, no. 86 .

13. Zegering Hadders heeft tegenover mij bevestigd dat hij van zijn fractiegenoot en woordvoerder voor Justitie Molenaar, die wegens het bijwonen van een conferentie in Genève verhinderd was, drie onderwerpen had gekregen die hij, naar gelang er tijd voor was, tijdens de begrotingsbehandeling ter sprake zou kunnen brengen. Hij besloot uitsluitend de vraag te stellen omtrent de mogelijkheid van herziening van het B.W. - door Molenaar niet bovenaan gezet - "omdat een nieuw Burgerlijk Wetboek mij erg praktisch leek." Zie ook K. Wiersma, Meijers en de hercodificatie, WPNR 5504 (1980).

14. G.E. Langemeijer, Het achterlopen van de wetgever, in: Politiek, Parlement, Democratie, (Duynstee-Bundel, Deventer 1975), p. 117 e.v. In een in het voorjaar van 1987 gehouden vraaggesprek wees Langemeijer bovendien op de omstandigheid dat men over een zo uitzonderlijk jurist als Meijers kon beschikken: "Een jurist van het formaat van Meijers kun je in het gunstigste geval eens in de honderd jaar tegenkomen, dus daar moest gebruik van gemaakt worden. Dat was heel duidelijk het algemeen gevoelen, een enkele tegenstander daargelaten, zoals Pitlo." 
belangrijke voorstudies zou hebben verricht voor het nieuwe wetboek. Beekhuis ${ }^{15}$ voegde hieraan toe dat het aan iedereen bekend was dat Meijers zich er voor interesseerde een nieuw Burgerlijk Wetboek te ontwerpen en meende bovendien dat de opdracht gunstig lag in de na-oorlogse drang tot vernieuwing. Belinfante ${ }^{16}$ heeft erop gewezen dat Meijers destijds de grootste en meest gezaghebbende jurist was, de enige van wie men kon verwachten dat hij tot een dergelijk werk in staat was. Wiersma ${ }^{17}$ tenslotte, veronderstelt dat het voorstel de Minister welkom moet zijn geweest aangezien inwilliging ervan een tegenwicht zou kunnen vormen tegen de algemene onvrede over de bijzondere rechtspraak.

Al deze verklaringen lijken plausibel. Zo is het bijvoorbeeld niet onmogelijk dat het in 1947 nog niet geheel verdwenen bevrijdingsoptimisme een zekere rol heeft gespeeld. Volgens een aantekening, gemaakt tijdens de bespreking met Meijers, heeft Van Maarseveen de opmerking gemaakt dat Koningin Wilhelmina - een groot voorstander van maatschappelijke vernieuwing - het denkbeeld om tot codificatie over te gaan "mooi zal vinden". Zegering Hadders verzekerde mij dat vele van zijn collega's zijn suggestie een "goed en plezierig idee" vonden. ${ }^{18}$ Men hoede zich er echter voor, zoals in het verleden wel is gebeurd ${ }^{19}$, al te zeer de nadruk te leggen op dit argument. Het gegeven dat Meijers geen wijzigingen mocht voorstellen ten aanzien van die gedeelten van het recht die de grondslag van het familieleven uitmaken een terrein waar de Franse commissie onder leiding van Léon Julliot de la Morandière wel hervormend wenste op te treden ${ }^{20}$ - duidt erop dat Van Maarseveen niet méér wenste dan een overwegend technische herziening. ${ }^{21}$

15. J.H. Beekhuis, Meijers en de vernieuwing van onze codificatie, Rechtsgeleerd Magazijn Themis, 1950, p. 260. Vergelijk ook Holthöfer, a.w., p. 1296.

16. W.G. Belinfante, De totstandkoming van het nieuwe Burgerlijk Wetboek, in: Het ontwerp B.W., Deventer-Antwerpen 1961, p. 36. Zie ook T.J. Dorhout Mees, het ontwerp voor een nieuw Nederlands Burgerlijk Wetboek, in: Mededelingen van de Koninklijke Vlaamse Academie voor Wetenschappen, Letteren en Schone kunsten van België, Brussel 1964, p. 12.

17. K. Wiersma, Meijers en de hercodificatie, WPNR 5504 (1980), p. 28.

18. Ook J.P. Fockema Andreae, Naar een nieuw Burgerlijk Wetboek, NJB 1947, p. 349, noemt als één van de argumenten, waardoor zijn standpunt ten gunste van het denkbeeld van een algehele herziening is gewijzigd, het feit dat er een "sterke drang naar vernieuwing" is ontstaan.

19. Zie bijvoorbeeld A. Pitlo, Enige bezwaren tegen de huidige vernieuwing van ons Burgerlijk Wetboek, in: Het ontwerp BW, Deventer-Antwerpen 1961, p. 21-22; J.M. van Dunné, Het werk aan het nieuw BW: jeugdsentiment uit de jaren vijftig? NJB 1977, p. 342 e.v.; P. Zonderland, Nieuw vermogensrecht als hamerstuk? NJB 1977, p. 410 e.v.

20. Zie daarover E.J.A. Fischer-Keuls, Hercodificatie in Frankrijk en ten onzent, in: ' $t$ Exempel dwinght, Zwolle 1975, p. 135 e.v.; L.J. de la Morandière, De hervorming van het Burgerlijk Wetboek in Frankrijk, 's-Gravenhage 1948 (onuitgegeven), p. 24 e.v.: "Wij hebben onze arbeid aangevangen in de atmosfeer door de bevrijding geschapen, toen het Parlement de weg van een vergevorderd socialisme scheen op te gaan, toen men de wetten inzake de nationalisatie van belangrijke industriële ondernemingen, de wetten inzake de ondernemingscomite's, inzake de pachtregeling afkondigde en toen de rantsoenering en de geleide economie tot een steeds strengere reglementering aanleiding gaven."

21. Vergelijk ook de opmerking van J. Drion, Waarom nieuwe codificatie van het Burgerlijk Recht, in: Het Ontwerp B.W., Deventer-Antwerpen 1961, p. 12, dat Meijers zelfs met de grootste moeite niet als een representant van een na-oorlogse "Sturm und Drang-mentaliteit" kon worden gezien; E.J.A. Fischer-Keuls, a.w., p. 146, noot 49. 
Ook valt niet te ontkennen dat er tijdens ${ }^{22}$ en na de bezetting aan Meijers een bovenpersoonlijke verering was gaan toevallen - Beekhuis ${ }^{23}$ heeft geschreven dat Meijers "op het moment van de bevrijding kon gelden als een nationaal figuur, wiens naam in alle lagen van het volk bekend geworden was" - zodat de wens hem hulde te brengen een motief kan zijn hem op wetgevend gebied de plaats te geven die hem zolang was onthouden. Dat het daarvoor, zoals Wiersma ${ }^{24}$ tegenwerpt, in 1947 toch al rijkelijk laat was, waag ik te betwijfelen. Direct na de oorlog waren er dringender problemen die om een oplossing vroegen, waarbij tevens dient te worden bedacht dat het hier de eerste naoorlogse gelegenheid betrof om - zoals bij een begrotingsbehandeling meestal het geval is - vragen te stellen en suggesties te opperen met betrekking tot de voornemens van de Minister op wetgevend terrein. Meijers had overigens al eerder in de schijnwerpers van de publieke belangstelling gestaan. In 1946 was hij door de Regering aangezocht voor de functie van President van de Hoge Raad om de tussen beide bestaande vertrouwenscrisis op te lossen. ${ }^{25}$

Het motief dat Wiersma zelf aandraagt - de hercodificatie als tegenwicht voor de algemene onvrede over de bijzondere rechtspraak - is moeilijk te beoordelen. Wél is duidelijk dat de achtereenvolgende Ministers in dat opzicht weinig zijn gebaat door het werk aan het nieuwe wetboek, want tot ver in de jaren vijftig staan de "Handelingen" vol met klachten over de bijzondere rechtspleging, waarbij niet zelden de naam van Meijers opduikt. ${ }^{26}$

Dit alles neemt echter niet weg dat het onwaarschijnlijk moet worden geacht dat alleen deze factoren ertoe hebben geleid dat in 1947 de grote stap zo vlot werd gezet. Zeker, het is duidelijk dat als men het besluit zou nemen een nieuw Burgerlijk Wetboek te ontwerpen, Meijers daarvoor de aangewezen persoon was. En eveneens kan worden gezegd "dat als Nederland in 1947 niet had beschikt over de persoon van Meijers, niemand zou hebben voorgesteld om er aan te beginnen een nieuw Burgerlijk Wetboek te maken. ${ }^{27}$ Maar hiermee is strikt genomen slechts de aanleiding tot de

22. Vooral de 26 November-rede van Cleveringa, uitgesproken naar aanleiding van het ontslag in 1940 van Meijers als Joods hoogleraar door de Duitse bezetter, heeft tot gevolg gehad dat Meijers sterk in de publieke belangstelling kwam te staan. Cleveringa's "vlammend protest" leidde het studentenverzet in. Zie L. de Jong, Het Koninkrijk der Nederlanden in de Tweede Wereldoorlog, deel 4, tweede helft, Den Haag 1972, p. 792-803.

23. J.H. Beekhuis, Meijers en de vernieuwing van onze codificatie, Rechtsgeleerd Magazijn Themis, 1950 , p. 260 . Beekhuis lichtte deze bewering in een vraaggesprek nader toe door erop te wijzen dat Meijers pas na de oorlog werd gevraagd lid te worden van de Staatscommissie-Limburg. In het vorige hoofdstuk is er echter op gewezen dat Meijers reeds voor de oorlog toetrad tot de Staatscommissie en dat hij daarvoor pas zo laat werd gevraagd niets te maken had met een miskenning van zijn wetenschappelijke kwaliteiten.

24. K. Wiersma, Meijers en de hercodificatie, WPNR 5504 (1980), p. 27.

25. J. Donner werd in zijn plaats benoemd, omdat de Hoge Raad, die tijdens de oorlog fout was geweest, Meijers niet wilde accepteren. Zie daarover L. de Jong, a.w., deel 12, eerste helft, Leiden 1988, p. 381 .

26. Zie L. de Jong, a.w., deel 12, tweede helft, Leiden 1988 , p. 676-710, waarin uitgebreid aandacht wordt besteed aan de rol van Meijers.

27. J. Drion, a.w., p. 12. Zie ook M.H. Bregstein, Meijers en de poging tot hercodificatie in Nederland, Rechtskundig Weekblad 1956, p. 176. 
opdracht en het feit dat Meijers de opdracht kreeg, verklaard, niet het besluit tot herziening zelf.

Naar mijn mening zijn het vooral de volgende factoren geweest die Van Maarseveen tot het besluit hebben gebracht de burgerlijke wetgeving ingrijpend te herzien: dat het Burgerlijk Wetboek en het Wetboek van Koophandel sterk verouderd waren; de langzaam gegroeide voorkeur voor een algehele herziening boven een reeks van partiële; de daadkracht van de Minister; en tenslotte - maar dat mag nauwelijks een verrassing heten - de omstandigheid dat men over een zo uitzonderlijk jurist als Meijers kon beschikken.

Over de wenselijkheid om tot herziening van het Burgerlijk Wetboek over te gaan de eerste factor - is hiervoor al het nodige gezegd. Argumenten van deze strekking komen voor in het verslag van de bespreking tussen Van Maarseveen en Meijers, in de nota aan de Ministerraad, in de voordracht aan de Koningin en in de nota die Meijers schreef ter inleiding van de vraagpuntenprocedure. ${ }^{28}$ Van Maarseveen zelf zei er het volgende over:

"Het Burgerlijk Wetboek van thans dateert van 1838 en is meer dan een eeuw oud. Vooral in de laatste decennia heeft de rechtspraak over het burgerlijk recht zich moeten losmaken van het wetboek. Niet zelden gaat deze ontwikkeling zo ver dat de rechtspraak tegen de beginselen van het wetboek indruist. Maar evenmin als het verouderde wetboek kan de rechtspraak het gecompliceerde maatschappelijke leven omvatten.

Ook de rechtswetenschap is in haar ontwikkeling gehandicapt doordat zij met een verouderd wetboek moet opereren.

De tijd is daarom aangebroken voor de samenstelling van een nieuw Burgerlijk Wetboek. Ook in Frankrijk heeft men dit ingezien; daar heeft een Staatscommissie bereids een aanvang gemaakt met het ontwerpen van een nieuwe Code Civil." ${ }^{29}$

Nu vertelt Van Maarseveen hiermee niet zoveel nieuws: dat het Burgerlijk Wetboek verouderd was en tal van dubia en leemten kende, werd door niemand bestreden, zelfs niet door een notoire tegenstander als Pitlo. ${ }^{30}$ Discussie bestond "slechts" over de vraag of het gehele wetboek op de helling moest of dat kon worden volstaan met een reeks van partiële herzieningen. Of was dat inmiddels een gepasseerd station?

28. Deze nota is opgenomen in Parl. Gesch. NBW, Algemeen Deel, Deventer-Antwerpen 1961, p. 712.

29. Dit is een fragment uit een studie voor de circulaire van 14 mei 1947, waarin overigens slechts gesproken wordt over de "noodzakelijke vernieuwing van ons burgerlijk wetboek." Deze studie, die werd geschreven na 25 april 1947, is vermoedelijk van de hand van mr. Eijssen en bevat een gestylleerde weergave van een vraaggesprek met Van Maarseveen.

30. Zie bijvoorbeeld diens artikel "Het Erfrecht in het Ontwerp-Meijers", Rechtsgeleerd Magazijn Themis, 1950, p. 463 e.v.: "Een wet van meer dan honderd jaren kan niet vrij zijn van anachronismen. Onelegant zijn de vele overbodige artikelen, die niets anders dan herhaling inhouden. De rechtspraak van meer dan honderd jaren verdient codificatie. Op andere plaatsen is het van nut de leer de rechtspraak op onmiskenbare wijze uit het recht te bannen (..). Men snijde discussies af. Men verbetere aperte fouten." 
Er valt naar mijn mening veel voor te zeggen dat het antwoord op die vraag een min of meer uitgemaakte zaak was en dat Van Maarseveens enige zorg was Meijers te interesseren voor de opdracht.

De veronderstelling, dat aan het eind van de dertiger jaren steeds meer mensen tot het inzicht kwamen dat het onmogelijk was het vermogensrecht op partiële basis te herzien, klinkt op het eerste gezicht niet erg geloofwaardig. Een voor de hand liggend tegen-argument is bijvoorbeeld dat van de negenentwintig auteurs die meewerkten aan het in 1938 verschenen "Gedenkboek Burgerlijk Wetboek 1838-1938" er slechts één was die ondubbelzinnig aandrong op een algehele herziening: Meijers. Verder zou men erop kunnen wijzen dat de redevoeringen die in hetzelfde jaar werden gehouden, geen ander beeld te zien gaven: alleen in de door Meijers uitgesproken rede werd de wenselijkheid van een algehele herziening bepleit. Buiten Scholten en Minister Goseling keurde niemand de denkbeelden van Meijers een bespreking waardig.

Opmerkingen als de hiervoorgaande zijn stellig niet zonder grond. Het is nu eenmaal een niet te ontkennen feit dat Meijers rond 1938 de enige was die in woord en geschrift opriep tot hercodificatie. Wel lijden zij naar mijn smaak aan het euvel dat zij én te weinig doordacht én te weinig genuanceerd zijn. Het is namelijk de vraag of het terecht is om op basis van de ter gelegenheid van het eeuwfeest verschenen bijdragen te concluderen dat Meijers omstreeks 1938 alleen stond in zijn streven naar hercodificatie. Niet alleen zijn er bronnen die in een andere richting wijzen - ik noem slechts de opmerking van Fockema Andreae ${ }^{31}$ die in 1947 verklaarde dat in de jaren die volgden op het besluit van de NJV van 1912 veel ten gunste van het denkbeeld van een algehele herziening was veranderd en het feit dat Van Oven, in 1912 nog een verklaard tegenstander van hercodificatie, in zijn uit 1917 daterende Groningse oratie al een geheel ander geluid liet horen ${ }^{32}$ - maar bovendien is hiervoor vastgesteld dat vanaf 1870 een duidelijke principiële voorkeur voor algehele herzieningen heeft bestaan.

Daarnaast is het onzeker of deze opstellen en redevoeringen als kenbron mogen worden aangemerkt. Bij het merendeel lag het accent namelijk op het schetsen van de rechtsontwikkeling sinds 1838 en niet, zoals bij Meijers het geval was, op de toekomst van het Burgerlijk Wetboek. Daarbij komt dat, gelet op de feestelijke achtergrond waartegen een en ander moest plaatsvinden, er vooral aandacht was voor het goede dat het Burgerlijk Wetboek had gebracht en er voor kritiek, uitmondend in een pleidooi voor algehele of partiële herziening eigenlijk geen plaats was ${ }^{33}$

31. J.P. Fockema Andreae, Naar een nieuw Burgerlijk Wetboek, NJB 1947, p. 348 e.v.

32. Tegenover het Eerste Kamerlid mr. I.A. Diepenhorst liet Van Oven zich als volgt uit: "Al moge ik dan, zeer lang geleden, in 1912, bij de stemming in de vergadering der Nederlandse Juristenvereniging van een andere opvatting hebben getuigd, mijn denkbeelden zijn sindsdien niet ongewijzigd gebleven. En sinds 1947, toen aan mijn vriend Meijers de opdracht is gegeven een nieuk Burgerlijk Wetboek te ontwerpen, heb ik in woord en geschrift naar vermogen gepoogd steun te verlenen aan dit denkbeeld en de verwezenlijking daarvan." Handelingen Eerste Kamer 1955-1956. p. 2228.

33. Ook Meijers kon kennelijk geen verband ontdekken tussen de herdenkingsbijdragen en de kwestie "algehele of partiële herziening", want voor de beantwoording van Van Maarseveens vraag of er wellicht oppositie zou rijzen tegen de voorgenomen methode van herziening, volstond hij met een verwijzing naar het votum van de NJV van 1912. 
Alles overziende ben ik daarom van mening dat het niet mogelijk is een betrouwbare uitspraak te doen over het streven naar hercodificatie omstreeks 1938, al lijkt het mij, gelet op de ontvangst die het denkbeeld in 1947 ten deel viel - de redactie van het NJB schreef er zeker van te zijn dat het overgrote deel van de Nederlandse juristen zich ten zeerste verheugde over de opdracht aan Meijers ${ }^{34}$-, weinig aannemelijk dat er sprake was van principiële oppositie. Men was niet tegen, maar men geloofde niet dat het kon. "Een nieuw Burgerlijk Wetboek ontstaat alleen uit politieken drang", schreef Scholten. ${ }^{35}$

Daarnaast moet de invloed van het artikel van Meijers niet worden onderschat. Het is zeer wel voorstelbaar dat de visie die hij in 1938 ontvouwde, zozeer de aandacht trok, dat hij daarmee de openbare meningsvorming niet alleen nieuw leven inblies, maar ook positief heeft beïnvloed. ${ }^{36}$ Ik herinner er aan dat van Apeldoorn, die het "Gedenkboek" voor de lezers van Themis recenseerde, bijna de helft van de hem toegemeten ruimte besteedde aan een vergelijking tussen de opvatting van Scholten enerzijds en die van Meijers anderzijds, dat hij de houding van de eerste "teleurstellend en tegenstrijdig" noemde en aan de hand van de door Meijers aangevoerde argumenten tot de slotsom kwam dat de tijd rijp was om aan één jurist opdracht te verlenen het burgerlijk recht te herzien. Scheltema, die het onderwerp dat Meijers had aangesneden klaarblijkelijk van een zodanig belang oordeelde dat hij er onder de titel "De toekomst van het Burgerlijk Wetboek" een afzonderlijke beschouwing aan wijdde, was zo mogelijk nog duidelijker. Met een verwijzing naar Minister Van Raalte, die 1905 het initiatief nam om Molengraaff te belasten met de herziening van het zeerecht, beëindigde hij zijn betoog als volgt:

"Op soortgelijke wijze ware thans o.i. de voorbereiding van de door ons bedoelde doorlopende technische herziening van ons vermogensrecht aan een of enige vooraanstaande juristen op te dragen. Wie met ons een herziening, als in het voorgaande bepleit, binnen de grenzen van het bereikbare acht te liggen, zal moeten erkennen, dat de kosten, aan zulk een maatregel verbonden, in het niet vallen, wanneer men ze vergelijkt met de ideële en materiële voordelen, die bij welslagen der poging voor de gemeenschap zouden kunnen worden verkregen."

34. NJB 1947, p. 288. Zie ook A.M. Vroom, NJB 1955, p. 150 e.v.: "Bestaat niet in sterke mate de opvatting, dat de tijd gekomen is om een B.W. van 1838, ondanks de sedertdien in enkele onderdelen daarvan aangebrachte wijzigingen, in zijn geheel te vernieuwen?", een opmerking die geen enkele tegenspraak uitlokte. Pitlo vermeldde in zijn aangehaald artikel dat "bij de vele schriftelijke en mondelingen beschouwingen uit die jaren (d.w.z. sinds 1947), gewijd aan de wenselijkheid van een hercodificatie van ons Burgerlijk Recht, zich meer voorstanders dan tegenstanders lieten horen."

35. P. Scholten, Gedenkboek Burgerlijk Wetboek 1838-1938, Zwolle 1938, p. 30.

36. Zie ook J. Verdam, Enkele opmerkingen omtrent het nieuwe B.W., Utrecht 1954, p. 4: "Schokkende gebeurtenissen welke speciaal noopten tot herziening van het B.W. zijn moeilijk aan te wijzen, maar de zienswijze van Meijers won veld (..). Elke reële poging om te geraken tot meer eenheid in het privaatrecht, tot reformering van verouderde bepalingen in het B.W. en tot aanpassing van het B.W. aan de ontwikkeling van het rechtsleven dient te worden toegejuicht. En wanneer nu een man van het gezag en de bekwaamheid van prof. Meijers (...) bereid is zich hieraan te geven, dan mag deze gelegenheid niet worden voorbijgegaan." 
De invloed van het opstel van Meijers bleef echter niet beperkt tot de lezerskring van Themis en Rechtsgeleerd Magazijn Themis. Voor het eerst sinds jaren bleek een aantal Kamerleden, onder aanvoering van de Amsterdamse hoogleraar Kranenburg, bereid het denkbeeld van een algehele herziening bij de Minister te bepleiten. ${ }^{37}$ Zoals ik hiervoor vermeldde, leidde dit initiatief, dat een jaar later aan de overzijde van het Binnenhof nog eens werd herhaald ${ }^{38}$, niet tot het gewenste resultaat. Dat was voorspelbaar, want Minister Goseling had in zijn rede ter gelegenheid van de herdenking van de honderdjarige burgerlijke wetgeving ondubbelzinnig te kennen gegeven dat hij meer voelde voor het standpunt van Scholten dan dat van Meijers. ${ }^{39}$

Toch bestaat er een groot verschil tussen datgene wat de respectievelijke ambtsvoorgangers van Minister Goseling naar aanleiding van een dergelijke vraag gewoon waren op te merken en het antwoord dat hij zelf geeft. Werd voordien namelijk gewezen op de mogelijkheid om door middel van een reeks van partiële herzieningen het Burgerlijk Wetboek te vernieuwen, nu erkent Minister Goseling dat deze wijze van herziening, gegeven de vele gebreken van het B.W., alleen theoretisch gezien reden van bestaan heeft. In de Memorie van Antwoord, die veel weg heeft van een overdruk van Meijers' betoog over de nadelen, verbonden aan partiële herzienin$\operatorname{gen}^{40}$, lezen we het volgende:

"Indien onder technische herziening mag worden verstaan herziening tot herstel van gebleken onjuistheden, aanvulling van onderkende leemten en wegneming van gerezen dubia met behoud van het rechtsstelsel van het wetboek, dan doet de behoefte daaraan zich het meest gevoelen op het stuk van het vermogensrecht, met inbegrip van het erfrecht. Juist op dit terrein hangen de onderscheidene regelingen onderling zòo nauw samen, dat niet op eenigermate uitgebreide schaal en eerst recht niet naar min of meer stelselmatigen opzet in de eene bepaling kan worden ingegrepen zonder gevaar te loopen andere en menigmaal vele andere bepalingen te treffen, terwijl het niet mogelijk is, vooraf de consequenties geheel te overzien. (..) Doelmatige technische herziening van grooteren omvang kan de ondergeteekende zich alleen denken als algeheele herziening. Ook aan deze zijn echter zoo niet volstrekt onoverkomelijke, dan toch ernstige, bezwaren verbonden. Daarbij wordt niet zoozeer gedacht aan de zware taak, welke zou worden gelegd op de schouders van hen, die zich met den arbeid zouden belasten. Mits opgedragen aan één enkelen bewerker of althans aan zeer weinigen, schijnt de taak, hoe veelomvattend ook, uit een oogpunt van het daaraan verbonden werk, niet onuitvoerbaar. ${ }^{\text {"41 }}$

37. Handelingen Eerste Kamer 1938-1939, p. 387. Vergelijk ook zitting Tweede Kamer 1938-1939. nr 2, stuk nr 6, p. 5: "Enkele leden (waaronder Van Maarseveen en Donker) zouden het op prijs stellen, indien de Minister een algemeene technische herziening van het Burgerlijk Wetboek, zoals in de laatste maanden wel is bepleit, ter hand zou willen nemen."

38. Zitting Tweede Kamer 1939-1940, nr 2, stuk nr 6, p. 4.

39. Gedenkboek Burgerlijk Wetboek 1838-1938, (redevoeringen), Zwolle 1939, p. 4-5.

40. Zie bijvoorbeeld het "feilloze deel", WPNR 3031 (1930), waar Meijers schrijft: "Hangen de rechtsregelen, die het vermogensrecht vormen, niet zoozeer samen, dat het niet aan te raden is incidenteel op verschillende plekken verbeteringen aan te brengen? Loopt men anders niet het gevaar met het oplossen van éen moeilijkheid, twee nieuwe te scheppen en het systematische van ons Wetboek geheel te loor te doen gaan?"

41. Zitting Tweede Kamer 1939-1940, nr 2, stuk nr 7, p. 4. 
Dat de Minister het uiteindelijk toch niet aandurfde aan "één enkelen bewerker of althans aan zeer weinigen" opdracht te verlenen tot het samenstellen van een nieuw Burgerlijk Wetboek, is voor mijn betoog slechts van indirect belang. Zijn argument, dat vertrouwd moet worden op de rechtsvormende kracht van de rechtspraak, kan alleen begrepen worden als een poging om van een dergelijk ambitieus wetgevingsprojekt gevrijwaard te blijven. Het is immers weinig reëel te veronderstellen dat waar de Staatscommissie-Limburg verstek moest laten gaan, de rechter wél tot een bevredigende regeling zou kunnen komen. Belangrijk slechts is dat wordt ingezien dat Meijers niet de enige was die de mogelijkheid het Burgerlijk Wetboek door middel van partiële herzieningen op doelmatige wijze te moderniseren, ernstig in twijfel trok. Het was slechts wachten op een Minister die deze opvatting zou delen en bereid was de daaruit voortvloeiende consequenties te trekken.

Met deze opmerking ben ik aangeland bij de rol van Minister Van Maarseveen. Van der Grinten heeft onlangs te kennen gegeven dat naar zijn mening bij het ter hand nemen van het project voor een nieuw Burgerlijk Wetboek vooral twee mensen van betekenis zijn geweest. Van Maarseveen als Minister en Meijers zelf. Letterlijk zei hij: "Als je die twee niet had gehad, was het helemaal niet gebeurd naar mijn mening (...). Van Maarseveen was typisch een man die van doorzetten hield. Hij kon uitstekend vergaderingen leiden, er werden altijd besluiten genomen, hij zette door. " ${ }^{42}$

Deze typering lijkt mij volkomen juist. Zegering Hadders vertelde mij dat Van Maarseveen het woord "praktisch" hoog in zijn vaandel had staan, terwijl De Vries, voormalig hoofd van de stafafdeling Wetgeving Privaatrecht van het Ministerie van Justitie, Van Maarseveen omschreef als een bijzonder praktisch man, iemand die "zeer snel iets kon aanpakken als hij daar enige politieke winst in zag. "43 Van Maarseveen hield duidelijk niet van halve maatregelen; binnen een maand nadat hij aan Meijers opdracht had verleend nam hij contact op met prof.mr. T.J. Dorhout Mees over het vormen van een commissie ter voorbereiding van een algehele herziening van het Burgerlijk Procesrecht. ${ }^{44}$ Gegeven Van Maarseveens daadkracht is het dus niet zo opmerkelijk dat hij de gedachte, het Burgerlijk Wetboek van de grond af opnieuw te laten opbouwen, met instemming begroette.

Er is echter een nog duidelijker aanwijzing voor de theorie dat de persoon van de Minister in deze een belangrijke rol heeft gespeeld. Vier maanden voordat Zegering Hadders zijn bekende vraag stelde, had Van Maarseveen namelijk al laten weten dat hij wilde breken met het beleid van zijn voorgangers en dat hij voornemens was het Burgerlijk Wetboek een algemene technische herziening te laten ondergaan, zij het dat hij toen uiteraard nog niet dacht aan een opdracht aan één persoon, maar aan de

42. W.C.L. van der Grinten in: Ex tunc, ex nunc, (J.M.van Dunné) Zwolle 1990, p. 197.

43. Justitiële Verkenningen, jaargang 14, no. 6, p. 87, noot 5. Van Maarseveen werd door de Kamer ook zeer gewaardeerd vanwege het "respectabel aantal wetsontwerpen" dat hij gedurende zijn ambtsperiode had weten in te dienen. Zie handelingen Tweede Kamer 1947-1948, p. 582; zitting Eerste Kamer 1947-1948, nr 600, stuk nr 57.

44. Zie NJB 1947, p. 348 . De Commissie-Proceshervorming, volgens Beekhuis een typisch uitvloeisel van de vernieuwingsdrang, werd op 9 september 1947 geïnstalleerd. Zie NJB 1947, p. 
Staatscommissie-Limburg. ${ }^{45}$ Het voorstel van Zegering Hadders sloot dus voor wat betreft de aard van de te ondernemen herziening exact aan op de ideeën die de Minister daarover had.

Eind februari 1947, dus iets meer dan drie maanden nadat Van Maarseveen had bekend gemaakt dat hij de bedoeling had het Burgerlijk Wetboek door de Staatscommissie geheel te laten herzien, was aan dit voornemen in zoverre gevolg gegeven, dat bekend was wie zitting zouden nemen in de sinds 10 mei 1940 opengevallen plaatsen. Met betrekking tot het voorzitterschap bestond echter nog geen duidelijkheid, want mr. G.H.A. Grosheide, de enige overlevende (onder-)voorzitter, had kort daarvoor te kennen gegeven geen deel meer te willen uitmaken van de Staatscommissie. De Minister besloot daarop de Utrechtse hoogleraar S. van Brakel, het oudste lid van de Staatscommissie, te verzoeken het voorzitterschap op zich te nemen.

Op 2 maart, twee dagen voordat Zegering Hadders zijn suggestie lanceerde, liet Van Brakel echter weten niet op het verzoek te kunnen ingaan in verband met andere, eveneens tijdrovende werkzaamheden. Dit bedankje betekende dat nu Meijers, na Van Brakel de oudste in jaren, in aanmerking kwam om te worden aangezocht. De vraag van Zegering Hadders kon dus ook in dit opzicht nauwelijks op een beter moment komen. ${ }^{46}$

Met deze opmerking ben ik terechtgekomen bij het vierde en tevens laatste motief, het vertrouwen dat de herziening van het Burgerlijk Wetboek bij Meijers, destijds algemeen beschouwd als de grootste en meest gezaghebbende jurist van ons land ${ }^{47}$, in goede handen zou zijn en spoedig vruchten zou kunnen afwerpen.

Iets van dit motief klinkt al door in het antwoord dat Van Maarseveen gaf op de vraag waarom hij zo snel en zonder voorbehoud had gereageerd op de suggestie van Zegering Hadders. Het gerucht dat Meijers zich tijdens de oorlog had beziggehouden met het ontwerpen van een nieuw Burgerlijk Wetboek, was voldoende reden hem uit te nodigen voor een gesprek. Letterlijk zei Van Maarseveen:

"Gedurende de bezettingstijd en met name tijdens zijn internering heeft prof. Meijers zijn gedachten laten gaan over de noodzakelijke vernieuwing van ons burgerlijk wetboek en hij heeft daaraan zelfs ten dele concrete vorm gegeven.

45. Uit het Voorlopig Verslag bij de begroting voor 1946-1947, (zitting Tweede Kamer 1946-1947, nr 300, stuk nr 7, p. 3): "Sommige leden meenden, dat de tijd voor een algemeene technische herziening van het Burgerlijk Wetboek is aangebroken. Wil de Minister hiertoe het initatief nemen?" Van Maarseveen antwoordde op 14 november 1946 (zitting Tweede Kamer 1946-1947, nr 300, stuk nr 8 , p. 3): "Hoe belangrijk op zich zelf dit onderwerp ongetwijfeld is, zoo moet ook hier gelden, dat het in urgentie niet in de voorste rijen staat. (..) De technische herziening van het Burgerlijk Wetboek nu is een onderwerp, dat zich wel bij uitstek leent voor bestudering door bedoelde Staatscommissie."

46. Dat Van Maarseveen onmiddellijk heeft beseft welke voordelen verbonden waren aan het gevolg geven aan de suggestie van Zegering Hadders, blijkt m.i. hieruit dat hij in zijn uitnodiging aan Meijers tevens sprak over het weer op gang brengen van de Staatscommissie. Bovendien had hij vóór dit gesprek plaatsvond reeds te kennen gegeven dat de Staatscommissie tot taak zou krijgen de door Meijers opgestelde ontwerpen te behandelen.

47. $\mathrm{Na} 1954$ is er in deze waardering een kentering opgetreden. Men zie daarover o.a. N.H.M. Roos, De Nederlandse privaatrechtsleer in dramatisch perspectief, Groningen 1987; T.J. Veen, Over leven en werk van Eduard Maurits Meijers, Ars Aequi 1991, p. 1059 e.v.; 
Toen onlangs in de Eerste Kamer de Heer Zegering Hadders het denkbeeld lanceerde, dat aan prof. Meijers een opdracht tot het ontwerpen van een nieuw burgerlijk wetboek zou worden verleend, leek dat denkbeeld mij dadelijk buitengewoon aantrekkelijk. Ik heb toen prof. Meijers tot een bespreking uitgenodigd."

Nog duidelijker is het te herkennen in de volgende passages uit het "vraaggesprek" met Van Maarseveen.

"Eén van mijn vroegere leermeesters aan de universiteit noemde nog onlangs prof. Meijers een jurist, zoals ons land er slechts één in een eeuw krijgt. De Koninklijke opdracht aan prof. Meijers moet men in dit verband zien. In volle gerustheid op het welslagen mag de taak aan prof. Meijers worden overgelaten. $\mathrm{Ik}$ heb het daarom ten zeerste gewaardeerd en het heeft mij ook een zeer verheugd, dat prof. Meijers zich bereid heeft verklaard de opdracht te aanvaarden."

Kan (...) een nieuw Burgerlijk Wetboek snel worden verwacht?

"Ik heb het volle vertrouwen, dat prof. Meijers zijn taak met voortvarendheid zal volbrengen."

Tenslotte vermeld ik nog een opmerking van Zegering Hadders, gemaakt tijdens het vraaggesprek dat ik met hem voerde. Hij vertelde altijd sterk de indruk te hebben gehad dat de veronderstelling dat het grote werk binnen de reguliere kabinetsperio$\mathrm{de}^{48}$ tot stand zou worden gebracht, voor Van Maarseveen de belangrijkste drijfveer was om Meijers, en niet een ander, ook niet een commissie, met de opdracht te belasten. Ter toelichting wees Zegering Hadders erop dat hij, enige tijd na het verlenen van de opdracht, Van Maarseveen naar het "waarom" van de opdrachtverlening had gevraagd. Deze zou toen geantwoord hebben: "Zoudt $U$ het dan niet leuk vinden wanneer uw naam op het titelblad van het Burgerlijk Wetboek zou prijken?"49

Dat er voor die opvatting veel is te zeggen, behoeft eigenlijk geen betoog. Desalniettemin laat ik hier nog éenmaal een citaat volgen. Meijers zelf zei namelijk in antwoord op de vraag of hij zou slagen waar in het verleden zovelen hadden gefaald:

"Anders had ik het werk niet aangenomen. Tijdens de zitting van dit kabinet wil ik het werk voor het grootste deel hebben voltooid. Staatscommissies kunnen niet snel werken, omdat de leden het als bijwerk doen. Maar ik ben van plan mij van al

48. Omdat reeds in het najaar van 1946 duidelijk was dat het kabinet, wilde een reeds aanhangig gemaakt voorstel tot grondwetsherziening doorgang kunnen vinden, een bredere basis nodig had, mocht Van Maarseveen er van uitgaan dat zijn ambtstermijn - onvoorziene omstandigheden daargelaten - zich uitstrekte tot medio 1952.

49. Zie ook de Memorie van Antwoord bij de begroting voor 1948 (zitting Tweede Kamer 19471948 , nr 600, stuk nr 5, p. 2), waarin Van Maarseveen verklaarde dat hij reden had om aan te nemen "dat met de samenstelling van het gehele ontwerp een tijd van niet meer dan drie jaren gemoeid zal zijn." 
mijn andere werk zoveel mogelijk los te maken en zelfs mijn colleges te beperken. ${ }^{\text {50 }}$

\section{De werkwijze van Meijers}

Meijers is inderdaad voortvarend te werk gegaan. ${ }^{51}$ Zoals reeds in de circulaire was aangekondigd, zette hij zich eerst aan het ontwerpen van de Inleidende titel en van de bepalingen voor Boek 5, bevattende de zakelijke rechten. Een eerste concept voor tekst en toelichting van de inleidende titel, bestemd om in de Staatscommissie (subcommissie Burgerlijk Recht) te worden besproken, kwam gereed op 11 december 1947, de grondtekst van Boek 5 werd in het voorjaar van 1948 voltooid. ${ }^{52}$

Begin Juli 1947 vertrok Meijers naar Zwitserland om zich op de hoogte te laten stellen van het praktisch functioneren van het Zwitserse burgerlijk recht, in het bijzonder met betrekking tot het stelsel van de Grondboekhouding (art. 973 ZGB) en het rechterlijk matigingsrecht (art. $39 \mathrm{ZGB}$ ). Bovendien had hij aanvankelijk enig contact met de commissie die in Frankrijk onder leiding van Julliot de la Morandière de herziening van de Code Civil voorbereidde. ${ }^{53}$ Tevens zocht hij in die periode contact met prof. Van Dievoet te Leuven en prof. Pont te Pretoria, teneinde na te gaan of het mogelijk was dat ook in België en Zuid-Afrika iets werd gedaan aan de hervorming van het burgerlijk recht of dat vandaar medewerking zou kunnen worden verleend aan de Nederlandse poging tot hercodificatie. Daarmee zette hij zijn ten tijde van het eeuwfeest geopperde suggesties in daden om. ${ }^{54} 55$

50. Het Parool, 14 mei 1947, p. 8. Zie voor een overdruk NJB 1992, p. 4-5.

51. "Omdat andere werkzaamheden hem voorlopig beletten in de eerstkomende tijd eens per week als raadsheer zitting te nemen", werd Meijers op 17 oktober 1947 ontslag verleend uit zijn functie van raadsheer-plaatsvervanger in het Hof te 's-Gravenhage.

52. In zijn rede "De herziening van ons Burgerlijk Wetboek", uitgesproken op 8 mei 1948, V.P.O. I, Leiden 1947, p. 146 e.v., gaf Meijers te kennen "dat van de 7 boeken, waaruit het ontwerp zal bestaan, er ongeveer 2 gereed zijn." Uit de M.v.A. bij de begroting voor 1949 (zitting Tweede Kamer 1948-1949, nr 1000, stuk nr 6, p. 4) blijkt welke twee boeken hij daarbij op het oog had: "De ontwerper van het nieuwe Burgerlijk Wetboek heeft een boek over het vermogensrecht in het algemeen en een boek over het zakenrecht voltooid, terwijl hij met het verbintenissen- en erfrecht een eindweegs gevorderd is."

53. Zie E.J.A. Fischer-Keuls, Hercodificatie in Frankrijk en ten onzent, a.w., p. 135, noot 2.

54. E.M. Meijers, Wijzigingen en aanvullingen van het Burgerlijk Wetboek na 1838, V.P.O. I, Leiden 1947, p. 136: "Geen boek van het Burgerlijk Wetboek leent zich beter om een aanvang met een zoodanige herziening te maken dan juist datgene, hetgeen nooit in zijn geheel door staatscommissies ter hand genomen is, het derde boek, regelende het verbintenissenrecht. En waarom zou hier niet op dit gebied naar samenwerking met andere naties gestreefd worden, b.v. met België en Zuid-Afri$\mathrm{ka}$, gelijk in Frankrijk en Italië de herziening van dit boek door een gemeenschappelijke commissie voorbereid is?"

55. Het contact met Van Dievoet, op 8 mei 1939 door Meijers gelegd, leidde na de oorlog op 19 september 1947 tot de oprichting van de Vereniging voor de vergelijkende studie van het recht van België en Nederland. Tevens werd op initiatief van Meijers op 17 april 1948 de Benelux Studiecommissie tot eenmaking van het recht opgericht. Beide instellingen werkten in hoofdzaak op door Meijers voor het nieuwe Burgerlijk Wetboek ontworpen teksten. Zie L. Fredericq, prof. Meijers en de éénmaking van het Belgisch-Nederlands Recht, Rechtskundig Weekblad 1955, p. 875 e.v.; P. Eijssen, Benelux en unificatie van privaatrecht, Utrecht 1951. Meijers' poging om tot een geza- 
Tenslotte ontwierp Meijers nog in 1947 een wetsvoorstel "tot vaststelling van enige regels betreffende het internationaal privaatrecht", een ontwerp dat volgens ingewijden het beste deed verwachten van de overige resultaten van Meijers' arbeid. ${ }^{56}$ Het ontwerp voor Boek 3 (Vermogensrecht in het algemeen) werd op 24 april 1948 aan de leden van de Staatscommissie gepresenteerd. De discussie over titel 3.2 (Rechtshandelingen), die mede gevoerd werd aan de hand van het Franse voorontwerp, had toen reeds plaatsgevonden.

Met betrekking tot het tijdstip waarop de ontwerpen voor de overige Boeken in eerste lezing gereed kwamen is weinig met zekerheid te zeggen. Meijers voorzag zijn ontwerpen niet van een datum en had meestal zo'n drie à vier Boeken tegelijk onderhanden. Wel staat vast dat het concept voor de tekst van Boek 6 ruim voor mei 1950 moet zijn opgesteld, want vanaf dat ogenblik vingen in de Staatscommissie de beraadslagingen over het verbintenissenrecht aan. Het erfrecht, na veel omzwervingen uiteindelijk in Boek 4 beland, stamt vermoedelijk uit dezelfde periode. In ieder geval werd het ontwerp voltooid voor september 1950 , het tijdstip waarop Jan Drion ontslag nam als assistent van Meijers wegens zijn benoeming tot hoogleraar. ${ }^{57}$ In zijn papieren die betrekking hebben op de periode van het assistentschap komt namelijk een afgerond concept voor Boek 4 voor, waaronder Meijers het woord "einde" heeft geschreven. Feit is ook dat Meijers in verband met de bespreking van titel 3.6 (Bewind) de leden van de subcommissie Burgerlijk Recht in februari 1949 een aantal bepalingen van het nieuwe erfrecht ter discussie voorlegde ${ }^{58}$

Wanneer het eerste concept voor Boek 2 verscheen is mij niet bekend. In 1947 legde Meijers de leden van de Belgisch-Nederlandse "Vereniging" echter een preadvies voor met betrekking tot "De regeling der rechtspersonen in het Nederlands recht", zodat het aannemelijk is dat hij toen al een eind was gevorderd. Zeker is echter dat het ontwerp zelf, tezamen met de concepten voor de Boeken 3 en 5 , omstreeks 1 mei 1950 zijn definitieve vorm had bereikt. ${ }^{59}$

\footnotetext{
55. $\rightarrow$

menlijk codificatieproject te komen, liep op niets uit, voornamelijk als gevolg van de tegenwerking van de Walen. Zie daarover Marcel Storme, Het nieuw Nederlands BW: Het verdriet van België?, NJB 1992, p. 48. Reacties uit Zuid-Afrika zijn mij niet bekend. Wel studeerden destijds in Leiden vele Afrikaanders (Zie het slot van het voorwoord in Deel I van de Observationes Tumultuariae).

56. R.D. Kollewijn, het wetsontwerp betreffende het I.P.R., NJB 1952, p. 237. Dit ontwerp zou de basis vormen voor de Eenvormige wet betreffende het internationaal privaatrecht $(1951,1969)$, die 0.m. als gevolg van een groeiend streven naar unificatie op Europees niveau, nooit zou worden ingevoerd. Zie M.V. Polak, Codificatie van het internationaal privaatrecht, NJB 1988, p. 695 e.v. Inrniddels is op Justitie niettemin besloten de codificatie van het IPR opnieuw ter hand te nemen; "Het voornemen bestaat de wetgeving betreffende het internationaal privaatrecht in Boek 10 op te nemen." (zitting Tweede Kamer 1993-1994, nr 23400, stuk nr 2, p. 20).

57. Jan Drion (1915-1964) werd op 15 november 1947 benoemd als tijdelijk ambtenaar bij het Ministerie van Justitie, uitsluitend ter assistentie van Meijers. In verband met zijn benoeming tot hoogleraar te Leiden, op de leerstoel die vacant geworden was doordat Meijers de zeventigjarige leeftijd had bereikt, zou hij op 15 september 1950 ontslag nemen. Eerder, op 28 januari 1949, was hij benoemd tot adjunct-secretaris van de subcommissie Burgerlijk Recht van de Statscommissie voor de Burgerlijke Wetgeving, in de plaats van De Meijere. Op 28 september 1950 zou Drion worden benoemd tot gewoon lid van de Staatscommissie.

58. Notulen van de 77e vergadering van de subcommissie Burgerlijk Recht van 19 februari 1949.

59. Aldus Meijers in een op 12 januari 1950 gehouden bespreking met Minister Wijers.
} 
Met betrekking tot het tijdstip waarop het fundament werd gelegd voor de overige groene Boeken kan evenmin een precieze uitspraak worden gedaan, maar het is alleszins aannemelijk dat Meijers één en ander in de eerste helft van 1951 heeft weten te voltooien. Franken, die in de zomer van 1951 Drion opvolgde als assistent van Meijers $^{60}$, meent zich althans te herinneren dat omstreeks die tijd de concepten een zodanig stadium hadden bereikt dat Meijers ze aan derden zond met het verzoek om commentaar. Prof. Rood-De Boer, die in de periode januari 1949 - september 1951 als werkstudente de concepten voor alle Boeken ${ }^{61}$ heeft getypt, liet zich als volgt uit: "Toen ik wegging in 1951 en vroeg of ik dat zou melden bij de VVSL, vertelde hij dat hij niemand meer voor dit werk nodig had. Hij heeft zich daar, achteraf gezien, nogal in vergist, maar destijds meende hij dat zijn werk voor een belangrijk deel klaar was en dat vanaf dat moment het Departement het technisch verbeteren maar moest overnemen. Van hem kreeg ik toen de indruk dat het hem, met de tijdsplanning die hij zich voorstelde, ook eigenlijk best uitkwam."

Het is een interessante vraag in hoeverre Meijers kon profiteren van werk dat hij tijdens of voor de oorlogsjaren had verricht. Feit is, dat hij reeds in zijn studietijd rondliep met de gedachte een nieuw Burgerlijk Wetboek te maken ${ }^{62}$ en dat hij tijdens zijn internering in Westerbork een program voor de rest van zijn leven opstelde, waarop het herscheppen van het Burgerlijk Wetboek eveneens voorkwam. ${ }^{63}$

Zeker is dat Meijers tijdens de oorlog heeft gewerkt aan een concept voor een nieuw Burgerlijk Wetboek. Mevrouw Van Taalingen-Dols, advocate van Meijers tijdens de oorlog, vermeldt bijvoorbeeld in haar boek "De strijd om een mensenleven", dat de koerier van de Joodse Raad, de latere Amsterdamse hoogleraar De Winter, vlak voor Meijers' deportatie naar Theresienstadt materiaal betreffende een nieuw Burgerlijk Wetboek heeft ontvangen. ${ }^{64}$ P.J. Idenburg ${ }^{65}$, Stella Simons ${ }^{66}$, Rijpperda Wierdsma ${ }^{67}$, Van Oven ${ }^{68}$ en Van den Bergh ${ }^{69}$ hebben onafhankelijk van elkaar verklaard dat Meijers zowel in Westerbork als in Theresienstadt de geestkracht

60. Mr. R. Franken (1927), wiens studieprestaties van dien aard waren dat zij Meijers waren opgevallen, werd met ingang van 6 juni 1951 benoemd tot tijdelijk ambtenaar van Meijers, in dienst van Justitie. Anders dan Drion zou Franken nooit officieel deel uitmaken van de Staatscommissie voor de Burgerlijke Wetgeving. Wel zou hij vanaf eind 1952 regelmatig de vergaderingen van de subcommissie Burgerlijk Recht bijwonen, en bij ontstentenis van adjunct-secretaris mr. S.L. Buruma, Drions opvolger, ook dikwijls de notulen verzorgen. Franken zou met ingang van 1 januari 1954 voor het Departement gaan werken.

61. Met uitzondering van het Zeerecht (Boek 8), dat Meijers aan de subcommissie Handelsrecht had uitbesteed.

62. J.C. van Oven, Meijers voor het Professoraat, Themis, 1950, p. 110-111: "Reeds in deze jaren (omstreeks 1900) liep Meijers rond met het denkbeeld om een nieuw B.W. te maken en als ik mij wel herinner, heeft hij toen al een cahier aangelegd om aantekeningen voor dit werk neer te leggen."

63. Zie R. Feenstra, Meijers' beroep op de rechtsgeschiedenis bij de behandeling van privaatrechtelijke leerstukken, WPNR 5504 (1980).

64. L.M.I.L. Van Taalingen-Dols, De strijd om een mensenleven 1940-1945, Goes 1960, p. 290; zie ook p. 298, 299 en 308.

65. P.J. Idenburg, Aantekeningen betreffende het Leids universitair verzet, (z.j.), p. 57.

66. Aukje Holtorp en Selma Sevenhuijsen, Vrouwelijke advocaat van het eerste uur, Nemesis 1987 p. 20.

67. Virtus Concordia Fides, 41 e jaargang, no. 1017, p. 4.

68. J.C. van Oven, Meijers voor het Professoraat, Themis, 1950, p. 111.

69. Parl. Geschiedenis NBW, Invoeringswet Boek 1, Deventer 1969, p. 1006. 
wist op te brengen om door te werken aan "De Algemene Begrippen", waarmee als het ware het patroon van het nieuwe B.W. werd blootgelegd ${ }^{70}$, én aan de herziening van het Burgerlijk Wetboek. ${ }^{71}{ }^{72}$

Minder duidelijkheid bestaat er ten aanzien van de vraag wat Meijers in 1947 precies gereed had. Mevrouw Rood-de Boer vertelde dat zij op een gegeven moment tamelijk vergeelde teksten moest uittypen - gedachtenspinsels die Meijers voor de oorlog op papier had gezet en bewaard - die met name betrekking hadden op het verbintenissenrecht. Belinfante heeft geschreven dat Meijers "naar zijn weten" voor de opdrachtverlening teksten betreffende Boek 1 gereed zou hebben gehad. ${ }^{73}$ In het met hem gehouden gesprek zei hij zich echter niet te kunnen herinneren hoe hij aan die wetenschap was gekomen, maar dat hij wel voor de juistheid ervan instond.

Inderdaad is het mogelijk dat Meijers zich primair heeft geconcentreerd op het personen- en familierecht. Dat rechtsgebied lag hem na aan het hart en volgens Samkalden, schoonzoon van Meijers, was de herziening van het personen- en familierecht voor Meijers ook één van de oogmerken om tot hercodificatie over te gaan. ${ }^{74}$ Wel is het zo, dat van Boek 1 geen enkele voorstudie is aangetroffen. Als het juist is wat Belinfante en Samkalden zeggen, dan is het aannemelijk dat het ontwerp daarvoor in hoofdlijnen al lang gereed lag.

Omtrent de wijze waarop Meijers zijn teksten ontwierp voordat ze door enkele leden van de Staatscommissie of mensen uit de praktijk aan een nauwkeurig onderzoek werden ontworpen, is niet erg veel bekend. Meijers heeft zich er slechts een paar maal over uitgelaten, en dan nog weinig nadrukkelijk. ${ }^{75}$ De volgende schets, voorna-

70. Zie ook de beroemde zin in het voorwoord van de "Algemene Begrippen", Leiden 1948, p. IX: "Met uitzondering van de twee laatste hoofdstukken is dit boek geschreven in een tijd, toen mij geen enkel rechtsgeleerd werk ter beschikking stond."

71. Uit het interview met het Parool uit 1947: "Met bewonderenswaardige en benijdenswaardige geestkracht heeft professor Meijers in de meer dan drie jaar die hij in kampen doorbracht, zijn eigen werk voortgezet. Elk ogenblik, dat hij zich van het verplichte kampwerk kon losmaken, heeft hij daarvoor gebruikt, of hij nu directeur van het postkantoortje in Westerbork, of boekhouder in Theresienstadt was. (...) Zonder studiemateriaal schreef hij in Theresienstadt een boek over de algemene begrippen van het burgerlijk recht, dat binnenkort zal uitkomen. En zonder boeken begon hij in zijn gevangenschap aan de herziening van het Burgerlijk Wetboek, de taak, die hem nu is opgedragen." Zie ook Boris de Munnick, Uitverkoren in uitzondering? Het verhaal van de Joodse 'Barneveld-groep' 1942-1945, Barneveld 1991.

72. Daar bleef het overigens niet bij. Meijers legde in diezelfde tijd de laatste hand aan de bewerking van "Het Kort Geding", bracht na bemiddeling van het Vaticaan een advies uit aan de universiteit van Bologna over de heiligverklaring van de advocaat Ivo (K. Wiersma, WPNR 5504) en verrichtte studies naar het recht van Nancy en Metz. Daarnaast deed hij nog ander werk, zoals blijkt uit een schrijven van Meijers uit Theresienstadt van 15 mei 1945: "Groet ook Salverda en zeg hem, dat ik met vele andere manuscripten ook slot Metz gereed heb." (Van Taalingen-Dols, p. 299).

73. W.G. Belinfante, a.w., p. 36.

74. Samkalden lichtte deze bewering nader toe met de opmerking dat Meijers vier dochters had.

75. Zie de aanbiedingsbrief bij de eerste vier Groene Boeken, Parl. Gesch. NBW, Algemeen Deel, p. 115 e.v., en Meijers' rede "De herziening van ons Burgerlijk Wetboek", V.P.O. I, p. 152-153. Dorhout Mees vertelt in Acht civilisten in burger, Zwolle 1977, p. 80, dat hij eens een diescollege van Meijers heeft bijgewoond waar deze zou praten over zijn werk aan het nieuwe Burgerlijk Wetboek: "Er waren toen natuurlijk twee stampvolle zalen, en toen heeft hij kans gezien om drie 
melijk gebaseerd op mededelingen van derden en aanwijzingen die in Drions nalatenschap met betrekking tot Boek 3 zijn aangetroffen, wordt dan ook met het nodige voorbehoud gegeven.

Iets wat ogenblikkelijk opvalt wanneer men de achtereenvolgende concepten die Meijers voor een bepaalde titel of afdeling opstelde, naast elkaar legt, is dat er vrij snel een tekst lag waaraan, althans naar de voorstelling van Meijers, niet veel meer behoefde te worden veranderd. Zelfs wanneer het een voor het Burgerlijk Wetboek onbekende materie betrof, zoals de (algemene) regeling van het het bewind, de mandeligheid of de openbare registers, stonden de grote lijnen doorgaans na zo'n twee à drie schetsen grotendeels vast. Het opstellen van de tekst hield Meijers over het algemeen strict in eigen hand. Het was, volgens Franken, niets voor Meijers om te zeggen "stelt u nu eens teksten op." Wel werd, maar dat spreekt voor zich, de invloed van derden op standpuntbepaling- en formulering groter, naarmate de concepten een meer definitief karakter kregen.

Ook in deze voorfase zocht Meijers contact met de praktijk en deskundigen, zij het op incidentele basis. Een illustratie hiervan is het in de vijftiger jaren actuele vraagstuk of bij overdracht van onroerende goederen een authentieke akte moet worden geëist. Meijers probeerde aanvankelijk door middel van een enquête tot een verantwoorde beslissing te komen, maar vond de antwoorden die hij ontving zo tegenstrijdig en weinig overtuigend, dat hij met betrekking tot deze aangelegenheid een uitspraak van de Kamer wenste. ${ }^{76}$

Een andere, duidelijk herkenbare karakteristiek van Meijers' werkwijze was, dat hij bij het formuleren van het eerste concept voor een bepaalde titel of afdeling zoveel mogelijk aansluiting zocht bij het geldende recht. Met andere woorden, als basis voor de te ontwerpen regeling ging Meijers in beginsel uit van de tekst van 1838, met deze aantekening dat hij onmiddellijk vereenvoudigingen aanbracht, onduidelijke artikelen opnieuw formuleerde, tegenstrijdigheden rechtzette. "Schrappen, daar ben ik voor", schijnt een gevleugelde uitdrukking van Meijers te zijn geweest, terwijl hij in het Parool-interview uit 1947 zijn oogmerk als volgt omschreef: "Al kan ik dan ook niet een wetboek maken, dat bij het gehele volk populair wordt, ik wil er toch een samenstellen, dat tenminste voor juristen hanteerbaar is. ${ }^{n 77}$

75. $\rightarrow$

kwartier lang hele goeie grapjes te vertellen en niets los te laten over wat hij van plan was met het ontwerp Burgerlijk Wetboek. "

76. Zie de op 4 augustus 1947 verzonden vragenlijst met betrekking tot het recht op onroerende goederen (vraag B4) en de toelichting bij het tweede vraagpunt, Parl. Gesch. NBW, Algemeen Deel, p. 116.

77. Vergelijk ook de anekdote van G.J. Scholten in WPNR 6039 (1992), die als lid-rapporteur van de subcommissie Burgerlijk Recht een nota schreef over solidariteit en daarbij de opmerking maakte dat Meijers in zijn concept iets vergeten had te regelen. Scholten: "Meijers zei daarop: 'dat is een aardig puntje, dat heb ik nergens gevonden, dat is in geen enkel wetboek geregeld, dus wij hoeven dat ook niet te doen.' Voor de volledigheid: De opmerking van Scholten had betrekking op de overneming van art. 145 lid 2 ZGB betreffende het regresrecht tussen de hoofdelijke schuldenaren.

Een ander voorbeeld. Commissie-lid F.J. de Jong betoogde dat de regeling van de zakelijke rechtsvorderingen in het ontwerp té summier was, waarbij hij zich beriep op verschillende binnen- en buitenlandse schrijvers. Meijers antwoordde: "De geldende wet bepaalt daaromtrent echter niet meer, hetgeen nimmer tot moeilijkheden aanleiding gaf." (Notulen van de 73e vergadering van de subcommissie Burgerlijk Recht van 11 december 1948). 
Nadat aldus de tekst een belangrijke technische verbetering had ondergaan, ging Meijers na of het raadzaam was de regel te behouden voor zijn ontwerp. Daartoe maakte hij zowel gebruik van historische bronnen, zoals Assers "Vergelijking" en Voorduins "Geschiedenis en beginselen", als van vanuit wetstechnisch oogpunt betrekkelijk recent materiaal, zoals de ontwerpen van de Staatscommissie-Van Meerbeke. ${ }^{78}$ Leidde dit onderzoek tot een gunstig oordeel, dan vergeleek Meijers tenslotte het naar inhoud zo min mogelijk gewijzigde voorschrift met de gevestigde jurisprudentie die zich rondom het artikel had gevormd en paste zijn concept, voorzover deze rechtspraak een twijfelachtig principieel punt had opgelost, zonodig aan.

De concept-toelichting zette Meijers op volgens hetzelfde procédé. Vermoedelijk schreef hij de toelichting, die hij zo beknopt mogelijk wenste te houden - "want een Toelichting is men na jaren vergeten, een voorschrift blijft"79 - , met niets anders dan de tekst van de toe te lichten regeling voor ogen, want in de eerste concepten ontbrak elke verwijzing naar literatuur of jurisprudentie. Vanzelfsprekend leidde deze methode - een toepassing van de gedachte dat de waarde van een voorschrift dat de eeuwen heeft getrotseerd meestal aanmerkelijk hoger is dan wat het individuele denken voortbrengt - niet altijd tot bevredigende resultaten. Dan moest Meijers al in dit stadium zijn toevlucht nemen tot aan vreemd recht ontleende oplossingen of bedenksels van eigen makelij. ${ }^{80}$

Nadat op deze wijze een eerste of tweede concept voor tekst en toelichting was ontworpen, brak de voorlopig laatste fase in het ontwerpproces aan, waarna de teksten aan derden voor commentaar werden voorgelegd. In dit stadium, waarin de rechtsvergelijking centraal stond, was een belangrijke rol voor de secretarissen van Meijers weggelegd. Hun taak viel uiteen in twee delen. Het eerste, en vermoedelijk voor Meijers belangrijkste onderdeel, bestond uit het opstellen van rechtsvergelijkende overzichten. Voor dat doel gingen zij - eerst Drion, later Franken - tenminste één ochtend in de week naar de bibliotheek van het Vredespaleis om daar, aan een voor hen gereserveerde tafel, alle buitenlandse juridische tijdschriften en andere aanwinsten door te nemen ${ }^{81}$ Of daarbij een bepaalde procedure werd gehanteerd, heb ik niet kunnen vaststellen. Vermoedelijk was hun opzet er allereerst op gericht zoveel moge-

78. Zie bijvoorbeeld de "Algemene opmerking" bij afdeling 3.9.2. Parl. Gesch. Boek 3, p. 743.

79. Aldus J.C. Van Oven, De vergadering van de Juristenvereniging in Amhem, NJB 1954, p. 562.

80. Een aardig voorbeeld hiervan is de volgende passage uit een verslag van Drion van een bespreking met Meijers over titel 3.2 (rechtshandelingen), gehouden op 2 januari 1948: "EMM vertelde van zijn moeilijkheden met de nulliteitenleer. Wat er over gepubliceerd is, geeft geen antwoord op de essentièle vraag, wanneer nu een rechtshandeling nietig is, wanneer vernietigbaar. Eggens' preadvies vindt hij waardeloos. Bespreekt even de 'Anfechtbarkeit' van het BGB en de onderscheiding void - voidable. Moeten, anders dan in het Engelse recht, derden te goeder trouw ook bij rechtshandelingen die void zijn beschermd worden? Het Ontwerp Zakenrecht 1898 heeft het niet aangedurfd, maar werd deswegen van inconsequentie beticht."

81. Drion heeft deze gewoonte ook na zijn vertrek bij Meijers volgehouden. Vandaar ook dat hij in de toelichting bij artikel 6.3.9. O.M. (Parl. Gesch. Boek 6, p. 718) kon verwijzen naar één van de eerste Amerikaanse bijdragen over de economische analyse van het recht, het in Nederland pas aan het eind van de jaren tachtig "ontdekte" artikel van Calabresi over "Some thougths on risk distribution and the law of torts" (The Yale Law Journal 1960/61, p. 499-553). 
lijk gegevens op te sporen teneinde de rechtskennis te verdiepen ${ }^{82}$, inspiratie op te doen en werd pas later, bijvoorbeeld naar aanleiding van een concrete vraag van Meijers, gericht gezocht.

Het tweede onderdeel van de taak die Meijers zijn secretarissen had opgedragen, bestond erin dat zij, mede aan de hand van de rechtsvergelijkende voorstudies, de teksten van Meijers kritisch moesten beoordelen, en met hem daarover van gedachten moesten wisselen, iets wat meestal enkele dagen in beslag nam. In deze fase werd het concept voortdurend aangepast, totdat het een stadium had bereikt waarvan Meijers vond dat het goed genoeg was om aan derden te worden voorgelegd.

Uit deze beschrijving kan worden afgeleid dat bij de beslissing over vrijwel ieder punt van betekenis het rechtsvergelijkende argument een rol heeft gespeeld. Van een doorslaggevende invloed is naar mijn mening echter geen sprake geweest. Meijers hield, indien men één en ander afmeet aan de hoeveelheid energie die bijvoorbeeld Drion in zijn rechtsvergelijkende voorstudies had gestoken, slechts in beperkte mate rekening met de daardoor verkregen resultaten. ${ }^{83}$

Voor een deel kan deze terughoudendheid wellicht worden toegeschreven aan het feit dat Meijers, ofschoon hij als geen ander thuis was in vreemde rechtsstelsels ${ }^{84}$, enigszins beducht was de elders gekozen oplossingen te gebruiken voor de Nederlandse situatie en in ieder geval geen genoegen nam met een simpele "wetsvergelijking". In de toelichting bij het eerste Groene Boek schreef Meijers althans:

"Tot opheffing van twijfel kan dikwijls een rechtsvergelijkende studie nuttige diensten bewijzen; een wetgever kan met de in andere landen opgedane ervaringen zijn voordeel doen. Maar ook hier is voorzichtigheid geboden, omdat vreemde wetsteksten niets zeggen, wanneer men daarnaast ook niet de in het vreemde land bestaande maatschappelijke verhoudingen en de wijze waarop aldaar de teksten toegepast worden kent. Dikwijls immers ontwikkelen zich de rechtstoestanden in het ene land geheel anders dan in het andere land. Een zuiver toevallige omstandigheid kan de oorzaak zijn, dat de verhoudingen in beide landen een geheel verschillende ontwikkeling hebben gehad, maar desniettemin hebben zich dientengevolge in het ene land geheel andere gebruiken en instellingen ingeburgerd dan in het andere land. ${ }^{85}$

82. Met betrekking tot titel 3.2 raadpleegde Drion bijvoorbeeld in eerste instantie:

- Von Tuhr/Siegwart, Planiol/Ripert, Lutzesco (Théorie et Pratique des Nullités, 1930).

- B.W. van Italië, Guatemala, China, Venezuela;

- Ontwerp-B.W. Hongarije, Code International des Obligations van Cosentini (1937).

Zijn beschrijving van de gevonden regelingen bepaalde zich doorgaans tot het citeren van wetsartikelen of commentaren of het samenvatten daarvan.

83. Dat betekent overigens niet, dat al deze inspanningen tevergeefs zijn geweest. Veel van het doot Drion en Franken verzamelde materiaal vond zijn weg naar de noten in de Toelichting-Meijers.

84. Volgens M.H. Bregstein, Meijers en de poging tot hercodificatie in Nederland, Rechtskundig Weekblad 1956, p. 169, was "Meijers' kennis van vreemde rechtstelsels onbegrensd." G.J. Scholier verklaarde in WPNR 6039 (1992): "Dit was zijn grote kracht, dat hij dat overzicht had van de wetgeving in zeer veel landen. Ik heb dat nooit elders aangetroffen."

85. Parl. Gesch. NBW, Algemeen Deel, p. 124. 
Voor een ander deel hangt deze terughoudendheid vermoedelijk hiermee samen, dat Meijers zijn ontwerp zo eenvoudig mogelijk wilde houden, meer uit was op een bewerking van het bestaande recht dan op het scheppen van werkelijk nieuw recht. Rechtsvergelijking is weliswaar nuttig, omdat men leert inzien dat voor ieder probleem een veelvoud aan oplossingen bestaat, maar heeft als gevaar dat men, in de wens het beste uit deze oplossingen te verenigen tot één of meer regels, zich verliest in een vlechtwerk van onderscheidingen of kiest voor een oplossing die is afgestemd op een voor de praktijk niet erg belangrijke situatie.

Dat Meijers deze bezwaren zeker liet meetellen in zijn beslissing een buitenlandse rechtsregel al dan niet te codificeren, blijkt bijvoorbeeld uit zijn reactie op een voorstel van Drion om naar analogie van art. 938 e.v. ZGB te bepalen dat de waarde van de genoten vruchten in aftrek komt van de genoten kosten (zie art. 3.5.14 lid 2 O.M.). Meijers zei toen:

"Voor de Zwitserse bepaling is wel iets te zeggen, het is alleen de vraag of zo de zaak niet nodeloos ingewikkeld gemaakt wordt. Het is vaak van meer belang, dat er een regel is en dat die eenvoudig is, dan dat men via vrijheid van de rechter of een genuanceerde regeling tot een voor alle gevallen billijke oplossing komt; rechtsverfijning heeft ook een gevaar."

Het typeert Meijers als wetgever. ${ }^{86}$ In dit verband is het ook van belang erop te wijzen dat Meijers een sterke voorkeur aan de dag legde voor de meer "moderne" codificaties, zoals het Italiaanse en Zwitserse B.W. Het Franse recht had voor hem vrijwel afgedaan, bol als het stond van eindeloze discussies over de bedoelingen van de wetgever, terwijl uit het BGB een zo andere geest sprak dat Meijers het alleen in uitzonderlijke gevallen raadpleegde.

Tenslotte dient te worden bedacht dat Meijers bij het schrijven van zijn ontwerp voor een belangrijk deel putte uit zijn ervaring als hoogleraar, raadsheer-plaatsvervanger, advocaat en adviseur. De rechtsvergelijkende argumenten moesten wel zeer sterk in een bepaalde richting wijzen, eer hij ertoe overging zijn ontwerp aan te passen. De rechtsvergelijking was bij hem geen doel op zich, maar hoofdzakelijk een controlemiddel. Het ging er bij Meijers niet om het beste uit verschillende rechtsstelsels te kopiëren of zo mogelijk nog wat te verbeteren; primair ging het om de vraag of een tekst of grondgedachte van het B.W. zonder bezwaar voor de praktijk kon worden gehandhaafd. ${ }^{87}$

86. Vergelijk M.H. Bregstein, Meijers en de poging tot hercodificatie in Nederland, Rechtskundig Weekblad 1956, p. 174: "Meijers zelve weerlegde in de discussie van de Staatscommissie critische opmerkingen van de leden herhaaldelijk met de opmerking, dat men noodzakelijkerwijze vertrouwen moest hebben in de 'juge raisonable'." Zie ook R.H. Stutterheim, Regelzucht en de overbodigheid van de exceptio non adempleti contractus in het Nieuw BW, in: Omwille van de consument, Zwolle 1990 , p. 139 e.v.

87. Een aardig voorbeeld hiervan levert de volgende gedachtenwisseling tussen Drion en Meijers op over de vraag of onder curatele-stelling wegens lichamelijke gebreken mogelijk is.

Op 22 januari 1948 vroeg Drion naar aanleiding van Meijers' concept voor artikel 3.2.1. O.M.: "Heeft U 'geestelijke of lichamelijke toestand' gewijzigd in 'geestelijke stoornis' om stelling te kiezen in de controverse of de zwakheid van vermogens in 487 B.W. alleen psychische of ook lichamelijke 


\section{De Staatscommissie}

Zoals hiervoor al enkele malen ter sprake kwam, kreeg de Staatscommissie voor de Nederlandse Burgerlijke Wetgeving, begin 1948 uitgedijd tot meer dan twintig leden ${ }^{88}$, tot taak de door Meijers opgestelde concepten van commentaar te voorzien. Dat betekende voor deze commissie een belangrijk verschil met de voor de oorlog gegroeide situatie, toen de nadruk lag op het zelfstandig ontwerpen van wetsvoorstellen en adviseren. In een rede, uitgesproken op de eerste vergadering van de Staats-

87. $\rightarrow$

vermogens omvat?" Meijers antwoordt dan: "Neen, ik zocht alleen naar een term, die zowel debiliteit als verkwisting en drankmisbruik kan omvatten. Voor de mogelijkheid van onder curatele stelling van geestelijk geheel normalen, ook al zijn ze lichamelijk een wrak, voel ik niet veel. Ik geloof ook niet, dat het in de moderne wetgevingen mogelijk is."

Een dag later blijkt dat Drion deze kwestie niet van zich af heeft kunnen zetten: "Ik ben nagegaan in hoeverre hier en elders ook curatele wegens zwakheid van lichamelijke vermogens erkend is: 400 Wetb. 1809; 733 Ontwerp 1820; verworpen bij vraagpunten van stellige wetgeving maar bij wijziging van 1832 weer ingevoerd (i.p.v. zwakte van geestvermogens, zwakheid van vermogens, expres om curatele 'uit hoofde van hoogen ouderdom of eigen gevoel van zwakte' weer mogelijk te maken). Uitdr. ook 462, 2e Ontwerp 1886. Voorts Diephuis V, 536; Land-Star Busmann I, 673; Völlmar I, Anders Opzoomer II, 477 en Scholten, Asser I (1947), 528. 11 Japan; 372 ZGB; 446 Brazilië; 15 China; 415 Italië." Het antwoord van Meijers is veelzeggend: "Dan zullen we artikel en toelichting maar wijzigen. Het is anders merkwaardig, dat in de praktijk naar mijn weten nooit geprobeerd is curatele enkel wegens de lichamelijke toestand te verkrijgen."

88. Naast Meijers waren lid:

1 = Subcommissie Burgerlijk Recht; 2 = Subcommissie Handelsrecht; 3 = Subcommissie Burg. Rechtsvordering

(2) Prof.mr. J.H. Beekhuis, hoogleraar aan de Rijksuniversiteit te Groningen; (1) prof.mr.dr. S. van Brakel, hoogleraar aan de Rijksuniversiteit te Utrecht; (1) prof.mr. M.H. Bregstein, hoogleraar aan de Universiteit van Amsterdam; (2) prof.mr. R.P. Cleveringa, hoogleraar aan de Rijksuniversiteit te Leiden; (1) mr. L.A. Donker, lid van de Tweede Kamer der Staten-Generaal; (2) prof.mr. T.J. Dorhout Mees, hoogleraar aan de Rijksuniversiteit te Utrecht; (1) prof.mr. J. Eggens, hoogleraar vanwege het Fonds ten behoeve van Indologische studiën aan de Rijksuniversiteit te Utrecht; (3) prof.mr.dr. W.F. de Gaay Fortman, hoogleraar aan de Vrije Universiteit te Amsterdam; (3) prof.mr. P.S. Gerbrandy, Voorzitter van de Raad voor het Rechtsherstel; (1) mr. F.J. de Jong, raadsheer in de Hoge Raad der Nederlanden; (2) mr. J.A.L.M. Loeff, advocaat en procureur te Rotterdam; (1) prof.mr. Ch.J.J.M. Petit, hoogleraar aan de R.K. Universiteit te Nijmegen; (2) mr. H. Schadee, advocaat en procureur te Rotterdam; (3) mr. M.W. Scheltema, griffier van de Provinciale Staten van Groningen; (3) mr. G.J. Scholten, advocaat en procureur te 's-Gravenhage; (1) Mevrouw mr. L.C. Schönfeld-Polano, oud-raadadviseur in algemene dienst bij het Ministerie van Justitie; (3) prof.mr. C.W. Star Busmann, oud-hoogleraar aan de Rijksuniversiteit te Utrecht; (1) mr. A.F. Visser yan IJzendoorn, advocaat en procureur te 's-Gravenhage; (3) mr. A.W.J. van Vrijberghe de Coningh, raadsheer in het Gerechtshof te 's-Gravenhage; (3) mr. C.R.C. Wijckerheld Bisdom, advocaat en procureur te 's-Gravenhage;

Lid en algemeen secretaris: mr. W.G. Belinfante, raadadviseur in algemene dienst bij het Ministerie van Justitie; Adjunct-secretaris: mr. R. van den Bergh, advocaat en procureur te Amsterdam; Jhr.mr. W.L. Schorer, advocaat en procureur te Rotterdam; Tijdelijk toegevoegd secretaris: mr. C.A. de Meijere, raadadviseur bij het Ministerie van Justitie. 
commissie sinds de bevrijding, lichtte Minister Van Maarseveen deze verandering als volgt toe:

"Te voorzien is, dat, althans in de nabije toekomst, het werk der Commissie enigszins anders zal worden dan voorheen. Hoewel, zoals ik opmerkte, de Commissie reeds bijkans van haar instelling af méér omvattende onderwerpen heeft aangepakt, dan aanvankelijk was bedoeld, bepaalde toch haar werk zich tot het voordragen van partiële wijzigingen in onze wetboeken. Thans wordt er, enerzijds door prof. Meijers, anderzijds door een Commissie onder voorzitterschap van prof. Dorhout Mees, gewerkt aan algehele herzieningen van het Burgerlijk Wetboek en het Wetboek van Burgerlijke Rechtsvordering.

Het is de bedoeling, dat het resultaat van beider werkzaamheid in Uw Commissie zal worden behandeld. Ik stel mij voor, dat Uwe Commissie daarbij meer een reviserende dan een scheppende taak zal hebben. Een andere taak derhalve dan vroeger, doch, naar mij voorkomt, zeker geen minder aantrekkelijke. ${ }^{89}$

In zijn antwoord ging Meijers niet verder in op dit punt. Wel gaf hij, met gebruikmaking van een beeld uit de rede die Cambacérès hield bij de invoering van de Code Napoleon, nog eens aan waarom het noodzakelijk was het burgerlijk recht opnieuw vorm te geven:

"Het tragische moment in ons hedendaags staatsbestel is, dat nieuwe wetten noodzakelijk zijn juist in een tijd, dat de maatschappij meer dan ooit voor haar herstel rust nodig heeft. Een wet, hoe voortreffelijk ook haar beginselen zijn, brengt een Staat geen voordeel, wanneer zij niet leeft in het volk en in diens geest wordt toegepast. Willen echter wetten dit gezag en deze doelmatige toepassing vinden, dan moeten zij niet te veel regelen en niet te dikwijls gewijzigd worden. De groei van het recht moet zijn gelijk die van een boom, die ieder jaar om haar merg een nieuwe houtlaag vormt en zo in grootte en kracht toeneemt. De boom wordt sterker, maar haar kern blijft hetzelfde.

Desalniettemin is thans een diepgaande herziening van het burgerlijk recht een dringende noodzakelijkheid. Te talrijk zijn de nog uit het begin der vorige eeuw stammende bepalingen, die niet meer leven in ons volk en waaraan de rechtspraak tracht te ontkomen door steeds meer gewaagde uitleggingen, die de rechtszekerheid in gevaar brengen. ${ }^{190}$

$\mathrm{Al}$ in de openingsvergadering viel het besluit om, evenals voorheen het geval was, de Staatscommissie te verdelen in drie subcommissies: Burgerlijk Recht, Burgerlijke Rechtsvordering en Handelsrecht. Alleen de subcommissie Burgerlijk Recht, waarvan

89. Notulen 253 e vergadering d.d. 24 januari 1948.

90. Volgens Rood-De Boer was Meijers, die dit beeld ook gebruikte bij zijn promotie tot Doctor honoris causa van de Katholieke Universiteit te Leuven (V.P.O. I, p. 174 e.v.) gefascineerd door de zich voortwoekerende slingerplanten van de jurisprudentie, maar stelde hij de eik uiteindelijk toch hoger: "Hij wilde als het ware een nieuw eikeboompje planten, dat toch ook weer gelijkenis zou moeten vertonen met de oude, omdat de nieuwe ontstaan was uit denkwerk waarbij gebruik werd gemaakt van datgene wat de uitdenkers van slingerplanten hadden geleerd." 
Meijers voorzitter werd, zou zich intensief bezighouden met het beoordelen van Meijers' concepten. ${ }^{91}$

Een andere afspraak die werd gemaakt was het besluit om als vanouds de onderwerpen eerst te bespreken in de daarvoor aangewezen subcommissie en vervolgens de resterende vragen in de plenaire vergadering te behandelen. Besluiten zouden alleen door het laatste orgaan kunnen worden genomen. Van dit voornemen is echter, voorzover het de ontwerpen voor het nieuwe wetboek betreft niets, en voorzover het andere zaken betreft, weinig terecht gekomen. Meijers had als voorzitter van de plenaire vergadering uiteraard geen behoefte om de onderwerpen die in "zijn" subcommissie aan de orde waren geweest, opnieuw ter discussie te stellen. Bovendien was de opdracht tot het ontwerpen van een nieuw Burgerlijk Wetboek een opdracht aan hem persoonlijk. De Staatscommissie stond daarbuiten.

Van de onderwerpen die in de andere subcommissies werden besproken, kwamen in feite alleen de werkelijk belangrijke in het plenum aan de orde. Met betrekking tot de overige beperkte Meijers zich ertoe het advies waartoe de desbetreffende subcommissie was gekomen, over te brengen aan de Minister. Het aantal plenaire vergaderingen bleef daardoor gering. Tot de gedwongen stopzetting in 1940 vergaderde de voltallige vergadering 252 maal, onder voorzitterschap van Meijers nog slechts zes maal.

"De besprekingen, welke de Commissie ten aanzien van voornoemde onderwerpen mocht houden, zullen geen afbreuk doen aan de eigen verantwoordelijkheid van de voorzitter voor de hem opgedragen taak tot samenstelling van een ontwerp B.W."

Deze woorden, die de inleiding vormden tot de eerste gedachtenwisseling van de subcommissie Burgerlijk Recht over enkele teksten van Meijers, illustreren dat de ontwerper geen enkele twijfel liet bestaan over zijn verhouding tot de subcommissie. De verantwoordelijkheid voor het ontwerp lag bij hem alleen, de subcommissie beschouwde hij als een klankbodem, een plaats waar hij kon horen wat er wel en niet in goede aarde viel. ${ }^{92}$

Vandaar ook dat de - later - veelvuldig bekritiseerde indeling van het OntwerpMeijers en het consequent hanteren van de term "zaak" waar "zaak" bedoeld is, in de subcommissie in feite niet ter discussie werden gesteld. De opzet en indeling van het voorontwerp werden als een gegeven beschouwd, iets waaraan niet te tornen viel, al

91. Het werkzaam aandeel van de subcommissie Handelsrecht in de vernieuwing van het Burgerlijk Wetboek bleef gedurende het leven van Meijers beperkt tot het opstellen van een concept voor Boek 8. De subcommissie Burgerlijke Rechtsvordering viel buiten de directe belangstelling van Meijers en leidde onder voorzitterschap van Gerbrandy een nagenoeg zelfstandig bestaan, al was er wel een tweetal leden - Scholten en Van Vrijberghe de Coningh - dat regelmatig de vergaderingen van de subcommissie Burgerlijk Recht uit belangstelling bezocht. Beekhuis zou in maart 1953 overgaan naar de subcommissie Burgerlijk Recht, tengevolge van het overlijden van Van Brakel.

92. G.J. Scholten zei daarover in WPNR 6039 (1992): "Meijers luisterde scherp, maar hield meestal vast aan zijn eigen versie. (..) Hij was tegen de eigensomsoverdracht tot zekerheid. Eggens en Bregstein, de laatste met het oog op de praktijk, trokken één lijn, ze waren voor handhaving. Meijers zei: "heren, ik ken uw argumenten, ik heb ze gewogen en ben niet overtuigd. U heeft voor mij niets nieuws gezegd, en ik verander er niets aan. (..) Er werd door de vergaderingen van de staatscommissie in het algemeen niet veel gewijzigd." 
moet ik hier onmiddellijk aan toevoegen dat de "nieuwe" terminologie met name vanuit onderwijskundig oogpunt door de leden van de subcommissie in het algemeen werd gewaardeerd. Bregstein schreef bijvoorbeeld dat hij de verwisseling van zaak en goed vanuit pedagogisch oogpunt een grote verbetering vond: "Met behulp van deze terminologie bereikt men - zulks in overeenstemming met de te onzent heersende rechtsopvatting - dat de zakelijke rechten uitdrukkelijk beperkt worden tot de absolute rechten met betrekking tot stoffelijke voorwerpen. Het wil mij voorkomen dat deze verandering van terminologie slechts kan worden toegejuicht. Vooral uit didactisch oogpunt biedt zij grote voordelen." 93

Met betrekking tot de wijze waarop Meijers de subcommissie bij zijn werk betrok, heeft de algemeen secretaris, Belinfante, al de nodige wetenswaardigheden verschaft. ${ }^{94}$ Een citaat:

"Aanvankelijk ging dit zo, dat Meijers onderdelen van het ontwerp in de subcommissie ter bespreking bracht. Deze werkwijze bleek niet geheel bevredigend omdat de leden niet de tijd bleken te hebben zich op al deze onderwerpen voldoende te prepareren. Later koos Meijers daarom de volgende werkwijze: Voor ieder onderwerp werd één lid aangewezen om schriftelijk opmerkingen te maken, en een tweede lid om bij die opmerkingen kanttekeningen te plaatsen. Deze nota's werden rondgezonden en kwamen in de vergaderingen van de subcommissie in behandeling. Aldus waren er ter vergadering altijd twee leden die zich speciaal in de materie hadden verdiept, en de overigen waren tenminste voorzien van een handleiding van de belangrijkste twistpunten."

Zoals Belinfante terecht opmerkt, heeft de eerste methode die Meijers toepaste slechts betrekkelijk korte tijd gewerkt. Zij beviel Meijers niet goed, omdat de groep te groot was en het te veel tijd vergde alle onderwerpen met de gehele commissie te bespreken. Na drie bijeenkomsten besloot men daarom op voorstel van Meijers over te stappen op de tweede methode, waarbij ik overigens onmiddellijk moet aantekenen dat het systeem van de tegenrapportage ("kanttekeningen" is m.i. te zwak uitgedrukt) een modificatie was die pas enige tijd daarna werd aangebracht. ${ }^{95}$

93. Rapport betreffende titel 3.4 (Verkrijging en verlies van goederen). Van Brakel, Belinfante en De Jong waren uitdrukkelijk dezelfde mening toegedaan. Alleen Eggens had bezwaren, omdat hij voor verwarring vreesde (notulen van de $80 \mathrm{e}$ vergadering van de subcie. Burgerlijk Recht van 9 april 1949; Rapport betreffende titel 5.1). Wel erkende Meijers dat het naast elkaar stellen van stoffelijke voorwerpen en rechten in artikel 3.1.1 theoretisch niet juist was, omdat lichamelijke zaken op dit punt slechts als object van recht een rol spelen. Het andere stelsel zou echter speciaal bij bezit en vruchtgebruik tot een onbegrijpelijke terminologie leiden: wanneer men het volledig recht steeds eigendom zou noemen, zou men een afzonderlijke term moeten verzinnen voor het volledig recht op een stoffelijke voorwerp.

94. W.G. Belinfante, De totstandkoming van het nieuwe Burgerlijk Wetboek, a.w., p. 37-38.

95. Het besluit tot rapportage over te gaan is van 24 april 1948, het besluit opmerkingen te maken naar aanleiding van de rapportage stamt van eind 1949. Soms nam de rapporteur dan weer de gelegenheid te baat kanttekeningen te maken bij de tegenrapportage, een methode die Meijers volgens L. Fredericq (Rechtskundig Weekblad 1954, p. 877) met veel succes had toegepast in de BelgischNederlandse vereniging. In de notulen van 24 april 1948 wordt de verandering als volgt toegelicht: "Het vergt te veel tijd al deze onderwerpen (bedoeld is Boek 3 ) met de gehele commissie te behan- 
Meijers heeft deze methode tot eind oktober 1953, het tijdstip waarop de besprekingen over zijn concepten tot een afronding kwamen, met veel succes toegepast. Voor de leden had zij het voordeel dat iedereen de kans kreeg zijn of haar opvattingen naar voren te brengen, voor de ontwerper betekende zij dat tijdverlies, veroorzaakt door overbodige discussies, werd voorkomen. ${ }^{96}$

Naast deze methode, die vooral van betekenis is geweest voor hetgeen later de (groene) Boeken 3, 5 en 6 zouden worden ${ }^{97}$, besloot Meijers eind november 1951 een derde werkwijze te volgen, en wel één die hij eerder met succes had toegepast bij de regeling van het pand- en hypotheekrecht en het stelsel van overdracht van onroerend goed. Dit betekende dat hij afzonderlijke commissies instelde ten aanzien van onderwerpen waarvoor hij de subcommissie niet voldoende deskundig achtte, bij raadpleging van haar voor ernstige vertraging vreesde of eenvoudig behoefte had aan voorlichting uit de praktijk. Deze commissies, in totaal zo'n tien in getal en in grootte variërend van vier tot negen leden, bestonden steeds uit twee of drie leden van de Staatscommissie, versterkt met vertegenwoordigers uit het bedrijfsleven en andere deskundigen uit de praktijk.

Anders dan tot dan toe gebruikelijk was, legde Meijers zijn voorontwerpen aan elk van de commissieleden voor, met het verzoek schriftelijk commentaar te leveren en eventuele wensen kenbaar te maken. Niet-commissieleden kregen de concepten op verzoek toegestuurd. Deze commentaren, die, voorzover het nota's van de leden van de Staatscommissie betrof, steeds in de vorm van een rapportage en een tegenrapportage waren gegoten, werden vervolgens onder de leden van de commissie verspreid, waarna Meijers een tijdstip vaststelde voor een bespreking. Deze besprekingen, die altijd bij Meijers thuis werden gehouden, om tien uur begonnen en uiterlijk

95. $\rightarrow$

delen. Overeenkomstig het voorstel zal de commissie, na de bepalingen omtrent de rechtshandeling, die omtrent de vertegenwoordiging bespreken. De ontwerpen betreffende de andere hierbovengenoemde onderwerpen zullen onder de leden worden gedistribueerd, zodat elk lid een bepaald onderwerp in studie kan nemen."

96. Ten aanzien van de frequentie waarmee Meijers en de subcommissie Burgerlijk Recht vergaderden, valt het volgende op te merken. Alle bijeenkomsten begonnen om 10.00 uur en werden uiterlijk om 16.00 uur beëindigd. Per jaar (1948-1953) kwam men gemiddeld zo'n vijftien keer bijeen. Een uitzondering vormt 1952, toen slechts drie keer werd vergaderd - een aanwijzing wellicht dat Meijers van mening was dat Justitie onvoldoende belangstelling had voor zijn werk. Het reces werd meestal in de maanden mei, juni, juli en augustus gehouden, hoewel er ook uitzonderingen waren: in mei 1950 organiseerde Meijers ter gelegenheid van de 100e vergadering van de subcommissie Burgerlijk recht een driedaagse bijeenkomst over titel 6.1. in Hotel Stameren te Maarn.

Enkele cijfers: in 1948 vergaderde men van januari tot eind april vijf keer; in september 1948 werd de draad weer opgepakt. Daarna volgden ongeveer zestien bijeenkomsten, tot juni 1949. In september van dat jaar werd het overleg voortgezet in twintig bijeenkomsten tot juni 1950. Van september 1950 tot juli $1951 \mathrm{kwam}$ men twaalf maal bijeen, waarna de besprekingen eind september werden hervat. In februari 1952 zou het werk, na zes voorgaande besprekingen, voor lange tijd worden stilgelegd. Pas eind oktober, direct na het aantreden van Minister Donker, wordt het overleg voortgezet, tot juni 1953 (zestien bijeenkomsten). Daarna zouden nog twee vergaderingen volgen. De besprekingen over Boek 3 werden in april 1950 voltooid, die over de Boeken 6 en 5 in respectieve. lijk februari 1952 en oktober 1953.

97. Met uitzondering van de concepten van afdeling 6.1.4 (voorwaardelijke verbintenissen) en 6.1.5 (verbintenissen onder tijdsbepaling), die nooit onderwerp van bespreking zijn geweest, is elke titel of afdeling van het derde, vijfde en zesde Boek op deze wijze behandeld. 
om vier uur werden beëindigd - "want ziet $u$, op mijn leeftijd moet ik 's avonds niet meer werken. Ik moet dus op dezelfde dag de opmerkingen die u gemaakt hebt, verwerken, want morgen zijn er weer andere vergaderingen" -, leidden meestal tot een gewijzigd ontwerp, gevolgd door nadere besprekingen, waarna de tekst - kleine technische verbeteringen daargelaten - in de regel vaststond.

Op deze wijze heeft Meijers binnen een bestek van ongeveer twee jaar in iets meer dan vijftig vergaderingen alle teksten voor de Boeken 2 (inclusief het Regeringsontwerp voor de Wet op de Stichtingen), 7 en 9 besproken, alsmede die titels van Boek 1 die naar verwachting buiten de vraagpuntenprocedure zouden kunnen worden gehouden. ${ }^{98}$

Voor het erfrecht tenslotte, heeft Meijers een soortgelijke werkwijze toegepast. Een door hem met assistentie van Drion opgesteld ontwerp werd ter beoordeling voorgelegd aan de op dit gebied meest deskundige leden van de Staatscommissie, Eggens en Van Vrijberghe de Coningh, die respectievelijk als eerste en tweede rapporteur optraden. Daarnaast zond Meijers zijn ontwerp aan een door de Notariële Broederschappen ingestelde commissie die onder leiding stond van notaris G.J.A. Kuyk, voorzitter van de Broederschap der notarissen. ${ }^{99}$ In de aanbiedingsbrief bij de eerste groene Boeken schreef Meijers dat "beiden schriftelijke rapporten hebben ingeleverd, die tot een gewijzigde tekst hebben geleid, die eveneens tot nadere gedachtenwisseling heeft aanleiding gegeven. ${ }^{100}$ Men mag dus aannemen dat deze werkwijze in weinig verschilde van de bij de Boeken 2, 7 en 9 toegepaste methode.

De samenwerking van Meijers met de subcommissie Burgerlijk Recht en de diverse commissies ad hoc is zonder twijfel uitstekend geweest. Dat blijkt zowel uit de notulen die van de meeste besprekingen zijn gemaakt als uit de mededelingen van hen die het voorrecht genoten bij deze besprekingen aanwezig te zijn. Ter verduidelijking wijs ik op het volgende.

Iets wat vrijwel direct opvalt wanneer men de notulen doorbladert, is dat Meijers er alles aan deed om het overleg op een zo harmonisch mogelijke wijze te laten verlopen. Hij stelde zijn gesprekspartners op hun gemak, droeg er zorg voor dat iedereen die iets te zeggen had aan het woord kwam en stelde eigener beweging de behandeling van een omstreden onderwerp uit wanneer de naar verwachting belangrijkste opponent verhinderd was. ${ }^{101}$ Daarnaast was hij hoffelijk in zijn replieken en vermeed met zorg het debat in een bepaalde richting te sturen door zijn eigen opvat-

98. Het betrof de titels inzake het recht op de naam, de woonplaats, curatele, levensonderhoud, afwezigheid en vermissing en het wetsvoorstel over adoptie.

99. Naast Kuijck hadden zitting Libourel, Van der Ploeg, Van Veen en de twee secretarissen van de beide Broederschappen.

100. Parl. Gesch. NBW, Alg. Deel, p. 119. Zie ook H.W. Schraagen, De geschiedenis van het notariaat en van de Broederschap der notarissen in Nederland over de jaren 1943-1967. Amsterdam 1968, p. 42. Volgens Van der Ploeg, één van de commissieleden, is nooit sprake geweest van een nadere gedachtenwisseling: "Toen de officieuze Commissie Erfrecht haar rapport aanbood, schreef Meijers wel een vriendelijk briefje, maar dat was het dan ook. Hij ging zijn eigen gang. Dat kón hij ook doen. En hij zal ongetwijfeld gedacht hebben, als ik niet mijn gang ga, dan komt er nooit iets van terecht."

101. Een voorbeeld is de behandeling van de regeling betreffende onvoorziene omstandigheden (art. 6.5.2.11 O.M.), die drie maal werd verdaagd omdat Bregstein en Eggens niet aanwezig konden zijn. 
ting aan anderen op te dringen of de mogelijkheid van een alternatieve oplossing bij voorbaat uit te sluiten. ${ }^{102}$ Een paar voorbeelden.

Wanneer in de subcommissie Burgerlijk Recht het concept voor een conversieartikel aan de orde wordt gesteld, leidt Meijers de gedachtenwisseling in met de vraag of men eigenlijk wel prijs stelt op een wettelijke regeling en niet liever de voorkeur zou geven aan een verwijzing in de toelichting naar de conversie-mogelijkheden die het beginsel van de goede trouw biedt. Als dan na verloop van tijd blijkt, dat er vele haken en ogen zitten aan een wettelijke regeling en Meijers de discussie afsluit met de mededeling dat hij op grond van het naar voren gebrachte er toe neigt het artikel maar te schrappen, laat hij zich "op verzoek van vele leden" toch overhalen zich nog eens over dit punt te beraden. ${ }^{103}$ De discussie over afdeling 6.4.1 (Zaakwaarneming) vangt Meijers aan met een door Bregstein geopperde suggestie of het niet gewenst zou zijn conform het Italiaanse en Franse B.W. te bepalen dat zaakwaarneming slechts onverplicht kan geschieden. ${ }^{104}$ En wanneer bij de bespreking van een concept voor een algemene regeling van het vervoersrecht Meijers' voorstel om het vervoer ter land en over de binnenwateren aan dwingende aansprakelijkheidsbepalingen te onderwerpen, van deskundige zijde vrij algemene bestrijding ondervindt, concludeert hij dat het geen zin heeft zijn standpunt door te drijven en belast hij de subcommissie Handelsrecht met het opstellen van een ontwerp "omdat hij het in deze omstandigheden ongewenst vindt zelf een regeling te ontwerpen. " 105

Meijers streefde dus naar een open overleg ${ }^{106}$, telde alleen de argumenten en bereikte daardoor dat iedereen zich inspande een zo goed mogelijk resultaat te bereiken. Zelfs Eggens, die toch op fundamentele punten met Meijers van mening verschilde en zeker niet uitblonk in de achting voor andersdenkenden, deed zijn best en ontwikkelde zich tot een van de meest produktieve leden van de subcommissie Burgerlijk Recht.

102. Een passage uit het met Schadee gehouden vraaggesprek: "In Leiden had je het dispuut Juri Sacrum. Eens in de maand werd er vergaderd en dan moest de jongste jurist een voordracht houden. Daarop werd vervolgens kritiek geleverd al naar gelang de jaargang. Op den duur was er niets meer te zeggen. Meijers luisterde geduldig toe en gaf het laatste kwartier een glasheldere uiteenzetting van hoe het was. Daarna gingen wij beschaand uiteen. Dat deed hij in de Staatscommissie ook. Hij kon buitengewoon duidelijk uiteenzetten wat hij eigenlijk wilde."

103. Notulen 122e vergadering subcommissie Burgerlijk Recht d.d. 29 september 1951. Ook tijdens de vergadering van de NJV 1954, waar het tweede lid van conversie-artikel kritiek ontmoette, bleek dat Meijers heel gemakkelijk was en hij dadelijk bereid het artikellid te schrappen.

104. Notulen $118 \mathrm{e}$ vergadering subcommissie Burgerlijk Recht d.d. 17 maart 1951.

105. Verslag van besprekingen op 29 april en 1 mei 1953 van de subcommissie Handelsrecht onder leiding van Meijers. De subcommissie kreeg van Meijers een blanco volmacht: "De Voorzitter verzoekt genoemde Subcommissie haar ontwerp uiterlijk 1 November 1953 aan hem in te dienen, doch laat haar volledige vrijheid haar regeling op te stellen zoals haar goeddunkt."

106. De volgende anekdote, verteld door W.G. Belinfante, geeft daarvan een beeld: "Op een keer was er een aantal heren, dat kennelijk nogal had opgezien tegen het overleg met Meijers, omdat ze eigenlijk dachten dat hij nauwelijks naar hen zou luisteren. Bij het afscheid zeiden ze echter dat ze het erg prettig hadden gevonden en besloten ze met de opmerking 'We hebben gezegd wat we te zeggen hadden en we zijn heel blij over de ontvangst die we gehad hebben en over de lessen die we hebben gehad.' Toen zei Meijers in zijn eenvoud, want het was een doodeenvoudige man: 'Tja, weet u, ik heb er ook zoveel van geleerd'." Zie ook NJB 1980, p. 456. 
Het was echter niet de goede sfeer alleen die ertoe leidde dat het overleg vruchtdragend was. Minstens zo belangrijk was dat Meijers, zoals Van Oven uit eigen ondervinding kon mededelen ${ }^{107}$, zeer redelijk stond ten opzichte van de op zijn werk geleverde kritiek. Meijers ontving graag weerwerk, was steeds bereid de juistheid van de door hem gekozen formulering ter discussie te stellen. F.J. de Jong, de latere Drieman, vond zelfs dat hij daarin wel erg ver ging:

"Meijers was, dat heeft mij eigenlijk altijd een beetje verbaasd en ik was er soms ook wat ontsteld van, steeds bereid meteen iets te veranderen als wij wat zeiden. Soms was dat echter maar een losse gedachte, helemaal niet uitgewerkt. " 108

Anders dan Bregstein ${ }^{109}$ zou ik ter verklaring van deze grote mate van welwillendheid geen beroep willen doen op het feit dat ook Meijers er niet altijd in slaagde zijn gedachten op een juiste wijze onder woorden te brengen. Zeker, zijn teksten waren bepaald niet vlekkeloos en bij vrijwel elke titel of afdeling is naar aanleiding van de besprekingen in de Staatscommissie wel een aantal amendementen aangebracht of althans overwogen. Maar in het merendeel van deze gevallen ging het toch om kleinigheden zoals verschrijvingen, interpunctiefouten, verkeerde zinsbouw of een niet streng volgehouden terminologie, fouten waaraan iedereen zich wel eens bezondigt. ${ }^{110}$

Zelf houd ik het erop dat de meeste redactionele wijzigingen een gevolg waren van het probleem dat het nu eenmaal buitengewoon lastig is zich een voorstelling te vormen van alle mogelijke toepassingen van een abstracte regel. Bregstein, die dit argument ook noemt, wekt de indruk dat het vooral Meijers was die hieronder gebukt ging. Ik geloof echter, dat dat nogal meeviel en dat de opmerking van Meijers dat het hem "bij zijn voorbereidend werk steeds meer en meer had getroffen hoe beperkt het denkvermogen van de mens is"111 eerder betrekking had op zijn ervaringen met sommige gesprekspartners dan op zijn eigen intellect. Mijns inziens is verreweg het belangrijkste deel van de naar aanleiding van het overleg tot stand gebrachte wijzigingen te wijten aan het feit dat de teksten van Meijers dikwijls vragen opriepen, omdat hij door zijn onfeilbare geheugen en schier onuitputtelijke reserve van parate kennis meer dan enig ander individu in staat was in grote lijnen te denken en geen behoefte had aan al te gedetailleerde regels. Wie de notulen aandachtig leest, bemerkt al snel dat Meijers in negen van de tien gevallen een vraag beantwoordt met de opmerking

107. NJB 1954 , p. 830 e.v.

108. Het Vaderland, 28 april 1967.

109. M.H. Bregstein, Meijers en de poging tot hercodificatie in Nederland, Rechtskundig Weekblad, 1956, p. 172.

110. Mr. K.T.M. van Rijckevorsel, die van mening was dat zijn lidmaatschap van de vaste Commissie voor Justitie van de Tweede Kamer er als het ware toe verplichtte zitting te nemen in de Staatscommissie - hij volgde begin 1953 Donker op, wegens diens aantreden als Minister -, vond het werk (mede) daarom minder aantrekkelijk: "Ik zag geweldig tegen die Staatscommissie op, maar toen ik eenmaal lid was viel het me zwaar tegen. Ik vond dat niet efficiênt werd gewerkt. Het ging allemaal moeizaam, er werd veel over komma's en punten gesproken, dat heb je veel bij juristen onder elkaar. Er veranderde ook vrijwel niets, want wat er lag was goed. Bovendien, Meijers maakte uiteindelijk toch wel uit hoe het ging worden."

111. E.M. Meijers, De herziening van ons Burgerlijk Wetboek, V.P.O. I, p. 150. 
dat zij eigenlijk overbodig is, omdat de kwestie elders geregeld is, uit een verwijzing naar een ander artikel de oplossing al voldoende blijkt of het geval waarnaar men vraagt niets anders is dan een verbijzondering van de hoofdregel. Het aardige is dan dat Meijers dikwijls afsluit met de opmerking dat hij in de toelichting niettemin aandacht zal schenken aan het punt. Met andere woorden, hoewel Meijers het overgrote deel van de gemaakte opmerkingen op betrekkelijk eenvoudige wijze wist te weerleggen, deed hij er wel zijn voordeel mee. Het gevolg daarvan was, dat het ontwerp voor de "gewone" jurist aan hanteerbaarheid won. En daar was het hem om te doen.

Daarnaast heeft ongetwijfeld een rol gespeeld - Meijers heeft daar ook geen geheim van gemaakt - dat hij de kansen van zijn ontwerp niet onnodig wilde verkleinen en daarom lang niet altijd de oplossing koos die naar zijn mening de juiste was, maar welke in of buiten de Staatscommissie het beste viel. ${ }^{112}$ Zoals Fredericq ${ }^{113}$ schreef in een beschouwing over Meijers' betekenis voor de eenmaking van het recht, wist Meijers dat "een toegeven op het juiste moment, de hoogste kunst kan betekenen om te slagen." Veegens ${ }^{114}$ heeft Meijers in dit verband geprezen om zijn voorbeeldige afstandelijkheid ten opzichte van zijn eigen werk. Ik geloof dat die lof niet geheel terecht is. Meijers, die een pragmaticus bij uitstek was, had er geen behoefte aan een ontwerp te vervaardigen met een louter theoretische kans op verwerkelijking. Hij koos de oplossing die op de meeste stemmen kon rekenen, of zocht welbewust naar een formulering, die ook door iemand die in het tegenovergestelde veld stond, als een compromis-oplossing kon worden aanvaard. De volgende anekdote vormt hierbij een goede illustratie.

Op mijn vraag of Meijers, wanneer een tekst veel kritiek ontmoette, zonder meer bereid was met een gewijzigde versie te komen, gaf W.G. Belinfante dit antwoord:

"Meijers begon aldus dat hij teksten in de commissie bracht en daar werd dan over gediscussieerd. Dan nam hij ze weer mee, en dan kwam er daarna een tweede versie waarin dikwijls rekening was gehouden met de opmerkingen uit de Staatscommissie. Eén van de eerste dingen die er in kwamen, dat was wat later de

112. Zie E.M. Meijers, Het arrest van de Hoge Raad van 5 mei 1950 betreffende de eigendom van roerend goed, V.P.O. II, Leiden 1955, p. 169. Meijers schrijft daar: "Ik wens mij bij voorbaat te verdedigen tegen een verwijt, dat men mij wellicht in de toekomst zou maken, wanneer mijn ontwerp algemeen bekend zou zijn geworden, het verwijt n.l. dat men daarin oplossingen zal vinden volkomen tegenstrijdig aan hetgeen ik tot heden heb verdedigd. $\mathrm{Zij}$, die mij dit zouden verwijten, vergeten daarbij, dat voor mij de tekst en vooral het stelsel der bestaande wet meer waarde hebben, dan voor hen, die menen alles uit de wet te mogen halen, wat hun redelijk en billijk voorkomt. Zo heb ik voor onze wet het causale stelsel steeds bestreden hetgeen mij echter niet beletten zal in mijn ontwerp het causale stelsel op te nemen. Echter men zal daar ook vinden andere regels die in ons tegenwoordig wetboek ontbreken en zonder welke het causale stelsel dikwijls onbillijk werkt." Vergelijk ook de Toelichting-Meijers bij art. 3.4.2.2., Parl. Gesch. Boek 3, p. 316 e.v.

Een ander voorbeeld is de gelijkstelling van de langstlevende echtgenoot met een kindsdeel (art. 4.2.2. O.M.), niettegenstaande de strenge kritiek die Meijers daartegen in 1920 en 1923 had uitgesproken. (Zie WPNR 2616 en 2776).

113. L. Fredericq, prof. Meijers en de éénmaking van het Belgisch-Nederlands Recht, Rechtskundig Weekblad 1955, p. 879.

114. D.J. Veegens, Een herwaardering van Meijers, Juri Sacrum, Deventer 1982, p. 203. 
Inleidende titel is geworden. Dat is nou net het moeilijkste, tenminste voor gewone mensen en voor juristen. Meijers had het nogal moeilijk opgezet, vond men, dus er werd in die commissie alleen gedebatteerd door de twee knapsten, Eggens en De Jong. Die vonden een bepaald artikel niet goed. Meijers hield echter voet bij stuk. Die heren zeiden 'Nou, als u vindt dat het goed is, dan moet het maar zo blijven, maar wij kunnen het niet begrijpen.' Toen kwam in de volgende vergadering een tweede versie en daarin was het bewuste artikel weggelaten. Daarop zei iedereen 'Hé, professor, wij dachten dat u voet bij stuk zou houden.' 'Nee', zei Meijers, 'mijn B.W. is bestemd voor de gewone jurist. Maar als ik nu zie dat een gezelschap van geselecteerde juristen het niet begrijpt, nou, dan moet ik het er niet inzetten.' Het woord 'geselecteerde', waar hij even bij nadacht, was waarschijnlijk hierom gedacht, omdat hij ze niet allemaal goed vond. Hij zei niet 'een gezelschap van goede juristen', nee, hij zei 'geselecteerde juristen'. Meijers was dus zeer precies in zijn uitdrukkingswijze, want geselecteerde juristen, dat waren het."

De derde reden waarom het overleg buitengewoon plezierig verliep en veel bijdroeg aan het uiteindelijke resultaat, was dat Meijers open stond voor nieuw opkomende behoeften van het rechtsleven. Daarvan is hiervoor al het nodige gebleken. Ik kan daarom met een enkel voorbeeld volstaan.

Wanneer Eggens en Drion tijdens de bespreking van het concept voor titel 6.3 (onrechtmatige daad) erop wijzen dat het arrest van de Hoge Raad over de aansprakelijkheid van ouders voor hun minderjarige kinderen (HR 26 november 1948, NJ 1949, 149) niet goed is ontvangen, besluit Meijers zonder al te veel discussie in zijn ontwerp de regel op te nemen dat de ouders van kinderen beneden de veertien jaar altijd aansprakelijk zijn en daarboven alleen indien zij zich niet van schuld kunnen vrijpleiten. ${ }^{115}$ Een blauwdruk derhalve van de regeling die in 1980 na veel discussie tot wet zou worden verheven. Als eind 1951 in de subcommissie Burgerlijk Recht de ook nu nog omstreden vraag ter sprake komt of het afbreken van onderhandelingen zou moeten leiden tot de verplichting de vergeefs gemaakte kosten te vergoeden, weet Meijers zijn commissieleden er van te overtuigen dat in een modern wetboek een dergelijke regeling niet mag ontbreken. ${ }^{116}$ Tenslotte zij vermeld dat elke uitnodiging voor een bespreking over een gedeelte van Boek 7 besloot met de opmerking dat men vooral niet moest schromen eventuele wensen naar voren te brengen, een verzoek waaraan, als men de notulen mag geloven, in ruime mate gehoor is gegeven. Er was dus eigenlijk, zoals Meijers later tegenover de leden van de vaste Commissie voor Privaat- en Strafrecht zou verklaren, niets van principiële betekenis waarover hij op zijn eigen houtje besliste. ${ }^{117}$

115. Notulen van de $115 \mathrm{e}$ vergadering van de subcommissie Burgerlijk Recht van 3 februari 1951. Later zou Meijers, naar aanleiding van een opmerking van De Jong, deze grens bepalen op zes jaar. 116. Notulen van de $123 \mathrm{e}$ vergadering van de subcommissie Burgerlijk Recht van 6 oktober 1951. Deze knoop is pas bij de behandeling van de invoeringswetgeving in 1987 doorgehakt; zie Parl. Gesch. Boek 6 (invoering), p. 1438 e.v.

117. Vergadering van de vaste Commissie van 29 november 1953. Dit verklaart ook dat geen van de leden van de Staatscommissie ooit kritiek heeft uitgeoefend op de eerste vier Groene Boeken. Zij hadden daar wellicht ook geen behoefte aan, maar bovendien zou het niet erg stijlvol zijn geweest. Meijers bleef immers tot het laatst open staan voor opmerkingen, en als hij daar dan uiteindelijk niets mee deed, ja, dan was dat jammer, maar geaccepteerd. 


\section{De vraagpuntenprocedure}

Ofschoon de opdracht aan Meijers om een nieuw Burgerlijk Wetboek te ontwerpen over het algemeen met instemming was begroet, viel er kort na de opdrachtverlening toch wel enige kritiek te beluisteren. Deze kritiek richtte zich met name tegen de gevolgde methode van herziening, die geen enkele waarborg zou bevatten tegen het gevaar dat Meijers' persoonlijke opvattingen ten aanzien van beginselkwesties teveel zouden domineren. In het dagblad Trouw, destijds de spreekbuis van confessioneel Nederland, verscheen een redactioneel commentaar met de veelzeggende kop "Een Burgerlijk Wetboek-Meijers?" In dit artikel werd erop gewezen dat Meijers één van die juristen was "die bij hun juridisch werk hun principiële overtuigingen weten te verbergen" en werd de methode van "hearings van belanghebbenden op voorhand" afgewezen omdat de openbare mening op die wijze pas aan bod zou komen als de wetsontwerpen bij de Kamer zouden worden ingediend.

Tijdens de mondelinge behandeling van de begroting voor 1948, de eerste gelegenheid om te spreken over de door Minister Van Maarseveen gekozen weg met betrekking tot de herziening van het Burgerlijk Wetboek, bleek dat het Tweede Kamerlid Terpstra de in "Trouw" aan de dag gelegde ongerustheid tot de zijne had gemaakt. Hij betoogde dat, in tegenstelling tot wat de Minister in zijn circulaire had verklaard, er geen sprake was van een louter formele herziening, maar van een totale herziening van "een wetboek, dat de rechtsbetrekkingen van het dagelijks leven van ons volk in al zijn verbanden en van het rechtsverkeer in de ruimste zin zal regelen." Het B.W. zou volgens Terpstra de uitdrukking moeten zijn van het rechtsbewustzijn van heel ons volk, zou een nationaal wetboek moeten zijn. Het feit nu dat de opdracht was verleend aan een persoon, wiens beginselen men bovendien niet eens kende, deed hem vrezen dat het eindprodukt een eenzijdig stuk werk zou zijn. Dat Meijers voornemens was tal van personen en instellingen in de gelegenheid te stellen hem hun inzichten te doen blijken en in de Staatscommissie alle belangrijke politieke groeperingen vertegenwoordigd waren, maakte volgens Terpstra geen wezenlijk verschil. De belangrijkste beslissingen zouden toch binnenskamers door de ontwerper worden genomen. Van amendering door de Kamer verwachtte hij niet veel: daarvoor zou er in het door Minister van Maarseveen opgestelde schema, dat er van uitging dat het ontwerp eind 1950 kon worden aangeboden, waarna de vaststelling spoedig zou kunnen volgen, te weinig tijd zijn. Bovendien zou de Kamer niet geheel andere beginselen in het ontwerp kunnen brengen, zonder de eenheid van het geheel te schaden. ${ }^{118}$

Hoewel de woordvoerders van de andere partijen van deze bezwaren niet wilden weten en hun vertrouwen uitspraken in Meijers, bleef Terpstra zijn bedenkingen houden. Ook de uiteenzetting van Minister Van Maarseveen, dat Meijers zou aanknopen bij en letten op de historische groei en de ontwikkeling van ons recht, alsmede dat de meest principiële punten door de Kamer zouden kunnen worden 
afgedaan voordat de voorstellen van Meijers de Kamer zouden bereiken ${ }^{119}$, kon de bij Terpstra aanwezige ongerustheid niet wegnemen. In zijn repliek wees hij erop dat de methode hem deed denken aan het stichten van een geheel nieuw gebouw, waarbij men over de tekening van het geheel geen overleg pleegt, doch slechts over een onderdeel: "Het gaat hier om het geheel en daaromtrent ben ik niet gerust, ondanks de toezegging van de Minister, dat hij de Kamer er incidenteel in zal kennen. "120

Deze kritiek, gevoegd bij het feit dat het al snel duidelijk werd dat de parlementaire behandeling van tal van principiële wetsontwerpen minder snel verliep dan Van Maarseveen en Meijers hadden gehoopt, leidde ertoe dat Meijers door tussenkomst van de inmiddels aangetreden Minister Wijers op 26 maart 1949 aan de vaste Commissie voor Privaat- en Strafrecht het verzoek richtte "in kennis te worden gesteld met de inzichten van Uw Commissie omtrent bepaalde hoofdpunten van het nieuwe burgerlijke recht." Daarmee werd de basis gelegd voor de zogenaamde vraagpuntenprocedure, een methode die, hoewel zij bij de totstandkoming van het Burgerlijk Wetboek met veel succes was toegepast, nadien alleen nog tijdens de behandeling van het ontwerp Arbeidsziekte (1910-1911) een rol had gepeeld. ${ }^{121}$

Minister Wijers had in zijn brief de Commissie laten weten dat hij de wijze waarop het overleg zou moeten worden ingericht gaarne aan de beoordeling van de Commissie overliet:

"Het zou mogelijk zijn dat Uw Commissie haar mening omtrent dergelijke punten kenbaar maakt aan de hand van vraagpunten door professor Meijers op te stellen. Dergelijke vraagpunten zouden voor een schriftelijke beantwoording vatbaar kunnen zijn.

Het zou ook mogelijk zijn aan professor Meijers het antwoord te verstrekken in of na een van zijnentwege met Uw Commissie te plegen mondeling overleg, waarbij ik mij onder meer door professor Meijers zou willen laten vergezellen."

119. Handelingen Tweede Kamer 1947-1948, p. 585. Een nadere uiteenzetting werd door de Minister gegeven bij de behandeling van deze begroting in de Eerste Kamer. In antwoord op een vraag in het Voorlopig Verslag deed Van Maarseveen (zitting 1947-1948, nr 600, stuk nr 57A, p. 1) mededeling van zijn streven de Staten-Generaal in de gelegenheid te stellen zich naar aanleiding van wetsvoorstellen over bepaalde onderwerpen te beraden over de meest principiële vraagstukken (handelingsonbekwaamheid van de gehuwde vrouw, echtscheidingsrecht) voordat Meijers een algemeen ontwerp voor een nieuw wetboek zou indienen. Dit beraad zou langs de gewone weg dienen te geschieden, terwijl voor het overige de beraadslagingen zouden moeten worden gevoerd aan de hand van de ontwerpen, die het nieuwe Burgerlijk Wetboek zouden vormen.

120. Handelingen Tweede Kamer 1947-1948, p. 585.

121. In zijn rede van 8 mei 1948, V.P.O. I, p. 146 e.v., had Meijers overigens al wel op de mogelijkheid gewezen om ten aanzien van die punten waar de Regering niet het voortouw had genomen, vraagpunten te stellen: "Het liefst zou ik zodanige kwesties in de vorm van vraagpunten aan de blijvende commissies uit de Eerste en Tweede Kamer voorleggen. Men heeft dit systeem van vraagpunten met veel succes toegepast bij de totstandkoming van onze tegenwoordige wetboeken. Het ware nogmaals te beproeven. Intussen dit netelige terrein, waarbij de politiek een rol speelt, en waarbij een onoordeelkundig optreden het ganse werk in gevaar kan brengen, ligt hoofdzakelijk op het terrein van het Personen- en het Familierecht. In overleg met de Minister en mede omdat er nog belangrijke ontwerpen op dit gebied te wachten zijn, houd ik mij voorlopig van deze stof afzijdig." 
Bij brief van 20 april 1949 liet de Commissie bij monde van haar voorzitter, mr. L.A. Donker, weten dat zij nog geen besluit had genomen over de te volgen werkwijze, maar dat zij de wenselijkheid van overleg gaarne onderschreef. Volledigheidshalve voegde de Commissie hieraan toe "dat, indien zij over bepaalde punten een mening zal uitspreken, zulk een uitspraak de Kamer als zodanig nooit kan binden. De taak der Commissie blijft immers steeds van voorbereidende aard; beslissingen kunnen slechts door de Kamer als geheel worden genomen." Met die wetenschap kon Meijers aan de slag.

Merkwaardig genoeg gebeurde er daarna helemaal niets. Meijers, die in 1952 in iets minder dan één maand bijna veertig vraagpunten met bijbehorende toelichting uit zijn mouw zou schudden, liet niets meer van zich horen. Wijers, die zijn ministerschap als een loden last op zich voelde drukken ${ }^{122}$, deed kennelijk geen enkele poging de procedure in gang te zetten. Daardoor verstreek een aantal kostbare maanden en werd pas in december 1949 de draad weer opgepakt. De aanleiding daarvoor was dat in het Voorlopig Verslag bij de begroting voor 1950 werd gevraagd of het wellicht mogelijk zou zijn dat de Kamer kennis zou kunnen nemen van de reeds door Meijers voltooide gedeelten. Wijers herinnerde de Kamer daarop aan Meijers' suggestie om bepaalde vraagpunten aan de vaste Commissie voor te leggen. De vaste Commissie zou tegen die tijd haar wensen omtrent de verdere vorm van het overleg kenbaar kunnen maken. ${ }^{123}$

Ook nu kwam Terpstra in het geweer. Hij herhaalde zijn al eerder genoemde argument dat aan een min of meer interne behandeling het bezwaar was verbonden dat men pas na de publicatie van het ontwerp zou weten hoe de praktijk over de voorstellen dacht. Daarnaast wees hij erop dat door het overleg een zekere binding zou ontstaan, waardoor de Commissieleden niet meer geheel vrij zouden zijn in de beoordeling van de reacties van het publiek. ${ }^{124}$ In zijn antwoord erkende Minister Wijers dat hij wel iets voelde voor de bezwaren van Terpstra en dat een andere wijze van overleg wellicht beter zou voldoen. Een keuze wilde de Minister echter nog niet maken, omdat daarvoor zowel de instemming van de vaste Commissie als van Meijers gewenst was. Wel deed hij de suggestie de vraagpunten, desnoods voorzien van een korte uiteenzetting omtrent de voorgestelde regeling, te publiceren. ${ }^{125}$

De Minister moet de zaak daarna snel met de Commissie hebben opgenomen, want op 23 december 1949 vond een eerste, oriënterende bespreking plaats.

Uit het verslag dat daarvan is gemaakt, blijkt dat de Commissie, die voor deze gelegenheid werd vertegenwoordigd door haar voorzitter, weinig voelde voor Meijers' suggestie de Eerste Kamer bij het overleg te betrekken: op die manier zou een soort van recht van amendement worden binnengesmokkeld. Een ander punt dat ter sprake kwam, was de status van het overleg. Donker deelde de Minister mee dat het overleg principieel moest worden gezien als een overleg met de Regering, niet als een overleg

122. De Kamer was weinig in zijn schik met deze Minister, die verweten werd "weinig actief te zijn" (zitting Tweede Kamer 1949-1950, nr 1400, stuk nr 8, p. 1) en na een ambtstermijn van nog geen twee jaar op 15 mei 1950 om gezondheidsredenen zou aftreden.

123. Zitting Tweede Kamer 1949-1950, nr 1400, stuk nr 9, p. 6.

124. Handelingen Tweede Kamer 1949-1950, p. 1061-1062, 1074 en 1075.

125. Handelingen Tweede Kamer 1949-1950, p. 1071 en 1072. 
met Meijers, hoewel deze er uiteraard wel bij aanwezig zou moeten zijn. Duidelijk is ook dat de vaste Commissie er veel belang aan hechtte dat in ieder geval de werkelijk belangrijke vragen aan het oordeel van de gehele Kamer zouden worden onderworpen. Dat zou betekenen dat Meijers zijn denkbeeld uitsluitend met de vaste Commissie overleg te plegen, zou moeten prijsgeven. ${ }^{126}$ Een laatste belangrijk punt dat ter sprake kwam, was de vraag of het niet verstandig zou zijn, om bij de vragen waarover de Kamer zich zou uitspreken, een schets te voegen van de door Meijers voorgestelde regeling. Deze suggestie was al eerder door Wijers in de Kamer geuit en toen door Terpstra met instemming begroet. Met name dit punt zou op verzet van Meijers stuiten.

Op 2 januari werd Meijers in kennis gesteld van de resultaten van het onderhoud en enkele dagen later, op 12 januari, maakte hij voor het eerst zijn opwachting bij de Minister.

Het verslag van deze bespreking, die bedoeld was om tot een gemeenschappelijk standpunt te komen alvorens de discussie met de vaste Commissie aan te gaan, zet meteen krachtig in:

"Prof. Meijers voelt er niets voor om gedeelten van het ontwerp met toelichting te publiceren voordat het geheel gereed is. Bij publicatie bij gedeelten zal men allerlei kritiek daarop krijgen, hetgeen de arbeid van de ontwerper ongunstig zal beïnvloeden en hem wellicht het plezier in het verdere werk zal ontnemen, terwijl het ook beter is, dat men het ontwerp in zijn geheel zal kunnen zien en beoordelen."

Wel verklaart Meijers zich, indien mocht blijken dat de Commissie haar verzet tegen de door hem gewenste vorm van overleg niet wil opgeven, bereid de vraagpunten te publiceren. Daarbij zou dan zonodig een uitvoerige toelichting kunnen worden verstrekt, "en, indien zulks wenselijk mocht zijn, ook een schema van de gedachte oplossing." Beiden worden het er ook over eens dat het in dat geval dringend gewenst is het aantal vragen waarover een voorafgaande uitspraak van de Kamer moet worden gevraagd, zo beperkt mogelijk te houden en Meijers verenigt zich met de suggestie een deel van de vragen die hij zou willen stellen, alleen in overleg met de vaste Commissie te behandelen. Een uitspraak van de Kamer zou dan alleen behoeven te worden gevraagd over die kwesties die hetzij uit juridisch oogpunt, hetzij uit politiek oogpunt van principiële betekenis zijn.

126. Uit het verslag blijkt overigens dat niet ieder lid van de vaste Commissie en het Seniorenconvent (dat tezamen met de Commissie over deze kwestie had vergaderd) overtuigd was van het nut van de te volgen procedure. Een citaat: "Enkele leden - doch hun plan vond weinig instemming meenden dat het beter zou zijn, dat prof. Meijers zijn ontwerp zou publiceren, dat men publiek en wetenschap gelegenheid zou geven daarover hun oordeel kenbaar te maken en dat de regering daarna zou komen met een definitief ontwerp.

Nog weer anderen - doch ook dit was een kleine minderheid - suggereerden om ten aanzien van gedeelten van het B.W., waarin principiële twistpunten zitten afzonderlijke wetsontwerpen in te dienen, waarna dan als deze ontwerpen, al dan niet gewijzigd, zouden zijn aangenomen, die onderdelen zouden kunnen worden aangevuld met de rest van het ontworpen nieuwe B.W. waardoor dan het geheel zijn nieuwe vorm zou krijgen." 
Een ander punt dat tijdens deze bijeenkomst aan de orde werd gesteld, betrof de vraag met welke vraagpunten zou moeten worden begonnen. Ofschoon Meijers het liefst met Boek 1 zou willen beginnen, omdat de voorbereiding daarvan in verband met het grote aantal netelige vragen weinig opschoot, kwam men tot de conclusie dat het beter zou zijn eerst de meer eenvoudige kwesties aan de orde te stellen. Zodoende hoopte men ervaring op te doen met de wijze van overleg voordat het gevaarlijke terrein zou worden betreden. Omdat Meijers verwachtte omstreeks 1 mei met de Boeken 2, 3 en 4 gereed te zijn, zou er bij de Commissie op worden aangedrongen te starten met een reeks vragen over het zakenrecht.

De positie van de Eerste Kamer kwam ook ter sprake. Hoewel de Minister wel iets voelde voor de opvatting van de vaste Commissie was hij nog niet overtuigd:

"Wanneer men een bepaalde uitspraak vraagt van de gehele Tweede Kamer omtrent een vraagpunt van principiële aard, ligt het dan niet voor de hand om een dergelijke uitspraak ook te vragen van de Eerste Kamer, althans in de gevallen, waarin de meerderheid voor een bepaalde oplossing in de Tweede Kamer gering was? Ook zou nog een mogelijkheid zijn de volgende: dat men, zodra de Kamer zich ten aanzien van een bepaalde kwestie heeft uitgesproken, terstond daarop bij de Kamer indient een wetsontwerp, houdende de wettelijke regeling van het besliste vraagpunt of onderdeel van het wetboek en dat dan de Kamer dit onderdeel van het toekomstige B.W. aanvaardt, waarna het automatisch ook aan het oordeel van de Eerste Kamer zal worden onderworpen."

Enkele dagen later, op 9 februari 1950, vond de lang verbeide bespreking met de vaste Commissie plaats. ${ }^{127}$ Het werd een tamelijk verwarde en ook enigszins bewogen vergadering waarin Meijers al zijn tact en overredingskracht moest aanwenden om de Commissie tot zijn standpunt over te halen. Omdat het te ver zou gaan het besprokene tot in detail weer te geven, wordt volstaan met het vermelden van de interessantste punten.

De kernvraag waar het allemaal om draaide betrof de kwestie of alle vraagpunten die in de Commissie aan de orde zouden worden gesteld, openbaar moesten worden gemaakt.

Minister Wijers, die een kort overzicht gaf van de tot dan toe naar voren gebrachte opvattingen, verklaarde daar weinig voor te voelen omdat een dergelijke procedure zeer veel tijd in beslag zou nemen en er naar zijn mening slechts weinig punten waren waarvoor de publieke opinie zich zou interesseren. Zijns inziens zouden de meeste vraagpunten dus door de Commissie zelf kunnen worden afgedaan.

Zoals te verwachten was kon Terpstra, die daarin werd bijgevallen door mevrouw Tendeloo, zich met deze opvatting niet verenigen. Herinnerend aan hetgeen hij bij de begrotingsbehandeling had gezegd, betoogde hij dat het voor de Kamer en de Commissie van het grootste belang was te weten hoe de praktijk over de voorstellen zou denken. Goede voorlichting was naar zijn mening alleen te bereiken indien de vraagpunten een behoorlijke tijd voordat ze door de Kamer of de Commissie zouden

127. Tegenwoordig waren Minister Wijers, Meijers en Eijssen, de leden Donker, Terpstra, Bachg, Tendeloo, Stokvis en de plaatsvervangende leden Burger, N. van den Heuvel, Cals en Ten Hagen. 
worden behandeld gepubliceerd zouden worden: "Wat hier geschiedt moet een nationaal werk zijn, het kan niet in een onderonsje tot stand komen."

Meijers was vanzelfsprekend weinig ingenomen met deze stellingname en hij wees er dan ook op dat aan een al te uitgebreide raadpleging het gevaar was verbonden dat Kamer en Regering zich teveel zouden vastleggen op bepaalde punten: "Het ontwerp moet dat van een particulier zijn, ten opzichte waarvan men vrij blijft staan." Bovendien was hem uit brieven gebleken dat het grote publiek zich alleen interesseerde voor huwelijk en echtscheiding. Ten aanzien van de meer technische punten behoefde men ook niet bang te zijn voor gebrek aan voorlichting. Gehele stukken van zijn ontwerp werden opgesteld in goed overleg met belanghebbenden, die op punten waarop hij van hun opvatting wilde afwijken, reeds bezig waren met het voorbereiden van adressen.

Bij enige leden rees daarop de vraag wat dan de waarde van het overleg was, mede omdat het Regeringsontwerp niet voor de komende verkiezingen te verwachten was en de besluiten die nu zouden worden genomen een toekomstige Kamer nooit zouden kunnen binden. Meijers gaf daarop te kennen hij het ook liever anders had gezien, maar inmiddels wel van de noodzaak van overleg overtuigd was geraakt:

"Ik zou het met U eens zijn, indien Nederland niet Nederland was. In Frankrijk bijvoorbeeld vindt men het denkbeeld van overleg met de volksvertegenwoordiging dwaas. Ik wil echter gaarne resultaat zien en heb juist daarom deze methode aanbevolen. Als er geen eerste boek was, zou het misschien nog gaan. Hier betreft het echter geen kwesties van wetenschap, maar kwesties van levensopvatting, van democratie. Ik had aanvankelijk de hoop, dat allerlei wijzigingen sneller tot stand zouden komen dan mijn ontwerp, maar dit blijkt niet zo te zijn. Ik acht overleg niet zo eenvoudig en zou daarom graag de juiste methode vinden voordat wij aan de moeilijke dingen toekomen. Ik ben niet alleen hoogleraar en beoefenaar van de wetenschap, maar heb ook een opdracht met de bedoeling, dat er iets van terecht komt." 128

Hoewel de meerderheid van de Commissie dit standpunt wel kon billijken, drong zij er toch met kracht op aan om dan tenminste de niet-controversiële gedeelten van het ontwerp te publiceren. Daarbij ging Terpstra zelfs zover te verklaren dat hij ten aanzien van die delen de noodzaak van het stellen van vraagpunten niet inzag. Ook die suggestie werd echter, zoals op basis van het gesprek met Minister Wijers ook wel kon worden verwacht, door Meijers pertinent van de hand gewezen:

"Er zou dan immers dadelijk critiek op die gedeelten komen en dat kan of zoveel tijd kosten, dat er geen tijd tot verder werken overblijft of zelfs de animo tot verder werken geheel wegnemen. Ik heb dan ook als persoonlijke wens bij het

128. Deze uitlating lichtte Meijers nog nader toe door er op te wijzen dat "in geen land zoveel verschil van mening bestaat over kwesties van burgerlijk recht, en wel op grond van het sterke verband met religieuze en politieke inzichten." Zie ook zijn rede "De herziening van ons Burgerlijk Wetboek", VPO I, p. 147 e.v. waar Meijers verklaarde dat het "vrijwel onmogelijk (is), dat in Nederland met zijn uiteenlopende politieke richtingen één persoon belangrijke sociale hervormingen zou kunnen formuleren zonder dat eerst de politieke partijen zich dienaangaande ten minste in beginsel hebben uitgesproken." 
aannemen van de opdracht uitgesproken, dat ik het ontwerp pas als geheel gepubliceerd zou willen zien. U moet dit eerbiedigen."

Ofschoon Donker er nog eens op wees dat het nu alleen maar ging om de vraag of de Commissie bereid was mee te werken aan het schiften van de vraagpunten en daarbij benadrukte dat de Regering uiteindelijk toch vrij was om te beslissen welke vraagpunten zij aan de Kamer wilde voorleggen, bleek dat een aantal leden deze verantwoordelijkheid niet durfde te aanvaarden. Hun verzoek om dan toch in ieder geval inzage te krijgen in het ontwerp, ontlokte aan een enigszins gepikeerde Meijers de volgende reactie:

"Indien men meent de vraagpunten niet te kunnen beoordelen zonder de hele tekst te zien, dan heeft vooroverleg geen zin. Wenst men dat, dan moet men mij rustig mijn gang laten gaan. Maar dan moet men ook niet vragen, wie die prof. Meijers is, van wie men niet eens weet wat zijn politieke richting is en aan wie toch zo'n belangrijk werk is opgedragen. Ik zal dan in mijn ontwerp echter een witte plek moeten laten: het gehele huwelijksrecht. (...) Ik wil graag door vooroverleg de kansen van mijn ontwerp vergroten. Kan dat niet, dan zal ik de meest omstreden punten van mijn ontwerp blanco moeten laten."

Uit de notulen kan worden opgemaakt dat deze uitspraak de nodige opschudding veroorzaakte. Als een blad aan een boom draaiden de meeste Commissieleden om, beseffend dat een negatieve beslissing wel eens tot gevolg zou kunnen hebben dat er van een nieuw Burgerlijk Wetboek niets zou komen. Hoewel er nog wel enige kritiek te beluisteren viel en erop aangedrongen werd in ieder geval tijdens de openbare behandeling het ontwerp aan de Commissie ter beschikking te stellen, gaven de meeste sprekers als hun mening te kennen dat, nu Meijers niet tot publicatie wenste over te gaan, het overleg over vraagpunten de enige mogelijkheid was om dubbel werk te voorkomen. Tevens verklaarden zij zich bereid om in een aantal voorbesprekingen na te gaan welke vraagpunten aan de gehele Kamer zou moeten worden voorgelegd en ten aanzien van welke punten met een gedachtenwisseling in de Commissie kon worden volstaan.

Alleen Terpstra, door wie het allemaal was begonnen, verklaarde zich tegen deze vorm van overleg en vond dat het juister zou zijn indien Meijers zijn gehele ontwerp zou publiceren, zodat iedereen zich daarover zou kunnen uitspreken. Daarmee had zijn standpunt, zonder dat hij dat wellicht besefte, een verandering van 180 graden ondergaan. Immers, de aanleiding tot de vraagpuntenprocedure was juist zijn kritiek dat de Kamer geen enkele invloed had op de totstandkoming van het OntwerpMeijers.

Ofschoon Meijers zich van de medewerking van de vaste Commissie verzekerd wist en daarmee de grootst mogelijke zekerheid had dat zijn arbeid niet vergeefs zou zijn, betekende dit allerminst dat het laatste woord was gesproken over de vraagpuntenprocedure. Al snel bleek namelijk dat in de Ministerraad enig verzet rees dat de Kamer zou worden betrokken bij de voorbereiding van het nieuwe Burgerlijk Wetboek. ${ }^{129}$ 
Minister Van Schaik meende dat op deze wijze werd voorbijgegaan aan het Kabinet en verklaarde bovendien dat hij niet veel verwachtte van het horen van de vaste Commissie. Naar zijn oordeel zou het daarom gewenst zijn dat het Kabinet zelf met een plan in de Commissie zou komen.

Hoewel Minister Wijers het tij nog probeerde te keren door erop te wijzen dat de vraagpunten in overleg met zijn Departement werden opgesteld en hij er tevens op wees dat het vooral de mening van de Kamer was waaromtrent onduidelijkheid bestond, kon hij niet voorkomen dat de Raad na enige discussie besloot dat de vraagpunten pas nadat zij door het Kabinet waren besproken aan de vaste Commissie zouden mogen worden voorgelegd. Bovendien zou het aantal vraagpunten zo beperkt mogelijk moeten worden gehouden, omdat er verschil van mening bleef bestaan over de vraag of het wel juist was de Kamer bij de voorbereiding van een wetsontwerp te betrekken.

Omdat het niet geheel duidelijk was wat de Raad verstond onder de eis dat de vragen eerst "besproken" zouden moeten worden voordat ze aan de vaste Commissie konden worden voorgelegd, en Meijers niet in het minst behoefte had zich op enigerlei wijze te binden, besloot hij de uitspraak van de Raad letterlijk op te vatten en in de toelichting bij de vraagpunten geen voorkeur uit te spreken voor een bepaalde oplossing. Toen begin januari 1951 het overleg op het Departement zover was gevorderd dat Minister Struycken, die de portefeuille van Wijers had overgenomen, een eerste reeks van vraagpunten (twaalf in getal) aan de Ministerraad kon voorleggen, wees deze er dan ook met nadruk op dat Meijers de wens te kennen had gegeven dat bij de voorlegging van deze vragen, eerst aan de Commissie en naderhand aan de Kamer, geen Regeringsstandpunt zou worden bekendgemaakt, opdat hij en de Regering vrijheid zouden behouden om al of niet uitspraken of andere resultaten van de besprekingen in de Kamer op te volgen. ${ }^{130}$

De Ministerraad, van wie sommige leden vermoedelijk bevreesd waren dat Justitie op deze wijze een te sterke positie zou krijgen, besliste evenwel anders: bij ieder vraagpunt zou een positief standpunt moeten worden ingenomen, met als gevolg dat interdepartementaal overleg onontkoombaar werd. Daarnaast zou Meijers zich moeten beperken tot "enkele in de volksovertuiging levende vraagpunten", want met betrekking tot de meer technische zaken zouden Kamer en Kabinet er verstandig aan doen het oordeel van Meijers te respecteren. Bovendien werd afgesproken dat ieder Departement voor zichzelf zou nagaan over welke andere punten het oordeel van de Kamer zou kunnen worden gevraagd. ${ }^{131}$ Het tragisch gevolg hiervan was, maar dan loop ik wat vooruit op de gebeurtenissen, dat tengevolge van de vertraging die hierdoor ontstond, Meijers' verwachting dat hij zijn ontwerp voor december 1952 zou

130. Nota van 6 januari 1951.

131. Vergadering van 29 januari 1951. Met name Minister-President Drees had tegen de voorgestelde procedure "groot bezwaar": "Het is de taak van de Kamer om een uitspraak over wetsontwerpen te doen aan het einde van de voorbereidingen en het overleg. Wel kan de Regering, als zij zelf haar standpunt heeft vastgesteld, een beslissing van de Kamer vragen over bepaalde vraagpunten. In vele jaren heeft de Regering echter niet op deze wijze om het standpunt van de Kamer gevraagd." 
kunnen voltooien ${ }^{132}$, tot een illusie werd. Dat was des te betreurenswaardiger, omdat al snel duidelijk werd dat de opmerkingen die van de zijde van de andere Departementen naar voren werden gebracht, in de regel weinig om het lijf hadden. De meeste vraagpunten hadden namelijk een veel geringere sociaal-politieke inslag dan de meeste Ministers hadden gevreesd. Daardoor voelden zij vermoedelijk ook minder behoefte zich er over uit te spreken. ${ }^{133}$

Op 31 januari 1951, twee dagen na de beslissing van de Ministerraad, ging er een brief uit van Minister Struycken aan zijn ambtsgenoten, met daarin het verzoek om binnen drie á vier weken mede te delen in welke zin zij de beantwoording van de vraagpunten gewenst achtten. Het zou zijn laatste daad zijn in het kader van de totstandkoming van het nieuwe Burgerlijk Wetboek, want enkele dagen later viel het Kabinet.

Hoewel het tijdverlies als gevolg van de Kabinetscrisis niet noemenswaardig was de nieuwe ploeg trad reeds op 15 maart 1951 in functie - en de wisseling van de wacht op zichzelf niet leidde tot een verandering in het denken over de vraagpuntenprocedure, had één en ander toch consequenties voor het verloop daarvan: de ambtenaren van Justitie verzuimden namelijk de nieuw aangetreden Minister op de hoogte te stellen van het feit dat er zoiets bestond als een vraagpuntenprocedure! $\mathrm{Zo}$ kwam het, zoals uit de volgende notitie van Minister Mulderije blijkt, dat deze bewindsman bijna vier maanden na zijn aantreden uit de mond van Meijers moest vernemen dat er in het verleden een afspraak was gemaakt met de vaste Commissie over het voorleggen van bepaalde vraagpunten:

"Prof. Meijers zeide mij op de vergadering van de Nederlandsche Juristenvereniging op 29 Juni j.1., dat de vragen betreffende het B.W., die naar hier ingezonden moeten zijn, nog met de vaste Commissie voor Privaat- en Strafrecht uit de Tweede Kamer der Staten-Generaal moeten worden besproken. Ik weet niet, of hiervoor nog een mogelijkheid bestaat voor 1 Augustus e.k., doch mogelijk wilt U zich eens op de hoogte stellen hoe dit in elkaar steekt."

Het antwoord dat Mulderije naar aanleiding van zijn briefje ontving was zo mogelijk nog onthullender: niet alleen bleek dat slechts een vijftal Departementen gebruik had gemaakt van de mogelijkheid hun standpunt kenbaar te maken over de door Meijers opgestelde vraagpunten, hetgeen bij elkaar niet meer dan negen pagina's aan commentaar had opgeleverd, maar bovendien werd duidelijk dat Meijers niet was ingelicht over het jongste besluit van de Ministerraad:

132. Op 7 december 1950 (zitting Tweede Kamer 1950-1951, nr 1900, stuk nr 7, p. 2) werd bericht: "prof. Meijers heeft de hoop uitgesproken binnen een tijd van twee jaar met het ontwerp voor een nieuw Burgerlijk Wetboek gereed te zijn."

133. Bij dit beeld, dat de vraagpuntenprocedure is ontstaan doordat sommige mensen spraken voordat zij één en ander goed hadden overwogen, behoort ook te worden vermeld dat Minister-President Drees tot tweemaal toe heeft geprobeerd op het Kabinetsbesluit terug te komen, eerst omdat hij van de raadpleging van de Kamer weinig resultaat verwachtte, later omdat hij er bezwaar tegen had dat bij de vraagpunten een voorlopig antwoord werd gevoegd. (Notulen van de Ministerraad van 10 december 1951 en een bericht van het Dep. van Alg. Zaken naar aanleiding van de tweede serie vraagpunten). 
"Prof. Meijers heeft een reeks van vraagpunten opgesteld en elke vraag van een toelichting voorzien, waarin hij niet systematisch van zijn voorkeur omtrent de oplossing doet blijken.

De Ministerraad heeft in zijn vorige samenstelling het standpunt ingenomen, dat het wel gewenst is, dat prof. Meijers van de door hem gewenste oplossing aan de vaste Commissie doet blijken.

Dit moet nog met prof. Meijers worden besproken. Mr. Eijssen meent, dat dit wel enige overreding zal vergen, want prof. Meijers heeft vroeger reeds zeer duidelijk doen blijken, dat hij zich liever voor en na het overleg met de vaste Commissie geheel vrij houdt. Zo is vroeger door de vaste Commissie de wens geuit, dat prof. Meijers haar een voorontwerp zou voorleggen, hetgeen toen door hem om dezelfde reden zeer beslist is afgewezen." 134

Hoewel het inderdaad wel "enige overreding" zal hebben gevergd om Meijers er van te overtuigen dat het besluit van de Ministerraad niet kon worden genegeerd - ik kom daar nog op terug -, leek ook Minister Mulderije aanvankelijk niet erg overtuigd van de noodzaak de vraagpunten in het Kabinet te brengen. Ondanks een negatief advies van Eijssen, zijn voornaamste adviseur, besloot Mulderije namelijk de brieven van de verschillende Departementen zonder enig commentaar van zijn kant in de Raad te brengen en goedkeuring te vragen het overleg met de vaste Commissie te openen. ${ }^{135}$

Dit bravourestukje mislukte echter. De Raad hield vast aan het door zijn voorganger ingenomen standpunt en bepaalde nadrukkelijk dat het niet Meijers, maar de Regering was die in overleg met de Kamercommissie zou treden, al zou Meijers daarbij in feite de man zijn. Het tegenargument van Mulderije, dat het toch meer dan voldoende zou zijn indien de Minister van Justitie de vergadering van de vaste Commissie zou presideren, vond geen genade in de ogen van Minister-President Drees. Het eind van het liedje was dat Mulderije verplicht werd de opmerkingen van de Departementen samen te vatten en de vragen met de adviezen in de Raad te brengen. ${ }^{136}$

Ook nu bleek de Minister niet voor één gat te vangen, want in de Nota die hij op 10 augustus 1951 aan de Ministerraad zond was weliswaar een uittreksel opgenomen van de opmerkingen die de diverse Departementen hadden gemaakt, maar ontbrak een standpuntbepaling van de Minister zelf. De Ministerraad kon deze handelwijze echter niet waarderen en bepaalde zonder verdere discussie dat Mulderije in overleg met Meijers ten aanzien van elk vraagpunt zou moeten aangeven naar welke oplossing zijn voorkeur uitging. ${ }^{137}$ Het gevolg hiervan was dat het begin november 1951 werd bijna een jaar nadat het voornemen tot het inzenden van de vraagpunten was aangekondigd - voordat Mulderije het groene licht kreeg om de eerste reeks vraagpunten, vergezeld van het antwoord dat de Regering in overleg met Meijers op deze vragen wilde geven, aan de vaste Commissie voor te leggen. En het meest beschamende daarvan was misschien wel, dat de Ministerraad zonder discussie akkoord ging met de voorgenomen beantwoording van de vraagpunten, omdat hij eerst het verloop van het 
overleg in de vaste Commissie wilde afwachten alvorens een beslissing te nemen. ${ }^{138}$

Zoals ik hiervoor schreef was Meijers waarschijnlijk allesbehalve tevreden met de gang van zaken rond de vraagpuntenprocedure. Van zijn opzet om in een paar informele bijeenkomsten met enkele Kamerleden tot een hem tot weinig verplichtende gedachtenwisseling te komen, was niets terecht gekomen. En ik vraag mij dan ook af of hij eigenlijk nog wel behoefte had aan overleg, mede omdat het vermoedelijk toch zijn opstelling is geweest die er toe heeft geleid dat tot driemaal toe een Minister het besluit van de Ministerraad trotseerde. Zelf denk ik, maar dat is niet veel meer dan een indruk die ik heb overgehouden aan het raadplegen van de notulen van de bespreking met de vaste Commissie over de eerste reeks vraagpunten ${ }^{139}$, dat Meijers het inderdaad liever anders had gezien ${ }^{140}$, maar dat hij, toen uit het verloop van de discussie duidelijk werd dat zowel de Minister als de vaste Commissie zich op het standpunt stelden dat de gehele procedure een voorlopig en niet bindend karakter zou dragen ${ }^{141}$, wel vrede kon hebben met het resultaat.

Daarbij komt, en ook dat zal er toe hebben bijgedragen dat Meijers zijn verzet tegen de beslissing van de Ministerraad opgaf of althans niet langer naar buiten liet blijken, dat de houding van de vaste Commissie ten aanzien van de vraagpuntenprocedure totaal was veranderd en in geen enkel opzicht meer herinnerde aan die van twee jaar daarvoor. $\mathrm{Zij}$ was nu, zoals de volgende uitspraak van Donker illustreert, overtuigd van de noodzaak van overleg en bereid aan een vlot verloop daarvan mede te werken:

"Er bestaat nu een kans op het tot stand brengen van een nieuw Burgerlijk Wetboek, omdat wij nu kunnen beschikken over de kennis en ervaring van prof. Meijers. Indien de Kamer echter geen grote zelfbeperking in acht neemt, komt er van de algemene herziening niets terecht. Wat de Kamer moet doen is prof. Meijers' werk vergemakkelijken, voorkomen dat hij monnikenwerk moet doen. Er is geen bezwaar tegen dat de Commissie voor deze voorbesprekingen veel vragen krijgt; wij zullen echter moeten trachten er maar weinig aan de Kamer door te zenden."

138. Vergadering van 5 november 1951.

139. Deze bespreking vond plaats op 29 november 1951 . Tegenwoordig waren Mulderije, Meijers en Eijssen, de leden Donker, Bachg en Wttewaall en Gerbrandy, plaatsvervangend lid.

140. Dat het Meijers moeite moet hebben gekost het Kabinetsbesluit in al zijn consequenties te aanvaarden, leid ik af uit het feit dat hij, zonder dat het punt aan de orde was, de vaste Commissie verzocht terug te komen op haar beslissing de behandeling van de vraagpunten in het openbaar te doen plaatsvinden, waarbij hij er nogmaals op wees "dat een openbare behandeling en hem en de Kamer zelf enorm zou kunnen binden."

141. Donker zei bijvoorbeeld dat "besluiten in comite-generaal even veel of weinig bindend zijn als die in een openbare vergadering" en wees er voorts op dat de Regering niet positief gebonden zou zijn aan een uitspraak van de Kamer. Mulderije benadrukte het vrijblijvend karakter van het overleg door in het bijzonder de betekenis van de door de Regering voorgestelde oplossing te bagatelliseren. In antwoord op een opmerking van Donker "of men niet min of meer een prestigekwestie krijgt, indien de oplossingen welke de Regering voorstelt, door de Kamer worden verworpen" verklaarde hij daarvoor niet bang te zijn: "De Regering kan spreken van haar voorlopig standpunt; dit is een kwestie van formulering: "c'est le ton qui fait la musique." 
Kortom, ik vermoed dat Meijers, zijn aanvankelijke bezwaren tegen deze vorm van overleg ten spijt, uiteindelijk het contact met de volksvertegenwoordiging toch niet wilde missen. Uit het vervolg van de bespreking met de vaste Commissie heb ik in ieder geval geen aanknopingspunten kunnen vinden voor het tegendeel. Meijers was uiterst hoffelijk ten opzichte van de leden van de Commissie, getroostte zich veel moeite het overleg in goede harmonie te laten verlopen ${ }^{142}$ en kwam geregeld zelfs geestig uit de hoek.

Omdat, zeker wanneer het erom gaat die sfeer weer te geven, een blik op de notulen vermoedelijk meer verhelderend werkt dan een betoog van vele tientallen bladzijden, wordt hieronder een aantal passages vermeld uit een tussen Meijers, Mulderije en de vaste Commissie gevoerde discussie naar aanleiding van de vraag of de bestaande omschrijving van het eigendomsrecht (art. 625 B.W.) meer in overeenstemming zou kunnen worden gebracht met de maatschappelijke werkelijkheid. ${ }^{143}$ Deze discussie, die tenslotte eindigde in de aanbeveling het betreffende vraagpunt niet aan de Kamer voor te leggen, werpt een wel heel bijzonder licht op het betoog van hen die in later jaren het ontbreken van een dergelijk vraagpunt aangrepen om het onnutte karakter van de hercodificatie te illustreren ${ }^{144}$, danwel daarin juist een aanleiding vonden hun betrokkenheid bij het grote werk nader tot uitdrukking te brengen. ${ }^{145}$

De tekst van het eerste vraagpunt dat de Commissie onder ogen kreeg, luidde als volgt: "Moet bij de omschrijving van het recht van eigendom tot uitdrukking gebracht worden, dat dit recht door wetgevende organen slechts beperkt, doch niet opgeheven kan worden?"

Nadat de Minister, conform het voorlopig antwoord, had uiteen gezet dat het zijns inziens hoogst twijfelachtig was of het Burgerlijk Wetboek wel de geëigende plaats was om te bepalen hoever de verordenende bevoegdheid van lagere wetgevende organen moet gaan, lichtte Meijers de reden voor opneming van dit vraagpunt nader toe: "De regel: wel beperken, niet opheffen (is) eigenlijk een middel om de 'keuromanie' van de lagere colleges tegen te gaan", al zou het volgens hem ongetwijfeld beter zijn om de controle op deze colleges te regelen in een wet op de administratieve rechtspraak.

142. Meijers stelde bijvoorbeeld geen limiet aan het aantal vragen, was altijd bereid een discussie aan te gaan over de juistheid van de door hem gekozen formulering en liet de Commissie de vrijheid zelf bepaalde vraagpunten naar voren te brengen, een mogelijkheid waarvan overigens slechts eenmaal gebruik is gemaakt.

143. Deze bespreking vond plaats op 29 november 1951.

144. Zie het betoog van Jurgens naar aanleiding van de invoeringswet van Boek 2 en wetsontwerp 12897, Parl. Gesch. Boek 2 (invoering), p. 1021, een betoog dat in 1976 bij de vaststelling van de Boeken 3, 5 en 6 werd voortgezet door Kaulingfreks (handelingen Eerste Kamer 1975-1976, p. 715 e.v.). Zie ook G.C.J.J. van den Bergh, Schijnbewegingen. Hercodificatie en eigendomsdefinitie in historisch perspectief, Recht en kritiek, 1987, p. 327-341, waarin deze afrekent met deze goedkope vormen van sociale bevlogenheid.

145. Zie Parl. Gesch. Boek 5, p. 31-33; B. De Gaay Fortman, Parlement en hercodificatie, WPNR 5617 (1982). 
Vervolgens ontspon zich een discussie over de vraag of het wel mogelijk was één en ander op een bevredigende wijze te formuleren. Mulderije wees er daarbij op dat de Hoge Raad de ontoelaatbaarheid van opheffing van eigendom reeds baseerde op artikel 625 B.W., zodat het artikel in het nieuwe Burgerlijk Wetboek geen andere redactie behoefde te krijgen. ${ }^{146}$ Meijers deelde daarop mede dat hij in de door hem ontworpen redactie voor artikel $625 \mathrm{~B} . \mathrm{W}$. (nieuw) het woord "beperkingen" had opgenomen, waaruit men dit alles kon afleiden, al erkende hij dat de Hoge Raad met behulp van de tekst van artikel 625 tot hetzelfde resultaat kwam.

Deze uiteenzetting verleidde Donker tot de opmerking dat het eigenlijk geen kwestie was om aan de Kamer voor te leggen, aangezien het stelsel van het B.W. er toch niet door zou veranderen. Meijers beaamde dit: "Ik heb", zo vertelde hij, "het punt eigenlijk alleen maar genoemd omdat men met deze kwestie honderd jaar geleden veel moeilijkheden heeft gehad. "147

Eén lid van de vaste Commissie, de heer Bachg, kon zich met dit standpunt echter niet verenigen. Ofschoon hij het toejuichte dat de totstandkoming van het nieuwe Burgerlijk Wetboek niet zou worden aangegrepen om te sleutelen aan de eigendomsverhoudingen, zou het vraagpunt wel aan de Kamer dienen te worden voorgelegd, "al ware het slechts ter verkrijging van de nodige helderheid." Mulderije voelde daar echter niets voor: "Ik vrees dat een debat hierover van alles overhoop zal halen, zonder resultaat." Hoewel Donker zich achter het standpunt van de Minister schaarde door te stellen dat het punt voor het Burgerlijk Wetboek "inderdaad generlei betekenis had" en Meijers nogmaals benadrukte dat er geen enkele reden bestond voor ongerustheid, bleef Bachg zijn bedenkingen houden: "Ik ben van mening, dat als er een van de vraagpunten de hele Kamer zal interesseren, het dit punt is." Wel was hij, zoals hij de vergadering mededeelde, bereid zijn bezwaren te laten vallen indien de nota ter inleiding van de vraagpuntenprocedure de "geruststellende" mededeling zou bevatten dat het in de bedoeling lag de bestaande omschrijving van het eigendomsrecht te handhaven.

Na enig beraad werd aldus besloten, al kon Meijers het niet nalaten er nog eenmaal op te wijzen dat de gedachte, dat de ontwikkeling van de algemene vraagstukken van het eigendomsrecht rechtstreeks verband zou houden met de omschrijving van het recht van eigendom, ver buiten de werkelijkheid stond. Mocht, zo zei Meijers, tijdens het debat alsnog blijken dat de Kamer aan een andere omschrijving van het eigendomsrecht de voorkeur zou geven, dan had hij er geen bezwaar tegen aan die wens te voldoen: "Men kan desgewenst natuurlijk in de wet zetten dat eigendom geen recht, maar een plicht is. Zo'n uitspraak betekent immers niets. Ik ben daarvoor ook te nuchter."

146. Zie HR 8 mei 1939, NJ 1939, 965.

147. Vermoedelijk doelde Meijers daarmee er op dat dit probleem in 1823 zo belangrijk werd geacht, dat er een vraagpunt van werd gemaakt, waarna een ellenlange discussie volgde: het wetswoorstel met betrekking tot de eigendomstitel werd namelijk viermaal afgewezen, tweemaal door de Tweede Kamer en tweemaal door de Eerste. Zie Voorduin, Geschiedenis en Beginselen van de Nederlandsche Wetboeken, deel III, Utrecht 1838, p. 379-413. Zie ook Peter van den Berg, De mythe van het onbegrensde in de negentiende-eeuwse eigendomsopvattingen, Recht en kritiek 1984. p. 293-314. 


\section{Minister Donker treedt aan}

Verliep dus het overleg met de vaste Commissie, na een wellicht enigszins stroef begin, in goede harmonie, één en ander betekende niet dat snel vooruitgang werd geboekt. Omdat geen van beide partijen ervaring had met deze vorm van overleg en de leden van de Commissie aanvankelijk de neiging hadden vrij diep op de materie in te gaan, konden slechts zes van de twaalf punten in die eerste bijeenkomst worden afgedaan. En aangezien men de behandeling van de resterende vraagpunten het liefst zou willen combineren met een volgende serie, werd besloten de volgende vergadering te verschuiven tot een nader te bepalen tijdstip. Minister Mulderije had daarbij nog opgemerkt dat de Commissie niet zou moeten verwachten dat alles in een zeer snel tempo zou kunnen gaan, omdat het Kabinet ook in deze materie gekend wilde worden. Die voorspelling zou maar al te waar blijken te zijn.

Op 6 april 1952 ontving Minister Mulderije eenentwintig vraagpunten over het verbintenissenrecht, compleet met bijbehorende toelichting. Vermoedelijk had het opstellen daarvan Meijers nogal wat tijd gekost, omdat de Commissie te kennen had gegeven dat de toelichting die bij de eerste reeks vragen was verstrekt soms wel erg summier was. Bovendien kon Meijers maar weinig tijd besteden aan het opstellen van de vraagpunten. Hij had in deze periode vrijwel dagelijks besprekingen met diverse commissies over Boek 7, moest eens in de veertien dagen een gehele dag uittrekken om met de subcommissie Burgerlijk Recht van gedachten te wisselen over zijn andere concepten voor het nieuwe Burgerlijk Wetboek. Tenslotte had hij eind 1951 ook nog deelgenomen aan de eerste Internationale Conferentie over de Koop en was hij benoemd tot lid van een commissie die tot taak had de daar bereikte resultaten om te zetten in een ontwerp-tekst.

Ruim een maand later, en daaraan kan men zien dat Mulderije zich niet erg intensief met het nieuwe B.W. bemoeide, werd Meijers medegedeeld dat de Minister het wenselijk had geoordeeld één vraagpunt te schrappen in verband met een aanhangig wetsvoorstel, doch dat hij voor het overige geen bezwaren had en daarom het oordeel van zijn collega's over vraagpunten en toelichting had gevraagd. ${ }^{148}$ Die maand vertraging, die onder normale omstandigheden geen enkel probleem zou hebben opgeleverd, bleek nu echter de zoveelste hindernis op de weg naar de totstandkoming van het nieuwe Burgerlijk Wetboek. Omdat het niet mogelijk bleek de reacties van de diverse Ministeries tijdig, dat wil zeggen, vóór de verkiezingen van 1952 in de Ministerraad te brengen, duurde het tot september van datzelfde jaar, de maand waarin het Tweede Kabinet-Drees in functie trad, voordat de draad weer kon worden opgepakt.

In het nieuwe Kabinet nam Donker, het Kamerlid dat we hierboven al hebben leren kennen als Voorzitter van de vaste Kamercommissie en als lid van de Staatscommissie tot herziening van de Burgerlijke wetgeving, de plaats van Mulderije in. En daarmee verkeerde, zoals Wiersma terecht heeft opgemerkt, "de vertraging in haar tegendeel." 149 Donkers faam als iemand van grote begaafdheid, toewijding en doorzet-

148. Het schrijven aan Meijers was gedateerd 19 mei 1952. Per gelijke datum ontvingen de ambtgenoten van Mulderije het verzoek hun standpunt ten opzichte van de vraagpunten en toelichting kenbaar te maken.

149. K. Wiersma, Meijers en de hercodificatie, WPNR 5504 (1980). 
tingsvermogen was hem reeds voor zijn Ministerschap vooruitgesneld, hetgeen in het bijzonder te danken was aan de voortvarende wijze waarop hij als voorzitter van de Parlementaire Enquêtecommissie Regeringsbeleid 1940-1945 vijf van de in totaal acht volumineuze verslagen tot stand had weten te brengen. Bij zijn aantreden als Minister zei freule Wttewaall van Stoetwegen: "Door mijn lidmaatschap van de Enquêtecommissie weet ik welk een grote werkkracht deze nieuwe Minister van Justitie kan ontwikkelen. Wij hebben er wel eens onder gezucht, Mijnheer de Voorzitter, maar de overige leden van de Enquêtecommissie zullen het met mij eens zijn, dat er nooit zoveel tot stand zou zijn gebracht, als de heer Donker als voorzitter niet zulk een stimulans was geweest voor de overige leden. " ${ }^{150}$ Illustratief voor Donkers inzet en werkdrift is dat het tweede verslag dat hij als Minister te beantwoorden kreeg, al opende met de opmerking, dat, hoewel men groot respect had voor de voortvarenheid en werkkracht van de Minister, men niettemin meende te moeten opmerken dat zich ook een teveel aan ijver kon manifesteren ${ }^{151}$ - een geluid dat Donker gedurende de rest van zijn Ministerschap zou blijven achtervolgen. ${ }^{152}$

Ofschoon de verwachtingen ten aanzien van zijn optreden als Minister daardoor toch al niet laag gespannen waren, kan zijn Ministerschap met recht spectaculair worden genoemd: toen Donker op 4 februari 1956 op zesenvijftigjarige leeftijd overleed, had hij 69 wetten tot stand weten te brengen, waren nog 21 wetsvoorstellen aanhangig bij de Tweede Kamer en had hij er nog eens 25 in voorbereiding. In het "In Memoriam" dat in het WPNR verscheen, werd dan ook opgemerkt dat het moeilijk zou zijn uit de geschiedenis van het Departement van Justitie een Minister naar voren te halen die in zo korte tijd zoveel werk had weten te verzetten. ${ }^{153}$ Behalve door zijn dadendrang en verwoestende werkkracht, onderscheidde Donker zich van de meeste van zijn ambtsvoorgangers doordat hij een groot voorstander was van hercodificatie en die visie ook met kracht uitdroeg. Hij ging daarbij uit van de opvatting, dat de herziening alleen kans van slagen had indien men zou weten door te tasten, een standpunt waarmee hij Mulderije eens danig in verlegenheid had gebracht. Toen namelijk tijdens de bespreking van de vaste Commissie over de eerste reeks vraagpunten de positie van Meijers ter sprake kwam en Mulderije daarbij een suggestie om Meijers reeds bij de openbare behandeling van de vraagpunten als Rege-

150. Handelingen Tweede Kamer 1952-1953, p. 2104. Mevrouw Zeelenberg (handelingen Tweede Kamer 1952-1953, p. 2114) was eveneens vol lof: "Tot de leden die veel vertrouwen hebben in het optreden van deze Minister en die van zijn beleid bijzondere verwachtingen hebben, behoor ik uiteraard ook. Dat is niet te verwonderen, omdat ik zes jaren naast hem gezeten heb in de raad der gemeente Rotterdam en hem in die periode nogal goed heb leren kennen. Het verwondert mij daarom niet in het minst, dat ik uit de Memorie van Antwoord heb kunnen afleiden, dat de Minister grote plannen heeft."

151. Zitting Tweede Kamer 1953-1954, nr 3200, stuk nr 9, p. 1.

152. Uit het Voorlopig Verslag over de begroting voor 1955 - Donker was toen pas tweeëneenhalf jaar aan het bewind - blijkt dat het verlangen naar wetgeving bij sommige Kamerleden al geheel was gestild: "In de weinige jaren dat deze bewindsman op Justitie zetelt, is aan een zo groot gedeelte van deze verlangens tegemoet gekomen, dat, naar de mening van deze leden, een wijze zelfkritiek op dit ogenblik meebrengt eerst de reeds ingediende of aangekondigde wetsontwerpen af te handelen en thans niet op nog meer belangrijke wijzigingen en verbeteringen aan te dringen." (zitting Tweede Kamer 1954-1955, nr 3700, stuk nr 9, p. 1).

153. WPNR 4432 (1956). Zie over Donker ook mijn artikel in NJB 1992, p. 32-47; F. Bruinsma en N. Huls, De Vries en de kunst van het wetgeven, NJB 1989, p. 591. 
ringscommissaris te laten optreden, in twijfel had getrokken "omdat het Departement ongetwijfeld nog veranderingen zou willen voorstellen met betrekking tot Meijers' ontwerpen", had Donker de volgende gedenkwaardige woorden gesproken:

"Naar mijn persoonlijke mening wordt het Burgerlijk Wetboek, verouderd als het is, drijvende gehouden door de jurisprudentie en de wetenschap. Als prof. Meijers er nu een wetenschappelijk systeem van zou maken, dan zou ik, als ik Minister was, daaraan zo min mogelijk willen gaan tornen. In elk geval wordt het nieuwe Burgerlijk Wetboek een enorme vooruitgang; de kleine verbeteringen, die dan nog door het Departement of door anderen zouden kunnen worden voorgesteld, verzinken daarbij vrijwel in het niet."

Bij de mondelinge behandeling van de vraagpunten zei Donker:

"Wij moeten ons goed bewust zijn, wat de opzet is van het maken van het nieuwe B.W. op de wijze, zoals wij ons dit voorstellen. Het uitgangspunt is geweest dat dit Burgerlijk Wetboek door één man gemaakt zal worden, omdat de ervaring heeft geleerd dat een zo omvangrijke arbeid alleen tot stand kan komen door één persoon, die visie op het totaal heeft, die het geheel kan overzien. Ik mag in dit verband wijzen op de geschiedenis van de totstandkoming van het Zwitserse Wetboek. Wanneer nu de heer Oud zegt, dat het op de uitwerking aankomt, meen ik daartegenover te moeten stellen, dat Regering en Staten-Generaal verstandig zullen doen, wanneer eenmaal de principiële beslissingen over de vraagpunten zijn gevallen, wat de uitwerking betreft, zich niet te verdiepen in details. Wil het werk slagen, dan moet men de man, die de opdracht heeft, een faire en royale kans geven." 154

In het licht hiervan mag het daarom nauwelijks verbazingwekkend heten dat Donker de dag na zijn ambtsaanvaarding aan Eijssen, die als raadadviseur in algemene dienst nog steeds fungeerde als intermediair tussen Meijers en het Ministerie van Justitie, de opdracht gaf een schema op te stellen dat ertoe zou moeten leiden dat het ontwerp van Meijers in september 1954 bij de Tweede Kamer zou kunnen worden ingediend. Een schema, waarover Van Oven later zou schrijven: "Het schema was voor Donker karakteristiek; Bij voorbaat onvervulbaar was het niet, maar wel was het erop berekend, door een vergen van het uiterste van alle betrokkenen, door een niet in

154. Parl. Gesch. NBW, Algemeen Deel, p. 91. Tijdens de begrotingsbehandeling voor 1955 zei Donker (handelingen Tweede Kamer 1954-1955, p. 2166): "Men moet bij deze zaken ook niet al te zwaarwichtig zijn, want het maken van een nieuw Burgerlijk Wetboek betekent toch voor een groot gedeelte het beslissen over kwesties, die in de loop der jaren uitgediscussieerd zijn, waarover beslissingen in de jurisprudentie gevallen zijn, of waarover zo lang in de literatuur is geschreven en gestreden dat er eigenlijk niet veel nieuws over te zeggen is. (..) Men moet bovendien wat durven. Juist verleden week kreeg ik een citaat in handen, dat mij wel erg aansprak in verband met de situatie, waarin wij ten aanzien van het Burgerlijk Wetboek op het ogenblik verkeren. Het luidt als volgt:'Waarlijk, ons leven is te kort om, wanneer wij iets tot stand willen brengen, het volmaakte te bereiken en geen fouten te begaan. Veel beter is het daarom van tijd tot tijd maar eens door te tasten of door te hakken op gevaar af, nu en dan eens een fout te begaan.'" 
rekening brengen van enige tegenslag, het hoogst bereikbare ook te bereiken." $15 s$ Daarnaast moest Eijssen zich buigen over de vraag op welke wijze vraagpunten en ontwerp bij de Staten-Generaal zouden moeten worden aangeboden en tevens advies moeten uitbrengen over de status van Meijers, twee kwesties die al lang slepende waren en waarvan het gewenst was dat zij op korte termijn tot een oplossing zouden worden gebracht.

Enkele dagen later, op 6 september 1952, ontving Donker de gevraagde adviezen, waarna hij contact opnam met Meijers, die, ofschoon het schema op hem een zeer zware druk zou leggen, het initiatief van de Minister vermoedelijk hogelijk heeft gewaardeerd. Tijdens het laatste overleg met de vaste Commissie had Meijers er namelijk al op gewezen dat hij het op prijs zou stellen indien een zodanige procedure kon worden gevolgd, dat zowel vraagpunten als wetsontwerp door eenzelfde Kamer zouden kunnen worden behandeld. Hij had daarbij tevens de hoop uitgesproken dat alle vraagpunten een jaar na het optreden van de nieuwe Kamer zouden zijn afgedaan. Het schema van Donker, dat tot uitgangspunt had dat de behandeling van de vraagpunten in september 1953 zou zijn voltooid en mei 1955 noemde als tijdstip waarop een begin zou moeten worden gemaakt met de mondelinge behandeling van het wetsontwerp, sloot dus uitstekend aan op Meijers' wensen. ${ }^{156}$

Wél vond Meijers het bezwaarlijk, maar dit terzijde, dat in het door Donker getrokken kader voor de herziening geen plaats was ingeruimd voor het vragen van advies aan de rechterlijke macht. Hij achtte het, mede gelet op de circulaire van 14 mei 1947, waarin de rechterlijke macht in het vooruitzicht werd gesteld dat zij in de herziening van het Burgerlijk Wetboek zou worden gekend, "dringend geraden" dat op zijn minst de Hoge Raad bij de voorbereiding van het nieuwe Burgerlijk Wetboek zou worden ingeschakeld. Donker stelde zich daarop in verbinding met de President van de Hoge Raad, Donner, die, nadat hij de overige leden had gepolst, de Minister kon mededelen dat men "algemeen van oordeel bleek dat in het door U getrokken kader voor een weloverwogen advies van den Hogen Raad inzake de herziening geen plaats is te vinden." Omdat men wel grote belangstelling had voor het werk van Meijers, gaf Donner de Minister in overweging de Hoge Raad op de hoogte te houden van de gang van zaken, zodat deze in de gelegenheid zou zijn eventuele bezwaren nog voor de publicatie van het Ontwerp-Meijers kenbaar te maken. Aldus geschiedde. ${ }^{157}$

Op 11 september 1952 stelde Donker de Ministerraad van zijn voornemen op de hoogte en vier dagen later, op 15 september 1952, hechtte deze zonder veel discussie zijn goedkeuring aan het schema. Donker wist zijn collega's zelfs zover te krijgen, dat men er mee akkoord ging dat de Departementen aan de in het schema vermelde behandelingstermijnen gebonden waren. Dé constatering, dat een termijn van één

155. NJB 1956, p. 117.

156. Zie ook WPNR 4432 (1956), waarin Van Oven, die Meijers van zeer nabij had gekend, schreef: "Het plan had Meijers' volle instemming; hij verheugde zich dat hem de kans werd geboden de verdediging van zijn ontwerp in de Kamer zelf op zich te nemen; dat niet meer te duchten was, dat zijn ontwerp zou blijven rusten zoals zo vele vroegere herzieningspogingen van ons wetboek." 157. Briefwisseling van 2 en 9 oktober 1952. Met name Smits en Langemeijer hebben in de periode januari/maart 1954 gebruik gemaakt van de gelegenheid de drukproeven van de eerste vier groene Boeken te becommentariëren. 
maand wel erg kort was, ontlokte aan Minister-President Drees de opmerking dat een verlenging niet gewenst was, omdat "het belangrijkste gevolg hiervan zou zijn, dat het nieuwe wetboek niet of niet binnen een redelijke termijn tot stand komt." Kennelijk had de dadendrang van Donker de voorzitter van de Raad ook al in zijn ban gekregen.

Twee dagen daarna - ik geef deze data met opzet omdat er uit blijkt dat Donker van opschieten hield - wendde Donker zich schriftelijk tot de voorzitter van de Tweede Kamer, Kortenhorst, om uitsluitsel te krijgen over de vraag of ook van de zijde van de Tweede Kamer de wenselijkheid van totstandbrenging van het wetboek vóór de volgende periodieke verkiezingen zou kunnen worden onderschreven. Kortenhorst riep daarop op 27 september de vaste Commissie ${ }^{158}$ en de Seniores Burger, Romme, Tilanus en Oud bijeen, terwijl later ook Donker, Meijers en Eijssen ter vergadering verschenen.

Tot Donkers voldoening werd deze bespreking een groot succes. Nog voordat hij een toelichting had kunnen geven op zijn schema, dat toch van alle betrokkenen het uiterste zou vergen, bleek reeds dat de aanwezigen de wenselijkheid om het Burgerlijk Wetboek voor de zomer van 1956 tot stand te brengen, van harte onderschreven. Men vond het, zo valt uit de notulen op te maken, als het ware een erezaak om niet achter te blijven bij de Minister, nu deze tot een zo grote krachtsinspanning bereid was. ${ }^{159}$ Vanzelfsprekend werden er wel enige kanttekeningen geplaatst bij de manier waarop Donker zijn doel wilde bereiken. Zo stelde Oud dat hij het systeem van het voorleggen van vraagpunten niet juist vond, al liet hij daar onmiddellijk op volgen dat het niet zijn bedoeling was op dit besluit terug te komen. ${ }^{160}$ Romme gaf als zijn mening te kennen dat hij het uitgesloten achtte dat het grote werk in vier jaar voltooid zou kunnen worden, een opmerking die, zoals hij later schriftelijk aan Donker toelichtte, louter uit bezorgdheid werd ingegeven:

"Ik zou om verschillende overwegingen graag zien, dat Gij in Uw voornemen, het nieuwe B.W. althans door de Tweede Kamer heen te halen, zoudt slagen. Ik kan echter niet zien, dat Uw schema daartoe kan voeren - ik vind het, als ik het onder ons mag zeggen, bepaald niet reëel. Ik ben dan ook stellig ervan overtuigd, dat dit op een teleurstelling uitloopt.

De enige juiste oplossing - indien nog mogelijk - lijkt mij, om radicaal een einde te maken aan de vraagpuntenmethode, eenvoudig over te gaan tot de directe voorbereiding van een ontwerp van wet. (...) Ik geloof, dat dit alleen maar schadelijke tijdroof is, en over de tijdruimte, welke er voor noodig zal blijken, beschikt Gij niet.

Houdt mij dezen aandrang ten goede - hij komt slechts voort uit een doelstelling, gelijk gericht met de Uwe."

158. Tegenwoordig waren Terpstra, die Donker was opgevolgd als voorzitter, de leden Wttewaall van Stoetwegen, Tendeloo, Oud en Van Rijckevorsel, en de plaatsvervangende leden Zeelenberg, Gerbrandy, Van Leeuwen en Lemaire.

159. Zie ook handelingen Tweede Kamer 1952-1953, p. 2104 (Wttewaall van Stoetwegen): "In ieder geval is het zo, dat als de Minister van zijn kant zich aan het schema voor de behandeling van het nieuwe Burgerlijk Wetboek houdt, het een erezaak voor de Kamer is, dat zij haar bijdrage ook binnen de gestelde tijd levert."

160. Zie ook handelingen Tweede Kamer 1952-1953, p. 2108. 
Een ander punt dat ter sprake werd gebracht, was de vraag in hoeverre de in het schema opgenomen data een bindend karakter zouden dragen.

Begrijpelijkerwijs wilde de vergadering zich, zoals Kortenhorst in zijn openingswoord mededeelde, niet bij voorbaat binden aan de in het schema voorkomende termijnen: "Wij kennen immers noch de vraagpunten (met uitzondering van de eerste reeks), noch de definitieve tekst van het ontwerp. Er kan ook, geheel afgezien van de moeilijkheden, welke de tekst zelf kan opleveren, nog van alles tussenbeide komen." Niettemin ontving Donker wel aanstonds de verzekering dat de Kamer haar uiterste best zou doen vraagpunten en ontwerp zo snel mogelijk te behandelen, dat wil zeggen, binnen de in het schema aangegeven termijnen: "Wij zullen ons best doen de vraagpunten en het wetsontwerp zo snel mogelijk te behandelen, maar of dat binnen de door de Minister gestelde termijnen mogelijk zal zijn, is niet te beoordelen. Een toezegging dat wij dit zullen doen, kunnen wij niet geven, en zelfs is de opmerking gemaakt, dat de Regering dit ook eigenlijk niet mag vragen."

Hoewel Donker met deze uitspraak alleszins vrede kon hebben "als men het in beginsel maar eens is met mijn redenering, dan ben ik daarmee al tevreden", waarschuwde hij er voor bij de beoordeling van vraagpunten en ontwerp niet al te zeer in details te treden. Een dergelijke werkwijze zou er niet alleen toe kunnen leiden dat het schema zou moeten worden prijsgegeven, maar bovendien het welslagen van de gehele onderneming in gevaar kunnen brengen: "Ik ben", zo zei hij, "bij het opstellen van mijn schema uitgegaan van de volgende twee uitgangspunten: a. Het is een gelukkige omstandigheid, dat nu juist een nieuwe zittingsperiode is aangevangen. Het is wel zeer wenselijk, dat dezelfde leden en de vraagpunten en het wetsontwerp behandelen. Dat kan alleen, indien men daarvoor een volle vierjarige periode tot zijn beschikking heeft. b. Het is een bijzonder gelukkige omstandigheid, dat wij voor dit werk beschikken over prof. Meijers, die omnium consensu hiervoor de beste deskundige van ons land is."

Donker vervolgde: "Natuurlijk is de Kamer vrij om deze aangelegenheid te behandelen zoals zij dat het beste vindt. Het zou echter jammer zijn, indien door een uiterste perfectionisme de totstandkoming van het nieuwe Burgerlijk Wetboek in gevaar zou komen. Als prof. Meijers zijn ontwerp klaar heeft, zal het Departement van Justitie er niet meer over gaan puzzelen, al zouden de ambtenaren er misschien hier en daar nog wel verbeteringen in kunnen voorstellen. Ik heb dezer dagen ook met de President van de Hoge Raad gesproken; deze was aanvankelijk ook wel van oordeel, dat mijn opzet de enige manier is om binnen de gestelde termijn het werk af te krijgen. Men moet nu eenmaal kiezen tussen perfectionisme en de kans iets tot stand te brengen. "161

161. Zie ook handelingen Tweede Kamer 1952-1953, p. 2130, waar Donker naar aanleiding van een opmerking van Oud erkende dat de herziening van het Burgerlijk Wetboek normaal gesproken niet tot de meest urgente zaken behoorde, maar dat nu sprake was een uitzonderingssituatie: "Het feit, dat wij op het ogenblik beschikken over een geleerde, die omnium consensu, als de meest gequalificeerde op dit gebied wordt beschouwd, maakt deze vernieuwing van het Burgerlijk Wetboek thans wel tot een urgente zaak. Wij moeten deze kans met beide handen grijpen, en wel nu, omdat de Tweede Kamer juist een vierjarige periode is ingegaan, zodat vraagpunten en ontwerpen door dezelfde Kamer kunnen worden behandeld." 
Een opmerking, dat de Kamer met het onderzoek van de nota met de vraagpunten wellicht zou willen wachten totdat deskundigen en belanghebbenden zich er over hadden uitgesproken, werd door Donker om dezelfde reden van de hand gewezen:

"Over elk van de vraagpunten bestaat reeds een zee aan literatuur. Ik acht het onwaarschijnlijk dat er naar aanleiding van de publicatie van de vraagpunten nog zo heel veel nieuws naar voren zal komen. Alle kwesties zijn tevoren uitvoerig behandeld in de Staatscommissie voor de burgerlijke wetgeving. Bovendien is er over tal van zaken overleg geweest met belanghebbenden. Als men nu iedereen nog weer ruime tijd wil laten om zich over de vraagpunten en het ontwerp uit te spreken, komt er waarschijnlijk niets tot stand. Wil men een algemene herziening van een wetboek, dan moet men weten door te tasten. De ervaring in andere landen leert, dat een algehele herziening door één man kan slagen, als men in hem vertrouwen heeft."

Ofschoon een en ander niet tot gevolg had dat de Commissie terugkwam op haar standpunt, dat alleen een confrontatie met de door Meijers opgestelde stukken zou leren of het schema werkelijkheidszin had ${ }^{162}$, ontving Donker tot driemaal toe de verzekering dat de Commissie alles in het werk zou stellen haar verslagen tijdig uit te brengen. "Wij zullen ons best doen", was de boodschap die de Minister meekreeg. In die ook voor hem geruststellende wetenschap kon Meijers aan het werk.

\section{Het interdepartementaal overleg}

Daarna is het allemaal zeer snel gegaan. Meijers had kennelijk een aantal vraagpunten in voorraad, want volgens schema ontving Donker nog voor het eind van september de derde reeks vraagpunten, dertien in getal, inzake Algemene bepalingen van wetgeving, Rechten van de scheppende mens, Rechtspersonen en het Handelsrecht. Op 10 oktober werd deze reeks aangevuld met acht vragen over het Erfrecht, omdat de Minister het bij nader inzien juister vond de vierde reeks uitsluitend te bestemmen voor vragen met betrekking tot het personen- en familierecht. De vierde reeks tenslotte, telde vijftien vragen en werd door Meijers in de laatste week van oktober afgeleverd. Aangezien geen van deze vragen tot opmerkingen van de kant van het Ministerie zelf leidden, betekende dit dat Donker zich tot zover aan zijn schema had kunnen houden.

Op 29 september 1952 werd Donker door de Ministerraad gemachtigd de tweede reeks vraagpunten aan de vaste Commissie voor te leggen. Het interdepartementaal overleg, waaraan ook ditmaal door slechts een vijftal Departementen was deelgenomen, had weinig verrassingen opgeleverd en de Minister was er dan ook zonder al te veel problemen in geslaagd zijn visie ten aanzien van de beantwoording van de vraagpunten door de Ministerraad heen te loodsen. In feite had de Raad slechts ten aanzien van twee, niet inhoudelijke kwesties enige kritiek doen horen. Zo werd, het besluit van de Ministerraad van 10 december 1951 ten spijt, opnieuw de vraag gesteld

162. Mogelijk was het Donker er meer om te doen de Commissie er van te doordringen dat de mogelijkheid om met het gezag van Meijers op korte termijn een nieuw wetboek tot stand te brengen, niet tot in lengte van jaren zou blijven bestaan. 
of het wel verstandig was het voorlopig standpunt van de Regering kenbaar te maken. Dit probleem werd opgelost doordat besloten werd dat het voorlopig antwoord niet langer de naam van de Regering maar van de Minister van Justitie zou dragen. ${ }^{163}$ Daarnaast werd uitvoerig gedebatteerd over de vraag of sommige van de in de vraagpunten aangeroerde kwesties niet zozeer betrekking hadden op sociaal-economisch terrein, dat inschakeling van de SER gewenst was. Deze kwestie wist Donker echter te omzeilen door er onder meer op te wijzen dat bij een zo ruime uitleg van de termen "sociaal" en "economisch" ook het beleid inzake de Nederlandse Antillen, de herziening van de onderwijswetgeving, de defensie-uitgaven en de perikelen rond Nieuw-Guinea voor voorlegging aan de SER in aanmerking zouden komen. Bovendien zegde hij de Raad toe contact op te nemen met de Voorzitter van de SER, waarmee hij een soortgelijke afspraak zou maken als met de president van de Hoge Raad. ${ }^{164}$

Het ambtelijk overleg over de derde reeks vraagpunten verliep eveneens uiterst voorspoedig, waarbij het gegeven dat Donkers collega's opnieuw maar weinig belangstelling toonden voor de diverse vragen, zeker van betekenis is geweest. ${ }^{165}$ Alleen de reactie van de Minister van Economische Zaken leverde enige moeilijkheden op, omdat tussen de regels door viel te lezen dat deze van oordeel was dat Donker door het opnemen van vraagpunten over de rechten van de scheppende mens zijn bevoegdheid had overschreden. Hoewel deze stellingname pas na de publicatie van Boek 9 tot problemen zou kunnen leiden - Minister Zijlstra sprak nog geen definitief oordeel uit, maar beperkte zich ertoe de betreffende vraagpunten "onder alle voorbehoud" te beantwoorden -, nam Donker in zijn nota aan de Ministerraad, waarin de argumenten

163. Een belangrijke overweging daarbij was dat het op de vaste Commissie een wel zeer zonderlinge indruk zou maken indien het bijvoegen van een voorlopig antwoord beperkt zou blijven tot de eerste reeks, die immers al in het bezit van de Commissie was.

164. Op 17 november 1952 deed Donker verslag van zijn besprekingen met de voorzitter van de SER, professor F. de Vries. Deze zou volgens Donker geen kans zien om op korte termijn advies uit te brengen. Bovendien zou De Vries ook niet weten hoe uit de SER commissies van op het terrein van het B.W. deskundigen zouden zijn te vormen. Wel maakte hij het voorbehoud, dat voor het geval de SER zelf een vraagpunt ter overweging zou willen geven, daarvoor gelegenheid zou zijn.

165. Slechts acht van de in totaal vijftien Departementen reageerden op de eerste vier categorieën vragen (Algemene bepalingen van wetgeving, Rechten van de scheppende mens, Rechtspersonen en Handelsrecht). Dat levert het volgende staatje op:

Departement

aantal reacties

Economische Zaken 8

Verkeer en Waterstaat

Publiekrechtelijke Bedrijfsorganisatie

Onderwijs, Kunsten en Wetenschappen

Wederopbouw en Volkshuisvesting

Sociale Zaken en Volksgezondheid

Uniezaken en Overzeese Rijksdelen

Marine

Met betrekking tot de acht toch niet onbelangrijke vragen over het Erfrecht reageerden slechts drie Departementen, hetgeen in totaal tot zestien opmerkingen leidde, waarvan het Ministerie van Marine er de helft voor zijn rekening nam. 
van Economische Zaken gemakkelijk zijn te herkennen, wél een voorschot op de dan te verwachten discussie:

"Prof. Meijers heeft verklaard het zeer onaangenaam te vinden dat voortdurend regelingen van burgerlijk recht buiten hem om worden voorbereid en dat hij zodoende voor een fait accompli wordt gesteld. Het is een verouderde opvatting, dat de rechten van de scheppende mens buiten een Burgerlijk Wetboek moeten staan. De sterke samenhang van die rechten met formele bepalingen levert geen beletsel op tegen opneming van de materiële bepalingen in het Burgerlijk Wetboek, evenmin als zulks het geval is voor andere onderdelen van het Burgerlijk Wetboek. (...) De kwesties, welke in de vraagpunten zijn aan de orde gesteld, behandelen punten, waarover stemmen uit de praktijk hebben gesproken. Het is daarom gewenst met die stemmen rekening te houden bij de totstandbrenging van het nieuwe wetboek. Het heeft weinig zin voor wat betreft de inhoud welke aan het nieuwe wetboek moet worden gegeven, zonder meer te wachten op het lot, dat aan internationale (voor)ontwerpen, zoals die van de Benelux en van de Raad van Europa zijn beschoren. ${ }^{166}$

De meeste oppositie bij de derde reeks vraagpunten kwam eigenlijk van geheel andere kant, namelijk van de zijde van de ontwerper zelf. Eijssen, die in overleg met Meijers de Minister moest adviseren over het standpunt dat deze zou moeten innemen in de Ministerraad, schreef op 10 november aan Donker dat het hem grote moeite had gekost Meijers er van te overtuigen dat het ongewenst was de Koninklijke goedkeuring van statuten van verenigingen af te schaffen en te vervangen door het systeem van oprichting door middel van een notariële akte, een gedachte waarmee Meijers zijn tijd dus dertig jaar vooruit was. ${ }^{167}$ Uit de nota van Eijssen blijkt verder dat Meijers erop stond, dat de wettelijke voorschriften die in de Wet op de Coöperatieve Verenigingen in het belang van schuldeisers en leden waren te vinden, eveneens van toepassing zouden worden verklaard op verenigingen met een commercieel karakter (vraagpunt C. 2), ofschoon het niet denkbeeldig was dat de Minister in het debat met de Kamer op dat standpunt zou moeten terugkomen. Die consequentie zou Meijers echter ook willen aanvaarden, volgens Eijssen. Tenslotte bleek verschil van mening te bestaan over de vraag of de instelling van een boedelrechter gewenst was (vraagpunt E. 8), een vraag die Meijers uitdrukkelijk in positieve zin beantwoord wilde zien, maar door de "werkgroep-Mulder" van het Ministerie van Justitie in volstrekt

166. Nota van 13 november 1952 , p. 5 . In de Ministerraad (vergadering van 17 november 1952) kwam dit punt niet meer ter sprake.

167. Eerst in het kader van de invoering van Boek 2, die in 1976 plaats vond, werd het preventieve toezicht op verenigingen afgeschaft. Een amendement van Van Rijckevorsel (KVP) tot afschaffing van het preventieve toezicht in Boek 2 werd in 1958 met 60 tegen 59 stemmen verworpen. Zie Parl. Gesch. Boek 2, p. 269-347. Van Rijckevorsel zei daarover: "Nadat mijn voorstel in de Kamer met één stem verschil was getorpedeerd, wandelde ik terug met W.G. Belinfante, de raadadviseur bij Justitie. Hij zei mij toen, met een zeker genoegen, dat bij aanvaarding van het amendement een afdeling, waar alleen maar katholieken zaten, zou zijn opgeheven. Ik had me daar gelukkig niet in verdiept! Anders kun je je werk ook niet doen. Dat preventieve toezicht had mijns inziens niet de minste zin." 
tegenovergestelde zin werd beantwoord. Donker koos echter zonder morren partij voor Meijers.

Met betrekking tot de vierde reeks vraagpunten was het met de belangstelling van de andere Departementen helemaal treurig gesteld. Slechts één Departement maakte gebruik van de mogelijkheid een voorkeur uit te spreken ten aanzien van de door Meijers bij elk vraagpunt genoemde mogelijkheden van beantwoording, hetgeen in totaal drie reacties opleverde. Een respons van minder dan anderhalf procent.

Desalniettemin verliep het overleg in de Ministerraad stroef. ${ }^{168}$ In de eerste plaats bleek dat de Raad, net zoals eerder Minister Van Maarseveen, er niets voor voelde de vragen over het materiële echtscheidingsrecht aan de Kamer voor te leggen. Binnen het Kabinet zou over dit punt toch nooit overeenstemming kunnen worden bereikt en het voorleggen van deze vraagpunten zonder vermelding van antwoord zou gelijk staan aan politieke zelfmoord. Het initiatief zou dan immers bij de Kamer liggen. ${ }^{169}$ Deze beslissing betekende ook het einde voor een vraagpunt, dat de mogelijkheid openliet om in de toekomst het kerkelijk huwelijk gelijk te stellen met een voor de ambtenaar van de burgelijke stand voltrokken huwelijk, een vraag die Meijers niet alleen had opgenomen met de bedoeling om een einde te maken aan een sinds jaren bestaande controverse ${ }^{170}$, maar die vooral haar waarde zou kunnen bewijzen als onderhandelingsmiddel ten opzichte van het katholieke volksdeel in de strijd om de verruiming van de echtscheidingsgronden.

Een tweetal vragen, dat betrekking had op de rechtspositie van het natuurlijke kind - en ook hier dringt zich een parallel op met het door Van Maarseveen getrokken kader voor de herziening -, stuitte eveneens op politieke bezwaren, ofschoon naar buiten toe als reden werd opgegeven dat het kinderrecht onlangs was herzien en het dus beter zou zijn die materie voorlopig te laten rusten. Daarmee misleidde het Kabinet niet alleen de Kamer, maar werd bovendien de ratio van de " 25 jarentermijn" geweld aangedaan. De opzet van Meijers om zo min mogelijk te tornen aan de wetten die in de laatste tijd tot stand waren gekomen, had immers voornamelijk tot doel om die vragen, ten aanzien waarvan de hoop op een oplossing door de recht-

168. Vergaderingen van 17 november en 8 december 1952. Ik hecht er aan te verklaren dat de volgende opmerkingen zijn ontleend aan een (ongedateerde) notitie van Eijssen. De notulen van de Ministerraad zijn namelijk betrekkelijk summier en vermelden slechts dat de punten uit de vierde reeks worden geschrapt "omdat het geen aanbeveling verdient vraagpunten op te nemen, waaromtrent de Regering niet haar standpunt erbij vermeldt."

169. Formeel werd als reden opgegeven dat de Regering de overtuiging had, "dat de opvattingen van het Nederlandse volk op dit punt, zoals die voor en na in de Staten-Generaal zijn tot uiting gekomen, geen grond opleveren voor het aanbrengen van principiële veranderingen in het materiële echtscheidingsrecht en dat een meerderheid van de Kamers der Staten-Generaal zodanige veranderingen niet wenst. (..) Onder deze omstandigheden kan geen nut worden verwacht van een behandeling van vraagpunten dienaangaande." (Brief van de Minister van Justitie aan de Voorzitter van de Tweede Kamer. zitting 1952-1953, nr 2846, stuk nr 6).

170. Nog in 1948 verzocht Minister Van Maarseveen naar aanleiding van een schriftelijke vraag bij de begrotingsbehandeling aan het Interkerkelijk Overleg der Nederlandse Kerken om medewerking voor de instelling van een commissie ter bestudering van dit vraagstuk. De commissie kwam echter niet van de grond, hetgeen in 1949 tot nieuwe Kamervragen leidde. Zie ook Parl. Gesch. Boek 1, p 115-124. 
spraak nog niet verloren was gegaan, of waarvan alle argumenten pro en contra nog niet bekend konden zijn, buiten de herziening van het Burgerlijk Wetboek te houden. ${ }^{171}$ Een motief derhalve, dat zeker niet de strekking had de Kamer buiten het overleg over politiek gevoelige vragen te houden, hetgeen overigens ook onverenigbaar zou zijn met de gedachte achter de vraagpuntenprocedure.

Een vraagpunt dat aanstuurde op schrapping van het huwelijksbeletsel van overspel (art. 89 B.W.) onderging hetzelfde lot. De Ministerraad sprak er zijn veto over uit omdat "vraagpunt en antwoord psychologisch gezien een slechte indruk zouden maken", waarmee waarschijnlijk erop werd gedoeld dat men het niet had aangedurfd een einde te maken aan de door de Hoge Raad gesanctioneerde praktijk van de "grote leugen". Tenslotte sneuvelden nog eens twee vragen, één waarin werd voorgesteld de termijn voor omzetting van een scheiding van tafel en bed terug te brengen tot één jaar, een ander waarin werd bepleit de gemeenschap van goederen als verrekengemeenschap aan te merken. Deze vragen waren volgens de Raad politiek gezien niet interessant en bovendien bestonden er geen grote bezwaren tegen de door Donker voorgestelde antwoorden.

Het is niet moeilijk te begrijpen dat de handelwijze van de Raad ten aanzien van de vierde reeks, waarvan tenslotte maar zes van de vijftien vragen aan de vaste Commissie mochten worden voorgelegd, een voor Meijers (en ook voor Donker) moeilijk te verteren zaak moet zijn geweest. De methode van het voorleggen van vraagpunten, die juist was gekozen om uit te vinden ten aanzien van welke punten een vernieuwing van het personen- en familierecht kans van slagen bood, had door het Kabinetsbesluit sterk aan betekenis ingeboet. De behoedzaamheid, waarmee Meijers tot dan toe had geopereerd, was voor niets geweest. ${ }^{172}$ Buiten de goedgekeurde vragen van de vierde reeks, waarvan alleen het vraagpunt inzake adoptie nog voor problemen zou kunnen zorgen, waren alleen die vragen overgebleven die vanuit juridisch-technisch of sociaal-economisch oogpunt een zekere betekenis hadden, vragen die Meijers had opgenomen om het overleg te oefenen of waarvan hij het nuttig vond een uitspraak van de Kamer te krijgen.

\section{Het vooroverleg; criteria voor voorlegging}

Op 31 oktober $1952 \mathrm{kwam}$ de vaste Commissie weer bijeen om te spreken over de vraag welke vraagpunten uit de eerste en de gehele tweede reeks aan de Kamer

171. Zie de algemene inleiding bij de eerste vier Groene Boeken, Parl. Gesch. NBW, Algemeen Deel, p. 124: "Een telkens opnieuw wijzigen van voorschriften betreffende eenzelfde onderwerp is alleen te rechtvaardigen, wanneer daarvoor een dringend motief bestaat. Is dit niet het geval, dan dient men iedere wet, die na rijp beraad is tot stand gekomen, de gelegenheid te geven in de praktijk te tonen wat zij waard is. Burgerlijk recht verlangt stabiliteit."

172. Tekenend hiervoor is bijvoorbeeld dat Meijers van plan was in Boek 1 de "duurzame ontwrichting" als enige grond voor echtscheiding op te nemen, maar dat hij op verzoek van Donker hiervan afstapte en de bestaande gronden voor echtscheiding (art. 264 B.W.) handhaafde en aanvulde met de "Zerrüttung" (ais in het Zwiterse Wetboek) en krankzinnigheid. Donker motiveerde deze beslissing met het argument "dat men bij de verandering van de echtscheidingsgronden niet verder moet gaan dan de bevolking kan dragen en dit de Kamer moet beoordelen." (Notulen Ministerraad d.d. 17 november 1952). 
zouden moeten worden voorgelegd. Op 18 december volgde een bespreking over de derde reeks, terwijl de laatste reeks op 6 januari 1953 aan het oordeel van de Commissie werd onderworpen. Het schema werd dus met glans gehaald.

Ofschoon tijdens deze bijeenkomsten slechts incidenteel werd ingegaan op de merites van de diverse vraagstukken, - daartoe zou immers bij de officiële gedachtenwisseling meer dan voldoende gelegenheid zijn - zijn de besprekingen wel in zoverre interessant doordat men een aardige indruk krijgt van de overwegingen die ten grondslag lagen aan het besluit een vraagpunt al dan niet aan de Kamer door te zenden. Daarbij speelden in beginsel drie criteria een rol, zo blijkt uit de notulen.

Het eerste en ook belangrijkste criterium was, dat het moest gaan om een punt dat hetzij vanuit sociaal-economisch, hetzij vanuit technisch-juridisch, hetzij vanuit praktisch oogpunt van belang was. Zuiver theoretische kwesties, zoals de vraag of de eigendom reeds door de enkele akte overgaat danwel eerst door de overschrijving daarvan ${ }^{173}$, of de vraag of het onderscheid tussen een ongeoorloofde erfstelling over de hand en een wel toegelaten making in de vorm van een voorwaardelijke beschikking logisch gezien wel te rechtvaardigen was ${ }^{174}$, vielen om die reden buiten de boot. Vanzelfsprekend moest de kwestie ook belangrijk genoeg zijn om aan het oordeel van de gehele Kamer te worden onderworpen. Een vraag waarin een aantal aspecten van de in Boek 7 op te nemen regeling van de uitgave-overeenkomst aan de orde werd gesteld, werd mede daarom te licht bevonden, terwijl een vraagpunt over het in artikel $1287 \mathrm{~B} . \mathrm{W}$. neergelegde verbod van rente op rente, dat, tengevolge van de jurisprudentie van de Hoge Raad en de bijzondere wetgeving op dit terrein, vrijwel van zijn functie was beroofd, hetzelfde lot onderging.

Wat nu precies het criterium was dat bepaalde of een vraag werkelijk belangrijk was, is niet eenvoudig te beantwoorden. Soms was het al voldoende wanneer Meijers zijn keuze motiveerde met de opmerking dat het principe dat hij in de wet wilde neerleggen nog niet door alle juristen werd aanvaard, zodat een uitspraak van de Kamer een welkom tegenwicht zou vormen tegen eventuele kritiek (handelszaak). Soms werd een vraagpunt opgenomen omdat het Nederlandse recht op dat punt zeer onzeker was en betwijfeld kon worden of de Hoge Raad bij machte was die onzekerheid op te heffen (trust, verzuim en ontbinding, onrechtmatige overheidsdaad). Soms ook kreeg een vraagpunt van de Commissie het "groene licht" omdat het een zaak betrof die bij de Kamer "leefde" (onderhandse of notariële akte) of omdat belanghebbenden sterk op een regeling aandrongen (oneerlijke concurrentie, erfpacht). Kortom, de criteria varieerden nogal en het was niet altijd te voorspellen in welke vragen de Commissie wel en in welke vragen zij geen belang stelde.

Tot de vragen die een zekere sociaal-economische betekenis hadden, behoorden behalve de vraagpunten over het personen- en familierecht en het erfrecht - bijvoorbeeld de vraagpunten met betrekking tot de eigendomsoverdracht tot zekerheid, de cessie, de grondboekhouding en de erfpacht. Van de vragen met een meer technischjuridisch karakter, vragen die veelal betrekking hadden op kwesties die de juristenwereld al jarenlang verdeeld hielden, noem ik het vraagpunt betreffende de handelszaak, de trust, de verzuim- en ontbindingsregeling, het matigingsrecht, de onrechtmatige overheidsdaad, de goede trouw, onvoorziene omstandigheden en de reeks vragen die

173. Vraagpunt 3, Ie reeks.

174. Vraagpunt 6, IIle reeks. Zie ook de Toelichting Meijers bij artikel 4.4.5.6. 
was gewijd aan de Algemene bepalingen van wetgeving. De vraagpunten met betrekking tot het recht van aanwas en de regeling van de oneerlijke concurrentie werden vooral gekozen vanwege hun praktisch belang. De opneming van het eerste punt verdedigde Meijers door erop te wijzen dat een regeling gewenst was om talrijke procedures te voorkomen - de naar aanleiding van de zijde van de Waterstaatscommissie ontvangen antwoorden op de enquete betreffende het recht van onroerende goederen (vraag D.) waren naar de mening van Meijers dermate vaag, dat hijzelf met een voorstel moest komen -, terwijl hij het vraagpunt betreffende oneerlijke concurrentie motiveerde door te verklaren dat hem uit overleg met belanghebbenden gebleken was dat dezen een nadere regeling op prijs stelden.

Het tweede criterium dat beslissend was of een vraagpunt aan de voltallige Kamer zou worden voorgelegd of dat Meijers geheel vrij zou zijn zelf een oplossing voor te stellen, hield verband met de kwestie of de in het vraagpunt aangeroerde kwestie kon worden aangemerkt als een hoofdbeginsel. Alleen vraagpunten die van invloed zouden kunnen zijn op de opzet van een bepaalde titel of afdeling, punten dus waarbij amendering ingrijpende consequenties zou kunnen hebben voor de opzet van het geheel, werden aan de Kamer voorgelegd. Een punt dat op betrekkelijk eenvoudig wijze kon worden geamendeerd, een vraagstuk dat niet bepalend was voor de opzet van het wetboek of een kwestie die - in welke zin zij ook geregeld zou worden - niet zou behoeven te leiden tot een ingrijpende omwerking van het ontwerp, werd buiten het overleg met de Kamer gehouden.

Om deze reden sneuvelde bijvoorbeeld een vraagpunt dat het privilege van de verhuurder wilde inperken, terwijl dit criterium er mede-verantwoordelijk voor was dat het vraagpunt over de uitgave-overeenkomst en het verbod van rente op rente verviel. Anderzijds was de overweging, dat de vraag naar een negatief of positief stelsel bepalend was voor de opzet van een groot gedeelte van het Zakenrecht, één van de redenen die ertoe leidde dat het vraagstuk van de grondboekhouding aan de Tweede Kamer werd voorgelegd. Overigens was die voorlegging in wezen pro forma en had zij voornamelijk tot doel om de niet-juristen onder de Kamerleden een indruk te kunnen geven van de wijze waarop Meijers bij zijn voorbereidend werk te werk ging. Zijn ontwerp, dat aan derden te goeder trouw meer bescherming bood doordat meer feiten voor inschrijving vatbaar zouden zijn, had, zoals Meijers met gepaste trots verklaarde, bij de belanghebbenden algemene instemming gevonden.

Het derde belangrijke criterium tenslotte dat een rol speelde bij de selectie van de diverse vragen, was dat de discussie wel tot een bruikbaar resultaat zou moeten leiden. Hiervoor bleek al dat om die reden het vraagpunt met betrekking tot de definitie van het eigendomsrecht sneuvelde, terwijl dezelfde reden mede ten grondslag aan het besluit om een vraagpunt dat een voorrecht voor de leverancier van bouwmaterialen tegenover de aannemer wilde invoeren, te schrappen. Minister Donker was namelijk van mening dat dan ook de verhouding tot het loon-voorrecht van de arbeider zou moeten worden herzien, hetgeen niet alleen tot gevolg zou hebben dat het gehele systeem van voorrechten nader bezien zou moeten worden, maar er tevens toe zou kunnen leiden dat de roep om het arbeidsrecht geheel te herzien, nog sterker zou worden. En dat zou er, volgens Donker, wel eens toe kunnen leiden dat er van de beoogde herziening van het Burgerlijk Wetboek niets terecht zou komen: "Als men de 
gehele regeling voor het arbeidsrecht wil gaan herzien, is het einde nog lang niet in zicht. Dit zou wellicht zelfs het gehele werk kunnen doen mislukken. "175

Van deze voorwaarde, dat het aan de Kamer voor te leggen vraagpunt daadwerkelijk tot resultaat zou moeten kunnen leiden, is slechts eenmaal bewust afgeweken. Van het vraagpunt betreffende het geneeskundig onderzoek voor het huwelijk ${ }^{176}$ verwachtte de Commissie namelijk niet veel. Desondanks werd besloten het aan de Kamer voor te leggen, teneinde de zaak door middel van vraag en antwoord in de publieke belangstelling te brengen. Voor de Kamerleden zou het bovendien een welkom aanknopingspunt zijn hun oratorische talenten ten beste te geven.

Naast deze scheiding tussen vragen die wel of niet belangrijk genoeg werden gevonden om aan de Kamer voor te leggen, waren er twee vraagpunten die niet aan de Kamer werden gezonden omdat men reeds in het vooroverleg tot overeenstemming wist te komen. Zo ging men akkoord met een vraagpunt dat misbruik van recht definieerde als "de uitoefening van een recht, waardoor een ander op onevenredige wijze wordt benadeeld in vergelijking met het door de rechthebbende beoogde voordeel." Daarmee distantieerde de Commissie zich van de rechtspraak van de Hoge Raad. ${ }^{177}$ Later, in 1955, is er in de Kamer de nodige strijd geweest over de vraag of dit "leerstuk in opkomst" wel rijp was voor een wettelijke regeling. ${ }^{178}$ Daaruit blijkt dat Donker volkomen gelijk had toen hij verklaarde dat het van het hoogste belang was dat dezelfde Kamer én vraagpunten én ontwerp zou afdoen.

Het andere vraagpunt waarover overeenstemming bestond tussen Meijers en de vaste Commissie betrof de vraag of de in de bijzondere wetten voorkomende bescherming van de huurder (maximum huurprijs, opzeggingsverboden voor de verhuurder) een regeling zou moeten krijgen in het nieuwe Burgerlijk Wetboek. Conform het door de Minister voorgestelde antwoord besloot de Commissie dat dit niet gewenst was: deze bijzondere bescherming moest als noodmaatregel beschouwd moest worden en paste derhalve niet in het Burgerlijk Wetboek, dat gemaakt werd voor een verre toekomst.

\section{De vaste Commissie}

De volgende stap uit het tijdschema hield in dat het nu de beurt was aan de vaste Commissie om in maart 1953 een Voorlopig Verslag uit te brengen over de eerste twee reeksen vraagpunten, terwijl het verslag over de derde reeks in juni en over de

175. Notulen van de bespreking over de eerste en tweede reeks vraagpunten van 31 oktober 1952, p. 5. Mede hierom waren er onder de vraagpunten geen over het arbeidsrecht opgenomen.

176. Zie daarvoor Parl. Gesch. Boek 1, p. 91 e.v. Naar de mening van Minister Donker zou de wet, anders dan bijvoorbeeld in Frankrijk en de Scandinavische landen het geval was, een geneeskundig onderzoek voor het huwelijk niet verplicht moeten stellen. Een amendement-Zeelenberg, dat van de tegenovergestelde gedachte uitging, maar aan de uitslag van zulk een onderzoek geen consequenties wilde verbinden, werd verworpen met 42 tegen 25 stemmen.

177. Vóór zijn uitspraak van 17 april 1970, NJ 1971, 89 (grensoverschrijdende garage), waarin de Hoge Raad de door Meijers ontworpen formulering vrijwel woordelijk overnam, stelde dit college zich op het standpunt, dat alleen dan sprake zou zijn van rechtsmisbruik, indien het recht werd uitgeoefend met geen ander doel dan om de ander te schaden.

178. Zie de parlementaire geschiedenis bij artikel 3.1.1.14 R.O., Parl. Gesch. Boek 3 (invoering), p. 1041 e.v. 
vierde in juli zou moeten volgen. Gerekend vanaf de datum waarop de vraagpunten bij de Kamer waren ingediend, zouden de leden van de vaste Commissie, de juridische pers alsmede de organisaties van belanghebbenden voor elke reeks dus vier maanden de tijd hebben om hun bevindingen kenbaar te maken.

Het hoeft geen betoog dat dit schema, gelet op alle andere wetsvoorstellen die Donker reeds had ingediend - tijdens de begrotingsbehandeling van 1952 was al door enige bezorgde Kamerleden de vraag gesteld of Donkers wetgevingsprogram niet enigszins overladen was -, in het bijzonder van de leden van de vaste Commissie het uiterste zou vergen. Het is eveneens duidelijk dat het schema alleen kon worden gevolgd indien men bereid was aan de behandeling van het Burgerlijk Wetboek onder alle omstandigheden prioriteit te geven. Men wás echter bereid om tot het uiterste te gaan, bereid om zich voor Donker en Meijers te "geven". Want daar kwam het wel op neer. "Donker vergde niet alleen het uiterste van mensen, maar deze aanbaden hem ook, in de zin dat ze het werk graag op zich namen", volgens Franken. ${ }^{179}$ Van Rijckevorsel zei daarover: "Donker was geweldig goed. Als ik dan soms tegen hem inging, dan riep dat de woede van de Partij van de Arbeid op, zo groot was de bewondering die men voor hem koesterde."

De Commissie slaagde er dus in zich aan het schema te houden - misschien wel het meest tot haar eigen verbazing. En, en dat is een nog belangrijker constatering, zonder dat dit "spoedwerk", de kwaliteit van het Voorlopig Verslag merkbaar beinvloedde. Twee opmerkingen daarover.

In de eerste plaats is het zo dat de Kamer indertijd een aantal goede juristen telde, civilisten zelfs, mensen die in staat waren een schifting te maken tussen vragen die het waard waren om in het Voorlopig Verslag te worden opgenomen en vragen die dat niet waren. Van Rijckevorsel bijvoorbeeld, was voordat hij aan een politieke carrière de voorkeur gaf, enige tijd als raadadviseur verbonden aan het Ministerie van Justitie (zonder dat hij overigens in actieve dienst trad) en Van der Feltz, die een wetenschappelijk achtergrond had - hij was bij Meijers gepromoveerd - verloochende die niet door bij elk vraagpunt een korte, maar kwalitatief hoogstaande notitie te schrijven, die dan ook vrijwel integraal in de parlementaire stukken is terecht gekomen. ${ }^{180}$ Het gevolg hiervan was dat de verslagen een compact en homogeen geheel vormden, waarin alleen de belangrijke vragen waren opgenomen.

179. Illustratief hiervoor is het volgende briefje van Van Rijckevorsel naar aanleiding van een verzoek van Donker om de verslagen met betrekking tot de derde en vierde reeks vóór de in het tijdschema voorziene termijn in te leveren. Van Rijckevorsel schreef: "Dit verzoek heeft onderwerp van bespreking uitgemaakt van onze vergadering van heden en het spijt mij $U$ te moeten mededelen, dat, alhoewel alle leden tot het uiterste wilden gaan om aan Uw verlangen tegemoet te komen, onze Commissie tot het eenstemmig inzicht is gekomen, dat zulks in redelijkheid onmogelijk is. (...) Tengevolge van andere afspraken en verplichtingen (...) was het onmogelijk om extra vergaderingen der Commissie voor die week vast te stellen, doch voor de week van 27 Juli tot 1 Augustus zijn wel twee extra vergaderingen vastgesteld, zodat wij in die week vier dagen zullen vergaderen. De Commissie meent hiermede tot het uiterste te zijn gegaan en vertrouwt dat $U$ haar standpunt zult willen billijken."

180. Van der Feltz maakte overigens geen deel uit van de vaste Commissie voor Justitie, hetgeen zijn prestatie nog indrukwekkender maakt. Eerbied voor de "grote Meijers" speelde daarbij zeker een rol; zie WPNR 5533 (1980). 
Daarbij kwam, hierboven is daar al op gewezen, dat de leden van de Commissie, een enkeling zoals Gerbrandy buiten beschouwing gelaten, grote waardering en bewondering hadden voor Meijers en Donker en daarom alles op alles zetten om zo goed mogelijk voor de dag te komen. Zelfs Oud, die toch enigszins sceptisch stond tegenover de vraagpuntenprocedure en ook meermalen publiekelijk liet weten dat naar zijn mening de totstandkoming van het nieuwe Burgerlijk Wetboek in het wetgevingsprogram van de Minister een té prominente plaats innam ${ }^{181}$, deed in zijn nieuw verworven kwaliteit van Voorzitter van de vaste Commissie al het mogelijke om de Verslagen op tijd uit te brengen. Het nieuwe Burgerlijk Wetboek moest er komen, en het moest er snel komen, daar bestond geen discussie over.

De tweede factor, die er toe leidde dat de verslagen van de Commissie op tijd verschenen, zonder dat daarbij concessies behoefden te worden gedaan aan de kwaliteit, bestond er in dat de Commissie op haar verzoek bijstand kreeg van een bijzonder griffier, een maatregel die sindsdien, zij het met wisselend succes, bij de gehele parlementaire behandeling van het Burgerlijk Wetboek en daarmee verwante wetsontwerpen is toegepast. Mr. E.H. Thijssen, die weliswaar verbonden was aan de afdeling wetgeving van het Ministerie van Justitie, maar geen aandeel had in het werk aan het nieuwe Burgerlijk Wetboek, viel op deze wijze de eer te beurt om de eerste te zijn uit een lange rij van griffiers die de Commissie zouden assisteren bij het werk aan het nieuwe Burgerlijk Wetboek.

Zijn werk bestond, naast het schrijven van het Voorlopig Verslag en het op papier zetten van hetgeen bij het Mondeling Overleg ter sprake zou komen, in hoofdzaak uit het verzamelen van literatuur die met de vraagpunten verband hield, waarbij uiteraard de nadruk lag op die bronnen die in de toelichting bij de vraagpunten niet waren vermeld. Ofschoon deze documentatie qua opbouw bij geen van de vraagpunten hetzelfde was - ten aanzien van sommige vraagpunten bestond bijvoorbeeld vrijwel geen literatuur - bevatten de memoranda van Thijssen over het algemeen tenminste een opsomming van relevante Nederlandse en buitenlandse wetten, een uittreksel uit de Nederlandse handboeken, een bonte verzameling van literatuur, zoals dissertaties, monografieën, preadviezen en tijdschriftartikelen alsmede een overzicht van de belangrijkste parlementaire stukken. Publicaties die moeilijk verkrijgbaar waren, ontvingen de Commissieleden in kopie of samenvatting, terwijl de griffier er tevens zorg voor droeg dat de Commissie kennis kon nemen van jurisprudentie die alleen in het Weekblad van het Recht was verschenen.

Daar bleef het echter niet bij, want bij het merendeel van de vraagpunten schreef Thijssen een korte notitie - soms niet meer dan twee à drie alinea's - waarin hij niet alleen de door hem verzamelde literatuur op kritische wijze besprak, maar ook, indien dat zo uitkwam, kanttekeningen plaatste bij het voorlopig standpunt van de Minister. De Commissie had dus niet alleen de beschikking over een schat aan gegevens, maar beschikte in de meeste gevallen ook over een zeer bruikbare en handzame leidraad, hetgeen overbodige discussies voorkwam.

181. Zie handelingen Tweede Kamer 1952-1953, p. 2108. Zie ook Ouds opmerkingen bij de behandeling van de Nota ter inleiding van de vraagpuntenprocedure, Parl. Gesch. NBW, Algemeen Deel, p. 46. 
Een nadeel van deze methode, en ook Minister Donker werd dat verwijt gemaakt ${ }^{182}$, is dat er van al dat werk in de parlementaire stukken weinig is terug te vinden. Daardoor is soms de indruk ontstaan dat de Kamer, maar ook het Ministerie, weinig rekening zou houden met de in de literatuur naar voren gebrachte denkbeelden. Dat is een misverstand. De Commissie werd van alle zijden voorgelicht - er bestond in het begin van de jaren vijftig zelfs een directe lijn met de redacties van het WPNR en het NJB, zodat zij ook kennis kon nemen van niet-gepubliceerde manuscripten. Als een schrijver in het Voorlopig Verslag niet werd genoemd, was dat niet omdat er geen aandacht aan zijn opvattingen was geschonken, maar omdat men ze niet de moeite waard had gevonden.

\section{De procedure}

De merkwaardige omstandigheid dat er geen precedent of procedurevoorschrift bestond omtrent de wijze van behandeling van de vraagpunten, leidde ertoe dat deze kwestie vooraan in het Voorlopig Verslag over de Nota en de eerste reeks vraagpunten werd uiteengezet. De Commissie kwam daarbij tot de conclusie dat een nieuwe weg moest worden ingeslagen, waarbij zoveel mogelijk aansluiting zou moeten worden gezocht bij het Reglement van Orde.

Daarbij deden zich twee mogelijkheden voor: enerzijds kwam in aanmerking de procedure met betrekking tot de wijze van behandeling van wetsontwerpen, anderzijds die welke was voorgeschreven met betrekking tot van Regeringswege ingekomen stukken (art. 106 R.v.O.). Na ampele overweging besloot de Commissie beide procedures te combineren. Enerzijds stelde zij voor om, evenals dit bij wetsontwerpen het geval is, over de Nota en de vraagpunten een Voorlopig Verslag uit te brengen, waarop dan van Regeringswege een Memorie van Antwoord zou kunnen volgen, maar anderzijds meende zij dat zij de Nota en de vraagpunten inzoverre diende te behandelen als een "Regeringsbescheid", dat zij zelf een antwoord op elk vraagpunt diende te formuleren, dat dan als grondslag voor de openbare behandeling zou dienen. ${ }^{183}$

Met het eerste gedeelte van het voorstel van de vaste Commissie kon Minister Donker zich geheel verenigen. Tegen het tweede deel had hij echter grote bezwaren. Op 7 april 1953, drie weken voordat de Memorie van Antwoord over de eerste reeks vraagpunten zou worden ingezonden, wendde Donker zich per brief tot de leden van de vaste Commissie waarin hij zijn bezwaren tegen de door de Commissie voorgestelde procedure ontvouwde. Uit dit schrijven bleek dat de Minister de analogie met de behandeling van een wetsontwerp gedurende de gehele behandeling van de Kamer doorgetrokken wenste te zien. Het toevoegen van een voorlopig antwoord aan elk van de vraagpunten, had, aldus Donker, niet uitsluitend ten doel de Kamer in kennis te stellen van het voorlopig standpunt van de Regering, maar had de verdergaande strekking, dat het standpunt de Kamer tot uitgangspunt zou dienen voor de openbare beraadslaging en voor de gedachtenwisseling met de Minister: 
"Het is mijn overtuiging, dat de geschetste procedure, welke de Regering in overeenstemming met prof. Meijers zich heeft voorgesteld, ook de meeste waarborgen biedt dat de grondslagen, waarop het nieuwe Burgerlijk wetboek zal komen te rusten, met bekwame spoed in gemeen overleg tussen Regering en Kamer kan worden vastgesteld. Bij de keuze van de te volgen procedure mag niet uit het oog worden verloren, dat de bedoeling daarvan is aan de Regering en prof. Meijers een redelijke zekerheid te verschaffen, dat de ontwerpen voor het nieuwe Burgerlijk Wetboek (..) althans in hun grondgedachten zullen beantwoorden aan hetgeen de Kamer als de meest wenselijke regeling van deze belangrijke materie beschouwt. In deze gedachtengang schijnt het voor de hand te liggen, dat de beraadslagingen van de Kamer worden gevoerd aan de hand van samenvattingen van de te bespreken punten, zoals zij door de Minister van Justitie zijn opgesteld in overleg met degene, aan wie het redigeren van de ontwerpen voor een nieuw wetboek is opgedragen." ${ }^{184}$

Op 16 april schaarde de voltallige Commissie zich zonder protest achter de zienswijze van Donker. "Er was", zoals Oud later zou verklaren, "geen enkel bezwaar aan het verlangen van de Minister te voldoen." ${ }^{185}$ Ook die uitspraak toont iets aan van de waardering die er voor Donker bestond. Want het is duidelijk dat de Kamer, door voor deze procedure te kiezen, de Minister de mogelijkheid gaf de conclusies op de vraagpunten zodanig te formuleren, dat politiek "harde" uitspraken zoveel mogelijk werden vermeden.

Dit verschil in wijze van behandeling kwam duidelijk naar voren bij de behandeling van het tweede vraagpunt, luidende:

"Dient de mogelijkheid van overdracht van onroerende zaken door overschrijving van een onderhandse akte gehandhaafd te blijven?" 186

Het voorlopige antwoord van de Minister was vaag. Men kon er alle kanten mee uit:

"Er zijn zwaarwichtige argumenten met name ontleend aan de overdrachten, waarbij publiekrechtelijke lichamen zijn betrokken, tegen het verplicht stellen van de authentieke akte bij overdracht van onroerende zaken. Overigens is hierbij een zeer uitdrukkelijke wens van het notariaat in het geding, die niet zonder gezonde zin is."

De Commissie was het hiermee niet eens. In haar Voorlopig Verslag over de Nota en de eerste reeks vraagpunten koos zij de verplichte akte tot uitgangspunt; deze zou over de gehele lijn en zonder uitzondering moeten worden doorgevoerd. Donker antwoordde dat hij er de voorkeur aan gaf alleen het beginsel van de verplichte authentieke akte in discussie te brengen en daarnaast de weg open te houden voor

184. Vergelijk Parl. Gesch. NBW, Algemeen Deel, p. 26-28.

185. Parl. Gesch. NBW, Algemeen Deel, p. 46-47.

186. Met dit vraagpunt werd beoogd een einde te maken aan de "kwakzalverij van de zaakwaamemerij" (Eggens, notulen van de 91e vergadering van de subcommissie Burgerlijk Recht d.d. 17 december 1949, p. 294), door F. Bordewijk in "Karakter" zo beeldend beschreven. 
uitzonderingen op dit beginsel. Hij had hierbij twee of drie uitzonderingen op het $00 \mathrm{~g}$.

In de eerste plaats zou een uitzondering moeten worden gemaakt voor de "erkende" zaakwaarnemers, een groep van ongeveer negentig personen met wier hulp onroerend goed bij onderhandse akte kon worden overgedragen. De Minister wilde ten aanzien van hen geen voorbarige beslissing. In de tweede plaats meende Donker dat het noodzakelijk was voor publiekrechtelijke lichamen een uitzondering te maken, eventueel te beperken tot die takken van dienst, die voortdurend bij zeer veel overdrachten of vestigingen van zakelijke rechten zijn betrokken. Tenslotte zou hetzelfde moeten gelden voor de grotere particuliere lichamen, mits zij over deskundig personeel zouden beschikken. Om deze veiligheidsklep in te bouwen stelde hij het volgende (gewijzigde) antwoord voor:

"Als regel moet voor overdracht van onroerende zaken een authentieke akte worden geëist. Op deze regel kunnen uitzonderingen worden toegelaten voor gevallen, bij Algemene Maatregel van Bestuur aan te wijzen."

Tijdens het Mondeling Overleg bleek dat een meerderheid van de Commissie, die, zoals gezegd, aanvankelijk geen enkele uitzondering wilde toelaten, zich kon vinden in het compromis, dat een overgangsregeling zou worden gemaakt voor erkende zakwaarnemers, voor zover deze hun beroep uitoefenden voor 1 juli 1953. De uitzondering voor publiekrechtelijke lichamen en de eventuele uitzondering voor particuliere lichamen bleef zij echter afwijzen. Ook was zij tegen regeling bij A.M.v.B. Donker wilde dit amendement niet overnemen. Hij was bevreesd dat de Kamer later toch weer op haar standpunt zou terugkomen en moest overigens ook met de wensen van zijn collega-Ministers rekening houden. Donker verklaarde daarom dat het op dit moment niet mogelijk was de uitzonderingen zo nauwkeurig te definiëren dat zij rijp zouden zijn om in een wettelijke regeling te worden opgenomen. De conclusie zou daarom als volgt moeten luiden:

"Als regel moet voor overdracht van onroerende zaken een authentieke akte worden geëist. Op deze regel kunnen worden uitzonderingen worden toegelaten."

Aan deze wijziging verbond hij de mededeling dat de aanwijzing van de uitzonderingen bij Algemene Maatregel van Bestuur eerst ter sprake zou komen wanneer de onmogelijkheid zou blijken de uitzonderingen bij wet te regelen. Met dit tussenvoorstel, dat op de keper beschouwd het probleem slechts verschoof, kon de Commissie vrede hebben. Zij trok haar amendement in en de conclusie op het tweede vraagpunt werd zonder hoofdelijke stemming aangenomen.

Het interessante hiervan is, dat toen de Minister zijn conclusie zodanig wijzigde, dat zowel het aantal uitzonderingen als de wijze waarop deze uitzonderingen zouden worden geregeld, in het midden werd gelaten, het bezwaar tegen de conclusie verdween. Weliswaar had de Commissie haar amendement kunnen handhaven, maar dat zou betekend hebben dat zij haar standpunt aan de Minister wilde opdringen. En dat paste niet in de procedure zoals die was was overeengekomen, wél in de procedure zoals die aanvankelijk was gedacht. Immers, de uiteindelijke conclusie was vaag; had de vaste Commissie ze opgesteld, dan zou ze ongetwijfeld scherper zijn ge- 
formuleerd en zou daarover zijn gestemd. Nu echter lag het initiatief bij Donker. Hij - en niet de Commissie - bepaalde uiteindelijk de gedetailleerdheid van het antwoord. ${ }^{187}$

\section{Het debat in de Kamer}

Het debat in de Kamer over de Nota en de vraagpunten was in wezen een afspiegeling van de wijze waarop het vooroverleg met de vaste Commissie was verlopen. Z0 gebeurden er aanvankelijk enkele ongelukjes in die zin dat de Kamer niet meeging met de opvatting van de Regering: Ook Meijers moest kennelijk nog leren hoe hij met de Kamer moest omgaan. Na korte tijd was deze onwennigheid echter verdwenen en wist de tijdelijk raadadviseur ${ }^{188}$ een zodanig stempel op de debatten te drukken, dat de Kamer nog slechts een enkele keer afweek van het door de Minister voorgestelde, dat wil zeggen door Meijers gewenste, antwoord.

Bij de discussie over de Nota werden voornamelijk lovende woorden vernomen over de door Van Maarseveen ingeslagen weg. Zo noemde mevrouw Zeelenberg het een "eis van praktische hanteerbaarheid" om het recht opnieuw te codificeren en kon volgens haar het Burgerlijk Wetboek van 1838 alleen "modern" worden genoemd, als men zou uitgaan van een tijdrekening, waarbij de uren voor minuten tellen, en bruikbaar, indien men het buitenwettelijk recht zou kennen en weten te hanteren. ${ }^{189}$ Jonkvrouwe Wttewaall van Stoetwegen verklaarde dat zij de vraag of vernieuwing nodig was, zonder aarzeling bevestigend beantwoordde, al was het alleen maar "omdat partiële herzieningen tot nu toe mislukt zijn en wij nu de persoon hebben, die het onmisbare scheppend vermogen heeft getoond te bezitten." 190

Slechts twee Kamerleden plaatsten enige kritische kanttekeningen. Oud was er naar zijn eigen zeggen allerminst van overtuigd dat de Kamer in staat zou zijn de ontwerpen van Meijers binnen de door Donker gestelde termijnen te behandelen. Bovendien vreesde hij dat de zaak eigenlijk nog niet rijp was voor behandeling, dat het "geforceerde" tempo van Donker Minister en Kamer nog zou gaan opbreken: "Men haalt op deze wijze ontzaglijk veel overhoop; allerlei punten, die op dit ogenblik volstrekt niet urgent zijn en die wij thans rustig zouden kunnen laten rusten,

187. De kwestie van de "uitzonderingen" bleek overigens van marginaal belang voor het nieuwe Burgerlijk Wetboek. De misstanden rond het terrein van de zaakwaarneming waren namelijk zo ernstig, dat een oplossing moest worden gevonden vóór de invoering van het nieuwe B.W. Bij Wet van 28 juni 1956, Stb. 376 werd dan ook de notariële akte verplicht gesteld bij levering van onroerende zaken (art. 671a B.W.) Voor de "erkende" zaakwaarnemer werd een uitzondering gemaakt. Hetzelfde gold voor één kind voor zover dat op 4 november 1954 op het kantoor van zijn vader werkzaam was. Met deze vondst, die Eijssen uit zijn hoed had getoverd, was het verzet van de zaakwaarnemers gebroken.

188. Meijers werd op 28 april 1953 benoemd tot tijdelijk raadadviseur voor een nieuw Burgerlijk Wetboek. Een aanwijzing als bijzonder commissaris op de voet van artikel 113, lid 2 Grondwet (1938) was niet mogelijk, omdat die aanwijzing alleen mogelijk was voor voorstellen van de Koningin, "hetzij van wet, hetzij andere", als bedoeld in artikel 113, lid 1 Grondwet, tot welke voorstellen de vraagpunten niet behoorden. De enige mogelijkheid was daarom dat de Minister zich door Meijers liet bijstaan als ambtenaar, daartoe door hem aangewezen overeenkomstig artikel 97, lid 1 , derde zin Grondwet.

189. Parl. Gesch. NBW, Algemeen Deel, p. 37.

190. Parl. Gesch. NBW, Algemeen Deel, p. 70. 
zullen thans moeten worden besproken (...)." Principieel gezien was hij het echter volkomen eens met het besluit tot herziening: "Ik stel er (..) prijs op hieraan toe te voegen, dat mijn sympathie voor de persoon van de Minister en voor de persoon van zijn voortreffelijke medewerker prof. Meijers het mij niet de minste moeite doet kosten hun beiden toe te wensen, dat de zaak inderdaad binnen het schema, dat de Minister zich heeft gesteld, kan worden afgewerkt. ${ }^{n 191}$

Gerbrandy, de andere kriticus, had wel principiële bezwaren tegen het hercodificatieproject. Zijns inziens was het B.W. in vergelijking met het Engelse en Franse recht lang niet zo onoverzichtelijk als de Minister wilde doen geloven. Bovendien zou aan de wens tot hercodificatie een soort van "perfectionistisch naturalisme" ten grondslag liggen, waarin geen ruimte zou zijn voor het eerbiedigen van de gevoelens van andersdenkenden. Daarbij richtte Gerbrandy zich met name tot Meijers, die hij een ulitaristische levensbeschouwing verweet, waarin het recht tot gewoonten en bewustzijnsinhouden zou zijn gereduceerd en waarin voor christelijke normen geen plaats zou zijn. ${ }^{192}$

De sprekers die na Gerbrandy aan het woord kwamen, lieten duidelijk blijken diens opmerkingen aan het adres van Meijers onder de maat te vinden. Lemaire ${ }^{193}$ wees erop dat hiermee de bestaansreden van het stellen van vraagpunten al meer dan voldoende was aangetoond. Donker noemde de wijze waarop Gerbrandy Meijers attaqueerde zelfs "onheus", een kwalificatie waaraan hij ook na protest van Gerbrandy vasthield: "Het is reeds lang van algemene bekendheid, dat prof. Meijers erop alle mogelijke wijzen naar streeft om niet een wetboek te maken naar zijn persoonlijk inzicht, maar een wetboek, dat een waarlijk nationaal wetboek is. (...) Wanneer dan een spreker in deze Kamer van prof. Meijers zegt, dat hij hem op grond van zijn levensopvatting niet toevertrouwt een nieuw Burgerlijk wetboek te maken - en daarop kwamen de woorden van de heer Gerbrandy in wezen neer (..) -, dan noem ik dit onjuist en onheus. " 194

Meijers zelf stelde zich bescheiden op, bevreesd als hij was een grondslagendiscussie te laten ontbranden. "Ik ben", zo zei hij, "volstrekt niet van plan een ontwerp samen te stellen, uitgedacht in de studeerkamer en een persoonlijk ideaal verwezenlijkende. Meer dan iemand gevoel ik de noodzakelijkheid, dat een wetboek, zoveel als mogelijk is, een nationaal product zij. Daarom heb ik er juist naar gestreefd met juristen van alle richtingen en met deskundigen uit alle maatschappelijke groepen voortdurend overleg te hebben. Daartoe dienen ook juist, naar ik meen, de vraagpunten die

191. Parl. Gesch. NBW, Algemeen Deel, p. 53. Tijdens de behandeling van de Justitiebegroting voor 1955 (handelingen Tweede Kamer 1954-1955, p. 2146) verklaarde Oud: "Wanneer men er in slaagt vóór 1960 dit wetboek tot stand te brengen en wanneer dit gebeurt onder deze Minister, dan zal ik dat toejuichen. Het klinkt misschien een beetje vreemd dit van een lid van de oppositie te horen, maar ik wil wel zeggen, dat ik van oordeel ben, dat, zo er één Minister is, die het verdient zijn handtekening onder het nieuwe wetboek te zetten, het wel deze Minister is, en dat ik mij, als ik tijd van leven heb, er hartelijk over zal verheugen, als het aldus verloopt."

192. Parl. Gesch. NBW, Algemeen Deel, p. 58 e.v. Gerbrandy nam het Donker en Meijers vooral kwalijk dat geen voorstel werd gedaan tot herziening van het echtscheidingsrecht. Het Kabinet voelde daar, zoals reeds opgemerkt, niets voor, omdat men wel inzag dat Gerbrandy de bedoeling had met een negatieve beantwoording door de Regering deze discussie af te snijden.

193. Parl. Gesch. NBW, Algemeen Deel, p. 67.

194. Parl. Gesch. NBW, Algemeen Deel, p. 107. 
hier zijn voorgelegd." $195 \mathrm{Om}$ dezelfde reden deed Meijers bij de meer politiek getinte vraagstukken er het zwijgen toe of beperkte hij zich tot een technische uiteenzetting. ${ }^{196}$

Desondanks zou er altijd een zekere wrijving blijven bestaan tussen Meijers en Donker enerzijds en Gerbrandy anderzijds. Zo rees er bijna een conflict over de naamgeving van Boek 9 (rechten van de scheppende mens) - Gerbrandy sprak zelf over dat "afschuwelijke woord" - en kwamen beiden werkelijk met elkaar in aanvaring bij de behandeling van het $25 \mathrm{e}$ vraagpunt. Nadat Meijers als zijn mening te kennen had gegeven dat er wel geen rechter te vinden zou zijn die de gewoonte zou laten prevaleren boven een regel van dwingend recht, ontspon zich de volgende discussie:

Gerbrandy:

"Ik ben dit met u eens; de rechter zal dat niet zeggen, want dan hangt hij bij de Hoge Raad, maar hij zal het doen."

Meijers:

"Is de Hoge Raad dan geen rechter? Dat is de rechter bij uitnemendheid."

Gerbrandy:

"Dat zijn mummies."

Meijers:

"Ik schaar mij onder die mummies, ik ben zelfs ouder dan de maximumleeftijd, die voor de Hoge Raad is gesteld. Op dit argument zal ik niet antwoorden."

Gerbrandy:

"Ik zou de Raadadviseur willen vragen: Hebt u nagegaan, wat de Hoge Raad heeft gedaan, toen u in Theresienstadt zat?"

Meijers:

"Mijnheer de Voorzitter! Ik moge mij tot het onderwerp bepalen." 197

Ook nadien zou Gerbrandy regelmatig blijven ageren tegen het nieuwe Burgerlijk Wetboek omdat hij de codificatiegedachte een heidens verschijnsel vond, een teken van decadentie, onstaan in tijden waarvan hij en zijn politieke geestverwanten met

195. Parl. Gesch. NBW, Algemeen Deel, p. 100.

196. Zo verklaarde Meijers tijdens het vooroverleg over vraagpunt 46 dat hij het niet met het regeringsstandpunt eens was - "mijns inziens is de algehele gemeenschap van goederen ook voor de 95\% weinig-vermogenden verkeerd indien men werkelijk gelijkheid wil bereiken tussen man en vrouw" - en daarom de verdediging van het principe aan de Minister overliet. Tijdens de openbare behandeling van het tweede vraagpunt (zaakwaarnemerij) hield hij z'n kaken stijf op elkaar, omdat, zoals hij tijdens het tussentijds Mondeling Overleg verklaarde, "ik mij voorgenomen heb mij niet in politieke verwikkelingen te mengen."

197. Handelingen Tweede Kamer 1952-1953, p. 2878-2879. Aan het eind van zijn betoog zou Meijers op de hem eigen wijze nog even op dit punt terugkomen: "Als de wet bepaalt, dat de meerderjarigheid met het 21 ste levensjaar intreedt, kan men niet zeggen: de jeugd is tegenwoordig zo wijs, ook in vergelijking met oudere mensen, die de jeugd dan mummies noemt, dat wij de jonge mensen in afwijking van de positieve wetsbepaling in het Burgerlijk Wetboek betreffende de meerderjarigheid reeds eerder dezelfde rechten moeten geven dan de mummies." 
afschuw waren vervuld. ${ }^{198} \mathrm{Hij}$ kreeg met zijn felle betogen echter nooit een voet aan de grond, mede omdat zijn mede-lid in de vaste Commissie wél voor het nieuwe B.W. was. Van Rijckevorsel: "Gerbrandy had geen grote sympathie voor Meijers. Ik weet niet hoe dat kwam, want hij moet toch ook gezien hebben wat voor een geweldige kennis en gezag Meijers had?"199

Het overleg over de vraagpunten verliep dus aanvankelijk enigszins stroef, Meijers moest duidelijk nog wennen aan de parlementaire zeden en gebruiken. Het gevolg hiervan was dat de behandeling van de eerste drie vraagpunten maar liefst twee dagen in beslag nam, waarbij zij aangetekend dat de verhouding in werkelijkheid nog ongunstiger was, omdat de conclusie op het eerste vraagpunt zonder openbare beraadslaging en hoofdelijke stemming werd aangenomen. De resterende 46 zouden echter in minder dan acht dagen worden afgedaan.

De onwennigheid van Meijers openbaarde zich het duidelijkst bij het derde vraagpunt, waarbij werd aangedrongen op een totaal verbod van de eigendomsoverdracht tot zekerheid. Niet alleen gaf hij daar wel zeer duidelijk te kennen dat hij weinig van zins was zich iets van de uitspraak van de Kamer aan te trekken ${ }^{200}$, maar bovendien slaagde hij er naar mijn smaak onvoldoende in de Kamer duidelijk te maken dat de door hem voorgestane regeling van een registerpandrecht op de instemming van het bedrijfsleven kon rekenen. In 1947 had Meijers namelijk een nieuwe, uitgebreide enquête gehouden, waaruit bleek dat een meerderheid van de ondervraagden (waaronder De Nederlandse Bank en de "grote" Kamers van Koophandel) wel degelijk profijt verwachtten van de invoering van een registerpandrecht. ${ }^{201}$ In zijn betoog kwam dit aspect wel aan de orde, maar lag het accent toch op de technische kant van de zaak. Daardoor liet Meijers zich de gelegenheid ontgaan de Kamer voor zijn standpunt te winnen. Het gevolg daarvan was dat zijn opvolgers lange tijd in tweestrijd hebben verkeerd ten aanzien van de vraag aan welke mening zij voorrang moesten verlenen, om tenslotte maar te zwichten voor de stem van de niet door de praktijk voorgelichte auteurs en Kamerleden. ${ }^{202}$

Meijers wende echter snel en na korte tijd had het "gemeen overleg" voor hem weinig geheimen meer. Hij wist hoe hij de Kamerleden voor zich moest winnen, vermeed een al te geleerde betoogtrant, doorvlocht zijn betoog met tal van sprekende voorbeelden en antwoordde ieder naar zijn of haar vermogen. Hij had, zoals Drion

198. Zie handelingen Tweede Kamer 1953-1954, p. 2103 e.v.; 1954-1955, p. 2131 e.v.

199. Mogelijk was Gerbrandy, die tevens voorzitter was van de Raad voor het Rechtsherstel, nogal geprikkeld door de felle en soms bijna grove kritiek die dit college ondervond van Joodse zijde, vooral na de clash met de beurs in 1953, onder aanvoering van een comité waarvan Meijers voorzitter was.

200. Meijers besloot zijn betoog voortijdig met de opmerking "Ik onderwerp dit alles aan het oordeel van de Kamer. Ik zal natuurlijk trachten haar besluiten zo goed mogelijk uit te voeren. In ieder geval verheugt het mij, dat wij gelegenheid hebben gehad aldus van gedachten te kunnen wisselen." (Parl. Gesch. Boek 3, p. 719).

201. In 1935 had Meijers ook al een enquête gehouden onder deurwaarders. De resultaten daarvan zijn gepubliceerd in het Correspondentie-blad van de Broederschap der Notarissen in Nederland, 1936, p. 272 e.v.

202. Anders: G.E. van Maanen, De eigengereidheid van een genie, Kwartaalbericht NBW 1992, p. 31 e.v. 
later zou verklaren, "de wonderlijke gave een zware zaak licht te kunnen maken. ${ }^{203}$

Het overwicht van Meijers en het respect dat er in de Kamer voor Donker bestond, maakten dat de vraagpunten exact binnen de door het tijdschema aangegeven termijn worden afgedaan. Tekenend voor de inzet van de Kamerleden is dat men op een gegeven moment besloot niet meer elk vraagpunt afzonderlijk te behandelen, maar de behandeling groepsgewijs te laten plaatsvinden. Illustratief is ook dat de vaste Commissie het Voorlopig Verslag over de derde en vierde reeks in gedeelten uitbracht, zodat de Minister in staat werd gesteld de Memorie van Antwoord kort na het verschijnen van het laatste deel in te dienen. ${ }^{204}$

Het is niet alleen de prestatie van de Commissie die bewondering afdwingt. Uit het volgende staatje blijkt dat ook Meijers, die, met uitzondering van de beantwoording van het Voorlopig Verslag over de Nota, tekende voor de gehele Memorie van Antwoord over de vraagpunten ( \pm 50 pagina's), uiterst snel heeft gewerkt.

\section{Voorlopig Verslag $\quad$ Memorie van Antwoord Eindverslag}

1e reeks

27-3-1953

29-4-1953

19-5-1953

$2 \mathrm{e}$ reeks

3e reeks

$4 \mathrm{e}$ reeks

Hoewel men geenszins de indruk krijgt dat dit een bovenmenselijke inspanning betekende voor Meijers, stelde het tijdschema niettemin hoge eisen aan het interne overleg van de Regering. Dat Donker steeds opnieuw de gewijzigde voorlopige antwoorden door de Ministerraad wist te krijgen, is een prestatie die ontzag afdwingt, want in een periode van telkens maar een paar dagen moest hij het met elk van zijn collega's eens zien te worden. Dat dezen soms maar vijf dagen de tijd kregen om te reageren op de voorstellen, heeft daarbij misschien wel in zijn voordeel gewerkt. Ik kan mij namelijk niet aan de indruk onttrekken, dat het debat in de Kamer soms al voorbij was, voordat de betrokken ambtenaren goed en wel door hadden dat Donker zijn standpunt had gewijzigd.

203. Parl. Gesch. NBW, Algemeen Deel, p. 181.

204. Vergelijk ook de volgende reactie van Tendeloo (handelingen Tweede Kamer 1952-1953, p. 2880) naar aanleiding van het feit dat enkele dagen voordat de beraadslagingen over de derde reeks vraagpunten zouden plaatsvinden, nog een bundel preadviezen van de Vereniging voor Handelsrecht uitkwam: "Ik moet zeggen, dat ik mij, hoezeer ik ook waardering kan hebben voor het feit, dat deze vereniging geprobeerd heeft, haar bijdrage te leveren tot de discussies in de Tweede Kamer, heb afgevraagd, waarom dat nu zo weer op het allerlaatste nippertje moest. Wij zijn al maanden en maanden met deze materie bezig (..) en waarom is het nu nodig, op het allerlaatste moment, nadat, praktisch gesproken, de gehele zaak al is doorgepraat, (..) die adviezen te geven?" 
Aan deze episode uit het werk aan het nieuwe Burgerlijk Wetboek is een aantal anekdotes verbonden. Ik vermeld er één.

Het genieten van een vakantie in het buitenland was één van de voorrechten die Meijers genoot door zijn werk aan het nieuwe Burgerlijk Wetboek. Kort na de oorlog werd het reizen naar het buitenland nog ernstig bemoeilijkt door de strenge deviezenbepalingen van De Nederlandse Bank, maar Meijers had daar niet de minste hinder van. Donker schoot de valuta die Meijers nodig had eenvoudig voor uit het potje "buitenlandse reizen" van het Departement. Bovendien werd Meijers door de dienstauto naar zijn vakantiebestemming gebracht en ook weer opgehaald. Donker stond er namelijk op dat Meijers ook gedurende zijn vakantie alle B.W.-stukken bij zich zou hebben en vond het eigenlijk maar niets dat Meijers ging "pierewaaien" op BelleIle. ${ }^{205}$

Zoals uit het hierboven weergegeven schema blijkt, moest Meijers op 25 en wellicht ook op 26 augustus 1953 beschikbaar zijn voor Mondeling Overleg met de vaste Commissie. Naarmate deze datum dichterbij kwam, raakte Donker echter steeds meer verontrust. Meijers, die zich nog steeds op zijn vakantieadres bevond, maakte, naar het scheen, namelijk nog geen aanstalten om richting Nederland af te reizen. De reden daarvoor was, maar dat begreep Donker pas veel later, dat er in Frankrijk een poststaking was uitgebroken, waardoor Meijers' verzoek om te worden opgehaald, ergens in Normandië was blijven steken. Ten einde raad besloot Donker daarom enkele dagen voordat het overleg met de Kamercommissie zou beginnen, een dienstauto op pad te sturen met de opdracht Meijers mee te brengen. Tevens liet hij, door tussenkomst van het Ministerie van Buitenlandse Zaken, via de ambassade in Parijs een telegram verzenden naar Belle-Ile om zowel Meijers als de Franse autoriteiten van één en ander op de hoogte te brengen. Op het eiland was namelijk geen telefoonverbinding aanwezig.

Belinfante vertelde eens, dat Donker de gehele wereld in beweging bracht om het nieuwe Burgerlijk Wetboek af te krijgen. Dat er in die opmerking veel waars school, lijkt nauwelijks overdreven.

\section{De betekenis van de vraagpuntenprocedure}

Zoals hiervoor is uiteengezet, was de opzet die Meijers zich had gedacht bij de vraagpuntenprocedure, zeer beperkt. Meijers' bedoeling was niet meer dan op een min of meer informele wijze met een aantal geïnteresseerde Kamerleden van gedachten te wisselen over een aantal politiek gevoelige kwesties, zoals de adoptie, de duali-

205. Franken vertelde daarover: "Op een zeker moment werden Belinfante, die mijn directe chef was op het Ministerie, en ikzelf bij Donker geroepen. Hij zei: 'Wat mij nu overkomen is, Meijers gaat het land uit. Hij gaat pierewaaien op Belle-Ile. Dat kan niet, want hij moet voor een bepaalde datum zijn ontwerpen inleveren. Hij zegt wel dat hij de stukken meeneemt op vakantie, maar ik geloof nooit dat hij de zaak op tijd gereed krijgt.' Belinfante merkte op dat Donker tegen de vakantiereizen van Meijers toch weinig kon doen en vervolgde gekscherend: 'Maar misschien kunt u met behulp van uw collega van Buitenlandse Zaken zijn paspoort laten intrekken.' Donker zei luidlachend (maar met een ondertoon van ernst) dat dat een prachtidee was. Hij vervolgde: 'Maar ik zal in ieder geval de eis stellen dat hij alle stukken waaraan hij werkt, meeneemt naar Belle-lle, al is het een wagon vol. Hij zal daar iedere dag moeten werken, er kan geen sprake van zijn dat hij daar pierewaait, ik verander niets meer aan de termijnen.'" 
teit van het huwelijk en de gronden voor echtscheiding. Dit voornemen mislukte volkomen. Niet alleen vond de vaste Commissie het beslist noodzakelijk dat de zaak in de publiciteit werd getrokken, maar bovendien wenste ook de Regering een woordje mee te spreken. Het uiteindelijk gevolg daarvan was dat het debat in de Kamer voornamelijk liep over punten waarover Meijers ook zelf wel een beslissing had kunnen nemen. In zoverre is de vraagpuntenprocedure - met alle moeite die het kostte haar van de grond te krijgen - dus een volslagen mislukking gebleken.

Daar kwam nog bij dat de conclusies op de vraagpunten veel te laat kwamen. Meijers was immers begin 1950 al zover dat hij het overleg kon starten. In feite vormde zijn ontwerp op het moment dat de eerste reeksen met vraagpunten de Kamer bereikten, al een afgerond geheel dat rijp was voor publicatie. Alleen met het afronden van het ontwerp voor Boek 1 heeft Meijers tot september 1953 gewacht, juist omdat hij op dat punt de inbreng van de Kamer wilde afwachten.

Vanuit het oogpunt van de ontwerper gezien is de vraagpuntenprocedure dus een tijdrovende aangelegenheid geweest, voornamelijk een hinderpaal op weg naar de voltooiing van de voorontwerpen. Niettemin heeft de vraagpuntenprocedure wellicht uiteindelijk het werk aan het nieuwe Burgerlijk Wetboek van de ondergang gered. Doordat de zaak in de openbaarheid werd gebracht, waren de Kamerleden wel verplicht hun beste beentje voor te zetten en kon geen enkele zichzelf respecterende politieke partij het zich veroorloven zijn steun aan het werk aan het nieuwe Burgerlijk Wetboek te onthouden. Daardoor werd, ook toen in de zestiger jaren de hoop op een spoedig resultaat iedereen al lang ontzonken was, nooit het onaanvaardbaar uitgesproken: "De vraagpuntenprocedure droeg veel bij aan het aanvankelijke enthousiasme van de Kamer", volgens Van Rijckevorsel. ${ }^{206}$

En het werk aan het nieuwe Burgerlijk Wetboek stond in 1953 en 1954 sterk in de publieke belangstelling! De persconferentie waarop Donker de Nota met de eerste twee reeksen vraagpunten presenteerde, werd bijvoorbeeld door niet minder dan veertig journalisten bezocht. Ten gerieve van de buitenlandse verslaggevers verschenen de vraagpunten zelfs in het Duits, Engels, Frans en Italiaans. Tijdens de debatten was het al niet anders. De grote landelijke bladen zoals het Parool, de Volkskrant en het Algemeen Handelsblad deden elke dag nauwgezet verslag van de discussies in de Kamer en van de eerste tot de laatste dag was minstens de helft van de groene bankjes bezet. Met andere woorden, niemand kon geheel onverschillig blijven onder het "grote werk", zoals Donker het hercodificatieproject placht aan te duiden. ${ }^{207}$

Juist deze noodzaak om actief mee te doen is vermoedelijk één van de factoren geweest waardoor de Kamer ook na het overlijden van Meijers en Donker zich nog lange tijd bewust is geweest van haar mede-verantwoordelijkheid als wetgever. Meijers had door zijn optreden in de Kamer een onuitwisbare indruk gemaakt. Dat zou ongetwijfeld anders zijn geweest wanneer hij in alle stilte had doorgewerkt. Dan

206. Anderzijds dient te worden bedacht dat de vraagpuntenprocedure tenminste één jaar heeft gekost. Hoe zouden de zaken er in 1954 hebben voorgestaan als Donker of zijn voorgangers aan Meijers instructie zouden hebben gegeven ogenblikkelijk tot publicatie van het ontwerp over te gaan? 207. Dat het werk aan het nieuwe B.W. ook de aandacht van het grote publiek had getrokken, blijkt hieruit dat in 1954 een 93 pagina's tellende brochure verscheen van de hand van E. Brongersma, samengesteld uit een reeks dagbladartikelen over de vraagpunten, getiteld: "Wat wordt de wet? Hoofdpunten van de herziening van het burgerlijk recht, voor niet-juristen verklaard", UtrechtAntwerpen 1954. 
was hij, althans voor het merendeel van de Kamerleden, een onbekende gebleven, was er voor hen ook geen gelegenheid geweest zich met het project te identificeren.

Dat deze democratische wijze van wetgeving hogelijk werd gewaardeerd (deze zin valt dubbelzinniger uit dan de bedoeling was), illustreert de volgende herinnering van Van Raalte aan Meijers' optreden tegenover de parlementaire pers aan de vooravond van de behandeling van de vraagpunten: "Wat viel er toen te genieten van de glasheldere uiteenzetting, opgeluisterd door sprekende, leerrijke voorbeelden, bovendien veelal in geestige vorm tot ons gebracht. Zelden valt het journalisten ten deel op zulk een meesterlijke wijze enig begrip bijgebracht te krijgen omtrent een verre van eenvoudige materie. Maar hier hadden wij in ons midden een figuur van uitzonderlijk kaliber, als kenner van het recht en als docent een grootmeester. "208

Evenzeer is het begrijpelijk dat Meijers in de kringen van juristen al helemaal geen kwaad meer kon doen. Ik breng slechts in herinnering wat Van Oven schreef naar aanleiding van de vergadering van de Nederlandse Juristenvereniging in 1954, waarop Meijers voor het laatst het woord zou voeren: "Keer op keer was in het debat het conversie-artikel in het Ontwerp-Meijers ter sprake gebracht. Een enkele maal had de ontwerper geïnterrumpeerd, maar in de middag liet hij het hier niet bij, beklom (onder luid applaus) het spreekgestoelte en zette met de van hem gekende helderheid, slagvaardigheid en scherpte uiteen, waarom hij zijn voorschrift in deze vorm ontworpen had." 209

Dezelfde Van Oven schreef met Houwing en Bregstein in het W.P.N.R: "In ons nummer van 5 Januari 1952 hebben wij zijn veertigjarige werkzaamheid voor ons weekblad herdacht, maar wat wij toen niet konden schrijven, nu kunnen wij het wel: Meijers was een waarlijk groot man, een geniaal mens; zijn kennis was fenomenaal, zijn blik ongewoon scherp, zijn voorstellingsvermogen, zijn scherpzinnigheid, zijn gaven van zich in te denken in juridische problemen, gingen verre uit boven die van alle anderen. Laat ons het thans openlijk erkennen: hij was niet zo maar "de eerste onzer privaatrechtsjuristen", maar hij stond torenhoog boven wie na hem kwamen." 210

Wat Meijers voor de Nederlandse juristen altijd al was geweest, werd hij nu ook voor de leden van de vaste Commissie voor Justitie. Men beschouwde het als een voorrecht om te mogen vertoeven "in de schaduw van deze Titaan." Dit is vermoedelijk de reden geweest dat toen het project door het overlijden van Meijers (en Donker) op een dood spoor dreigde te geraken, het werk toch is voortgezet. Meijers had in 1954 nog slechts de eerste vier boeken van zijn voorontwerp laten zien. Iedereen kon op zijn vingers natellen dat het een verre van eenvoudige zaak zou zijn het werk zonder diens leiding te voltooien. Als er één gelegenheid was het werk te staken, dan was dat wel in 1954. Dat het denkbeeld zelfs niet werd overwogen, zegt voldoende.

208. E. van Raalte, prof. Meijers, geleerde en sportbeoefenaar, in: Gezien, gehoord ... geschreven, Zwolle 1972 .

209. J.C. van Oven, De vergadering der Juristenvereniging in Arnhem, NJB 1954, p. 562.

210. WPNR 4354 (1954) 


\section{Mei 1954: Het eerste deel van het Ontwerp-Meijers gepubliceerd}

Nadat op 17 september 1953 in de Kamer de laatste stemming over de vraagpunten had plaatsgevonden, was Meijers weer aan zet. Zijn taak viel uiteen in drie delen. In de eerste plaats moest hij er voor zorgdragen dat de besprekingen, die over onderdelen van zijn concept nog gaande waren, op korte termijn zouden worden afgerond. Uit diverse bronnen blijkt dat hij er naar streefde dit overleg uiterlijk per 31 oktober 1953 te beëindigen, zodat hij minimaal twee maanden de tijd zou hebben voor het maken van correcties, aanvullingen etc.

Deze opzet lukte aardig. De laatste vergadering van de subcommissie Burgerlijk Recht over het voorontwerp voor het zakenrecht vond plaats op 28 oktober 1953, terwijl Meijers het ontwerp voor Boek 8, dat was opgesteld door de subcommissie Handelsrecht, op 31 oktober 1953 zou ontvangen. Ook het overleg over Boek 7 kon vrijwel binnen de termijn worden afgerond. Op 14 november 1953, slechts twee weken later dan voorzien, vond de laatste bespreking plaats. De beraadslagingen over Boek 9 daarentegen zouden nog geruime tijd voortduren. Als gevolg van de discussie over het 26e vraagpunt was namelijk eind oktober door Minister Donker de "Commissie-modellenbescherming" ingesteld, die tot taak kreeg Meijers' concept voor titel 9.3 te bestuderen en desgewenst voorstellen te doen tot verbetering ${ }^{211}$ Daardoor werd het maart 1954 alvorens ook onder de discussies over dit deel van Meijers' ontwerp een streep kon worden gezet.

Het tweede deel van Meijers' taak bestond uit het persklaar maken van het voorontwerp. Oorspronkelijk was het de bedoeling het Ontwerp-Meijers omstreeks de jaarwisseling te publiceren. Toen medio oktober 1953 echter duidelijk werd dat vooral het afronden van de Boeken 7 en 9 nog geruime tijd zou vergen - de concepten voor Boek 7 waren nog niet toegelicht en bij Boek 9 kwam het overleg over titel 9.3 er tussendoor - besloot Donker dat het gewenst was dat Meijers de Boeken 1-5 bij voorrang zou afwerken. Op die wijze zou publicatie omstreeks 1 januari 1954 nog tot de mogelijkheden behoren. ${ }^{212}$ Eind december 1953 zou Donker het tijdschema opnieuw aanpassen. In overleg met Meijers werd besloten het zakenrecht, dat daartoe vernummerd werd tot Boek 5, met de "tweede worp" te laten meedoen en alle inspanningen te concentreren op de afwerking van de concepten voor de Inleidende

211. Zie hieronder, Hoofdstuk 10.

212. In een nota voor de Ministerraad, gedateerd 13 november 1953, lichtte Donker deze wijziging als volgt toe: "prof. Meijers verwacht tegen het einde van het jaar slechts de volgende delen gereed te hebben: Algemene Bepalingen, Personen- en familierecht, Rechtspersonen, Vermogensrecht in het algemeen, Zakelijke rechten en Erfrecht.

Het resterende gedeelte: Verbintenissen in het algemeen, Bijzondere overeenkomsten, Zee- en binnenvaartrecht en Rechten van de scheppende mens, zal dus eerst later verschijnen. Gerekend wordt op maart 1954. De taak blijkt namelijk van prof. Meijers meer tijd en werkkracht te verlangen dan hij - ook nog kort geleden - kon voorzien. Het uitoefenen van sterker aandrang op prof. Meijers dan bereids is gedaan, zou noch passend, noch doelmatig zijn." 
titel en de eerste vier Groene Boeken. ${ }^{213}$ Deze tweede worp werd nu medio september 1954 voorzien.

Voor de afwerking van de voorontwerpen voor de eerste vier boeken maakte Meijers gebruik van de diensten van J.M. Polak, daarvoor substituut-griffier bij de Haagse Rechtbank. ${ }^{214}$ Franken ging terug naar het Ministerie. ${ }^{215}$ Polak kreeg "zonder veel toelichting" opdracht de titels 8 tot en met 11 van Boek 3 van een toelichting te voorzien. Zijn enige inspiratiebron daarbij waren de verslagen van de Staatscommissie, die bovendien ook nog bijzonder summier waren. Kennelijk waren de teksten van Meijers ook zonder toelichting gemakkelijk te begrijpen, want binnen drie maanden was Polak met zijn taak gereed. Polak: "Ik bleef bij die toelichtingen zo nauw mogelijk bij de tekst en vond daarin ook nog steun bij Meijers, die dat prima vond. Het waren toelichtingen die met niet veel andere woorden zeiden wat je ook in de tekst kon lezen. Er zijn ook tegenwoordig nog hopen wetsontwerpen waar de toelichting niet veel meer biedt. I k had gewoon niet meer aan kennis ter beschikking dan wat in dat stuk is gevloeid. Later zijn het veel meer verhalen geworden. "216

Ondanks deze assistentie bleef er voor Meijers nog voldoende werk over. Zo stond van de "algemene inleiding", die de toelichting bij de eerste vier groene Boeken vergezelde, in november 1953 geen letter op papier en moest ook de Inleidende titel nog worden toegelicht. Daarnaast was er een aantal titels van Boek 1 waarvan de tekst in oktober 1953 niet veel verder was gevorderd dan een eerste concept. Meijers was voor de uiteindelijke redactie daarvan namelijk afhankelijk geweest van de uitkomst van de vraagpuntenprocedure. ${ }^{217}$

213. Meijers (Parl. Gesch. NBW, Algemeen Deel, p. 119) gaf zelf de volgende verklaring voor het overschrijden van het tijdschema: "Ondergetekende heeft gemeend goed te doen het door hem samen te stellen ontwerp zoveel als mogelijk was bij de conclusies van de Tweede Kamer te doen aansluiten. Dit heeft echter op belangrijke punten een omwerking van het ontwerp, zoals het aanvankelijk was gedacht, noodzakelijk gemaakt. Bovendien heeft het schrijven van de toelichting ondergetekende langer opgehouden dan hij aanvankelijk gedacht had. Het is hem dientengevolge tot zijn spijt niet mogelijk gebleken het indertijd door de Minister van Justitie opgestelde tijdschema volledig in acht te nemen."

214. Polak (1922) was in maart 1947 benoemd tot substituut-griffier bij de Rechtbank Den Haag, na daarvoor waarnemend griffier bij de Bijzondere Raad van Cassatie te zijn geweest. In 1951 zou hij Eggens gaan assisteren bij de Hoge Raad. Met ingang van 1 september $1953 \mathrm{kwam}$ daar het werk aan het nieuwe B.W. bij. Polak was kort tevoren gepromoveerd op "Theorie en praktijk van de rechtsvinding", Zwolle 1953, en had in Leiden gestudeerd.

215. Franken zei daarover: "Vanaf het najaar van 1953 had ik al niet veel meer met Meijers te maken en was ik voor het overgrote deel van mijn werktijd op het Departement ingeschakeld, binnen het kader van de zogenaamde B.W.-club. (..) Langzamerhand nam dat werk mij meer in beslag dan het werk dat ik nog voor Meijers kon doen. Hij was toen ook bezig met ontwerpen waarbij ik daarvoor nooit betrokken was geweest, zoals het erfrecht."

216. Zie ook J.M. Polak, Van Groene Boek (1954) naar invoering (1992), NJB 1992, p. 28 e.v.

217. Het betrof hier met name de titels 1:5 (Huwelijk) en 1:7 (De wettelijke gemeenschap van goederen). De eerste werd om die reden zelfs niet in de Staatscommissie besproken. De notulen van de $128 \mathrm{e}$ vergadering van de subcommissie Burgerlijk Recht van 18 oktober 1952 vermelden daaromtrent: "De voorzitter deelt mede, dat hij de artikelen 1-47, welke gaan over het huwelijk, thans niet in discussie wil brengen, omdat deze artikelen - meer nog dan de bepalingen over de rechten en plichten van echtgenoten - hoofdzakelijk vanuit politiek oogpunt bezien zullen moeten worden." 
Diezelfde vraagpuntenprocedure leidde er ook toe dat in de andere Boeken een aantal wijzigingen moest worden aangebracht. In Boek 2 bijvoorbeeld, keerde het door Meijers geschrapte preventieve toezicht op verenigingen terug in de vorm van de "verklaring van geen bezwaar" (zie de Toelichting-Meijers bij artikel 2.2.1.3), terwijl Boek 3 moest worden aangepast in verband met de door de Kamer aanvaarde conclusies op het $3 \mathrm{e}$ en het 6e vraagpunt (zie art. 3.4.2.2 O.M. [eigendomsoverdracht] en afdeling 3.9.3 [registerpandrecht]). Ook Boek 4, waaraan vijf vraagpunten waren gewijd, zou als gevolg daarvan op een aantal details nog sterk veranderen.

Tenslotte vond Meijers het noodzakelijk tekst en toelichting van zijn ontwerp voor Boek 3, waaraan hij sinds het voorjaar van 1950, toen de discussie over Boek 3 in de Staatscommissie werd afgesloten, niet meer had gewerkt, enigszins bij te schaven. Karakter en omvang van deze wijzigingen waren echter uiterst beperkt. Zo liet Meijers de tekst van de titels 2, 3, 7, 8, 9, 10 en 11 geheel ongewijzigd en voegde hij in de toelichting alleen een handvol noten toe. In de titels waar wel wat in veranderde, waren de aanpassingen op de vingers van één hand te tellen. Bij titel 3.4 bijvoorbeeld, bleven de wijzigingen in de tekst beperkt tot de toevoeging van artikel 3.4.2.8 (afhankelijk recht volgt hoofdrecht), terwijl de enige verandering in de toelichting betrekking had op het aanhalen van de nieuwste jurisprudentie van de Hoge Raad omtrent artikel 2014 lid 2 B.W. ${ }^{218}$ Titel 3.5 werd uitgebreid met artikel 13, waardoor nog eens ten overvloede de aandacht werd gevestigd op de processuele functie van het bezit. De wijzigingen in titel 3.1 hadden evenmin veel om het lijf. Artikel 3 werd uitgebreid met lid 3 (eigendomsvoorbehoud doorkruist natrekking), terwijl aan artikel 5 een tweede lid werd toegevoegd, inhoudende dat vorderingsrechten, ook al strekken zij niet tot stoffelijk voordeel, toch als vermogensrechten moeten worden aangemerkt.

Belangrijk waren alleen de wijzigingen die Meijers in de bewindstitel (3.6) aanbracht. Bijna de helft van de bepalingen kreeg een andere formulering. Voor het overige bleven tekst en toelichting van Boek 3 O.M. zoals ze al in 1948 door Meijers waren geformuleerd.

Begin februari 1954 was Meijers met het eigenlijke redactiewerk gereed en konden de eerste drukproeven worden gemaakt. Daarmee brak het derde en voorlopig laatste deel van Meijers' taak aan. Zodra een drukproef gereed kwam, werd deze naar het Departement gestuurd, waarna de ambtenaren in de gelegenheid werden gesteld op- of aanmerkingen te maken. Deze opmerkingen werden vervolgens ter kennis van Meijers gebracht, die geheel vrij was er al dan niet rekening mee te houden. Door voor deze procedure te kiezen hoopte Donker te bereiken dat de verschillen tussen het OntwerpMeijers en het Regeringsontwerp minimaal zouden zijn. ${ }^{219}$

218. Een saillant detail is dat deze jurisprudentie (HR 5 mei 1950, NJ 1951, inzake Damhof/De Staat) was gebaseerd op het toen nog vertrouwelijke concept van Meijers voor artikel 3.4.2.2 O.M. Meijers was daar nogal gepikeerd over; zie M.H. Bregstein, Meijers en de poging tot hercodificatie, Rechtskundig Weekblad 1956, p. 182; N.J.P. Giltay Veth, Damhof/De Staat: J.C. van Oven en F.J. de Jong, NJB 1976, p. 19-20.

219. Zie W.G. Belinfante, De totstandkoming van het nieuwe Burgerlijk Wetboek, in: Het Ontwerp B.W., Deventer-Antwerpen 1961, p. 39: "Het zou de verdere behandeling schaden, indien naar buiten zou blijken dat de Regering gemeend had in de ontwerpen veel te moeten "verbeteren". Dat 
Het becommentariëren van de drukproeven vond plaats binnen het kader van de zogenaamde B.W.-club. Franken zei daarover: "De B.W.-club bestond geheel uit juristen van het Departement, die puur uit interesse op zich hadden genomen naar de concepten van Meijers te kijken voordat ze gepubliceerd zouden worden als Groen Boek. Belinfante was voorzitter en de andere leden waren Van Ewijk, ikzelf, Polak, De Vries, mevrouw Van Delden-Van der Belt en Thijssen. Verreweg de grootste inbreng kwam van Belinfante, van Van Ewijk en van mij. Ik kon natuurlijk meer dan wie dan ook aan de mensen van het Ministerie iets vertellen over de achtergronden en de bedoelingen van Meijers met bepaalde ontwerpen."

De werkwijze van de B.W.-club was efficiënt en doordacht. Dat was ook nodig, omdat onder hoge druk moest worden gewerkt als gevolg van de termijnen die Donker stelde. Franken: "Elk van de leden leverde voor de vergadering zijn opmerkingen op schrift in. We praatten dus nooit over onderwerpen waarvan niet iedereen kennis had genomen; centraal stond de titel die op de agenda stond. De verzamelnota, die alle opmerkingen van de individuele nota's bevatte, gerangschikt naar wetsartikel, werd dan bediscussieerd. De conclusies werden dan vaak voorzien van een min of meer uitgebreide documentatie en argumentatie, geput uit de individuele nota's en uit de beraadslagingen van de club, en verzonden aan Meijers."

Gelet op het krappe tijdschema - Donker stond erop dat de tekst begin april 1954 zou worden afgesloten - kon de behandeling natuurlijk niet erg grondig zijn. Het ging vaak nog slechts om een signaleren, niet het oplossen van een moeilijkheid. Belinfante: "We vlooiden de teksten van Meijers nog eens na en dan vonden we wel eens iets, een komma of een woord dat verwijderd moest worden." Franken: "Het waren opmerkingen die te hooi en te gras bij ons opkwamen, die zeker niet beoogden een grondig, totaal tableau te geven van de inzichten van het Ministerie over een bepaalde titel. Daar hadden wij niet genoeg tijd voor, omdat ook wij te maken hadden met de limieten die Donker stelde." Donker stelde die termijnen met opzet zo krap, omdat hij wilde voorkomen dat het Departement de ontwerpen geheel zou omwerken. In zijn nota voor de Ministerraad verwoordde hij het aldus: "Nu een persoon van de bekwaamheden als prof. Meijers bezit, ter beschikking staat, moet het werk der vormgeving dat op zijn schouders is gelegd, ook aan hem in beginsel worden overgelaten. (...) Het ligt dan ook geenszins in de bedoeling, dat het Ministerie van Justitie bij het gereedmaken van ontwerpen voor indiening, op de stoel van prof. Meijers zal gaan zitten."

Een vergelijking tussen de eerste drukproef van Meijers' ontwerp en de tekst van het groene Boek leert, dat de aanpak van Donker succesrijk is geweest. Het aantal veranderingen is klein en niet erg ingrijpend. Het is vergelijkbaar met de verschillen tussen de eerste vier (Groene) Boeken en de daarop gebaseerde Regeringsontwerpen. Ook die hadden niet veel om het lijf. Het gros van de opmerkingen had betrekking op "punten en komma's", richtte zich op zaken als verschrijvingen, onvolledige literaturverwijzingen en interpunctie. Veel invloed ging er dus niet van uit. Dat hing ook daarmee samen, dat Meijers vrij was de voorstellen van het Ministerie zonder opgaaf van redenen naast zich neer te leggen. Franken: "Hij heeft zeker gebruik gemaakt van

zou de eerbied die een ieder had voor het werk van Meijers, verminderen, en de kans op verwerping of destructieve amendering vergroten." 
onze opmerkingen, maar ik weet niet meer in welke mate dat gebeurde, of het voor ons stimulerend of demotiverend werkte. Hij veranderde in ieder geval zijn ontwerpen meer dan een heel klein beetje." Belinfante: "Meijers deed met onze opmerkingen wat hij dacht dat nodig was."

Een interessante vraag is, waarom Meijers brak met het streven zijn ontwerp pas te publiceren wanneer het in zijn geheel zou zijn voltooid. Waarschijnlijk is dat de invloed van Minister Donker geweest. Franken: "Dat kwam omdat Donker toen tot de conclusie kwam dat negen Boeken in één worp, iets teveel van het goede was; en vooral omdat hij tegenover de buitenwereld een tastbaar bewijs wilde leveren dat de operatie 'nieuw B.W.' in volle gang was, en allerminst in een sluimertoestand verkeerde." Polak: "Donker was natuurlijk helemaal een opschieter en wilde na die voorspoedige vraagpuntenbehandeling snel iets laten zien. Hij vond dat je de Kamer aan de gang moest houden." 220

Daarbij komt, dat er voor Meijers ook niet zoveel reden was om vast te houden aan zijn oorspronkelijke uitgangspunt. De eerste vier Boeken waren af, het waren geen schetsen meer. Ze hadden de kritiek van de Staatscommissie, Kamer en Departement doorstaan. Bovendien zou het restant (Boek 5-9) binnen een paar maanden volgen, waardoor de kans dat het ontwerp "kapot gepraat" zou worden en Meijers de lust zou verliezen om verder te werken, niet erg waarschijnlijk was. De omvang van het te publiceren gedeelte stond er bovendien borg voor dat de rechtsgeleerde kritiek zich zou beperken tot de hoofdlijnen. Voor het kritisch bestuderen van de details zou voor het gros van de geïnteresseerden eenvoudig onvoldoende tijd beschikbaar zijn. Alleen zij die thuis waren in de materie, zouden tijdig kunnen reageren.

Daarnaast zal Meijers ongetwijfeld hebben ingezien dat het gewenst was een begin te maken met de parlementaire behandeling. Zou met publicatie worden gewacht totdat het gehele ontwerp gereed zou zijn, dan zou nóg een aantal maanden verloren gaan. En dat was, gelet op het tijdschema, waarin toch al niet teveel rek zat, alleen maar schadelijke tijdroof. ${ }^{221}$ Het deel dat voor publicatie rijp werd geacht, was per slot van rekening omvangrijk genoeg om het afzonderlijk de parlementaire weg te laten doorlopen. Daarbij bood de fasegewijze publicatie en indiening het voordeel dat de Kamer en de rechtsgeleerde kritiek niet al te zeer zouden terugschrikken voor de

220. Zie ook W.G. Belinfante, De totstandkoming van het Burgerlijk Wetboek, in: Het Ontwerp B.W., Deventer-Antwerpen 1961, p. 39: "Donker vreesde dat te lang wachten met publicatie de aandacht, die er was, ook door de vraagpuntenprocedure, weer zou verslappen. Hij was zich bovendien zeer bewust van zijn eigen slechte gezondheidstoestand en van Meijers' leeftijd. Hij wenste bovendien met dezelfde Kamer die de vraagpunten had beantwoord, ook zoveel mogelijk stof van het nieuwe wetboek te behandelen. Hij drong aan op publicatie van hetgeen er gereed was."

221. Hierboven is reeds benadrukt dat Donker meende dat de hercodificatie alleen dán een redelijke kans van slagen zou hebben, indien de ontwerpen zouden worden afgedaan door dezelfde Tweede Kamer, die de vraagpunten had behandeld. Het was daarom van het grootste belang dat de Tweede Kamer uiterlijk mei 1955 de laatste serie van de ontwerpen zou behandelen. Het najaar van 1955 zou zijn belast door de behandeling van de begrotingen, terwijl in de eerste helft van 1956, het jaar van de periodieke verkiezingen, ernstig rekening moest worden gehouden met de kans, dat de Minister van de nodige medewerking van de Tweede Kamer niet meer verzekerd zou zijn. 
omvangrijke hoeveelheid werk die zij in de komende maanden zouden moeten verstouwen..$^{222}$

Er waren dus voldoende argumenten om tot publicatie te besluiten. Volgens Polak zou Meijers dan ook niet erg hebben tegengestribbeld: "Ik heb niet het gevoel gehad dat hij echt over de streep moest worden getrokken of dat hij het vervelend vond dat maar een deel werd gepubliceerd. Meijers was heel praktisch en had zeker begrip voor het standpunt van Donker. "223

Op Goede Vrijdag legden Polak, De Vries en Franken de laatste hand aan de drukproeven voor de Groene Boeken. Ook dat was een nogal spannend gebeuren. Meijers was namelijk enkele dagen daarvoor naar Rome vertrokken, waar hij van 20 tot 30 april de vierde zitting van de internationale diplomatieke conferentie over de internationale Koop bijwoonde. Dat was op zich niet zo'n groot bezwaar, maar hij had nog enkele stukken onder zich, die uiterlijk die vrijdag op het Ministerie zouden moeten arriveren om nog te kunnen worden verwerkt in de drukproef.

Op de bewuste vrijdag waren de stukken er niet, zeer tot ongenoegen van Donker. Meijers had, zo berichtte hij Donker telefonisch, de stukken wel gereedgekregen, maar voelde er niets voor de conferentie, waarin hij een actief aandeel had, te onderbreken. ${ }^{224}$ Franken: "Donker ging de afdeling rond met het bericht: 'Vanmorgen zouden de stukken gearriveerd moeten zijn. Ze zijn er niet, maar dat accepteer ik niet. Iemand zal ze vanmiddag in Rome moeten ophalen. Meneer Thijssen, u gaat nu meteen naar Rome.' Om het krankzinnige van de situatie te beseffen, moet u bedenken dat een vliegreis toendertijd nog iets aparts was. Je kon het bijna vergelijken met een maanreis, het was extravagant."

's Avonds kwam Thijssen - buiten adem, volgens Franken - met de laatste ontbrekende stukken aan. Men zou tot het ochtendgloren doorwerken om de stukken tijdig bij de Staatsdrukkerij in te kunnen leveren. Polak: "We moesten van Donker de Boeken 1-4 voor de Paasvakantie bij de Staatsdrukkerij inleveren, zodat ze direct na Pasen konden worden uitgegeven. De vrijdag voor Pasen hebben we tot diep in de

222. Zie ook Meijers in de aanbiedingsbrief bij de eerste vier groene Boeken, (Parl. Gesch. NBW, Algemeen Deel, p. 115): "Het aanvankelijk voornemen het ontwerp na voltooiing in zijn geheel aan Uwe Majesteit aan te bieden, heeft ondergetekende in overleg met de Minister van Justitie laten varen, opdat zij, die het ontwerp vóór een mogelijke indiening bij de volksvertegenwoordiging critisch moeten bezien en eventueel moeten omwerken, niet met te veel arbeid ineens zouden worden belast."

223. Dat Meijers een pragmaticus was en alleen oog had voor het nut van een bepaalde handeling, illustreert de volgende opmerking van Dorhout Mees. In 1950 had een commissie uit de Bedrijfsgroep Schadeverzekering een ontwerp voor titel 7.17 opgesteld, dat zij met enig ceremonieel wilde aanbieden aan Meijers. Dorhout Mees, om advies gevraagd, raadde dit echter af: "Overhandiging door de post schijnt mij de meest economische weg en voorzover ik Meijers ken zal hij er niet anders over denken."

224. G. Oly, Rome in het voorjaar van 1954, Trouw, 3 februari 1992, p. 12, geeft nog de volgende bijzonderheden: "De vierde zitting van de speciale commissie werd voorgezeten door de president van Unidroit, M. Pilotti. Meijers werd tot vice-president benoemd. Hij heeft de helft van de zestien zittingen tussen 20 en 30 april voorgezeten, van de andere acht zijn er vijf onder zijn leiding begonnen. Er werd meestal dagelijks vergaderd van 10 tot 12 à 13 uur en van 16 tot 19 uur. Op enkele dagen werd plenair en slechts eenmaal vergaderd en op 25 april was een vrije dag. Blijkens de notulen leverde Meijers een grote bijdrage aan de discussie." 
nacht doorgewerkt. 's Ochtends om half vijf is Lodewijk de Vries met de tekst van de Boeken 1-4 naar de Staatsdrukkerij gegaan en daar hebben ze het hele weekeinde doorgewerkt. Op Tweede Paasdag of de dag er na hebben we op Justitie de proeven nagekeken of de correcties goed waren verwerkt. Een paar dagen later kwamen de groene Boeken uit."

\section{25 juni 1954: Meijers overlijdt}

Met de publicatie op 3 mei 1954 van het eerste deel van zijn ontwerp had Meijers aan het grootste deel van zijn opdracht voldaan. De Inleidende titel en de eerste vier Boeken, met de titels 3.1-3.3 als belangrijkste afwijking ten opzichte van het geldende recht, vormden het meest wezenlijke deel van zijn ontwerp. Wat nog volgen zou, was, het zakenrecht en het algemeen deel van het verbintenissenrecht uitgezonderd, voornamelijk verguldsel. In de bijzondere overeenkomsten zou maar weinig veranderen, terwijl het zeerecht en de rechten van de scheppende mens altijd buiten het B.W. hadden gestaan.

Het accent van het werk aan het nieuwe B.W. kwam in deze fase te liggen bij de medewerkers van de afdeling Wetgeving van het Departement van Justitie. Aan hen was de taak het voorontwerp gereed te maken voor indiening bij de Tweede Kamer. Daarbij dienden zij zich uiteraard te richten naar de aanwijzingen van Meijers. De toekomstige Regeringscommissaris immers, moest de wijzigingen die de Regering wilde voorstellen, kunnen onderschrijven. ${ }^{225}$

Het gereedmaken van de Groene Boeken als Regeringsontwerp werd in handen van de B.W.-club gelegd. Omdat Donker erop gebrand was de ontstane vertraging waar mogelijk in te lopen, moest alles in zeer korte tijd geschieden. Voor Justitie zelf was er daarom nauwelijks tijd om de ontwerpen te bestuderen. Terwille van de spoed beperkte de B.W.-club zich er dan ook veelal toe de lijsten, die waren opgesteld naar aanleiding van de eerste drukproeven van het Groene Boek, opnieuw aan Meijers voor te leggen. Punten die door hem niet waren overgenomen, maar waaraan door het Departement desalniettemin betekenis werd gehecht, werden zo nogmaals onder zijn aandacht gebracht. Daarnaast ontving Meijers ook die opmerkingen, die indertijd te laat waren gekomen om nog in de drukproeven van het Groene Boek te worden verwerkt, en daarom nu met de tweede ronde meededen. Franken over deze periode: "Naar onze zin ging de voorbereiding van het Regeringsontwerp veel te oppervlakkig, vanwege de haast die er mee gemoeid was. Als Donker zijn zin had gekregen, was het Regeringsontwerp letterlijk gelijk aan het groene Boek geweest. Wij vonden daarentegen dat een paar al te gekke dingen veranderd moesten worden, als dit gemakkelijk en snel ging. Punten waar wij erg aan gehecht waren, en die wij al voor de totstandkoming van het Groene Boek hadden ingezonden, waren soms door Meijers niet overgenomen. Het Regeringsontwerp bood dan de kans ons standpunt alsnog aan te brengen. De tijd die we ervoor kregen, was echter zo gering, dat we maar een duizendste konden veranderen van wat we werkelijk hadden willen doen. Donker paste wel op dat die wijzigingen niet tot gehele boekwerken zouden uitgroeien."

225. Aldus ook Minister Donker in de Memorie van Antwoord bij de begroting voor 1956, zitting Tweede Kamer 1955-1956, stuk nr 4100, stuk nr 10, p. 6. 
Ook de andere Departementen moesten buigen voor de termijnen die Donker stelde. Kregen zij in het oorspronkelijke tijdschema nog drie maanden de tijd om bezwaren tegen het werk van Meijers naar voren te brengen, nu bracht Donker deze termijn, zonder daar overigens de Ministerraad in te kennen, terug tot minder dan een maand: vóór 1 juni 1954 werden eventuele reacties ingewacht. ${ }^{226}$ Donker zou Donker niet zijn als ook deze procedure niet was gericht op het bereiken van een zo groot mogelijke doelmatigheid. Zo werd, teneinde te voorkomen dat het Departementaal onderzoek zich zou uitstrekken tot alle onderdelen van het ontwerp, ten behoeve van elk Departement een lijstje met punten opgesteld, waarvoor men vermoedelijk belangstelling zou hebben. Daarnaast kreeg men het verzoek bondig te zijn en eventuele tekstkritiek te verpakken in een alternatieve tekst, bij voorkeur voorzien van een pasklare toelichting. Tenslotte werd, teneinde de verwerking van de ingekomen antwoorden zo systematisch mogelijk te laten verlopen, een bijlage bijgevoegd, waarop duidelijk werd aangegeven op welke wijze men zijn opmerkingen moest inrichten. Er werd dus niets aan het toeval overgelaten.

Het door Donker getrokken kader voor de herziening van het Burgerlijk Wetboek had niet alleen gevolgen ten aanzien van de snelheid van het project. Een niet minder opmerkelijk detail was, dat de ontwerpen die aan de collega-Departementen werden voorgelegd, niet de concept-wetsvoorstellen bevatten, maar uitsluitend bestonden uit de tekst van het groene Boek. Van de veranderingen die Justitie zelf wilde voorstellen, bleven de andere Departementen vooralsnog onkundig. Een ander novum was, dat reeds in deze fase de Raad van State werd ingeschakeld. Krachtens de afspraken, in september 1952 met Donker gemaakt, zette dit college zich direct na het verschijnen van het groene Boek aan de bestudering van Meijers' werk, in het vertrouwen dat de Regeringsontwerpen daarvan weinig zouden afwijken. ${ }^{227}$

Donkers aanpak werkte dus in dubbel opzicht arbeidsbesparend. Door de groene Boeken te presenteren als Regeringsontwerp, kon het interdepartementaal overleg direct na het uitkomen van de groene Boeken beginnen en hoefde ook de Raad van State niet te wachten op de eigenlijke wetsontwerpen. Anderzijds betekende het feit dat Meijers' voorontwerp tot basis van de beschouwingen werd gemaakt, dat de mogelijkheden voor Justitie om zelf nog wijzigingen voor te stellen, uiterst beperkt waren. Een teveel aan veranderingen zou er immers toe kunnen leiden dat het interdepartementaal overleg zou moeten worden heropend, terwijl in dat geval ook de

226. In zijn nota van 13 november 1953 had Donker reeds voorgesteld het interdepartementaal overleg te beperken tot zes weken. Dat was in zoverre verdedigbaar, orndat hij er toen van uitging dat in januari 1954 niet het gehele ontwerp, maar slechts de eerste vijf Boeken zouden worden gepubliceerd.

227. Het Nader Rapport aan de Koningin bij de Boeken 1-4 (Parl. Gesch. NBW, Algemeen Deel, p. 137) legt daarvan als volgt getuigenis af: "Alvorens tot een bespreking van het advies van het Hoge College over te gaan stelt ondergetekende het op prijs zijn bijzondere erkentelijkheid tegenover de Raad tot uitdrukking te brengen, dat de Raad zich na het in druk verschijnen van het door prof. Meijers opgestelde eerste gedeelte van het ontwerp voor een nieuw Burgerlijk Wetboek aanstonds aan de studie van deze voor het rechtsleven van alle dag uiterst belangrijke stof heeft willen zetten en dat de Raad na korte tijd een doorwrocht advies ter beschikking van de Regering heeft willen stellen. De Raad is de Regering hiermede tot grote steun geweest." 
Raad van State tot nader onderzoek zou worden verplicht. ${ }^{228}$ Het gevolg was, dat het interdepartementaal overleg voor weinig verrassingen zorgde. Het aantal reacties was in elk geval opvallend gering, waaraan de snelheid die Donker wist te ontwikkelen, ongetwijfeld in belangrijke mate debet is geweest. Wie langer dan een week verspilde aan het op papier zetten van zijn kritiek, was zo goed als zeker een geslagen man. ${ }^{229}$ Daarbij kwam dat de herziening van het B.W. niet iedereen in even sterke mate aansprak. Belinfante: "We hebben in het begin de teksten naar alle Departementen gestuurd, maar dat leverde niet veel op. Er waren er maar een paar die daar belangstelling voor hadden. Waar het wel gebeurde, was bij het vijfde Boek, omdat daar de overheidseigendom ter sprake kwam. Over de andere Boeken zijn eigenlijk alleen maar opmerkingen door Justitie gemaakt. Die opmerkingen waren niet erg ingrijpend."

Hierdoor kon het interdepartementaal overleg, met inbegrip van het noodzakelijke overleg met Meijers als toekomstig Regeringscommissaris, in minder dan twee weken worden afgerond. Op 1 juni liep de termijn voor het inzenden van schriftelijk reacties af, reeds op 11 juni zouden de eerste zes wetsontwerpen ${ }^{230}$ naar de Ministerraad gaan. Niet alleen qua inhoud, maar ook qua vorm sloten zij nauw aan bij de tekst van het groene Boek. Zo bleef de voorlopige nummering, zoals die in de ontwerpen van

228. Illustratief hierbij is het commentaar van de Raad bij Boek 5 toen bleek dat het in 1957 ingediende Regeringsontwerp nogal afweek van het door het Driemanschap afgeleverde werk: "Kon bij de vorige boeken van een voorstudie van de in druk verschenen voorstellen van professor Meijers gemakkelijk worden overgegaan op een beoordeling en bespreking van de ministeriële ontwerpen voor die boeken, thans is het zo, dat na de voorstudie van het in druk verschenen vijfde Boek, de Minister nog vele en belangrijke wijzigingen in dat boek, - uitvoerig toegelicht - heeft aangebracht, waardoor vaak op het bij de voorstudie gevolgde spoor moest worden teruggelopen. Deze omstandigheid moge de bestudering van het geheel aan belangwekkendheid hebben doen winnen, zij heeft aan de andere kant meer arbeid gevergd." (Parl. Gesch. Boek 5, p. 5).

229. Het volgende voorval, dat overigens plaatsvond in het kader van de vraagpuntenprocedure, is het waard aan de vergetelheid te worden ontrukt. Hiervoor schreef $\mathrm{ik}$, dat EZ weinig ingenomen was met Meijers' voornemen de rechten van de scheppende mens in het Burgerlijk Wetboek op te nemen. Dit leidde ertoe dat tussen beide Ministeries voortdurend contact bestond over de positie die tijdens de vraagpuntenbehandeling moest worden ingenomen.

Op een zeker moment bleek uit het overleg met de Kamer dat het "voorlopig antwoord" gewijzigd diende te worden. Donker pleegde daarop overleg met EZ, maar kennelijk ging én en ander zo snel in het werk, dat de contactambtenaar van EZ er niet in slaagde de gehele ambtelijke top van de voorgenomen standpuntwijziging op de hoogte te stellen. Het gevolg was, dat Donker enige tijd later een boze brief ontving, waarin hem eigenmachtig optreden werd verweten. "Tot mijn verwondering heb ik moeten constateren", zo schreef de Staatssecretaris van EZ, "dat in de aan de Kamer op 3112 -'52 voorgelegde reeks de beantwoording van één der vraagpunten principieel was gewijzigd, zonder dat daarover enig overleg met dit Departement had plaatsgehad. (..) In het bij Uw brief gevoegde concept Memorie van Antwoord is te dezen sprake van met de Minister van Economische Zaken gepleegd overleg en wordt zelfs zijn mening gemotiveerd weergegeven, doch ik herhaal dat hier van zulk overleg niets bekend is."

De verwondering van de Staatssecretaris zou ongetwijfeld nog groter zijn geweest, indien hij zou hebben geweten dat de fout niet bij Justitie, maar bij zijn eigen Departement lag.

230. Deze wetsontwerpen (zitting Tweede Kamer 1954-1955, nrs. 3766-3771) bevatten elk én Boek van het nieuwe wetboek, uitgezonderd de Inleidende titel en de titels 9 en 10 van Boek 1 (ontbinding van het huwelijk en de scheiding van tafel en bed), die in een apart wetsontwerp waren gegoten. Donker hoopte op deze manier te bereiken dat een eventuele nederlaag in de Kamer op het stuk van de echtscheiding geen gevolgen zou hebben voor de overige Boeken. 
Meijers werd voorgesteld, geheel behouden. Ook de aanduiding van de Boeken, titels, afdeling en wijze van indeling werd zoveel mogelijk overgenomen. En ter toelichting op de wetsontwerpen volstond Donker in het algemeen met een verwijzing naar de door Meijers bij het voorontwerp geschreven toelichting, daarmee "ten volle benadrukkend, dat de Regering niet het werk van de ontwerper wil overdoen en in de structuur en de juridische gedachte-ontwikkeling van het ontwerp-Meijers niet dan met de grootste voorzichtigheid ingrijpt. ${ }^{\text {"231 }}$ Alleen de punten waarop het wetsontwerp afweek van Meijers' voorontwerp werden afzonderlijk toegelicht.

In nauwelijks een week had Donker voor elkaar weten te krijgen, waarvoor hij oorspronkelijk nog twee maanden dacht nodig te hebben. Kritici van het project, die na het overlijden van Meijers erop wezen dat de Minister veel te snel van stapel liep en dat zelfs hij niet in staat was gebleken zijn eigen tijdschema te volgen, zouden dan ook te horen krijgen dat hij druk bezig was de achterstand in te lopen.

Met de aanbieding van de voorontwerpen voor de Inleidende titel en de eerste vier Boeken was Meijers' taak niet voltooid. Nog vijf Boeken zouden moeten volgen. Het jongste schema ging er van uit dat het tweede deel van het Ontwerp-Meijers medio september 1954 zou worden gepubliceerd.

Vermoedelijk heeft Meijers zich tussen 3 mei en 11 juni vooral beziggehouden met het overleg over de opstelling van het Regeringsontwerp voor de Boeken 1-4. Aan de concepten van de nog te publiceren voorontwerpen veranderde op het oog in ieder geval niets. ${ }^{232}$ Een aanwijzing hiervoor is ook, dat pas enkele dagen nadat de zes wetsontwerpen naar de Ministerraad waren gegaan, de eerste concepten voor Boek 5 de Staatsdrukkerij bereikten.

Het afronden van het concept voor Boek 5 O.M. heeft Meijers vermoedelijk niet al te veel moeite gekost. In ieder geval - en dat tekent nog eens zijn grote werklust en uithoudingsvermogen - leverde hij om de dag een titel in bij de Staatsdrukkerij. ${ }^{233}$ Zou het Meijers gegeven zijn geweest in hetzelfde tempo door te werken, dan lijkt het alleszins waarschijnlijk dat het voorontwerp voor Boek 5, dat 11 titels zou tellen (waarvan de laatste vrijwel geheel zou zijn gebaseerd op de in 1951 tot stand gekomen appartementenwet) omstreeks de tweede week van juli gereed zou zijn gekomen. Dat klopt ook in zoverre, dat Meijers al voorbereidingen had getroffen om half juli af te reizen naar zijn vakantiehuisje te Belle-lle, om daar de laatste hand te leggen aan de groene Boeken 6 en 7.

Overigens hoeft deze regelmaat niet te verbazen. Reeds in 1948 lag een volledig concept voor de tekst en toelichting van Boek 5 gereed. En aangezien deze concepten, ondanks de soms stevige discussies in de Staatscommissie, alleen op details veranderden en het vrijwel nooit voorkwam dat een titel of afdeling geheel nieuw moest

231. Parl. Gesch. NBW, Algemeen Deel, p. 139. Deze zinsnede komt voor in het Nader Rapport naar aanleiding van het Advies van de Raad van State over de Inleidende titel en de Boeken 1-4.

232. Wel zag hij, een week nadat het Groene Boek in de band was verschenen, nog kans om in Gent een voordracht te houden over het Ontwerp-NBW. Zie voor een verslag van deze lezing, Rechtskundig Weekblad 1954, p. 1835 e.v.

233. Het concept voor titel 5.1 en 5.2 verscheen op 12 juni, voor $5.3,5.45 .5$ en 5.6 respectievelijk op 14, 20, 23 en 25 juni. Met betrekking tot de toelichting lagen deze data als volgt: 5.1 en 5.2 op 15 juni, $5.3,5.4,5.5$ en 5.6 respectievelijk op $16,21,23$ en 25 juni. 
worden opgezet, hoefde er doorgaans weinig meer aan te gebeuren. ${ }^{234}$ Zo ook hier. De wijzigingen die Meijers aanbracht, waren voornamelijk redactioneel. Hij liet een paar bepalingen van plaats veranderen, controleerde of de terminologische verbeteringen consequent waren toegepast, ging de verwijzingen naar de reeds gepubliceerde boeken na en vulde de toelichting aan naar aanleiding van de discussies binnen de Staatscommissie. In titel 5.1 (Eigendom in het algemeen) bijvoorbeeld, kreeg de jongste jurisprudentie omtrent de Voorste Stroom (HR 19 december 1952, NJ 1953, 643) een plaats, terwijl in titel 5.2 (Eigendom van roerende zaken) een drietal kleine wijzigingen werd aangebracht. Naar het voorbeeld van art. 724 ZGB werd een bepaling opgenomen voor het vinden van zaken van bijzondere wetenschappelijke, geschiedkundige of artistieke waarde. ${ }^{235}$ Daarnaast werden de regels met betrekking tot zaaksvorming uitgebreid. Enerzijds nam Meijers een regel op voor het geval de zaak aan twee eigenaren toebehoorde (vergelijk art. 5.2.12 O.M.) in welk geval elk van de eigenaars recht krijgt op een deel in de nieuwe zaak, evenredig aan het deel dat hij had in de gebruikte zaak, anderzijds werd zijn concept-voorontwerp verrijkt met een bepaling waardoor het mogelijk werd dat degene die de eigendom over zijn zaak verloor, restitutie kon verlangen indien het bestandeel zonder enige beschadiging weer tot de oorspronkelijke zaak was terug te brengen. ${ }^{236}$

Titel 5.3 (Eigendom van onroerende zaken) bleef qua tekst ongewijzigd. Wel werd de toelichting van de twee artikelen die gewijd waren aan aanwas en afslag, belangrijk uitgebreid. In titel 5.4 (Zaken, die aan openbare lichamen toebehoren of ten algemene nutte zijn bestemd) onderging slechts één van de vijf artikelen een bescheiden toevoeging. In titel 5.5. (Bevoegdheden en verplichtingen van eigenaars van naburige erven) werd in het eerste en in het laatste artikel een kleine redactionele wijziging aangebracht, beide naar aanleiding van de discussie in de Staatscommissie. Titel 5.6 (Mandeligheid) tenslotte, werd in die zin gewijzigd dat mandeligheid niet langer alleen uit de feitelijke toestand van een zaak zou mogen worden afgeleid, maar dat zij ook door middel van inschrijving van een akte in de openbare registers kon worden bewerkstelligd. Het aantal wijzigingen was dus beperkt.

Het gereedmaken van de drukproef voor de tekst en toelichting voor titel 5.6 was waarschijnlijk Meijers' laatste daad in het kader van zijn werk ten behoeve van het nieuwe Burgerlijk Wetboek. Op vrijdag 25 juni 1954 overleed hij, geheel onverwacht,

234. Volgens Belinfante is het slechts éen keer voorgekomen dat Meijers een concept heeft moeten terugnemen. Dit betrof titel 1:18 (afwezigheid en vermissing). Belinfante: "Meijers had een titel gemaakt die gebaseerd was op het oude B.W., terwijl wij toen in die tijd een nieuwe wet hadden in verband met de talrijke gevallen van vermoedelijk overlijden die er waren na de oorlog. (Wet van 30 november 1950 , S. K 537). Toen heeft mevrouw Schönfeld, op de manier zoals ze dat deed, een nota geschreven van zo'n dertig bladzijden om - zeer beleefd maar toch pertinent - aan te tonen, dat het stuk van Meijers niet deugde en dat hij een stuk moest maken in de geest van de nieuwe wet. Dat heeft hij aangenomen. Dat is de enige keer dat ik heb gezien, dat hij het hele concept heeft teruggenomen en een nieuw concept heeft gemaakt."

235. Dit artikel werd overigens direct weer door het Driemanschap geschrapt. Zie de ToelichtingMeijers bij art. 5.2.9, Parl. Gesch. Boek 5, p. 103.

236. Ook deze bepaling, die overigens niet kon worden ingeroepen tegen derden die te goeder trouw rechten op de hoofdzaak hadden verkregen, sneuvelde als gevolg van de beraadslagingen in het Driemanschap. Wel wordt in de toelichting bij artikel 5.2.14 O.M. terloops op de mogelijkheid van restitutie gewezen. 
op vierenzeventigjarige leeftijd. Hij had die dag nog het woord gevoerd op de vergadering van de Nederlandse Juristen Vereniging, "levenskrachtig en strijdvaardig als immer" over conversie van rechtshandelingen.

Er is wel eens gesuggereerd, dat het werk aan het nieuwe B.W. Meijers teveel is geworden. Feit is, dat die bewering al direct na zijn overlijden van verschillende zijden werd tegengesproken. Van Oven schreef bijvoorbeeld in zijn "In Memoriam" over Meijers: "Dat hem na de oorlog die taak (nl. tot het ontwerpen van een nieuw Burgerlijk Wetboek) is opgedragen, hij heeft het in hoge mate gewaardeerd, is er zeer verheugd over geweest. Hij heeft het niet als een last gevoeld, dat van Regeringszijde een schema werd opgezet, waarin hij tot een werktempo werd gebracht dat geen ander mens had kunnen volhouden. Want hij wist, dat hij het aan kon en het is een fabel, dat hij zich er aan "dood gewerkt" heeft. Wie Meijers goed heeft gekend, weet dat hij zich nimmer "overwerkte". Wanneer hij moe was geworden van een werkdag, tweemaal zo zwaar als die van een ander, dan hield hij op en ... ging rechtshistorie beoefenen of hij nam een roman ter hand, of zette zich aan het beantwoorden van een kruiswoordpuzzle. "237 238

Ook het gegeven dat Meijers tot op het laatst de redactievergaderingen van het WPNR bezocht en nog de kracht kon opbrengen naar Rome en Gent te reizen, duidt erop dat hij bepaald niet aan het werk aan het nieuwe B.W. ten onder is gegaan. Hij vond, zoals Minister Donker in de Kamer zou verklaren, in die internationale werkzaamheden de rust en het evenwicht dat hij nodig had om zijn ontwerp op te stellen. Voor zijn vertrek naar Frankrijk zou Meijers nog een gesprek met Minister Donker hebben over de loop van het tweede gedeelte van het B.W. De tekst van het Koninklijk Besluit, waarbij hij tot "Koninklijk Commissaris" zou worden benoemd, was reeds opgesteld.

237. NJB 1954, p. 553 e.v. Dat Meijers en Donker goed met elkaar overweg konden, blijkt ook uit het optimisme dat uit Meijers' Gentse lezing straalt. Erover sprekend dat hij bij het aannemen van zijn opdracht weinig illusies had gekoesterd over het lot dat zijn ontwerp zou zijn beschoren, vervolgde Meijers met de opmerking dat Nederland "voor het ogenblik echter een Minister van Justitie had die in een volledige herziening van het B.W. ten zeerste belang stelde en reeds een plan had uitgestippeld opdat het ontwerp met bekwame spoed door de Kamers zou behandeld worden."

238. Kamphuisen, die op die bewuste vrijdag nog met Meijers had ontbeten, zou later schrijven: "Hoe weinig kon ik toen vermoeden dat mijn grote leermeester - multis ille bonis flebilis occidit dienzelfden avond voor altijd van ons zou heengaan." (P.W. Kamphuisen, De collectieve en de individuele arbeidsovereenkomst, Leiden 1956). 


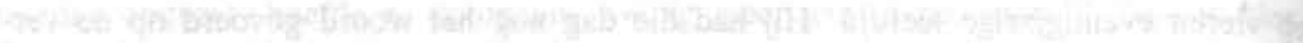

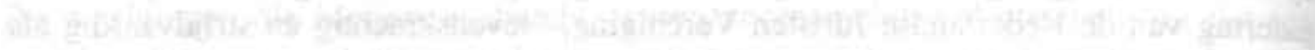

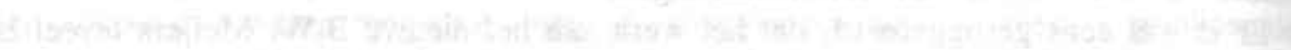

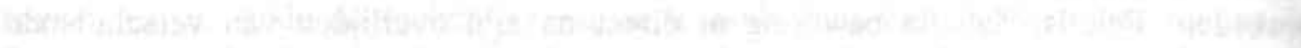

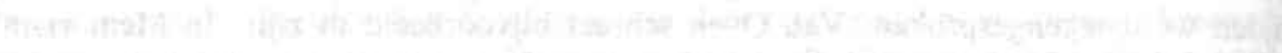

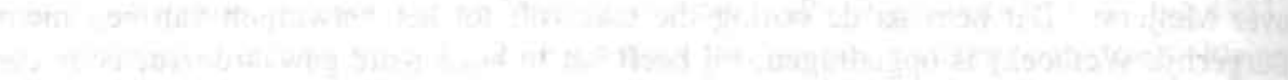

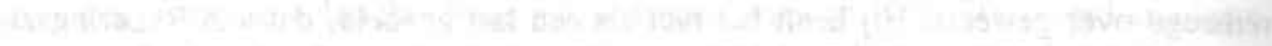

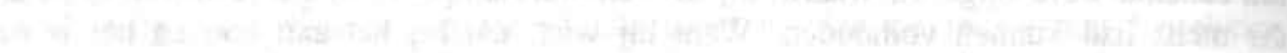

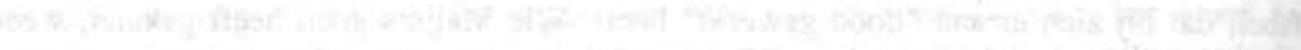

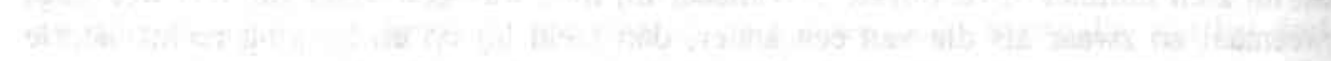


Hoofdstuk 4

HET DRIEMANSCHAP (1954-1961)

\section{De opvolging van Meijers: Drion, Eggens en De Jong}

Hoewel er na 25 juni 1954 ongetwijfeld sommigen zijn geweest die van mening waren dat de hercodificatie maar beter kon worden afgeblazen ${ }^{1}$, was het niets voor Donker om te wijken voor zulke defaitistische gevoelens: "Men had op Justitie simpelweg het idee, dit moet afgemaakt worden", volgens Belinfante.

Op 15 juli 1954, drie weken na het overlijden van Meijers, stelde Minister Donker de Tweede Kamer er schriftelijk van op de hoogte dat hij erin was geslaagd de vacature van Meijers te vervullen. In zijn brief aan de Kamer schreef hij: "Hierbij heb ik de eer u mede te delen, dat tot voltooiing van het nog niet verschenen gedeelte van het ontwerp voor een nieuw Burgerlijk Wetboek aan de hand van de door wijlen prof. Meijers voor een groot deel bewerkte stof en overeenkomstig de door hem ingeslagen wegen zich hebben bereid verklaard de volgende Heren: prof.mr. J. Drion, hoogleraar aan de Rijksuniversiteit te Leiden, prof.mr. J. Eggens, advocaat-generaal bij de Hoge Raad der Nederlanden en mr. F.J. de Jong, raadsheer in de Hoge Raad der Nederlanden. ${ }^{2}$ Ter verklaring wees Donker erop dat de drie nauw betrokken waren geweest bij Meijers' werk aan de hercodificatie: "Zij zijn allen als lid van de Staatscommissie inzake herziening van de Nederlandse Burgerlijke Wetgeving intensief betrokken geweest bij het overleg, dat prof. Meijers met deze Staatscommissie over zijn ontwerpen heeft gevoerd." ${ }^{3}$

Het driemanschap Drion-Eggens-De Jong was vermoedelijk niet de eerste keus van Donker. Uit verschillende bronnen kan worden opgemaakt, dat de Minister in eerste instantie heeft geprobeerd alleen Jan Drion voor de opdracht te interesseren. Een begrijpelijk streven, want Drion was gedurende drie jaar de naaste medewerker van Meijers geweest, hij kende de gedachten achter het ontwerp als geen ander en gold in zekere zin ook als de kroonprins van Meijers, omdat hij hem in 1950 in Leiden als hoogleraar was opgevolgd. Bovendien zou Meijers zèlf Drion hebben aangewezen als zijn opvolger. Mr. Donner, door Donker om raad gevraagd, deelde de Minister althans mede dat Meijers zich eens in die richting zou hebben uitgelaten. ${ }^{4}$ Drion, net 38 jaar oud, durfde deze zware taak echter niet alleen op zich te nemen. Hij wilde, volgens mevrouw Drion, de opdracht alleen aanvaarden indien één of meer anderen

1. Zie daarover J.C. Van Oven, Het werk aan het nieuwe Burgerlijk Wetboek, NJB 1957, p. 1-5. Anders: P.W. van der Ploeg, Nu of nooit, WPNR 4397 (1955); A.M. Vroom, Het nieuwe B.W., NJB 1956, p. 150.

2. Handelingen Tweede Kamer 1953-1954, p. 1387.

3. Bij de begrotingsbehandeling voor 1955, handelingen Tweede Kamer 1954-1955, p. 2128, liet Donker zich als volgt uit: "Ik ben na het overlijden van prof. Meijers onmiddellijk geconfronteerd met de vraag, hoe het verder moest gaan. Ik heb gemeend de oplossing te moeten vinden in een verzoek aan een drietal juristen, die bij de voorbereidende arbeid van prof. Meijers in de Staatscommissie voor de Burgerlijke Wetgeving nauw betrokken zijn geweest, zijn werk voort te zetten."

4. Dit blijkt althans uit een (ongedateerde) telefoonnotitie van Donker, naar aanleiding van zijn gesprek met de President van de Hoge Raad. 
hem daarbij zouden assisteren. Ook dat is begrijpelijk. Drion gold weliswaar als een veelbelovend en bijzonder knap jurist, maar buiten zijn bekende artikelenreeks in het WPNR over de jurisprudentie van de Hoge Raad inzake de Voorste Stroom ${ }^{5}$ en zijn doorwrochte en kundige annotaties in het sinds twee jaar verschijnende Ars Aequi had hij nog weinig gepubliceerd. Zijn proefschrift "Administratie contra rechter", waarop hij op 28 juni 1950 cum laude promoveerde, had betrekking op het Conflictenbesluit, een publiekrechtelijk onderwerp.

Drions keuze viel in eerste instantie op mr. F.J. de Jong (1901-1974). Deze was niet alleen een goede vriend van Drion en, volgens Langemeijer, een "vurig bewonderaar" van Meijers, maar hij bracht als lid van de Hoge Raad ook kennis in van de praktijk, kennis die Drion miste. Bovendien had De Jong - met Eggens - tot de actiefste leden van de Staatscommissie behoord. Er was vrijwel geen vergadering die hij niet had bijgewoond, terwijl het merendeel van de rapportages door hem was opgesteld. Een betere keuze was dus moeilijk denkbaar.

Met de benoeming van Drion en De Jong leek de opvolging van Meijers tot ieders tevredenheid te zijn geregeld. De notulen van de Ministerraad van 5 juli 1954 vermelden: "Minister Donker heeft zijn gedachten laten gaan over de voorziening, die getroffen moet worden nu prof. Meijers is overleden en de voltooiing van de grote taak van de vernieuwing van het Burgerlijk Wetboek door anderen zal moeten worden gedaan. Spreker meent dat dit zal kunnen worden opgedragen aan prof.mr. J. Drion en mr. F.J. de Jong. (..) Het is niet de bedoeling een nieuwe Koninklijke opdracht te geven; prof. Meijers had deze opdracht wegens zijn bijzondere capaciteiten gekregen."

Een week later moest Donker echter opnieuw de aandacht van zijn collega's vragen. Het tweemanschap was, tegen zijn zin, uitgegroeid tot een driemanschap: "Minister Donker deelt mede, dat prof. Drion en mr. De Jong op het standpunt staan, dat per se een derde jurist aan hen beiden moet worden toegevoegd, waarvoor zij de naam van prof.mr. Eggens, advocaat-generaal bij de Hoge Raad hebben genoemd. Spreker ziet hiertegen wel bezwaren, maar meent zich erbij te moeten neerleggen, dat prof. Eggens ook voor deze zaak wordt vrijgemaakt." ${ }^{6}$

Waarom Drion en De Jong het "per se" noodzakelijk vonden een derde erbij te halen, blijkt niet uit het citaat van Donker. Franken zei daarover het volgende: "Ik meen dat het zo is geweest, dat men aanvankelijk alleen aan Drion heeft gedacht, die dat alleen niet aandurfde of dat niet de meest wenselijke methode vond, en dat hij daarop heeft voorgesteld De Jong als tweede man te nemen. $\mathrm{Zij}$ vonden dat echter een te smalle basis, omdat bij verschil van mening geen meerderheidsbeslissing zou

5. J. Drion, Een nieuwe koers in 's Hoogens Raads jurisprudentie over de onrechtmatige daad, WPNR 3992-3996 (1947).

6. Notulen van de vergadering van de Ministerraad van 12 juli 1954. Ten aanzien van de vraag waarom Donker bezwaren had tegen de komst van een derde man, geven de notulen geen uitsluitsel. Mogelijk is Donker echter beïnvloed door Samkalden, die de inschakeling van meer mensen "niet verstandig" vond, zoals eveneens uit de hiervoor vermelde telefoonnotitie blijkt. Een interessant detail is verder, dat voordat Drion werd benaderd, in het geheel nog niet aan Eggens en De Jong werd gedacht. De notitie vermeldt naast de naam van J. Drion (Boeken 5 en 6 ) die van W.F. de Gaay Fortman en W.C.L. van der Grinten, die beiden Boek 7 voor hun rekening zouden moeten nemen. 
kunnen afgedwongen, zodat een derde persoon vereist was." Volgens Polak was het erbij halen van Eggens (1891-1964) een uitvinding van De Jong: "Voordat ik bij het nieuwe Burgerlijk Wetboek kwam, was ik hulpje van Eggens bij de Hoge Raad en ik heb meegemaakt hoe enorm Eggens werd gewaardeerd als advocaat-generaal, met name door De Jong, die in de Hoge Raad zat." Franken bevestigde die lezing: "Veel later heeft De Jong mij gezegd, - terugblikkend op de moeizame samenwerking binnen het Driemanschap, met name de verhouding De Jong en Eggens, die elkaar totaal niet lagen - , 'ik ben nota bene degene geweest die erop heeft aangedrongen bij de Minister om Eggens als derde man te benoemen. Wat heb ik daar spijt van.'"

De financiële regeling was eenvoudig. Drion, Eggens en De Jong werden in hun functie van respectievelijk hoogleraar, advocaat-generaal en raadsheer vrijgesteld van hun werk en hun bezoldiging liep door. De salarissen voor Eggens en De Jong werden op de post voor de Hoge Raad betaald, het salaris van Drion werd verrekend met Onderwijs. ${ }^{7} \mathrm{Zij}$ ontvingen daarnaast een toelage voor telefoon, reis- en verblijfkosten, uiteenlopend van $f 1.250$,- per jaar voor Drion en $f$ 550,- per jaar voor Eggens en De Jong. ${ }^{8}$

Het Driemanschap werd bijgestaan door drie medewerkers: mr. J.M. Polak, die van Meijers werd "overgenomen" en die al in april 1956 het werken voor het Driemanschap voorgoed voor gezien hield, mr. R. Franken, die na september 1953 weinig meer met Meijers te maken had gehad en feitelijk reeds werkzaam was op het Departement, en mevrouw mr. E.J.A. Fischer-Keuls (1908), die met ingang van 1 september 1954 de notulen van de besprekingen van het Driemanschap zou gaan verzorgen. Haar man, de bekende rechtshistoricus H.W.F.D. Fischer, was een goede bekende en collega van Jan Drion. Mr. D.C. Fokkema (1929), de latere Leidse hoogleraar in de rechtsvergelijking, trad in het najaar van 1955 op voordracht van Langemeijer toe - hij was op dat ogenblik afgestudeerd en zonder werk -, zodat er op een gegeven ogenblik zelfs vier medewerkers waren. Van hen was echter alleen Fokkema voor de volle honderd procent ingeschakeld bij het werk aan de nog onvoltooide groene Boeken.

Polak bijvoorbeeld, werd in de zomer van 1955 naar het Ministerie gehaald om onder leiding van Drion de Memorie van Antwoord bij de Inleidende titel te schrijven en keerde pas begin oktober weer terug. Franken kreeg in 1956 opdracht het Advies van de Raad van State bij Boek 5 te beantwoorden en werd ook nadien regelmatig inschakeld bij het werk op het Departement: "Het ene moment werkte ik voor het Driemanschap, het andere voor Justitie." Fischer tenslotte, had slechts een aanstelling voor driekwart van de werktijd en zou de eerste jaren haar handen meer dan vol hebben aan het verzorgen van de notulen. Het Driemanschap vergaderde aanvankelijk namelijk twee á driemaal per week, meestal van tien uur tot vijf uur. Het voorstel om Fokkema te benoemen werd door de Driemannen dan ook gemotiveerd met de

7. Vergelijk de Justitiebegroting voor 1955, zitting Tweede Karner 1954-1955, nr 3700, stuk nr 2, art. 5 en 40.

8. Drion kreeg, in verband met zijn benoeming tot Regeringscommissaris, met ingang van 1 juli 1958 een toelage van $f 8.000$,- per jaar, die met ingang van januari 1962 verhoogd zou worden tot $f$ 12.000 ,- , en per 1 januari 1964 tot $f 16.800$,- 
opmerking dat men behoefte had aan "een kracht uitsluitend ter assistentie van het Driemanschap. ${ }^{n 9}$

\section{Het werk aan Boek 5 O.M. ${ }^{10}$}

\section{a. organisatie en werkwijze}

Zoals uit de kennisgeving, die Donker op 15 juli aan de Tweede Kamer stuurde, blijkt, lag het hoofdbestanddeel van het werk van het Driemanschap in het afwerken van de concepten van Meijers voor de Boeken 5 en 6: "Genoemde Heren zullen zich in de eerste plaats zetten aan de voltooiing van Boek 5 (Zakelijke rechten) en Boek 6 (Verbintenissen in het algemeen). " Met de voltooiing van de voorontwerpen voor de andere Boeken (7-9) zou het Driemanschap in beginsel niet veel te maken hebben. Door voor de afwerking daarvan enige andere juristen van naam in te schakelen, zoals M.H. Bregstein, T.J. Dorhout Mees, J.C. Van Oven en P.W. Kamphuisen, hoopte Donker te bereiken dat zij gelijktijdig of in elk geval kort na de verschijning van de Boeken 5 en 6 O.M. zouden worden gepubliceerd.

Het Driemanschap, dat per 1 augustus 1954 formeel in functie trad, concentreerde zich allereerst op de afwerking van Meijers' concept voor het Zakenrecht. Dat had het grote voordeel dat het een weinig gecompliceerde materie betrof, die bovendien voor het grootste deel al in drukproef gereed lag. Eén van de problemen waarmee de opvolgers van Meijers namelijk werden geconfronteerd, was dat het uitermate moeilijk was na te gaan welke van de door Meijers nagelaten teksten als de meest recente moesten worden aangemerkt. Weliswaar kon worden beschikt over het archief van de Staatscommissie, waarin alle teksten van Meijers waren opgeslagen in de vorm zoals zij destijds aan de Commissie waren aangeboden, maar voor de teksten die hij naar aanleiding van de daarop volgende besprekingen had opgesteld, was men aangewezen op Meijers' particuliere aantekeningen. Deze nu, bevonden zich niet in een bijzonder geordende staat. Meijers studeerde namelijk temidden van een ontelbaar aantal boeken, schots en scheef door zijn kamer verspreid, op de tafel, de verwarming en de grond enz., en schreef op alles wat hem daarbij enigszins van dienst kon zijn, zoals de achterkant van de Nederlandse Jurisprudentie, luciferdoosjes, omslagen van tijdschriften en dergelijke. ${ }^{11}$ Bovendien had hij, omdat hij over een uitstekend geheugen beschikte, ook nooit de moeite genomen een archief of een enigszins compleet dossier aan te leggen. Typerend is, dat hij pas na zijn 65e een agenda aan-

9. Notulen van de $82 \mathrm{e}$ vergadering van het Driemanschap d.d. 3 oktober 1955.

10. In deze paragraaf zal voornamelijk aandacht worden besteed aan de ontwikkeling van en het werk aan het voorontwerp voor Boek 5. Weliswaar zijn er overeenkomsten met het werk aan het Zesde Boek, maar omdat de werkwijze van het Driemanschap in de tijd belangrijk is veranderd, leek het wenselijk de beschrijving van het ontwikkelingsproces van beide boeken gescheiden te houden. De bij dit hoofdstuk gevoegde bijlage I geeft een globaal overzicht van de veranderingen die het Driemanschap in Meijers" werk heeft aangebracht. De tekst van deze en de volgende paragraaf is tegen de achtergrond van die bijlage geschreven.

11. In zijn rede ter gelegenheid van het door de Katholieke Universiteit van Leuven verleende eredoctoraat (V.P.O. I, p. 176) stak Meijers de draak met zichzelf en gebruikte hij dit beeld om de consequenties van het loslaten van de codificatiegedachte te illustreren. Dergelijke juristen zouden volgens Meijers ten onrechte hun speurzin vereenzelvigen met kennis van het recht. 
schafte, nadat hij vergeten was een tentamen af te nemen. Het is de verdienste van Franken geweest, dat hij, door tekst na tekst geduldig met elkaar te vergelijken, na een half jaar speurwerk de "vermoedelijk laatste versie" van de concepten voor de Boeken 6-9 aan het Driemanschap en de andere medewerkers kon presenteren. ${ }^{12}$

Op 28 juli 1954 kwam het Driemanschap, toen nog zonder medewerkers, voor het eerst bijeen. Franken en Polak zouden drie weken later, op 23 augustus, voor het eerst aanwezig zijn, terwijl mevrouw Fischer op 2 september haar opwachting kwam maken. Vanaf dat moment werd ook daadwerkelijk een begin gemaakt met het op schrift stellen van het besprokene. Fokkema tenslotte, zou op 20 oktober 1955 als medewerker worden aangetrokken. Het werk aan Boek 5 O.M. was toen al afgerond.

Met ingang van 30 augustus 1954 kreeg het Driemanschap de beschikking over een kamer in het gebouw van de Hoge Raad aan het Plein, na de eerste vier bijeenkomsten afwisselend bij één van de Driemannen thuis te hebben gehouden. Het Driemanschap zou daarna nog twee maal verhuizen. Op 28 mei 1956 vestigde men zich aan het gebouw op de Lange Voorhout 16, waarna op 26 augustus 1959 een kamer in het huis aan het Emmapark 1 werd betrokken. Het werk aan de concepten voor de Boeken 5 en 6 O.M. speelde zich dus volledig buiten het Departement af. Om die reden hadden het Driemanschap en zijn medewerkers ook de beschikking over een uitgebreide verzameling boeken, die geheel los stond van de bibliotheek van het Ministerie van Justitie. Volgens $\mathrm{mr}$. Th.B. ten Kate, die van december 1958 tot januari 1961 de noten bij Boek 6 controleerde, waren veel van de ruim 400 werken, artikelen en wetboeken waarnaar in de toelichting werd verwezen, daar te vinden.

De besprekingen in het Driemanschap over Boek 5 begonnen op 28 juli 1954; Op 2 mei 1955, zevenenvijftig vergaderingen later, kon onder het overleg een streep worden gezet en ging het voorontwerp naar de drukker. Van deze zevenenvijftig vergaderingen heeft het Driemanschap er ongeveer zevenenveertig geheel of gedeeltelijk besteed aan het doorspreken van het voorontwerp voor Boek 5. De overige vergaderingen waren gewijd aan het Regeringsontwerp voor de Inleidende titel en de Boeken 1-4 en het advies van de Raad van State daarover. Aan dit werk, dat buiten de opdracht van het Driemanschap viel, moest men ingevolge een instructie van Donker, die verlangde dat het Regeringsontwerp uiterlijk op 15 oktober 1954 zou verschijnen, voorrang geven. ${ }^{13}$

Een aantal van zevenenveertig vergaderingen lijkt niet veel, zeker indien het wordt afgezet tegen de tweehonderdvijfendertig die het Driemanschap nog nodig zou hebben voor het voltooien van Boek 6 O.M. Toch kan al uit dit getal worden afgeleid dat de besluitvorming in het Driemanschap niet erg snel verliep. Meijers had namelijk aan elf vergaderingen genoeg gehad om zijn concept voor Boek 5 O.M. door de - voltallige - subcommissie Burgerlijk Recht te loodsen.

12. Deze "inhoudsopgave van stukken, opgesteld vóór het overlijden van prof. Meijers", die exclusief betrekking had op Boek 6, verscheen op 26 januari 1955 zelfs in druk.

13. Drion rapporteerde over de Inleidende titel, Eggens over $\mathrm{nr} 1$ en 2 en Boek 2, De Jong over nr $1-10,12-14,25$ en Boek 3. Het overige gedeelte van het advies van de Raad van State nam het Departement voor zijn rekening. Daarnaast heeft het Driemanschap in deze periode drie vergaderingen besteed aan het doorspreken van w.o. 1430 (opheffing van de handelingsonbekwaamheid van de gehuwde vrouw). 
De bestudering van de nagelaten concepten van Meijers voor Boek 5 verliep volgens een vaste procedure. Deze procedure kwam erop neer dat elk van de Driemannen een bepaalde titel of onderwerp onder zijn hoede nam, daarover een rapportje schreef en dat dan vervolgens in het Driemanschap bracht. Daarop vonden dan één of meer besprekingen plaats, waarbij, afhankelijk van de uitkomsten van het overleg, het concept werd goedgekeurd of tot verdere bestudering werd besloten. Dit proces herhaalde zich totdat de tekst en toelichting een zodanig stadium hadden bereikt, dat het Driemanschap het verantwoord vond de concepten titelsgewijs aan éen of meer externe deskundigen - meestal leden van de Staatscommissie - voor te leggen.

Uit het archief blijkt, dat Jan Drion, daarin bijgestaan door Eggens, het leeuwedeel van de titels 5.1 - 5.5 voor zijn rekening heeft genomen. Eggens zelf heeft zich vooral beziggehouden met titel 5.6, terwijl De Jong tekende voor de titels 5.7, 5.8 en 5.9. De Driemannen werden bij dit werk geassisteerd door Polak en Franken, die speciaal waren belast met het schrijven van concept-toelichtingen bij de door het Driemanschap voorgestelde tekstwijzigingen, maar die overigens tijdens de vergaderingen ook volledig recht van spreken hadden. Als rapporteur traden op: M.G. de Baat, P.H. Smits, C.H.F. Polak, A.P. Funke en M.H. Bregstein. Mr. Plantenga voorzag het Driemanschap namens het Ministerie van Financiën van advies. ${ }^{14}$

Zodra een rapportage gereed kwam, werd door het Driemanschap een datum bepaald om het concept en de kritische kanttekeningen daarop met de rapporteur te bespreken, waarna meestal nog een aantal tekstrevisies van beperkte betekenis werd voorgesteld, gevolgd door evenzovele besprekingen in het Driemanschap. Deze fase nam niet al te veel tijd in beslag, omdat het concept voor Boek 5 goed in elkaar zat en slechts op een aantal punten afweek van het door Meijers nagelaten werk. Prof.mr. J.H. Beekhuis, de latere Regeringscommissaris voor Boek 5, zei daarover: "De Staatscommissie kon zich vinden in het resultaat wat later in de groene Boeken werd neergelegd. Van het Zakenrecht weet ik dat zeker." 15

Tenslotte werd een (nieuwe) drukproef gemaakt en kreeg het Departement als laatste gelegenheid opmerkingen te maken. ${ }^{16}$ Net zoals bij de eerste vier Boeken het geval was, nam ook ditmaal de B.W.-club deze taak op zich. Dit betekende dat ieder van de leden (in 1955 waren dat Polak, Belinfante, Franken, Van Ewijk, De Vries, Thijssen en mevr. Appelboom) een aantal "voorlopige opmerkingen" maakte bij het concept, die vervolgens op een verzamelnota werden geplaatst en in de B.W.-club werden besproken. Opmerkingen, die de instemming van de voltallige vergadering kregen, werden ter kennis van het Driemanschap gebracht, dat ermee mocht doen wat het nodig vond.

14. De opmerking in de aanbiedingsbrief (Parl. Gesch. Boek 5, p. 2), dat het Driemanschap bij het opstellen van Boek 5 "bij tal van onderwerpen een beroep heeft mogen doen op de kennis en ervaring van anderen", is, gelet op de intensiteit van het overleg en het aantal geraadpleegde personen, enigszins overtrokken, zeker indien men één en ander vergelijkt met Meijers' activiteiten op dit gebied.

15. Na het overlijden van Van Brakel in februari 1953, was Beekhuis lid geworden van de subcommissie Burgerlijk Recht en had hij in die kwaliteit ook verschillende besprekingen over de concepten voor Boek 5 O.M. meegemaakt.

16. Op de nog door Meijers verzorgde drukproeven had het Departement op verzoek van het Driemanschap overigens al eerder commentaar geleverd. 
In de praktijk betekende dit, dat, evenals bij Meijers het geval was, slechts een klein aantal opmerkingen van het Departement werd overgenomen, al was de invloed van de B.W.-club naar mijn indruk wel groter dan bij Meijers. Een anwijzing daarvoor is dat het Driemanschap er ruim de tijd voor nam - ongeveer twee maanden - om alle opmerkingen door te spreken. Meijers had daar bij de eerste vier Boeken maar een paar dagen voor nodig gehad.

\section{b. oorzaken voor vertraging}

Hierboven is uiteengezet, dat Meijers met het werk aan Boek 5 O.M. dusdanig was gevorderd, dat hij het in de loop van juli 1954 had kunnen voltooien. Zijn ontwerp was zo goed als definitief, zij het dat het als gevolg van de inspanningen van de B.W.-club vermoedelijk nog wel enigszins van vorm zou zijn veranderd. Dat blijkt ook uit de volgende woorden van Donker, die zich op 12 juni 1954, minder dan twee weken voor Meijers' overlijden, tegenover enkele leden van de subcommissie Handelsrecht als volgt uitliet: "Het zal in September 1954 niet mogelijk zijn om, zoals aanvankelijk in de bedoeling lag, ontwerpen voor het gehele nieuwe Burgerlijk Wetboek bij de Tweede Kamer in te dienen, doch slechts ontwerpen voor de Inleidenden titel en de eerste vier Boeken. De ontwerpen van prof. Meijers voor het $5 \mathrm{e}$ en $6 \mathrm{e}$ Boek (Zakenrecht en Algemeen deel van het Verbintenissenrecht) worden in September 1954 gepubliceerd." 17

Toen het Driemanschap in functie trad, bestond op Justitie dan ook de verwachting dat de Driemannen ongeveer twee jaar nodig zouden hebben voor het voltooien van Meijers' concepten voor de Boeken 5 en 6 en voor het coördineren van het werk aan de onvoltooide voorontwerpen voor de Boeken 7, 8 en 9, waaraan, onder verantwoordelijkheid van het Driemanschap, door anderen werd gewerkt. Minister Donker, die van zijn collega Cals, Minister van Onderwijs, toestemming moest hebben om Drion tijdelijk te onttrekken van zijn universitaire verplichtingen, formuleerde het in de Ministerraad als volgt: "Het zal (..) dan nodig zijn dat beiden (Drion en De Jong) twee jaar worden vrij gemaakt. In de Hoge Raad zal dat mogelijk zijn, omdat er over twee jaar een vacature bij de raadsheren zal komen."

Daar kwam nog bij dat het Driemanschap een beperkte en daardoor overzichtelijke taak had, volgens Donker: "Niet omwerking van hetgeen door prof. Meijers is gereedgemaakt, maar afwerking daarvan is het doel. ${ }^{18}$

17. Notulen van de $114 \mathrm{e}$ vergadering van de subcommissie Handelsrecht. Zie ook handelingen Tweede Kamer 1954-1955, p. 2166, waar Donker onthult dat het in Meijers' bedoeling lag het tweede gedeelte van het ontwerp (Boeken 5-9) in oktober 1954 te publiceren: "Hoe groot de slag van het overlijden van prof. Meijers is, kan ik niet beter illustreren dan door mede te delen, dat volgens afspraken, die ik met hem had gemaakt, het B.W. in ontwerpvorm als ontwerp-Meijers voltooid zou zijn geweest omstreeks October van dit jaar."

18. Zitting Tweede Kamer 1954-1955, nr 3700, stuk nr 11, p. 3. Vergelijk ook de Memorie van Toelichting bij de Inleidende titel, ingezonden 4 november 1954 (Parl. Gesch. Alg. Deel, p. 141): ${ }^{n} B i j$ het overlijden van prof. Meijers lag de stof voor deze Boeken (5-9) voor een groot deel klaar in voorontwerpen. De familie Meijers heeft deze voorontwerpen gaarne ter beschikking van de Regering gesteld. (..) Naar ondergetekendes inzicht moeten die voorontwerpen, waarop gedeeltelijk toelichtingen in eerste tekst voorhanden zijn, tot voltooiing worden gebracht, zoveel mogelijk met handhaving 
Ook tegenover de Kamer liet Donker zich op dergelijke wijze uit, al wilde hij geen precieze termijn noemen. Zo werd in de Memorie van Antwoord bij de begroting voor 1955 opgemerkt: "Met betrekking tot het tijdstip, waarop voorstellen van de heren Drion, Eggens en Jong kunnen worden gepubliceerd, wil ondergetekende zich op het ogenblik liever nog niet begeven in het aangeven van een concreet tijdstip. Wel kan hij zeggen, dat er met kracht aan gewerkt wordt dit tijdstip zo spoedig mogelijk te doen aanbreken." ${ }^{19}$ Even later schreef Donker, dat hij ondanks het overlijden van Meijers er nog steeds naar streefde alle negen Boeken voor het einde van de parlementaire periode, dat wil zeggen vóór mei 1956, door de Tweede Kamer te laten afhandelen: "Naar zijn oordeel moet het streven blijven, dat dezelfde Kamer, die, door de behandeling van de vraagpunten en door de vaststelling van de conclusies daarop, een aantal betekenisvolle hoofdlijnen heeft getrokken, ook het geheel, dat op die hoofdlijnen is gebaseerd, ten einde behandelt. Hij houdt daarom voortdurend het oog op de afwerking van de nog onvoltooide Boeken en hij zal ook overigens al het mogelijke doen, opdat de wetsontwerpen voor het overblijvende gedeelte zo spoedig mogelijk worden ingediend. 20

Desondanks zou het Driemanschap nog bijna een jaar nodig hebben om Boek 5 te voltooien: Pas op 25 mei 1955 zou het voorontwerp officieel worden aangeboden. Bovendien was er nogal wat aandrang van Donker voor nodig geweest om het Driemanschap te bewegen het voorontwerp voor Boek 5 uit handen te geven. De notulen van de 4le vergadering van het Driemanschap van 7 februari 1955 vermelden: "Het Zakenrecht zal worden gepubliceerd vóór het Verbintenissenrecht omdat de Minister iets wil laten zien en het goed is dat tussen de publicatie van het groene Boek en het Regeringsontwerp geruime tijd ligt, waarin de wetenschap gelegenheid heeft zich te uiten." Franken zei daarover: "Boek 5 O.M. hebben we ingediend in de overtuiging dat we daar goed mee voor de dag konden komen, al hadden we er nog wel een half jaar aan kunnen werken."

Een eerste verklaring voor het feit dat het allemaal zoveel langer duurde, is dat het Driemanschap, ondanks hun duidelijk omschreven taak, al snel in de verleiding kwam een eigen stempel op het werk te drukken. Weliswaar werd, als gevolg van de voortdurende pressie van Donker, ten aanzien van Boek 5 een veel meer gereserveerde

18. $\rightarrow$

van de inzichten die prof. Meijers daarin heeft neergelegd. Het is dus niet ondergetekendes bedoeling, dat geheel nieuwe ontwerpen worden opgesteld voor het onvoltooid gebleven deel. Waar het op ankomt, is afwerking van de voorhanden stof (..). De weg tot succes zal slechts ten einde kunnen worden afgelegd, indien de door prof. Meijers getrokken richtlijnen gehandhaafd blijven en alle zeilen worden bijgezet."

19. Zitting Tweede Kamer 1954-1955, nr 3770, stuk nr 11, p. 2.

20. Zie ook handelingen Tweede Kamer 1954-1955, p. 2166 . Donker verklaarde daar onder meer: "Nu geloof ik wel te kunnen zeggen, dat het ten aanzien van de voorontwerpen van de laatste vijf Boeken wel te overzien is, wanneer die zullen verschijnen. Dat duurt uiteraard langer dan het geval was geweest, wanneer prof. Meijers die voorbereiding geheel voor zijn rekening had kunnen nemen. Aan de andere kant lijkt mij dat toch een te overziene zaak. (...) In het aanvankelijke schema was het inderdaad de bedoeling het nieuwe Burgerlijk Wetboek in vier jaar tot stand te brengen en dat zou misschien met behulp van prof. Meijers een heel eind zijn gelukt. $\mathrm{Nu}$ is de zaak natuurlijk anders komen te liggen, maar aan de andere kant zat er in het schema nog ruimte, want er was ook een jaar berekend voor de behandeling in de Eerste Kamer, dat gevoeglijk kan afvallen. ${ }^{n}$ 
houding ingenomen dan later met betrekking tot Boek 6 het geval zou zijn, maar dat neemt niet weg dat men bij haast elke titel wel iets deed. Er veranderde niet echt veel - het Driemanschap is uiteindelijk alleen op het vlak van de aanwas fundamenteel van de gedachten van Meijers afgeweken -, maar bij elkaar was het wel genoeg om voor het nodige oponthoud te zorgen. Zo werd bijvoorbeeld in titel 5.1 (Eigendom in het algemeen) een nieuwe en tot dan toe in de literatuur onbekende constructie bij de Voorste-stroom jurisprudentie bedacht, kreeg titel 5.2 (Eigendom van roerende zaken) een belangrijk gewijzigde "gevonden voorwerpen"-regeling, en werden in titel 5.3 (Eigendom van onroerende zaken) de uitgangspunten van het aanwas- en afslagrecht opnieuw in kaart gebracht en geformuleerd. ${ }^{21}$ Andere voorbeelden zijn het schrappen van de door Meijers opgestelde regeling van het onus publicum ${ }^{22}$ en de door het Driemanschap geïntroduceerde mogelijkheid bij overeenkomst mandeligheid te vestigen (art. 5.4.1 lid 2 O.M.). Allemaal zaken, die, zoals de onderstaande tabel leert, de nodige tijd en moeite hebben gekost.

Overzicht van het aantal keren dat een bepaalde titel of onderdeel daarvan in het Driemanschap ter sprake is gekomen;

Titel I Eigendom in het algemeen.

Titel II Eigendom van roerende zaken. 12

Titel III Eigendom van onroerende zaken. ${ }^{23} \quad 24$

Titel IV Bevoegdheden en verplichtingen van eigenaars van naburige erven.

Titel V Mandeligheid.

Titel VI Erfdienstbaarheden.

Titel VII Erfpacht en beklemming.

Titel VIII Opstal.

24

Titel IX Grondrente.

Titel X Appartementen.

24

21. Zoals uit het Nader Rapport op artikel 5.3.12 R.O. blijkt, heeft het Driemanschap bij het opstellen van het nieuwe aanwas-en afslagrecht de Staatscommissie voor de Waterstaatswetgeving voor advies benaderd. Merkwaardig is, dat Meijers zich in 1948 ook al tot die Commissie had gewend (vergelijk de aanbiedingsbrief bij de eerste vier groene Boeken). Het antwoord dat hij op zijn vragen ontving, was echter dusdanig vaag en verdeeld, dat hij besloot zelf met een regeling te komen. Zoals uit Bijlage I blijkt, zitten de artikelen 5.3.9-13 O.M. technisch nog beter in elkaar dan Meijers' concept. Het lijkt er dus op, alsof het Driemanschap in overleg met deze Commissie die stap heeft gedaan, die Meijers alléén nog niet doen kon.

22. Dit onderwerp, door Meijers geprojecteerd in titel 4, werd door het Driemanschap geschrapt "omdat een algemene regeling in het Burgerlijk Wetboek van de ten openbare dienste bestemde zaken de ondergetekenden minder gewenst is voorgekomen." (Parl. Gesch. Boek 5, p. 1). Vergelijk ook de toelichting bij artikel 5.3.8 O.M., waar wordt opgemerkt dat het onmogelijk is een algemene regeling op te stellen, die op alle onroerende zaken, die ten algemene nutte worden bestemd, toepasselijk is: "Het is daarom beter voorgekomen een algemene regeling achterwege te laten en te vertrouwen, dat een bijzondere wet tot stand zal komen zo dikwijls voor een nauwkeurig te omschrijven groep van zaken - men denke bijvoorbeeld aan de openbare wateren - in de praktijk blijkt dat aan een regeling behoefte bestaat."

23. Inclusief de 7 vergaderingen die werden gewijd aan de stof die door Meijers in Titel 4 (Zaken die aan de Staat toebehoren of die ten openbare dienste zijn bestemd) was geprojecteerd. 
Een tweede, eveneens belangrijke verklaring voor het feit dat het Driemanschap niet reeds na een maand of drie met het voorontwerp voor Boek 5 voor de dag kwam, was dat men sterk de neiging had het allemaal wat beter, diepgaander en uitvoeriger an te pakken dan Meijers. Men werkte als het ware in de overtreffende trap, vond het concept van Meijers in bepaalde opzichten onder de maat, wilde zijn werk op een hoger niveau brengen.

Een voorzichtige schatting is, dat voor ongeveer een kwart van alle bepalingen, ook die artikelen die naar het oordeel van het Driemanschap niet voor algehele omwerking in aanmerking kwamen, wel een nieuwe redactie is voorgesteld of althans overwogen. Waar Meijers nog wel eens genoegen wilde nemen met een blote verwijzing naar het Ontwerp-1898, vond het Driemanschap het gewenst zelf vormend op te treden, de materie verder te doordenken en daarvan ook verantwoording af te leggen in de toelichting. Heel karakteristiek daarvoor is, dat in één van de eerste versies van de aanbiedingsbrief voor Boek 5 O.M. werd gesteld dat men, omdat het groene Boek voortijdig moest worden losgelaten, "niet naar volmaaktheid heeft kunnen streven. ${ }^{24}$

Sprekende voorbeelden van deze tendens tot perfectionisme zijn de algemene inleiding bij Boek 5 over de essentie van het zakelijke recht, de indrukwekkende, maar voor een wetboek minder gebruikelijke uiteenzetting over de gedachten die bij het formuleren van het nieuwe aanwasrecht een rol hebben gespeeld en de gefundeerde beschouwingen over de mandeligheid. Maar ook aan de afzonderlijke artikelen werd het nodige gesleuteld, geperfectioneerd. Men zie artikel 5.1.2 lid 3, voortgekomen uit een diepgravende analyse van de verhouding tussen art. 5.1.1 lid 2 en art. 8 Inleidende titel, het in artikel 5.4.4 geïntroduceerde bijzondere onrechtmatigheidsbegrip en de reeds gememoreerde "Voorste Stroom"-bepaling. Veelzeggend is ook, dat als gevolg van de inspanningen van het Driemanschap de toelichting van de eerste vijf titels van eenendertig naar zesenveertig bladzijden groeide, ondanks het halveren van de titels 5.4 en 5.5 en het schrappen van de bepalingen omtrent het onus publicum.

Het merendeel van deze bepalingen en beschouwingen is technisch veel scherper geformuleerd dan bij Meijers het geval was. De keerzijde daarvan is echter dat zij soms tamelijk ver afstaan van datgene wat de praktijk nodig heeft. Want hoewel er zie de Bijlage - zeker onderwerpen zijn aan te wijzen waar dit retoucheren nuttig is geweest, zijn er toch ook voorbeelden te bedenken, waarbij men zich kan afvragen of het Driemanschap niet al te zeer in de ban van de perfectie is geraakt. Voor Polak was dit ook één van de redenen om het Driemanschap langzaam maar zeker de rug toe te keren en zich steeds meer te gaan toeleggen op de behandeling van lopende wetsontwerpen: "Het werk in het Driemanschap was juridisch gezien uiterst interes-

24. Vergelijk daarbij Meijers' opmerking in de algemene inleiding bij zijn ontwerp (Parl. Gesch. NBW, Algemeen Deel, p. 8): "Evenmin als enig wetboek geeft ook het ontwerp een volledige regeling van alle in het burgerlijk recht zich voordoende vragen. Dit is niet alleen een gevolg van de omstandigheid, dat men niet van te voren alles voorzien kan, maar ook van de opzet niet naar volledigheid te streven. Een teveel in bijzonderheden tredende regeling schaadt de overzichtelijkheid van het geheel en schept meestal meer kwesties dan zij oplost." 
sant, maar de debatten waren zwaar academisch en dat was niet hetgeen wat mij nu het meest boeide. ${ }^{25} 26$

Een derde, evenmin te onderschatten factor die het trage verloop van de werkzaamheden kan verklaren, is dat het Driemanschap tot zijn schade moest ervaren dat elke wijziging hier leidde tot een veelvoud aan wijzigingen daar. Want hoewel ruw geschat een derde van de teksten inhoudelijk geen wijziging van betekenis heeft ondergaan, is de toelichting als gevolg van de vele omzettingen soms wel ingrijpend veranderd. Onder verwijzing naar Bijlage I noem ik de artikelen 5.1.1, 5.1.3, 5.2.3-8, 5.2.11, 5.3.1-2, en de titels 5.4 en 5.5.

Dat deze factor van veel gewicht is geweest, illustreert het Nader Rapport, dat, naar aanleiding van vragen over het auteurschap van Boek 5, uitgebreid aandacht aan deze kwestie besteedt. Nadat de Minister heeft uiteengezet dat het concept van Meijers tamelijk ingrijpende veranderingen moest ondergaan, vervolgt hij: "Vanzelfsprekend heeft deze op verscheidene punten min of meer ingrijpende wijziging van het voorlopig concept van prof. Meijers tot een nog verder gaande wijziging van de voorlopige toelichting van Meijers genoodzaakt. Ook indien in een bepaalde titel van de tekst slechts enkele artikelen min of meer ingrijpend worden gewijzigd, kan in de meeste gevallen immers niet worden volstaan met het schrijven van een nieuwe toelichting bij deze artikelen, doch noopt de onderlinge samenhang tussen alle bepalingen van de titel - en in vele gevallen ook die tussen de onderscheidene titels tot een omwerking van de gehele toelichting bij de desbetreffende titel en in vele gevallen ook tot een herziening van verscheidene onderdelen van de toelichting bij andere titels. "27 Even later wordt nog duidelijker gesteld dat de herziening van de toelichting vrijwel geheel is te wijten aan omzettingen in de tekst: "De herziening van de toelichting (betreft) in zeer vele gevallen meer de - door een aantal tekstwijzigingen noodzakelijke - uitwendige rangschikking en de formuleringen van de toelichtende beschouwingen (..) dan de onderkenning van de nader toe te lichten vraagstukken en de bepaling van het daarbij in te nemen standpunt."

Naar mijn overtuiging hebben het Driemanschap en zijn medewerkers dan ook ten minste de helft van de werktijd besteed aan dit noodzakelijke, maar buitengewoon tijdrovende "reparatiewerk".

Een vierde factor, die een rol heeft gespeeld bij de tegenslag in de totstandkoming van het vijfde groene Boek, is dat men er met $z$ 'n drieën moest zien uit te komen. Omdat een duidelijke leider ontbrak, moest elk punt tot de bodem toe worden uitgepraat en bestond het risico dat men verstrikt raakte in onoplosbare verschillen van

25. Zie ook NJB 1992, Van Groene Boek (1954) naar invoering (1992), p. 28 e.v.: "Het kwam mij zeer gelegen dat ik mij daaraan (het werk in het Driemanschap) kon onttrekken doordat ik andere opdrachten kreeg."

26. De rechtsvergelijking, later een van de stokpaardjes, speelde nog geen grote rol. Er is mij maar één nota bekend, waarin wordt ingegaan op rechtsvergelijkende aspecten. Bovendien gold dat de aanwas, het enige punt van Boek 5 dat geheel nieuw is opgezet. Ook uit de lijst van aangehaalde werken en buitenlandse wetgeving die achterin boek 5 O.M. is opgenomen, blijkt niet van een bijzondere aandacht voor het rechtsvergelijkende aspect. De daarin gegeven opsomming komt grotendeels overeen met de nog door Meijers zelf gebruikte bronnen.

27. Parl. Gesch. Boek 5, p. 7. 
mening. "Die discussies over Boek 5 logen er niet om", volgens Polak. En omdat er veel punten werden aangeroerd, kostte dat veel tijd, ondanks dat er hard en intensief werd gewerkt en men tegen de klippen op vergaderde. Veelzeggend is, dat voor het opstellen van de aanbiedingsbrief voor Boek 5 O.M., een kleurloos stukje proza, uiteindelijk niet minder dan vier besprekingen nodig waren.

Het Driemanschap heeft deze moeilijkheden niet verzwegen. In de aanbiedingsbrief wordt opgemerkt: "Een werkzaamheid in commissoriaal verband heeft, naast grote voordelen, het nadeel, dat verschillen van mening blijven bestaan die niet kunnen worden opgelost. Het aantal gevallen, waarin de ondergetekenden een keuze moesten doen tussen twee of meer verdedigbare opvattingen, was zeer groot. Het stemt hen tot grote voldoening dat zij in de grote meerderheid van die gevallen tot een eenstemmig oordeel zijn gekomen. ${ }^{28}$

Dat er in deze tijd al sprake zou zijn geweest van strubbelingen tussen Eggens enerzijds en de Jong anderzijds, zoals later bij de bewerking van Meijers' concepten voor Boek 6, lijkt niet erg waarschijnlijk. De notulen bieden daarvoor althans geen duidelijke aanknopingspunten en uit de langzame, maar over het algemeen toch vrij gelijkmatige ontwikkeling van de afzonderlijke titels kan worden afgeleid dat erop dit punt geen bijzondere problemen zijn geweest. Ook moet worden bedacht dat Boek 5 voor een deel wortelde in het Ontwerp-1898, waaraan, ondanks zijn hoge leeftijd, niet elk gezag kon worden ontzegd. Bovendien bood Boek 5 waarschijnlijk minder aanknopingspunten voor fundamentele theoretische discussies dan het verbintenissenrecht.

Niet vergeten mag worden, dat ook de medewerkers in deze fase een bescheiden, zij het niet onbelangrijke rol hebben gespeeld. Want dat het Driemanschap ruim twee maanden nodig had om de opmerkingen van het Departement door te spreken, kan niet uitsluitend aan de werkwijze of de instelling van Drion, Eggens en De Jong worden toegeschreven. Polak en Franken waren zowel medewerker van het Driemanschap als lid van de Departementale B.W.-club. Hun aandeel in het werk aan het nieuwe B.W. gaf hen ten opzichte van de andere leden van de B.W.-club een zeker overwicht. Daarom kon het gebeuren, dat standpunten, die binnen het Driemanschap niet meer ter discussie stonden, maar waartegen Polak of Franken hun bedenkingen hadden, met steun van de B.W.-club opnieuw op de agenda van het Driemanschap werden geplaatst. En dat hield op, leidde er soms toe dat het debat van voren af aan begon. Meijers daarentegen, communiceerde uitsluitend schriftelijk. Uitsluitend aan de door hem gecorrigeerde drukproeven kon worden afgelezen in hoeverre hij akkoord was gegaan met de opmerkingen van het Departement. Dat werkte natuurlijk een stuk gemakkelijker.

Een laatste verklaring, zij het een naar mijn mening minder belangrijke, is dat het Driemanschap zich moest inwerken in het concept van Meijers. Weliswaar was de behandeling van het concept voor Boek 5 in de Staatscommissie pas begin oktober 1953 afgesloten, zodat het onderwerp nog vers in het geheugen lag, maar men was er natuurlijk niet zo vertrouwd mee als Meijers dat als ontwerper was geweest. Omdat soms tamelijk ingrijpende wijzigingen werden voorgesteld, moest bovendien rekening worden gehouden met de reeds gepubliceerde Boeken. De aanbiedingsbrief vermeldt

28. Parl. Gesch. Boek 5, p. 1. 
in dit verband: "Bij de samenstelling van het ontwerp voor het Vijfde Boek is gestreefd naar een volledige aansluiting bij de reeds gepubliceerde vier Boeken, niet alleen ten aanzien van de inhoud, doch ook ten aanzien van taal en stijl. (..) Dat er oneffenheden zullen blijken te zijn overgebleven, is intussen wel te verwachten; alleen de ontwerper zelf kon het ontwerp van de eerste vier Boeken op ieder ogenblik in al zijn bijzonderheden voor ogen hebben. "29

Dat het Driemanschap de plank inderdaad wel eens heeft misgeslagen, blijkt uit het besluit titel 5.10 (Appartementsrechten) niet in Boek 5 O.M. op te nemen, maar in plaats daarvan te volstaan met een verwijzing naar het Regeringsontwerp voor Boek 5. Het argument daarvoor was dat Meijers het niet eens zou zijn geweest met de constructie die was neergelegd in de in 1952 in werking getreden Appartementenwet (Wet van 20 december 1951, Stb. 571) ${ }^{30}$ Hierbij is kennelijk over het hoofd gezien, dat Meijers het weliswaar niet eens was met het wetsvoorstel dat oorspronkelijk ten grondslag lag aan de Appartementenwet, maar dat hij zich wel degelijk kon vinden in het uiteindelijke resultaat. ${ }^{31}$ Het was namelijk mede aan zijn opstelling te danken dat in 1951 werd gekozen voor de constructie van de mede-eigendom, in plaats van de volle eigendom van de privé-gedeelten, waarop het oorspronkelijke ontwerp was gebaseerd. $^{32}$

In de aanbiedingsbrief geeft het Driemanschap nóg een verklaring voor het tegenvallend verloop van de werkzaamheden aan Meijers' concept voor Boek 5. Het is zelfs het argument dat als eerste wordt genoemd en waarop veel nadruk wordt gelegd: De onvoltooidheid van Meijers' werk. Zo wordt opgemerkt dat het concept van Meijers "nog ver verwijderd was van de definitieve gestalte, die het in handen van prof. Meijers zou hebben gekregen. De ondergetekenden hebben dan ook in het concept op tamelijk ingrijpende wijze veranderingen moeten aanbrengen. ${ }^{n 3}$ Ten overvloede wordt hieraan toegevoegd, dat, in verband met het ingrijpend karakter van deze wijzigingen, ervan wordt afgezien aan te geven op welke plaatsen van het concept van Meijers is afgeweken: "Anders zou een concept, dat daarvoor niet bestemd was, aan de openbaarheid moeten worden prijsgegeven."

\section{Parl. Gesch. Boek 5, p. 1.}

30. Notulen van de 39e vergadering van het Driemanschap d.d. 31 januari 1955.

31. Zie $\S 2$ van de algemene inleiding bij de eerste vier groene Boeken (Parl. Gesch. Algemeen Deel, p. 124) waar Meijers zijn voornemen om de wettelijke regeling van 1951 met slechts geringe wijzigingen over te nemen, aankondigt en motiveert.

32. Zie R.F.H. Mertens, Appartementsrecht en de welstandsbepalingen, Deventer 1989, p. 16 e.v. Dat Meijers in de gelegenheid werd gesteld zijn oordeel te geven op het oorspronkelijke ontwerp, opgesteld door Beekhuis, Scholten en Schepel, kwam doordat in het Voorlopig Verslag de veronderstelling werd uitgesproken dat het ontwerp Meijers' instemming had. Aangezien het wetsvoorstel echter was opgesteld voordat Meijers zijn opdracht kreeg en Meijers er dus niet in gekend was, was deze opmerking voor Minister Wijers aanleiding alsnog het oordeel van Meijers te vragen. Deze nu bleek grote kritiek te hebben. Hij vond het ontwerp te gedetailleerd en ontkende bovendien dat een "flat" object van eigendom kon zijn. Om een conflict te voorkomen werd daarom als derde partij de Staatscommissie gehoord, die na ampel beraad enkele bepalingen vereenvoudigde en wat de dogmatische kant betreft het tussenstandpunt koos door zich uit te spreken voor een stelsel van mede-eigendom.

33. Parl. Gesch. Boek 5, p. 1. 
Hiervoor is reeds aangegeven, dat deze voorstelling van zaken weinig in overeenstemming met de werkelijkheid is. ${ }^{34}$ Het enige wat kan worden gezegd, is dat de tekst van Boek 5 grotendeels van Meijers afkomstig is en dat de toelichting in belangrijke mate door het Driemanschap is gemaakt. Maar zelfs die opmerking geeft nog een vertekend beeld, omdat, zoals ik reeds aanstipte, veel van de door het Driemanschap aangebrachte wijzigingen een gevolg waren van de omzettingen die men op diverse plaatsen aanbracht, zonder dat ze inhoudelijke veranderingen bevatten. Dat het Driemanschap zich van deze vertekening ook wel bewust was, kan worden opgemaakt uit de volgende passage uit de notulen van het Driemanschap. Wanneer Drion zijn eerste concept voor de aanbiedingsbrief heeft voorgelezen, waarin de verdiensten van Meijers voor Boek 5 nog lager worden aangeslagen, vat Fischer de slotsom van de daarop volgende discussie als volgt samen: "Het is, politiek gezien, beter iets minder de nadruk te leggen op afwijkingen van het concept van Meijers. Van zijn gedachten is men ook slechts op enkele punten afgeweken (aanwas). ${ }^{35}$

Deze opmerking was niet nieuw. Toen de Staatscommissie voor de Waterstaatswetgeving het concept van Meijers voor de aanwas voor advies kreeg voorgelegd, deed Drieman De Jong de leden daarvan het volgende verzoek: "Het ontwerp 5e Boek (..) is in de nalatenschap van prof. Meijers aangetroffen. Deze beschouwde het ongetwijfeld niet als een definitief ontwerp. Desondanks vraagt spreker de vertrouwelijkheid zorgvuldig in acht te nemen, daar het t.z.t. nodeloos complicaties zou verwekken, indien bekend werd, wat de tekst van prof. Meijers was en wat de wijzigingen van het Driemanschap zijn. ${ }^{\text {"36 }}$

\section{Het werk aan Boek 6 O.M.}

\section{a. organisatie en werkwijze}

Nadat op 25 april 1955 de drukproeven voor Boek 5 O.M. voor de laatste maal waren gecorrigeerd, zette het Driemanschap zich aan de afwerking van Meijers' concepten voor het verbintenissenrecht. Op 2 mei werd een plan de campagne opgesteld. De notulen vermeldden: "Boek 6 wil men afdelingsgewijs bespreken. Het Departement zou reeds opmerkingen kunnen inzenden op de laatste tekst van Meijers. Elke afdeling moet na bespreking worden gedrukt en op het geheel komt men pas terug als alle afdelingen zijn behandeld. Bij die laatste behandeling, waarbij het vooral om technische kwesties zal gaan, kan het Departement wederom opmerkingen inzenden."

Tevens nam men zich voor geregeld een beroep te doen op de subcommissie Burgerlijk Recht van de Staatscommissie, waarvan Drion inmiddels voorzitter was

34. Zie in dit verband ook de discussie tussen Zonderland en Fischer-Keuls in NJB 1974, p. 14081410. Fischer schrijft daar (p. 1410) dat, met uitzondering van het concept voor Boek 5, de achtergelaten stukken van Meijers nog geenszins de vorm van een min of meer definitieve redactie hadden bereikt: "Bij Boek 5 (..) was het concept van Meijers daarvoor bij zijn dood vrijwel voltooid."

35. Notulen van de 55e bespreking van het Driemanschap van 6 april 1955.

36. Notulen van de Staatscommissie voor de Waterstaatswetgeving van 13 november 1954. 
geworden. ${ }^{37}$ Omdat het naar de mening van het Driemanschap praktisch onmogelijk was het gehele ontwerp met de voltallige subcommissie door te nemen, besloot men de werkwijze toe te passen, die Meijers in de latere jaren volgde. "Zodra een voorlopig ontwerp van een titel of afdeling gereed is", zo is in een medio 1955 aan de leden van de subcommissie gericht schrijven te lezen, "zal daarvan een drukproef worden gemaakt, die aan alle leden van de subcommissie vertrouwelijk zal worden toegezonden. Het Driemanschap stelt grote prijs op de opmerkingen, die de leden naar aanleiding van deze concepten zullen willen maken. Bovendien zal voor elk onderwerp afzonderlijk aan één of meer leden van de subcommissie worden verzocht het concept grondiger te bestuderen en daarover schriftelijk rapport uit te brengen. ${ }^{38}$

Dat het de Driemannen ernst was, blijkt hieruit dat de subcommissie Burgerlijk Recht bij K.B. van 11 oktober 1955, $\mathrm{nr}$ 49, op voorstel van het Driemanschap werd uitgebreid met de heren M.G. de Baat (Unilever) en P.H. Smits (H.R.), die eerder al over de concepten voor Boek 5 O.M. hadden geadviseerd. Ter motivering werd aangevoerd: "Zij (het Driemanschap) gevoelen behoefte voor enkele onderwerpen het oordeel van de subcommissie te vragen. Gezien het feit dat zijzelf lid zijn van de subcommissie, die het gevraagde oordeel moet geven, houden zij de samenstelling ervan te beperkt om tot een weloverwogen oordeel te kunnen komen." ${ }^{39}$

Zoals aangegeven, nam elk van de Driemannen éen of meer titels of afdelingen van Boek 6 onder zijn hoede. De werkzaamheden waren niet erg gelijk verdeeld. Drion kreeg met de titels 6.2 (Overgang van vorderingen en schulden) en 6.3 (Onrechtmatige Daden) de moeilijkste, maar tevens ook de meest aantrekkelijke onderwerpen in handen, Eggens daarentegen was met "kleintjes" als 6.1.3 en 6.1.4 (Alternatieve respectievelijk voorwaardelijke verbintenissen) enigszins onderbedeeld.

Hier volgt een overzicht van de werkverdeling in het Driemanschap.

37. De benoeming van Drion vond plaats bij K.B. van 17 februari 1955. Cleveringa werd bij hetzelfde besluit benoemd tot algemeen voorzitter van de Staatscommissie. De Jong zou Cleveringa bij K.B. van 4 september 1962, nr 25, opvolgen; Drion werd in organisatorisch opzicht niet als ideale voorzitter gezien.

38. De brief vervolgt: "Het Driemanschap stelt zich voor de definitieve teksten vast te stellen na mondeling overleg met de rapporteurs. Uiteraard zullen de rapporteurs het als een bezwaar ondervinden, dat zij een concept moeten beoordelen zonder te weten hoe samenhangende onderwerpen zullen worden geregeld. Dit bezwaar is helaas niet te ondervangen daar het Driemanschap voor tal van titels voorlopig niet met een ontwerp gereed zal zijn. Tenslotte zal het Driemanschap, gelijk ook thans reeds gebeurt, een aantal zeer dubieuze vragen aan de gehele subcommissie voorleggen."

39. Vergelijk ook het antwoord van Minister Donker naar aanleiding van Kamervragen over de verhouding tussen het Driemanschap en de Staatscommissie: "Drion, Eggens en De Jong zijn leden van de Staatscommissie. De samenwerking tussen het Driemanschap en de Staatscommissie is dus gewaarborgd en de door prof. Meijers ingeslagen weg blijft dus gevolgd. Daaraan kan nog worden toegevoegd, dat het Driemanschap, dat thans bezig is met Boek 6 (Verbintenissen in het algemeen), zich voorstelt over bepaalde kwesties overleg te plegen met de betrokken subcommissie uit de Staatscommissie onderscheidenlijk met één of meer leden van de Staatscommissie." (Zitting Tweede Kamer 1955-1956, nr 3766, stuk nr 5, p. 1 en nr 4100, stuk nr 10, p. 6.) 
Titel 1. Verbintenissen in het algemeen ${ }^{40}$

Afd. 1 Verb. naar burgerlijk recht en natuurlijke verb.

Afd. 2 Hoofdelijke en ondeelbare verbintenissen

Afd. 3 Alternatieve verbintenissen

Afd. 4 Voorwaardelijke verbintenissen

Afd. 5 Verbintenissen onder tijdsbepaling

Afd. 6 De nakoming van verbintenissen

Afd. 7 De gevolgen van het niet-nakomen ener verbintenis

Afd. 8 Het tenietgaan van verbintenissen

Titel 2. Overgang van vorderingen en schulden
Eggens

Drion

Eggens

Eggens

Eggens

De Jong

De Jong

De Jong

Drion

\section{Titel 3. Onrechtmatige Daden}

Afd. 1 Algemene bepalingen

Drion

Afd. 2 Bijzondere onrechtmatige daden

Drion

Titel 4. Andere verbintenissen uit de wet

Afd. 1 Zaakwaarneming

Afd. 2 Onverschuldigde betaling

Eggens

Afd. 3 Ongerechtvaardigde verrijking

Drion

Drion

\section{Titel 5. Overeenkomsten in het algemeen}

Afd. 1 Algemene bepalingen

Afd. 2 Het tot stand komen van overeenkomsten

Afd. 3 Gevolgen van overeenkomsten

Eggens

De Jong

Afd. 4 Wederkerige overeenkomsten

Eggens

Eggens

Evenals bij Boek 5 het geval was, bestond de eerste activiteit van de Driemannen hierin, dat ieder van hen een tekst in studie nam, daarbij - indien nodig - een aantal kanttekeningen maakte, om deze vervolgens aan de anderen voor commentaar te doen toekomen. Vaak bleef het daar dan bij en kon het onderwerp op de agenda van één van de eerstvolgende vergaderingen worden bijgeschreven. Het gebeurde echter ook wel dat een actieve nota-wisseling volgde, voordat de standpunten voldoende waren uitgekristalliseerd om de zaak plenair aan de orde te stellen.

40. Deze indeling, gebaseerd op de door Meijers gehanteerde systematiek, wijkt enigszins af van die, neergelegd in het voorontwerp voor Boek 6 . Het Driemanschap heeft aan de pluraliteit van schuldeisers namelijk een afzonderlijke afdeling gewijd (afdeling 6.1.3), ontwierp een aparte regeling voor het schuldeisersverzuim (afdeling 6.1.7), bracht de bepalingen over verbintenissen onder tijdsbepaling onder in de afdeling nakoming van verbintenissen (afdeling 6.1.6) en creëerde een afzonderlijke afdeling voor de bepalingen over de verplichting tot schadevergoeding (6.1.9), bij Meijers opgenomen in de afdeling over de gevolgen van de niet-nakoming. Daarnaast werd de afdeling bijzondere onrechtmatige daden geschrapt. 
Deze kanttekeningen, ook wel "glossen" genaamd, waren over het algemeen niet erg diepgaand. Het was een eerste indruk, een voorlopige oriëntatie op de teksten van Meijers, mede ter voorlichting van de andere leden van het Driemanschap. Men vroeg zich heel in het algemeen af wat Meijers met een bepaalde tekst bedoelde, welk systeem aan de onderzochte artikelen ten grondslag lag, of een andere wijze van zeggen niet zuiverder was. Van werkelijke tekstkritiek was nog geen sprake.

Een voorbeeld. Op 30 juni 1955 verschijnt een aantal glossen van De Jong over het concept van Meijers voor titel 6.3. Eén van zijn opmerkingen heeft betrekking op de door Meijers ontworpen regel met betrekking tot de aansprakelijkheid voor schade, veroorzaakt door zaken. Het is, zo blijkt uit de kanttekening, De Jong een raadsel waarom Meijers niet eenvoudig gesproken heeft over "gevaarlijke zaken" in plaats van "een zaak, waarvan het bekend is dat zij een bijzonder gevaar oplevert". De Jong schrijft dan: "Ik kan mij voorstellen, dat de gedachtegang ongeveer als volgt is geweest. Het moet worden voorkomen, dat het proces begint met een discussie en een bewijslevering over de vraag of de concrete zaak die de schade veroorzaakt heeft, gevaarlijk is of niet. Voor de toepassing van het artikel is het nodig en voldoende, dat de zaak behoort tot een soort van zaken, waarvan de gevaarlijkheid vaststaat. Betrekt men de eis van gevaarlijkheid op het genus en niet op de concrete zaak, dan is gewoonlijk geen bewijslevering nodig. De rechter kan meestal uit eigen wetenschap vaststellen of zaken van een bepaalde soort gevaarlijk zijn en ieder geval kan een deskundige zich daarover uitspreken zonder dat hij er enig onderzoek voor behoeft in te stellen." Zijn slotsom is: "Of men deze vereenvoudiging bereikt door in de wet te zetten, dat het een zaak is, waarvan het "bekend" is, dat zij bijzondere gevaren oplevert, betwijfel ik. Beter lijkt het mij om in de toelichting aan de rechter een vingerwijzing te geven, dat de uitbreiding van dit artikel tot andere zaken dan motorrijtuigen en machinerieën groepsgewijze moet geschieden."

De bespreking van Meijers' concepten en de daarover verschenen opmerkingen, kanttekeningen en nota's luidde de tweede fase van het werk aan Boek 6 O.M. in. Omvang en intensiteit van deze besprekingen waren nogal verschillend. Soms was het Driemanschap er al na een paar vergaderingen uit en besloot men dat de verantwoordelijke Drieman het concept óf op een aantal punten moest aanpassen, of compleet diende om te werken, soms ook lagen de standpunten verder uiteen en kostte het veel tijd voordat overeenstemming kon worden bereikt over de te volgen gedragslijn. Vooral wanneer het vragen betrof, waarover Meijers nog geen definitieve beslissing had durven nemen, of kwesties waarover in rechtstheoretisch opzicht verschillend kon worden gedacht, kon dat soms wel enige maanden duren. Dat betekende dat zo'n afdeling of titel regelmatig terugkwam in het Driemanschap en dat men elkaar tussen de vergaderingen door bestookte met nota's en tegen-nota's, amendementen, proeven van redactie en andersoortig commentaar.

Zo waren er vijftien vergaderingen (of delen daarvan) nodig voor het doorspreken van Meijers' concept voor afdeling 6.1.7 (niet-nakoming) en de naar aanleiding daarvan verschenen commentaren, besteedde men twaalf vergaderingen aan afdeling 6.1.8 (tenietgaan van verbintenissen), werd titel 6.3 (Onrechtmatige Daden) in tweeëntwintig vergaderingen ontleed en zouden de wederkerige overeenkomsten (afd. 6.5.4) veertien maal de revue passeren. 
Als deze fase was afgesloten, was het de taak van de Drieman om, met inachtneming van de door het Driemanschap uitgezette lijnen en met gebruikmaking van inmiddels goedgekeurde voorstellen, een eerste concept-tekst op te stellen. Vaak bleef dit beperkt tot het redigeren van de tekst alleen, het schrijven van de toelichting was iets dat in een later stadium gebeurde, meestal nadat de tekst door het Driemanschap was goedgekeurd.

$\mathrm{Bij}$ het formuleren van deze tekstvoorstellen, die in gestencilde vorm verschenen, maakten de Driemannen gebruik van de diensten van de medewerkers. Fokkema zei daarover: "Wij maakten als assistenten vaak voorstudies, ook vaak met een rechtsvergelijkend karakter, en dan kwam er een ontwerp dat óf eerst door één van de Driemannen was gemaakt en daarna was doorgesproken met één van de medewerkers, of andersom." Schets na schets werd zo opgesteld, totdat de Drieman de tijd gekomen achtte zijn concept aan de andere leden ter goedkeuring voor te leggen. De fiattering in de algemene vergadering bleek echter bepaald geen sinecure. Er was dikwijls kritiek op de stijl, op de manier waarop de besluiten van de vergadering waren uitgewerkt. Regelmatig ook stuitte men op leemten of overlappingen, of waren inmiddels met betrekking tot andere afdelingen besluiten genomen, waarmee in het concept nog geen rekening was gehouden. Dit betekende dat er doorgaans nog wel enkele vergaderingen nodig waren, voordat een aangepaste versie aan de Staatsdrukkerij kon worden aangeboden.

Uitgesproken stroef verliep de ontwikkeling van de drie laatste afdelingen van Boek 6 O.M. Voor afdeling 6.5.2 (Het totstandkomen van overeenkomsten) waren ongeveer acht, voor afdeling 6.5.3 (Rechtsgevolgen van overeenkomsten) tien en voor afdeling 6.5.4 (Wederkerige overeenkomsten) waren maar liefst dertig besprekingen nodig, voordat de intussen ingrijpend gewijzigde concepten naar de drukker konden.

Wanneer het Driemanschap zover was, dat een drukproef kon worden gemaakt, dan werd daarmee aangegeven dat het concept een eerste graad van voldragenheid had bereikt. Dit betekende dat grote delen ervan niet meer behoefden te worden gewijzigd. Fokkema: "Op een gegeven moment werd gezegd "laten we hier maar eens een drukproef van maken'. Op die manier hield men de vaart erin en probeerde men als het ware uit te drukken 'dit moet het wel zo ongeveer zijn.'"

Er zijn inderdaad wel delen van Boek 6 aan te wijzen waar deze gedachte juist bleek en waarvan de behandeling na enig schaafwerk kon worden afgesloten. Voorbeelden daarvan zijn de afdelingen 6.1.1 (Algemene bepalingen), 6.1.4 (Alternatieve verbintenissen) en 6.1.5 (Voorwaardelijke verbintenissen), die, omdat zij tot weinig opmerkingen van de kant van het Ministerie en de Staatscommissie leidden, na eén of twee afrondende besprekingen van de agenda konden worden afgevoerd. Beide laatste afdelingen - de afronding van afdeling 6.1.1 zou als gevolg van andere, dringender werkzaamheden wat later plaatsvinden - zouden het dan ook reeds in Juni 1957 tot een tweede en definitieve drukproef brengen. Aanmerkelijk moeizamer echter ging het met de meeste andere delen van het voorontwerp voor Boek 6 . Het archief bevat verscheidene nota's van vele tientallen bladzijden over een bepaalde titel, afdeling of soms ook maar een enkele bepaling, met kritiek op de door het Driemanschap voorgestelde oplossingen, hun redactionele vormgeving of de behandeling van de stof. In de woorden van Fokkema: "Het resultaat was, dat er na de opmerkingen van het Departement weer wijzigingen in het ontwerp werden aangebracht, 
die vaak tot een tweede en derde drukproef leidden, die niet alleen een verbetering van zetfouten inhield. Bij zo'n eerste drukproef was het in feite nog lang niet af."

Een voorbeeld. Op 7 augustus 1956 gaat er - na negentien voorafgaande besprekingen - een eerste drukproef voor de tekst en toelichting van afdeling 6.1.7 (Schuldeisersverzuim) voor advies naar de Staatscommisie en het Departement. Een jaar later en drie besprekingen verder, is mevrouw Fischer onder leiding van Drion bezig deze drukproef om te werken naar aanleiding van de ontvangen rapporten. In 1958 en 1959 werkt het Driemanschap dit nieuwe concept, compleet met glossen, alternatieve tekstvoorstellen, nota's en tegennota's, in veertien vergaderingen door. Dan blijkt dat het nog steeds niet definitief is, want de slotsom van deze besprekingen is dat het concept opnieuw zal moeten worden omgewerkt. De nieuwe drukproef komt uiteindelijk medio 1960 in concept gereed, vier jaar nadat de adviezen waren ontvangen.

Dit voorbeeld lijkt wellicht enigszins extreem, maar dat is toch niet het geval. De drukproef van afdeling 6.5.2 (Het tot stand komen van overeenkomsten) en de nota van het Departement daarover werden in vijftien bijeenkomsten doorgewerkt, compleet met de daaropvolgende tussenteksten die, naarmate de besprekingen voortduurden, drukproef en nota als satellieten vergezelden. Het bespreken van de afdelingen 6.4.2 (Onverschuldigde betaling) en 6.4.3 (Ongerechtvaardigde verrijking), bepaald geen zware kost, vergde zes vergaderingen. Het ging dus uiterst moeizaam.

Zoals werd aangegeven, lag het in de bedoeling het werk aan het voorontwerp voor Boek 6 af te sluiten met een eindcorrectie. Daarbij zou het Departement nogmaals in de gelegenheid worden gesteld commentaar te leveren. Tevens zou dan ook plaats zijn voor het maken van opmerkingen over taal en stijl, een taak die bij de eerste vier groene Boeken was uitbesteed aan prof.dr. N.J.H. Royen, ten Departemente beter bekend als de "punten- en kommapater".

Voor zover kan worden nagegaan, heeft deze eindcorrectie nooit plaatsgevonden. Dat zou ook merkwaardig zijn, omdat de hierbovenbeschreven procedure zelfs voor wat betreft de eerdere stadia slechts ten aanzien van een aantal afdelingen volledig is gevolgd. Alleen de afdelingen 6.1.4 (Alternatieve verbintenissen) en 6.1.5 (Voorwaardelijke verbintenissen) hebben de gehele procedure doorlopen. Ten aanzien van de andere delen van Boek 6 O.M. heeft het Driemanschap, in verband met een chronisch gebrek aan tijd, stukken overgeslagen, zijn in vergaande mate procedurele vereenvoudigingen toegepast en zijn er zelfs tal van onderwerpen aan te wijzen die nooit behoorlijk zijn afgerond. Zo is, om een enkel voorbeeld te noemen, voor slechts vier afdelingen de Staatscommissie voor advies benaderd, werd over belangrijke delen van Boek 6, zoals titel 6.3 (Onrechtmatige daad) en afdeling 6.5.4 (Wederkerige overeenkomsten), nooit het oordeel van het Departement ingewonnen, en zou titel 6.3 - afgezien van een eerste, zeer voorlopig concept voor de tekst - de plenaire vergadering nooit halen.

Het groene Boek 6 was daarom bepaald niet af, toen het na zes jaar ploeteren in oktober 1961 aan Minister Beerman werd aangeboden. Het uiteindelijke produkt was volgens Franken een 'mixtum compositum': "Het bestond uit onderwerpen die in de eerste twee jaren van het Driemanschap waren behandeld en grondig waren doorgesproken in de plenaire vergadering, vervolgens uit onderwerpen die en petit comité in de drie opeenvolgende jaren waren behandeld en slechts summier werden doorgesproken in de plenaire vergadering om ze vervolgens al dan niet goed te keuren, en ten- 
slotte uit onderwerpen uit het laatste jaar die alleen en petit comité zijn besproken." Fischer-Keuls: "We hadden bepaald niet het gevoel "nu is het af, dit is gereed om snel te worden aangenomen.' Het aanbieden van het voorontwerp was mede bedoeld om de discussie in de literatuur op gang te brengen en de aandacht van de Kamer gevangen te houden."

Dat het Driemanschap, zoals Franken aangaf, na een jaar of twee afweek van de tot dan toe gehanteerde besluitvormingsprocedure en daarmee de eenheid van Boek 6 O.M. ondergeschikt maakte aan een "snelle" totstandkoming, kwam in de eerste plaats doordat het werk niet erg opschoot. Ondanks dat men twee á driemaal per week bijeenkwam en het archief als gevolg van de vele geproduceerde nota's en tekstvoorstellen een alarmerende omvang begon aan te nemen, was nauwelijks enige vooruitgang meetbaar. Zelfs voor eenvoudige zaken, zoals het beoordelen van Meijers' concepten en het formuleren van nieuwe uitgangspunten, had men veel, heel veel tijd nodig. In 1955 bijvoorbeeld, werden alleen Meijers' concept voor afdeling 6.1.6 (Nakoming van verbintenissen) en de titels 6.2 en 6.3 grondig doorgesproken, terwijl daarnaast aandacht werd besteed aan afdeling 6.1.8 (De gevolgen van het niet nakomen van een verbintenis). Aan een bespreking van de overige titels kwam het Driemanschap niet toe. In 1956 - er was toen al zo'n tachtig keer beraadslaagd over het concept voor Boek 6 O.M. - waren nog niet alle titels voor de eerste maal besproken. Dat zou pas in het voorjaar van 1957 het geval zijn. ${ }^{41}$ Illustratief is ook, dat De Jong, die het vermoedelijk allemaal veel te traag ging, zijn eerste concept voor de afdelingen 6.1.8 en 6.5.2 O.M. had opgesteld vóórdat de anderen ernaar hadden gekeken. Veelbetekend is verder, dat hij in september 1957 weer zou teruggaan naar de Hoge Raad ${ }^{42}$, omdat Drion en Eggens er geen kans toe zagen de door hem opgestelde stukken binnen een redelijke termijn te beoordelen. ${ }^{43}$

Een tweede factor die vermoedelijk een rol heeft gespeeld bij het besluit het werk aan Boek 6 O.M. omstreeks eind 1956 anders in te delen en niet langer elke bepaling of afdeling als het ware al pratend van de grond af op te bouwen, was de verwachting dat het Ministerie in de komende jaren in toenemende mate een beroep zou moeten doen op Drion in zijn kwaliteit van regeringscommissaris. De behandeling van de vaststellingswet van Boek 1 (Personen- en familierecht) was in 1957 namelijk aanstaande en het Voorlopig Verslag van de Tweede Kamer over Boek 2 (Rechtsper-

41. Men moet zich daar overigens geen overdreven voorstelling van maken. Van afdeling 6.5 .3 (Rechtsgevolgen van overeenkomsten) was begin mei 1957 slechts éen artikel besproken. En over afdeling 6.5.2 (Het tot stand komen van overeenkomsten) is tot maart 1958 uitsluitend schriftelijk van gedachten gewisseld.

42. Vergelijk de Memorie van Toelichting bij de begroting voor 1958, zitting Tweede Kamer 19571958, nr 4900, stuk nr 7 (art. 41): "Voor de Hoge Raad is 1 raadsheer minder begroot, aangezien de in vorige jaren extra toegestane plaats van een raadsheer, in verband met de werkzaamheden van mr. F.J. de Jong aan de totstandkoming van het nieuwe Burgerlijk Wetboek, is vervallen. De heer De Jong heeft nl. zijn normale taak van lid van de Hoge Raad weer hervat." In de Memorie van Antwoord werd dit antwoord als volgt gepreciseerd: "Mr. F.J. De Jong zal, ofschoon hij zijn werkzaamheden als lid van de Hoge Raad heeft hervat, voor zover de tijd hem dit zal toelaten, zijn medewerking blijven geven."

43. Hierbij ging het met name om de concepten voor afdeling 6.1.8 en 6.5.2 O.M. Het concept voor de niet-nakoming zou niet meer diepgaand worden besproken, de eerste lezing van afdeling 6.5 .2 zou pas een jaar na het vertrek van De Jong plaatsvinden. 
sonen) zou in juni van hetzelfde jaar verschijnen. In de nabije toekomst zouden daarbij ook nog de verslagen over de Boeken 3, 4 en 5 komen. Als gevolg van deze ontwikkeling zou er voor Drion minder tijd zijn om zijn aandeel in de totstandkoming van Boek 6 O.M. te leveren, terwijl er ook weinig gelegenheid zou overblijven om met de andere leden van het Driemanschap over de concepten voor Boek 6 van gedachten te wisselen.

Dat met name dit laatste een reël gevaar was, kan worden afgeleid uit de daling van het aantal vergaderingen van het Driemanschap wanneer Drion bij de Kamer is. In 1955 bijvoorbeeld, werd Drion tussen half juli en begin oktober in beslag genomen door de voorbereiding van de Memorie van Antwoord van de Inleidende titel en de mondelinge behandeling daarvan. In diezelfde periode vergaderde het Driemanschap maar dertien maal, hetgeen ongeveer de helft is van hetgeen gebruikelijk was. De parlementaire behandeling van Boek 1, die Drion van februari 1957 tot september 1957 in zijn greep zou houden, zou een nog groter beslag op zijn tijd leggen. In die periode zou het Driemanschap slechts acht keer bijeenkomen, waarbij in de maanden augustus en september in het geheel niet werd vergaderd. ${ }^{44}$ Daarbij kwam, dat Drion reeds de grootste moeite had het tempo van de anderen bij te benen. Zo zou hij bijvoorbeeld pas in november 1958 een zeer voorlopig concept voor de tekst van titel 6.3 presenteren, bijna twee jaar nadat het Driemanschap hem daartoe opdracht had gegeven. Er was dus ook in dat opzicht alle reden om naar vermindering van de vergaderlast te streven en de verantwoordelijkheid van elke individuele ontwerper te vergroten.

De derde en laatste reden om het ontwerpproces een nieuwe impuls te geven, werd vermoedelijk ingegeven door de komst van Minister I. Samkalden, die op 13 oktober 1956 in functie trad. De nieuwe Minister, een groot voorstander van een nieuw Burgerlijk Wetboek, was van oordeel dat het met het oog op de houding van de Kamer van het grootste belang was een nieuw tijdschema op te stellen, omdat hij wel inzag dat het oude schema van Donker niet langer te handhaven was. De voortdurende confrontatie met dat schema zou ten onrechte voedsel geven aan de gedachte dat het een illusie was de hercodificatie binnen een redelijke termijn tot een goed einde te brengen. Dit leidde ertoe dat hij met de Kamer de afspraak maakte elk jaar één Boek in openbare behandeling te brengen. ${ }^{45} \mathrm{Om}$ dat doel te bereiken was het echter noodzakelijk dat Boek 6 O.M. medio 1957 zou verschijnen, opdat Drion vanaf dat tijdstip al zijn aandacht en werkkracht zou kunnen geven aan de vaststelling van de Boeken 1

\footnotetext{
44. De openbare behandeling van Boek 2, die in juni 1958 plaatsvond, heeft vermoedelijk eveneens een negatieve invloed gehad op de vergaderfrequentie van het Driemanschap. In de twee maanden daarvoor werd namelijk slechts één keer vergaderd.

45. Letterlijk zei Samkalden: "Een tijdschema is dringend gewenst, omdat het ontbreken ervan tijdverlies medebrengt; Alleen bij aanwezigheid van een program kunnen de werkzaamheden tijdig worden geordend. Uitgaande dus van de noodzaak èn van een schema èn van een beperkte opzet daarvan, wil de ondergetekende voorshands daarin niet verder gaan dan Boek 6. (..) Om het genoemde doel te bereiken, zou het de ondergetekende geraden voorkomen als richtlijn aan te nemen, dat in de Kamer per zittingsjaar van deze parlementaire periode tenminste één Boek, ook in de mondelinge openbare behandeling, wordt afgehandeld." (zitting Tweede Kamer 1956-1957, nr 4500, stuk nr 9, p. 2).
} 
en 2 en aan het beantwoorden van de Voorlopige Verslagen van de Boeken 3 en 4 , die eveneens omstreeks die tijd werden verwacht. ${ }^{46}$

De nieuwe aanpak bestond hierin, dat elke Drieman, daarin bijgestaan door een medewerker, opdracht kreeg de onder zijn verantwoordelijkheid berustende onderwerpen van een concept-tekst en -toelichting te voorzien. Doordat de voorstudies en nota's, die de basis vormden voor elk ontwerp, alleen nog maar in het subgroepje aan de orde zouden komen, zou het uiteindelijke concept sneller in de vergadering kunnen worden gebracht. De plenaire vergadering, zo was de gedachte, behoefde het concept dan alleen nog maar op hoofdpunten te beoordelen en door te spreken. Voor een grondslagendiscussie zou geen plaats meer zijn.

Eén van de consequenties van deze nieuwe werkwijze was dat de medewerkers een belangrijk grotere verantwoordelijkheid kregen. Van assistent werden zij gepromoveerd tot wetsontwerper en bewerkte ieder van hen óf zelfstandig, óf onder leiding van een Drieman een aantal afdelingen of titels - de notuliste, mevrouw Fischer, niet uitgezonderd. Vooral na september 1957, toen De Jong was teruggekeerd naar de Hoge Raad en Drion zijn onderwijsverplichtingen weer voor een deel op zich zou nemen, kwam het regelmatig voor dat de medewerker de feitelijke ontwerper was en de Drieman de rol van begeleider vervulde. ${ }^{47}$ Franken zei over de situatie vóór 1957

46. Vergelijk de Memorie van Antwoord bij de begroting voor 1957: "De ondergetekende heeft zich, gelei op verkregen ervaring, voor ogen (..) gehouden, dat de stof, waarop een tijdschema betrekking heeft, moet kunnen worden overzien. Daarom heeft hij zich er tot dusver toe beperkt een schema op te stellen, dat aangeeft hoe de Boeken 1 tot en met 4 in deze parlementaire periode door de Tweede Kamer kunnen worden afgehandeld, wanneer Boek 6 kan worden ingediend (Boek 5 is ingediend) en of de schriftelijke behandeling van de Boeken 5 en 6 met de Tweede Kamer in genoemde periode kan worden voltooid." (zitting Eerste Kamer 1956-1957, nr 4500, stuk nr 88a, p. 9).

47. Dat de inbreng van de assistenten na 1957 snel belangrijker werd, blijkt uit het volgende schema dat de werkverdeling per 1 januari 1957 aangeeft.

Titel 1. Verbintenissen in het algemeen

Afd. 1

Afd. 2

Afd. $2 \mathrm{a}$

Afd. 3

Afd. 4

Afd. 5

Afd. 6

Afd. 6 a

Afd. 7

Afd. 8
Verbintenissen in het algemeen

Hoofdelijke verbintenissen

Pluraliteit van schuldeisers

Alternatieve verbintenissen

Voorwaardelijke verbintenissen

(Vervallen)

De nakoming van verbintenissen

(Geldschulden: Drion)

Verzuim van de schuldeiser

De gevolgen van het niet-nakomen

van een verbintenis

Het tenietgaan van verbintenissen

(Compensatie: Fokkema en Eggens)
Eggens

Drion en Franken

Eggens en Franken

Franken en Fokkema

Eggens en Franken

De Jong

Fischer-Keuls

De Jong

De Jong

Titel 2. Overgang van vorderingen en schulden 
en daarna: "In de eerste jaren van het Driemanschap verliep de discussie voor zo'n 90 procent tussen de Driemannen onderling. In de voltallige vergadering hadden wij recht van medespreken, maar we werden niet geacht het hoogste woord te voeren. Daarentegen had je een geheel andere situatie in de werkgroepjes die zich afsplitsten van de plenaire vergadering en waartoe in de loop der jaren steeds meer werd overgegaan. In deze subcommissies kregen we het volle pond en mochten we naar hartelust discussiëren, waarbij de Drieman uiteraard de knopen doorhakte."

De nieuwe opzet slaagde maar zeer gedeeltelijk. Weliswaar kwamen de meeste teksten nog maar een enkele keer per jaar in de plenaire vergadering aan de orde en daalde de frequentie van de besprekingen van ongeveer zestig in het eerste jaar, tot minder dan de helft in het (voor-)laatste jaar ${ }^{48}$, maar de verwachte versnelling bleef desondanks uit. In maart 1958 bijvoorbeeld, was er, met uitzondering van de afdelingen 6.1.4 (Alternatieve verbintenissen) en 6.1.5 (Voorwaardelijke verbintenissen), die reeds in Juni 1957 gereed waren gekomen, nog geen enkel onderwerp aan te wijzen waarvan de voltooiing op korte termijn kon worden verwacht. Drie factoren waren daaraan debet.

Een eerste moeilijkheid was, dat het niet altijd meeviel de plenaire vergadering ervan te overtuigen dat de door het subgroepje gegeven uitwerking van haar besluiten

47. $\rightarrow$

Titel 3. Onrechtmatige Daden

Drion

Titel 4. Verbintenissen uit rechtmatige daad buiten overeenkomst
Afd. 1
Zaakwaarneming
Fischer-Keuls
Afd. 2
Onverschuldigde betaling
Fischer-Keuls
Afd. 3
Ongerechtvaardigde verrijking
Fischer-Keuls

Titel 5. Overeenkomsten in het algemeen
Afd. 1
Algemene bepalingen
Eggens
Afd. 2
Het tot stand komen van
overeenkomsten
De Jong
Afd. 3
Gevolgen van overeenkomsten
Afd. 4
Wederkerige overeenkomsten
Eggens en Fokkema
Fokkema en Eggens

48. Deze verandering laat zich illustreren aan de hand van het volgende staatje.

$\begin{array}{llc}\text { jaar } & \text { vergadering } & \text { aantal verg. per jaar } \\ 1954\left(21-6--^{-54)}\right. & 1-30 & 30 \\ 1955 & 31-95 & 65 \\ 1956 & 96-141 & 46 \\ 1957 & 142-166 & 25 \\ 1958 & 167-203 & 37 \\ 1959 & 204-250 & 47 \\ 1960 & 251-279 & 29 \\ 1961(28-7-61) & 280-282 & 3\end{array}$


de juiste was. Elk clubje ontwerpers had zijn eigen stijl en zijn eigen denkbeelden over de eisen die aan een goede tekst moeten worden gesteld. Ook kwam het voor dat de bepalingen van de verschillende afdelingen niet goed op elkaar aansloten of te weinig samenhang vertoonden. Het was als een slecht pianist: de linkerhand wist niet wat de rechterhand deed. Tenslotte ontstonden er coördinatieproblemen, omdat de ontwikkeling van de verschillende afdelingen niet gelijk opging, waardoor de behandeling van bepaalde onderwerpen steeds opnieuw moest worden uitgesteld of waardoor sommige ontwerpen al weer verouderd waren voordat ze eindelijk toe waren aan een bespreking.

Dit betekende dat er veel mondelinge en schriftelijke discussies nodig waren om het opnieuw met elkaar eens te worden. Zo leidde het commentaar op het concept voor een drukproef van afdeling 6.1.6 (Nakoming van verbintenissen) tot vijf interne besprekingen, waarna een tweede, ingrijpend gewijzigd concept werd opgesteld. Voor afdeling 6.5.2 (Het tot stand komen van overeenkomsten) lag dit cijfer op acht, voor afdeling 6.5.3 (Rechtsgevolgen van overeenkomsten) op tien, terwijl een (gewijzigd) concept voor afdeling 6.5.4 (Wederkerige overeenkomsten) pas na dertig besprekingen de goedkeuring van het Driemanschap kon wegdragen.

Een tweede factor was, dat de opmerkingen van het Departement en van de rapporteurs van de Staatscommissie in het algemeen veel stof tot overdenking gaven. Fokkema wees daar reeds op. Zo had het Driemanschap zeven vergaderingen nodig om het commentaar op afdeling 6.1.2 (Hoofdelijke verbintenissen) door te nemen en te verwerken, werden aan de afdelingen 6.1 .6 (Nakoming van verbintenissen) en 6.1.7 (Schuldeisersverzuim) elk drie vergaderingen besteed, vergde de bespreking van de adviezen over afdeling 6.4.2 (Onverschuldigde betaling) en 6.4.3 (Ongerechtvaardigde verrijking) maar liefst zes bijeenkomsten, en zouden naar aanleiding van de drukproef voor afdeling 6.5.2 (Het tot stand komen van overeenkomsten) zelfs vijftien vergaderingen worden belegd.

Ofschoon deze commentaren er uitsluitend op gericht waren de ontwerpen in wetstechnisch en redactioneel opzicht te verbeteren, leidde de hernieuwde overweging er vaak toe dat de ontwerpers het besluit namen het desbetreffende concept geheel om te werken. De volgende citaten, ontleend aan de overzichtnota's die het Driemanschap op last van Minister Samkalden elk kwartaal aan het Departement instuurde, spreken duidelijke taal. Naar aanleiding van de adviezen bij afdeling 6.1.8 (De gevolgen van het niet nakomen van een verbintenis) schreef Franken: "Er moet rekening mee worden gehouden dat deze verdere behandeling waarschijnlijk niet beperkt zal zijn tot kleine punten van redactionele aard." Bij afdeling 6.5.3 (Rechtsgevolgen van overeenkomsten) tekende hij aan dat er "tamelijk veel zal moeten worden gewijzigd", terwijl bij afdeling 6.1.10 (Tenietgaan van verbintenissen) door hem werd opgemerkt dat na bespreking van de ingekomen adviezen een tweede, "sterk gewijzigde" drukproef in voorbereiding was. Voor titel 6.2 alsmede de afdelingen $6.1 .2,6.1 .7,6.4 .2,6.4 .3$ en 6.5.2 O.M. gold iets dergelijks. Uit de kritiek van het Departement bleek eigenlijk dat het ontwerp nog lang niet af was.

Tenslotte liep het werkschema in de war, doordat de maatregelen die waren genomen om Drion te ontlasten al snel weer achterhaald waren. Drion zou het namelijk nóg drukker krijgen, omdat hij met ingang van het cursusjaar 1957-1958 wekelijks weer een aantal uren college ging geven en ook zijn bestuurlijke verplichtingen weer op zich nam. Daarbij kwam dat juist in deze periode Drions taak van Regerings- 
commissaris al zijn aandacht voor zich zou opeisen. In 1958 gaf Drion niet alleen leiding aan de voorbereiding van de Memorie van Antwoord voor Boek 1 en verdedigde hij het ontwerp in de Eerste Kamer, maar werd ook de schriftelijke en de mondelinge behandeling van Boek 2 bij de Tweede Kamer afgesloten. Met name de behandeling van dit laatste boek, die zou leiden tot een Memorie van Antwoord van 150 bladzijden en vier nota's van wijziging, waarin maar liefst 114 verbeteringen werden voorgesteld, zou veel tijd en aandacht vergen, aanmerkelijk meer dan begin 1957 werd voorzien. Het was volgens mevrouw Drion "een niet te overkomen hoeveelheid werk", gelet op de drie taken die er uiteindelijk waren.

Het gevolg was, dat het werk aan het voorontwerp voor Boek 6 bij Drion min of meer op de laatste plaats kwam. Wellicht had hij soms een uurtje over om iets aan Boek 6 te doen, maar veel kan het niet zijn geweest. Bovendien is voor dit werk volledige concentratie onontbeerlijk. Drion slaagde er dan ook niet in de aan hem toebedeelde gedeelten tijdig af te leveren. In de periode januari 1957 - maart 1958 leverde hij zelfs geen enkele naar buiten blijkende prestatie. Het werk aan afdeling 6.1.1 (Algemene bepalingen), dat hij na het vertrek van Eggens op zich had genomen, bleef bijvoorbeeld tot de zomer van 1959 liggen, het bijwerken van afdeling 6.1.2 (Hoofdelijke verbintenissen), waartoe hij zich eind 1956 had verplicht, zou blijven liggen tot eind 1960 in verband met het werk aan de titels 6.2 en 6.3, die nog meer haast hadden. Van titel 6.3 liet Drion in november 1958 niet meer zien dan een eerste, zeer voorlopig concept voor de tekst. Treffend is dat Franken, die Drion assisteerde bij het werk aan titel 6.2, reeds in september 1957 de door hem aan te leveren stukken in eerste concept gereed had, terwijl Drion, in verband met zijn werk aan Boek 2, pas in de zomer van 1958 zijn aandeel zou leveren.

Minister Samkalden, die, zoals vermeld, bij zijn aantreden aan de hand van door het Driemanschap gegeven informatie had aangekondigd dat het groene Boek 6 in de loop van 1957 zou verschijnen, begreep, nadat hij het nog een jaar had aangezien, dat krachtig ingrijpen noodzakelijk was. De Minister behoefde bepaald niet helderziend te zijn om uit de driemaandelijkse overzichten, die Franken op zijn verzoek opstelde, af te leiden dat het werk aan Boek 6 O.M. bij ongewijzigd beleid nog vele jaren zou duren. ${ }^{49}$ Daarbij kwam, dat de Kamer ook tekenen van ongeduld begon te vertonen. Tijdens de begrotingsbehandeling voor 1957 hadden "verscheidene leden" er hun teleurstelling over uitgesproken dat Boek 6 zo lang op zich liet wachten ${ }^{50}$, terwijl een jaar later stemmen zouden opgaan om onderdelen van het nieuwe personen- en familierecht in te voeren vóór de andere delen van het nieuwe Burgerlijk Wetboek. ${ }^{51}$

49. Het Driemanschap was zich daar zelf overigens niet van bewust. De notulen van 29 oktober 1958 (196e verg.) vermelden: "In maart 1959 hoopt het Driemanschap Boek 6 af te hebben."

50. Zitting Tweede Kamer 1956-1957, nr 4500, stuk nr 8, p. 2.

51. Zitting Tweede Kamer 1957-1958, nr 4900, stuk nr 8, p. 2: "Het zal de bewindsman bekend zijn, dat er in brede kringen een zekere teleurstelling bestaat, dat het nieuwe recht, ook na de behandeling door de Eerste Kamer, nog vele jaren op invoering moet wachten. (..) Zonder op de behandeling in de Eerste Kamer vooruit te willen lopen, wilden deze leden gaarne worden ingelicht omtrent de vraag, of de Minister het voornemen heeft om, wanneer deze beide wetsontwerpen ook door de Eerste Kamer zullen zijn afgehandeld, een enkel onderdeel daaruit te lichten en neer te leggen in een ontwerp tot wijziging van het huidige Burgerlijk Wetboek, welke wijziging dan aanstonds, vooruitlopend op het nieuwe B.W., in werking zou kunnen treden." 
Op 19 november 1958 ging Samkalden daarom naar het gebouw aan de Lange Voorhout om met het Driemanschap van gedachten te wisselen over de vooruitzichten van Boek 6. Zijn boodschap was duidelijk: Het werk moest zo snel mogelijk worden afgerond, aan de beraadslagingen diende een eind te komen. Om de impasse te doorbreken werd besloten dat het Driemanschap ernaar zou streven van alle onderdelen van Boek 6, die op dat moment nog niet in druk waren verschenen, tussen begin december 1958 en eind januari 1959 een drukproef te maken. Het Departement zou vervolgens commentaar kunnen leveren, waarna de Driemannen de definitieve redactie zouden kunnen opstellen.

Deze opzet, waarvan Samkalden kennelijk een groot psychologisch voordeel verwachtte ${ }^{52}$, mislukte echter volkomen. Sommige teksten waren na twee maanden werken nog dermate onvoldragen, dat daarvan met goed fatsoen geen drukproef kon worden gemaakt. Op andere teksten kwam zoveel kritiek, dat men terug moest naar af. Tenslotte kon Drion het vele werk onmogelijk aan.

Een paar cijfers. Afdeling 6.1.1 (Algemene bepalingen) zou volgens het schema half december 1958 in drukproef moeten verschijnen; Juli 1959 was er nog niets aan gebeurd. Afdeling 6.1.2 (Pluraliteit van schuldenaren en hoofdelijke verbondenheid) zou in de eerste helft van januari in drukproef moeten verschijnen; September 1960 was er nog niets aan gedaan. Afdeling 6.1.6 (Nakoming van verbintenissen) zou eind januari zijn vierde drukproef moeten beleven; September 1960 was de situatie nog onveranderd. Om een lang verhaal kort te maken: In juli 1959 waren slechts de titels 6.2 en 6.4, alsmede de eerste drie afdelingen van titel 6.5 in drukproef verschenen. Bij elkaar de helft van Boek 6. Een jaar later waren daar slechts twee afdelingen (6.1.7 en 6.5.4 O.M.) bijgekomen. Zozeer verkeek het Driemanschap zich op de eigen mogelijkheden.

Toen mr. A.C.W. Beerman op 19 mei 1959 de boedel van Samkalden overnam, was er eigenlijk dus nog niets klaar. De overzichten die Franken opstelde, suggereerden weliswaar een behoorlijke progressie, maar wie de moeite nam een paar daarvan naast elkaar te leggen, kon al na enige oefening tussen de regels doorlezen dat het werk volkomen stagneerde, of bleek uit de confrontatie met een volgend overzicht dat de voorspellingen (weer) niet waren uitgekomen. Aan een groot aantal onderdelen was, als gevolg van de overbelasting van Drion, al een paar jaar niets meer gedaan ${ }^{53}$

52. Zie de Memorie van Antwoord bij de begroting voor 1959, ingezonden 31 oktober 1958, waar Samkalden aankondigde dat het wetsontwerp voor Boek 6 uiterlijk eind 1959, begin 1960 bij de Kamer zou worden ingediend: "Wat Boek 6 betreft, meent hij tenminste te mogen rekenen op indiening van het wetsontwerp, hetzij in het lopende, hetzij in het volgende zittingsjaar." (Zitting Tweede Kamer 1958-1959, nr 5300, stuk nr 9, p. 2).

53. Het werk aan afdeling $6.1 .2 \mathrm{lag}$ bijvoorbeeld al sinds januari $1957 \mathrm{stil}$, in verband met de voorrang die Drion moest geven aan titel 6.3 (Onrechtmatige Daden). Om dezelfde reden zou Drion eind 1958 afdeling 6.1.6 (Nakoming van verbintenissen) overdoen aan De Grooth, terwijl het schuldeisersverzuim (afd. 6.1.7) in handen van De Jong werd gelegd. De perikelen met betrekking titel 6.3 hadden ook een terugslag op de andere delen. Zo wachtte afdeling 6.1.8 (De gevolgen van het niet nakomen van een verbintenis) sinds januari 1959, en afdeling 6.5.3 (Rechtsgevolgen van overeenkomsten) sinds december 1959 op Drions eindvoorstel voor titel 6.3, dat overigens nooit zou komen. 
en bij die afdelingen waar wel iets gebeurde, vorderde het werk uiterst langzaam, hoewel het vergadertempo in 1959 weer was opgevoerd.

Beerman zag al snel in, dat Drion zoveel mogelijk moest worden vrijgemaakt voor het werk aan het groene Boek 6. Dit betekende allereerst dat hij het werk aan de invoeringswetgeving voor Boek 1, waartoe reeds door Van Oven de aanzet was gege$v^{5}{ }^{54}$, tot nader order opschortte. Daardoor kon er meer mankracht worden gestopt in de beantwoording van het Voorlopig Verslag over Boek 2, dat door de Eerste Kamer op 25 juli 1959 zou worden uitgebracht. Daarnaast legde Beerman het werk aan de Memorie van Antwoord voor Boek 3 stil, omdat Drion niet bij machte bleek de voorbereidende nota's die Van Ewijk en Belinfante voor dat doel schreven, door te nemen en met hen te bespreken. Deze concentratie van werkzaamheden had bovendien tot gevolg dat Van Ewijk, de "baas" van het nieuwe B.W., in de gelegenheid werd gesteld het Driemanschap bij de bewerking van het verbintenissenrecht met raad en daad terzijde te staan. Fischer zei daarover: "Sinds 1959, 1960 is Van Ewijk als vertegenwoordiger van het Ministerie bij vrijwel alle vergaderingen van het Driemanschap aanwezig geweest. Van Ewijk was geen vertegenwoordiger in de normale betekenis van het woord. Hij was er enorm actief bij betrokken."

Tevens besefte de Minister dat hij tegenover de Kamer voorzichtig moest zijn met het doen van voorspellingen. Een nieuw tijdschema, waarop de Kamer verscheidene malen aandrong, wilde hij niet geven zolang Boek 6 O.M. niet was verschenen: "Een tijdschema voor de behandeling van de ontwerpen voor het nieuwe Burgerlijk Wetboek kan moeilijk worden vastgesteld, nu het Zesde Boek nog niet is vastgesteld, en niet met zekerheid te voorspellen valt, wanneer dat het geval zal zijn." 55 Ook bereidde hij de Kamer voor op de mogelijkheid dat de Memorie van Antwoord van Boek 4 (Erfrecht) vóór die van Boek 3 beantwoord zou worden: "Ondergetekende streeft ernaar de Memorie van Antwoord op het Voorlopig Verslag van de vaste Commissie inzake Boek 3 in de loop van het jaar 1960 te voltooien. (...) Inmiddels mocht hij reeds het eerste gedeelte van het Voorlopig Verslag over Boek 4 ontvangen. Mocht ook het tweede gedeelte binnen enkele maanden gereed komen, dan zal hij gaarne trachten te bereiken dat ook dit verslag, zo mogelijk al vóór de voltooiing van de Memorie van Antwoord inzake Boek 3, wordt beantwoord." ${ }^{\text {s6 }}$ Tenslotte vroeg Beerman de Kamer om maar vast aan het Voorlopig Verslag over Boek 5 (Zakelijke rechten) te beginnen: "Daarmede zou namelijk voor het geval, dat onverhoopt Boek 6

54. Mr. C.J. van Zeben: "Op 1 mei 1957 ben ik aangesteld op het Ministerie van Justitié, waarbij ik speciaal en uitsluitend werd belast met het voorbereiden van het overgangsrecht voor het nieuwe B.W. Ik was daarvoor assistent bij Hijmans van den Bergh geweest. Hij had in 1956 een pre-advies geschreven voor de Broederschap van Notarissen over het overgangsrecht, waar ik het nodige aan had gedaan. Van Oven, de toenmalige Minister van Justitie, was ook op de vergadering aanwezig en vroeg aan Hijmans of hij iemand wist voor het overgangsrecht."

55. Zitting Tweede Kamer 1959-1960, nr 5700, stuk nr 8, p. 1. Tijdens de openbare behandeling van de begroting voor 1959 sprak Beerman de volgende woorden: "Terecht heeft de geachte afgevaardigde de heer Meulink opgemerkt, dat wij meer zekerheid zouden hebben, indien wij precies wisten wanneer Boek 6 (de verbintenissen in het algemeen) uit handen van het Driemanschap gereed zou komen. Zolang wij dit niet nauwkeurig weten, is het moeilijk, een werkprogramma definitief op te stellen." (Handelingen Tweede Kamer 1959-1960, p. 2137).

56. Zitting Tweede Kamer 1959-1960, nr 5700, stuk nr 2, p. 1. 
later gereed zou komen dan ik verwacht, worden bereikt, dat er in ieder geval voldoende stof is voor een continue voortzetting van de behandeling. " 57

Beermans hoop, dat Boek 6 als gevolg van deze maatregelen in de loop van 1960 in het groene kaft zou kunnen verschijnen ${ }^{58}$, bleek ongegrond. De Memorie van Antwoord bij de begroting voor 1961 was dan ook nogal somber gestemd: "Het ontwerp voor het Zesde Boek zal, anders dan verleden jaar werd gehoopt, in 1960 nog niet kunnen verschijnen. Er bestaat ook nog geen zekerheid over het verschijningstijdstip. ${ }^{59}$ Daarmee was ook iedere grond ontvallen aan zijn opmerkingen over de verschijning van de Memorie van Antwoord over de Boeken 3 en 4 . Alleen een resoluut ingrijpen, zo besefte Beerman, kon de hercodificatiepoging nog redden.

Op 23 november 1960, enkele dagen voordat de Tweede Kamer Beerman de oren zou wassen over zijn beleid ten aanzien van het nieuwe B.W., liet de Minister het Driemanschap bij zich komen. De inzet was duidelijk: Boek 6 moest af. In de Kamer verklaarde Beerman zich als volgt: "Mijn aandacht en geladenheid zullen in de eerste plaats gericht zijn om er vóór alles op toe te zien, dat het vrijwillig conclave wordt gehandhaafd ten aanzien van het Zesde Boek, en dat daarna alles wordt gezet op het gereedmaken van de Memorie van Antwoord van het Vierde Boek. ${ }^{60}$ De Minister gelastte de Driemannen het werk aan het verbintenissenrecht op korte termijn af te ronden, de besprekingen in het Driemanschap te staken en de afwerking van elke afdeling of titel in handen te leggen van een subgroepje, bestaande uit de verantwoordelijke Drieman en één van de medewerkers. Ieder moest dus afwerken wat hij onder handen had, voor coördinatie was geen plaats. Boek 6 O.M. zou dan ook allerminst een eenheid vormen. ${ }^{61}$

Ditmaal slaagde Beerman wèl in zijn opzet. Het vergadertempo werd drastisch teruggeschroefd, bij de meeste onderwerpen zou de eindcoördinatie een wassen neus zijn of zelfs geheel achterwege blijven. Een vergelijking van het werkschema van nog te behandelen zaken in september 1960 met de onderwerpen die nadien nog in het Driemanschap zijn besproken, leert dat alleen afdeling 6.4.1 (Zaakwaarneming), die

57. Handelingen Tweede Kamer 1959-1960, p. 2138.

58. "Ik ben (..) ten aanzien van Boek 6 niet pessimistisch. Al heb ik geen zekerheid, ik heb bepaaldelijk toch wel goede hoop, dat Boek 6 in de loop van 1960 zal verschijnen", aldus Minister Beerman, handelingen Tweede Kamer 1959-1960, p. 2137.

59. Zitting Tweede Kamer 1960-1961, nr 6100, stuk nr 9, p. 4.

60. Handelingen Eerste Kamer, zitting 1960-1961, p. 2220.

61. Berucht zijn in dit verband de talloze redactieverschillen tussen afdeling 6.1.8 en afdeling 6.5.4, in het bijzonder met betrekking tot de artikelen 6.1.8.11 (omzetting) en 6.5.4.6 (ontbinding), die op vijf punten van elkaar afweken. Daarnaast is veel kritiek gekomen op de exceptio non adempleti contractus, waarvan de regeling betreffende wederkerige overeenkomsten (afd. 6.5.4) geheel los stond van de algemene regeling (afd. 6.1.9).

Ook ten opzichte van de andere Boeken zijn vergissingen begaan. Art. 6.5.2.7 bijvoorbeeld, is geschreven voor dezelfde casuspositie als art. 3.2.4 lid 2. De omstandigheden die aanleiding geven tot toepassing van art. 3.2.4 worden in dit laatste artikel echter geheel anders aangeduid. Terwijl art. 3.2.4 het heeft over de eigen handeling, de handeling van personen waarvoor de aanbieder aansprakelijk is en over omstandigheden die de persoon van de verklarende betreffen en rechtvaardigen dat hij het nadeel draagt, wordt in art. 6.5.2.7 slechts gesproken van een omstandigheid, waarvan het risico "naar de opvattingen van het verkeer" ten laste van de aanbieder komt. In het Gewijzigd Ontwerp is deze discrepantie uiteraard opgeheven. Artikel 6.5.2.7 G.O. verwijst nu - eenvoudigheidshalve - rechtstreeks naar artikel 3.2.4. 
medio 1959 gereed lag maar op het laatste moment nog werd opengebroken, en titel 6.2 (Overgang van vorderingen en afstand van vorderingen), die nog nooit in zijn geheel in het Driemanschap was geweest, voorwerp van overleg zijn geweest. De andere in $1960 \mathrm{nog}$ te behandelen onderwerpen, zoals de afdelingen 6.1.2 (Hoofdelijke verbintenissen) 6.1 .6 (m.b.t. geldschulden), 6.1.7 (Schuldeisersverzuim), 6.1.8 (De gevolgen van het niet nakomen van een verbintenis) en 6.1.10 (Tenietgaan van verbintenissen), waaraan met uitzondering van afdeling 6.1.7 sinds de door Samkalden bevolen drukproef uit eind 1958 niets meer was gedaan, bleven onaangeroerd liggen en zouden alleen nog en petit comité worden besproken.

Het gevolg was, dat toen het Driemanschap na veel aandringen in oktober $1961^{62}$ eindelijk het groene Boek 6 aan Beerman aanbood, alleen de afdelingen 6.1.3 en 6.1.4, in 1957 gereedgekomen onder Eggens, en de afdelingen 6.1.1 (september 1960 definitief), 6.5.1 en 6.5.2 (in maart 1960 vrijwel gereed; Het ging bij afdeling 6.5.1 nog om één artikel) als definitief konden worden aangemerkt. Voor het overige was het ontwerp minder ver gevorderd of doodgewoon niet af. Franken licht toe: "Men wenste het als af te beschouwen, maar het was onvoldragen. We hadden er nog een paar jaar langer aan moeten werken."

\section{Oorzaken voor vertraging}

Bij de bespreking van de lotgevallen van Meijers' concept voor Boek 5 O.M. bleek reeds dat Meijers ernaar streefde het voorontwerp voor Boek 6 omstreeks september 1954 te kunnen afleveren. Dat was geen grootspraak. Het werk aan Boek 6, zoals dat door Meijers was bedoeld, was in juni 1954 op een oor na gevild. Dat blijkt uit de tijdschema's die Meijers voor zichzelf opstelde, dat blijkt ook doordat hij in de concepten meestal al volledig rekening had gehouden met de opmerkingen van de Staatscommissie. Volgens Franken, die de concepten na het overlijden van Meijers van een "vermoedelijke" datering voorzag, waren alle teksten eind 1951 of later opgesteld, in elk geval ruim nadat de besprekingen erover in de Staatscommissie waren beëindigd. Illustratief voor de rijpheid ervan was dat sommige onderwerpen een nog verdergaande bewerking hadden ondergaan en waren gewijzigd onafhankelijk van het in de Staatscommissie besprokene. ${ }^{98}$ Het enige verschil met het concept voor het groene Boek 5 was dat nog geen rekening was gehouden met de uitkomsten van de vraagpuntenprocedure en dat Meijers met betrekking tot drie of vier moeilijke vragen nog geen definitieve beslissing had durven nemen of nog niet in de gelegenheid was geweest de daarover gevraagde adviezen te verwerken. ${ }^{99}$

Ook de toelichting was grotendeels compleet. Met uitzondering van de titels 6.2 (Hoofdelijke verbintenissen), 6.4 (Verbintenissen uit rechtmatige daden buiten over-

62. Door problemen bij de Staatsdrukkerij zou het groene Boek 6 eerst in februari 1962 uitkomen.

98. Dit betrof met name de afdelingen 6.1.1-6.1.4 O.M., waarvan de tekst volgens Franken medio 1952 was ontstaan, twee jaar na de afronding van de besprekingen in de Staatscommissie, terwijl de toelichting uit 1951 stamde.

99. Het ging daarbij met name om kwesties als exoneratie, matiging en enkele onderdelen van titel 6.2. Met betrekking tot de regeling van het verzuim was de door Meijers ontworpen regeling nog gebaseerd op het ontwerp van Rome voor een uniforme regeling van de Koop van 1951, ten aanzien waarvan Meijers c.s. op 30 april 1954 van Unidroit opdracht kreeg deze op enkele punten te wijzigen. Als gevolg van zijn plotselinge overlijden is daar niets meer van gekomen. 
eenkomst) en afdeling 6.5.4 (Wederkerige overeenkomsten) was elke bepaling toegelicht. Wel was de toelichting soms wat kaal en spoorde zij niet altijd met de laatste tekst - het ontwerp moest hier en daar nog wat worden aangevuld, geretoucheerd. Maar over de grote lijnen kon geen enkel misverstand bestaan. Wat ontbrak, was de laatste schaaf. Belinfante, die én als secretaris van de Staatscommissie én als verantwoordelijk ambtenaar op Justitie bij uitstek op de hoogte was van Meijers' vorderingen, zei in dit verband: "Het ontwerp was wel af. Het is een verkeerd idee geweest om een Driemanschap te benoemen."

Het Driemanschap dacht duidelijk anders over de kwaliteit van het door Meijers nagelaten werk. Fischer-Keuls: "Van Boek 6 lag er praktisch niets. Er waren wel teksten, maar die waren erg summier. Jan Drion wist ook dat die ontwerpen door Meijers helemaal niet als definitief werden beschouwd. Hij had er immers ook al met Meijers aan gewerkt." Fokkema: "Meijers had in feite een complete set klaarliggen voor Boek 6 O.M., zij het ook dat we wel moesten aannemen, dat er naar Meijers' voorstelling nog heel wat aan moest veranderen. Het zag er niet als definitief bedoeld uit." "Iedereen", volgens Franken, "was ervan doordrongen dat er van het concept van Meijers niets deugde, dat het geheel opnieuw moest worden opgezet."

Dat het Driemanschap hiermee een ernstige fout maakte en Meijers' werk veel te laag aansloeg, blijkt wel doordat Kamphuisen, die uitsluitend over een tekst van de door hem te bewerken titels uit Boek 7 (Bijzondere overeenkomsten) beschikte, er wél in slaagde het werk van Meijers in drie maanden te voltooien, en bovendien op een dusdanige wijze, dat van de door hem afgewerkte titels twintig jaar later nog grote delen ongewijzigd in het groene Boek 7 zouden belanden. ${ }^{100}$

Dat aan dit omwerken een weloverwogen besluit ten grondslag heeft gelegen, lijkt mij onwaarschijnlijk. Het was, zo is mij uit studies naar de ontstaansgeschiedenis van diverse titels gebleken, een onbewust proces, dat, eenmaal in gang gezet, een sneeuwbal-effect tot gevolg had. Fokkema zei in dit verband: "Naarmate men zich er meer in verdiepte en Duitse en Zwitserse literatuur naging, bleek dat er meer werk verzet moest worden en dat je je het niet kon permitteren om de zaak al snel afgesloten te verklaren." En: "Het ongemak is, dat als je je opnieuw verdiept in het burgerlijk recht je steeds met nieuwe vragen wordt geconfronteerd. Je ziet steeds meer fouten, en als je tracht die te verhelpen door een nieuwe tekst te schrijven, dan blijkt het anders uit te komen dan je je het tevoren had gedacht."

Er was al heel snel geen weg meer terug. Het Driemanschap raakte als het ware verstrikt in de (dogmatische) vragen die het zelf had opgeworpen, stuitte door het steeds verder doordenken op problemen die nog nooit tot moeilijkheden aanleiding hadden gegeven en die wellicht ook niet waren op te lossen, dreef zichzelf op tot een steeds hoger niveau van volmaaktheid. Zoals in Boek 5 de ene wijziging hier leidde tot een veelvoud aan wijzigingen daar, zo zou het Driemanschap met het werk aan

100. Zie hierna, Hoofdstuk 8. Dit gegeven plaatst de mededeling van Fischer in NJB 1974, p. 1038 , Jat "Meijers zelf de concepten voor de Boeken 6 en 7 in het stadium waarin zij zich bij zijn dood bevonden, in het geheel niet rijp achtte voor publicatie, ze meer als uitgangspunt beschouwde voor de besprekingen met zijn medewerkers" in een ander licht. Zie ook NJB 1974, p. 1410, waar Fischer stelt dat "de achtergelaten stukken nog geenszins de vorm van een definitieve redactie hadden bereikt." 
Boek 6 O.M. ervaren dat hoe verder men zich van de bron verwijderde, des te ingrijpender het karakter van de wijzigingen werd. De houding die de buitenwereld pas in het begin van de jaren tachtig zou aannemen, door elke komma en elk punt van de invoeringswetten kritisch door te lichten en alternatieven voor te stellen, die houding had het Driemanschap eigenlijk al vanaf het begin in zijn greep. De allerdwaaste casusposities werden met evenveel eerbied behandeld als de praktijkvragen, voorkomend in de Nederlandse Jurisprudentie. Het werd daardoor ook steeds moeilijker overeenstemming te bereiken en met een werk uit één stuk te komen.

Eén gevolg was, dat belangrijke delen van Boek $6 \mathrm{O}$.M. een sterk wetenschappelijke inslag kregen, extreem gedetailleerd waren en teveel afweken van datgene waaraan de Nederlandse rechtspraktijk en -wetenschap gewend was. "Wanneer men dan voor de eerste maal tekst en toelichting leest" schreef Van Oven, "dan voelt men zich vóór alles gegrepen door bewondering, maar daarnaast ook door verbijstering als gevolg van de omvang en het zware gewicht van hetgeen ons te lezen wordt gegeven. (..) Nog meer dan de door Meijers ontworpen artikelen der eerste vier Boeken zijn die van het Zesde duidelijk het werk van geleerde juristen, geschreven en bestemd voor hun vakgenoten, werk vàn en vóór rechtsgeleerden." ${ }^{101}$ Pitlo oordeelde: "Waarschijnlijk is in gans Europa geen B.W. te vinden, dat geleerder en tegelijkertijd voor de praktijk van het rechtsleven onbruikbaarder is dan het hier voor ons liggende ontwerp. Deze tekst is niet de tekst van een wetboek, maar van een studieboek." 102

Een ander gevolg was, dat de roep om stopzetting van de hercodificatie, die tot 1961 door slechts enkelen werd gesteund, na de publicatie van het ontwerp snel sterker zou worden. In het rapport van de beide Broederschappen van Notarissen over Boek 6 werd de vraag gesteld of het niet beter zou zijn een geheel nieuw ontwerp op te stellen in plaats van proberen dit te verbeteren ${ }^{103}$, terwijl het Studiegenootschap van bedrijfsjuristen in zijn "conclusies" de vraag opwierp of niet beter zou kunnen worden teruggekeerd tot de weg van partiële herzieningen. ${ }^{104}$

\section{a. perfectionisme versus impressionisme}

Eén van de factoren, waarom Boek 6 O.M. zo moeizaam van de grond kwam, was dat de visie van het Driemanschap op de hercodificatie sterk verschilde van die van Meijers. In het kader van de bespreking van de totstandkoming van Boek 5 O.M. is daar al het een en ander over gezegd. Waar Meijers volstond met het aangeven van de grote lijn en bewust ruimte liet voor rechtsvorming door de rechter, vond het Driemanschap het noodzakelijk iedere regel tot in detail uit te werken. Waar Meijers,

101. J.C. van Oven, Een eerste indruk van het ontwerp voor het verbintenissenrecht, NJB 1962, p. 109 e.v. Van Oven bekende verder dat hij bij het doorlezen van deze "rijstebrijberg van geleerdheid" meermalen door een gevoel van moedeloosheid was overvallen en dat bij de bestudering van afdeling 6.5.4 (Wederkerige overeenkomsten) bij hem de beduusdheid de bewondering had overwonnen: "Wat zijn wij begonnen door na Meijers' heengaan en zonder zijn gave van zelfbeperking zijn werk voort te zetten."

102. Geciteerd uit "Het ontwerp voor een nieuw B.W.", p. 7, een inleiding die Pitlo op 16 januari 1963 hield in Hotel Wittebrug voor een aantal geïnteresseerde Kamerleden.

103. Zie WPNR 4790 (1963).

104. Zie voor een indruk van de kritiek op het groene Boek 6 de auteurs die zijn vermeld in het advies van de Raad van State en dit advies zelf (Parl. Gesch. Boek 6, p. 1 e.v.). 
volgens Jan Drion ${ }^{105}$, als stelregel aannam dat alles wat in de praktijk zonder veel problemen functioneerde, ongewijzigd moest blijven, legde het Driemanschap zichzelf de verplichting op het gehele verbintenissenrecht op zijn theoretische bruikbaarheid te doorvorsen en tot een logisch sluitend geheel te maken. Het werk van Meijers was daardoor niet meer dan een vertrekpunt, op basis waarvan men verder bouwde. Men bekeek zijn werk, alsof het een vroege voorstudie betrof. Daarbij werden niet alleen de punten ten aanzien waarvan kon worden getwijfeld over de opzet van Meijers, of die gevallen waarin zijn tekst echt fout was, opnieuw opgezet; Het Driemanschap draaide er ook zijn hand niet voor om om tegen de uitdrukkelijke bedoeling van Meijers in te gaan. "Wij beriepen ons bijna nooit op teksten van Meijers", volgens Fischer. "Boek 6 is geheel opnieuw doorgepraat. Er hing geen sfeer van 'dit is van Meijers' en daarom onaantastbaar. We hebben de ontwerpen niet 'beschermd', ieder van ons stond open voor kritiek, voor andere denkwijzen, ieder van de medewerkers was volstrekt vrij zijn mening te geven, het werd helemaal opengehouden." ${ }^{106}$ Franken vult aan: "Wij wilden alleen de grote lijnen handhaven. Ik meen dat daarvoor de term 'restatement' werd gebruikt. Je moest niet alles helemaal van de grond af opnieuw opzetten, maar een samenvatting geven van de rechtsontwikkeling en die een wettelijke basis geven."

Dat het Driemanschap een andere opvatting had over de hercodificatie en zich niet vereenzelvigde met het werk van Meijers, blijkt uit de volgende opmerkingen van Bregstein, die als lid van de Staatscommissie rapport uitbracht over het eerste concept van het Driemanschap voor afdeling 6.4.1 O.M. (Zaakwaarneming). Bregstein schreef:

"Laten wij ons toch vooral houden aan Meijers' raad, dat men bij bestaande teksten, die in de praktijk geen moeilijkheden hebben opgeleverd, zoveel mogelijk moet aansluiten. (...) Onder het wetboek van 1838 heeft dit probleem nimmer aanleiding tot moeilijkheden gegeven en ik acht het daarom ongewenst deze theoretisch ongetwijfeld zeer interessante vraag in de wet te beantwoorden. Terecht heeft Meijers ervan afgezien om in de wet nader uit te werken, wanneer iemand anders gehandeld heeft dan in het maatschappelijk verkeer betaamt. Dit is volkomen jus in causa positum. Een Burgerlijk Wetboek is een codificatie, d.w.z. een samenbundeling van het geldend recht en is niet bestemd om een oplossing te geven voor alle denkbare problemen."

Bregstein zou er niet in slagen de Driemannen op andere gedachten te brengen. Zijn argument, dat een wetboek geen leerboek moest zijn, werd door het Driemanschap als volgt bestreden: "Drion is het er niet mee eens dat dit de opzet van Meijers zou zijn:

105. Ars Aequi 1954, S.U. congres, p. 54.

106. Illustratief is ook de volgende opmerking van Fischer naar aanleiding van een verzoek van Zonderland om de nagelaten concepten van Meijers te publiceren (NJB 1974, p. 1410): "Naar het mij voorkomt, dient te worden vooropgesteld, dat de opvolgers van Meijers volledige vrijheid hadden van diens concepten af te wijken en hun eigen opvattingen in het ontwerp neer te leggen, althans binnen het kader van algemene beginselen (Inleidende titel) en opzet van het ontwerp. Dit is de noodzakelijke consequentie van het feit dat het Meijers niet gegeven was zijn werk tot rijpheid te brengen en dit zou ook zo geweest zijn als Meijers' concepten zich in een verdergevorderd stadium hadden bevonden dan in feite het geval was." 
hij wilde wel degelijk een nieuw wetboek voor de toekomst geven. Het argument dat in de praktijk van geen moeilijkheden omtrent $1390 \mathrm{~B} . \mathrm{W}$. zijn gebleken, is volgens Drion geen sterk argument: Dat er over een bepaald onderdeel geen jurisprudentie is, zegt niets: Dit kan hieraan liggen, dat er te veel controversen zijn." 107108

Een ander voorbeeld van het streven van het Driemanschap om tot een uitputtende, allesomvattende regeling te komen, waarbij het werk van Meijers natuurlijk wel schril moest afsteken, vinden we in de toelichting van het voorontwerp voor Boek 6 . Titel 6.3 (Onrechtmatige Daad), het topstuk van Boek 6, begint met de opmerking dat de regeling wel zo uitvoerig moest uitvallen, omdat deze titel voor een verre toekomst is gemaakt: "In deze titel is er in de eerste plaats naar gestreefd om het recht van de onrechtmatige daad, zoals zich dat in Nederland heeft ontwikkeld in de rechtspraak en doctrine, vast te leggen. Daarenboven moesten de nieuw te ontwerpen bepalingen voldoende steun en mogelijkheden bieden voor een toekomstige ontwikkeling van dit leerstuk, mede in verband met de zich steeds wijzigende maatschappelijke verhoudingen. Hierbij kon en moest worden geprofiteerd van de resultaten waartoe de jurisprudentie en de schrijvers op dit gebied zijn gekomen in andere landen met een vergelijkbare maatschappelijke ontwikkeling. Wellicht op geen ander terrein van het burgerlijk recht werpt de rechtsvergelijkende methode zoveel vruchten af, omdat in alle landen het recht van de onrechtmatige daad grotendeels judge-made law is." En dan volgen nog bijna vijf bladzijden met opmerkingen over opzet en systeem van het ontwerp.

Wat schreef Meijers zelf als inleidende opmerking bij zijn concept voor titel 6.3? Slechts dit: "Wegens de grote invloed, die ten allen tijde de rechtspraak op de ontwikkeling der aansprakelijkheid voor onrechtmatige daden heeft gehad, zijn de algemene bepalingen omtrent de onrechtmatige daad zo sober mogelijk geredigeerd." Vervolgens begint de toelichting met het verklaren van de afzonderlijke artikelen, zonder ook maar één rechtsvergelijkend gegeven te noemen. Een groter verschil in stijl, in manier van codificeren, is nauwelijks denkbaar.

Wie waren verantwoordelijk voor deze koerswijziging, waardoor uiteindelijk geen regel uit het concept van Meijers kon worden behouden? Dat Drion een onafhankelijk man was, die, toen hij de leiding kreeg, in allerlei opzichten van Meijers afweek, is hierboven al gebleken. Toen hij, in zijn hoedanigheid van Regeringscommissaris, de

107. Notulen van de 134 e bespreking van het Driemanschap van 15 oktober 1956. Vergelijk echter Meijers' bekende uitspraak, dat het B.W. geen geschikt terein is voor juridische experimenten: "De voorschriften van burgerlijk recht bevatten de bezonken wijsheid van vele eeuwen. Er dient dus deugdelijk te worden aangetoond, dat een sinds eeuwen bestaand voorschrift verouderd is, voordat men het besluit op te heffen." En: "Evenmin als enig wetboek geeft ook het ontwerp een volledige regeling van alle in het burgerlijk recht zich voordoende vragen. Dit is niet alleen een gevolg van de omstandigheid, dat men niet van te voren alles voorzien kan, maar ook van de opzet niet naar volledigheid te streven. Een teveel in bijzonderheden tredende regeling schaadt de overzichtelijkheid van het geheel en schept meestal meer kwesties dan zij oplost." (Parl. Gesch. NBW, Algemeen Deel, p. 123 e.v.).

108. Drion dacht hierbij waarschijnlijk aan artikel 963a B.W., een artikel dat regelmatig in zijn voordrachten over het nieuwe B.W. ter sprake kwam en dat volgens sommigen alleen geschikt was om de studenten voor het notarieel examen ( $3 \mathrm{e}$ deel) het leven zuur te maken. Maar, en daarom gaat zijn stelling niet op, er was tegelijkertijd wel een levendige discussie over het artikel gaande. Ten aanzien van artikel 1390 B.W. lag dat volstrekt anders. 
Kamer voor het eerst moest toespreken, heeft hij zijn verhouding tot Meijers als volgt gekenschetst:

"Het is gisteren gezegd (..) dat hier Meijers had moeten staan. Meijers, degene, zonder wie dit grote werk nooit begonnen zou zijn, zonder wiens arbeid, verricht aan het nieuwe Burgerlijk Wetboek in de zeven jaar vóór de dood hem wegnam, het onmogelijk zou zijn geweest om het werk voort te zetten. Ik zie slechts één troost. In sommige opzichten kan een dwerg even hoog en even ver, soms zelfs hoger en verder zien dan een reus, op voorwaarde, dat hij het voorrecht geniet op de schouders van die reus te mogen staan. Alleen dat besef kan de dwerg, voor zover hij zich dit voortdurend realiseert, de kracht geven om te trachten het werk voort te zetten. Dat besef ook moet hij voortdurend hebben om zich te behoeden voor een vertekening van de realiteit. "109

Drion besefte dus heel goed dat hij aan Meijers' enorme kennis en intellect niet kon tippen en had ook veel waardering voor Meijers, maar dat betekende niet dat hij zijn leermeester in alles zou volgen of diens opvattingen klakkeloos zou overnemen. Hij behield zich het recht voor zijn eigen weg te gaan, het ontwerp te verbeteren, te vervolmaken. Van lieverlede schiep de dwerg een titanenwerk, door in te gaan op kwesties waar de reus zich wijselijk bescheiden had opgesteld. Beekhuis zei daarover: "Drion was iemand die uitermate knap was, maar die geneigd was de artikelen uiterst kritisch te bezien. Daardoor ontstonden er nieuwe, ingewikkelde formuleringen, die soms moeilijk te vatten waren. ${ }^{110}$

Men krijgt overigens niet de indruk dat Drion zich de ambitie had gesteld Meijers naar de kroon te steken. Het werk zo perfect mogelijk te doen was typerend voor zijn algehele instelling en daarnaast een wijze waarop hij zijn eerbied ten opzichte van zijn leermeester meende te moeten uitdrukken. Ook was Drion zelf volledig overtuigd van de wenselijkheid van de hercodificatie, volgens mevrouw Drion: "Hij zag het als een taak, zeker ook als een plicht, maar hij was er ook erg door geboeid. Het werk sloot direct aan bij zijn belangstelling voor de rechtsvergelijking." $\mathrm{H}$. Drion zei daarover: "Het is niet zo dat hij in de eerste plaats vond dat hij dat moest doen, alsof er in dat opzicht een morele plicht bestond tegenover Meijers. Hij geloofde zelf volledig in de noodzaak van een nieuw B.W. en hij hield ook regelmatig lezingen over het belang daarvan. "111

Ook Eggens koesterde zeker geen overdreven eerbied voor de teksten van Meijers. Als het aan hem lag, waren zelfs de beginselen waarop zij waren gebaseerd, overboord gezet. Polak: "Eggens bewonderde ik persoonlijk zeer, al was het natuurlijk wel iemand die alles weer opnieuw ter discussie stelde en dat was bij het B.W. toen nog ongebruikelijk." Bij De Jong, oud-leerling en bewonderaar van Meijers, was dat stellig anders. Franken zei daarover: "De Jong heeft talloze malen gezegd als we weer zo'n verhitte discussie achter de rug hadden: 'Luister eens Eggens, het kan best

109. Parl. Gesch. NBW, Algemeen Deel, p. 162.

110. Zie ook J.H. Beekhuis, Herinneringen aan mijn werk voor het nieuwe B.W., in: Goed en trouw, Zwolle 1989, p. 333.

111. Vergelijk ook Drions artikel Codificatie of 'gemeen recht'?, WPNR 4073 (1949), waarin hij de wenselijkheid van codificatie in Zuid-Afrika betoogt. 
waar zijn dat als we een totaal nieuw Burgerlijk Wetboek zouden moeten maken, ik meer aandacht zou moeten schenken aan jouw theorieën, maar wil je alsjeblieft bedenken dat wij bezig zijn met het afmaken van het Ontwerp-Meijers, dus heeft een discussie over de grondslagen geen zin meer.'"

Daarbij kwam dat Eggens weinig ophad met de a-dogmatische en pragmatische aanpak die het werk van Meijers kenmerkte. Terwijl Meijers meer een man van de grote lijnen was, zocht Eggens het vooral in het detail en de dogmatiek. Suyling ${ }^{112}$ schreef vol bewondering over de grotendeels door Eggens vormgegeven Londense besluitenwetgeving: "Tot in de hoogste verfijning is zij afgewerkt; spleten of scheuren vallen in haar niet te ontdekken." Iemand als Beekhuis stond het al te gedetailleerde daarin juist tegen: "Deze regeling wordt gekenmerkt door een uiterst simplistisch karakter, al zouden de lange en dikwijls nodeloos ingewikkeld geformuleerde artikelen iets anders doen vermoeden. " 113 Zelfs Franken, die door sommigen als een al te grote perfectionist wordt gezien, werd het daarom wel eens teveel: "Ik ergerde me eraan dat aan sommige titels en afdelingen meer werd geklungeld dan dat er serieus en constructief aan werd gewerkt. Vaak werden toch allerlei dingen, die in eerste opzet misschien niet volmaakt waren, maar toch ook niet te slecht waren, steeds meer verknoeid door steeds meer 'geknutsel' en steeds meer uitzonderingen op uitzonderingen te formuleren. In de tijd van het Driemanschap kwam dat het ergst uit de koker van Eggens en Fokkema."

Kenmerkend voor Eggens' hang naar perfectie is het volgende commentaar van Drion bij een concept van Eggens voor afdeling 6.1.3 (Alternatieve verbintenissen), dat nogal uitvoerig was uitgevallen: "Dit zijn naar mijn mening voorbeelden van vragen, die de codificator bij een behoorlijke codificatie-techniek niet behoort te beantwoorden in het wetboek. De wetgever moet mijns inziens alleen zorgen dat hij in tekst en toelichting niet een terminologie bezigt, die een juiste beantwoording van deze en andere vragen in de weg staat."

Hieraan moet worden toegevoegd dat de medewerkers in dit opzicht weinig voor Drion en Eggens onderdeden. Afdeling 6.5.4 (Wederkerige overeenkomsten), grotendeels vormgegeven door Fokkema en in die vijf jaar gegroeid van elf artikelen bij Meijers tot tweeëntwintig in het voorontwerp, kreeg van Van Oven het volgende commentaar mee: "De ontwerpers gaan hier zo diep in op bijzonderheden, zij speuren de consequenties der door hen ontworpen bepalingen zover na, de betoogtrant is vaak zo zwaar en de documentatie zo overvloedig, dat ik mij niet schaam te erkennen, dat het mij te veel werd en ik voorshands 't bij een eerste lezing heb moeten laten." 114 Fischer ontving van De Jong eens de volgende kanttekening bij haar concept voor

112. Rechtsgeleerd Magazijn Themis 1950, p. 380.

113. NJB 1946, 123. "Eggens, die toch een van onze grote juristen was, heeft door de wetgeving in Londen bewezen, dat hij geen groot wetgever was. Dat bleek trouwens ook toen hij lid was van het Driemanschap", volgens Beekhuis, interview, p. 23, in: Geschriften van J.H. Beekhuis, Zwolle 1989.

114. J.C. van Oven, Een eerste indruk van het ontwerp voor het verbintenissenrecht, NJB 1962, p. 107 e.v. Vergelijk ook T.J. Dorhout Mees (WPNR 4761 [1963]) die oordeelde dat het Driemanschap, wat de grote lijnen van afdeling 6.5 .4 betreft, bijzonder goede en praktische oplossingen had gevonden, wat niet zou wegnemen dat de redactie hier en daar te wensen overliet en de toelichting zich in zo onvoorstelbaarbaar veel details verloor, dat men dikwijls door de bomen het bos niet meer 
afdeling 6.4.3 O.M.: "Van een toelichting in de trant van de drukproef zal de praktijk onnoemelijke last hebben. Laten wij toch de rechtspraak en de wetenschap gelegenheid geven het uitgesproken beginsel op praktische wijze uit te werken, zonder dat zij daarbij door onze - ten dele zeer betwistbare - beschouwingen worden gehinderd."

Maar dergelijke zelfkritiek was uitzonderlijk.

\section{b. lager tempo; méér rechtsvergelijking en grotere invloed van het Departement}

Een tweede verklaring waarom Boek 6 niet reeds een jaar na het afronden van Boek 5 O.M. van het groene kaft kon worden voorzien, was dat na het overlijden van Donker in 1956 de ergste druk van de ketel was. Er was daardoor meer tijd om zich te bezinnen op de concepten van Meijers, met als gevolg dat de opmerkingen uitvoeriger werden, de kritiek meer diepgang kreeg en er steeds meer aandacht kwam voor het detail. Fokkema zei in dit verband: "Misschien kreeg het Driemanschap, als gevolg van het voortschrijden van de tijd, hoe langer hoe minder het gevoel te kunnen volstaan met het puur retoucheren van het ontwerp van Meijers. (..) De Ministers wilden natuurlijk wel opschieten, maar toen Meijers eenmaal was weggevallen, was ook de illusie voorbij dat het snel klaar zou zijn. Men kon ook niet meer profititeren van de kennis van Meijers, zodat de echte spoed verdween."

Deze grotere belangstelling voor het detail uitte zich met name in een sterk toegenomen aandacht voor de rechtsvergelijking. De toelichting op Boek 6 O.M. vormt daarvan het overtuigend bewijs. Verwees Meijers in de eerste vijf groene Boeken (inclusief Inleidende titel) in totaal 144 maal naar buitenlandse wetgeving of uitheemse commentaren, in het voorontwerp voor het verbintenissenrecht bedroeg het aantal bronverwijzingen maar liefst $231 .^{115}$ Een ander cijfer: De eerste helft (p. 638-672) van de toelichting op titel 6.3 O.M. (Onrechtmatige Daad) bevat 220 noten; 120 daarvan verwijzen naar wetgeving, rechtspraak of literatuur in vijftien landen. ${ }^{116} \mathrm{Er}$ is dus door het Driemanschap een zeer geprononceerd gebruik gemaakt van rechtsvergelijkende gegevens.

115. Op de laatste pagina's van elk groen Boek is een verantwoording opgenomen van gebruikte literatuur, onderverdeeld in verwijzingen naar Nederlandse werken, buitenlandse wetgeving en/of tijdschriften en Nederlandse tijdschriften. Zo wordt in de Algemene Inleiding en de Inleidende titel zeventien maal naar Nederlandse werken verwezen, zeventien maal naar uitheemse wetgeving of andere werken en acht maal naar publicaties in Nederlandse tijdschriften. Voor de eerste zes groene Boeken liggen deze cijfers als volgt:

Boek 1 11, 29 (incl. 2 tijdschr.) en 4

Boek 2 9, 3 (incl. 1 tijdschr.) en 3

Boek 3 51, 76 (incl. 5 tijdschr.) en 3

Boek 4 8, 19 en 1

Boek 515,16 en 8

Boek 6 82, 231 (incl. 60 tijdschr. en 21 jurisp. verz.) en 107

Hieruit blijkt dat het aantal verwijzingen in Boek 6 alleén (420) het aantal in de andere Boeken gezamenlijk overtreft (257), of, uitgesplitst naar categorie, 82 tegen 94, 231 tegen 144 en 107 tegen 19.

116. Ontleend aan A.S. Hartkamp, Aard en opzet van het nieuwe vermogensrecht, tweede druk, Deventer 1990, p. 14-15. 
Cijfers zeggen niet alles. Dat Meijers ook al tot een respectabel aantal verwijzingen kwam, moet vermoedelijk aan de inzet en de belangstelling van Drion worden toegeschreven, die tijdens zijn assistentschap bij Meijers er zoveel mogelijk wetsteksten op nasloeg. Opvallend is dat met uitzondering van Boek 3 O.M., waaraan Drion mede vorm gaf, in de eerste groene Boeken geen enkele verwijzing wordt aangetroffen naar een buitenlands commentaar. Meijers had er blijkbaar weinig behoefte aan de tekst van zo'n aangehaald artikel te vergelijken met wat de praktijk er inmiddels van had gemaakt, nam zo'n verwijzing louter ter informatie op. ${ }^{117}$ Bovendien ontbrak het hem waarschijnlijk aan tijd voor een gedegen onderzoek. Polak, die Meijers assisteerde bij het werk aan de voorontwerpen voor de Boeken 1-4, zei daarover: "In de toelichtingen stond voorzichtigheidshalve niet veel meer dan: 'Men vergelijke' en dan noemde je een aantal artikelen. Dat betekende zoiets als 'zoek het zelf maar een beetje uit'. Het betekende niet dat het allemaal zo precies in de buitenlandse wetboeken stond, dat waren dingen waar ik me in die tijd niet mee bezig hield. Daar had ik geen tijd voor."

$\mathrm{Bij}$ het Driemanschap was het juist andersom. Bij vrijwel elk land dat werd gevisiteerd werd naast de code wel een lijstje met handboeken, seriewerken of monografieën opgenomen, die stuk voor stuk waren bestudeerd. Franken licht toe: "Ten aanzien van het Griekse rechtsstelsel moesten wij ons om praktische redenen beperken tot de wetstekst, aangezien geen bruikbare commentaren voorhanden waren. Bij het Duitse recht gebruikten wij zeer veel Von Staudinger en Enneccerus-Lehman en het Bundesgerichthofes Kommentar. We raadpleegden dus zeker niet alleen de teksten, maar lazen ook de commentaren daarbij, al was het maar omdat die commentaren intussen toch wel aanzienlijk afweken van datgene wat de tekst deed veronderstellen."

Een schaduwzijde hiervan was dat het werk enorm veel zwaarder werd en aanzienlijk trager zou verlopen. "Voor het goed doorgronden van de toelichting zou men eigenlijk over een bibliotheek moeten beschikken die geen Nederlands jurist bezit", volgens Van Oven. ${ }^{118}$ Vandaar ook dat Meijers in zijn Boek 3 naar maar liefst 32 verschillende landen kon verwijzen, terwijl het Driemanschap in Boek 6, met zijn veelvoud aan verwijzingen, uiteindelijk "maar" tot 22 landen zou komen.

Wat dreef het Driemanschap tot het zo uitgebreid en intensief raadplegen van buitenlandse rechtsstelsels? Vermoedelijk ging het er allereerst om bepaalde problemen, waarop het Driemanschap bij de bewerking van Meijers' concepten was gestuit, tot een oplossing te brengen. ${ }^{119}$ Typerend is dat de nota's aan de Staatscommissie of de interne rapportages altijd beginnen met een weergave van Meijers' standpunt, onmiddellijk gevolgd door een overzicht van de toepasselijke buitenlandse regels. In vreemd recht werd naar vergelijkbare of ondersteunende opvattingen over juridische dogmatiek gezocht.

117. Vergelijk A.R. Bloembergen, Over de methode van Meijers, WPNR 5504 (1980).

118. J.C. van Oven, Een eerste indruk van het ontwerp voor het verbintenissenrecht, NJB 1962, p. 110.

119. Zie hierover ook D.C. Fokkema, De invloed van de rechtsvergelijking op de ontwikkeling van het nieuwe B.W., NJB 1983, p. 1223 e.v. Vergelijk ook zijn Leidse openbare les Begrensde gerechtigheid, Deventer-Antwerpen 1963. 
Het praktische element was echter niet overheersend. Mevrouw Drion vertelde dat haar man het werk aan het nieuwe B.W. ook dáárom een uitdaging vond omdat hij "heel erg geboeid" was door het leggen van het verband met het buitenlandse recht. ${ }^{120}$ Bovendien sloot de rechtsvergelijking ook goed aan bij de houding die het Driemanschap ten opzichte van Meijers' werk aannam: Het moest allemaal beter, diepgravender, volmaakter, en dat betekende dat je je het niet kon permiteren geen kennis te nemen van de oplossingen die in de moderne buitenlandse rechtsstelsels waren neergelegd. ${ }^{121}$ "Een eenzijdig Franse inslag past voor ons wetboek niet," volgens Drion, die het nieuwe B.W. het best meende te kunnen omschrijven als "een overgang tussen de sterk uiteenlopende structuren van het Franse, het Angelsaksische en het Germaanse recht." ${ }^{122}$ Vandaar ook dat in Boek 6 O.M. zo sterk de nadruk wordt gelegd op het Duits-Zwitserse recht, met zijn grote en zware commentaren, terwijl in de eerste vijf Boeken de Franse rechtsfamilie nog de boventoon voert.

Fokkema: "Een feit is natuurlijk, dat als je aan de gang gaat met een werk als dit, je haast automatisch naar de Duitse literatuur grijpt, omdat je bij andere schrijvers vaak ervaart, dat het probleem eenvoudigweg niet aan de orde is gekomen. Bij de Duitsers daarentegen, is het meestal zo, dat wat je zelf bedenkt, al een keer eerder door hen is gesignaleerd. Hetzelfde geldt ten aanzien van de Amerikanen. Dat brengt je automatisch tot deze houding. Dat betekent niet, dat je altijd de oplossingen overneemt, maar wel dat je er kennis van neemt en verder zoekt op basis van de discussie die daar is gevoerd." Franken: "Oudere schrijvers, van voor 1940, halen, als ze naar het buitenland willen verwijzen, altijd Planiol-Ripert of De la Morandiére aan. Wij daarentegen, raadpleegden zeer veel het B.G.B., het Z.G.B., en namen verder kennis van wat het Italiaanse of Griekse wetboek over de door ons te onderzoeken materie vermeldden. Het Franse recht had bij ons afgedaan, omdat het nog minder bruikbaar was dan ons wetboek. Bovendien, het rechtsvergelijkende aspect was al uit de doeken gedaan door de vaderlandse auteurs, zelfstudie was niet meer nodig. Om werkelijk nieuwe en verfrissende ideeën te krijgen, moest je terugvallen op de moderne wetboeken. ${ }^{\text {"123 }}$

Dat het Driemanschap heel ver ging in het naast elkaar leggen van vreemde wetboeken en commentaren, blijkt doordat in de toelichting regelmatig verwijzingen worden aangetroffen naar exotische wetboeken, zoals het Braziliaanse, het Egyptische en het Chinese B.W. Voor een deel was dat een gevolg van het feit dat die vreemde wetboeken een vertaling zijn van Europese wetboeken, zoals de Code Civil of het B.G.B. en daarom bruikbaar vergelijkingsmateriaal vormden. Voor een ander deel speelden echter andere overwegingen een rol, die, hoewel niet onbegrijpelijk, toch

120. Voor een inzicht in Drions ideeẻn over rechtsvergelijking, zie zijn "Common Law and Continental Law" en "De doeleinden van rechtsvergelijking", in Verzamelde geschriften van J. Drion, Leiden-Deventer, 1968, p. 235-243 en 315-317.

121. Ten dele verklaart dat ook de benoeming van Fokkema, die in de eerste jaren vooral rechtsvergelijkend zou optreden: "Het Driemanschap heeft mij daarvoor speciaal gevraagd, omdat men er behoefte aan had wat meer inzicht in andere rechtsstelsels te krijgen."

122. De Tijd, 24 oktober 1955.

123. Vergelijk ook D.C. Fokkema, De invloed van de rechtsvergelijking op de ontwikkeling van het nieuwe B.W., NJB 1983, p. 1224: "Standaardprocedure was zeker dat nagegaan werd wat gold in Frankrijk, België, Duitsland, Zwitserland, Oostenrijk en Italië; Al naar het geval werd ook Engels en Amerikaans recht in de vergelijking betrokken." 
een wat merkwaardig licht werpen op de rechtsvergelijkende activiteiten van het Driemanschap. Zo werd volgens Ten Kate het Japanse wetboek bijvoorbeeld gebruikt omdat de tekst-editie tweetalig was en werd aan het Nordisk Lovbog van Vinding Kruse aandacht geschonken omdat De Jong de Deense taal meester was. ${ }^{124}$ De vergelijkbaarheid, toch dé voorwaarde voor rechtsvergelijking, werd nauwelijks als probleem onderkend. Niet de functionaliteit, maar de toegankelijkheid en de verkrijgbaarheid van het werk speelde een beslissende rol. Het is tekenend voor de manie naar volledigheid. ${ }^{125} 126$

Die grotere aandacht voor het detail bleef niet beperkt tot de leden van het Driemanschap. Ook het Departement ademde op na het overlijden van Meijers en Donker en raakte evenzeer in de ban om alles te verbeteren. Het aandeel van de departementale BW-club in de hercodificatie werd allengs groter, nota's van vele tientallen bladzijden over een bepaald onderwerp, afdeling of titel met daarin een grondig en totaal tableau van de inzichten die op het Ministerie leefden, waren geen uitzondering. Belinfante zei daarover: "Ook het Driemanschap wenste te voorkomen dat haar ontwerpen, na publikatie, door de Regering belangrijk zouden moeten worden gewijzigd. Ook het Driemanschap schakelde dus het Departement in. Zodra van een onderdeel een drukproef is verschenen - dus veelal pas na verscheidene versies welke in de kring van het Driemanschap zijn besproken - wordt het Departement in de gelegenheid gesteld opmerkingen te maken. Het tempo is langzamer, dus de opmerkingen kunnen uitvoeriger zijn dan in de tijd van Meijers en Donker. ${ }^{127}$ Franken vult aan: "In de tijd

124. Het heeft bovendien maar weinig gescheeld, of Boek 6 O.M. zou ook zijn verrijkt met verwijzingen naar de Venezolaanse code. Op Justitie doet althans nog steeds het verhaal de ronde dat de bibliothecaris een verzoek van het Driemanschap dit werk zo snel mogelijk te bestellen, als volgt beantwoordde: "Heren, ik heb het gevoel dat dit nog wel even kan duren." Het boekwerk zou pas in 1964 arriveren, drie jaar nadat het Driemanschap had opgehouden te bestaan. Zie ook Interview mr. A.S. Hartkamp, BW-NBW Twee sporen, BW-krant jaarboek 1985, Leiden 1985, p. 6.

125. Tot welke vreemde situaties een dergelijke houding kan leiden. illustreert ook de volgende anekdote van Ten Kate, die vertelde dat er in de eerste drukproeven voor Boek 6 O.M. nogal veel verwijzingen naar het jonge en daarom voor het Driemanschap aantrekkelijke Russische B.W. voorkwamen. Ten Kate, die in opdracht van het Driemanschap de noten moest controleren, maakte daarvoor gebruik van de diensten van de heer Szirmai van het Oosteuropees Documentatiebureau. Ten Kate: "Szirmai kende Pools en Hongaars, maar geen Russisch. Hij kon echter wel teksten vertalen met behulp van een woordenboek, dus we hebben heel nijver op die teksten zitten werken om te kijken wat er nu allemaal stond. In het algemeen waren die verwijzingen van Boek 6 naar het Russische wetboek terecht, want er stond inderdaad ongeveer hetzelfde in als in het nieuwe B.W. 'Maar', zei Szirmai op een gegeven moment, 'er is natuurlijk wel een merkwaardigheid, want wat u waarschijnlijk wel niet zult weten, is dat deze bepalingen in het geheel geen toepassing vinden.' Daarmee werd de bewijswaarde van zo'n verwijzing nul. Dat verhaal heb ik gemeld aan het Driemanschap en daarmee zijn dergelijke dingen wel weer verdwenen."

126. Vergelijk ook Z. Szimai, De bruikbaarheid van het sowjet burgerlijk recht voor de westerse wetgever, Deventer 1971 , p. 25 : "Indien de westerse wetgever het sowjet burgerlijke recht heel voorzichtig en zonder te veel illusies benadert, als een mogelijke bron van verrijking van zijn eigen recht, en een groot deel van het Russische recht opzij zet aangezien het te nauw verbonden is met de bijzondere leerstukken van het sowjet systeem, vindt hij formules en instituten die hem kunnen helpen, en mogelijk zelfs in meerdere mate dan hij in het begin verwacht had."

127. W.G. Belinfante, De totstandkoming van het nieuwe Burgerlijk Wetboek, in: Het Ontwerp B.W., Deventer-Antwerpen 1962, p. 41. 
van Meijers ging de departementale voorbereiding van het groene Boek en de daarop gebaseerde Regeringsontwerpen naar onze zin veel te oppervlakkig. Als Donker zijn zin had gekregen was het Regeringsontwerp letterlijk gelijk aan het groene Boek geweest. De tijd die we er voor kregen, was zo gering, dat we maar een duizendste konden veranderen van wat we werkelijk hadden willen doen. Donker paste er wel op dat die wijzigingen niet tot hele boekwerken zouden uitgroeien. Toen Donker was overleden hadden we als BW-club dus ook meer tijd om een diepgravende behandeling toe te passen."

Datgene waar Minister Donker dus altijd voor had gewaarschuwd, werd bewaarheid: "Wanneer voor het nieuwe wetboek niet in het algemeen een snel tempo wordt aangelegd is het werk van de totstandbrenging van het wetboek tot een mislukking gedoemd. "128 De kring van mensen die zich met het werk van Meijers ging bemoeien, werd steeds groter, het aantal meningen waarmee rekening moest worden gehouden nam voortdurend toe. Daardoor kostte het steeds meer moeite en tijd om tot overeenstemming te komen, en kreeg de kritiek een steeds grotere stem.

\section{c. gebrek aan samenwerking}

Een derde factor waardoor het werk aan het voorontwerp voor Boek 6 weinig opschoot en het ontwerp steeds ingewikkelder werd, was dat men het gezamenlijk eens moest zien te worden. Dat kostte bijzonder veel moeite. Omdat het Driemanschap, vooral in de beginjaren, soms twee- à driemaal per week bijeenkwam, was er eigenlijk nooit voldoende tijd om alle stukken te bestuderen, het besprokene te overdenken en te laten bezinken. Men verloor zich al snel in allerlei bijkomstigheden en vergat de grote lijn. De nadruk kwam te liggen op het creatieve moment, erkende toetsstenen, zoals wet en jurisprudentie, waren niet langer van doorslaggevende betekenis voor de standpuntbepaling.

Ook was er geen echte leider, iemand die een stempel op het geheel kon drukken, voor de anderen een beslissing kon nemen, met een enkel woord de discussie kon afsluiten, kon zeggen: Hier is voldoende over nagedacht.

Tenslotte viel een teamgedachte eigenlijk nauwelijks te bespeuren, in die zin dat men er samen zo snel mogelijk uit wilde komen en men ook bereid was eventuele kritiek in te slikken of achterwege te laten. Het ontwerp maakte daardoor de indruk te zijn doodgepraat. Fischer: "Men discussieerde net zo lang door totdat men het met elkaar eens was, er was niemand die voor de ander besliste, de knoop doorhakte of als voorzitter optrad." Belinfante: "Het ging heel langzaam. Ze werden het wel over veel dingen eens, maar dat kostte heel veel moeite, heel veel vergaderingen, veel schriftelijke stukken." Fokkema: "Er zijn wel meerderheidsbeslissingen genomen, maar meestal probeerde men om dat te voorkomen. Het is ook wel gebeurd dat een beslissing tot een volgende vergadering werd uitgesteld, zeker in de tijd van Eggens."

Bij de beschrijving van de werkwijze van het Driemanschap zijn al enkele voorbeelden gegeven van de moeizame besluitvorming binnen het Driemanschap. Ik licht er twee uit. Het eerste voorbeeld is, dat de eerste lezing van titel 6.1 (Verbintenissen 
in het algemeen) drieëneenhalve maand of twintig vergaderingen in beslag nam. ${ }^{129}$ Daarmee was de besluitvorming met betrekking tot deze titel echter nóg niet afgerond: Voordat het Driemanschap uitvoering had kunnen geven aan het in oktober 1955 uitgesproken voornemen om enkele leden van de Statscommissie voor een rapportage uit te nodigen, zou de discussie opnieuw losbarsten. Pas een jaar later, op 12 september 1956, werd in de notulen melding gemaakt dat een aantal rapporteurs was benaderd. ${ }^{130}$ Het tweede voorbeeld heeft betrekking op de perikelen rond afdeling 6.1.1 O.M. (verbintenissen naar burgerlijk recht en de natuurlijke verbintenis). Fokkema: "Als je vraagt of Eggens zijn spoor heeft kunnen nalaten, dan had het moeten zijn bij de vraag of een verbintenis kan voortkomen uit de billijkheid. Dat was zijn hobby en dat was ook één van de punten waarover binnen het Driemanschap de meeste wrijving bestond. Drion en De Jong waren ervan overtuigd dat het zo niet moest. Daar kreeg Eggens gewoon zijn kans niet." Dat de spanningen bij dit onderdeel hoog opliepen, blijkt doordat dit het enige onderwerp is waarbij in de notulen uitdrukkelijk wordt vermeld dat er géén aanleiding bestaat om terug te komen op wat reeds in de Staatscommissie is besproken. ${ }^{131} \mathrm{Er}$ was kennelijk een machtswoord voor nodig om Eggens tegen te houden. Bovendien werd het werk aan deze afdeling, nadat Eggens in augustus 1956 een eerste concept-tekst en toelichting had opgesteld, voor onbeperkte tijd opgeschort en werd de naam van de bewerker in de volgende overzichten blanco gelaten. Pas in oktober 1957, toen Eggens zijn vertrek naar Amsterdam had aangekondigd, werd het overleg hervat, nu onder verantwoordelijkheid van Drion.

Dat er het nodige schortte aan de bereidheid het met elkaar eens te worden blijkt indirect ook uit de volgende opmerking van Fischer. Sprekend over haar werk onder leiding van Regeringscommissaris Langemeijer vertelde zij: "We hebben in die tijd weinig vergaderd. Een ander verschil met het werk tijdens het Driemanschap was, dat er sneller knopen werden doorgehakt door Langemeijer." Snijders daarentegen merkte op: "Langemeijer was een man die bij uitstek geschikt was voor het maken van conclusies voor de Hoge Raad, maar hij had ontzettend veel moeite om de knoop door te hakken. Eén van de taken als Regeringscommissaris met twee lastige assistenten die allemaal hun eigen ideeën hebben en die ook wel eens wat willen, is dat je op een goed moment tegen de mensen moet zeggen; dit is voldoende uitgepraat. Maar dat is iets dat Langemeijer absoluut niet lag."

Dát de leden van het Driemanschap moeite hadden met elkaar tot overeenstemming te komen, was niet uitsluitend een kwestie van gebreken in de besluitvorming. Het was ook min of meer eigen aan de instelling van het Driemanschap: Alleen het beste was goed genoeg. Vooral Drion was geen moeite teveel om zo perfect mogelijk werk af te leveren. "Hij was de meest begeesterde, de man die iedere keer de stimulans was om de materie nog eens opnieuw te doordenken", volgens Wiersma.

Bovendien waren de leden van het Driemanschap niet uitgekozen op hun geschiktheid samen iets op te zetten. Eggens duldde eigenlijk geen andere mening dan de

129. De besprekingen begonnen op 12-5-55 (58e vergadering) en kregen een voorlopig einde op 258-55 (77e vergadering).

130. Notulen van de 130 e bespreking van het Driemanschap.

131. Notulen van de 59e bespreking van het Driemanschap van 16 mei 1955. 
zijne naast zich, en ook Jan Drion was een moeilijk debater en weinig inschikkelijk. Van der Ploeg, die als voorzitter van de Commissie Erfrecht in het begin van de jaren zestig regelmatig contact had met Drion, karakteriseerde diens onverzettelijkheid als volgt: "Toen de Canadezen aan het eind van de oorlog vlakbij de grens stonden, toen we in spanning zaten, wanneer gebeurt het nu, wanneer worden we bevrijd, is er met het oog op de hongersnood in de Randstad overleg geweest tussen de geallieerden en Von Blaskowitz, de Duitse bevelhebber. Jan Drion was daar fel op tegen: 'Je onderhandelt niet met dergelijke schurken'. Dat is natuurlijk wel mooi als het gaat om tienduizend gulden, maar niet in dit geval, waar honderdduizenden mensen dreigden te verhongeren. Dat typeert het rechttoe-rechtaan van deze man. Je hebt van die mensen die zo rechtuit zijn, dat ze verder alles vergeten."

Wat ook een rol speelt, is dat de discussies niet alleen tussen de Driemannen onderling werden gevoerd, maar dat de medewerkers van het Driemanschap, althans met name Franken en Fokkema, ook hun partijtje meebliezen. In wezen was dus geen sprake van een driemanschap, maar van een vijfmanschap met een vrouw; Zes mensen die allemaal goede ideëen hadden, maar die ook moeilijk te overtuigen waren. Werd hiervoor opgemerkt dat bij de voorbereiding van het voorontwerp voor Boek 5 de taak van Franken en Polak in hoofdzaak beperkt bleef tot het schrijven van toelichtende stukken, bij Boek 6 O.M. zouden de medewerkers een geheel eigen rol spelen als gevolg van de steeds verder doorgevoerde werkverdeling. Hun oordeel, mits deugdelijk gefundeerd, woog even zwaar als dat van de leden van het Driemanschap. ${ }^{132}$ "In de subcommissies kregen wij het volle pond en mochten we naar hartelust discussiëren", volgens Franken." ${ }^{133}$ Het gevolg was, dat zij ook tijdens de vergaderingen van het Driemanschap langdurig en nadrukkelijk aan het woord waren, met name Fokkema, wiens bijdrage aan het debat na 1958 blijkens de notulen steeds belangrijker werd. Ook werd het ontwerp daardoor weer gedetailleerder. ${ }^{134}$

132. Fokkema zei daarover: "Het Driemanschap was verantwoordelijk voor de gang van zaken en voor de afgeleverde ontwerpen. Als het dus op beslissen aankwam, dan telden de drie assistenten niet mee, alleen, bij de voorbereiding was dat niet zo merkbaar. Elk van de Driemannen had een aantal afdelingen onder zijn hoede. (.) Vaak was de procedure dan als volgt, dat elk van de medewerkers werd 'toegevoegd' aan een Drieman voor bepaalde afdelingen. Zo heb ik aanvankelijk veel samengewerkt met Eggens, en later veel met De Grooth en De Jong. Wij maakten als assistenten vaak voorstudies, ook vaak met een rechtsvergelijkend karakter, en dan kwam een ontwerp dat, of door een van de Driemannen eerst was gemaakt en doorgesproken was met een van de medewerkers, óf andersom."

133. Vandaar ook dat Franken de werkwijze van het Driemanschap in organisatorisch opzicht prefereerde boven die van Meijers (Zie NJB 1992, p. 11). Ook bij Meijers kreeg hij weliswaar gelegenheid om commentaar te leveren op de teksten, maar het moest allemaal snel gebeuren, waardoor er weinig gelegenheid was voor langdurige discussies of diepgaande bespiegelingen. Franken kreeg als het ware alleen gelegenheid om een eerste indruk op te doen; Als die positief uitviel was naar de mening van Meijers verdere discussie overbodig.

134. Eén van de kritieken op Boek 6 O.M. was dan ook dat de hoofdregel dikwijls bedolven ging onder de uitzonderingen of zelfs niet meer kon worden teruggevonden. De regel bijvoorbeeld, dat de schuldeiser bij blijvende onmogelijkheid recht heeft op schadevergoeding, was noch in de tekst noch in de toelichting te vinden. In het Voorlopig Verslag (Parl. Gesch. Boek 6, p. 284) werd opgemerkt: "Eerst na veel heen en weer geblader, vooral in de toelichting, kan men erachter komen dat men het antwoord op deze vraag - welgeteld - tien artikelen eerder moet zoeken." De conclusie: "Het ontwerp is hier veel te gedetailleerd en voor een deel zelfs onbegrijpelijk. Door de talloze regels, uitzonderin- 
Daarbij kwam, dat Franken en Fokkema evenmin gemakkelijk te overtuigen waren en zich moeilijk bij een beslissing konden neerleggen. Franken was iemand die van compromissen eigenlijk niet wilde weten en had volgens Belinfante, zijn directe chef, bovendien "een sterke geneigdheid om zijn eigen overtuiging door te zetten in een richting tegen een hem bekend hoger oordeel." Net zoals Drion indertijd Meijers wel eens verraste doordat hij uit eigen beweging nieuwe nasporingen had verricht, zo werd het Driemanschap niet zelden geconfronteerd met een dikke nota van Franken of Fokkema, waarin werd betoogd dat de zaak tóch iets anders lag dan in de vorige vergadering was verondersteld en waardoor het wankele evenwicht werd doorbroken. Ten Kate: "Franken hield vreselijk vast en had ook de vervelende eigenschap, dat wanneer het in de commissie was uitgesproken, om zijn tekstvoorstel vervolgens op het Ministerie nog eens te gaan verdedigen."

Iets dergelijks gold met betrekking tot Fokkema, door Ten Kate niet ten onrechte als een "wandelende encyclopedie" aangeduid. Fokkema was net als Franken knap, bijzonder knap zelfs, maar ook iemand die zich bijzonder moeilijk neer kon leggen bij andermans mening, omdat hij het, als gevolg van zijn enorme kenis van zaken, altijd "beter wist". Dat het bijna dertig besprekingen duurde alvorens er in het Driemanschap overeenstemming werd bereikt over een eerste voorlopig concept voor afdeling 6.5.4 (Wederkerige overeenkomsten) kan naar mijn gevoel dan ook niet uitsluitend aan de moeilijkheidsgraad van het te behandelen onderwerp of aan coördinatieproblemen worden geweten. Zijn persoon speelt daarbij waarschijnlijk minstens een zo belangrijke rol.

\section{d. gezag en onderlinge verhoudingen}

Een factor die ongetwijfeld eveneens een belangrijke rol heeft gespeeld bij de trage totstandkoming van het zesde groene Boek, is dat de onderlinge verhoudingen binnen het eerste Driemanschap nogal te wensen overlieten. Eggens, die volgens Pitlo ${ }^{135}$ zijn hele leven heeft geleden onder de gedachte dat hij onvoldoende erkenning had gekregen, greep het werk in het Driemanschap aan om te proberen het nieuwe verbintenissenrecht conform zijn inzichten op te zetten. Omdat het voorzitterschap "open" bleef en Drion, Eggens en De Jong overigens volledig aan elkaar gewaagd waren, betekende dit dat over vrijwel ieder onderwerp van betekenis strijd moest worden geleverd. Franken zei daarover: "Eggens deed herhaaldelijk met een opgezet hoofd mee aan de discussies, verzamelde dan op een gegeven moment de stukken, propte ze in zijn tas, stond op en zei: 'Het heeft verder geen zin dat ik in dit gezelschap meedoe aan het debat.' Nog voordat hij bij de deur stond, begonnen de beide

\section{4. $\rightarrow$}

gen en uitzonderingen op uitzonderingen - met telkens rijke nuances - is een warwinkel ontstaan, waarin jurist noch leek de weg kan vinden. Wat moet de praktijk hiermee aan?"

Een ander voorbeeld is de regeling van de hoofdelijkheid. Het uitgangspunt van het ontwerp werd in de toelichting omschreven: de lotgevallen van het vorderingsrecht tegen de een hebben geen invloed op de vorderingsrechten tegen de anderen, tenzij uit de wet het tegendeel voortvloeit. Het belangrijkste voorbeeld daarvan was art. 6.1.2.2 O.M. Merkwaardig was echter dat in de tekst vrijwel alleen gevallen werden vermeld waaruit het tegendeel voortvloeide, hetgeen bovendien aanleiding zouden kunnen geven tot een analogische toepassing op andere gevallen.

135. G.P. Hoefnagels, Interview met Pitlo, Tijdschrift voor Familie- en Jeugdrecht 1985, p. 229. 
anderen hem toe te spreken en na een kwartier ging de bespreking dan weer in een mokkende stemming verder. De oorzaak lag vrijwel altijd bij Eggens." En: "U moet zich niet voorstellen dat dit schering en inslag was. Het deed zich zo om de vijf vergaderingen voor. Het merendeel van de vergaderingen verliep toch in betrekkelijk goede harmonie waarbij het antagonisme Eggens/De Jong in sterk afgezwakte vorm voelbaar bleef, omdat ze het vaak niet eens werden. Ongetwijfeld heeft het discussieren meer tijd gekost door het optreden van Eggens. Ik wil hiermee niet suggereren dat De Jong en Drion het allebei veel vlugger zouden hebben gedaan, of dat zij nooit flinke meningsverschillen hadden, maar bij hen betrof het uitsluitend zakelijke aspecten en bestond enerzijds de oprechte wens de zaak goed door te praten en daar zonodig extra tijd voor uit te trekken, anderzijds om het zo snel mogelijk met elkaar eens te worden. Er ontstonden nooit van die vervelende fricties. "136

Zoals Franken al aangaf, was het vooral De Jong die zich eraan ergerde dat Eggens keer op keer probeerde de grondbeginselen van Meijers' concept voor Boek 6 ter discussie te stellen. Polak: "De Jong was een wat kort aangebonden man, die resultaten wilde zien. Als wij vergadering hadden gehad en er was iets veranderd, dan lag er de volgende dag van De Jong een nota met een tekst. Eggens begon dan weer opnieuw te discussiëren over grondbeginselen die op zich niet terzake deden als je keek naar de verandering die De Jong in de tekst had aangebracht. Die werkwijze van Eggens irriteerde De Jong buitenmate." Franken: "Veel van de discussies die ontstonden en een venijnig karakter kregen, gingen over punten die niet meer discutabel waren." Volgens De Vries kwam het regelmatig voor dat De Jong, moedeloos geworden van het eindeloze geruzie, zijn stoel omdraaide, met zijn rug naar de anderen ging zitten en zijn handen aan het hoofd bracht. Fokkema had deze lezing: "De Jong, die meer een praktische geest was, kon het doordrammen van Eggens over bepaalde filosofische stokpaardjes niet verdragen, eenvoudig omdat het ophield. Hij had dan de neiging om een beetje voorover te gaan zitten en te doen alsof hij sliep. Hij sliep echter allerminst."

Een ander punt dat de ergernis van De Jong opwekte en de werksfeer niet ten goede kwam, was dat Eggens zich dikwijls laatdunkend uitliet over Meijers. H. Drion: "Eggens was een nogal agressieve man, die geweldig irriterend werkte op De Jong, omdat hij altijd, voor een deel een beetje spottend, voor een ander deel werkelijk gemeend, geweldig zat af te geven op Meijers. 'Meijers sprak altijd onzin, had er niets van begrepen' en dergelijke. Polak was bezig met een proefschrift bij

136. Dat er met Eggens moeilijk te praten was, illustreert ook de volgende anekedote van Van der Ploeg, die in 1958 plaats in de redactie van het WPNR zou nemen: "Op die eerste redactievergadering waren aanwezig de redactiesecretaris, Van Oven, Houwing, Eggens en ikzelf. Men had Eggens namelijk gevraagd weer in de redactie te komen omdat hij tot hoogleraar was benoemd. Op een gegeven moment kwamen we aan de verdeling van de rechtsvragen toe. Van Oven zei tegen mij 'Jij had altijd het erfrecht, vennootschapsrecht en huwelijksrecht, ga daar mee door.' Houwing nam ook wat en toen kwam Eggens aan de beurt. 'Eggens, wat neem jij?' 'Ik doe geen rechtsvragen.' 'Ja', zei Van Oven, 'maar als je lid van de redactie bent, dan moet je een paar rechtsvragen voor je rekening nemen.' 'Ik doe geen rechtsvragen'. Houwing, vriendelijk, 'Och Eggens, als je soms ergens mee zit omdat die materie je eigenlijk niet zo ligt, stuur die vraag dan naar mij.' 'Ik doe geen rechtsvragen.' Van Oven zei toen: 'Als jij geen rechtsvragen wilt beantwoorden, moet jij geen lid worden van de redactie van het WPNR.' Eggens: 'Zo. Meen je dat?' Van Oven: 'Ja.' Eggens: 'Dan ga ik weg.' Van Oven: 'Dat moet je doen ook.' En weg was ie." 
Eggens en had daarin een bepaald standpunt ingenomen. Eggens vroeg hem: 'Hoe bent u op dat vreemde denkbeeld gekomen?', waarop Polak antwoordde: 'Dat is de opvatting van professor Meijers.' Eggens repliceerde door te zeggen: 'Daar noemt u me nu ook iemand.' Zulke kreten uitte hij ook in de vergaderingen van het Driemanschap, tot groot ongenoegen van De Jong. Die kon dat helemaal niet hebben, werd er razend van."

Drion had minder moeite met Eggens' oncollegiale gedrag. Hij stond er, volgens Polak, "een beetje boven en buiten", het ging hem zozeer om de zaak zelve, dat hij geen oog had voor de persoonlijke irritaties. Fischer: "Tussen Drion en Eggens ging het beter. Eggens kon erg goed provoceren, maar Drion was zo verstandig daar niet op in te gaan. De Jong daarentegen liep rood aan, dat kon je duidelijk merken, en dan betuigde Eggens ook wel weer zijn spijt." Fokkema: "Drion probeerde als het ware langs de wrijvingen heen te praten met een goed, zakelijk betoog. Hij was ook degene die zich het meeste had ingedacht dat het speciaal tot zijn verantwoordelijkheid behoorde dat het werk tot een goed einde kwam. Bij de anderen was het iets dat een zekere tijd kostte, dat belangrijk was, maar niet zo belangrijk dat ze daardoor hun hele leven lieten bepalen."

Eggens zou per 1 januari 1958 opstappen, in verband met zijn benoeming tot gewoon hoogleraar aan de Universiteit van Amsterdam. Waarschijnlijk hebben daarbij twee overwegingen een rol gespeeld. De eerste was, dat hij na verloop van tijd wel begreep dat hij in het Driemanschap niet zo op z'n plaats was. Daarnaast zou hij altijd de ambitie hebben gehad hoogleraar te worden, een functie die voor hem onbereikbaar was door zijn eigenzinnig karakter en scherpe tong. Nu Amsterdam via Pitlo hem deze kans bood, wilde hij zich die niet laten ontgaan.

Fokkema zei het als volgt: "Eggens zal gevoeld hebben dat als hij met het werk zou doorgaan, hij toch altijd een zekere wrijving zou houden met De Jong, en dat hij anderzijds die vier jaar in Amsterdam, als een nieuw gedeelte van zijn leven, nog graag door wilde brengen. Ze zijn beslist niet met slaande ruzie uit elkaar gegaan. Een andere reden kan zijn geweest, dat het langer duurde dan men zich oorspronkelijk had voorgesteld. Iedereen leefde in de gedachte 'we maken dat even af en wat klaar ligt, is zo goed, dat hoeft slechts hier en daar wat bijgewerkt te worden. Bij Boek 6 ging dat niet. (..) Drion was ten volle bereid om ermee door te gaan, want hij vond het werk zo belangrijk, dat hij er al zijn energie in wilde stoppen. Eggens werd het waarschijnlijk te veel en daarom zocht hij werk dat voor hem aantrekkelijker was." 137

Met de komst van G. de Grooth (1892-1965), die Eggens in 1958 opvolgde, verbeterde de sfeer aanzienlijk. De Grooth was evenals Drion en De Jong leerling van Meijers geweest. Franken: "De Grooth was een bijzonder aardige man, dus de sfeer was meteen perfect, ondanks dat hij in wetenschappelijk opzicht niet op kon tegen De

137. Ook uit andere bronnen blijkt niet dat Eggens met ruzie is opgestapt. Het overleg over afdeling 6.1.1, waarvan de behandeling in maart 1956 was opgeschort, zou eind 1957 worden heropend en kon met goed gevolg worden afgesloten. Ook is Eggens zo vriendelijk geweest De Grooth, die met ingang van 3 oktober 1957 de vergaderingen in het Driemanschap ging bijwonen, in te werken. Wel kwam het vertrek van Eggens ook voor het Ministerie nogal onverwacht. In de begroting voor 1958 was het aantal advocaten-generaal bij de Hoge Raad juist van drie op vier gebracht in verband met de omstandigheid dat Eggens alleen voor het Driemanschap werkzaam zou zijn. 
Jong en Drion." Fokkema: "Toen De Grooth zijn intrede deed, veranderde de werkmethode niet of nauwelijks. Wel was het minder spannend, want de spanningen die er rond Eggens konden heersen, waren er bij De Grooth helemaal niet." Opvallend is, dat De Jong, die met ingang van september 1957 weer voluit werd ingeschakeld bij het werk in de Hoge Raad omdat hij klaar was met de aan hem toegewezen gedeelten, direct na Eggens' vertrek zou terugkeren en tot het eind zou blijven.

\section{e. moeilijkheidsgraad stof}

Een laatste factor die ter verklaring van de vertraging in de afwerking van Boek 6 O.M. zou kunnen aangevoerd, is dat het Driemanschap, toen men eenmaal de houding aannam dat de door Meijers gemaakte keuzen allesbehalve bepalend konden zijn voor het eindresultaat, ook op bijzonder weinig kon terugvallen. Boek 1 was doorlopend gemoderniseerd, het zakenrecht was kort voor de eeuwwisseling nog door een Staatscommissie bekeken en voor het erfrecht was Meijers dé specialist. Over een nieuwe structuur van het verbintenissenrecht, het centrale deel van het B.W., was in 1954 echter nog maar weinig nagedacht. Het verbintenissenrecht stamde nog uit 1838 en was door de wetgever stelselmatig veronachtzaamd.

Aan de doctrine had het Driemanschap ook niet veel. Wie bijvoorbeeld Ruttens bewerking van de onrechtmatige daad in de Asser-serie leest - het deel zou pas in 1954 voor het eerst verschijnen - en die vergelijkt met wat Drion er uiteindelijk van heeft gemaakt, kan niet anders dan tot de conclusie komen dat de behandeling daarvan door de literatuur wel heel magertjes was. Hetzelfde geldt ten aanzien van onderwerpen als hoofdelijkheid, subrogatie en de niet-nakoming. Op deze terreinen zou Boek 6 O.M. de wetenschap jaren vooruit zijn, zoals door zijn critici ook werd toegegeven.

Van der Grinten, die afdeling 6.1.7 in het WPNR voor het voetlicht hield, schreef dat het ontwerp "hoogst ingenieus" was samengesteld en "bijzonder knap geconstrueerd" (maar ook wel erg gecompliceerd). ${ }^{138}$ Volgens Dorhout Mees had het Driemanschap voor de vele vragen die zich bij de wederkerige overeenkomsten voordoen, wat de grote lijnen betreft, "bijzonder goede en praktische oplossingen" gevonden (wat niet wegneemt dat de redactie hier en daar te wensen overlaat en de toelichting zich in zo onvoorstelbaar details verliest dat men dikwijls door de bomen het bos niet meer ziet). ${ }^{139}$ Van der Ploeg tenslotte schreef aan het eind van zijn beschouwingen over artikel 6.5.3.4 en 12, dat bij aanvankelijke bestudering zijn eerste reactie was: Wat hebben ze nu weer uitgehaald? "Gaat men echter nauwkeurig studeren, dan wijzigt allengs deze weerstand zich in waardering. 'T slot van het lied is dat men de tekst aanvaardt zoals ze is bedoeld". ${ }^{140}$

Het groene Boek 6 was, om het Van Opstall na te zeggen, "als bron van kennis en problematiek van het verbintenissenrecht zeer waardevol", maar als wetsontwerp zag het er "heel wat minder gunstig" uit. ${ }^{141}$

138. W.C.L. van der Grinten, Verzuim van de schuldeiser, WPNR 4741 (1962).

139. T.J. Dorhout Mees, De wederkerige overeenkomsten, WPNR 4761 (1963).

140. P.W. van der Ploeg, De kwalitatieve verbintenis, het kettingbeding en de overbelasting van de grond; art. 6.5.3.4 en 12, WPNR 4738 (1962).

141. S.N. van Opstall, Het ontwerp voor het zesde Boek van het nieuwe Burgerlijk Wetboek, WPNR 4754 (1963). 
Dat in Boek 6 moeilijke vragen niet uit weg zijn gegaan, dat de ontwerpers de moed hebben gehad allerlei problemen tot de bodem te doordenken, dat oude, tot het bot afgekloven onderwerpen nieuw leven werd ingeblazen, is ongetwijfeld geheel de verdienste van het Driemanschap geweest. De publicatie van het voorontwerp voor Boek 6 O.M. was voor de wetenschappelijke bestudering van het verbintenissenrecht een geweldige stimulans. In zoverre was de hercodificatie een succes. Voor de praktijkjurist, die uiteindelijk met het wetboek zou moeten werken, was het een ramp. Er was teveel ingevoegd van de leer en de wetenschap, het ontwerp bevatte op verschillende punten regelingen waaraan in rechtspraak en literatuur nooit behoefte was gebleken. Bovenal was het onnodig. Meijers' concept voor Boek 6, dat weliswaar in wetenschappelijk opzicht niet kon tippen aan het werk van de Driemannen, gaf naar alle waarschijnlijkheid wél een voor de praktijk werkzame regeling.

\section{Het Driemanschap en de rol van de Ministers}

Hieronder zal een beeld worden geschetst van de rol van de verschillende Ministers bij het werk aan Boek 6 O.M. Daaruit zal blijken, dat hun betrokkenheid eigenlijk zonder uitzondering groot is geweest, zij het dat zij als gevolg van de werkwijze van het Driemanschap voornamelijk waren veroordeeld tot het toekijken langs de zijlijn. Zelfs Donker, die zó betrokken was bij het werk aan het nieuwe B.W., dat hij zijn eigen gezondheid niet ontzag en daardoor zichtbaar zijn einde verhaastte ${ }^{142}$, verloor zijn greep op de hercodificatie in een paar maanden tijds, althans voorzover het de nog onvoltooide Boeken betrof.

Eén van de factoren waardoor de achtereenvolgende Ministers weinig greep hadden op het Driemanschap, was dat het werk volledig was uitbesteed. Daardoor had het Ministerie lange tijd geen duidelijk beeld van de verrichtingen van het Driemanschap en ontbrak het ook aan mogelijkheden tot beïnvloeding. Een andere factor die ertoe leidde dat de invloed van de Ministers gering was, was dat het Driemanschap de controle over het werk had verloren. Men had, naar een woord van Pitlo, om zichzelf een labyrinth geschapen en er was geen draad van Ariadne om hen daar weer uit te helpen. Hulp van buiten, anders dan op het organisatorische vlak, zou de verwarring vermoedelijk alleen maar hebben doen toenemen. Tenslotte leden pogingen tot beïnvloeding schipbreuk, omdat het Driemanschap de werkelijkheid niet onder ogen durfde te zien en de zaken steevast mooier voorspiegelde dan ze in werkelijkheid waren.

\section{a. Donker}

Ook na het overlijden van Meijers was de Kamer lange tijd bereid zich volledig voor het "grote werk" in te zetten. Begrijpelijk, want de vaste Commissie voor Justitie had er in 1953 alles aan gedaan om de vraagpunten binnen de door het tijdschema gestelde termijnen af te ronden en stond nu voor de taak de vruchten van die arbeid

142. "Ik tracht de zaken, die aan mijn zorg zijn toevertrouwd, met zo groot mogelijke toewijding en ook met zo groot mogelijke snelheid (..) tot voortgang te brengen. Ik doe daarbij wat mijn hand te doen vindt. Of ik alles zelf zal kunnen verwezenlijken, is voor mij een volkomen secundaire factor." Handelingen Eerste Kamer 1953-1954, p. 2203. 
binnen te halen. De grote waardering die men voor de ontwerper had, droeg daaraan nog bij. De herhaalde betogen van Van Oven ${ }^{143}$ om het tempo wat te matigen en de wetenschap en praktijk meer gelegenheid te geven het werk van Meijers te beoordelen, vonden in eerste instantie dan ook weinig gehoor. De Kamer beschouwde het als "een erezaak tegenover de nagedachtenis van prof. Meijers om de aangekondigde en nog volgende Regeringsontwerpen nog in deze parlementaire periode (d.w.z. vóór mei 1956) de openbare behandeling in de Tweede Kamer te doen passeren", zo werd in het Voorlopig Verslag bij de begroting voor 1955 opgemerkt. ${ }^{144}$

Ofschoon Minister Donker de Kamer dus achter zich wist, kon hij van die bereidwilligheid niet werkelijk profiteren en moest hij zijn befaamde tijdschema al snel laten varen. Had hij kort na het overlijden van Meijers nog de hoop uitgesproken dat het werk vóór de verkiezingen in mei 1956 zou kunnen worden afgerond, tijdens de begrotingsbehandeling voor 1955 , zes maanden later, was hij al veel pessimistischer. Donker kon nog wel de verschijning van het vijfde groene Boek aankondigen - hij had het Driemanschap een maand daarvoor tenslotte opdracht gegeven een punt achter de beraadslagingen te zetten - maar hij begreep kennelijk al wel dat er nog een lange weg te gaan was. Zonder dat ook maar één van de sprekers daarop had aangedrongen, gaf hij zijn befaamde tijdschema prijs. Donker zei: "Het is, ook voor wie dat op het moment van het overlijden van prof. Meijers niet zou hebben gezien, op dit ogenblik volkomen duidelijk, dat dit overlijden een gans andere situatie heeft geschapen. (..) Men kan op zijn vingers natellen, dat de zaak niet in hetzelfde tempo en volgens het schema zal worden afgewikkeld, en dus behoeven noch de wetenschap, noch de Staten-Generaal zich bezorgd te maken over de vraag, of zij voldoende tijd zullen hebben zich in de ontwerpen te verdiepen." ${ }^{145}$

Donker, die op 4 februari 1956 plotseling overleed, heeft vermoedelijk weinig plezier beleefd aan het optreden Drion, Eggens en De Jong. Hij wist immers dat Meijers het werk naar alle waarschijnlijkheid in drie maanden had kunnen afronden.

143. Zie NJB 1953, p. 716; NJB 1954, p. 1 e.v.; NJB 1954, p. 897 e.v. en NJB 1955, p. 1 e.v.: "Het ijltempo, door den Haag verkozen, beneemt ons buitenstaanders de mogelijkheid, de plannen voor de nieuwe burgerlijke wetgeving met de vereiste rustige bezonnenheid te bestuderen." Van Oven kreeg bijval van Pitlo (Themis 1954, p. 463), G.W. van der Does (NJB 1955, p. 55-56) en Benno Stokvis (NJB 1955, p. 81-82). Notaris A.M. Vroom, die Meijers nog had geadviseerd over de stichtingen, gaf in NJB 1955, p. 150-151, enig tegengas. Aan zijn woorden kan een profetisch karakter niet worden ontzegd: "De vrees lijkt gerechtvaardigd, dat uitstel van de behandeling in de Kamer een grotere kans zal doen ontstaan dat tot in lengte van tijd geen nieuw B.W. tot stand komt. Een langdurig bestaande gelegenheid om individueel van min of meer grote bezwaren tegen die onderdelen te doen blijken zou de totstandkoming van het geheel kunnen belemmeren of verhinderen."

144. Zitting Tweede Kamer 1954-1955, nr 3700, stuk nr 9, p. 1-2. Vergelijk ook zitting Eerste Kamer 1954-1955, nr 3700, stuk nr 92, p. 2: "Vele leden deelden 's Ministers opvatting, dat de wetsontwerpen, waarvan hier sprake is, zoveel mogelijk in de tegenwoordige wetgevende periode behoren te worden afgedaan. Kennisneming van de argumenten, daarvoor aangevoerd door prof. Meijers - wiens verscheiden de hier aan het woord zijnde leden eveneens uitermate betreurden - had hen in hun overtuiging nog versterkt."

145. Handelingen Eerste Kamer 1954-1955, p. 2128. Wel verzekerde de Minister dat hij zijnerzijds alles zou doen om het werk zo snel mogelijk te laten verlopen: "Ik geloof, dat men moeilijk van mij kan verwachten, dat ik een vertragende actie zal voeren, waar het mijn natuurlijke taak is, zoveel mogelijk te trachten nog iets te bereiken in de richting van een spoedige totstandkoming van een nieuw Burgerlijk Wetboek." 
Hij wist ook dat medio 1955 de ontwerpen voor de Boeken 8 en 9 vrijwel geheel, en voor Boek 7 voor driekwart gereed waren. Een verzoek aan de bewerkers van Boek 7 O.M. om hun concept op korte termijn in te leveren, moest hij herroepen, omdat het Driemanschap voor de beoordeling daarvan voorlopig geen tijd had. ${ }^{146}$ Belinfante vertelde dat Donker er tureluurs van werd dat het Driemanschap maar niet opschoot. De Minister zou daarom zelfs hebben overwogen het voorbeeld van Napoleon te volgen, door het Driemanschap te gelasten punten van twijfel aan hem voor te leggen, om vervolgens zelf de knoop door te hakken. ${ }^{147}$ Dat het daar nooit van gekomen is, werd vermoedelijk ingegeven door de vrees dat de drie dan zouden opstappen, waardoor het werk vrijwel zeker verloren zou zijn geweest. Want wie zou de boedel van het Driemanschap hebben willen overnemen?

\section{b. Van Oven}

Donker werd opgevolgd door mr. J.C. Van Oven. Van Oven, hoewel evenals Donker zeer begaan met het lot van Meijers' werk, was niet in de gelegenheid zelf een stempel op het werk te zetten. Daarvoor zou hij te kort aanblijven als Minister. Bovendien lag zijn taak in de eerste plaats bij de herziening van het huwelijksvermogensrecht. ${ }^{148}$

Niettemin heeft Van Oven toch wel iets gedaan, aangezien het in januari 1957 door Minister Samkalden ingediende Regeringsontwerp voor Boek 5 voor een belangrijk deel onder zijn verantwoordelijkheid was opgesteld. Wel kan men aan dat ontwerp zien, dat de vaart er uit was en dat de invloed van de Minister kleiner en die van het Departement groter werd. Er lag namelijk ruim anderhalf jaar tussen het verschijnen van het groene Boek, dat op 25 mei 1955 aan Minister Donker was aangeboden, en het indienen van het Regeringsontwerp - bij de eerste vier Boeken waren het nog slechts zeven maanden. Bovendien week het R.O. op een aantal punten af van het

146. Zie hierna, Hoofdstuk 8. Vergelijk ook de enigszins van moedeloosheid getuigende opmerking bij de begroting voor 1956 over de vorderingen ten aanzien van Boek 7 (zitting Tweede Kamer 1955. 1956, $\mathrm{nr} 4100$, stuk $\mathrm{nr} 10$, p. 6: "De uiteindelijke vormgeving kan eerst aan de orde komen, wanneer Boek 6 zal zijn voltooid. Alsdan zal veelal overleg tussen de medewerkers en het Driemanschap nodig zijn. De bewerking van geen der onderdelen, die aan bepaalde medewerkers zijn toevertrouwd, kan dus als afgesloten worden beschouwd. Gelet op deze werkwijze heeft het naar de mening van de ondergetekende weinig zin mede te delen, in welke graad van voltooiing de verscheidene onderdelen verkeren."

147. Zie voor een beknopte karakteristiek van de figuur van Donker mijn artikel in NJB 1992, p. 32 e.v. Het Eerste Kamerlid Willemse herdacht Donker bij de Justitiebegroting van 1957 (handelingen Eerste Kamer 1956-1957, p. 2209) als volgt: "Mijnheer de Voorzitter! U zult mij waarschijnlijk nog een andere vermelding van een zeer persoonlijke herinnering aan Donker veroorloven. Ik heb hem heel regelmatig bezocht tijdens zijn langdurige voorlaatste ziekte. (...) Bij een van die bezoeken heeft hij mij eens van zijn plannen en voornemens anderhalf uur in een aaneengesloten relaas verteld. Ik behoefde daaraan niets toe te voegen. Ik heb anderhalf uur achter elkaar naar Donker geluisterd; toen hij klaar was met zijn exposé, lachte hij wat schuchter en zeide hij: Nu heb ik een half uur achter elkaar zitten praten en jij hebt een half uur achter elkaar naar mij moeten luisteren. Het was niet een half uur, het was anderhalf uur."

148. Zie daarover G.E. Langemeijer, Bij de honderdste geboortedag van J.C. van Oven, WPNR 5586 (1981); vergelijk ook NJB 1992, p. 37-38. 
voorontwerp, hetgeen de Raad van State, die zich als gevolg daarvan voor dubbel werk geplaatst zag, tot een onvriendelijke reactie zou verleiden.

Of Van Oven regelmatig contact heeft gehad met het Driemanschap is moeilijk vast te stellen, omdat het archief met betrekking tot deze periode een aantal hiaten vertoont. Zeker is echter dat Van Oven buitengewoon goed begreep dat de onderneming als gevolg van een vergaand perfectionisme, zowel aan de kant van het Driemanschap als aan de kant van het Departement, dreigde te stranden. In het eerste artikel dat hij na zijn aftreden schreef, benadrukte hij dat het schema van zijn opvolger, Samkalden, om elk jaar eén boek in openbare behandeling te brengen, wel uitvoerbaar was, maar dat zelfbeperking dan het parool zou moeten zijn: "Datgene wat de verwezenlijking der plannen bedreigt, is het perfectionisme, is de zucht naar volmaaktheid der formuleringen, welke zich van eenieder meester maakt, die aan dit oeuvre meewerkt. Deze leidt tot grote vertraging en heeft tot resultaat, dat de voorschriften zwaar worden van bouw, ondoorzichtig, moeilijk leesbaar." ${ }^{149}$ In de laatste regel gaf Van Oven een duidelijk signaal af in de richting van de ontwerpers: "Men late het wetboek zijn het wetboek-Meijers, voltooid door het Driemanschap."

\section{c. Samkalden}

Van Oven werd in oktober 1956 opgevolgd door dr. I. Samkalden, indoloog en schoonzoon van Meijers, voor wie het uiteraard een bijzondere voldoening was aldus een bijdrage te leveren aan de totstandkoming van het nieuwe B.W. Samkalden, die al snel begreep dat de onderneming zou stranden als het werk niet beter zou worden gecoördineerd, maakte met de Kamer de afspraak elk jaar één boek in openbare behandeling te brengen. Uitgangspunt daarbij was dat Boek 6 O.M. medio 1957 zou kunnen verschijnen. De Minister lichtte zijn aanpak in de Kamer als volgt toe: "De ervaring heeft geleerd, dat een schema met vrucht kan worden opgezet voor de behandeling van de stof, die men ten tijde van de opstelling van het schema kan overzien. (..) De Memorie van Antwoord beperkt zich daarom tot een prognose over de behandeling van die delen van het wetboek, die in zekere mate kunnen worden overzien." ${ }^{150}$

Was Samkalden té optimistisch? Spiegelde hij de Kamer maar wat voor? Het tegendeel is waar. Op 16 januari 1957, een paar dagen voordat de Kamerbehandeling zou plaatsvinden, had hij nog een overzicht van het Driemanschap gekregen, waaruit kon worden afgeleid dat het merendeel van de teksten voor Boek 6 O.M. in concept gereed lag. Bovendien zou Drion, naar aanleiding van Kamervragen over de duur van zijn terbeschikkingstelling ${ }^{151}$, de Minister enkele weken later nog laten weten dat het zesde Boek vermoedelijk eind 1957 gereed zou komen. In de woorden van Van Ewijk: "Naar Drions mening zit te zijnen aanzien de moeilijkheid niet zozeer in de voortzetting van het eigenlijke driemanschapswerk, dat na de voltooiing van het zesde Boek minder intensieve arbeid vergt, maar in het daarbij komen van het commissoriaat. (..) Zijns inziens ware met het oog hierop nieuw contact met de Universiteit op te nemen, waarbij gesteld zal moeten worden dat hij voor 1960 niet full time voor zijn

149. J.C. van Oven, Het werk aan het nieuwe Burgerlijk Wetboek, NJB 1957, p. 5.

150. Handelingen Tweede Kamer 1965-1957, p. 2304.

151. Zitting Eerste Kamer 1956-1957, nr 4500, stuk nr 88, p. 7. 
hoogleraarsambt beschikbaar zal zijn. Wel zou hij bijvoorbeeld éen uur in de week college kunnen geven. Vermoedelijk zal het zesde Boek in de tweede helft van dit jaar gereed komen. ${ }^{n} 152$

Bij de volgende begroting moest Samkalden al zijn ongelijk bekennen. Hij waagde zich toen ook niet meer aan een voorspelling over Boek 6 O.M.: "Niet verzwegen kan worden, dat enige belangrijke onderdelen ervan nog geen afronding hebben gevonden. " ${ }^{153}$ Een jaar later schreef de Minister dat hij "ten minste" rekende op "indiening hetzij in het lopende, hetzij in het volgende zittingsjaar. ${ }^{154}$ Samkalden kón dat doen, althans zo meende hij, omdat hij het Driemanschap kort daarvoor te verstaan had gegeven dat het afgelopen moest zijn met het gedelibireer en dat hij drukproeven wilde zien. Helaas bleken sommige teksten nog zo onvoldragen en kwam op andere teksten zoveel kritiek, dat het rendement van die maatregel vrijwel nihil was.

\section{d. Beerman}

Toen Minister Beerman in mei 1959 het roer overnam, was de situatie dus allerminst rooskleurig. Zolang het Driemanschap er niet in slaagde het vrijwillig conclaaf ten aanzien van Boek 6 te beëindigen, zolang was elk tijdschema uit den boze. De Minister ging dan ook schoorvoetend in op de dominante wens van de Kamer een nieuw tijdschema op te stellen en wimpelde vragen om invoering van de reeds vastgestelde boeken zoveel mogelijk af.

Deze handelwijze, gevoegd bij het feit dat Beerman ook op andere terreinen dan het nieuwe Burgerlijk Wetboek een weinig actieve indruk maakte, leidde ertoe dat deze Minister het in de Kamer zwaar moest ontgelden. Een aantal willekeurige uitspraken, ontleend aan de parlementaire behandeling van de begroting voor 1961 . Kranenburg: "Het zal de Minister niet ontgaan zijn, dat de Staten-Generaal vanouds het hoogst mogelijke tempo voorstaan voor het tot stand brengen van ons nieuwe Burgerlijk Wetboek. (..) De mededeling in de Memorie van Antwoord op dit stuk is wel erg teleurstellend. Het dreigt een zaak van tientallen jaren te worden." "155 Van Doorn: "Met het tempo, hetwelk de bewindsman thans blijkbaar zonder al te groot bezwaar aanvaardt, valt het te betwijfelen of het grote werk van de algehele herziening van het burgerlijk Wetboek ooit de eindstreep haalt." ${ }^{156}$ Samkalden: "Men behoeft waarlijk geen pessimist te zijn om, zoals de zaken er nu bijstaan, te geloven, dat in deze parlementaire periode misschien Boek 4 de eindstreep haalt. (..) Ik hoop werkelijk, dat ik dit alles te somber zie, maar als het anders zou kunnen gaan, dan is er mijns inziens een nieuw élan nodig van de kant van de Minister, dat bepaald geen genoegen neemt met de ietwat vermoeide uitspraak in de Memorie van Antwoord, dat

152. Nota van 30 maart 1957. Vergelijk ook zitting Eerste Kamer 1956-1957, nr 4500, stuk nr 88a, p. 8. Samkalden schreef op 9 april 1957 aan de Eerste Kamer: "Het ontwerp voor Boek 6 is nog in bewerking; gehoopt wordt, dat dit in de loop van dit jaar zal kunnen verschijnen en dat alsdan een wetsontwerp met bekwame spoed kan worden voorbereid."

153. Zitting Tweede Kamer 1957-1958, nr 4900, stuk nr 9, p. 2.

154. Zitting Tweede Kamer 1958-1959, nr 5300, stuk nr 9, p. 2.

155. Handelingen Tweede Kamer 1960-1961, p. 2441.

156. Handelingen Tweede Kamer 1960-1961, p. 2444. 
het nu eenmaal waar is, dat wetgeving altijd trager verloopt dan men wel zou wensen." 157

Voor een deel was deze kritiek ongetwijfeld terecht. Beerman had weinig affiniteit met wetgeving en zou zich na zijn aftreden in een interview eens quasi-komisch laten ontvallen dat hij Minister was geworden omdat hij zo'n hekel had aan ambtenaren. ${ }^{158}$ Zeelenberg gaf in 1962 de volgende kenschets van Beermans wetgevende productie: "Er is een aantal juridische grote zaken bij deze Kamer aanhangig gemaakt voordat hij optrad. Deze zijn in de twee jaar, dat hij hier is, nog niets verder gekomen. (..) Bij de tien wetsontwerpen, die de Minister zelf heeft ingediend, die zijn eigen handtekening dragen, is, helaas, niet één werkelijk groot ontwerp. Toen Donker een keer zijn opsomming gaf en die betrekkelijk sober hield, zei hij: De wetsontwerpen van minder belang noem ik niet. De wetsontwerpen die deze Minister zelf heeft ingediend, zijn bijna allemaal ontwerpen van minder belang." 159 Op het Ministerie was iedereen ingeslapen, er heerste een sfeer van sombere gelatenheid. Toen in 1963 , na een ambtsperiode van ruim vier jaar, de balans werd opgemaakt, bleek dat er maar vijf wetsontwerpen van meer dan ondergeschikte betekenis waren, waartoe Beerman het initiatief had genomen.

Toch viel de Minister op het terrein van het nieuwe B.W. naar mijn mening niet veel te verwijten. Weliswaar bemoeide hij zich niet inhoudelijk met het werk aan het nieuwe B.W., zoals Donker, Van Oven en wellicht ook Samkalden, maar het was wel aan zijn optreden te danken dat het Driemanschap eindelijk beviel van het groene Boek 6. Hij wist hen tenslotte te bewegen een onvoltooid, onvolledig werkstuk in te leveren, iets wat bij Boek 5 O.M. kennelijk nog onbespreekbaar was. Dát Beerman niet minder actief was dan bijvoorbeeld Samkalden, blijkt doordat hij de toezending van werkoverzichten continueerde, regelmatig bijeenkomsten hield met het Driemanschap, Drion zoveel mogelijk ontlastte en tenslotte zelfs Van Ewijk inschakelde bij het werk aan het groene Boek $6 .{ }^{160}$ Wel denk ik dat de Minister vooral bij vlagen actief was en dat zijn hoofd er niet werkelijk bij was. Zijn opmerkingen over het nieuwe B.W. droegen altijd een enigszins plichtmatig karakter, veel inspiratie was er niet bij.

157. Handelingen Eerste Kamer 1960-1961, p. 2184.

158. Vergelijk ook Beermans antwoord op een opmerking van Diepenhorst, dat van de elf wetten die de Minister in de eerste drie jaar van zijn ambtsperiode in het Staatsblad had weten te krijgen, geen enkele daarvan voor een plaats in de eredivisie in aanmerking kwam: "Ik heb eens, toen ik nog maar kort Minister was, een gesprek gehad met een ambtsvoorganger, die mij kwam opzoeken. Hij zeide toen: Een goede Minister van Justitie maakt zo weinig mogelijk wetten. Dat vind ik wel een wat boude uitspraak, maar wetgeving forceren is toch ook bepaald niet goed." Zitting Eerste Kamer 1961-1962, p. 2151.

159. Zitting Eerste Kamer 1961-1962, p. 2137.

160. Andere voorbeelden betreffen het besluit Boek 6 O.M. ongewijzigd in te dienen (zie hieronder. Hoofdstuk 5) de reorganisatie van het werk aan de Boeken 7 en 8, waarbij Beerman zeer actief was in het werven van ontwerpers (zie hieronder, Hoofdstuk 8) en dat hij zelfs de moeite nam te reageren op uitlatingen in de pers, waarin zijn opmerking dat het nieuwe B.W. mogelijk reeds verouderd zou zijn wanneer het eenmaal wordt ingevoerd, maar in ieder geval minder verouderd dan het oude B.W., ten onrechte als een "van wijsheid getuigende berusting" werd afgedaan (zitting Tweede Kamer 1962-1963, p. 2101). Beerman schreef: "Het was in feite een nogal scherpe reactie op defaitistische uitlatingen, welke reeds eerder buiten de Kamer, doch bij deze gelegenheid voor het eerst ook in de Kamer werden gehoord." 
Dat hing wellicht ook samen met zijn zwakke gezondheid - Beerman zou na een slepende ziekte in 1967 op vijfenzestigjarige leeftijd overlijden. ${ }^{161}$

Intussen is het goed te begrijpen dat Beerman door het Driemanschap in een bijzonder moeilijk parket werd gebracht en dat alle kritiek op zijn beleid hem wel eens te veel werd. Hij kon in het belang van de voortgang van de hercodificatie geen volstrekte te opening van zaken geven ${ }^{162}$, maar het gevolg was wel dat hij alle kritiek alleen moest dragen. In zijn laatste optreden in de Kamer, toen Boek 6 al lang en breed was gepubliceerd, heeft Beerman wél een tipje van de sluier gelicht en de verantwoordelijkheid voor het debâcle rond het nieuwe B.W. min of meer bij het Driemanschap gelegd. Beerman zei toen:

"Bij mijn optreden trof ik op het terrein van het Burgelijk Wetboek als propellor buiten het Departement het Driemanschap aan. Dat Driemanschap was toen werkende aan het zesde Boek, het algemene deel van het verbintenissenrecht, waarschijnlijk de moeilijkste materie van het Burgerlijk Wetboek. Het zesde Boek is zeer veel later dan mij oorspronkelijk was gezegd tot stand gekomen. Dat is waar. Er zijn ook persoonlijke omstandigheden van ziekte geweest. De stafafdeling van mijn Departement heeft aan dat zesde Boek meegewerkt, maar het tempo werd door het Driemanschap bepaald. ${ }^{n 163}$

161. Van Rijckevorsel zei in dit verband: "Beerman was een hele goede jurist, maar hij was niet zo ambitieus, hij deed het in een kalmer tempo. Hij was niet tégen het nieuwe B.W., maar er gebeurde in die tijd weinig in de Kamer. De vaart was er helemaal uit, al geloof ik dat Beerman daar weinig aan kon doen. Samkalden vond ik erg goed - over hem niets dan lof -, maar voor Beerman had ik toch ook persoonlijk wel een zwak. Ik ben van oktober 1962 tot mei 1963 ernstig ziek geweest en toen nam hij toch maar de moeite mij thuis in Driebergen op te zoeken. G.J. Scholten, die hem kende van de Rotterdamse balie, was ook altijd vol lof over hem. Achteraf bleek dat Beerman geen goede gezondheid had, dat kan zijn functioneren ook hebben beïnvloed."

162. Vergelijk in dit verband de discussie tussen oud-minister Samkalden en Beerman over de invoering van Boek 1 (handelingen Eerste Kamer 1960-1961, p. 2231-2236). Beerman had de Kamer, die nu eindelijk wel eens resultaten wilde zien, medegedeeld dat invoering van Boek 1 voorlopig nog niet aan de orde was, in verband met de inschakeling van het Departement bij de afwerking van Boek 6 O.M. Samkalden, die indertijd Van Zeben aan het overgangsrecht voor Boek 1 had gezet, begreep daar natuurlijk niets van: "Er zijn indertijd voorzieningen getroffen voor wat betreft de bezetting van de afdeling Wetgeving op het Departement van Justitie - en de Minister weet dat natuurlijk net zo goed als ik dat weet - die het mogelijk maakten, tijdig met de invoeringswetgeving te beginnen."

Wat kon Beerman anders doen dan het Driemanschap in bescherming nemen en de ten aanzien van Boek 1 opgelopen vertraging wijten aan de stagnatie in de behandeling van Boek 4 ? Want anders dan uit het antwoord van de Minister blijkt, lag de voorbereiding van de invoeringswet Boek 1 al jaren stil en speelde het verband met Boek 4 nog geen enkele rol. Het was een leugentje om bestwil: "Het is namelijk zo, dat de vervroegde invoering van het 1ste Boek al aan het Departement wordt voorbereid, maar de invoeringswet kan pas worden voltooid, wanneer Boek 4 als ontwerp definitief zijn vorm heeft gevonden, nadat het de Tweede Kamer is gepasseerd."

163. Handelingen Eerste Kamer 1962-1963, p. 2158. Vergelijk ook handelingen Tweede Kamer 1962-1963, p. 2100 . Beerman zei daar: "Een Minister (kan) op de gang van zaken bij het Burgerlijk Wetboek minder rechtstreeks invloed uitoefenen dan op de gang van zaken bij de overige wetgeving. hoewel hij daarbij toch ook dikwijls is gebonden aan allerlei adviserende instanties en aan het plegen van overleg met andere Departementen. Hierbij kan hij echter sterker coördinerend en stimulerend optreden dan bij het Burgerlijk Wetboek, waarbij, zoals tijdens mijn komst op het Departement het 
Het was echter te laat om zijn geloofwaardigheid als Minister te herstellen. Belinfante zei daarover: "Het gekke is dat Beerman, van wie gezegd werd dat hij erg weinig aan het nieuwe B.W. deed, - hij kon er ook niets aan doen, want er werd niets ingediend - wel heeft bereikt dat het Driemanschap eindelijk het zesde Boek heeft afgemaakt. Ze konden het niet afsluiten. Drion was een ontzaglijk knappe man, maar hij kon heel moeilijk een einde aan het werk maken."

Dat er met het Driemanschap eigenlijk geen afspraken waren te maken, was voor een belangrijk deel het gevolg van wishful thinking, een verschijnsel waartegen Justitie vrijwel machteloos stond. Ter afronding nog een aantal voorbeelden.

Ten Kate werd begin december 1958 aangesteld als arbeidscontractant met als taak de in Boek 6 aangehaalde teksten, jurisprudentie en andere verwijzingen te controleren. In eerste instantie werd daarbij gedacht aan een periode van zes á acht maanden. Ten Kate zou echter pas op 1 januari 1961 vertrekken. Toen in 1954 De Jong samen met Drion en Eggens Meijers opvolgde, behoefde er voor hem geen financiële regeling te worden getroffen: Hij werd tijdelijk ontheven van zijn werkzaamheden als raadsheer en behield zijn salaris als zodanig. In september 1957 kwam een einde aan deze situatie, omdat De Jong de aan hem opgedragen gedeelten had afgeleverd en weer volledig werd ingeschakeld bij het werk in de Hoge Raad. De gedachte was toen dat De Jong weliswaar niet geheel zou ophouden met zijn werk als Drieman, maar dat hij daarin nog slechts een gering aandeel zou hebben. In de praktijk liep het echter anders en zou De Jong na 1958 aan vrijwel alle vergaderingen deelnemen. Op grond hiervan én omdat het Departement verwachtte dat De Jong na de voltooiing van Boek 6 O.M. ontslag zou nemen, werd hem na veel vijven en zessen voor het jaar 1960 op voorstel van Justitie door Binnenlandse Zaken een toelage toegekend. In 1961 moest de Minister zich echter opnieuw tot zijn ambtsgenoot van Binnenlandse Zaken wenden, met een verzoek om verlenging. ${ }^{164}$

Dat de Driemannen weinig oog hadden voor de realiteit blijkt ook uit Drions' opmerking, dat hij verwachtte dat Boek 6 O.M. in de loop van 1957 gereed zou komen. Die opmerking was volslagen onbegrijpelijk: bepaalde afdelingen waren op dat moment nog nooit in het Driemanschap geweest en van titel 6.3 stond nog geen letter op papier. Een jaar later was men nog niet veel wijzer: "In maart 1959 hoopt het Driemanschap Boek 6 af te hebben", zo werd op 29 oktober 1958 opgemerkt. ${ }^{165}$ Ook Minister Beerman, die al snel inzag dat het werk aan Boek 6 een gebed zonder eind dreigde te worden, zou niettemin een aantal malen worden verrast door nietingeloste toezeggingen van het Driemanschap. Illustratief daarvoor is de volgende anekdote van Franken, die zich naar eigen zeggen steeds weer verbaasde over de struisvogelpolitiek van zijn bazen, die op het punt van de termijnen niet meer in staat waren nuchter te denken. Franken: "Op een zeker moment was er een vergadering

163. $\rightarrow$

geval was, het werk in handen was gelegd van een Driemanschap en waarbij, zoals nu het geval is, de parlementaire bewerking en voorbereiding van de verschillende hoofdstukken zijn geconcentreerd bij de commissaris prof. Drion, die daarbij uiteraard wordt gesteund door de stafafdeling Wetgeving van het Departement."

164. Nota van 29 januari 1960.

165. Notulen van de 196e vergadering van het Driemanschap. 
van ons zessen met Minister Beerman. Op zijn vraag, of Boek 6 nu eens eindelijk binnen redelijke tijd te verwachten zou zijn, antwoordde het Driemanschap dat, nu zij bepaalde wijzigingen in de behandeling hadden aangebracht, zij verwachtten binnen een half jaar klaar te zijn. Beerman vroeg mij toen point blanc: 'En wat denkt u daarvan?' lk vertelde dat ik die voorspelling een volslagen utopie vond en dat het zeker vijf à zesmaal zo lang zou duren. In de volgende vergadering met de Minister bleek het ongelijk van het Driemanschap al duidelijk en besloot Beerman met woorden van de volgende strekking: 'De ervaring heeft uitgewezen dat ik beter van de voorspelling van de heer Franken kan uitgaan.'

Het Driemanschap bleef tot het eind geloven in de eigen tijdschema's, zoals het volgende voorbeeld illustreert. Het werk aan de Memorie van Antwoord voor Boek 4, eind 1960 stilgelegd in verband met de problemen rond Boek 6 O.M., zou pas na de afronding daarvan, eind oktober 1961 worden opgepakt. Niettemin had Minister Beerman tijdens een bespreking met het Driemanschap op 20 februari 1961 van Drion nog de verzekering ontvangen dat hij na 1 mei beschikbaar zou zijn voor het werk aan Boek 4. Dat werd dus nog eens zeven maanden later.

\section{Het Driemanschap en de rechtsvergelijking}

Hiervoor is de rechtsvergelijking opgevoerd als één van de redenen waardoor het werk aan Boek 6 moeizaam verliep en waardoor het ontwerp steeds gecompliceerder werd. Is het niettemin de moeite waard geweest?

Ik betwijfel dat. De buitenlandse wetgeving, literatuur en jurisprudentie waren weliswaar een belangrijke inspiratiebron voor het Driemanschap, maar niettemin allesbehalve bepalend voor het uiteindelijke resultaat. Dat hangt enerzijds samen met de wijze waarop het Driemanschap de rechtsvergelijking bedreef en het doel dat men ermee voor ogen had, anderzijds met de manier waarop door het Driemanschap in het algemeen werd gewerkt.

Wat het eerste aspect betreft, het onderzoek was niet echt diepgaand. De beschrijving van de gevonden regeling in de voorbereidende nota's bepaalde zich meestal tot het citeren van wetsartikelen of tot het samenvatten daarvan. Alleen bij onderwerpen die blijkbaar lastig lagen, werd het onderzoek uitgebreider en diepgaander en werd in meerdere instanties naar het buitenland gekeken. Een systematische dimensie, in die zin dat het Driemanschap een verklaring probeerde te bedenken voor de gevonden verschillen en overeenkomsten, of de aangetroffen varianten met elkaar vergeleek, was zelden te bemerken.

166. Franken vervolgt: "Vooral in de laatste jaren dat het Driemanschap aan het zesde Boek bezig was, werden ze steeds meer onder druk gezet, maar zij waren daarzelf in hoge mate debet aan door hun ongegrond optimisme. Ik begreep daardoor steeds minder van hun mentaliteit. Ook al somde ik een groot aantal kwesties op die nog afgedaan moesten worden en waarvoor veel meer tijd ingeruimd moest worden dan waaraan zij dachten, stuitte ik steeds op een psychische blokkade. Ze waren niet meer in staat om nuchter te denken."

167. Een bijzonderheid is nog dat op enige, door Franken opgestelde stencils aantekeningen van Drion voorkwamen, vooral daar waar de nota te onbarmhartig het trage tempo van de voortgang liet zien. De nota ging dan geamendeerd naar de Minister, omdat men natuurlijk wel begreep dat deze graag resultaten wilde zien. 
Kenmerkend is dat de gestelde vraag betrekking had op de vorm van het vreemde recht, niet op de werking ervan in de maatschappij. Weliswaar werden er regelmatig handboeken op nageslagen, maar verder ging men toch niet. Ook was, en dat is gegeven de fase waarin het werk aan Boek 6 verkeerde wel verklaarbaar, de vraag geformuleerd met het geldende Nederlandse recht en de hoofdlijnen van het te ontwerpen wetboek in het achterhoofd. Het vreemde recht werd door een Nederlandse bril bekeken, voor de ideëen en discussies die in het vreemde rechtsstelsel zelf leefden over het eigen recht, had men weinig oog.

Illustratief voor de enigszins "laconieke" benadering is verder dat de vergelijkbaarheid nauwelijks als probleem werd onderkend. De keuze van de rechtsstelsels was in elk geval opvallend breed. Van echt belang was de vergelijking met het recht van Duitsland, Zwitserland, Frankrijk, België, Italië, Oostenrijk, Engeland en de Scandinavische landen. De meeste invloed ging uit van het Zwitserse en Duitse stelsel, getuige de frequente verwijzing naar die landen. ${ }^{168}$ De gelding van sommige wetboeken was gering of afwezig, zoals het Hongaarse Ontwerp en de Russische en Chinese codificaties.

Zoals ook uit de toelichting op het groene Boek duidelijk wordt, gebeurde de motivering van voorstellen primair vanuit het bestaande recht. Indien het Driemanschap daarvan wilde afwijken, werd eerst gezocht naar juridische (met name dogmatische) argumenten, vervolgens naar praktische argumenten en tenslotte naar rechtsvergelijkende gegevens. Een rechtsvergelijkend gegeven alleen was nooit voldoende om een wijziging te forceren. "Waar het op aankomt is dat de rechtsvergelijking krachtige aanwijzingen kan geven, doch ons nimmer ontslaat van een uiteindelijk waardeoordeel", volgens Fokkema. ${ }^{169}$ Bovendien hing van de uitkomst af of een gegeven uiteindelijk argumentatief werd gebruikt, hetzij ter motivering van een bepaalde keuze, hetzij ter bezegeling daarvan. ${ }^{170}$

Dát de rechtsvergelijking niet veel meer dan wetsvergelijking was, hing ook samen met de werkwijze van het Driemanschap. Door de overvloed aan weinig-gestructureerde informatie, het vrijblijvend gebruik daarvan en het gebrek aan samenwerking stuitte men al snel op zoveel problemen, dat de grote lijn vergeten werd, dat de discussie werd verplaatst naar de eigen beschouwingen over wat zou moeten behoren. Het gebeurde eigenlijk maar zelden dat men zo'n nota tot aan het eind doorliep. Maar ook als dat wél het geval was, ging het vaak mis als gevolg van het oppervlakkige karakter van de bijeengebrachte informatie en de concurrentie tussen de verschillende

168. Daarbij kan de vraag worden gesteld of, gelet op de onderlinge verbondenheid van de diverse codifcaties, wel werkelijk sprake was van bestudering van een "vreemd" rechtsstelsel.

169. D.C. Fokkema, De invloed van de rechtsvergelijking op de ontwikkeling van het nieuwe B.W., NJB 1983, p. 1223 e.v.

170. Zie daarover N.A. Florijn, Rechtsvergelijking in het wetgevingsproces, Zwolle 1993, p. 123 e.v. Florijn noemt daarbij het voorbeeld dat in de regeling van de niet-nakoming tot en met de derde drukproef werd vastgehouden aan de regel dat een aanmaning, om ingebrekestellende kracht te hebben, niet noodzakelijk een bepaalde termijn hoeft te stellen. In de vierde drukproef week De Jong echter zonder nadere motivatie af van dit beginsel. Stond er eerst: "In afwijking met de jurisprudentie, doch in overeenstemming met de in noot 1 vermelde wetgevingen, stelt het ontwerp niet de algemene eis, dat in de aanmaning de termijn wordt aangegeven waarbinnen de schuldeiser nakoming verlangt," dat werd: "In overeenstemming met de jurisprudentie eist het ontwerp, dat in de aanmaning de termijn wordt aangegeven, waarbinnen de schuldeiser nakoming verlangt." 
afdelingen. Het aantal malen dat het Driemanschap in eerste instantie een voorkeur uitspreekt voor een bepaalde oplossing, maar als men die gaat uitwerken toch weer tot een andere keuze komt, is legio. Er werd van het rechtsvergelijkende voorwerk dus nauwelijks gebruik gemaakt, met uitzondering wellicht van de na 1960 individueel afgewerkte stukken.

Een voorbeeld. Eerder schreef ik dat De Jong het concept van Meijers voor titel 6.3 van een aantal glossen voorzag. Vergeefs. Het Driemanschap kwam aan het bekijken daarvan niet eens toe. De discussie begeeft zich, na een weinig zorgvuldige analyse van het concept-Meijers, al heel snel in vragen van wenselijk recht. Met terzijdestelling van de mening van Meijers, de Staatscommissie, de jurisprudentie van de Hoge Raad en het votum van de Kamer wordt besloten dat er een aansprakelijkheid voor alle gebrekkige zaken en gevaarlijke activiteiten moet komen. ${ }^{171}$ Een week later blijkt dat men wat al te voortvarend is geweest. Besloten wordt niet voor alle gebrekkige zaken aansprakelijkheid te creëren, omdat deze aansprakelijkheid bij de niet-nakoming inmiddels is geschrapt. Een paar dagen later wordt afgesproken de regeling uit het Egyptische wetboek over te nemen, voorzover het de aansprakelijkheid voor onbekende gebreken betreft. Drie maanden later komt men daar weer op terug, omdat het Egyptische artikel "niet te hanteren is". Zo gaat het nog een tijdje door, totdat het overleg over deze bepalingen in totale verwarring eindigt ${ }^{172}$ en Drion opdracht krijgt orde op zaken te stellen. Zijn voorstel, neergelegd in het groene Boek, herinnert in vrijwel geen enkel opzicht aan de discussies binnen het Driemanschap. Verloren tijd dus.

Hoewel de rechtsvergelijking één van de stokpaardjes van het Driemanschap was en er veel tijd en energie in is gestoken, valt het uiteindelijke resultaat daarom bepaald niet mee. Het streven naar rechtseenheid, naar unificatie speelde geen enkele rol, het enige doel was inspiratie. Maar ook dat was betrekkelijk, omdat de rechtsvergelijking niet in een degelijk kader was geplaatst en de resultaten ervan nauwelijks werden benut, zelfs niet bij de gedachtenvorming.

\section{Het Driemanschap en de consultatie van de praktijk}

Eerder is er met enige nadruk op gewezen dat één van de belangrijkste kanten van Meijers was, dat hij een open oog en oor had voor de wensen van de praktijk. Hoewel hij op goede voet stond met tal van vooraanstaande leden van de rechterlijke macht en tot één van de gezochtste cassatie-adviseurs behoorde, schroomde hij niet voor het werk aan de hercodificatie een nog uitgebreidere kring van adviseurs te raadplegen. Zijn kennis van wat voor de praktijk van belang was en wat als wetenschappelijk interessant kon worden afgedaan, moet daarom fenomenaal zijn geweest.

171. Notulen van de 84e vergadering van het Driemanschap van 13 oktober 1955.

172. Omdat het Driemanschap er zelf niet uitkwam, werd besloten een aantal vragen en een voorlopig concept voor een tekst aan de Staatscommissie voor te leggen. De Staatscommissie bleek evenwel weinig gecharmeerd van de ideeën van het Driemanschap. De Driemanschapsnotulen van 5 maart 1956 vermelden dat de Staatscommissie niets voelde voor een risico-aansprakelijkheid voor gevaarlijke activiteiten: "Men voorzag niet waartoe dit zou leiden. Het resultaat was dus erg negatief, want een probleem is er wel degelijk." 
Geheel anders het Driemanschap. Geen van de Driemannen kon bogen op grote praktijk-ervaring. Drion was een man van de theorie, Eggens, die in zijn hart toch altijd docent is gebleven, evenzeer. Alleen De Jong had het voordeel dat hij in 1954 al geruime tijd lid was van de Hoge Raad, maar ook hij kon qua kennis, ervaring en levenswijsheid niet tippen aan Meijers.

Men zou dus verwachten dat de Driemannen iedere gelegenheid zouden aangrijpen om hun voorstellen te toetsen aan de mening van anderen. Het tegendeel is echter het geval. De Staatscommissie werd zo goed als in de ban gedaan en alleen nog in uitzonderlijke gevallen ingeschakeld. Welgeteld zijn de leden van de subcommissie Burgerlijk Recht slechts een keer of vijf in volledige vergadering bijeengeroepen. Drion, Eggens en De Jong waren bij de bewerking van het concept voor Boek 6 O.M. namelijk op een aantal moeilijke vragen gestuit en wilden daarover nu het oordeel van de commissie weten. Zo wilden zij met betrekking tot het $10 \mathrm{e}$ vraagpunt (matiging van de schadevergoeding) afwijken van het votum van de Kamer, door, in plaats van een algemeen matigingsrecht slechts één grond voor matiging op te nemen. Het Driemanschap voelde zich kennelijk toen nog zo gebonden aan de conclusies van de Kamer, dat de steun van de Staatscommissie werd ingeroepen. ${ }^{173}$

Naar de reden voor deze veranderde werkwijze kan slechts worden gegist, maar waarschijnlijk vond het Driemanschap zich mans genoeg om zelf te kunnen beslissen. Franken zei daarover: "Een rol kan hebben gespeeld dat de Driemannen zelf lid waren van de Staatscommissie en zichzelf voldoende competent achtten. Bovendien hadden zij de opdracht gekregen en niet de Staatscommissie als geheel. Meijers moest de Staatscommissie wel raadplegen, want hij had in het geheel geen klankbord, buiten zijn particulier secretaris. De Driemannen konden daarentegen over in totaal zes mensen beschikken." Belinfante vult aan: "Men had geen behoefte alles nog eens met de Staatscommissie door te spreken, waardoor je er nog meer mensen bij zou halen, die zeker niet knapper waren."

Feit is, dat het raadplegen van de Staatscommissie als gevolg van de werkwijze van het Driemanschap niet bijzonder veel opleverde. In plaats van dat de subcommissie een concept-tekst werd voorgelegd met daarin een stellig standpunt, zoals bij Meijers, werd de subcommissie met dikke nota's bestookt waarin wel alle mogelijke problemen werden besproken, maar waarin geen voorkeur voor een bepaalde oplossing werd aangegeven. Het advies van de subcommissie bleef daardoor vrijblijvend en algemeen.

Daarnaast heeft ongetwijfeld een rol gespeeld dat het Driemanschap van lieverlede in grote tijdnood raakte. Opmerkelijk is dat de ontwerpers de subcommissie aanvankelijk toch wel een zekere rol hadden toebedacht, getuige de benoeming van Smits en De Baat eind 1955. Het zou echter grotendeels bij een voornemen blijven. Voor zover ik dat heb kunnen nagaan, is slechts vier maal, en dan voornamelijk in de beginfase ook al een aanwijzing - een beroep gedaan op individuele leden, en dan nog alleen

173. Zie daarvoor Parl. Gesch. Boek 6, p. 437. Andere vragen hadden betrekking op de uitsluiting van aansprakelijkheid van hulppersonen, de aansprakelijkheid voor onrechtmatige daden van ondergeschikten, de aansprakelijkheid voor gevaarlijke zaken, wettelijke interessen, inbewaringgeving van een zaak bij geschil omtrent het schuldeiserschap, verval van de termijn bij vermindering van de zekerheid (art. 1307 B.W.) en cessie met medewerking van de debiteur. 
met betrekking tot titel 6.1 . $^{174}$ Aan het voorleggen van de concepten voor de andere titels is het Driemanschap eenvoudig niet toegekomen, druk als men was met het weerleggen van de intern steeds weerkerende kritiek.

Ook voor het raadplegen van deskundigen buiten verband van de Staatscommissie had het Driemanschap weinig oog, al waren het maar collega's die de teksten op hun begrijpelijkheid konden beoordelen. Alleen Koopmans is wel eens geconsulteerd over de door Meijers ontworpen bepalingen inzake geldschulden, terwijl Bregstein, zoals vermeld, zijn licht mocht laten schijnen over titel 6.4. H. Drion tenslotte, heeft een vroege voorstudie van titel 6.3 bekeken, terwijl Dorhout Mees in het kader van zijn werk aan de Koop met het Driemanschap heeft gediscussieerd over afdeling 6.1.8. Dat was alles. Daarnaast heeft het Driemanschap zich eenmaal tot het notariaat gewend met vragen over het kettingbeding. Merkwaardig is dat men daarvan - net zoals van het raadplegen van de Staatscommissie voor de Waterstaatswetgeving - geen verantwoording heeft afgelegd in de toelichting. Slechts in de lijst van gebruikte literatuur komt een verwijzing naar die enquête voor. Het tekent de gesloten sfeer waarin het voorontwerp voor het nieuwe verbintenissenrecht werd ontworpen.

\section{Gevolgen van lange duur}

\section{a. dalende belangstelling buitenwereld}

Eén van de gevolgen van het steeds opnieuw uitstellen van de publicatie van het voorontwerp voor Boek 6 was een sterk gedaalde interesse van het rechtsgeleerde publiek in de hercodificatie. In de eerste jaren na de verlening van de opdracht aan Meijers bestond er tamelijk veel enthousiasme voor het werk aan het nieuwe B.W. IIlustratief daarvoor is dat de eerste oplage van het groene Boek, 3700 stuks groot, in een oogwenk was uitverkocht. ${ }^{175}$ Ook na Meijers' overlijden was de hoop dat er binnen een jaar of vijf, zes een geheel nieuw Burgerlijk Wetboek zou zijn, niet direct vervlogen. Het hoge tempo van Donker, de in de eerste vier groene Boeken belichaamde autoriteit van Meijers, het feit dat Van Oven als hoofdredacteur van het NJB geen kans ongebruikt liet om het belang van de hercodificatie te benadrukken en de burger moed in te spreken, dit alles maakte dat de literatuur zich opvallend spaarzaam betoonde met het uitoefenen van kritiek en dat men de toekomst met vertrouwen tegemoet zag. Zo werd in de jaren 1956 en 1957 door de Stichting tot Bevordering van de Notariële Wetenschap het initiatief genomen om een aantal informatieve lezingen te verzorgen over de eerste vier Boeken. Er bleken toen in een minimum van tijd tussen de 1700 en 1800 aanmeldingen te zijn. ${ }^{176} \mathrm{Bij}$ dit beeld past ook dat

174. Daarbij werd Meijers' beproefde systeem van rapportage en tegen-rapportage gevolgd: Vrijberghe en Belinfante, Scholten en Petit, Smits en Hijmans van den Berg, en Visser en De Baat kregen respectievelijk de volgende titels toegewezen: $6.1 .4,6.1 .2,6.1 .7$ en 6.1.8.

175. De vraag was dermate groot, dat in 1959 voor een "antiek" exemplaar al enkele guldens meer moest worden betaald dan de oorspronkelijke verkoopprijs. In 1960 zou daarom worden besloten tot een herdruk, die 2400 exemplaren groot was. Vermoedelijk is van die tweede reeks wel een aantal exemplaren in het cellofaan gebleven. (Vergelijk Advocatenblad 1991, p. 668).

176. Zie NJB 1955, p. 54-55. De voordrachten werden gepubliceerd in "Ter eerste kennismaking", Ars Notarius IV, Haarlem 1955. Polak zei daarover: "In 1955 ben ik met De Bruyn, Van der 
Beekhuis zijn bewerking van Scholtens Zakenrecht in 1957 al geheel op de leest van het nieuwe B.W. had geschoeid, terwijl Van der Grinten twee jaar later met "De vertegenwoordiging" hetzelfde zou doen. "Voor mijn generatie, die zo rond 1950 studeerde, was er weinig reden reeds in 1954 , toen het eerste gedeelte van het ontwerp Meijers verscheen, ontevreden te zijn" volgens Schoordijk. ${ }^{17}$

Pas omstreeks 1958, 1959 was de magie gebroken. Men begon in te zien dat het nog heel lang kon duren voordat het nieuwe B.W. in het Staatsblad zou staan. Zelfs Van Oven liet zijn optimistische toon varen en bereidde juridisch Nederland voor op een lange en moeizame weg. "Met opzet heb ik de moeilijkheden waarvoor wij heden staan zo breed uitgemeten", zo schreef hij na afloop van zijn bijna eénjarig verblijf op het Ministerie van Justitie, "omdat men ze duidelijk voor ogen moet hebben, wil men er zich niet door laten afschrikken. ${ }^{178}$ Van Oven sloot zelfs de mogelijkheid van een mislukking niet uit: "En ja, mochten de zaken tegenlopen, mocht er nog meer tijd gemoeid zijn met de voltooiing dan wij nu hopen, ja zelfs mocht het tenslotte dan toch nog mislukken, dan is nochtans al wat er gedaan is en wat er nog gedaan zal worden geen verloren moeite. Nu reeds heeft 't geen gepubliceerd werd onze rechtsgeleerdheid op een hoger plan gebracht. (..) De rechtspraak beziet vaak, als zij voor een vraag is gesteld, niet meer alleen het oude wetboek, maar gaat ook eens na, wat Meijers ervan gemaakt heeft. Kortom, de grond is losgewoeld, ons rechtsleven maakt zich Meijers' rijke nalatenschap reeds ten nutte."

Omstreeks dat tijdstip komt ook de eerste kritiek op en begint de wetenschap zich te roeren. Denkbeelden, waarvan de ontwikkeling door de publicatie van het ontwerpMeijers was gestold of die als een gepasseerd station konden worden aangemerkt, werd nieuw leven ingeblazen. Eind 1958 onderneemt Van Oven zijn aanval op het voorstel een legitieme portie voor de langstlevende echtgenoot in te stellen, in 1960 verschijnt het eerste rapport van de Commissie Erfrecht, door Van Oven aangeduid als een "wijzigingsvoorstel over de gehele linie, zowel ten aanzien van principiële punten als in bijzonderheden." In datzelfde jaar komt Langemeijer met een voorstel de positie van het natuurlijke kind voor het erfrecht te verbeteren, waarmee hij lijnrecht ingaat tegen de gedachten die Meijers onder druk van Van Maarseveen in zijn ontwerp had neergelegd. ${ }^{179}$ Een jaar later wordt in Groesbeek het landelijk congres van de juridische studenten gehouden, waar Jan Drion mag komen uitleggen waarom hij vóór herziening van het Burgerlijk Wetboek is, terwijl Pitlo de bezwaren van de tegenstanders onder woorden brengt.

176. $\rightarrow$

Grinten, Hoetink, Houwing en Pitlo de boer opgegaan om over het nieuwe B.W. te praten. We zijn op elf plaatsen in Nederland geweest en de zalen zaten tjokvol met advocaten, rechters en andere praktijkjuristen, die allemaal dachten "daar moeten we bij zijn, want voor je het weet hebben we een nieuw wetboek."

177. H.C.F. Schoordijk, Een relatieve bekering, NJB 1992, p. 50.

178. J.C. van Oven, Het werk aan het nieuwe Burgerlijk Wetboek, NJB 1957, p. 1 e.v.

179. G.E. Langemeijer, Het erfrecht van het natuurlijke kind, NJB 1960 , p. 693 e.v. Wel bekende Langemeijer dat hij de nodige aarzeling had moeten overwinnen om met zijn gedachten naar buiten te komen: "Wanneer men een wijziging verdedigt, die vierkant staat tegenover hetgeen onze grote Meijers juist heeft geacht, zelfs zonder de behoefte aan een motivering aanwezig te achten, gevoelt men een schroom, die alle reden van bestaan heeft." 
Tegelijk ebt de belangstelling van de praktijk weg en wordt het werk aan het nieuwe B.W. vrijwel een puur interne aangelegenheid. De publicatie in het NJB van een uittreksel van het Voorlopig Verslag over Boek 3, om de "aandacht der belangstellenden op dit lijvige stuk (76 bladzijden) te vestigen, de bestudering te vergemakkelijken, en belanghebbenden ertoe te brengen, tijdig met hun eventuele bezwaren of opmerkingen voor de dag te komen", leidt tot niets. In 1958 is de respons nihil, het jaar daarop verschijnen drie korte bijdragen over respectievelijk de pauliana, conversie en volmacht, in 1960 wordt de "oorzaak" belicht. Dat is alles. Veelbetekend is dat een tweede reeks lezingen, die de notarissen in 1963 denken te organiseren naar aanleiding van het verschijnen van de Boeken 5 en 6 O.M., op een mislukking uitloopt. Het aantal aanmeldingen overschrijdt nauwelijks de driehonderd, zodat het project moet worden afgelast. De slakkegang waarmee de hercodificatie van het burgerlijk recht zich sinds het overlijden van Meijers en Donker voltrekt en de teleurstelling over Boek 6, zijn daaraan in belangrijke mate debet. ${ }^{180}$

\section{b. afnemende interesse Kamer}

Een tweede nadelig gevolg van de problemen rond de totstandkoming van Boek 6 O.M. was dat de betrokkenheid van de Kamer bij het werk aan het nieuwe B.W. sterk daalde. Weliswaar zou dit effect zich pas tegen het midden van de zestiger jaren openbaren, maar dat neemt niet weg dat de kiem ervoor tijdens het bewind van het Driemanschap werd gelegd. Als de Driemannen erin waren geslaagd het werk van Meijers op korte termijn te voltooien, dan zou de hercodificatie in de publieke belangstelling zijn blijven staan en zou de Kamerbehandeling ongetwijfeld vlotter zijn verlopen.

Dat de interesse van de Kamer voor het werk aan het nieuwe B.W. in die eerste jaren behoorlijk groot was, kwam hiervoor reeds ter sprake. Het Voorlopig Verslag van de Tweede Kamer over de Inleidende titel werd bijvoorbeeld reeds in de zomer van 1955 uitgebracht ${ }^{181}$, het eerste deel van het verslag over Boek 1 kon in april 1956 worden vastgesteld.

Wel deed de Kamer er aanzienlijk langer over om verslag uit te brengen dan de zes maanden die er in het schema van Donker voor waren uitgetrokken. Feit is echter dat de vaste Commissie voor Justitie in die dagen bedolven werd onder wetsontwerpen, afkomstig van Justitie. In het laatste verslag dat tijdens Donkers regeerperiode verscheen komt dan ook de opmerking voor dat "men (..) niet van de Kamer (mag) eisen dat zij het tempo van de Minister ten volle bijhoudt." ${ }^{182}$ Bovendien liet de vaste

180. Zie daarover W.C.L. van der Grinten, De betekenis van de herzieningsarbeid voor de rechtsontwikkeling, in: Het Ontwerp B.W., Deventer-Antwerpen 1962, p. 64-66.

181. In de aanhef van het verslag over de Inleidende titel werd opgemerkt dat de Commissie gaarne zou streven naar "een zo groot mogelijke energie-ontplooiing, opdat de behandeling door de Kamer met de spoed, die maar enigszins bij het gewicht van deze arbeid past, voortgang kan hebben." Parl. Gesch. Algemeen Deel, p. 144.

182. Zitting Tweede Kamer 1955-1956, nr 4100, stuk nr 9, p. 2. Vergelijk ook handelingen Tweede Kamer 1955-1956, p. 2197. Jonkvrouwe Wttewaall van Stoetwegen zei toen: "Om de Kamer niet in het onzekere te laten omtrent 's Ministers bedoelingen op wetgevend gebied, wordt ons de stuipen op 
Commissie al snel liet blijken dat zij zorgvuldiger naar de ontwerpen zou kijken, nu zij niet meer kon steunen op het inzicht van Meijers. Een citaat uit het verslag over de Inleidende titel: "Tegenover een opmerking van een lid, dat verklaarde zich bij de behandeling der ontwerpen aan de grote lijn te willen houden (..) verklaarde de meerderheid van de commissie van een ander gevoelen te zijn; deze meerderheid meende, dat een minder grondige behandeling door Commissie en Kamer, omdat de persoon van de ontwerper borg staat voor een goed wetboek en omdat anders de invoering van het nieuwe burgerlijke recht zou worden vertraagd, niet op haar plaats zou zijn. Hoe groot ook de bewondering is, die de Commissie voor het ontwerpMeijers koestert, de genoemde meerderheid oordeelde de nagedachtenis van de ontwerper niet beter te kunnen eren dan door zijn werk met opbouwende kritiek te benaderen." 183

Desalniettemin was de Kamer over het algemeen vrij terughoudend in haar kritiek. Zo schreef de Eerste Kamer in haar verslag over Boek 1 dat het niet op haar weg lag om het nieuwe personen- en familierecht aan een diepgaand onderzoek te onderwerpen ${ }^{184}$, terwijl ook de Tweede Kamer de nodige zelfbeperking in acht had genomen. Detailkritiek bleef achterwege, alleen saillante punten werden naar voren gebracht. ${ }^{185}$ Dit was ook de reden dat de Kamer weinig problemen maakte over het ontbreken van een regeling van het bezoekrecht na echtscheiding (droit de visité), de continuatie van de "grote leugen" in het echtscheidingsrecht en het ongewijzigd overnemen van de Lex Van Oven, waartegen in de praktijk inmiddels grote bezwaren waren gerezen. Het appél van Minister Samkalden om, gelet op het belang van de voortgang van de hercodificatie, elkaar te vinden, was daar ongetwijfeld debet aan. ${ }^{186}$ Een uitzondering vormde het Voorlopig Verslag van de Tweede Kamer over

182. $\rightarrow$

het lijf gejaagd met maar liefst een lijst van 25 wetsontwerpen, die òf aanhangig zijn òf aanhangig gemaakt zullen worden. En ik wel wel eerlijk bekennen, Mijnheer de Voorzitter, dat ik naarstig heb gespeurd naar ontwerpen, die nog overleg met andere Departementen van node hebben. Men kan dan nog hopen, dat deze althans niet binnenkort zullen worden ingediend, want wat van Justitie moet komen, wordt prompt ingediend, na de aankondiging dat er iets komende is."

183. Parl. Gesch. Algemeen Deel, p. 144. Zie ook handelingen Tweede Kamer 1954-1955, p. 2145. Oud, de voorzitter van de vaste Kamercommissie voor Justitie, zei toen: "Ik heb volkomen begrepen en ook erkend, dat er een groot belang bij was betrokken, dat wij het wetboek zouden tot stand brengen met medewerking van prof. Meijers. Gezien zijn leeftijd, hebben wij van het begin af aan begrepen, dat dit betekende, dat met de totstandkoming van het wetboek meer spoed zou moeten worden betracht dan normaal anders met een dergelijk omvangrijk werk het geval zou zijn. Nu heeft het ongeluk ons getroffen, dat prof. Meijers ons ontvallen is, maar dat is tegelijkertijd ook een reden om, nu wij zijn voorlichting missen bij het werk, dat wij hebben te verrichten, nog zorgvuldiger te werk te gaan." Vergelijk ook Lemaire, handelingen Tweede Kamer 1954-1955, p. 2140.

184. Parl. Gesch. Algemeen Deel, p. 165.

185. Vergelijk de betogen van Berkhouwer, Van Rijckevorsel en Wttewaall naar aanleiding van Boek 1, Parl. Gesch. Algemeen Deel, p. 151-158.

186. Samkalden zei: "Wanneer wij ertoe willen meewerken, dat het tot stand komende wetboek een werkelijk nationaal wetboek is, en er ons vervolgens rekenschap van geven, dat de legislatieve procedure, die wordt gevoerd, tot wetgevende arbeid van vele jaren moet leiden, dan zal het allen duidelijk zijn, dat het doel alleen maar kan worden bereikt, wanneer er een grote mate van openheid en van bereidheid bestaat, ten eerste natuurlijk om elkaar te vinden, maar ten tweede ook om elkaar te vinden op oplossingen, die meebrengen, dat ervan zou kunnen worden afgezien om bepaalde 
Boek 2, dat bijna honderd pagina's telde. ${ }^{187}$ Wel gold daarvoor als bijzonderheid dat elk van de deelnemende partijen een deel van het verslag voor zijn rekening had genomen.

Dat de Kamer in die eerste jaren zeer belangstellend was en ook bereid was de vaart erin te houden, blijkt ook uit het gegeven dat het Minister Samkalden enige moeite kostte om zijn nieuwe tijdschema van één boek per jaar aanvaard te krijgen. Weliswaar waren de meeste Kamerleden zich ervan bewust dat ook dit schema het nodige van de werkkracht van de Kamer zou eisen en verheugde men zich op de mogelijkheid van diepgaander studie, maar de instemming was niettemin enigszins negatief geformuleerd: Men had op méér gerekend. Zeelenberg zei het als volgt: "Ik heb eens gehoopt, dat het werk in de vorige parlementaire periode tot stand zou hebben kunnen komen. Dat was toen Meijers en Donker nog samen hun schouders onder dit werk zetten. Ik heb nog een ogenblik gehoopt, dat het in déze parlementaire periode tot stand zou kunnen komen. Dat was toen ik nog hoopte op een vlottere verschijning van de nog ontbrekende boeken en wetsontwerpen. Waar de dood tweemaal heeft toegeslagen en anderen het werk moeten voltooien, moet een nieuw tempo worden aanvaard, maar het verheugt mij buitengewoon, dat deze Minister, die een nieuw en langzamer tempo voorstelt, daaraan toevoegt: Een nieuw tijdschema is dringend gewenst, omdat het ontbreken ervan tijdsverlies medebrengt." ${ }^{188} \mathrm{Bij}$ de begrotingsbehandeling voor 1961 zei Samkalden, inmiddels senator, in een terugblik op die periode: "Wanneer er dan aan het einde van de volgende parlementaire periode geen tegenvallers zullen blijken te zijn (..), dan is men ongeveer vijf jaar achter op het schema, waarvan men in 1956 zeide, dat het natuurlijk wel aanzienlijk minder snel was dan Minister Donker zich had voorgesteld, maar dat men dan toch een vrij redelijk schema achtte: één boek per jaar. ${ }^{189}$

Een laatste voorbeeld waaruit kan worden afgeleid dat de Kamer begaan was met het lot van Meijers' werk, is dat zij de vorderingen met betrekking tot de totstandko-

186.

denkbeelden, die men zelf voor goed en juist houdt, dat zij nog niet zijn te verwezenlijken (..) door het gebruik van toevallige omstandigheden door te zetten. Ik geloof, dat, als men dat zou doen, men schade zou doen aan de voortgang van het werk en daarmede schade aan het doel." (Parl. Gesch. Algemeen Deel, p. 161).

187. Zie over de daarop volgende openbare behandeling ook de gedachtenwisseling tussen Van Oven en Van Rijckevorsel in NJB 1958, p. 543 e.v. en p. 574-576: "De discussiepraktijk in ons parlement is voor zulke detailzaken (van juridisch-technische aard) zeer ongeschikt, ja, salva reverentia, op het belachelijke af."

188. Handelingen Tweede Kamer 1956-1957, p. 2264. Zie ook het Voorlopig Verslag van de Eerste Kamer bij de begroting voor 1957, zitting Eerste Kamer 1956-1957, nr 4500, stuk nr 88, p. 2: "Vele leden achtten het van zeer groot belang, dat aan het tot stand brengen van een nieuw Burgerlijk Wetboek een hoge graad van prioriteit wordt toegekend, wijl het omvangrijke, daaraan verbonden werk nimmer tot een goed einde zal kunnen worden gebracht, indien het niet voortdurend de volle aandacht heeft." Diepenhorst verklaarde: "Met de grootst mogelijke klem wil ik de Minister, die, naar ik meen, van de beste voornemens bezield is, op het hart binden om met het door prof. Meijers en $\mathrm{mr}$. Donker aangevangen werk (..) voort te varen." (Handelingen Eerste Kamer 1956-1957, p. 2183).

189. Handelingen Eerste Kamer 1960-1961, p. 2184. Dat de Kamer van de beste voornemens bezield was, blijkt ook hieruit dat zij zonder veel mopperen Boek 3 R.O. van een Voorlopig Verslag voorzag, ofschoon toen reeds duidelijk was dat het Driemanschap in Boek 6 O.M. wilde afwijken van titel 3.2. Zie handelingen Tweede Kamer 1957-1958, p. 2117 en 2124. 
ming van het groene Boek 6 nauwlettend en kritisch volgde. Toen Minister Beerman eind 1960, na jaren van geruststellende mededelingen, onomwonden te kennen gaf dat er zelfs nog geen zekerheid bestond over het verschijningstijdstip van Boek 6, leidde dat tot felle kritiek in de Kamer. Berkhouwer: "Ik zou weleens willen weten, hoe het nu eigenlijk gesteld is met het Driemanschap. Dat Driemanschap is nu toch al geruime tijd geleden ingesteld; Wat is de oorzaak, dat het zo bijzonder lang duurt, voordat het Driemanschap gereedkomt met zijn ontwerp-zesde boek (..)." ${ }^{190}$ Wttewaall van Stoetwegen: "Er zit geen schot in. Ook in 1960 is de indiening van het zesde Boek niet te verwachten. En er is zelfs geen perspectief voor 1961. Ik begrijp dit niet. Is dit een geleerdenruzie of wat zit daar achter? Dit Driemanschap zit nu al jaren op dat zesde Boek te broeden; Daarom kan het derde Boek niet beantwoord worden en is er van voortgang geen sprake. Wellicht zal de Minister hier persoonlijk achterheen moeten zitten, want op deze wijze komen wij er nooit uit. " ${ }^{191}$ De Gaay Fortman; "Het lijkt mij niet een overstatement, wanneer ik zeg dat wij voor wat betreft de totstandkoming van het nieuwe B.W. in een impasse verkeren. Niet de minsten onder de deskundigen in den lande zijn van mening, dat voltooiing niet meer zal worden bereikt. (..) $\mathrm{Ik}$ hoop, dat het de Minister gegeven zal zijn de nieuwe codificatie een stuk dichter bij haar voltooiing te brengen. Hij zal haar dan echter moeten tillen uit het spel en het tegenspel van de wetenschappelijke vertogen. ${ }^{n} 192$

Aan de Kamer lag het dus niet dat het werk aan het nieuwe B.W. in de versukkeling raakte. Om nog eenmaal Wttewaall aan te halen: "Als ik goed ben geïnformeerd zou Meijers dit binnen drie maanden klaar hebben gehad. (..) Ik vind, dat de Minister maar eens tegen de heren moet zeggen: Wij moeten afdalen naar de begane grond en dan zal ik zeggen wat ik wil en wanneer het moet worden ingediend. Het is te jammer, dat wij met dit prachtige ontwerp van Meijers niet verder komen."

Pas toen de Kamer met het werk van het Driemanschap werd geconfronteerd, verdween de echte animo voor de hercodificatie. Men begreep dat de herziening van het Burgerlijk Wetboek nog lang kon duren. De slechte ontvangst van Boek 6 O.M. in de literatuur, de volstrekte afwijzing ervan door de praktijk, het feit dat de reeds vastgestelde ontwerpen in de kast stonden te vergelen, dit alles maakte dat de Kamer op een langzamer tempo overging en pleidooien voor partiële herziening en boeksgewijze invoering weer een kans kregen. Men verzoende zich min of meer met de gedachte dat het nog lang zou gaan duren en vond dat op zichzelf niet eens zo onaantrekkelijk.

De omslag, die er in het denken van de Kamer plaatsvond, laat zich illustreren aan de hand van enkele citaten rond de openbare behandeling van de begroting voor 1964 . Het was tevens de laatste maal dat tijdens de Algemene Beschouwingen aandacht zou worden besteed aan het nieuwe B.W.; de hercodificatie was voor de politiek niet langer interessant. Berkhouwer: "Als ik mijn standpunt op dit moment wil bepalen, zou ik zeggen: Laten wij rustig voortgaan met onze arbeid aan de nieuwe burgerrechtelijke codificatie en zien waartoe wij komen. Het heeft geen zin zich te verdiepen in tempobepalingen. Wij hebben zo vaak gepoogd tot een tempobepaling te komen en 
telkens hebben wij moeten ervaren, dat het schema werd achterhaald door de feiten." ${ }^{193}$ Baeten: "Ik heb ooit - ik was toen nog zeer jong - behoord tot de optimisten, die meenden, dat het ambitieuze program van Minister Donker uitvoerbaar zou zijn, maar naarmate diens krappe tijdschema werd overschreden, kwam ik van lieverlede terecht in het kamp van de pessimisten, die dachten, dat de huidige generatie de invoering van het nieuwe Burgerlijk Wetboek zelfs niet meer zou beleven. (..) Uit de choc des opinions is in mij tenslotte de realist te voorschijn gekomen, die aanvaardt, dat een periode van rond de vijfentwintig jaar werkelijk nodig is om een geheel nieuwe codificatie van ons burgerlijk recht tot stand te brengen." 194

c. stagnatie andere boeken

Tenslotte leidde de vertraging in de afwerking van Boek 6 O.M. ertoe dat de voortgang van de andere boeken eveneens stagneerde. In het bijzonder gold dat voor de nog niet gepubliceerde delen van het Ontwerp-Meijers, die immers moesten worden geënt op het voorontwerp voor Boek 6, maar ook de parlementaire behandeling van de reeds uitgekomen delen ondervond hiervan ernstige hinder. De belangrijkste reden daarvoor was dat Drion, die als Regeringscommissaris leiding moest geven aan de voorbereiding van diverse Memories van Antwoord, na 1958 zozeer door zijn andere activiteiten in beslag werd genomen, dat de nota's die de departementsambtenaren voor dat doel opstelden, ongelezen bleven. Bovendien verergerde deze situatie omstreeks 1960 nog, omdat vanaf dat moment een groot deel van de inspanning van de wetgevingsafdeling van het Departement erop was gericht het Driemanschap te laten bevallen van Boek 6 O.M., zodat ook dit voorbereidende werk moest worden gestaakt. Het gevolg was dat de gepubliceerde tijdschema's keer op keer moesten worden herroepen, waardoor met name Minister Beerman in grote verlegenheid zou worden gebracht. Een paar voorbeelden.

In de begroting voor 1957 schreef Samkalden dat, voor zover hij dat op dat moment kon overzien, het werk aan het voorontwerp voor Boek 6 de tijd van het Driemanschap tot in de zomer van 1957 zou opeisen. Het Regeringsontwerp zou aan het einde van dat kalenderjaar kunnen worden ingediend. Op die wijze kon, volgens de Minister, "zelfs rekening worden gehouden met de in het Voorlopig Verslag neergelegde zienswijze, dat kennisneming van de opzet van Boek 6 zo al niet onontbeerlijk, dan toch zeker gewenst is voor een deugdelijke bestudering van Boek 3." Verder sprak Samkalden de hoop uit dat de behandeling in de Tweede Kamer van de Boeken $1 \mathrm{t} / \mathrm{m} 4$ in deze parlementaire periode kon worden afgehandeld. Ten aanzien van de Boeken 5 en 6 zei de Minister ernaar te streven beide boeken in deze periode schriftelijk af te doen: "Indien voorts voor de Boeken 5 en 6 de schriftelijke behandeling tussen de Tweede Kamer en de Regering in de loop van deze parlementaire periode zou worden beëindigd, zou een belangrijke stap in de richting van de voltooiing van het nieuwe wetboek zijn gedaan." 195

Bij de volgende begroting moest Samkalden al zijn ongelijk bekennen, althans voor zover het ging om de publicatie van het Zesde groene Boek. "Niet verzwegen kan 
worden, dat enige belangrijke onderdelen ervan nog niet hun afronding hebben gevonden", was de boodschap die Samkalden op 11 november 1957 voor de Kamer in petto had. Ook had de Minister zich rekenschap gegeven in hoeverre de niet-tijdige verschijning van Boek 6 O.M. een bezwaar zou kunnen opleveren bij de parlementaire behandeling van Boek 3: "Indien in het niet tijdig ter beschikking zijn van tekst en toelichting van Boek 6 een bezwaar mocht worden gezien tegen behandeling van Boek 3, zou dit bezwaar toch wel uitsluitend kunnen rijzen met betrekking tot de titel "Rechtshandelingen" van Boek 3, zodat de behandeling van het overige gedeelte van Boek 3 haar normale loop kan hebben." 196197

Een jaar later bleek dat het Driemanschap nog weinig was opgeschoten. De begroting voor 1959 meldde, uiterst sober: "Aan Boek 6, waarvan de bewerking meer tijd vordert dan aanvankelijk was geraamd, wordt gestaag voortgewerkt." 198 Het tijdschema kwam volgens de Minister nog niet in gevaar, omdat de Kamer bezig was met het Voorlopig Verslag voor Boek 3 en voorlopig nog vooruit kon met de Boeken 4 en 5. Samkalden streefde er nog steeds naar om Boek 3 in 1959, Boek 4 in 1960 en Boek 5 eveneens in 1960 door de Tweede Kamer te laten vaststellen. Inderdaad zouden in 1958 wel enige voorbereidende nota's met betrekking tot Boek 3 worden opgesteld, maar aan een bespreking daarvan met Drion kwam het Departement niet toe voor april-juni 1959. Samkalden zou zijn toezegging op dat punt dus nooit hebben kunnen waarmaken.

Op 19 mei 1959 nam Beerman de fakkel over, na een half jaar weinig vruchtbaar interimaat van Struycken. Beerman was al direct voorzichtig met voorspellingen en gaf aan dat Boek 4 mogelijk voor Boek 3 zou worden behandeld, vanwege de samenhang tussen Boek 3 en Boek 6 . Kort na zijn aantreden zouden de besprekingen over Boek 3 inderdaad worden gestaakt en begin januari 1960 zou op het Departement een werkverdeling plaatsvinden, met als doel de Memorie van Antwoord op Boek 4 in maart 1960 te publiceren. In de resterende maanden zou dan gewerkt kunnen worden aan de Memorie van Antwoord over Boek 3, waarbij de Minister ervan uitging dat Boek 6 inmiddels zou zijn verschenen en Drion zijn handen vrij had. ${ }^{199}$

De begroting voor 1961 was een stuk somberder. Beerman sprak nu alleen de hoop uit dat de Memorie van Antwoord over Boek 4 in de eerste helft van 1961 zou kunnen worden ingediend. Eén van de redenen daarvoor was het in april 1960 verschenen rapport van de Commissie Erfrecht uit de Broederschap, waarin Boek 4 R.O. zowel op hoofdlijnen als in bijzonderheden werd bekritiseerd. Een andere reden was de voortdurende stagnatie rond Boek 6. Daardoor werd het werk aan de Memorie van Antwoord voor Boek 3 weer verder naar achteren geschoven, "de behandeling van Boek 3 kan voortgang vinden zodra Boek 6 zal zijn verschenen", terwijl over het bestaan van Boek 5 zelfs niet meer werd gerept. ${ }^{200}$ Tijdens de openbare behandeling in de eerste Kamer, vier maanden later, deelde Beerman enigszins besluikt mede dat

196. Zitting Tweede Kamer 1957-1958, nr 4900, stuk nr 9, p. 2.

197. Gelukkig voor de Minister was de vaste Commissie al ijverig bezig met de voorbereiding van het Voorlopig Verslag over Boek 3, zodat zijn vrees, dat zij de behandeling daarvan zou opschorten tot de verschijning van Boek 6, niet terecht was. Zie handelingen Tweede Kamer 1957-1958, p. 2117.

198. Zitting Tweede Kamer 1958-1959, nr 5300, stuk nr 2, p. 1.

199. Zitting Tweede Kamer 1959-1960, nr 5700, stuk nr 2, p. 1.

200. Zitting Tweede Kamer 1960-1961, nr 6100, stuk nr 2, p. 1. 
het werk aan de Memorie van Antwoord voor Boek 4 ook was stilgelegd, omdat alles moest wijken voor Boek 6 O.M.: "Mijn aandacht en geladenheid zullen in de eerste plaats gericht zijn om vóór alles erop toe te zien, dat het vrijwillig conclave wordt gehandhaafd t.a.v. het zesde Boek, door het Driemanschap, en dat daarna alles wordt gezet op het gereedmaken van de Memorie van Antwoord voor het vierde Boek. "201

Eind 1961 kan Beerman dan eindelijk mededelen dat Boek 6 O.M. ter perse ligt en dat met volle kracht wordt gewerkt aan de Memorie van Antwoord voor Boek 4. In het Voorlopig Verslag wordt dienaangaande opgemerkt: "In de Memorie van Antwoord inzake de begroting voor 1961 (..) werd verondersteld, dat de Memorie van Antwoord op het vierde Boek van het nieuwe B.W. in de eerste helft van 1961 zou kunnen worden ingediend; thans lijkt het streven erop gericht, deze Memorie van Antwoord in de loop van dit zittingsjaar, zo mogelijk dit najaar, te doen verschijnen. Kan de Minister mededelen, waaraan deze aanmerkelijk afwijking van de prognose moet worden geweten?" Het antwoord van Beerman laat aan duidelijkheid weinig te wensen over. De Minister was ten aanzien van Boek 4 uitgegaan van de eerste helft van 1961 "omdat hij toen hoop had dat het Driemanschap het ontwerp voor Boek 6 geruime tijd eerder zou voltooien dan tenslotte is mogelijk gebleken." Voltooiing van het overleg over Boek 4 bleek niet verenigbaar "met het aandeel van prof. Drion in de arbeid van het Driemanschap aan Boek 6." 202

Een jaar later zou Beerman zijn beleid nogmaals toelichten, ditmaal naar aanleiding van een opmerking dat wellicht teveel objecten tegelijk in het oog werden gevat, zodat daaruit de vertraging kon worden verklaard. Op alle fronten nam de Minister gas terug, van beleid was eigenlijk geen sprake meer. Enkele delen uit zijn betoog:

"De ondergetekende kan niet beamen dat bij de werkzaamheden voor de totstandkoming van het nieuwe Burgerlijk Wetboek te veel objecten tegelijk in het oog werden gevat. In de eerste plaats merkt hij op dat - gezien de samenhang tussen Boek 3 en Boek 6 - het bezwaarlijk was de Memorie van Antwoord op Boek 3 in te dienen zolang Boek 6 niet was verschenen. Dit is dan ook niet geschied. Voorts bleek, dat bij de organisatie der werkzaamheden, zoals die was vóór het verschijnen van Boek 6, prof. Drion overbelast werd tengevolge van de omstandigheid dat hij een dubbele taak had: Zowel die van ontwerper - Drieman - als die van verdediger - Commissaris ex artikel 120 Grondwet. Er was dientengevolge, in tegenstelling tot hetgeen in deze vraag wordt gezegd, niet een gebrek aan concentratie van krachten, doch juist een overmaat van concentratie. "203

Invoering van Boek 1 bleek om dezelfde reden niet aan de orde:

"De ondergetekende had in de Memorie van Antwoord op de Justitiebegroting voor 1962 de verwachting uitgesproken, dat dit wetsontwerp nog in het zittingsjaar 1962/63 zijn Departement zou kunnen verlaten. Die verwachting was gebaseerd op de helaas niet vervulde veronderstelling dat de Memorie van Antwoord op Boek 4 nog in de loop van het vorige zittingsjaar zou kunnen worden ingediend. Doordat

201. Handelingen Eerste Kamer 1960-1961, p. 2220.

202. Zitting Tweede Kamer 1961-1962, nr 6500, stuk nr 10, p. 2.

203. Zitting Tweede Kamer 1962-1963, nr 6900, stuk nr 10, p. 2. 
de voltooiing van dit stuk de werkkracht van prof. Drion en de betrokken ambtenaren van zijn Departement langer in beslag heeft genomen dan toen werd verwacht, is de voorbereiding van de invoeringswet voor Boek 1 niet zo snel voortgeschreden als verleden jaar gedacht werd."

Boek 5 werd zo goed als afgeschreven:

"De Memorie van Antwoord op Boek 5 komt de ondergetekende minder urgent voor. $\mathrm{Zij} \mathrm{zal}$ in ieder geval pas kunnen worden voltooid nadat de Memorie van Antwoord op Boek 3 is ingediend." 
Bijlage I Vergelijking concept-Meijers - Ontwerp-Meijers

Om een indruk te geven van de veranderingen die het Driemanschap in de concepten van Meijers heeft aangebracht, volgt hieronder een globale aanduiding van de belangrijkste verschillen. Daarbij heb ik mij beperkt tot de eerste zes titels (in het groene Boek teruggebracht tot vijf), omdat die nog door Meijers zelf van een drukproef zijn voorzien.

\section{Titel 5.1: Eigendom in het algemeen}

De belangrijkste wijzigingen die het Driemanschap in deze titel heeft aangebracht, hebben betrekking op de omschrijving van het eigendomsrecht in artikel 1 en de regeling van de hinder, neergelegd in artikel 5.1.2 $0 . M$. Voor het overige bleef deze titel vrijwel ongewijzigd. Artikel 3 (exclusiviteit eigendom) kreeg weliswaar een nieuwe formulering, maar dit was voomamelijk het gevolg van inteme verschuivingen. Artikel 4 (revindicatie) moest het zonder tweede lid doen ${ }^{204}$ omdat deze materie reeds in artikel 3.1.1.7 O.M. was geregeld. Uit artikel 5 (natrekking) tenslotte, werden de hulpzaken verwijderd. Dat was alles.

Ook in de toelichting veranderde weinig of niets, de artt. 5.1.1 en 2 buiten beschouwing gelaten. Bij de artikelen 4, 5 en 6 waren de veranderingen minimaal, van de toelichting van Meijers bij artikel 3 bleef ongeveer de helft (vanaf de $5 e$ alinea) behouden. Wel compleet nieuw waren de drie bladzijden met "algemene opmerkingen", die bij Meijers niet voorkwamen. Bovendien leidde de omwerking van de artikelen 1 en 2 tot een groei van de toelichting met drie bladzijden. Ter vergelijking: Meijers' concept-toelichting telde drie bladzijden, die van het Driemanschap (inclusief algemene opmerkingen) elf.

Tot de meer ingrijpende wijzigingen die het Driemanschap in titel 5.1 aanbracht, reken ik allereerst de nieuwe formulering van art. 5.1.1. Alleen het eerste lid werd ongewijzigd overgenomen. Het tweede lid werd geheel herschreven, terwijl de regel van lid 3, dat de eigenaar van de zaak eigenaar wordt van de afgescheiden vruchten, in Meijers' drukproef zelfs niet voorkwam. Het Driemanschap nam haar "volledigheidshalve" op, al zou Regeringscommissaris Snijders later betogen dat lid 3 een noodzakelijk complement vormde van artikel 5.2 .15 .205

Meijers' concept voor lid 2 luidde als volgt: "De eigenaar mag zijn zaak gebruiken, daarvan de vruchten trekken en daarover beschikken, alles behoudens de op wet of verordening gegronde beperkingen." Vergelijken we hiermee de door het Driemanschap ontworpen tekst ${ }^{206}$, dan vallen de volgende verschillen op: de woorden "naar goedvinden" zijn toegevoegd, de eigenaar "mag" zijn zaak niet langer gebruiken, maar heeft daartoe "de bevoegdheid" en deze bevoegdheid kan niet alleen door wet of verordening worden beperkt, maar ook door "ongeschreven rechtsregels".

Door deze veranderingen moest een geheel nieuwe toelichting worden geschreven. Achteraf gezien is het echter de vraag of de tijd die het Driemanschap in deze bepaling heeft gestoken, wel zo goed besteed is geweest. De woorden "heeft de bevoegdheid om" sneuvelden bijvoorbeeld al in het Regeringsontwerp en werden vervangen door het "mogen" van Meijers: "Een verordening kan wel de eigenaar beperken in het mogen beschikken, maar kan hem niet beperken in het kunnen beschikken", zoals in de Memorie van Toelichting ampel wordt uiteengezet. ${ }^{207}$ De uitdrukking "naar goedvinden", in het Gewijzigd Ontwerp afgezwakt tot "zoals hem goeddunkt" zou de eindstreep evenmin halen; zij deed teveel aan willekeur denken, zoals het in een amendement van het Tweede Kamerlid De Gaay Fortman werd verwoord ${ }^{208}$ Blijft over de verwijzing naar de "ongeschreven rechtsregels". Uit de toelichting op dit artikel blijkt dat het Driemanschap lang heeft geworsteld met de vraag of deze verwijzing naast artikel 8 van de Inleidende titel (misbruik van bevoegdheid; nu geregeld in art. 3.13) wel zin had. De uitkomst van die afweging - zij beslaat vier alinea's - was positief, een standpunt dat door alle latere codificatoren is geëerbiedigd. Een bescheiden winst dus.

204. Artikel 4 lid 2 drukproef-Meijers luidde als volgt: "Wanneer iemand ten onrechte op een beperkt recht op een zaak aanspraak maakt, is de eigenaar van die zaak bevoegd door een rechterlijke verklaring te doen vaststellen, dat zijn zaak niet met dat beperkte recht is bezwaard."

205. Parl. Gesch. Boek 5, p. 29.

206. Art. 5.1.1 lid 2 luidt: "De eigenaar heeft de bevoegdheid om, met inachtneming van de op de wet, verordening en ongeschreven rechtsregels gegronde beperkingen, de zaak naar goedvinden te gebruiken en daarvan de vruchten te trekken, alsmede om over de zaak te beschikken, een en ander behoudens rechten van anderen."

207. Parl. Gesch. Boek 5, p. 23.

208. Parl. Gesch. Boek 5, p. 31 e.v. 
De tweede min of meer ingrijpende wijziging heeft betrekking op de tekst en structuur van art. 5.2.1 O.M., het "hinderartikel". Een eerste verschil met de drukproef-Meijers is, dat Meijers de in lid 1 genoemde categorieên van hinder (overlast door uitzending van imponderablia en overlast door het onthouden van vroeger verleende medewerking en steun) over twee leden had verdeeld. Het Driemanschap daarentegen, bracht beide in een lid onder. Materieel gezien maakte dat echter weinig verschil, zodat grote gedeelten van de toelichting van Meijers behouden bleven.

In de tweede plaats was de regel van lid 2, die een oplossing bedoelde te geven voor de Voorste Stroomproblematiek, door Meijers in een apart artikel geregeld. Daarbij had hij, in afwijking van de jurisprudentie van de Hoge Raad, maar conform de in zijn "Algemene Begrippen" verdedigde opvatting ${ }^{209}$, gekozen voor de regel dat de rechtmatigheid van de in het algemeen belang verrichtte handeling afhankelijk is van een aanbod tot schadevergoeding vóór of op het ogenblik van de handeling. In de woorden van de drukproef: "Het algemeen belang kan vorderen, dat de normale grens van hinder, die aldus een eigenaar te dulden heeft, belangrijk kan worden overschreden, mits hem bij voorbaat schadevergoeding is betaald of aangeboden."

Het Driemanschap koos in overleg met P.H. Smits, destijds raadsheer in de Hoge Raad, voor een geheel andere, volgens hen "eenvoudiger" constructie. Hinder, die in de regel als ongeoorloofd zou moeten worden gekwalificeerd, maar in het algemeen belang zou moeten worden geduld, zou volgens het voorontwerp aanspraak geven op schadevergoeding. Deze vordering was niet gebaseerd op een overeenkomst of een onrechtmatige daad, maar berustte rechtstreeks op artikel 5.1.2. Een derde lid bepaalde, dat wanneer de schadevergoeding niet werd voldaan, de gedraging alsnog verboden kon worden en daardoor wél onrechtmatig werd. Anders gezegd, de hinder werd door het algemeen belang rechtmatig, maar de rechter kon haar onrechtmatig maken als geen schadevergoeding werd betaald.

Het Gewijzigd Ontwerp van Boek 6 bewees dat het allemaal nog "eenvoudiger" en vooral ook minder gekunsteld kon. Op grond van artikel 6.3.1.5b (thans 6:168) kan de rechter een vordering, strekkende tot verbod van een onrechtmatige gedraging, afwijzen op de grond dat deze gedraging in het algemeen belang behoort te worden geduld. De benadeelde behoudt echter zijn recht op vergoeding uit onrechtmatige daad. Daarmee staat het Ontwerp weer meer in de traditie van Meijers.

\section{Titel 5.2: Eigendom van roerende zaken}

De 'Inleidende opmerkingen' bij titel 5.2 bleven ongewijzigd. De eerste verandering die het Driemanschap aanbracht, had betrekking op de tekst van artikel 1, waar "toeëigenen" werd vervangen door "in bezit nemen" en enigszins ten overvloede werd benadrukı dat men "door toeëigening" de eigendom verkrijgt. Dat laatste had men beter niet kunnen doen, want het R.O. zou weer terugkeren tot de versie van Meijers.

Artikel 2 (eigendom van wilde bloemen) kreeg een sterk gewijzigde structuur, ofschoon de toelichting, afgezien van de laatste regel, die door het Driemanschap werd toegevoegd, ongewijzigd bleef.

De regeling van het vindersrecht (artt. 3-8 O.M) werd eveneens aangepast. De door Meijers ontworpen regeling, die naar mijn mening zeer geslaagd was, kwam erop neer dat de vinder (de exploitant van een openbaar vervoermiddel uitgezonderd) verplicht werd aangifte te doen bij de politie van de gemeente waarbinnen de zaak werd gevonden. Bij tijdige aangifte verkreeg de vinder drie jaar na de aangifte de eigendom van de gevonden zaak. Werd de zaak echter gevonden in een gebouw of in een openbaar vervoermiddel, dan was de vinder verplicht de zaak af te geven aan de beheerder daarvan, die, met uitzondering van het recht op beloning, de rechten van de vinder kreeg. Verder werd in het concept van Meijers een regeling gegeven met betrekking tot aan bederf onderhevige of moeilijk of tegen hoge kosten te bewaren zaken, in welk geval de ambtenaar van politie en/of de exploitant van het openbaar middel van vervoer bevoegd waren de zaak in het openbaar te verkopen. Tenslotte kende de drukproef-Meijers de vinder een recht van terughouding toe met betrekking tot de kosten, tot behoud en bewaring van de zaak gemaakt, alsmede voor de opsporingskosten. In een slotartikel werd bepaald dat de eigendom van de zaak overgaat op de gemeente waar de zaak in bewaring werd gegeven, indien de vinder, na daartoe te zijn aangemaand, na drie maanden nog geen gevolg gegeven heeft aan het verzoek de gevonden zaak tot zich te nemen.

Zoals aangegeven, is het Driemanschap op een aantal punten van de gedachten van Meijers afgeweken, zonder dat dit overigens merkbare gevolgen had voor de toelichting. ${ }^{210} \mathrm{Zo}$ werd bijvoorbeeld met betrekking tot de verplichting om aangifte te doen (art. 3) een voorbehoud gemaakt voor het geval dat de vinder zich reeds aan de eigenaar bekend heeft gemaakt. Deze regel ligt echter zo voor de hand ligt dat kan worden afgevraagd of een uitdrukkelijke bepaling vereist is. Een ander verschil is, dat de vinder in het Driemanschapsontwerp drie

209. E.M. Meijers, De Algemene Begrippen van het Burgerlijk Recht, Leiden 1948, p. 308.

210. In werkelijkheid is alleen bij artikel 3 een alinea veranderd en zijn aan de toelichting bij artikel 5 twee alinea's "volledigheidshalve" toegevoegd. Wel heeft men, omdat er nogal met de teksten is geschoven, enkele passages van plaats laten veranderen. 
jaar na de vondst eigenaar werd en dat hij verplicht was de zaak af te geven indien deze op een afgesloten erf werd aangetroffen. Anders dan bij Meijers waren de exploitanten van openbare middelen van vervoer ook tot aangifte bij de politie verplicht, al werd in artikel 5 lid 3 aangegeven dat bij of krachtens Algemene Maatregel van Bestuur uitzonderingen mogelijk waren. Tenslotte werd in het voorontwerp niet de bevoegde ambtenaar van politie, maar de gemeente waar de zaak in bewaring was gegeven, aangewezen om de zaak in het openbaar te verkopen. Gelijke bevoegdheid kwam toe aan de exploitant van een openbaar vervoermiddel, mits daartoe bij A.M.v.B. aangewezen.

De regeling van de gevonden voorwerpen is sinds de publicatie van het groene Boek in 1955 sterk gewijzigd, vooral in de details. Wanneer je die wijzigingen, die voor een deel het gevolg zijn van de toegenomen welvaart, waardoor een verloren zaak steeds vaker wordt "opgegeven", buiten beschouwing laat en de tekst, zoals die in 1992 van kracht werd, naast die van Meijers en van het Driemanschap legt, dan kan de conclusie mijns inziens geen andere zijn, dan dat van de laatste twee Meijers de betere wetgever was. Zo verdween bijvoorbeeld in de loop van de parlementaire geschiedenis de enigszins dubieuze verwijzing naar het afgesloten erf en werd het tijdstip van aangifte weer als uitgangspunt genomen voor het begin van de verjaringstermijn. Daamaast werd het recht op beloning opnieuw afhankelijk gesteld van het nakomen van alle wettelijke verplichtingen door de vinder ${ }^{211}$ en verviel de verplichting aangifte te doen van in openbare vervoermiddelen aangetroffen zaken, naar men mag veronderstellen tot opluchting van vervoersorganisaties en gemeenten.

Dat het Driemanschap de door Meijers ontworpen regeling met betrekking tot de eigendomsverkrijging van schatten met een bijzondere wetenschappelijke, geschiedkundige of artistieke waarde schrapte, is hiervoor al uiteengezet. Het algemene schatvindingsartikel (art. 5.2.9 O.M.) bleef ongewijzigd, zij het dat Meijers het begrip "schat" als volgt had omschreven: "Een schat is een zaak van waarde, die aan iemand heeft toebehoord, maar die zolang verborgen is geweest, dat daardoor de eigenaar niet meer kan worden opgespoord." De gecursiveerde woorden werden door het Driemanschap niet overgenomen, terecht naar mijn mening, omdat uit de slotzin duidelijk genoeg valt op te maken dat het artikel niet geschreven is voor zaken die nooit een eigenaar hebben gehad. ${ }^{212}$

De natrekking en de vermenging van roerende zaken waren door Meijers in tén artikel samengevat. Bijzonder is, dat het artikel in strijd was met het bekende sleepbootarrest (HR 26 maart 1936, NJ 1936, 757), omdat de ontwerper, en met hem de subcommissie Burgerlijk Recht, het ongewenst vond iemand de revindicatie te onthouden op grond van het enkele feit dat zijn zaak volgens "verkeersopvattingen" bestanddeel van de andere zaak was geworden. ${ }^{213}$ In het concept-Meijers werd de eigendomsverkrijging door middel van natrekking dan ook beperkt tot zaken, "die op zodanige wijze met elkaar verbonden worden, dat zij zonder emstige beschadiging of onevenredig grote kosten en arbeid niet gescheiden kunnen worden". Daarnaast werd, in afwijking van het bepaalde in de artikelen 662 en 663 B.W., maar in overeenstemming met $\$ 947$ BGB, art. 727 ZGB en art. 72 Ontwerp-1898, de eigendom van het geheel aan de eigenaar van de hoofdzaak toegekend. Kon geen van de verbonden (of gemengde) zaken als hoofdzaak worden aangemerkt, dan werd elk van de eigenaars van de oorspronkelijke zaken mede-eigenaar, eenieder voor een aandeel in evenredigheid met de waarde van zijn zaak.

Het is niet geheel duidelijk of het Driemanschap Meijers' visie met betrekking tot het eerste hierboven besproken punt heeft willen overnemen. Artikel 5.2.10 O.M. lid 1 bepaalt namelijk, dat wanneer een rocrende zaak door verbinding bestanddeel van een andere onroerende zaak wordi, deze in eigendom overgaat op de eigenaar van de hoofdzaak. Voor de vraag, wanneer een zaak bestanddeel wordt van een andere zaak, verwijst de toelichting naar artikel 3.1.1.3 O.M. Het problematische is, dat wanneer aangenomen wordt dat de term "verbinding" letterlijk moet worden opgevat, de verwijzing naar artikel 3.1.1.3 te ruim is, omdat krachtens lid 1 al hetgeen volgens verkeersopvatting onderdeel van een zaak uitmaakt, bestanddeel van die zaak is. ${ }^{214}$ Wordt daarentegen aangenomen dat het Driemanschap voor de opvatting van de Hoge Raad heeft gekozen, dan is de term "verbinding" eveneens misplaatst, omdat een voorwerp ook zonder verbinding bestanddeel van ecn andere zaak kan worden. ${ }^{215}$

211. Vergelijk art. 5.2.4 O.M.

212. Zie ook J. de Boer, De schatvinding in het ontwerp B.W. en de Monumentenwet, mede in het licht van haar geschiedenis, Rechtsgeleerd Magazijn Themis, 1973, p. 421 e.v.

213. Notulen van de $144 \mathrm{e}$ vergadering van de subcommissie Burgerlijk Recht van 26 september 1953.

214. Zie ook de Memorie van Antwoord bij artikel 5.2.10, Parl. Gesch. Boek 5, p. 105.

215. In het Gewijzigd Ontwerp is aansluiting gezocht bij de leer van de Hoge Raad (zie echter art. 
Artikel 5.2.11 O.M. kwam in Meijers' concept niet voor, omdat hij de eigendomsverkrijging door middel van vermenging op één lijn stelde met de "gewone" natrekking. Geen wezenlijk verschil dus, maar een kwestie van systematiek. De door het Driemanschap gegeven regeling van de zaaksvorming (art. 5.2.12) was inhoudelijk gelijk aan de door Meijers ontworpen regel, met dit verschil dat vraag wat rechtens is indien de zaak in dienstbetrekking werd gevormd, door Meijers in de tekst werd beantwoord. Ook ontbrak in Meijers' concept het tweede lid, dat bepaalt dat onder zaken ook "stoffen" zijn begrepen. Meijers zei daarover in zijn toelichting: "Het ontwerp 1898 meende in artikel 77 van "een nieuwe zaak of stof" te moeten spreken. Daar echter bij de zaaksvorming steeds een nieuw concreet voorwerp gemaakt moet worden, is ook de stof die nieuw gevormd wordt steeds een zaak, zodat het spreken van een nieuwe zaak of stof slechts verwarrend kan werken." Het Driemanschap dacht daar dus anders over, al zoekt men in de toelichting tevergeefs naar het "waarom".

De tekst en toelichting van de artikelen 5.2.13-17 bleef ongewijzigd, enkele onbelangrijke wijzigingen of aanvullingen buiten beschouwing gelaten. Wel werd een artikel geschrapt dat de (gewezen) eigenaar van een roerende zaak, die buiten zijn wil aan de hoofdzaak van een ander was toegevoegd, het recht gaf dit bestanddeel onder bepaalde condities als zijn eigendom op te vorderen. De subcommissie, waaronder Drion en Eggens, vond het artikel indertijd "niet-onaantrekkelijk".

\section{Titel 5.3: Eigendom van onroerende zaken}

Hiervoor heb ik al aangegeven dat, voor zover ik dat kan beoordelen, het Driemanschap alleen met betrekking tot het recht van aanwas en afslag (art. 5.3.9 - 13) principiëel is afgeweken van de uitgangspunten van Meijers. Dat betekent uiteraard niet, dat er in de overige bepalingen van deze afdeling geen wijziging is aangebracht. In feite zijn alleen de artikelen 3-5, 8, 12 en 13 O.M. rechtstreeks ontleend aan Meijers' concept. Wel is het zo, dat in veel van de nieuwe bepalingen Meijers' hand nog duidelijk is te herkennen. Met andere woorden, veel wezenlijks is er niet veranderd. Alleen omdat het Driemanschap voor een andere opzet koos en bijvoorbeeld ook de door Meijers ontworpen bepalingen voor titel 4 (Zaken die aan de Staat toebehoren) in deze titel integreerde, moesten veel bepalingen worden omgewerkt of worden herschreven. Om een voorbeeld te geven, artikel 5.3.1 O.M., dat een definitie geeft van de inhoud van de eigendom van de grond, was door Meijers in drie artikelen geregeld, die bovendien niet uitsluitend op deze ene vraag betrekking hadden.

Omdat het, gelet op dit veelvuldige verschuiven en verknippen, vrijwel ondoenlijk is een compleet overzicht te geven van de overeenkomsten en verschillen tussen de drukproef-Meijers en het Ontwerp-Meijers, bepaal ik mij tot een vergelijking van de regeling van de aanwas en de afslag, die niet uitsluitend in systematisch opzicht "afwijkend" genoemd kan worden.

De gedachten van Meijers over de afslag en de aanwas laten zich als volgt samenvatten:

\section{AFSLAG}

- De eigendom van het water volgt de eigendom van de grond, tenzij sprake is van openbaar water, waarvoor het omgekeerde geldt. (vergelijk art. 646 B.W.).

- Het normaal hoogwaterpeil bepaalt de eigendomsgrens van openbaar water.

- Met andere dan waterplanten begroeid land wordt niet tot het openbare water gerekend, ook al wordt dat land met vloed of hoog water overstroomd.

- Tijdelijke overstroming doet de eigendom niet verliezen. (Vergelijk art. 646 B.W.)

\section{AANWAS}

- Het recht van aanwas is beperkt tot aanwas ten koste van een openbaar of mandelig water. De aanwasregel geldt dus waar het afslagbeginsel ook werkt.

- Aanwas tengevolge van kunstwerken wordt erkend, tenzij sprake is van werken die door de oevereigenaar zijn aangelegd met het oogmerk om die aanwas te bevordereri,

- Aanwas ten koste van de zee blijft mogelijk; door middel van grensvastlegging, in onderling overleg tot stand gebracht, kan zij worden uitgesloten.

- Bij daling van het waterpeil door natuurlijke oorzaken (peilverlaging, grintwinning) behoren drooggevallen stroken grond in beginsel als aanwas te gelden.

\section{5. $\rightarrow$}

5.2.10 lid 2), omdat het niet wenselijk werd geoordeeld dat de bestanddelen van één en dezelfde zaak aan meerdere eigenaars kunnen toebehoren. Praktisch gezien lijkt mij het verschil met het conceptMeijers echter niet groot, omdat de gevallen waarin een roerende zaak naar verkeersopvatting een onderdeel vormt van een andere roerende zaak betrekkelijk zeldzaam zijn. 
Vergelijken we hiermee nu de in het voorontwerp neergelegde regeling (art. 5.3.9), dan blijkt in de eerste plaats dat de annwasregel en de afslagregel in beginsel bij alle wateren, dus ook de niet-openbare, toepassing vinden. Deze keuze wordt in de toelichting o.a. gemotiveerd met een beroep op de ratio van deze rechtsregels, namelijk dat er grote onzekerheid zou ontstaan "over de loop van de grens van percelen die vanouds de facto aan een perceel water liggen". "Men zou immers", volgens de toelichting, "tot een ver verleden terug kunnen gaan om aan te tonen dat vroeger de oeverlijn geheel anders liep dan thans. ${ }^{\text {"216 }}$

Uit het vervolg van de toelichting blijkt echter dat het praktisch belang van deze wijziging niet moet worden overschat. Bij sloten, niet bevaarbare stromende wateren en andere watergangen - vaak zullen dit niet-openbare wateren $\mathrm{zijn}^{217}$ - loopt de grens van het oeverland in het algemeen niet langs, maar in het water. Daardoor kan van grensverandering door aanwas of afslag geen sprake zijn. ${ }^{218}$ Hetzelfde doet zich voor, indien de grens niet door het water wordt bepaald, maar zich op het land, op enige afstand van de oeverlijn bevindt, een eveneens gebruikelijke wijze van grensbepaling. Mijns inziens schuilt de werkelijke reden waarom het Driemanschap van Meijers' concept afweek dan ook niet zozeer hierin dat men het gewenst vond voor alle wateren een gelijk regime te laten gelden, maar in het gegeven dat op deze wijze afscheid kon worden genomen van de niet geheel vlekkeloze constructie van het oude B.W., dat de eigendomsovergang door aanwas of afslag beschouwde als een bijzondere vorm van natrekking. ${ }^{219}$ Het Driemanschap ging waarschijnlijk iets puristischer te werk dan Meijers, die ter motivering van zijn opvatting volstond met een verwijzing naar het Ontwerp1898.

Een tweede verschil tussen het werk van Meijers en dat van de Driemannen is, dat in het voorontwerp geen onderscheid wordt gemaakt tussen de natuurlijke aanwas en de aanwas ten gevolge van kunstwerken. Alleen met betrekking tot de opzettelijk drooglegging wordt, conform de beslissing op het vijfde vraagpunt, het aanwasbeginsel van rechtswege uitgesloten. Heeft de oevereigenaar dus werken aangelegd met het oogmerk de aanwas te bevorderen zonder dat sprake is van drooglegging, dan komt deze aanwas hem in beginsel toe. Ter motivering wijst het Driemanschap erop dat het, ook bij de zeer ruime uitleg die de Hoge Raad aan het begrip natuurlijke aanwas gaf, "in een concreet geval meermalen onmogelijk is uit te maken, welk aandeel de door de oevereigenaren gemaakte kunstwerken in de aanwas hebben gehad. "220

Met het Driemanschap kan inderdaad de vraag worden gesteld of de door Meijers gemaakte onderscheiding, die weliswaar bruikbaarder was dan die van de Hoge Raad, omdat het naburigheidsvereiste was vervallen, niet té subtiel was. Daar staat echter tegenover, dat in de Driemanschapstoelichting de eigenaar van het waterperceel enkele middelen aan de hand worden gedaan om de aanwas te voorkomen of ongedaan te maken, met als gevolg dat het verschil met Meijers minder groot is dan men op het eerste gezicht zou denken: "Uiteraard kan hij wegruiming vorderen van werken, die de oevereigenaar zonder zijn toestemming in het water aanbracht en kan hij het water zodanig uitdiepen, dat van aanwas van de grond geen sprake zal zijn. Voorts kan hij uit onrechtmatige daad ageren, als de oevereigenaar reeds in zijn opzet is geslaagd om de oeverlijn ten koste van het perceel water te verplaatsen. ${ }^{\text {"22I }}$ Bovendien lijkt de door het Driemanschap gekozen weg niet de meest gelukkige. Het heeft iets gewrongens om enerzijds de (onrechtmatige) eigendomsverkrijging toe te laten, maar anderzijds de effecten daarvan weer zoveel mogelijk ongedaan te maken. Ook missen deze oplossingen iedere betekenis, indien de kunstwerken niet in het water van de oevereigenaar, maar in "eigen" water werden aangelegd, waarmee en passant het naburigheidsvereiste in ere wordt hersteld. Tenslotte is het zo, dat bij de laatst voorgestelde oplossing (onrechtmatige daad) het bewijs moet worden geleverd dat de aanwas het gevolg was van een door de oevereigenaar gegemaakt kunstwerk, waardoor het causaliteitsprobleem zich weer in zijn volle omvang openbaart.

De laatste en meest belangrijke wijziging die de ontwerpers aanbrachten, is dat volgens het voorontwerp van Boek 5 zowel de eigenaar van het oeverland als die van het water aan de grensverschuiving door middel van aanwas of afslag een einde kan maken door vastlegging van de grens uit te lokken. In Meijers' concept werd weliswaar ook de mogelijkheid geboden door middel van een notariële akte grensvastlegging te bereiken en

216. Parl. Gesch. Boek 5, p. 146.

217. Zie voor de omschrijving van de term "openbaar water" de Toelichting-Meijers bij artikel 5.3.11, Parl. Gesch. Boek 5, p. 166.

218. Parl. Gesch. Boek 5, p. 146.

219. De in verband daarmee in Meijers' concept voor de niet-openbare wateren nog noodzakelijke regel, dat de eigendom van het water de eigendom van de grond volgt, kon zo eveneens vervallen. Zie verder de toelichting bij artikel 5.3.11 O.M., Parl. Gesch. Boek 5, p. 166.

220. Parl. Gesch. Boek 5, p. 147.

221. Parl. Gesch. Boek 5, p. 147. 
aldus het aanwas- en afslagbeginsel terzijde te stellen, maar alleen voor aanwassen aan de zeekant en de wadden. Bovendien wilde Meijers niet zover gaan, dat deze mogelijkheid van delimitatie ook tegen de wil van eén van de betrokken partijen zou kunnen worden doorgezet, al achtte hij het uitoefenen van een zekere dwang niet ongerechtvaardigd. ${ }^{222}$

Intussen is ook hier het verschil tussen het concept-Meijers en het Ontwerp-Meijers minder groot dan men in eerste instantie zou denken. Feitelijk is de situatie namelijk zo, dat het recht van aanwas alleen nog betekenis heeft voor een kleine strook kust ( \pm 2 k.m.), ten aanzien waarvan de Staat er nog niet in geslaagd is zogenaamde delimitatiecontracten af te sluiten. ${ }^{23}$ Voor de grote rivieren, traditioneel het andere terrein dat van groot belang is voor de aanwas, geeft artikel 19 van de Rivierenwet 1908 een bijzondere, aan het B.W. derogerende regeling, terwijl hiervoor reeds is vastgesteld dat het recht van aanwas met betrekking tot de oevers van niet-openbare wateren geen rol van betekenis speelt. Ook hier dus een uit praktisch oogpunt bescheiden winst. ${ }^{224}$

\section{Titel 5.4: Bevoegheden en verplichtingen van eigenaars van naburige erven}

Titel 5.4. is één van die titels die alleen in de details is aangescherpt. Dat wil overigens niet zeggen dat er weinig is veranderd. Integendeel, het Driemanschap heeft vrijwel geen enkele bepaling heel gelaten. Zo is ongeveer een derde van de artikelen van plaats veranderd, verknipt of herschreven, heeft een kwart van de bepalingen van Meijers' concept een uitbreiding of verduidelijking ondergaan en zijn er tenslotte ook nog vijf artikelen, die het groene Boek in het geheel niet hebben gehaald. 225

Opmerkelijk is echter, dat veel van de wijzigingen die het Driemanschap aanbracht, in een latere fase van de hercodificatie weer geheel of gedeeltelijk zijn ongedaan gemaakt. Twee voorbeelden daarvan. Als gevolg van de inspanningen van het Driemanschap verdween

- de reeds in het Romeinse recht bekende regel (Dig. 39.2.24.12) dat een eigenaar op zijn erf niet zodanig mag graven of bouwen, dat hij de grond van de naburige erven in beweging brengt;

- de regel die de nabuur het recht geeft te vorderen dat bomen, planten of heesters, die binnen de twee metergrens geplant zijn, worden weggenomen (B.W. 714 lid 1);

- de aan het tweede lid van art. 673 C.C. ontleende regel, dat een erfdienstbaarheid, die de bevoegdheid geeft overhangende beplanting of op het naburige erf doorschietende wortels te hebben, niet door verjaring kan worden verkregen:

de actio damno infecto, die, indien gebouwen, schoorstenen of andere werken door bouwvalligheid gevaar voor andermans erf opleveren, de eigenaar van dat erf het recht geven te vorderen dat maatregelen worden genomen om dat gevaar op te heffen (vergelijk B.W. 702);

- de regel, dat het recht van uitweg alleen recht geeft op de aanwijzing van een noodweg, niet op toegang op al of niet aangrenzende openbare wegen.

Vergelijken we hiermee nu de tekst van Boek 5 B.W., zoals die op 1 januari 1992 in werking is getreden, dan blijkt dat drie van deze regels uiteindelijk toch in het nieuwe Burgerlijk Wetboek zijn terecht gekomen. Zowel het recht tot wegneming $(5: 44)$, de actie bij dreigende beschadiging $(5: 55)$ als de bepaling over openbare wegen (toel. 5:77) zijn door de wetgever in ere hersteld. Bovendien kan het verbod om wijziging in de gronddruk te brengen met enige goede wil onder het hinderartikel (het ontnemen van zijdelingse steun) worden gebracht, waardoor de band tussen het concept-Meijers en de wetstekst nog sterker is. Dat de regel met betrekking tot de overhangende beplanting en de doorschietende wortels geen plaats heeft gekregen in het B.W., is bij mijn weten door niemand bekritiseerd, al is het wel weer opmerkelijk dat de makers van het Ontwerp 1898 de regel wel de moeite waard vonden. ${ }^{26}$

222. Zie de gedachtenwisseling over het vijfde vraagpunt, Parl. Gesch. Boek 5, p. 145.

223. Zie Asser-Beekhuis II Zakenrecht, Zwolle 1990, p. 107.

224. Volledigheidshalve wordt opgemerkt dat het Driemanschap de overige gedachten van Meijers ten aanzien van de aanwas en afslag wél heeft overgenomen. In artikel 5.3.9 wordt bepaald dat de aanwasregel ook geldt bij het terugtrekken van de oeverlijn door een daling van het waterpeil en wordt met betrekking tot de afslag een uitzondering gemaakt voor tijdelijke overstromingen. Artikel 12 geeft aan dat de normale hoogwaterlijn geldt als oeverlijn, terwijl men in hetzelfde artikel ook de voor uiterwaarden geldende regeling vindt.

225. Ongewijzigd of nagenoeg ongewijzigd bleven de artikelen 5, 7, 8, 10, 11, 13-15, 17 en 19 , terwijl artikel 20 bij Meijers in de titel over mandeligheid was geplaatst.

226. Artikel $163 \mathrm{c}$ Ontwerp 1898 sloot de verjaring uitdrukkelijk uit. 
Het andere voorbeeld heeft betrekking op de redactie van de artikelen 5.4 .4 (beplanting bij grenslijn) en 5.4.12 O.M. (vensters, balkons) en wel met betrekking tot het in deze artikelen gehanteerde onrechtmatigheidsbegrip, de verjaringstermijn en het verband met het servitutenrecht. Volgens het eerste lid van deze artikelen zou het planten van bomen, heesters of heggen, respectievelijk het aanbrengen van vensters, balkons en andere soortgelijke werken binnen twee meter afstand van de grens met een ander erf, eerst onrechtmatig zijn nadat de eigenaar van dat erf zich tegen de aanwezigheid van die planten, openingen of werken heeft verzet. In het tweede lid werd bepaald, dat verzet niet mogelijk was ten aanzien van planten die reeds meer dan twintig jaren aldaar hebben gestaan.

Met de regel van eerste lid week het Driemanschap af van het B.W., dat bepaalde dat planten en gebouwen, die zich binnen de twee metergrens bevinden, onvoorwaardelijk konden weggenomen, zij het dat de literatuur algemeen van oordeel was dat een vordering tot afbraak van een gebouw veelal zou stranden op het verweer dat sprake was van misbruik van recht. Dat de mogelijkheid een vordering tot wegneming in te stellen door verjaring verviel - in het B.W. na dertig jaar - werd door sommige schrijvers wel betwist, zodat het ontwerp hier een twijfelachtig punt oploste.227 Over de vraag, of een dergelijke "verboden toestand" zich door verkrijgende verjaring kon ontwikkelen tot een erfdienstbaarheid, bestond eveneens onduidelijkheid. In 1901 besliste de Hoge Raad ten aanzien van bomen nog dat dit slechts mogelijk was indien er ook werkelijk sprake was van de wil om als rechthebbende de bevoegdheid tot het verboden gebruik te hebben, twee jaar later werd die eis met betrekking tot vensters echter niet meer gesteld. De in het voorontwerp voorgeschreven termijn was dan ook mede bedoeld om aan deze onzekerheid een einde te maken. Wel voegde het Driemanschap eraan toe, dat het verkregen servituut zeer beperkt was: "De eigenaar (heeft) in dit geval slechts het recht (...) op planten en vensters, die zich meer dan twintig jaren binnen de verboden afstand bevonden, in de bestaande toestand te handhaven, en geenszins het recht de bestaande planten te vervangen door andere, of naast de bestaande planten (of vensters) andere aan te brengen. (..) Hij kan zich er evenmin tegen verzetten, dat de buur door werken op eigen terrein hem het uitzicht ontneemt. "228

De Kamer was niet erg ingenomen met het stelsel van beide artikelen. In het Voorlopig Verslag kwam ferme kritiek voor op het "ongebruikelijke karakter van het hier gehanteerde onrechtmatigheidsbegrip" en werd een terugkeer tot het "duidelijke artikel 714, eerste lid" bepleit. ${ }^{229}$ Het gevolg was, dat het Gewijzigd Ontwerp een betrekkelijke ommezwaai liet zien. Het eerste lid bepaalt nu dat bomen en vensters enz. die zich binnen de verboden afstand bevinden, op vordering van de nabuur moeten worden weggenomen. Ter zake van schade als gevolg van de overtreding van het verbod (lid 4), bestaat echter slechts een verplichting tot vergoeding voor zover de schade is ontstaan na het tijdstip waartegen tot opheffing van de verboden toestand is aangemaand. Het uitgangspunt, dat geen schadevergoeding verschuldigd behoort te zijn, zolang de eigenaar van het erf niet weet dat wegneming verlangd wordt, is dus behouden. Tenslotte is in afwijking van de jurisprudentie van de Hoge Raad en het voorontwerp bepaald dat de nabuur na de voltooiing van de verjaring verplicht is geen gebouwen of werken aan te brengen die de eigenaar van het andere erf onredelijk zouden hinderen, tenzij dit gebouw of werk zich daar reeds voor het voltooien van de verjaring bevond. De regel, dat de vordering tot wegneming van de bomen enz. verjaart twintig jaren na aanvang van de dag waarop wegneming kan worden gevorderd, werd om systematische redenen overgebracht naar titel 3.11 (Rechtsvorderingen).

Vergelijken we nu het stelsel van het Gewijzigd Ontwerp met het concept-Meijers, dan zijn de overeenkomsten frappant. In de eerste plaats vinden we in Meijers' concept de regel dat de eigenaar gedwongen kan worden het onrechtmatig geplante of gebouwde weg te nemen. Meijers vond het onwenselijk met betrekking tot planten een uitzondering op de regels van de titel 6.3 (Onrechtmatige Daad) toe te laten. Zijn concepttoelichting vermeldde: "Anders dan het Ontwerp-1898 in artikel 163 heeft gedaan, is ook het eerste lid van artikel 714 B.W. opgenomen. Het staat geenszins volgens de algemene beginselen van de onrechtmatige daad vast, dat datgene wat iemand op onrechtmatige wijze op eigen terrein gebouwd of geplant heeft, onder alle omstandigheden door de nabuur mag worden weggenomen; wanneer het nadeel van afbreken voor de eigenaar te groot is, kan in sommige gevallen met een vergoeding in geld worden volstaan; dit wordt voor het gebouwde in artikel 13 (= art. 5.4.12 O.M.) nog eens uitdrukkelijk gezegd. Bij wegneming van onrechtmatig gedane beplantingen daarentegen is een zodanig onevenredig groot nadeel voor de eigenaar niet te vrezen. Daarom kan hier de wet in geval van overtreding van het in het vorige artikel gegeven verbod onvoorwaardelijk de bevoegdheid geven om wegneming van het onrechtmatig aangebrachte vorderen."

Een gezond uitgangspunt dunkt me, en in overeenstemming met de literatuur van die dagen. Wat stelt het Driemanschap echter?: "Het in artikel 714 lid 1 bepaalde (is niet) overgenomen, zodat aan de rechter de vrijheid is gegeven om in bijzondere omstandigheden aan de nabuur alleen een vergoeding in geld toe te ken-

227. Zie Asser-Beekhuis II Zakenrecht, Zwolle 1990, p. 171.

228. Parl. Gesch. Boek 5, p. 190 en 203.

229. Parl. Gesch. Boek 5, p. 191. 
nen. In het algemeen immers pleegt de rechter, indien de eiser terecht klaagt over een door de gedaagde geschapen of gehandhaafde onrechtmatige toestand hoewel hij niet kan stellen dat daardoor zijn eigendomsrecht wordt aangetast, de gedaagde te veroordelen tot het ongedaan maken van die onrechtmatige toestand, tenzij om bijzondere redenen de eiser met schadevergoeding in geld genoegen moet nemen. Er is geen reden om in het in dit artikel bedoelde geval af te wijken van hetgeen bij de onrechtmatige daad in het algemeen geldt."

De vraag of door verjaring de mogelijkheid vervalt een vordering tot wegneming in te stellen, werd in Meijers' concept voor titel 5.4 niet beantwoord. Kennelijk vond hij dat de algemene bepalingen van titel 3.11 een afdoende regeling boden (vergelijk an. 3.11.10). ${ }^{230}$ Blijft over de relatie tot de erfdienstbaarheden. Ook die vraag werd door Meijers met een volmondig ja beantwoord. De toelichting bij artikel 5.5.4 luidde: "In tegenstelling met het in het vijfde lid bepaalde ${ }^{231}$ kan een strijdige toestand wel tot de verkrijging van een erfdienstbaarheid door verjaring leiden. Men vergelijke Suyling n. 201 (noot) en Scholten-Asser II, 8e druk, 1945 , p. 253." In deze verwijzing was tevens de door het Driemanschap ontworpen toevoeging besloten, dat de aldus verkregen erfdienstbaarheid tenietgaat, indien de omstandigheden zich wijzigen.

\section{Titel 5.5: Mandeligheid}

De mandeligheid is slechts vijf maal ter sprake geweest in het Driemanschap. Het hoeft daarom niet te verbazen dat het aantal wijzigingen dat het Driemanschap in Meijers' werk aanbracht, beperkt is en niet al teveel voorstelt. Er is wat geschoven met de volgorde van de bepalingen, in de toelichting is hier en daar wat verplaatst, geschrapt of aangevuld, maar het heeft allemaal weinig om het lijf.

Niettemin zijn er twee zaken die vermelding verdienen. De eerste is, dat het Driemanschap het merendeel van de door Meijers uit het B.W. overgenomen regels met betrekking tot de gemene muur, schutting, heg, boom en sloot schrapte, waardoor de door hem ontworpen regeling met zes artikelen kon worden bekort. Uit de toelichting bij artikel 5.5.7 O.M. blijkt dat het Driemanschap tot deze sanering besloot, omdat men van mening was dat de meeste van deze artikelen niet anders zouden zijn dan toepassingen van de algemene regels, die bij iedere gemeenschap gelden. ${ }^{232}$ Bovendien zouden de artikelen omtrent de verhoging van de gemene muur (artt. 685, 687 en 692 B.W.), heining ( 691 B.W.) en bomen ( 710 B.W.) te bevoogdend zijn en zou het beter zijn de oplossing van de zich daarbij voordoende vragen aan de betrokkenen zelf over te laten. Aangezien noch de literatuur, noch de wetgever sindsdien op herstel van de band met het B.W. heeft aangedrongen, kan worden geconcludeerd dat deze beslissing van het Driemanschap een juiste is geweest. ${ }^{233}$ Zij illustreert tevens, dat het het Driemanschap bepaald niet aan zelfverzekerdheid ontbrak. Want zowel Meijers als de Staatscommissie vonden deze artikelen nog belangrijk genoeg om ze in het ontwerp voor een nieuw Burgerlijk Wetboek op te nemen, terwijl zij ook in het technisch knappe Ontwerp-1898 nog een voorname plaats innamen. ${ }^{234}$

Het tweede niet-onbelangrijke verschil heeft betrekking op de vereisten voor het ontstaan van mandeligheid, een kwestie die tot aan de invoering toe omstreden is geweest en waarvan de wettelijke regeling op het laatste moment nog ingrijpend werd veranderd. Meijers omschreef mandeligheid als volgt:

Artikel 1.1. Mandeligheid is aanwezig, wanneer een onroerende zaak het gemeenschappelijk eigendom van twee of meer eigenaars van naburige erven is en door hen is bestemd die erven tot gemeenschappelijk nut te zijn.

2. De bestemming ten gemeenschappelijke nutte moet hetzij uit de feitelijke toestand, hetzij uit een in de daartoe bestemde openbare registers ingeschreven akte blijven.

230. Blijkens de notulen van de $143 \mathrm{e}$ vergadering van de subcommissie Burgerlijk Recht van 20 juni 1953 was Meijers het in elk geval niet eens met de opvatting van commissielid Beekhuis, dat de vordering tot wegneming niet aan verjaring onderhevig zou ziin.

231. Het vijfde lid bevat de regel dat een erfdienstbaarheid, die de bevoegdheid geeft overhangende beplanting of op het naburige erf doorschietende wortels te hebben, niet door verjaring kan worden verkregen.

232. Parl. Gesch. Boek 5, p. 240.

233. Zie ook de opmerking in het Eindverslag van de Eerste Kamer over artikel 5.5.5 lid 2 G.O., Parl. Gesch. Boek 5, p. 236.

234. Alleen Meijers' voorstel de artikelen 692 lid 1 (vensters in gemene mur) en 689 leden 2 en 3 B.W. (werken op of tegen gemene muur) te behouden, had in de Staatscommissie tot een korte gedachtenwisseling geleid. De Jong achtte het eerste artikel overbodig, want "al te specieus en bovendien vanzelfsprekend"; De regel van het tweede zou reeds bestreken zou worden door de regeling van de onrechtmatige daad. 
3. (...)

Met deze regels brak Meijers met het stelsel van het Burgerlijk Wetboek, dat niet verder kwam dan tot het opstellen van enkele wettelijke vermoedens met betrekking tot een aantal in het burenrecht genoemde zaken, zoals gemene scheidsmuren, regenbakken, putten en riolen (art. 681 e.v.). Door middel van deze bepaling werd de mogelijkheid geschapen om iedere onroerende zaak, die eigendom is van de eigenaars van twee of meer naburige erven, tot een mandelige te maken.

Het Driemanschap nam beide regels niet alleen vrijwel ongewijzigd over (art. 5.5 .1 lid 1 en 3$)^{235}$, maar voegde er nog één aan toe, waardoor het toepassingsgebied van deze figuur nog belangrijk werd uitgebreid. In een nieuw tweede lid werd namelijk bepaald dat gebouwen of werken, opgericht op één of meer van de erven tot welker gemeenschappelijk nut zij worden bestemd, gemeenschappelijke eigendom, en daarmee dan weer ingevolge art. 5.5.1 lid 1, een mandelige zaak worden. De enkele afspraak van partijen leidt hier dus tot medeeigendom, zonder dat een notariële akte, gevolgd door inschrijving in de registers, vereist is. Hiermee nam het Driemanschap duidelijk afstand van Meijers, die met betrekking tot het ontstaan van mede-eigendom vasthield aan de gewone voor eigendomsverkrijging geldende regels (art. 3.4.2.4 O.M.) en die de mogelijkheid om bij overeenkomst mandeligheid (d.w.z mede-eigendom, gevolgd door mandeligheid) in het leven te roepen, in beginsel verwierp.

Zoals bekend, is artikel 5.5.1 vrijwel van het begin af omstreden geweest, met name omdat het niet onmogelijk werd geacht dat rechtsopvolgers in verwarring zouden kunnen worden gebracht doordat de gemeenschappelijke bestemming van een gebouw of werk wél uit de feitelijke situatie zou kunnen worden afgeleid, maar de mede-eigendom niet. ${ }^{236}$ Kort voor de invoering besloot de Minister dan ook het stelsel van het ontwerp geheel over boord te zetten en voor mandeligheid (het bestemmen) een notariële akte, gevolgd door inschrijving in de openbare registers, verplicht te stellen. In de nieuwe opzet heeft artikel 5.5.1, zoals in de toelichting breedvoerig wordt uiteengezet, nog slechts deze beperkte functie dat de gemeenschappelijke eigendom, die reeds langs de weg van artikel 3.4.2.4 tot stand kan zijn gebracht, door de bestemming tot gemeenschappelijk nut tot mandelige eigendom kan worden gemaakt. ${ }^{237}$ Daarmee is de wetgever na veertig jaren studie weer teruggekeerd tot de opzet van Meijers, met dit verschil dat nimmer tot mandeligheid kan worden geconcludeerd op grond van het feit dat een gemeenschappelijke zaak tot nut van de andere erven strekt.

Of met de verplichte gang naar de notaris het recht een dienst wordt bewezen, kan worden betwijfeld. Niet alleen zal er vermoedelijk weinig animo bestaan een gemeenschappelijk muur in te schrijven, waardoor de regeling in veel gevallen een dode letter zal blijven, maar bovendien lijkt zij overbodig. Voor die gevallen waarin de derde de bestemming zonder moeite uit de feitelijke toestand kan afleiden, geschiedt de inschrijving in wezen ten overvloede en dient zij slechts de belangen van de notaris. En zo zij niet uit de feitelijke toestand volgt en een akte ontbreekt, kan men veilig aannemen dat het nut voor alle erven is vervallen en de mandeligheid heeft opgehouden te bestaan. Complicaties als vermeld in het verslag van de Kamer over artikel 5.1.1 (invoeringswet) waren in de door Meijers ontworpen redactie althans uitgesloten.

235. Wel sloop in de "vertaling" van Meijers' tweede lid een fout. Door te bepalen dat de bestemming ten gemeenschappelijke nutte óf uit de feitelijke toestand of uit een in de daartoe bestemde openbare registers ingeschreven akte moest blijken, had het er alle schijn van dat voor het ontstaan van mandeligheid niet alleen de bestemming zelf werd geëist, maar ook het bewijs van het bestaan ervan. Dat laatste is echter alleen van belang met betrekking tot de vraag of rechtsopvolgers en derden van het bestaan van de mandeligheid op de hoogte konden zijn. Zie hierover uitvoerig de Memorie van Antwoord bij art. 5.5.1 lid 3 R.O. (Parl. Gesch. Boek 5, p. 226-228).

236. Zie daarvoor met name de tekst van het Mondeling Overleg, Parl. Gesch. Boek 5, p. 228-229 en de vragen, opgenomen in de Memorie van Antwoord bij de invoeringswet, Parl. Gesch. Boek 5 (invoering), p. 1042.

237. Parl. Gesch. Boek 5 (invoering), p. 1042. 


\section{Bijlage II Voortgang Boek 6 O.M.}

Bij het maken van dit overzicht is gebruik gemaakt van de overzichtnota's die Franken ten behoeve van het Ministerie van Justitie had opgesteld. Deze overzichten verschenen achtereenvolgens op 16 januari 1957, 6 mei 1957, 19 september 1957, 7 maart 1958, 20 november 1958, 6 juli 1959, 22 september 1960, 23 november 1960. Daamaast is geput uit de Driemanschapsnotulen van 7 november 1959,12 maart 1960 en 2 juli 1960 , waarin eveneens mededelingen ten aanzien van de voortgang waren opgenomen. Kortheidshalve is hieronder niet altijd de datum van het gebruikte overzicht voluit aangegeven. "September 1960" betekent dan dat gebruik gemaakt is van het overzicht van 22 september 1960.

\section{Afdeling 6.1.1: Algemene bepalingen}

Uit het overzicht van 16 januari 1957 blijkt dat deze titel direct terzijde is gelegd: "De concepten van prof. Meijers zijn laatstelijk (16 mei 1955, 59e vergadering) besproken, zonder dat men het eens is geworden over de opzet van deze afdeling. Prof. Eggens heeft een concept voor een nieuwe tekst gemaakt (20-8-56), doch de behandeling is op verzoek van $\mathrm{mr}$. De Jong voorlopig uitgesteld voor het bestuderen van buitenlandse literatuur en met het oog op de samenhang met andere afdelingen." In september 1957, toen een nieuwe taakverdeling werd voorgesteld, was nog niet beslist wie deze titel onder zijn hoede zou nemen. Een maand later, in oktober 1957, zou Eggens' concept voor het eerst worden besproken. De Grooth was toen reeds van de partij.

Na Eggens' vertrek ontfermt Drion zich over deze titel. Het overzicht van 7 maart 1958 vermeldt dat Drion gestencilde concepten voor tekst en toelichting voorbereidt en dat hij daarmee in een gevorderd stadium is. Toegevoegd wordt, dat een eerste drukproef pas kan worden vervaardigd, wanneer deze concepten in het Driemanschap zijn besproken. Op 20 november 1958 is echter nog niets gebeurd en dringt Samkalden aan op een drukproef, die per half december zou moeten verschijnen. Acht maanden later - het is dan 6 juli 1959 - blijkt dat Drion nog geen stap verder is gekomen: "prof. Drion is vrijwel gereed met het opstellen van een gestencild concept voor tekst en toelichting. Na mondelinge of schriftelijke bespreking hiervan in het Driemanschap zal een eerste drukproef worden vervaardigd, waarna de B.W.-club van het Departement rapport kan uitbrengen." Deze bespreking vond plaats op 4 november 1959 (244e vergadering), terwijl het advies van de B.W.-club op 4 mei 1960 werd besproken (262e vergadering). Op 22 september was de tweede drukproef verschenen. Commentaar van Franken: "Deze afdeling kan waarschijnlijk wel als voltooid beschouwd worden."

\section{Afdeling 6.1.2: Hoofdelijke verbintenissen}

In de periode mei/juni 1955 besteedde het Driemanschap vijf vergaderingen aan het doorspreken van Meijers' concept voor afdeling 6.1.2. Dit resulteerde in 1956 in een drukproef (tekst, geen toelichting), gevolgd door een actieve notawisseling van de rapporteurs Scholten en Petit, de B.W.-club en een zevental vergaderingen van het Driemanschap. Drion zou, volgens het overzicht van januari 1957, de tekst bijwerken en vervolgens bespreken met Franken. De laatste en Eggens namen op zich een concept te maken voor de zgn. actieve pluraliteit (afdeling 6.1.3), alsmede voor de toelichting bij afdeling 6.1.2. Blijkens het overzicht van 7 maart 1958 was er aan beide afdelingen nog niets gebeurd in verband met de voorrang voor de titels 6.2 en 6.3, die meer haast hadden. In de eerste helft januari 1959 verscheen een drukproef, maar die bood niets nieuws. Bepalingen over de actieve hoofdelijkheid ontbraken nog steeds en bovendien moesten de binnengekomen rapporten nog steeds worden verwerkt. Op 22 september 1960 was de situatie onveranderd. November 1960 werd afgesproken dat De Grooth en Franken de actieve hoofdelijkheid maar voor hun rekening moesten nemen. Hun werk, alsmede de correcties die Drion in afdeling 6.1.2 zou aanbrengen, zijn nooit in het Driemanschap besproken. $\mathrm{Na} 1956$ zijn beide onderwerpen dus niet meer plenair aan de orde geweest.

\section{Afdeling 6.1.4: Alternatieve verbintenissen}

In oktober 1956 was de eerste drukproef, met daarop opmerkingen van het Departement, Belinfante en Van Vrijberghe in een tweetal bijeenkomsten doorgesproken. Eggens verzorgde het concept voor de tweede drukproef van de tekst, Fokkema schreef de toelichting erbij. Mei 1957 lagen beide gereed, behoudens dat Franken er nog naar moest kijken en dat het Driemanschap het geheel nog moest goedkeuren. Juni 1957 was het werk aan deze afdeling voltooid.

\section{Afdeling 6.1.5: Voorwaardelijke verbintenissen}

In januari 1957, na acht besprekingen, lag een eerste drukproef van Eggens en Franken bij de drukker. Mei 1957 had het Departement opmerkingen ingezonden. Rapporteurs van de Staatscommissie werden niet aangewezen, ofschoon dat aanvankelijk wel in de bedoeling lag. In juni 1957 verscheen de tweede en definitieve drukproef. 
Afdeling 6.1.6: Nakoming van verbintenissen

Deze afdeling had het in december 1956 tot een tweede drukproef (De Jong) gebracht, na een tiental intensieve besprekingen in het Driemanschap. Gewacht werd op advies van Staatscommissie (Belinfante en De Baat) en het Departement, waarna besprekingen in het Driemanschap zouden volgen. Mei 1957: de adviezen zijn binnen en worden geglosseerd door De Jong en daarna van kanttekeningen voorzien door Eggens en Drion. September 1957: de voltooiing is, na een nieuwe ronde van drie besprekingen, niet ver meer. De vierde drukproef is in voorbereiding, maar dient nog te worden beproken in het Driemanschap. Op 22 september 1960 is dat nog niet gebeurd. Bovendien blijkt dat sommige bepalingen moeten worden herzien in verband met inmiddels ten aanzien van andere afdelingen genomen beslissingen. Op 23 november 1960 wordt besloten dat De Jong en De Grooth er nog eens naar moeten kijken. Daarna is deze afdeling, die als zeer gedetailleerd werd beoordeeld, nog slechts één keer in het Driemanschap ter sprake gekomen.

\section{Geldschulden}

De artikelen 6.1.6.13 en 14 werden door Drion ontworpen. Na zeven besprekingen in het Driemanschap presenteerde Drion in het voorjaar van 1957 zijn eerste concept-tekst aan De Baat, om er daarna uitvoerig met hem over van gedachten te wisselen. De herziening van dit concept, alsmede het schrijven van een toelichting zou Drion ter hand nemen na de voltooiing van titel 6.3. Ondanks de november-instructie van Samkalden blijft het concept-Drion buiten de drukproef van 6.1.6. In Juli 1959 legt Drion zijn oude concept, voorzien van enige toelichtende aantekeningen, voor aan Drieman De Grooth, met de bedoeling daarna het voltallige Driemanschap en het Departement te consulteren. Op 23 november 1960 was er van dit alles echter nog niets gebeurd. Drion en De Groot zouden deze artikelen uiteindelijk samen afwerken, zodat ook dit vraagstuk het Driemanschap niet zou halen.

\section{Afdeling 6.1.7: Schuldeisersverzuim}

Op 7 augustus 1956 lag er - na negentien voorgaande beprekingen in het Driemanschap - een eerste drukproef tekst en toelichting voor advies bij de Staatscommissie (Smits en Hijmans van den Bergh) en het Departement. Een jaar later en drie besprekingen verder, is mevr. Fischer - onder leiding van Drion - bezig de eerste drukproef om te werken naar aanleiding van de ontvangen rapporten. In 1958 en 1959 neemt het Driemanschap het nieuwe concept in veertien besprekingen door. Besloten wordt dat Fischer (in samenwerking met De Jong) het geheel nogmaals zal omwerken. Op 22 september 1960 is de nieuwe drukproef in concept gereed, maar dient hij nog wel in het trio te worden besproken. Dit laatste is nooit gebeurd. Alleen De Grooth heeft er nog naar gekeken.

Afdeling 6.1.8: De gevolgen van het niet nakomen van een verbintenis

Meijers' concept werd van augustus 1955 tot mei 1956 in vijftien vergaderingen aan de tand gevoeld. Medio 1956 lag er volgens het overzicht een eerste concept van De Jong, dat, in tegenstelling to de normale procedure, nog niet was besproken in het Driemanschap en wachtte op adviezen van Departement en Staatscommissie (Visser van IJzendoom en De Baat). Maart 1958 waren alle adviezen binnen. Het overzicht meldt: "Deze drie rapporten - alsmede een aantal nota's van leden van het Driemanschap - zijn nog niet in het Driemanschap besproken. Deze afdeling is dus rijp voor verdere behandeling ter voorbereiding van een derde drukproef. ${ }^{238} \mathrm{Er}$ moet rekening mee worden gehouden dat deze verdere behandeling waarschijnlijk niet beperkt zal zijn tot kleine punten van redactionele aard." In september 1960 blijkt dat de situatie onveranderd is. Waarschuwend wordt opgemerkt: "De derde drukproef en de rapporten en nota's moeten nog worden besproken (..). Voorts moet deze afdeling nog op verschillende punten worden aangepast aan hetgeen bij de bespreking van andere afdelingen is besloten en aan hetgeen omtrent de Onrechtmatige Daad zal worden beslist. Inmiddels zijn door $\mathrm{mr}$. De Jong (maart 1960) voorstellen tot wijziging van de tekst en de toelichting ingezonden. Evenals de voornoemde stukken moet deze nota nog worden besproken in het Driemanschap. Verschillende van de nog te behandelen stukken behelzen tamelijk ingewikkelde en controversiêle punten."

Desalniettemin zou deze afdeling, die in het geheel niet spoorde met afdeling 6.5.4 en 6.1.6, spoedshalve door De Grooth en Fokkema worden afgemaakt. Alleen in het kader van de behandeling van titel 6.2 zou er na september 1960 nog een enkele keer over deze afdeling worden gesproken.

Afdeling 6.1.9: De verplichting tot schadevergoeding

Deze afdeling werd pas op het laatste moment (na november 1960) uit afdeling 6.1.8 gelicht. Er bestaan geen notulen van.

238. Bedoeld is: een derde concept voor de drukproef. 


\section{Afdeling 6.1.10: Tenietgaan van verbintenissen}

In januari 1957 was deze afdeling sinds 1955 al een keer of vijftien aan de orde geweest. Toch had men sindsdien alleen het concept van Meijers besproken en was er een concept van Fokkema over compensatie (ar. 6.1.10.4 - 6.1.10.18). De Jong nam de eerste drie artikelen voor zijn rekening. September 1957 lag er een eerste drukproef. In augustus 1958 besteedde het Driemanschap drie vergaderingen aan het bespreken van het advies van Departement. Ook nu verzuimde men, waarschijnlijk door tijdgebrek, de Staatscommissie advies te vragen. Juli 1959: De Jong en Fokkema bereiden een tweede, sterk gewijzigde drukproef voor. September 1960 wordt nog steeds gewacht op nota's van Fokkema. Besloten wordt dat De Grooth en Fokkema het werk zullen afmaken. Deze afdeling zou, als eén van de weinige, daarna nog zevenmaal in het Driemanschap aan de orde worden gesteld.

\section{Titel 6.2: Overgang van vorderingen en schulden}

$\mathrm{Na}$ zes besprekingen werd in oktober 1955 besloten dat deze afdeling, mede gezien de samenhang met de andere afdelingen, geheel moest worden herzien door Drion. In januari 1957 zou Franken regelmatig hulp gaan bieden. Uiteindelijk zou het werk vrijwel geheel op hem neerkomen. September 1957 was Frankens tekst gereed voor schriftelijke of mondelijke becommentariëring door het Driemanschap. Maart 1958 was er nog niets aan gebeurd in verband met Drions werk aan Boek 2. Pas in de 185 e en 190e vergadering (juli/september 1958) werd een aantal bepalingen doorgenomen.

Ondanks de afspraak met Samkalden verschijnt in 1959 geen eerste drukproef. In Juli 1959 wordt vermeld dat De Jong en De Grooth schriftelijk enige opmerkingen hebben ingediend, op basis waarvan Drion en Franken een nieuw concept hebben opgesteld, dat nu naar het Departement zal worden gestuurd. Op dat moment is dan nog niet eerder een tekst met complete toelichting in bespreking geweest. Wel worden vanaf half oktober 1959 enkele onderdelen besproken. Maart 1960: Er is nog veel aan te doen. September 1960 is een tweede, sterk herziene drukproef verschenen; De titel blijkt nog steeds niet in zijn geheel in het Driemanschap te zijn geweest. In november 1960 besteedt bet Driemanschap vier vergaderingen aan deze ingewikkelde materie. Het uiteindelijk resultaat van deze als moeilijk leesbaar gekwalificeerde titel werd nooit aan het voltallige Driemanschap voorgelegd.

\section{Titel 6.3: Onrechtmatige Daad}

De concepten van Meijers voor deze titel werden op 6 februari 1956 - er waren toen tweeëntwintig vergaderingen aan besteed - voor het laatst besproken. Drion belastte zich met de omwerking. In november 1958 diende hij een eerste, zeer voorlopig concept voor de tekst in, waarop De Grooth en De Jong enkele aantekeningen inzonden. Daarna werd het volkomen stil rond deze titel.

\section{Titel 6.4: Zaakwaarneming, Onverschuldigde Betaling en Ongerechtvaardigde Verrijking}

Het concept van Meijers voor de Zakwaameming (6.4.1) was in juli 1956 in drie bijeenkomsten met rapporteur Bregstein doorgesproken. De bewerking daarvan werd uitgesteld in verband met de besprekingen van Meijers' tekst voor de Onverschuldigde Betaling (6.4.2) en de Ongerechtvaardigde Verrijking (6.4.3), waarvoor men acht bijeenkomsten nodig zou hebben. September 1957 lag er een tweede concept (tekst en toelichting) van Fischer-Keuls en Eggens voor 6.4.1 en werd een eerste concept van Fischer-Keuls en Drion voor de afdelingen 2 en 3 "binnenkort" verwacht. Maart 1958 wordt deze mededeling herhaald. Afdeling 6.4.1 kwam medio Juli 1959 gereed, de andere twee waren intussen naar aanleiding van de opmerkingen van het Departement ingrijpend omgewerkt - het Driemanschap besteedde maar liefst zes vergaderingen aan het bespreken van de drukproeven - en moesten nog in het trio worden besproken. In september 1960 was dat gebeurd en lag er een derde drukproef. Merkwaardig genoeg werd toen besloten de opzet van afdeling 6.4.1 vrij drastisch om te werken. Het resultaat daarvan (auteurs: Drion en Fischer) hebben de andere leden van het Driemanschap pas kunnen beoordelen na de publicatie van het groene Boek 6.

\section{Afdeling 6.5.1: Algemene bepalingen}

Januari 1957 waren de concepten van Meijers nog niet besproken. Wel had Eggens omstreeks november 1956 een nieuwe tekst gemaakt, waarop de Driemannen schriftelijk hadden gereageerd. Vijf maanden en drie besprekingen later zijn de concepten en nota's besproken. Eggens en Fokkema zullen deze afdeling op zich nemen. September 1957 ligt er een eerste concept tekst en toelichting van Eggens, die wacht op commentaar van Drion. Maart 1958 zijn de besprekingen over artikel 6.5.1.4 met betrekking tot de gemengde contracten (concept-Fokkema) nog in volle gang. Juli 1959 zijn de eerste drukproef, de nota van het Departement en de tweede drukproef door het Driemanschap besproken. September 1960 bereidt De Grooth een derde, vrijwel definitieve drukproef voor. Een moeilijk punt waren toen nog de gemengde contracten en de do-ut-des verhoudingen, die in de $272 \mathrm{e}$ vergadering $(2-11-1960)$ van het Driemanschap nogmaals aan de orde zouden worden gesteld. De uiteindelijke vormgeving werd in handen van De Grooth, Fokkema en De Jong gelegd. 


\section{Afdeling 6.5.2: Het tot stand komen van overeenkomsten}

In januari 1957 is over de nagelaten concepten van Meijers door het Driemanschap schriftelijk van gedachten gewisseld. De Jong bereidt inmiddels een nieuwe tekst en toelichting voor. In maart 1957 is De Jong met dit werk gereed en liggen de concepten klaar voor besprekingen binnen het Driemanschap. Zes maanden later hebben Drion, Fokkema en Eggens schriftelijk commentaar geleverd. In maart 1958 zijn er twee besprekingen in het Driemanschap, die in september worden voortgezet (zes maal). De eerste drukproef-Samkalden verschijnt in december 1958, de Departementale nota in het voorjaar van 1959. Kennelijk is er nogal wat kritiek, want het Driemanschap zal daarna aan de hand van diverse opeenvolgende drukproeven nog vijftien besprekingen wijden aan deze titel. De vierde drukproef (september 1960) was volgens Franken "nagenoeg definitief". Fokkema en De Grooth zorgen voor de afronding.

\section{Afdeling 6.5.3: Rechtsgevolgen van overeenkomsten}

Omstreeks januari 1957 was er nog niet diepgaand naar de concepten van Meijers gekeken. Vijf maanden later was er één artikel van het concept van Meijers besproken, naar aanleiding van een nota van Fokkema over het derdenbeding. Eggens en Fokkema zouden spoedig een nota over de rest van deze afdeling laten verschijnen. Van oktober 1957 tot februari 1958 hield het Driemanschap zich in tien vergaderingen bezig met besprekingen over het gehele concept-Fokkema. Omdat men over het kettingbeding een enquête onder het notariaat wenste te houden, viel in maart 1958 nog niet te voorspellen wanneer de eerste drukproef zou verschijnen. Half december zou het concept voor afdeling 6.5.3 als gevolg van de inspanningen van Samkalden naar de drukker gaan. In juli 1959 zijn deze drukproef en de nota van het Departement daarover uitgebreid (vijf maal) besproken. Volgens Franken moet er "tamelijk veel (..) worden gewijzigd." Het overzicht van 22 september 1960 heeft niets nieuws te melden. De afdeling werd "afgewerkt" door Drion en Fokkema. De beschikbaarheid van de tekst van titel 6.3, die pas midden 1961 gereed zou komen, was daarvoor een voorwaarde.

\section{Afdeling 6.5.4: Wederkerige overeenkomsten}

De veertien beprekingen van Meijers' concepten van april tot juli 1956 leidden ertoe dat Fokkema en Eggens op zich namen een nieuwe concept-tekst op te stellen. Deze tekst, die ingrijpend zou verschillen van die van Meijers, verscheen in november 1956. De bespreking daarvan werd echter al na zes bijeenkomsten afgebroken, "daar de wenselijkheid bleek nader de samenhang met enkele bijzondere contracten, zoals Koop en Huur, te bestuderen." In juli 1959 was men - ondanks veertien nieuwe gespreksronde's - nog geen stap verder, in verband met de ontwikkelingen rond de Benelux-Koop en de besprekingen met Nypels, Dorhout Mees en Van der Feltz. In September 1960 en tien besprekingen later, lag er eindelijk een gewijzigd concept van Fokkema voor de tekst en een eerste concept voor de toelichting. Het Departement had toen nog niet gereageerd. De op 23 november 1960 vastgestelde werkwijze vermeldt uitdrukkelijk dat deze afdeling in vergadering zal moeten worden besproken aan de hand van de opmerkingen van het Departement. Niettemin is deze titel na september 1960 nooit meer in het Driemanschap is geweest. 


\section{Bijlage III Vergelijking concept-Meijers - Ontwerp Meijers}

Hoewel het onbegonnen werk is ook maar bij benadering aan te geven op welke punten het Driemanschap is afgeweken van Meijers' werk - er is, naar een woord van Houwing, zo vreselijk in gewroet dat Meijers onherkenbaar is geworden - wordt hieronder een globaal, beperkt en zeker niet als volledig bedoeld overzicht gegeven van de belangrijkste verschillen.

\section{Afdeling 6.1.1: Verbintenissen in het algemeen}

Een eerste belangrijk verschil is dat artikel 1374 lid 2 B.W. in deze afdeling werd ondergebracht, waar het bij Meijers bij de nakoming was geregeld. Een tweede wijziging is dat de natuurlijke verbintenis, conform de beslissing van de Hoge Raad in De Visser-Harms (HR 30 november 1945, NJ 1946, 62), wordt omschreven als een dringende verplichting uit "moraal en fatsoen". Meijers vond dat niet aanbevelenswaardig, omdat fatsoensregels in zijn visie geen onderdeel uitmaakten van het recht, althans niet leidden tot een meerdere bepaaldheid. ${ }^{239}$ In plaats daarvan sprak hij over "redelijkheid en billijkheid."

Artikel 1269 nieuw - de bronnen van de verbintenis - bleef inhoudelijk ongewijzigd. Wel was de motivering die het Driemanschap daarbij gaf een enigszins andere. De opmerking in de toelichting, 'dat inmiddels wel zou zijn gebleken in welke opzichten de wettelijke regeling tekortschoot', was niet de opvatting van Meijers, die de discussie over een gesloten, halfopen of open systeem van verbintenissen plaatste in het kader van het algemene vraagstuk van de verhouding tussen wet en rechter. Omdat hij de instelling van een permanente herzieningscommissie overwoog, werd de voorstanders van een open systeem hun belangrijkste argument uit handen geslagen.

\section{Afdeling 6.1.2: Hoofdelijke verbintenissen}

Bij Meijers telde deze afdeling, afgeleid van de artikelen 1314-1339 B.W., nog zeventien artikelen. Drion en Franken maakten er zeven artikelen van, onder meer doordat zij de regeling van de veelheid van schuldeisers in een afzonderlijke afdeling (6.1.3) onderbrachten. De hoofdlijnen van Meijers' opzet werd door hen overigens vrijwel overgenomen. De hoofdelijkheid en ondeelbaarheid waren bij Meijers ook al in één afdeling verenigd, en alle vroegere onderscheidingen tussen soorten van ondeelbaarheid vervallen. Ook het beginsel dat hoofdelijke schuldenaren door de tekortkomingen van een medeschuldenaar niet in een ongunstiger positie behoren te komen, kwam in Meijers' concept voor. De regel bijvoorbeeld, dat bij schade door meerdere personen tezamen veroorzaakt, ieder van hun voor de gehele schade aansprakelijk wordt, was door hem reeds gecodificeerd. Hetzelfde gold met betrekking tot de regel dat stuiting alleen gevolg heeft tegenover de schuldenaar, een afwijking ten opzichte van artikel 2020 B.W., alsmede ten aanzien van de schrapping van artikel 1322 B.W., waaruit wel werd afgeleid dat een aanmaning, gericht tegen één van de schuldenaren, werking had tegen allen. Tenslotte was ook in het concept van Meijers de regel te vinden dat iedere wijze van tenietgaan van de verbintenis alle hoofdelijke schuldenaren ten aanzien van de schuldeiser bevrijdt.

Andere wegen werden door het Driemanschap ingeslagen op het punt van de persoonlijke verweermiddelen (art. 1323 B.W.), de afstand, schuldvernieuwing en het onderling regres, vooral in de toelichting.

\section{Afdeling 6.1.3: Pluraliteit van schuldeisers}

Pas in september 1961 besloot het Driemanschap tot formulering van deze bepalingen. Ook in Meijers' ontwerp voor afdeling 6.1.2 was reeds gebroken met het delingsbeginsel van artikel $1355 \mathrm{~B}$.W. voorzover de vordering behoort tot een gemeenschap. Artikel 2, geschreven voor het zeldzame geval dat er tussen hoofdelijke schuldeisers geen gemeenschap bestaat, kwam in Meijers' concept niet in deze vorm voor.

\section{Afdeling 6.1.4: alternatieve verbintenissen}

Meijers verminderde de zes artikelen van het B.W. (1308-1313) tot een vijftal. Eggens kwam na lang nadenken op vier uit. Door de artikelen zo te redigeren dat zij ook toepasselijk zijn indien de verbintenis in iets anders dan het leveren van een zaak bestaat of op meer dan twee prestaties betrekking heeft, werd de verwijzingsregel van artikel 1313 B.W. overbodig. Andere technische verbeteringen die Eggens aanbracht waren het schrappen van de "derde prestatie" uit artikel 1308 B.W., en het weglaten van de term "uitdrukkelijk" in artikel 1309 B.W. Artikel 1309 B.W. bepaalde namelijk dat de keuze welke verbintenis zal worden nagekomen aan de schuldenaar behoort, "indien dezelve niet uitdrukkelijk aan de schuldeiser is toegestaan." Eggens schreef daaromtrent: "De eis dat dit toestaan "uitdrukkelijk" moet zijn geschied, is in het ontwerp weggelaten; naar huidige rechtsopvatting moet het voldoende zijn dat uitleg van het geheel der feiten welke de rechtsbetrekking

239. E.M. Meijers, De algemene begrippen van het burgerlijk recht, Leiden 1948, p. 8. e.v. 
van partijen bepalen - speciaal van de kennelijke strekking van het alternatief gesteld zijn der verbintenis -, de schuldeiser als de tot keuze gerechtigde aanwijst."

De regel van artikel 2, dat een altematieve verbintenis enkelvoudig wordt door het uitbrengen van een keuze door de daartoe bevoegde, ontbrak in Meijers' concept. De regeling van de overgang van keuzebevoegdheid (art. 3) werd redactioneel verder vereenvoudigd, evenals de regeling van de onmogelijke prestatie (art. 4).

\section{Afdeling 6.1.5: Voorwaardelijke verbintenissen}

Ook de regeling van de voorwaardelijke verbintenissen werd slechts op details aangepast. Door rechtstreeks te verwijzen kon Eggens herhaling vermijden en nog eens twee artikelen weglaten, zodat de winst ten opzichte van het B.W. uiteindelijk tien artikelen zou bedragen. Bij Meijers omvatte deze afdeling bovendien de vier artikelen over verbintenissen onder tijossepaling (B.W. 1304-1307), door Eggens verplaatst naar artikel 6.1.6.9 en 10. Inhoudelijk bleven de veranderingen beperkt tot het schrappen van de artikelen 1290 en 1291 B.W. (onzedelijke of verboden voorwaarden) in verband met de regeling van titel 3.2 en het weglaten van een bijzonder voorschrift betreffende de gevolgen van een in een leveringsovereenkomst opgenomen ontbindende voorwaarde. De regeling van artikel 3 lid 2 is een uitbreiding die Eggens aanbracht, doordat het artikel niet alleen een regeling geeft terzake van het beletten van de vervulling van de voorwaarde door schuldenaar of schuldeiser, maar ook het teweegbrengen daarvan door één van de bij de vervulling belanghebbende partijen.

\section{Afdeling 6.1.6: Nakoming van verbintenissen}

De nakoming van verbintenissen, in het B.W. van 1838 geregeld bij het tenietgaan (1417-1492), werd door Meijers in zevenentwintig artikelen verwoord. De Jong verplaatste artikel 1374 B.W. naar afdeling 6.1.1, bracht de mora creditoris in een aparte afdeling onder (Meijers vond dat niet doelmatig en had én en ander per titel uitgewerkt), verplaatste de bepalingen over consignatie naar afdeling 6.1.7, schrapte om niet geheel opgehelderde redenen de bepalingen over de betaling van een geldsom, en nam in deze titel de regels met betrekking tot de verbintenissen onder tijdsbepaling op, door Meijers in afdeling 6.1 .5 geprojecteerd. Tensiotte werd deze afdeling uitgebreid met een algemene regeling van opschortingsrechten (art. 19 en 20).

Een belangrijke vernieuwing die het Driemanschap aanbracht was artikel 6.1.7.3, dat de schuldenaar de bevoegdheid geeft in geval van schuldeisersverzuim een vordering in te stellen, ertoe strekkend dat de rechter hem van zijn verplichtingen zal ontslaan. Daardoor kon de regeling van het gerechtelijk aanbod, gevolgd door consignatie, worden vervangen door een veel eenvoudiger regeling van de gevolgen van inbewaringstelling (art. 9-13). Een voorschrift dat bij twijfel wie schuldeiser is, de schuldenaar de bevoegdheid geeft tot gerechtelijke inbewaringstelling totdat duidelijk is wie schuldeiser is, werd door het Driemanschap geschrapt.

\section{Afdeling 6.1.7: Verzuim van de schuldenaar}

Het verzuim van de schuldeiser werd door Meijers niet in een afzonderlijke afdeling geregeld. Zijn ontwerp kende, afgezien van het hierboven bij afdeling 6.1.6 opgemerkte, uitsluitend het aan artikel 1271 ontleende voorschrift dat de zorgplicht van de schuldenaar gedurende het verzuim van de schuldeiser vermindert (an. 7).

\section{Afdeling 6.1.8: De gevolgen van het niet nakomen van een verbintenis}

De eenvoudige, beknopte en traditionele opzet van deze afdeling (tekortkoming, verzuim, ingebrekstelling. bijzondere gevolgen van het verzuim) werd door het Driemanschap geheel omgegooid en aanzienlijk gecompliceerd (van zes naar elf artikelen). Een tweede verschil was, dat in Meijers' concept de bevoegdheid tot omzetting (en ontbinding) aan het verzuim was gerelateerd, terwijl het Driemanschap daarvoor nog een afzonderlijk vereiste stelde (art. 11). In de derde plaats werden de door Meijers opgestelde regels met betrekking tot de wettelijke verplichting tot schadevergoeding door het Driemanschap ondergebracht in een nieuwe afdeling 6.1.9. Meijers had in plaats daarvan volstaan met een verwijzingsbepaling. De door Meijers beraamde aansprakelijkheid voor zaken werd geschrapt; in het G.O. zou zij weerkeren.

Nieuw was de regeling van artikel 6.1.8.5, met daarin uitzonderingen op het vereiste van opeisbaarheid.

\section{Afdeling 6.1.9: De verplichting tot schadevergoeding}

Nieuw in deze afdeling waren de bepaling dat de rechter de schade mag schatten (art. 3) en de voordeelstoerekening (art. 5). Het Driemanschap schrapte een bepaling betreffende reèle executie, de Bovag-clausule en de dwangsom. De door Meijers vormgegeven algemene matigingsbevoegdheid werd teruggebracht tot het geval dat de schuldenaar in een noodtoestand zou komen te verkeren. Het artikel over letselschade (art. 11) werd uitgebreid tot het futiele geval dat iemand het oogmerk heeft een ander ideële schade toe te brengen. In de regeling van overlijdensschade werd de mogelijkheid geschrapt om volledige schadevergoeding te vorderen zo de aansprakelijke opzet of grove schuld kon worden verweten. Deze regel zou leiden tot "onredelijke consequenties", bijvoorbeeld dat de minderjarige en dus onderhoudsgerechtigde kinderen van het slachtoffer wel vergoeding wegens vermindering van de erfenis zouden kunnen vorderen als gevolg van het ontijdig 
verscheiden, maar hun oudere broers en zusters niet. Daarnaast werd de kring van onderhoudsgerechtigden uitgebreid tot bloed- en aanverwanten, niet zijnde de langstlevende of de kinderen, indien de overledene hen reeds voor het ongeval levensonderhoud verschafte. In geen van beide ontwerpen was een regel opgenomen betreffende vergoeding van schade die het gevolg is van aan anderen toegebracht letsel.

\section{Afdeling 6.1.10: Tenietgaan van verbintenissen}

De drieënveertig artikelen van het B.W. inzake het tenietgaan van verbintenissen (1449-1481) werden door Meijers in tien artikelen samengevat. Fokkema maakte er negentien van. Niettemin zou het Driemanschap de uitgangspunten van Meijers grotendeels trouw blijven. De opruiming van de objectieve schuldvernieuwing, het schrappen van artikel 1457 B.W. (oude voorrechten en hypotheken), het benadrukken van het tweezijdige karakter van de afstand, het scherp onderscheiden tussen afstand en kwijtschelding en de soepele regeling van de aanvaarding bij kwijtschelding kwamen alle reeds in Meijers' concept voor. Het Driemanschap schrapte slechts Meijers' equivalent van artikel 1475 B.W., "omdat aan een wettelijke regel over de gevolgen van het teruggeven van een schuldbekentenis geen behoefte bestaat en omdat het artikel, welke uitlegging men daaraan ook geeft, niet tot een bevredigend resultaat leidt."

Ten aanzien van de regeling van de verrekening is nog heel weinig van het B.W. en Meijers' werk over. Illustratief daarvoor is dat Meijers de verrekening in vijf bepalingen samenvatte, terwijl Fokkema er daarvoor zestien nodig had. Niettemin is de opzet van Meijers, namelijk dat de verrekening geschiedt door verklaring en niet van rechtswege, behouden gebleven. Wijzigingen die het Driemanschap aanbracht betroffen de artikelen 5 , $6,9,10,11,13,16,17$ en 19. De in eerste vijf artikelen geregelde onderwerpen kwamen in het B.W. niet voor en zijn in belangrijke mate op het BGB geinnspireerd. De artikelen 13,16 en 17 werden door het Driemanschap ontleend aan het B.W., artikel 19 was een doorontwikkeling van een verwante bepaling in Meijers' concept. Ook werd de liquiditeitiseis van artikel 1463 B.W. en het vereiste dat beide schulden opeisbaar zijn, geschrapt.

\section{Titel 6.2: Overgang van vorderingen en schulden}

De regels met betrekking tot de overgang van vorderingen en schulden waren door Meijers in zeven artikelen samengevat. Drion en Franken maakten er veertien van. De materie van de artikelen 2 (afgifte bewijsstukken), 3 (instaan vorige schuldeiser) en 5 (vervalsing) kwamen niet in Meijers' concept voor. Wel kwam daarin reeds de gedachte voor dat ingeval van hoofdelijk schuldenaarschap de subrogatie van de schuldenaar wel, die van de derde niet door interne verhoudingen wordt bepaald. De schuldoverneming werd aanzienlijk gecompliceerd; Het G.O. zou tot de gedachte van Meijers terugkeren door te onderscheiden tussen de bevoegdheid tot schuldoverneming en de werking daarvan ten opzichte van de schuldeiser.

\section{Titel 6.3: Onrechtmatige daad}

Nieuw in deze titel waren de bij G.O. overigens weer geschrapte uitlegregel betreffende overtreden wetsbepalingen (art. 2), de regel ten aanzien van schade die het gevolg is van twee of meer gebeurtenissen (art. 3), de groepsactic (art. 5), de aansprakelijkheid voor ondergeschikten ten aanzien van buiten de hun opgedragen taak vallende onrechtmatige daden (art. 9), de aansprakelijkheid voor zelfstandige opdrachtnemers (art. 10), de produktenaansprakelijkheid (art. 13) en de limitering van aansprakelijkheid (art. 17).

Meijers' codificatie van het arrest Lindenbaum/Cohen bleef ongewijzigd - materieel gezien. Alleen werd in het derde lid van artikel 1 de reeds ver voorgeschreden objectivering van het schuldvereiste verankerd, hetgeen tot menig misverstand aanleiding zou geven. Gehandhaafd bleef ook het relativiteitsbeginsel van artikel 2 lid 1. waarmee Meijers terugkwam op zijn opvatting dat een en ander reeds besloten zou zijn in de elementen schuld, onrechtmatigheid en causaal verband. Tenslotte werden de billijkheidsaansprakelijkheid van kinderen en andere ontoerekeningsvatbaren overgenomen (art. 6), alsmede de regeling van de aansprakelijkheid voor motorrijtuigen (art. 14) en de mogelijkheid van matiging (art. 17 lid 1).

Geschrapt werd een artikel betreffende de onrechtmatige overheidsdaad, waarin werd bepaald dat de overheid evenals een privaat persoon op grond van onrechtmatige daden tot schadevergoeding is gehouden, een gedachte die in 1953 nog niet algemeen was aanvaard, maar in 1961 wel. Ook verdween de tweede afdeling (bijzondere onrechtmatige daden), waarin door Meijers regels waren gegeven over misleidende reclame (vergelijk art. 1416a-d B.W.) en belediging. Tenslotte verviel een regel waarin iemand te wiens behoeve een in nood verrichte daad werd verricht, verplicht werd een aan de benadeelde een naar billijkheid te bepalen vergoeding te geven. Deze regel, die Meijers had ontleend aan het BGB, kon naar de mening van het Driemanschap vervallen in verband met de regeling van de ongerechtvaardigde verrijking.

Gewijzigd werden de artikelen 4 (hoofdelijkheid), 7 (aansprakelijkheid voor kinderen), 11 (aansprakelijkheid voor dieren), 12 (aansprakelijkheid voor opstallen), 15 (gebrekkige zaken) en 16 (gevaarlijke stoffen). De door Meijers beraamde risico-aansprakelijkheid van ouders voor kinderen tot zes jaar werd vervangen door een schuldaanprakelijkheid met onkering van de bewijslast, welke regeling Meijers uitsluitend voor kinderen boven 
de zes jaar wilde laten gelden. Met betrekking tot de aansprakelijkheid voor dieren daarentegen introduceerde Drion een risico-aansprakelijkheid voor de degene die het dier onderhoudt, waar Meijers - tegen zijn eigen opvatting in (zie zijn noot onder HR 15 oktober 1915, W9937 (1916)) - niet verder wilde gaan dan een schuldaansprakelijkheid met omkering van de bewijslast voor de eigenaar van het dier. De werkingsfeer van artikel 1405 B.W. werd door het Driemanschap nog verder uitgebouwd, doordat aansprakelijkheid ook kon bestaan buiten het geval van een gehele of gedeeltelijke instorting. Het concept van Meijers kende buiten dit geval geen afzonderlijke aansprakelijkheid voor de gebruiker van een gebrekkige zaak, tenzij het een gebrek in een als gevaarlijk bekend staande zaak betrof. In dat geval was de gebruiker ook buiten schuld aansprakelijk. Kon het gebrek niet worden aangegetoond, dan kon de gebruiker zich van aansprakelijkheid vrijpleiten door het bewijs van zijn onschuld. In het Driemanschapsontwerp was zowel de gebruiker van een gebrekkige zaak als de bezitter van een gevaarlijke stof aansprakelijk buiten schuld.

\section{Afdeling 6.4.1: Zaakwaarneming}

In Meijers' concept werd het begrip zaakwaarneming als volgt omschreven: "Zaakwaarnemer is hij, die zich vrijwillig en opzettelijk met de behartiging van eens anders belangen heeft ingelaten." Het Driemanschap schrapte het vereiste van "vrijwilligheid" in verband met artikel $450 \mathrm{Sr}$. (niet helpen van in levensgevaar verkerende), omdat het "immers mogelijk is, dat er wel een rechtsplicht tot handelen voor de handelende bestaat (..) zonder dat echter deze plicht voortvloeit uit een tussen partijen bestaande, elders in de wet geregelde rechtsverhouding." Meijers was aan dit bezwaar, dat ook in de subcommissie Burgerlijk Recht was geopperd, voorbijgegaan, omdat deze kwestie onder het geldende recht nooit tot problemen aanleiding had gegeven. ${ }^{240}$

Een tweede verschil is, dat de Driemannen het beginsel, dat de zaakwaameming op redelijke grond moet zijn aangegaan, in de definitie van zaakwaarneming opnamen. Het gevolg hiervan is, dat de belanghebbende in die gevallen waarin de zaakwaarneming zonder noodzaak geschiedde en er evenmin sprake is van verrijking, zijn schade alleen kan opvorderen door middel van aansprakelijkheid uit onrechtmatige daad.

Met betrekking tot de plichten van de zaakwaamemer hield Meijers vast aan de materiële inhoud van het B.W. en bepaalde hij dat de zaakwaamemer verplicht is een begonnen zaakwaarneming met de nodige zorg voor te zetten en te voltooien. Het Driemanschap dacht daar kennelijk anders over: Artikel 2 lid 1 verplicht de waamemer bij de waameming de nodige zorg te betrachten en, voor zover dit redelijkerwijze van hem kan worden verlangd, de begonnen waarneming voort te zetten. ${ }^{241}$

Artikel 3, dat de verplichtingen van de belanghebbende omschrijft, bleef inhoudelijk ongewijzigd. Zowel de verruiming van het recht op schadeloosstelling tot de vergoeding van de geleden schade, als de beperking van het recht op schadevergoeding tot het geval dat de waarneming op redelijke grond geschiedde, stammen uit de koker van Meijers. Wel zou in de vertaling daarvan door het Driemanschap een aantal foutjes sluipen. ${ }^{242}$

Vernieuwingen die het Driemanschap introduceerde waren de regeling van de vertegenwoordiging (ar. 4) en de goedkeuring (art. 5). Meijers' codificatie van H.R. 10 december 1948, N.J. 1949, 122, inzake het retentierecht van de zaakwaarnemer, werd door het Driemanschap niet overgenomen. Het feit dat het ontwerp voor afdeling 6.1.7 van de hand van De Jong was, terwijl afdeling 6.4.1 aan Fischer was toevertrouwd, lijkt de ontwerpers parten te hebben gespeeld. ${ }^{243}$

\section{Afdeling 6.4.2: Onverschuldigde betaling}

De regel van artikel 1395 lid 1 B.W., - er is pas dan sprake van een onverschuldigd betalen als je presteert in de veronderstelling dat je daartoe verplicht bent - werd door het Driemanschap niet overgenomen.

Een tweede verschil tussen het concept-Meijers en het ontwerp van het Driemanschap is dat in plaats van een "onverschuldigd" ontvangen goed, gesproken wordt van een "zonder rechtsgrond" gegeven goed. Dit

240. Vergelijk ook H.C. Cohen Jehoram, WPNR 5015 (1968), die spreekt over "dit in onze literatuur rondspokende rijk academische geval."

241. Intussen lijkt het niet uitgesloten dat beide teksten tot hetzelfde resultaat leiden. Meijers rekent er als het ware op dat de rechter verstandig genoeg zal zijn om het artikel toe te passen in de geest waarin het werd geschreven, het Driemanschap heeft die door elke rechter te verrichten afweging als het ware meegecodificeerd.

242. Terwijl in de toelichting wordt opgemerkt dat alleen die schade voor vergoeding in aanmerking komt, die de zaakwaarnemer tengevolge van de waarneming heeft geleden, wordt in de tekst een ander en vooral ruimer criterium gehanteerd: "De belanghebbende is (..) gehouden de door de zaakwaarnemer geleden schade te vergoeden."

243. Vergelijk in dit verband de toelichting bij artikel 5.2.7 O.M., Parl. Gesch. Boek 5, p. 94. 
laatste heeft een ruimere strekking dan de term onverschuldigd, want in deze woorden valt niet meer te lezen dan dat zonder rechtsgrond moet zijn betaald.

Artikel 2, bedoeld ter verdere omlijning van de gevallen waarin een prestatie wel of niet als onverschuldigd kan worden teruggevorderd, kwam in Meijers concept niet voor. In het Gewijzigd Ontwerp zou dit artikel, dat min of meer een uitvloeisel was van de in afdeling 6.1.5 gegeven regel, dat een voorwaardelijke verbintenis een verbintenis is, waarvan de werking afhankelijk is gesteld van een voorwaarde, komen te vervallen.

De artikelen 3, 4, 5 en 7, betreffende de rechten en de verplichtingen van de ontvanger, werden door het Driemanschap alieen redactioneel aangepast. Artikel 6 , dat de ontvanger van een onverschuldigde betaling recht geeft op vergoeding van andere nadelen, dan de kosten aan de betaling verbonden, kwam in Meijers' concept niet voor. Volgens Meijers werd hiermee het terrein van de ongerechtvaardigde verrijking betreden, iets wat het Driemanschap in een nootje eigenlijk ook wel toegeeft. ${ }^{24}$

De regel met betrekking tot de onzedelijke overeenkomsten (art. 9) ontbrak in Meijers' concept. Meijers vond het niet nodig deze kwestie te regelen, zoals blijkt uit de notulen van de Staatscommissie bij artikel 3 concept-Meijers: "De heer Drion vraagt of het de bedoeling is dat deze regel (t.w. dat de bezitter te kwader trouw tot ongedaanmaking verplicht is) ook zal gelden als beide partijen te kwader trouw waren. De voorzitter antwoordt bevestigend. Zou men het anders regelen, dan zou men komen tot de regel nemo auditu. Die heefi echter bij ons nimmer gegolden en leidt tot onaannemelijke consequenties. ${ }^{245}$

\section{Afdeling 6.4.3: Ongerechtvaardigde verrijking}

Een eerste verschil tussen het concept-Meijers en het ontwerp-Meijers is dat de voorwaarde dat de verrijking "zonder voldoende rechtsgrond", is geschied, werd vervangen door de term "ongerechtvaardigd." Intussen lijkt dit verschil vooral van academische aard. Indien wordt vastgesteld dat een verrijking, die het gevolg is van een onverschuldigde betaling "zonder rechtsgrond" is, dan is een verrijking, die op andere wijze is ontstaan, inderdaad niet zonder rechtsgrond (dus: zonder voldoende rechtsgrond) maar wel in strijd met het recht (dus: ongerechtvaardigd).

Een tweede verschil is, dat in het Driemanschapsontwerp de toelaatbaarheid van de vordering uit ongerechtvaardigde verrijking wordt getoetst aan de clausule "voor zover dit redelijk is". Hierdoor wordt aan de rechter de bevoegdheid gegeven alle omstandigheden in aanmerking te nemen en in verband daarmee een vordering tot schadevergoeding geheel of gedeeltelijk af te wijzen. De vraag is echter, of de vordering uit ongerechtvaardigde verrijking niet allereerst strekt tot teruggave in natura, een gedachte die ten grondslag lag aan een door het Driemanschap niet overgenomen tweede lid van Meijers' concept. Die regel bood de rechter de mogelijkheid het goed te restitueren tegen de wil van de verarmde.

Een derde verschil is, dat het Driemanschap het subsidiariteitsvereiste heeft laten vallen. Het feit dat ook op een andere grond kan worden gereageerd, staat niet aan een vordering uit artikel 6.4.3.1 in de weg. Niettemin wordt in de toelichting opgemerkt, dat van geval tot geval moet worden nagegaan of de voor een bepaalde situatie geschreven regel exclusieve werking heeft.

\section{Afdeling 6.5.1: Algemene Bepalingen}

Deze afdeling werd door Fokkema voltooid. Nieuw ten opzichte van Meijers' concept zijn de correcties "voor zover de strekking van de betrokken bepalingen zich in verband met de aard van de overeenkomst daartegen verzet" in artikel 1 lid 2 en artikel 4 lid 2 . In artikel 1 werd daarmee een voorbehoud gemaakt voor het geval dat er sprake is van een meerpartijencontract, in artikel 4 werd aldus een correctie aangebracht op de regel dat bij een gemengde overeenkomst de voor elk van die soorten gegeven bepalingen naast elkaar op de overeenkomst van toepassing zijn. Meijers bepaalde in plaats daarvan dat bij strijd tussen de diverse soorten bepalingen het meest op de voorgrond tredende contract de rechtsverhouding domineert.

Arikel 3, betreffende de (snelle) gebondenheid aan algemene voorwaarden, kwam in Meijers' concept niet voor, evenmin als de mogelijkheid tot vernietiging indien de wederpartij wist of moest begrijpen dat de ander, als hij het beding had gekend, de overeenkomst niet zou hebben gesloten. Wel bevatte Meijers' concept een veel verdergaande bepaling, inhoudende dat aan de tot formulier of algemene voorwaarden toetredende partij bedingen van min of meer vitale betekenis niet tegengeworpen kunnen worden. Deze bedingen waren slechts geldig, indien zij door de wederpartij "met bijzondere vermelding" schriftelijk waren goedgekeurd. Daarbij werd met name gedacht aan bepalingen tot beperking van de wettelijke aansprakelijkheid; tot toekenning van de

244. Parl. Gesch. Boek 6, p. 814: "In de wetboeken waarin de aanspraak uit onverschuldigde betaling een vorm is van de aanspraak uit ongerechtvaardigde verrijking, kunnen kosten en uitgaven welke de ontvanger i.v.m. het ontvangen van de betaling heeft gemaakt, ten laste van de betaler komen ten gevolge van de beperking van diens aanspraak tot de verrijking van de ontvanger."

245. Notulen van de 120 e vergadering van de subcommissie Burgerlijk Recht van 28 april 1951. 
bevoegdheid om de overeenkomst eenzijdig op te zeggen of haar uitvoering op te schorten; concurrentiebedingen; afstand van door de wet toegekende rechten of verweermiddelen. Een regeling derhalve, die wel wat weg had van de bij de invoeringswet Boek 6 gevolgde methode van "zwarte" en "grijze" lijsten. Daarnaast kende het concept van Meijers de regel dat bij strijdigheid tussen algemene voorwaarden enerzijds en de bijzondere bepalingen van de overeenkomst of daaraan toegevoegde geschreven voorwaarden anderzijds, de laatste als overeengekomen gelden.

\section{Afdeling 6.5.2: Het tot stand komen van overeenkomsten}

Met uitzondering van de dwaling, die ingrijpend werd omgewerkt, bleef het werk van Meijers op hoofdpunten bewaard. De opvatting, dat een aanbod in beginsel herroepelijk is zolang de overeenkomst niet is tot stand gekomen, was van Meijers, evenals de daarop aangebrachte correctie, dat het ogenblik van verzending beslissend is wanneer schriftelijk wordt aanvaard (art. 2). Met Meijers verwierp het Driemanschap de opvatting dat een schriftelijk aanbod onbeperkt geldt (art. 4), en nam men de regel over dat de dood van een aanbieder een aanbod niet doet vervallen (art. 5). Ook handhaafde het Driemanschap de in artikel 7 geformuleerde correctie op de ontvangsttheorie, de aan het Scandinavische recht ontsproten regel betreffende een te late aanvaarding (art. 8), de voorovereenkomst (art. 9) en het schrappen van de geoorloofde oorzaak als geldigheidsvereiste voor de overeenkomst (art. 10).

In het ontwerp van het Driemanschap keerde niet de regel terug dat hij, die een ander uitnodigt tot het doen van een aanbod of zelf ongevraagd aan een ander een aanbod doet, bij het afbreken van de onderhandelingen verplicht is aan die ander, voor zover de billijkheid dit eist, de kosten te vergoeden die deze tengevolge van de uitnodiging of het aanbod heeft gemaakt. Ook verdween een bepaling, inhoudende dat een reeds bij het sluiten van de overeenkomst bestaande onmogelijkheid van uitvoering, deze overeenkomst nietig maakt, tenzij deze onmogelijkheid wel aan de schuldenaar maar niet aan de schuldeiser bekend was of behoorde te zijn. Met betrekking tot het garantiebeding bepaalde Meijers dat dit slechts nietig is wanneer de schuldeiser bij het maken van het beding wist, dat de schuldenaar onmogelijk zijn woord gestand kon doen. Tenslotte verdween de regel dat een schriftelijk gedane aanvaarding kan worden herroepen, mits de herroeping de aanbieder voor de aanvaarding bereikt. Deze regel sprak voor zichzelf, nu het ontwerp de ontvangsttheorie had aanvaard.

Andere correcties die het Driemanschap aanbracht waren de regel dat bij herroeping van een uitloving onder bepaalde omstandigheden een billijke schadeloosstelling dient te worden toegekend (art. 3 lid 2); de regel dat een aanbod vervalt door verwerping (art. 4 lid 2); en de problematiek van de voorbouwende overeenkomst, overigens in een zeer algemeen en weinig omlijnde regel neergelegd (artikel 12). De door Meijers gegeven regeling van de dwaling was grotendeels in overeenstemming met de leer van de Hoge Raad, waarin dwaling werd omschreven als een onjuiste bij één der partijen bij het sluiten van de overeenkomst bestaande veronderstelling, die hij uitdrukkelijk of stilzwijgend als wezenlijk bestanddeel van de overeenkomst heeft beschouwd, terwijl de andere partij dit wist of althans behoorde te weten. In aanvulling daarop gaf Meijers een bijzondere regeling voor het geval de dwaling te wijten was aan een onjuiste inlichting of het verzwijgen van bijzonderheden, die hem behoorden te zijn medegedeeld. In dit geval werd de eis van een wezenlijk bestanddeel niet gesteld, terwijl de wederpartij evenmin wist of behoorde te weten dat de omstandigheid voor de dwalende beslissend was. Het Driemanschap (het dwalingsartikel is voomamelijk het werk van De Grooth geweest) versmalde de toepassing van de eerste regel door daarenboven de eis te stellen dat de wederpartij begrepen moest hebben dat de ander dwaalde (11 a lid 1 sub a), terwijl zij de situatie waarin spreken plicht is, schrapte. In het Gewijzigd Ontwerp werd de eerste wijziging als een verbetering beschouwd, maar zou ten aanzien van het laatste punt worden teruggegrepen op de opvattingen van Meijers.

\section{Afdeling 6.5.3: Rechtsgevolgen van overeenkomsten}

Deze afdeling bestond bij Meijers uit zes artikelen, bij Fokkema uit twaalf. De artikelen 6 (derdenbeding zonder gevolg), 7 (nakoming) 10 (redelijkheid en billijkheid) en 12 (kettingbeding) zijn volledig nieuw. Beide eerste artikelen lijken de vrucht van rechtsvergelijking te zijn, artikel 10 is een doorontwikkeling van arikel 6.1.1.2, terwijl het laatste artikel geheel van de hand van het Driemanschap is, hetgeen daaruit blijkt dat elke verwijzing naar literatuur of jurisprudentie ontbreekt.

Met betrekking tot de vraag of de goede trouw en de billijkheid het tussen partijen overeengekomene opzij kunnen zetten, hield het Driemanschap vast aan het standpunt van Meijers door de de billijkheid niet boven maar naast het tussen partijen bepaalde te plaatsen. Ook de regeling van de overgang van rechten en verplichtingen onder algemene titel (art. 2) waarin, anders dan in het B.W., een voorbehoud werd gemaakt voor het geval de overeenkomst een persoonlijk karakter draagt. was van Meijers. Ook Meijers' voorstel met betrekking to de kwalitatieve rechten en verplichtingen werd door het Driemanschap overgenomen (art. 3-4), zij het dat de uitwerking door hen veel nauwkeuriger en ook uitgebreider was. De regel van artikel $1353 \mathrm{~B}$.W., dat een derdenbeding slechts geldig is indien het is toegevoegd aan een beding, dat de contractant voor zichzelf heeft gemaakt, was door Meijers reeds opgeruimd. In overeenstemming met het spraakgebruik definieerde hij 
het derdenbeding als een beding waarbij aan een derde het recht om nakoming van een verplichting te vorderen wordt gegeven. Ook werd door hem het derdenbeding reeds aangemerkt als een tot die derde gedaan aanbod, dat herroepen kan worden zolang de derde het nog niet heeft aangenomen (vergelijk art. 5 lid 1 en 2).

Met betrekking tot de regeling van de onvoorziene omstandigheden hanteerde het Driemanschap als criterium dat de wederpartij "naar maatstaven van redelijkheid en billijkheid ongewijzigde instandhouding van de overeenkomst niet mag verwachten". Meijers schreef daar: "Wanneer tengevolge van een niet voorzienbare omstandigheid de nakoming van een verbintenis uit overeenkomst voor een partij uitermate bezwaarlijk wordt kan de rechter indien hij dit redelijk oordeelt op vordering van die partij de overeenkomst wijzigen of ontbinden." Volgens het Driemanschap zou die formule slechts passend zijn "voor de aan overmacht grenzende categorie van gevallen, waarin de nakoming van een verbintenis uit de overeenkomst, zonder bepaald onmogelijk te worden, toch wel uitermate bezwaarlijk wordt." Naar hun mening - geïnspireerd door de Duitse doctrine - zou de bepaling ook moeten kunnen worden toegepast wanneer de waardeverhouding tussen de wederzijds prestaties ernstig is verstoord, of wanneer presteren geen zin meer heeft.

\section{Afdeling 6.5.4: Wederkerige overeenkomsten}

Deze afdeling tenslotte, telde bij Meijers elf artikelen, in het Ontwerp-Meijers maar liefst tweeëntwintig. Meijers' werk is daardoor praktisch onherkenbaar, met name vanaf artikel 10. Eén voorbeeld. De exceptio non adempleti contractus werd door Meijers in één artikel geregeld, terwijl Fokkema er drie nodig zou hebben. Ook de verfijnde clausules 'tenzij in strijd met de redelijkheid en billijkheid" kwamen in Meijers' werk niet voor.

Niettemin zijn de vele belangrijke verbeteringen die deze afdeling in zich borg voor een groot deel geïnspireerd door Meijers. Genoemd werd reeds de toelaatbaarheid van de exceptio non adempleti contractus. Andere voorbeelden zijn het vervallen van de verplichte rechterlijke tussenkomst bij ontbinding, het breken met de terugwerkende kracht van de ontbinding, de ontbinding ook in geval van overmacht, de mogelijkheid van gedeeltelijke ontbinding en de uitvoerige regeling van de gevolgen van de ontbinding. 
Hoofdstuk 5

DRION EN VAN EWIJK (1961-1964)

\section{Organisatie van het werk}

Als gevolg van de impasse waarin het werk aan Boek 6 O.M. na het overlijden van Meijers was terecht gekomen, was het werk aan de andere delen van het Ontwerp eveneens gestagneerd. Niet alleen was medio 1955 het werk aan de concepten voor de Boeken 7-9 O.M. stil komen te liggen, maar bovendien had ook de parlementaire behandeling van de reeds gepubliceerde delen ernstige vertraging opgelopen. Het Voorlopig Verslag over Boek 3 lag al sinds 1958 bij het Departement, dat over Boek 4 sinds 1959 en het Voorlopig Verslag over Boek 5, het laatste boek dat bij de Tweede Kamer was ingediend, werd op 25 oktober 1961 vastgesteld, ruim vóórdat het voorontwerp voor Boek 6 zou verschijnen. De achterstand van het Departement op de Kamer bedroeg medio 1961 daarom tenminste een jaar of twee, drie.

Om te voorkomen dat de Tweede Kamer langere tijd zonder werk zou komen te zitten en iedere belangstelling voor het nieuwe B.W. zou verliezen, was het zaak alle aandacht te concentreren op de parlementaire behandeling van de reeds ingediende boeken, waaraan Drion in zijn hoedanigheid van Regeringscommissaris leiding zou moeten geven. Om dezelfde reden was het evenzeer gewenst dat het Regeringsontwerp voor Boek 6 op een zo kort mogelijke termijn zou kunnen verschijnen en dat zo mogelijk een begin werd gemaakt met een vervroegde invoering van Boek 1 . Er moest gehandeld worden naar de omstandigheden, overwegingen met betrekking tot haalbaarheid en wenselijkheid waren nauwelijks in tel.

Een en ander leidde ertoe, dat de organisatie van het werk aan het nieuwe B.W. eind 1961 geheel anders werd opgezet. In de eerste plaats betekende dit dat met de aanbieding van het voorontwerp voor het nieuwe verbintenissenrecht een einde kwam aan het Driemanschap. Begrijpelijkerwijs voelde geen van de partijen er veel voor op dezelfde voet door te gaan. ${ }^{1}$ Bovendien had de ervaring met de totstandkoming van Boek 6 O.M. uitgewezen, dat het voor Drion niet mogelijk was zijn werk als ontwerper te combineren met dat van Regeringscommissaris. Het werk aan de nog onvoltooide gedeelten van Meijers' ontwerp (Boeken 7 en 8) werd daarom aan anderen uitbesteed, zij het dat ex-Drieman De Jong in beginsel de eindcoördinatie van Boek 7 (Bijzondere overeenkomsten) voor zijn rekening zou nemen. In de tweede plaats betekende dit dat Minister Beerman de tekst van het voorontwerp voor Boek 6 tot grondslag maakte van het interdepartementaal overleg, evenals Donker indertijd bij de eerste vijf Boeken had gedaan. Daarmee gaf de Minister te kennen dat het Regeringsontwerp in beginsel weinig zou afwijken van het voorontwerp, ofschoon dit, anders dan de ontwerpen van Meijers, verre van definitief was. ${ }^{2}$

1. Zie ook hieronder, Hoofdstuk 8.

2. De betrokken Ministeries dienden uiterlijk voor 1 september 1962 commentaar te leveren. Uit het begeleidend schrijven van Minister Beerman (brief van 7 maart 1962): "Evenals is geschied na de publicatie van het eerste deel van het Ontwerp-Meijers (..) en van het tweede deel daarvan (Boek 5), 
Beide maatregelen maakten dat Drion zijn handen vrij kreeg voor het beantwoorden van het Voorlopig Verslag over Boek 4, dat al ruim twee jaar op een antwoord wachtte. Direct daarna zou de invoeringswet van Boek 1 kunnen worden voorbereid. Boek 3 werd voorlopig terzijde gelegd in verband met de samenhang tussen Boek 4 en Boek 1. Het zou namelijk weinig elegant zijn de verbetering van de familierechtelijke positie van de onwettige kinderen wél in te voeren en hun erfrechtelijke positie voorlopig bij het oude te laten. Voorts zou het niet doenlijk zijn de lex hac edictali uit Boek 1 te schrappen en in het erfrecht te handhaven. Tenslotte was de samenhang tussen de schrapping van het "voordeel" van de langstlevende echtgenoot uit Boek 1 en zijn erfrechtelijke positie te nauw, dan dat men Boek 1 zonder wijziging van het erfrecht zou kunnen invoeren.

\section{Het Voorlopig Verslag over Boek 4}

Het Regeringsontwerp voor Boek 4 was op 4 november 1954 aan de Tweede Kamer aangeboden. Minister Donker was van het door Meijers opgestelde ontwerp slechts op een aantal detailpunten afgeweken. De Memorie van Toelichting telde enkele bladzijden.

De literatuur die daarna verscheen, was eveneens zeer tevreden, op een geruchtmakend artikel van Pitlo na. ${ }^{3}$ Petit beëindigde zijn pre-advies over het nieuwe erfrecht met de volgende woorden: "Zo moge ik besluiten met posthume hulde en dank (..) aan hem, die ons in het kort vóór zijn dood verschenen deel van zijn ontwerp een zo bewonderenswaardig erfrecht heeft nagelaten. ${ }^{44}$ Van der Ploeg, toen reeds op weg de woordvoerder van het notariaat te worden, toonde aan dat het ontwerp, ondanks zijn compacte formulering, een waar meesterwerk was. ${ }^{5}$ Ook de vaste Commissie voor Justitie van de Tweede Kamer "was getroffen door de wijze, waarop de ontwerper (..) systematische veranderingen in, ten opzichte van het vigerende erfrecht, een-

2. $\rightarrow$

moge ik u verzoeken mij uw opmerkingen over het voorontwerp voor Boek 6 te doen toekomen opdat ik hiermede rekening kan houden bij het opstellen van het Regeringsontwerp voor Boek 6, dat ook thans weer grotendeels gelijkluidend zal zijn aan het voorontwerp-Meijers." Vergelijk ook zitting Tweede Kamer 1961-1962, nr 6500, stuk nr 10, p. 2-3. Beerman sprak daar overigens tegen dat het R.O. Boek 6 weinig zou afwijken van het door het Driemanschap opgestelde ontwerp.

3. A. Pitlo, Het Erfrecht in het Ontwerp-Meijers, Rechtsgeleerd Magazijn Themis 1954, p. 463 e.v. Pitlo betoogde onder andere dat Meijers de grenzen van zijn opdracht had overschreden door op vele plaatsen zonder noodzaak buiten het vertrouwde kader te treden. Een furieuze Van der Ploeg reageerde in WPNR 4397 (1955) en betichtte Pitlo van schromelijke overdrijving en achterhoedegevechten. Van der Ploeg: "Het was een smerig artikel, nonsensicaal. Het zou een 'schok geven door het gehele erfrecht' dat de legitieme van de grootouders zou worden afgeschaft. Pitlo had ook kritiek op de taal van het ontwerp, zonder ook maar één spoor van bewijs aan te voeren. Ik ben toen boos geworden en heb de redactie van het WPNR geschreven 'Nu of nooit'." Ook bij de vaste Commissie (zitting Tweede Kamer 1959-1960, nr 3771, stuk nr 4, p. 1) zou Pitlo geen voet aan de grond krijgen: "Anders dan deze auteur was de commissie van oordeel, dat deze vernieuwingen over het algemeen een grondslag hebben in levende rechtsopvattingen en goed aansluiten bij de antwoorden op de aan de Kamer voorgelegde vraagpunten."

4. Ch.J.J.M. Petit, Annalen van het Thijmgenootschap, Aflevering III, 1954.

5. Vergelijk P.W. van der Ploeg, De legitieme portie, WPNR 4351 (1954); Het erfrecht in het Ontwerp-Meijers, WPNR 4399 (1955); De prae-adviezen over het nieuwe erfrecht, WPNR 4403 (1955). 
voudiger vormen had weten te gieten. ${ }^{6}$ De tweeëntwintig tekortkomingen en leemten die het erfrecht opeiste in Meijers' uit 1928 daterende opsomming van de gebreken van het Burgerlijk Wetboek ${ }^{7}$ waren inderdaad alle gerepareerd. Zijn meesterschap manifesteerde zich in het bijzonder door de beknoptheid waarmee hij de erfopvolging bij versterf had geregeld; zes artikelen tegen tweeënveertig voor het B.W. Het Ontwerp-Meijers omvatte in totaal 132 artikelen; de bestaande wet 257.

Het Voorlopig Verslag werd in twee delen uitgebracht. Op 8 juli 1959 bracht de vaste Commissie verslag uit over de titels 1 en 2 , groot tien bladzijden. Op 1 december 1959 volgde het tweede deel, dertien pagina's, over de rest van Boek 4, te weten de titels 3,4 en 5 . Uit het verslag bleek dat de Commissie over het algemeen bijzonder ingenomen was met het ontwerp. Zo sprak zij haar instemming uit met de verdere verzwakking van het familie-erfrecht ten gunste van het gezinserfrecht, zoals die tot uiting kwam in de versterking van de positie van de langstlevende echtgenoot, het parentele stelsel met afschaffing van de kloving, het niet terugkeren van het "droit de retour", het onthouden van een legitieme portie aan de grootouders en de beperking van het versterferfrecht tot de zesde graad.

Op de redactie van de afzonderlijke artikelen werd slechts spaarzaam kritiek geleverd. Wel plaatste de vaste Commissie enige vraagtekens bij de positie van de van tafel en bed gescheiden echtgenoot, de positie van het natuurlijke kind en de vererving van bedrijven. ${ }^{8}$ Daarnaast was een belangrijk deel van het verslag gewijd aan de erfrechtelijke positie van de langstlevende echtgenoot. In de eerste plaats was enige twijfel gerezen omtrent de juistheid van de gelijkstelling van de echtgenoot met de kinderen, waarmee het ontwerp overigens vasthield aan de in 1923 in de wet neergelegde regeling en uitvoering gaf aan de beslissing op het $37 \mathrm{e}$ vraagpunt. ${ }^{9}$ Een aantal leden wilde het erfdeel van de langstlevende op een vaste breuk stellen, bijvoorbeeld een kwart, zodat de grootte van het erfdeel niet langer omgekeerd evenredig zou zijn aan het aantal kinderen. Daarbij werd herinnerd aan de scherpe kritiek die Meijers indertijd op deze regeling had uitgeoefend: hij noemde haar "bijkans een straf op de vruchtbaarheid. "10

Het tweede belangrijke punt dat door de vaste Commissie ter sprake werd gebracht betrof de door Van Oven ${ }^{11}$ opgeworpen vraag of de echtgenoot geen verzorgingsaan-

6. Zitting Tweede Kamer 1959-1960, nr 3771, stuk nr 4, p. 1.

7. E.M. Meijers, Het feillooze deel van ons Burgerlijk Wetboek, WPNR 3031 (1928).

8. Door deze vragen in het Voorlopig Verslag op te nemen, roerde de Commissie overigens kwesties aan waarover in het kader van de vraagpuntenprocedure reeds een beslissing was gevallen. Zie met name de discussie n.a.v. het 37 e en 38 e vraagpunt.

9. De conclusie op vraagpunt 37 luidde (voor zover van belang): "Het is niet gewenst aan de echtgenoot een ander erfdeel bij versterf toe te kennen dan een kindsdeel."

10. E.M. Meijers, Het wetsontwerp tot wijziging der erfopvolging, WPNR 2616 (1920). In plaats daarvan bepleitte Meijers fixatie van het erfdeel van de echtgenoot op een vaste breuk, gecombineerd met een hem toekomend "voordeel". Vergelijk ook E.M. Meijers, Het erfrecht-ontwerp, WPNR 2776 (1923): "Ik blijf het betreuren (..) dat het aandeel bij de versterfopvolging op een kindsgedeelte gesteld is. Men kan het kindsdeel moeilijk hiermede verdedigen, dat het datgene is, wat de echtgenoten zelf meestal wensen (..); het meest gebruikelijk is de algehele erfstelling." Zie ook P.W. van der Ploeg in WPNR 4295 (1953).

11. J.C. van Oven, Moet aan de langstlevende echtgenoot een legitieme portie worden toegekend?, WPNR 4560/1 (1958) en $4598 / 9$ (1959). Reeds eerder, in het kader van de vraagpuntenprocedure, 
spraak zou moeten worden toegekend in plaats van een legitieme. Van Oven had er daarbij op gewezen dat de legitieme in veel gevallen ontoereikend is om aan de verzorgingsbehoefte te voldoen en dat het ontwerp derhalve botste met de algemeen aanvaarde stelling dat de positie van de echtgenoot een andere is dan die van de kinderen. ${ }^{12}$ Daarnaast had het verzorgingsrecht zijns inziens het voordeel dat het facultatief is, dus alleen geldend gemaakt kan worden voor zover de langstlevende voor zijn onderhoud is aangewezen op de nalatenschap. Bovendien zou daardoor worden voorkomen dat het deel van het vermogen dat niet nodig is voor verzorging, bij hertrouwen in een andere familie overgaat. Van Oven zei daarover: "Zeker kan het voorkomen, dat men 't wel gewenst acht, dat kinderen vermogen van hun stiefmoeder via hun vader verwerven, maar niet goed is het, dat de wet daartoe dwingt. De stiefmoeder moet daarom de hertrouwde echtgenoot kunnen onterven - evenals de eerste vrouw het haar man moet kunnen doen - om te voorkomen, dat haar goederen na diens dood te beurt vallen aan personen die haar niet aangaan. ${ }^{13}$

Hoewel de leden van de vaste Commissie niet ongevoelig bleken voor deze argumenten, bleef men in meerderheid echter vóór toekenning van een wettelijk erfdeel aan de echtgenoot, zoals neergelegd in het ontwerp en overeenkomstig de conclusie op het 38e vraagpunt. Men meende namelijk dat het stelsel van Van Oven tot tal van processen aanleiding zou kunnen geven, als gevolg van de onzekerheid over de hoogte van de verzorgingsaanspraak. "Het mag niet zo zijn", aldus deze leden, "dat de langstlevende echtgenoot in een positie kan komen te staan, waarbij hij de keuze heeft tussen afhankelijkheid van de kinderen of het voeren van een proces tegen hen." Wel werd door enige leden een voorbehoud gemaakt voor het geval het mogelijk zou zijn in de wet een procedure neer te leggen, waardoor in het overgrote deel van de gevallen de grootte van de verzorgingsaanspraak objectief zou kunnen worden vastgesteld, zonder dat processen behoeven te worden gevoerd. Naar hun mening zou wellicht ook een oplossing kunnen worden gevonden door legitieme en verzorgingsaanspraak met elkaar te combineren.

Van Rijckevorsel herinnert zich: "Wij vonden als Kamer de regeling van het groene Boek en van het Regeringsontwerp met een legitieme portie voor de langstle-

\section{1. $\rightarrow$}

had Van der Ploeg als zijn mening uitgesproken dat de testeervrijheid slechts haar grenzen in de verzorgingsplicht jegens de nabestaanden vindt. Zie WPNR 4295 (1953); WPNR 4351 (1954).

12. Eerder had Meijers in WPNR 2616 (1920) hetzelfde betoogd ten aanzien van het ontwerp-1920: "Het stelsel van het ontwerp wordt in de literatuur verdedigd met de opmerking, dat het niet aangaat in het erfrecht de echtgenoot een gunstiger positie dan het kind te geven. M.i. miskent men daarmede, dat in het erfrecht de echtgenoot een andere positie heeft dan een kind, een andere positie, die in sommige gevallen inderdaad tot een bevoordeling van de echtgenoot boven het afzonderlijke kind moet leiden." Aantekening verdient dat Meijers van oordeel was dat het inboedelvoordeel een belangrijke stap was ter versterking van de positie van de langstlevende. Meijers achtte het in elk geval "niet geraden de kinderen een beroep op de legitieme te onthouden. Hij zou het liever zoeken in een versterking van de positie van de langstlevende door middel van levensverzekering", zo blijkt uit de notulen van zijn bespreking met Minister van Maarseveen op 15 april 1947.

13. Volgens Van Oven was dit ook één van de redenen geweest die de wetgever in 1923 deed besluiten de echtgenoot geen legitieme te geven "omdat de legitieme leiden kan tot ongewenste overgang van vermogen van de ene familie in de andere, die vaak - denk aan kinderloze huwelijken afhangt van het toevallig 't eerste overlijden van man of vrouw." 
vende en het inboedelvoordeel ${ }^{14}$ heel aanvaardbaar, omdat deze rechten bij een klein vermogen toch wel de gehele boedel absorberen. Iedereen was het erover eens dat de langstlevende zoveel mogelijk in de toestand moest worden gelaten zoals voor het overlijden van de echtgenoot."

\section{Rapport I van de Commissie Erfrecht}

Aanvankelijk lag het in de bedoeling de Memorie van Antwoord en het Gewijzigd Ontwerp Boek 4 in de loop van 1960 in te dienen. Om dit voornemen kracht bij te zetten was op 21 januari 1960, kort nadat het laatste deel van het Verslag over Boek 4 was vastgesteld, op het Departement een werkverdeling gemaakt, erop gericht de Memorie van Antwoord eind maart 1960 te produceren. ${ }^{15}$

Die voorbereiding schoot al niet erg op, blijkens een mededeling van Van Ewijk, toen in maart 1960 de zogenaamde Commissie Erfrecht ${ }^{16}$ van de beide Broederschappen een boekwerk van honderd pagina's publiceerde, door Van Oven aangeduid als een "wijzigingsvoorstel over de gehele linie." ${ }^{17}$ Dat het notariaat pas in een zo laat stadium met een eigen standpunt naar buiten $\mathrm{kwam}^{18}$ werd vermoedelijk veroorzaakt doordat over de grote materiële vragen van het erfrecht reeds veel was gepubliceerd ter gelegenheid van de vraagpunten, en - wat de technische kant betreft Meijers al een voorontwerp van Boek 4 aan een commissie uit het notariaat ter becommentariëring had voorgelegd ${ }^{19}$. Dat de notarissen eind 1959 alsnog tot een rapport besloten, kwam waarschijnlijk doordat er bij sommige leden van de vaste Commissie een aarzeling bestond over de regeling die het ontwerp te zien gaf met betrekking tot de positie van de langstlevende echtgenoot. Daarnaast kan een rol hebben gespeeld dat ook binnen het notariaat de gedachten over het nieuwe erfrecht sinds 1954 niet stil waren blijven staan, althans na het overlijden van Meijers en Donker ruimte was ontstaan voor het oppakken van door het Ontwerp-Meijers afgesneden draden. ${ }^{20}$

14. Artikel 1.7.3.4 gaf de langstlevende echtgenoot bij eerste huwelijk het recht de eigendom van de tot de gemeenschap behorende en ten gebruike van de langstlevende strekkende kleren en kleinodiën en de daartoe behorende inboedel tot een waarde van $f 15.000,-$ zonder enige vergoeding of verrekening tot zich te nemen.

15. Mrs. Belinfante en Van Zeben zouden titel 4.2 (behalve het erfrecht van onwettige kinderen) en titel 4.3 (behalve afdeling 4.3.1, artikel 4.3.2.3 en de afdelingen 5 en 6) voor hun rekening nemen. De overige delen van Boek 4, alsmede de boven genoemde uitzonderingen, kwamen voor rekening van Van Ewijk en Van Zeben. Drion werd belast met de eindcoördinatie.

16. De samenstelling van de Commissie was als volgt: P.W. van der Ploeg (voorzitter); H.P.J.M. Coebergh; W.C. Treurniet; W. Heuff; G.L. Meuwissen en G. Meijling.

17. J.C. Van Oven, Het erfrecht in het nieuwe Burgerlijk Wetboek, NJB 1960, p. 300. Overigens moet hierbij worden bedacht dat kritiek op Meijers in die dagen nog vrij uitzonderlijk was.

18. Ten aanzien van Boek 3 was reeds vóor het verschijnen van het Voorlopig Verslag voor commissoriale opmerkingen gezorgd.

19. Zie hiervoor, Hoofdstuk 3.

20. Illustratief daarvoor is bijvoorbeeld dat Van der Ploeg, die zich in het kader van de vraagpuntenprocedure tevergeefs had uitgesproken tegen een legitieme van de langstlevende echtgenoot en daarom Pitlo in 1955 (WPNR 4397) nog toevoegde dat diens bezwaren tegen de regeling van het ontwerp "mosterd na de maaltijd" waren, in 1960 (Rapport I, p. 9 e.v.) niettemin opnieuw afschaf- 
Ofschoon het notariële rapport in slechts drie maanden tot stand was gebracht - het Departement zou immers in beginsel maar vier maanden uittrekken voor het beantwoorden van het Voorlopig Verslag - en maar drie van de zes commissieleden actief hadden meegewerkt ${ }^{21}$, was het rapport kwalitatief indrukwekkend en veel meer dan een doorlopend, kritisch commentaar op Meijers' ontwerp. De nadruk van het rapport lag vooral op voorlichting van notariaat en Kamer. Zo wordt in het rapport herhaaldelijk uitleg gegeven bij de door Meijers ontworpen bepalingen en treft men verhelderende voorbeelden aan bij al te beknopt uitgevallen passages. Daarbij was de Commissie kennelijk geen moeite teveel. Men keek bijvoorbeeld naar het oude en zeer oude (Romeinse) recht, ontrafelde de overeenkomsten en verschillen tussen het Burgerlijk Wetboek en de Code Civil, sloeg oude drukken van Asser-Meijers op en raadpleegde Meijers' rechtsvragenrubriek in het WPNR alsmede het eerste, ongepubliceerde ontwerp voor Boek 4. Daarnaast kan worden geconstateerd dat de Commissie zich op vele plaatsen akkoord verklaart met de door Meijers voorgestelde oplossingen of het ontwerp in bescherming neemt tegen ondoordachte aanvallen uit de literatuur. Van der Ploeg: "We vonden het echt een goed ontwerp, we stonden er positief tegenover. We keken ook wel heel erg tegen Meijers op. Er waren, naar ik meen, inhoudelijk alleen aarzelingen over de regeling van de vereffening."

Vanzelfsprekend ontbrak kritiek niet. Voor een deel was deze kritiek erop gericht "het ontwerp op allerlei punten meer naar de praktijk toe te buigen", volgens Heuff. De kritiek op de regeling van de vereffening, "die vele testateurs ervan zou kunnen weerhouden een overigens nuttige executeursbenoeming te doen ${ }^{\text {"22 }}$, is daarvan een voorbeeld. Voor een ander deel sprak de Commissie zich echter ook uit over meer politiek getinte kwesties, zoals het versterferfrecht van de langstlevende echtgenoot en de erfrechtelijke positie van het natuurlijke kind. Zo werd - het antwoord op het 38e vraagpunt ten spijt - met grote stelligheid opgemerkt dat de legitieme portie van de tafel en bed gescheiden echtgenoot een "onding" was, die "met het versterferfrecht van de van tafel en bed gescheiden echtgenoot in elk geval behoort te verdwijnen." ${ }^{23}$

Met betrekking tot het voorstel van de vaste Commissie om het erfdeel van de

20. $\rightarrow$

fing van de legitieme zou bepleiten. Rapport II (1963-1966) is op dit punt nog stelliger (p. 66): "Naar het oordeel van de Commissie is die vraag niet definitief beslist door de bevestigende beantwoording door de Tweede Kamer van het 38e vraagpunt. $\mathrm{Na}$ die uitspraak zijn de belangrijke artikelen van Van Oven verschenen, die menigeen tot een andere opvatting hebben gebracht. Tot die menigeen behoort de Voorzitter van de Commissie, die zich in zijn bespreking van het 38e vraagpunt in WPNR 4295 voor de legitieme van de echtgenoot uitsprak; ook daar het bekende argument: geeft men de kinderen een legitieme, zo zal men deze aan de echtgenoot niet kunnen onthouden. Doch ook ten aanzien van deze uitspraak wordt thans erkend, dat zij niet meer was dan een dooddoener."

21. Van der Ploeg zei daarover: "Het was een hele zwakke commissie. Coebergh was een erkend opleider, maar hij zei altijd: 'Die oude heren - daarmee bedoelde hij de generatie van Opzoomer en Diephuis - die waren nog niet zo gek.' Hij kwam nooit veel verder dan de kennis die hij als opleider had. Meuwissen was er nooit. Meijling was assistent van Pitlo - daar hadden we niks aan. Heuff was wel zeer actief. Treurniet wilde het graag eenvoudig houden." Heuff: "Van der Ploeg heeft in het eerste rapport een bijzonder groot aandeel gehad. Niet iedereen had de gelegenheid of wellicht ook de lust om te gaan schrijven. Van die zes mensen zijn er eigenlijk maar drie geweest, waaronder ikzelf, die de uiteindelijke redactie van het rapport voor hun rekening hebben genomen."

22. Rapport I, p. 91.

23. Rapport I, p. 9. 
langstlevende echtgenoot te vergroten van een kindsdeel tot een kwart of een derde, stelden de notarissen: "Een kwart is hier naar het oordeel van onze Commissie al even willekeurig als een derde. Wil men de kant uit van een vaste breuk, zo komt nog het meest in aanmerking de helft." ${ }^{24}$ Een meerderheid van de Commissie zou echter nog verder willen gaan. Volgens haar zou aan de kinderen hun legitieme tegen de langstlevende ouder moeten worden ontnomen, terwijl de echtgenoot bij versterf de gehele nalatenschap zou moeten worden toegekend: "Wat de notariële praktijk leert is, dat het merendeel van de testateurs wil: 'Langstlevende al'. "25

Ten aanzien van de legitieme nam de Commissie, in navolging van Van Oven, het standpunt in dat aan de langstlevende echtgenoot geen legitieme zou moeten worden toegekend, maar een verzorgingsrecht. Volgens haar zou het echter niet mogelijk zijn in de wet vaste, scherp omlijnde maatstaven aan te geven, zoals de vaste Commissie had gevraagd. Door nu echter aan de kinderen een beroep op de legitieme tegen de langstlevende ouder te onthouden zouden de problemen, verbonden aan de toekenning van deze aanspraak, in het merendeel van de gevallen verdwijnen. "Slechts bij hoge uitzondering", zo was de indruk van de Commissie, zal de langstlevende zijn onterfd of zullen de door de eerststervende echtgenoot getroffen beschikkingen aan de verzorging van de langstlevende echtgenoot tekort doen." Een regeling in de vorm van een periodieke uitkering, zoals door Van Oven voorgesteld, vond de Commissie niet aanbevelenswaardig: "Zij is een bron van conflicten. Een ware verzorging eist zekerheid, en zekerheid eist dat de nalatenschap geheel of ten dele wordt geblokkeerd. Uit maatschappelijk oogpunt een verwerpelijk middel." Een vruchtgebruik met interingsbevoegdheid, zoals voorgesteld in artikel 3.8.13, zou met eigendom gelijk staan en daarom velen te ver gaan. De slotsom van de Commissie was daarom dat een uitkering ineens misschien nog wel de beste oplossing zou zijn: "Dit alles maakt, dat voor de Commissie uit praktisch, maatschappelijk en familiaal oogpunt slechts aanvaardbaar is de uitkering van een som ineens." 26

\section{Naar een Gewijzigd Ontwerp}

Omdat er uit het rapport ook voor het Ministerie het nodige viel te leren, besloot Minister Beerman dat het gewenst was alle op- en aanmerkingen van de Commissie Erfrecht grondig te overwegen. Dat het tijdschema hierdoor opnieuw enige vertraging zou oplopen was niet anders. Van Ewijk schreef in dit verband aan de Minister: "Het is nu duidelijk èn excusabel dat de Memorie van Antwoord op zijn vroegst in juni 1960 kan verschijnen. Drion, Belinfante en ik zullen blij zijn als het lukt u vóór de zomer eerst een aantal nota's over materiële vragen en vervolgens een volledig concept-antwoord voor te leggen. Dit is zo duidelijk, dat men niet verontrust zal zijn dat aldus het tijdschema voor het nieuwe B.W. nog wat tegenvalt." ${ }^{27}$

\section{Rapport I, p. 9.}

25. Rapport I, p. 10. Het citaat vervolgt: "Het merendeel van de testateurs is nog niet het merendeel van de erflaters, doch naar het oordeel van de grootst mogelijke meerderheid der Commissie leeft in ons volk zeer sterk de overtuiging, dat de langstlevende "al" moet hebben."

26. Rapport I, p. 32.

27. Nota van 5 april 1960. 
Niettemin zou de Memorie van Antwoord, 150 bladzijden groot, met daarbij een ingrijpend gewijzigd ontwerp, pas op 1 november 1962 bij de Tweede Kamer worden ingediend. Twee factoren waren daaraan debet. In de eerste plaats vormde de steeds uitgestelde publicatie van Boek 6 O.M. een struikelblok van jewelste. Op het moment dat Van Ewijk zijn prognose deed, leefde men op het Ministerie namelijk nog in de verwachting dat Boek 6 O.M. in de loop van 1960 zou verschijnen. Het groene Boek 6 zou echter pas in oktober 1961 aan Minister Beerman worden aangeboden. In de tweede plaats achtten Drion en Van Ewijk, de voornaamste ontwerpers, een groot aantal wijzigingen ten opzichte van het oorspronkelijke ontwerp noodzakelijk en waren zij bij verschillende onderdelen sterk in details getreden.

Enkele cijfers. Het Gewijzigd Ontwerp telde 183 artikelen, bijna anderhalf maal zoveel als het groene Boek 4. Afdeling 4.3.3 (Legitieme portie) groeide van zestien artikelen met tweeënveertig leden naar zevenentwintig artikelen met eenenzestig leden. De bepalingen over executeurs (Afdeling 4.4.6) verdubbelden zelfs in aantal: van vijf artikelen met elf leden ging men naar elf artikelen met zevenentwintig leden. In wezen was, zoals later door de Eerste Kamer zou worden opgemerkt, voor "een niet onaanzienlijk deel sprake van een geheel nieuw ontwerp, ten opzichte waarvan het werk van Meijers niet meer dan als een voorstudie was te beschouwen. ${ }^{28}$ Grofweg de helft van de in de Memorie van Antwoord behandelde vragen stond los van het Voorlopig Verslag.

Van Oven, merkbaar aangeslagen, schreef begin 1963 dat het Gewijzigd Ontwerp qua ingewikkeldheid weinig onderdeed voor het voorontwerp voor Boek 6 . Hij voegde daaraan toe dat hij verheugd was, dat tijdens de jongste begrotingsbehandeling geen stem was opgegaan om het grote werk te stoppen. "Toen ik bijna een jaar geleden de eerste indruk onder woorden trachtte te brengen die het ontwerp voor het zesde Boek op mij maakte, gaf ik - ondanks mijn grote bewondering - uitdrukking aan de beduchtheid, dat hier zo zware kost werd geboden, dat juridisch Nederland deze niet zou kunnen verwerken. (..) Sindsdien verscheen de Memorie van Antwoord voor het vierde Boek, het erfrecht en deze maakte de beduchtheid vooral niet minder. ${ }^{\text {"29 }}$ Zijn slotzin luidde: "Laten wij ons liever niet verdiepen in de vraag, hoe lang het wel zal duren eer wij een nieuw B.W. rijk zijn. De toekomst kan nieuwe verrassingen brengen."

Dát het Gewijzigd Ontwerp voor Boek 4 zo sterk afweek van Meijers' werk kwam in de eerste plaats doordat Drion en Van Ewijk streefden naar een allesomvattende, uitputtende regeling. Van Rijckevorsel zei daarover:

"Ik heb onlangs het groene Boek van Meijers er nog eens bijgepakt, in het bijzonder de afdeling bewindvoering en executele. Daar zitten allerlei schoonheidsfoutjes in, maar het zou in de praktijk vermoedelijk redelijk hebben gewerkt. Drion zette echter in al die andere bepalingen ook het mes.

In de Napoleontische tijd meende men aanvankelijk dat een rechter het wetboek eenvoudig kon openslaan en zo alles kon oplossen. Dat was een primitieve

28. Zitting Eerste Kamer 1967-1968, nr 3771, stuk nr 73, p. 3.

29. J.C. van Oven, Het werk aan het nieuwe Burgerlijke Wetboek: de stand van zaken, NJB 1963. p. $5-9$. 
gedachte en daar ging het ontwerp van Van Ewijk en Drion ook veel te veel van uit. Er werd van alles en nog wat gecodificeerd, alle mogelijke gevallen werden geregeld. (..) Drion stoeide bijvoorbeeld met erfstellingen over de hand, iets dat heel weinig voorkomt."

Een tweede factor die de uitvoerigheid en de grote mate van gecompliceerdheid van Boek 4 G.O. kan verklaren, is dat Drion en Van Ewijk goed aan elkaar waren gewaagd. Kenmerkend voor de instelling van Drion is de uitspraak van zijn vrouw, dat hij net zolang aan een tekst schaafde totdat deze nog slechts voor één uitleg vatbaar was:

"Ik denk dat hij heel erg geboeid was door het zorvuldig formuleren van de teksten. Heel veel avonden hebben we bijvoorbeeld doorgepraat over een bepaald artikel van Boek 4. We waren uren achter elkaar bezig een casus te maken en te kijken wat de beste oplossing was en of de bepaling daarbij voldeed. Het kwam voor dat hij er dan aan ging sleutelen en we verder gingen met toetsen. Mijn man was ontzettend precies, enorm nauwgezet en hij spaarde tijd noch moeite om elke tekst of toelichting zo perfect mogelijk te krijgen."

Over Van Ewijk $(1905-1978)^{30}$ zei Van Zeben, tot 1963 diens assistent:

"De eerste dag dat ik op Justitie kwam, zei Polak tegen mij, 'Je moet er niet van schrikken dat in elk stuk dat je schrijft veranderingen worden aangebracht. Sommige zijn niet meer dan een verandering, alleen, als je stukken van Van Ewijk terugkrijgt, is het altijd een verbetering.' Dat was ook zo." ${ }^{31}$

Mr. M.W. Scheltema, die Van Ewijk vanaf 1966 zou bijstaan, geeft de volgende karakteristiek: "Van Ewijk had het systeem van het nieuwe B.W. heel goed in zijn hoofd en was tegelijkertijd iemand die toch ook wel precies wilde uitzoeken hoe de zaak in elkaar zat. En dat deed hij met een grote mate van vasthoudendheid. Hij gold wel heel duidelijk als een perfectionist. ${ }^{32}$ Volgens $\mathrm{H}$. Drion beheerste Van Ewijk

30. O.W. van Ewijk was in de jaren 1930 en 1931 werkzaam als advocaat en procureur te Makassar; en gedurende 1931 tot 1946 (onderbroken door de tijd van internering 1942-1945) in Semarang. Van 1946 tot 1949 was hij hoofdambtenaar op het Departement van Justitie van het toenmalige Batavia. In 1949 en 1950 was hij Hoofd van de Afdeling Juridische Zaken van het Hoge Commissoriaat van de Republiek Indonesië in Nederland. Op 1 januari 1951 trad Van Ewijk op uitnodiging van de secretaris-generaal, die iemand zocht voor het rechtsherstel, in dienst als raadadviseur bij het Ministerie van Justitie bij de Afdeling Wetgeving. De bedoeling van de "sollicitant" was echter zich te gaan bezighouden met de hercodificatie. (Ontleend aan Het Vaderland van 28 april 1967). In 1968 ontving Van Ewijk een eredoctoraat van de Leidse Universiteit voor zijn werk aan het nieuwe B.W.

31. Vergelijk ook C.J. van Zeben, Een korte terugblik, in: Liber Amicorum NBW, Arnhem 1991, p. 175: "Ik kreeg een Kamer in de gewelven van het Ministerie en had het voorrecht daar mijn huidige collega J.M. Polak aan te treffen. Vooral zijn mededeling dat nota's die 'naar boven gingen' altijd met kanttekeningen terug kwamen omdat dat nu eenmaal zo hoorde en dat ik mij dat vooral niet moest aantrekken, stelde mij gerust."

32. Scheltema vervolgt: "Ik denk dat dat ook wel een beetje samenhing met zijn ziekte - hij was zwaar reumatisch en daar leed hij al een buitengewoon lange tijd aan - waardoor hij zich met enorme 
"het bestaande en het komende recht zo volmaakt, in details èn in grote lijnen, dat het bijna beklemmend was. ${ }^{13}$

Tenslotte ontbrak het beiden aan de bereidheid tot samenwerking. Drion en Van Ewijk hadden wel waardering voor elkaar, maar zij gaven elkaar als gevolg van een soort van intellectuele bezetenheid in het debat niets cadeau, de één wilde voor de ander niet onderdoen. Al pratende werden zij zo opgedreven tot een steeds hoger abstractieniveau en werd de ene uitzondering op de andere gestapeld. Cohen Jehoram: "Er heerste op het Ministerie een soort broeikas-klimaat. Drion en Van Ewijk waren op dat moment wellicht de knapste civilisten van Nederland. Er ontsponnen zich dan ook discussies op het scherp van de snede waardoor je als notulist soms vertwijfeld naar je hoofd greep. Dat ging tot in de kleinste details." ${ }^{34}$ Van Rijckevorsel: "Van Ewijk was heel, heel erg vasthoudend, ook soms in dingen waarvan je dacht, is dat nu wel nodig, kan dat nu niet anders? Drion was ook vasthoudend, maar misschien toch nog iets gemakkelijker." Van der Ploeg vat samen: "Het waren geen mensen om in een gemeenschappelijke discussie samen iets op te zetten. Een cliënt van mij kende beide. Hij vertelde mij dat hij met Van Ewijk had gesproken en dat deze zich erover had beklaagd dat Drion zo moeilijk te overtuigen was: 'Een dag heb je met elkaar vergaderd, eindelijk ben je er, maar de volgende dag komt hij terug en begint opnieuw'. Even later ontmoet mijn cliënt Drion en die zegt hetzelfde over Van Ewijk!"

Valt Minister Beerman, onder wiens verantwoordelijkheid Memorie van Antwoord en Gewijzigd Ontwerp Boek van 4 werden opgesteld, ook nog iets te verwijten? Ik denk het wel. Een voortvarende behandeling van Boek 4 kon van beslissende betekenis zijn voor het welslagen van de hercodificatie. Details waren bijzaak. Bovendien was Boek 4 goed ontvangen en was het het stadium van voorontwerp al lang gepasseerd. Niemand zou het de Minister hebben kwalijk genomen indien alleen de opmerkingen van het Voorlopig Verslag waren beantwoord, aangevuld met een standpuntbepaling ten aanzien van de belangrijkste opmerkingen van de literatuur. In zoverre is Boek 4 G.O. dus mede het produkt van een gebrek aan ministeriële betrokkenheid.

Inhoudelijk bracht het Gewijzigd Ontwerp geen verandering ten aanzien van het erfdeel bij versterf van de langstlevende echtgenoot. De Minister wees erop dat het kindsdeel in overeenstemming was met de conclusie op vraagpunt 37 en met het in 1923 opgenomen artikel 899a B.W. Met betrekking tot het voorstel van Van der Ploeg c.s. om de langstlevende "al" te geven, deed de Memorie er het zwijgen toe. In

32. $\rightarrow$

wilskracht moest verzetten tegen inconveniënten die zijn ziekte met zich meebracht. Daar heeft hij toch bepaald veel last van gehad, waardoor hij zich tegelijkertijd met een grote verbetenheid met het wetboek bezighield. Hij leefde in heel sterke mate voor het nieuwe B.W. Dat hield hem in belangrijke mate op de been."

33. Het Vaderland, 17 september 1968.

34. Cohen Jehoram vervolgt: "Als ik bijvoorbeeld een tekst schreef of een nota voor de Tweede Kamer, dan kreeg je dat stuk van Van Ewijk terug, waarin zinnen waren verplaatst, komma's waren verwijderd, kortom, het zag zwart van de verbeteringen. Dat was een vorm van perfectionisme, die op zichzelf heel goed was, maar die perfectie ging tot in de tiende graad." 
een later stadium van de parlementaire behandeling zou Minister Samkalden erop wijzen dat het oordeel van de Commissie Erfrecht niet het laatste woord kon zijn ter bepaling van de rechtsovertuiging, en voorts, dat het voorstel blijkens een in 1960 gehouden enquête door een meerderheid van het notariaat was afgewezen. ${ }^{35}$

Met betrekking tot de legitieme van de langstlevende echtgenoot hadden Drion en Van Ewijk zich aangesloten bij de meerderheid van de vaste Commissie en de legitieme gehandhaafd, tegen de wens van de notarissen. ${ }^{36}$ Het argument was dat de echtgenoot, ongeacht diens behoefte aan verzorging, recht heeft op een deel van het vermogen van de erflater. Deze conclusie werd nog geschraagd met een verwijzing naar de toelichting op vraagpunt 38: "Voor het toekennen van een legitieme portie kan worden aangevoerd, dat wanneer men de echtgenoot in het erfrecht niet meer bij een kind achterstelt, deze gewijzigde opvatting ook in de toekenning van een legitieme portie tot uiting moet komen." Daarnaast echter introduceerde het Gewijzigd Ontwerp een verzorgingsaanspraak voor de langstlevende in de vorm van een som ineens, zoals bepleit door de notarissen (art. 4.3.4.1b). Deze aanspraak kon evenwel geen afbreuk doen aan de rechten van legitimarissen, ook niet indien zij kinderen zijn van de langstlevende. Met deze combinatie van legitieme en verzorgingsrecht, een mogelijkheid die in de literatuur tot dan toe niet was gesignaleerd, volgde het Gewijzigd Ontwerp de middenweg, die ook in het Voorlopig Verslag was geopperd. Elke nadere motivering ontbrak echter. Later zei Minister Samkalden daarover: "In het Gewijzigd Ontwerp vervulde de legitieme van de langstlevende de functie van "bodem" in het verzorgingsrecht. Hierdoor zouden processen over de hoogte van de onbepaalde verzorgingsaanspraak althans tot de hoogte van de legitieme worden afgesneden."

Tenslotte werd in het Gewijzigd Ontwerp de mogelijkheid geopend dat de ene echtgenoot aan de andere echtgenoot zijn nalatenschap vermaakt zonder dat hun kinderen zich daartegen kunnen verzetten wegens inbreuk op hun legitieme. Anders dan door de Commissie Erfrecht was bepleit, gold daarbij wel de eis dat een dergelijk "langstlevende al" noodzakelijk was voor de verzorging van de langstlevende (art. 4.3.3.12a lid 2).

35. De resultaten van deze enquête, die werd gehouden naar aanleiding van het verschijnen van Rapport I, zijn gepubliceerd in WPNR 4630 (1960). Door $471 / 2 \%$ van de Candidaat-Notarissen werd het inzicht van de Commissie gedeeld. Bij de Notarissen lag dit cijfer op $51 \%$.

36. Blijkens de in 1960 gehouden enquête (zie WPNR 4630) sprak $69 \%$ van de deelnemende notarissen en $88 \%$ van de deelnemende kandidaat-notarissen zich uit voor een onaantastbaar verzorgingsrecht. 


\section{Voortgang Boeken 1, 3 en 6}

Omdat de Tweede Kamer er in het najaar van 1962 begrijpelijkerwijs niet veel voor voelde het Mondeling Overleg over het loodzware Boek 4 te beginnen ${ }^{37} 38$ - een rol speelde daarbij ook dat de verkiezingen in aantocht waren ${ }^{39}$ - en het ook juister werd geoordeeld dat de notariële wereld in de gelegenheid zou worden gesteld zich een oordeel over het ontwerp te vormen, kon Drion, met steun van het Departement, eindelijk beginnen aan het werk aan de Invoeringswet voor Boek 1 en de Memorie van Antwoord over Boek 3. Dat Minister Beerman tot vervroegde invoering van Boek 1 had besloten, was geen signaal dat Justitie de moed had verloren het grote werk tot een goed einde te brengen. ${ }^{40}$ De invoering van Boek 1 was vooral bedoeld om de Kamer tegemoet te komen in haar verlangen dat er nu eindelijk eens een tastbaar resultaat kon worden geboekt ${ }^{41}$ en omdat de papieren codificatie, die met de vaststelling van Boek 2 in 1958 een voorlopig einde had gevonden, dreigde te verouderen.

Ook nam Minister Beerman in de herfst van 1962 het besluit het voorontwerp voor Boek 6, zonder daarin enige wijziging te brengen, in de vorm van een wetsontwerp te laten drukken en bij de Ministerraad in te dienen. De opmerkingen van de andere

37. Zie daarover in het bijzonder Meulink (handelingen Tweede Kamer 1962-1963, p. 2075): "Het zal de Minister verheugen, zo lezen we in de Memorie van Antwoord, wanneer de Kamer in de loop van dit zittingsjaar de tijd zal vinden voor een openbare behandeling. Ik ben ervan overtuigd, dat de vreugde van de Kamer niet minder groot zou zijn. (..) Het zal nu toch wel nodig zijn, dat na de vele wijzigingen gelegenheid gegeven wordt, dat er vanuit de juridische wereld nog reacties komen. Voorts hebben Kamerleden, vooral in de begrotingstijd, toch beslist enige tijd nodig, dit omvangrijke werk te bestuderen. Daarna zal wel een Mondeling Overleg met de Minister nodig blijken, gevolgd door weer een aantal wijzigingen. En dan komt zo langzamerhand de publieke behandeling van de Kamer in zicht. Naar mijn idee is tegen die tijd het vraagstuk van de vorming van een nieuw Kabinet wel actueel geworden."

38. Oud-Minister Samkalden had Beerman reeds voor deze voor het tijdschema nadelige ontwikkeling gewaarschuwd (handelingen Eerste Kamer 1960-1961, p. 2184): "Het moet bijvoorbeeld niet zo zijn, dat als gevolg van de indiening van de Memorie van Antwoord op Boek 4 de Tweede Kamer tot de conclusie komt, dat dit zo ingrijpend is gewijzigd, dat er (..) een nieuw Voorlopig Verslag noodzakelijk is. Dan loopt men de kans, dat ook t.a.v. Boek 4 in deze parlementaire periode niets vóór de verkiezingen van 1963 zal gebeuren."

39. Vergelijk handelingen Tweede Kamer 1963-1964, p. 361.

40. Uit een nota van Van Ewijk d.d. 3 januari 1961, geschreven ter voorbereiding van een in dat jaar te houden Mondeling Overleg over het nieuwe B.W.: "Wordt dit (werk) ter hand genomen na de voltooiing van Boek 6 als ontwerp van het Driemanschap en zeer kort nadat vervolgens Boek 4 de beide Kamers is gepasseerd, en wordt de vervroegde invoering beperkt tot Boek 1 of de Boeken 1 en 2 , dan kan in de voltooiing van Boek 4 in hetzelfde tijdvak een duidelijk teken worden gezien, dat ondanks partiële vervroegde invoering het grote werk onverdroten wordt voortgezet."

41. Dit verlangen was zeer pregnant naar voren gekomen bij de begrotingsbehandeling voor 1963. Meulink (handelingen Tweede Kamer 1962-1963, p. 2075) zei toen: "Laten we door talmen de tegenstanders van het nieuwe Burgerlijk Wetboek niet de kans geven hun kritiek waar te maken. Juist daarom acht ik ook erg belangrijk het voornemen van de Minister om te streven naar eerdere invoering van Boek 1 van het nieuwe Burgerlijk Wetboek. Misschien is het mogelijk, daarop nog meer boeken te laten volgen. Te overwegen zou b.v. zijn om ook Boek 2 apart in te voeren." Zie ook p. 2093-2094. 
Departementen - overigens weinig talrijk ${ }^{42}$ - zouden dan worden verwerkt na ontvangst van het advies van de Raad van State, aldus Belinfante in een nota aan Minister Beerman van 10 oktober $1962 .{ }^{43}$ Eén reden voor deze ongebruikelijke procedure was dat de studie van Boek 6 O.M. op Justitie nog niet ver was gevorderd; slechts over twee - en dan nog wel minder belangrijke - afdelingen was men zover dat daarover binnen afzienbare tijd een bespreking met Drion zou kunnen plaatsvinden.4 Een tweede reden was, dat de literatuur over Boek 6 O.M. nog zeer onvolledig was. Tenslotte is het niet uitgesloten dat Minister Beerman zo nog iets van zijn geschonden prestige hoopte te kunnen terugwinnen.

Dat de Raad van State op deze wijze een gerede kans liep advies uit te brengen over bepalingen, waarvan reeds vaststond dat zij gewijzigd zouden worden, was een bezwaar dat de Minister en zijn adviseurs in het belang van de voortgang van de hercodificatie wel voor lief wilden nemen. Bovendien zou deze handelwijze voor de Kamer verborgen blijven, omdat het advies van de Raad van State destijds nog geheim was. Wel was het onvermijdelijk dat in het deel van de Parlementaire Geschiedenis, dat betrekking zou hebben op Boek 6, deze gang van zaken aan het licht zou komen. Maar dat zou zich pas afspelen als Boek 6 wet was geworden. ${ }^{45}$

42. Alleen Verkeer en Waterstaat, Binnenlandse Zaken en Economische Zaken plaatsten een paar kanttekeningen. Van twee Departementen - Algemene Zaken en Volkshuisvesting en Bouwnijverheid - kwam bericht binnen dat er geen opmerkingen waren. De andere Departementen lieten niets van zich horen.

43. Franken sloot overigens niet uit dat het Departement eerst op een later tijdstip in de gelegenheid zou zijn het ontwerp te bestuderen en te wijzigen. Op 5 november 1962 schreef hij in een reactie: "Denkbaar is ook dat sommige tijdrovende opmerkingen pas kunnen worden afgehandeld in de tijd dat de Tweede Kamer het Voorlopig Verslag voorbereidt. (..) Onze eigen desiderata zullen terwille van het tijdschema voor een niet onbelangrijk deel moeten worden uitgesteld tot de tijd dat de Kamer het Voorlopig Verslag voorbereidt."

44. De Die: "Op een gegeven moment werd besloten dat de mensen van de Wetgevingsafdeling Privaatrecht twee aan twee commentaar moesten leveren op het voorontwerp van Boek 6. Met Franken heb ik toen de zaakwaarneming gedaan, maar erg veel is daarvan niet gekomen, vooral omdat het ontwerp onder onze handen nóg ingewikkelder werd."

45. Bij K.B. van 8 februari 1963, nr. 9, werd machtiging van de Koningin verkregen tot toezending van het ontwerp aan de Raad van State. De Raad van Ministers was op 26 november 1962 akkoord gegaan. De begeleidende Memorie van Toelichting luidde: "Met het door het Driemanschap prof.mr. J. Drion, prof.mr. G. de Grooth en mr. F.J. de Jong - aan de ondergetekende op 30 oktober 1961 aangeboden en inmiddels gepubliceerde ontwerp voor Boek 6 van het nieuwe Burgerlijk Wetboek, bevattende het algemeen gedeelte van het verbintenissenrecht, kan de ondergetekende zich verenigen. Daarmee is niet gezegd dat er in dit ontwerp niet op sommige punten nog veranderingen zouden kunnen worden aangebracht. De ondergetekende meent echter dat het, speciaal in verband met de verdere behandeling van de Boeken 4 en 3 van het nieuwe wetboek in de Tweede Kamer, gewenst is met de indiening van Boek 6 niet te wachten totdat meer dan tot nu toe de rechtsgeleerde auteurs zich omtrent de verschillende onderdelen van de stof zullen hebben geuit, en de in verband daarmede eventueel gewenste wijzigingen zullen zijn geredigeerd. Door de indiening, reeds thans, van het ontwerp voor Boek 6 conform het aan de ondergetekende aangeboden ontwerp moge de Tweede Kamer voldoende steun vinden bij de verdere behandeling van die onderwerpen van de Boeken 4 en 3, welke met regelingen uit Boek 6 samenhangen." 


\section{Andere maatregelen}

Minister Scholten, die Beerman op 24 juli 1963 zou opvolgen, nam de uitgangspunten van het beleid van zijn voorganger ongewijzigd over. ${ }^{46}$ Wel voegde hij een aantal eigen accenten toe, alle erop gericht meer vaart in het project te krijgen. In de eerste plaats vond de Minister het beslist noodzakelijk de hercodificatie op korte termijn een speciale impuls te geven, omdat anders het risico dat van uitstel afstel zou komen gaandeweg groter zou worden. Naar zijn mening zou daartoe de invoering van het eerste Boek krachtig gepousseerd moeten worden: "Ik meen, dat juist de invoering van het eerste Boek een stimulans kan geven omdat men dan ziet, dat het ernst is om dit werk te voltooien en van kracht te doen zijn in de werkelijkheid. Dat zal weer een motorisch effect kunnen hebben op het verdere werk. ${ }^{47}$ In concreto betekende dit dat het werk aan de invoeringswet van Boek 1 in dertien onderdelen werd gesplitst en dat voor elk onderdeel een ambtenaar of commissie werd aangewezen om de noodzakelijke voorstellen te doen. ${ }^{48}$ Een belangrijk onderdeel van dit plan vormde de inschakeling van prof. L.J. Hijmans van den Bergh voor het overgangsrecht, waartoe overigens nog door Minister Beerman, enkele weken voor zijn aftreden, het initiatief was genomen.

In de tweede plaats besloot de Minister tot het opstellen van een werkverdeling voor de stafafdeling wetgeving privaatrecht, speciaal voor het nieuwe B.W., alsmede tot een uitbreiding van de totale formatie tot zes personen. In de Memorie van Antwoord bij de begroting voor 1964 zei Scholten het als volgt: "Ten einde een zo hoog mogelijk tempo te bereiken en toch de eenheid te bewaren heeft de ondergetekende één der raadadviseurs in algemene dienst zoveel mogelijk voor het werk aan het nieuwe wetboek vrijgemaakt en hem opgedragen de medewerking aan dat wetboek door de overige ambtenaren van de onderafdeling privaatrecht van de stafafdeling wetgeving te coördineren. ${ }^{\text {"49 }}$ Met de leiding en de coördinatie van de departementale

46. Zie daarover uitdrukkelijk de Minister tijdens het debat over de begroting voor 1964, handelingen Tweede Kamer 1963-1964, p. 397 e.v.

47. Handelingen Tweede Kamer 1963-1964, p. 398.

48. Deze onderdelen bestonden in:

a. wijzigingen in Boek 1 en in de geldende Boeken 2, 3 en 4

b. overgangsrecht

c. wetsontwerp requestprocedure

d. wetsontwerp bewijsrecht

e. aanpassing Wetboek van Burgerlijke Rechtsvordering

f. I.P.R.-regels met betrekking tot competentie echtscheiding

g. aanpassing andere wetten

h. algemene Maatregelen van Bestuur betreffende verandering van geslachtsnaam en registers Burgerlijke stand

i. idem t.a.v. kinderbescherming en gezinsvoogdij

j. overige A.M.v.B's.

k. herziening huwelijksgoederenrecht

1. regeling van het désaveu

m. regeling van de echtscheiding en scheiding van tafel en bed.

De onderdelen a, f, g, $\mathrm{i}$, en $\mathrm{j}$ werden voorbereid onder toezicht of in overleg met Van Ewijk. Drion werkte uitsluitend aan het eerste onderdeel.

49. Zitting Tweede Kamer 1963-1964, nr 7400, stuk nr 9, p. 1. De nieuwe werkverdeling met bijbehorend werkprogramma werd vastgesteld op 16 december 1963. 
werkzaamheden voor het nieuwe B.W. werd Van Ewijk belast, die zich, zoals de Minister ook al aangaf, ook overigens hoofdzakelijk tot het werk voor het nieuwe wetboek zou moeten bepalen. Vóór 1964 was het namelijk zo, dat Van Ewijk ongeveer twee á drie ochtenden per week in beslag werd genomen door Rechtsherstelzaken, ofschoon dat werk ook door een minder ervaren jurist kon worden verricht.

Tenslotte nam Scholten een aantal maatregelen, met het oogmerk de overbelasting van Drion te verminderen en het werk daardoor vlotter te laten verlopen. Dat het met de werkdruk van Drion al enige tijd moeilijk was gesteld, kwam hiervoor al ter sprake. Sinds de voltooiing van Boek 6 O.M. was de situatie evenwel nog zorglijker geworden. In 1962 werd een voorstel om Drion een substantieel hogere toelage te geven gemotiveerd met de opmerking dat Drions werk aan het nieuwe B.W. in de verdrukking kwam door zijn vele andere bezigheden, die hij, zonder zichzelf in acht te nemen, steeds weer op zich nam: "Met de voorgestelde verhoging heeft de Minister tevens beoogd te onderstrepen dat het voor de totstandkoming van het nieuwe wetboek binnen niet al te lange tijd noodzakelijk is dat prof. Drion hieraan zoveel mogelijk al zijn tijd en werkkracht besteedt en dus het werk voor de universiteit zoveel als maar enigszins mogelijk is, aan zijn collega-hoogleraren overlaat." 50 Scholten kreeg in 1963, kort na zijn aantreden, het volgende te horen: "Geconstateerd wordt, dat ontlasting van prof. Drion noodzakelijk is, omdat anders de georganiseerde inspanning van het Departement toch niets helpt. (..) De heer Van Ewijk deelt mede binnengekomen eerste concepten voor enige titels van het zevende Boek reeds niet aan prof. Drion te hebben gegeven. "51

Besloten werd daarom dat Drion voorlopig uitsluitend zou werken aan de Invoeringswet Boek 1, die ultimo 1 maart 1964 bij de Ministerraad zou moeten worden ingediend, en aan de Memorie van Antwoord voor Boek 3, die vóór 1 augustus 1964 in concept gereed zou moeten zijn - voor Boek 4 moest worden afgewacht wat de vaste Commissie voor Justitie zou doen. Met betrekking tot Boek 5 (Zakenrecht) werd afgesproken dat Franken, die daarvoor voor de helft van zijn werktijd werd vrijgesteld, een volledige nota over Boek 5 zou schrijven. Deze nota zou als basis moeten dienen voor de besprekingen met Drion, die na de afronding van de Memorie van Antwoord voor Boek 3 zouden kunnen beginnen. Voor de beantwoording van het advies van de Raad van State over Boek 6 en mogelijk ook enige wijzigingen in de tekst en de toelichting zou een beroep worden gedaan op De Grooth, die met assistentie van mr. J. Swart en Cohen Jehoram het Nader Rapport voor zijn rekening zou

50. Nota Van Van Ewijk van 31 juli 1962. Van Ewijk vervolgt: "Ik maak mij op dit punt zorgen. De grote welwillendheid van de heer Drion jegens een ieder die een beroep op hem doet en zijn onbegrensde optimisme doen hem - vrees ik - zijn, weliswaar zeer grote, werkkracht overschatten."

51. Notulen van een bespreking van 11 september 1963 tussen Scholten, de SG, Belinfante en Van Ewijk inzake uitgangspunten voor een nieuw wetgevingsbeleid. Het citaat vervolgt: "Voor wat Boek 6 betreft, hier is van belang, hoe het advies van de Raad van State, dat binnenkort te verwachten is, uitvalt. Brengt de afdoening daarvan weinig werk mee, dan kan het Departement zelf voor de indiening bij de Tweede Kamer zorgen. Is het advies wel ingrijpend, dan zou bijvoorbeeld prof. $\mathrm{H}$. Drion kunnen worden ingeschakeld, die zowel voor prof. J. Drion als voor prof. De Grooth en $\mathrm{mr}$. De Jong aanvaardbaar is. (..) De heer Van Ewijk vestigt er verder de aandacht op, dat prof. J. Drion voor de M.v.A. over Boek 5 thans geen tijd heeft." 
moeten nemen. ${ }^{52} \mathrm{H}$. Drion viel af, omdat zijn taak als hoogleraar in het komende jaar belangrijk zou worden uitgebreid en te voorzien was dat er bij de curatoren van de Leidse Universiteit overwegende bezwaren zouden bestaan hem met dit werk te belasten.

Om het Regeringsontwerp van Boek 6 zo snel mogelijk bij de Kamer te krijgen beval Scholten dat van een zelfstandige toetsing door het Departement geen sprake kon zijn: "De Minister wenst bij het opstellen van het Regeringsontwerp alleen rekening te houden met de opmerkingen van de Raad van State en van de andere Departementen (voor zover dit is toegezegd). In dit stadium zou hij dus geen rekening willen houden met andere in de literatuur gemaakte opmerkingen, noch met eventuele opmerkingen van het Departement van Justitie zelf, één en ander ter bevordering van een spoedige indiening van het Regeringsontwerp. Die verdere opmerkingen kunnen in een later stadium alsnog onderwerp van studie vormen." Daarmee werden Frankens sombere voorspellingen van een jaar eerder dus bewaarheid.

\section{Het tweede rapport van de Commissie Erfrecht}

Hiervoor bleek, dat Drion en Van Ewijk bij het voorbereiden van de Memorie van Antwoord en het opstellen van het Gewijzigd Ontwerp Boek 4 geen contact meer hadden gezocht met de Commissie Erfrecht. Wél werd in de toelichting op het ontwerp én in een brief aan de besturen van de beide Broederschappen, gedateerd 8 november 1962, dank betuigd over de ontvangen opmerkingen:

"Uit de hierbij gevoegde Memorie van Antwoord op het Voorlopig Verslag van de vaste Commissie voor Justitie uit de Tweede Kamer der Staten-Generaal over het ontwerp van wet tot vaststelling van Boek 4 van het nieuwe Burgerlijk Wetboek, en het bij die Memorie behorende Gewijzigd Ontwerp van wet, moge u blijken dat bij de opstelling van deze stukken een ruim gebruik is gemaakt van de waardevolle adviezen en gegevens, vervat in het rapport dat de onder voorzitterschap van $\mathrm{mr}$. Van der Ploeg ingestelde commissie in maart 1960 heeft uitgebracht, en van de enquête die de hoofdbesturen van de beide notariële broederschappen hebben gehouden."

De brief besloot met een oproep tot verdere medewerking:

"Het is mij een behoefte de beide broederschappen en de voorzitter en de overige leden van de Commissie-Van der Ploeg dank te zeggen voor de medewerking die de notariële wereld aan de totstandkoming van het nieuwe wetboek en in het

52. Uiteraard moesten het concept voor het Nader Rapport en de eventuele voorstellen tot wijziging in de tekst en van de Memorie van Toelichting vervolgens nog worden bekeken door Drion, Belinfante en Van Ewijk. Uit een nota van Van Ewijk d.d. 23 december 1963 aan Minister Scholten: "Afgesproken is dat volledige concepten voor Nader Rapport, Regeringsontwerp en Memorie van Toelichting zullen worden voltooid vóor 1 maart 1964, omdat prof. De Grooth dan voor een maand naar New Orleans (Universiteit van Louisiana) gaat. Opmerkingen over die concepten kunnen dan in maart door prof. J. Drion en mr. De Jong worden gemaakt en in april zou de laatste hand aan de $u$ voor te leggen concepten kunnen worden gelegd, zodat indiening bij de Tweede Kamer in mei zou kunnen geschieden." 
bijzonder aan het vierde boek daarvan, heeft willen verlenen en, naar ik hoop en vertrouw, ook verder zal willen verlenen."

Op het moment van schrijven was reeds bekend dat commentaar zou komen. Uit een nota van Van Ewijk van 5 november 1962: "Prof. Drion heeft met mr. Van der Ploeg afgesproken dat de door deze voorgezeten commissie zal trachten spoedig haar licht over het Gewijzigd Ontwerp voor Boek 4 B.W. te laten schijnen. Vertraging van de verdere parlementaire behandeling behoeft niet te worden gevreesd, gezien de grote voortvarendheid waarmee in 1960 het rapport is uitgebracht." Dezelfde, 7 mei 1969: "Van rapport II kan men dus wel zeggen dat het door ons is uitgelokt."

De Commissie-Van der Ploeg ${ }^{53}$ onderwierp het werk van Drion en Van Ewijk aan een nieuw onderzoek en kwam tot bijzonder kritische conclusies. Een eerste deel van het rapport ( 15 bladzijden), behandelende de titels 1 en 2, werd uitgebracht op 30 april 1963, een tweede deel ( 29 bladzijden), behandelende afdeling 1 van titel 3 , ontving het Departement op 20 december $1963 .^{54}$ Vóór de verschijning daarvan waren Minister en Kamer nogal optimistisch gestemd over de kansen van Boek 4 en over de haalbaarheid van het tijdschema. Gemeend werd dat de behandeling van het ontwerp vrijwel geheel door de vaste Commissie zou kunnen geschieden, en dat de mondelinge behandeling nog slechts een formaliteit zou zijn. ${ }^{55}$ De voortgang van het werk aan de andere Boeken zou dus nauwelijks te lijden hebben.

Begin 1964 was er van die stemming echter weinig meer over. Van Ewijk, 27 januari 1964: "De Commissie voor Justitie heeft enige tijd geleden aangekondigd in maart met het Mondeling Overleg te beginnen, opdat de openbare behandeling in de Tweede Kamer in juni kan plaatsvinden. Het zou mij niet verwonderen als zij van dit plan zou moeten terugkomen, omdat de commissie uit de notariële broederschappen met haar gedegen rapport nog niet verder is gekomen dan de titels 4.1 en 4.2 (april 1963, 15 blz) en afdeling 4.3.1 (januari 1964, 29 blz). Prof. Drion, mr. Belinfante en ik beginnen, met assistentie van mr. Cohen Jehoram, dezer dagen met onderlinge bespreking van deze rapporten."

Deze concentratie van alle beschikbare krachten op Boek 4 betekende dat het werk aan de Boeken 1 en 3, dat toch al minder voorspoedig verliep dan was gehoopt, tijdelijk moest worden stilgelegd. Het tijdschema voor de voltooiing van de ontwerpInvoeringswet Boek 1 (maart 1964) en een eerste concept voor de Memorie van

53. Inmiddels was in de samenstelling van de Commissie een verandering opgetreden. In plaats van de kandidaten Meuwissen en Meijling namen nu W.M. Kleijn en A.L.M. Soons zitting. Heuff, Treurniet en Coebergh waren lid gebleven.

54. Beide delen werden respectievelijk in juni 1963 (WPNR 4774) en januari 1964 (WPNR 4797) gepubliceerd.

55. Uit een verslag van een bespreking met Minister Scholten van 16 september 1963: "De Minister heeft met de heer Van Rijckevorsel, voorzitter van de vaste Commissie voor Justitie, gesproken, en deze opperde het denkbeeld, om na het M.O. met de vaste Commissie op de gewone wijze, de verdere behandeling in eerste instantie te doen plaatshebben in openbare vergaderingen van de vaste Commissie, gelijk dat ook met andere begrotingsontwerpen geschiedt. Boek 4 immers, is voor het overgrote deel een zeer technische materie, waarvoor de andere Kamerleden niet veel belangstelling hebben. Op de wijze als door de Heer Van Rijckevorsel gedacht, zou men voor de mondelinge behandeling in de volle Kamer niet meer dan hoogstens één dag nodig hebben." 
Antwoord Boek 3 (augustus 1964) was op eenmaal achterhaald. 1964 was een rampjaar.

Het tweede rapport van de Commissie Erfrecht verschilde nogal van het eerste. Weliswaar was opnieuw sprake van een zeer gedegen en uitvoerig werkstuk, met vele aanhalingen van voorbeelden uit het Franse, Duitse, Engelse en Amerikaanse recht, maar de toonzetting van het rapport had een radicale wijziging ondergaan. Er was niets "aardigs" aan, elk waarderend woord, hoe gering ook, ontbrak. Het rapport was in stijgende lijn kritisch, de pen waarmee het geschreven was, leek in alsem te zijn gedoopt. Zo kreeg bijvoorbeeld de regel, dat vermogensverschuivingen als gevolg van een huwelijk van de erflater als een gift worden beschouwd, indien dit huwelijk binnen zes maanden door de dood wordt ontbonden, van de Commissie het volgende commentaar mee: "In deze gedachtengang wordt het dus redelijk geacht, dat de overblijvende echtgenoot, die reeds zwaar persoonlijk getroffen wordt door het verlies van zijn echtgenoot, daarnaast nog een financieel offer moet brengen. Een echtgenoot van nog geen zes maanden is maar een echtgenoot van de tweede soort." Een bepaling die de erfgenaam een zakelijk werkend vervreemdingsverbod oplegde ten aanzien van het gelegateerde, kon evenmin op instemming van de notarissen rekenen: "De erfgenaam, die de gelegateerde goederen vervreemdt, is een hersenschim, die geen van de leden van de Commissie ooit in de praktijk is tegengekomen." Met betrekking tot de voorgestelde regeling van de rechten en bevoegdheden van de executeur stelde de Commissie: "'Bemoeizucht' is een hard woord. Niettemin moet het hier worden uitgesproken. Uit het onderhavig en het vorig artikel, zomede uit de regeling van de executele, blijkt een instelling jegens de praktijk, die de funktie van het notariaat bij de boedelpraktijk miskent en bovendien de testeervrijheid, die in het huidig recht zo ruim is, te kort doet. ${ }^{\text {"36 }}$

Cohen Jehoram: "Het betrof een zeer ongezouten kritiek op wat de ontwerpers tot dan toe hadden voorbereid. Het had een toon die dermate scherp en persoonlijk was, dat de twee mensen die op het Ministerie zaten te debatteren, Van Ewijk en Jan Drion, daar steeds zenuwachtiger van werden. Het was een eindeloze reeks van opmerkingen, die erop neerkwam dat er werkelijk niets van het erfrecht deugde en dat de ontwerpers toonden er absoluut geen verstand van te hebben. Van der Ploeg was toendertijd de belangrijkste specialist op het gebied van het erfrecht, dus zijn kritiek had een groot effect."

Dat het tweede rapport zo uitermate kritisch was, had verschillende oorzaken. Een belangrijk gegeven was, dat Drion en Van Ewijk niet altijd voldoende rekening hadden gehouden met de opmerkingen van de notarissen en sommige fundamentele bezwaren en verlangens te weinig serieus hadden genomen. ${ }^{57}$ Weliswaar zou het ook

56. Deze voorbeelden zijn ontleend aan p. 108, 181 en 183 van Rapport II (1963-1966).

57. Een voorbeeld daarvan is dat in het G.O. het "langstlevend al" geen erkenning had gevonden, ofschoon de moderne ouderlijke boedelverdeling tussen ' 60 en '70 als een storm over het land ging. Dat de Hoge Raad al in 1969 (HR 19 september 1969, NJ 1969, 402) geroepen werd een uitspraak te doen over deze vóór 1958 nog onbekende rechtsfiguur, illustreert de populariteit ervan. Andere belangrijke punten van kritiek hadden betrekking op meer technische kwesties, zoals de grens van hetgeen als een uiterste wilsbeschikking moet worden aangeduid, de regeling van het legaat en de wilsgebreken bij testament. 
merkwaardig zijn geweest indien zij alle opmerkingen en aanbevelingen zonder meer zouden hebben overgenomen, maar het zou alleen al uit een oogpunt van waardering verstandig zijn geweest de Commissie Erfrecht op enigerlei wijze bij het werk aan het Gewijzigd Ontwerp te betrekken. Drion en Van Ewijk hadden nu eenmaal niet de statuur van Meijers, die met een eenvoudig bedankbriefje kon volstaan, maar overigens wel goed luisterde naar kritiek.

Cohen Jehoram licht toe: "Drion en Van Ewijk hadden beslist wel rekening gehouden met het eerste rapport van de Commissie Erfrecht, maar er moesten knopen worden doorgehakt en soms vielen die in het nadeel van de notarissen uit. Zo gaat dat. (..) Het niet zoeken van contact met de auteurs van dat rapport heeft echter kwaad bloed gezet. De notarissen hadden immers laten zien hoe belangstellend ze waren, maar daar is nooit enig vervolg op gekomen van de zijde van het Ministerie." Heuff: "Op allerlei punten hadden ze wel naar ons geluisterd, maar er waren toch ook heel veel punten - wat wij essentiële punten vonden - waar dat niet het geval was."

Nog belangrijker was, dat het Gewijzigd Ontwerp op tal van punten nieuwe wegen insloeg en de band met het werk van Meijers doorsneed, zonder dit op overtuigende wijze te motiveren. Heuff: "Op de wijzigingen die het Gewijzigd Ontwerp bracht was naar onze mening ook het nodige te zeggen. Het voorstel van de Regering ging veel te ver in allerlei verfijningen, die voor de praktijk niet toe te passen waren. Ook leidde de regeling tot onbillijkheden. We hebben erg lang over dat rapport gedaan, waardoor het nog uitvoeriger is geworden dan het eerste." Soons: "Wij waren het erover eens dat het ontwerp, zoals het er toen lag, niet werkbaar was. Over de legitieme hebben wij in feite een veto uitgesproken. Theoretisch zat het bijna perfect in elkaar, maar als je het moest gaan toepassen, dan zag je door de bomen het bos niet meer."

Daarbij kwam dat Van der Ploeg, die het rapport grotendeels alleen zou schrijven, zich in zijn beoordeling van het ontwerp in sterke mate liet leiden door zijn bewondering voor Meijers. Omdat Drion en Van Ewijk met hun ontwerp al het voorgaande leken te willen vergeten, betekende dit dat Van der Ploeg zijn eerdere respectvolle bescheidenheid volledig liet varen, integendeel het werk van Drion en Van Ewijk met een extra kritisch oog bezag. Dat leidde ertoe dat zijn commissie ook punten aan de kaak stelde, die voordien nooit aanleiding tot discussie waren geweest. Van der Ploeg licht toe: "Mij is verweten, ik meen door Drion, dat het eerste rapport van de Commissie Erfrecht veel minder kritisch was dan het tweede en dat in het tweede ook punten aan de orde werden gesteld die in het eerste rapport onbesproken waren gebleven. Had ik toen moeten zeggen, ik ga niet, als Meijers er nog is, hem afvallen? Als Drion enige mensenkennis had gehad, dan had hij toch wel kunnen begrijpen dat ik mij, als woordvoerder van het notariaat, niet geroepen voelde met kritiek op Meijers te komen? Want wie heeft het erfrecht in Nederland gemaakt? Meijers toch! Je leverde geen kritiek, dat deed niemand, want ook in het eerste Regeringsontwerp van Boek 4 vind je eigenlijk geen kritiek op Meijers." 58

58. Van der Ploeg vervolgt: "Er zat bij mij ook een onwillekeurige reactie in de zin van, verdikkie, er is geen artikel van Meijers, of ze hebben het veranderd. Ze hebben echt gedacht, nu zullen wij eens met een beter, een echt goed ontwerp komen. Die overweging heeft zeker een rol gespeeld. Ik was geschokt toen ik het Gewijzigd Ontwerp onder ogen kreeg. De anderen waren dat misschien minder, maar we hadden toch alle zes het gevoel, wat hebben ze nu weer uitgehaald." 
Tenslotte zou ook een zekere mate van rivaliteit - om het sterkere woord te vermijden - tussen Van der Ploeg en Van Ewijk een rol hebben gespeeld. Soons: "In het begin van de zestiger jaren is er een enorme ruzie geweest tussen het Ministerie in de persoon van Van Ewijk en Van der Ploeg met betrekking tot artikel 992 B.W. over de zogenaamde noodtestamenten. ${ }^{59}$ Het was al nooit goed, maar dat heeft, denk ik, ook meegespeeld bij het schrijven van het rapport over het Gewijzigd Ontwerp." Bovendien was Van der Ploeg iemand met een uitgesproken mening, die hij onbetwistbaar als de enige juiste zag, volgens Wiersma: "Ik heb er een herinnering aan dat hij eigenlijk vond, dat iemand als Meijers, - Meijers behandelde hij met wat meer egards -, en het soort mensen die Regeringscommissaris waren en die bij het Departement zich sterk met het Erfrecht bemoeiden, toch eigenlijk niet op zijn terrein moesten komen. Hij had ook een heleboel voorstellen die erop neerkwamen, dat je het net zo goed bij het oude kon laten."

De stemming op het Ministerie werd er niet beter op toen Van der Ploeg aan Drion begin februari 1964 vertelde dat hij een concept-rapport over de afdelingen Legitieme portie (4.3.3) en Andere wettelijke rechten (4.3.4) klaar had, waarin zijn Commissie dit deel van het Gewijzigd Ontwerp onaanvaardbaar noemde. ${ }^{60}$

Het oordeel van de notariële commissie over de in het ontwerp voorgestelde regeling van de erfrechtelijke positie van de langstlevende echtgenoot loog er niet om. Men bleef de legitieme afwijzen, daarin gesteund door de enquête uit 1960 waarin $69 \%$ van de notarissen en $88 \%$ van de kandidaat-notarissen zich uitspraken voor een onaantastbaar verzorgingsrecht en tegen de legtieme. Om dezelfde reden moest ook de combinatie legitieme/verzorgingsaanspraak het ontgelden. Een citaat:

"Laten we eens veronderstellen dat een wetgever niet verder kan gaan dan, gelijk in art. 4.3.4.1b en in het arrest De Visser-Harms, het uitspreken van een algemene vage formule, het aan de rechter en notaris overlatende tot een precisering te komen. Rechtvaardigt dit dan de konklusie van de toelichting, dat naast het verzorgingsrecht aan de echtgenoot een legitieme moet worden gegeven? De onmogelijkheid om aan het verzorgingsrecht een scherpe omlijning te geven zou zodoende rechtvaardigen de toekenning aan de gerechtigde tot het verzorgingsrecht, de langstlevende echtgenoot, van een legitieme met wel vaste omlijning, doch die naar haar aard met de behoefte aan verzorging geen doen heeft. Dit is naar het oordeel

59. Wet van 27 september 1961, Stb. 304.

60. Van der Ploeg: "Ik was begin 1964 met Drion en enkele anderen in Brussel voor een vergadering van de zogenaamde Benelux-commoriẻntencommissie. Op een gegeven moment gingen we lunchen. Op weg naar het restaurant liep ik op met Drion. Voordat ik in de trein naar Brussel was gestapt, had ik echter een brief laten tekenen door de voorzitter van de Broederschap, dat afdeling 4.3.3 onaanvaardbaar was. Ik vond dat ik dat niet voor mij kon houden en heb toen tegen Drion gezegd 'Ik ben het helemaal niet met je eens, het is heel moeilijk aanvaarbaar, het is te moeilijk.' De andere leden van de Commissie wisten van die stap niets af. Misschien hebben zij mij die ontboezeming wel kwalijk genomen." 
van de Commissie geen rechtvaardiging, elk juridisch verband tussen het een en ander ontbreekt. "61

Daarnaast werd scherpe kritiek geuit op het feit dat makingen ten behoeve van de langstlevende en de som ineens zonder noodzaak verschillend behandeld werden; de makingen, voor zover nodig ter verzorging, waren niet aantastbaar door de legitimarissen, de som ineens wel. Tenslotte werd betreurd dat het langstlevende al in het Gewijzigd Ontwerp geen onvoorwaardelijke erkenning had gevonden.

Het gevolg van dit alles was dat Drion, voor wie deze kritiek als een buitengewoon onaangename verrassing $\mathrm{kwam}^{62}$, onmiddellijk contact opnam met Minister Scholten, die Van der Ploeg voor een bepreking op het Departement uitnodigde. Van der Ploeg: "Mij is toen gevraagd of ik vóór een nieuw Burgerlijk Wetboek was. Want ik moest mij wel realiseren, dat ik met mijn kritiek Pitlo c.s. de wind in de zeilen zou geven. Ik meen dat ik toen heb verwezen naar mijn artikel 'Nu of Nooit', maar ik dacht erbij: mits het een goed ontwerp is. Ik heb toen, op verzoek van Scholten, de toezegging gedaan dat het concept over afdeling 4.3.3 eerst met Drion en Van Ewijk zou worden besproken, voordat het in het WPNR zou worden gepubliceerd. " ${ }^{63}$

\section{1 maart 1964: Drion overlijdt}

Zoals in de bovenaangehaalde nota van Van Ewijk werd aangekondigd, waren Drion en hijzelf omstreeks eind januari 1964 begonnen met besprekingen van het commentaar van de Commissie Erfrecht op het Gewijzigd Ontwerp. Wiersma, die een "In Memoriam" schreef, verhaalt: "Een nauwgezet onderzoek van de naar voren gebrachte bezwaren had reeds aanleiding gegeven tot een dertiental dagbesprekingen op het Departement (de laatste op 20 februari 1964) toen Drion zich minder goed ging voelen en zijn bestudering van de materie voorlopig thuis ging voortzetten. Aan rust kon hij echter niet goed toekomen en het was midden in dit en ander onafgemaakt werk dat de dood hem op 1 maart 1964 overviel." Cohen Jehoram: "Het is in zoverre dramatisch afgelopen, dat er dagelijks over vergaderd werd, van 's ochtends vroeg tot 's avonds laat, in een klein kamertje onder de pijp van Drion en de sigaret van Van

61. Rapport II, p. 70-71. Het citaat vervolgt: "De moeilijkheid verbonden aan het geven van wettelijke gestalte aan het verzorgingsrecht moge niet tot een legitieme naast het verzorgingsrecht leiden. Wel kan deze moeilijkheid voor de wetgever aanleiding zijn de toepassing van het verzorgingsrecht zoveel mogelijk te beperken. En dit klemt des te meer, omdat de ontwikkeling in de maatschappij steeds verder in die richting gaat dat een weduwe - en wanneer wij over het verzorgingsrecht van de langstlevende echtgenoot spreken doelen wij toch voornamelijk op de weduwe - door sociale wetgeving en pensioenregeling niet onverzorgd achterblijft. De onverzorgde weduwe wordt een rara avis."

62. De Minister was absoluut niet bedacht op deze sterk afwijzende kritiek, zo kan althans worden opgemaakt uit de notulen van een hoorzitting van 1 maart 1961 van de vaste Commissie voor Justitie: "Prof. Drion zet uiteen, dat het adres van de notarissen over het erfrecht helemaal in de Memorie van Antwoord verwerkt wordt. Van die zijde verwacht hij niet zo heel veel opmerkingen meer. De heer Van Ewijk verwacht niet weer een doorlopend preadvies over het gehele erfrecht. Hij acht een reeks van artikelen van verschillende deskundigen ook beter."

63. Aldus ook Van Ewijk in een nota van 4 maart 1964: "Van der Ploeg heeft (..) verteld dat zijn rapport over de legitieme eerst met Drion en mij zou worden besproken vóór de toezending aan de Commissie voor Justitie en de publikatie in het WPNR." 
Ewijk, waardoor de spanning steeds verder steeg. Midden daarin overleed Jan Drion. Mijn theorie is dat dat werd veroorzaakt door al die geweldige spanningen rond het erfrecht."

Slechts een enkeling twijfelt eraan dat het werk aan het nieuwe B.W. Drion, die vreselijk hard en intens werkte, uiteindelijk teveel is geworden. Weliswaar leed Drion aan een hartkwaal, maar niet in een mate dat een fataal verloop kon worden voorzien.

Drie opmerkingen daarover.

In de eerste plaats was Drion vanaf het moment dat hij Meijers' taak overnam regelmatig overbelast geweest. Hij had dat ongetwijfeld voor een groot deel aan zichzelf te wijten. Door voortdurend en met groot enthousiasme nieuwe uitdagingen aan te gaan, laadde hij steeds meer werk op zijn schouders en werd de geestelijke belasting alsmaar groter. Tekenend is dat toen de Leidse faculteit in 1958 problemen maakte omdat zijn beschikbaarstelling ten einde liep, het Drion zélf was die de oplossing aandroeg, doordat hij zich bereid verklaarde weer enkele uren in de week college te gaan geven.

Van Zeben, die als medewerker van Van Ewijk Drion tot 1963 meemaakte, formuleerde het als volgt: "Drion is, maar dat is mijn persoonlijke mening, aan het nieuwe B.W. ten onder gegaan, ook lichamelijk. Hij was in de eerste tijd nog vrijgesteld van zijn werkzaamheden verbonden aan het hoogleraarschap, maar na verloop van tijd moest hij toch weer colleges geven en examens afnemen. Dat werd hem te veel. Hij had erg veel last van migraine en dus kwam het nogal eens voor dat hij een vergadering afbelde omdat hij helemaal niet in staat was om te komen. Zo gauw als hij zich weer enigermate hersteld voelde, verscheen hij weer op het Departement en dan legde Van Ewijk hem weer voor een aantal vergaderingen vast. Drion zei dan geen nee, terwijl dat misschien wel beter was geweest." Van Ewijk zelf zou later schrijven: "Drion heeft eerst als tijdelijk ambtenaar van het Ministerie van Justitie (ter assistentie van prof. Meijers), vervolgens, naast zijn functie van hoogleraar, als lid van het Driemanschap en als commissaris tot bijstand van de Minister van Justitie, zozeer zijn krachten gewijd aan het ontwerpen en tot stand brengen van de wetten tot vaststelling van het nieuwe Burgerlijk Wetboek, dat deze welhaast bovenmenselijke krachtsinspanning voor zijn gezondheid fataal is gebleken. "64

Een tweede punt dat van belang is, is dat Drion zich in zekere zin persoonlijk verantwoordelijk voelde voor het welslagen van de hercodificatie, en die last (of zo men wil: roeping) al bijna tien jaar met zich mee torste. Elke dag opnieuw moest Drion de strijd aangaan, eerst met Eggens en De Jong, later met Van Ewijk en tenslotte ook met zichzelf. Elk punt moest worden uitgepraat, elke beslissing moest worden verantwoord. En als zo'n dag was voorbijgegaan, dan leek het dikwijls alsof het ideaal van een nieuw Burgerlijk Wetboek weer verder verwijderd was. Drion kreeg eenvoudig niet de gelegenheid om afstand te nemen van zijn werk, om zich te ontspannen. Daarbij kwam dat hij zich inmiddels terdege realiseerde dat door het uitblijven van aansprekende resultaten de kans op een mislukking allengs groter werd en dat het door Pitlo geëntameerde verzet steeds meer aan invloed zou winnen. H.

64. Nota van 4 maart 1965. In een interview in het Algemeen Dagblad van 25 juli 1968 ter gelegenheid van zijn erepromotie zei Van Ewijk: "Het werk was te zwaar en ik vrees dat dit het leven van prof. Drion heeft bekort." 
Drion: "Ik herinner me dat mijn broer de laatste jaren heel gespannen was over de opmerkingen van Pitlo, die argumenten gebruikte die in feite niet meer te goeder trouw waren en bovendien vaak onderling tegenstrijdig waren." 65

Tenslotte kwamen er eind 1963 de spanningen over het erfrecht bij. H. Drion: "Mijn broer heeft zich aan het eind, vooral toen Boek 4 in een kritieke fase verkeerde, kapot gewerkt. Hij is er emotioneel door opgeslokt als het ware." Mevrouw Drion: "Begin 1964 verscheen een nota van Van der Ploeg of een artikel waarin hij een aantal punten van het vierde Boek heel sterk aanviel. Ik herinner me dat Jan daar erg verontwaardigd over was. Aan de hand van de ontstaansgeschiedenis van het wetsontwerp is hij ieder bezwaar in dat stuk nagegaan met de vraag of dat bezwaar van Van der Ploeg niet al vijf jaar eerder naar voren had kunnen worden gebracht. Tweederde van die punten van Van der Ploeg, zeg dat het er dertig waren, lagen er al jaren en daar had nog nooit iemand iets over gezegd. Maar nu het eigenlijk tien voor twaalf was, kwamen ze daar nog even mee. Dat speelde een paar weken voor zijn dood. Voor mij is dat één van de dingen geweest, die hem te zeer hebben aangegrepen. Hij is er ontzettend mee bezig geweest en dat heeft zeker nog even extra spanningen teweeggebracht."

Niet alleen de "dertig punten" zullen Drion zwaar zijn gevallen. De essentie van het rapport ging nog verder en kwam erop neer dat de ontwerpers toonden geen enkel verstand van het erfrecht te hebben. Het was bovenal een aanklacht tegen Drion en Van Ewijk in hun hoedanigheid van wetsontwerper. Het is niet moeilijk in te zien, dat ook dit punt beiden zwaar heeft gegriefd en ontsteld. Niét in de zin dat zij als gevolg van deze kritiek het hoofd in de schoot zouden leggen - Van Ewijk heeft tenslotte ondanks zijn ziekte tot aan zijn dood zijn krachten gegeven aan de verwezenlijking van zijn ideaal. ${ }^{66}$ Wél dat als gevolg van deze oppositie opnieuw langdurig uitstel dreigde, waardoor het werk aan de andere Boeken, waaronder de politiek belangrijke invoeringswet voor Boek 1, eveneens grote vertraging zou oplopen. Met één klap veegde het rapport van de Commissie Erfrecht alle tijdschema's van tafel en maakte het duidelijk dat het werk nog lang zou gaan duren. Juist dat werd Drion, die het werk aan het nieuwe B.W. altijd had beschouwd als een een tijdelijk iets ${ }^{67}$, vermoedelijk teveel. De illusie, dat hij binnen afzienbare tijd zou kunnen terugkeren naar

65. Drion vervolgt: "Naar mijn gevoel is die kritiek altijd méér geweest dan dat zij alleen betrekking had op juridische punten. Het leek mij meer het resultaat van een controverse tussen Meijers en Pitlo." Van der Ploeg: "Meijers heeft Pitlo op een gegeven moment bij zich ontboden - dat kon hij doen - om hem de mantel uit te vegen omdat hij min of meer grote stukken had overgenomen van C.H.F. Polak in zijn personen- en familierecht. De wereld is klein. Ik behandel de nalatenschap van een oom van Pitlo. Er waren twee neven. De ambtenaar O.M. Pitlo en de professor A. Pitlo. Die twee waren niet goed met elkaar. De ambtenaar O.M. was voornemens te promoveren over de historie van de executele en was daarom voor een bespreking bij Meijers. Hij vertelde mij, 'Ik kom daar aan, en wie komt de deur uit, met zijn bolhoed scheef op: mijn waarde neef, de hooggeleerde prof.mr. A. Pitlo, zo had hij van Meijers op z'n duvel gehad.' Pas heb ik ergens gelezen dat Pitlo een appeltje had te schillen met Meijers. Het was precies andersom!"

66. Illustratief daarvoor is dat Van Ewijk in 1963 niet inging op de mogelijkheid raadsheer in de Hoge Raad te worden, ofschoon dit tot een hoger pensioen en salaris zou hebben geleid. Bij die beslissing heeft het belang van het nieuwe B.W. zwaar gewogen. Zie Vox Justitiae, april 1971, p. 2, Afscheid is geen afscheid.

67. Mevrouw Drion: "Ik had de indruk dat hij dacht aan zo'n 10 jaar, dan is het klaar en dan gaat dat hoogleraarschap in volle omvang door, want dat was wat hij wilde." 
de universiteit, naar het hoogleraarschap waar hij bijzonder veel voldoening in had, werd hem ruw ontnomen.

\section{De opvolging van Drion}

Het plotselinge overlijden van Drion, nog in de kracht van zijn leven, veroorzaakte een schok in juridisch Nederland en kreeg ook daarbuiten veel aandacht. De redactie van het WPNR schreef: "Op een leeftijd die nog grote verwachtingen toeliet van wat hij voor de rechtswetenschap zou zijn, midden in de uitvoering van een werk van zo grote betekenis als slechts aan heel weinigen wordt toevertrouwd, is Drion ons, volkomen onverwachts, ontvallen. Bij zeer velen heeft dit heengaan een persoonlijke verslagenheid veroorzaakt. $\mathrm{Zij}$ heeft nog de zo voor de hand liggende vraag teruggehouden, hoe het moet gaan met dat werk; is het vatbaar om overgenomen te worden, is er iemand, van een gehalte als Drion, in staat het over te nemen?" ${ }^{168} \mathrm{Bij}$ de crematie, waar zo ongeveer de gehele juridische wereld was opgekomen, spraken Minister Scholten en Van Rijckevorsel en roemden zij de overledene, die, zonder aan zichzelf te denken zich aan deze taak en aan vele andere had gegeven. ${ }^{69}$ Als Drion er niet was geweest, dan was het werk nooit zover gekomen.

Nog groter was de slag op het Ministerie. Drion was de eerste man van het Driemanschap geweest, hij had leiding gegeven aan de parlementaire behandeling van de verschillende boeken, hij was hét gezicht geweest van het nieuwe Burgerlijk Wetboek. Sinds 1961 was de organisatie van het werk aan de hercodificatie geheel op zijn persoon afgestemd en hij was voorbestemd om het gehele ontwerp tot aan de invoering te begeleiden. Zijn overlijden vormde daarom het dramatisch dieptepunt in de geschiedenis van het nieuwe B.W. en kwam bovendien op een moment dat het er somberder uitzag dan ooit. De Memorie van Antwoord Boek 3 was nog verre van definitief, het Gewijzigd Ontwerp Boek 4 werd door het notariaat unaniem afgewezen, Boek 6 R.O. lag onder een spervuur van kritiek, De Jong - coördinator van Boek 7 O.M. - was enkele dagen daarvoor met ernstige oogklachten in het ziekenhuis opgenomen en ook de voorbereiding van Boek 8 (Verkeersmiddelen en vervoer) dreigde averij op te lopen als gevolg van een gebrek aan samenwerking tussen de ontwerpers. Daarnaast bleken er aan het overgangsrecht een groot aantal haken en ogen te zitten, waarbij enerzijds de aard van de materie, anderzijds de onbekendheid

\section{WPNR 4808 (1964).}

69. Minister Scholten memoreerde in het bijzonder Drions functies in de illegaliteit. Uit zijn toespraak: "Op 4 oktober 1940 verscheen het eerste nummer van 'De Geus', een illegaal studentenblad, opgericht en geleid door de 'Gebroeders de Jong', schuilnaam van J. en H. Drion. Het boekwerk 'Onderdrukking en Verzet' (III, p. 314) zegt: 'Het werd al spoedig door vriend en vijand als richtinggevend erkend. Het richtte zich allereerst tegen de geestelijke verwarring en al te gemakkelijke vernieuwingszucht.'

Het was de voorloper van het Studentenverzet, dat later voor de financiering en verspreiding van De Geus heeft gezorgd, nadat dit blad aanvankelijk geheel gemaakt, vermenigvuldigd en verspreid was door Jan Drion en zijn broer. In het laatste oorlogsjaar was Jan Drion lid en secretaris van de Contact-commissie der Illegaliteit, waarin hij de zgn. middengroep vertegenwoordigde, waartoe o.m. behoorden het Studentenverzet, het Hooglerarenverzet en het Medisch Contact. Jan Drion was een van hen die geprotesteerd hebben, al in de oorlog in zijn blad en daarna, tegen de bijzondere rechtspleging, die z.i. niet in onze rechtsorde paste. Het tekent zijn gevoel voor onafhankelijkheid en fair play." 
met wetgeving van de ontwerper een rol speelde, terwijl de voorbereiding van de nota over Boek 5 aanzienlijk minder ver was voortgeschreden dan begroot. Cohen Jehoram benadrukt: "Dat is een heel kritieke fase geweest. Er waren natuurlijk altijd al tegenstanders geweest van het gehele project, die nu hun kans schoon zagen omdat de kroonprins van Meijers nu ook overleden was. Daarom zijn toen snel drie Regeringscommissarissen benoemd, Beekhuis, Langemeijer en Wiersma, die de kar verder hebben getrokken. Maar het was natuurlijk een crisis. ${ }^{70}$

Minister Scholten heeft vermoedelijk geen ogenblik geaarzeld ten aanzien van de vraag of het werk moest worden voortgezet en op welke wijze dat zou dienen te geschieden. Twee dagen na het overlijden van Drion, op 4 maart 1964, circuleerde op het Ministerie al een lijstje met namen van mogelijke opvolgers, opgesteld door de Minister. Daaruit blijkt, dat Scholten aanvankelijk dacht aan een Driemanschap, bestaande uit K. Wiersma (Boek 4), H. Schadee (Boek 8) en H. Drion $(3,5,6$ en 7). Met het overlijden van Drion was de gedachte aan een opdracht voor één persoon dus definitief voorbij. In de voordracht aan de Koningin schreef Scholten: "De ondergetekende heeft zich beraden omtrent de vraag door welke persoon of personen deze zware en belangrijke taak zou kunnen worden overgenomen. Dit beraad heeft hem geleid tot de conclusie dat het aanbeveling verdient deze taak te verdelen over verschillende personen, omdat zij voor één persoon te zwaar moet worden geacht." ${ }^{71}$ Later, in een interview, zei hij: "Ik dacht eerst: ik kan beter snel een man vinden, die voor negentig procent voldoet, dan lang zoeken naar één met honderd procent. Maar ik ben zo gelukkig geweest snel deze drie te vinden, die meer dan honderd procent zijn. ${ }^{\text {"72 }}$

De Minister doelde daarmee op K. Wiersma, die het erfrecht onder zijn hoede zou nemen, G.E. Langemeijer die zich zou wijden aan het vermogensrecht in het algemeen (Boek 3) en het algemeen deel van het verbintenissenrecht (Boek 6) en J.H. Beekhuis, die belast werd met het zakenrecht (Boek 5) ${ }^{73}$ Bovendien kon de Minister nog de bereidverklaring van een vierde man onthullen, $\mathrm{H}$. Schadee, die te zijner tijd belast zou worden met de verdediging van Boek $8 .^{74}$

Dat voor de verdere bewerking van de Boeken 3 en 6 de keuze op Langemeijer viel, Procureur-Generaal bij de Hoge Raad, is waarschijnlijk de verdienste van De Jong geweest. Langemeijer, die zelfs nooit lid was geweest van de Staatscommissie voor de

70. Gewezen zij op de rede van Pitlo, Verdedig Themis, uitgesproken op 8 januari 1964, waarin de hercodificatie werd afgedaan als een "zinloze verspilling van intelligentie en energie", een "forse schrede terug op de weg naar unificatie".

71. Nota van 25 maart 1964, Stafafdeling Wetgeving nr. 101/664.

72. Het Vaderland, 26 maart 1964.

73. Zie verder de brief van de Minister aan de Tweede Kamer van 16 april 1964, zitting 1963-1964, $\mathrm{nr} 7617$, stuk $\mathrm{nr}$ 1, waarin de benoeming van de drie Regeringscommissarissen (K.B. van 6 april 1964, nr 80) officieel wordt medegedeeld.

74. Waarom de Minister afweek van zijn oorspronkelijk voorkeur voor $\mathbf{H}$. Drion is mij niet bekend. Gelet echter op de ervaringen van een jaar eerder met de beantwoording van het advies van de Raad van State over Boek 6 ligt het voor de hand dat de Minister heeft gemeend dat de Leidse faculteit voor deze constructie nooit toestemming zou hebben gegeven, mede omdat zij Wiersma ook al langdurig zou moeten missen. Deze zou overigens na het overlijden van J. Drion lange tijd naast $\mathrm{H}$. Drion colleges Burgerlijk recht geven. 
Burgerlijke Wetgeving, had er namelijk niet veel zin in. Dat zei hij dan ook tegen Scholten toen deze hem vroeg de taak van Drion over te nemen: "Nee, daar voel ik mij niet geschikt voor en daar heb ik eigenlijk ook niet veel zin in." Dat de Minister uiteindelijk toch aan het langste eind trok, kwam doordat beide mannen een compromis bereikten (aan de aard van Langemeijer niet vreemd): Langemeijer zou zich richten naar het oordeel van De Jong. Als die zei: "Hij moet het doen", dan zou hij zwichten. ${ }^{75}$

Wiersma zei over zijn benoeming tot Commissaris voor Boek 4: "Jan Drion was mijn buurman, ik was dus redelijk op de hoogte van de gang van zaken; we praatten regelmatig over het nieuwe B.W. Ik ben toen door Minister Scholten gevraagd om toe te treden tot dat team, maar uitsluitend voor Boek 4, het Erfrecht. Dat hield waarschijnlijk verband met het feit dat ik in Leiden notarieel recht gaf."

De naam van Beekhuis tenslotte, was op het Ministerie al langer bekend. Beekhuis was sinds 1947 lid van de Staatscommissie voor de Burgerlijke Wetgeving, had een belangrijk aandeel gehad in de totstandkoming van de appartementenwet uit 1951, had eind jaren vijftig geadviseerd over oude zakelijke rechten en was sinds 1961 ontwerper van het luchtrecht. Bovendien gold hij, als bewerker van het onderdeel Zakenrecht van de Asser-serie, als dé expert met betrekking tot Boek 5. Een betere keus was dus moeilijk denkbaar.

Dat de Minister reeds in dit stadium de toekomstige benoeming van Schadee aankondigde was vooral om psychologische redenen. Het was enerzijds bedoeld als signaal aan de Kamer, dat het werk aan het nieuwe B.W. ondanks het overlijden van Drion nu op nog meer fronten tegelijk werd aangepakt, anderzijds was het een signaal naar Swart, de ontwerper van het binnenvaartrecht, dat deze zich voortaan diende te richten naar de wensen van Schadee.

\section{Andere maatregelen}

De benoeming van dit drietal als opvolger van Drion - in wezen een noodoplossing, omdat coördinatieproblemen niet konden uitblijven - was niet de enige maatregel waarmee Minister Scholten te kennen gaf dat er wat hem betreft de vaart nog lang niet uit was. De Minister zou kort daarop nog drie belangrijke beslissingen nemen, namelijk (a) ongewijzigde indiening van Boek 6, (b) oprichting van de Stafafdeling Wetgeving Nieuw Burgerlijk Wetboek, en (c) het starten van een Mondeling Overleg over Boek 4. Beide eerste maatregelen worden hieronder toegelicht; de verdere lotgevallen van het erfrecht zijn beschreven in Hoofdstuk 6.

\section{a. indiening Boek 6}

Bij Koninklijk Besluit van 8 augustus 1964 (zitting 1963-1964, no. 7729, stukken nrs 1,2 en 3) werd het Regeringsontwerp van Boek 6 ingediend, dat, behoudens de rechtzetting van enige drukfouten en misstellingen, geheel gelijkluidend was aan het Ontwerp-Meijers. In de Memorie van Toelichting werd volstaan met een verwijzing naar de toelichting van het Driemanschap: "Geen aparte toelichting wordt geschreven

75. Ontleend aan een interview met De Jong in het Vaderland van 5 mei 1967. 
naast de ampele toelichting van het ontwerp van wet, zoals deze door het Driemanschap is opgesteld." 76

In beginsel lagen drie factoren ten grondslag aan het besluit van de Minister in dit stadium geen rekening te houden met het advies van de Raad van State: tijdgebrek, de inhoud van het rapport van de Raad van State ${ }^{77}$ en de overwegend persoonlijke aard van de geleverde (en nog te leveren) kritiek. Het overlijden van Drion kwam daar nog bij. Eén en ander kan worden afgeleid uit een nota van P.J. Swart, die samen met De Grooth en Cohen Jehoram werkte aan de opstelling van een Nader Rapport voor Boek 6 , alsmede uit een naar aanleiding van deze nota gehouden bespreking tussen de medewerkers aan Boek 6 en de Minister. Over beide hieronder meer.

Op 24 februari 1964, een week voor het overlijden van Drion, deed Swart uitgebreid verslag van de loop van de werkzaamheden en gaf hij zijn visie op de toekomst. Volgens hem moest het uitgesloten worden geacht dat, zoals voorzien, het R.O. voor Boek 6 vóór het einde van het parlementaire jaar (zomer 1964) bij de Kamer kon worden ingediend. Weliswaar was het door De Grooth ontworpen antwoord op het advies van de Raad van State inmiddels wel voor het grootste deel besproken, maar het Departement was nog niet in de gelegenheid geweest wijzigingsvoorstellen te formuleren. Alleen al om deze reden bepleit Swart een koerswijziging:

"De stand van zaken is dat prof. De Grooth zijn reactie op het rapport van de Raad van State op schrift heeft gesteld in de vorm van een concept-nader rapport, en dat bedoeld rapport door ondergetekende grotendeels is besproken, laatstelijk aan de hand van dat concept, met prof. De Grooth en de heer Cohen Jehoram. Professor De Grooth vertrekt dezer dagen naar Louisiana. Het was onze bedoeling geweest genoemd concept een meer definitieve vorm te geven bij een bespreking in tweede lezing van het rapport en dan tevens concepten op te stellen voor wijzigingen in het ontwerp van het Driemanschap en voor de Memorie van Toelichting. Hiertoe heeft echter tot dusver de tijd ontbroken."

Een tweede probleem waar Swart op wijst, is dat het advies van de Raad van State, dat grotendeels werd geschreven door Cleveringa, op sommige punten dermate kritisch is, dat nadere studie vereist is. Dit zou betekenen dat het werk aan Boek 6 langdurig beslag zou leggen op de medewerkers van de afdeling Wetgeving Privaatrecht van het Ministerie, alsmede op de ex-leden van het Driemanschap, wier bijstand "onontbeerlijk" is. Mede daarom vindt Swart het rapport van De Grooth, waarin deze na lang aarzelen slechts een klein aantal minder belangrijke wijzigingen voorstelt, niet geschikt als basis voor het Nader Rapport. Swart:

"Meningen over de wenselijkheid van wijzigingen kunnen en zullen vooral in een materie als de onderhavige uiteenlopen. Min of meer persoonlijke factoren, waartoe zowel rechtsfilosofische inzichten als intuïtief rechtsgevoel, (meer of mindere) behoudendheid en stokpaardjes kunnen worden gerekend, zullen hier een

76. Parl. Gesch. Boek 6, p. 24.

77. Het advies van de Raad van State dateert van 20 november 1963, het Nader Rapport van 3 augustus 1964. 
betrekkelijk grote rol spelen. (..) Het voorgaande kan ten dele verklaren, dat en waarom professor De Grooth anders dan ondergetekende zich nog niet overtuigd heeft getoond van de wenselijkheid van enige wijziging van meer ingrijpende aard als bovenbedoeld. Daarop zal ongetwijfeld mede van invloed zijn, dat hij tot het Driemanschap behoort en dat hij slechts één van de driemannen is. Zonder ook maar iets aan mijn grote waardering voor zijn concept te willen afdoen, zie ik het te veel als een oratio pro domo, als een conclusie van repliek. De uiteindelijke formulering zou ik bepaald beknopter wensen. Op sommige punten overtuigt het betoog mij niet voldoende. Op andere punten zou ik er de voorkeur aan geven minder sterk voor het ingenomen standpunt te pleiten, teneinde het niet moeilijker te maken dan strikt nodig te zijner tijd een ander standpunt in te nemen. ${ }^{\text {78 }}$

Tenslotte onderstreept Swart dat wijzigingen alleen te verdedigen zijn indien het ontwerp daarmee zowel formeel als materieel "up to date" wordt gebracht en daaruit op zijn minst een standpunt spreekt ten aanzien van alle inmiddels verschenen literatuur, ook voor zover die de Raad van State niet tot opmerkingen aanleiding heeft gegeven. Daarmee zou volgens Swart veel tijd gemoeid zijn, terwijl het zeer de vraag is of zodoende de duur van de verdere behandeling van het ontwerp noemenswaardig zal worden bekort:

"Het is, waar het materiële wijzigingen betreft, mede gezien de aard van de materie, zeker niet uitgesloten, dat de Kamer uiteindelijk de voorkeur geeft aan de oorspronkelijke oplossing of aan een derde mogelijkheid, ook al omdat de Kamer zich bij haar uiteindelijk oordeel mede kan laten leiden door de inmiddels nog te verschijnen literatuur. Bovendien kan, gezien de ervaring opgedaan met de andere boeken, in het bijzonder Boek 4 en Boek 3, en de samenhang van Boek 6 met de Boeken 3 en 7, met aan zekerheid grenzende waarschijnlijkheid worden verwacht, dat bij Memorie van Antwoord talrijke min of meer ingrijpende wijzigingen in het ontwerp zullen moeten worden aangebracht. ${ }^{179}$

Zijn slotsom: "Het achterwege laten van iedere wijziging lijkt mij nog de meest aantrekkelijke propositie."

Swart was dus al vóór het overlijden van Drion tot de conclusie gekomen dat het ontwerp in dit stadium niet moest worden gewijzigd, ofschoon hij de nadelen daarvan

78. Het citaat vervolgt: "Volledigheidshalve zij opgemerkt, dat professor De Grooth zijn concept als zeer voorlopig beschouwde, dat hij geen gelegenheid had het te corrigeren en a fortiori niet om het te herzien en te bekorten." Later, tijdens een bespreking met Minister Scholten op 2 april 1964, zou De Grooth ook "uitdrukkelijk vaststellen dat het door hem ontworpen antwoord op het advies van de Raad van State niet bedoeld was als een concept Nader Rapport, maar slechts als een leidraad voor de hierover intussen gehouden besprekingen."

79. In het verlengde van deze opmerking ligt het argument "dat het ontwerp van het Driemanschap door zijn publicatie als het ware een afzonderlijke, zij het onofficiële, fase in de geschiedenis van dit ontwerp heeft ingeluid, die niet meer ongedaan gemaakt kan worden en die, wil een extra fase met alle bezwaren van dien voorkomen worden, beter kan worden gecontinueerd tot het moment waarin het parlement - althans de vaste Commissie voor Justitie - de gelegenheid heeft gehad zich daarover te uiten." 
best inzag. ${ }^{80}$ Het plotselinge overlijden van Drion maakte echter aan alle onzekerheid een einde. Van Ewijk, die nu voor de taak stond Boek $1 \mathrm{~min}$ of meer in $z^{\prime} n$ eentje in veilige haven te brengen, schreef twee weken later aan De Jong: "Ik begin ertoe over te hellen de Minister aan te raden, elke wijziging in dit stadium achterwege te laten. Niemand zal ontkennen dat het ontwerp voor verbetering vatbaar is. Dit is met elk werkstuk zo. Maar in casu leidt het geen twijfel dat het voorontwerp over het geheel als Regeringsontwerp moet worden overgenomen. De vraag is dan: waar wel en waar thans niet te wijzigen? Een duidelijk criterium doet zich niet voor. Elke wijziging is (op een doodenkele drukfout na) een subtiel werk, wanneer men al studerende ziet hoezeer alles met elkaar samenhangt en doordacht is. "81

Tijdens de bespreking met de Minister ${ }^{82}$ op 2 april 1964 kwam de vraag "wijzigen of niet" zelfs niet meer uitdrukkelijk aan de orde; iedereen was ervan overtuigd dat het Departement al zijn aandacht diende te richten op de parlementaire behandeling van de eerste vijf boeken. ${ }^{83} \mathrm{Er}$ bestond bij de Minister alleen een twijfel over de rechtzetting van de meest evidente onjuistheden, maar verder ging de discussie vrijwel volledig over de vraag welke argumenten men zou aanvoeren voor de ongewijzigde indiening, dit mede in verband met de nadrukkelijke wens van de Raad van State een nieuwe Memorie van Toelichting op te stellen. ${ }^{84}$ Op voorstel van Van Ewijk werd

80. Swart wijst daarbij op het argument dat zodoende òf de indruk wordt gewekt dat de Minister in deze geen mening heeft, of dat hij niet volledig achter het ontwerp staat, zodat het eigenlijk geen Regeringsontwerp is: "Men zou kunnen stellen dat gebleken is dat het ontwerp nog niet rijp is om ingediend te worden." Het ongewijzigd indienen zou voorts de indruk kunnen wekken dat de Regering zich wel wat erg gemakkelijk van haar taak in dit opzicht zal kwijten. Zijn conclusie: "Deze bezwaren zouden wel voor een belangrijk deel kunnen worden weggenomen door te wijzen op op de hierboven genoemde argumenten tegen wijziging in dit stadium, maar dit zal niet alle bezwaren tegen de ongebruikelijke gang van zaken kunnen wegnemen. In ieder geval zal het zeer onbevredigend zijn voor degenen die opmerkingen hebben gemaakt; dit zou wellicht aanleiding kunnen zijn hen persoonlijk omtrent de motieven in te lichten."

81. Brief van 23 maart 1963. Daarnaast wees Van Ewijk op de mogelijkheid dat na de aanbieding van het Voorlopig Verslag en na verschijning van meer literatuur weer nieuwe wijzigingen noodzakelijk zouden zijn: "Dat gevaarlijke werk zou nog te doen zijn, wanneer wij op Drions supervisie en, op het ogenblik, op volledige supervisie van jou konden rekenen. Onder de tegenwoordige omstandigheden zou bovendien Langemeijer hierin moeten worden betrokken, hetgeen al dadelijk veel tijd van hem zou vergen, terwijl het urgente werk aan Boek 3 ligt te wachten."

82. Aanwezig waren Minister Scholten, De Grooth, Langemeijer, Van Ewijk, Swart en Cohen Jehoram.

83. Hierbij moet worden bedacht dat nog steeds met een uiterst beperkte bemanning aan het nieuwe B.W. werd gewerkt. Illustratief daarvoor is dat Swart, die zich bezighield met de invoeringswetgeving van Boek 1, zijn werk daaraan moest staken in verband met de opstelling van het Nader Raport over Boek 6. Bovendien is het de vraag of de Kamer verder uitstel zou hebben geaccepteerd.

84. Zie voor dit laatste Parl. Gesch. Boek 6, p. 2 e.v. De Raad van State had overigens al eerder bezwaar gemaakt tegen deze gang van zaken, nl. bij de eerste vijf Boeken waarbij de toelichtingen van Meijers respectievelijk het Driemanschap eenvoudig werden geïnsereerd geacht in de officiële Memories van Toelichting, die zich beperkten tot het aangeven van de wijzigingen die de Regering in de oorspronkelijke ontwerpen had aangebracht. Ook voor de Kamercommissie heeft de Regering indertijd verantwoording afgelegd van deze procedure (zitting Tweede Kamer 1954-1955, nr 3766, stuk nr 3). De Kamer schreef toen in antwoord daarop dat "de algemene beschouwingen, in de Memorie van Toelichting vervat, (..) de commissie geen aanleiding gaven tot het maken van opmerkingen." (zitting Tweede Kamer 1954-1955, nr 3766, stuk nr 4). Volgens Minister Scholten rechtvaardigde deze opmerking het antwoord dat dat Kamer met deze procedure had ingestemd. 
besloten dat niet alleen in het Nader Rapport maar ook in de toelichting uitvoerig moest worden ingegaan op de argumenten die ongewijzigde indiening wenselijk maakten. ${ }^{85}$ Kennelijk bestond op het Ministerie een zekere vrees dat de Kamer het bijltje erbij neer zou gooien, zelfs al zouden de bezwaren van de Raad van State tegen inhoud en vorm van het ontwerp niet voortijdig bekend worden. Door dit complexe en onvoldragen ontwerp in te dienen, werd zij immers geconfronteerd met een last die blijkbaar zelfs voor de wetgevingsambtenaren op Justitie nauwelijks te dragen was. Bovendien zou de Kamer, anders dan het Departement, niet in de gelegenheid zijn kennis te nemen van het rapport van de Raad van State en het antwoord daarop. ${ }^{86}$

Het gevolg was wel, dat het Nader Rapport een aaneenschakeling van vage toezeggingen, halve ontkenningen en quasi-juridische argumenten zou zijn. In de woorden van Van Ewijk: "Voor instemming zowel als voor verwerping van voorstellen (zal) een zeer voorzichtig, niemand verbindend antwoord moeten worden gevonden. Evidente misvattingen e.d. kunnen uiteraard meer positief afgedaan worden. Bij alles moet ook bedacht worden dat een en ander later gepubliceerd zal worden."

\section{b. oprichting Stafafdeling Wetgeving NBW}

Een tweede maatregel waarmee Scholten liet zien dat hij zijn vertrouwen in de hercodificatie nog niet had verloren, bestond in de splitsing van de Stafafdeling Wetgeving in drie afzonderlijke afdelingen, te weten de afdeling Wetgeving Publiekrecht, Wetgeving Privaatrecht en Wetgeving Nieuw Burgerlijk Wetboek. De Minister had eind 1963 , toen in de Kamer de uitbreiding van de bezetting van de Stafafdeling Wetgeving ter sprake kwam, er al op gewezen dat hij, indien noodzakelijk, niet zou schromen verdergaande maatregelen te nemen: "Ik meen, dat op dit ogenblik, gezien de bestaande behoefte, het werk kan worden gedaan; uitbreiding heeft ook plaatsgehad in de publieke sector van de stafafdeling Wetgeving. Dit alles is dus niet alleen gericht op de kwestie van het nieuwe B.W. Mocht mij in de loop van de tijd echter blijken, dat het toch niet voldoende is en dat het inderdaad ook efficiënt is om nog een verdergaande uitbreiding te bereiken, dan zal ik dit zeker overwegen. ${ }^{87}$

Deze splitsing werd in de vroege herfst van 1964 geëffectueerd. Van Ewijk werd daarbij benoemd tot hoofd van de afdeling NBW, Belinfante kreeg Privaatrecht onder zijn hoede en Duk Publiekrecht. Tevens besloot Scholten de bezetting van de

85. Van Ewijk vatte tijdens de discussie de naar voren gebrachte argumenten als volgt samen: "Behalve aflossing van de wacht is hier nog aan te voeren het argument dat wij wachten op meer literatuur over het zesde Boek en het V.V. alvorens nu incidentele wijzigingen aan te brengen. Ook zullen wijzigingsvoorstellen die nu onze instemming hebben, in een iets later stadium toch minder juist kunnen blijken. Vervolgens moet ook worden aangevoerd dat het ontwerp een zo ragfijn en organisch geheel vormt, dat incidentele voorstellen tot wijziging zoals ze tot nu toe veelal gedaan zijn, door juristen die nog niet een vergaande kennis van het geheel hadden - en ook niet konden hebben - tot de grootste ongelukken en verstoringen van het bouwsel zouden kunnnen leiden. Tenslotte mag ook wel gezegd worden dat wijzigingsvoorstellen in ieder geval besproken moeten zijn met de nog levende driemannen." Zie ook Parl. Gesch. Boek 6, p. 12, 24 en 26.

86. In dit verband is het wellicht nog een voordeel geweest dat de Kamer haar werk geheel had uitbesteed aan de bijzonder griffier, waardoor zij pas begin 1966 daadwerkelijk werd geconfronteerd met de feilen van het ontwerp.

87. Handelingen Tweede Kamer 1963-1964, p. 399. 
Stafafdeling Wetgeving NBW uit te breiden tot zes man, waarvan twee uitsluitend belast zouden zijn met het voeren van het secretariaat. ${ }^{88}$ In de begroting voor 1965 werd één en ander als volgt toegelicht:

"Voor een juiste vervulling van de ten Departemente van de ondergetekende te behartigen taken dient er naar te worden gestreefd, dat de organisatie van het Ministerie op adequate wijze aangepast blijft aan zich veranderende omstandigheden en inzichten. Dit streven heeft de ondergetekende ertoe gebracht het voor de voorbereiding van de wetgeving in zijn ressort bestemde departementale apparaat, t.w. de Stafafdeling Wetgeving, nader in te delen in een drietal stafafdelingen. De naaste aanleiding hiertoe is de ontwikkeling van de werkzaamheden aan het nieuwe Burgerlijk Wetboek. De omvang, de bijzondere aard en de te verwachten duur van de werkzaamheden, vereist voor het tot stand brengen en invoeren van een algehele hercodificatie van het privaatrecht (..) rechtvaardigen naar zijn oordeel de instelling van een afzonderlijke stafafdeling, die zich geheel op deze werkzaamheden kan concentreren. ${ }^{189}$

Door voor deze aanpak te kiezen werd het belang dat Scholten persoonlijk hechtte aan de totstandkoming van een nieuw B.W. niet alleen nog eens extra benadrukt, maar gaf de Minister tevens aan dat de herziening niet tot gevolg moest hebben dat op zichzelf wenselijke herzieningen door het werk aan het nieuwe B.W. vertraging zouden oplopen. Juist die laatste categorie nam sinds het begin van de jaren zestig sterk toe, als gevolg van de internationale ontwikkelingen (E.E.G.). In 1970, in zijn rede bij de invoering van Boek 1, zei Scholten het als volgt: "Het feit dat het tot standbrengen van het nieuwe B.W. veel en veel meer tijd kost dan aanvankelijk werd gedacht, levert een apart probleem op, een probleem van wetgevingsbeleid. Het is het probleem van het tussentijds partieel wijzigen van het bestaande Burgerlijk Wetboek of het wachten met een wijziging tot het betreffende boek gereed zal zijn en bovendien de invoeringswet is tot stand gebracht. (..) Donker dacht nog in termijnen van vier en vijf jaar. Hij kon nog volstaan met de stelling dat de waarschijnlijkheid van partiële wijzigingen van geval tot geval moest worden bezien. Nu kan men daar niet meer mee volstaan. Wij hebben ons ingesteld op een langdurig en stug werk aan het nieuwe B.W. en weten dat daardoor meer partiële wijzigingen van het bestaande recht tussentijds nodig zijn, dan aanvankelijk werd gedacht." 9091

88. Overigens zou het tot ver in de zeventiger jaren duren alvorens deze uitbreiding volledig zou zijn gerealiseerd. Van Ewijk stelde namelijk bijzonder hoge eisen aan zijn medewerkers, waardoor het moeilijk was iemand voor een dergelijke loopbaan te interesseren. Tot 1968 werd het werk op het Departement aan het nieuwe B.W. dan ook voornamelijk door Van Ewijk gedragen, bijgestaan door slechts één medewerker.

89. Zitting Tweede Kamer 1964-1965, nr 7800, stuk nr 2, p. 1. Het citaat vervolgt: "Zij (de Stafafdeling NBW) heeft derhalve tot taak deze werkzaamheden ten dele zelf te verrichten en ook voor het overige, voor zover deze door anderen worden verricht, de gehele arbeid aan het nieuwe Burgerlijk Wetboek te coördineren en het contact te onderhouden met de rechtsgeleerden die zich buiten het departement van de ondergetekende aan deze arbeid wijden."

90. Het nieuwe personen-en familierecht, bijzonder nummer van het Nederlands Juristenblad ter gelegenheid van de invoering van Boek 1 van het nieuwe B.W., p. 11 e.v. 
Ongetwijfeld heeft het besluit van Scholten tot oprichting van een afzonderlijke wetgevingsafdeling voor het nieuwe Burgerlijk Wetboek een positief effect gehad op de gang van zaken. Critici van het project werd de wind uit de zeilen genomen, doordat het normale wetgevende werk geen nadeel ondervond van het werk aan het nieuwe B.W., voor Van Ewijk en zijn staf werd een eigen positie gecreëerd, die zo nodig ook bescherming bood tegen wijzigingen in de top van het Ministerie. Niettemin zouden de leden van de Stafafdeling NBW na verloop van tijd steeds vaker worden ingeschakeld bij belangrijke beleidsaangelegenheden, het nieuwe B.W. niet rakend. Dat was echter louter een gevolg van de op de afdeling aanwezige kennis en expertise. $^{92}$

91. $\rightarrow$

91. Overigens waren het niet alléén overwegingen van wetgevingsbeleid die bij Scholten een rol speelden. Bij het uitstippelen van de promotiegang van de hoofdambtenaren bij de Stafafdeling Wetgeving werd namelijk steeds ermee rekening gehouden dat Van Ewijk eind 1963 benoemd zou worden tot raadsheer in de Hoge Raad. Toen dit niet gebeurde, omdat Van Ewijk het belang van het nieuwe B.W. liet prevaleren, had dit tot gevolg dat de promotiegang van de anderen werd belemmerd. In verband hiermee én met het oog op de inmiddels aan de dag getreden stagnatie in het werk voor het nieuwe B.W. werd besloten tot oprichting van de afdeling NBW.

92. Zie hieronder, Hoofdstuk 7. 
Hoofdstuk 6

BOEK 4: ERFRECHT (1964-1994) ${ }^{1}$

\section{Inleiding}

In Hoofdstuk 5 is aangegeven welke gevolgen het overlijden van Drion had voor de voortgang van de hercodificatie, alsmede de reactie van Minister Scholten daarop. Als gevolg daarvan moest de beschrijving van de geschiedenis van Boek 4 tijdelijk worden onderbroken. In dit hoofdstuk pakken we de draad weer op, en wel bij het Mondeling Overleg over Boek 4 G.O.

\section{Mondeling Overleg Boek 4}

Een derde en laatste maatregel waarmee Scholten aangaf dat het werk onverminderd doorgang zou vinden, was het doorzetten van de behandeling van Boek 4, ondanks het verzet van de notarissen.

Hiervoor bleek, dat Van der Ploeg aan de Minister de toezegging had gedaan dat zijn concept-rapport over afdeling 4.3.3 eerst met Drion en Van Ewijk zou worden besproken, voordat het in het WPNR zou worden gepubliceerd. Op 5 maart 1964, enkele dagen na het overlijden van Drion, ontving het Ministerie echter het concept, met daarbij de boodschap dat men het in overleg met het Tweede Kamerlid Versteeg, die een deel van de vergaderingen van de Commissie Erfrecht had bijgewoond, ook maar alvast aan de Kamercommissie had gezonden. Van der Ploeg: "Na het overlijden van Drion kreeg ik alleen met Van Ewijk te maken. Ik heb toen tegen mijzelf gezegd, ik vind dat als wij dat overleg gaan voeren, de Kamercommissie dan net zo goed recht heeft op informatie."

Zoals te verwachten was, liet dit deel van het rapport van de Commissie Erfrecht de vaste Commissie niet onberoerd. Op 18 maart 1964 vond op uitnodiging van haar een bespreking plaats met een delegatie van de Broederschap, waarin de problemen met betrekking tot de positie van de langstlevende echtgenoot en de legitieme uitgebreid aan de orde kwamen. ${ }^{2}$ De slotsom dit overleg was dat de vaste Commissie

1. "Men dient eerbied te hebben voor de kennis en kunde van hen, die onze wetsontwerpen voorbereiden. Maar dat behoeft geen beletsel te zijn om daarnaast te erkennen, dat men een zoo technisch en nauwkeurig in elkaar passend deel van het recht als het erfrecht niet wijzigen kan zonder bij de voorbereiding hen te betrekken, die door hun dagelijkschen werkkring op dit gebied meer deskundig zijn dan de meesters en doctors in de rechten, die tijdens hun academische studie meestal zeer weinig van het erfrecht hooren en leeren, in ieder geval niet die eigenaardige technische vaardigheid bezitten die dit recht in zijn toepassing verlangt. Waarom heeft de Minister niemand uit de notariële wereld bij de voorbereiding van dit ontwerp geraadpleegd? Ik heb het reeds meermalen gevraagd, maar nog nimmer een bevredigend antwoord op deze vraag gekregen. " E.M. Meijers, WPNR 2778 (1923).

2. Uit het verslag van die bespreking blijkt dat de broederschap sterk afwijzend stond tegenover een legitieme voor de echtgenoot, omdat deze figuur slechts interessant zou zijn voor een zeer kleine groep van de grotere vermogens $(5 \%)$ en de testeervrijheid zou beperken. Bovendien zou zij tot gevolg hebben dat op zichzelf gewenste huwelijken om dit punt niet door zouden gaan. Wel was men voor een verzorgingsrecht, even dwingend als de legitieme. Voor de kinderen werd een legitieme 
mét de notarissen voorlopig van mening was dat met het oog op de legitieme een nieuw ontwerp nodig zou zijn, en dat in verband daarmee een Nader Voorlopig Verslag zou worden uitgebracht. Tevens werd daarbij de afspraak gemaakt dat het notariaat zo mogelijk bij het vervolgens met de Minister te voeren overleg aanwezig zou zijn. In de herinnering van Van der Ploeg: "Van Rijckevorsel kwam toen met het voorstel dat wij de vergaderingen zouden bijwonen zodra Wiersma het ontwerp in het Mondeling Overleg zou gaan verdedigen. Toegegeven, het was een hoogst ongelukkige oplossing, maar het was toch door de voorzitter van de vaste Commissie zo naar voren gebracht en wij hadden ons daarbij akkoord bevonden. ${ }^{\text {"3 }}$

Voor Van der Ploeg, die, gelet op zijn eerdere ervaringen met Van Ewijk, weinig vertrouwen had in het overleg met het Ministerie, was er na deze toezegging weinig reden meer contact met Wiersma op te nemen. Van Ewijk, 15 april 1965: "Na zijn benoeming heeft Wiersma contact met Van der Ploeg opgenomen, zonder het beoogde resultaat, bespreking van het concept. ${ }^{4}$ Pas op 2 februari 1965 zou er een kort gesprek plaatsvinden tussen Van Ewijk, Wiersma, Van der Ploeg en Treurniet, met als onderwerp de legitieme (afd. 4.3.3). Het gesprek liep op niets uit. Wel werd de afspraak gemaakt dat de publicatie van het rapport (na enige heroverweging) in het WPNR zou worden voortgezet. Van der Ploeg: "Na drie uur praten waren we niets verder. Toen hebben Treurniet en ik gezegd, we moeten nu weer naar ons kantoor. Van Ewijk nam ons dat in hoge mate kwalijk. Hij had de illusie gehad dat we een paar dagen achtereen konden vergaderen. Maar met Van Ewijk kon je moeilijk overleggen. Ik ben maar een amateur, hij zat er volledig in. Wij hebben dus niet van harte meegedaan."

Omstreeks september 1964 was de vaste Commissie zover dat het Nader Voorlopig Verslag in concept gereed was. Uit dit verslag bleek dat over sommige vraagstukken, met name wat betreft de legitieme, zich een evolutie in de gedachtengang had voorgedaan.

Samengevat kwam het standpunt van de Commissie erop neer dat de voorkeur werd gegeven aan een systeem waarin de legitieme werd gehandhaafd, met uitzondering van de legitieme van de echtgenoot, die in plaats daarvan een verzorgingsrecht en een ongeclausuleerd voordeel zou moeten krijgen. Een dubbele regeling, zoals voorgesteld in het Gewijzigd ontwerp, werd afgewezen omdat er bij de Commissie twijfels bestonden aan de practische hanteerbaarheid. Bovendien zou de regeling "van het goede teveel" zijn. De legitieme van de ouders wenste de vaste Commissie te

2. $\rightarrow$

bepleit, liefst in geld uitkeerbaar. Het voordeel diende ook te vervallen. In plaats daarvan zou er een automatisch recht op de inboedel moeten bestaan, hetgeen de zaak veel eenvoudiger zou maken.

3. Uit het (korte) verslag van de vergadering d.d. 18 maart 1964: "Commissie: Het ziet er naar uit, dat met het oog op de legitieme een nieuw ontwerp nodig zal zijn. Is delegatie Broederschap bereid bij een overleg commissie-Minister aanwezig te zijn? Broederschap: Men is ertoe bereid. Voor goed begrip wordt gesteld, dat de Broederschap dan aanwezig zou zijn als "derden-deskundigen", natuurlijk niet "ter ondersteuning van deze of gene partij".

4. Eerder, op 2 april 1964, schreef Van Ewijk: "Ik schat dat prof. Wiersma vanaf een tijdstip over enkele maanden ( 1 juni of 1 juli) eerst ongeveer een jaar in beslag zal worden genomen door besprekingen ten departemente en met mr. Van der Ploeg, het Mondeling Overleg met de Commissie voor Justitie en de openbare behandeling van Boek 4 in de Tweede Kamer." 
behouden, evenals die van de kinderen. Deze zou op de helft van het versterferfdeel moeten worden gesteld. In de moderne ouderlijke boedelverdeling zag de Commisie ook wel iets, zij het dat de aanspraak van de legitimarissen op de waarde daarvan niet zou mogen worden gefrustreerd door een beding van niet-opeisbaarheid.

Kort voor de publicatie kreeg Minister Scholten echter lucht van de onderneming. Scholten, die na alle tegenslag eindelijk wel eens resultaat wilde zien, stelde zich daarop in verbinding met Van Rijckevorsel, en bracht hem van dit plan af. In de Kamer beargumenteerde Scholten deze stap als volgt: "De voorbereiding van het vierde Boek is wat betreft de behandeling door deze Kamer in een laatste stadium; ik hoop dat wij daaromtrent spoedig tot een Mondeling Overleg kunnen komen, opdat wij niet door het eindeloos wisselen van stukken de zaak langer vertragen dan nodig is. Ik meen dat, al zouden er verschillen van mening zijn, het Mondeling Overleg, ook ten aanzien van het hele erfrecht, vruchtbaarder zou zijn dan weer een lang schriftelijk verhaal enerzijds en een nog langer schriftelijk verhaal anderzijds. ${ }^{\text {"5 }}$

Snel daarna, op 9 december 1964, startte het Mondeling Overleg, om aan te sturen op behandeling vóór de zomer van 1965. Het doel van dit overleg werd in de eerste bijeenkomst als volgt omschreven: "Het doel van het Mondeling Overleg (..) is het zo mogelijk bereiken van overeenstemming ten opzichte van wat met het Gewijzigd Ontwerp moet worden gedaan. Minister en Commissie geven er de voorkeur aan, "als het even kan", niet elk met een "eenzijdig" stuk te komen, maar met een gemeenschappelijk slot van de schriftelijke voorbereiding: een verslag Mondeling Overleg gepaard aan een Nota van Wijzigingen (met definitief ontwerp). " 6 Leidraad daarbij waren de niet geacheveerde proeve van het Nader Voorlopig Verslag, te zien als een "voorlopige" commissie-inbreng in het overleg, het verschenen deel van het tweede rapport-Van der Ploeg (titels 1 en 2) en zijn concept-rapport (inmiddels gevorderd tot en met afdeling 4.6.6). De Commissie Erfrecht werd door de Minister buiten de deur gehouden. $^{7}$

Het Mondeling Overleg werd in december tot en met maart voltooid in negen vergaderingen ( 9 en 12 december 1964; 27 januari, 9, 10, 17, 24 en 25 februari, en 3

5. Handelingen Tweede Kamer 1964-1965, p. C 204.

6. In het verslag zelf (zitting Tweede Kamer 1964-1965, nr 3771, stuk nr 8, p. 1) werd één en ander als volgt omschreven: "Het leek raadzaam niet te komen met een verdere verslaggeving in de vorm van een Nader Voorlopig Verslag, maar in een Mondeling Overleg met de bewindsman te streven naar verduidelijking van wat verduidelijking behoefde en naar wijziging van wat de Commissie voor wijziging in aanmerking wilde zien gebracht."

7. Van der Ploeg zei daarover: "Nadat Van Rijckevorsel namens de vaste Commissie het voorstel had gedaan onze Commissie bij het Mondeling Overleg te betrekken, hebben we vier, vijf maanden op een uitnodiging gewacht. Op een avond werd ik opgebeld door Van Rijckevorsel, met de boodschap dat het Mondeling Overleg was begonnen en dat Scholten niet erg op het idee inging. Van Rijckevorsel heeft niet tegen mij gezegd, ik heb me ertegen verzet, hij heeft zich ook niet verontschuldigd dat ik niets had gehoord, want het was voor mij een totale verrassing. Onze Commissie had ook al die tijd het werk laten liggen, we waren nog niet tot een einde. Later heb ik vernomen dat vooral Van Ewijk zich met hand en tand heeft verzet tegen de gedachte dat er zou worden vergaderd tussen de Minister, de Volksvertegenwoordiging en een groepje notarissen." Van Rijckevorsel: "Ik kan me, gezien mijn goede verhouding met Van der Ploeg, moeilijk voorstellen dat ik me niet aan mijn afspraak heb gehouden. Ik denk dat Minister Scholten de Commissie Erfrecht er gewoon niet bij wilde hebben. Hij moest daar waarschijnlijk niets van hebben, want dan zou het Ministerie het natuurlijk heel moeilijk hebben gekregen." 
maart 1965) van de vaste Commissie voor Justitie, die volgens Van Ewijk "buitengewoon plezierig" verliepen. In dezelfde periode zouden Van Ewijk, Wiersma en Cohen Jehoram het rapport van de Broederschap in achtennegentig (!) besprekingen doornemen. Uit het verslag van het overleg, dat uiteindelijk maar liefst negenentachtig pagina's zou tellen, blijkt dat met name de erfrechtelijke positie van de langstlevende echtgenoot, die van het onwettig kind, de legitieme portie, de definitie van de uiterste wilsbeschikking en die van het legaat en de last in hun onderlinge verhouding centraal stonden.

De belangstelling van de Kamer was mager. Tijdens de vergaderingen waren steeds Van Rijckevorsel en Van den Tempel, meestal mevrouw Singer en soms Berkhouwer, Van Gelder en Meulink present. Versteeg was afwezig wegens ziekte. Dit gebrek aan belangstelling was volgens Regeringscommissaris Wiersma één van de redenen voor de betrekkelijk eenvoudige wijze waarop het overleg zou verlopen. Wiersma:

"Iemand die buitengewoon goed in de materie thuis was, was Van Rijckevorsel. Hij was voorzitter van de vaste Commissie, was zelf in het notariaat werkzaam geweest en daarbij ook voorstander van het nieuwe B.W. Hij heeft een hele positieve rol gespeeld. Verder waren er van de andere partijen ook wel bekwame juristen, maar die vroegen eigenlijk meer om uitleg: 'Of dat nu werkelijk zo erg was', en ja, dat werd van de kant van het Ministerie natuurlijk ontkend. Op die manier schoot dat Mondeling Overleg wel op. Vaak bleek ook dat de Kamer zich bij de kritiek van de Broederschap niet aansloot. Tenslotte waren er ook wel gevallen waarin aanvankelijk van de kant van de Minister of eventueel door de Commissie werd gezegd "nee, dat aanvaarden we niet", maar dat naar aanleiding van de manier waarop de Kamer zo'n punt naar voren bracht, en dat lag dan vaak ook ergens tussen wat het oorspronkelijk ontwerp was, en wat van de kant van de notarissen voorgesteld was, men tot een oplossing kwam die door de Kamer ook werd geaccepteerd."

\section{Heuff vult aan:}

"In de Tweede Kamer zat eigenlijk niet genoeg deskundigheid op dit gebied om weerwoord te geven. Van Rijckevorsel heeft, om er in te komen, nog wel een tijdje meegelopen met onze Commissie. We hebben ook contact gehad met prof. Versteeg. Deze twee mensen, die er inderdaad ook wat van wisten, want ze waren beiden kandidaat-notaris, hebben uiteindelijk toch wel voor het nodige vuurwerk gezorgd. Maar het heeft onvoldoende zoden aan de dijk gezet. Het Ministerie heeft hier toch wel sterk de doorslag kunnen geven."

Het resultaat van het Mondeling Overleg was, dat de vaste Commissie geneigd was het Gewijzigd Ontwerp (legitieme + verzorgingsrecht) te aanvaarden, ofschoon zij met de notariële commissie van mening bleef dat van een zekere overlapping sprake was. Daarvoor was wel één belangrijke concessie van de Minister voor nodig geweest. Om aan de kritiek van de Commissie Erfrecht op de regeling van het verzorgingsrecht van de langstlevende in verhouding tot de legitieme van de kinderen tegemoet te komen, werd nu voorgesteld de aanspraken van de verzorgingsgerechtigden en legitimarissen gelijke rang te geven. Zou de nalatenschap niet groot genoeg 
zijn om ieder tot zijn recht te laten komen, dan werden alle aanspraken met een gelijk percentage verminderd. Omgekeerd betekende dit wel, dat het pleidooi van de Commissie Erfrecht, dat het verzorgingsrecht zonodig de gehele nalatenschap zou moeten kunnen omvatten, door Minister en vaste Commissie van de hand werd gewezen. Tevens werd daardoor de mogelijkheid ontnomen een langstlevend altestament te maken, onaantastbaar voor legitimarissen.

Het voorstel van de vaste Commissie om de 15.000 gulden-grens van het voordeel te laten vervallen, kon de Minister niet overtuigen. De gedachte van het notariaat om de langstlevende "al" te geven in plaats van een kindsdeel, werd door de minister evenmin overgenomen. Het erfdeel van de kinderen moest naar zijn mening iets voor blijven stellen. Van Rijckevorsel was het daarmee eens: "Wat Van der Ploeg destijds wilde, de langstlevende al, dat kun je bij testament doen, want daarvoor is een testament. Alleen als je als notaris beide partijen voor je ziet, kun je alle factoren die je daarbij moet betrekken, zoals leeftijd, onderlinge verhoudingen en vermogensgrootte, laten meewegen. Maar een wetgever kan dat niet."

\section{3. "Een geroepen verdediger"}

Minister Scholten zou niet het genoegen smaken Boek 4 in de Kamer te kunnen verdedigen. In het voorjaar van 1965 viel het Kabinet, met als onverwacht resultaat een troostprijs, volgens Van Ewijk - dat Samkalden op 14 april 1965 opnieuw de leiding kreeg over het Departement. De openbare behandeling van Boek 4, voorzien in het voorjaar van $1965^{8}$, liep als gevolg van deze crisis opnieuw enkele maanden vertraging op.

Samkalden werd weinig rust gegund. Reeds een dag na zijn aantreden ontving hij een nota van Van Ewijk, waarin het voorlopig resultaat van het Mondeling Overleg uit de doeken werd gedaan, alsmede een opsomming werd gegeven van punten die zich niet leenden voor een beslissing op ambtelijk niveau. Uiteraard hoorde daarbij de problematiek van de afdelingen 4.3.3 en 4.3.4.

Kennelijk putten ook de notarissen hoop uit het aantreden van Samkalden, want op 15 april 1965 ontving de Minister tevens een brief van de beide Broederschappen, waarin de publicatie van het beruchte derde deel van het rapport (inzake afdeling 4.3.3 en 4.3.4) werd aangekondigd en waarin zij het onaanvaardbaar over dit deel van het ontwerp uitspraken:

"De ontworpen regeling van de legitieme en van de wettelijke rechten ondervindt in het hierbij aangeboden rapport ernstige kritiek. De Hoofdbesturen van de beide Broederschappen stemmen met die kritiek in en zijn van oordeel dat het hun plicht is van de overwegende bezwaren die het Notariaat tegen de ontworpen regeling heeft, duidelijk te doen blijken. De nieuwe regeling over de legitieme is dermate ingewikkeld, dat de praktijk er niet mee zal kunnen werken.

8. Op 23 maart 1965 (handelingen Eerste Kamer 1964-1965, p. 551) zei Scholten: "Op het ogenblik is de griffier van de commissie bezig het verslag op te maken. Ik hoop dat nog in de loop van de maand mei een nota van wijzigingen in verband met het gevoerde overleg zal kunnen worden ingediend, zodat het mogelijk moet zijn nog in dit parlementaire jaar (..) tot de behandeling van Boek 4 in de Tweede Kamer te komen." 
Dit alles is voor de Hoofdbesturen aanleiding deze nieuwe regeling onaanvaardbaar te achten." 9

Minister Samkalden zette echter door, ofschoon hij eerder zijn voorganger Scholten nog min of meer had gekapitteld omdat diens weinig uitgewerkte tijdschema ertoe zou kunnen leiden dat Kamer en belanghebbenden onvoldoende gelegenheid zouden hebben hun oordeel te vormen over de Regeringsvoorstellen. ${ }^{10}$ Wél zou de Minister, die zich ter voorbereiding op de openbare behandeling in de week van 6 mei met Van Ewijk, Wiersma en Cohen Jehoram ${ }^{11}$ terugtrok op de Hoge Veluwe, de notarissen nog in zoverre tegemoetkomen, dat op zijn voorstel de legitieme portie van de echtgenoot bij Nota van Wijzigingen werd geschrapt. In plaats daarvan werd de langstlevende een som ineens in het vooruitzicht werd gesteld, minimaal gelijk aan de legitieme portie, maximaal tot het bedrag, waarover de legitieme porties worden berekend, indien, zijn vermoedelijke levensduur in aanmerking genomen, het bedrag van deze som niet toereikend is voor zijn verzorging. Aldus konden volgens de Minister de te verwachten complicaties van de samenloop van legitieme en verzorgingsaanspraak worden vermeden zonder de gedachte die aan de legitieme voor de echtgenoot ten grondslag ligt prijs te geven.

Het Eindverslag (vastgesteld 22 juni 1965) van het op 3 maart 1965 beëindigde Mondeling Overleg bevatte daarom nog een aanhangsel, reagerende op de te zelfder tijd verschenen Nota van Wijzigingen (met toelichting) van Samkalden, waarin achtenzeventig veranderingen werden voorgesteld. De in dit aanhangsel opgenomen vraagpunten werden beantwoord in een nota van 26 augustus 1965, en ging vergezeld van een tweede Nota van Wijzigingen, opgesteld door Van Ewijk en Cohen Jehoram. De Minister leverde vanuit Meijers' oude vakantiehuis te Belle-Ile commentaar.

Kort voordat de openbare behandeling zou plaatsvinden, deed de Broederschap nog een laatste, vermetele poging Minister en volksvertegenwoordiging op andere gedachten te brengen. Bij brief van 7 september (ook wel gedateerd op 27 augustus 1965 en afgedrukt als bijlage bij WPNR 4871) werd de Minister gevraagd de behandeling op te schorten en met de Commissie Erfrecht in overleg te treden. Tevens werd het laatste deel van het rapport ingezonden, onder mededeling dat daarin

9. Het citaat vervolgt: "De Hoofdbesturen van de Broederschappen hebben enerzijds grote bewondering voor de wijze waarop in het Gewijzigd Ontwerp door de ontwerpers de regeling ten einde toe is doorgedacht. Anderzijds betreuren de Hoofdbesturen het dat het Gewijzigd Ontwerp niet meer bij het bestaande recht aansluit en dat vrijwel geheel nieuw recht is ontworpen. Naar het oordeel van de Hoofdbesturen is het evenwel met het bestaande recht niet zo gesteld, dat daarvoor in de plaats een geheel nieuw recht moet treden. Dit ontwerpen van nieuw recht heeft er, tezamen met de neiging teveel in bijzonderheden tredende regelingen te geven, toe geleid, dat regeling van de legitieme en de wettelijke rechten van 18 artikelen, behelzende 47 alinea's, in het ontwerp-Meijers, is uitgedijd tot 31 artikelen, behelzende 73 alinea's in het Gewijzigd ontwerp. Een en ander is geresulteerd in een voor de praktijk onhanteerbaar geheel." (Zie WPNR 4860 en Bijlage I Rapport Erfrecht II, 1963-1966.)

10. Zie handelingen Eerste Kamer 1963-1964, p. 395.

11. Langemeijer zou één dag aanwezig zijn. Cohen Jehoram zei daarover: "Samkalden besteedde er nóg meer aandacht aan dan Scholten. Hij was meer Indoloog dan jurist en kende het erfrecht niet. Samkalden, Wiersma, Van Ewijk en ikzelf hebben ons toen een week teruggetrokken op de Hoge Veluwe. Daar heeft hij zich door ons laten "repeteren". In de kortst mogelijke keren had hij het erfrecht onder de knie en kon hij het in de Kamer verdedigen." 
geen rekening was gehouden met de reeds verschenen Nota's van Wijzigingen. ${ }^{12}$ Een citaat:

"Het ontwerp moge theoretisch en dogmatisch verre uitsteken boven de bestaande, dikwijls gebrekkige, wettekst, doch deze suprematie weegt voor de rechtspraktijk niet. Het huidige erfrecht is boven de wettekst uitgegroeid. Een bijna 130-jarige rechtspraak heeft grotendeels aangevuld, wat aanvulling behoefde, ook de wetenschap heeft haar taak in deze verstaan. Prof. Meijers heeft de stof geordend en op de meeste punten vaste leiding gegeven.

Aan veel van het nieuwe, dat het ontwerp brengt, is in de praktijk geen behoefte gebleken.

Het rapport van de Commissie Erfrecht onthult vele bezwaren, die de praktijk van dit nieuwe zal ondervinden.

De Hoofdbesturen delen deze bezwaren, ook na kennisneming van de hiervoor bedoelde nota's van wijziging, en zij geven in ernstige overweging met de gegronde kritiek, welke de Commissie in haar rapport naar voren heeft gebracht, rekening te houden, en de openbare behandeling in de Staten-Generaal op te schorten tot nader overleg met de Commissie."

Voor Samkalden was deze brief aanleiding Van der Ploeg bij zich te ontbieden. Er was echter al teveel voorgevallen. Bovendien zou alleen een radicale wijziging het ontwerp voor het notariaat aanvaardbaar hebben gemaakt, gezien de strekking van rapport II. Van der Ploeg: "Samkalden heeft mij opgebeld om á titre personel bij hem te komen spreken. Ik werd als het ware opgeroepen. Dat was enkele dagen voor de Kamerbehandeling. Ik ging daar met een bezwaard hart naar toe, ik ben geen groot onderhandelaar. Samkalden opende het gesprek, begon over koetjes en kalfjes om de weg een beetje te effenen. Toen we dan tot zaken kwamen, moest ik zeggen, het spijt me, maar het is uit. Toen is hij ontzettend teleurgesteld geweest."

In zijn antwoord aan de Broederschap, gedateerd 21 september 1965, gaf de Minister aan waarom hij er niets voor voelde de behandeling in dit stadium nog af te breken: "Een opschorting zou, gegeven de talrijke andere werkzaamheden die de Staten-Generaal in dit zittingsjaar wachten, een vertraging van zeer vele maanden betekenen, welke de voortgang van de voor de vaststelling van het nieuwe Burgerlijk Wetboek in zijn geheel nodige arbeid in ernstige mate zou schaden. Deze omvangrijke arbeid dient met alle beschikbare krachten te worden voortgezet en na de aanstaande openbare behandeling van Boek 4 te worden geconcentreerd op de behandeling van de ontwerp-Invoeringswet van Boek 1 en op de vaststelling van de Boeken 3 en 5." ${ }^{13}$

12. Van der Ploeg: "Ik was het min of meer beu toen de Tweede Kamer zonder ons het Mondeling Overleg begon. Wij hadden toen nog geen reactie gegeven op de vereffening. Ik was daarmee nog niet klaar, want ik had al die tijd moeten wachten omdat Van Rijckevorsel pas zo laat mededeelde dat de vaste Commissie zonder ons aan het werk was gegaan. Heuff heeft dat onderdeel toen afgemaakt." 13. Wél gaf de Minister aan dat wat hem betreft de deur niet helemaal dicht was: "U kunt er intussen van verzekerd zijn dat ik ernstig zal overwegen in hoeverre in een later stadium alsnog gezette aandacht aan diverse in het tweede rapport gemaakte opmerkingen kan worden besteed." Vergelijk ook handelingen Tweede Kamer 1965-1966, p. 106. Samkalden zei daar: "Zou aan de wens van de beide notariële Broederschappen worden voldaan, dan zou (..) het codificatiewerk niet alleen voor 
Inderdaad zou pas in 1971 weer een onderdeel van het nieuwe B.W. de Kamer bereiken; Bovendien zou het overleg met het notariaat over Boek 4 in 1974 in grote verwarring eindigen.

\section{Boek 4 door de Tweede Kamer aanvaard}

De openbare behandeling vond plaats op 22 september 1965. Daarna werd op 30 september Mondeling Overleg gevoerd over de amendementen. Het belangrijkste amendement was dat waarbij de erfrechtelijke positie van het natuurlijke kind werd gelijkgetrokken met die van het wettige. Dit amendement werd - volkomen onverwachts - bij meerderheid van stemmen aanvaard. ${ }^{14}$ Een voorstel van Van Rijckevorsel om, conform de wens van de notarissen, de "bodem" te schrappen en het verzorgingsrecht van de langstlevende te laten prevaleren boven de legitimarissen, moest bij gebrek aan steun worden ingetrokken. Wiersma zou later zeggen dat de Kamer in alle fasen de kinderlegitieme heeft willen handhaven, te beginnen met Zeelenberg in 1953. ${ }^{15}$

Op 5 en 6 oktober 1965 werd de openbare behandeling voortgezet en voltooid, waarbij het ontwerp zonder hoofdelijke stemming werd aangenomen. De aanvaarding van het ontwerp was op geen enkel moment in gevaar gekomen. Wel werd het enthousiasme enigszins getemperd door de kritische houding van het notariaat. Het was dan ook moeilijk aan het laatste, dat in het Gewijzigd Ontwerp werd geboden, de gedachte te verbinden dat het de oplossing was waarop door de praktijk reeds jaren werd gewacht.

13. $\rightarrow$

Boek 4 maar vooral voor de andere Boeken die nu aan de orde moeten komen, grote vertraging ondervinden. Noch de Minister, noch de ambtenaren van het Departement die met de voorbereiding van het nieuwe B.W. zijn belast, kunnen meer dingen tegelijk doen dan zij thans reeds op dit gebied doen. Opschorting van de arbeid aan Boek $4 \mathrm{om}$ overleg met de notarissen te kunnen plegen, zou noodzakelijkerwijs betekenen een opschorting van de arbeid aan de Memories van Antwoord met betrekking tot Boek 3 en Boek 5 voor wat betreft het deel - dat is niet het onbelangrijkste deel - dat ten departemente in overleg met degenen, die bij de voorbereiding van die memories de leiding hebben, moet worden beslist."

14. Cohen Jehoram zei daarover: "Op een gegeven moment kwam Van den Tempel (PvdA) bij Van Ewijk om een amendement te laten formuleren teneinde de positie van onwettige kinderen gelijk te stellen aan die van wettige. Van Ewijk en ikzelf waren daar honderd procent voor, maar Van Ewijk vond het heel gevaarlijk, want als het zou worden afgestemd, en daar zag het gezien de krachtsverhoudingen in de Kamer naar uit, kon je een dergelijk voorstel de eerste twintig jaar wel vergeten. Van den Tempel zei: "Als ik het niet doe, dan komt de PSP ermee". Grommend voldeed Van Ewijk aan het verzoek en formuleerde het amendement, dat ook werd ingediend.

Bij het openbare debat kwam op een zeker moment de woordvoerder van de KVP, Van Rijckevorsel aan het woord, die, haaks op eerdere uitlatingen, zijn steun betuigde aan het voorstel. Van Ewijk en ik vielen in de ambtenarenloge van onze stoel van verbazing, want het betekende dat het amendement was aangenomen. De ARP die daarna aan het woord kwam, verzette zich volgens verwachting hevig tegen het amendement en de CHU meende zich op haar beurt af te moeten zetten tegen de "kleine luyden" en stemde ook voor. Dit gebeuren was een dramatisch punt bij de behandeling van Boek 4 en liet zien dat dingen waar Meijers alleen nog van kon dromen, toch in beweging kwamen."

15. Zie A.G. Lubbers, Parlementaire geschiedenis der erfrechtelijke verzorgingsaanspraken, WPNR 4953 (1967). 
Dat het echte vuurwerk uitbleef, was aan verschillende factoren te wijten. Een zeer belangrijk argument was dat de Kamer zich al sinds 1959, toen het Voorlopig Verslag over Boek 4 werd uitgebracht, diepgaand met dit moeilijke, maar politiek niet bijster interessante onderwerp had beziggehouden. Het dossier met witte stukken was inmiddels uitgedijd tot meer dan vierhonderd bladzijden, de dikke rapporten van de Commissie Erfrecht, die eveneens terdege waren bestudeerd, nog niet meegerekend. ${ }^{16}$ De erfrechtwoordvoerders van de vaste Commissie wilden nu eindelijk wel eens de vruchten plukken van deze arbeid.

Bovendien meende men dat een verder oponthoud het einde van de hercodificatie zou inhouden, enerzijds vanwege het verband met Boek 1 , anderzijds vanwege de penibele situatie op Justitie. Een stem tegen Boek 4, betekende een stem tegen de hercodificatie en daar was de Tweede Kamer destijds nog niet aan toe, vooral omdat ervan werd uitgegaan dat de Boeken $1 \mathrm{t} / \mathrm{m} 7$ omstreeks 1970 voltooid zouden zijn. ${ }^{17}$ Van Rijckevorsel, die er zeer voor heeft geijverd Boek 4 in openbare behandeling te brengen, zei het in 1965 als volgt: "Die voorbereiding heeft lang geduurd, ik wil niet zeggen te lang, maar de openbare behandeling moest nu toch eindelijk weleens plaatsvinden. Willen wij namelijk ooit komen tot de invoering van het gehele nieuwe Burgerlijk Wetboek, dan moest nu - gelet op het tot dusverre gevolgde tempo - de openbare behandeling van Boek 4 plaatsvinden om die totstandkoming niet nog verder te vertragen. ${ }^{18}$

Een tweede factor die bij de beslissing van de Kamer een rol speelde, was dat de kritiek van het notariaat niet op alle punten overtuigend was geweest, mede omdat de Commissie Erfrecht maar een deel van de notarissen achter zich had weten te krijgen. ${ }^{19}$ Van Rijckevorsel zei daarover: "Ik meen ook dat de Commissie Erfrecht niet met alternatieven kwam, dat men niet zei hoe het dan wél moest, dat daarover binnen het notariaat althans geen eenstemmigheid bestond. Ik voelde me best thuis in hun gezelschap, ik voelde veel voor hun kritiek, maar met die houding wist ik geen raad." Bovendien leek de reactie op het Gewijzigd Ontwerp wat al te heftig, vooral ook omdat in Rapport II allerlei punten aan de orde waren gesteld die eerder geen kritiek hadden ontmoet. In de herinnering van Wiersma: "Er was in de rapporten veel overhoop gehaald en uit het Mondeling Overleg hadden de Kamerleden die daaraan deelnamen toch wel de indruk gekregen dat er teveel was overhoop gehaald. Zij hadden daarom een zekere reserve om dat in het politieke debat nog weer te berde te brengen." Heuff beaamde dit: "Men heeft het idee gehad dat het van de zijde van het notariaat een enigszins overtrokken reactie is geweest. Er werd ook wel gezegd: we maken nu een wetgeving die voor het gehele Nederlandse volk is en niet alleen voor de opvattingen die in het notariaat leven."

16. Een uitzondering moet worden gemaakt voor het laatste deel van het rapport II, betreffende de afdelingen 2, 5 en 6 van titel 3 en de titels 4 en 5. Dit gedeelte zou immers eerst in september 1965 uitkomen, tengevolge van de communicatiestoornis tussen Van der Ploeg en Van Rijckevorsel.

17. Zie handelingen Tweede Kamer 1965-1966, p. 105; p. 122-123.

18. Handelingen Tweede Kamer 1965-1966, p. 22. Vergelijk ook Stoffels-van Haaften (p. 38); en Versteeg (p. 37).

19. Het voorstel om de langstlevende "al" te geven, werd in de enquête van 1960 bijvoorbeeld door slechts de helft van de notarissen onderschreven en strookte ook niet met de opvattingen van Van Oven. 
Daarnaast woog zwaar, dat de oproep van de notarissen te laat kwam en dat de rapporten bovendien al weer in bepaalde opzichten waren verouderd, omdat de opstellers geen rekening meer hadden kunnen houden met de wijzigingen, aangebracht na het Gewijzigd Ontwerp. ${ }^{20}$ Daarbij kwam, dat de vraag om de behandeling op te schorten - een vraag die tijdens de "Scheveningse" rede van 23 september 1965 door Van Hoff, de voorzitter van de Broederschap nog eens met klem was herhaald ${ }^{21}$, onvoldoende was gemotiveerd ${ }^{22}$ en ook geen recht deed aan de inbreng van de Kamer. Versteeg, die overigens bepaald niet gerust was op de kwaliteiten van Boek 4, zei daarover: "Ik vind dit een nogal erg ingrijpende vraag. Wij moeten immers wel bedenken - en dat wil ik er ook bij bedenken, bij alle kritiek die ik verder heb - dat wij door een opschorting van de bespreking een aanmerkelijk uitstel krijgen. Wij krijgen niet alleen een aanmerkelijk uitstel; Wanneer een opschorten van de besprekingen leidt tot tegenstrijdige besprekingen, tot besprekingen die spaak lopen, dan zou dat kunnen betekenen dat wij het gehele werk aan het nieuwe Burgerlijk Wetboek in de waagschaal stellen. Ik vind dit een té ingrijpende aangelegenheid. Ik vind het ook niet helemaal juist (..) dat men zegt: De behandeling in de Staten-Generaal opschorten tot nader overleg met de commissie. De "commissie" is waarschijnlijk de commissie uit de broederschappen, maar dat verzoek kan mijns inziens onmogelijk worden ingewilligd. "23

Tenslotte speelde bij sommige woordvoerders de overweging mee, dat met de vaststellingswet slechts een eerste stap werd gezet op weg naar de voltooiing van Boek 4 en dat in het kader van de invoeringswet nog alle gelegenheid was één en ander te heroverwegen, liefst in overleg met de notarissen. ${ }^{24}$ Versteeg verwoordde

20. Zie handelingen Tweede Kamer 1965-1966, p. 45. Zoals aangegeven, kan de Commissie Erfrecht daarvan onmogelijk een verwijt worden gemaakt. In de eerste plaats was er het misverstand tussen Van Rijckevorsel en Van der Ploeg, in de tweede plaats was het niet realistisch te veronderstellen dat de Commissie in een week of zes haar visie zou kunnen geven op het Eindverslag, de Nota van Wijzigingen, het Nader Gewijzigd Ontwerp en de Nota naar aanleiding van het Eindverslag, alles bij elkaar zo'n 135 pagina's witte stukken, de wetsteksten nog niet meegerekend.

21. Zie WPNR 4876 (1965). Van Hoff wees twee oorzaken aan voor de ongelukkige gang van zaken met betrekking tot wetsontwerp 3441: "Ten eerste. De ontwerpers mogen knappe theoretici zijn, zij hebben onvoldoende inzicht in en ervaring met de rechtspraktijk van zo'n specialistisch deel van het recht als het Erfrecht. (..) De Commissie Erfrecht toont in haar rapporten meerdere malen aan, dat het Gewijzigd Ontwerp teveel 'Professorenrecht' bevat, dat door 'Juristenrecht' vervangen dient te worden. Als tweede oorzaak van de 'kortsluiting' tussen de ontwerpers en het notariaat noem ik: $\mathrm{Er}$ is vrijwel geen overleg geweest tussen de ontwerpers en de Commissie Erfrecht."

22. Het oordeel, dat de rechtspraktijk niet gediend zou zijn met de aanvaarding van het ontwerp, had immers voornamelijk betrekking op afdeling 4.3.3 en niet op het ontwerp in zijn geheel. Ten aanzien van de andere onderdelen had de Commissie Erfrecht wel grote bezwaren, maar tot een zo algemene veroordeling kwam zij nergens.

23. Handelingen Tweede Kamer 1965-1966, p. 37. Vgl. ook Van Gelder, p. 45: "Ik laat even in het midden, dat men opschorting van de beraadslagingen verzoekt, wat in deze vorm natuurlijk nooit kan."

24. Van Gelder (handelingen Tweede Kamer 1965-1966, p. 45): "Het zou naar mijn mening goed zijn, dat de Minister in enigerlei vorm (..) in contact treedt met deze mensen om te zien, of men in de praktijk de mogelijke bezwaren zal kunnen ondervangen." Dezelfde, p. 47: "Naar mijn mening is het goed aan het slot nog eens te onderstrepen, dat het van belang is, dat de mensen, die er in de praktijk mee moeten werken, zich zo goed mogelijk bij dit ontwerp zullen kunnen aanpassen." Ver- 
dit punt als volgt: "Na de eventuele aanneming door deze Kamer en door die aan de overzijde (..) zal ongetwijfeld geruime tijd verlopen voordat we aan invoering toe zijn. Het zal een periode zijn, waarvan mag worden verwacht, dat de materie, die wij nu van alle kanten aan het bekijken zijn, tot rust kan komen. De kritische bestudering in die periode kan en moet een beter overzicht geven over de nieuwe regeling van het erfrecht. (..) $\mathrm{Bij}$ de invoeringswet moge de dan aan het bewind zijnde Minister niet aarzelen alsnog gebleken gebreken te doen herzien." ${ }^{25}$

Dit punt zou door Minister Samkalden ook volledig worden uitgespeeld: "Er blijft gelegenheid te over om zich met die rapporten bezig te houden en ik kan de verzekering geven, (..), dat bij de voorbereiding van de invoeringswet ook aan deze rapporten en aan hetgeen nader over het nieuwe erfrecht zal worden gepubliceerd zorgvuldig aandacht zal worden gegeven. ${ }^{\text {"26 }} \mathrm{Bij}$ repliek zei hij: "De deur (naar de notarissen) is helemaal niet dicht. Het is bepaald het tegendeel, wat ik in mijn betoog heb bedoeld tot uitdrukking te brengen. De procedure die, als dit ontwerp eenmaal wet wordt, gevolgd zal worden, zal volledig gelegenheid bieden om de bezwaren die in de rapporten van de Commissie Erfrecht tot uitdrukking zijn gebracht onder het oog te zien en daarover overleg te plegen." 27

Mede daarom zou Van Rijckevorsel, die als voorzitter van de vaste Commissie toch wel de toon aangaf in het debat, ook geen aandacht schenken aan de oproep van de notarissen: "Ik heb er volgens mij niets over gezegd. Ik geloof niet dat $\mathrm{ik}$ dat opzettelijk heb verzwegen. Het kan natuurlijk zijn - het is eigenlijk geen argument, dat geef ik onmiddellijk toe - dat ik inmiddels de ervaring had, dat het nog wel een jaar of vier, vijf kon duren voordat het nieuwe erfrecht ingevoerd was. En als het echt niet goed was, dan was er in die tussentijd nog alle gelegenheid voor verbetering. Dat is gelukkig ook zo uitgekomen. Dat was een gedachte, die, als ik het mij goed herinner, bij mij heeft meegespeeld. Ik kon dat natuurlijk niet hardop zeggen, want het is een schijnargument. Ik vond het ontwerp-Wiersma niet je dat, maar ik vond er toch voldoende positieve punten in om er ja tegen te zeggen. Ik heb er toen ook tien genoemd. Alleen de uitwerking van de erfrechtelijke positie van de langstlevende echtgenoot vond ik niet bevredigend."

Van der Ploeg schreef na afloop aan Wiersma en Van Ewijk: "Ik wil niet nalaten U beiden geluk te wensen met de aanneming door de Tweede Kamer van het nieuwe

\section{4. $\rightarrow$}

steeg, p. 37: "Zou het niet mogelijk zijn dat de Minister, wanneer dit ontwerp de beide Kamers is gepasseerd, wanneer het door H.M. de Koningin is ondertekend en wanneer het wet is geworden, niet wacht op de invoeringswet, maar binnen vrij korte tijd de Staatscommissie voor de Burgerlijke wetgeving opdracht geeft hem voor te lichten over de vraag, of er aanleiding is om deze wet op een aantal punten te herzien, voordat te zijner tijd de invoering aan de orde komt?"

25. Handelingen Tweede Kamer 1965-1966, p. 32. J.M. Polak had deze weg overigens al eerder aanbevolen, in een speciaal voor deze gelegenheid geschreven artikel: "Mocht blijken dat op bepaalde punten een andere oplossing wordt gewenst, dan zal bij de formulering de steun van de ontwerpers niet kunnen worden gemist. En als de consequenties niet terstond kunnen worden overzien, zal men er verstandig aan doen de tekst ongewijzigd te laten en in die vorm aan te nemen. Er is immers nog alle gelegenheid later, als voor en tegen rustig is overwogen, wijzigingen aan te brengen. In de invoeringswet kunnen alle oneffenheden worden gladgestreken. "WPNR 4871 (1965).

26. Handelingen Tweede Kamer 1965-1966, p. 107.

27. Handelingen Tweede Kamer 1965-1966, p. 125. 
erfrecht. (..) Al ben ik het op vele punten niet met $\mathrm{U}$ eens, dit neemt niet weg dat ik bewondering heb voor Uw werk. Tevens versta ik, dat voor $\mathrm{U}$ beiden in het bijzonder deugd doet dat het werk van Drion zijn bekroning heeft gekregen. Ik deel die gevoelens."

\section{Boek 4 bij de Eerste Kamer}

De bijzondere Commissie voor het nieuwe B.W. van de Eerste Kamer deed erg lang over het uitbrengen van haar Voorlopig Verslag over Boek 4. Pas op 12 maart 1968, ruim tweeëneenhalf jaar na de openbare behandeling in de Tweede Kamer, werd het eerste deel ingezonden, eenenvijftig bladzijden groot. Dit deel, ongewoon uitvoerig, gedetailleerd en kritisch, was geheel gevuld met algemene beschouwingen. Het tweede deel, een artikelgewijs commentaar, verscheen op 18 juni 1968 en telde zestien bladzijden. Aanvankelijk was de Minister overigens de toezegging gedaan dat het verslag in het voorjaar van 1967 zou verschijnen, hetgeen ook al rijkelijk laat was.

Eén van de redenen voor de trage totstandkoming was dat de Eerste Kamer het werk totaal niet aankon en het daarom steeds voor zich uitschoof. ${ }^{28}$ Daarbij kwam, dat de bijzonder griffier, mr. Rueb, zeer bekwaam en grondig te werk ging, maar ook zwaartillend en langzaam; Bijgevolg werd elke opmerking die over het ontwerp was gemaakt in het verslag opgenomen. In wezen had hij - met steun van de toenmalige kandidaat-notaris Van Solkema - het tweede rapport van de Commissie Erfrecht praktisch overgenomen. Ook beschikte de griffier nog over een afzonderlijke nota van de Commissie Erfrecht, handelende over die bezwaren van de notarissen, die nog niet in de Tweede Kamer waren behandeld. ${ }^{29}$

Met name van het eerste gedeelte werd op het Ministerie, zoals de Memorie van Antwoord nogal onderkoeld zegt, met "enige bezorgdheid" kennis genomen. De eerste zeven bladzijden van het verslag vormden een scherpe aanklacht tegen het vele nieuwe dat het ontwerp bracht, het gebrek aan leesbaarheid, de neiging alles tot in de details te willen regelen en de praktijkonvriendelijkheid. Met name de paragrafen 4-6 van dit zeer kritische verslag waren geheel gebaseerd op het tweede rapport van de Commissie Erfrecht.

Het Voorlopig Verslag begon met te herinneren aan het aandeel van Meijers in Boek 4 en zijn visie op de hercodificatie: "Zonder dat de Commissie in enig opzicht tekort wilde doen aan de langdurige, zich in een groot aantal verfijnde regelingen manifesterende denkarbeid van bekwame rechtskundigen en erfrechts-specialisten, meende zij het bij de beschouwing van het in het onderhavige ontwerp verrezen monumentale bouwwerk mér dan ooit te moeten betreuren, dat de oorspronkelijke bouwmeester, prof. Meijers, niet tot het einde leiding heeft mogen geven aan de schepping van dat bouwwerk." Het is mede daarom, dat zij grote moeite heeft met het voorliggend ontwerp, waarin, volgens de Commissie, tal van vernieuwingen worden geïntroduceerd, zonder dat de noodzaak daarvan "invoelbaar" is: "Wat thans

28. Het Vaderland, 28 april 1967: "Het gaat dr. Samkalden zeer ter harte dat dit vierde Boek nu maar rust bij de Eerste Kamer, zonder dat er iets aan gebeurt."

29. Deze nota is opgenomen als Bijlage IV in het Rapport Erfrecht II, 1963-1966. 
voor ons ligt (..) is een ontwerp, dat in zo sterke mate in materieel en formeel opzicht verschilt van wat tot de huidige dag als ons erfrecht geldt, dat gesproken moet worden van een geheel nieuw erfrecht, bij de schepping waarvan de grote kennis en ervaring en bovenal de wijze voorzichtigheid van prof. Meijers van onschatbare betekenis zouden zijn geweest." ${ }^{30}$

Ook de leesbaarheid van het ontwerp moest het ontgelden. ${ }^{31}$ Als één van de redenen van het gebrek aan helderheid wees de Commissie erop dat de eigenlijke basis van het ontwerp pas werd gelegd bij het gewijzigd ontwerp van 1 november 1962 , en, op het vlak van de legitieme portie en het verzorgingsrecht in maart-april 1965: "Vergelijking van dat ontwerp met het ontwerp-Meijers en met het oorspronkelijk regeringsontwerp toont aan, dat deze laatste ontwerpen thans nog slechts zijn te beschouwen als voorstudies. (..) Terwijl nu de openbare mening zich, sedert het verschijnen van het ontwerp-Meijers in april 1954 gedurende meer dan acht jaren had kunnen vormen op basis van dit, in vergelijking met de latere ontwerpen, tamelijk eenvoudige ontwerp, dat, voorbereid als het was door de behandeling van de vraagpunten in 1953, geen al te grote verrassingen inhield, heeft men drie jaren de tijd gehad voor de bestudering van een ontwerp, dat door talrijke vernieuwingen en, bovenal, door een geheel nieuwe conceptie van belangrijke delen van het erfrecht waardoor het ontwerp van hercodificatie tot herschepping werd - een geheel nieuwe problematiek schiep."

Als tweede oorzaak van het gebrek aan helderheid noemde de Commissie dat binnen een zeer kort tijdsbestek de beslissing was genomen om de legitieme portie van de langstlevende echtgenoot uit het ontwerp te schrappen, evenals het onderscheid tussen eerste en tweede echtgenoten, onder gelijkstelling van verzorgingsaanspraken en legitimarissen. Deze beslissing maakte een groot aantal wijzigingen in de tekst noodzakelijk; "Het was de indruk van de Commissie dat door deze textuele veranderingen op zichzelf reeds de leesbaarheid en overzichtelijkheid van het ontwerp zijn geschaad." Belangrijker nog was het dogmatische bezwaar: "Het zijn immers geen échte legitiemen en geen echte legaten en men moet dus steeds bedacht zijn op het bijzonder karakter van deze rechten. ${ }^{32}$

Tenslotte memoreerde de Commissie de passage uit de brief van de beide broederschappen, waarin het ontwerp werd betiteld als "een voor de praktijk onhanteerbaar geheel". Hoewel de Commissie erkende dat zij niet in staat was alle ingebrachte bezwaren op haar praktische waarde te beoordelen, noemde zij de ministeriële weerlegging met een verwijzing naar de mogelijkheid om bij de invoeringswet nog

30. Zitting Eerste Kamer 1967-1968, nr 3771, stuk nr 73, p. 1.

31. "Na bestudering van de stukken hadden," aldus p. 2-3 van het verslag, "de aan het woord zijnde leden de indruk behouden, dat de tekst van het ontwerp alléén zelfs aan vakjuristen en deskundigen op het gebied van het erfrecht te weinig houvast zal bieden om te komen tot een vlotte en juiste toepassing, dat steeds hernieuwde kennisneming van de toelichtende stukken onontbeerlijk zal zijn en dat voor een vaste interpretatie van tal van bepalingen eerst een gedegen jurisprudentie zal moeten groeien. Het is niet voldoende (..) dat de tekst van iedere afzonderlijke bepaling leesbaar en in abtracto begrijpelijk is - er zijn er ook die dat niet zijn; (..); belangrijk is ook, dat door de samenhang der bepalingen het denkpatroon van de wetgever ook zonder nadere toelichting toegankelijk is. Betwijfeld moet worden of het ontwerp aan deze eis voldoet; Met name moet dit worden betwijfeld op het stuk van de regeling van het wettelijk erfdeel enerzijds en de verzorgingsrechten anderzijds."

32. Zitting Eerste Kamer 1967-1968, nr 3771, stuk nr 73, p. 5. 
een aantal punten recht te zetten of de hoop "dat de soep der bezwaren niet zo heet zal worden gegeten als zij wordt opgediend" ${ }^{33}$, onaanvaardbaar: "Het (is) plicht die bezwaren grondig te onderzoeken, waarbij de bewijslast van haar ongegrondheid op de Regering drukt."

Het vervolg van het verslag was gewijd aan de belangrijkste thema's van het erfrecht. Onderwerpen die aan de orde kwamen waren de grondslag van het erfrecht, het erfrecht bij versterf, de kring van erfgenamen bij versterf, plaatsvervulling, versterferfrecht van aanverwanten, uiterste wilsbeschikkingen in het algemeen, legitieme portie en verzorgingsrecht, erfstelling, legaat en last en de boedelrechter. Naar aanleiding van de opmerkingen over de legitieme zij vermeld dat het Gewijzigd Ontwerp bij de Commissie "gevoelens van onbehagen had gewekt door de al te grote zucht naar het detail, waarvan dit ontwerp op vele punten blijk geeft." ${ }^{34}$ Wel bleek de Commissie, onder meer met het oog op de positie van voorkinderen, in meerderheid voor handhaving van de legitieme, ofschoon zij het moeilijk vond voor haar als zodanig en voor de regeling daarvan in het ontwerp veel enthousisme op te brengen.

Met betrekking tot de positie van de langstlevende echtgenoot stelde de meerderheid van de Commissie dat het wettelijk verzorgingsrecht, indien nodig, de gehele nalatenschap zou moeten kunnen omvatten - een minderheid meende dat de omstandigheden van het geval (restverdiencapaciteit langstlevende, positie kinderen etc.) beslissend zouden moeten zijn. Met deze uitspraak stelde de Eerste Kamer zich dus achter het standpunt van de Commissie Erfrecht. De constructie van het verzorgingsrecht in de vorm van een som ineens, te stellen op minimaal de legitieme portie van een kind, werd om dezelfde reden afgewezen. Enerzijds omdat het nogal willekeurig was aan te nemen dat iedere langstlevende dit minimum nodig zou hebben, anderzijds omdat er ook gevallen zouden zijn waarin zelfs het maximum van de som ineens niet voldoende zou zijn om de behoeften van de langstlevende te dekken ${ }^{35}$ Daarnaast vond de Commissie het bezwaarlijk dat bij hertrouwen dit deel de kinderen zou kunnen ontgaan. ${ }^{36}$ Tenslotte zou de Commissie gaarne zien, dat de mogelijkheid om een langstlevende al-testament te maken, zou worden heropend. Letterlijk stelde zij: "De Commissie was van mening, dat er alle reden was om op dit punt gehoor te geven aan de steeds sterker wordende stem van hen, die de positie van de langstlevende echtgenoot zo sterk mogelijk willen maken door haar desnoods de gehele nalatenschap te laten. ${ }^{37}$

De slotopmerking sprak voor zich: "De Commissie wilde, aan het eind van dit deel van haar beschouwingen gekomen, niet nalaten op te merken, dat vele van haar leden ernstige bezwaren hebben tegen meerdere onderdelen van het ontwerp in zijn huidige vorm. Alvorens zich echter een eind-oordeel te vormen over het ontwerp in zijn geheel, zouden zij gaarne kennis nemen van het antwoord van de bewindsman."

33. Zie handelingen Tweede Kamer 1965-1966, p. 106-107.

34. Zitting Eerste Kamer 1967-1968, nr 3771, stuk nr 73, p. 23.

35. Zie daarover A.G. Lubbers, Parlementaire geschiedenis der verzorgingsaanspraken, WPNR 4953 (1967), die aantoonde dat bij aanwezigheid van drie kinderen of meer, reeds eenderde deel van de nalatenschap zou moeten worden afgestaan, ondanks maximale behoeftigheid van de langstlevende.

36. Zie zitting Eerste Kamer 1967-1968, nr 3771, stuk nr 73, p. 28-35.

37. Zitting Eerste Kamer 1967-1968, nr 3771, stuk nr 73, p. 41. 


\section{De Memorie van Antwoord}

De Memorie van Antwoord bij Boek 4, zesenzestig bladzijden groot, werd op 3 juni 1969 door Minister Polak ingezonden aan de Eerste Kamer. Auteurs waren Wiersma, Van Ewijk en Cohen Jehoram.

De Minister begon met uiteen te zetten, dat de "enigszins ongebruikelijke" omvang van de gewisselde stukken het voordeel had, dat in de Memorie van Antwoord vele bepalingen, waarover vragen waren gesteld, konden worden verduidelijkt en toegelicht. In de Tweede Kamer was de aandacht vooral geconcentreerd geweest op de politieke keuze, nu stond vooral de technische uitwerking daarvan centraal. Wiersma zei daarover: "De behandeling in de Eerste Kamer leverde geen grote moeilijkheden op, want men had alle kracht verschoten op de Memorie van Antwoord (II) die hele zwakke plekken had, dus dat kon allemaal schriftelijk worden weerlegd."

Omdat de Minister wel inzag, dat verduidelijking alleen niet voldoende was om het ontwerp door de Kamer te krijgen, bevatte de Memorie van Antwoord daarnaast op maar liefst negenentwintig punten de toezegging dat een wijziging van het betreffende punt bij de Invoeringswet in overweging diende te worden genomen. Cohen Jehoram licht toe: "De senatoren waren inmiddels natuurlijk ook bewerkt door de Broederschap en dat leidde ertoe dat het ontwerp wel door de Eerste Kamer werd gesleept, maar niet dan nadat Minister Polak had beloofd dat er contact zou worden opgenomen met de notarissen en dat eventuele veranderingen alsnog in de wet zouden worden aangebracht." Heuff memoreert: "Eigenlijk was het zeer tot onze verrassing dat de Tweede Kamer verder niet meer naar ons wilde luisteren. Van der Ploeg heeft zich dat ook bijzonder aangetrokken. Er was echter één gelukkig ding; Onze kritiek is wel opgenomen door de Eerste Kamer en die heeft van de Minister de toezegging weten los te krijgen - anders had zij misschien wel tegen gestemd - dat bij de Invoeringswet nog allerlei dingen aan de orde zouden kunnen worden gesteld, waarbij het notariaat zou moeten worden betrokken."

De Minister ging zeer ver in zijn toezegging bepaalde onderdelen van Boek 4 opnieuw te bezien. In wezen werd de zaak volledig opengebroken, zelfs ten aanzien van het meest essentiële onderdeel, de positie van de langstlevende echtgenoot. In de Memorie van Antwoord werd daaromtrent gesteld: "Van de gevallen waarin ernstige afweging van onderdelen van het ontwerp tegen de door de Commissie in haar verslag daarop uitgeoefende kritiek, tot het inzicht heeft geleid, dat een wijziging daarvan bij de invoeringswet in overweging dient te worden genomen, noemt de ondergetekende in de eerste plaats de zo belangrijke regeling van de rechtspositie van de langstlevende echtgenoot. Zoals (..) nader wordt uiteengezet, is de ondergetekende door de in het verslag genoemde argumenten enerzijds niet geheel overtuigd van de onjuistheid van de, door de Tweede Kamer aanvaarde, regeling voor de concurrentie van het verzorgingsrecht van de langstlevende echtgenoot en de legitieme portie van afstammelingen. Anderzijds hij niet ongevoelig voor het denkbeeld van de Commissie dat het verzorgingsrecht zonodig de gehele nalatenschap moet kunnen omvatten. Hij meent derhalve dat het vraagstuk van de rechtspositie van de langstlevende echtgenoot - een materie die in sterke mate onderhevig is aan ontwikkeling van de rechtsover- 
tuiging - bij de voorbereiding van de Invoeringswet opnieuw in beraad dient te worden genomen. ${ }^{38}$

Wiersma: "Die mededeling is gedaan, omdat de Kamer weliswaar niet concreet kon zeggen, dit vinden we onaanvaardbaar, maar omdat men toch een soort van "unheimisch" gevoel had, dat er nog zoveel kritiek bleef van de kant van de notarissen, die ermee zouden moeten werken. Daarom heeft de Minister toegezegd nog eens kritisch naar de tekst te kijken en deze zonodig aan te passen bij de Invoeringswet."

Met deze toezeggingen op principiële punten en verduidelijkingen ${ }^{39}$ was Boek 4 nog niet in veilige haven. Veel zou er immers van afhangen of de te zijner tijd te presenteren voorstellen ook binnen het notariaat op voldoende steun zouden kunnen rekenen. Een toezegging van de Minister dat de nieuwe voorstellen zoveel mogelijk in overleg met de praktijk zouden worden opgesteld, was daarom onontkoombaar.

Daarnaast was het van groot belang dat deze voorstellen op korte termijn zouden kunnen verschijnen. De senaat zou er waarschijnlijk geen genoegen mee nemen indien de invoering van Boek 4 volgens plan eerst ná de afhandeling van de vaststellingswetten van de Boeken 3, 5 en 6 aan de orde zou worden gesteld. Gerekend naar het in 1967 al weer verder afgezakte tempo én de noodzaak de Boeken 3-6 gelijktijdig te behandelen, zou het in dat geval nog weleens een jaar of tien kunnen duren voordat het vernieuwde erfrecht in werking zou kunnen treden. Een onaanvaardbare situatie, temeer omdat de achterstelling van het natuurlijke kind en van de tweede of latere echtgenoot in het personen- en familierecht met de invoering van Boek 1 in 1970 zou gaan verdwijnen. Een voortrein op Boek 4 leek dus geboden, ondanks dat het vanuit een oogpunt van werklast weinig aantrekkelijk was Boek 4 te herschrijven op basis van het oude B.W., om dan enige tijd later met het oog op de invoering van de Boeken 3, 5 en 6 weer een zwaai in de andere richting te maken.

38. Zitting Eerste Kamer 1968-1969, stuk 3771, stuk nr 133, p. 1. Het citaat vervolgt: "Ook van de andere bezwaren, welke de Commissie tegen het ontwerp heeft aangevoerd, zijn er vele die de ondergetekende hebben overtuigd van de wenselijkheid om bij de Invoeringswet een wijziging van de betrokken regeling in overweging te nemen. In een aantal gevallen is daarbij een dankbaar gebruik gemaakt van de door de Commissie in haar Voorlopig Verslag met instemming vermelde voorstellen voorkomend in rapport II van de Commissie Erfrecht van de beide Broederschappen." Zie ook p. 2223.

39. De Ministeriële weerlegging van de algemene kritiek, laat ik, behoudens het hierna opgemerkte, achterwege. Betoogd werd onder andere dat Meijers de opdracht had een nieuw Burgerlijk Wetboek te maken, zodat de kritiek dat het G.O. de grenzen van een technische herziening verre te buiten was gegaan, niet terecht was; Dat Meijers zelf reeds op belangrijke punten was afgeweken van het geldende recht; Dat het notariaat voldoende gelegenheid tot inspraak had gehad, zelfs al in de tijd van Meijers. Zachtjes werd daarbij ingevlochten, dat Van Rijckevorsel een aantal vergaderingen van de Commissie Erfrecht had bijgewoond en dat het tweede rapport kritiek leverde op punten die in het eerste onbesproken waren gebleven. In de woorden van Van Ewijk, die ten behoeve van Minister Polak de gang van zaken nog eens op een rijtje zette: "Met het rapport van 1960 en met het grootste deel van het nader rapport is in de Memorie van Antwoord, respectievelijk in het Mondeling Overleg ten volle rekening gehouden, al hebben Uw ambtsvoorgangers (Scholten, Samkalden) en de Tweede Kamer de vrijheid genomen niet alle kritiek en alle voorstellen en nadere voorstellen van de Commissie Van der Ploeg over te nemen. Daargelaten dat Van der Ploeg c.s. dan waarschijnlijk nog niet uitgepraat zouden zijn, in aanmerking genomen dat allerlei, in het Gewijzigd Ontwerp niet veranderde, bepalingen van het ontwerp die in het rapport van 1960 werden onderschreven, althans niet bekritiseerd, in het nader rapport alsnog werden afgekeurd." 
Het eerste probleem loste Minister Polak op door kort voor de openbare behandeling een vertegenwoordiging uit het notariaat uit te nodigen voor een gesprek. ${ }^{40} \mathrm{De}$ in het verleden gerezen problemen hield de Minister - een kundig en charmant onderhandelaar - verre van zich, door te verklaren dat hij wat betreft Boek 4 een "erfenis had aangetroffen", en daarom "zo min mogelijk wilde ingaan op de in verband daarmee in het verleden gerezen moeilijkheden, waar hijzelf niet bij betrokken was geweest." Inzet van de bespreking was zijns inziens de vraag wat er met het erfrecht zou moeten gebeuren ná de behandeling van Boek 4 in de Eerste Kamer.

De opzet van Polak slaagde wonderwel. Van der Ploeg zei daarover: "Boek 4 is tóch aangenomen door de Eerste Kamer. Dat was de fout van onze voorzitter. Die man had geen bestuurlijke ervaring, hij kon niet tegen Minister Polak op. Kort voordat de behandeling in de Eerste Kamer zou beginnen, werden wij bij Polak ontboden. 'Wat zijn nu precies de bezwaren van het notariaat?' De voorzitter zei toen, dat de notarissen niet gelukkig waren met het ontwerp en vooral niet met het gebrek aan overleg tussen het Ministerie en het notariaat. Polak kreeg een lachje op zijn gezicht en zei, "daar kunnen we wel wat aan doen. We spreken af dat het notariaat alle gelegenheid krijgt voor overleg bij de Invoeringswet.' Dat is het keerpunt van Boek 4 geweest, anders was Boek 4 nooit aangenomen. Polak heeft toen ook duidelijk gezegd, denk erom, ik ben bang dat als het niet wordt aanvaard, het nieuwe B.W. in gevaar komt."

In concreto betekende dit, dat de afspraak werd gemaakt dat het notariaat een brief aan de Minister zou richten waarin onder andere zou worden vermeld dat er in het verleden niet voldoende overleg was geweest en dat er bij het notariaat nog allerlei wensen waren in verband met de herziening van het erfrecht, maar dat men gaarne bereid was tot overleg met de Minister hierover. De Minister zou dan vervolgens de inhoud van deze brief aan de Kamer mededelen en verslag uitbrengen over de gehouden bespreking. Het overleg zou uitdrukkelijk beperkt blijven tot technische punten.

Met deze toezegging was het gevaar van de zijde van het notariaat en - ten dele ook dat van de Eerste Kamer bezworen ${ }^{41}$. Van der Ploeg: "De Gaay Fortman vertelde mij later, toen ik mijn teleurstelling over de houding van de Kamer uitsprak: "Dát er zo'n afspraak lag, heb ik niet geweten. Anders weet ik nog niet of mijn stem wellicht niet anders zou zijn uitgevallen."

Het tweede probleem loste Polak op door ter gelegenheid van de openbare behandeling aan te kondigen dat de invoering van Boek 4 in twee fasen zou geschieden: "Ik wil onderzoeken, en ik denk dat dit ook wel zal gelukken, de invoering van het ontwerp in twee fasen te doen plaatsvinden, waarbij de eerste fase beperkt zal blijven tot enige onderwerpen van groot materieel belang, zoals het erfrecht bij versterf met de daarin opgenomen opheffing van de achterstelling van het natuurlijke

40. Deze bespreking vond plaats op 20 augustus 1967. Aanwezig waren, naast de Minister en Regeringscommissaris Wiersma, de voorzitters van de beide Broederschappen (resp. J. Schrijner en A. de Gier), hun secretarissen (resp. C.J. Boswijk en J.H. Westra van Holthe) alsmede Van der Ploeg, Heuff en Treurniet namens de Commissie Erfrecht.

41. De Minister was overigens juist op tijd geweest met zijn aanbod tot overleg. Uit het verslag blijkt dat het notariaat op het punt stond zijn veto over het ontwerp uit te spreken, en dat men voomemens was de Eerste Kamer op het gebrek aan overleg te attenderen. In de M.v.A. werd de indruk gewekt dat er wél voldoende overleg was geweest. 
kind, en voorts de rechtspositie van de langstlevende echtgenoot." 42 Daarmee werd de voornaamste critici van het ontwerp, De Gaay Fortman en commissievoorzitter Van Meeuwen ook dit argument ontnomen.

\section{Boek 4 aanvaard}

De Eerste Kamer debateerde op 9 september 1969 over het nieuwe erfrecht. Minister Polak antwoordde op 10 september, waarna het wetsontwerp vervolgens na enige korte replieken zonder hoofdelijke stemming werd aangenomen. Dat de openbare behandeling zo snel volgde op het uitbrengen van de Memorie van Antwoord, kwam doordat dit de laatste keer was waarop de Eerste Kamer in deze samenstelling bijeen zou komen. Zouden de stemmingen een week later zijn gehouden, dan zouden twee van de vijf leden die het Voorlopig Verslag hadden ondertekend, niet meer in de Kamer aanwezig zijn.

Zoals hiervoor al tot uitdrukking kwam, was het debat weinig spectaculair. Van een werkelijke gedachtenwisseling was geen sprake, de sprekers beperkten zich tot het uitspreken van zorg over het voorliggende wetsontwerp en plaatsten daarnaast enkele kanttekeningen. Boek 4 werd - met de hakken over de sloot - aangenomen, omdat men, evenals de Tweede Kamer eerder, het gevoel had dat er anders van een nieuw B.W. nooit meer iets zou komen. ${ }^{43}$ Cohen Jehoram: "Het was zoiets als "we willen niet lastig zijn en er zijn natuurlijk ook voorstemmers, maar bedenk wel dat er nog heel wat aan moet veranderen.'"

Ik vat de belangrijkste opmerkingen samen. Piket (CHU): "Ik heb enige kritische noten laten horen en gezegd dat mijn fractie geen juichtonen zal aanheffen wanneer het onderhavige wetsontwerp zal worden aangenomen. Er is echter door de Minister in de Memorie van Antwoord zo bijzonder veel toegezegd (..) dat mijn fractie vóór het onderhavige ontwerp zal stemmen." ${ }^{44}$ Delprat (VVD): "Er zal dus alle gelegenheid zijn (..) hetgeen nu vastgelegd wordt te toetsen aan de desiderata, die zeker in de naaste toekomst weer tot uiting zullen komen. (..) Ik zie trouwens geen andere oplossing, want met verwerping van het huidige wetsontwerp zou vermoedelijk niemand gediend zijn, nog daargelaten het gevaar, dat dan de animo voor de verdere herziening van het B.W. wel alom in den lande tot nul gedaald zou zijn. ${ }^{n 5}$ Brongersma

42. Handelingen Eerste Kamer 1968-1969, p. 1034.

43. Mogelijk heeft de Kamer zich ook laten imponeren door de uitspraak van G.J. Scholten op de jaarvergadering van de NJV 1969: "De Eerste Kamer, juist zij, moge bedenken dat snellere aanpassing van het recht essentieel is voor een goed rechtsbestel als zij op in hoge mate technische kwesties een aantal maatschappelijk werkelijk belangrijke wijzigingen van ons erfrecht dreigt op te houden." De Gaay Fortman repliceerde: "Het gaat zeker bij het verzorgingsrecht van de langstlevende echtgenoot om veel en veel meer dan technische kwesties. Als het alleen om technische kwesties ging zou ik zeggen: Wij behoren ons, nadat de wijzere zuster zich heeft uitgesproken naar haar beter oordeel te schikken. Wij hebben hier echter te maken met een wetsontwerp, dat op tal van punten belangrijke verbeteringen brengt." (Handelingen Eerste Kamer 1968-1969, p. 1020).

Van der Ploeg: "Scholten heeft mij in WPNR 6039 (1992) de schuld gegeven van het fiasco van het nieuwe erfrecht. 'Van der Ploeg, daar kun je niet omheen, die heeft het altijd tegengehouden.' Hetzelfde heeft hij als voorzitter van de Nederlandse Juristen Vereniging in 1969 gezegd. Ik heb me daar toen erg aan geërgerd. Het waren geen maatschappelijke ontwikkelingen. Integendeel."

44. Handelingen Eerste Kamer 1968-1969, p. 1010.

45. Handelingen Eerste Kamer 1968-1969, p. 1010-1011. 
(PvdA): "Ik weet niet hoe de stemming van de Minister op het ogenblik is, maar ik moet wel zeggen, dat ik vandaag niet bepaald een zeer grote vreugde kan voelen. Het uiteindelijke resultaat staat voor een grote vreugde bepaald nog te weinig vast. Ik kan mij in zoverre verheugen, dat ik erken dat de voordelen van het voor ons liggende wetsontwerp groter zijn dan de nadelen, waarvan ik er enige heb gesignaleerd. Ik begrijp dat de studie moet doorgaan en dat het wetsontwerp daarvoor een zeer geschikte basis is. Die hebben wij dan tenminste. Het is een beter uitgangspunt voor het komen tot een definitieve regeling van ons erfrecht dan het geldende Burgerlijk Wetboek." ${ }^{46}$

\section{De voortrein-Van Agt}

Op 20 maart 1974 werd een ontwerp van wet tot partiële wijziging van het erfrecht bij de Tweede Kamer aanhangig gemaakt. Daarmee loste Minister Van Agt de toezegging van zijn ambtsvoorganger Polak in, om onderdelen van Boek 4, waarvan de invoering niet té lang meer op zich kon laten wachten, met voorrang af te werken.

In dit zogenaamde voortrein-wetsontwerp (12863) werd de langstlevende echtgenoot tot enig erfgenaam van de eerststervende gepromoveerd. Omdat dit enig erfgenaamschap van de langstlevende echtgenoot de kinderen als erfgenamen uitsloot, kregen zij een - zes maanden na het overlijden van de erflater - opeisbaar uitkeringsrecht bij versterf ter grootte van het erfdeel dat zij zouden hebben ontvangen als zij tezamen met de langstlevende tot de nalatenschap zouden zijn geroepen. Als ze dan legitimaris zouden zijn geweest, verkregen ze - eveneens in geld - aanspraak op een quasi-legitieme. Indien de langstlevende bij testament was onterfd of niet in staat zou zijn de kinderen uit te keren, kon hij onder andere aanspraak maken op een som ineens ter verzorging, die zonodig de gehele waarde van de nalatenschap kon omvatten. Voor zover de nalatenschap na aftrek van de uitkeringsrechten bij versterf niet toereikend zou zijn voor voldoende verzorging, kwam de benodigde som ineens bovendien ten laste van de uitkeringsgerechtigden.

Met deze regeling was in feite de situatie bereikt die door een groot deel van het notariaat reeds was bewerkstelligd met de ouderlijke boedelverdeling. "De jurisprudentiële status quo ten aanzien van de ouderlijke boedelverdeling wordt gepromoveerd tot erfrecht bij versterf", schreef Van Mourik in een commentaar op het wetsvoorstel. ${ }^{47}$ Wel was er dit verschil dat de vordering van de kinderen (bijna) onmiddellijk opeisbaar was. Inzoverre verschilde het ontwerp dus niet zoveel van de bestaande wettelijke regeling, waarin aan de nakomelingen reeds dadelijk na het overlijden van de erflater een kindsdeel in de nalatenschap wordt toegekend. Bovendien verkregen in het wetsvoorstel de kinderen hun deel niet als erfgenamen, maar werden zij schuldeiser van de echtgenoot. Als de erflater bij testament zijn boedel verdeelt, zijn zijn kinderen erfgenamen, ook al krijgen zij slechts een overbedelingsvordering. Als de wetgever echter die boedel aan de langstlevende toewijst, zijn die kinderen geen erfgenamen, maar (alleen) schuldeisers van de langstlevende.

46. Handelingen Eerste Kamer 1968-1969, p. 1016.

47. M.J.A. van Mourik, Kanttekeningen bij het ontwerp voor een erfrechtelijke voortrein, WPNR 5262 (1974). 
Het wetsontwerp was niet zonder slag of stoot tot stand gekomen. Er was een langdurige periode van overleg tussen het Departement en de Commissie Erfrecht aan vooraf gegaan. Daarmee leek ook de andere belofte te zijn ingelost die Polak in 1969 had gedaan: Een ruime mate van overleg met het notariaat. In de toelichting op het ontwerp stond in dit verband te lezen: "Het verheugt de ondergetekende dat het hierbij aangeboden ontwerp kon worden opgesteld op de grondslag van in dit overleg bereikte resultaten." Niettemin zou die vreugde niet overslaan op het notariaat als geheel. Op 24 september 1974 zou de Broederschap tijdens haar jaarvergadering het ontwerp ten grave dragen.

\section{De totstandkoming van w.o. 12863}

Eén van de oorzaken waarom de voortrein zo slecht bij het notariaat zou vallen, was dat de notarissen van oordeel waren dat het Ministerie in onvoldoende mate was tegemoetgekomen aan hun wensen, dat wil zeggen, de wens van de gemiddelde erflater. Daarnaast vonden zij het ontwerp, dat geïnspireerd was door de testamentaire praktijk van de ouderlijke boedelverdeling, te ingewikkeld en praktisch niet uitvoerbaar.

Wat het eerste punt betreft, viel er wel wat te zeggen voor het standpunt van het ontwerp, dat de kinderen niet volledig moeten worden uitgespeeld tegen de langstlevende. Afgezien nog hiervan, dat de wens van de erflater slechts één van de motieven van het erfrecht bij versterf kan zijn, zijn er toch ook omstandigheden denkbaar, waarin het voor de kinderen van het grootste belang is reeds dadelijk over hun aandeel in de nalatenschap te kunnen beschikken, terwijl de langstlevende dit deel niet nodig heeft. Ook had de Tweede Kamer zich in 1965 uitdrukkelijk uitgesproken tegen een langstlevend al, terwijl daarvoor in 1960 binnen het notariaat evenmin een meerderheid was te vinden. Tenslotte moet worden bedacht, dat in 1969 de afspraak was gemaakt dat het notariaat zich zou beperken tot het oefenen van kritiek op technische punten. Veel van de kritiek zou reeds daarom haar doel missen.

De kritiek dat het ontwerp te ingewikkeld zou zijn, ondanks de bemoeienissen van de Commissie Erfrecht, is veel meer terecht. In de eerste plaats was het contact tussen het Departement en de Commissie Erfrecht weinig innig geweest; Van Ewijk, de voornaamste gesprekspartner van de zijde van het Ministerie, vond het bijvoorbeeld niet nodig dat de voltallige Commissie Erfrecht bij de besprekingen aanwezig was. Aanvankelijk was het zelfs zo, dat de deelnemers aan het overleg dit als vertrouwelijk moesten beschouwen, zodat het voor de notariële delegatie ook niet mogelijk was navraag te doen in de praktijk. Er was geen sprake van overleg, maar van een dictaat. Heuff, die Van der Ploeg in 1969 was opgevolgd als voorzitter van de Commissie Erfrecht, zei daarover: "De Broederschap heeft prof. Kleijn uit Leiden en mijzelf aangewezen als de mensen die het gesprek met Justitie moesten aangaan. We hebben toen direct tegen Justitie gezegd dat we het zeer op prijs zouden stellen als de Commissie Erfrecht bij dat overleg betrokken zou mogen worden, zodat wij een klankbodem zouden hebben om de voorstellen te bediscussiëren. Dat bleek niet 
mogelijk. Pas na een aantal gesprekken hebben we het eindelijk zover weten te krijgen dat de hele Commissie Erfrecht 'op papier' kon meepraten. "48

Niet alleen de vertegenwoording van de Commissie Erfrecht in het overleg was problematisch. Ook verliep het overleg moeizaam, omdat Van Ewijk liet blijken niet al te veel respect te hebben voor het oordeel van de praktijk. Heuff: "Van Ewijk was iemand die de notariële praktijk niet kende, bij hem ging het echt van achter het bureau. Het was wel heel knap zoals hij zich allerlei eigen wist te maken, maar hij bleef een theoreticus. Dat hij weinig oog had voor de wensen van de praktijk, heeft bijzonder veel wrijving gegeven. Telkens weer kwamen wij met allerlei bezwaren, vaak geillustreerd aan de hand van praktijkvoorbeelden, waaruit duidelijk bleek dat het anders moest. Maar daar kwam eigenlijk geen enkele reactie op. Aan het eind van zo'n gesprek kreeg je dan te horen, 'men zou het wel verder overwegen.' We hadden maar af te wachten wat er van onze opvattingen zou worden geaccepteerd, al werd ten aanzien van technische punten wel een enkele keer gezegd dat men aan onze opvatting gehoor kon geven." 49 Scheltema, die met Wiersma aanzat bij het overleg, zegt hierover het volgende: "Van Ewijk was niet een erg soepele figuur. Dat bleek ook in dat overleg, doordat zo af en toe duidelijk werd uiteengezet wat het nut was van de standpunten die wij hadden ingenomen. Het was voor een gedeelte toch het aanhoren van datgene wat de notarissen vonden, en uitleggen dat hun ideeën niet altijd verstandig waren. Als zij met voorstellen kwamen, dan wilde het ook wel eens zo zijn dat van de kant van Van Ewijk werd gezegd, want die voerde toch wel in belangrijke mate het woord bij het overleg, dat het voorstel aan de Minister zou worden voorgelegd, waarbij ik niet altijd zeker wist of het nou de Minister was of Van Ewijk." Volgens De Die, die nog de laatste vergadering over de voortrein meemaakte, werd er - althans tijdens dié bijeenkomst - meer gezwegen dan gesproken.

Tenslotte werd het overleg bedorven doordat het Ministerie altijd nog kon terugvallen op de vaststellingswet. Heuff: "Er hing boven de vaststellingswet een soort zwaard van Damocles, zij het dat het Ministerie vrij stevig stond, omdat de wet was aangenomen. Dat argument kwam in het overleg zo nu en dan wel weer even opzetten. Dan zei men, als we er nu niet uitkomen, nou, dan houden we toch vast aan de tekst van Boek 4." Luijten: "Dat men kon terugvallen op de vaststellingswet was een heel belangrijk argument."

Het gevolg was, dat het compromis dat uiteindelijk uit de bus kwam, schoorvoetend door de Commissie Erfrecht en het Hoofdbestuur van de Broederschap zou worden geaccepteerd. De Notariële Raad deed er dan ook een jaar over om antwoord

\footnotetext{
48. De Die: "Toen ik, na het drama van de voortrein, weer wilde gaan praten met de Commissie Erfrecht, kwam, een beetje bedremmeld, het verzoek of ze er allemaal bij aanwezig mochten zijn. Ik was daar wat verbaasd over. Ze waren dat niet gewend. Het tekent dat de verhoudingen een beetje stroef waren."

49. Luijten (benoemd in de vacature-Van der Ploeg): "Wij hadden niet de indruk dat Heuff en Kleijn in Den Haag veel gehoor kregen. Op het Ministerie had men een ambtelijke opvatting die, veel minder dan nu, weinig rekening hield met de praktijk. Ik ben ook wel eens meegeweest. Je werd uiterst vriendelijk ontvangen en er werd ook uitvoerig naar je geluisterd, maar wij hadden toch de indruk dat wij daar min of meer voor dovemansoren spraken. Er kwam van onze kritiek in elk geval maar weinig in de stukken terecht en er veranderde ook weinig in de geesten. Het denkpatroon, de visie op het erfrecht, bleef in wezen onveranderd."
} 
te geven op het laatste tussenvoorstel van het Ministerie. Scheltema noteerde op 21 oktober 1971: "Aan de voorbereiding van de invoeringswet is reeds vrij veel gedaan en heeft herhaaldelijk overleg met de notarissen plaatsgevonden. Daarbij bleek dat de notarissen de door ons op basis van Boek 4 ontworpen regeling een grote verbetering vonden, maar nog meer voelden voor een stelsel waarin de langstlevende niet alleen een verzorgingsrecht zou worden toegekend, maar waarin deze steeds enig intestaaterfgenaam zou worden, ongeacht of de langstlevende verzorging behoeft of niet. In de laatste bespreking, gehouden half juni (..) is van onze kant een voorlopig tussenvoorstel gedaan. De notarissen zouden hun oordeel over dat voorstel aan ons kenbaar maken, maar hebben dat nog steeds niet gedaan."

Pas op 20 juni 1972 zou "overeenstemming" worden bereikt tussen Heuff en Kleijn als vertegenwoordigers van het notariaat enerzijds en het Ministerie anderzijds. De Notariële Raad verklaarde zich bij brief van 27 juni 1972 akkoord. Heuff: "Op een gegeven moment heb ik, in overleg met het Hoofdbestuur van de Broederschap, gezegd, dit is het resultaat, het lijkt ons nu wel acceptabel. Je moet tenslotte ook

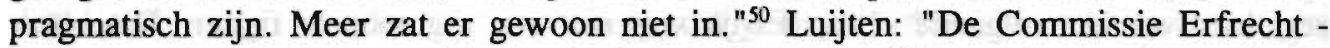
ik was er toen al niet meer bij - heeft uiteindelijk het hoofd maar in de schoot gelegd. Men kon er ook niets aan veranderen." Heuff: "Het is bepaald niet zo dat alles wat van de kant van het Ministerie kwam, door ons zonder slag of stoot werd geaccepteerd. Er zijn voortdurend heel pittige discussies geweest. Alleen, op bepaalde momenten kreeg je dat er een onwrikbaar standpunt lag aan de kant van het Ministerie. Men wilde niet verder gaan, hoewel onze Commissie daar best bedenkingen tegen bleef houden."

\section{Kritiek}

Al snel na de publicatie van het ontwerp kwam van verschillende zijden heftige kritiek los. ${ }^{51}$ De voornaamste bezwaren betroffen de spoedige opeisbaarheid van de uitkeringsrechten van de kinderen, en de moeilijkheden, verbonden aan de vaststelling van de som ineens. Heuff: "De voortrein was onder andere bijzonder ingewikkeld door de wijze waarop de rechten van legitimarissen en rechten op sommen ineens een rol speelden. Zodanig, dat je allerlei voorbeelden naar voren kon halen waar geen

50. Zie ook het jaarverslag 1972 van de Notariële Raad (Maandblad voor het notariaat, 6e jaargang (1973), p. 62 e.v. Daaruit blijkt dat "de meningen van enerzijds de Commissie Erfrecht en anderzijds het Departement sterk uiteen liepen met betrekking tot het in het ontwerp te volgen systeem."

51. Ook het Hoofdbestuur van de Broederschap maakte zich niet sterk voor het ontwerp. In het jaarverslag 1974 treft men de volgende passage aan: "De Commissie Erfrecht is de afgelopen tijd mede opgetreden als gesprekspartner van het Departement van Justitie ter bespreking van voorontwerpen die dienden te resulteren in een wetsontwerp op het erfrecht van de langstlevende. Over dit overleg bestaan weleens misverstanden. Het overleg is volstrekt informeel en dient alleen om het Departement deskundige bijstand en een deskundig klankbord te geven bij het opstellen van een wetsontwerp. Niet juist is dan ook de gedachte dat er tijdens het overleg standpunten uit het notariaat zouden zijn vastgelegd." De briefwisseling ter voorbereiding van het overleg spreekt echter duidelijk andere taal. De gezamenlijke hoofdbesturen schreven eind 1969 aan de Minister: "Ook met de door $\mathrm{U}$ voorgestelde procedure, waarin waarborgen voor zoveel mogelijk overleg neergelegd zijn, kunnen de Hoofdbesturen zeer wel hun instemming betuigen en zij zijn dan ook gaarne bereid vertegenwoordigers aan het overleg over het ontwerp van wet daartoe te laten deelnemen (..)." 
mens meer uitkwam. Van Ewijk had daar echter geen boodschap aan. Men zag dit kennelijk als de enige weg. " 52

Van Mourik, die in 1970 al krachtig had gepleit voor een ongeclausuleerd enig erfgenaamschap van de langstlevende echtgenoot, vocht het ontwerp aan met de stelling dat de regeling principieel de mogelijkheid zou scheppen dat ter zake van ieder overlijden wordt gestreden over de vraag wat dan wel voldoende verzorging inhoudt. ${ }^{53}$ Daarnaast zou ook de invalshoek van de wetgever een onjuiste zijn. Volgens Van Mourik zouden de kinderen pas erfrechtelijke aanspraken mogen hebben na het overlijden van beide ouders: "Wie kan de familie-Doorsnee in onze tijd duidelijk maken waarom de wetgever een versterf-erfrecht baseert op het principe dat weerbarstige en brave kinderen erf-rechten (lees: uitkeringsrechten) hebben jegens degene die een leven in lief en leed met de erflater heeft gedeeld?" ${ }^{34}$

Scherpe kritiek was er ook van de zijde van Van der Ploeg, die na het debâcle van de vaststellingswet uit de Commissie Erfrecht was gestapt. In een reeks van vijf artikelen brak hij op een knappe wijze het ontwerp woord voor woord af, waarbij hij zowel het uitgangspunt als de technische uitwerking daarvan ter discussie stelde. Heuff: "Nadat het compromis er lag hebben wij als Commissie ten behoeve van de praktijk in het WPNR enkele voorlichtende artikelen gegeven, waarin het onderhandelingsresultaat werd uiteengezet. Van der Ploeg is daarop woedend uitgevallen en heeft gezegd, zie je wel, jullie accepteren het. Dat was niet zo. Wij legden uit wat er uit was gekomen, we hebben nooit ook zelfs maar de indruk gewekt dat we met het ontwerp geheel akkoord waren."

Eén van de hoofdpunten van Van der Ploegs kritiek was, dat in het ontwerp de verhouding tussen de langstlevende en de kinderen volledig werd verzakelijkt: "De wetgever dient de langstlevende echtgenoot niet in de positie van schuldenaar ten opzichte van de kinderen te brengen, die zes maanden na het overlijden moet uitbetalen. (..) De ouder kan zich volgens artikel 894 lid 3 tot de rechter wenden met het verzoek om uitstel, maar wanneer het zover is, dat een ouder zich ter bescherming tegen zijn kinderen tot de rechter moet wenden, dan is de verhouding erger dan verzakelijkt, dan is ze verziekelijkt. ${ }^{n 55}$ Dat het wetsontwerp de ouderlijke boedelverdeling zeer nabij kwam, vond Van der Ploeg dan ook bepaald geen pluspunt, omdat elk echtpaar weer verschillend is en alleen de notaris alle daarbij in aanmerking ko-

52. Een ander voorbeeld is dat de inkorting, die op drie plaatsen in het wetsontwerp ter sprake kwam, op geheel verschillende wijze was uitgewerkt, terwijl deze regelingen ook weer verschilden van die welke te vinden waren in de wet van 1969.

53. M.J.A. van Mourik, Kanttekeningen bij het ontwerp voor een erfrechtelijke voortrein, WPNR 5262 (1974). Dat het ontwerp direct was geënt op de OBV, die door een belangrijk deel van het notariaat al sedert de jaren zestig met veel succes werd toegepast, was kennelijk geen voldoende argument. Dat de Commissie Erfrecht zich tot dusverre óók altijd voor een verzorgingssom in plaats van een legitieme had uitgesproken, bracht Van Mourik niet ter sprake.

54. Daamaast wees Van Mourik er onder andere op dat de tijd waarin kinderen op het paard getild moesten worden, voorbij is: "Doorstroming van vermogen naar een jongere generatie is geen door de wetgever na te streven doel, integendeel, het verdient (..) om meerdere redenen bestreden te worden." Ook zou "het vooruitzicht dat een overlijden verrijking ten gevolge heeft, bevruchtend werken op de in iedere mens gelegen akker van immoraliteit, welke akker vrucht voortbrengt indien die mens met het oog op de verrijking verlangend uitziet naar het moment van overlijden."

55. P.W. van der Ploeg sr., Het nieuwe erfrecht bij versterf, in het bijzonder het erfrecht bij versterf van de langstlevende echtgenoot, WPNR 5266 (1974). 
mende factoren zoals leeftijd, familieverhoudingen en vermogensgrootte, kan afwegen: "De notaris is geen automaat, die voor ieder echtpaar dat bij hem komt voor het opmaken van een testament, de ouderlijke boedelverdeling uit de la haalt. Bij vermogens met een grote effectenportefeuille zal de notaris het niet in zijn hoofd halen een ouderlijke boedelverdeling voor te stellen."

De Commissie Erfrecht tenslotte, liet eveneens blijken dat het ontwerp haar niet ver genoeg ging in de bescherming van de langstlevende: "De hoofdlijn: "langstlevende echtgenoot enig erfgenaam - kinderen uitkeringsgerechtigd' is met instemming door de commissie begroet; De Commissie wil echter niet verhelen dat steeds haar voorkeur is uitgegaan naar een wettelijk niet opeisbaar stellen van het uitkeringsrecht gedurende het leven van de langstlevende echtgenoot (eventueel aan te vullen met hertrouwen en daarmee gelijk te stellen omstandigheden). ${ }^{\text {"56 }}$

Naast deze kritiek op het stelsel van het ontwerp was er ook kritiek op de formulering. Eén van de vele klachten was dat het ontwerp te ingewikkeld en moeilijk leesbaar werd gevonden. Nève ${ }^{57}$ vergeleek het ontwerp met "een vocht, dat eens koffie is geweest, doch waaraan te zorgzame handen twee maal suiker en driemaal melk hebben toegevoegd", Santen ${ }^{58}$ kritiseerde de "vergaande detailering, gecompleteerd door talmudische nuanceringen', terwijl Van der Ploeg schreef: "Degene, die tenslotte de formulering tot stand heeft gebracht en kans heeft gezien alles in een drietal artikelen te regelen, is een knap man. Van hem kan gezegd worden wat van de beroemde Amerikaanse physicus Wiener gezegd werd: Hij is zo knap, dat hij niet begrijpt hoe dom wij zijn. ${ }^{59}$

Uit een enquête die enige tijd na de jaarvergadering onder het notariaat werd gehouden, bleek echter dat men wel bereid was over deze taalkundige bezwaren heen te stappen. ${ }^{60}$ Dat was ook min of meer onontkoombaar, want het systeem van de ouderlijke boedelverdeling zélf dwong de wetgever tot het bezigen van omslachtige formuleringen: Omdat de echtgenoot enig erfgenaam werd, moest het ontwerp, om de

56. In 1982 (Opnieuw erfrechtelijke vernieuwingen, Deventer 1982, p. 5), schreef de Commissie over het overleg van vóór 1974: "In dit overleg is naast een praktisch hanteerbare regeling van de legitieme in het bijzonder de erfrechtelijke positie van de langstlevende echtgenoot aan de orde geweest. Van de kant van de Commissie is daarbij steeds aangedrongen op een wettelijk erfrecht, dat een zo sterk mogelijke positie aan de langstlevende echtgenoot toekent. Verdedigd werd door de Commissie een wettelijke regeling, welke neerkomt op de gevolgen van de zgn. ouderlijke boedelverdeling, zoals die in de notariële praktijk thans veelvuldig wordt gehanteerd, d.w.z. de langstlevende is door het overlijden van de eerststervende rechthebbende op alle bezittingen van de overledene, terwijl de kinderen een in beginsel tot aan het overlijden van de langstlevende uitgestelde renteloze vordering ten laste van de langstlevende verkrijgen. Het Ministerie van Justitie daarentegen voelde meer voor een wettelijke regeling, waarbij het belang van de kinderen minder ten voordele van de langstlevende echtgenoot zou worden teruggedrongen."

57. P.L. Nève, Enkele opmerkingen over het wetsontwerp tot partiële wijziging van het erfrecht, WPNR 5266 (1974).

58. A.H.M. Santen, Partiële wijziging van het erfrecht - enkele opmerkingen over wetgevingstechniek, WPNR 5274 (1974).

59. P.W. van der Ploeg sr., Het nieuwe erfrecht bij versterf, in het bijzonder de quasi-legitieme. WPNR 5269 (1974). Vergelijk ook P.A. Regnery, Gedachten over het nieuwe erfrecht, WPNR 5295 (1975), die spreekt over "een onwaarachtig studeerkamerprodukt".

60. De resultaten van deze enquête werden gepubliceerd in WPNR 5281 (1974). 
legitieme van de kinderen te handhaven, wel een quasi-legitieme invoeren. Om dezelfde reden kende het ontwerp ook figuren als quasi-inbreng en quasi-inkorting.

\section{De jaarvergadering van 1974}

Op 24 september 1974 wijdde de Broederschap haar najaarsvergadering aan de behandeling van wetsvoorstel 12863. De kritiek die in de preadviezen, artikelen en commentaren was geuit, beloofde voor het verloop ervan weinig goeds. Daar kwam nog bij, dat door opmerkingen van Van der Ploeg en Van Mourik de indruk was ontstaan dat het ontwerp geheel in overeenstemming was met de denkbeelden van Hoofdbestuur en Commissie Erfrecht, en dat een nadere enquête of een beginseluitspraak van de ledenvergadering voor het resultaat van geen betekenis meer zouden zijn. De irritaties zouden daardoor hoog oplopen en het resultaat merkbaar beïnvloeden. Het feit dat Heuff, voorafgaand aan de bespreking van de pre-adviezen over het nieuwe erfrecht, er nog eens op wees dat zijn Commissie de bekende notariële verlangens herhaaldelijk en met klem naar voren had gebracht, maar dat het uiteindelijke resultaat toch wel heel sterk door het Departement was bepaald, maakte die onlustgevoelens er niet kleiner op. Preadviseur Hermans verwoordde deze kritiek het duidelijkst: "Het notariaat is in een onaanvaardbare positie gemanoeuvreerd, doordat de toenmalige hoofdbesturen geen overleg met hun achterban mochten plegen over wezenlijke veranderingen in Boek 4." ${ }^{61}$

Ter vergadering traden tien sprekers op, waarvan acht het ontwerp in scherpe bewoordingen afkraakten. Veel kritiek was er op de uitkeringsrechten van de kinderen en op de vaststelling van de som ineens, een punt waarvan met name Van Mourik, die regelmatig werd onderbroken door applaus, veel werk maakte. De Die: "Ik heb op die vergadering voor het eerst kennisgemaakt met Van Mourik. Hij kraakte het ontwerp af op zo'n manier, dat Neleman en ik geneigd waren om mee te klappen. We hebben het uiteindelijk toch niet gedaan, dat wel. " Het bemiddelende voorstel van de preadviseurs en de Commissie Erfrecht om de niet-opeisbaarstelling te schrappen, zodat de wettelijke regeling een kopie zou zijn van de OBV, kon in de ogen van Van Mourik (toen nog) geen genade vinden: "Met Van der Ploeg en anderen meen ik dat niet-opeisbaarstelling van het uitkeringsrecht niet mag dienen als reddingsboei voor het ontwerp: het ontwerp als zodanig dient verpletterd te worden onder de wals der praktische realiteit." Naar zijn mening zou het "langstlevende al" in de meest zuivere

61. Preadviseur Soons, tevens lid van de Commissie Erfrecht, verklaarde daaromtrent: "Het overleg was geheim: daar is in de loop van de besprekingen met het Ministerie nog weer eens uitdrukkelijk van de zijde van het Ministerie op geattendeerd. (..) Wij hebben als leden van de Commissie Erfrecht herhaaldelijk problemen met dat geheime karakter gehad, omdat ook wij voor de vraag zaten, datgene wat wij nu hier bespreken, zijn dat nu wel gedachten die door het notariaat onderschreven worden? In dat geheim overleg is in navolging van datgene wat in de eerdere rapporten van de Commissie Erfrecht, en met name in rapport II, aan de orde gesteld was, gepleit voor een andere oplossing dan uiteindelijk in dit ontwerp is vastgelegd. Dat bleek niet aanvaardbaar (...). Uiteindelijk kwam dan de gedachte, die in dit ontwerp vorm gekregen heeft, op de tafel. (...) De Commissie heeft gemeend te mogen en te moeten constateren, dat kennelijk in het overleg, om welke reden dan ook (..) een verdergaande oplossing op dat moment in ieder geval niet aanvaardbaar was en dat we dan toch maar moesten proberen met deze constatering in ons achterhoofd (..) andere verlangens te realiseren." 
vorm de meest acceptabele oplossing zijn, gezien de wil van een meerderheid van de erflaters, de omvang van de meeste nalatenschappen, het primaat van de relatie, de verhouding tot de $\mathrm{ABW}$ en het streven naar eenvoud.

Notaris Kingma daarentegen wees erop dat de door Van Mourik beleden voorkeur voor eenvoud niet in gemakzucht zou mogen ontaarden, terwijl Luijten memoreerde dat w.o. 12863 in wezen de OBV in de wet was, zij het met de verplichting tot uitkering aan de kinderen van tenminste de quasi-legitieme. Bij kleine boedels zou zijns inziens voor uitkering door de langstlevende niet behoeven te worden gevreesd, omdat het verzorgingsrecht de gehele nalatenschap zou omvatten. Bij grote boedels zou er zijns inziens minder bezwaar tegen uitkering zijn. Verder wees Luijten op de hertrouwproblematiek, een punt dat de laatste tijd op de achtergrond was geraakt: "Ik zou met name bij het betoog van Van Mourik willen aantekenen, dat deze dan wel met zoveel pathos toejuicht, dat alles dan ook naar de langstlevende moet gaan, maar acht hij het dan zo'n gelukkig resultaat als de kinderen hun vaderlijk of moederlijk erfdeel zien verdwijnen na een hertrouwen van hun ouder, gevolgd door allerlei manipulaties ten gunste van de nieuwe huwelijkspartner?"

Ook de beide preadviseurs wezen er in hun antwoord op dat het ontwerp zo gek nog niet was. Een "langstlevende al"-regeling zou velen te ver gaan en was overigens ook in 1960 door de toenmalige Commissie Erfrecht zonder vrucht bepleit. Bovendien zou de kritiek, dat het bepalen van de verzorgingsbehoefte een schier onmogelijke opgave zou zijn, worden gelogenstraft door de praktijk van de OBV, in welk kader de vorderingen van de kinderen evenzeer dienen te worden vastgesteld. Soons benadrukte verder dat het zeker niet de bedoeling was van de meeste ouders hun kinderen te onterven en vond het opmerkelijk dat de verzorgingsaanspraak a la De Visser/Harms nu ineens werd bestreden: "Er is jarenlang, de heer Van Oven is, als ik me goed herinner, daarmee begonnen in zijn bekende WPNR-artikelen, bepleit een verzorgingsaanspraak van de langstlevende echtgenoot vast te leggen in de wet. Er is vanuit het overgrote deel van het notariaat duidelijk aan deze gedachte adhesie betuigd en nu ineens blijkt dat deze gedachte toch weer op weerstand stuit. (..) De heer Van Mourik heeft voor wat betreft de omvang van het recht het wat algeméén gesteld als hij opmerkt dat de omvang van de som ineens niet is vast te stellen. Ja, we kunnen deze inderdaad niet exact vaststellen. Aan de andere kant, dacht ik, dat we met onze clausules in de ouderlijke boedelverdeling tot op dit moment ergens de pretentie gehad hebben dat we het wel konden vaststellen en ik dacht, dat we die pretentie ook nu zullen moeten waarmaken." Heuff: "Er bleef bij de praktijk enige wrevel heersen. Ik geloof dat er ook wel een beetje angst voor de vernieuwingen bij kwam."

Uit een enquête die enige tijd na de vergadering werd gehouden, bleek dat de overgrote meerderheid, $83 \%$ van de 1111 deelnemers vóór een enig erfgenaamschap van de langstlevende was, ook bij de aanwezigheid van afstammelingen. Volgens $88 \%$ zouden deze afstammelingen wel recht moeten kunnen doen gelden op een uitkering, die naar de mening van $70 \%$ van de inzenders pas bij het overlijden van de langstlevende opeisbaar zou dienen te zijn. Indien het wetsontwerp in die zin zou worden aangepast, dan zou ongeveer 68 procent het ontwerp positief beoordelen.

Soons: "Het ontwerp is op 27 september 1974 behandeld op de jaarvergadering van de Broederschap. Het ontwerp is toen afgewezen, met name omdat het recht van de kinderen niet was uitgesteld. Als het Ministerie toen had gezegd, akkoord, de 
vordering van de kinderen is niet opeisbaar gedurende het leven van de langstlevende, dan had de Broederschap, dacht ik, ja gezegd." De Die beaamde dit: "Dat is juist, want dan had je hélemaal de ouderlijke boedelverdeling gehad. Het ontwerp werd, althans zeker niet op dié vergadering, zo afgekeurd dat het onwaarschijnlijk was dat het het uiteindelijk, na enige aanpassingen, niet zou halen. Die indruk was veel sterker bij het Voorlopig Verslag, op gronden die mij ook veel meer aanspraken."

\section{Nog méér kritiek}

Al snel bleek dat ook in rechtspolitiek opzicht het laatste woord nog niet was gesproken. Uit het Voorlopig Verslag, dat in december 1974 zou verschijnen, bleek dat de vaste Commissie voor Justitie van de Tweede Kamer het ontwerp in zijn toenmalige vorm vrijwel afwees, maar tevens dat zij diepgaand verdeeld was over de richting die nu moest worden ingeslagen. Soons: "Uit dat verslag bleek dat men er eigenlijk geen raad mee wist. De een zei dit, de ander zei dat, de verdeeldheid liep zelfs door de partijen heen. Daaruit heeft het Ministerie de conclusie getrokken - terecht of ten onrechte, dat kun je denk ik in het midden laten - dat een wettelijke regeling, geënt op de ouderlijke boedelverdeling, voor de politiek niet acceptabel was."

Voor een deel van de vaste Commissie bleken de voorstellen van de Minister ter verbetering van de positie van de langstlevende echtgenoot niet ver genoeg te gaan. De PvdA drong er met klem op aan het votum van de Broederschap te honoreren en in elk geval de uitkeringsvordering van de kinderen slechts opeisbaar te maken in geval van overlijden, hertrouwen en faillissement van de echtgenoot, maar zij bleek, geïnspireerd door Van Mourik, ook een zuiver "langstlevende-al", waarbij de kinderen elk recht op de nalatenschap van hun ouders wordt ontzegd, niet bij voorbaat te verwerpen.

Anderzijds verzetten het CDA en de VVD zich er krachtig tegen dat de kinderen in beginsel genoegen zouden moeten nemen met een geldvordering, omdat de langstlevende als enig erfgenaam vrij over de nalatenschapsgoederen kon beschikken en het systeem van het ontwerp er bovendien toe zou kunnen leiden dat de goederen van hun ouders niet bij hen, doch na hertrouwen van de langstlevende in een geheel andere familie terecht komen. ${ }^{62}{ }^{63}$ Enigszins verwarrend was wel, dat men direct hierna de

62. Het volgende citaat, ontleend aan de inbreng van het CDA, maakt duidelijk dat dit een principieel punt was: "Zeer grote bezwaren hadden deze leden (..) tegen de artikelen welke bewerkstelligen dat kinderen geen erfgenamen bij versterf meer zijn, wanneer de erflater een echtgenoot achterlaat en hun dan slechts een recht op uitkering van de langstlevende toekent. $\mathrm{Zij}$ meenden dat de algemene rechtsovertuiging nog altijd ervan uitgaat dat de kinderen erfrecht hebben en dienen te delen in de nalatenschap van hun ouders. (..) In bepaalde gevallen moet het voor de kinderen een bijzonder moeilijke gedachte zijn dat een tweede of volgende echtgenoot onder alle omstandigheden voorrang heeft ten aanzien van de tijdens een eerste huwelijk verworven inboedel. Ook de gescheiden echtgenoot, die afstand heeft gedaan van zijn recht om bepaalde waardevolle stukken bij de boedelscheiding op te eisen, in de veronderstelling dat de kinderen deze stukken later zouden erven, kan het als zeer schrijnend ervaren dat deze stukken nu naar een andere familie overgaan. Moet de erflater niet minstens de bevoegdheid hebben om krachten, uiterste wilsbeschikking aan de echtgenoot dit krachtens artikel 902 gegeven recht, te ontnemen, of de kinderen bij voorgenomen vervreemding een voorkeursrecht tot koop gegeven worden, dan wel de langstlevende het vruchtgebruik en de kinderen de blote eigendom?" Zitting Tweede Kamer 1974-1975, nr 12863, stuk nr 4, p. 6-8. 
vraag liet volgen "waarom in beginsel niet is gekozen voor een legalisatie van de praktijk van de ouderlijke boedelverdeling." De Die: "Ze hebben niet in de gaten gehad, dat als je kiest voor een wettelijke boedelverdeling, geen sprake meer is van een erfgenaamschap van de kinderen."

Uit het verslag bleek dat de leden van het CDA en de VVD in het bijzonder onder de indruk waren geraakt van een brief van de vice-president van de Hoge Raad, mr. Dubbink, waarin werd gesteld dat nergens ter wereld een wet te vinden was waarin de kinderen elk deel in de nalatenschap van hun ouders werd ontzegd. Eerder had ook de Raad van State de indiening van het ontwerp om dezelfde, fundamentele bezwaren ontraden. ${ }^{64}$ Een citaat: "Het is de Raad opgevallen dat noch in het ontwerp noch in de Memorie van Toelichting enige aandacht is geschonken aan de mogelijkheid dat er bij het openvallen van de nalatenschap voorkinderen van de erflater uit een vroeger huwelijk aanwezig zijn. Blijkbaar is Uw minister van de gedachte uitgegaan dat na de afschaffing van de zogenaamde lex hac edictali ${ }^{65}$ (..) het niet noodzakelijk is in dit verband nog enige bijzondere voorziening te treffen. De Raad zou dit uitgangspunt niet juist achten: De afschaffing van de lex hac edictali had alleen ten doel aan de achterstelling van de tweede en verdere echtgenoot, indien er voorkinderen aanwezig waren, een einde te maken. Onder het huidige recht hebben de voorkinderen verder dezelfde rechten als de kinderen uit een volgend huwelijk. Als gevolg van de thans voorgestelde bepalingen dreigt er echter een ongelijkheid tussen de voorkinderen en de kinderen uit het latere huwelijk te ontstaan. "66

63. $\rightarrow$

63. Van Mourik vergist zich, wanneer hij in WPNR 6086 (1993) stelt dat uit het verslag "toch niet anders kan worden opgemaakt dan dat de leden van de vaste Commissie niet in de gaten hadden dat Van Agt in feite de ouderlijke boedelverdeling omarmde maar om redenen van systematiek de kinderen geen geldvordering als erfgenaam kon laten verkrijgen." Het is zonder meer duidelijk dat het bezwaar van een meerderheid van de Kamer erin bestond dat de kinderen geen goederen erven.

Bovendien brengt hij zijn lezers op een dwaalspoor als hij stelt dat de kinderen in het stelsel van de ouderlijke boedelverdeling "wel degelijk erven maar dat hun verkrijging om technische redenen niet steunt op erfgenaamschap." Wanneer kinderen alleen een vordering krijgen, zijn ze eigenlijk niet veel meer dan legataris, in elk geval geen erfgenaam.

64. Het advies van de Raad van State dateert van 30 mei 1973 en is op mijn verzoek openbaar gemaakt. De gebruikte citaten zijn ontleend aan de pagina's 16 tot en met 19 .

65. Tot de invoering van Boek 1 van het nieuwe Burgerlijk Wetboek op 1 januari 1970 mocht de tweede of verdere echtgenoot bij de aanwezigheid van voorkinderen van de overledene niet meer genieten dan het minste deel, dat een van die voorkinderen ontvangt en nooit meer dan een kwart van de nalatenschap.

66. Daarbij wees de Raad o.a. op de consequenties van artikel 884 (nieuw), dat de kinderen slechts recht gaf op een uitkering in geld: "Dit brengt bijvoorbeeld mee dat wanneer de erflater een bedrijf uitoefende, de bedrijfsgoederen aan de tweede echtgenoot toevallen, en na haar overlijden, aan haar eigen kinderen of andere erfgenamen. (..) Er bestaat hier dus een duidelijke achterstelling van de kinderen uit het eerste huwelijk ten opzichte van de kinderen uit het later huwelijk en zelfs ten opzichte van personen die in geen enkele relatie met de erflater stonden, zoals voorkinderen van de tweede echtgenoot en een eventuele latere echtgenoot van deze."

Daarnaast noemde de Raad het "niet juist" dat ingevolge artikel 902 (nieuw) inboedelgoederen zonder noodzaak van de ene op de andere familie kunnen overgaan: "Bedoeld artikel kan tot onredelijke resultaten leiden, wanneer het typische familiestukken betreft, afkomstig uit de familie van de overledene. Het lijkt niet juist dat deze, zelfs zonder dat de erflater anders kan beschikken, overgaan op de langstlevende echtgenoot en vervolgens op zijn erfgenamen, terwijl de voorkinderen zelfs na het overlijden van de langstlevende echtgenoot, er geen enkel recht op kunnen doen gelden." 
Van Rijckevorsel zei daarover: "Toen ik lid was van de Raad van State heb ik mij gestort op het advies over het nieuwe erfrecht, de zogenaamde voortrein-Van Agt. Het was een slecht ontwerp en ik weet nog dat één van de andere leden mij later complimenteerde met het advies, omdat hij het van de eerste tot de laatste alinea had kunnen volgen. Ik heb toen ook naar die artikelen van Van Mourik gekeken, die een zuiver 'langstlevende-al' bepleitte, maar zijn visie sprak mij totaal niet aan. Ik vond het allemaal veel te eenzijdig."

\section{Een nieuwe koers wordt ingeslagen}

Eind 1974 werd De Die belast met de verdere behandeling van het erfrecht. Bij het werk aan de voortrein was hij, anders dan Van Mourik ${ }^{67}$ meent, zelf niet betrokken geweest. ${ }^{68}$

De Die's eerste werk bestond in het verstrekken van een opdracht aan het Wetenschappelijk Onderzoek- en Documentatiecentrum van het Ministerie van Justitie om een enquête te houden onder de Nederlandse bevolking over het wenselijk erfrecht. De enquête was volgens De Die vooral bedoeld om het Departement meer 'zekerheid en richting' te geven: "Toen we daarmee begonnen, wisten we nog helemaal niet welke richting we zouden uitgaan, anders hadden we de vragen ook ten dele anders gesteld. We dachten eigenlijk vooral aan één of andere variant van de ouderlijke boedelverdeling. We hadden toen nog geen goede derde weg." Beantwoording van het Voorlopig Verslag werd niet overwogen. De Die: "Ik zag daar geen heil in, gezien de principiële tegenstand van twee van de vier grote partijen. Je zou misschien een kleine meerderheid voor het ontwerp hebben gekregen, maar omdat de samenstelling van de achtereenvolgende Kabinetten altijd nogal ongewis is en de invoering van Boek 4 zeker jaren zou kosten, vond ik dat ik naar een oplossing moest zoeken die op een brede meerderheid kon rekenen."

Uit de enquête bleek dat ruim $80 \%$ van de ondervraagden voorstander was van versterking van de positie van de langstlevende. Een zuiver 'langstlevende-al', zoals voorgestaan door de fractie van de PvdA, werd echter door slechts $17 \%$ van hen aanvaardbaar geacht. Van de vier in de enquête tegenover elkaar gestelde alternatieven waaronder overigens niet het vruchtgebruik met beschikkingsbevoegdheid - verwierf de ouderlijke boedelverdeling relatief de meeste steun. Frappant was dat de populariteit daarvan sterk afnam, als het de geënquêteerde duidelijk werd gemaakt dat bij tweede huwelijk dat stelsel impliceert dat voorkinderen veelal geen goederen van hun ouders zullen erven. De Die: "Dat resultaat en ook gesprekken die ik in die tijd voerde, hebben mij geleidelijk op het spoor gezet, dat ik nadien ben gaan volgen. Veel indruk maakte op mij een gesprek met mr. Dubbink, die, als "voorkind" uit eigen ervaring kon spreken. Ook al zijn de onderlinge verhoudingen goed, de wetgever moet het niet van de gunst van de stieffamilie laten afhangen, of een voorkind goederen - ook al is het maar het klokje op de schoorsteen - van zijn eigen ouders

67. M.J.A. van Mourik, Onoverbrugbare tegenstellingen, WPNR 6041 (1992).

68. De Die: "Ik heb nog wel de laatste vergadering meegemaakt tussen Van Ewijk, die voorzat, Scheltema, mijn rechtstreekse voorganger en de Commissie Erfrecht. Ik was toen al wel aangewezen om hoofd van de Stafafdeling NBW te worden, maar ik was nog niet in functie. Ik zat er een beetje bij, ik was ook nog niet op de hoogte van de details." 
erft." Daarbij kwam dat hij later ook zelf zou ervaren dat het een onderwerp is om rekening mee te houden. ${ }^{69}$

Het gevolg was dat uiteindelijk de figuur van het vruchtgebruik met beschikkingsbevoegdheid (art. 3:215) als een mogelijke variant voor een wettelijk stelsel uit de bus kwam, die, naar men meende, zowel voor de Kamer en de Raad van State als voor het notariaat aanvaardbaar zou kunnen zijn. De Die: "Al piekerend kwam ik geleidelijk op het idee dat je eigenlijk alleen een goed compromis tussen de belangen van de langstlevende en die van de kinderen kunt vinden, als je het erfdeel van de kinderen tijdens het leven van de langstlevende laat "slapen", als je dus de langstlevende een "tijdelijke eigendom" tijdens diens leven verschaft, om het populair uit te drukken. In gesprekken wees Hartkamp er toen bijvoorbeeld op dat je daarvoor de oude erfrechtelijke figuur van het fideïcommis kon gebruiken, Van Ewijk dat Meijers' ontwerp al een beschikkings- en interingsbevoegdheid van de vruchtgebruiker toeliet. Omdat in het nieuwe B.W. zowel de tijdelijke eigendom als het fideïcommis tenslotte in het vruchtgebruik uitmonden - zie resp. de artt 3.8.5 en 4.4.5.1 - is die vorm als uitgangspunt gekozen. ${ }^{70}$

Het voorstel bood een compromis tussen erfrechtelijke vormen die de langstlevende een maximum toedenken - ouderlijke boedelverdeling, langstlevende al - en die welke de rechten van kinderen, in het bijzonder de voorkinderen, niet tekort doen. Door de langstlevende tijdens zijn leven de vrije beschikking over de nalatenschap toe te kennen, werd bereikt dat hij op dezelfde voet kon voortleven als voor het overlijden. Bovendien werd daarmee recht gedaan aan de bezwaren van notariële zijde tegen de voortrein, doordat de uitkeringsrechten van de kinderen werden geschrapt en de verzorgingssom verviel. Anderzijds garandeerde de keuze voor het vruchtgebruikstelsel dat de goederen die na het overlijden van de langstlevende nog aanwezig zijn, van rechtswege toevallen aan de kinderen-erfgenamen van de eerststervende echtgenoot. Voor de tijdens het vruchtgebruik vervreemde goederen voorzag het voorstel in een vergoeding van de langstlevende aan de kinderen, opeisbaar bij diens overlijden. De Die: "Voor de langstlevende is het resultaat dus nimmer slechter dan ouderlijke boedelverdeling en "langstlevende-al" ${ }^{\text {"71 }}$, voor voorkinderen is het bijna altijd beter tot veel beter; slechts indien de langstlevende over alle nalatenschapsgoederen heeft beschikt, komt het voor de voorkinderen neer op hetzelfde als de ouderlijke boedelverdeling hun biedt: een geldvordering."

Om te voorkomen dat deze keus - weer - niet goed zou vallen bij de Tweede Kamer, stuurde Minister De Ruiter op 16 maart 1978 een brief aan de vaste Commis-

69. Die Die: "Later heb ik dat ook in eigen familie meegemaakt: de vrouw, na echtscheiding hertrouwd, overlijdt vrij plotseling en laat bij langstlevende-testament al haar goederen aan haar tweede man na, met het, door haar zeker niet voorziene, gevolg dat nu haar stiefdochter en niet haar eigen dochter, in het bezit van haar sieraden loopt. Dat vind ik niet goed, zeker niet, als dat het wettelijk stelsel wordt."

70. De Die vervolgt: "Toen dat eenmaal gebeurd was, vielen de stukjes ook op hun plek. Neleman bijvoorbeeld droeg eraan bij door aan te geven dat je de bezwaren van de verzorgingssom voor de langstlevende kon omzeilen door hem in plaats daarvan eveneens een vruchtgebruik toe te kennen, wat toen zijn regeling in art. 4.2A.2.3 heeft gevonden."

71. Wél is er dit verschil dat de langstlevende de goederen van de nalatenschap niet kan wegschenken en legateren. Maar ook daarmee werd recht gedaan aan de wens van de Kamer, wier bezwaren algemeen waren en niet beperkt tot "tweede huwelijken". 
sie, waarin hij zijn "synthese-voorstel" vergeleek met de ouderlijke boedelverdeling en de voor- en nadelen van zijn voorstel uitvoerig schetste. Op 5 april 1978 en 8 juni 1978 voerde de vaste Commissie voor Justitie daarover Mondeling Overleg. De slotsom van deze bespreking was dat alle in het overleg vertegenwoordigde fracties zich met het voorgestelde principe akkoord verklaarden. Wel werd door de drie grote fracties geen definitief standpunt ingenomen ten aanzien van het vruchtgebruikstelsel, omdat men eerst het ontwerp wilde afwachten. Van de uitwerking zou het afhangen.

\section{Wetsontwerp 17141}

Op 14 januari 1981 zond Minister De Ruiter het vruchtgebruikontwerp, inmiddels omgewerkt tot een onderdeel van de invoeringswet Boeken 3-6, in aan de Raad van State. De meest ingrijpende wijziging was een geheel nieuwe titel $2 a$, waarin het vruchtgebruik met beschikkingsbevoegheid in 19 uitvoerige artikelen, verdeeld over honderd leden, was uitgewerkt. ${ }^{72}$

Vooral het middenstuk van het ontwerp, dat de zaaksvervanging en de verplichting voor de vruchtgebruiker tot jaarlijkse opgave van mutaties regelde, was buitengewoon uitvoerig en blonk niet uit in doorzichtigheid. Want hoewel juist met het oog op de praktische werkbaarheid de administratieve last van beide figuren sterk was teruggedrongen, waren allerlei andere voorzieningen in het ontwerp opgenomen om het recht van de kinderen op goederen niet geheel illusoir te maken. De zaaksvervanging (art. 3.8.11) werd bijvoorbeeld beperkt tot uitdrukkelijk aangewezen goederen, omdat het volgens de ontwerper aan gegronde twijfel onderhevig was of "in de weinig zakelijke verhouding die tussen ouders en kinderen nu eenmaal bestaat" nauwgezet de hand zou worden gehouden aan de verplichting ieder jaar opgave te doen van mutaties in het vruchtgebruik. ${ }^{73}$ Maar om dit goed te laten lopen, waren wel vier nieuwe artikelen nodig, uitgewerkt in meer dan twintig uitvoerige leden.

Het advies van de Raad van State, dat op 21 augustus 1981 zou verschijnen, was bijzonder negatief. Volgens de Raad zou het wetsvoorstel niet aanvaardbaar zijn als wettelijk stelsel, omdat - nog steeds - geen sprake was van een redelijk evenwicht tussen de belangen van de langstlevende en de kinderen: "De voorgestelde constructie van dit van rechtswege op het tijdstip van overlijden intredende wettelijk vruchtgebruik kan juridisch en economisch niet anders worden gezien dan als een - door de Tweede Kamer blijkens het Voorlopig Verslag op wetsontwerp 12863 afwijzend

72. Eerder, in een nota d.d. 22 mei 1980, had De Die Minister De Ruiter geschreven: "Het idee zelf is Departementaal, maar er is nauw overleg met de Commissie Erfrecht gepleegd over de uitwerking. Daarvan hebben wij zeer veel profijt getrokken, zowel voor de bezinning over juridische vraagstukken als om het systeem voor de praktijk hanteerbaar te maken. Zo hebben wij de zaaksvervanging in het ontwerp afgesneden toen de Commissie ons ervan overtuigde dat deze in de praktijk tot grote moeilijkheden zou leiden. Wij hebben begrepen dat 'het notariaat' officieel nog steeds voorkeur voor de ouderlijke boedelverdeling heeft - d.w.z. toedeling van alle goederen en schulden aan de langstlevende; Met een tot overlijden of faillissement uitgestelde schuld aan de kinderen -, doch dat voor de Commissie - en het Hoofdbestuur? - de uitwerking van het vruchtgebruik in het ontwerp aanvaardbaar is." Op 27 mei 1980 echter verklaarden Hoofdbestuur en Commissie Erfrecht zich ten overstaan van de Minister geheel akkoord.

73. Zitting Tweede Kamer, 1977-1978, nr 12863, stuk nr 5, p. 12. 
tegemoetgetreden - langstlevende al stelsel."74 Naar zijn oordeel zou het wettelijk erfrecht en de legitieme porties van de kinderen slechts dienen te wijken, indien en voorzover het aan de echtgenoot toekomende verzorgingsrecht van toepassing blijkt te zijn. Daarnaast had de Raad kritiek op de ingewikkeldheid van het ontwerp, zoals de voorgeschreven boedelbeschrijving en de jaarlijkse opgaven.

De Minister antwoordde op 14 oktober 1981. Naar zijn mening was de kwalificatie van de Raad "geenszins gerechtvaardigd". In de eerste plaats niet, omdat de goederen waarover de langstlevende niet heeft beschikt, na zijn dood van rechtswege toevallen aan de kinderen-erfgenamen van de eerststervende echtgenoot. In de tweede plaats niet, omdat voor zover die bevoegdheid wel werd uitgeoefend, daar een geïndexeerde vergoedingsvordering voor de erfgenamen tegenover staat. In de derde plaats niet, omdat het vruchtgebruikstelsel voorkomt dat het familievermogen op drift raakt. Tenslotte wees de Minister er nog op, dat het in het ontwerp neergelegd beginsel door de vaste Commissie was aanvaard, en dat - gegeven het politieke uitgangspunt - het notariaat ermee had ingestemd: "In dit verband wil ik niet verzwijgen dat het Hoofdbestuur van de Koninklijke Notariële Broederschap - waarvan de Commissie Erfrecht intensief bij de voorbereiding van het ontwerp is betrokken - mij heeft medegedeeld dat het stelsel van het ontwerp, bevattende een vruchtgebruik met beschikkingsbevoegdheid, in zijn hoofdlijnen op de steun van het notariaat kan rekenen."

De Minister kreeg daarbij nog een duwtje in de rug, doordat het Hoofdbestuur van de Broederschap op 21 december 1981 een brief richtte aan de leden van de vaste Commissie voor Justitie van de Tweede Kamer, waarin het wetsvoorstel een voor de praktijk werkzame oplossing werd genoemd: "Het in het ontwerp geregelde vruchtgebruik voor de langstlevende echtgenoot geeft - gegeven het uitgangspunt van de Tweede Kamer - een voor de praktijk werkzame oplossing, mits dat gepaard gaat met een volledige beschikkingsbevoegdheid van de langstlevende echtgenoot."

\section{Opnieuw bedenkingen}

In het voorjaar van 1982 pakten zich opnieuw donkere wolken samen boven het erfrecht. Van Mourik stroopte opnieuw de mouwen op en bepleitte in krachtige bewoordingen een terugkeer naar de ouderlijke boedelverdeling of, liever nog, een zuiver "langstlevende al." Voor wat de principiële kant betreft wees hij erop dat het feitelijk resultaat de ouderlijke boedelverdeling zeer nabij kwam: "Wat gepresenteerd wordt als een vruchtgebruik met beschikkingsbevoegdheid is in feite een vruchtgebruik met beschikkings- én verteringsbevoegdheid en is daardoor - bezien vanuit de positie van de langstlevende - een versierd 'langstlevende al'. In zoverre doet de regeling denken aan de moderne ouderlijke boedelverdeling en verdient zij warme bijval." ${ }^{75}$ Daarnaast herhaalde hij zijn mening, dat het niet nodig was het versterferfrecht af te stemmen op de problematiek van hertrouwen omdat "de doorsnee-weduwnaar en de doorsnee-weduwe niet hertrouwen." De opmerking van Rombach aan

74. Zitting Tweede Kamer 1981-1982, nr 17141, A-C.

75. M.J.A. van Mourik, De meeslepende avonturen van de langstlevende echtgenoot, NJB 1982, p. 45. 
Van Mourik, enkele jaren eerder, dat hertrouwen bij jonge, gescheiden mensen zelfs eerder regel dan uitzondering is, was hem kennelijk ontgaan. ${ }^{176}$

Voor wat de technische kant betreft had Van Mourik vooral bezwaren tegen de verplichting om elk jaar opgave te doen van de wijzigingen, die zich in het vruchtgebruikvermogen hebben voorgedaan en de - overigens sterk teruggedrongen - regeling van de zaaksvervanging: "Wie enig gevoel voor de praktijk heeft, zal met mij verwachten dat in het doorsnee-geval van de jaarlijkse opgave niets terecht komt." Het voorschrift om binnen een jaar na het overlijden een boedelbeschrijving te maken, ontmoette bij hem minder kritiek: "Gegeven het feit dat in het algemeen ook de successie-aangifte via de notaris wordt ingediend, kan niet worden gesproken van een hinderlijke uitbreiding van formaliteiten."

Ook de Commissie Erfrecht, die namens de Broederschap technische kritiek had geleverd bij het opstellen van het ontwerp, bleek gegronde bedenkingen te hebben. In een brochure, die zij kort voor de jaarvergadering van 1982, waar het ontwerp behandeld zou worden, uitbracht, werd de haalbaarheid van het voorschrift jaarlijks opgave te doen van de aan het vruchtgebruik onttrokken goederen eveneens in twijfel getrokken. Daarnaast werd gevreesd voor een "zware administratieve terugblik" aan het einde van het vruchtgebruik, omdat per geval zou moeten worden nagegaan wat er met de vruchtgebruikgoederen is gebeurd, of zaaksvervanging heeft plaatsgevonden, etc. Als gevolg daarvan vreesde zij vele problemen, alleen op te lossen met hulp van de rechter. ${ }^{77}$

Tenslotte deed ook oud-notaris P.W. van der Ploeg sr. nog een duit in het zakje door een veto over het ontwerp uit te spreken. Naar zijn mening zou het ontwerp wat de technisch-juridische uitwerking betreft tekortschieten, in de praktijk niet hanteerbaar zijn en ook te ver gaan in zijn versterking van de positie van de langstlevende echtgenoot. Daarnaast werd de Commissie Erfrecht slapheid verweten, een argument dat op de jaarvergadering veel indruk zou maken: "In het verleden werd over een wetsontwerp, het erfrecht betreffende, een rapport uitgebracht door een Commissie Erfrecht, ingesteld door de Hoofdbesturen van de beide Broederschappen (...). De betrokken Commissie Erfrecht stelde zich onafhankelijk op en schroomde nooit kritiek uit te oefenen. De huidige Commissie Erfrecht beperkt zich in een recente artikelenreeks tot voorlichting van het notariaat; Kritiek is er niet bij. De Commissie heeft zich volledig achter het ontwerp gesteld. De voorlichting is niet veel meer dan een uittreksel uit de toelichting op het ontwerp van de Minister. (..) Een zelfstandige opstelling van het notariaat tegenover het ontwerp ontbreekt derhalve. ${ }^{78}$

De Die, 21 april 1982: "Het ziet er naar uit dat 'het notariaat' ook het nieuwe ontwerp weer gaat afwijzen - ook al hebben het Hoofdbestuur van de Broederschap en haar Commissie Erfrecht het ontwerp aanvaardbaar geacht." Volgens De Die zou men het ontwerp vooral te moeilijk vinden. Voor een vereenvoudiging in de richting naar een zuiver langstlevende al, zoals aanbevolen door Van Mourik c.s. voelde hij echter

76. J. Rombach, Hoe het "langstlevende al", ook bij hertrouwen, juridisch bevredigend te verwezenlijken?, WPNR 5126 (1971). Opmerkelijk is dat Van Mourik ook in zijn jongste bijdragen bij de erfrechtelijke positie van voorkinderen nog dikwijls in de eerste plaats denkt aan de kinderen van hertrouwende weduwnaars en weduwen. Zie over deze beeldvertekening B.C. de Die, Tegen-stellingen, WPNR 6041 (1992).

77. Commissie Erfrecht, Opnieuw erfrechtelijke vernieuwingen, Deventer 1982, p. 30 e.v.

78. Echtgenoot krijgt volledige nalatenschap erflater, Zwolle 1982, p. 1. 
niets: "De wetgever moet dan bereid zijn de belangen van voorkinderen aan zijn laars te lappen - en aan de tweede echtgenoot ook de nalatenschap van zijn voorganger, de eerste eerstoverleden echtgenoot, toe te spelen met voorbijgaan van diens kinderen. De prijs lijkt me hoog, en ik zou het zelf niet verantwoord achten, die te betalen." Bovendien waren zijns inziens de diverse reacties nogal overtrokken: "De hoofdlijnen van het ontwerp zijn best uit te leggen, en practisch verschilt het systeem van het ontwerp nauwelijks van wat thans reeds gebeurt in de talloze gevallen waarin de boedel onverdeeld blijft, zolang de overblijvende ouder blijft leven: in die periode heeft hij de vrije beschikking over de goederen, pas na zijn overlijden wordt de boedel tussen de kinderen verdeeld. "79

Naar zijn mening zou een oplossing voor deze-problemen kunnen worden gevonden door a. de bezwaren tegen het langstlevende al en de ouderlijke boedelverdeling niet onder stoelen of banken te steken; b. op de consequentie van verwerping van deze voorstellen te wijzen, en c. de mogelijkheid te onderzoeken het ontwerp optisch te vereenvoudigen: "Nu is een vrij groot aantal bevoegdheden - mede om de praktijk te dienen! - uitgeschreven. Het is denkbaar, die in één begrip samen te vatten. Zelf zou ik daarbij denken aan het begrip 'bestuursbevoegdheid' dat wij in het huwelijksvermogensrecht kennen, en dat wij daarin nu, bij de aanpassing aan de Boeken 3-6, beter en $\mathrm{m}$.i. meer bevredigend, hebben beschreven. Maar deze vereenvoudiging zou - ik wil daarop wel de nadruk leggen - niet meer kunnen zijn dan een gebaar en een optisch verschijnsel, en ik kan nog geen garantie geven dat het ontwerp daarvan ook in werkelijkheid zou opknappen."

\section{24 September 1982}

Tijdens de jaarvergadering over het erfrecht, die op 24 september 1982 werd gehouden, zouden in eerste instantie vooral de door Van Mourik en de Commissie Erfrecht genoemde bezwaren de discussie beheersen. Voor het ochtendgedeelte bleken dertien sprekers zich te hebben opgegeven, twaalf van hen wezen het ontwerp vierkant af. Over de strekking van het ontwerp was men het wel eens, niet over de technische uitwerking. ${ }^{80}$

Soons: "De oplossing viel slecht, omdat in het ontwerp een groot aantal bepalingen - en dat is van uit de filosofie van de wetgever terecht - van de vruchtgebruiktitel toepasselijk werden verklaard. Allereerst waren er grote bezwaren tegen het voorschrift van artikel 3:205, dat de vruchtgebruiker verplicht jaarlijks opgave te doen van de wijzigingen die zich hebben voorgedaan. Daarvan zei men, dan kunnen de kinderen ieder jaar vragen, Moe, wat heb je uitgespookt? Het tweede grote probleem betrof de regeling van de zaaksvervanging, ontleend aan artikel 3:213. Wanneer bevoegd vervreemd is, vindt namelijk zaaksvervanging plaats. Dat werd onwerkbaar gevonden,

79. De Die vervolgt: "Aan het begin van de rit wordt een boedelbeschrijving met waardebepaling gemaakt - wat toch al moet voor de successiebelasting, en trouwens ook in het stelsel van de ouderlijke boedelverdeling. Tijdens de rit moet de langstlevende de kinderen op de hoogte houden van belangrijke veranderingen in de boedel - bijv. de verkoop van het huis - en moet hij de papieren die daarop betrekking hebben, voor zover ze prijzen behelzen, en liefst de aan - en verkoopnota's van de effectenportefeuille bewaren. Ook aan het eind van de rit zullen in 9 van de 10 boedels geen grote problemen ontstaan, zeker niet groter dan nu in de bovenbedoelde gevallen."

80. Zie voor een kort verslag van deze vergadering WPNR 5628 (1982). 
want het betekent dat je vanaf het begin, dus de periode volgend op het overlijden van de eerststervende, precies moet uitzoeken wat er allemaal is gebeurd en of er al dan niet zaaksvervanging heeft plaatsgevonden. Dat waren de twee hoofdbezwaren. Het waren praktische bezwaren, maar toch ook wel psychologische bezwaren. Met name ten aanzien van de jaarlijks opgave had men - ook al was er in zo'n jaar niets veranderd - toch een beetje het idee dat de kinderen teveel over de schouder van de langstlevende meekeken."

De dertiende spreker was De Die. De Die bracht allereerst naar voren dat het ontwerp zo slecht nog niet was en dat het qua opzet overeenstemde met de wensen van de Kamer. Ook met de praktische uitvoerbaarheid zou het zijns inziens wel loslopen. Wel gaf hij aan dat het ontwerp zich wellicht leende voor vereenvoudiging. Door de verplichte jaarlijkse opgaven te schrappen en de vergoedingsvordering voor de aan het eind van het vruchtgebruik "verdwenen goederen" uitsluitend op de boedelbeschrijving te baseren, zou men voor de vaststelling van deze vordering dan hetzelfde systeem hebben als voor de ouderlijke boedelverdeling. Tenslotte wees hij op de consequenties van verwerping van het wetsontwerp. Omdat Boek 4 deel uitmaakte van de invoeringswet Boeken 3-6 zou men - bij gebreke aan een werkbaar alternatief - bij een negatief votum terugvallen op de tekst van Boek 4, zoals die in 1969 was aangenomen. ${ }^{81}$

Aanvankelijk leek het of hiermee het pleit was gewonnen. De in overweging gegeven vereenvoudigingen werden beapplaudisseerd en althans éen van de moties tegen het ontwerp werd in deze geest gewijzigd. Niettemin zou in de (besloten) middagvergadering alsnog een motie worden aangenomen, waarin werd uitgesproken dat de "aanvaarding van wetsontwerp 17141 in hoge mate onwenselijk is." Van Os, die het voorstel in stemming bracht, zei: "De kern van dit voorstel is: dit vruchtgebruik moet niet, ook niet in gewijzigde vorm." Hiervoor zijn twee gronden te vinden.

In de eerste plaats was de motie vooral een manifestatie van de voorkeur van het notariaat voor de ouderlijke boedelverdeling. Een alternatief werd namelijk niet gegeven. Heuff: "De stemming die in 1982 heerste was mede een uiting van de verkleefdheid van het notariaat aan de ouderlijke boedelverdeling als een eenvoudig stelsel. En dan kun je wel zeggen, het werkt onder het nieuwe B.W. niet meer zoals dat nu werkt, omdat je nu een automatische overgang hebt door de OBV terwijl in de toekomst een levering vereist is, maar zo'n argument sneeuwt in zo'n jaarvergadering volledig onder. Dat tekent toch een beetje de emoties, want er is geen enkele notaris die afhankelijk wil zijn van de medewerking van de kinderen. Het vruchtgebruik bood in dat opzicht wel de ideale oplossing."

In de tweede plaats was door de toezeggingen van De Die bij veel notarissen de indruk ontstaan dat Hoofdbestuur en Commissie Erfrecht voor hun beurt hadden gesproken en dat er nog veel meer mogelijk was. ${ }^{82}$ Van Mourik: "In 1982 is bij de

81. Daar kwam nog bij, dat onder het nieuwe B.W. de zgn. automatische werking van de ouderlijke boedelverdeling zou komen te vervallen, omdat krachtens artikel 3:186 de medewerking van de erfgenamen voor de levering na boedelscheiding is vereist. Daarmee zou aan de testamentaire praktijk van de ouderlijke boedelverdeling een zeker einde komen, hetgeen een wettelijke regeling dubbel noodzakelijk maakte.

82. Enkele kenmerkende citaten. Santen: "Ik heb het aldoor zo begrepen, dat de Commissie Erfrecht in nauw overleg met het Ministerie het ontwerp mede heeft begeleid. Ik moet u eerlijk zeggen, dat ik 
rondvraag de bom gebarsten. We zijn toen in de middagvergadering nog eventjes teruggekomen op wat er die ochtend gepasseerd was. De Commissie Erfrecht is toen volledig afgebrand. Waarom? In de toelichting op het ontwerp stond dat het ontwerp tot stand was gekomen mede dankzij de belangrijke inbreng van de Commissie Erfrecht. Toen zeiden wij, jullie zijn dus eigenlijk voor het geheel verantwoordelijk? En nu blijkt dat nog van alles mogelijk is!" Heuff: "Wij hadden in 1981 van het Ministerie te horen gekregen 'meer zit er echt niet in'. Toen hebben wij, na enige discussie en in overleg met het Hoofdbestuur, besloten om het ontwerp op de jaarvergadering te verdedigen. De vergadering is toen over ons heen gerold. Waarom? De Die was één van de sprekers, en uit zijn opmerkingen bleek dat hij bereid was het notariaat op allerlei punten tegemoet te komen. Daardoor stonden wij met onze mond vol tanden. Wij hadden drie jaar gehoord dat dat juist niët mogelijk was. Wij kregen daardoor heel scherpe kritiek over ons heen: 'Zie, er kan tóch meer'. En dat, terwijl wij echt de overtuiging hadden dat de grenzen waren bereikt. Maar dat was blijkbaar toch niet het geval."

Cruciaal bij dit alles was de rol van Van Mourik, die er geen geheim van maakte dat hij het vruchtgebruikontwerp het liefst volledig onder de tafel zag verdwijnen. Creutzberg, secretaris van de Commissie Erfrecht: "Dat de kritiek van Van Mourik en van Van der Ploeg door vrijwel iedereen werd overgenomen, kwam werkelijk als een complete verrassing. Op een gegeven moment had ik ook het gevoel dat de zaal werd bespeeld, dat er een stemming werd gecreëerd. Men liet zich ontzettend ophitsen." Soons: "Er is toen tijdens de vergadering door De Die nog het een en ander toegezegd - hij zei, op die punten kunnen we misschien toch wel tot een oplossing komen -, maar hij had daarbij het ongeluk dat hij Van Mourik tegenover zich vond. En als Van Mourik eenmaal met zo'n zaal bezig is, dan kan hij er van alles mee en wat je dan bij wijze van spreken ook nog aan tegemoetkomingen geeft, dat valt daar weg."

Dat de emoties de boventoon voerden blijkt ook doordat de Commissie voorafgaand aan de jaarvergadering diverse malen had benadrukt dat het idee van het

82. $\rightarrow$

toch wat zorgen heb over die manier van begeleiding, want als in deze fase blijkt, dat het toch zo gemakkelijk is om nu tot overeenstemming te geraken, dan vraag je je af, wat is er daarvoor aan overleg geweest." Van Mourik: "De Memorie van Toelichting op dit wetsontwerp maakt ook melding van de aangename contacten, die het Ministerie had met de Commissie Erfrecht. Er wordt over dit overleg het volgende gezegd: "Voor dit overleg en voor de wijze waarop het is gevoerd ben ik de commissie zeer erkentelijk.' En dan komt het: 'Op vorm en inhoud van de in dat ontwerp vervatte voorstellen heeft het grote invloed gehad. (..) Plotseling blijkt nu mogelijk te zijn, dat we van die jaarlijkse opgaven afkomen. Het is mij een raadsel, dat een dergelijk voorstel het blijkbaar in het overleg niet heeft gehaald. (..) Ik denk dat de heer De Die hier gewoon met een zak vol wisselgeld is gekomen." Perrick: "Ik geloof, dat de positie waarin de Commissie Erfrecht zich heeft gemanoeuvreerd principieel onjuist is. De verantwoordelijkheid voor het ontwerp moet berusten bij de Minister van Justitie, die dat indient bij de Tweede Kamer. Als je als Commissie Erfrecht in overleg met de Minister van Justitie meewerkt aan de totstandkoming van dat ontwerp, dan kun je inderdaad als je het er niet mee eens bent alleen maar een ding doen en dat is afhaken en dat had dan ook moeten gebeuren." Kerkhoff: "Vanmorgen is gebleken, dat hoewel er wel wat kleine verschillen waren, de overgrote meerderheid toch anders denkt dan het Hoofdbestuur dacht. En dat komt er nu vanmorgen duidelijk uit en ik denk ook dat daardoor de heer De Die geschrokken is en zei: we zullen toch maar wat gaan doen. Het is inderdaad niet zo mooi." 
vruchtgebruik niet aan haar brein was ontsproten, zodat over haar rol eigenlijk geen misverstand kon bestaan. ${ }^{83}$ Daarbij komt, dat het ook wel wat simpel gedacht was om te veronderstellen dat de Commissie Erfrecht in het overleg met het Ministerie deze bezwaren had verzwegen. Soons: "Het is niet zo, dat De Die doof was voor onze verlangens. Wij hebben, toen we als Commissie met dat eerste vruchtgebruikontwerp aan de slag zijn gegaan, beslist een aantal verbeteringen kunnen realiseren ten opzichte van zijn oorspronkelijke ontwerp. Maar op deze twee punten wilde hij niet toegeven." De Die: "Ik herinner me inderdaad dat de Commissie regelmatig op schrapping van verschillende verplichtingen van de langstlevende aandrong. Maar ik heb het nooit gevoeld als een groot probleem. Mijn gedachte bij het opstellen van dat ontwerp was, dat ik alle rechten en verplichtingen zo veel mogelijk uit wilde schrijven, zodat de notaris en de erfgenamen precies zouden weten waar ze aan toe waren. Ik heb zelf nooit erg aan die bepalingen gehecht, het was mijn intentie om de praktijk een duidelijke richtlijn te geven. En omdat ikzelf het idee had dat van die jaarlijkse opgave wel niet veel terecht zou komen, stelde die 'principiële concessie' ook niet zoveel voor. Want je krijgt ook bij het ontbreken daarvan precies hetzelfde, namelijk de waarde die bij het opmaken van de boedelbeschrijving is vermeld. ${ }^{184}$

\section{Wetsontwerp 17141 ontkoppeld}

Op 23 december 1982 vond een gesprek plaats op Justitie tussen Minister Korthals Altes, die pas was aangetreden, De Die en een delegatie van het Hoofdbestuur van de Broederschap, ter uitvoering van de motie. Een beslissing over de toekomst van wetsontwerp 17141 was toen nog niet genomen. De Die: "Kort na die beruchte vergadering is er een bespreking geweest met het bestuur van de KNB. De Minister heeft toen voor die bijeenkomst tegen mij gezegd, ik neem geen standpunt in, want ik kan het onvoldoende beoordelen, maar ik wil ze wel aanhoren."

Desalniettemin zou het pleidooi van de notarissen om de voortrein in ere te herstellen, worden afgewezen. Uit het verslag van de bespreking: "De Tweede Kamer heeft de voorkeur uitgesproken voor een systeem, dat de nakomelingen uitzicht op de goederen geeft. Bij de constructie van de ouderlijke boedelverdeling is het denkbaar,

83. Het volgende citaat, ontleend aan een voorlichtend artikel dat de Commissie eind 1981 in WPNR 5590 ten behoeve van de jaarvergadering schreef, illustreert dat. Na te hebben gesignaleerd dat bij verschillende gelegenheden duidelijk is gebleken dat een meerderheid van het notariaat voorstander is van de OBV, schrijft de commissie: "Aangezien tijdens het overleg met het MvJ herhaaldelijk bleek, dat dit stelsel, mede gezien de standpunten van de diverse politieke partijen, niet haalbaar was, heeft de Commissie Erfrecht na ruggespraak met het Hoofdbestuur, desondanks besloten het overleg met het $\mathrm{MvJ}$ voort te zetten teneinde betrokken te kunnen blijven bij het opstellen van het nieuwe erfrecht en daarbij te trachten de in het notariaat levende wensen zoveel mogelijk te realiseren. Gegeven de door het MvJ voorgestelde constructie 'vruchtgebruik met beschikkingsbevoegdheid' is gezocht naar een stelsel, dat voor een ieder (Tweede Kamer en notariaat) in ieder geval bevredigend zou zijn. Daarbij is van de kant van de Commissie Erfrecht steeds aangedrongen op een voor het notariaat werkbaar systeem."

84. Om deze reden was ook de hierboven uitgesproken vrees van de Commissie Erfrecht voor een "zware administratieve terugblik" als bij het einde van het vruchtgebruik blijkt dat er vruchtgebruikgoederen spoorloos verdwenen zijn, in hoge mate hypothetisch. Zie artikel 13 lid 4: als waarde van de verdwenen goederen geldt dan de waarde volgens de boedelbeschrijving: Dezelfde dus als bij de ouderlijke boedelverdeling! 
dat goederen van de ene naar de andere familie worden overgeheveld. Dit probleem wordt juist door de vruchtgebruikconstructie opgelost." 85 Een compromis-voorstel om het voortrein-ontwerp aan te vullen met een optierecht, zodat de nakomelingen de door de eerststervende nagelaten goederen, die nog in de nalatenschap aanwezig zijn, over kunnen nemen tegen de prijs waarvoor zij bij het overlijden van de eerststervende waren geschat, haalde het evenmin. De kinderen zouden dan weliswaar de naam van erfgenaam houden, maar realiter niets erven. Bovendien zouden de kinderen, ten nadele van de erfgenamen van de langstlevende, de beste van twee werelden hebben: zij kunnen van de optie gebruik maken als de goederen in waarde zijn gestegen, en kunnen dat laten - en hun vordering verzilveren - als zij in waarde zijn gedaald.

Dit betekende dat er voor de notariële delegatie - gecompromitteerd door de aanvaarding van het ontwerp, in het nauw gebracht door de achterban - weinig anders overbleef dan het bepleiten van vereenvoudigingen van het vruchtgebruikontwerp, iets waartoe de Minister tot vreugde van het Hoofdbestuur wél bereid bleek. Zoals De Die al voorzichtig had geopperd, werd allereerst voorgesteld de jaarlijkse opgaven en zaaksvervanging radicaal af te snijden. Daarmee waren de twee belangrijkste bezwaren tegen het ontwerp weggewerkt. Daarnaast kwam de Minister met een niet onbelangrijk nieuwtje: gelden, effecten en toonderrechten zouden, tenzij anders overeengekomen, aan de langstlevende worden gelaten; De zgn. toeëigeningsbevoegdheid. De langstlevende zou op die wijze zijn huishouding ongestoord kunnen voortzetten, zonder dat de kinderen over zijn schouder kunnen meekijken. Met deze aanpassingen zou het praktisch verschil tussen het vruchtgebruik en de ouderlijke boedelverdeling nog slechts gelden voor goederen die op het tijdstip van overlijden van de langstlevende nog aanwezig zijn.

Het zou echter enige jaren vergen, voordat de Minister zijn toezeggingen, waarvoor hij overigens wel de instemming van de Kamer nodig had, gestand kon doen. In 1983 werd Boek 4 namelijk losgekoppeld van de invoeringswetgeving, een onvoorzien gevolg van de door Korthals Altes zelf geëntameerde Brede Wetenschappelijke Discussie. Met name de PvdA, en in mindere mate het CDA, zagen in Boek 4 een groot struikelblok voor het aanhouden van het tijdschema, hetgeen gelet op de verdeeldheid van beide partijen, zoals die in 1974 tot uiting was gekomen, weinig verwonderlijk was.

\section{Een nieuw geluid?}

Toen begin 1988 het probleem van de positie van de langstlevende echtgenoot weer actueel werd in verband met de afhandeling van de invoeringswetgeving Boeken 3, 5 en 6 van het nieuwe Burgerlijk Wetboek in de Tweede Kamer, besloot de Commissie Erfrecht, versterkt met Van Mourik, nog eenmaal de confrontatie met het Ministerie aan te gaan. Om de meningsvorming onder het notariaat te bevorderen werd daartoe allereerst in april 1988 een studieochtend belegd, bijgewoond door ruim 600 deelnemers, waarin alle mogelijke stelsels de revue passeerden. Belangrijk nieuws leverde die discussie niet op. Creutzberg: "Er is toen geweldig gediscussieerd over het meest wenselijke erfrecht, zonder dat men ook maar één stap verder kwam. Je kunt daaruit maar één conclusie trekken: welk systeem je ook kiest, er zijn altijd bezwaren aan 
verbonden, hetzij voor de langstlevende zelf, hetzij voor de kinderen, hetzij voor beiden. De uiteindelijke keuze zal dan ook niet een juridische keuze zijn, maar een maatschappelijke. ${ }^{186}$

Daarnaast werd naar een beproefd middel gegrepen: De enquête. De stemming in 1982 had namelijk ook duidelijk gemaakt dat het notariaat allesbehalve eensgezind was over de te volgen koers. Weliswaar was het vruchtgebruik bij duidelijke meerderheid van stemmen verworpen, maar in de motie werd niet aangegeven hoe het nu verder moest. ${ }^{87}$ Van Mourik: "Er is eensgezindheid voor wat betreft de ouderlijke boedelverdeling. Iets anders is, hoe ga je dat in de wet vastleggen."

Voor de uitvoering van de enquête werd een beroep gedaan op het NIPO, teneinde een zo objectief mogelijk beeld te krijgen. Creutzberg: "Rond 1988 begrepen wij dat Justitie het erfrecht weer zou gaan oppakken. Toen heeft de Commissie tot zichzelf gezegd, áls wij verder gaan met het nieuwe erfrecht, d.w.z. de regeling van de langstlevende, dan gaan we alleen verder als we eerst de achterban geraadpleegd hebben, want wij moeten een beeld hebben van wat het notariaat nu eigenlijk wil. De Commissie heeft toen een aantal vragen geredigeerd. Vervolgens is men naar het NIPO gestapt, waar alle vragen zijn gescreend. Het NIPO heeft vervolgens het onderzoek uitgevoerd, iedereen aangeschreven en de formulieren verwerkt. Ruim de helft van de ondervraagden reageerde. Het NIPO vond dat een hoge respons, men vond het beslist een respresentatieve enquête."

Uit de enquête bleek dat de ouderlijke boedelverdeling het meest populaire stelsel was ( $48 \%$ ), terwijl $18 \%$ van de notarissen nog verder zou willen gaan en een stem uitbracht op een wettelijk 'langstlevende-al'. Het stelsel van w.o. 17141 (wettelijk vruchtgebruik met beschikkingsbevoegdheid) kreeg $12 \%$ van de stemmen. Anderzijds bleek uit de enquête dat het 'langstlevende-al' door $25 \%$ van de notarissen als het minst wenselijke systeem werd gezien, terwijl het bestaande erfrecht en het wettelijk vruchtgebruik volgens het oude B.W. door respectievelijk 22 en $21 \%$ als onwenselijk werden beschouwd ${ }^{88}$ Creutzberg: "Mijn conclusie was eigenlijk dat je niet duidelijk kon zeggen dat er één systeem heel duidelijk uitsprong."

Minister Korthals Altes toonde zich niet erg onder de indruk van de enquête. In de eerste plaats niet, omdat hij inmiddels tot de overtuiging was gekomen dat het vruchtgebruik een goed systeem was, dat, mits vereenvoudigd, op principiële gronden de voorkeur verdiende boven de wettelijke ouderlijke boedelverdeling. In de tweede plaats niet, omdat hij van mening was dat niet hijzelf of het notariaat, maar de Kamer in deze kwestie uiteindelijk het laatste woord zou hebben. ${ }^{89}$ Een hernieuwd pleidooi

86. Zie voor een verslag van deze studieochtend WPNR 5871 (1988).

87. Zie daarover E. Boeser, Vruchtgebruik of ouderlijke boedelverdeling, WPNR 5661 (1982); W.G. de Vries, De positie van de langstlevende echtgenoot, WPNR 5661 (1982) en J.D. le Grand, De langstlevende in opmars?, WPNR 5682 (1982). Anders: S. Perrick, Het erfrecht: een kwestie van politiek?, WPNR 6041 (1992).

88. De resultaten van deze enquête zijn samengevat in WPNR 5890 (1988).

89. Aldus blijkt uit een nota van De Die van 1 november 1988 . Uit deze nota volgt, dat de beslissing, de discussie na 1974 ten spijt, op dat moment nog geheel open was en dat de Minister nog geen definitief standpunt had ingenomen; Sinds 1982 was er ten Departemente niet meer over het erfrecht gesproken. Anders dan Van Mourik in WPNR 6041 (1992) suggereert - "Het betoog van De Die kan slechts worden begrepen tegen de wens van hem (en het Ministerie) het ontwerp, koste wat het kost, 
van de Commissie Erfrecht om - op basis van de resultaten van de enquête - de in 1974 verlaten voortrein weer op de rails te zetten, vond bij de Minister dan ook geen gehoor. Soons: "Naar aanleiding van die studieochtend en de uitslag van de enquête is het Hoofdbestuur bij De Die langs geweest, waarbij de voorkeur van het notariaat nog eens uitdrukkelijk naar voren is gebracht. De Die heeft toen gezegd, dat kun je wel vergeten, dat is politiek niet verkoopbaar." Wel bleek de Minister, bij monde van De Die, nog steeds bereid tot vereenvoudiging.

Voor Van Mourik was dit het sein om af te haken: "Een reden was dat ik geen tijd had. Een andere reden was dat ik al zag aankomen dat ik daar in een zeer moeilijke positie zou komen. Als je in zo'n commissie zit, dan kun je moeilijk buiten de commissie om met kritiek komen. Ik dacht bij mijzelf, ik zit er dan in, maar eigenlijk wordt mij zo de mond gesnoerd. Dat vond ik onaanvaardbaar." Soons: "Hij heeft zelf bedankt, omdat hij geen tijd had - dat was zijn officiële reden. De tweede reden was dat hij begreep dat het de verkeerde kant uitging. Hij had graag gezien dat de Commissie in 1988 het onaanvaardbaar had uitgesproken, maar zover was de Commissie zeker niet. Er waren zeker aarzelingen binnen de Commissie, maar onaanvaardbaar? Nee."

Kort hierna zou de Kamer een brief bereiken, waarin aan de vaste Commissie voor Justitie de vraag werd voorgelegd of zij bereid was met deze oplossing van een vereenvoudigd vruchtgebruik in te stemmen. ${ }^{90}$ Enkele weken later liet de vaste Commissie de Minister weten dat op de ingeslagen weg mocht worden voortgegaan. Wel was, evenals in 1978 het geval was geweest, sprake van een zekere reserve. Soons: "De Kamer heeft die vraag voorzichtig positief beantwoord, zij het dat zij zich niet wilde vastleggen. Maar de Minister heeft toen toch het idee gehad, als ik op die lijn doorga, dan heb ik de meerderheid van de Kamer wel achter me."

\section{Het "tweede" vruchtgebruikontwerp}

Op het moment dat de vaste Commissie voorzichtig "ja" zei tegen de voorstellen van Minister Korthals Altes, was het tweede vruchtgebruikontwerp zo goed als gereed. De Die: "Ik heb vrij kort na 1982 een Gewijzigd Ontwerp gemaakt. Boek 4 moesten we als gevolg van de Stofkamoperatie helaas laten vallen, waardoor er jarenlang niet over is gepraat. In 1985, toen het overgangsrecht was ingediend, ben ik weer met het erfrecht aan het werk gegaan. Ik heb het ontwerp toen nog een keer aangepast en ik heb opnieuw contact gezocht met de Commissie Erfrecht." Heuff: "Op een gegeven moment kwamen er weer nieuwe teksten van De Die, voorstellende een vereenvoudigd vruchtgebruikontwerp. Daarop heeft het Hoofdbestuur gevraagd of wij bereid zouden zijn daar onze kritiek op te gaan leveren, met inachtneming van wat er in 1982 was gezegd en met de uitdrukkelijke opdracht ons niet tegenover het Ministerie te binden, ook geen standpunten in te nemen, maar zuiver op het technische vlak bezig te zijn. Gezien de vergadering in 1982 wilde het bestuur niet zonder meer met een vruchtgebruikconceptie akkoord gaan."

89. $\rightarrow$

naar het Staatsblad te leiden" - is het dus de Minister zelf geweest die, na afweging van de andere alternatieven, deze conclusie heeft getrokken.

90. Tweede Kamer 1988-1989, nr 17141, stuk 5. Deze brief was gedateerd op 23 maart 1989. 
Het overleg over het nieuwe erfrecht werd in de tweede helft van 1989 afgesloten. Het nieuwe ontwerp was ongeveer eenderde korter dan het eerste ontwerp. Daarnaast bracht het, zoals was toegezegd, drie belangrijke materiële verbeteringen. Allereerst was de verplichting om jaarlijks opgave te doen van mutaties geschrapt. Daardoor kon - het tweede verschilpunt - de berekening van de vergoedingssom na het einde van het vruchtgebruik sterk worden vereenvoudigd. Tenslotte werd de constructie van vruchtgebruik op geld en toonderstukken, met de daarbij behorende theoretische en praktische complicaties, vermeden door de langstlevende een toeëigeningsbevoegdheid te geven. "In het resultaat zit alles wat de notarissen zich maar kunnen wensen met hun voorkeur voor de ouderlijke boedelverdeling", volgens De Die bij de aanbieding van het ontwerp.

Vervolgens zond het Departement de definitieve tekst in aan de Broederschap, met de vraag of het nieuwe voorstel op de steun van het notariaat kon rekenen. Portefeuillehouder In 't Hout: "Eind 1989 werd Boek 4 in hoofdlijnen afgerond. De uitspraak uit 1982 kennende, moesten wij als Bestuur de ringen in om onze leden te raadplegen. Op een gegeven moment werd dat gestimuleerd doordat de Tweede Kamer aankondigde een hoorzitting te willen beleggen over het wetsontwerp. Het wetsontwerp was niet bij ons bekend, wel inhoudelijk natuurlijk, maar het mocht niet naar buiten worden gebracht. Wat moesten wij onze leden adviseren? We hebben daarover met de Commissie Erfrecht overlegd en zij heeft gezegd, met alle mitsen en maars die er waren, dit is een aanvaardbaar ontwerp, hier is mee te leven."

Uit de interviews blijkt dat de Commissie Erfrecht zich niet zomaar gewonnen gaf. Creutzberg: "De Commissie heeft toen allerlei berekeningen gemaakt, en geprobeerd nauwkeurig uit te werken hoe je uitkomt met een (wettelijke) OBV en hoe met een vruchtgebruik. Zij heeft daartoe allerlei aan de praktijk ontleende casusposities bedacht, eerste huwelijk, tweede huwelijk, eigen huis, geen eigen huis, getrouwd onder huwelijkse voorwaarden, algemene gemeenschap van goederen, etc. Daarnaast zijn de voordelen van de ouderlijke boedelverdeling tegenover de voordelen van het vruchtgebruikstelsel gezet, waarbij de laatste bleken te overwegen."

De kritiek op de Commissie Erfrecht, dat zij zich zou hebben gecommitteerd aan het wetsvoorstel ${ }^{91}$, wordt door voorzitter Heuff dan ook zeer beslist tegengesproken: "Van Mourik heeft, evenals Perrick, een andere voorstelling van zaken gegeven en de Commissie Erfrecht allerlei verweten, wat niet terecht was. Alsof dit ontwerp iets was dat uit de Commissie Erfrecht was gekomen! Het is zuiver een ontwerp geweest van het Ministerie, dat, naar aanleiding van onze technische kritiek, nog op allerlei punten is bijgeslepen." De Die vult aan: "Na 1982 kreeg de Commissie heel duidelijk het consigne mee, dat alleen technische kritiek mocht worden geleverd. Ik heb dus ook nooit gevraagd, staan jullie achter het ontwerp? Daar mochten ze zich niet over uitlaten. ${ }^{92}$

91. M.J.A. van Mourik, Reactie, WPNR 6035 (1992); Naschrift, WPNR 6050 (1992); Het erfrecht van de langstlevende echtgenoot en de Memorie van Antwoord, WPNR 6086/7 (1993); S. Perrick, Het erfrecht, een kwestie van politiek?, WPNR 6041 (1992).

92. De Die vervolgt: "Ik denk, maar dat weet ik ook niet, dat er in de Commissie Erfrecht ook heel verschillend wordt gedacht over het vruchtgebruikontwerp. Van Kleijn weet ik dat hij ter gelegenheid van een studentencongres heeft gezegd dat hij vóor het vruchtgebruik was. Maar dat las ik pas later, eigenlijk tot mijn verbazing, want in het overleg kwam dat niet tot uiting. Soons is naar mijn indruk 


\section{Een "rondje ringen"}

Begin oktober 1990 wendde het Hoofdbestuur zich tot de leden met de vraag of het bestuursstandpunt door hen werd ondersteund. Anders dan in 1974 en 1982 het geval was, toen het erfrecht tijdens de reguliere jaarvergadering aan de orde werd gesteld, werd ditmaal gekozen voor een ingelast "rondje ringen". De reden daarvoor was dat men een herhaling van 1982, toen de discussie toch wel heel duidelijk werd gedomineerd door voorstanders van de ouderlijke boedelverdeling, wilde voorkomen. "We hadden natuurlijk een extra jaarvergadering kunnen beleggen", volgens In 't Hout, "maar dat was geweldig moeilijk, alleen al omdat er vergaderd moest worden terwijl de teksten niet aanwezig waren. Bovendien, waar een grote hoeveelheid mensen zitten kom je nooit tot een goede besluitvorming. Dat kom je veel beter in de ringen, waar veel meer mensen aan het woord kunnen komen. De gewone notaris, die in een zaal met 1200 mensen niet zo snel naar de microfoon zou lopen, zou misschien nu wel iets durven te vragen."

Zoals In 't Hout aangaf, was het ontwerp in oktober 1990, toen de rondgang van start ging, nog niet officieel beschikbaar. Van Mourik heeft in dit verband gesproken van een "zorgvuldig overdacht aanvalsplan"93, maar in werkelijkheid blijkt van een krijgslist geen sprake te zijn geweest; De Tweede Kamer, kennelijk NBW-moe, had eenvoudig geen zin het erfrecht, dat inmiddels al weer bijna een jaar gereed lag om te worden ingediend, in behandeling te nemen. De Die: "De indiening is een hele tijd opgehouden omdat de Minister van de Kamercommissie het sein had gekregen dat het nog niet opportuun was het ontwerp in te dienen. Dat was heel vreemd en het pakte ook helemaal verkeerd uit, omdat de Commissie Erfrecht het ontwerp toen moest uitleggen in de ringen, zonder dat zij op stukken kon wijzen." Creutzberg: "De indiening van het wetsontwerp is tegengehouden door de Tweede Kamer, ik meen door Van der Burg. Toen is de Broederschap op een gegeven moment zover gegaan, dat zij aan de vaste Commissie heeft verzocht of nu eindelijk dat wetsontwerp kon worden ingediend. Dat was een heel vreemd punt." 94

Om in dit manco te voorzien, ontving iedere deelnemer vooraf een summiere notitie betreffende de politieke voorgeschiedenis van Boek 4, een ruwe schets van de gewijzigde versie van w.o. 17141, een weergave van het standpunt van de Broederschap, alsmede de bekende brief van 23 maart 1989 van de Minister van Justitie aan de Tweede Kamer inzake het nieuwe erfrecht. Daarnaast kreeg het Bestuur bij de rondgang in de ringen ondersteuning van de Commissie Erfrecht, ook weer uitsluitend

92. $\rightarrow$

wel altijd 'tegen' geweest. Maar dat ik dat niet weet, daar blijkt wel uit dat de Commissie daar niet over praatte. Het illustreert dat het overleg zuiver technisch werd gehouden."

93. M.J.A. van Mourik, Naschrift, NJB 1991 p. 1553.

94. De reden daarvoor was dat het CDA-Kamerlid Van der Burg indiening niet wenselijk vond. Op een onbewaakt ogenblik - de voorzitter van de vaste Commissie, mevrouw Swildens, was afwezig had hij het voorstel gedaan Boek 4 van de lijst van in behandeling te nemen wetsontwerpen af te voeren en daarbij de andere commissieleden overruled. De omstandigheid dat Minister Hirsch Ballin Van der Burg, die bleef zeuren over het rapport van de Commissie van Wijzen, kort tevoren een gevoelige nederlaag had toegebracht, is daarbij wellicht van betekenis geweest. Zie hieronder, Hoofdstuk 11. 
op het technische vlak. Soons: "Wij hebben als Commissie toen een notitie samengesteld, waarin we een weergave hebben gegeven hebben van het systeem van het ontwerp. Daarbij hebben we gezegd, voorzover wij het kunnen bekijken, is ermee te werken. In een aantal ringen hebben we ook met voorbeelden gewerkt en hebben we heel duidelijk de verschillen tussen de ouderlijke boedelverdeling en het systeem zoals het er toen al lag, uiteengezet."

Het resultaat van de rondgang was dat elke ring akkoord ging, met uitzondering van de ring Arnhem. Heuff: "Er waren soms wel de nodige aarzelingen, er is soms ook heel veel discussie geweest, die twee á drie uur kon duren, maar men heeft de uitspraak van het bestuur tenslotte vrijwel algemeen onderschreven." In 't Hout: "Alle ringen hebben ons na raadpleging gesteund, behalve de ring van Van Mourik, volgens hem omdat hij de enige was die erover had nagedacht, maar een deel zal ook wel helpen dat hij daarzelf bij aanwezig was en zijn verbale kwaliteiten kon uitleven. De ringen die hij daarna heeft bezocht - daar waren overigens vele faxen en tirades van hem aan voorafgegaan - , hebben het ontwerp namelijk wél gesteund." Van Mourik daarover: "Die instemming werd gevraagd voordat het ontwerp er was. Op grond van een verhaal van het bestuur - een politiek verhaal, een beleidsverhaal - en een technische uiteenzetting door een lid van de Commissie Erfrecht. Er werd geen enkele vorm van kritiek geleverd. Nee, het was de bedoeling dat de leden allemaal 'ja' zouden zeggen. Het is ze overal gelukt, na een discussietje van drie kwartier, een uur. Twee verhaaltjes, nog vragen? Nee? Dat kon ook niet, want niemand wist waar het over ging. Niemand had het ontwerp gezien. Behalve in Arnhem, want daar zat ik. Ik wist het wel, ik beschikte ook over de ontwerp-tekst. Ik heb daar een enorme stampij gemaakt, met als gevolg dat Heuff en het bestuurslid de zaal zo ongeveer zijn ontvlucht omdat bij stemming bleek dat 97 procent van de aanwezigen tegen het vruchtgebruik was."

De omstandigheid dat 18 van 19 ringen zich akkoord hadden verklaard met het verbeterde vruchtgebruikontwerp, leidde ertoe dat het Hoofdbestuur van de ledenraad het groene licht kreeg. In 't Hout: "We zijn toen naar de vaste Kamercommissie geweest en hebben daar ons standpunt uiteengezet, namelijk: Het notariaat is voorstander van de ouderlijke boedelverdeling, maar het vruchtgebruik is voor ons een werkbaar compromis. Niet aanvaardbaar, maar werkbaar, in de praktijk hanteerbaar."

\section{Van Mourik slaat terug}

Van Mourik, die zijn afkeer voor het vruchtgebruikstelsel nooit onder stoelen of banken had gestoken, wilde zich niet bij voorbaat neerleggen bij de uitspraak van ledenraad en bestuur. Geholpen doordat de Tweede Kamer opnieuw weinig haast maakte met het in behandeling nemen van het erfrecht, opende hij in september 1991 het vuur op het Gewijzigd Ontwerp door te betogen dat de voorgestelde regeling "door een verstandig mens in gemoede niet aan Nederland als versterferfrecht kan worden opgedrongen." ${ }^{\text {95 }}$ Volgens Van Mourik zou het sop de kool niet waard zijn "het gesignaleerde erfrechtelijke risico van hertrouwen betreft ongeveer $11 \%$ van de gevallen" -, was de keuze voor de vruchtgebruikfiguur in strijd met de sociale realiteit

95. M.J.A. van Mourik, De meeslepende avonturen van de langstlevende echtgenoot (III), NJB 1991, p. 1251 e.v. 
- "men beschouwt de langstlevende in de praktijk als enige gerechtigde" -, en werd op deze wijze het vruchtgebruik vergaand gedenatureerd - "wat als vruchtgebruik gepresenteerd wordt, mag die naam niet hebben." Bovendien zou de regeling onnodig gecompliceerd zijn door de "moeilijk bepaalbare vergoedingsrechten en de eis dat in ieder geval een boedelbeschrijving moet worden opgemaakt. ${ }^{96}$

Daarnaast kwam Van Mourik op 1 februari 1992 met een eigen wetsvoorstel, gestoeld op het beginsel van de ouderlijke boedelverdeling: De langstlevende echtgenoot is enig erfgenaam, de kinderen ontvangen een geldvordering, niet opeisbaar gedurende het leven van de langstlevende. ${ }^{97}$ Wel was er dit verschil, dat de aansprakelijkheid van de kinderen voor de schulden van de langstlevende werd uitgesloten. In de toelichting schreef Van Mourik: "Dit ontwerp doet denken aan de voortrein-Van Agt uit 1974. Daarmede heeft het 'slechts' echter het enig erfgenaamschap gemeen. De twee belangrijkste bezwaren tegen de voortrein worden thans omzeild. Er is geen sprake van opeisbare vorderingen en nimmer behoeft een som-ineens ter voldoende verzorging van de langstlevende echtgenoot te worden vastgesteld. Wie goed ziet, constateert dat dit voorstel materieel gelijk is aan de vruchtgebruikconstructie van 1990." Géén rekening had Van Mourik echter gehouden met de wens van Kamer en Raad van State om de kinderen uitzicht op goederen te geven. In feite waren dus uitsluitend "de twee belangrijkste bezwaren" van het notariaat "omzeild". Bovendien was de legitieme van de kinderen geschrapt, ondanks dat deze al sinds 1969 in Boek 4 stond en bij de enquête in 1988 door $74 \%$ van de notarissen als wenselijk werd beschouwd. De Commissie Erfrecht schreef in een commentaar: "Indien in het ontwerp-Van Mourik wel rekening zou moeten worden gehouden met een legitieme portie van de kinderen bij aanwezigheid van een echtgenoot, zou de regeling veel ingewikkelder worden, zoals de regeling van de voortrein (..) laat zien." Volgens haar zou het ontwerp dan ook "op enige essentiële punten" niet voldoen aan de verlangens van het notariaat. ${ }^{98}$

Tenslotte kwam Van Mourik in februari/maart 1992 met een eigen opiniepeiling, teneinde het bestuur van de KNB en de Commissie Erfrecht te "corrigeren". Het Hoofdbestuur was niet erg gelukkig met dit initiatief, volgens Van Mourik: "Met name In 't Hout, de portefeuillehouder, heeft geprobeerd de discussie volledig buiten de deur te houden. De ringvoorzitters kregen opdracht alle opiniepeilingen tegen te houden, met name de tweede. Daarin vroeg ik, 'Wie is bereid om ook nog in deze

96. In WPNR 6018 (1991) werkte Van Mourik deze laatste stelling nog verder uit met betrekking tot de bevoegdheid van de langstlevende om goederen die van zuiver financiële waarde zijn zich toe te eigenen tegen vergoeding van hun waarde. Uit zijn conclusie: "De toekenning van toeëigeningsbevoegdheid aan de langstlevende echtgenoot leidt, mede gelet op de vervreemdingsbevoegdheid, tot een diskwalificatie van het vruchtgebruik. Het gekunstel wordt nog vergroot door het feit dat de goederen die zich voor toeëigening lenen, vooralsnog veelal niet tot de nalatenschap maar tot de ontbonden huwelijksgemeenschap behoren."

97. M.J.A. van Mourik, Voorstel van wet betreffende de regeling van de erfrechtelijke positie van de echtgenoot in Boek 4 nieuw BW, WPNR 6034 (1992). Bij het ontwerp was een verslag gevoegd van een onderzoek naar de grootte van de nalatenschappen in het rayon Arnhem, waaruit bleek dat in $198956 \%$ van de nalatenschappen van eerststervende echtgenoten minder dan fl 10.000,- bedroeg, terwijl 73\% de fl 40.000 ,- niet te boven ging. Vergelijk ook WPNR 5109/10 (1974) en NJB 1982, p. 1 e.v., waar men een verslag vindt van Van Mouriks eerdere onderzoeken op dit terrein.

98. Het langstlevende-ontwerp-Van Mourik een alternatief?, WPNR 6034 (1992), met een reactie van Van Mourik, WPNR 6035 (1992). 
omstandigheden het vruchtgebruikstelsel te verwerpen.' Ik dacht bij mijzelf, als ik alleen vraag hoe men tegenover de OBV staat, dan is de uitslag van te voren bekend en zegt men, 'dat wisten we al'. Die tweede peiling heb in ongeveer zeven ringen kunnen houden. Men heeft er alles aan gedaan om die tegen te houden. "99 In 't Hout heeft een andere lezing: "Wij zijn integendeel die discussie met Van Mourik aangegaan en hebben daarom de Commissie Erfrecht met hem mee gestuurd, want het erfrecht is natuurlijk zoiets wezenlijks voor ons dat je niet kunt zeggen, je bent te laat, dus mag je niet meer meedoen. Maar aan de andere kant moet je als bestuur niet vergeten dat je je wel hebt gecommitteerd. Je hebt een uitspraak gedaan naar de Tweede Kamer toe. We hebben gezegd, hier is voor ons mee te leven. We hebben ook gezegd dat de ouderlijke boedelverdeling een prachtig systeem was, en of dat nu alleen uit gemakzucht voortkomt of niet, het is ook een mooi systeem. Maar goed, als de wetgever dat niet wil, dan willen wij ook verder meedenken. Dat hebben wij ook gedaan."

Het voorstel van Van Mourik kreeg in eerste instantie veel bijval. J.M. Polak kritiseerde in NJB 1992, p. 197 het vruchtgebruikstelsel met de woorden dat "de wetgever niet meer aanknopingspunten voor procedures moet geven dan onvermijdelijk is", Van der Burght (WPNR 6037) noemde het voorstel van Van Mourik "een heldere bij eerste lezing begrijpelijke regeling", Perrick (WPNR 6041) sprak van "een sympathiek voorstel", terwijl Heyman (WPNR 6043) schreef dat "het nieuwe erfrecht na veertig jaar tobben niet mag uitmonden in een politiek compromis, dat niet wordt gesteund door een ruime meerderheid binnen het notariaat." 100 Alleen Luijten, die zich al eerder achter de plannen van de Regering had gesteld en voor nieuwe vertragingen in het wetgevingsproces vreesde, reageerde terughoudend: "Zou het notariaat in meerderheid toch een eenvoudiger stelsel (dan w.o. 17141) wensen, dan heb ik het voornemen hieromtrent met eigen gedachten te komen." 101

Ook de "notaris uit de straat" toonde zich bijzonder ingenomen met Van Mouriks voorstel: Blijkens de stemmingen was $91,29 \%$ vóór de OBV en tegen het vruchtgebruik. Volgens $72,05 \%$ van de deelnemers zou het vruchtgebruik zelfs onder alle omstandigheden moeten worden afgewezen. ${ }^{102}$ De Die, die op 21 maart 1992 in het WPNR aan de hand van vele voorbeelden betoogde dat het ontwerp door zijn critici niet in het juiste daglicht werd gesteld, kon aan die uitslag niets meer veranderen. ${ }^{103}$

Frappant is wel dat de enquête van 1988 geheel andere cijfers oplevert, zelfs indien de voorstanders van een "langstlevende al" bij de voorstanders van de OBV worden

99. Vergelijk M.J.A. van Mourik, Het erfrecht van de langstlevende echtgenoot, WPNR 6048 (1992).

100. Overigens is er op de kwaliteit van deze steunbetuigingen wel het een en ander af te dingen. Polak zal het wel met mij eens zijn dat eenvoud niet het hoofdcriterium mag zijn bij de inrichting van het erfrecht, Van der Burght geeft in zijn bewerking van Pitlo's erfrecht blijk van een veel genuanceerder en gematigder oordeel, Perrick geeft niet aan wat er mis is en verliest zich in onjuiste verdachtmakingen en stemmingmakerij, terwijl Heijman het erven over een kam scheert met het ontvangen van een vordering ter grootte van een erfdeel.

101. E.A.A. Luijten, Een nieuw geluid, WPNR 6034 (1992).

102. De resultaten van beide peilingen zijn gepubliceerd in WPNR 6048 (1992).

103. B.C. de Die, Tegen-stellingen, WPNR 6041 (met een reactie van Van Mourik). Zie ook WPNR 6050 , waarin een reactie van De Die met daarbij een naschrift van Van Mourik. "Fundamentele bedenkingen" werden ook geuit door Luijten in WPNR 6034 (allen 1992). 
opgeteld (66\%). Luijten: "Van Mourik verstaat de kunst, net zoals Willem I, om de cijfers te groeperen. Toen de Grondwet van 1815 aangenomen moest worden met een tweederde meerderheid, telde Willem I alle afwezige Belgen als voorstemmers. Dat heeft Van Mourik niet gedaan, maar door de ringen te bewerken heeft hij daar een stemming gekweekt die door onkunde van de toehoorders tot dit soort resultaten leidde. Wil je de OBV in de wet? Dan zegt niemand nee."

\section{8 April 1992}

De strijd over het nieuwe erfrecht beleefde zijn voorlopige dieptepunt op 8 april 1992, toen Van Mourik "na veel problemen en een hoop lawaai" het bestuur van de Broederschap zover wist te krijgen dat hij op de voorjaarsvergadering van 1992, waar het erfrecht aanvankelijk niet op de agenda stond, mocht spreken.

In de toelichting op het agendapunt stond vermeld: "Het is niet de bedoeling om op de vergadering tot een discussie over het erfrecht te komen. Het bestuur, daartoe gemachtigd door de ledenraad, heeft naar de politiek toe het standpunt uitgedragen dat het wetsontwerp 17141, het wettelijk vruchtgebruik, voor de Broederschap als compromis, aanvaardbaar is. Derhalve is het bestuur, daartoe gesteund door de ledenraad, van mening dat op het eerder ingenomen standpunt thans niet kan worden teruggekomen." Soons: "Je kunt je natuurlijk afvragen waarom het Hoofdbestuur het in april 1992 zo hoog heeft gespeeld, met name ten opzichte van Van Mourik. De reden daarvan was, dat men benauwd was dat er een uitspraak zou komen met de strekking, het enige dat acceptabel is, is de OBV, de vruchtgebruikoplossing is dat niet. Het bestuur vond dat zij dat ten opzichte van het Ministerie niet kon maken, omdat zij nog geen anderhalf jaar daarvoor had gezegd dat zij wel kon leven met het vruchtgebruik."

In zijn rede "het erfrecht van de langstlevende echtgenoot" beklemtoonde Van Mourik allereerst dat het politieke draagvlak voor de vruchtgebruikregeling "allesbehalve stevig" was. Van Mourik licht toe: "Ik heb heel nadrukkelijk gesproken met Wolffensperger, omdat de leden van D '66 het minst gebonden zijn. (..) Verder heb ik met de CDA-fractie gesproken, waar Van der Burg geacht moet worden enig verstand van het erfrecht te hebben, evenals Van der Camp, en daar bleek mij ook alras, dat men in de CDA-fractie nu niet overloopt van enthousiasme voor het vruchtgebruikidee." Daarnaast herhaalde Van Mourik zijn bezwaren tegen het vruchtgebruikontwerp: "In mijn ontwerp ontstaat geen aansprakelijkheid voor de kinderen ${ }^{104}$, geen onverdeeldheid en kan de langstlevende doen en laten wat hij of zij wil." Tenslotte kwam hij met twee nogal opzienbarende amendementen op zijn voorstel, namelijk de invoering van een quasi-legitieme, -inbreng en -onwaardigheid, en de inbetalinggeving. Van Mourik zei over deze laatste figuur: "Door te bepalen dat de kinderen kunnen verlangen dat hun vorderingen, ten laste van de nalatenschap van de overleden langstlevende ouder, door de stiefouder worden voldaan in zaken, afkom-

104. Dat de kinderen in het systeem van het vruchtgebruikontwerp aansprakelijk zijn voor de schulden van de erflater, lijkt m.i. ernstiger dan het is: Het is althans opvallend dat dit bezwaar, dat eveneens tegen de testamentaire ouderlijke boedelverdeling kan worden ingebracht, nog niet eerder werd vernomen. 
stig uit het vermogen van de overleden ouder, wordt inderdaad een grote politieke angel weggenomen." 105

Enig tegengas werd geleverd door W.M. Kleijn, die namens de Commissie Erfrecht een tamelijk bloedeloos verhaal afstak, en Minister Hirsch Ballin, die, in reactie op een nogal eenzijdige bijdrage van Van Mourik van een paar weken daarvoor, op 4 april een artikel liet plaatsen in de Telegraaf waarin hij zijn steun voor het vruchtgebruikstelsel onomwonden uitsprak. ${ }^{106}$

Het gevolg was, dat uiteindelijk met grote meerderheid van stemmen een motie werd aangenomen, waarin enerzijds "met klem" werd aangedrongen op een wettelijke regeling op basis van de voorstellen van Van Mourik, maar waarin anderzijds het oordeel van een jaar eerder, dat het vruchtgebruik een voor de praktijk werkbare regeling is, werd onderschreven. ${ }^{107}$ Een "slappe uitspraak", volgens Van der Grinten. ${ }^{108}$ Van Mourik: "Die motie is in die bewoordingen gesteld omdat het bestuur met aftreden dreigde. Wij moesten kiezen tussen óf een overweldigende meerderheid, óf een enorme ruzie in de vergadering en een stemverhouding van $55 \%$ vóór, omdat men het bestuur niet wil laten vallen. Van Dam, opvolger van De Die: "Die bemoeienis van de Minister heeft er in ieder geval toe geleid dat de motie die op de ledenvergadering is aangenomen, toch enigszins dubbelzinnig was. Aan de ene kant werd er gezegd dat het notariaat een voorkeur heeft voor een wettelijke ouderlijke boedelverdeling, maar aan de andere kant bleef het notariaat vasthouden aan het standpunt dat in 1990 was ingenomen, namelijk dat het vruchtgebruiksysteem een werkbaar systeem was. In de publiciteit is dat wat minder naar voren gekomen, omdat die voor een groot deel gestuurd is door Van Mourik. Meteen nadat de motie was aangenomen stond hij in een telefooncel om aan de pers door te bellen dat de motie was aangenomen."

Merkwaardig is wel, dat het voorstel-Van Mourik ook na de amendementen op de vrijwel volledige steun van het notariaat kon rekenen. Want in feite werd hiermee het Paard van Troje binnengehaald. Enerzijds, omdat op deze wijze dezelfde oneigenlijke figuren worden ingevoerd die in 1974 de Voortrein deden stranden: "Op deze wijze hebben wij de quasi-legitieme weer terug, die in een vroeger ontwerp zoveel kritiek ontmoette", volgens een verbaasde Luijten. ${ }^{109}$ Anderzijds, omdat tegen de inbetalinggeving - in 1982 nog vergeefs bepleit door de Commissie Erfrecht - identieke bezwaren kunnen worden aangevoerd als tegen het vruchtgebruikstelsel. De Die:

105. M.J.A. van Mourik, Het erfrecht van de langstlevende echtgenoot, WPNR 6048 (1992). Het Gewijzigd-Ontwerp Van Mourik verscheen in WPNR 6050. (1992).

106. Van Mourik is daar nóg verontwaardigd over. De Telegraaf, 25 april 1992: "Het feit dat Minister Hirsch Ballin zich enige weken geleden in deze krant zelf met deze zaak bemoeide was hoogst verrassend. Te meer nu de minister een groot staatsrechtgeleerde is die geen enkele deskundigheid bezit op het gebied van het erfrecht. Uit alles bleek dan ook dat de tekst was voorgekookt door de (inmiddels gepensioneerde) ambtenaar die het ontwerp heeft gemaakt." De Die: "Ik heb dat artikel niet geschreven. Het is heel grappig, maar mijn vrouw en ik waren op dat moment met vakantie in Sousse in Tunesië. Ik had er ook geen flauw benul van dat dat artikel zou verschijnen. Ik liep daar langs zo'n krantestalletje en zag toen opeens die kop 'Hirsch Ballin over het erfrecht.' Ik heb die krant natuurlijk direct gekocht."

107. Zie het persbericht van de KNB van 8 april 1992, gepubliceerd in WPNR 6046 (1992).

108. W.C.L. van der Grinten, De strijd over het erfrecht, WPNR 6055 (1992).

109. E.A.A. Luijten, Het erfrecht van de langstlevende echtgenoot; het einde in zicht?, WPNR 6053 (1992). 
"Van Mouriks systeem loopt alleen als je voorschrijft dat na het overlijden van elke gehuwde een boedelbeschrijving wordt gemaakt van zijn nalatenschap of de gemeenschap die door zijn overlijden werd ontbonden, en je zo'n gemeenschap ook verdeelt; Anders kun je immers niet aangeven op welke goederen de kinderen hun optie moeten uitoefenen. Dat is veel meer werk dan het wetsontwerp vergt, en Van Mourik moet om te beginnen dan al zijn verwijt inslikken dat juist het ontwerp een boedelbeschrijving verlangt. ${ }^{110}$

Volgens de Groningse notaris Wolf, deskundige op het gebied van het vruchtgebruiktestament, zouden op 8 april de emoties opnieuw de overhand hebben gehad: "Ik vond dat op die vergadering de andere kant onvoldoende werd belicht. Sprekers die voor het vruchtgebruik waren, werden min of meer weggehoond door Van Mourik c.s. Er heerste geen plezierige sfeer. (...) Een groot deel van de aanwezigen heeft het ontwerp ook nooit van de binnenkant gezien: "Wij zien wel wat er uit komt."

\section{Het voorstel-Luijten}

Wie mocht menen dat na 8 april de strijd over het erfrecht definitief was beslist, komt bedrogen uit. Kort daarop verscheen het zgn. ontwerp-Luijten, dat volgens zijn schepper eenvoudiger zou zijn dan het ontwerp-Van Mourik en ook beter zou aansluiten op de praktijk van de ouderlijke boedelverdeling, omdat aan het erfgenaamschap van de kinderen niet wordt getornd. ${ }^{111}$ Luijten benadrukt dat zijn voorstel een substitutief karakter heeft en niet is gericht tegen het Regeringsontwerp: "Ik vind de oplossing van De Die voortreffelijk. Ik sta nog steeds volledig achter zijn ontwerp, maar wanneer de politiek zegt, dat willen we niet, dan kom ik met een andere oplossing."

In Luijtens voorstel kan de langstlevende de goederen van de nalatenschap aan zich doen toedelen onder de verplichting alle schulden van de nalatenschap als eigen schulden over te nemen en de overige erfgenamen het aandeel in de nalatenschap te voldoen. Dit toedelingsrecht moet binnen een jaar na het overlijden van de erflater worden uitgeoefend; Laat de echtgenoot de daartoe strekkende verklaring achterwege. dan wordt hij, indien de omstandigheden daarop wijzen, niettemin geacht het toedelingsrecht te hebben uitgeoefend. Daarnaast is de echtgenoot bevoegd zich roerende zaken, geldswaarden en effecten toe te eigenen.

Het voornaamste bezwaar tegen deze oplossing is, dat na de uitoefening van het toedelingsrecht door de langstlevende, de desbetreffende goederen zullen moeten worden geleverd door de andere erfgenamen. Dit betekent dat, gezien artikel 3:186, de langstlevende afhankelijk is van de medewerking van de andere erfgenamen, een punt waartegen het notariaat nu juist altijd te hoop is gelopen en waarvoor de testamentaire ouderlijke boedelverdeling een pasklaar antwoord bood. ${ }^{112}$ Is het ont-

110. Merkwaardig is ook dat Van Mourik in 1982 de noodzaak van een boedelbeschrijving nog niet als een ernstig bezwaar voelde. Vergelijk ook de Commissie Erfrecht, Twee nieuwe voorstellen voor het erfrecht van de langstlevende echigenoot, WPNR 6055 (1992).

111. E.A.A. Luijten, Het erfrecht van de langstlevende echtgenoot: het einde in zicht?, WPNR 6053 (1992).

112. Zie daarover de Commissie Erfrecht, Twee nieuwe voorstellen voor het erfrecht van de langstlevende echtgenoot, WPNR 6055 (1992); M.J.A. van Mourik, Kanttekeningen bij het voorstel- 
werp-Luijten in zoverre de mindere van het ontwerp-Van Mourik en als alternatief zelfs enigszins onbegrijpelijk, anderzijds kan het ook moeilijk als een versterking van de positie van Van Mourik worden gezien. Niet alleen blijkt hieruit dat van een communis opinio binnen het notariaat geen sprake is, maar bovendien weerspiegelen beide ontwerpen tot op zekere hoogte elkaars gebreken, daarmee illustrerend dat de bescherming van de belangen van de langstlevende en de kinderen beide met de figuur van de wettelijke ouderlijke boedelverdeling niet goed is te realiseren. ${ }^{113} \mathrm{Zo}$ opgevat is het niet onmogelijk dat achteraf moet worden geconcludeerd dat het voorstel-Luijten de weg heeft vrijgemaakt voor het vruchtgebruikontwerp.

\section{De laatste wending?}

De laatste en mogelijk beslissende wending op weg naar het nieuwe erfrecht werd op 3 juni 1993 gezet. Tot verrassing van vriend en vijand presenteerde de Notariële Broederschap tijdens de viering van haar 150 -jarig bestaan namelijk een eigen voorstel voor het wettelijk erfrecht, teneinde het notariaat weer op één lijn te krijgen. "Het ziet er naar uit", aldus het begeleidende persbericht, "dat met dit voorstel binnen het notariaat de tegenstellingen over het meest wenselijke erfrecht, met name ten opzichte van de langstlevende echtgenoot, zijn beslecht."

Het "nieuwe" van dit voorstel is dat de langstlevende echtgenoot en de kinderen erfgenamen zijn - evenals in het huidige erfrecht en in het Regeringsontwerp het geval is. Dit erfgenaamschap van de kinderen is evenwel minder dan het lijkt, want voor het overige volgt het voorstel de praktijk van de ouderlijke boedelverdeling: Op het moment dat één van de echtgenoten overlijdt, worden alle bezittingen eigendom van de achterblijvende echtgenoot, tenzij deze binnen drie maanden blijk geeft anders te willen. Tegelijkertijd wordt vastgesteld wat de aard van de bezittingen is en op welk bedrag de kinderen aanspraak hebben. Deze vordering is pas opeisbaar als ook de andere echtgenoot is overleden.

Het grote verschil tussen dit voorstel en het vruchtgebruikontwerp blijft dat de kinderen geen recht hebben op een erfdeel in goederen. De langstlevende kan vrij over de goederen beschikken, het erfgenaamschap van de kinderen voorkomt niet dat de goederen bij hertrouwen op drift raken. Een voordeel is wel dat men zich een feitelijke verdeling van de boedel bespaart; De complicatie van het vruchtgebruiksysteem is, dat die verdeling bovendien tot na de dood van de langstlevende wordt uitgesteld.

Of dit initiatief-ontwerp datgene brengt waar iedereen op heeft zitten wachten, is twijfelachtig. Het voorstel sluit - beter dan dat van Van Mourik of Luijten - aan op de praktijk van de ouderlijke boedelverdeling, maar doet geen recht aan de bezwaren van

\footnotetext{
112. $\rightarrow$

Luijten, WPNR 6055 (1992). Het ontwerp-Luijten is met enige amenderingen en aanvullingen gesteund door W.G. de Vries, WPNR 6066 (1992).

113. De keuze voor het enig erfgenaamschap van de langstlevende (de zgn. automatische werking van de OBV) impliceert dat de rechten van de kinderen als erfgenamen worden uitgeschakeld. Om hun rechten tegenover anderen dan de langstlevende veilig te stellen zijn daarom aanvullende maatregelen noodzakelijk, zoals het ontwerp-Van Mourik en de voortrein laten zien. In het ontwerpLuijten kunnen deze voorzieningen achterwege blijven, maar zijn daarentegen weer extra regels ten behoeve van de langstlevende vereist.
} 
Kamer en Regering. De technische en praktische bezwaren die tegen de voorstellen van Van Mourik (quasi-erfgenaamschap, inbetalinggeving) en Luijten (medewerkingsvereiste) kunnen worden aangevoerd, zijn met dit voorstel geëcarteerd, de fundamentele bezwaren tegen de ouderlijke boedelverdeling niet. In zoverre lijkt het voorstel vooral geschikt om de verdeeldheid binnen het notariaat op te lossen, waar de meeste notarissen het zicht op de materie inmiddels hebben verloren. Maar of de wetgever daarmee geholpen is?

\section{Pro en contra}

\section{a. Een oud probleem}

Laat de weergave van de geschiedenis van de herziening van het erfrecht tot nu toe al zien dat sprake is van een herhaling van zetten, dit beeld wordt nog versterkt als we een blik werpen op de geschiedenis vóór 1974, met name op het punt van de positie van voorkinderen.

Een voorbeeld. Als de wetgever in 1920 voorstelt de langstlevende echtgenoot een kindsdeel te geven, wijst Meijers o.a. op het bezwaar dat de langstlevende echtgenoot te veel kan worden bevoordeeld, hetgeen hij als volgt illustreert: "Een echtgenoot met zeer veel voorkinderen hertrouwt; in het tweede huwelijk wordt één kind geboren. De tweede echtgenoot overlijdt. Het erfdeel van de hertrouwde, overlevende echtgenoot is nu $1 / 2$. Dit belangrijk erfdeel zal, na het overlijden van deze hertrouwde echtgenoot voor slechts een gering deel aan het kind van de erflater te goede komen, daarentegen voor het grootste deel aan de voorkinderen die gans niet tot de familie van de tweede echtgenoot behoren. Zeker niet een gewenst resultaat. "114 115

Een ander voorbeeld. Als de Kamer in 1953 in het kader van de vraagpuntenprocedure besluit de langstlevende een legitieme portie te geven, illustreert notaris De Raadt aan de hand van enige praktijkvoorbeelden dat men, door de tweede echtgenoot volledig recht te doen, de voorkinderen schromelijk onrecht kan aandoen. In een van die voorbeelden is sprake van een vermogend man met éen kind, die hertrouwt in gemeenschap van goederen; Uit het tweede huwelijk wordt nog een kind geboren. Vervolgens overlijdt de man. De Raadt tekent aan: "Overlijdt daarna de weduwe en heeft deze haar kapitaal intact gelaten, dan wordt dit geheel verkregen door háár enig kind, het jongste van de twee half-broers-of zusters. De jongste krijgt hierdoor vele malen meer dan de oudste en toch is alles afkomstig van hun beider vader. (..) Zou de tweede echtgenoot vóór haar man overlijden, dan krijgt men plotseling een heel ander beeld. (..) Als de vader het vermogen intact laat, wordt dit later normaliter door beide kinderen gelijkelijk geërfd en zullen beider uiteindelijke totale verkrijgingen niet zo heel veel meer uiteenlopen. Is hier echter geen sprake van pure willekeur,

114. E.M. Meijers, Het wetsontwerp tot wijziging der erfopvolging, WPNR 2616 (1920). Meijers had het voorbeeld overigens ontleend aan een pre-advies van H.M.J. Janssen, uitgebracht in 1918 aan de Broederschap van notarissen, die het op zijn beurt weer had ontleend aan de Motive op het eerste ontwerp van het Duitse Burgerlijk Wetboek.

115. Overigens geldt hetzelfde als w.o. 17141 wet wordt, omdat daarin niet wordt getornd aan het kindsdeel van de langstlevende echtgenoot. Het vruchtgebruik rust immers alleen op de erfdelen van de kinderen. 
dat het eerder overlijden van hetzij de man, hetzij de vrouw, voor bedoelde kinderen dergelijke vérstrekkende consequenties kan hebben?" 116

Een laatste voorbeeld. Als de Commissie Erfrecht in maart 1960 voorstelt de langstlevende de gehele nalatenschap te geven en de kinder-legitieme te schrappen, voegt zij daar aan toe dat de kinderen tegenover de tweede echtgenoot wel een legitieme moeten hebben. De reden: "Wat de langstlevende ouder krijgt ontgaat de kinderen niet, voor zover de verzorging het vermogen niet heeft ingeteerd. Maar hieruit volgt, dat de verkrijging door de tweede echtgenoot anders gewaardeerd moet worden dan die door de langstlevende ouder. Wat de tweede echtgenoot erft, is meermalen voor de kinderen uit het eerste huwelijk verloren. Daar moeten de kinderen dus wel rechten kunnen doen gelden op hun legitieme, al staat deze achter bij de verzorgingsaanspraak." 117

\section{b. De ouderlijke boedelverdeling}

$\mathrm{Nu}$ kan men zich natuurlijk afvragen, waarom dit geluid in 1974 zo weinig heeft doorgeklonken. ${ }^{118}$ Als de Raad van State en de Tweede Kamer destijds hun bezwaren voor zich hadden gehouden, dan hadden we het immers met de voortrein moeten doen.

Een mogelijk antwoord op deze vraag zou kunnen zijn dat de maatschappelijke opvattingen sinds de laatste helft van deze eeuw sterk zijn gewijzigd, dat de familieband veel losser is geworden en dat de kinderen blij moeten zijn met het geld dat zij ontvangen, als er tenminste nog wat over is. Want, en dat moet men bij het lezen van de hierboven geciteerde opmerkingen wel in het oog houden, de kinderen stonden in de daar genoemde gevallen geheel met lege handen, terwijl zij in het stelsel van de ouderlijke boedelverdeling in ruil voor hun verloren gegane erfdeel tenminste nog een geldvordering ontvangen.

Dit standpunt, dat het erfrecht van de kinderen eigenlijk uit de oude doos is, is aanvankelijk wel verdedigd door Van Mourik, maar hij heeft niettemin zijn voorstel nu aangevuld met de inbetalinggeving. Dat argument valt dus af. Van Mourik daarover: "Ik ben niet blind voor dat argument. Ik vind ook dat Opa's zakhorloge naar de familie terugmoet. "119 120

116. P.C. de Raadt, Tweede - en langstlevende - echtgenoot en de legitieme portie in het nieuwe B.W., WPNR 4333 (1953).

117. Rapport I, p. 34.

118. Een uitzondering moet worden gemaakt voor notaris C.H. Kingma en E.A.A. Luijten, die tijdens de jaarvergadering van 1974 een oppositioneel geluid lieten horen. Na de vergadering zou P.L. Nève - overigens geen notaris - in WPNR 5393 (1975) aan de hand van een brief die hij had ontvangen van een grote provinciale landbouworganisatie, erop wijzen dat de voortrein "zeer onaangename gevolgen kan hebben" omdat het ontwerp ertoe kan leiden dat voorkinderen nooit enig recht krijgen op het onroerend goed van hun vader of moeder.

119. Ook volgens de andere geïnterviewden bestaat nog wel degelijk de gedachte dat bepaalde verwanten, in de eerste plaats de kinderen, gerechtigd zijn om in de goederen van de erflater op te volgen. Wolf: "In zestig á zeventig procent van de gevallen - en dan overdrijf ik echt niet - is er bij de ouders een duidelijk emotionele band met de kinderen, die er in resulteert dat men zegt: Wij hebben eigenlijk maar éen probleem, wij willen dat ons vermogen uiteindelijk bij onze kinderen terecht komt. Ik heb nog nooit mensen gehoord die zeggen, niks ervan, het is ons geld, ons 
Mijn indruk is dat het er bij het notariaat in 1974 ook niet zozeer om ging de (voor-) kinderen te onterven, maar dat men zich blind staarde op de mogelijkheden die de ouderlijke boedelverdeling bood om de positie van de langstlevende te versterken. Luijten zegt hierover het volgende: "De enorme opgang van OBV-testamenten heeft zich voltrokken tussen de jaren zestig en zeventig. Men heeft toen, en dat is de fout geweest van het notariaat, nauwelijks verschil gemaakt tussen eerste en tweede huwelijk. Dat heeft geleid tot grote conflicten. Gelukkig zijn daarop uitspraken van de Hoge Raad (HR 19 september 1969, NJ 1969, 402) gekomen. In 1970 heb ik, om verder onheil te voorkomen, in mijn noot onder het Makkum-arrest gewaarschuwd tegen een automatische toepassing van de OBV in de testamentaire praktijk $^{121}$. (..) Met andere woorden, pas na 1970 zie je dat er een differentiatie optreedt, dat men zich afvraagt of de figuur van het vruchtgebruik toch niet beter bij een bepaalde situatie past. Het automatisme, dat voor 1970 heel gewoon was, wordt nu minder." Wolf vult aan: " $\mathrm{k}$ heb het idee dat er in die tijd binnen het notariaat te weinig aandacht is besteed aan de belangen van de kinderen. Men heeft er te lichtvaardig over gedacht. Pas na de Makkumse boedelverdeling is er veel meer aandacht besteed aan de gerechtvaardigdheid van de boedelverdeling. Ons is toen pas uitvoerig op de haken en ogen van de OBV gewezen."

Dat het notariaat zich in 1974 de waarschuwing van Luijten kennelijk nog niet had aangetrokken, hangt waarschijnlijk samen met een ander aspect, namelijk de opheffing van de lex hac edictali. Soons: "Het hertrouwbezwaar heeft onderhuids natuurlijk altijd wel meegespeeld, maar, dat moet u zich ook realiseren, de discussie rond de voortrein speelde in de tijd dat we juist de lex hac edictali hadden afgeschaft. 'Alle huwelijken moeten gelijk behandeld worden, geen onderscheid tussen eerste en tweede huwelijken', was toen het parool. In 1970 was iedereen blij dat we van die lex hac edictali afwaren - niet zozeer vanuit principiële overwegingen, maar veel meer vanuit praktische overwegingen; Je zat toen met gecontinueerde gemeenschappen. Dat

119. $\rightarrow$

vermogen, wij willen er mee doen wat we willen." Luijten: "Waarom zou je in een wetsbepaling met deze sentimenten geen rekening mogen houden, als je ziet dat affectieve goederen zonder zo'n bepaling kunnen verdwijnen naar de stieffamilie, die er in elk geval nog minder prijs op zal stellen dan de stiefkinderen? De plaats die een kind in het gezin heeft, behoort ook in het erfrecht tot uitdrukking te komen, zoals overal elders in de wereld."

120. Vergelijk ook B.J. de Leeuw in NJB 1927, p. 81 e.v., die om deze reden de legitieme voor de langstlevende echtgenoot verwierp. "Men kan staande houden dat er een maatschappelijk belang bestaat dat het fortuin in de familie blijft, maar ook zij dit dit ontkennen of dit een beginsel vinden dat uit den tijd is, zullen toch moeten erkennen dat er generlei maatschappelijk belang is aan te wijzen dat eist dat het fortuin op de langstlevende echtgenoot en van deze op diens familie vererft. Bedenkt men bovendien dat de tegenwoordige erfrechtsregeling van het toeval laat afhangen of het fortuin van de familie van hem die het ten huwelijk aanbracht behouden blijft of verloren gaat gevolg van de omstandigheid dat men het erven in eigendom boven het erven in vruchtgebruik voor de langstlevende echtgenoot verkozen heeft, - dan schijnt het geen verder betoog te behoeven, dat er geen goede grond aanwezig is om de echtgenoot van een kinderloze erflater een legitieme in eigendom te geven."

121. Ars Aequi 1970, p. 110 e.v. In dit arrest vernietigde de Hoge Raad een ouderlijke boedelverdeling wegens benadeling van meer dan $1 / 4$ (art. 1170), omdat de overbedelingsvordering van de kinderen was afgedekt door clausules van niet-opeisbaarheid en renteloosheid, hetgeen te meer sprak omdat de langstlevende echtgenoot bij het openvallen van de nalatenschap slechts 54 jaar oud was. 
was een hopeloos iets. Pas veel later heeft men zich gerealiseerd, is dat nu wel zo verstandig geweest? Het probleem van hertrouwen komt dan weer wat sterker naar voren."

\section{c. De rol van de traditie}

Een volgende vraag is, waarom het notariaat ook nu nog zo sterk hecht aan de ouderlijke boedelverdeling. Daarvoor zijn drie redenen aan te voeren. ${ }^{122}$

In de eerste plaats is het zo, dat onder het stelsel van het oude B.W. een vruchtgebruiker niet tot beschikking en intering bevoegd was. Dat betekende dat hij zich tevreden moest stellen met de opbrengst van het vruchtgebruik, de vruchten, zodat deze figuur alleen bij zeer grote nalatenschappen interessant was. De moderne ouderlijke boedelverdeling, waarbij alle goederen aan de langstlevende worden toebedeeld en de kinderen in beginsel genoegen moeten nemen met een niet-opeisbare vordering, was, beoordeeld tegen deze achtergrond, daarom een prachtvondst. Luijten: "De drang naar een nieuw erfrecht is eigenlijk na de oorlog begonnen, omdat sindsdien de betekenis van het vruchtgebruik als verzorgingsmaking terugliep. Twee oorzaken waren daaraan debet. De eerste is, dat het vruchtgebruik in de naoorlogse tijd, waarin de kinderen zich steeds onafhankelijker gingen opstellen ten opzichte van hun ouders, bepaalde nadelen te zien gaf, omdat het vruchtgebruik de langstlevende wel een bepaald inkomen biedt maar geen zeggenschap geeft. De tweede oorzaak was dat de vermogens hoe langer hoe meer werden afgeroomd door de hoge belastingen en sociale lasten. Het inkomen uit vermogen tegenover de inkomsten uit arbeid was een post die steeds minder betekende. ${ }^{123}$

Het bezwaar, dat het vruchtgebruik onvoldoende soulaas biedt voor kleine nalatenschappen, is met de invoering van het nieuwe B.W. echter verdwenen. Het merkwaardige is $\mathrm{nu}$, dat in de discussie over het ontwerp de oude strijd tussen boedelverdelers en vruchtgebruikers soms toch weer de kop lijkt op te steken. ${ }^{124}$ Soons: "Het wordt door de tegenstanders van het huidige ontwerp wel eens vergeten, maar een vruchtgebruik met beschikkingsbevoegdheid is in het nieuwe B.W. een vruchtgebruik. Wij, die opgegroeid zijn met het B.W. van 1838 vinden dat misschien gek, maar die gedachte kom je reeds tegen in het groene Boek. Het is dan ook de grote verdienste geweest van De Die - ik weet niet geheel zeker of hij de uitvinder is - dat hij met deze oplossing is gekomen. Hij zei, wat willen jullie? Jullie willen een langstlevende

122. Aan het argument dat de ouderlijke boedelverdeling een eenvoudig systeem is, ga ik in deze paragraaf voorbij. Bij het zoeken naar een goed wettelijk erfrecht behoort de principiële kant van de zaak op de voorgrond te staan, niet de technische.

123. Illustratief hierbij is de volgende uitlating van Van der Ploeg in WPNR 4295 (1953), dat men de langstlevende zeker geen vruchtgebruik zou moeten geven: "De langstlevende moet kunnen interen, ja, zonodig alles voor zich besteden. (..) Wat heeft in echtgenoot in de meeste gevallen aan een legitieme in vruchtgebruik? Wanneer de legitieme bij een kinderloos huwelijk de helft van de nalatenschap zou uitmaken, dan betekent de legitieme in vruchtgebruik, dat de echtgenoot bij een nalatenschap van f. 50.000,- een jaarlijks inkomen zou geniet van f. 1.000,-. De legitieme Drees zouden we dat kunnen noemen." Vergelijk ook Meijers in WPNR 2616 (1920).

124. Zie W.G. Huijgen, Het vruchtgebruik van Boek 4 nieuw BW of What's in the name?, WPNR 5948 (1990); Daartegen: J.B. Vegter, Over de wenselijkheid van het vruchtgebruik voor de langstlevende in Boek 4 titel 2a, WPNR 5971 (1990), met een naschrift van Huijgen. 
echtgenoot die over de spullen kan beschikken, die tegen de kinderen kan zeggen, je moet overal van afblijven en je hebt niets te vertellen. Wat doe ik dus? Ik maak gebruik van het vruchtgebruik met beschikkingsbevoegdheid, verbind daaraan de consequentie dat de blote eigenaar niet beschikkingsbevoegd is, en pas de regels van het vruchtgebruik toe." Luijten: "De voorstanders van de OBV willen een vruchtgebruik zien als een recht om vruchten te trekken, niet als een recht om te vervreemden. Dat is oneigenlijk, zegt men. Men vergeet dan één ding, namelijk dat het vruchtgebruik dat in Boek 3 staat al sinds 1954 kan worden toegerust met een vervreemdingsrecht."

Een tweede reden, die de voorkeur van de notarissen voor de ouderlijke boedelverdeling kan verklaren, is dat het notariaat nogal behoudend is, althans in sterkere mate dan menige andere beroepsgroep. ${ }^{125}$ Dat het vruchtgebruiktestament in het Oosten en het Zuiden van het land nog steeds een zekere populariteit bezit, heeft daarom, anders dan Van Mourik ${ }^{126}$ veronderstelt, niet meer zoveel met grootgrondbezit te maken - Wolf: "De room is er inmiddels wel af"- maar met gewenning. Soons: "Ik kan mij althans niet voorstellen dat de wezensaard van de mensen in het Noorden zo anders is dan in de rest van het land." Maar zoals deze macht der gewoonte tot op zekere hoogte bepalend is voor de voorkeur van de vruchtgebruiknotarissen, zo verklaart zij evenzeer de sympathie van een groot deel van het notariaat voor de ouderlijke boedelverdeling. Anders is het ook niet goed te verklaren dat men de inbetalinggeving toejuicht, maar tegelijk het recht op goederen verwerpt. Heuff: "Ik geloof dat de voorkeur voor het ene of voor het andere stelsel veel te maken heeft met wat men gewend is in de praktijk te hanteren. (..) De weerstand tegen het vruchtgebruikstelsel komt ook voor een deel uit deze hang naar traditie voort. Dat blijkt ook wel, omdat het nieuwe stelsel in de praktijk voor betrekkelijk eenvoudige gevallen niet geheel anders uitpakt dan wanneer je naar het systeem-Van Mourik had gemoeten." Van Mourik: "De oudere generatie is niet gewend om regelmatig te studeren. Dat verklaart ook een beetje dat er in sommige gebieden niets verandert in de erfrechtelijke praktijk. Het is altijd zo geweest, het is altijd goed gegaan, waarom zouden we dat veranderen?"127

De macht der gewoonte kan vanzelfsprekend gemakkelijk worden opgewaardeerd als voortkomend uit de bewuste keuze van de cliëntèle van het notariaat. Dat is echter een stelling die met de nodige scepsis moet worden beoordeeld. Soons: "In 1988 is een enquête gehouden onder het notariaat en daaruit bleek dat zo'n $48 \%$ de OBV in de wet wilde omdat dat de wens van de Nederlandse bevolking zou zijn. Persoonlijk

125. Bekend is het verhaal dat in een nog niet zo grijs verleden op menig kantoor de testamenten nog werden geschreven, omdat de wetgever van 1838, die geen rekening had kunnen houden met de komst van de typemachine, dat nu eenmaal verlangde.

126. M.J.A. van Mourik, De meeslepende avonturen van de langstlevende echtgenoot, NJB 1991, p. 1254.

127. In 't Hout: "Op mijn eerste kantoor in Utrecht deed ik ook vruchtgebruik. Het is naar mijn idee maar waarmee je gewend bent te werken, waar je in de praktijk mee in aanraking komt. De ouderlijke boedelverdeling wordt in de praktijk zonder problemen opgelost, maar datzelfde geldt ook voor de vruchtgebruiktestamenten." Creutzberg: "Niet onbelangrijk in de gehele discussie is verder, dat de voorkeur van het notariaat voor de OBV ten dele op gemakzucht berust. Men kent de OBV, men kan er goed mee werken. Akkoord, maar met het vruchtgebruik kunnen de Noordelijke notarissen naar eigen zeggen ook goed werken." 
zet ik daar nog wel eens een vraagteken bij, want ik heb zo'n idee dat het notariaat de mensen soms wel eens wat in de mond legt." Wolf: "Als er iemand bij me komt en zegt, er komen dadelijk twee mensen die je een ouderlijke boedelverdeling moet aanpraten, dan lukt me dat. Dat is helemaal niet moeilijk. Want laten we wel zijn, het hangt voor een groot deel ervan af, hoe ik als notaris dat hele verhaal verkoop." Van Mourik: "Ik geef toe, een zekere beïnvloeding door de manier van vragen is er natuurlijk wel bij, je vraagt of de kinderen 'praatjes' moeten kunnen maken, je vraagt niet of de kinderen rechten moeten hebben."

\section{d. Hertrouwen}

Is dus de voorkeur van het notariaat voor de ouderlijke boedelverdeling in zoverre discutabel, nog merkwaardiger wordt het indien men weet dat er geen notaris in Nederland is, die bij tweede huwelijk zonder meer een OBV-testament zal aanbevelen. ${ }^{128}$ Toch is dat de consequentie van de ouderlijke boedelverdeling als intestaat-erfrecht.

Notaris J. Rombach, met Luijten in vroeger jaren de grote propagandist van de ouderlijke boedelverdeling, kritiseerde de voorkeur voor een wettelijke ouderlijke boedelverdeling eens als volgt: "M.i. zou geen enkel echtpaar met kinderen, dat deze (wettelijke) mogelijkheid serieus overwoog, nalaten dit bij testament anders te regelen. Dit wordt bevestigd door de dagelijkse notariële praktijk, dat weldenkende weduwen en weduwnaars met kinderen hertrouwen aanvoelen als het stichten van een nieuw gezin, dat hoort te beginnen met een schone lei, d.w.z. na afrekening met de kinderen - en wie niet wél denkt, zou wettelijk tot hetzelfde verplicht moeten worden." ${ }^{129}$ Luijten blijkt hier niet anders over te denken: "Meent u nu werkelijk dat iemand met kinderen uit zijn eerste huwelijk, die op latere leeftijd hertrouwt, ook al heeft hij maar één huisje, de rechten van zijn kinderen zomaar zal uitschakelen? Dan trekt de notaris maar even een OBV uit de kast? Dan ga ik toch nadenken?"

Dat het notariaat niettemin onverkort vasthoudt aan de OBV in de wet, komt dan ook vooral doordat men erop speculeert dat hertrouwers bedacht zijn op de vermogensrechtelijke consequenties van hun volgend huwelijk en zonodig bij testament een andere regeling treffen. Een voorbeeld daarvan levert Van Mourik in een recent commentaar, geschreven naar aanleiding van het verschijnen van de Memorie van Antwoord: "Geen woord wijdt de Minister aan de praktijk voor zover het betreft de maatregelen die hertrouwende personen nemen in de sfeer van huwelijksvermogensrecht en erfrecht en die het door de Minister opgeblazen probleem tot geringe proporties terugbrengen." 130

Tegen deze opvatting zijn echter twee bezwaren aan te voeren. In de eerste plaats is het nog maar de vraag of iedereen, die voor een tweede keer trouwt, op de hoogte

128. Zie daarover W. Huijgen, WPNR 5948 (1990) die om deze reden zelfs het voorstel heeft gedaan de positie van de tweede echtgenoot te laten zoals zij is. Een eenvoudige oplossing, maar elementair onbillijk. Niet voor niets heeft de Tweede Kamer al in 1953 bij de beantwoording van het $47 \mathrm{e}$ vraagpunt beslist dat de wet in het huwelijksgoederen- en het erfrecht geen onderscheid dient te maken tussen de eerste, tweede of verdere echtgenoot.

129. J. Rombach, Hoe het 'langstlevende al', ook bij hertrouwen, juridisch bevredigend te verwezenlijken?, WPNR 5126 (1971).

130. WPNR 6087 (1993). Zie ook Van Mourik, NJB 1991, p. 1252. 
is van de consequenties die dat met zich meebrengt en tijdig maatregelen treft. Weliswaar is het zo dat de overblijvende echtgenoot gewoonlijk niet vandaag of morgen hertrouwt, dat men de toekomstige echtgenoot al wat langer kent, en dat in zo'n situatie bij zowel de langstlevende echtgenoot als bij de kinderen de vraag opkomt wat men aan moet met de onverdeelde nalatenschap, maar er zijn toch ook genoeg voorbeelden waarbij dat niet het geval is. ${ }^{131}$

In de tweede plaats maakt het nogal wat verschil of een erflater zélf bij testament bepaalt dat de rechten van voorkinderen zoveel mogelijk moeten worden uitgeschakeld, of dat de wetgever dat doet. "Men zegge niet dat deze bezwaren door een testamentaire regeling ondervangen kunnen worden", schreef Meijers al in 1920. "Ware de testeervrijheid voldoende waarborg voor een verwezenlijking der billijkheid, dan had dit gehele wetsontwerp achterwege kunnen blijven." 132 J.C. van Oven, die men toch onmogelijk een gebrek aan aandacht voor de positie van de langstlevende echtgenoot kan verwijten, dacht hierover niet anders: "Zeker kan het voorkomen, dat men het wel gewenst acht, dat de kinderen vermogen van hun stiefmoeder via hun vader verwerven, maar niet goed is het dat de wet daartoe dwingt. (..) Dit zijn oud-bekende bezwaren die men placht samen te vatten onder de formule van de ongewenstheid dat 'vermogen van de ene familie in de andere komt'; edoch, dit is een veel te slappe en koude formulering van een schrijnende en vaak voorkomende onrechtvaardigheid. "133 Veelbetekenend is, dat de notarissen die het beginsel "langstlevende al" verdedigen, daarbij steeds een uitzondering plegen te maken voor het geval van tweede huwelijk. Zo ook Van Mourik in één van zijn vroegere bijdragen: "Ook in het systeem van 'de langstlevende-al' zullen bijkomende regels moeten worden gegeven voor gevallen van scheiding van tafel en bed, hertrouwen en mogelijk ook voor onder curatele stelling van de langstlevende (..) Het betreft hier allemaal exeptionele aangelegenheden. In een wettelijke regeling mogen zij niet aan de aandacht ontsnappen." ${ }^{134}$ Ook Rombach is daarover heel duidelijk: "Een "langstlevende-al' dat niet zou zijn voorzien van een redresserende regeling voor de gevallen van hertrouwen enz. is juridisch een onding."

\section{e. Het sop is de kool niet waard}

$\mathrm{Nu}$ kan worden tegengeworpen - een punt dat ook nogal tegen het Regeringsvoorstel wordt aangevoerd - dat de omvang van het probleem sterk wordt overschat. Van Mourik heeft er in dit verband op gewezen dat van de 180.000 mensen die momenteel

131. In 't Hout: "Volgens de statistieken trouwen er elk jaar 20.000 mensen die eerder getrouwd zijn geweest. Als ik dan zie wat er op mijn kantoor zou moeten komen, dan klopt dat niet. En als men komt, dan komt men in een veel latere fase aan. Men heeft vroeger geen huwelijkse voorwaarden gemaakt, daar denkt men niet aan, het leeft niet bij de mensen. Dat argument klopt dus niet."

132. E.M. Meijers, WPNR 2616 (1920).

133. J.C. van Oven, Moet aan de langstlevende echtgenoot een legitieme portie worden toegekend?, WPNR 4560 (1958). Hierbij moet in het oog worden gehouden dat de bezwaren van beide schrijvers zich richtten tegen dat deel van de nalatenschap (een breukdeel van het kindsdeel) dat via de legitieme portie onaantastbaar vererft naar de de stieffamilie. Bij een wettelijke ouderlijke boedelverdeling, waar de langstlevende enig erfgenaam is, spreken deze bezwaren nog veel sterker.

134. M.J.A. van Mourik, De realiteit en de positie van de langstlevende echtgenoot in het komend erfrecht, WPNR 5110 (1970). 
jaarlijks trouwen er ongeveer 30.000 zijn die al een eerder huwelijk achter de rug hebben. Aangenomen dat er daarvan 20.000 zijn die kinderen uit een vroegere betrekking meebrengen - daarover zijn geen cijfers bekend -, betekent dit dat het gesignaleerde erfrechtelijke risico ongeveer $11 \%$ bedraagt. ${ }^{135}$ Verder weten we dat de omvang van de meeste nalatenschappen bitter klein is, of zoals één van de geïnterviewden zei: "De meeste mensen hebben nauwelijks een cent. Men heeft een huis, met daarop een schuld. Zodra er enige overwaarde in het huis zit, dan nemen ze een tweede hypotheek en kopen ze er een grote auto voor, omdat de buren ook een grote auto hebben." Tenslotte is het zo dat over de gerechtvaardigdheid van de claim van de kinderen in de meeste gevallen geen enkele twijfel bestaat. "Het is vaak al naar de kinderen gegaan van degene die het afstopt, en er is eigenlijk nooit twijfel aan dat de spulletjes die van moeder waren naar zijn kinderen gaan en die van vader naar haar kinderen gaan. Zo expliciet regelt men die zaken niet, maar ik merk dat daar toch weinig twist over is," volgens In 't Hout.

Dat zal allemaal wel, maar daar gaat het niet om. Elk geval is er één, en zelfs één procent is nog geweldig veel. Van Oven schreef in 1958: "Deze gevallen komen dagelijks voor; men mag hier niet met procenten werken. Natuurlijk, meestal zal van dit alles geen sprake zijn, doordat de nalatenschap zo klein is, dat de langstlevende met alles gaat strijken. Het gaat hier dus niet om wat men noemt de kleine man, zelfs niet om de grote groep die een klein vermogentje bezitten, maar het gaat om de welgestelden. Intussen zijn die er gelukkig nog vrij veel en de wetgever dient, vooral in het erfrecht, ook met hen rekening te houden en aan zulke sterk sprekende casusposities aandacht te wijden." 136

Ook ten aanzien van het tweede punt, dat de meeste nalatenschappen uit niet meer dan wat geld en inboedelgoederen bestaan waarvoor eigenlijk niemand van de kinderen zich interesseert, kan een blik op het verleden verhelderend werken. Luijten, die in 1965 in zijn inaugurale rede 'Si mulier virum supervixeret' het "langstlevende al" in verband met de hertrouwproblematiek meende te moeten afraden bij de grotere boedels, kreeg van Rombach het volgende toegevoegd: "Deze redenering 'waar weinig is, maakt het weinig uit', is m.i. eenzijdig materialistisch en miskent het rechtsgevoel, dat los van de knikkers zijn spel-eisen stelt, zoals men als boedelnotaris dagelijks ook bij de kleinste boedeltjes kan ervaren." 137 Anno 1994 is dat niet anders. Wolf: "Zestig á zeventig procent van de mensen wil dat die kast, ook al is het louter klatergoud, bij die zoon of die dochter terecht komt. Hoe kleiner het bezit, des te groter zijn de sentimenten. Je hebt veel mensen die alleen maar AOW genieten.

135. M.J.A. van Mourik, De meeslepende avonturen van de langstlevende echtgenoot (III), NJB 1991 , p. 1251 e.v. Volgens Van Mourik moet men van deze $11 \%$ nog aftrekken het aantal gevallen waarin de andere echtgenoot, die voor de eerste keer trouwde, het eerst overlijdt. Mijns inziens klopt dat niet, want in al die huwelijken zou de echtgenoot met voorkinderen dan een testament moeten maken ter correctie van de o.b.v., want hij weet immers tevoren niet of hij dan wel zijn echtgenoot vooroverlijdt.

136. J.C. Van Oven, Moet aan de langstlevende echtgenoot een legitieme portie worden toegekend?, WPNR 4560/61 (1958). lets eerder schreef hij: "Bovendien is een tiende van de dagelijks in ons land openvallende nalatenschappen nog altijd een groot getal, groot genoeg om ons de moeite te doen nemen, ook hiervoor een goede regeling in de wet neer te leggen."

137. J. Rombach, Het 'langstlevende-al', ook bij hertrouwen, juridisch bevredigend te verwezenlijken?, WPNR 5126 (1971). 
Toch slagen zij er in elke maand iets over te houden, niet voor zichzelf, maar voor de kinderen." En wat te denken van artikel 899b BW, dat door Van Mourik in dit verband in de strijd wordt gemengd? ${ }^{138}$ Het lijkt erop dat De Die het bij het rechte eind heeft als hij schrijft dat dit artikel juist tegen de visie van Van Mourik pleit: Door het inboedelvoordeel te onthouden aan de echtgenoot die met de kinderen erft, geeft de wetgever te kennen dat hij niet wil dat de inboedelgoederen voorgoed uit het bereik van die kinderen raken. ${ }^{139} 140$

Tenslotte het argument dat de voorkinderen met de stieffamilie meestal wel tot een vergelijk komen. Eigenlijk is dat het beste argument om tot een wettelijke regeling op dit punt te komen. Want wat is er mooier dan een regel die feilloos aansluit bij het rechtsbewustzijn? Dat betekent dat als de wet goed in elkaar zit, zo'n regel automatisch wordt toegepast. Niet de sanctie, die op overtreding van de regel staat, is dan bepalend voor het gedrag van de erven, maar de eigen zedelijke betekenis van het wetsvoorschrift. De wet heeft tenslotte een symboolfunctie, in die zin dat zij een uitdrukking behoort te zijn van de heersende zede of van het moreel inzicht van de wetgever. Ook als men, zoals in het erfrecht uitdrukkelijk het geval is, via de mogelijkheid van een testamentaire voorziening uitzonderingen toelaat, dient het beginsel in de wet te staan.

\section{Het wenselijke systeem}

$\mathrm{Nu}$ is gebleken dat het recht op goederen een te waarderen belang is, dient nog de vraag aan de orde te worden gesteld op welke wijze dit recht het best kan worden veiliggesteld: Door middel van de figuur van een vruchtgebruik met beschikkingsbevoegdheid (w.o. 17141) of door de ouderlijke boedelverdeling met inbetalinggeving (stelsel-Van Mourik)?

138. M.J.A. van Mourik, Onoverbrugbare tegenstellingen, WPNR 6041 (1992).

139. B.C. de Die, reactie, WPNR 6050 (1992). Meijers kwam in 1923 (WPNR 2778) tot dezelfde conclusie: "Waarom de tweede echtgenoot dit recht, dat niemand in zijn vermogen benadeelt, niet is toegekend, wanneer er voorkinderen zijn, is vermoedelijk met het oog op familiestukken, die tot den inboedel behoren, geschied." Het vervolg is overigens nog sprekender: "Maar waarom heeft men dit motief hier zo zwaar laten gelden, waar het ontwerp er anderzijds geen bezwaar in ziet om bij gebreke van kinderen de langstlevende echtgenoot tot universeel erfgenaam te maken, waardoor alle goederen - en zelfs zonder vergoeding voor de familie verloren gaan?" Trek er het 'zelfs zonder vergoeding' af, en men heeft het standpunt dat Meijers vermoedelijk ten aanzien van de voortrein of het voorstel-Van Mourik zou hebben ingenomen.

140. Vergelijk ook A.A.L. Minkenhof, Het erfrecht van de langstlevende echtgenoot, WPNR 4626 (1960), die om deze reden verandering van deze regel afwees: "Het meeste bezwaar heb ik tegen het voordeel van de tweede echtgenoot, die met de voorkinderen erft. Die mag het weliswaar alleen tegen vergoeding van de waarde uitoefenen, maar dat is bepaald niet zo'n hoog bedrag en het gaat hier bepaald niet om de waarde, het gaat om de goederen zelf. Soms in het oog van een buitenstaander verfoeilijk lelijke dingen, van geringe waarde, soms ook inderdaad kostbare antiquiteiten. maar in elk geval familiestukken, en vaak juist afkomstig uit de familie van de eerste echtgenoot. Dergelijke familiestukken komen bij rijk en arm voor en die horen naar mijn mening in de familie te blijven en dus juist niet naar de tweede echtgenoot te gaan."

In w.o. 17141 wordt dit probleem opgelost doordat artikel 4.2a.2.2 de langstlevende het vruchtgebruik over de inboedelgoederen toekent. 
a. vruchtgebruik. Eén van de meer principiële bezwaren die tegen het Regeringsontwerp wordt aangevoerd, is dat het vruchtgebruik gedenatureerd is. Daargelaten dat dit voor de moderne ouderlijke boedelverdeling in nog veel sterkere mate geldt ${ }^{141}$, is dit argument stellig onjuist.

Het kan geen kwaad nog eens te herhalen dat Meijers al in 1954 het vruchtgebruik van Boek 3 had uitgerust met een vervreemdings- en een verteringsbevoegdheid, waarmee een brug werd geslagen tussen de figuur van het klassieke vruchtgebruik enerzijds en het fideïcommis de residuo anderzijds. ${ }^{142}$ Dat deze regeling snel als een bruikbare en dogmatische volwaardige figuur werd erkend, die ook voor het erfrecht van belang zou kunnen zijn, blijkt doordat Van Oven haar al in 1958 als een mogelijkheid noemde waardoor aan de verzorgingsbehoefte van de langstlevende echtgenoot vorm zou kunnen worden gegeven. Dat hij haar uiteindelijk toch verwierp, kwam omdat hij van mening was dat deze oplossing - we schrijven 1958 - voor velen te ver zou gaan: "Dit gemoderniseerd fideïcommissum de residuo impliceert een volledig gebruiksrecht, staat dus praktisch gelijk met (..) eigendom." ${ }^{143}$ De Commissie Erfrecht kwam in 1960 tot dezelfde conclusie kwam: een mooie, goede regeling, maar té vooruitstrevend. Dogmatische bezwaren, praktische bezwaren werden niet vernomen.

$\mathrm{Nu}$ is het zo dat met name de tweede versie van wetsontwerp 17141 op nogal wat punten verschillen laat zien met de algemene vruchtgebruikregeling; De zaaksvervanging is afgesneden, de jaarlijkse opgave geschrapt, een bijzondere vorm van toeëigening ingevoerd. De vraag is echter of deze kritiek niet teveel aan het moment is gebonden. Over het hoofd dreigt dan te worden gezien dat de Tweede Kamer, Regering en wetenschap in 1954 de legitieme voor de langstlevende en het inboedelvoordeel al een enorme stap voorwaarts vonden op de weg naar versterking van de positie van de langstlevende. De tijd was - althans voor zover het het erfrecht betrof nog niet rijp voor deze nieuwe rechtsfiguur. Dat blijkt ook hieruit, dat Meijers tijdens de besprekingen in de Staatscommissie over titel 3.8 de noodzaak tot verdergaande vereenvoudiging wel onderkende, maar daar kennelijk van afzag omdat in Boek 4 voor andere figuren werd gekozen. ${ }^{144}$ Vermoedelijk zou Meijers, die voor alles een

141. Het eigenlijke (historische) doel van de boedelverdeling was het voorkomen van twist tussen de kinderen, niet de bevoordeling van de langstlevende echtgenoot.

142. Zie daarover uitgebreid J.B. Vegter, Over de wenselijkheid van het vruchtgebruik van de langstlevende in Boek 4 titel 2a, WPNR 5971 (1990).

143. J.C. van Oven, Moet aan de langstlevende echtgenoot een legitieme portie worden toegekend?, WPNR 4560 (1958). Zie ook P.W. van der Ploeg in WPNR 4295 (1953), die om deze reden een fideicommis de residuo voor de langstlevende bepleitte ten behoeve van de kinderen.

144. Notulen van de Staatscommissie voor de Burgerlijke Wetgeving, subcommissie Burgerlijk Recht, d.d. 27 november 1948: "Gedebatteerd wordt over de vraag of aan de vruchtgebruiker de verplichting tot rekening en verantwoording behoort te worden opgelegd. De voorzitter acht dit niet nodig. (..) De verplichting tot rekening en verantwoording zou met zich meebrengen, dat de vruchtgebruiker gehouden zou zijn een gedetaileerde boekhouding te voeren, om aan de hand van de cijfers een nauwkeurige opgave van feiten te kunnen doen. Dit is wel zeer ingrijpend, vooral indien men in aanmerking neemt, dat vruchtgebruik veelal aan de langstlevende echtgenoot wordt gegeven. (..) Art. 10 (3:215) heeft betrekking op vervreemden en verteren en bevat mitsdien een variant van het fideicommis de residuo en dient vooral om de gevolgen te regelen van de bevoegdheid om te verteren. Zou men er toe overgaan het f.d.r te schrappen, dan zou het zelfs wenselijk zijn de regeling van art. 10 aan te vullen met regels omtrent het vruchtgebruik van een gehele nalatenschap." 
praktisch man was, niet zoveel moeite hebben gehad met het vervallen van de jaarlijkse opgave en de zaaksvervanging. ${ }^{145}$

Blijft over de toeëigeningsbevoegdheid. Inderdaad is dat een figuur die op het eerste gezicht weinig met het vruchtgebruik te maken heeft. Maar het is wel een praktische regel, omdat het klassieke vruchtgebruik op dit punt soms problemen te zien geeft. Wolf: "Eén van de dingen die in de praktijk duidelijk als een negatief punt van het vruchtgebruik naar voren komt, is dat de bank of de giro enige tijd na het overlijden de rekening blokkeert en aan de weduwe of weduwnaar een verklaring van erfrecht vraagt. Dat heeft men niet verwacht. Als ik een jas koop van duizend gulden, dan wil ik niet eerst bij de kinderen langs om te vragen of ik die duizend gulden mag opnemen. Dat is een praktisch bezwaar, een maatschappelijk bezwaar en een politiek bezwaar van het huidige vruchtgebruik. Het doet mij daarom goed dat de langstlevende in het ontwerp zoals het er nu ligt een grote beschikkingsbevoegdheid heeft."

b. ouderlijke boedelverdeling. Hiervoor is reeds een aantal maal benadrukt dat het belangrijkste juridische verschil tussen de boedelverdeling en het vruchtgebruik per saldo het verschil in eigendomsconstructie is. Bij de OBV is de eigendom bij de langstlevende, die een schuld aan de kinderen krijgt, bij het vruchtgebruik blijft de eigendom van de erfdelen bij de kinderen, maar belast met het vruchtgebruik. Verder is vastgesteld, dat menig weldenkend echtpaar thans naar de notaris stapt om de positie van de langstlevende echtgenoot te versterken, en dat daarbij - uitzonderingen daargelaten - geenszins de bedoeling voorzit om de kinderen elk deel in de nalatenschap te ontzeggen. Het gaat er bij hen om dat de langstlevende echtgenoot in de spulletjes kan blijven, op de oude voet kan doorleven, kortom: Hoofd van de familie kan blijven.

Zoals De Die opmerkt, heeft de langstlevende echtgenoot "geen enkele behoefte aan een bevoegdheid om de goederen waarbij de kinderen belang hebben, aan een 'lief kind' of aan een ander weg te schenken, om ze bij hertrouwen in de nieuwe huwelijksgemeenschap te laten opgaan, om ze naar andere erfgenamen dan de kinderen van de erflater of naar legatarissen te laten verdwijnen." Toch krijgt de langstlevende dat alles in de wettelijke ouderlijke boedelverdeling tot schade van de kinderen er van rechtswege bij, volgens De Die, die in dit verband de term "giftige bijwerking" in de mond heeft genomen. ${ }^{146}$

Van Mourik heeft zich over deze karakterisering nogal opgewonden, ten onrechte. De opmerking van De Die is namelijk niet nieuw - wat is er eigenlijk wel nieuw aan

145. Vergelijk ook Meijers in WPNR 2616 (1920), waar hij juist met het oog op deze situatie een verbeterd wettelijk fideicommis de residuo voorstelt: "Voor het geval, dat de langstlevende echtgenoot de ganse nalatenschap ontvangt, komt mij de door Jansen met zoveel talent verdedigde oplossing de meest gewenste voor: Wat van het geërfde op het ogenblik van het overlijden van de langstlevende nog overig is, komt aan de bloedverwanten van de vooroverledene toe. Een wettelijk fideicommis de residuo, als men wil, maar dan een, waarbij men zich niet moet laten afschrikken door de moeilijkheden, die het thans in de wet voorkomende oplevert. Gelijk reeds meermalen door mij is opgemerkt, is deze instelling volstrekt niet een, die krachtens haar aard is voorbestemd tot complicaties; het tegendeel is eerder waar. De moeilijkheden zijn alle slechts voortgekomen uit de gebrekkige regeling in onze wet en de onvoldoende steun, die rechtspraak en praktijk aan de instelling gegeven hebben."

146. B.C. de Die, Tegen-stellingen, WPNR 6041 (1992). 
deze discussie - en zou Van Mourik zelfs heel bekend in de oren moeten klinken. Niemand minder dan Rombach wees - naar aanleiding van een artikel van Van Mourik - mede om deze reden de wettelijke ouderlijke boedelverdeling af: "Het behoud van het erfdeel (bij hertrouwen) is bij een boedelverdeling niet te vermijden, en leidt tot een eigendomsverschuiving, waaraan enerzijds de langstlevende echtgenoot geen behoefte heeft nu hij vrij over de gehele boedel kan beschikken, en die anderzijds de nakomelingschap van de eerst-overledene benadeelt. "147

$\mathrm{Nu}$ is het zo, dat Van Mourik deze angel uiteindelijk toch uit zijn ontwerp heeft gehaald, door de kinderen een recht op overneming te geven. Volgens De Die is de remedie echter nog erger dan de kwaal, omdat je daardoor altijd genoodzaakt bent een boedelbeschrijving te maken. De Die: "Van Mourik heeft, aangespoord door Heyman, de weg gevolgd die Heuff al voorzichtig had aanbevolen door een optie te verlenen aan de kinderen op de goederen van hun overleden ouders, maar zijn uitwerking deugt niet. Als de echtgenoot in gemeenschap van goederen was getrouwd, dan betekent dat bij het overlijden van de één (A), in zijn systeem de langstlevende (B) de enige erfgenaam wordt. Door zuivere aanvaarding verdwijnt die hele nalatenschap, die is er als zodanig niet meer. Als de langstlevende (B) dan hertrouwt en vervolgens overlijdt vóór de tweede echtgenoot (C), dan erft deze eveneens als enig erfgenaam het gehele vermogen, waarin nog altijd A's nalatenschap onherkenbaar, immers nooit door boedelbeschrijving, laat staan boedelscheiding, geïdentificeerd, begrepen is. En dan wil Van Mourik aan de voorkinderen het recht geven om uit de nalatenschap van B goederen uit A's nalatenschap tot zich te nemen. Maar die zijn er niet. Er is geen beschrijving van gemaakt, ze zijn geruisloos verdwenen in het vermogen van B."

\section{De praktijk van het erfrecht}

$\mathrm{Nu}$ is vastgesteld dat het recht op inbetalinggeving niet werkt, leidt dit tot de conclusie dat de uiteindelijke keuze moet gaan tussen het gemoderniseerde vruchtgebruik en de "normale" ouderlijke boedelverdeling, d.w.z. zonder de inbetalinggeving. In wezen dus de oplossing waartoe het gezamenlijk wetsvoorstel voert. Benadrukt is, dat het vruchtgebruik vanuit principieel oogpunt de voorkeur verdient boven de wettelijke ouderlijke boedelverdeling. Maar niet alles wat wenselijk is, is vatbaar voor verwezenlijking. Daarom een uitstapje naar de praktijk van het erfrecht.

In de eerste plaats is het van belang vast te stellen dat in slechts ongeveer $30 \%$ van de gevallen waarin er sprake is van een overlijden, een testament op het langste leven aanwezig is. Dat betekent dat 60 à 70 procent van de erflaters is aangewezen op het wettelijk erfrecht, dat de langstlevende slechts recht geeft op een kindsdeel, niet eens in de vorm van een legitieme. Desondanks gebeurt het maar hoogst zelden dat de kinderen hun deel van vader of moeder opeisen.

In de tweede plaats is het een feit dat de meeste testamenten niet tot afwerking komen. Het percentage mensen die een OBV-testament hebben en die alert zijn op het vaststellen van de vorderingen van de kinderen, bijvoorbeeld in verband met eventuele schenkingen, is bijzonder klein. Dat betekent dat er ook binnen deze groep een

147. J. Rombach, Hoe het 'langstlevende-al, ook bij hertrouwen, juridisch bevredigend te verwezenlijken?, WPNR 5126 (1971). 
bijzonder grote categorie is, waarbij geen moeilijkheden zijn te verwachten. En in die gevallen, waar dat wel zo is - de onverbeterlijk drugsverslaafde, het kind dat al jaren niet meer in huis komt - doet het vruchtgebruik of de OBV er niets toe: ruzie zal er komen, ruzie zal er blijven. Belangrijk is slechts dat de langstlevende zich daarvan niets hoeft aan te trekken.

Blijft over de groep waarbij de keuze voor het vruchtgebruik of de OBV er in beginsel wel toe doet, namelijk bij het hertrouwen van de langstlevende. Veel hangt daarbij af van de feitelijke situatie. Als de kinderen jong zijn, dan spelen die emotionele overwegingen nog niet zo'n grote rol en is er geen enkele noodzaak hun erfdeel "af te zonderen." En als de langstlevende op latere leeftijd hertrouwt, dan bestaat er wellicht de mogelijkheid de kinderen uit te boedelen; Als die mogelijkheid er is, dan zal dat zeker gebeuren, zoals blijkt uit de hierboven weergegeven opmerking van Rombach. Tenslotte behoeft de relatie tussen kinderen en stiefkinderen niet per definitie slecht te zijn; Vaak zal de stieffamilie affectiegoederen of erfstukken dan graag afstaan.

Ook binnen deze groep zullen er derhalve veel gevallen zijn waarbij de wet min of meer automatisch wordt toegepast en waarbij de keuze tussen w.o.b.v en vruchtgebruik er in wezen niet toe doet. Zijn er wel problemen te verwachten, dan kan voor de zekerheid een boedelbeschrijving worden gemaakt opdat de goederen achteraf kunnen worden geïndentificeerd als toebehorend aan de eerstoverledene. Maar het is zelfs de vraag of dát nodig is: De klok van Opa is door de gehele familie heen bekend. In elk geval levert zo'n boedelbeschrijving, die ook nu in sommige gevallen reeds is voorgeschreven, praktisch gezien weinig problemen op. Luijten: "In alle ontwerpen staat wel dat er een boedelbeschrijving moet komen, maar in de gevallen dat men het met elkaar eens is, blijft die natuurlijk achterwege. Net als nu. Als er geen aangifte is voor het successierecht, is er niets aan de hand. Dat zijn de $70 \%$ min-en onvermogenden van Van Mourik. Als er wel een aangifte successie nodig is, ben je toch al bezig een formulier in te vullen; Dat kun je dan als boedelbeschrijving gebruiken." 148

\section{Tenslotte}

Het wordt tijd tot een afronding te komen. Prof.mr. W.C.L. Van der Grinten heeft onlangs de suggestie gedaan de behandeling van het ontwerp maar te staken en de zaak in handen te leggen van een Staatscommissie. Tegen dit voorstel pleit een aantal overwegingen.

In de eerste plaats meen ik dat sprake is van een verkeerde taxatie van de verhoudingen. Van alle geïnterviewden bespeurde ik alleen bij Van Mourik enige sympathie voor dit voorstel, en dan alleen nog tegen de achtergrond dat hij het vruchtgebruik ten stelligste afkeurt. Een bloemlezing. Luijten: "Je kunt het erfrecht niet laten bestaan uit

148. Vergelijk ook J. Rombach, WPNR 5126: "Dat aldus elke langstlevende echtgenoot de privévermogens zal moeten inventariseren, lijkt op het eerste gezicht een onduldbaar zware last te leggen op justiciabelen en notariaat. Maar omdat erfgenamen voor oude huis-tuin-en keukenboedels niet de minste belangstelling meer hebben, zal dit in de praktijk alleen gebeuren in boedels waarin onroerend goed of andere baten van importantie aanwezig zijn, en die worden ook nu al meestal geïnventariseerd, zodat dit in de praktijk wel zal meevallen." 
de activiteiten van de mensen zelf en de notarissen die hun wil formuleren." Creutzberg: "De meeste geluiden die wij hier horen, zijn "laten we het nu maar wettelijk regelen.'" De Die: 'We moeten nu doorgaan. Het is te gek dat je het recht uit 1838 zo maar laat voortbestaan. Boek 4 bevat veel meer dan de rechten van de langstlevende - over het nut daarvan bestaat geen enkel verschil van mening. En wat de langstlevende betreft, het heeft geen enkele zin dit probleem voor zich uit te schuiven."

In de tweede plaats is het, zoals De Die al aangaf, niet waarschijnlijk dat zo'n Staatscommissie er wél uit zal komen, omdat de discussie over de positie van de langstlevende zich nu al over meer dan een halve eeuw uitstrekt en volledig is uitgekauwd. Het is zelfs de vraag of je wel ooit tot een vergelijk kunt komen, omdat de belangen van de kinderen nu eenmaal anders zijn dan de belangen van de langstlevende. Van de kinderen zijn ze erfrechtelijk, van de langstlevende zijn ze huwelijksvermogensrechtelijk. Dat betekent dat op dit punt alleen de politiek uitkomst kan brengen. Het voorstel van Van der Grinten, dat van de tegenovergestelde gedachte uitgaat, is daarom de geijkte vorm van een herhaling van zetten. Dat Boek 4 er nog steeds niet is, is in essentie het gevolg van de uitverkoop van beslissingsmacht van de Tweede Kamer, haar ondeskundigheid en pure onverschilligheid. Daardoor ontstaat steeds opnieuw ruimte voor discussie, zowel binnen als buiten het notariaat. Inspraak is leuk, maar het moet geen circus worden. In 't Hout: "Het zijn theoretische verschillen waar het om draait, nuances die voor de praktijk van niet zoveel belang zijn, maar er wel voor kunnen zorgen dat we over tien jaar nog steeds niets hebben. Ik denk dat de tijd nu gekomen is om in dat erfrecht eens een paar knopen door te hakken, bijvoorbeeld de legitieme van ouders. Die is echt uit de tijd. Die verdwijnt dan ook wel - in elk ontwerp - maar het beroerde is dat die ontwerpen nooit worden ingevoerd. (..) Als het nu niet komt, dan voorzie ik het deze eeuw zeker niet meer. Want dan komt iedereen met een eigen voorstel."

In de derde plaats is het van belang op te merken dat Boek 4 méér is dan alleen de positie van de langstlevende echtgenoot. Het besluit het erfrecht te hercodificeren werd niet ingegeven door de overweging dat de positie van de langstlevende echtgenoot dringend verbetering behoefde, maar omdat het erfrecht vooral in technischjuridisch opzicht tekortschoot en nog steeds tekortschiet. Heuff: "Je kunt nog discussieren over de positie van de langstlevende echtgenoot, maar er zijn toch hele grote brokken in Boek 4 waar eigenlijk geen discussie over is, behalve misschien op een enkel punt, zoals het gebied van de legitieme portie. Maar verder zou ik zeggen, niet laten liggen, maar zeker doorvoeren." Soons: "Onbegrijpelijk. Het erfrecht is meer dan titel $4.2 \mathrm{a}$. Ik hoop dat het zo snel mogelijk wordt ingevoerd."

Tenslotte is het zo, dat er geen enkele reden is om aan te nemen dat het vruchtgebruik niet zou werken. De kritiek op het Regeringsontwerp is afkomstig van boedelverdelers, niet van vruchtgebruiknotarissen. Veel van de kritische bedenkingen lijken te zijn ingegeven door koudwatervrees. Heuff: "Het is net zoiets als met de nieuwe systematiek en terminologie van het B.W.; Als je er eenmaal aan gewend bent geraakt, dan zul je er ook geen problemen meer mee hebben. Dat is onze stelling ook min of meer geweest bij de beoordeling van het ontwerp." Creutzberg: "De ouderlijke boedelverdeling is inderdaad ietsje eenvoudiger, maar het is zeker niet zo dat het vruchtgebruik verschrikkelijk ingewikkeld is. Het vergt iets meer werk. Dat is alles." 


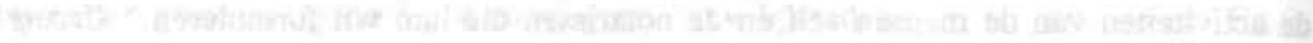

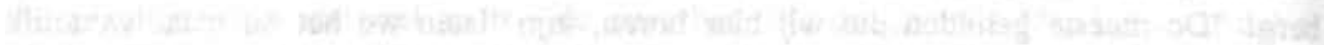

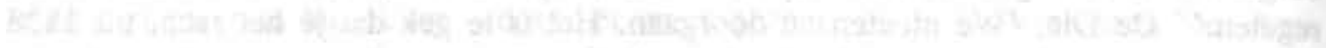

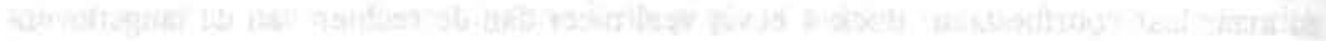

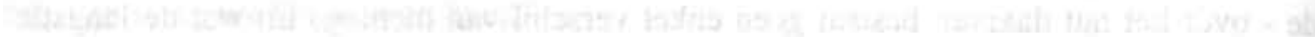

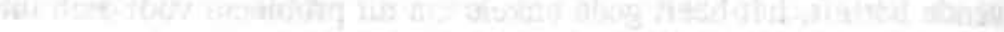

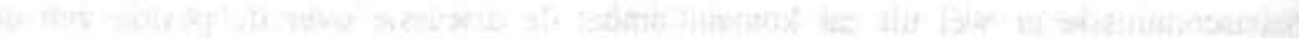

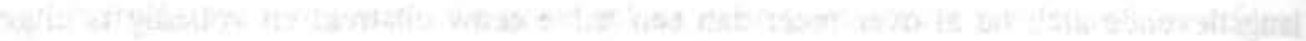

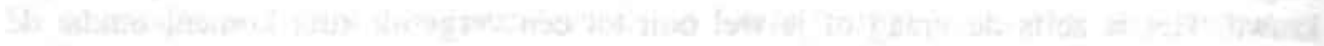

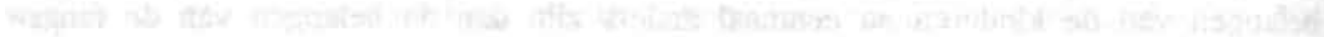

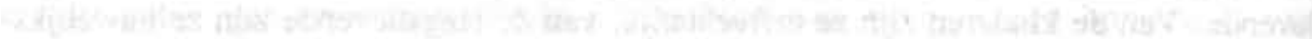

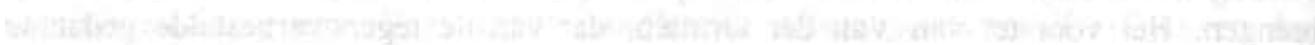

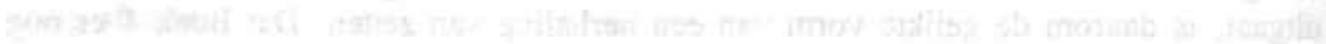

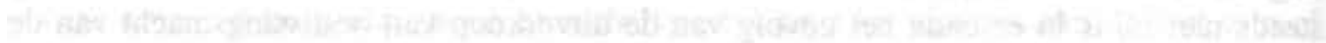

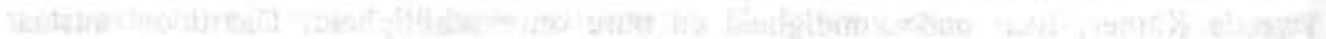

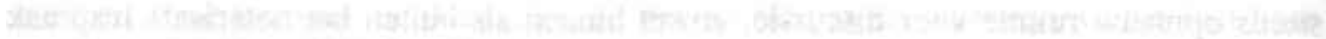

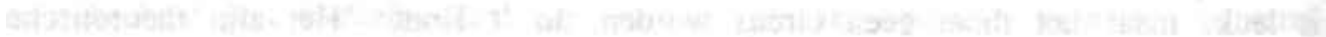

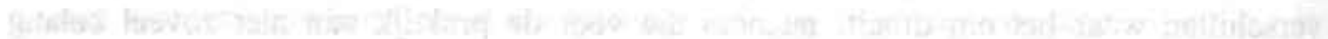

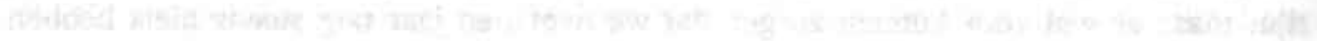


Hoofdstuk 7

\section{HET WERK AAN DE BOEKEN 3, 5 en 6 (1964-1980)}

"Je mag schrijven wat je wilt, als er maar geen fou-
ten instaan."1

\section{Inleiding}

In dit hoofdstuk zal een beschrijving worden gegeven van het ontstaan en de ontwikkeling van de Gewijzigde Ontwerpen (G.O.) voor de Boeken 3, 5 en 6. Hoewel deze drie boeken elk hun eigen verhaal hebben, is voor deze wijze van behandeling gekozen, omdat zij qua wijze van ontstaan, inhoud en betekenis sterk met elkaar samenhangen. Ook heeft na 1964 het accent van het werk aan het nieuwe B.W. sterk op deze boeken gelegen.

Als eerste zal worden ingegaan op het ontstaan en de ontwikkeling van het Gewijzigd Ontwerp voor Boek 3 (Vermogensrecht in het algemeen), waaraan door het Ministerie altijd de grootste prioriteit is gegeven. Vervolgens komt de interne geschiedenis van Boek 5 G.O. (Zakelijke rechten) aan de orde. Tenslotte zal aandacht worden geschonken aan de totstandkoming van het Gewijzigd Ontwerp voor Boek 6 (Algemeen gedeelte van het verbintenissenrecht). Met betrekking tot dit laatste boek zal de nadruk worden gelegd op de fase van de voorbereiding van het Voorlopig Verslag door de Tweede Kamer.

In een afsluitende paragraaf zullen enkele beleidsvragen uit deze periode, het gehele nieuwe B.W. rakend, aan de orde worden gesteld.

\section{Het werk aan Boek 3}

\section{Boek 3 vóór Boek 6}

Regeringscommissaris Langemeijer (1903-1990), die op 6 april 1964 officieel in functie was getreden, kreeg als eerste taak het voorbereiden van de Memorie van Antwoord voor Boek 3. Op Justitie werd het namelijk van het grootste belang gevonden dat dit boek, dat de basis vormt van het gehele vermogensrecht, zo spoedig mogelijk vaste vorm zou krijgen. Zowel voor de Kamer - met name in verband met het werk aan het Voorlopig Verslag Boek 6 - als voor het werk aan de voorontwerpen voor de Boeken 7 en 8 , was het dringend gewenst dat Langemeijer zijn volledige aandacht concentreerde op Boek 3 . Dit betekende dat de bestudering en aanpassing van Boek 6 R.O. voorlopig werd uitgesteld, ofschoon daardoor, in verband met de verwevenheid van beide, dubbel werk waarschijnlijk niet zou zijn te vermijden. ${ }^{2}$

1. W. Snijders, geciteerd door J. de Boer in Now, gods, stand up for bastards", Arnhem 1993, p. 25.

2. "In ieder geval zou het aanbeveling verdienen dat het werk ten Departemente aan het uiteindelijk ontwerp ondanks de indiening regelmatig wordt voortgezet, naast het werk aan meer urgente onderwerpen", aldus eerder Swart in zijn nota over Boek 6 O.M. van 24 februari 1964. Zie hierboven, Hoofdstuk 5. 
Langemeijer: "Als je de geschiedenis van het nieuwe Burgerlijk Wetboek nu retrospectief ziet, kun je het nauwelijks geloven, maar het werk gold toen als spoedeisend. Het Regeringsontwerp voor Boek 6 werd snel na de dood van Drion ongewijzigd bij de Kamer ingediend, dus zonder dat de opmerkingen van de Raad van State door het Departement waren verwerkt, zodat de Kamer, die de Boeken 3 en 6 als een eenheid zag, weer aan het werk kon. Omstreeks die tijd werd Scholten Minister van Justitie. Hij heeft ons op het hart gebonden zo min mogelijk aan het Regeringsontwerp voor Boek 6 te veranderen. We moesten zo min mogelijk vooruitlopen op het Voorlopig Verslag. Het gevolg is geweest dat mijn aandeel in het werk zich eigenlijk heeft geconcentreerd op Boek 3."

De nieuwe Regeringscommissaris, die zich, naar eigen zeggen, vóór 1964 nooit bijzonder intensief met het nieuwe Burgerlijk Wetboek had bezig gehouden, behoefde niet met een geheel schone lei te beginnen. Er lag het nodige aan voorwerk, soms betrekkelijk onvolledig en enigszins gedateerd, soms ook ook tamelijk vergevorderd en van recente datum. Vooral na oktober 1962, toen Drion zijn handen vrij kreeg in verband met de afronding van de Memorie van Antwoord voor Boek 4, was er intensief gewerkt aan onderdelen van het Derde Boek.

Zo was er voor titel 3.1 (Algemene Bepalingen) een eerste concept-M.v.A. van Belinfante, die met Drion in vijftien besprekingen was doorgenomen, waarna op 17 januari 1964 een tweede concept het levenslicht had gezien; voor titel 3.3 (Volmacht) een eerste concept-M.v.A. van Van Ewijk, waarover hij en Drion het na negen besprekingen met elkaar eens waren geworden; voor titel 3.6 (Bewind) een eerste concept van Van Ewijk (maart 1962), waarmee Drion grotendeels akkoord ging, maar die niet meer systematisch met hem was besproken; voor titel 3.7 (Gemeenschap) een schriftelijke weergave van tweeëndertig intensieve besprekingen tussen Drion en Van Ewijk, die wegens tijdgebrek nog niet door een concept waren gevolgd. Ten aanzien van de overige titels was de situatie echter minder rooskleurig, al betekende dat niet dat er sinds 1954 niets aan was gebeurd. In een overzicht van de stand van zaken van 27 januari 1964 schreef Van Ewijk: "Mr. Swart heeft gewerkt aan de voorbereiding van de besprekingen over titel 3.10, maar haar onderbroken wegens het werk aan het Nader Rapport Boek 6. Prof. Drion werkt aan de titels 3.2 en 3.4. Ook over vele onderdelen van de rest van Boek 3 zijn er wel oriënterende besprekingen geweest, maar van eerste concepten is nog geen sprake."

Er viel dus nog het nodige te doen, ondanks dat er op onderdelen al veel werk was verzet. Tekenend is, dat Minister Scholten nog tijdens het leven van Drion de prognose voor de verschijning van de Memorie van Antwoord over Boek 3 met een vol jaar opschoof tot eind 1964. In zijn begroting voor het dienstjaar 1964 schreef hij: "De indiening van de Memorie van Antwoord over Boek 3 zal (..), naar hij zich voorstelt, dit zittingsjaar en de eerste helft van het tweede in beslag nemen." ${ }^{3}$

3. Zitting Tweede Kamer 1963-1964, nr 7400, stuk nr 9, p. 2. Zijn voorganger, Minister Beerman had én jaar daarvoor verklaard: "Na het verschijnen van de Memorie van Antwoord op het vierde Boek zal de Memorie van Antwoord op het derde Boek moeten worden voltooid. De ondergetekende streeft emaar dat de indiening van deze Memorie in 1963 zal kunnen plaatsvinden." (Zitting Tweede Kamer 1962-1963, nr 6900, stuk nr 2, p. 1). 
Vermoedelijk was dat nóg te optimistisch. Van Ewijk schreef aan het slot van zijn bovenvermelde overzicht: "Ik acht het dus uitgesloten dat een eerste concept voor de Memorie van Antwoord Boek 3 vóór augustus 1964 kan worden voltooid."

\section{Snijders en Ten Kate}

Ofschoon het Voorlopig Verslag over Boek 3 het werk van Meijers niet bijzonder kritisch was gezind ${ }^{4}$ en Langemeijer persoonlijk "de grootste bewondering" had voor Meijers' werk - "als je bedenkt hoeveel tijd hij eraan heeft kunnen besteden en dat het éénmanswerk was, dan vond ik het geweldig" - moet de Regeringscommissaris aan de nota's en concept-voorstellen van vooral Van Ewijk en Drion waarschijnlijk toch de overtuiging hebben overgehouden dat Boek 3 op hoofdpunten grondig diende te worden herzien: "De hele grote lijnen van het ontwerp van Meijers waren wel acceptabel, maar wij hadden kritiek op de uitwerking, de details." Het zou daarom bepaald moeilijk worden de Memorie van Antwoord zó tijdig te voltooien, dat afdoening in de Tweede Kamer binnen de lopende parlementaire periode, die in 1967 zou eindigen, mogelijk zou zijn, zoals steeds de wens van Scholten was geweest. De Memorie zou in dat geval uiterlijk eind 1965 of begin 1966 dienen te verschijnen.

Dit gegeven, gecombineerd met de wetenschap dat Langemeijer het werk aan Boek 3 R.O. verrichtte naast zijn ambt van Procureur-Generaal bij de Hoge Raad ${ }^{5}$, leidde ertoe dat de Minister al snel op het denkbeeld kwam Langemeijer personele versterking aan te bieden. Tenslotte beschikten de beide andere commissarissen, wier werk belangrijk lichter was dan dat van Langemeijer, ook over gedegen juridische assistentie. Bovendien was het het streven van Scholten de Boeken 3 en 5 samen vóór 1967 door de Tweede Kamer te krijgen, in verband met de samenhang tussen de beide boeken op vele punten. ${ }^{6}$

4. Van Oven gaf in NJB 1958, p. 771, de volgende kenschets: "Met één belangrijke uitzondering is de commissie meegegaan met de beginselen van Meijers' ontwerp en dat van de regering. Het principieel vernieuwde systeem van het vermogensrecht, door Meijers ontworpen en samenhangend met zijn terminologie inzake 'goederen' en 'zaken' vond instemming. De modernisering van de in artikel 2014 B.W. en 637 B.W. geregelde stof eveneens, althans bij een aantal commissieleden. De regeling van de volmacht, verjaring, nietigheid en vernietigbaarheid, bewind, vruchtgebruik, privileges, rechtsvorderingen etc. ervoer kritiek in bijzonderheden, maar niet wat de principes betreft. Dit alles niettegenstaande de bezwaren die ten aanzien van verscheidene dezer onderwerpen in de literatuur of adressen waren geopperd. Alleen de regeling der zekerheidsrechten in Titel 9 werd principieel bestreden door 'een aantal leden', waarbij zich een aantal anderen aansloot."

5. Langemeijer ontving, als enige van de Regeringscommissarissen, naast zijn bezoldiging als Procureur-Generaal geen honorering voor het werk aan het nieuwe B.W. Wel was er bij de Hoge Raad een regeling getroffen, waardoor Langemeijer iets ruimer in zijn tijd kwam te zitten. Minister Samkalden verklaarde althans in de Kamer dat zijn voorganger "reeds regelingen (had) getroffen om $\mathrm{mr}$. Langemeijer in de gelegenheid te stellen zich in voldoende mate aan Boek 3 en straks aan Boek 6 te kunnen wijden." (Handelingen Tweede Kamer 1965-1966, p. 104).

6. Minister Scholten (handelingen Eerste Kamer 1964-1965, p. 551): "Wat Boek 3 en Boek 5 betreft, het algemene deel van het vermogensrecht en het zakenrecht, kan ik zeggen, dat de Memories van Antwoord beide in voorbereiding zijn, zodat zij ongeveer gelijktijdig kunnen verschijnen. Er is sterk verband tussen beide onderdelen en gestreefd wordt ook naar afdoening van beide boeken in de Tweede Kamer binnen deze parlementaire periode, die in 1967 eindigt." 
Langemeijer hoorde op 16 oktober 1964 voor het eerst van het voornemen van de Minister en was er klaarblijkelijk direct voor gewonnen. Het werk beviel hem niet al te best en hij was ook veel te weinig opgeschoten. ${ }^{7}$ Van Ewijk, die het onderwerp bij hem aanroerde, schreef drie dagen later aan de Minister: "Met het oog op uw voornemen mr. Langemeijer tot een gesprek uit te nodigen, is het wellicht praktisch dat ik u meedeel uit het gesprek dat ik op 16 dezer met hem had. Hij juicht het denkbeeld toe zo mogelijk een tweetal leden van de rechterlijke macht enkele jaren op het Departement te detacheren voor het werk aan het nieuwe B.W. Hij zal zijn gedachten over geschikte kandidaten laten gaan."

De Regeringscommissaris was kennelijk goed geïnformeerd, want enkele dagen later circuleerde op Justitie een lijstje met zeven namen, die door het hoofd van de Hoofdafdeling Rechterlijke Organisatie van het Ministerie zonder uitzondering positief werden beoordeeld. ${ }^{8}$

De keuze van Langemeijer en de Minister viel aanvankelijk op de mrs. Snijders en Ras. Hun leeftijd en wetenschappelijke belangstelling gaven daarbij waarschijnlijk de doorslag. ${ }^{9}$ Snijders nam de opdracht aan, Ras niet. Uit een briefje van Langemeijer aan Van Ewijk d.d. 19 november 1964: "De vrijdag voor je vertrek kreeg ik een telefoontje van mr. Snijders, dat hij de uitnodiging aanneemt. (..) Ras heeft helaas afgeschreven. Hij is bezig aan een proefschrift en is, begrijpelijkerwijze, bang dat dit in het gedrang zal komen."

Dit betekende dat nu nummer drie op de lijst, Ten Kate, aan de beurt was te worden aangezocht om Langemeijer bij het werk aan Boek 3 te assisteren. Enigszins een probleem daarbij was, dat Ten Kate eerst nog tot rechter moest worden benoemd en dan uiteraard niet dadelijk bij de Rechtbank kon worden weggehaald. Voor Langemeijer was dat echter geen onoverkomelijk bezwaar: "Voor zover het van mij afhangt, kan ik op de tweede man wel enkele maanden langer wachten."

7. In de zes maanden die Langemeijer in functie was, had hij

- een commentaar geschreven bij het door het Departement opgestelde concept voor de Memorie van Antwoord bij titel 3.1;

- met Van Ewijk gesproken over de door Van Ewijk en Drion opgestelde concept-M.v.A. bij titel 3.3, waarna op veel punten tot een terugkeer tot Meijers' ontwerp was besloten;

- een notitie geschreven over de problematiek van het bezitloos zekerheidsrecht (3.9.2);

- een commentaar geschreven bij de (Departementale) concept-M.v.A. over titel 3.6.

8. In alfabetische volgorde waren dat:

mr. V.A.D.M. van Haren - raadsheer hof Den Bosch;

mr. Th. B. ten Kate

- subst.gr. rechtbank 's-Gravenhage;

mr. D.A. van der Linde

mr. H.E. Ras

mr. J. de Ruiter

mr. W. Snijders

mr. J.N. van Veen

- raadsheer hof Amsterdam;

- raadsheer hof Arnhem;

- rechter rechtbank Zutphen;

- rechter rechtbank Rotterdam;

- rechter rechtbank Amsterdam.

9. Met betrekking tot Ras (1921) had het hoofd van de Rechterlijke Organisatie althans opgemerkt dat deze zeer gewaardeerd werd om zijn kwaliteiten op civiel gebied, over Snijders (1928), die van 1954 tot 1958 advocaat in Rotterdam was geweest, en in 1961, na drie jaar als raio werkzaam te zijn geweest, werd benoemd tot rechter in de Arrondissementsrechtbank te Rotterdam, was zijn oordeel nog positiever geweest: "Mr. Snijders zou ik de 'diepgraver' willen noemen, iemand dit t.z.t. bestemd lijkt voor de Hoge Raad." Inderdaad zou Snijders reeds in 1968 op de voordracht voor de Hoge Raad staan. 
Hij zou echter snel bijdraaien. Op 17 december 1964 berichtte Van Ewijk aan Secretaris-Generaal Tenkink: "Mr. Langemeijer uitte in een vroeger gesprek de wens dat mr. Snijders (die op 1 februari begint) en mr. Ten Kate niet op dezelfde dag zouden aantreden. Maar ten eerste bedoelde hij dit slechts letterlijk en ten tweede begint hij meer en meer in te zien dat het aan Boek 3 te verrichten werk om tot een Memorie van Antwoord en Gewijzigd Ontwerp te komen, heel veel werk eist. En dit laatste zou ik met zéér grote stelligheid willen onderschrijven. Anderzijds is het de pertinente wens van Minister Scholten, dat de Memorie van Antwoord en het Gewijzigd Ontwerp zo spoedig mogelijk verschijnen; inderdaad is dit een "levensbelang" voor de totstandkoming van het nieuwe wetboek. Mr. Langemeijer en ik zijn dan ook van oordeel dat het in hoge mate gewenst is dat mr. Ten Kate zo spoedig mogelijk begint."

Het gevolg was, dat Ten Kate, na enig touwtrekken, op 11 januari 1965 met voorrang werd benoemd tot rechter in de Rechtbank te 's-Gravenhage, zodat hij met ingang van 1 februari kon gaan meewerken aan de voorbereiding van het nieuwe B.W. Dát er een dergelijke koppeling bestond, werd hem overigens pas op het laatste ogenblik duidelijk. Ten Kate: "De hele sollicitatieprocedure verliep uiterst zonderling, want ik solliciteerde op dat moment naar het rechterschap en moest bij de Minister komen in verband met die sollicitatie. Struycken nam toen waar als Minister. Ik werd binnengelaten door de Kamerbewaarder. Zonder een inleidend praatje vroeg Struycken aan mij wat mijn antwoord was. Ik dacht, dat is gek, als je komt solliciteren en er wordt een antwoord van je verwacht. Toen bleek dat er iets was foutgegaan. Hij vertelde dat het de bedoeling was dat ik aan het nieuwe B.W. zou gaan werken. Het was voor de Minister van belang om mijn antwoord te weten, omdat de Rechtbank bij een positief antwoord met een vacature bleef zitten."

Tenslotte zou ook mevrouw Fischer-Keuls worden ingeschakeld bij het werk aan Boek 3 G.O. ${ }^{10}$ Mevrouw Fischer, die De Jong terzijde moest staan bij zijn werk als coördinator van Boek 7 O.M., kon gemakkelijk voor het werk aan Boek 3 R.O. worden vrijgemaakt, omdat de totstandkoming van het voorontwerp van Boek 7 aanmerkelijk langzamer verliep dan verwacht. In de praktijk kwam het erop neer dat zij tot de tweede helft van 1967 afwisselend voor De Jong en voor Langemeijer werkzaam zou zijn. Na 1967 zou zij alleen nog maar werken voor De Jong.

\section{Het eerste begin}

Omdat Langemeijer een schriftelijke aanpak prefereerde boven een mondelinge behandeling verliep het contact tussen hem en zijn medewerkers en tussen de medewerkers onderling in eerste instantie volledig schriftelijk. Het kwam erop neer dat de Regeringscommissaris tussen september 1964 en mei 1965 bij vrijwel elke titel of afdeling een klein verhaaltje schreef, waarin hij zijn persoonlijke visie op het ontwerp ontvouwde - artikelgewijs. Het waren zijn eigen gedachten, overwegingen en conclusies, die niet altijd direct verband hielden met de in de Kamer of in de litera-

10. Vermoedelijk begon Fischer haar werk aan Boek 3 R.O. in december 1965. Over de achtergronden van haar "terbeschikkingstelling" heb ik niets kunnen vinden, maar het ligt voor de hand dat Justitie wilde profiteren van haar grote kennis van Boek 6 O.M. en van haar wetgevingservaring. 
tuur naar voren gebrachte kritiek. Langemeijer schreef, concludeerde op de wijze zoals hij voor de Hoge Raad schreef. Hij observeerde.

Vervolgens was het de taak van de medewerkers, die elk een stel titels ter bewerking hadden gekregen ${ }^{11}$, om zo'n nota naar eigen inzicht verder uit te werken, literatuuronderzoek te verrichten, rechtsvergelijkend te werk te gaan, kortom, eerste concepten voor de Memorie van Antwoord en het Gewijzigd Ontwerp te formuleren. In deze fase was er geen geregeld contact tussen de individuele medewerkers en Langemeijer. Wel kwam het soms voor dat een medewerker bepaalde punten van twijfel aan Langemeijer voorlegde. Deze eerste, voorlopige concepten verschenen tussen februari 1965 en december 1965. Dat was overigens al wat later dan voorzien: tijdens een bespreking op 18 maart 1965 met Minister Scholten had Langemeijer medegedeeld dat hij het niet uitgesloten achtte dat in september 1965 een eerste, voorlopige concept-M.v.A. zou kunnen worden overgelegd. ${ }^{12}$

Zodra zo'n concept was verschenen en de Regeringscommissaris met de hoofdpunten daarvan akkoord was gegaan, werd het gestencild en ontvingen de twee andere medewerkers ook een exemplaar, met daarbij het verzoek om commentaar te leveren. Het plan was dat deze reacties snel zouden verschijnen, maar omdat aanvankelijk ieder van de medewerkers de door hemzelf te bewerken titels liet voorgaan, duurde het soms wel enige maanden tot een half jaar voordat de eerste nota's met opmerkingen verschenen. Tevens ontving het Ministerie een set, zodat men zich ook daar desgewenst kon oriënteren. Het commentaar van Justitie was steeds afkomstig van

11. Deze titelverdeling zag er begin 1965 als volgt uit:

Fischer-Keuls: $\quad 1$ (Algemene Bepalingen)

7 (Gemeenschap)

Ten Kate: $\quad 4$ (Verkrijging en verlies van goederen)

5 (Bezit en houderschap)

afd. 9.1 (Algemene bepalingen Pand en hypotheek)

afd. 9.2 (Pandrecht)

10 (Verhaalsrecht op goederen)

Snijders: $\quad 2$ (Rechtshandelingen)

3 (Volmacht)

6 (Bewind)

afd. 9.4 (Recht van hypotheek)

11 (Rechtsvorderingen)

Afdeling 3.10.4a (Retentierecht), die bij het G.O. werd ingevoegd, werd door Langemeijer ontworpen.

12. Een rol kan daarbij hebben gespeeld dat organisatie en coördinatie niet vlekkeloos waren. Enerzijds was er het probleem dat Boek 3 zich vanwege het innig verband der delen bijzonder moeilijk in brokken liet opsplitsen, anderzijds was er de moeilijkheid dat de vorderingen van de medewerkers nogal uiteenliepen. Het is daarom voorstelbaar dat een concept voor titel A kort na zijn afronding al weer achterhaald was door het verschijnen van een concept voor titel B. Zo bleek een nieuw ontwikkelde versie van artikel 3.1.1.2 absoluut niet te sporen met titel 3.4. Van Ewijk schreef in dit verband: "Zijn beplantingen in het G.O. nu registergoederen of blijft men hen als vruchten beschouwen, waarvoor artikel 3.1.1.9 lid 4 blijft gelden, zodat zij pas zelfstandige zaken worden als zij door afscheiding onroerend worden? Bij Meijers kon je door middel van artikel 9 lid 5 of 3.4.2.10 veilig leveren, in het G.O. is dat laatste op z'n minst onduidelijk." 
Van Ewijk en Cohen Jehoram, sinds 1963 de medewerker van Van Ewijk; de B.W.club had kennelijk opgehouden te bestaan.

Deze commentaren waren meestal behoorlijk uitvoerig en ook tamelijk kritisch van aard, zodat een reactie van de ontwerper van het stuk niet kon uitblijven. In de meeste gevallen verschenen na verloop van tijd derhalve één of meer tegennota's, wijzigingsvoorstellen etc., soms gevolgd door een nadere notawisseling, totdat Langemeijer er een eind aan maakte en een vergadering uitschreef. Men was dan inmiddels wel zo'n vier tot acht maanden verder. Meestal ging aan zo'n vergadering dan nog een overkoepelende, bemiddelende reactie van Langemeijer vooraf of werd door mevrouw Fischer een samenvattende nota opgesteld, die, beter dan de concepten zelf, geschikt was als grondslag voor de te houden besprekingen.

Een voorbeeld. In juni 1965 presenteerde Ten Kate zijn eerste concept voor titel 3.4 G.O. met toelichting (en toelichtende aantekeningen). Op 8 augustus van dat jaar gaf Langemeijer een eerste reactie, in de eerste week van oktober gevolgd door twee nota's van Snijders, groot 27 pagina's. In de twee volgende maanden schreef Ten Kate diverse nota's aan Langemeijer, met het verzoek om advies. Op 5 januari 1966 verscheen de bemiddelende nota van Langemeijer, twee weken later gevolgd door een nieuwe nota van Ten Kate met wijzigingsvoorstellen (50 bladzijden). Enkele dagen daarna kwam een "eerste reactie" van Langemeijer, op 1 februari gevolgd door een "nadere reactie". Op de $17 \mathrm{e}$ februari klom Ten Kate opnieuw in de pen, een dag later gevolgd door Snijders. Tenslotte verscheen op 22 februari nog een nota van Ten Kate, waarmee de schriftelijke behandeling, eerste fase, was afgesloten. ${ }^{13}$

Van het overgrote deel van de concepten voor Boek 3 G.O. vond de eerste ronde besprekingen vermoedelijk in de periode februari-mei en augustus-oktober 1966 plaats, ongeveer een jaar nadat Fischer, Ten Kate en Snijders bij het werk aan het nieuwe B.W. waren ingeschakeld. Voor Ten Kate was dat eerste jaar niet meegevallen, met name door het ontbreken van iedere vorm van persoonlijk contact: "De nota van Langemeijer kreeg je thuis, je schreef een eigen nota daarover, die nota's werden uitgewisseld, waarna je een soort commentaar schreef als je daar behoefte aan had. Die periode heeft een half jaar, misschien nog langer, geduurd. Toen had ik Snijders en mevrouw Fischer nog nooit gezien, althans niet in het kader van het werk aan Boek 3. Dat is niet zo'n gelukkige opzet. Je krijgt die stukken van elkaar te zien, je krijgt commentaar op je eigen werk, en dat commentaar is vaak zwart op wit. Men is betrekkelijk kort in de wijze van uitdrukken. Je kon die wijze van formuleren verschillend uitleggen. Ik wist niet of het zakelijk was of dat het korzelig was bedoeld. Ik had soms dat ik bij mezelf dacht, wat moet ik nu, moet ik me nu teweer stellen tegen zo'n nota of is het eenvoudiger ermee in te stemmen? Je kende elkaar niet. Dat is heel vreemd, er waren momenten bij waarvan je ijskoud werd."

$\mathrm{Na}$ die eerste bespreking was het ijs echter snel gebroken. Ten Kate: "Bij de eerste ontmoeting die we met elkaar hebben gehad, bleek dat het allemaal vreselijk gemakkelijk ging. Vanaf dat ogenblik scheelde het zeer aanmerkelijk in het werk, omdat je nu wist met wie je te maken had en hoe je de geschriften moest opvatten." En: "Ik

13. Van Ewijk zou pas begin 1967 de tijd vinden de concepten voor titel 3.4 - inmiddels al gevorderd tot een derde versie - te beoordelen. In februari 1967 schreef hij 67 bladzijden vol, waarop twee maanden later een nog uitvoeriger reactie kwam van Ten Kate (101 blz.). 
heb eigenlijk nooit meegemaakt, dat er moeilijkheden waren. We vonden altijd een oplossing in goede harmonie met elkaar. Ik heb nooit veren hoeven te laten. Wel moest je soms toegeven dat je eenvoudig iets over het hoofd had gezien."

Bovendien werd er vanaf dat moment meer geregeld vergaderd, omdat iedereen met het hem toegewezen deel in eerste concept klaar was.

\section{Voortgang en vertraging}

Nadat de besprekingen in eerste ronde waren afgerond, was het de taak van de medewerkers om, met inachtneming van de door de vergadering genomen besluiten, een nieuw concept voor de onder hun verantwoordelijkheid vallende gedeelten op te stellen. Langemeijer beperkte zich ook nu tot het houden van toezicht, waagde zich in het algemeen niet aan het formuleren van teksten. Hij liet dat liever aan zijn medewerkers over.

Soms ging dat vrij voorspoedig, omdat de vergadering weinig bedenkingen had gehad tegen de gekozen opzet, soms ook waren er diverse voorstudies, nota's, tegennota's en pittige discussies voor nodig voordat er een nieuw en meestal aanzienlijk uitgebreid concept voor bespreking gereed lag. Dat hing daarmee samen, dat men door het gezamenlijk steeds verder doordenken steeds nieuwe en verdergaande gedachten ontwikkelde, of op vragen stuitte waarop de tekst van Meijers geen antwoord gaf of waarbij het antwoord qua detaillering tekortschoot. Snijders: "Heel vaak bleek dat als je wat Meijers in zijn hoofd had, ging uitwerken, dat op de keper beschouwd niet houdbaar bleek. En dan werd het anders, niet heel anders, maar toch net anders." Door de bank genomen duurde het daarom ongeveer een jaar, dus tot eind 1966, voordat er van de meeste titels een tweede concept gereed was.

Eind 1966 was de situatie aldus, dat de titels 2 en 7 - na een uitvoerig en diepgaand commentaar van Van Ewijk - het tot een eerste of tweede drukproef hadden gebracht. Van titel 3.1 lag er een derde concept, evenals van 3.5, 3.9 en 3.11. De overige titels $(4,6$, en 10) waren gevorderd tot een tweede concept, met uitzondering van titel 3.3 (Volmacht) en 3.8 (Vruchtgebruik), waarvan de behandeling lage prioriteit had. ${ }^{14}$ Daarmee was echter niet gezegd dat deze concepten - de titels 2 en 7 uitgezonderd gereed waren om te worden ingediend, zoals steeds de bedoeling was geweest. Het overgrote deel ervan moest intern nog gerecenseerd en besproken worden en daarna in de molen van Van Ewijk, die, als gevolg van zijn werk, eerst aan Boek 4 en later

14. Tijdens een bespreking tussen Beekhuis, Langemeijer en Van Ewijk d.d. 21 oktober 1965 was een volgorde vastgesteld van behandeling van de titels en afdelingen naar hun zakelijke samenhang en importantie. Er werden drie categorieën onderscheiden.

a) $3.1 .1,3.4,3.5,3.11$ (verjaring). 3.9;

b) 3.7 en 3.1.2;

c) $3.2,3.3,3.6,3.8,3.10,3.11$ (rest).

De titels van a vertonen samenhang in de aangegeven volgorde. De titels van $\underline{b}$ zijn hiernaast van bijzonder belang i.v.m. het vijfde Boek. De titels van $\underline{c}$ vormen de restgroep. 
aan Boek 1, aan een werkelijke beoordeling nog niet was toegekomen. ${ }^{15}$ Ook waren sommige principiële kwesties nog niet tot een oplossing gebracht, zoals de problematiek van artikel 2014 B.W. en de omwerking van het door Meijers ontworpen registerpandrecht in een bezitloos pandrecht. Tenslotte was de afstemming met Boek 5 G.O. verre van optimaal. Weliswaar was in maart 1965, in overleg met Minister Scholten, tussen de Regeringscommissarissen Langemeijer en Beekhuis de afspraak gemaakt dat zij elkaar zouden attenderen op wijzigingen die voor de ander van belang zouden kunnen zijn, maar in praktijk was daar nog weinig van terecht gekomen, vooral omdat de vorderingen van Beekhuis en Franken sterk waren achter gebleven bij die van Langemeijer en zijn assistenten.

Naar de mening van Van Ewijk was de Memorie van Antwoord de eerste maanden dan ook nog niet te verwachten. In zijn toelichting bij de Justitiebegroting voor 1967 schreef hij: "De prognose met betrekking tot de Boeken 3 en 5 heb ik zachtjes naar 'omstreeks' de jaarwisseling opgeschoven. Vóór de jaarwisseling zie ik geen van deze stukken gereed komen." ${ }^{16}$ In een nota aan de Minister, gedateerd 12 oktober 1966, schetste hij de vooruitzichten van Boek 3 G.O. als volgt: "Het werk is zwaar, vereist overleg met prof. Beekhuis en zeer gewenst is ook de medewerking van de zijde van het Departement, omdat Langemeijer c.s. weinig of geen wetgevende ervaring hebben. (..) Er zijn eerste concepten voor alle elf titels, van uiteenlopende kwaliteit. Van de titels 2 en 7 zijn er nu tweede concepten, waaraan ik in ruime mate heb meegewerkt en die m.i. in het algemeen wel als definitief kunnen worden beschouwd (behoudens raakpunten met andere titels); zij worden dezer dagen gedrukt. Zodra ik wat tijd heb, zal ik mij ertoe zetten over de eerste concepten voor de meest centrale titel - 4 - een nota te schrijven. Hoewel Langemeijer c.s. zeer hard en efficiënt werken, lijkt het mij zeker dat e.e.a. niet voor 1 januari 1967 klaar zal zijn. Wel reken ik op februari, maart, behoudens het hierna bij Boek 5 opgemerkte. "17

De prognose moest al snel worden bijgesteld. Op 12 april 1967 schreef Van Ewijk aan Minister C.H.F. Polak, die juist een week in functie was, dat hij zich zou verblijden als de Memorie van Antwoord nog in 1967 zou kunnen verschijnen: "Ik hoop dat de M.v.A. met ingrijpend gewijzigd ontwerp tegen het eind van dit kalenderjaar kan gereed komen, maar aan een vaste voorspelling kan ik mij nog niet wagen. Mijn indruk is dat mr. Langemeijer optimistischer is dan mr. Snijders en ik. ${ }^{18}$

Een maand later zou Van Ewijk ook die uitspraak niet meer voor zijn rekening durven te nemen. In zijn toelichting voor de Minister op het concept voor de begro-

15. Slechts de concepten voor de titels 1, 2, 3, 6 en 7 waren eind 1966 door Van Ewijk van een commentaar voorzien. Cohen Jehoram, zijn enige medewerker, was medio 1966 naar Amsterdam vertrokken om daar hoogleraar te worden, zodat al het werk op de schouders van Van Ewijk terecht kwam.

16. Nota van 24 mei 1966.

17. Met deze verwijzing naar Boek 5 doelde Van Ewijk erop dat ook dit Boek dan vrijwel voor indiening gereed moest zijn. Eerder, in een nota van 16 augustus 1965, had hij geschreven: "Nu ik dezer dagen begonnen ben aan de bestudering van enige eerste concepten van Langemeijer en zijn medewerkers (..) ben ik nog versterkt in mijn overtuiging dat de Memories van Antwoord over deze boeken gelijktijdig moeten worden voltooid, gezien de wisselwerking tussen beide."

18. Zie ook hieronder, Hoofdstuk 8. 
ting voor 1968 schreef hij: "Tijdsvoorspellingen bevat het concept niet. Het heeft m.i. weinig zin die thans, in mei, te concipiëren voor een stuk dat in september zal verschijnen. En ook dan zouden zij nog kunnen worden bewaard tot de behandeling van de begroting in de Tweede Kamer. Tegen die tijd zullen we, hoop ik, voorspellingen kunnen doen die ten dele op korte termijn kunnen worden gehonoreerd en niet weer, zoals zo dikwijls, door de loop der feiten worden achterhaald. ${ }^{19}$

Inderdaad zouden Langemeijer c.s. er bij lange niet in slagen in 1967 een punt achter het werk te zetten. Weliswaar verscheen ongeveer de helft van de M.v.A. en van het G.O. Boek 3 in de loop van dat jaar in drukproef ${ }^{20}$, maar daar stond tegenover dat zo'n zes titels nog volop in ontwikkeling waren. Dit betrof allereerst de titels 4 , 8 en 9, die door Van Ewijk in 1967 van uitvoerige opmerkingen werden voorzien en nog niet eerder door hem waren becommentarieerd. Aan het becommentariëren van de titels 5, 10 en 11 zou Van Ewijk als gevolg van de perikelen met betrekking tot het overgangsrecht voor Boek 1 overigens pas in februari 1968 toekomen, bijna drie jaar nadat de eerste concepten voor deze titels waren verschenen.

Dit commentaar, erop gericht de concepten te vereenvoudigen en te verhelderen, leidde ertoe dat op tal van punten hernieuwde studie en overweging noodzakelijk waren, ook al zou men verwachten dat de gedachten na drie jaar studie wel zouden zijn uitgekristalliseerd. In feite begon de discussie weer van voor af aan en zag je een herhaling van datgene wat zich in de jaren daarvoor had afgespeeld. Problematisch was vooral titel 3.4 (Verkrijging en verlies van goederen), waar werkelijk eindeloos aan gedokterd is. Pas in het voorjaar van 1968 zou daarvan een eerste, gedeeltelijke drukproef verschijnen.

Een interessante vraag is, waarom de Kamer geen onraad rook, toen de prognoses alsmaar moesten worden bijgesteld. Het vermoedelijke antwoord daarop is, dat men het allang goed vond, of, zoals het Tweede Kamerlid Van Schaik het verwoordde: "Het Nederlandse volk zal geen dag en geen nacht wakker liggen op grond van het feit, dat het B.W. een jaar vertraging oploopt." ${ }^{21}$ Omdat de Kamer zelf grote moeilijkheden had Boek 6 van een Voorlopig Verslag te voorzien, was niemand die eraan dacht te informeren naar de voortgang van de overige boeken. Minister Polak, wiens problemen met Boek 3 en 4 nauwelijks kleiner waren, behoefde daarom niets uit te leggen.

Omgekeerd had dat ook weer consequenties voor het werk aan Boek 3 G.O. Omdat medio 1967 duidelijk werd dat het Voorlopig Verslag Boek 6 nog lang niet te verwachten was, ging daar ook geen aansporing van uit om met Boek 3 voort te maken. Beide factoren versterkten elkaar.

19. Nota van 16 mei 1967. Minister Polak zou later in de Kamer verklaren dat aan Boek 3 het meeste werk was gedaan: "De commissaris de heer Langemeijer verwacht, in dit zittingsjaar met zijn voorbereiding van de Memorie van Antwoord gereed te komen. Ik hoop haar dan zo spoedig mogelijk aan de Kamer te kunnen voorleggen." (Handelingen Tweede Kamer 1967-1968, p. C 9.)

20. Dit betrof de titels $1,2,3,6,8$ en 9 .

21. Handelingen Tweede Kamer 1967-1968, p. c 8. 


\section{Exit Langemeijer (en Fischer-Keuls)}

Medio 1968 was de stand van zaken aldus, dat elke titel tenminste éénmaal door Van Ewijk was beoordeeld en de hand daarvan was aangepast. Dit betekende echter niet dat de Memorie van Antwoord en het Gewijzigd Ontwerp rijp waren om te worden ingediend. Met name op het punt van de redactie en coördinatie bleek er aan de M.v.A. nog veel te ontbreken, vrucht van het feit dat er na 1964 door drie verschillende mensen aan was gewerkt; het ontwerp sprak niet met één stem. Bovendien was het een bijzonder lijvig en complex geheel geworden, weinig geschikt om het enthousiasme voor het nieuwe BW te bevorderen. "Indikken" was dus noodzakelijk.

Omdat dit moeilijke werk het best door - of onder leiding van - éen persoon kon worden verricht, betekende dit dat deze taak in hoofdzaak op de schouders van het Departement, dat wil zeggen op die van Van Ewijk zou terechtkomen. Langemeijer had namelijk een half jaar eerder te kennen gegeven te willen stoppen met het werk aan het nieuwe B.W. En daarmee ontstond opnieuw een moeilijk punt in de geschiedenis van Boek 3.

In de eerste plaats zou Van Ewijk er dan geheel alleen voor komen te staan, een vrijwel onmogelijk opgave, gelet op het vele werk dat er vóór 1969 nog aan de Boeken 1 en 4 (beantwoording Voorlopig Verslag Eerste Kamer) moest worden verricht. Aan delegeren viel niet te denken: mr. M. Scheltema, die in september 1966 in de vacature Cohen Jehoram was benoemd, werd namelijk geheel in beslag genomen door de parlementaire behandeling van de invoeringswet van Boek 1 en van Boek $2 .^{22}$ Mr. E. Lukács, een raio die in april 1967 de afdeling NBW op proef was komen versterken, had begin 1968 zijn handen nog vol aan het notuleren van de besprekingen van Beekhuis en Franken in het kader van het werk aan Boek 5 G.O. Bovendien stond vrijwel zeker vast dat hij aan het eind van dat jaar zou overgaan naar de afdeling Privaatrecht van het Ministerie van Justitie.

In de tweede plaats zou het zelfs voor een bekwaam iemand als Van Ewijk moeilijk zijn het werk van Langemeijer c.s. tot in al haar facetten te doorgronden. Weliswaar was er in de loop der jaren een intens contact geweest tussen beiden ${ }^{23}$, maar Van Ewijk had zelf geen regel ontworpen en was, ondanks zijn grote invloed op de gang

22. Scheltema trad op 1 september 1965 in dienst bij de afdeling Wetgeving Publiekrecht van het Ministerie van Justitie. Over zijn overstap naar het nieuwe B.W. zei hij: "Op een bepaald ogenblik was het zo, dat Cohen Jehoram wegging en Van Ewijk als enige overbleef van de departementale afdeling NBW. Er moest toen in die vacature worden voorzien. Ik zat op de kamer met Van Agt, die toen ook medewerker was op publiekrecht. Er werd beslist dat hij zou over gaan naar het NBW. Hij vond dat niet leuk. Hoewel hij officieel al tot de afdeling NBW behoorde, wist hij steeds werkzaamheden op het terrein van het publiekrecht te vinden die het moeilijk maakten om te gaan werken bij de afdeling NBW. Het was duidelijk dat hij er geen zin had. Toen ik dat merkte, heb ik gezegd, als jij niet wilt, dan ga ik wel. Want ik vond die kant wél leuk."

23. Een voorbeeld hiervan, waarbij tevens de onderlinge verhoudingen tot uitdrukking komen, is de volgende passage uit een brief van Langemeijer aan Van Ewijk van 29 september 1966 over titel 3.7: "Ik heb de stencils voor Gewijzigd Ontwerp en Memorie van Antwoord betreffende titel 3.7 grondig bekeken. Ik heb een aantal amendementen, een enkel in de tekst en meer in de memorie, praktisch alle van stylistische aard. Je zult ze, neem ik aan, in het hierbij gaande exemplaar zonder moeite herkennen. Gewichtig zijn ze geen van alle. Wat niet je instemming heeft kan gerust vervallen, het overige zou bij wijze van correctie in de proef kunnen worden aangebracht." 
van zaken, niet werkelijk in de gelegenheid geweest de discussie over een bepaalde regel of leerstuk op de voet te volgen. Gevaar voor dubbel werk, mistasten of zelfs een heropenen van de discussie, was daarom niet denkbeeldig. Illustratief daarvoor is, dat Van Ewijk zijn eerste indrukken over het zoveelste concept voor artikel 3.4.2.3a pas aan Langemeijer c.s. wilde openbaar maken na eerst daarover met Snijders van gedachten te hebben gewisseld. ${ }^{24}$

Tenslotte was het in het belang van de continuitteit van de hercodificatie dringend gewenst dat de eindredacteur van Boek 3 tevens de toekomstige ontwerper van Boek 6 G.O. zou zijn. Ook om die reden was er alle reden om naar een tweede man naast Van Ewijk uit te zien. Deze hoopte namelijk in 1971 de pensioengerechtigde leeftijd te bereiken.

Van Ewijk was natuurlijk niet blind geweest voor deze problemen en had tijdig zijn maatregelen getroffen. Daarom was de oplossing, toen puntje bij paaltje kwam, niet echt moeilijk.

Toen medio 1966 duidelijk werd dat Cohen Jehoram van werkkring zou veranderen, had Van Ewijk zich tot Langemeijer gewend met het verzoek Snijders te willen polsen voor een loopbaan op het Departement: "Wellicht is het al tot je doorgedrongen dat Cohen Jehoram mij gaat verlaten - om professor in Amsterdam te worden met het resultaat dat "mijn" afdeling tot één persoon (ikzelf) wordt gereduceerd. Zoals je weet was ik toch al, jarenlang, op zoek naar versterking, hetgeen nu dus dubbel urgent wordt. Uitzicht op een ervaren aanwinst, waaraan ik spoedig iets zal hebben, heb ik nog steeds niet. De gedachte is bij mij opgekomen of Snijders er wat voor zou voelen enige jaren bij mij te komen - uiteraard niet voor de M.v.A. Boek 3 klaar is - in afwachting van een verdere carrière, waarbij ik meen de H.R. niet uitgesloten zou zijn wanneer hij wat ouder is. ${ }^{25}$ Weliswaar zou de beschikbaarstelling van Snijders in oktober 1968 eindigen - toen hij zijn werk in februari 1965 aanving was de verwachting dat deze taak (inclusief vaststelling door de beide Kamers) drieëneenhalf jaar in beslag zou nemen -, maar omdat in 1966 nog de verwachting bestond dat de M.v.A. Boek 3 begin 1967 zou kunnen verschijnen, zou Van Ewijk althans de eerstvolgende twee jaar uit de zorgen zijn.

Tot Van Ewijks grote opluchting - hij lichtte nog dezelfde dag de Minister in - ging Snijders akkoord. Erg gemakkelijk was dat niet gegaan: "De conclusie van het uitvoerige gesprek, waarbij ik zijn vooruitzichten voor de H.R. heb aangeroerd (gelijk ook Langemeijer al had gedaan) en de nadruk heb gelegd op de onmogelijke situatie waarin de stafafdeling wetgeving nieuw B.W. verkeert, was aldus: mr. Snijders heeft mij toegezegd bereid te zijn om na de indiening van de M.v.A. Boek 3 hier te komen werken, in afwachting van het V.V. over Boek 6 , gedurende de resterende tijd van de genoemde drieëneenhalf jaar. Hoe hij deze resterende tijd zal doorbrengen wanneer eenmaal het V.V. Boek 6 voor ons ligt, valt dan te bespreken. Hoe het zal gaan als

24. Aldus blijkt uit een schrijven van Van Ewijk aan Snijders, gedateerd 14 februari 1967: "In het bijzonder artikel 3.4.2.3a kost me nogal wat hoofdbrekens en ik ben bang dat ik hier en daar het spoor bijster raak als ik niet eerst de stapels stukken, ook over andere titels, doorwerk.

Daarom ben ik op de gedachte gekomen mijn eerste indrukken van artikel 3.4.2.3a alvast zeer voorlopig op papier te zetten en jou te vragen hierover eerst met me van gedachten te wisselen. Mogelijk kan dit voorkomen dat mijn definitieve nota onnodig wijdlopig en kritisch uitvalt."

25. Brief van 14 juli 1966. 
de drieëneenhalf jaar om zijn, is van later zorg. Enige toezegging hieromtrent heeft hij begrijpelijkerwijs niet gedaan. ${ }^{\text {"26 }}$

\section{De laatste loodjes}

Eén en ander leidde ertoe dat Snijders omstreeks 1 maart 1968 een kamer zou betrekken op het Ministerie van Justitie om daar, samen met Van Ewijk en - minder prominent - Ten Kate, de laatste hand te leggen aan de Memorie van Antwoord en het Gewijzigd Ontwerp Boek $3 .^{27}$ Snijders: "Het eind van het hele liedje is geweest, dat in het werk dat Langemeijer, Ten Kate en ikzelf hebben gedaan aan Boek 3 het Departement vrij diep heeft ingegrepen. En dan kunt u een merkwaardige draai meemaken. Van Ewijk meende dat hij het niet alleen kon. Hij heeft, toen wij met zijn drieën klaar waren, tegen mij gezegd dat $\mathrm{ik}$ op het Departement moest komen om samen met hem de hele zaak nog eens door te exerceren." In de praktijk betekende dit dat Snijders de verbindende teksten schreef en indikte en dat Van Ewijk er dan met zijn commentaar overheen kwam. Daarna werd het concept in kleine kring (Snijders, Langemeijer of Ten Kate) voor de laatste keer doorgenomen. De eindredactie berustte echter bij Snijders.

Ook zou in deze fase met betrekking tot sommige onderdelen van Boek 3 G.O. nog contact worden gezocht met de praktijk, een punt waaraan na het overlijden Meijers vrijwel geen aandacht meer was besteed. ${ }^{28}$ Langemeijer zei daarover: "In de tijd dat ik Regeringscommissaris was, heb ik slechts een enkel gesprek gehad, niet erg omvangrijk en alleen met mensen die op persoonlijke titel kwamen. Het zijn misschien niet meer dan twee gesprekken geweest. "29

Dit hernieuwde overleg, dat ondanks Snijders' beduidend grotere invloed op de eindtekst van Boek 3 G.O. door Langemeijer zelf werd geleid, nam, inclusief de voor-rapportage, besprekingen en de schriftelijke verwerking, nog enkele maanden in beslag. In de herinnering van Van der Ploeg: "Ik heb met Treurniet en mijn compagnon Van Solinge gesproken over Boek 3, titels 6 en 7. We hebben tweemaal twee dagen daarover gedebatteerd met Langemeijer, Snijders en Ten Kate. Daar was Langemeijer heel, heel aimabel. Hij deed het heel aardig. Je kon zien dat hij Snijders al eigenlijk niet meer aankon. Snijders was daar de man die domineerde, ofschoon hij zich wel rekenschap gaf van het feit dat niet hij, maar Langemeijer de Regeringscommissaris was. Langemeijer had er niet veel aan gedaan, die vond het eigenlijk allang goed." Ten Kate: "Wanneer je niet zelf in de praktijk staat, dan is het moeilijk je te realiseren of het redelijk is wat de partijen vragen, of dat juist tegendruk moet

26. Nota van 24 augustus 1966. Iets eerder had Van Ewijk opgemerkt: "Hij (Snijders) stelde zich zeer bepaald voor na die drieëneenhalf jaar (dus oktober 1968) terug te keren in zijn rechterswerk te Rotterdam."

27. Langemeijer zou overigens pas bij K.B. van 23 april 1976, nr. 76, worden ontheven van zijn aanwijzing als Regeringscommissaris voor Boek 3. Bij hetzelfde besluit werd Snijders als Regeringscommissaris aangewezen.

28. Het betrof hier de titels $3.4,3.6$ en 3.7. Afgevaardigd waren de mrs. Van Daalen, Blaauw en Bossard (advocatuur) en Van der Ploeg, Treurniet en Van Solinge (notariaat).

29. Men bedenke echter dat Boek 3 nogal theoretisch getint is, waardoor overleg minder voor de hand ligt dan bijvoorbeeld ten aanzien van Boek 6 . Bovendien was op Boek 3 lang niet zoveel principiële kritiek gekomen als op Boek 6. 
worden gegeven. Dat betekent in feite, en Langemeijer deed dat buitengewoon, dat je met de partners spreekt, dat je ze niet afschrikt, maar aan de andere kant niets weggeeft."

Medio 1969 waren alle titels definitief en konden zij aan Minister Polak ter goedkeuring worden voorgelegd. Ten Kate ging toen - geleidelijk - terug naar de Rechtbank. Een uitzondering vormde het zorgenkind titel 3.4, waarvan de definitieve drukproef pas in juni 1970 zou verschijnen. Ten Kate: "Wanneer zo'n stuk klaar is, dan gaat het natuurlijk niet rechtstreeks naar de Kamer. Het wordt eerst met de Minister besproken, want uiteindelijk hangt het toch van hem af. Minister Polak nam onze voorstellen onder zijn arm mee en kwam dan met enkele zeer 'to the point' gesneden vragen. Wij gaven natuurlijk wel aan waar eventueel nog politieke punten inzaten. Daardoor is er nog wel eens iets veranderd. Dat speelde heel sterk bij de fiduciaire eigendom. ${ }^{\text {"30 }}$

Op 18 maart 1971 zou de Memorie van Antwoord van Boek 3, met daarbij een Gewijzigd Ontwerp van wet, bij de Tweede Kamer worden ingediend. Dat was ruim twaalf jaar nadat het Voorlopig Verslag was vastgesteld. Boek 3 werd op 20 april 1977 met "een hamerslag" door de Tweede Kamer aangenomen. De Eerste Kamer zou op 6 mei 1980 volgen.

\section{Oorzaken voor vertraging}

Dat het werk aan de Memorie van Antwoord en het Gewijzigd Ontwerp voor Boek 3 niet reeds in 1966 maar pas in 1971 kon worden beëindigd was aan verschillende factoren te wijten. Hierboven zijn de belangrijkste al de revue gepasseerd: de keuze voor een drietal weinig ervaren codificatoren in plaats van één begenadigd ontwerper, een weinig volmaakte organisatie en, tenslotte, een behoorlijke mate van perfectionisme.

In deze paragraaf zal worden geprobeerd één en ander aan de hand van verschillende voorbeelden en citaten wat verder uit te werken. De voorbeelden zijn alle ontleend aan een studie naar de ontwikkeling van afdeling 3.1.1 G.O., de indeling in stadia is gemodelleerd naar de ontwikkeling van Boek 3 als geheel.

Hierboven schreef $\mathrm{ik}$, dat het ondanks het voorwerk van Belinfante, Drion en Van Ewijk, nogal wat voeten in aarde had voordat de eerste concepten voor de M.v.A. en het G.O. Boek 3 gereed kwamen. Pas tegen het eind van 1965, toen het voorbereidende werk naar de voorstelling van Minister Scholten zo goed als klaar had moeten zijn, verscheen een eerste voorlopig concept.

Naar de oorzaak daarvoor is het niet moeilijk zoeken. Eén van de zaken, die het eerst opvalt wanneer je de verrichtingen van Langemeijer c.s. bestudeert, is dat er van meet af aan niet alleen bijzonder hard, maar vooral ook bijzonder kritisch is gewerkt. Er is - $66 \mathbf{k}$ in de eerste maanden - vrijwel geen regel, zinsnede of woord te vinden, die niet ondersteboven werd gekeerd. Alles werd uitgepluisd, geen enkele bepaling ontkwam aan kritiek. Dat begon al bij artikel 1, de definitie van "goederen". In het Ontwerp-Meijers en het Regeringsontwerp luidde de omschrijving daarvan als

30. "De bijdrage van Polak was groot, dat was een snelle geest die thuis was in de materie", aldus Snijders in een vraaggesprek met NRC Handelsblad van 12 december 1991. 
volgt: "Goederen zijn alle zaken en alle vermogensrechten". Naar de mening van Langemeijer c.s. moest daar echter komen te staan: "Goederen zijn alle zaken en vermogensrechten." Waarom? Omdat het woord "alle" door de herhaling een "onwelluidende" nadruk kreeg. ${ }^{31}$

Zo zijn er vele voorbeelden te geven. ${ }^{32}$ Het werk van Meijers werd nog eens dunnetjes overgedaan, dikwijls zonder dat daarvoor een duidelijke rechtvaardiging bestond. Een citaat uit de studie betreffende afdeling 3.1.1: "Zeven van de dertien onderzochte voorstellen tot wijziging waren het gevolg van opmerkingen van de ontwerpers zelf. Van deze dertien gevallen had de kritiek acht maal betrekking op een stylistisch/redactioneel punt en twee maal op een juridisch-technisch probleem. Slechts een maal werd een probleem behandeld dat in de praktijk tot moeilijkheden zou kunnen leiden. De beide overige problemen waren het gevolg van hersenspinsels en puzzeldrang." Langemeijer: "We hebben geprobeerd het geheel opnieuw te maken."

Waarom Langemeijer en zijn medewerkers zo scrupuleus te werk gingen en het werk van Meijers bezagen als ware het een voorstudie, is moeilijk te zeggen. Want het is opvallend dat Belinfante, die in 1958 enige tijd aan de Memorie van Antwoord Boek 3 werkte, het ontwerp wél goed vond, zich er althans toe beperkte het Voorlopig Verslag weg te schrijven.

Belangrijk lijkt mij in elk geval dat Langemeijer c.s. van Justitie volledige vrijheid kregen bij de bewerking van Boek 3. Er werden geen voorwaarden gesteld, men mocht het zo mooi maken als men wilde, mits het maar binnen de termijn afkwam. Dat was een groot verschil met de situatie in 1954, toen Minister Donker er persoonlijk op toezag dat zijn ambtenaren niet te veel "verbeterden" in het werk van Meijers. Langemeijer:

"Dat is heel gek, en ik realiseer het me nu eigenlijk pas, maar we hebben nooit enige aanwijzing gehad hoe we ons werk moesten inrichten, of welk resultaat van ons werd verlangd. Wij hebben in eerste instantie ook geen bijzondere aandacht besteed aan het Voorlopig Verslag, maar zijn eenvoudig begonnen bij artikel 1 en hebben zo artikel na artikel doorgewerkt.

Ik heb daar nooit bij stilgestaan, maar die artikelgewijze behandeling was eigenlijk een vreemde procedure, want het was ons niet uitdrukkelijk gevraagd om het zo uitgebreid te doen."

Een tweede factor die het "omwerken" kan verklaren, is dat er een precedent was in de vorm van voorstudies van Drion en Van Ewijk. Hiervoor werd aangegeven dat er in de concepten uit 1958 nog weinig aan de hand was. Maar dat wordt anders

31. Concept-M.v.A. en G.O. van 15 februari 1965. Overigens hadden Drion en Belinfante al eerder deze wijziging overwogen.

32. Het bewijs? Ook het volgende artikel - "zaken zijn stoffelijke voorwerpen, die voor bezit vatbaar zijn" - moest er aan geloven. Lange tijd was daaraan de zinsnede toegevoegd "die niet bestanddeel van een zaak zijn". Daarmee zou, "duidelijker dan voorheen het geval was", tot uitdrukking worden gebracht dat "een bestanddeel niet zelfstandig als een zaak in de zin der wet kan worden beschouwd." 
wanneer Drion en Van Ewijk zich ermee gaan bemoeien. Je krijgt dan heel duidelijk de aanzet tot discussies die ook Langemeijer c.s. hebben beziggehouden.

Een voorbeeld. In zijn toelichting op artikel 3.1.1.11 O.M. (algemeenheid van goederen) schrijft Meijers dat het door giften bijeengebrachte vermogen toebehoort aan de gezamenlijke gevers. De vaste Commissie is het hiermee oneens, maar wil er niet te veel woorden aan vuil maken: "Als het een massale actie betreft en de gevers geen enkele invloed kunnen uitoefenen op de wijze, waarop het doel met de geschonken gelden zal worden gediend, komt de gedachte, dat zij niettemin de eigenaren zijn, wel zeer ver van de werkelijkheid te staan. Intussen, de vraag van het toebehoren van dit vermogen behoeft naar aanleiding van het onderhavige artikel niet te worden beantwoord, al is het wel nuttig uit te spreken, dat het bijeengebrachte fonds in geen geval toebehoort aan een beherend comité. ${ }^{n 3}$

Belinfante is snel klaar met zijn antwoord: "Ook de ondergetekende meent dat voor de vaststelling van het onderhavige artikel het niet nodig is eenstemmigheid te bereiken over de vraag wie eigenaar is van een door giften voor een bepaald doel bijeengebracht vermogen. Hij moge zich derhalve van het uitspreken van een mening onthouden." Niet echter Drion. Hij vindt dat de opmerking, dat de gevers geen enkel recht hebben, niet onweersproken mag blijven. Dus komt er begin 1964 een nieuw concept: "In het stelsel van prof. Meijers bestaat er tussen de gevers een gemeenschap, de gemeenschap van een algemeenheid van goederen. Weliswaar zijn de rechten van de individuele deelgenoten daarin sterk beperkt, maar dat wil nog niet zeggen dat hun iedere bevoegdheid ontbreekt. Zo kan men zich denken dat een gever zal kunnen eisen dat het door hem gestorte geld zal worden gerestitueerd omdat het doel waarvoor het geld werd ingezameld inmiddels onbereikbaar is geworden."

Het opvallende is nu, dat Langemeijer c.s. niet op deze mijns inziens heilloze weg terugkeren, maar integendeel de concept-Memorie aanvankelijk nog verder uitbreiden: "Ook is denkbaar dat de gevers de bevoegdheid hebben gezamenlijk ieders aandeel over te dragen, bijvoorbeeld in een stichting onder te brengen. Ook de giften van anonieme gevers blijven naar de mening van de ondergetekende in beginsel aan de gevers toebehoren tot de gift haar bestemming heeft bereikt, al zal men meestal uit de anonimiteit mogen afleiden dat de gever afstand heeft gedaan van de uit zijn eigendomsrecht voortvloeiende bevoegdheden." Met andere woorden, het is niet onmogelijk dat Langemeijer c.s. aan de voorstellen van Drion de overtuiging hebben overgehouden dat er aan Boek 3 nog veel mankeerde. ${ }^{34}$

33. Parl. Gesch. Boek 3, p. 100.

34. Een ander voorbeeld, eveneens ontleend aan afdeling 3.1.1 R.O., betreft een discussie rond artikel 2, dat de hoofdindeling van zaken in onroerende en roerende zaken gaf. Volgens de tekst van het artikel werden, naast de grond en de nog niet gewonnen delfstoffen, ook de door hun wortels met de grond verbonden bomen en planten, alsmede de opstallen met hun hulpzaken als onroerende zaken aangemerkt. Daarmee wilde Meijers niet méér aangeven dan dat de in het artikel opgesomde zaken zelfs dan onroerend zijn, indien van een bestanddeel van de grond geen sprake zou zijn. Drion kwam echter tot een gedeeltelijk andere afleiding. Redenerend vanuit de gedachte dat het artikel alleen betrekking kon hebben op zelfstandige zaken, verwierp hij de opvatting van Meijers dat beplantingen en opstallen meestal reeds wegens hun organische of mechanische verbinding met de grond als een bestanddeel van de grond zouden zijn aan te merken. Naar zijn mening zou de praktijk van het rechtsleven er althans mee gebaat zijn indien de niet-duurzaam met de grond verbonden beplantingen 
Tenslotte kan een rol hebben gespeeld dat het werken aan wetgeving voor ieder van hen - mevrouw Fischer uitgezonderd - een volstrekt nieuwe ervaring was, werk dat men nooit eerder had gedaan en waarvan men misschien alleen al om die reden het beste wilde maken. Ook dat kan een specieuze opmerking als die over de "anonieme gevers", waarbij men "meestal" zal kunnen aannemen dat de gever afstand heeft gedaan van zijn eigendomsrechten, verklaren.

Toen tegen het eind van 1965 een eerste, voorlopig concept voor M.v.A. en G.O. Boek 3 gereed kwam, leek het er misschien op dat het werk al halverwege was. Dat was echter maar ten dele het geval.

In de eerste plaats bleek uit de overigens toen nog spaarzame commentaren van het Ministerie dat er een aantal beginnersfouten was gemaakt. Daaronder waren kleine fouten, maar ook grotere. Wat de eerste categorie betreft, er schortte bijvoorbeeld het één en ander aan de nummering, omdat men inmiddels verplaatste artikelen onder het oude nummer bleef bespreken of grondig gewijzigde artikelen ten onrechte van een nieuw nummer voorzag. Al minder overkomelijk was, dat de bewerkers weinig aandacht hadden geschonken aan de notulen van het Driemanschap, ofschoon daarin vele verwijzingen naar Boek 3 voorkwamen ${ }^{35}$ Bij de bewerking van afdeling 6.5.2 bijvoorbeeld, waren de Driemannen vaak tegen titel 3.2 aangelopen, hetgeen Langemeijer c.s. uiteindelijk zou inspireren tot de splitsing van artikel 3.2.3. Wérkelijk vervelend was, dat grote stukken van de M.v.A. niet al te tactisch waren geformuleerd en dus moesten worden herschreven.

Een voorbeeld. $\mathrm{Al}$ in een betrekkelijk vroeg stadium kwamen Langemeijer c.s. op de gedachte artikel 3.1.1.4 O.M. (hulpzaken) te schrappen. Een belangrijke overweging daarbij was een opmerking in het Voorlopig Verslag bij artikel 3.9.1.1 lid 2, waarin werd bepaald dat de rechten van pand en hypotheek zich uitstrekken tot de hulpzaken van de zaak waarop het zekerheidsrecht is gevestigd. Volgens de Kamer zou die regel in verband met artikel 3.1.1.4 lid 2, dat de eigenaar van de hoofdzaak het recht geeft een zaak tot hulpzaak daarvan te bestemmen, tot een grove toevallige bevoordeling van de hypotheekhouder leiden, als na de vestiging van de hypotheek aangebrachte hulpzaken onder de hypotheek zouden vallen, en tot grove benadeling,

34. $\rightarrow$

voortaan als roerende zaken zouden worden aangemerkt. Daardoor zou het namelijk mogelijk zijn hen voor hun afscheiding als zelfstandige zaken te leveren.

Deze gedachte, die in strijd was met één van de fundamentele uitgangspunten van Boek 5 , vele moderne wetboeken en ook voor het geldende recht door de meeste schrijvers werd afgewezen, zou door Langemeijer c.s. nog aanzienlijk worden uitgebouwd. Omdat hierbij echter steeds opnieuw bleek dat het onmogelijk was een duidelijke maatstaf te vinden - in het groeiseizoen zijn ook niet voor duurzame verbondenheid bestemde planten zodanig met de grond verbonden dat afscheiding onmogelijk is -, zou de regel uiteindelijk toch worden geschrapt. Pas veel later, tijdens de voorbereiding van het Mondeling Overleg, zou blijken dat aan deze figuur ook geen praktische behoefte bestond. Studeerkamerwerk dus, zowel van Drion als van zijn opvolgers.

35. Tijdens een bespreking op 25 oktober 1965 wees Franken op deze leemte: "Het Driemanschap heeft tijdens de bewerking van het 5 e en het 6 e Boek ook vaak gesproken over onderwerpen van het 3e Boek. Hele nota's zijn hieraan soms gewijd (..). Het is wel zaak dat men via de registers op de notulen van het Driemanschap besprekingen en vervolgens nota's over onderwerpen van het $3 \mathrm{e}$ Boek opspoort." 
als ten tijde van de hypotheek aanwezige machines daarna aan hun bestemming zouden worden onttrokken.

Daarnaast was er bij de bewerkers zelf kritiek op de omgrenzing van het begrip hulpzaken in lid 2. Volgens de toelichting-Meijers zou de regeling van het artikel in een behoefte voorzien, omdat een hoofdzaak en de daarbij behorende hulpzaken gezamenlijk in het economische verkeer een grotere waarde vertegenwoordigen dan de som van elk der beide zaken afzonderlijk. Bij een dergelijk uitgangspunt zou het, volgens Langemeijer c.s., echter onverschillig moeten zijn of degeen die de zaak de bestemming van hulpzaak verleent, daarvan de eigenaar is, zoals lid 2 eistte. ${ }^{36}$

In plaats van dat nu in de Memorie van Antwoord alle nadruk op deze onevenwichtigheid werd gelegd, werd begonnen met het beantwoorden van de in het Voorlopig Verslag opgeworpen vragen, uitgaande van het behoud van het artikel en van de regel van lid 2, om pas daarna die regel zelf, als essentiale van het begrip hulpzaak, te bestrijden en te concluderen dat het begrip, en daarmee het gehele artikel diende te vervallen. De hoofdvraag, de bestaansreden van het begrip hulpzaak naast het begrip bestanddeel, werd niet behandeld, evenmin als de functie van de categorie hulpzaken in het geldend recht. Het enige andere dat werd aangevoerd voor schrapping was een dogmatisch bezwaar, namelijk dat de vraag wie eigenaar is ten onrechte het zaaksbegrip zou beïnvloeden. ${ }^{37}$ Een zwak verhaal dus, ook omdat voor de afschaffing van hulpzaken nauwelijks rechtsvergelijkende argumenten konden worden aangedragen ${ }^{38}$.

Een tweede tegenvaller die zich eind 1965, na het gereedkomen van de eerste concepten openbaarde, was dat het niet eenvoudig bleek de vergadering op één lijn te krijgen, de discussie snel af te ronden. Verschillende factoren speelden daarbij een rol.

Allereerst liep de kwaliteit van die eerste concepten ook inhoudelijk nogal uiteen, een gevolg van de gehanteerde "losse" werkwijze, verschillen in aanpak, smaak etc.

Dat in eerste instantie alleen schriftelijk werd gecommuniceerd, deed de voortgang van het werk evenmin goed. Illustratief is de reeds geciteerde opmerking van Ten Kate, dat de commentaren op elkaars werk soms uitvoeriger en kritischer uitvielen dan nodig, omdat men niet wist hoe die kritiek moest worden verstaan.

Daar kwam bij, dat Langemeijer weliswaar een voortreffelijk civilist, maar een slecht voorzitter was. Meerderheidsbeslissingen werden door hem zoveel mogelijk vermeden, voortgang door overreding was het motto. Daardoor stapelden de discussienota's zich hoog op. Langemeijer bemiddelde, schreef mooie en uitvoerige over-

36. Parl. Gesch. Boek 3, p. 84. Een staartje van deze discussie vindt men nog terug in de Memorie van Antwoord, vierde alinea (Parl. Gesch. Boek 3, p. 87).

37. Zie W.C.L. Van der Grinten, WPNR 4701 (1961): "Behoren dienstbare zaak en hoofdzaak toe aan verschillende eigenaren, dan gelden zij rechtens als zelfstandige zaken, is er éen eigenaar, dan is er slechts én zaak." Deze lichte onhelderheid werd veroorzaakt doordat in het systeem van het ontwerp - evenals in het B.W. - slechts de eigenaar van de hoofdzaak een hem toebehorende zaak tot hulpzaak kon bestemmen.

38. Snijders, die onder verwijzing naar enkele moderne wetboeken erop wees dat met de afschaffing van hulpzaken tegen de stroom werd opgeroeid, kreeg van Langemeijer bij nota van 26 december 1965 te horen dat hij zich dáár niets van aan moest trekken: "Het kan zijn dat we met de afschaffing van de hulpzaken tegen een "stroom"' oproeien, maar het kan ook zijn dat we hier een toepassing hebben van "Es erbe sich Gesetze und Rechte" enz. Dus doen we wat ons zelf goed lijkt." 
zichtsnota's, maar waagde zich uitdrukkelijk niet aan het formuleren van teksten. Hij hakte pas na lang aandringen de knoop door, liet dat liever aan zijn medewerkers, de ontwerper zelf of aan Van Ewijk over. Snijders: "Langemeijer was typisch iemand voor compromis-oplossingen waarin alle facetten worden bekeken. Hij was een man die bij uitstek geschikt was voor het maken van conclusies. Hij had ontzettend veel moeite de knoop door te hakken. Eén van de taken als Regeringscommissaris met twee lastige assistenten die hun eigen ideëen hebben, is dat je op een goed moment tegen de mensen moet zeggen: 'Dit is voldoende uitgepraat.' Maar dat is iets wat hem absoluut niet lag. "39

Een illustratie daarvan is dat diezelfde Snijders aan het slot van zijn nota over artikel 3.1.1.4 de volgende bekentenis moest doen: "Ziende, dat na onze definitief geachte bespreking deze nota zijn tiende bladzijde heeft bereikt, stijgt het schaamrood mij naar de kaken. Ik hoop nu maar geen zwijggebod te krijgen. "40 Typerend is ook de volgende reactie van Langemeijer op de kritiek van Van Ewijk ten aanzien van de schrapping van "alle" in artikel 3.1.1.0 G.O. Van Ewijk had op 19 augustus 1965 geschreven: "De stelling (..) dat de herhaling van het woord "alle" onwelluidend is, overtuigt mij niet van de wenselijkheid dit woord voor "vermogensrechten" te laten vervallen. Het artikel bevat een nevenschikking van twee zeer uiteenlopende categorieën." Wat zei nu Langemeijer? "Ben neutraal. 2 maal 'alle' is misschien iets zuiverder, 1 maal iets welluidender. In dubio staat hier beslissing over concept m.i. aan Van Ewijk." 41

Beide factoren leidden ertoe, dat het ruim een jaar, tot eind 1966, duurde voordat er van de meeste titels een tweede of derde versie voor bespreking gereed lag. Naar de mening van Langemeijer c.s. was het meeste werk toen wel gedaan, enkele politieke problemen daargelaten. Men was erover uitgepraat, zo moest het ongeveer worden. Illustratief daarvoor is een opmerking in het dagblad Het Vaderland, dat Langemeijer in het voorjaar van 1967 over zijn werk aan Boek 3 interviewde. Daarin staat: "Voor een belangrijk deel heeft $\mathrm{mr}$. Langemeijer met zijn medewerkers nu aan deze opdracht voldaan. Alle titels zijn opnieuw door hem bewerkt, ten dele ingrijpend herzien. Verschillende zijn ook reeds ten Departemente doorgesproken." 42

Het ongeluk was echter dat de concepten naar de mening van Van Ewijk, die toen eigenlijk pas tijd kreeg ze te toetsen, nog lang niet rijp waren om te worden ingediend. Toelichtingen van tien bladzijden of meer, waar Meijers nog met drie had volstaan, waren bepaald geen uitzondering. Al pratende en schrijvende was men in steeds dieper vaarwater terecht gekomen, waardoor de Memorie van Antwoord, of in elk geval de aanzet daarvoor, vervuld was van de meest steriele bedenksels. Snijders:

39. Vergelijk ook J. Leijten, NJB 1990, p. 622 e.v., Herinneringen aan Gerard Langemeijer: "Het dispuut met Langemeijer werd, ook als het onder vier ogen plaatsvond, steeds gevoerd op voet van gelijkheid."

40. Niet-gedateerde nota n.a.v een concept-M.v.A. van 20 december 1965.

41. Nota van 11 oktober 1965.

42. Het Vaderland, 5 mei 1967. Een aanwijzing daarvoor is ook dat begin januari 1966 een drukproef verscheen van afdeling 3.1.1 (deze titel was overigens wel wat verder voortgeschreden dan de meeste andere, vanwege de bemoeienis van Drion en Belinfante) waarbij met betrekking tot artikel 3.1.1.11 werd opgemerkt dat de uitkomst van de discussie van de NJV van 1966 die o.a gewijd was aan een Pre-advies van prof. Gerbrandy over de handelszaak, niet meer kon worden verwerkt. 
"Het valt niet mee om het met z'n drieën te doen. Dat stelt je voor de noodzaak om ieder punt uit te praten. Dat is in beginsel een vrij logge methode. (..) Dat leidt tot een zekere uitvoerigheid. Het is typisch zoals compromissen werken, de één zegt dit, de ander heeft er bezwaar tegen, je komt met een compromis, maar het bevredigt niet helemaal. Dan haal je er niet iets af, maar je doet er steeds iets bij. Het maakt het niet overzichtelijker."

Een voorbeeld van dit "geknutsel" is het al eerder gememoreerde artikel 3.1.1.2, waarbij Langemeijer c.s. de onroerende konijnen, duiven en vissen van artikel 563 B.W. wilden inruilen voor de figuur van roerende wortelvaste beplantingen als struiken en bomen. Een ander voorbeeld is artikel 3.1.1.3 lid 3. Dit artikel, dat door Meijers ontegenzeglijk wel heel haastig in zijn definitieve vorm was gegoten, gaf de verkoper van een roerende zaak de mogelijkheid zich de eigendom van die zaak voor te behouden door inschrijving van de akte in de openbare registers. Daarmee werd voorkomen dat de zaak vóór de betaling tot bestanddeel van een bepaalde onroerende zaak werd gemaakt. ${ }^{43}$ Deze gedachte, een nouveauté van Meijers, werd door Drion en Langemeijer overgenomen, zij het in een andere vorm en met een veel groter toepassingsgebied. ${ }^{44}$ Met deze verfijningen, die in theorie zeker verdedigbaar waren, haalde men zich steeds meer problemen op de hals. ${ }^{45}$ De toelichting werd daardoor steeds langer en ingewikkelder en bood, als gevolg van de vergaande detaillering, ook steeds meer aanknopingspunten voor kritiek: op een gegeven moment konden op basis van de tekst zelfs vier casusposities worden onderscheiden, die elk tot een ander antwoord leidden, zonder dat voor dit verschil in behandeling een rechtvaardiging viel te bedenken.

Het commentaar van Van Ewijk, dat de kwaliteit van het uiteindelijke ontwerp zeer ten goede zou komen, betekende dus dat er nogal veel moest worden veranderd. Dat kostte natuurlijk tijd, veel tijd zelfs, maar Van Ewijk formuleerde in het algemeen zo precies, dat grote delen van zijn commentaar zonder al te veel problemen in tekst of toelichting konden worden overgenomen. Snijders: "Van Ewijk was buitengewoon uitvoerig in zijn nota's en in zijn gesprekken, maar in zijn teksten niet. Er zit bepaald een scheiding tussen wat hij produceerde als parlementair stuk en zijn nota's. Hij

43. Waarschijnlijk vormde dit artikel een reactie tegen het Sleepboot Egbertha-arrest (HR 26 maart 1936, NJ 1936, 757), waarvan één van de consequenties was dat de eigendom van een gestolen of ontvreemde zaak wordt verloren wanneer een ander haar tot een bestanddeel van een hem toebehorende zaak maakt, zélfs wanneer deze zaken zonder beschadiging zouden kunnen worden gescheiden.

44. Dit nieuw ontworpen artikel $2 \mathrm{~b}$ beschermde niet alleen de verkoper, maar ook anderen van wie een zakelijk recht was teniet gegaan. Ook was het artikel van toepassing indien de hoofdzaak roerend was. Aan degene wiens zakelijk recht verloren was gegaan, gaf het artikel de mogelijkheid op eigen kosten afscheiding te vorderen, tenzij dit met een aantasting van de hoofdzaak gepaard zou gaan. De rechten van een derde te goeder trouw op het goed bleven echter gewaarborgd, tenzij de hoofdzaak een registergoed was en de akte was ingeschreven.

45. De voorwaarde bijvoorbeeld, dat de afscheiding van het bestanddeel niet mocht leiden tot aantasting van de hoofdzaak, was op zichzelf een nuttige gedachte: op die wijze wordt voorkomen dat kapitaalsvernietiging plaatsvindt. Alleen, bij nadere analyse bleek dat men met die eis in de knoei kwam met een andere regel, namelijk dat éen van de kenmerken van een bestanddeel nu juist is dat hij slechts met aanmerkelijke schade van de hoofdzaak kan worden gescheiden. 
bestookte ons destijds met stukken die aanzienlijk omvangrijker waren dan ontwerp en toelichting, maar die waren er juist op gericht de zaak te vereenvoudigen."

Anders ging het echter ten aanzien van die punten waarop Van Ewijk - terecht of niet - principiële wijzigingen voorstelde, een andere koers wilde inslaan. Want dikwijls was het dan zo, dat elk wijzigingsvoorstel van zijn kant tot gevolg had dat nieuwe, verdergaande wijzigingsvoorstellen loskwamen. In feite begon daarmee het circus van nota's en tegennota's opnieuw. Ten Kate was daar niet altijd gelukkig mee: "Wij kwamen met teksten en dan ging Van Ewijk er kritiek op uitoefenen. Dan moest je er vaak nog een keer doorheen. Dat proces herhaalt zich. Ik moet zeggen dat ik dat niet het meest aangename vind. Op dat moment is voor mij de zaak klaar en dan weet ik wel dat er gebreken in kunnen zitten, maar dat moet je durven aanvaarden. (..) Je moet op een zeker moment durven zeggen dat het af is. Ik heb zoiets wel eens tegen Langemeijer gezegd: 'Wij maken ons als ontwerpers geweldig druk over allerlei regels, maar als puntje bij paaltje komt, dan blijkt de redelijkheid en de billijkheid of de onbetamelijkheid de uitweg te zijn om datgene te bereiken wat je wilt bereiken. Waarom is dan die regel, in al zijn nuanceringen nodig?' Dat gevoel heeft mij nooit helemaal losgelaten. De scherpe kantjes van een tekst worden door de praktijk wel bijgevijld."

In de loop van 1968 was alles wat er over Boek 3 te zeggen viel ook inderdaad gezegd en kon de laatste hand aan het ontwerp worden gelegd. Dat was noodzakelijk, enerzijds omdat er als gevolg van de jongste discussieronde ongemerkt weer nieuwe, nog subtielere compromissen in het ontwerp waren terecht gekomen, anderzijds omdat de teksten die naar aanleiding daarvan waren verschenen min of meer een samenvatting waren van alle meningen die er tot dan toe naar voren waren gebracht. De grote lijn was niet meer zichtbaar, de laatste schaaf ontbrak. De problemen waren opgelost, maar de tekst was onleesbaar.

Omdat de aardigheid er voor Langemeijer inmiddels wel af was en het Voorlopig Verslag over Boek 6 voorlopig nog niet te verwachten was, verzocht hij ontheven te worden van zijn taak. Dat besluit kwam niet als een verrassing, want hij had al eerder aangegeven te willen opstappen. In een brief aan Van Ewijk, gedateerd 26 juli 1967, schreef Langemeijer dat het gevoel, dat hij niet de juiste man was voor dit werk, gedurende de drie jaar die hij nu aan Boek 3 bezig was, hem nooit had verlaten: "Naar mijn gevoel is het zo dat alles even goed zou zijn gegaan, wanneer de zaak eenvoudig door Snijders en Ten Kate onder jouw leiding zou zijn behandeld. Vermoedelijk in zover nog iets beter dat iedere man die meepraat en -schrijft tijd kost. Ik heb nu net de proef nog eens genomen met Titel 8. Die heb ik eerst zelf nog eens doorgenomen met wat ik voor de vereiste kritische aandacht hield en pas daarna Snijders' nota van 13 dezer gelezen. Welnu, de dingen, waarop hij zowel als ik of ik wel en hij niet ben gekomen, zijn ver in de minderheid bij die, waarop hij wel en ik niet kwam. ${ }^{46} 47$

46. De slotzin was typisch Langemeijer: "Overzie ik het geheel dan is er heel weinig eigen prestatie van mij bij en heeft mijn rol vooral bestaan in het arbitreren van controversen tussen Els, Snijders en Ten Kate." Van Ewijk, die op 30 juli terugschreef, was het dáár dan ook in het geheel niet mee eens: "Het werk binnenkamers aan Boek 3, dat nu in gang is - de opstelling en afwerking van het G.O. en de M.v.A. aan de Tweede Kamer - is ploegwerk. Door niemand zou dit alleen kunnen worden gedaan, ook niet door Jan Drion en m.i. ook niet door Meijers zelf, als zij nog leefden. (..). Met de 
Ten Kate: "Ik denk dat het telkens weer moeten herkauwen van teksten voor Langemeijer vooral het breekpunt was. Als Advocaat- of Procureur-Generaal schrijf je je conclusie en dan is de zaak afgelopen, je vergeet het dan ook vrij snel. Maar dat kun je met wetgeving niet doen, je moet die dingen blijven vasthouden. ${ }^{\text {48 }}$

Het vertrek van Langemeijer betekende dat Snijders - met medewerking van Ten Kate en Van Ewijk - de eindcoördinatie voor zijn rekening zou nemen. En daarvan werd het ontwerp weer beknopt. Terminologische strijdpunten, voorzover opgelost door de nieuwe redactie, werden in de toelichting niet meer uitgebreid besproken, maar slechts gesignaleerd. Ongevraagde uitleg van bepalingen in andere boeken of toezeggingen tot wetswijziging verdwenen. Complexe artikelen werden geschrapt, praktijkvreemde constructies werden er uitgelicht.

Een voorbeeld. Door de regeling van het eigendomsvoorbehoud van artikel 3.1.1.3 lid 3, waarvan de toelichting medio 1969 inmiddels gevorderd was tot drie bladzijden, werd door Snijders een streep gehaald, "omdat een regeling als hier nagestreef, indien het tot toepassing ervan komt, tot menigvuldige twijfelpunten aanleiding zal kunnen geven, terwijl pogingen om de bezwaren van de voorgestelde regeling te ondervangen weer andere problemen zouden oproepen. ${ }^{\text {"49 }}$

Dezelfde wijze verging het artikel 3.1.1.9 lid 5. Deze bepaling berustte op de gedachte dat er naast de mogelijkheid nog niet tot zelfstandige goederen geworden vruchten over te dragen als toekomstige goederen - artikel 3.4.2.10 - in bepaalde gevallen behoefte was aan de mogelijkheid zulk een overdracht te bewerkstellingen met werking tegenover opvolgers onder bijzondere titel in de eigendom van het vruchtdragende goed, maar dan in een minder zware vorm dan door vestiging van het vruchtgebruik. Dit artikellid, waarvan Langemeijer in 1965 nog schreef dat het "wel enigszins een bepaling is, waarbij ik een praktische zin heb moeten zoeken", zou, nadat het begin juli 1968 was uitgegroeid tot een afzonderlijk artikel met drie leden en tien bladzijden toelichting, uiteindelijk door Snijders worden geschrapt met het argument dat in de praktijk aan de regeling geen behoefte zou bestaan. ${ }^{50}$

46. $\rightarrow$

bekwaamheid van degenen die nu onder jouw leiding aan Boek 3 werken kan niet worden volstaan. $\mathrm{Zij}$ - Snijders vooraan - kunnen tezamen telkens een etappe vorderen, maar behoeven dan je leiding en kritiek om daardoor gesteund verder te werken." Verder wees Van Ewijk er op dat een wisseling van de wacht op dit moment "funest" zou zijn: "Niet alleen zou zij een grote vertraging veroorzaken omdat een opvolger zich zou moeten inwerken, onvermijdelijk zou de buitenwereld de niet weg te redeneren indruk krijgen dat je het schip verliet wegens gebrek aan vertrouwen in de onderneming nieuw B.W."

47. In het interview met Het Vaderland zei Langemeijer het als volgt: "Het moeilijkste vind ik je eigen opponent zijn, steeds maar weer kritisch blijven, waar mogelijk overzien wat er tegen je eigen zienswijze kan worden ingebracht, waar men je bedoeling kan frustreren."

48. Dit was ook één van de redenen dat Ten Kate medio 1969, toen Boek 6 in zicht kwam, naar de Rechtbank zou terugkeren: "Het telkens weer terugkomen van zo'n tekst, daar heb ik zelf ook onder geleden. Iedereen, elke beroepsgroep heeft wel op een detail kritiek. En dan moet je er weer over gaan nadenken, weer over praten, weer aan schaven, waarbij je soms per ongeluk terugvalt op een oude tekst, waaraan de euvels zitten die je eerder had ontdekt, maar op dat moment vergeten was. Dat niet kwijtraken van zoiets, dat vreet aan je. Ik kon daar niet goed tegen."

49. Parl. Gesch. Boek 3, p. 76.

50. Parl. Gesch. Boek 3, p. 95. 
En zo verdwenen er nog meer van die steriele bedenksels. ${ }^{51}$

\section{Besluit}

Uit het voorgaande blijkt, dat de moeizame totstandkoming van Boek 3 G.O. allereerst een gevolg was van het feit dat de opvolgers van Meijers de door deze afgeleverde teksten veel te kritisch bezagen. Artikelen, die in eerste opzet misschien niet volmaakt waren, maar er toch best mee door konden, werden verknoeid doordat men steeds verder ging onderverdelen. Hoe langer men praatte, des te meer fouten men zag.

Wel moet ik hier onmiddellijk bij aantekenen, dat het allemaal gematigder was dan in de tijd van het Driemanschap. Aan rechtsvergelijking werd bijvoorbeeld niet veel gedaan en als het gebeurde, dan was het meestal ter aankleding van de toelichting. Ook vergaderden Langemeijer c.s. maar een fractie van het aantal keren dat het Driemanschap bijeenkwam. Echt "wilde invallen" waren daardoor alweer verdwenen voordat ze op papier waren gezet.

Voor een deel was dit perfectionisme een gevolg van onervarenheid, van een gebrek aan leiding, voor een ander deel een gevolg van het feit dat men er men $z$ 'n drieën moest zien uit te komen. Zoals Langemeijer reeds zei, elke man méér die meepraat, kost tijd.

Bovendien overschatte men de mogelijkheden van de wetgever. Des te gedetailleerder een regel wordt, des te vaker zullen er gevallen zijn die er buiten vallen. Illustratief hiervoor is, dat de zogenaamde "verruimde Pauliana"52 lange tijd in het concept-ontwerp was opgenomen. Snijders zou de regel eind 1969 schrappen, omdat het uiteindelijke produkt niet bevredigend was: "Aan de ene kant gaf de bepaling een te starre regel voor een omvangrijke groep gevallen, die moeilijk te overzien was. Aan de andere kant hield zij een beperking in tot een bepaalde groep van rechtshandelingen en trok zij daarmee een grens die op z'n minst willekeurig genoemd kan worden. Deze materie kan beter aan de rechtspraak worden overgelaten. " 53

In direct verband hiermee staat dat de bewerkers te veel de neiging hadden de zaak in eigen beheer af te doen. Overleg met de praktijk had bijvoorbeeld de moeizame, tijdrovende en op niets uitlopende discussies als die over de hulpzaak, eigendomsvoorbehoud en het vruchttrekkingsrecht kunnen voorkomen. Het zijn typisch voorbeelden van wat er gebeurt, wanneer in de studeerkamer de lust opkomt iets slims te zeggen over een stuk recht waarvan men de praktijk niet kent.

Tenslotte heeft de afwerking van Boek 3 vertraging ondervonden, doordat Van Ewijk pas in een zo'n laat stadium commentaar leverde, nog een nasleep van het overlijden van Drion. Vóór 1964 immers, stelde het Ministerie de concepten op, die dan vervolgens met Drion werden doorgenomen. Nu echter moest Van Ewijk zich,

51. Andere, reeds genoemde voorbeelden zijn de beschouwingen over de "anonieme gevers" (artikel 3.1.1.11) en de schijnproblematiek van de levering van roerende wortelvaste beplantingen.

52. De enge Pauliana geeft een schuldeiser de mogelijkheid tot vernietiging van rechtshandelingen van zijn debiteur die hem in zijn mogelijkheden tot geldelijk verhaal benadelen. De ruime Pauliana is reeds van toepassing wanneer een crediteur wordt benadeeld in zijn mogelijkheden om nakoming te verkrijgen.

53. Nota van 13 november 1969 aan Minister Polak bij de concepten voor de titel 3.2 en 3.3. 
als gevolg van zijn vele andere werk, noodgedwongen beperken tot het becommentariëren van de resultaten van de besprekingen van anderen, met als gevolg dat hij steeds een ronde achterliep. Hij kwam pas bij een tweede of derde concept aan een reactie toe, op een tijdstip dat naar de mening van Langemeijer c.s. de zaak al min of meer was beklonken. Dat Van Ewijk vanaf 1966 een steeds somberder beeld schetste van de loop van de werkzaamheden, kwam dus vooral omdat hij toen meer tijd kreeg de concepten te beoordelen en steeds meer feilen in het werk van Langemeijer c.s. ontdekte.

Hieruit volgt, dat het welslagen van Boek 3 uiteindelijk in belangrijke mate aan Regeringscommissaris Snijders is te danken. In een enorm tempo wist hij Boek 3 G.O. op de rails te krijgen, en wel op een zodanige wijze dat het in de literatuur vrij goed werd ontvangen. Wel is Boek 3 nog aanmerkelijk gedetailleerder, perfectionistischer en dus uitvoeriger dan Boek 6 in zijn herziene gedaante - ter vergelijking: de Memorie van Antwoord Boek 3 telt 328 bladzijden, die over Boek 6 250. Maar dat laatste boek is dan ook vrijwel geheel van de hand van Snijders. Bij Boek 3 is de invloed van Drion en Van Ewijk bij sommige onderdelen daarentegen nog duidelijk herkenbaar.

Uit bijlage I (zie hieronder) blijkt dat er op de keper beschouwd niet zoveel is veranderd. Het is technisch allemaal wat scherper geformuleerd, bepaalde figuren zijn doorontwikkeld, mede als gevolg van het verstrijken van de tijd. Maar zonder Snijders had men het niet gered. Hij was de eerste na Meijers die weer greep op het geheel kreeg. Dat werd ook al snel ingezien op het Departement: "Het zou voor het Ministerie een ramp zijn als hij vertrok", schreef Van Ewijk toen Snijders op de voordracht voor de Hoge Raad werd geplaatst. ${ }^{54}$ Duidelijker kan het niet worden gezegd.

\section{Het werk aan Boek 5}

\section{Beekhuis en Franken}

Toen in 1963 op initiatief van Minister Scholten een aantal maatregelen werd genomen om Drion zoveel mogelijk te ontlasten, zonder dat het werk aan het nieuwe B.W. daardoor schade zou leiden, bestond éen van die maatregelen erin dat op het Departement een nota zou worden opgesteld naar aanleiding van het Voorlopig Verslag over Boek 5. Deze nota zou, zo was de bedoeling, als handleiding moeten dienen bij de door het Departement op te stellen concepten voor de Memorie van Antwoord en voor de besprekingen met Drion daarover. Voor dit werk werd door Van Ewijk een beroep gedaan op Franken, die, hoewel hij zich na de voltooiing van het voorontwerp voor Boek 6 in 1961 bewust had toegelegd op de korte-termijn wetgeving, van alle ambtenaren op Justitie het meest bekend was met Boek 5. Franken had immers nog aan de wieg van Boek 5 gestaan, eerst als assistent van Meijers en later als medewerker van het Driemanschap. Ook was hij de belangrijkste auteur van het Regeringsontwerp voor Boek 5 en van het Nader Rapport naar aanleiding van het advies van de Raad van State.

54. Nota van 4 september 1968. 
Vanuit dit gezichtspunt beoordeeld was het daarom niet meer dan logisch, dat toen Beekhuis in april 1964 werd benoemd tot Regeringscommissaris voor Boek 5, hij Franken als medewerker kreeg toegewezen. Franken zei daarover: "Na de dood van Drion besloot men dat Beekhuis een geschikte man zou zijn voor het Zakenrecht. De gedachte dat je iemand alleen aan het werk moest zetten, bestond niet meer. Vereist was iemand die voldoende gezag had tegenover de buitenwereld met daarbij iemand die specialist was op het gebied van de wetgeving en die daarbij tevens als klankbord kon dienen. En dat is een goede manier gebleken. Beekhuis en ik konden goed met elkaar overweg."

Net zoals ten aanzien van Boek 3 het geval was, waren de verwachtingen met betrekking tot Boek 5 G.O. in 1964 hoog gespannen. De gedachte was dat de klus in ongeveer één jaar geklaard zou zijn. Dat was ook een uitdrukkelijke voorwaarde van Minister Scholten, die ernaar streefde de Memorie van Antwoord ultimo 1965 bij de Tweede Kamer in te dienen, gelijk met die over Boek 3. Op 2 april 1964, nadat bekend was geworden dat Beekhuis van zijn werkgever, de Rijksuniversiteit Groningen, toestemming had gekregen de opdracht te aanvaarden, schreef Van Ewijk aan de Minister: "Prof. Beekhuis zal vermoedelijk zijn ontwerp Luchtrecht (dat buiten zijn functie van Commissaris valt $)^{55}$ in eerste ronde voltooid hebben in september en dan - aan de hand van inmiddels door mr. Franken voltooide nota's - beginnen met de bewerking van de Memorie van Antwoord over Boek 5, die ongeveer een jaar in beslag zal nemen." Beekhuis beaamde dit: "Toen ik als Regeringscommissaris werd gevraagd, dacht ik, ik ben binnen een jaar klaar. Zo werd het mij ook voorgesteld."

\section{Werkwijze}

Beekhuis zou inderdaad in het najaar van 1964 met het werk aan Boek 5 beginnen, nadat hij zijn voorontwerp voor het Luchtrecht binnen de termijn had ingeleverd. Dat was weliswaar een half jaar later dan het tijdstip waarop Langemeijers bemoeienissen met het nieuwe B.W. waren begonnen, maar daar stond tegenover dat Boek 5 qua omvang nog niet de helft bedroeg van Boek 3. Strict genomen was de verhouding zelfs nog gunstiger - in bladzijden van het oorspronkelijk ontwerp bedroeg zij ongeveer een derde -, omdat de hercodificatie van het appartementsrecht buiten het kader van het werk aan het nieuwe B.W. plaatsvond. ${ }^{56}$ Bovendien schenen de opmerkingen van de Tweede Kamer in het Voorlopig Verslag "niet tot grote moeilijkheden aanleiding te geven", volgens Beekhuis. ${ }^{57}$

Beekhuis hield geregeld besprekingen met Franken, aanvankelijk gemiddeld zo'n drie keer per maand. Deze besprekingen strekten zich meestal over twee dagen uit.

55. Zie voor de achtergronden van Beekhuis' werk aan het Luchtrecht, Hoofdstuk 9.

56. Titel 5.10, ingevoegd bij het Regeringsontwerp voor Boek 5, was gebaseerd op de Wet van 20 december 1951, Stb. 571. In het begin van de zestiger jaren rees het denkbeeld deze wet op een aantal punten te herzien, hetgeen leidde tot de Wet van 7 september 1972, Stb. 467. Dit betrof een zogenaamde voortrein op de vaststelling en invoering van titel 5.10. De auteurs waren Beekhuis en Van Ewijk, die deze titel ook samen voor het Regeringsontwerp hadden bewerkt. Zie verder Kwartaalbericht NBW 1989 , p. 65 e.v.

57. J.H. Beekhuis, Herinneringen aan mijn werk voor het nieuwe B.W., in: Goed en Trouw, Zwolle 1984 , p. 335. 
De nadruk lag dus op het mondeling overleg. Uitgangspunt daarbij was de door Franken voor elke titel opgestelde nota. ${ }^{58}$ De start van deze besprekingen, die vrijwel zonder uitzondering op het Ministerie in Den Haag plaatsvonden, was op 14 oktober 1964. Doel daarvan was om in gezamenlijk overleg tot een concept-tekst voor het G.O. te komen. Vervolgens was het dan speciaal de taak van Beekhuis om aan de hand van de uitvoerige processen-verbaal, die van elke vergadering werden opgemaakt, concepten op te stellen voor de Memorie van Antwoord. Franken kon daar dan weer op reageren, Beekhuis ook, totdat de zaak naar hun beider oordeel rijp was voor een voorlopige afronding, een tweede concept, etc. Tot 1969, toen Franken blijvend ziek werd, zou het opstellen van eerste concepten voor G.O. en M.v.A. echter grotendeels een utopie blijven: het merendeel van de titels zou in de mondelinge fase blijven steken of zelfs niet in behandeling worden genomen.

Anders dan bij Langemeijer c.s. het geval was, werd door Beekhuis en Franken in de regel aan slechts één titel tegelijk gewerkt. Er werden dus niet eerst voorlopige concepten voor alle titels opgesteld, maar titel voor titel werd afgewerkt, tot vrijwel de eindredactie.

\section{Voortgang en vertraging}

Hoewel Boek 5, mede als gevolg van de inspanningen van het Driemanschap en de merkbare invloed van het ontwerp 1898 , waarschijnlijk één van de doordachtste en evenwichtigste delen van het Ontwerp-Nieuw B.W. was, bleken Franken en Beekhuis daar toch anders over te denken. Dat werd al in de eerste vergadering duidelijk, toen titel 5.6 (Erfdienstbaarheden) aan de orde was. De conclusie van die bespreking was dat behalve in Boek 5, ook in Boek 6 ingrijpende wijzigingen nodig waren om beide Boeken beter met elkaar te laten sporen. Van Ewijk, enigszins verbaasd, noteerde op één van zijn jaarlijkse overzichten: "Het groene boek is, behalve titel 10 , voltooid door het Driemanschap Drion, De Jong en Eggens in mei 1955 en is uiteraard veel geacheveerder dan de ontwerpen voor de Boeken 1-4. Voorts is het ook nog voor de indiening van het Regeringsontwerp (januari 1957) veel grondiger bekeken. (..) Volgens Beekhuis en Franken moet er toch nog vrij veel herzien worden bij het Gewijzigd Ontwerp en klopt Boek 5 niet overal met Boek 3 en met de kwalitatieve verbintenissen in Boek 6." ${ }^{\text {59 }}$

Betrekkelijk snel na de aanvang van hun werkzaamheden wendden Beekhuis en Franken zich daarom tot Van Ewijk met het verzoek om extra mankracht, helaas zonder succes: er was niemand die een paar jaar van zijn leven aan dit monnikenwerk wilde opofferen. Van Ewijk lichtte Minister Scholten op 15 januari 1965 in over deze nieuwe tegenslag voor het werk aan het nieuwe B.W.:

"Beekhuis en Franken zijn van mening dat, ofschoon Boek 5 met grote zorg door het Driemanschap is voltooid, het nog een aantal wijzigingen behoeft, mede met het oog op de aansluiting aan het later voltooide ontwerp voor Boek 6. Zij zouden gaarne beschikken over assistentie van een jonge medewerker. Ik heb een poging

58. Deze nota verscheen in het najaar van 1964, in afleveringen. In oktober 1964 was Franken nog slechts gevorderd tot titel 5.6. Beekhuis zou de ontbrekende delen in juli 1967 completeren.

59. Nota van 13 oktober 1966. 
gedaan, (...) maar deze heeft ervan afgezien, ofschoon ik hem een belangrijk hoger salaris in het vooruitzicht had gesteld. $\mathrm{Zij}$ zullen het dus zonder assistentie moeten doen."

Wel werd, als pleister op de wonde, tijdens een bepreking van de Minister met Beekhuis, Langemeijer en Van Ewijk op 18 maart 1965, afgesproken dat de titels 5.7 en 5.8 voorlopig zouden worden gereserveerd, "voor het geval dat een medewerker van mr. Langemeijer in het najaar tijdelijk beschikbaar zal blijken te zijn om hiervoor prof. Beekhuis terzijde te staan."

Van dit plan zou echter niets terecht komen, omdat het was gebaseerd op de achteraf niet realistisch gebleken verwachting, dat in september 1965 een voorlopig concept Boek 3 zou kunnen worden voltooid. Dat werd, zoals bekend, december 1965, zodat er weinig "najaar" overschoot. ${ }^{60}$

Een andere tegenvaller die zich al vrij snel openbaarde, was dat Beekhuis vanaf het begin - in de woorden van Van Ewijk - "ernstig gehandicapt" werd door zijn volle taak als hoogleraar in Groningen. Weliswaar hadden curatoren in Groningen bij de benoeming van Beekhuis tot Regeringscommissaris aan Justitie de verzekering gegeven dat alles in het werk zou worden gesteld om van Onderwijs een tweede hoogleraarsplaats te krijgen, maar acht maanden later was daar nog steeds niets van te merken. Ook dat kwam de voortgang niet ten goede, omdat Beekhuis zich daardoor onvoldoende op zijn wetgevende taak kon concentreren. Bovendien was, volgens Beekhuis, een reis van Groningen naar Den Haag vroeger wel iets anders dan tegenwoordig.

Van Ewijk, 15 januari 1965: "Een prognose durf ik niet te geven, noch over Boek 3, noch over Boek 5." Beekhuis zelf begrootte de vertraging in maart 1965 op ongeveer één jaar: "Als termijn voor de voltooiing van de Memorie van Antwoord noemt prof. Beekhuis 2 jaar, gerekend van oktober j.1. (1964), er van uitgaande dat, binnen die tijd, het concept nog, b.v. door mr. Van Ewijk, zal worden doorgenomen met het oog op de coördinatie met de andere boeken." ${ }^{61}$ Later, tijdens een bespreking op 1 september 1965 met de opvolger van Scholten, Minister Samkalden, bleef Beekhuis bij deze prognose. ${ }^{62}$

60. Bij brief van 4 april 1965 aan Van Ewijk kwam Beekhuis nog even op deze kwestie terug. Uit zijn brief blijkt dat het contact tussen Beekhuis en Franken enerzijds en Langemeijer anderzijds niet erg intens was, getuige het misverstand over Boek 6. Beekhuis schreef: "Het is Franken en mij opgevallen, dat door Langemeijer niet gesproken is over Boek 6. Mochten de medewerkers van Langemeijer hiervoor niet gebruikt worden, dan zouden zij inderdaad mij in bepaalde opzichten kunnen helpen."

61. Notulen van een bespreking tussen Minister Scholten, Van Ewijk, Beekhuis en Langemeijer d.d. 18 maart 1965. In het interview met Beekhuis, opgenomen in Geschriften van Beekhuis, Zwolle 1990 , p. 19, geeft Beekhuis een iets andere lezing: "Na de dood van Jan Drion, toen ik Regeringscommissaris werd, werd mij eerst voorgehouden dat we in een paar jaar klaar zouden moeten zijn. Ik heb toen gezegd: 'Het hangt helemaal vanaf wat er moet gebeuren; er is een ontwerp van het Driemanschap, maar als we dat helemaal moeten bewerken op de wijze zoals dat nu op het Departement gebeurt, dan hebben we zeker meer tijd nodig."

62. Dientengevolge zou Samkalden op 5 oktober 1965 in de Kamer verklaren: "Ik heb met degenen, onder wier leiding deze arbeid wordt verricht (..) overleg gepleegd over de wijze waarop en het 
Hoewel ik persoonlijk een vraagteken zet bij de opmerking dat Beekhuis bij zijn werk aan Boek 5 ernstig werd gehinderd door zijn taak als hoogleraar - zie verder hieronder - was deze kwestie voor Minister Samkalden belangrijk genoeg om bij brief van 21 april 1965, één week na zijn benoeming, rechtstreeks contact op te nemen met zijn ambtgenoot op Onderwijs, met het aanbod de financiering van deze tweede leerstoel voor zijn rekening te nemen. Samkalden schreef:

"Het blijven liggen van deze zaak (is) voor de behandeling van het 5e Boek van het B.W. bijzonder nadelig. Ik had hoop, dat Beekhuis zich na de vakantie daar zó veel mee bezig kon houden als noodzakelijk is om de Memorie van Antwoord in het parlementaire jaar 1965/1966 in te dienen. Daarvoor is nodig, dat een tweede hoogleraar voor het burgerlijk recht na de grote vakantie zijn werkzaamheden kan aanvangen. Het ziet er op het ogenblik niet naar uit, dat de maatregelen daartoe genomen worden met de besluitvaardigheid die voor dat doel is vereist. (..) Vóór alles is spoed nodig en ik ben volledig bereid om te bepleiten, dat gedurende de zeg twee jaar, dat Beekhuis een groot deel van zijn tijd zal moeten besteden aan het vijfde Boek de kosten van de tweede leerstoel door Justitie worden gedragen, indien daartoe langs de normale weg geen middelen beschikbaar zouden kunnen worden gesteld."

Uiteindelijk zou het toch nog bijna anderhalf jaar duren voordat Beekhuis eindelijk in september 1966 de steun van een secundus in Groningen zou krijgen. Niet het Ministerie van Onderwijs, maar de universiteit was de grootste dwarsligger ${ }^{63}$ Pas in de loop van januari 1966, een half jaar nadat de toestemming van Onderwijs was afgekomen, zou het faculteitsbestuur het eens worden over de voordracht. Inmiddels was de belasting van Beekhuis al weer zo toegenomen, dat het besluit tot verlichting vermoedelijk goeddeels was achterhaald. Beekhuis verklaarde althans in een interview in mei 1967: "Het werk werd mij absoluut te zwaar. Sinds kort heb ik bijstand bij mijn docerende taak, maar de zo vrijgekomen tijd wordt helemaal opgeslokt door het nieuwe B.W., de wetgeving die daar tussendoor nog moet worden voorbereid, publicaties en nog vele andere activiteiten. ${ }^{164}$

Bovendien was de juridische faculteit na 1960 sterk gegroeid: van enige tientallen studenten omstreeks 1955 tot enige honderden in 1965. Van Ewijk noteerde op 13 oktober 1966: "Beekhuis is trouwens ook nu nog belast met veel tentamens van studenten die bij hem college gelopen hebben." Opvallend is dat Beekhuis in het

\section{2. $\rightarrow$}

tempo waarin zij zich voorstellen dit eerste stadium van hun werkzaamheden te voltooien. Het is op grond van dit overleg dat ik u kan meedelen te verwachten, dat de beide Memories van Antwoord (Boek 3 en Boek 5) $u$ in het kalenderjaar 1966 zullen bereiken. Dat zal wel aan het eind van het kalenderjaar betekenen." (Handelingen Tweede Kamer, 1965-1966, p. 104.)

63. Zie ook handelingen Tweede Kamer 1965-1966, p. 104. Samkalden sprak daar: "Ik ben (..) erkentelijk voor de medewerking die nu ondervonden is van het Ministerie van Onderwijs en Wetenschappen, van curatoren van de Rijksuniversiteit te Groningen en van de faculteit der Rechtsgeleerdheid aldaar, medewerking die men doende is te verlenen, opdat (..) prof. Beekhuis ruimer tijd krijgt voor zijn aandeel in het codificatiewerk."

64. Het Vaderland, 5 mei 1967. 
interview van mei 1967 geen enkele prognose meer wilde doen: "Hoever de Memorie van Antwoord nog van ons verwijderd is wil prof. Beekhuis in het midden laten."

Tenslotte zou Beekhuis in 1967 worden benoemd tot lid van de Raad van State in de plaats van Cleveringa, een taak die eveneens een groot deel van zijn aandacht zou opeisen. Beekhuis zei daarover: "Ik was in het begin praktisch het enige lid dat gespecialiseerd was in het burgerlijk recht. Daarom heeft de voorzitter een rondschrijven gericht aan de leden dat zodra er civielrechtelijke vragen waren ze zich tot mij zou zouden kunnen wenden. (..) Ik was wel een beetje overbelast met wetgeving en ik werd daarom voor een deel vrijgesteld op het gebied van de geschillen van bestuur. "65

Omdat Beekhuis pas medio 1969 naar Driebergen zou verhuizen, zou het nieuwe B.W. niet echt van de kortere verbindingslijnen profiteren. Bovendien werd Franken, zoals gezegd, in januari 1969 blijvend ziek, zodat Beekhuis alleen verder moest. Nieuwe juridische assistentie voor Beekhuis was kennelijk uitgesloten, gegeven de hopeloze personeelssituatie op de Stafafdeling NBW.

In het voorjaar van 1971 zou Beekhuis zijn concepten inleveren op het Ministerie, met daarbij de mededeling dat hij, als gevolg van zijn drukke werkzaamheden bij de Raad van State, ernaar streefde zijn werk aan de voorbereiding van Boek 5 omstreeks 1 januari 1972 te beëindigen.

Dat doel werd niet gehaald. De Memorie van Antwoord aan de Tweede Kamer en het Gewijzigd Ontwerp werden op 16 oktober 1972 door Minister Van Agt ingezonden, op een paar dagen na elf jaar nadat het Voorlopig Verslag werd vastgesteld. De anwijzing van Beekhuis als Regeringscommissaris ex artikel 120 lid 2 Grondwet werd bij besluit van 5 oktober $1972 \mathrm{nr} 50$ met ingang van 1 november 1972 beëindigd. Per gelijke datum werd Snijders benoemd tot Regeringscommissaris.

Zonder noemenswaardige wijzigingen werd Boek 5 op 20 april 1977 door de Tweede Kamer aangenomen. De Eerste Kamer zou op 6 mei 1980 volgen.

\section{Oorzaken voor vertraging}

Eén van de verklaringen, waarom het werk aan Boek 5 R.O. niet al vóór 1966 kon worden beëindigd, kwam hiervoor al min of meer ter sprake, namelijk dat Beekhuis en Franken als gevolg van een soort over-kritische benadering allerlei fouten en foutjes in het werk van Meijers en het Driemanschap ontdekten, met als gevolg dat de opzet van Boek 5 al snel niet meer voldeed. "In werkelijkheid bleek men", zo schreef Beekhuis in een terugblik op deze periode, "op het Ministerie de opvatting te huldigen, dat niet alleen de opmerkingen van de Kamer besproken moesten worden en de teksten eventueel aan die opmerkingen zouden moeten worden aangepast, maar

65. Geschriften van Beekhuis, Zwolle 1990, p. 17. Om de leer van de machtenscheiding niet helemaal tot een illusie te maken, werd de afspraak gemaakt dat Beekhuis zou aftreden als Regeringscommissaris, zodra de Memorie van Antwoord van Boek 5 zou zijn ingediend. Zie daarover J.H. Beekhuis, Herinneringen aan mijn werk voor het nieuwe B.W., in: Goed en Trouw, Zwolle 1984, p. 337. 
men achtte het noodzakelijk het gehele werk (teksten en toelichting) van het Driemanschap opnieuw te bestuderen. ${ }^{\text {}} 6$

Evenmin als dat bij de bewerkers van Boek 3 R.O. het geval was, vond een bezinning plaats ten aanzien van het standpunt dat de wetgever heeft te kiezen bij het opstellen van de Memorie van Antwoord. Het gebrek aan eerbied voor de ideeën van Meijers en het Driemanschap was nagenoeg volledig.

Beekhuis had zich er wel over verwonderd, toen Franken in zijn nota's en bij de besprekingen direct al vergaande wijzigingen voorstelde, maar wist zich gesteund door de verrichtingen van Langemeijer c.s.: "Toen ik met Franken aan de gang ging bleek dat alles opnieuw bekeken moest worden, want dat deden de anderen ook. Ieder artikel werd van $\mathrm{A}$ tot $\mathrm{Z}$ bekeken, alle mogelijke gevallen werden nagegaan. Het zou niet mijn beslissing zijn geweest, maar men ging heel ver in het opnieuw opstellen van regels." Voor Franken sprak deze benadering echter vanzelf: "Gevoelsmatig en zakelijk maakt het weinig uit of je nu werkt aan een Regeringsontwerp of aan een Memorie van Antwoord. Als wij het nodig vonden om diverse dingen te wijzigen, dan deden we dat, ongeacht het stadium waarin de behandeling verkeerde, en zonder dat berustte op een a priori ingenomen standpunt van het Ministerie. Zelfs een Voorlopig Verslag, dat het in grote trekken eens is met de Regering, kun je benutten om in de Memorie van Antwoord toch weer allerlei dingen te wijzigen, zelfs meer dan de Kamer heeft gevraagd. Daarbij probeer je natuurlijk zoveel mogelijk datgene wat je zelf wilt wijzigen voor de goede sier op te hangen aan vragen in het Voorlopig Verslag." De Die: "Dat omwerken was een idee van Franken. Hij had zijn oordeel over de kwaliteit van het ontwerp van Meijers, ontdekte daarin kennelijk allerlei lekken en sleepte Beekhuis daarin mee."

Een tweede factor die voor vertraging zorgde, was dat als gevolg van deze benadering de behoefte om nieuw recht te scheppen vanzelf groter werd. Het werk van Meijers en zijn opvolgers, dat nog het karakter had van een bewerking van het bestaande recht, verdween daardoor langzaam maar zeker van het toneel. Dit leidde tot een grotere invloed van de dogmatiek en tot een vergaande mate van detaillering. Men ging daarin zo ver, dat het soms voorkwam dat men op vragen stuitte waarover de literatuur in binnen- en buitenland bij gebrek aan ieder praktisch belang geheel zweeg, of die misschien niet eens voor beantwoording vatbaar waren.

Een fraai voorbeeld is het volgende detail uit een discussie over titel 5.5 (Mandeligheid). Franken loopt daar op een gegeven moment tegen vier vragen aan, "die noch in het B.W., noch in titel 5.5, noch in de handboeken goed worden onderscheiden." Daarbij moet men zich realiseren dat tenminste één van die handboeken het veelgeprezen Asser-Beekhuis moet zijn geweest. Veelzeggend is verder, dat hooguit vijf procent van de opmerkingen die tijdens de vergaderingen worden gemaakt betrekking hebben op uitspraken van anderen. Het zijn de eigen vondsten, opmerkingen, kritieken die centraal staan. De bespreking van titel 5.7 bijvoorbeeld, heeft in eerste instantie niets met het Regeringsontwerp of het Voorlopig Verslag te maken. Men begint zomaar ergens en kijkt zelfs niet naar de nota die Beekhuis heeft opgesteld naar aanleiding van het Voorlopig Verslag. Het enige dat gebeurt is dat er een boom

66. J.H. Beekhuis, Herinneringen aan mijn werk voor het nieuwe B.W., in: Goed en Trouw, Zwolle 1984, p. 335-336. 
wordt opgezet over "het karakter van de erfpachtscanon en de overdraagbaarheid van het erfpachtsrecht." Enkele citaten daaruit: "Er zijn vier systemen (..), 't beste is systeem $\mathrm{x}$, maar dat heeft weer het tactische bezwaar dat men wel heel erg ingaat tegen de nadrukkelijk uitgesproken bezwaren van het Driemanschap daartegen. In de literatuur is dit nooit behoorlijk onderzocht...."

Deze voorbeelden illustreren mede, dat het werk van Beekhuis en Franken betrekkelijk weinig te maken had met het schrijven van een Memorie van Antwoord in de vorm van een reactie op het Voorlopig Verslag en eventueel daarna verschenen literatuur. Zo'n concept-Memorie, als zij al verscheen, reageerde niet primair op de opmerkingen van de Kamer, maar bevatte de bespiegelingen van Franken en Beekhuis. Daarom zou er in 1971 ook nog heel wat water door de Rijn stromen voordat de door hen opgestelde stukken beantwoordden aan het beeld van een normaal parlementair stuk.

Tenslotte ontbrak het Beekhuis, die een beminnelijk en zachtaardig man was, ten enen male aan voldoende gezag om leiding te geven aan de discussie, de beraadslagingen af te sluiten en Franken zijn wil op te leggen. Elke beslissing van enige importantie werd aangehouden, uitgesteld voor nadere overweging. Als Franken met bezwaren kwam, dan werden Beekhuis' pennevruchten onmiddellijk gedegradeerd tot "een zeer voorlopig aanloopje tot een verdere discussie, geenszins een min of meer definitief voorstel" etc. Het waren discussies zonder eind. De Die: "Franken was een groot virtuoos in het altijd maar moeilijker maken en elke opmerking die je er tussen probeerde te brengen om het wat te vereenvoudigen, compliceerde de zaak alleen maar, want dan ging hij nog verder in zijn onderverdelen."

En als er dan na lang touwtrekken op een zeker ogenblik een definitieve tekst lag, op basis waarvan Beekhuis zijn concepten voor de Memorie van Antwoord moest schrijven, dan kon het gebeuren dat de kwalificatie "definitief" een dag later alweer moest worden teruggenomen. De tekst van titel 5.7 (Erfpacht) bijvoorbeeld, werd blijkens een uitdrukkelijke vermelding in de notulen op 20 oktober 1966 definitief vastgesteld. Er was toen zo'n vijftien maal over vergaderd. Desalniettemin zou in de volgende vergadering al weer op dit besluit worden teruggekomen. Uiteindelijk zou het tot juli 1967 duren voordat er zo'n beetje het laatste woord over was gesproken. In totaal hadden Beekhuis en Franken toen zeventig (!) dagen over deze titel gedebatteerd.

Ten Kate: "Franken leed eraan dat als hij een regel moest formuleren, hij zich alle gevallen probeerde voor te stellen die zich konden voordoen. En dan ging hij die regel toetsen en kwam vroeg of laat tot de ontdekking dat die regel geen oplossing bood in alle gevallen." Snijders: "Franken was veel meer dan een ander in staat de zaak te doordenken in al zijn consequenties, maar zodra hij eindelijk zijn zin had, wijzigde hij onmiddellijk zijn standpunten en begon de discussie opnieuw."

Het is een interessante, maar moeilijk te beantwoorden vraag, waarom Beekhuis de samenwerking met Franken nooit ter discussie heeft gesteld. Vermoedelijk hield Beekhuis, op en top een heer, zijn moeilijkheden liever voor zich. Beekhuis is waarschijnlijk overrompeld geweest door het optreden van Franken. Deze was hem immers toegewezen door het Ministerie, hij was de assistent geweest van Meijers en van het Driemanschap, "dus het zou wel goed zijn." Daarbij kwam dat Franken bijzonder 
knap was, veel meer in de stof thuis was dan Beekhuis en de samenhang met Boek 6 ook veel beter kon overzien. Om die reden wilde Beekhuis hem aanvankelijk waarschijnlijk ook niet graag missen. Tenslotte werd door de bewerkers van Boek 3 R.O. een min of meer vergelijkbare houding ingenomen ten aanzien van Meijers' werk, zoals Beekhuis zelf had ervaren.

Wat opvalt, is dat Beekhuis ter verklaring van de tegenvallende gang van zaken steeds op andere factoren de nadruk heeft gelegd, zoals zijn problemen in Groningen en de kennelijke onvoldragenheid van het vijfde Boek. ${ }^{67}$ Eén blik op de notulen had Van Ewijk er echter van kunnen overtuigen dat de schoen ergens anders wrong. Daaruit blijkt namelijk dat Beekhuis tussen 1964 en 1966 in het geheel niet "ernstig gehandicapt" werd door andere werkzaamheden. Toen hij het zogenaamd druk had, kon hij wel twee- á driemaal per maand vergaderen, toen het minder druk werd sloeg hij soms maanden over. ${ }^{68}$

Dat Van Ewijk nooit ingreep, kwam omdat hij eenvoudig geen tijd had om Franken en Beekhuis te controleren. Op 13 oktober 1966 schreef hij aan de Minister: "Tot mijn spijt heb ik in het geheel geen tijd kunnen vinden de tot nu toe geproduceerde stukken concept, nota's en verslagen van besprekingen te bestuderen of zelfs maar te lezen." Van Ewijk wist van niets, getuige ook de volgende opmerking in een nota van 12 april 1967: "Ik hoop dat prof. Beekhuis in zijn samenwerking met mr. Franken zo snel opschiet dat ook de M.v.A. en het G.O. van dit boek tegen het eind van dit jaar klaar komen. Het is in ieder geval gewenst deze stukken niet los van M.v.A. en G.O. Boek 3 af te vuren, gezien de nauwe samenhang." Dat beiden al meer dan een jaar aan titel 5.6 knutselden, zonder ook maar enige vooruitgang van betekenis te boeken, was Van Ewijk kennelijk niet bekend.

\section{Gevolgen}

Eén van de meest in het oog springende gevolgen van deze manier van werken - het feit dat de prognoses keer op keer werden overschreden buiten beschouwing gelaten was dat de discussie tot slechts een paar titels beperkt bleef.

Een globaal overzicht. Pas in Juli 1965, toen het werk grotendeels gereed had moeten zijn, verscheen een eerste, voorlopige drukproef van G.O. en M.v.A. voor titel 5.1 (Eigendom in het algemeen); de hinder, het belangrijkste onderdeel, was daarbij nog steeds een onzeker punt. In de loop van dat jaar kwam er alleen de tekst van titel 5.6 (Erfdienstbaarheden) bij. Het jaar 1966 ging vrijwel geheel heen met de bespreking van Beekhuis' concepten voor de M.v.A. voor titel 5.6, waarvan er

67. Ook in het interview uit 1967 legde Beekhuis op andere factoren de nadruk: "De moeilijkheden van wetgeving zijn zeer groot. Minitieus moet iedere tekst worden bekeken, tientallen malen. Er moet gezorgd worden voor eenheid tussen de diverse Boeken. Al met al komt er veel meer bij kijken dan men denkt. Ik heb zelf ook het werk wat onderschat. Vooral de inpassing van het Vijfde Boek in het Derde en Zesde Boek gaat vergezeld van grote problemen."

68. In 1964 kwamen Beekhuis en Franken zes maal twee dagen achtereen bij elkaar. In 1965 werden zesentwintig twee-daagse bijeenkomsten gehouden, en één van een dag. In 1966 vergaderde men drieëndertig dagen, verdeeld over zeventien bijeenkomsten. Na de zomervakantie van 1966, toen Beekhuis bijstand kreeg in Groningen, verminderde de frequentie (slechts éen twee-daagse vergadering per maand). In 1967 kwamen beiden vijf maal twee dagen bijeen, en acht maal één dag. In 1968 zouden in totaal nog zestien ontmoetingen plaatsvinden. 
tenminste vier afleveringen verschenen: vijftien van de drieëndertig besprekingen in 1966 zouden geheel of ten dele aan deze materie zijn gewijd. In 1967 zou opnieuw veel aandacht worden besteed aan deze titel. Daarnaast verscheen in de loop van dat jaar een concept-M.v.A. van Beekhuis over titel 5.7 (Erfpacht). In 1968 tenslotte, het laatste jaar dat Franken en Beekhuis met elkaar werkten, werd uitgebreid gediscussieerd over titel 5.7. Daarvan zouden er dat jaar twee nieuwe concepten verschijnen. $\mathrm{Na}$ vier jaar van onafgebroken werken en 132 bijeenkomsten was dus nog geen kwart van Boek 5 bekeken.

Het steeds opnieuw heropenen van de discussie had niet alleen consequenties voor het tijdschema en voor het verloop van de werkzaamheden. Ook de kwaliteit van de concepten en de lengte van de Memorie van Antwoord werd daardoor in negatieve zin beïnvloed. Doordat compromis op compromis werd gestapeld, werd het allemaal steeds uitvoeriger en gedetailleerder. In feite deed zich dezelfde situatie zich voor als bij Boek 3, zij het in een veel heviger mate.

Een voorbeeld. In het eerste concept van 1966 telde de M.v.A. bij artikel 5.6.1 tien bladzijden, bij de artikelen 2 en 3 acht bladzijden, bij de artikelen 5 en 6 acht bladzijden en bij de artikelen 7 tot en met 10a veertien bladzijden. Aan het eind van het jaar was het concept voor artikel 1 al gevorderd tot dertien bladzijden en dat van de art. 7-10a tot negentien. Alleen over artikel 5.7.1.2, regelende de duur van de erfpacht, werd tussen augustus 1968 en januari 1969 zeven keer vergaderd, terwijl er negen nota's over verschenen; toen was het nog niet klaar. De M.v.A. voor artikel 5.6.7 - uitvoering Franken - telde eind 1968 zelfs zeventien bladzijden.

Tenslotte leidden de moeilijkheden met de voorbereiding van Boek 5 G.O. ertoe, dat het contact met de praktijk, voor een modern en goed functionerend zakenrecht toch van vitaal belang, verloren ging. Men kwam er vermoedelijk eenvoudig niet aan toe. Er is mij slechts één geval bekend, een briefwisseling van Beekhuis uit 1967 met de Groninger Maatschappij van Landbouw. Onderwerp was de door Beekhuis beraamde afschaffing van het beklemrecht.

Van de zo dringend aanbevolen coördinatie tussen Boek 3 en Boek 5, waartoe door Beekhuis en Franken zelf de stoot was gegeven ${ }^{69}$, kwam evenmin veel terecht. Weliswaar zouden tussen eind 1965 en begin 1967 enkele malen nota's worden uitgewisseld met punten die voor de andere medewerkers van belang zouden kunnen zijn, maar omdat in die fase het werk aan beide boeken nog in een beginstadium verkeerde en de concepten dus sterk aan verandering onderhevig waren, leverde dat weinig op. Bovendien hadden Franken en Beekhuis dadelijk al zoveel kritiek op de voorstellen van Langemeijer c.s. dat men aan een vergelijking van Boek 5 met Boek 3 eigenlijk niet toe kwam. Voor zover ik dat heb kunnen nagaan, zijn er alleen op 8 juni 1966, 14 juli 1966 en 11 januari 1967 besprekingen geweest tussen de Langemeijer c.s. en

69. Hun opmerking, dat in Boek 5 nogal wat wijzigingen noodzakelijk zouden zijn, evenals in de Boeken 3 en 6 in verband met Boek 5, was voor Minister Scholten aanleiding Langemeijer en Beekhuis op 18 maart 1965 bij zich te roepen. Tijdens die bespreking wees de Minister er met nadruk op dat hij het van groot belang achtte dat de memories ongeveer gelijktijdig gereed zouden komen, en zó spoedig dat de Boeken 3 en 5 nog binnen zijn ambtstermijn door de Tweede Kamer zouden kunnen worden afgehandeld. Daarom werd afgesproken dat Franken telkens zo spoedig mogelijk aan Langemeijer een opgave zou doen van wijzigingen die naar de voorlopige mening van Beekhuis in Boek 3 noodzakelijk waren. 
Beekhuis en Franken over schriftelijk gebleken discussiepunten, alle betreffende de titels 3.1 en 3.4. Daarna bleef het stil.

Ook van dit manco was Van Ewijk niet op de hoogte. Hij ging er in zijn verslaglegging aan de Minister van uit dat beiden zelf hun zaakjes in de gaten hielden en hij wist niet dat er maar een paar besprekingen en notawisselingen waren geweest. Typerend is de volgende opmerking, die dateert van 13 oktober 1966. Van Ewijk meende toen nog dat Boek 3 G.O. in februari of maart 1967 zou kunnen verschijnen: "Ongetwijfeld zal het eindresultaat (van Boek 5) grondig en betrouwbaar zijn, maar ik vrees dat Beekhuis niet tegelijk met Langemeijer klaar zal zijn. Maar het gevaar van clocheren van de Boeken 3 en 5 zal dan toch wel zijn overwonnen, zodat naar mijn mening Boek 3 niet op Boek 5 zal behoeven te wachten." Snijders: "De coördinatie werd door het Departement onvoldoende in de hand gehouden, omdat men er toen nog van uitging dat het werk aan de Boeken 3 en 5 zich buiten het Departement afspeelde."

\section{De laatste loodjes}

Toen Beekhuis begin 1971, na twee jaar in volstrekte eenzaamheid te hebben gewerkt $^{70}$, zijn werk inleverde op het Ministerie met de mededeling dat hij per 1 januari aanstaande wilde stoppen, bleek er nog veel aan te ontbreken. De stand van zaken ten aanzien van Boek 5 G.O. was min of meer vergelijkbaar met de '68-er versie van Boek 3, met dit verschil dat Beekhuis op onderdelen minder ver gevorderd was, de gereedgekomen stukken nóg uitvoeriger waren én inmiddels niet vier maar zeven jaren waren verstreken:

- Van alle titels was er een Gewijzigd Ontwerp, zij het dat de concepten voor de titels 5.3, 5.7 en 5.8 door Beekhuis nog niet als definitief werden beschouwd.

- De titels 5.3 en 5.7 moesten het zonder M.v.A. stellen, en ten aanzien van titel 5.8 bestonden er slechts korte toelichtende notities.

- Beekhuis had zijn plan om op dezelfde wijze als bij Boek 3 was gebeurd, deskundigen uit de praktijk te raadplegen, nog slechts zeer ten dele volvoerd. $\mathrm{Na}$ het vertrek van Franken had hij alleen met de ontwerper van Boek 8, Schadee, gecorrespondeerd over titel 5.2 alsmede met de VNG. Verder had Beekhuis in maart 1971, kort voordat hij zijn concepten aanbood, contact gehad met notaris Treurniet over de titels 5.7 en 5.8 .

- Het Gewijzigd Ontwerp moest grotendeels nog worden getoetst aan de Boeken 3 en 6. Verder was in het Gewijzigd ontwerp een aantal bepalingen toegevoegd - onge-

70. Wat de Regeringscommissaris tussen 1969 en 1971 precies deed, laat zich niet meer achterhalen. Het archief bevat geen enkel stuk uit deze periode en zelfs van de gebruikelijke verantwoordingen aan de Minister wordt men niets wijzer. Het lijkt erop alsof Justitie Beekhuis geheel uit het oog had verloren. Kennelijk hield dat daarmee verband dat alle inspanningen van het Departement gericht waren op het binnenhalen van Boek 4, de invoering van de Boeken 1 en 2 en het voltooien van het werk aan de Memorie van Antwoord voor Boek 3. 
Beekhuis en Franken over schriftelijk gebleken discussiepunten, alle betreffende de titels 3.1 en 3.4. Daarna bleef het stil.

Ook van dit manco was Van Ewijk niet op de hoogte. Hij ging er in zijn verslaglegging aan de Minister van uit dat beiden zelf hun zaakjes in de gaten hielden en hij wist niet dat er maar een paar besprekingen en notawisselingen waren geweest. Typerend is de volgende opmerking, die dateert van 13 oktober 1966. Van Ewijk meende toen nog dat Boek 3 G.O. in februari of maart 1967 zou kunnen verschijnen: "Ongetwijfeld zal het eindresultaat (van Boek 5) grondig en betrouwbaar zijn, maar ik vrees dat Beekhuis niet tegelijk met Langemeijer klaar zal zijn. Maar het gevaar van clocheren van de Boeken 3 en 5 zal dan toch wel zijn overwonnen, zodat naar mijn mening Boek 3 niet op Boek 5 zal behoeven te wachten." Snijders: "De coördinatie werd door het Departement onvoldoende in de hand gehouden, omdat men er toen nog van uitging dat het werk aan de Boeken 3 en 5 zich buiten het Departement afspeelde."

\section{De laatste loodjes}

Toen Beekhuis begin 1971, na twee jaar in volstrekte eenzaamheid te hebben gewerkt $^{70}$, zijn werk inleverde op het Ministerie met de mededeling dat hij per 1 januari aanstaande wilde stoppen, bleek er nog veel aan te ontbreken. De stand van zaken ten aanzien van Boek 5 G.O. was min of meer vergelijkbaar met de '68-er versie van Boek 3, met dit verschil dat Beekhuis op onderdelen minder ver gevorderd was, de gereedgekomen stukken nóg uitvoeriger waren én inmiddels niet vier maar zeven jaren waren verstreken:

- Van alle titels was er een Gewijzigd Ontwerp, zij het dat de concepten voor de titels 5.3, 5.7 en 5.8 door Beekhuis nog niet als definitief werden beschouwd.

- De titels 5.3 en 5.7 moesten het zonder M.v.A. stellen, en ten aanzien van titel 5.8 bestonden er slechts korte toelichtende notities.

- Beekhuis had zijn plan om op dezelfde wijze als bij Boek 3 was gebeurd, deskundigen uit de praktijk te raadplegen, nog slechts zeer ten dele volvoerd. $\mathrm{Na}$ het vertrek van Franken had hij alleen met de ontwerper van Boek 8, Schadee, gecorrespondeerd over titel 5.2 alsmede met de VNG. Verder had Beekhuis in maart 1971, kort voordat hij zijn concepten aanbood, contact gehad met notaris Treurniet over de titels 5.7 en 5.8 .

- Het Gewijzigd Ontwerp moest grotendeels nog worden getoetst aan de Boeken 3 en 6. Verder was in het Gewijzigd ontwerp een aantal bepalingen toegevoegd - onge-

70. Wat de Regeringscommissaris tussen 1969 en 1971 precies deed, laat zich niet meer achterhalen. Het archief bevat geen enkel stuk uit deze periode en zelfs van de gebruikelijke verantwoordingen aan de Minister wordt men niets wijzer. Het lijkt erop alsof Justitie Beekhuis gehee] uit het oog had verloren. Kennelijk hield dat daarmee verband dat alle inspanningen van het Departement gericht waren op het binnenhalen van Boek 4, de invoering van de Boeken 1 en 2 en het voltooien van het werk aan de Memorie van Antwoord voor Boek 3. 
reeds met mr. Beekhuis besproken, waarbij vrijwel steeds overeenstemming werd bereikt. De uitwerking van de definitieve teksten geschiedt in overleg met mr. Beekhuis in het algemeen door ons." Feitelijk betekende dit dat alles wat Beekhuis had gedaan, op het Departement weer helemaal werd veranderd. Ter illustratie: de concept-M.v.A. voor titel 5.6 (Erfdienstbaarheden), eind 1968 gevorderd tot omstreeks vijftig bladzijden, zou in het G.O. nog slechts tweeëntwintig bladzijden bedragen, een reductie van meer dan vijftig procent.

Begin oktober was het werk zover gevorderd dat het overleg met de praktijk kon beginnen. Uit de nota aan Van Agt: "Wij streven ernaar vóór 1 januari 1972 gereed te zijn, iets wat wij overigens niet geheel in de hand hebben, omdat op een aantal punten nog met andere Departementen en met deskundigen moet worden overlegd. Met name is van belang dat over daarvoor in aanmerking komende titels het notariaat wordt geraadpleegd. Dit geschiedt op overeenkomstige wijze als bij Boek 3 is gebeurd: ieder van deze titels wordt aan een vertegenwoordiger van het notariaat die in het bijzonder in de materie van deze titel thuis is, voorgelegd en met hem besproken."

Voor titel 5.1 was de gesprekspartner de VNG, voor 5.2 de VNG en het Ministerie van CRM, en voor titel 5.3 Financiën en Waterstaat. Met betrekking tot de toetsing van de titels $5.4,5.5$ en 5.6 werd een beroep gedaan op notaris J. Th. Smalbraak, voor de resterende titels 5.7 en 5.8 werden, naast de VNG, de notarissen W.B. Plantenga en W.C. Treurniet ingeschakeld. Beiden hadden in 1957 voor de Broederschap van Candidaat-notarissen een preadvies geschreven over de Erfpacht en erfpachtsvoorwaarden, waren in het Voorlopig Verslag uitbundig geciteerd en kregen nu loon naar werken. Naast Beekhuis was ook Snijders steeds bij deze besprekingen aanwezig.

Omstreeks mei 1972 waren de meeste besprekingen, waarvoor meestal niet meer dan één bijeenkomst nodig bleek, afgerond en verschenen de eerste titels in drukproef. Een uitzondering vormde titel 5.2 (eigendom van roerende zaken), waarvan het overleg maar niet opschoot en waarvan in februari, april en juni 1972 nog nieuwe concepten voor de tekst en toelichting zouden verschijnen. Pas in augustus 1972 zou van deze titel de eerste drukproef verschijnen. Beekhuis: "Eén van de punten die de meeste moeilijkheden opleverden, waren de verloren zaken, want daarbij hebben we niet alleen met Justitie te maken gehad, maar ook met andere Departementen. Dat schoot maar niet op."

En de coördinatie? Die stelde uiteindelijk minder voor dan Beekhuis en Franken altijd hadden aangenomen. Met betrekking tot Boek 3 behoefde alleen titel 5.7 aan titel 3.8 te worden aangepast. Meer wijzigingen waren noodzakelijk in verband met Boek 6, met name de synchronisatie tussen de regeling van titel 5.6 en de kwalitatieve verplichtingen van artikel 6.5.3.4. In het bijzonder zij gewezen op de regeling van de imprèvision (5.6.8-8b), die moest worden afgestemd op de artikelen 6.5.3.11 en 12 (onvoorziene omstandigheden; wijziging kettingbedingen). Overigens was dat een vrij nutteloos werk, omdat het concept-G.O. voor Boek 6 op dat moment nog in een pril stadium verkeerde. 


\section{Besluit}

In het voorgaande is duidelijk geworden dat het ontbreken van elke vorm van bezinning op de doelstellingen van de hercodificatie het werk aan Boek 5 parten heeft gespeeld. Door een teveel aan perfectionisme en doordat het tweemanschap BeekhuisFranken niet bijzonder effectief bleek te werken, is de totstandkoming van Boek 5 met vele jaren vertraagd.

Dat enige mate van zelfbeperking wenselijk zou zijn geweest, blijkt uit het uiteindelijk gepubliceerde resultaat. Want hoewel het Gewijzigd Ontwerp voor Boek 5 enkele belangrijke wijzigingen bracht, was er ten opzichte van het Regeringsontwerp niet zoveel veranderd. Boek 5 R.O. kende geen grote gebreken. De wijzigingen (zie Bijlage II) werden óf ingegeven door maatschappelijke ontwikkelingen - het vervallen van het beklemrecht en de grondrente, de regeling van de gevonden voorwerpen -, óf doordat er meer tijd was voor studie en overdenking. De weg die Meijers al had aangegeven, kon daardoor tot het eind worden afgelopen. Voorbeelden daarvan zijn de verruiming van de ontstaansvereisten van de erfdienstbaarheden, de erfpacht en de opstal.

Een tweede gevolgtrekking is dat veel afhangt van de ontwerper. In dit opzicht herinner ik nogmaals aan de figuur van Meijers, die Boek 5 met de Staatscommissie in twaalf vergaderingen doorsprak, de daarin aanwezige energie kennelijk kon transformeren in een voor hem bruikbare stroom. Nog belangrijker is dat hij blijkbaar direct de juiste toon te pakken had. Ontactische opmerkingen kwamen niet voor, over een gebrek aan soberheid in formulering en uitvoering kon onmogelijk worden geklaagd. Iets dergelijks geldt ook voor Snijders, die Boek 5, omgewerkt en wel, in iets meer dan een jaar door de praktijk aanvaard wist te krijgen. Zoiets lukt alleen bij iemand die kennis en inzicht aan een grote mate van onverzettelijkheid paart.

Een laatste les is dat eenmanswerk - indien mogelijk - op het gebied van de wetgeving verre te preferen is boven commissoriale arbeid, tenzij men elkaars grenzen kent en respecteert. Er kan slechts één kapitein op een schip zijn. Dat komt de duidelijkheid en beknoptheid van het afgeleverde werk ten goede, is bevorderlijk voor het tempo en maakt de coördinatie tot een kinderspel: je hebt alleen jezelf om mee te overleggen.

\section{Het werk aan Boek 6}

\section{A. De voorbereiding van het Voorlopig Verslag: kantje boord}

\section{Verwachtingen}

Het Regeringsontwerp voor Boek 6, dat door Minister Scholten op 8 augustus 1964, kort na het overlijden van Drion was ingediend om daarmee duidelijk te maken dat het werk aan het nieuwe B.W. onverminderd doorgang vond, zou pas in het najaar van 1965, na de afhandeling van Boek 4, door de Tweede Kamer in behandeling wor- 
den genomen. ${ }^{72}$ De omstandigheid dat de Memorie van Antwoord over Boek 4 door Minister Beerman indertijd kort voor de verkiezingen was ingediend, de oppositie van de beide Broederschappen tegen het nieuwe erfrecht en de kabinetscrisis die daar begin 1965 nog eens tussendoor kwam, maakten dat op het schema dat in 1957 nog voor redelijk werd gehouden, inmiddels een achterstand van vier jaar was ontstaan.

Ter voorbereiding van het Voorlopig Verslag Boek over 6 werd een beroep gedaan op de diensten van mr. C.H.M. Jansen, een rechterlijk ambtenaar in opleiding, die begin 1966 door de Kamer voor dit doel werd aangetrokken. Mr. Gerhard Verburg, die de vaste Commissie gedurende meer dan elf jaar als bijzondere griffier had bijgestaan en er ongetwijfeld veel toe had bijgedragen dat Boek 4 zonder ernstige moeilijkheden de Kamer was gepasseerd, had namelijk de wens te kennen gegeven met dit werk te willen stoppen; hij kon het Kamerwerk niet langer combineren met zijn drukke advocatenpraktijk. Voor het werk aan de invoeringswet Boek 1 deed de Kamer een beroep op mr. P. Neleman, wetenschappelijk medewerker in Leiden, die na de afhandeling van Boek 1 zou overstappen naar het Departement.

Toen Jansen in januari 1966 met zijn werk begon, bestond op het Ministerie de hoop dat het Voorlopig Verslag nog in de loop van dat jaar zou kunnen worden uitgebracht. Dat was ook bijzonder gewenst, omdat Regeringscommissaris Langemeijer, die naast Boek 3 ook Boek 6 in zijn portefeuille had, ernaar streefde het werk aan M.v.A. en G.O. van Boek 3 ultimo 1966 te beëindigen. Een tijdige verschijning van het Voorlopig Verslag over Boek 6 was tevens van belang voor de verdere behandeling van de Boeken 3 en 5, want zolang het Voorlopig Verslag over Boek 6 niet was verschenen zou de Kamer geen tijd hebben zich met deze ontwerpen bezig te houden. Om deze reden had Minister Samkalden al op 5 oktober 1965, nog vó́rdat de openbare behandeling van Boek 4 was afgesloten, de verwachting uitgesproken dat de Memories van Antwoord van de Boeken 3 en 5 tegen het eind van 1966 de Kamer zouden bereiken, ofschoon de vooruitzichten met betrekking tot Boek 5 toen al minder gunstig waren. ${ }^{73}$

Ook toen duidelijk werd dat de vorderingen van Beekhuis en Langemeijer allesbehalve naar wens verliepen en de urgentie van een voortvarende verschijning van het Voorlopig Verslag Boek 6 allengs minder werd, liet het Ministerie geen mogelijkheid onbenut om tijdens de jaarlijkse begrotingsbehandelingen aan te dringen op een vlotte afhandeling door de Tweede Kamer. Bij de vaste Commissie zou door het uitblijven van de Boeken 3 en 5 immers de gedachte kunnen postvatten dat het Departement niet meer geloofde in de wenselijkheid van een algehele herziening. Zo werd in de toelichting bij de begroting voor 1967 opgemerkt: "Gewerkt wordt nu van de zijde van de Regering aan de Memories van Antwoord aan de Tweede Kamer betreffende

72. Aldus verklaarde het Tweede Kamerlid Van den Tempel op 22 september 1965, handelingen Tweede Kamer 1965-1966, p. 26: "Boek 6 zal dit najaar door de vaste Commissie in behandeling worden genomen."

73. Handelingen Tweede Kamer 1965-1966, p. 104: "Ik kan u mededelen te verwachten, dat de beide Memories van Antwoord (Boek 3 en Boek 5) u in het kalenderjaar 1966 zullen bereiken." Van Ewijk schreef naar aanleiding daarvan op 12 oktober 1965 aan Beekhuis: "De Minister heeft (.) medegedeeld te verwachten dat de beide memories aan het eind van het jaar 1966 de Kamer zullen bereiken. Deze mededeling was nodig ter motivering waarom het zozeer gewenst is dat de Kamercommissie haar Voorlopig Verslag over Boek 6 vóór eind 1966 uitbrengt." 
de Boeken 3 en 5 (..). De Commissie voor Justitie heeft het Voorlopig Verslag over Boek $6(.$.$) in voorbereiding. Wanneer het door wederzijdse inspanning gelukt deze$ drie parlementaire stukken omstreeks de jaarwisseling te laten verschijnen, zal (..) een grote stap voorwaarts zijn gedaan. ${ }^{74}$ Een jaar later viel te lezen: "Over Boek 6 is de Commissie aan het woord om Voorlopig Verslag uit te brengen. ${ }^{175}$

Verder contact was er niet, omdat alle ontwerpen op het Departement in behandeling waren, met uitzondering van Boek 6. Illustratief voor dit gebrek aan contact was de toelichting die Van Ewijk schreef bij de stand van zaken in 1966: "Van de voorbereiding van het Voorlopig Verslag weet ik niet meer dan dat de vaste Commissie in januari 1966 de raio $\mathrm{mr}$. Jansen als griffier heeft aangetrokken en dat deze over een belangrijk gedeelte uitvoerige nota's (volgens $\mathrm{mr}$. Schepel van goede kwaliteit) heeft opgesteld. Of de Commissie al eens over Boek 6 vergaderd heeft, weet ik niet. (..) Wanneer Langemeijer aan Boek 6 kan beginnen, valt dus, voor zover ik weet, nog in het geheel niet te zeggen." ${ }^{176}$ Dezelfde, een half jaar later: "De griffier ad hoc mr. Jansen is vermoedelijk nog niet klaar met zijn nota voor de Commissie voor Justitie ter voorbereiding van haar beraadslagingen tot vaststelling van haar Voorlopig Verslag. "77

De enige keer dat de Minister en de vaste Commissie in deze periode bij elkaar kwamen, was op 19 oktober 1967. Minister C.H.F. Polak, die op 5 april 1967 in functie was getreden, bleef toen echter in het vage over de vooruitzichten van het werk aan het nieuwe B.W., terwijl de vaste Commissie niet werkelijk aandrong. Een uitzondering vormde mevrouw Goudsmit, die, kennelijk naar analogie van Pitlo ${ }^{78}$, de vrees uitsprak dat het nieuwe B.W. in de "valkuil" van Boek 6 zou vallen. ${ }^{79}$

\section{De begrotingsbehandeling 1968}

Groot was daarom de onsteltenis, toen de voorzitter van de vaste Commissie voor Justitie, Geertsema, op 14 december 1967 tijdens de begrotingsbehandeling voor 1968 onthulde dat de Commissie aan het werk ten behoeve van Boek 6 R.O. volledig ten onder dreigde te gaan en zelfs nog niet in de gelegenheid was geweest over Boek 6 te vergaderen:

"Het nieuwe B.W. vergt (..) van de vaste Commissie voor Justitie vrijwel het onmogelijke. Ik denk nu alleen even aan Boek 6 B.W., het algemene deel van het verbintenissenrecht, het enige boek, waarbij op dit moment de Tweede Kamer aan

74. Zitting Tweede Kamer 1966-1967, nr 8800, stuk nr 2, p. 1.

75. Zitting Tweede Kamer 1967-1968, nr 9300, stuk nr 2, p. 1.

76. Nota van 13 oktober 1966.

77. Nota van 12 april 1967. Op 30 juli 1967 schreef Van Ewijk aan Langemeijer: "Het Voorlopig Verslag van de Commissie is, vrees ik, niet te verwachten voor eind 1968 , veel later dan Scholten, Frits en ik dachten en je voorspelden toen je tevens voor Boek 6 werd gevraagd. Ook de voltooiing van de behandeling van Boek 6 zal dus enige jaren langer vergen dan wij verwachtten."

78. A. Pitlo, Verdedig Themis, Haarlem 1964, p. 16: "Met het zesde Boek van het Ontwerp (..) heeft na een voorbereiding van zeven jaar het Driemanschap zijn gemis aan wetgevend talent bewezen. Het heeft met zorg een labyrinth gebouwd - waarin zich geen Ariadne bevindt om de draad te bieden."

79. Handelingen Tweede Kamer 1967-1968, p. c. 8. 
het woord is. De medewerker van de vaste Commissie, die voor ons de literatuur bij elkaar zoekt en bewerkt, begint zijn verslag met de mededeling: 'Over het ontwerp voor Boek 6 zijn nogal wat kritische opmerkingen gemaakt'. Dat is bepaald een bijzonder eufemistische terminologie. Immers, het verslag van deze medewerker, die nog slechts gevorderd is tot de eerste twee titels van de vijf, beslaat al meer dan 600 bladzijden. Men zou geneigd zijn te zeggen: Het is bijna onbegonnen werk voor de vaste Commissie. ${ }^{80}$

Met die conclusie was Minister Polak - "een ogenblik sloeg mij de schrik om het hart" - het roerend eens. Weliswaar sprak hij in zijn antwoord aan Geertsema nog de hoop uit dat het Voorlopig Verslag van een zodanige omvang zou zijn, dat het nog in de lopende parlementaire periode zou kunnen worden beantwoord ${ }^{81}$, maar eenmaal op het Departement teruggekeerd ging hij onmiddellijk tot actie over. Deze gang van zaken was namelijk niet slechts fnuikend voor de definitieve vormgeving van het nieuwe verbintenissenrecht, maar meer nog bedreigend voor de hercodificatie als geheel. De Kamer zou er licht toe kunnen besluiten aan andere, minder bewerkelijke onderwerpen de voorrang te geven. Eind 1967 waren belangrijke wetsontwerpen betreffende het ondernemingsrecht en het echtscheidingsrecht in aantocht, om nog maar te zwijgen over andere wetsontwerpen van Justitie. Hulp was dus dringend geboden.

\section{Vraagpunten "nieuwe stijl"}

Eén en ander leidde ertoe dat Van Ewijk op 4 januari 1968 contact zocht met oudgriffier Verburg, met de vraag hoe in zijn tijd de gang van zaken was bij de voorbereiding van een Voorlopig Verslag. Van Ewijk rapporteerde: "Die gang van zaken was aldus: de griffier stelde een nota op, waarin hij een analytische en kritische weergave van de verschenen literatuur opnam, voor zover deze hem belangrijk genoeg voorkwam, plus een aantal eigen kritische opmerkingen over het ontwerp. Deze nota was in geen enkel geval - ook niet die over Boek 3 - langer dan 150 à 160 gestencilde bladzijden. Zijns inziens was dit ook wel het maximum van hetgeen de leden der Commissie naast hun vele andere werk als Kamerlid kunnen verwerken. Het getal van 600 bladzijden van de nota van zijn opvolger, mr. Jansen, over een deel van Boek 6, vond $\mathrm{mr}$. Verburg dan ook exorbitant. (..) Vervolgens werden deze nota's, zowel in de tijd van mr. Ouds voorzitterschap als in de tijd dat mr. Van Rijckevorsel voorzitter was, in een reeks vergaderingen, gedurende enige maanden, in principe eens in de week (volgens vooraf vastgelegd schema) besproken in vergaderingen van de

80. Handelingen Tweede Kamer 1967-1968, p. 677. Eerder (p. 675) zei mevrouw Haars: "Toch vraag ik mij af, of wij op dit moment niet bezig zijn volgens een negentiende eeuwse methode aan een twintigste eeuws wetboek te werken, ten behoeve van de eenentwintigste eeuw. Het tempo is traag, perfectionistisch (..). Daarom vraag ik mij af of het geen tijd wordt, de methodiek, waarmede het Burgerlijk Wetboek wordt gemaakt, te veranderen." Naar haar mening zou het werk voor de Kamer moeten worden beperkt tot dat deel van de wetgeving, dat principiële vragen behandelt: "Wij zullen dan heus niet bang behoeven te zijn, dat wij dan niet voldoende werk meer overhouden betreffende dit wetboek."

81. Handelingen Tweede Kamer 1967-1968, p. 697. 
Commissie. Het resultaat was dat ongeveer $90 \%$ van het Voorlopig Verslag werd ontleend aan een selectie uit de nota van de griffier. " ${ }^{22}$

Voor Van Ewijk en Verburg was de conclusie duidelijk: "Uit het bovenstaande moge blijken dat de voorbereiding van het Voorlopig Verslag dreigt te verzanden, als de Kamercommissie zou moeten werken met een nota van 2 x 600 bladzijden." Volgens hen zou de oplossing moeten worden gezocht in een reductie van de nota tot ongeveer 100 bladzijden door middel van aanstreping van de belangrijkste passages, terwijl de griffier zich bij het neerschrijven van het tweede gedeelte zeer aanzienlijke beperkingen zou moeten opleggen. Daarbij zou hij niet moeten schromen "verantwoordelijkheid te nemen bij het selecteren van wat zijns inziens werkelijk zo belangrijk is, dat het aan de Commissie wordt voorgelegd." Tevens werd geadviseerd de Commissie een vergaderschema te laten opstellen, waarbij zij met vaart een keus zou doen uit de aangestreepte gedeelten. ${ }^{83}$

Op 24 januari ontving Minister Polak Commissievoorzitter Geertsema om over de problemen rond Boek 6 te spreken. Afgesproken werd onder andere dat het Departement de nota van Jansen ter inzage zou krijgen, zodat men zich een beeld zou kunnen vormen over de gerezen problemen. Van Ewijk werd er niet echt vrolijker van:

"Mr. Geertsema heeft mij een exemplaar gezonden van de nota van mr. Jansen, die gevorderd is tot bijna het eind van titel 3 en thans reeds 725 gestencilde bladzijden bevat. (..) Gaat mr. Jansen op dezelfde voet voort, dan schat ik de omvang van zijn gehele nota op 12 à 1300 bladzijden. Van de leden der Commissie kan onmogelijk worden verwacht dat zij ieder de gehele nota doorlezen, laat staan doorwerken. Commissievergaderingen die de gehele nota op de voet volgen zullen dus niet mogelijk zijn. ${ }^{84}$

82. Nota aan Minister Polak van 11 januari 1968. Van Rijckevorsel vult aan: "De voorlopige verslagen kwamen onder sterke begeleiding van de bijzondere griffiers tot stand; Glastra van Loon, Verburg en Neleman. Wij hadden zo elk onze onderwerpen waar je dan een stuk voor inleverde met de opmerking dat je het er graag in wilde hebben. De griffier maakte er dan é̂n geheel van, er werd meestal niet over gediscussieerd."

83. In de kantlijn schreef Van Ewijk: "Bezwaar tegen deze werkwijze, die uiteraard inhoudt dat lang niet alles uit de verschenen literatuur in het Voorlopig Verslag belandt, zien mr. Verburg noch ik. Immers, het gaat voor een zeer groot deel - bij Boek 6 voor het overgrote deel - over juridischtechnische kwesties en Regeringscommissaris en Departement zijn zich bewust van hun verantwoordelijkheid om ter gelegenheid van de Memorie van Antwoord het ontwerp zo goed mogelijk te doen worden; dus ook te verbeteren op punten waarop het Voorlopig Verslag geen kritiek heeft laten horen. Niet in het verslag overgenomen, al dan niet pas na het verslag verschenen literatuur valt dus geenszins onder de tafel. (..) Daarbij valt te bedenken dat de Memorie van Antwoord bepaald niet alleen maar dient om het boek zonder kleerscheuren door de voorbereiding van de openbare behandeling te halen, maar ook om, op gelijke voet met de toelichting van de ontwerper(s), na de invoering te dienen als voornaam - in de eerste jaren na de invoering het voornaamste - interpretatiemateriaal."

84. Nota van 8 februari 1968. Wel was Van Ewijk vol lof over de kwaliteit van de nota: "Zij bevat niet alleen een nagenoeg complete weergave van de verschenen, zeer omvangrijke literatuur over Boek 6, maar wel degelijk ook een kritische bespreking daarvan, alsmede vele eigen opmerkingen over tekst en toelichting van Boek 6. Dit alles in een heldere stijl en klaarblijkelijk weloverwogen. 
Het denkbeeld om Jansen de belangrijkste passages uit zijn nota te laten aanstrepen opdat deze hun weerslag zouden vinden in het Voorlopig Verslag, was naar de mening van Van Ewijk niet uitvoerbaar, gelet op het karakter van de nota. Wel zag hij iets in een denkbeeld dat in de vaste Commissie was geopperd, namelijk dat ieder van de zes vertegenwoordigde partijen het Voorlopig Verslag over een part voor haar rekening zou nemen. Maar, zo vervolgde Van Ewijk, "mr. Geertsema heeft op 24 januari terecht het voorbehoud gemaakt, dat er een aantal punten zullen blijken te zijn, die de Commissie in vergaderingen moet bespreken. Hij dacht daarbij vooral aan politieke punten." Van Ewijk vond dit bij nader inzien onuitvoerbaar: "Neemt men dit begrip in een, gebruikelijke, enge zin, dan zijn zij uitermate schaars. (..) In mijn aanvankelijke denkbeeld een aantal punten in de nota van een of twee kruisjes te voorzien, ten gerieve van mr. Geertsema, zie ik dan ook weinig meer."

Volgens Van Ewijk zou de oplossing daarom moeten worden gezocht in een soort vraagpuntenprocedure nieuwe stijl. Vragen die slechts van technisch-juridisch belang zijn, zouden in beginsel door het Departement zelf kunnen worden afgedaan, waarbij de nota van Jansen uiteraard goede diensten zou kunnen bewijzen.

Aldus geschiedde. Op 22 februari 1968 ontving de vaste Commissie van het Departement een lijst met dertig punten die in aanmerking zouden komen voor discussie in de Commissie ter voorbereiding van haar Voorlopig Verslag. ${ }^{85}$ In de toelichting schreef Van Ewijk namens de Minister dat op de lijst vrijwel alleen punten waren

84. $\rightarrow$

De nota is dus een voortreffelijk stuk werk, dat ons (Commissaris en Departement) zeer van pas zou komen bij de studie die straks tot de Memorie van Antwoord en een, ongetwijfeld op verscheidene punten van het oorspronkelijk afwijkend, gewijzigd ontwerp moet leiden."

85. Deze lijst had betrekking op de volgende onderwerpen: van afdeling/titel

6.1.1 de artikelen 2 (redelijkheid en billijkheid), 3 en 5 (natuurlijke verbintenissen)

6.1.6 de artikelen 19 en 20 (opschorting van nakoming) i.v.m. de artt. 6.5.4.2/5 (retentierecht)

6.1.7 de artikelen 9-13 (inbewaringstelling bij crediteursverzuim)

6.1.7 de artikelen 1-3 (toerekenen van omstandigheden aan de schuldenaar) en 6.1.10.3

6.1.8 artikel 9 (i.v.m. geldontwaarding), de artikelen $11-13$ i.v.m. de artt. 6.1.8.6, 7 en 10 (omzetting in vordering tot schadevergoeding tegen de achtergrond van verzuim en ingebrekestelling) en artikel 18 (matiging van bedongen boete of gefixeerde schadeloosstelling)

6.1 .9 de artikelen 1 en 11 (ideële schade), 7 (matiging), 10 (toekomstige schade) en 12 (overlijdensschade)

6.2. artikel 14 (contractsovername)

6.3 artikel 6 (aansprakelijkheid personen met een gebrek), de artikelen 8-10 (aanspr. voor ondergeschikten en ondernemingen), 12 lid 2 (wegen), 13-17 (produkten, zaken, stoffen motorrijtuigen) en 19 (rectificatie van onjuiste of onvolledige gegevens)

6.4.1 artikel 4 (vertegenwoordigingsbevoegdheid krachtens zaakwaarneming)

6.4.2 artikel 6 (vergoeding van kosten van de ontvanger bij onverschuldigde betaling) en 9 ("nemo auditur propiam turpidinem allegans")

6.4 .3 artikel 1 (ongerechtvaardigde verrijking)

6.5.1 de artikelen 2 en 3 (standaardregelingen)

6.5.2 de artikelen 11 en 12 (dwaling)

6.5.3 de artikelen 3,4 en 12 (kwalitatieve rechten en verplichtigen), 5 (derdenbeding) en 11 (imprévision)

6.5.4 de artikelen 6-13 (ontbinding wederkerige overeenkomst), 21 (ongedaanmaking van een uitgevoerde overeenkomst na wijziging evenwicht) en 22 (meer-partijenovereenkomst) 
opgenomen waarop het ontwerp materiële wijziging beoogde te brengen in het geldende recht, zoals dit zich onder leiding van de rechtspraak van de Hoge Raad had ontwikkeld: "Soms gaat het om een wijziging waartoe de rechtspraak nog niet is kunnen komen, omdat zij te zeer zou ingaan tegen de tekst van de geldende wet, soms beperkt de wijziging zich tot een doortrekken van een reeds in de rechtspraak in gang zijnde ontwikkeling."

$\mathrm{Na}$ een toelichting op de niet opgenomen punten - veelal omdat die nog aan de orde zouden komen bij de behandeling van de Boeken 3, 5 of 7 - kwam hij tot des poedels kern:

"De op de bijlage dezes terzijde gelaten talloze juridisch-technische punten die in de toelichting en in de over het ontwerp verschenen literatuur zijn besproken, zouden, wanneer de Commissie ernaar zou streven van deze alle in het Voorlopig Verslag te bespreken, een mer à boire vormen en een grondige studie van het ontwerp in alle details vergen. Zij zijn, naar enige steekproeven mij leerden, helder en grondig behandeld in de nota van mr. Jansen, die u mij ter inzage hebt gegeven, maar het lijkt me voor de Commissie niet wel doenlijk deze alinea voor alinea te bespreken. Ik vraag mij af of in het Voorlopig Verslag niet zou kunnen worden volstaan met een, uiteraard enigszins willekeurige selectie van een klein aantal juridisch-technische punten, wanneer in de inleiding van het Voorlopig Verslag steunende op de nota van mr. Jansen, met recht - zou worden gezegd dat van de gehele over het ontwerp in onderscheidene rechtsgeleerde tijdschriften verschenen literatuur van de zijde der Commissie met grote belangstelling is kennis genomen en dat de Commissie vertrouwt dat van de zijde van de Minister daaraan evenzeer alle aandacht zal worden gegeven bij de opstelling van de Memorie van Antwoord en het daarbij behorend gewijzigd ontwerp van wet, ook op de talrijke in de literatuur besproken punten die in het Voorlopig Verslag niet afzonderlijk worden ter sprake gebracht. Op deze wijze zou kunnen worden bereikt dat de Minister deze gehele literatuur als het ware als een bijlage bij het Voorlopig Verslag zal hebben te beschouwen, al kan van de Minister uiteraard niet worden gevergd dat hij in de Memorie van Antwoord aan elke in de literatuur gemaakte opmerking een min of meer uitvoerige passage wijdt."

Hiermee leek het lek boven water. Opdat iedereen van de afspraak tussen Minister en Kamer zou weten, wees Geertsema tijdens de begrotingsbehandeling van 1969 nogmaals op de grote problemen die de Commissie had met Boek 6, en deed hij de suggestie het werk te beperken in de hierboven aangegeven zin:

"Ik meen, dat het goed is, in alle duidelijkheid en eerlijkheid te stellen, dat deze Kamer zich ten aanzien van het nieuwe B.W. voor een taak ziet gesteld, waarvoor zij in de eerste plaats nauwelijks is geëquipeerd en waarbij in de tweede plaats de geijkte wetgevingsprocedure volstrekt niet toepasbaar is. (..) Een Voorlopig Verslag volgens deze procedure zal honderden pagina's bevatten en voor iedereen volstrekt onleesbaar zijn. De Commissie, die tenslotte uit leden bestaat, die ook nog andere parlementaire arbeid moeten verrichten, zou daartoe ook niet in staat zijn. Het zal betekenen, dat het Voorlopig Verslag voor een zeer belangrijk gedeelte door haar medewerkers wordt opgesteld, en dat daarmee in feite toch 
onnutte arbeid wordt verricht, aangezien de Kamer erop mag vertrouwen, dat de meeste punten die in zo'n Voorlopig Verslag aan de orde worden gesteld, ook zonder dat door het Departement nauwgezet worden bekeken. (..) Dit betekent, dat de Commissie zich in haar Voorlopig Verslag voornamelijk zal moeten bepalen tot die hoofdzaken, die van werkelijk belang zijn. Wellicht zal het zelfs noodzakelijk blijken, dat daarover via door de Minister aan de Kamer voorgelegde vraagpunten een uitspraak wordt gedaan alvorens een gewijzigd ontwerp van wet wordt aangeboden. ${ }^{186}$

Minister Polak verklaarde zich uiteraard van harte akkoord: "Ik heb alle begrip voor de problemen die het Voorlopig Verslag ten aanzien van Boek 6 voor de vaste Commissie oproept. Het lijkt mij een verstandige suggestie, dat de Commissie zich hierbij beperkt tot het stellen van vragen van politieke aard en technische details buiten beschouwing laat. ${ }^{87}$

\section{1971: Eerste deel Voorlopig Verslag gepubliceerd}

Deze werkafspraak leidde er inderdaad toe dat het werk aan Boek 6 weer een zekere vaart kreeg. Uit een vergelijking tussen de lijst met vraagpunten en het Voorlopig Verslag (eerste stuk) blijkt dat Commissie en griffier zich strict aan de gemaakte afspraak hielden. Alle punten die door de Minister waren voorgesteld werden in het Voorlopig Verslag behandeld, bij slechts een beperkt aantal artikelen werden een paar technisch-juridische kanttekeningen geplaatst.

Maar ondanks dat vrijwel wekelijks werd vergaderd en voor bijzondere onderwerpen afzonderlijke commissies werden ingesteld, zou het toch nog tot 15 april 1971 duren alvorens het Voorlopig Verslag over de eerste van het vijf titels tellende Boek 6 kon worden vastgesteld. Dat was twee jaar later dan Geertsema, Polak en Van Ewijk ten aanzien van het gehele verslag voor Boek 6 voor wenselijk hadden gehouden.

Het is verleidelijk de oorzaak voor deze moeizame gang van zaken geheel en al bij de Kamer te leggen. De verwachting immers, dat de Kamer zich omstreeks einde 1966 zou kunnen uitspreken over de inhoud van Boek 6, was niet onrealistisch, aangezien de vaste Commissie tot dan toe vrijwel ieder jaar een belangrijke bijdrage had geleverd op het terrein van het nieuwe B.W., hetzij door het produceren van een schriftelijk stuk, hetzij door het afronden van een mondeling gedeelte. ${ }^{88}$

86. Handelingen Tweede Kamer 1968-1969, p. 1249. De leden Van den Bergh en Wttewaall van Stoetwegen sloten zich "van harte" aan bij dit betoog.

87. Handelingen Tweede Kamer 1968-1969, p. 1269.

88. Het volgende staatje illustreert dat:

1955 voorlopig verslag Inleidende titel

1956/57 voorlopig verslag Boek 1

1957 afhandeling Boek 1 en voorlopig verslag Boek 2

1958 voorlopig verslag Boek 3

1959 voorlopig verslag Boek 4

1960 afhandeling Boek 2

1961 voorlopig verslag Boek 5

1965 afhandeling Boek 4 (de m.v.a. was eind 1963 verschenen) 
Wél was er dit verschil, dat de materie van Boek 6 qua inhoud en formulering belangrijk gecompliceerder was dan die van de andere Boeken, dat het ontwerp kennelijk onvoldragen was en dat er inmiddels een vloed aan kritische literatuur over was verschenen. Dorhout Mees bijvoorbeeld schreef dat hij niet dan na dagenlange studie had begrepen wat het Driemanschap met een enkel artikel bedoelde, zijn Amsterdamse ambtgenoot De Gaay Fortman vroeg zich bekommerd af: "Is mijn denkraam wel groot genoeg om dit alles te bevatten?" Met betrekking tot de Boeken 3, 4 en 5 R.O. waren er tot op het moment dat de Kamer zich aan de bestudering van deze ontwerpen zette, ongeveer twintig artikelen en commentaren verschenen, voor Boek 6 alléén bedroeg dit cijfer in 1966 al meer dan het drievoudige. ${ }^{89}$

Voor de Kamer golden deze bezwaren uiteraard in nog sterkere mate. Diepenhorst sprak in 1963: "Het zesde Boek is in elk geval nagenoeg uitsluitend voor geleerden bestemd. Simpele rechters zullen er niet zoveel mee beginnen en eenvoudige Kamerleden wandelen hier nagenoeg geheel in het duister. Wordt de zaak niet te diep opgehaald?"90 Zeelenberg profeteerde: "Duidelijk is, dat hier een uitzonderlijk kostbaar werkstuk voor ons ligt, maar ook, dat er gaven van een groot man en van een groot Minister vereist zijn om dit werk in het Staatsblad te brengen." ${ }^{91}$ Bovendien was de interesse voor het werk aan het nieuwe B.W. na de problemen rond de totstandkoming van Boek 6 O.M. en de crisis ten aanzien van Boek 4 er niet groter op geworden. Illustratief is een al eerder aangehaalde uitlating van het Tweede Kamerlid Van Schaik, die in 1967 verklaarde: "Het komt mij voor dat er tal van hoogst urgente zaken zijn: vennootschapsrecht, ondernemingsrecht - nationaal en internationaal - onteigeningsrecht, versnelde proceduregang. Deze zaken hebben, dacht ik, veel hogere prioriteit dan het B.W. Het Nederlandse volk zal geen dag en nacht wakker liggen op grond van het feit, dat het B.W. een jaar vertraging oploopt." ${ }^{92}$ Feit is, dat het werk aan het Voorlopig Verslag over Boek 6 rond 19691970 een jaar werd stilgelegd in verband met de behandeling van het vennootschapsrecht.

$\mathrm{Al}$ met al is het dus niet zo verwonderlijk dat de voorbereiding van het Voorlopig Verslag Boek 6 vrijwel geheel aan de zorgen van de bijzonder griffier werd toevertrouwd. Die ontwikkeling tekende zich ook in breder verband af. De Die: "Ik herinner me, dat het eerste rommelige verslag dat ik onder ogen kreeg, het echtscheidingsrecht betrof. Dat was begin 1970. Daar was niet over gepraat." Onervarenheid, een perfectionistische inslag en - door een gebrek aan belangstelling van de zijde van de vaste Commissie - een maandenlang isolement, leidden ertoe dat Jansen uiteindelijk met een stuk naar buiten kwam waarin zoveel vragen werden opgeworpen, dat het

89. Bovendien waren er nogal wat bokken geschoten. Berucht is het artikel van Van Eikema Hommes in Themis 1965, p. 5-29 en 159-230, over de artikelen 6.3.1 e.v. waarbij de auteur in de eerste alinea al hopeloos in de fout ging en dat meer dan honderd bladzijden lang volhield. Een ander voorbeeld is Schoordijks frontale aanval op de subrogatieregeling in Rechtsgeleerd Magazijn Themis 1967. p. 147 e.v., die geheel langs de zaak heenging en om die reden ook niet werd aangehaald in de Memorie van Antwoord.

90. Handelingen Eerste Kamer 1963-1964, p. 380.

91. Handelingen Eerste Kamer 1961-1962, p. 2137.

92. Handelingen Tweede Kamer 1967-1968, p. c. 8. 
voor de Kamer volstrekt onhanteerbaar was. Het was een stuk, dat ook door Snijders of Van Ewijk had kunnen worden geschreven - ter voorbereiding van de Memorie van Antwoord. Scheltema zei daarover: "Omdat de Kamercommissie indertijd uitdrukkelijk wél goed naar Boek 6 wilde kijken, maar tegelijkertijd besefte dat zij de materie niet goed kon overzien, nam zij iemand in dienst die het allemaal heel grondig en op fraaie wijze toetste, maar tegelijkertijd niet zozeer de mening van de Kamer verkondigde. Ik vond dat een ongelukkige greep, omdat daarmee het project als geheel sterk werd vertraagd." Ten Kate: "De Kamer stond toendertijd nog positief ten opzichte van het nieuwe B.W. Als er toen een andere stemming had geheerst, was deze kwestie een aangrijpingspunt geweest om te stoppen."

\section{Hoe verder?}

1971 was voor het nieuwe B.W. in verschillende opzichten een belangrijk jaar. Niet alleen trad op 1 januari het nieuwe personen- en familierecht in werking, maar bovendien zou Scheltema met ingang van 1 februari Van Ewijk opvolgen als hoofd van de afdeling NBW. Samen met Snijders, Neleman en Herrmann vormde hij een hecht en goed op elkaar ingewerkt team.

Scheltema zag het als zijn belangrijkste taak om een schema op te stellen voor de verdere afwerking van het project, om zodoende de organisatie te verbeteren en het tempo te verhogen: "Boek 6 ging ontzettend traag, gedeeltelijk ook omdat de Kamer er wel heel erg diep in dook. Ik was van mening dat we moesten oppassen dat we door de invloed van de Kamer of van onszelf te veel dingen steeds opnieuw ter discussie zouden stellen. Het tempo moest worden versneld. Ik heb toen uitgerekend hoe lang het zou duren als we in hetzelfde tempo zouden voortgaan; ik kwam ergens in 1995 uit."

De eerste maatregel die Scheltema nam, was het uitschrijven van een bijzondere vergadering van de Stafafdelingen Wetgeving van Justitie met enkele genodigden. Onderwerp was de verhouding nieuw Burgerlijk Wetboek en politiek. Uit deze bespreking, die plaatsvond op 26 april 1971, kwam naar voren dat er bij de aanwezigen geen twijfel bestond ten aanzien van de vraag of het werk aan het nieuwe B.W. nog langer kon worden gecombineerd met het tegelijkertijd doorvoeren van urgente partiële wijzigingen, zoals bijvoorbeeld ten aanzien van het erfrecht het geval was. Wél bestond er grote zorg over de werkkracht van de Kamer, mede omdat het werk in het kader van het nieuwe B.W. de komende jaren alleen maar zou toenemen en zij de grenzen van haar capaciteit had bereikt. ${ }^{93}$

Zo vroeg Minister Polak zich af hoe men zou kunnen bereiken "dat het parlement het vele werk aan het nieuwe B.W. op de meest efficiënte en snelle wijze kan verzetten", omdat het zijns inziens politiek geen haalbare zaak was al te veel tijd en aan-

93. Geurtsen, de nieuwe voorzitter van de vaste Commissie voor Justitie zei het eind 1970 (handelingen Tweede Kamer 1970-1971, p. 617) als volgt: "De vaste Commissie voor Justitie is er, dankzij het feit dat voor bijzondere onderwerpen afzonderlijke commissies werden ingesteld, met kunst en vliegwerk in geslaagd de produktie van het Departement ongeveer bij te houden. Ondanks het vrijwel wekelijks vergaderen zal van Boek 6 van het nieuwe Burgerlijk Wetboek niet meer dan het Voorlopig Verslag over de eerste titel uitgebracht kunnen worden. Intussen zijn de indiening van de invoeringswet van Boek 2, de Memorie van Antwoord voor Boek 3 en partiële invoering van Boek 4 al aangekondigd." 
dacht van de vaste Commissie voor Justitie voor het nieuwe B.W. te vragen: "Juist de Tweede Kamer kan een vertragende factor zijn." Regeringscommissaris Snijders wees er met nadruk op dat het niet verstandig zou zijn de Tweede Kamer ten aanzien van de Boeken 3 en 6 teveel onder druk te zetten, opdat de "gewone" wetgeving normaal doorgang zou kunnen vinden: het zou voor de hercodificatie gevaarlijk zijn als de Kamer zou kunnen zeggen dat een bepaald stuk wetgeving niet tot stand komt, omdat gewacht moet worden op het nieuwe B.W. Dat de totstandkoming van het nieuwe B.W. daardoor nog verder zou worden vertraagd, was niet anders: "Er bestaat wel degelijk een behoefte aan het nieuwe B.W., alleen, men zou kunnen zeggen, het tempo wordt mede door de aard van die behoefte bepaald."

Een suggestie van De Vries om terwille van de overbelasting van de Kamer de stof te beperken tot de Boeken 3-6, werd afgewezen, omdat de bijzondere overeenkomsten geënt moesten worden op Boek 6 en bovendien het gevaar zou bestaan dat de grondidee van de hercodificatie zou worden achterhaald. ${ }^{94}$ De gedachte aan uitbreiding van het aantal voortreinen bood volgens de vergadering evenmin soulaas, omdat de wet dan op eenzelfde punt tweemaal zou moeten worden gewijzigd, waardoor de werkdruk van de Kamer alleen maar zou toenemen. Omdat uit de verdere discussie duidelijk werd dat bruikbare alternatieven niet voorhanden waren en de vaste Commissie in haar Voorlopig Verslag over titel 1 van Boek 6 blijk had gegeven van een beperkte taakopvatting ten aanzien van technisch-juridische punten, was de slotsom van de bespreking dat zo mogelijk op die wijze moest worden voortgewerkt. Verder werd besloten dat het nuttig zou zijn na de verkiezingen contact op te nemen met de vaste Commissie om met elkaar een zodanig werkschema te vinden, dat de Kamer op een zeker ogenblik toch aan de behandeling van de Boeken 3 en 6 zou toekomen.

Minister Polak vatte in zijn slotwoord de teneur van de bespreking als volgt samen: "Ik verwacht dat de hercodificatie wel zal slagen, waarbij het nu niet zo belangrijk is of dit een paar jaren korter of langer zal vergen. In ieder geval heb ik niet de indruk, dat bij de de politieke partijen een sterke neiging bestaat om nu maar op te houden met het werk aan het nieuwe B.W."

\section{De nota "Algemeen beleid Nieuw B.W." gepresenteerd}

De Kamerverkiezingen van 1971 brachten een nieuw gezicht op Justitie: op 1 juli 1971 zou Minister Polak worden opgevolgd door mr. A.A.M. van Agt. Een uitstekende gelegenheid om nieuw beleid te ontvouwen, mede omdat ook de Kamer een gedaanteverwisseling had ondergaan.

Op 27 augustus 1971 presenteerde Scheltema aan zijn voormalige collega en kamergenoot Van Agt een nota "Algemeen beleid Nieuw B.W.", die zijns inziens als

94. De Vries (Hoofd Stafafdeling Wetgeving Privaatrecht) motiveerde zijn suggestie onder andere als volgt: "Een hercodificatie van een dergelijke omvang is nog nimmer tot stand gekomen, althans niet in een land met rechtseenheid en een democratisch bestel. (..) Het aantal Kamerleden, dat zich met het nieuwe B.W. bezighoudt is beperkt en heeft bovendien talloze andere activiteiten. En men kan toch ook niet verwachten, dat de Tweede Kamer dan maar niet teveel aandacht gaat schenken aan het nieuwe B.W. Daar komt nog bij dat kwantiteit en kwaliteit van de civilisten in de Tweede Kamer in verhouding tot de negentiende eeuw is gedaald." Voor een interview, zie NJB 1989, p. 589-596:

"Wie iets wil hervormen, moet niet teveel overhoop halen." 
uitgangspunt zou moeten dienen voor het komende beleid met betrekking tot het nieuwe B.W. In deze nota kwam hij tot de conclusie dat in beginsel het accent zou moeten worden gelegd op het voortvarend doorwerken aan de hercodifcatie: "Wanneer zonder voldoende grond wordt besloten tot partiële herziening van bepaalde onderwerpen, vertraagt dit het nieuwe B.W., waardoor de partiële herziening van andere delen weer wenselijker gaat worden, enz. Het gevaar van een vicieuze cirkel is dan niet geheel denkbeeldig."

Een ander hoofdpunt uit zijn betoog was, dat het geraden was op korte termijn contact te zoeken met de vaste Commissie, teneinde te komen tot een zekere programmering van de werkzaamheden, zowel bij de Regering als bij de Tweede Kamer. Scheltema stelde zich daarbij voor dat de vaste Commissie zich allereerst zou moeten buigen over de invoeringswet van Boek 2 (gedeeltelijk in 1970 al ingediend, met als enig politiek belangrijk punt de afschaffing van het preventieve toezicht op verenigingen), alsmede de herziening van de Appartementenwet, een voortrein op titel 5.10. Daarna zou de aandacht van de Commissie zich moeten concentreren op het uitbrengen van het tweede deel van het Voorlopig Verslag Boek 6. In zijn optiek zou de behandeling van Boek 6 dus voorrang moeten hebben boven de verdere behandeling van Boek 3, waarover de Memorie van Antwoord en het Gewijzigd Ontwerp in het voorjaar van 1971 waren ingediend, en het herziene Boek 5, dat naar verwachting in 1972 zou verschijnen. Een belangrijk argument daarbij was dat Snijders nog tot 1976 vrijgesteld zou zijn van het werk in de Hoge Raad en zich dus geheel kon inzetten voor het opstellen van de Memorie van Antwoord. ${ }^{95}$

Tenslotte ging Scheltema in op de vraag hoe zou kunnen worden bereikt dat de vaste Commissie het werk aan het Voorlopig Verslag over Boek 6 nog in het zittingsjaar 1971-1972 zou kunnen afronden, zonder dat haar invloed op de uiteindelijke inhoud wezenlijk zou verminderen. Zijn voorstellen kwamen erop neer dat de methode van werken, zoals die zich in 1968 ten aanzien van Boek 6 had ontwikkeld, moest worden aangescherpt door a. de lijst van vraagpunten opnieuw te bezien en $b$. na te gaan hoe de behandeling van de uitgekozen punten zo praktisch mogelijk zou kunnen gebeuren:

"Nu vaststaat dat het ontwerp nog moet worden gewijzigd in verband met hetgeen door de schrijvers naar voren is gebracht kan men zich afvragen of het voor de Kamercommissie wat de technische kant betreft niet aantrekkelijker is nu eerst de Memorie van Antwoord en het Gewijzigd Ontwerp af te wachten om te zien op welke punten de literatuur tot wijzigingen aanleiding heeft gegeven, zodat de Commissie zich niet geheel zelfstandig in alle geschriften behoeft te verdiepen. Na de Memorie van Antwoord zou in een mondeling overleg, dat dan vrij uitvoerig zou moeten zijn, het Gewijzigd Ontwerp besproken kunnen worden, waarbij de Commissie alle gelegenheid zal hebben haar standpunt kenbaar te maken, met

95. Een andere overweging was dat in Benelux-verband werd gewerkt aan een regeling van de nietnakoming van verbintenissen, zodat het gewenst was dat de Kamer zich tijdig zou uitspreken over titel 6.5, die voor dit onderwerp van groot belang was. Bovendien was het het streven om de voortrein van Boek 4 eind 1972 bij de Kamer in te dienen, zodat het ook om die reden voor de vaste Commissie prettig zou zijn wanneer het Voorlopig Verslag over Boek 6 gereed zou zijn. 
name ook ten aanzien van in de literatuur bepleitte, doch in het ontwerp niet overgenomen veranderingen."

In de visie van Scheltema zou hierbij een belangrijke rol voor de griffier zijn weggelegd:

"De invloed van de Commissie zou nog vergroot kunnen worden doordat niet alleen de nota van mr. Jansen bij de voorbereiding van de Memorie van Antwoord ter beschikking staat, maar mr. Jansen ook in de gelegenheid wordt gesteld opmerkingen over concepten voor Memorie en Gewijzigd Ontwerp te maken. Op die manier kan het maximale profijt worden getrokken van het werk dat in het kader van het Voorlopig Verslag is verricht; bovendien heeft deze werkwijze het grote voordeel dat de Commissie bij het voorbereiden van het mondeling overleg door haar griffier betreffende technische punten beter kan worden voorgelicht."

\section{Een vruchtbaar overleg}

Deze onorthodoxe voorstellen, die, hoewel gericht op versnelling van de parlementaire procedure, paradoxaal genoeg het democratisch gehalte van Boek 6 mogelijk zeer zouden bevorderen, vonden bij Minister Van Agt een gunstig onthaal. Het kwam er nu op aan een goede gelegenheid te vinden om contact op te nemen met de voorzitter van de vaste Kamercommissie.

Deze gelegenheid diende zich weldra aan. Op 29 september 1971, nadat bekend geworden was dat Geurtsen voorzitter van de vaste Kamercommissie bleef, nam deze contact op met het Departement met de mededeling dat hij graag een indruk zou krijgen van de voortgang op het Departement, opdat de Commissie haar werkzaamheden zou kunnen indelen. Een initiatief van de kant van Van Agt zou dus in goede aarde vallen. ${ }^{96}$ Eén en ander leidde ertoe dat op 10 november 1971 mondeling overleg plaatsvond tussen de Minister en de vaste Commissie omtrent de verdere procedure bij de behandeling van het nieuwe B.W. Leidraad daarbij was de door Scheltema opgestelde nota.

Uit de besluitenlijst die van dit overleg werd gemaakt, bleek dat Scheltema de problemen waarin de vaste Commissie verkeerde bijzonder goed had getaxeerd. Het besef dat het nog wel een jaar of tien zou kunnen duren voordat men Boek 6 eindelijk kon dichtslaan, spookte door de hoofden van de Commissieleden, het water stond hen

96. Eerder, bij diverse begrotingsbehandelingen, had de vaste Commissie ook al signalen afgegeven. Het betoog van Geertsema uit 1969, om de procedure te bespoedigen door middel van een Voorlopig Verslag op vraagpunten, zou volgens Tweede Kamerlid Van Den Bergh "verdere uitdieping vragen", terwijl freule Wttewaall van Stoetwegen bij die gelegenheid de hoop uitsprak dat de Kamer een modus zou vinden "om sneller voort te gaan dan tot nu toe het geval is geweest." (Handelingen Tweede Kamer 1968-1969, p. 1257 en 1263). In het begin van het eerste deel van het Voorlopig Verslag over Boek 6 stond vermeld: "De Commissie vertrouwt erop, dat haar verslag aanleiding zal kunnen zijn tot deskundig commentaar en dat hierover mondeling overleg met de Minister zal kunnen plaatsvinden, alvorens haar verslag over de volgende titels zal worden uitgebracht." 
aan de lippen. ${ }^{97}$ De voorstellen van Van Agt vonden dan ook algemeen bijval; de Commissie wilde zelfs nog verder gaan en bijvoorbeeld de mogelijkheid niet uitsluiten rechtstreeks te onderhandelen met Snijders, vóórdat het Voorlopig Verslag of Mondeling Overleg plaatsvond. Een uitvoerig citaat:

"Uit de discussie komt naar voren dat enerzijds de wens bestaat het werk aan het nieuwe B.W. en speciaal aan het 6 de Boek zo snel mogelijk af te ronden maar dat anderzijds een aantal prioriteiten op ander gebied daarop een remmende invloed hebben. (..) Ten aanzien van het 6 de Boek wordt afgesproken dat de Minister gaat werken aan zijn Memorie van Antwoord naar aanleiding van het thans verschenen Voorlopig Verslag en dat de Commissie gaat werken aan het nog komende Voorlopig Verslag. Eén en ander zal in onderling overleg plaatsvinden, waarbij mr. Jansen als bemiddelaar en contactman zal optreden. (..) Verder wordt afgesproken dat de Commissie bij haar desbetreffende werkzaamheden aan technische punten uit de vakliteratuur zoveel mogelijk zal voorbijgaan en zich tot de meer principiële punten zal beperken en dat mr. Jansen voor wat die technische punten betreft bij het werk aan de Memorie van Antwoord zal worden betrokken, welk één en ander tenslotte zal uitmonden in een - na het Voorlopig Verslag te houden - mondeling overleg over de dan nog bestaande meningsverschillen omtrent principiële èn technische punten."

Begin 1972 waren Commissie en Minister het over de te volgen procedure eens. Uit een nota van Scheltema van 11 januari 1972: "mr. Snijders en ik hebben verschillende besprekingen gehad, eerst alleen met de griffier, mr. Jansen en vervolgens één waar ook mr. Geurtsen aanwezig was. (..) De Commissie zal aan Boek 6 werken aan de hand van een lijst met punten, die in onderling overleg is opgesteld. De lijst is wat korter geworden dan de lijst die vroeger was opgesteld. Bovendien is op de lijst aangegeven ten aanzien van welke daarop voorkomende punten het bepaald gewenst is dat de Commissie in het Voorlopig Verslag een bepaald standpunt inneemt. De bedoeling is dat de Commissie zich dan ook op die punten concentreert en de andere punten minder diepgaand bestudeert. (..) Mr. Geurtsen opperde ook nog de mogelijkheid dat bij de besprekingen in de Commissie mr. Snijders aanwezig zou zijn."

Snijders kon dus met een gerust hart aan het werk gaan: Samen met Jansen zou hij er wel uitkomen. ${ }^{98}$

97. Zie ook handelingen Tweede Kamer 1971-1972, p. 559, waar mevrouw Haars aan de vooravond van het M.O. verklaarde: "Ik heb zojuist al bij interruptie gezegd, dat Boek 6 een zaak van ad calendas greacas is. Wij hebben vier jaar nodig gehad om het eerste deel van het Voorlopig Verslag gereed te krijgen, terwijl wij echt ons best hebben gedaan om het snel te doen. Het zal duidelijk zijn, dat wij er niet optimistisch over zijn, dat het nieuwe B.W. heel snel komt."

98. Zie ook handelingen Eerste Kamer 1972-1973, p. 185; 1973-1974, p. 1007. In antwoord op een vraag van zijn voorganger Polak verklaarde Minister van Agt dat in overleg met de vaste Commissie voor Justitie "enkele organisatorische maatregelen" waren genomen om een vlottere behandeling mogelijk te maken. Daarmee doelde de Minister op de toezending van de nota van Jansen aan het Departement en op de voorgenomen aanstelling van mevrouw Fischer als bijzonder griffier voor Boek 3. Fischer zou in april 1973 haar werkzaamheden beginnen. 


\section{Een nieuw incident}

Toen Scheltema medio 1971 zijn uitgangspunten voor nieuw beleid formuleerde, ging hij daarbij uit van de veronderstelling dat het tweede deel van het Voorlopig Verslag over Boek 6 in de tweede helft van 1972 zou kunnen worden gepubliceerd. Cruciaal daarbij was dat het Voorlopig Verslag over de Invoeringswet Boek 2, dat een nog hogere prioriteit had, nog in 1971 zou verschijnen. Dit verslag zou echter pas eind juni 1972 gereedkomen. Kort daarna ging de Kamer met reces, terwijl in het najaar de begrotingsbehandeling tussenbeide zou komen. Dit betekende dat het werk aan het Voorlopig Verslag over Boek 6 pas omstreeks april 1973 weer actueel werd, dat wil zeggen ná de afronding van het Mondeling Overleg over Boek 2.

Door deze ontwikkeling was het zorgvuldig uitgestippelde tijdschema in feite achterhaald. Immers, Boek 3 lag al weer twee jaar bij de Kamer, Boek 5 G.O. was in 1972 ingediend, voor Boek 4 stond een voortrein op het punt van vertrek, het groene Boek 8 (eerste stuk) was begin 1972 gepubliceerd en het voorontwerp voor de Boek 7 zou op 10 april 1973 aan de Minister worden aangeboden. De Commissie zag in 1973 een lawine van politiek weinig interessante wetsontwerpen op zich afkomen en moest bovendien nog door de zure appel van Boek 6 heen: griffier Jansen was inmiddels gevorderd tot bladzijde 1017, supplementen niet meegerekend.

Al snel pakten zich daarom nieuwe donkere wolken samen boven het nieuwe B.W. ${ }^{99}$ Op 14 november 1973 ontving Minister Van Agt een brief van het PPRKamerlid mr. E.C.M. Jurgens, waarin deze aankondigde onder de leden van de vaste Commissie van de Regeringspartijen een notitie te hebben verspreid met daarin de oproep het werk aan de hercodificatie te staken. ${ }^{100}$ Ook lag het in zijn bedoeling in december van dat jaar de achterban van PPR, PvdA en D'66 te raadplegen. De brief besloot met de uitnodiging aan Van Agt de kwestie in het voorjaar "en bistro" te bespreken - kennelijk voelde Jurgens zich niet zo zeker van zijn zaak.

Daarmee dreigde opnieuw een klein drama, want het werk van Snijders aan Boek 6 was inmiddels een eind gevorderd, de voltooiing daarvan was binnen handbereik.

Het heeft weinig zin de argumentatie van Jurgens op de voet te volgen, omdat het eigenlijke argument, namelijk dat de Kamer haar tijd wel nuttiger kon besteden, niet of nauwelijks ter sprake werd gebracht. ${ }^{101}$ Het merendeel van zijn opmerkingen was

99. Oud-Minister Polak had daar overigens al voor gewaarschuwd: "Zorgwekkend vind ik de situatie ten aanzien van het nieuwe B.W. De Tweede Kamer die toch al zo zwaar is belast, althans veel werk op zich laadt, ziet zich geplaatst voor een enorme taak op het ogenblik. (..) Het is wel een zeer zware taak voor het steeds kleinere aantal echte juristen dat de Tweede Kamer telt." (Handelingen Eerste Kamer 1972, p. 166 . Zie ook zijn bekende rede "Hulp voor de wetgever", NJB 1976, p. 909 e.v.; Handelingen Eerste Kamer 1973-1974, p. 9.)

100. Enkele dagen eerder, op 8 november 1973, had Jurgens ook al een oppositioneel geluid laten horen en betoogd dat de voortgang van het nieuwe B.W. niet de meest wenselijke was. Geurtsen antwoordde daarop: "Het is veeleer zaak dat de Kamer en de Kamercommissie het voorbeeld van het B.W. aan zich trekken dan dat zij het aan de Minister voorleggen. Het gebrek aan planmatigheid van behandeling is niet aan het Departement te wijten, maar meer aan de overvloed van verder kamerwerk." (Handelingen Tweede Kamer 1973-1974, p. 797).

101. Zie echter NJB 1993, p. 1381-1386. Jurgens schrijft daar: "Een kras voorbeeld van formalisering van het legaliteitsbeginsel tot vrijwel pure fictie is de vaststelling van het Burgerlijk Wetboek in 
dogmatisch-anti-nieuw B.W., duidelijk geïnspireerd op de ideeën van Pitlo. Zo wees Jurgens erop dat de hercodificatie de oorspronkelijke opzet van een technischjuridische herziening verre te buiten was gegaan, dat de eerste vijftig jaren na invoering grote rechtsonzekerheid zou bestaan, dat een nieuw B.W. een stap terug was in de pogingen tot unificatie en dat de tijd nog niet rijp was voor een algehele herziening in verband met de roerige tijden: "Velen stellen zich voor een niet al te verre toekomst een geheel andere maatschappij voor, een maatschappij waarin het kapitalisme geen overheersende rol zal spelen." ${ }^{102}$

Hoofdargument was dat het B.W. en het Wetboek van Koophandel volkomen aan de praktijk van het leven zouden voldoen, zoals zij in door partiële wetswijzigingen op essentiële onderdelen zouden zijn bijgewerkt: "Dat de oude tekst voldoet, blijkt uit het feit, dat de voorstanders van een hercodificatie als zij een bewijs willen leveren van de onhelderheid van de bestaande tekst, steeds met hetzelfde voorbeeld komen (art. 2014). De ontwerpen scheppen evenwel heel wat groter onduidelijkheid en daardoor onzekerheid. Hieraan kan niemand twijfelen, die zich de moeite getroost de ontwerp-teksten kritisch te bestuderen. "103

Mevrouw Fischer heeft de volgende lezing van het gebeurde:

"Ik ben even voor mijn pensionering werkzaam geweest voor de vaste Commissie voor Justitie. Dat was een mislukking van mijn kant, omdat ik er niet tegen kon dat die mensen helemaal geen belangstelling hadden voor het nieuwe B.W. Ik had het gevoel dat ik tegen de bierkaai vocht. Je maakte bijvoorbeeld een nota over een aspect van het nieuwe B.W. waaraan politieke punten zaten, zoals de aansprakelijkheid van kinderen; in de literatuur bestonden daarover verschillende meningen. Van de Commissie had echter niemand mijn nota gelezen, behalve Anneke Goudsmit, Geurtsen en Stapel, die fatsoenshalve de stukken doorkeken. Ik kon niet tegen die sfeer. Ze vonden het zonde van hun tijd.

Jurgens heeft toen ook in de vergadering gezegd dat het zonde van hun tijd was. Toen heeft men het werk volledig stilgelegd. (..) Het argument van Jurgens om te stoppen met het nieuwe B.W., omdat het weinig nut had, werd voor een belangrijk

101. $\rightarrow$

de laatste vier decennia. Naar grondwettelijk bevel moest die operatie geschieden bij de wet. De feitelijke aandacht van het gros der volksvertegenwoordigers voor deze, onmatig grote, wetgevende arbeid is vanzelfsprekend marginaal geweest. Codificeren van bestaande jurisprudentie en het verdergaand zuiver stellen van civielrechtelijke doctrine is voot juristen gefundenes Fressen, maar voor volksvertegenwoordigers - op een aantal punten na - weinig belangwekkend. De medewetgeving was dan ook marginaal. (Ik geef toe dat deze boutade mede is ingegeven door mijn overtuiging dat het NBW na de vaststelling van Boek 2 in 1974 een zeer lage prioriteit in het wetgevingsbeleid had moeten krijgen, ten gunste bijvoorbeeld van de algemene wet bestuursrecht)."

102. Wel was Jurgens zo voorzichtig te beklemtonen dat de "nieuwe orde" misschien pas over een eeuw zou worden bereikt, en dat de grondtrekken daarvan nog onbekend waren.

103. Eén blik op de lijst van wijzigingswetten van het B.W. had Jurgens er echter van kunnen overtuigen, dat juist het vermogensrecht, met zijn talloze leemten en gebreken, sinds 1838 vrijwel onberoerd was gebleven. En wat artikel 2014 B.W. betreft is niet de formulering van het artikel, maar de inhoud - overigens tot het laatste moment - omstreden geweest. 
deel ingegeven door het feit dat men zich ook geen moeite gaf om zich in de materie te verdiepen. Het ene argument beïnvloedde het andere. ${ }^{104}$

\section{De "Nota voortgang NBW"}

Van Agt ging snel tot actie over. In de eerste plaats werd dadelijk contact opgenomen met Langemeijer en Cohen Jehoram om de PvdA in het gareel te krijgen. Cohen Jehoram: "Het was in de tijd dat er een program-akkoord bestond tussen de PvdA, PPR en D'66. Toen zag Jurgens de kans schoon om met Anneke Goudsmit, die ook altijd al tamelijk vijandig had gestaan tegenover het nieuwe B.W. ${ }^{105}$, de PvdA onder druk te zetten. Men zag zich als PvdA opeens belaagd en riep daarop een aantal Kamerleden van PvdA, PPR en D'66 bij elkaar, met daarbij Dubbink, Langemeijer, Huib Drion en mijzelf. Ik zat toen in de Wiardi Beckmanstichting, met als specialisme het nieuwe B.W. Jurgens hield een felle rede, met als slotsom dat de PvdA als progressieve partij nu ook eens een progressief geluid moest laten horen ten opzichte van het nieuwe B.W. Ik ben fel van leer getrokken en heb elk argument, dat min of meer op Pitlo viel terug te voeren, ontzenuwd."

In de tweede plaats werd op het Departement door Snijders een "Nota Voortgang NBW' voorbereid, opdat de vaste Commissie, die op 23 januari 1974 zou bijeenkomen om deze kwestie te bespreken, de visie van de Minister ten aanzien van deze aangelegenheid zou kennen. In deze nota werd in de eerste plaats benadrukt dat het grootste deel van het werk aan de vaststellingswetten al achter de rug was - dat nog een omvangrijke invoeringswetgeving vereist was, werd aan de wijsheid van de Kamer zelf overgelaten. Verder werden de nadelen van het oude B.W. en dus van stopzetting van het werk breed uitgemeten. Genoemd werden het verouderd karakter van onze wetboeken, de nadelen van rechtsvorming door de rechter (gebrek aan democratische controle, grilligheid rechtsvorming en gemis aan overleg met de praktijk) en het feit dat de verouderde wet voor de rechter vaak een obstakel blijkt om tot een redelijke oplossing te komen. Dit alles toegelicht met talrijke voorbeelden uit jurisprudentie en literatuur. Tenslotte werd uitgebreid gemotiveerd waarom partiële herzieningen in veel gevallen niet toereikend zouden zijn. Gewezen werd onder andere op inpassingsmoeilijkheden in verband met de terminologie en systematiek van het oude vermogensrecht, het aantal herzieningen dat nodig zou zijn om de wetboeken op de hoogte van de tijd te krijgen, het belang van het nieuwe B.W. voor de unificatie van het recht en het feit dat het altijd aan politieke wil had ontbroken het burgerlijk recht door middel van partiële herzieningen bij de tijd te houden.

104. Vergelijk ook B. de Gaay Fortman, Parlement en hercodificatie, WPNR 5617 (1981): "In de periode 1973-1975 ijverde mijn collega Jurgens voor stopzetting van deze sisyphusarbeid. Het parlement kon zijn krachten beter gebruiken, zo meende hij en de praktijk zat er ook niet op te wachten."

105. Zie daarvoor Parl. Gesch. Boek 1 (invoering), p. 1011, waar Goudsmit bij de behandeling van Boek 1 het voorstel deed onder juristen een enquête te houden over het nieuwe B.W., een suggestie die door Minister Polak met een woordspeling naar de groep-Aarden als "ontaard" werd bestempeld. Later (handelingen Tweede Kamer 1967-1968, p. c. 8) zou zij overigens verklaren dat zij niet afwijzend stond tegenover het nieuwe B.W., maar dat zij bezwaren had tegen het perfectionisme waarmee werd gewerkt. 
Een delicaat punt was de wijze waarop het verzoek om voortzetting van de behandeling van Boek 6 moest worden ingekleed. Zou de Minister, om de Kamer zoveel mogelijk in haar verlangen naar verlichting tegemoet te komen, een min of meer blanco volmacht vragen, dan zou de Commissie zich wellicht in haar taak van mede-wetgever tekort gedaan voelen. Dat was ook één van de punten van wrevel van Jurgens: "In de aanvang heeft men van ontwerpers-zijde de loftrompet gestoken over de deskundigheid, die het parlement terzake betoonde. Dit doet niet ernstig aan, want deze materie, zelfs voor uitstekend geschoolde juristen moeilijk te beheersen, is voor de overgrote meerderheid der parlementariërs geheimtaal. Het parlement hoort aan en veronderstelt dat als de Regering het wenst en zulke geleerde professoren het hebben samengesteld en het persoonlijk in de Kamer komen verdedigen, het wel in orde zal zijn. ${ }^{106}$

Zou de Minister daarentegen de wenselijkheid van de invloed van de Commissie voorop blijven stellen, dan was de kans dat zij het werk definitief zou staken nóg groter. De slotparagraaf van de nota werd dus een uiterst subtiel stuk en bevatte niet meer dan een opening naar de hoofdschotel van de discussie, opdat de Commisie de eer aan zichzelf kon houden. Het voorstel van de Minister kwam erop neer dat de Commissie bij de rest van het Voorlopig Verslag eventueel zou kunnen volstaan met een verwijzing naar literatuur, waarop de Minister in het bijzonder zou kunnen ingaan. In extenso:

"In beginsel is het wenselijk dat het parlement zoveel als doenlijk is, op de ontwerpen haar invloed blijft uitoefenen. Begrijpelijk is evenwel dat in het kader van de afweging tussen haar verschillende taken de Commissie gemeend heeft zich in haar werk aan Boek 6 te moeten beperken. Verwezen moge worden naar de lijst van belangrijke punten die reeds voor het eerste deel van het Voorlopig Verslag als richtlijn heeft gediend. Inderdaad is verdedigbaar dat bij het vermogensrecht van de zijde van het parlement in het algemeen met minder aandacht kan worden volstaan dan is gegeven aan de materie van personen- en familierecht, erfrecht en het recht van rechtspersonen als verenigingen en vennootschappen, waarvoor ook buiten de juristenwereld grote aandacht heeft bestaan.

Zou het voor de Commissie een te zware belasting betekenen om ook bij het resterende deel van het Voorlopig Verslag de vermelde richtlijn te volgen, dan ware dat te betreuren. Nog onwenselijker zou echter zijn, wanneer de Commissie hierin aanleiding zou zien om in het huidige ver gevorderde stadium de hercodificatie stop te zetten en te vertrouwen op toekomstige partiële herzieningen die de problemen waarom het gaat, nu eenmaal niet kunnen oplossen.

Zou de Commissie thans inderdaad haar werkzaamheden aan Boek 6 tot het uiterste willen beperken, dan kan worden gedacht aan de mogelijkheid dat voor het tweede deel van het Voorlopig Verslag volstaan wordt met verwijzing naar die over Boek 6 verschenen literatuur, waarvan de Commissie het wenselijk acht dat daarop in de

106. Vergelijk ook E.C.M. Jurgens, De Mythe van Meerenberg (over de betrekkelijke waarde die uitgaat van medewetgeving door de Staten-Generaal), NJB 1993, p. 1381-1386. Het Tweede Kamerlid mr. V.A.M. van der Burg, die in de jaren ' 80 tot tweemaal toe probeerde het nieuwe B.W. een stok tussen de benen te gooien, bediende zich van soortgelijke argumenten. Zie hieronder, Hoofdstuk 11. 
Memorie van Antwoord in het bijzonder wordt ingegaan. Aan de voorbereiding van deze Memorie en het daarbij behorende Gewijzigde Ontwerp is intussen - in afwachting van het tweede deel van het Voorlopig Verslag - al veel gedaan. ${ }^{107} \mathrm{Er}$ hebben op een aantal punten besprekingen met deskundigen, voornamelijk uit het bedrijfsleven, plaatsgevonden, en het reeds geruime tijd geleden voorgenomen overleg met de samenstellers van het rapport, door de Orde van advocaten uitgebracht over Boek 6 , is inmiddels op gang gebracht. Een voordeel van de boven gesuggereerde werkwijze zou zijn dat de Commissie zich niet zou behoeven te verdiepen in allerlei bepalingen waarvan tevoren reeds vaststaat dat zij niet ongewijzigd zullen blijven. Bij het mondeling eindoverleg zal dan - zo nodig uitvoeriger dan gebruikelijk - over het resultaat van gedachten kunnen worden gewisseld."

\section{De dreiging afgewend}

Van de bespreking in de vaste Commissie, waarbij naast de Minister ook Snijders en De Die, die Scheltema in september 1972 was opgevolgd als hoofd van de Stafafdeling NBW, aanwezig zouden zijn, is geen verslag gemaakt. Kennelijk echter liet een meerderheid van de Commissie -Jurgens was door ziekte verhinderd - zich overtuigen door de argumenten van de Minister en zijn adviseurs, waarbij het "eigen schuld" wellicht een niet onbelangrijke rol heeft gespeeld: door de griffier zoveel vragen te laten opwerpen had de Commissie het min of meer aan zichzelf te wijten dat zij in deze onmogelijke positie was geraakt.

Dat neemt niet weg dat de discussie een pittige moet zijn geweest. Snijders: "Het Nieuwe B.W. is een project dat het moet hebben van een brede parlementaire instemming. Die is er tot nu toe altijd geweest. De enige spectaculaire verandering die zich heeft voorgedaan was de opstelling van de PPR in het midden van de zeventiger jaren. Jurgens voelde zich aangesproken door de ideeën van Pitlo. Hij heeft in 1974-1975 geprobeerd om de PvdA en D'66 tegen het nieuwe B.W. te mobiliseren. Dat overleg heeft geleid tot de beslissing om door te gaan. Dat was een belangrijk moment, omdat toen in het parlement nog eens goed de principiële vraag 'willen we een nieuw B.W. of niet', onder ogen is gezien. 'Nee' zeggen zou op dat moment aannemelijker zijn geweest dan in 1983-1984, toen we de Stofkam-operatie hadden."

Het resultaat was dat de Commissie de suggestie van Van Agt overnam en zich bij de bespreking van literatuur in het vervolg van het Voorlopig Verslag een nog grotere mate van beperking zou opleggen. ${ }^{108}$ Fischer, die na haar ervaringen met Jurgens c.s. direct zou opstappen, zei in dit verband: "In de Kamer heeft men gezegd, wij onttrekken ons er zoveel mogelijk aan, doen jullie het verder maar zo."

107. In een eerdere versie stond te lezen: "Wat Boek 6 betreft, het werk aan de M.v.A. met bijbehorend gewijzigd ontwerp is intussen - ook op het terrein waarover nog geen V.V. is uitgebracht - een goed eind gevorderd." Die passage werd afgezwakt, omdat sommige commissieleden daar misschien wat heftig op zouden reageren.

108. Zie hetgeen onder het kopje Algemeen in het tweede gedeelte van het Voorlopig Verslag wordt opgemerkt en de uitvoerige opmerkingen van de Minister daarbij (Parl. Gesch. Boek 6, p. 28). 
Om aan te tonen dat het haar aan goede wil niet ontbrak, zou de vaste Commissie korte tijd daarna besluiten over Boek 8 (eerste stuk) een blanco verslag uit te brengen. Van Rijckevorsel benadrukt: "Het point of no return is in feite pas bereikt na het aanvaarden van het tweede Boek. Bij het eerste Boek had men die gedachte nog niet. Toen was de animo er volledig uit."

En Jurgens? Zijn motie met daarin de oproep het werk aan het nieuwe B.W. te beëindigen, zou pas bij de behandeling van de invoeringswet Boek 2 op 20 maart 1975 aan de orde komen, om vervolgens om onduidelijke redenen van de agenda te worden afgevoerd. ${ }^{109}$ Pas op 16 oktober 1975, tijdens de begrotingsbehandeling voor 1976, zou zij in stemming worden gebracht. ${ }^{110}$ Op dat ogenblik was zijn protest echter niet veel meer dan een symbolisch gebeuren. Een maand eerder, op 16 september, had de vaste Commissie namelijk de laatste hand gelegd aan het Voorlopig Verslag over Boek 6. De teerling was geworpen. ${ }^{111} 112$

\section{B. De voorbereiding van M.v.A en G.O. Boek 6}

\section{De "zwoegers in het vooronder"113}

Boek 6 R.O. kende drie grote manco's. Resumerend: In de eerste plaats was het ontwerp op diverse plaatsen moeilijk leesbaar of zelfs ronduit onbegrijpelijk, omdat het Driemanschap de eis van helderheid had opgeofferd aan het streven naar volledigheid en beknoptheid. In de tweede plaats sloten de verschillende titels, afdelingen en artikelen slecht op elkaar aan, omdat de ontwerpers noodgedwongen af hadden moeten stappen van het denkbeeld alle titels na afronding nog eens langs te lopen. Tenslotte waren naar de mening van vele critici de "redelijkheid en billijkheid" als poedersuiker over het ontwerp uitgestrooid, terwijl anderen juist van mening waren dat vele regelingen onnodig gedetailleerd waren. Daarnaast was er het algemene punt dat het Regeringsontwerp voor Boek 6 indertijd overhaast was ingediend, zodat noch het Advies van de Raad van State, noch de destijds bestaande literatuur over het ontwerp waren verwerkt.

Dit betekende dat Regeringscommissaris Snijders, die pas in 1972, na de afronding van het werk aan Boek 5 G.O., zijn handen vrij kreeg voor het werk aan Boek 6, eigenlijk op alle fronten tegelijk moest werken. Hij moest structuur in het ontwerp brengen, zonder de terminologie en systematiek van het Driemanschap geheel overboord te zetten. Hij moest de kritiek, die met het verstrijken van de tijd steeds verder in bijzonderheden was afgedaald, op een redelijke manier verwerken, zonder

109. Zie Parl. Gesch. Boek 2 (invoering), p. 1017-1027.

110. Handelingen Tweede Kamer 1975-1976, p. 427.

111. Vergelijk ook H. Drion en J.M. Polak, Een noot van twee voorstanders, WPNR 4508 (1981): "Eén van de belangrijkste argumenten van Jurgens in zijn achterhoede gevecht van enkele jaren terug was dat het werk aan het nieuwe B.W. teveel beslag legde op de Tweede Kamer. Nu de Boeken 3, 5 , en 6 die Kamer zijn gepasseerd is dat een argument dat moeilijk meer kan worden aangevoerd."

112. In de Eerste Kamer zou het verzet van Jurgens worden overgenomen door Kaulingfreks (KVP), ook zonder resultaat. Zie handelingen Eerste Kamer 1975-1976, p. 715 e.v.: Parl. Gesch. Boek 2 (invoering), p. 1048.

113. Zie de aan Van Agt ontleende titel van het opstel van Van Eijkern in: De jurist-ambtenaar. bundel opstellen opgedragen aan mr. J.M. Kan, Zwolle 1977, p. 39. 
dat hij aan alle critici tegemoet kon komen. Hij moest helderheid brengen, maar kon zich vanuit een oogpunt van tactiek niet al te afkeurend uitlaten over de oude tekst. Bovendien ontwikkelde juist in de periode dat het vermogensrecht zijn huidige vorm kreeg, de Benelux-commissie voor de Eenmaking van het Recht een grote activiteit. ${ }^{14}$ Snijders verkeerde dus in een heel kwetsbare positie, het was een voortdurend dansen op een slap koord.

De Regeringscommissaris werd bij zijn werk aan de Memorie van Antwoord en het Gewijzigd Ontwerp van Boek 6 bijgestaan door Neleman, wiens hoofdtaak overigens lag bij de invoeringswet van Boek 2, De Die, Herrmann en Hartkamp. Het zwaartepunt van het werk lag echter heel duidelijk bij Snijders, ook omdat voorkwam dat de leden van de Stafafdeling NBW bij andere, politiek actuele zaken werden ingeschakeld. ${ }^{115}$ Hartkamp zei daarover:

"Toen ik er in 1974 kwam, was het een hele kleine afdeling. Alles stond dat jaar eigenlijk in het teken van het afmaken van de Memorie van Antwoord van Boek 6. Snijders was toen vrijgesteld in de Hoge Raad en zat full time te werken aan het nieuwe B.W. Ik werd toegevoegd aan Snijders als zijn assistent en ik heb ook de eerste drie jaar, dat wil dus zeggen de periode van de Memorie van Antwoord Boek 6 en de verdere afhandeling (..) eigenlijk niets anders gedaan dan Snijders bijgestaan. Alles wat hij schreef, dat las ik en becommentarieerde ik en ik zocht dingen uit waarvan hij vond dat ik die uit moest zoeken. (..) De anderen, De Die, Neleman en Herrmann, deden in feite ook niet veel anders dan zich concentreren op de Boeken 3 en vooral 6." ${ }^{\text {116 }}$

De communicatie tussen de Stafafdeling en Snijders verliep voornamelijk schriftelijk, zoals ook al in de tijd van Meijers gebruikelijk was. Neleman: "Eén van de dingen waar je de afdeling NBW aan kunt herkennen, is dat als je kritiek had op een tekst je eigenlijk alleen maar ontvankelijk was als je daarna met een betere tekst kwam, althans een andere tekst produceerde." De Die zag in deze werkwijze veel voordelen: "Dat het schriftelijk moet gebeuren, heb ik geweldig weten te waarderen, in de eerste plaats wordt de criticus genoopt om alles onder woorden te brengen, dan laat je "onderweg" al een hoeveelheid kritiek achterwege en bovendien ligt alles vast."

Volgens Neleman was Snijders, mede gezien zijn wetenschappelijk overwicht, niet gemakkelijk te overtuigen: "Door de kracht van zijn argumentatie had je soms de indruk dat je volstrekte onzin aan het vertellen was." Hij zag er echter ook iets van een spel in: "Later bleek dan toch weer uit een nota dat hij de gedachte overnam of

114. Zie daarover W. Snijders, Vers une nouveau Code Civil Néerlandais: Etat des traveaux, Revue de droit international et de droit comparé (1978), p. 321 e.v.

115. Voorbeelden zijn de Menten-affaire en de problematiek van radiozendschepen. Zie ook W. Snijders, Privaatrechtelijke problemen, in: Problemen van wetgeving, Deventer 1982, p. 189: "De meeste ambtenaren van de toch al kleine afdeling die aan het nieuwe B.W. werken, hebben in de afgelopen periode zeker de helft van hun tijd aan andere onderwerpen besteed. Het is buitengewoon moeilijk hieraan weerstand te bieden, nu in ieder afzonderlijk geval onmiddellijk moet worden toegegeven dat hetgeen gevraagd wordt inderdaad veel meer haast heeft dan het Nieuw BW, dat uit zijn aard werk op lange termijn is."

116. Interview A.S. Hartkamp, BW-NBW Twee sporen, BW-krant jaarboek 1985, Leiden 1985, p. 8-9. 
daarop voortbouwde. Het was misschien ook wel enigszins het proberen om door discussie als het ware de argumentatie verder op te voeren. Wellicht beoefende hij het ook wel een beetje l'art pour l'art."

Niettemin had Snijders als Regeringscommissaris uiteraard formeel het laatste woord - na de Minister. Hartkamp: "Snijders kan natuurlijk zeggen dat hij een wetsontwerp dat door één van de leden van de afdeling is opgesteld, niet voor zijn verantwoordelijkheid neemt. Maar dat komt in de praktijk nauwelijks voor. Meestal winnen de argumenten."

Omdat het in 1976 gepubliceerde Gewijzigd Ontwerp ondanks zijn benaming realiter een nieuw ontwerp is en vrijwel ieder artikel, woord of komma althans naar de geest wel een ander accent heeft gekregen, is het een onmogelijke taak om aan te geven waar de ontwerper eigen wegen is gegaan. Zoals Van der Grinten als eerste indruk schreef, is "de materie in al haar onderdelen opnieuw (..) overwogen, met als resultaat dat vele nieuwe ideeën in het ontwerp zijn verwerkt, dat op vele plaatsen materieel-rechtelijk nieuwe regelingen worden voorgesteld, dat vrijwel geen formulering ongewijzigd is gelaten. ${ }^{117} \mathrm{Ik}$ zal hier evenmin trachten de ontwikkeling van een bepaald artikel of bepaalde afdeling te volgen. Parijs en Rome zijn ook niet op eén dag gebouwd, en het zou vermoedelijk meer tijd kosten een dergelijke ontwikkeling te beschrijven dan het de ontwerper gekost heeft haar te verzinnen. Bovendien is het soms allesbehalve gemakkelijk de portee van een bepaalde standpuntwijziging, notawisseling of discussie te schatten.

Drie herkenbare aspecten van het werk aan Boek 6 G.O. wil ik eruit lichten, namelijk de wijze waarop de literatuur is verwerkt, het gebruik van rechtsvergelijking en het overleg met de praktijk.

\section{a. Literatuurkritiek}

De omstandigheid dat de afwijzing van Boek 6 R.O. in de literatuur vrijwel algemeen was en het uiteindelijke succes van de hercodificatie daarom in belangrijke mate zou afhangen van het antwoord op de vraag of Snijders erin zou slagen de oorzaak van deze kritiek weg te nemen, maakte dat een zeer belangrijk deel van zijn werk zou bestaan uit het toetsen en verwerken van deze commentaren en opmerkingen. Dat betekende dat elk boek, proefschrift of artikel dat maar enigszins betrekking had op Boek 6 R.O., aandachtig werd bestudeerd, becommentarieerd en ontleed. Ieder tijdschrift werd uitgepluisd, elke publicatie - het zijn er zo'n 250 geweest - werd nauwgezet overwogen, bij elk daarvan schreef Snijders een kritische nota met zijn bevindingen. ${ }^{118}$

Daarmee is echter pas de helft van het verhaal verteld. Het Departement had immers ook de beschikking over de uitvoerige nota van de bijzonder griffier Jansen,

117. W.C.L. van der Grinten, Boek 6 van het nieuwe B.W., NJB 1976, p. 1189 e.v.

118. Een voorbeeld van deze manier van werken is opgenomen in BW-NBW Twee sporen, BW-krant Jaarboek 1985, Leiden 1985, p. 29-34. Een ander voorbeeld vormt de Memorie van Antwoord bij de Invoeringswet Boeken 3, 5 en 6 (vijfde gedeelte), zitting Tweede Kamer 1984-1985, nr 17541, stuk nr 8), die - bij wijze van uitzondering - vrijwel geheel uit dergelijke nota's is opgetrokken en J.H. Nieuwenhuis zelfs verleidde tot de verzuchting dat de bespreking van een door hem geschreven artikel het karakter had van een syllabus errorum. Zie WPNR 5771 (1986). 
waarin vaak op meer dan voortreffelijke wijze de literatuur over het ontwerp werd geanalyseerd en bekritiseerd, alsmede vele eigen opmerkingen over tekst en toelichting van Boek 6 R.O. werden gemaakt. Zo wijdde de griffier aan zijn bespreking van afdeling 6.1 .1 bijvoorbeeld vijfenveertig pagina's, werd aan afdeling 6.1.2 al meer dan het dubbele aantal besteed, terwijl zijn bespreking van titel 6.3. de kroon spande met honderd en vierenzeventig pagina's, alles in een heldere stijl en wel overwogen. Feitelijk fungeerde de griffier als vijfde man. Neleman: "Die literatuur had je zelf ook wel gevonden, en je had er zelf ook wel met de vereiste kritische aandacht naar gekeken, maar het is desalniettemin buitengewoon handig als er iemand is die met veel verstand en kritische zin al die literatuur schift en daar vragen aan ontleent. ledereen kijkt weer anders tegen een tekst aan."

De verwerking van de kritieken op Boek 6 R.O. geschiedde dus uiterst grondig en de nota van Jansen stond er als het ware borg voor dat de problemen van alle zijden uitputtend waren bekeken. Ik kan dat met één enkel voorbeeld, ontleend aan een studie naar afdeling 6.4.2 (Onverschuldigde betaling), illustreren. Het commentaar van Jansen bij deze titel telde negentien bladzijden en zou Snijders tot tal van wijzigingen en verduidelijkingen inspireren. Niettemin was het Voorlopig Verslag geheel blanco. Tijdens de openbare behandeling zei Snijders het zo: "Ik verklap geen geheim, wanneer ik zeg, dat vele van de opmerkingen van de heer Jansen hun weg buiten de Voorlopige Verslagen om naar het Departement gevonden hebben en daar ook tot wijzigingen hebben geleid, vooral in het Gewijzigde Ontwerp van Boek 6."119

Vanzelfsprekend is van deze toetsing niet op elk punt in de Memorie van Antwoord rekenschap afgelegd. Dat zou ook vrij zinloos zijn, omdat nogal wat opmerkingen op misverstanden berustten. Zo wordt in de Memorie van Antwoord bijvoorbeeld met geen woord gerept over de vernietigende, maar niettemin onjuiste kritiek die is uitgeoefend op artikel 6.3.1 lid 3 O.M., waarin verschillende schrijvers een zelfstandige bron van risico-aansprakelijkheid lazen. Daarnaast leidden weer andere opmerkingen tot een verdere gedachtenontwikkeling, waarbij het oorspronkelijk uitgangspunt soms nog nauwelijks viel te ontdekken. In zo'n geval is het uiteraard eenvoudiger en juister de nieuwe regeling toe te lichten dan uit te leggen waarom de oude verkeerd was. Een voorbeeld daarvan is de regeling van de dwaling in de artt. 6.5.2.11 en 12 O.M. die tot dermate veel vragen aanleiding gaf, dat bij het G.O. een geheel andere en opnieuw toegelichte regeling werd voorgesteld.

Desalniettemin is in de Memorie van Antwoord op vele punten een grotere uitvoerigheid betracht dan strikt genomen nodig zou zijn geweest. Dat is in zoverre verdedigbaar, dat de intense en subtiele samenhang tussen de verschillende titels, afdelingen en artikelen van één Boek en tussen de Boeken onderling, het bijna onvermijdelijk maakt dat de Memorie van Antwoord, ook op punten waarop het Voorlopig Verslag zwijgt, getuigenis aflegt van een grondige bestudering en heroverweging van het gehele ontwerp. Daarom is zelfs in de gevallen waarin kritiek niet tot enige wijziging van betekenis heeft geleid, soms duidelijkheidshalve deze literatuur vermeld. ${ }^{120}$ Een voorbeeld daarvan levert de regeling van de subrogatie, waarin, ter 
vermijding van in de literatuur gerezen misverstanden, de hoofdlijnen van dit stelsel nog eens duidelijk worden uiteengezet.

Ook komt het geregeld voor dat het betoog van het Driemanschap overzichtelijkheidshalve nog eens wordt samengevat, uitgewerkt of van verduidelijkende voorbeelden wordt voorzien. Illustratief daarvoor is de uiteenzetting over de achtergrond van de tenzij-formule in de artikelen 6.3.2.5 e.v. - met name de verwijzing naar het onontdekt gebleven artikel van Brevet - en het commentaar bij artikel 6.4.2.9 O.M. (ongedaanmaking bij nietige overeenkomst).

Tenslotte is vrij frequent van de gelegenheid gebruik gemaakt foutjes en misverstanden van de bijzondere griffier via de toelichting te "corrigeren." 121 De verwerking van de kritiek is dus voorbeeldig geweest, vele malen beter dan bij menig ander wetsontwerp. ${ }^{122}$

Wel is het zo, dat, zoals Bakels ${ }^{123}$ heeft opgemerkt, er hier en daar nogal wat toelichtende teksten in Boek 6 voorkomen die minder goed lijken te passen bij de artikelen waarnaar ze verwijzen. Daarnaast heeft de toelichting in bepaalde gevallen wel erg veel nadruk gekregen, zodat na het achtereenvolgens lezen van tekst en toelichting het inzicht in de betekenis van de betreffende bepaling weleens tijdelijk verloren gaat. Vermoedelijk is dat echter vooral een kwestie van taktiek geweest. Voorkomen moest worden dat de Kamer in het Gewijzigd Ontwerp aanleiding zou vinden een nieuw Voorlopig Verslag uit te brengen. Hartkamp: "Snijders had natuur-

121. Eén voorbeeld. Volgens Jansen werd in artikel 6.4.2.5 R.O. artikel 3.5.16 R.O. ten onrechte van toepassing verklaard, omdat "de verbintenis uit onverschuldigde betaling, zoals iedere andere verbintenis, uitsluitend tussen de daarbij betrokken partijen geldt, zodat de betaler nooit iemand anders dan alleen de ontvanger uit onverschuldigde betaling kan aanspreken: het geval waarop artikel 3.5.16 het oog heeft - een geval dat, toegespitst op de onderhavige situatie, aldus kan worden omschreven, dat iemand anders dan de ontvanger het onverschuldigd ontvangen goed voor deze laatste "houdt", terwijl voorts de betaler dat goed dan bij die ander komt opeisen - kan zich hier dus niet voordoen, omdat iemand die voor de ontvanger "houdt" nooit uit onverschuldigde betaling kan worden aangesproken."

In de Memorie van Antwoord (Parl. Gesch Boek 6, p. 813) reageerde Snijders als volgt op deze stelling: "De ondergetekende wijst erop, dat de verwijzing naar artikel 3.5.16 van belang is voor het geval dat de ontvanger tussenpersoon was die in eigen naam voor rekening van een lastgever handelde. Indien hij het teruggevorderde goed houdt voor de lastgever die bezitter werd, behoort de ontvanger niet bijv. vergoeding van kosten ten behoeve van het goed te kunnen vorderen, die hij jegens de lasthebber niet bevoegd was te maken en die deze hem dus ook niet hoeft te vergoeden. Hier behoort degene die het goed als onverschuldigd betaald terugvordert, zich te kunnen beroepen op de woorden "met inachtneming van de rechtsverhouding waarin hij tot die ander stond" in artikel 3.5.16. Zo zal de lasthebber ook niet moeten kunnen betogen dat hij ingevolge overeenkomstige toepassing van artikel 3.5.14 de inmiddels gewonnen vruchten mag houden, hoewel de lastgever deze als bezitter te kwader trouw zou moeten afgeven en de lasthebber in zijn verhouding tot de lastgever de vruchten aan deze laatste heeft af te dragen."

122. Zie ook WPNR 5361 (1976). De redactie schreef in een 'Ten geleide' bij een artikelenreeks over Boek 6 G.O.: "Teksten en toelichtingen zijn van een voortreffelijk gehalte. Alle schrijvers zijn het daar over eens. Maar niet alleen zijn de voorstellen goed doordacht en helder verwoord, opvallend is ook dat zo consciëntieus is rekening gehouden met de literatuur, met de wensen uit de praktijk, zoals die in de adviezen zijn neergelegd en door de mondelinge raadpleging naar voren gekomen en met internationale ontwikkelingen in Beneluxverband, ontwerpen van Unidroit e.d."

123. F.B. Bakels, De invoering van het nieuw Burgerlijk Wetboek, NJB 1984, p. 1282 e.v. 
lijk niet de behoefte op alle punten de toelichting tegen te spreken, want het ging niet om een nieuw ontwerp, maar om een Gewijzigd Ontwerp."

\section{b. Rechtsvergelijking}

Een tweede karakteristiek waaraan het werk van Snijders kan worden herkend is het bescheiden, maar weloverwogen gebruik dat is gemaakt van rechtsvergelijkende gegevens. Een dankbaar voorbeeld in dit opzicht is de regeling van het verzuim (artt. 6.1.8.6 e.v.).

In het Ontwerp-Meijers bracht verzuim van de schuldenaar het ontstaan van een verbintenis tot vergoeding van vertragingsschade mee, niet het recht op vervangende schadevergoeding en ontbinding. Voor dit laatste was in beginsel een tweede ingebrekestelling nodig, dat wil zeggen een aanmaning tot nakoming binnen een bepaalde redelijke termijn. De keuze voor dit gecompliceerde systeem hing samen met de introductie van een andere regel, namelijk dat de schuldenaar door het enkele verstrijken van een termijn in verzuim komt. Door voor ontbinding en omzetting nu een nadere ingebrekestelling te eisen, werden de consequenties van deze laatste regel verzacht.

In het Gewijzigd Ontwerp werd, mede op aandringen van de Kamer, de tweede aanmaning in feite geschrapt - een schriftelijke mededeling is dikwijls voldoende -, maar bleef de regel dat een termijn in beginsel fataal is, behouden. Snijders liet zich daarbij in belangrijke mate inspireren door rechtsvergelijkende gegevens. Uit deze vergelijking bleek namelijk dat het er niet zoveel toe doet van welke zienswijze men uitgaat, omdat in beide systemen bepaalde correcties worden aangebracht, waardoor zij elkaar in de praktijk dicht naderen. In Frankrijk en België, waar een bepaalde termijn voor de nakoming niet fataal is, fungeert de tweede aanmaning als pressiemiddel om alsnog tot nakoming over te gaan. In de Duits georiënteerde landen, waar een termijn in beginsel wél fataal is, wordt de werking daarvan afgezwakt door voor omzetting of ontbinding een tweede aanmaning te eisen. De mogelijkheden voor de schuldenaar om zijn verzuim te zuiveren lopen in de praktijk dus niet zover uiteen. Snijders koos daarom voor het minst gecompliceerde stelsel, maar wees er in de toelichting op dat de rechter niet moest aarzelen om nuances aan te brengen, door bijvoorbeeld de tekortkoming van ondergeschikte betekenis te achten, of de termijn als een niet fatale aan te merken. ${ }^{124}$

Een ander voorbeeld van deze benadering wordt aangetroffen in een passage van de Memorie van Antwoord bij de artikelen 6.3.2.5-10 G.O., waar wordt ingegaan op het "bezitscriterium" bij de aansprakelijkheid voor zaken. Volgens een nieuw artikel 10 is in het geval dat een zaak, opstal of dier wordt gebruikt in de uitoefening van een bedrijf, niet de bezitter daarvan aansprakelijk, maar degene die het bedrijf uitoefent. Een overweging daarbij was, dat de benadeelde aldus niet behoeft te kiezen uit een reeks potentiële aansprakelijken en - omgekeerd - dat het risico aan de zijde van het bedrijf, dat van de zaak gebruik maakt, overzichtelijk blijft. Uit de toelichting blijkt

124. Zie de M.v.A. bij de artikelen 6.1.8.1 e.v., Parl. Gesch. Boek 6, p. 252 e.v. Zie voor een uitgebreide weergave, alsook een evaluatie van de gebruikte argumentatie: N.A. Florijn, Rechtsvergelijking in het wetgevingsproces, Zwolle 1993, p. 119-128. 
dat bij deze keuze rechtsvergelijkende gegevens van doorslaggevende betekenis zijn geweest, zij het dat de uitwerking daarvan geheel orgineel is:

"Dit stelsel kan worden gezien in verband met een ontwikkeling in een aantal landen waar de problematiek die men met aansprakelijkheid voor zaken tracht op te lossen, wordt benaderd vanuit een andere gezichtshoek, nl. vanuit aansprakelijkheid voor gevaarlijke activiteiten. (..) Artikel 6.3.2.10 tracht - voor het sprekende geval van schade bij de uitoefening van een bedrijf - van deze benadering de voordelen over te nemen (voorkoming van versplintering van aansprakelijkheid - zonder te vervallen in de nadelen (de moeilijkheid van de maatstaf van 'abnormaal' of 'verhoogd' gevaar (..), alsook de vraag op wie van de bij de activiteit betrokkenen de aansprakelijkheid moet rusten). ${ }^{125}$

Uit beide voorbeelden blijkt dat Snijders zich niet heeft beperkt tot een droge opsomming van artikelen, maar integendeel met het aangetroffen materiaal aan de slag is gegaan. Hij analyseerde overeenkomsten en verschillen, zocht naar een synthese, maar schroomde ook niet nieuwe wegen in te slaan. De systematische dimensie, die bij het Driemanschap niet erg uit de verf kwam, is duidelijk aanwezig; er is met een zekere gerichtheid gekeken naar de wetgeving van andere landen. Ook zijn de gemaakte keuzen beargumenteerd, hetgeen bij het Driemanschap niet altijd het geval was. Om terug te keren tot het voorbeeld van het verzuim: de door het Driemanschap verzorgde toelichting kende slechts een beperkt aantal verwijzingen naar buitenlands recht, waarbij door middel van het noemen van een aantal artikelnummers vrijwel uitsluitend ondersteuningen van de in het ontwerp neergelegde regel werden gegeven. In het Gewijzigd Ontwerp daarentegen, wordt de hoofdinhoud van elk artikel kort weergegeven, de verscheidenheid in oplossingen niet verzwegen en daarbij ook gezegd wat ermee is gedaan. ${ }^{126}$

\section{c. Overleg met de praktijk}

Een derde punt waarmee Snijders zich uitdrukkelijk van zijn directe voorgangers onderscheidde, was het intensieve contact dat hij had met de praktijk. Zoals uit het lijstje, opgenomen onder punt 5 van de "algemene opmerkingen" van de Memorie van Antwoord blijkt, is bijvoorbeeld vrijwel elk onderdeel van het ontwerp doorgesproken met een werkgroep uit de Orde van Advocaten en met een door de Nederlandse Vereniging voor Rechtspraak ingestelde commissie. Voorts zijn over een aantal onderdelen juristen uit verschillende kringen van het bedrijfsleven geraadpleegd, zoals de banken en de verzekeringswereld. Tenslotte heeft Snijders met betrekking tot een aantal specifieke onderwerpen contact gezocht met vertegenwoordigers van het notariaat en de universitaire wereld. Bekende namen in dit verband zijn die van $\mathrm{H}$. Drion, J.Th. Smalbraak, O.K. Brahn en C.J.H. Brunner.

Hartkamp zei daarover: "In de anderhalf jaar voordat de Memorie van Antwoord Boek 6 af was, heb ik meegemaakt dat Snijders voor iedere afdeling van Boek 6 een commissie hoorde van de Vereniging voor Rechtspraak, van de Orde van Advocaten, 
van het Genootschap van Bedrijfsjuristen, en van de Broederschap van Notarissen, en zo hoorde hij over ieder onderwerp altijd de betreffende belangengroepen en als het specifieke problemen waren dan vaak ook specialisten van een groep." ${ }^{127}$ Neleman vult aan: "Het contact met de praktijk is over het algemeen tamelijk uitvoerig geweest. Er is bijvoorbeeld gesproken met een speciaal daartoe bijeengeroepen clubje van een aantal deskundigen uit de bankwereld en hoogleraren in de economie over de problemen van geldontwaarding en wettelijke rente. Dat heeft uiteindelijk geleid tot een niet heel spectaculaire wijziging van het stelsel, maar wel een belangrijke. $\mathrm{Zo}$ is er ook een discussie geweest over de kwestie van het huurbeding, iets wat overigens niet tot overeenstemming heeft geleid en daarom steeds is vooruitgeschoven. Verder zijn mensen uit de hypothecaire wereld geconsulteerd, banken, verzekeraars, etc."

Evenals bij Meijers het geval was, verliep het overleg informeel, ook al vonden de gesprekken op Justitie plaats. Meestal ontvingen de gesprekspartners vooraf een concept-tekst en -toelichting met daarbij het verzoek opmerkingen te maken. Soms gaf Snijders een aantal punten op waarnaar zijn bijzondere interesse uitging. Altijd eindigde de uitnodiging met de opmerking dat men geheel vrij was andere punten naar voren te brengen, of wensen en verlangens op papier te zetten. In de herinnering van Neleman:

"Het overleg werd veelal geïnitieerd door Snijders, die behoefte had om te weten hoe dingen in de praktijk liepen. Hij nam dan contact op met organisaties die op die terreinen werkzaam waren en vroeg of zij iemand hadden die daar eens over wilde praten. Dan was het vaak zo, dat er twee of drie mensen werden aangewezen en dat over zo'n onderwerp een keer werd gepraat. Soms, als de materie wat ingewikkelder lag, ontstond een werkgroepje, dat bijna altijd werd voorgezeten door Snijders, met één of twee leden van de Stafafdeling daarbij. Het was vaak zo, dat Snijders begon met op te merken dat iets op een bepaalde manier geregeld zou kunnen worden, waarbij hij dan een tekst gaf waarin die oplossing was neergelegd. Zo'n tekst werd als het ware vrijblijvend ter tafel gelegd om te laten zien hoe het zou kunnen. Aan de hand daarvan werd dan gediscussieerd. Ik wil niet uitsluiten dat er wel eens besprekingen zijn geweest waar nog geen tekst was, maar meestal was het toch wel zo dat er van de kant van het Departement iets werd opgesteld, al was het maar een praatstuk waarin in de laatste alinea een aantal opties werd gegeven als mogelijkheid."

Een verschil met Meijers was wel, dat de Regeringscommissaris mogelijk wat minder snel bereid was tot aanpassingen en het commentaar vooral gebruikte ter verduidelijking van tekst en toelichting. ${ }^{128}$ Door zijn gesprekspartners lijkt dat echter niet als een groot bezwaar te zijn gevoeld, want de vaststelling van Boek 6 zou rimpelloos verlopen. Hartkamp: "Het was natuurlijk wel vaak zo dat Snijders er anders over

127. Interview A.S. Hartkamp, BW-NBW Twee sporen, BW-krant jaarboek 1985, Leiden 1985, p. 9.

128. Ik moet hier onmiddellijk aan toevoegen, dat de besprekingen waarvan ik de verslagen heb bekeken, vrij kort voor de publicatie van het Gewijzigd Ontwerp plaatsvonden. Het is voorstelbaar dat in dat laatste stadium de beslissing over detailkwesties is vooruitgeschoven. 
dacht dan die belangengroepen, maar dan werd er in een gesprek toch een soort consensus bereikt en die werd dan toegepast in het wetsontwerp. Het is eigenlijk zelden voorgekomen, voor zover ik me kan herinneren, dat we echt ingingen tegen bepaalde wensen van belangengroepen. Zeker niet bewust of gewild om die mensen tegen te zitten. "129

Bovendien, zo'n tekst was natuurlijk niet uit de lucht komen vallen en Snijders was uiteraard veel meer thuis in het ontwerp dan zijn gesprekspartners. Daarnaast verkeerde Snijders in vergelijking tot Meijers in een weinig benijdenswaardige positie. Meijers was alleen zichzelf verantwoording schuldig, zijn ontwerp was dat van een particulier, althans tot aan de omzetting in Regeringsontwerpen. Snijders daarentegen, moest de opmerkingen vanuit de praktijk afwegen tegen de ideeën van de Kamer, de literatuur en - tenslotte - zijn eigen opvattingen. Dat hij daarin tot tevredenheid van vrijwel iedereen slaagde, maakt zijn prestatie in vergelijking tot die van Meijers er bepaald niet minder bewonderenswaardig op.

Dát Snijders een zo sterk accent legde op de raadpleging van topmensen uit advocatuur, rechterlijke macht en bedrijfsleven was aan het begin van de jaren zeventig nog tamelijk ongebruikelijk. Voor de uiteindelijke kwaliteit en bruikbaarheid van het ontwerp was het echter van levensbelang, mede omdat het gebrek aan contact met de praktijk als één van de grote gebreken van het werk van het Driemanschap werd gezien. Snijders: "Mijn taak was heel anders dan die van het Driemanschap. Ik zat in de fase van het parlementaire debat. Ik had te maken met een groen Boek dat zwaar onder vuur lag. Er waren series artikelen die bij velen de vraag deden rijzen, 'moet dat wel?' Dat gaf dus een heel andere instelling. Het was juist zaak de kritiek te verwerken op een manier die voor de praktijk aanvaardbaar was. Dat is gebeurd met drie commissies, de twee belangrijkste waren de advocatenclub en de rechtersclub. Er zijn notarissen, bedrijfsjuristen en verzekeraars gehoord over een aantal afdelingen en daardoor is het ontwerp sterk veranderd. (..) Ik ben helemaal niet gehinderd door het idee van 'dit is van Meijers of dit is van het Driemanschap en dat verander ik niet meer.' Integendeel. Ik dacht, het moet, ook waar het goed is, nog zo gedraaid worden dat het ook acceptabel wordt." Neleman: "Snijders stond heel open tegenover de materie, liet zich graag uitleggen hoe het nu in de praktijk in elkaar zat." 130

Daarnaast zou het overleg ook een tactisch voordeel hebben gehad. Fokkema: "Snijders heeft het gemis aan overleg waarschijnlijk als een gebrek in de totstandkoming van Boek 6 O.M. gezien. Hij heeft zich er met inzet van al zijn krachten op geworpen. (..) Het overleg met de praktijk heeft een duidelijk voordeel betekend voor het nieuwe B.W., alleen al als je het beschouwt uit tactisch oogpunt. Als je mensen tijdig de gelegenheid geeft inspraak te hebben, dan is er minder tegenstand te verwachten. Ik denk dat dat in belangrijke mate een rol heeft gespeeld."

129. Interview A.S. Hartkamp, BW-NBW Twee sporen, BW-krant jaarboek 1985, Leiden 1985, p. 9.

130. Een ander voorbeeld is dat Snijders incidenteel voorontwerpen met toelichting ter beschikking stelde, met als doel eventuele kritiek op zijn werk in een zo vroeg mogelijk stadium te kunnen verwerken. Vergelijk het voorwoord van W. Th. Braams, Buitencontractuele aansprakelijkheid voor gevaarlijke stoffen, Utrecht 1989. 
Een duidelijk voorbeeld daarvan is Schoordijk, die in het begin van de jaren ' 70 nog fel van leer trok tegen het nieuwe verbintenissenrecht, maar na 1976 bijzonder gecharmeerd raakte van Snijders' democratische wijze van wetgeving. ${ }^{131}$ Schoordijk verklaart:

"Pas met de komst van Snijders kreeg je een dialoog tussen de wetgever en de rechtswetenschap. Dat is het eindprodukt bepaald ten goede gekomen, biedt daarenboven een enorme rijkdom voor rechtspraak en wetgeving. Snijders opent de deuren van het Ministerie voor de wetenschap. Dat was voordat hij aan het bewind kwam niet het geval. Als ik kanttekeningen maakte, werden ze doodgezwegen. Als ik tegen het notariaat zei dat een wet niet voldeed, dan zei men 'We hebben met veel moeite een voet tussen de deur gekregen bij het Ministerie, jouw kritiek zou dat weer ongedaan maken bij Van Ewijk.' Het was een anti-democratie. Bij Snijders kreeg je de kans om je bezwaren naar voren te brengen en hoorde je ook argumenten die tegen je eigen opvatting pleitten. De kwaliteit van mijn handboek over het verbintenissenrecht is een stuk beter geworden, doordat ik voordurend kon terugvallen op Snijders. Als ik aan het schrijven ben en vastloop op bepaalde dingen - ik ben soms hele weekeinden bezig met iets dat ik niet direct begrijp -, dan bel ik ten einde raad Snijders op en krijg prompt antwoord. Dat is natuurlijk een fantastische sfeer om in te werken."

Niettemin zou in het midden van de jaren tachtig duidelijk worden, dat niet iedere in het overleg vertegenwoordigde belangengroep van de wenselijkheid van een nieuw Burgerlijk Wetboek overtuigd was geraakt. Volgens Snijders zou dat - enigszins paradoxaal - vooral een gevolg zijn geweest van deze werkmethode, naast factoren als invoeringspijn en het feit dat inmiddels een nieuwe generatie bestuurders was aangetreden. Snijders:

"Als je iets wilt doen waar je wat aan hebt, dan moet je een groep mensen hebben die bereid is om 'a fond' in de problemen te duiken. Wat je dan krijgt, is een groep van zeer bekwame lieden die door de advocatuur als gesprekspartner wordt aangewezen etc. Aan zo'n groep heb je ontzettend veel, die brengt ontzettend veel in aan feitelijke informatie. Men heeft ook kantoren achter zich, waar de problemen nog meer uitgevraagd kunnen worden. Maar wat je ook doet, het blijft altijd een kleine groep, en het is niet zo dat die kleine groep vervolgens kans ziet van wat daar bekokstoofd is, zonder meer door te geven naar alle advocaten in de beroepsgroep, in een stadium van het nieuwe B.W. waar de invoering nog niet onmiddellijk voor de deur staat.

Voor de advocaten heb ik grotendeels overleg gevoerd met de commissie burgerlijk recht, een commissie van een man of acht, die bereid zijn zich in te zetten. Maar dat brengt niet mee dat de advocatuur als zodanig van de zaak op de hoogte is, of het gevoel heeft dat zij dat heeft ingebracht." 


\section{Boek 6 G.O. voltooid; verdere procedure}

Op 30 januari 1976 werd de Memorie van Antwoord en het Gewijzigd Ontwerp officieel ingediend bij de Tweede Kamer. Het eerste deel had Snijders al enige tijd daarvoor, op 2 oktober 1975 afgeleverd. Het beantwoorden van het tweede deel van het Voorlopig Verslag - ontvangen op 15 oktober 1975 - kostte hem dus iets meer dan drie maanden. En het had nog sneller gekund. De Die, 2 september 1975: "Na jarenlang verblijf op de zandbank is nu ook Boek 6 in de Tweede Kamer vlotgemaakt. Mr. Snijders, geassisteerd door mr. Hartkamp, werkt op de grondslag van jarenlange voorbereidingen zo voortvarend aan M.v.A. en G.O. dat hij moet oppassen niet gereed te zijn voordat het V.V. officieel is verschenen."

Dát Justitie alles op alles had gezet om Memorie van Antwoord en Gewijzigd Ontwerp zo spoedig mogelijk te laten verschijnen, had drie redenen.

Allereerst zou - zoals eerder gezegd - de beschikbaarstelling van Snijders per 1 januari 1976 aflopen, zodat hij met ingang van die datum volledig zou worden ingeschakeld bij het werk in de Hoge Raad. Een combinatie van beide taken leek niet mogelijk. In de tweede plaats was met de vaste Commissie voor Justitie informeel afgesproken dat het eindverslag betreffende de Boeken 3, 5 en 6 eind 1976, begin 1977 zou worden voltooid. 1977 was namelijk een verkiezingsjaar en het was maar de vraag of de nieuwe Kamer zich gebonden zou voelen aan de procedure-afspraken die met haar voorganger waren gemaakt en bijvoorbeeld in het Gewijzigd Ontwerp van met name Boek 3 en Boek 6 geen aanleiding zou vinden met een nader Voorlopig Verslag te komen, dan wel de zaak op de lange baan te schuiven. ${ }^{132}$ Tenslotte zou aan wetenschap en praktijk voldoende gelegenheid moeten worden geboden hun oordeel over Memorie van Antwoord en Gewijzigd Ontwerp kenbaar te maken.

Voor de Boeken 3 en 5 vond het Mondeling Overleg op 8 en 9 september 1976 plaats, voor Boek 6 op 11 februari 1977. In feite werd daarbij dezelfde procedure gevolgd als bij de voorbereiding van het Voorlopig Verslag over Boek 6, namelijk dat de behandeling werd beperkt tot een aantal vraagpunten, uitgezocht op hun juridischtechnisch belang. Afspraak daarbij was dat de literatuur en het commentaar van de praktijk, die sinds 1971, respectievelijk 1972 en 1976 waren verschenen, door het Departement zelfstandig werden bezien, evenals de hier en daar noodzakelijke aanpassing aan de inmiddels verschenen voorontwerpen van de Boeken 7 en 8 . De Commissie en de Regering wisten zich hierbij gesteund door Van der Grinten ${ }^{133}$, die uit vrees dat de Kamer de behandeling steeds maar voor zich zou uitschuiven,

132. Vergelijk ook A. Geurtsen, Het werk aan het nieuwe B.W., NJB 1976, p. 1356 e.v. De voorzitter van de vaste Commissie voor Justitie benadrukt daar dat het dringend gewenst is dat de Tweede Kamer de vaststellingswetten van de Boeken 3, 5 en 6 vóor de verkiezingen aanneemt: "Ik moet er niet aan denken, wat er zal gaan gebeuren, als na de verkiezingen een nieuwe commissie samengesteld gaat worden. Nieuwe leden moeten zich niet alleen inwerken, zij hebben vaak ook eigen opvattingen (..) Op zichzelf is dat ook niet erg, maar het werkt wel erg vertragend, als die afwijken van de inzichten van hun voorgangers."

133. W.C.L. van der Grinten, Boek 6 van het nieuwe B.W., NJB 1976, p. 1201. Vergelijk ook Ex tunc, ex nunc, (J.M. van Dunné), Zwolle 1990, p 202: "Ik heb in het Juristenblad van 1976, toen de boel weer eens in het slop zat, een artikel geschreven in de trant van: 'Laten we niet te lang over het nieuwe B.W. blijven praten, want als het nog tien jaar duurt kunnen we beter ophouden.'” 
uiterste zelfbeperking aanbevool: "Men moest nu eindelijk eens doorzetten en niet eindeloos blijven vergaderen."

In concreto kwam de procedure erop neer dat, zoals in 1971 was afgesproken, Snijders speciaal ten behoeve van de griffier, mr. Jansen, een lijst opstelde van belangrijke wijzigingen, aangebracht bij het Gewijzigd Ontwerp. Deze lijst werd enige tijd later aangevuld door een nota van Snijders, waarin beknopt de aard van de wijziging werd aangegeven, de aanleiding daarvoor en een vermelding of de wijziging inmiddels (terecht) kritiek of bijval had geoogst. De punten, opgesomd in de hieronder bij de Boeken 3 en 5 gegeven bijlage, zijn in belangrijke mate, maar niet steeds, ontleend aan deze nota's. Soms ontving de griffier ook een aantal interne, vertrouwelijke notities, die hem desgewenst aanvullende gegevens konden verschaffen als om de één of andere reden buiten de opgegeven punten om in de vaste Commissie nog andere in de literatuur besproken kwesties ter sprake zouden komen. Dit betrof doorgaans een uittreksel van de nota's die het Departement (Snijders, Hartkamp, Herrmann) opstelde naar aanleiding van de over het ontwerp verschenen literatuur. Het kwam er dus op neer dat het Departement de vragen influisterde die de Kamer eventueel zou kunnen stellen, waarbij tevens een aanwijzing werd gegeven welke kant het op moest.

De volgende stap was dat de griffier een nota opstelde met vraagpunten betreffende het Ontwerp, bedoeld als grondslag voor de discussie en tevens als begrenzing van wat daarbij in beginsel aan de orde kon worden gesteld. Deze nota's kwamen voor wat betreft de aan de orde te stellen punten voor $98 \%$ overeen met de lijst van Snijders, maar waren wel uitvoeriger en meer dan voortreffelijk toegelicht. De griffier liep dus niet aan het handje van het Departement, maar profiteerde anderzijds wel duidelijk van dit voorwerk. Voor Snijders, die op zijn beurt weer de vraagpuntennota's van Jansen ontving, had deze werkwijze het onmiskenbare voordeel dat hij zo heel gemakkelijk kon anticiperen op de vragen die bij het Mondeling Overleg zouden worden gesteld. Ruim voordat het Mondeling Overleg zou plaatsvinden werden door hem dan ook concepten voor de Nota's van Wijziging opgesteld en kon het mogelijk opnieuw noodzakelijk geworden overleg met de praktijk worden afgesloten. Vandaar ook, dat deze nota's, ten dele opzettelijk zeer uitvoerig, reeds enkele dagen na afloop van het Mondeling Overleg zouden verschijnen. ${ }^{134}$ De Die: "Geurtsen heeft mij wel eens verteld, dat de vaste Commissie uiteindelijk maar heel weinig heeft gedaan aan Boek 6. Jansen zorgde overal voor, men hoefde als Commissie alleen maar de door Jansen geselecteerde knopen door te hakken."

Op 4 maart 1977 volgde een Openbare Commissie Vergadering over de drie Boeken gezamenlijk. Bijna was het nog fout gegaan. De Die, 2 maart 1977: "Naar wij van de griffier mr. Kerkhofs vernemen is blijkbaar tengevolge van een misverstand door de Minister-President niet opgegeven dat de bovengenoemde Boeken van het nieuwe B.W. nog in elk geval vóór het reces in april door de Tweede Kamer moeten worden

134. F.W. Grosheide, Invoering vermogensrecht NBW aanstaande?, WPNR 5407 (1977) heeft in dit verband de wetgever van overhaasting beticht. Ten onrechte evenwel. Aan het M.O. is een lange fase van schriftelijke voorbereiding voorafgegaan. Ter illustratie: de lijst met belangrijke wijzigingen in Boek 3 en Boek 5 verscheen op 25 februari 1976, het M.O. vond eerst op 8 en 9 september 1976 plaats. 
behandeld. (..) Welke rampen over ons komen als de afspraak niet wordt nagekomen, niemand heeft ze levendiger geschilderd dan de Voorzitter der vaste Commissie, mr. Geurtsen in NJB 1976, p. 1356/7."

De oplossing bestond hierin, dat Minister Van Agt aan het begin van de O.C.V. tegenover de Voorzitter van het Presidium een verklaring aflegde omtrent het misverstand en de werkelijke wens van de Regering: "Misschien is het u niet geheel bekend, mijnheer de Voorzitter - maar alle anderen weten dat wij in de startblokken ziten voor de eindsprint en dat het voor de voltooiing van het grote werk van de hercodificatie wel eens van beslissend belang zou kunnen zijn dat wij er in deze resterende weken in slagen, het hart van de zaak, het ganse vermogensrecht, te brengen door de Tweede Kamer der Staten-Generaal. Als dat niet gelukt, zou het werk wel eens jaren kunnen worden vertraagd. Die vertraging van jaren - dat is geen al te pessimistische veronderstelling - zou wel eens heel slechte gevolgen voor het lot van het gehele werk kunnen hebben." ${ }^{135}$

Daarmee waren de Boeken 3, 5 en 6 nog niet in veilige haven, want op 22 maart 1977 viel het Kabinet. Evenals in 1972 het geval was geweest, stuurde de MinisterPresident een lijstje met eventueel nog te behandelen wetsontwerpen naar de Kamer, met daarop ook het nieuwe B.W. Oppositieleider H. Wiegel was echter weinig geneigd zaken te doen met het demissionaire Kabinet, zo bleek tijdens een debat dat op 30 maart 1977 over dit lijstje gehouden werd: naast politiek belangrijke punten als de benoeming van een nieuwe burgemeester van Amsterdam en een gouverneur in Limburg, moest ook het nieuwe B.W. eraan geloven en werd het van de lijst afgevoerd. Tot grote onsteltenis van de Stafafdeling NBW. Onmiddellijk werd Minister Van Agt gewaarschuwd. Een ontgoochelde De Die schreef: "Het lijkt, of er alsnog een kink in onze NBW-kabel komt: naar mr. Kerkhofs mij meedeelde verzet blijkbaar de VVD-fractie zich tegen de behandeling van zo belangrijke wetsontwerpen als die van het nieuwe B.W. Ik heb getracht mr. Geurtsen te bereiken, maar deze vertoeft in Rome. Naar ik vrees, zal aan de houding van de VVD-fractie in deze weinig zijn te doen, en zal die houding ook de beslissing van de Kamer zijn. Mocht er echter nog enige beweging mogelijk zijn, dan zal die ons vanzelfsprekend uiterst welkom zijn." 136

Een dag later bleek het nieuwe B.W. toch op de lijst van niet-controversiële wetsontwerpen te zijn geplaatst. De Die: "Van Agt heeft er persoonlijk voor gezorgd dat de openbare behandeling van de Boeken 3, 5 en 6, ondanks het uitbreken van de Kabinetscrisis, is doorgezet." Wel werd afgesproken dat controversiële argumenten niet besproken zouden worden in verband met de demissionaire positie van het Kabinet. $^{137}$

Op 21 april 1977 vond de openbare behandeling plaats, met op de politieke tribune slechts drie aanwezigen. De Boeken 3, 5 en 6 zouden met een hamerslag worden

135. Parl. Gesch. Boek 3, p. 3.

136. Nota van 30 maart 1977.

137. Ingetrokken werd een amendement-De Gaay Fortman ten gunste van een ambtshalve uit te oefenen matigingsbevoegdheid van de rechter bij boetebedingen (art. 6.1.8.18 lid 1), alsmede een amendement-Haas-Berger tot schrapping van verplichting tot vergoeding van schade wegens het derven van levensonderhoud aan een gewezen echtgenoot van een overledene (art. 6.1.9.12 lid 1 sub c). 
aangenomen, volgens Zonderland. De Eerste Kamer zou drie jaar later, op 6 mei 1980 volgen. Ter bespoediging van het werk had zij een aantal schriftelijke vragen gesteld, die eveneens schriftelijk werden beantwoord.

\section{Conclusie}

Uit het voorgaande blijkt, dat de behandeling van Boek 6 bijzonder zorgvuldig is geweest, zowel aan de zijde van het Departement als aan de zijde van de Tweede Kamer, die het werk vrijwel geheel uitbesteedde aan Jansen. Dankzij het uniformerende werk van de bijzonder griffier en de hulp die daarbij vanuit het Departement werd aangeboden, is er waarschijnlijk geen ander wetsontwerp te vinden dat een zo gedegen behandeling heeft gekregen. ${ }^{138}$ Om het scherp te stellen: aan een onderwerp als euthanasie zijn minder woorden besteed. Uit een oogpunt van democratische legitimatie scoort het nieuwe B.W. daarom zeer hoog.

Dit kon allemaal - paradoxaal genoeg - doordat de politiek omstreeks 1964 niet langer in het nieuwe B.W. was geïnteresseerd, althans zelf niet bij machte was de op Boek 6 uitgeoefende kritiek op een goede manier te verwerken. Het strekt de Kamercommissie daarom tot eer, dat zij niet voor de verleiding is bezweken het werk te staken, maar naar wegen heeft gezocht om tot een redelijke oplossing te komen. Een vergelijking met de totstandkoming van het B.W. van 1838 dringt zich hierbij op. In 1822 werd, eveneens op aandrang van de Kamer, een vraagpuntenprocedure in het leven geroepen, omdat de Kamer van mening was dat het niet haar taak was voorstellen tot technische verbetering te doen. Dat is ook de enig aangewezen weg: de Kamer heeft een politieke functie, de leden daarvan zijn niet uitgekozen op hun geschiktheid juridische oordelen te vellen.

Door sommige juristen is negatieve kritiek geuit op de wijze waarop de Boeken 3 , 5 en 6 door de Kamer zijn vastgesteld. Zo gaf Van Dunné139 als zijn oordeel te kennen, dat de versnelde procedure "vrijwel zeker een uiterst middelmatig, haastig en slordig geconcipieerd, onderling tegenstrijdig produkt van wetgeving gaat opleveren" en zou zijns inziens de voorgenomen behandeling van Boek 6 "in hoge mate verwerpelijk zijn." Abas ${ }^{140}$ noemde het "ijltempo" waarmee de Boeken 3, 5 en 6 door de Kamer werden gejaagd "een belediging, zowel aan het adres van de privaatrechtswetenschap in Nederland als aan dat van de privaatrechtelijke wetgeving", terwijl Zonderland $^{141}$ de laatste van de door de Tweede Kamer opgestelde stukken als "quasi-wetenschappelijk" betitelde.

Het moge duidelijk zijn dat met opmerkingen als deze de ontwerper en de Kamer grof onrecht is aangedaan. In de eerste plaats wordt daarbij over het hoofd gezien dat de Kamer door het werk van de bijzonder griffier grote invloed heeft gehad op de uiteindelijke tekst van de ontwerpen, zeker in vergelijking met de wijze waarop de Kamer doorgaans haar wetgevende arbeid verricht. Ook wordt over het hoofd gezien

138. Wel meen ik, dat de Tweede Kamer voor wat betreft de verslaglegging wel het één ander van de Eerste Kamer kon leren.

139. J.M. van Dunné, Het werk aan het Nieuw B.W.: jeugdsentiment uit de jaren vijftig?, NJB 1977, p. 342.

140. P. Abas, NJB 1977, p. 419.

141. P. Zonderland, Nieuw Vermogensrecht als hamerstuk?, NJB 1977, p. 410. 
wat er sinds 1976 is gebeurd, met name de Eindverslagen en de uitvoerige Nota's van Wijziging betreffende alle drie de Boeken. Daaruit blijkt dat jurisprudentie en literatuur zeer nauwgezet zijn bijgehouden en dat van een versnelde procedure, in die zin dat onderdelen zouden zijn overgeslagen, geen sprake is geweest. Snijders zei daarover:

"Het is niet zo dat de Kamer me te weinig tegenspel kan bieden. Je moet daarbij niet denken aan een mondeling debat bij de plenaire behandeling, je moet ook niet denken aan een hevig debat over amendementen. Waar naar gekeken moet worden, dat is hoeveel er uit een Voorlopig Verslag en vanuit de Eindverslagen nog wordt overgenomen door de Regering. En dat is vrij veel. Als er inderdaad literatuur komt, met een stellig standpunt en de Kamer gaat er achter staan, dan is er een grote kans dat dit wordt overgenomen."

In de tweede plaats geeft een dergelijke opstelling blijk van een volstrekt gebrek aan kennis van de taak en de mogelijkheden van de Kamer. Het aantal juristen is beperkt, de meeste Kamerleden zijn drukbezet, er is slechts een enkeling die interesse kan opbrengen voor civielrechtelijke wetsontwerpen, afkomstig van Justitie. Tekenend is dat de openbare behandeling van de Boeken 3, 5 en 6 moest worden uitgesteld omdat het vereiste aantal Kamerleden niet aanwezig was. Bij de Openbare Behandeling in 1977 zei Geurtsen het als volgt: "Wie zou menen, dat Kamerleden maar uitspraak moeten doen bij gebleken verschillen van opvatting, waarvan er veel op leerstellig gebied liggen, overschat de capaciteiten van de Kamerleden, maar ook - wat erger is - hij miskent hun taak. (..) Kamerleden hebben geen wetenschappelijke, maar een politieke opdracht." ${ }^{142}$ Van Rijckevorsel vat de verhouding politiek en nieuw B.W. als volgt samen: "Het hele Burgerlijk Wetboek heeft met het Kabinetsbeleid, waar het altijd om de dubbeltjes gaat, niets te maken. Er was ook destijds al een heel groot deel van mijn fractie, die zich geen bal interesseerde voor het nieuwe B.W."

Tenslotte is het zo, dat de Boeken 3,5 en 6 allerwegen goed waren ontvangen, zodat er voor de Kamer weinig reden was nog verder te vragen dan zij al deed. Kortheidshalve verwijs ik nogmaals naar het redactioneel commentaar van het WPNR. Daarbij kwam, dat de animo voor de hercodificatie halverwege de jaren '70 zover was weggezakt, dat het niet reëel was op dat moment meer literatuur te verwachten. Snijders moest de redacties van WPNR en NJB zelfs benaderen met een lijst van mogelijke onderwerpen met daarbij een aantal namen van schrijvers, waaruit zou kunnen worden gekozen. De meeste juristen komen nu eenmaal pas in beweging als de invoering aanstaande is. De reacties van Van Dunné, Zonderland en Abas zijn daar geen uitzondering op. Zonderland had alleen twee keer uitgehaald tegen het oude Regeringsontwerp van Boek 6 , zonder overigens met argumenten te komen. ${ }^{143}$ Van

142. Parl. Gesch. Boek 3, p. 22-23. Het citaat vervolgt: "Het is mede de taak van Kamerleden, erop toe te zien dat de gebruikte formuleringen zo duidelijk mogelijk zijn en de bedoelingen zo exact mogelijk weergegeven. $\mathrm{Zij}$ moeten zich ervoor hoeden, als wetenschappelijk scheidsrechter op te treden. Daartoe zijn zij niet geroepen en daarvoor zijn zij onvoldoende geëquipeerd."

143. P. Zonderland, Het bedrijfsleven en het nieuwe Burgerlijk Wetboek, Maatschappijbelangen 1975, p. 511; Ontwerp nieuw BW is niet progressief, NRC 20 januari 1975. Overigens leidde de zeer negatieve kritiek van Zonderland in Maatschappijbelangen eind 1976 tot de instelling van een 
Dunné liet geheel verstek gaan. ${ }^{144}$ Abas tenslotte, had de gang van zaken rond het nieuwe B.W. blijkbaar zo slecht gevolgd, dat hij zich in zijn emoties liet meeslepen en werkelijk meende dat er na 1954 niets meer was gebeurd. Dan ga je natuurlijk snel zulke dingen denken.

143. $\rightarrow$

Commissie Boek 6 Nieuw B.W., uitgaande van de Nederlandsche Maatschappij voor Nijverheid en Handel. Bekende namen daarin waren G.H.A. Schut, W.M. Kleijn, H.J. Pabbruwe en E. Korthals Altes. De commissie kwam tot een zeer positief oordeel.

144. Merkwaardig is overigens dat Van Dunné vór de publicatie van de Gewijzigde Ontwerpen van de Boeken 3, 5 en 6 nog opgetogen was over de kwaliteit van het nieuwe B.W. Uit een brief van 21 april 1969 aan Scheltema: "Overigens, zo knutselend op een klein terreintje krijg ik wel respect voor het gigantenwerk wat jullie doen. Voor vele (..) produkten van de nieuwe wetgeving heb ik grote bewondering. Waarmee ik een eventueel verwijt, van een pitloze instelling te getuigen - mijn baas, Schoordijk, stelt zich wel eens zo op, maar meer t.a.v. Boek 6 - alvast wil ontzenuwen." 


\section{Bijlage I: Lijst van belangrijke wijzigingen aangebracht bii het Gewiizigd Ontwerp van Boek 3}

\section{Titel 3.1: Algemene bepalingen}

De regeling van art. 3.1.1.3 (zaken en hun bestanddelen) is sterk vereenvoudigd. Zowel de figuur van de bijzaak als die van de hulpzaak zijn wegens de daaraan in het oude B.W. verbonden complicaties geschrapt. Ter zake van zaken die bestanddeel van een andere zaak worden is - anders dan volgens art. 3.1.1.3 lid 3 ontwerp-Meijers - geen eigendomsvoorbehoud meer mogelijk, zulks wegens de complicaties van eindeloos in bestanddelen opgesplitste zaken bij beslag en faillissement.

\section{Titel 3.2: Rechtshandelingen}

Artikel 3.2.1 lid 3 (handelingsonbekwaamheid) is veranderd n.a.v een opmerking in het Voorlopig Verslag. (Bij de invoeringswet zou deze subtiliteit er overigens weer worden uitgegooid.)

Artikel 3.2.3 (vertrouwensbeginsel) is gesplitst in twee artikelen. De noodzaak daartoe is aan het licht gekomen bij het bewerken van Boek 6 door het Driemanschap, dat herhaaldelijk tegen de moeilijkheid aanliep dat de redactie van Meijers niet bruikbaar is in het geval het beroep op een omtrent een rechtsverhouding opgewekte schijn wordt gedaan door een derde die daarbij geen partij was.

Artikel 3.2.8 (conversie) is geheel herzien, ten dele i.o.m. het Voorlopig Verslag.

Artikel 3.2.10 lid 4 (misbruik van omstandigheden) evenzo.

Artikel 3.2.13-18: (vemietiging) Onder het oude B.W. is het een twistpunt geweest of vernietiging ook bij wege van verweer gevraagd kan worden. De Hoge Raad heeft dit tenslotte aanvaard, en dit stelsel schijnt ook door Meijers te zijn overgenomen. (De eiser dient te vorderen, de gedaagde kan met een beroep op vernietigbaarheid bij wijze van verweer volstaan). Het G.O. is nog een stap verder gegaan: ieder beroep op de vernietigbaarheid in rechte kan tot vernietiging bij vonnis leiden. De bepaling over alternatieve gevolgen (bezwaarlijk ongedaanmaken) van de vernietiging is nog belangrijk uitgebreid.

\section{Titel 3.3: Volmacht}

Het ontwerp van Meijers, waarin de kluwen tussen volmacht, vertegenwoordiging en lastgeving was ontward, bleek zeer deugdelijk. Slechts is in artikel 3.3.13 de mogelijkheid van een onherroepelijke volmacht aanzienlijk verruimd. Deze was in het oorspronkelijke ontwerp slechts toegelaten indien zij verband hield met een krachtens titel 3.6 aan de gevolmachtigde opgegedragen bewind (T.M. p. 207). Meijers was daar overigens al op teruggekomen, hetgeen blijkt uit het mede door hem opgestelde Beneluxontwerp. Het G.O. volgt globaal de daar voorgestelde redactie. $\mathrm{Nu}$ is een dergelijke volmacht steeds toegelaten wanneer het gaat om een of meer bepaalde rechtshandelingen die in het belang van de gevolmachtigde of een derde zijn.

De overige wijzigingen betreffen slechts details.

\section{Titel 3.4: Verkrijging en verlies van goederen}

De nieuwe regeling van art. $2014 \mathrm{BW}$ (art. 3.4.2.3a) is o.a. afgestemd op het feit dat in de praktijk de teruggave vrijwel altijd wordt afgewikkeld in het kader van een door politieonderzoek ingeleide strafvordering. Een te respecteren verkeersbelang - het belang van een vlot handelsverkeer - speelt, anders dan in het oude B.W., geen grote rol: het is geen maatschappelijke eis dat tweedehands goederen, antiek, kunst, juwelen etc. zo vlot mogelijk verhandelbaar moeten zijn. De nadruk ligt nu op een billijke verdeling nussen de gedeposseerde en de verkrijger; teruggave tegen vergoeding.

Het eigendomsvoorbehoud heeft een wertelijke grondslag gekregen en gaat voor bij bezitloos pandrecht.

\section{Titel 3.5: Bezit en houderschap}

Deze titel onderging ten opzichte van het Ontwerp-Meijers slechts wijzigingen van ondergeschikte aard. Zo is het Salomo's oordeel van 3.5.15 lid 2 geschrapt en een nieuw artikel 15a toegevoegd.

\section{Titel 3.6: Bewind}

Het stelsel betreffende bij rechtshandeling in te stellen bewind is ter tegemoetkoming aan het Voorlopig Verslag meer open gemaakt, teneinde toekomstige ontwikkelingen niet te dwarsbomen. In artikel 3.6.2.1 onder a is in feite alleen nog de beperking te vinden dat de rechthebbende niet zijn toekomstige goederen onder bewind kan stellen.

Deze regeling bleek echter weinig doorzichtig toegelicht, zodat naar aanleiding van het Mondeling Overleg een uitvoerige nota zou verschijnen.

\section{Titel 3.9: Rechten van pand en hypotheek}

Meijers verbood de zekerheidseigendom ten strengste, gaf in plaats daarvan een magere onherroepelijke volmacht, een gesloten bewind, een bezitloos pandrecht (uitsluitend voor ondernemingen) alsmede een register- 
pandrecht. In het G.O. vervangt het bezitloos pandrecht de zekerheidseigendom en is het registerpandrecht geschrapt. Belangrijkste overweging was dat het bedrijfsleven op een ruime mogelijkheid van kredietopneming tegen onderpand zeer gesteld is.

Art. 3.9.4.11 lid 2 makk rechterlijk verlof tot onderhandse executoriale verkoop door hypotheekhouder mogelijk. Een openbare veiling staat vaak aan een redelijke opbrengst in de weg. Deze wijziging werd ongevraagd in het ontwerp opgenomen.

\section{Titel 3.10: Verhaalsrecht op goederen}

In afdeling 3.10.4A is een regeling betreffende retentierecht ingevoegd. De twee belangrijkste vernieuwingen zijn de regel dat in bepaalde gevallen de retentor op grond van zijn goede trouw zelfs wordt beschermd tegenover derden die een ouder recht hebben (art. 2 lid 1), en de regel dat aan een retentierecht steeds een verhaalsrecht met voorrang vastzit. (art. 4).

Titel 3.11: Rechtsvorderingen

In de regeling van de extinctieve veriaring is een regel ingevoegd betreffende de verjaring van de bevoegdheid een rechterlijke of arbitrale uitspraak ten uitvoer te leggen; zie artikel 3.11.20.c 


\section{Biilage II: Lijst van belangriike wiizigingen aangebracht bii het Gewiizigd Ontwerp van Boek $5^{145}$}

\section{Titel 5.1: Eigendom in het algemeen}

art. 5.1.1 lid 1: Naar aanleiding van een opmerking in het Voorlopig Verslag is dit artikellid iets voorzichter geformuleerd, mede om iedere indruk te vermijden als zou worden vastgehouden aan het 'klassieke' eigendomsbegrip. In de M.v.A. vestigt de Minister er de aandacht op dat de bepaling niet moet worden gezien als een definitie, maar dat zij slechts twee kenmerken geeft; alleen een zaak kan voorwerp van eigendom zijn, en eigendom is van alle zakelijke rechten het meest omvattende recht, in die zin dat daaruit de beperkte rechten van artikel 3.1.1.7 kunnen worden afgeleid.

Art. 5.1.1 lid 2: Eveneens naar aanleiding van opmerkingen in het Voorlopig Verslag komt - in overeenstemming met Meijers' concept - in art. 2 geen bepaling meer voor betreffende de bevoegdheid van de eigenaar om over de zaak te beschikken. Het argument is, dat hetgeen voor deze bevoegdheid geldt, reeds voortvloeit uit algemene regels.

Ten aanzien van de bevoegdheid van de lagere wetgever het genot van de eigenaar te beperken, is het stelsel gehandhaafd dat zich in de rechtspraak heeft ontwikkeld. Beekhuis had in overleg met de Vereniging Nederlandse Gemeenten wel enige correcties hierop aangebracht, maar deze zijn er door Snijders weer uitgehaald. Het Voorlopig Verslag wilde deze materie, die een sterk publiekrechtelijke inslag heeft, ook buiten het B.W. houden.

Art. 5.1.2 Aan dit artikel betreffende de hinder die in het algemeen belang behoort te worden geduld, is een ruimere, minder eng met eigendom verbonden redactie gegeven. Ook hinder, toegebracht door of aan een ander dan de eigenaar van de zaak, valt binnen het toepassingsgebied van het artikel. Bij amendement zou deze regel in een nieuw artikel 5.4 .0 worden ondergebracht.

De zgn. Voorste Stroom-problematiek, geregeld in de leden 2-4, werd belangrijk vereenvoudigd en zou uiteindelijk bij amendement naar Boek 6 (art. 6.3.1.5b) worden overgebracht.

\section{Titel 5.2: Eigendom van onroerende zaken}

In deze titel onderging de regeling van de gevonden voorwerpen een niet onbelangrijke herziening, teneinde haar meer in overeenstemming met de praktijk te brengen. Gewijzigd werden onder andere de regeling van de aangifteplicht (mag in iedere gemeente gebeuren, niet alleen meer in de gemeente van de vondst) en de bepaling over vondsten in een gebouw of woning. In een nieuw artikel werd een gemeente de bevoegdheid gegeven bepaalde groepen van niet-kostbare zaken na drie maanden te verkopen. Dikwijls worden namelijk zeer grote hoeveelheden veelal weinig kostbare voorwerpen in bewaring gegeven, waarvan slechts een zeer klein deel door de verliezers wordt afgehaald. Dit maakt het wenselijk de last die de administratie en bewaring van deze voorwerpen op de gemeenten leggen, aanzienlijk te verlichten.

Deze regels waren, met uitzondering van de eerste, alle reeds in het concept-Meijers te vinden.

\section{Titel 5.3: Eigendom van onroerende zaken}

De ingewikkelde problematiek rondom het verloop van de grens tussen percelen land en water in geval van verplaatsing van de oeverlijn (aanwas en afslag) heeft in de artikelen $5.3 .9-10 \mathrm{~b}$ een wat bruikbaarder regeling gekregen.

Titels 5.4 en 5.5: Bevoegdheden en verplichtingen van eigenaars van naburige erven en mandeligheid Van deze titels kan in het bijzonder worden gewezen op artikel 5.4.16 (recht van overbouw), dat een aantal wijzigingen heeft ondergaan. De bepaling heeft betrekking op het onbevoegd plaatsen van een deel van een gebouw over de grens van een naburig erf. Het G.O. is daarmee teruggekeerd tot de uitgangspunten die Meijers al in 1950 formuleerde.

De regeling van de mandeligheid is in grote lijnen hetzelfde gebleven. Die veranderingen en aanvullingen zijn vrijwel steeds uitsluitend bedoeld om datgene wat in het ontwerp reeds was opgenomen, althans stilzwijgend was verwerkt, nog iets duidelijker te zeggen. Ook het aan mandeligheid toegekende ruime gebied was destijds al volledig afgepaald.

\section{Titel 5.6: Erfdienstbaarheden}

De belangrijkste wijziging die het ontwerp in de regeling van de erfdienstbaarheden brengt, is het schrappen van het nutsvereiste en het naburigheidsvereiste in artikel 1 lid 1. De enige eis die nog wordt gesteld is dat de erfdienstbaarheid moet strekken "ten behoeve van" het heersende erf. Deze verniming komt tegernoet aan praktische behoeften en leidt tot het vervallen van onnodige en subtiele onderscheidingen. 
Een andere verruiming geeft artikel 2 (dulden of niet doen), waarin de erfdienstbaarheid die verplicht tot een "doen" wordt toegelaten. De erfdienstbaarheden hebben dus een bijzonder ruim terrein gekregen, zij het dat één en ander tot op zekere hoogte kan worden beschouwd als een voortzetting van een tendens die al in rechtspraak bestond. (HR 28 juni 1957, NJ 1957, 495).

De "bestemming" als ontstaangrond voor erfdienstbaarheden is geschrapt in verband met de verkrijgende verjaring, waarmee gehoor is gegeven aan een opmerking in het Voorlopig Verslag.

\section{Titel 5.7: Erfpacht}

Artikel 1 geeft de mogelijkheid in de akte van vestiging het recht van erfpacht, zonodig in afwijking van de wettelijke regels, nader te vormen.

In artikel 5.7.2b wordt thans dwingend voorgeschreven dat opzegging van de erfpacht door de eigenaar of door de erfpachter slechts kan geschieden bij exploit.

In artikel 5.7.3 lid 2 is de bevoegdheid van de erfpachter de bestemming van de zaak zonder toestemming van de eigenaar te wijzigen beperkt. In het Regeringsontwerp werd bepaald dat een zodanige wijziging eerst geoorloofd zou zijn "indien daardoor de waarde van de zaak zou verminderen". Deze maatstaf zou niet tegemoetkomen aan de behoefte van de overheid die gronden in erfpacht heeft uitgegeven, om wijzigingen in de bestemming die niet de waarde van de grond raken, te voorkomen.

Naar aanleiding van een opmerking in het Voorlopig Verslag is ook in artikel 5.7.5 een nieuwe bepaling opgenomen ter versterking van de positie van de overheid, nl. de mogelijkheid bij de vestiging van het erfpachtrecht te bedingen dat overdracht of toedeling van de erfpacht niet meer mogelijk is zonder toestemming van de eigenaar.

Nieuw is ook artikel 5.7.8a, dat in aansluiting op art. 6.5.3.11 de mogelijkheid opent wegens onvoorziene omstandigheden aan de rechter opheffing of wijziging van de erfpacht te vragen. Deze wijziging werd wenselijk geacht in verband met de artt. 5.7.2 en 2a, waaruit volgt dat erfpacht in beginsel voor eeuwig gevestigd is. Het ontbreken van deze correctiemogelijkheid zou gemakkelijk tot grote starheid en tot ongewenste en moeilijk te vermijden consequenties aanleiding kunnen geven.

Het recht van Grondrente (afdeling 5.7.2) en van Beklemming (afdeling 5.7.3) zijn vervallen. Het valt op dat noch de in de M.v.A. genoemde Groninger Maatschappij van Landbouw, noch de Commissie-Beekhuis inzake een wettelijke regeling van het beklemrecht, schrapping voorstelden. ${ }^{146}$ Wél werd deze wens uitgesproken in een briefwisseling die Beekhuis in 1967-1968 met de Groninger Mij. voerde. Een mooi voorbeeld van de tijdgebondenheid van het recht?

Titel 5.8: Opstal

In het eerste lid van artikel 5.8.1 (omschriiving opstal) is de mogelijkheid van het vestigen van opstalrechten n.a.v. opmerkingen in het Voorlopig Verslag belangrijk verruimd: Behalve "in" en "op" zijn thans ook opstalrechten boven de grond mogelijk. Bovendien is "grond" vervangen door onroerende zaak, zodat opstalrecht ook mogelijk is ten aanzien van leidingen die b.v. dwars door een gebouw heen moeten, zelfs wanneer dit gebouw geen eigendom van de grondeigenaar is.

Een nieuw artikel 5.8.1a (bevoegdheden opstaller) geeft partijen de vrijheid tot beperking van de eigenaarsbevoegdheden van de opstaller ten aanzien van de opstal. Artikel 3 doet hetzelfde ten aanzien van de zaak waarop het opstalrecht rust. 


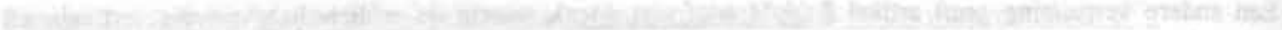

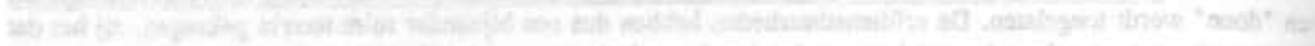

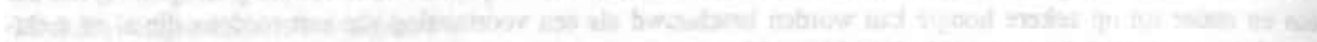

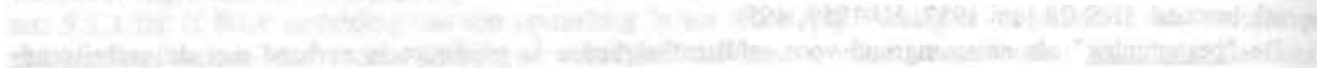
3750 
Hoofdstuk 8

BOEK 7: BIJZONDERE OVEREENKOMSTEN (1954-1972)

\section{Inleiding}

Met de officiële aanbieding aan Minister Van Agt van het voorontwerp voor Boek 7, bevattende regelingen voor een twintigtal bijzondere overeenkomsten, werd op 10 april 1973 een nieuwe stap gezet op de moeizame en langdurige weg naar een nieuw Burgerlijk Wetboek. ${ }^{1}$ Een niet onbelangrijke stap, want daarmee was als het ware het gehele Burgerlijk Wetboek gehercodificeerd, al moest de discussie over deze "bovenverdieping" van het nieuwe vermogensrecht uiteraard nog plaatsvinden.

Aan dit gedeelte van het Ontwerp-Meijers, dat in vergelijking met de andere groene Boeken het minste nieuws bracht, is, zij het met verschillende onderbrekingen, maar liefst vijfentwintig jaar gewerkt. Daarmee slaat het de voorbereiding van het nieuwe wegvervoersrecht, waartoe Schadee in 1964 opdracht ontving en dat ook niet bijster vlot verliep, zelfs nog met een kleine dertien jaar.

In dit hoofdstuk wil ik proberen een beeld te geven van de problemen die zich rond de voorbereiding van dit groene Boek hebben voorgedaan, en die, zoals bij vrijwel elk deel van het nieuwe Burgerlijk Wetboek het geval is, voornamelijk zijn te wijten aan een falende organisatie, diversiteit van de ontwerpers en coördinatieproblemen.

De periode van na de verschijning van het groene Boek blijft in deze paragrafen vrijwel geheel buiten beschouwing. Sinds 1973 is er, omdat het Departement indertijd heeft besloten voorrang te verlenen aan de invoering van de Boeken 3, 5 en 6, (in combinatie met de titels 1, 7, 9 en 14 van Boek 7) weinig aan dit Boek gebeurd. De bewerking van de meeste titels is dan ook pas onlangs ter hand genomen of moet zelfs nog beginnen. ${ }^{2}$

\section{Wat had Meijers voor met Boek 7?}

Eén van de belangrijkste doelen die Meijers zich had gesteld bij het ontwerpen van de teksten voor Boek 7, was het streven de in het Burgerlijk Wetboek voorkomende regelingen zoveel mogelijk te vereenvoudigen, af te slanken, zoals ook ten aanzien van de overige delen van zijn ontwerp duidelijk het geval was. De regeling van de bijzondere contracten zou naar zijn mening zo beknopt mogelijk moeten worden gehouden, zodat daarin - de enkele keer dat er behoefte was aan een meer in details tredende regeling buiten beschouwing gelaten - bijvoorbeeld geen plaats was voor regels die reeds in het algemeen deel (Boek 6) waren opgenomen.

1. De aanbiedingsbrief zelf was gedagtekend November 1972.

2. Een actueel overzicht geeft J. de Boer, Uitwendige wetsgeschiedenis van Boek 7 nieuw Burgerlijk Wetboek, WPNR 5982 (1990). Daaraan kan worden toegevoegd dat de titels 3, 12, 17 en 18 inmiddels bij de Tweede Kamer zijn ingediend en dat de titels 7, 9, 14 en 15 op 1 september 1993 in werking zijn getreden. (Wet van 27 mei 1993, Stb. 1993, 309). Volgens W.C.L. van der Grinten, Boek 7 BW, in: 'In het nu, wat worden zal', Deventer 1991, p. 87-95, zou zo ongeveer de helft van de nog resterende titels niet nader in de wet behoeven te worden geregeld. 
Dientengevolge werd de regeling van de schenking, in het Burgerlijk Wetboek van 1838 over achtentwintig artikelen verspreid, door Meijers samengevat in tien artikelen; de verbruikleen in vijf tegenover zestien; de bewaargeving (met inbegrip van een regeling met betrekking tot de aansprakelijkheid van de hotelhouder) in twaalf tegenover zesenveertig; de bruikleen in acht tegenover de veertien artikelen die de wetgever van 1838 daarvoor nodig had. ${ }^{3}$

Vereenvoudiging was uiteraard niet de enige doelstelling van Meijers. Minstens zo belangrijk was dat ook dit deel van het Burgerlijk Wetboek, dat zoveel jaren was genegeerd door de wetgever, weer op de hoogte van de tijd zou worden gebracht en de rechtsontwikkeling opnieuw richting zou kunnen geven en stimuleren. Geen opzienbarende doelstelling, want Meijers had in zijn artikel "Het feillooze deel van ons Burgerlijk Wetboek"4 al aangegeven dat de regeling van de bijzondere overeenkomsten op ten minste twintig punten diende te worden verbeterd of aangevuld. Zo lezen we onder no. 100 de wens om tot een algemene regeling van de vaststellingsovereenkomst te komen (ter aanvulling van de in de artt. 1888-1901 B.W. voorkomende regeling van de dading), onder no. 92 een pleidooi om de artikelen 302-308 van het Wetboek van Koophandel te vervangen door een op de behoefte van de praktijk afgestemde regeling van de levensverzekering, onder no. 86 een voorstel om de werkingssfeer van de verborgen gebrekenregeling (artt. 1541 B.W. e.v.) terug te dringen, en, om bij de koop te blijven, onder no. 85 het verlangen om in de wet duidelijker te doen uitkomen dat de verkoper verplicht is tot eigendomsverschaffing, een kwestie waarover de Hoge Raad pas in 1983, dus ruim vijftig jaar later, duidelijkheid wist te verschaffen. ${ }^{5}$

De laatste factor tenslotte, die een rol speelde bij de beslissing het contractenrecht te herzien, was de wens het burgerlijk recht weer tot een eenheid te smeden, onderwerpen die zonder deugdelijke reden buiten de codificatie waren geplaatst weer in het Burgerlijk Wetboek op te nemen. De privaatrechtelijke regeling van de collectieve arbeidsovereenkomst (Wet van 24 december 1927, Stb. 415), destijds buiten het Burgerlijk Wetboek gehouden omdat deze wet voor een deel verenigingsrecht bevatte en plaatsing in een afzonderlijke wet bovendien het voordeel zou bieden dat deze regeling later eenvoudig zou kunnen worden aangevuld met voorschriften van administratiefrechtelijke aard, kon, nu het verenigingsrecht in Boek 2 werd opgenomen en de publiekrechtelijke regeling, het voornemen van de wetgever ten spijt, toch in een afzonderlijke wet was geregeld ${ }^{6}$, zonder bezwaar worden overgebracht naar het Burgerlijk Wetboek. ${ }^{7}$ En de opneming van de pachtovereenkomst, bij de herziening in 1937 buiten het Burgerlijk Wetboek gebracht omdat op die wijze het gehele materiële en formele recht in één wet kon worden samengevat en ook eenvoudiger zou kunnen worden herzien, werd door Meijers gemotiveerd met de opmerking dat wens tot herziening van het pachtrecht met het nieuwe ontwerp voorlopig wel zou zijn

3. Deze gegevens zijn ontleend aan de teksten die Meijers zélf nog had opgesteld en hebben dus geen betrekking op de corresponderende titels van het groene Boek.

4. WPNR 3031 (1928).

5. H.R. 4 februari 1983, N.J. 1984, 628 (Ansink/Canjels).

6. Wet van 25 mei 1937 , Stb. 801 , tot het algemeen verbindend en het onverbindend verklaren van bepalingen van collectieve arbeidsovereenkomsten.

7. Vergelijk E.M. Meijers, Gedenkboek Burgerlijk Wetboek 1838-1938, Zwolle 1938, p. 41 en de

"Algemene Inleiding" tot de vier groene Boeken, Parl. Gesch. NBW, Algemeen Deel, p. 127. 
afgesloten en dat de splitsing tussen formeel en materieel recht, net zoals bij andere burgerrechtelijke onderwerpen het geval was geweest, geen bijzondere bezwaren met zich meebracht. ${ }^{8}$

\section{Opzet en werkwijze}

Het schema voor de indeling van de bijzondere overeenkomsten in Boek 7 werd door Meijers voor het eerst naar buiten gebracht tijdens het Mondeling Overleg met de vaste Commissie over de Nota. Deze rangschikking, waaraan Meijers hoogstwaarschijnlijk geen juridische consequenties wenste te verbinden - in de Algemene Begrippen (p. 323 e.v.) schreef hij dat wegens de verscheidenheid van de kenmerken van de bijzondere overeenkomsten een ordening naar een eenvoudig, voor elk van deze overeenkomsten geldend principe, niet meer mogelijk was - zag er als volgt uit:

A. Overeenkomsten strekkende tot overdracht van een goed (koop en ruil, verbruikleen, schenking) of tot verlening van het genot van een goed (huur, pacht, bruikleen).

B. Overeenkomsten tot het verrichten van arbeid (opdracht, uitgeversovereenkomst, bewaargeving, vervoers- en expeditie-overeenkomst, arbeidsovereenkomst, collectieve arbeidsovereenkomst, aanneming van werk, vennootschap).

C. Andere bijzondere overeenkomsten (borgtocht, vaststellingsovereenkomst, spel en weddenschap, schadeverzekering, lijfrente, persoonsverzekering, wissel- en chequerecht).

Zoals boven al eerder is gesteld, is het moeilijk vast te stellen wanneer Meijers zijn eerste, voorlopige concept voor Boek 7 gereed had. Het enige aanknopingspunt hiervoor is de datum waarop voor de eerste maal schriftelijk van gedachten werd gewisseld over de concepten die Meijers aan zijn gesprekspartners toezond, of - bij gebreke daarvan - het tijdstip waarop een concept voor het eerst besproken werd in een bijzondere commissie ad hoc. Vooral dit laatste gegeven dient echter met de nodige voorzichtigheid te worden gehanteerd: omdat Meijers meestal aan verschillende boeken tegelijk werkte en het overleg met de subcommissie Burgerlijk Recht, de diverse belanghebbenden en deskundigen nogal tijdrovend was, is het niet onmogelijk dat een tekst (inclusief rapportage) geruime tijd bleef liggen alvorens hij in de plenaire vergadering aan de orde werd gesteld. De rapportages voor Boek 6 bijvoor-

8. Parl. Gesch. NBW, Algemeen Deel, p. 127. Zie ook de opmerkingen van Meijers in zijn rede van 8 mei 1948, V.P.O. I, p. 146 e.v. Hij zei daar over de pacht: "Bij deze overeenkomst is het de steeds toenemende overheidsinmenging en het moeilijk aangeven, waar het burgerlijk recht eindigt en het publieke recht begint, die het verlangen doet rijzen, naar een afzonderlijk wetboekje: Het recht van de boerenstand. Maar op gelijke wijze kan men wegens de vermenging van het publieke en het privaatrecht verdedigen en vindt men verdedigd, dat wij moeten hebben: een wetboek van de arbeid, een wetboek voor het luchtrecht, een wetboek voor de kinderzorg, een wetboek voor de rechten van de scheppende mens, enz. Laten wij echter voorzichtig zijn met aldus het Burgerlijk Wetboek uiteen te rijten en die delen van het burgerlijk recht, die niet goed gekend kunnen worden, wanneer zij niet in onderlinge samenhang en verwantschap behandeld en bestudeerd worden, van elkander te vervreemden." 
beeld, waren begin april 1950 gereed: de besprekingen over dit concept, die op 5 mei 1950 begonnen, konden pas twee jaar later, op 2 februari 1952 worden afgerond.

Het bovenstaande in aanmerking genomen, is het aannemelijk dat Meijers zijn concept voor de bijzondere overeenkomsten tussen eind 1949 en de zomer van 1951 moet hebben voltooid. Uit de stukken blijkt namelijk dat hij op 26 januari 1950 voor de eerste maal een reactie ontving op een door hem ontworpen tekst - het betrof een commentaar van de bedrijfshoreca (Horecaf) over titel 7.9 -, terwijl de bespreking van die titels waarbij geen gedagtekend advies werd uitgebracht vrijwel zonder uitzondering in februari 1952 plaatsvond. Een andere aanwijzing is dat Meijers begin juli 1951 ertoe overging de subcommissie Burgerlijk Recht op te splitsen in een aantal ondercommissies, die elk een aantal titels van Boek 7 te behandelen kregen, een besluit dat op 2 februari 1952 definitief werd vastgesteld. ${ }^{9}$

Niet alle concepten voor Boek 7 waren overigens van Meijers' hand. De materie van de titels 11 en 12 (arbeidsovereenkomst en collectieve arbeidsovereenkomst) had Meijers - volgens De Jong ${ }^{10}$ - al in een vroeg stadium uitbesteed aan Levenbach, vermoedelijk omdat deze aan de wieg had gestaan van het "nieuwe" ontslagrecht (Wet van 17 december 1953, Stb. 619) en Meijers niet van plan was grote veranderingen aan te brengen in dit deel van het Burgerlijk Wetboek. " Het concept voor de schadeverzekering, in het najaar van 1953 door Dorhout Mees gecombineerd met de door Meijers ontworpen bepalingen inzake de persoonsverzekering, was opgesteld door een commissie onder voorzitterschap van Dorhout Mees, ingesteld door de Bedrijfsgroep Schadeverzekering. ${ }^{12}$ Dit ontwerp, dat in oktober 1950 aan Meijers werd aangeboden, was de vrucht van een initiatief van de voorzitter van deze bedrijfsgroep, de heer Gratama, die, toen hij in zijn kwaliteit van rechter-plaatsvervanger in de Rechtbank te Dordrecht de circulaire ontving waarin de herziening van het Burgerlijk Wetboek werd aangekondigd, onmiddellijk contact opnam met Meijers met het voorstel een wetsontwerp voor de schadeverzekering op te stellen. Dat tekent nog eens het enthousiasme waarmee de opdracht aan Meijers werd begroet. ${ }^{13}$ Het con-

9. Notulen van de 121 e (7 juli 1951), 126e (15 december 1951) en 127e ( 2 februari 1952) vergadering van de subcommissie Burgerlijk Recht. Aldus ontstonden: Commissie I (Koop en Huur), Ila (Arbeidsovereenkomst), IIb (Uitgave-overeenkomst), IIc (Opdracht, Makelaarsovereenkomst, enz.), III (Vennootschapsrecht), IV (Vaststelling, Dading en Borgtocht) en V (Verenigingen).

10. Nota van F.J. de Jong van 9 augustus 1965.

11. Zie hiervoor, Hoofdstuk 3. Minister Donker zei er tijdens de begrotingsbehandeling van 1955 het volgende over: "In dat arbeidsrecht en die collectieve arbeidsovereenkomst zal, praktisch gesproken, zeer weinig nieuws komen. Die contracten zullen alleen ondergaan een aanpassing aan de terminologie en aan het systeem van het nieuwe Burgerlijk Wetboek, maar hier komt geen ingrijpend nieuw recht." (Handelingen Tweede Kamer 1954-1955, p. 2166).

12. Meijers was overigens al vanaf het eerste begin van plan geweest het verzekeringsrecht uit te besteden. In de Nota aan de Koningin van 18 april 1947 wordt opgemerkt: "Indien hiertoe (tot een herziening van het B.W.) wordt overgegaan, kan de herziening van een op zichzelf staand onderwerp uit het Wetboek van Koophandel, zoals het verzekeringsrecht, dat in tegenstelling tot de andere delen van het Wetboek van Koophandel in de laatste decennia geen modernisering heeft ondergaan, op voordracht van prof. Meijers aan een ander worden toevertrouwd."

13. Het contact werd gelegd op 14 november 1947. De commissie, die op 21 april 1948 voor het eerst bijeen kwam, kreeg van Meijers de volgende richtlijn mee: "Ik voel veel voor de gedachte van prof. Van Dievoet om in de wet slechts enkele algemene principes neer te leggen, en verder het 
cept voor titel 7.10 tenslotte, de regeling van de vervoers- en expeditie-overeenkomst, die overigens in 1967 zou worden overgebracht naar Boek 8, was wel door Meijers zelf opgesteld, maar zou, omdat de ontwerper en de subcommissie Handelsrecht onderling van mening bleven verschillen over de opzet en de werkingssfeer van deze titel, uiteindelijk geheel worden omgewerkt door Cleveringa c.s. ${ }^{14}$

Dat Meijers bij de voorbereiding van zijn ontwerp veelvuldig contact zocht met de praktijk en dat hij een dankbaar gebruik maakte van de opmerkingen die in de subcommissie Burgerlijk Recht of in de diverse commissies ad hoc naar voren werden gebracht, is hiervoor al meer dan eens aan de orde geweest. In verband daarmee wordt hieronder volstaan met het geven van een opsomming van de organisaties of personen die Meijers bij het beoordelen van zijn concepten voor Boek 7 terzijde stonden, aangevuld met de data waarop de besprekingen plaatsvonden. Op die manier wordt een indruk verkregen van de uitgebreide wijze waarop Meijers zich oriënteerde en het tempo dat hij zichzelf en zijn gesprekspartners oplegde. ${ }^{15}$

Voor de volledigheid wijs ik er nog op dat uit het feit dat diverse titels slechts een enkele maal besproken zijn, niet mag worden afgeleid dat het overleg op het tijdstip van Meijers' overlijden nog niet zou zijn afgerond. Op 26 september 1953 liet Meijers de leden van de subcommissie Burgerlijk Recht namelijk weten dat van Boek 7 alleen nog de titels Koop, Schenking, Bruikleen, Verbruikleen en Bewaargeving besproken moesten worden, waarvoor de volgende data werden gereserveerd: Koop en Schenking op 14 en zo nodig ook op 21 november 1953, de overige titels op 4 november 1953. Uit het onderstaande schema blijkt, dat dit voornemen inderdaad ten uitvoer werd gebracht, zodat met de op 14 november gehouden bijeenkomst over de Koop het overleg over Boek 7 was voltooid.

13. $\rightarrow$

assurantierecht te regelen in uniforme polisvoorwaarden die door een daartoe in te stellen commissie zouden kunnen worden ontworpen. Op die wijze zal het verzekeringsrecht gemakkelijker de toekomstige ontwikkeling kunnen volgen. De wet zal kort moeten zijn en niet teveel gedetailleerd."

14. Zie hierna, Hoofdstuk 9.

15. Een berekening leert dat Meijers niet minder dan vijfentwintig organisaties of personen heeft geraadpleegd - de leden van de subcommissie Burgerlijk Recht niet meegerekend - waarmee hij de concepten in zo'n vijftig vergaderingen, alle bij hem thuis, doornam. Met ingang van $1952 \mathrm{kreeg}$ Meijers van Justitie dan ook een vergoeding voor representatiekosten omdat hij, zoals de toelichting op dat besluit meldt, "de leden van de door hem geraadpleegde commissies een koffietafel aanbiedt, teneinde de besprekingen te versnellen." 
SCHEMA OVERLEG BOEK 7

titel

7.1 Koop en ruil

7.2 Verbruikleen

7.3 Schenking

7.4 Huur

7.5 Pacht

7.6 Bruikleen

7.7 Opdracht

7.8 Uitgeversovereenkomst

7.9 Bewaargeving gesprekspartners

datum

Kamer van Koophandel te Amsterdam 20-09-51 en Rotterdam; 4 financierings-

14-11-53 maatschappijen; Van Brakel

Van Brakel/Drion

04-11-53

Drion

$14-11-53$

Ned. Bond van huis- en grondeige- 25-01-52 naren; Vakgroep Onroerende Zaken; Commissie v. Middenstandsvakcen28-03-52 $19-06-52$ trales; Not. Broederschap; Ver.v. 04-07-52 Bestuurders v. Instellingen tot 29-10-52 exploitatie van Onroerende Goede$12-10-52$ ren; Ver.v. Directeuren v. Instellingen tot financiering van Onroerende Zaken; Van Brakel/Drion, Eggens en mevr. Schonfeld

Beekhuis

14-10-50

21-10-50

04-11-50

02-12-50

$19-12-50$

Van Brakel/Drion, Belinfante

04-11-53

Unie van Handelsreizigers-organi-

14 en 15 saties; Kamer van Koophandel te maart' 52 Amsterdam en Rotterdam; Vereeni20-10-52 ging voor den Effectenhandel; Belinfante/Loeff

Vereniging van Letterkundigen;

01-02-52 Ned.Uitgeversbond; J.C.van Oven; mevr. Schonfeld

Horecaf; Bovag; KNAC; ANWB; Van Brakel/Drion 
7.10 Vervoers- en expeditieovereenkomst

7.11 Arbeidsovereenkomst

7.12 C.A.O.

7.13 Aanneming van werk

7.14 Vennootschap

7.15 Borgtocht

7.16 Vaststellingsovereenkomst

De Jong/Van Brakel en Drion

Stichting van de Arbeid;

De Gaay Fortman

Raad van Bestuur Bouwbedrijf;

Commissie-Groen (uit de R.v.B.

Bouwbedrijf); Commissie tot herziening van A.V. voor de bouwnijverheid; Beekhuis, Visser van IJzendoorn

De Gaay Fortman/Van Vrijberghe, Van der Grinten

14 en 15 febr ' 52

N.V. Nationale Borgmaatschappij; De Jong en Bregstein/Van Brakel

03-07-52 03-07-52

10-12-51 $12-02-52$ 04-11-52

De Jong en Bregstein/Van Brakel en Dorhout Mees

10-12-51 03-07-52

subcommissie Handelsrecht zekering

7.19 Lijfrente

7.20 Persoonsverzekering
Verzekeringskamer en het verzekeringsbedrijf
10-12-51

03-07-52

19-06-53 zekeringsbedrijf; De Jong en

Dorhout Mees/Van Brakel, Belinfante

27 april, 4 en 5 mei' 53 , 18 en 19 juni en 24-10-53 
De rapportage werd verzorgd door enkele leden van de subcommissie Burgerlijk Recht (hier aangegeven met een streep), die voor deze gelegenheid was opgesplitst in een vijftal ondercommissies. Bij enkele daarvan werd ook een lid van de subcommissie Handelsrecht uitgenodigd. Achter de opstaande streep (/) is de naam vermeld van degene(n) die de tegenrapportage heeft (hebben) verzorgd.

Van titel 7.5 zijn geen stukken aanwezig. De Pacht behoorde niet tot de bevoegdheid van Meijers en was uitbesteed aan een speciale commissie. Desalniettemin heeft Meijers een niet onbelangrijk aandeel gehad in de herziening van de Pachtwet (Wet van 23 januari 1958, Stb. 37), hetgeen onder meer blijkt doordat hij maar liefst vijf vergaderingen wijdde aan het omwerken van het door de commissie opgestelde ontwerp. Met betrekking tot het Wissel- en Chequerecht (titels 20 en 21) kon Meijers volstaan met het overnemen van de desbetreffende bepalingen uit het Wetboek van Koophandel, omdat deze materie geheel wordt beheerst door internationale verdragen. ${ }^{16}$

\section{Stand van zaken in juni '54}

Hierboven werd reeds aangestipt dat het overleg over Boek 7 half november 1953 werd beëindigd. Dat betekende niet dat het ontwerp voor het zevende groene Boek op dat moment ook "af" was. Meijers, die zich na het afronden van het overleg over Boek 7 volledig had gestort op het toelichten van Boek 1, het aanpassen van de toelichting op de Inleidende titel en het omwerken van de regeling voor het registerpandrecht (beide laatste punten in verband met de door de Kamer gegeven beschouwingen naar aanleiding van de vraagpunten), had bijvoorbeeld voor nog geen enkele titel een toelichting ontworpen. ${ }^{17}$ Daarnaast waren sommige van de in november besproken teksten nog niet volledig gereed, omdat enkele van de opmerkingen die tijdens die vergaderingen naar voren waren gebracht nog nader moesten worden uitgewerkt. Tenslotte was er een aantal punten ten aanzien waarvan Meijers de beslissing had aangehouden, vermoedelijk omdat hij er nog niet geheel uit was. Het ging daarbij met name om de regeling van de huur, die nogal kritisch was ontvangen door de organisaties van verhuurders, omdat zij een belangrijke verbetering van de positie van de huurder inhield (verbetering art. 1603 B.W., regeling onderverhuur, beperking opzeggingsrecht verhuurder) en om het aannemingscontract, dat volgens het bedrijfsleven zou moeten worden aangevuld met een afzonderlijke regeling voor de aanneming van een bouwwerk, iets waarvoor Meijers, gelet op de praktijk van de standaardvoorwaarden, begrijpelijkerwijs weinig voelde. ${ }^{18}$

Hoewel er dus nog het nodige werk moest worden verzet om Boek 7 persklaar te maken, in ieder geval méér dan bij de overige voorontwerpen het geval was ${ }^{19}$,

16. Zie ook de inleidende opmerkingen bij titel 7.19, p. 1203, in het bijzonder het onder I gestelde.

17. De opmerking van Zonderland (Indeling, uitlegging en regeling van overeenkomsten, Groningen 1976 , p. 211) dat "in Meijers' briefwisseling met allerlei belanghebbenden de toelichting grotendeels vast lag", moet dan ook op een misverstand berusten.

18. Vergelijk de "Inleidende opmerkingen" bij titel 7.12, p. 1062 en de daar gegeven literatuur.

19. Zo ook Minister Donker tijdens een bijeenkomst met de subcommissie Handelsrecht, gehouden op 12 juni 1954. Donker verklaarde daar dat hij van plan was de voorontwerpen voor de Boeken 5 en 6 in september 1954 te publiceren. De Boeken 8 en 9 zouden snel volgen, terwijl Boek 7 wellicht 
vermoed ik dat Meijers, als hij zijn werk had kunnen afmaken, toch zeker voor het eind van 1954 gereed zou zijn geweest. Ik wijs daarbij op het volgende.

In de eerste plaats herinner ik eraan dat Meijers ten aanzien van belangrijke delen van zijn ontwerp kon volstaan met het overnemen van bestaande wetgeving of kon beschikken over werk dat door anderen in zijn opdracht was verricht.

Het Benelux-voorontwerp voor de Koop bijvoorbeeld, dat overigens voor een groot gedeelte steunde op een concept van Meijers - op 15 juni 1954 had hij de Beneluxstudiecommissie nog een nieuw ontwerp voorgelegd -, vormde de basis waarop titel 7.1 zou worden opgericht, terwijl de Koop op afbetaling, die pas kort voor de oorlog een plaats had gekregen in het B.W., in beginsel ongewijzigd kon worden overgenomen in verband met Meijers' gedragslijn de resultaten van recente wetgeving zoveel mogelijk te eerbiedigen. ${ }^{20}{ }^{21}$. Ten aanzien van de Verzekeringsovereenkomst, één van de in juridisch opzicht moeilijkste contracten, kon Meijers, zoals reeds aangestipt, beschikken over een ontwerp van Dorhout Mees (tekst met toelichting) dat, voor zover het het schadeverzekeringsrecht betrof, geheel was doorgepraat met de subcommissie Handelsrecht, de commissie uit de bedrijfsgroep Schadeverzekering en de Vereniging voor de vergelijkende studie van Belgisch en Nederlands recht. ${ }^{22}$ De regeling van de vervoers- en expeditie-overeenkomst tenslotte, had Meijers op 31 oktober 1953, toegelicht en wel, van de subcommissie Handelsrecht ontvangen.

Of Levenbach tijdig, dat wil zeggen vóór 1 november 1953, gereed was met de bewerking van de aan hem opgedragen titels, heb ik niet kunnen vaststellen. De dossiers van de titels 7.10 en 11 bevatten slechts stukken die na 1965 zijn opgesteld. Overigens lijkt dat niet waarschijnlijk, gelet op de problemen die later rond beide titels zouden ontstaan.

19. $\rightarrow$

als laatste zou verschijnen. In de Kamer zei Donker: "Ik verwacht dat in ieder geval het Achtste en het Negende Boek niet zo heel veel later kunnen verschijnen. Het Zevende Boek zal wel achteraan komen". (Handelingen Eerste Kamer 1954-1955, p. 2128).

20. Wet van 23 april 1936, Stb. 202. Wel lag het in Meijers' bedoeling de regeling van de Koop op afbetaling en die van de Huurkoop grotendeels tot éen regeling samen te voegen, met uitzondering van de bepalingen die betrekking hebben op het eigendomsvoorbehoud bij Huurkoop. (Vergelijk de notulen van de 144 e vergadering van de subcommissie Burgerlijk Recht van 26 september 1953).

21. Zo ook Minister Donker (handelingen Tweede Kamer 1954-1955, p. 2166): "Wat de Boeken zes tot en met negen betreft, dat zijn grotendeels speciale contracten en min of meer op zich zelf staande onderwerpen. Dat zijn onderdelen van het burgerlijk recht, die geregeld worden naar de algemene beginselen. Daarbij is de regel in acht genomen, dat alles, wat in de laatste 25 jaar herzien is, niet opnieuw wordt opgezet, zodat daar dus veel recht bij is, dat praktisch ten opzichte van het tegenwoordige recht ongewijzigd is en alleen aanpassing heeft ondergaan in terminologie en in ander opzicht aan de opzet van het nieuwe Burgerlijk Wetboek."

22. Meijers diende (zo Dorhout Mees in een schrijven van 19 januari 1954) nog wel een aantal knopen door te hakken, omdat de commissie uit de bedrijfsgroep, die het ontwerp destijds had opgesteld, zich niet in elk opzicht kon verenigen met de wijzigingen die nadien door de subcommissie Handelsrecht waren aangebracht. Dorhout Mees, die van beide commissies lid was, vond het uiteraard minder gewenst zelf een uitspraak te doen. 
Een tweede punt dat van belang is, is dat de tekst, toch het meest kritieke punt in het wetgevingsproces, voor verreweg het grootste deel van de overige bijzondere overeenkomsten - met uitzondering van de schenking alle behorend tot de zogenaamde "kleine contracten" -, vast lag. En ten aanzien van die paar titels waar dat niet het geval was betrof het - de meer politiek getinte problemen rond de aanneming van werk en de huur buiten beschouwing gelaten - steeds een redactioneel probleem, dat, naar mijn oordeel, in de meeste gevallen wel viel op te lossen door nog eens een blik op de notulen te werpen of er een aantal handboeken op na te slaan. P.W. Kamphuisen, die na het overlijden van Meijers de bewerking van een zevental titels kreeg toegewezen, voelde zich dan ook slechts één of twee keer genoodzaakt een door Meijers ontworpen tekst tamelijk ingrijpend te wijzigen, terwijl (zie hieronder) vele teksten van het groene Boek rechtstreeks zijn ontleend aan de concepten van Meijers.

Om kort te gaan, aan het concept voor Boek 7 O.M. ontbrak slechts de toelichting. En aangezien Meijers zich bij de eerste vier groene Boeken al had doen kennen als iemand die streefde naar een zo beknopt mogelijke toelichting, veelal niet meer dan een parafrase van de wetstekst, soms aangevuld met een opsomming van de verschillen tussen het ontwerp en het geldende wetboek, lijkt de gevolgtrekking gerechtvaardigd dat hij dit "klusje" wel binnen een maand of twee zou hebben geklaard. ${ }^{23}$

Het laatste argument tenslotte, ontleen ik aan een opmerking van Kamphuisen, die in zijn voorwoord bij zijn boek over de arbeidsovereenkomst schreef dat Meijers hem op de dag van zijn overlijden, op 25 juni 1954, nog had verzekerd dat Boek 7 "zeer spoedig" zou verschijnen:

"In den zomer van 1954 kwam de onderhavige studie praktisch gereed en op Vrijdag 25 Juni van dat jaar, ter gelegenheid van de vergadering van de Nederlandsche Juristenvereniging te Arnhem, besprak ik aan het déjeuner uitvoerig met Meijers de vraag of ik al dan niet zou wachten op de verschijning van dat deel van zijn Ontwerp B.W., dat de arbeidsovereenkomst zou bevatten. Hij raadde mij sterk aan zulks te doen: al was hij van plan in dit deel van het wetboek zeer weinig veranderingen aan te brengen, ik kon op een zeer spoedige publicatie rekenen en dan zou ik ook de wijzigingen in mijn beschouwingen kunnen betrekken. "24

\section{Het Driemanschap en Boek 7 O.M.}

$\mathrm{Na}$ het overlijden van Meijers rees vanzelfsprekend de vraag op welke wijze en binnen welke termijn de door Meijers nagelaten concepten zouden kunnen worden voltooid. Donker, die, zoals ik hiervoor al schreef, aanvankelijk geen enkele concessie wilde doen met betrekking tot zijn tijdschema, besloot tot een aanpak die ertoe zou moeten leiden dat de Boeken 5-9 hetzij tezamen, hetzij kort na elkaar zouden kunnen

23. Zie ook het "In Memoriam" van Meijers in WPNR 4354 (1954) waarin Van Oven onthulde dat "Meijers verwachtte het resterende deel van zijn ontwerp in September openbaar te kunnen maken."

24. P.W. Kamphuisen, De collectieve en de individuele arbeidsovereenkomst, Leiden 1956. Een andere aanwijzing hiervoor is dat Minister Donker na het overlijden van Meijers op 24 november 1954 aan de Kamer mededeelde "dat volgens afspraken, die ik met hem had gemaakt, het B.W. in ontwerpvorm als Ontwerp-Meijers voltooid zou zijn geweest omstreeks October van dit jaar." (Handelingen Tweede Kamer 1954-1955, p. 2166). 
verschijnen. Dit betekende dat het Driemanschap zich in eerste instantie zou moeten beperken tot het afwerken van de Boeken 5 en 6 - de meest weerbarstige materie. De overige Boeken zouden dan, onder de uiteindelijke verantwoordelijkheid van het Driemanschap, door anderen kunnen worden bewerkt. Door middel van deze werkverdeling hoopte Donker te bereiken dat de voorontwerpen binnen afzienbare tijd - vermoedelijk dacht hij daarbij aan een periode van één á anderhalf jaar ${ }^{25}$ - zouden kunnen worden gepubliceerd.

Met betrekking tot Boek 7 werd besloten de te bewerken stof te verdelen over een aantal juristen. Daarmee werd, aldus Donker in zijn toelichting op dit besluit ${ }^{26}$, in feite voortgebouwd op de weg die Meijers, op een meer beperkte schaal, reeds had ingeslagen.

De lijst van personen op wie een beroep zou worden gedaan werd door Minister Donker tijdens de begrotingsbehandeling van 1955 op 17 november 1954 naar buiten gebracht. Tegen de zin van het Driemanschap overigens, maar de Minister had kennelijk geen zin om nog langer te wachten op de Driemannen, die, hoewel zij al vier maanden in functie waren, er nog steeds niet in waren geslaagd een definitief voorstel te doen met betrekking tot de voor Boek 7 aan te trekken bewerkers. Met deze actie van Donker was verder doorpraten in ieder geval overbodig. ${ }^{27}$

De bewerking van Boek 7 was als volgt geregeld:
1. Koop en ruil
2. Verbruikleen
3. Schenking
4. Huur
5. Pacht
6. Bruikleen

M.H. Bregstein

P.W. Kamphuisen

P.W. Kamphuisen (nadat aanvankelijk Petit was benaderd)

Drion, Eggens en De Jong (nadat aanvankelijk werd gedacht aan Drion alleen)

zou later worden ingevoegd

P.W. Kamphuisen

25. Tijdens de behandeling van de begroting voor 1955 (handelingen Tweede Kamer 1954-1955, p. 2166) beklemtoonde Donker een aantal malen dat de verschijning van de resterende vijf voorontwerpen "een te overziene zaak" was, dat hij hoop had deze ontwerpen "binnen afzienbare tijd te kunnen vertonen".

26. Zitting Tweede Kamer 1954-1955, nr 3700, stuk nr 11, p. 2: "Het inroepen van de medewerking van enige commissies en van enkele rechtsgeleerden voor de voltooiing van de Boeken 8 en 9 is een voortbouwen op de door prof. Meijers ingeslagen weg. Ook hij had de bewerking van die boeken, behoudens dat hij richtlijnen had getrokken en de supervisie bleef uitoefenen, in eerste instantie uitbesteed. Voor Boek 7 had prof. Meijers deze weg slechts voor enkele punten gevolgd; thans is ook voor dit boek op deze weg vrijwel algeheel de keuze gevallen. De verwachting kan worden gekoesterd, dat de ontwerpen voor de Boeken 5-9 hetzij tezamen, hetzij kort na elkaar zullen kunnen verschijnen, doordat verschillende commissies en personen tegelijk verschillende onderdelen bewerken."

27. De notulen van de 22e vergadering (19-11-1954) van het Driemanschap vermelden: "Men is het er niet over eens dat M.v.J. in M.v.A. bij begroting lijst van medewerkers heeft gegeven: onvolledig en prematuur." Donker had het Driemanschap overigens al eerder voor het blok gezet. Toen er problemen rezen over de "bemanning" van de titel Schenking, nam de Minister uit eigen beweging contact op met Kamphuisen, die zich prompt bereid verklaarde ook de bewerking van deze titel op zich te nemen. 
7. Opdracht

8. Uitgeversovereenkomst

9. Bewaargeving

10. Vervoers- en expeditieovereenkomst

11. Arbeidsovereenkomst

12. C.A.O.

13. Aanneming van werk

14. Vennootschap

15. Borgtocht

16. Vaststellingsovereenkomst

17. Spel en weddenschap

18. Verzekering

19. Lijfrente

20 en 21 . Wissel- en chequerecht
M.H. Bregstein

J.C. van Oven

P.W. Kamphuisen

subcie. Handelsrecht

M.G. Levenbach

M.G. Levenbach

P.W. Kamphuisen

P.W. Kamphuisen (nadat Van der Grinten had bedankt)

P.W. Kamphuisen (nadat eerst de keuze was geval len op Wery)

C.W. Star Busmann

De Jong (nadat eerst werd gedacht aan Dorhout Mees)

T.J. Dorhout Mees

T.J. Dorhout Mees

Chr. Zevenbergen

Dat voor deze personen en niet voor andere werd gekozen, spreekt mijns inziens in de meeste gevallen wel voor zichzelf. Dorhout Mees en Levenbach waren reeds door Meijers ingeschakeld, Bregstein had voor Nederland zitting in de Beneluxstudiecommissie tot eenmaking van het recht, Zevenbergen was de bewerker van Molengraaffs Handels- en faillissementsrecht en Kamphuisens naam prijkte op de drie delen "Bijzondere Overeenkomsten" van de Asser-serie.

\section{December 1954: Boek 7 bijna voor de helft gereed}

Omdat Donker, wellicht beter dan wie ook, wist dat de teksten voor het voorontwerp voor Boek 7 naar de voorstelling van Meijers zo goed als vast lagen, bond hij de diverse bewerkers op het hart in de concepten zo weinig mogelijk te veranderen. Het ging hem in de eerste plaats om de toelichting, zoals blijkt uit het volgende schrijven dat iedere bewerker ontving. Franken, die namens het Driemanschap het contact onderhield met de medewerkers aan Boek 7 en tevens belast was met het ordenen van de nalatenschap van Meijers, merkte daarin het volgende op:

"Zoals de Minister U ongetwijfeld reeds heeft medegedeeld, draagt het Driemanschap (de heren Drion, Eggens en De Jong) de uiteindelijke verantwoordelijkheid tegenover de Minister, ook t.a.v. de titels die zij voorlopig bij anderen uitbesteden. Het is dan ook de bedoeling, dat U zoveel mogelijk de door prof. Meijers opgestelde tekst aanvaardt en onveranderd laat. Het gaat in de eerste plaats om de toelichting. Niettemin zullen er stellig in de tekst nog wel evidente onjuistheden of onduidelijkheden voorkomen; U kunt dan aan het Driemanschap een gewijzigd ontwerp aanbieden (en dáárbij de toelichting maken), maar Z. Exc. en het Driemanschap zouden dan gaarne tevens een afzonderlijke nota voor het Driemanschap 
ontvangen, waarin $U$ alle door $U$ aangebrachte tekstwijzigingen vermeldt en zonodig nader toelicht. De Minister en het Driemanschap kunnen dan nader beslissen of de door $U$ aangebrachte amendementen worden overgenomen."

Deze richtlijn bleek in de praktijk uiterst waardevol te zijn. De bewerkers, die, ook dat moet worden gezegd, stuk voor stuk volledig overtuigd waren van de noodzaak van een nieuw Burgerlijk Wetboek ${ }^{28}$, begrepen dat het van het grootste belang was het werk van Meijers zoveel mogelijk intact te laten. Zelfs Van Oven, die er toch bepaald de man niet naar was Meijers kritiekloos te volgen, schreef bij de aanbieding van zijn concept dat hij "overeenkomstig het verzoek en op eigen verlangen de tekst zoveel hij kon onveranderd had gelaten."

Het gevolg van dit alles was dat, zoals het volgende staatje leert, tegen het eind van 1954 bijna de helft van de in Boek 7 op te nemen bijzondere overeenkomsten in drukproef gereed lag.

Gereed waren:

- Verbruikleen (7.2)

- Schenking (7.3)

- Bruikleen (7.6)

- Bewaargeving (7.9)

- Aanneming van werk (7.13)

- Vennootschap (7.14)

- Borgtocht (7.15)

(Kamphuisen leverde zijn laatste concept op 25 november 1954 in)

- Uitgeversovereenkomst (7.8)

(Van Ovens concept dateerde van 10 december 1954)

- Vervoers- en expeditieovereenkomst (7.10)

(Het ontwerp van de Subcommissie Handelsrecht lag sinds 31 oktober 1953 klaar)

Wordt hierbij in aanmerking genomen dat er in het arbeidsovereenkomstenrecht en de C.A.O. "praktisch gesproken zeer weinig nieuws zou komen"29, dat de tekst voor de Kooptitel eventueel rechtstreeks zou kunnen worden ontleend aan de laatste tekst van het Beneluxvoorontwerp, dat hetzelfde gold voor het Wissel- en chequerecht en dat Dorhout Mees nog slechts op een paar punten het advies van de praktijk moest inwinnen, dan blijkt zelfs dat er in december 1954 eigenlijk nog slechts vier titels

28. Kamphuisen bijvoorbeeld, droeg zijn in 1956 verschenen boek over de arbeidsovereenkomst "in eerbied en genegenheid" op aan Donker, "den hartstochtelijken stuwer naar een nieuw Burgerlijk Recht". Dorhout Mees (NJB 1992, p. 9) vond de opdracht aan Meijers een "zeer gunstige ontwikkeling".

29. Volgens Minister Donker, handelingen Tweede Kamer 1954-1955, p. 2166. 
waren waaraan elke vorm van toelichting ontbrak: Opdracht, Huur, Vaststellingsovereenkomst en Spel en Weddenschap.

Het voordeel van deze aanpak van Donker was dus evident, zij het dat de zaak er zonder Kamphuisen vermoedelijk geheel anders had voorgestaan. Zijn prestatie is natuurlijk zonder meer voorbeeldig, temeer omdat hij, ondanks dat hij geen lid was van de subcommissie Burgerlijk Recht en dus ook nooit betrokken was geweest bij de discussie over Meijers' concepten, in iets minder dan drie maanden ${ }^{30}$ er in slaagde zeven titels, waaronder de naar verhouding zware titels Aanneming van werk en Borgtocht, af te werken. Donker wist deze prestatie dan ook naar waarde te schatten en schreef Kamphuisen op 2 december een persoonlijk briefje waarin hij hem zijn "zeer grote erkentelijkheid en waardering betuigde." Met name de slotzin, karakteristiek voor Donker, is het waard om aan de vergetelheid te worden ontrukt:

"In het bijzonder heeft de grote snelheid, waarmede U deze omvangrijke arbeid heeft volbracht, mij ten zeerste getroffen. Mogen allen, die betrokken zijn bij dit werk, een zelfde voortvarendheid betrachten! ${ }^{n 31}$

Misschien zal nu iemand opmerken: de kwaliteit van het afgeleverde werk zal er dan ook wel naar zijn geweest. Het tegendeel is echter het geval. Van Ewijk, die in opdracht van Donker een oordeel moest geven over de concepten van Kamphuisen, althans van die voor één van de titels - hij beperkte zich tot de Borgtocht - vatte zijn bevindingen als volgt samen:

"Mijn conclusie is, dat de concepten het Driemanschap een voortreffelijke basis bieden voor wat betreft verreweg de meeste bepalingen van de bijzondere overeenkomsten, doch dat zij begrijpelijkerwijs de sporen tonen van het feit, dat prof. Kamphuisen aan de behandeling van het ontwerp niet van het begin af heeft deelgenomen. Het komt mij voor, dat dit bezwaar bij de bewerking van het tweede gedeelte van het algemene deel (Boek 6) sterker zou gelden dan bij die van de bijzondere overeenkomsten (Boek 7). ${ }^{32}$

Alle hulde dus voor Kamphuisen. Niets stond, zo meende ook Donker, die op 16 maart 1955 de andere bewerkers aanschreef met het verzoek hun bewerking te voltooien en de resultaten van hun werk voor 1 mei in te leveren, aan een spoedige publicatie van het zevende groene Boek in de weg. ${ }^{33}$ Immers, doordat er slechts hier

30. Op 31 augustus 1954 werd een begin gemaakt met het verzenden van dossiers van Meijers met betrekking tot de door Kamphuisen af te werken titels.

31. Overigens legde Kamphuisen, die bij de AKU (AKZO) werkte, niet alleen op het gebied van het nieuwe B.W. een verrassend grote activiteit aan de dag. De bewerking van zijn drie delen van de Asser-serie volvoerde hij bijvoorbeeld in twee jaar.

32. Nota van 15 november 1954. Zie ook de bijlage bij dit hoofdstuk, waarin een aantal overeenkomsten en verschillen tussen de teksten van Meijers, Kamphuisen en het zevende groene Boek worden behandeld.

33. De brief van Donker luidde als volgt: "Reeds het vorig jaar mocht ik de resultaten van de bewerking van een aantal van die onderdelen (van Boek 7) in de vorm van teksten en toelichtingen 
en daar iets gewijzigd was in de tekst, zou de afstemming op Boek 6, waarvoor Meijers een vrijwel complete set teksten en toelichtingen had nagelaten, een fluitje van een cent zijn. Het was slechts wachten op het Driemanschap.

\section{Tussen 1955 en 1961}

Tot wanhoop van alles en iedereen die de hercodificatie een goed hart toedroeg, slaagde het Driemanschap er niet in binnen een redelijke termijn met een acceptabel ontwerp voor de dag te komen, laat staan dat men tijd vond de concepten van anderen te beoordelen. Het gevolg daarvan was dat het werk aan Boek 7 én aan de Boeken 8 en 9 volkomen stil kwam te liggen en dat de concepten langzaam maar zeker verouderden. Bovenal verloren zij echter aan bruikbaarheid doordat het Driemanschap in Boek 6 O.M. nieuwe wegen insloeg.

Eén van de eersten die met deze problemen werd geconfronteerd, was Minister Donker zelf. De Minister, die bij de begrotingsbehandeling van 1955 nog tamelijk optimistisch was geweest in zijn prognose ten aanzien van Boek 7 - en terecht, want Kamphuisen zou de dag na het debat zijn zevende en laatste titel inzenden - moest de Kamer een jaar later mededelen dat, in tegenstelling tot eerdere berichten, van publicatie voorlopig nog geen sprake kon zijn:

"De uiteindelijke vormgeving kan eerst aan de orde komen, wanneer Boek 6 zal zijn voltooid. Alsdan zal veelal overleg tussen de medewerkers en het Driemanschap nodig zijn. De bewerking van geen der onderdelen, die aan bepaalde medewerkers zijn toevertrouwd, kan dus als afgesloten worden beschouwd." 34

Anderhalf jaar later, Minister Samkalden stond toen aan het roer, wilde het Departement zelfs geen voorspelling meer doen over het tijdstip waarop Boek 7 O.M. zou verschijnen: "Van een prognose omtrent de resterende boeken van het nieuwe Burgerlijk Wetboek zou de ondergetekende zich voorlopig nog willen onthouden. "35 Alle aandacht ging uit naar de problemen rond de voorbereiding van Boek 6 O.M. Na 1957 zweeg de toelichting bij de begroting dan ook geheel over het lot van de nog ongepubliceerde delen van Meijers' ontwerp.

33. $\rightarrow$

ontvangen. Ik zou het van groot belang achten, indien de rechtsgeleerden, die met een onderdeel nog niet zijn gereedgekomen, de bewerking daarvan thans zouden willen voltooien en mij de teksten voor 1 Mei a.s. zouden willen doen toekomen."

34. Zitting Tweede Kamer, 1955-1956, nr 4100, stuk nr 10, p. 6. Opmerkelijk is dat deze passage kennelijk op verzoek van het Driemanschap werd opgenomen. De notulen van de $89 \mathrm{e}$ vergadering van 3 november 1955 vermelden namelijk met enige nadruk dat de Driemannen zich niet alleen competent achten ten aanzien van Boek 6, maar dat het ook aan hen is het werk van de andere ontwerpers te voltooien. Het lijkt er daarom op alsof Drion c.s. door middel van deze uitspraak hebben willen aangeven dat het tempo waarin de resterende groene Boeken zouden worden gepubliceerd primair een zaak was van het Driemanschap en niet van de Minister.

35. Zitting Eerste Kamer 1956-1957, nr 4500, stuk nr 88b, p. 8. 
De gang van zaken met betrekking tot het algemeen deel van het verbintenissenrecht bezorgde niet alleen Minister Donker en diens opvolgers de nodige hoofdbrekens. Ook voor de diverse bewerkers, die veelal met opoffering van al hun vrije tijd er in waren geslaagd de ontwerpen van Meijers tijdig te voltooien, betekende het uitstel in de afwerking van Boek 7 en alles wat daarmee samenhing, een weinig plezierige verrassing.

Kamphuisen bijvoorbeeld, rekende er vast op dat het voorontwerp voor Boek 7 in de loop van 1955 zou kunnen verschijnen en hield daarom de publicatie van zijn boek, gewijd aan de arbeidsovereenkomst, nog eens een half jaar tegen, nadat hij dat al eerder voor Meijers had gedaan. Eind 1955 was er echter nog geen enkel teken dat erop wees dat het voorontwerp voor Boek 7 spoedig zou verschijnen, zodat hij zich tenslotte maar tot het Driemanschap wendde. Daar kreeg hij, ongetwijfeld tot zijn niet geringe verbazing, het advies zijn boek toch maar te publiceren. ${ }^{36}{ }^{37}$

Ook Zevenbergen, de auteur van het wissel- en chequerecht, zal met gemengde gevoelens hebben teruggekeken op deze fase van zijn werk aan Boek 7. Nadat hem eerst door Donker de stuipen op het lijf waren gejaagd met het verzoek zijn werk vóór 1 mei 1955 af te ronden, iets waarin hij, ten koste van grote inspanningen nog bijna slaagde ${ }^{38}$, bleef zijn concept bijna een jaar onaangeroerd liggen op het Departement: pas op 4 april 1956 ontving hij de drukproeven. En alsof dat nog niet erg genoeg was, was bij de stukken een briefje van Franken gevoegd, dat erop neer kwam dat hij zich de moeite om tijdig gereed te komen beter had kunnen besparen:

"Zeer tot mijn spijt heb ik door vele drukke werkzaamheden de afwerking van de drukproeven geheel uit het oog verloren. (...) Overigens is er thans uit zakelijk oogpunt geen bijzondere spoed meer vereist bij de afwerking van uw voorontwerpen voor de titels 7.20 en 7.21, aangezien de laatste tijd is gebleken dat de voorbereiding door het Driemanschap van een ontwerp voor het Zesde Boek (algemeen deel verbintenissenrecht) aanzienlijk meer tijd zal vergen, dan aanvankelijk werd verwacht, zodat het nog vrij geruime tijd zal duren voordat het

36. Notulen van de $92 \mathrm{e}$ vergadering van het Driemanschap van 5 december 1955. De volgende woorden uit het voorwoord van "De collectieve en de individuele arbeidsovereenkomst", Leiden 1956, herinneren daar nog aan: "Toen echter in den loop van 1955 duidelijk werd, dat de voltooiing van het Ontwerp-B.W. belangrijk meer tijd zou vorderen dan oorspronkelijk was gehoopt, heb ik, na overleg met diverse instanties, gemeend niet langer [met publicatie] te mogen wachten."

37. Op het gezicht van Losecaat Vermeer, indertijd door Meijers als rapporteur ingeschakeld bij de voorbereiding van de Borgtocht, moet ongeveer dezelfde uitdrukking te lezen zijn geweest. Toen deze, ongerust geworden door het uitblijven van Boek 7 O.M., begin 1957 contact opnam met het Driemanschap met de vraag welke plannen men had ten aanzien van deze titel, kreeg hij ten antwoord dat men voorlopig nog de handen vol had aan de bewerking van de concepten voor Boek 6 . Zijn vrees, dat de opvolgers van Meijers druk doende waren de concepten voor Boek 7 ingrijpend te herzien, was dus ongegrond.

38. De concepten voor de tekst van de titels 7.20 en 21 voltooide Zevenbergen op 21 juli 1955, de respectievelijke toelichtingen bereikten het Ministerie op 18 augustus 1955 . Met uitzondering van de huur (D-E-J), de opdracht (Bregstein), de vaststellingsovereenkomst (Star Busmann) en spel en weddenschap (De Jong) lag dus voor elke titel een concept-tekst en -toelichting gereed. 
Driemanschap zich zal kunnen zetten aan het Zevende Boek in het algemeen en het wissel- en chequerecht in het bijzonder. ${ }^{139}$

Het wonderlijkste verhaal, dat laat zien hoezeer het Driemanschap het overzicht over het geheel was kwijtgeraakt, komt echter van Van Oven. Nadat deze zijn ontwerp en toelichting voor titel 7.8 (uitgeversovereenkomst) had ingezonden, besloot hij dat het een goede gedachte zou zijn indien de Adviescommissie voor het Auteursrecht, die indertijd was belast met het afwerken van Meijers' concept voor titel 9.1 (Auteursrecht), er nog eens naar zou kijken. Aldus geschiedde, en naar aanleiding van deze gedachtenwisseling zond Van Oven op 16 juni 1955 aan het Departement een aantal nota's met wijzigingen in ontwerp en toelichting, bestemd om te worden verwerkt in de tweede drukproef die in voorbereiding was. Vervolgens werd het volkomen stil rond deze titel.

Pas in november 1961, toen Van Oven werd gevraagd zijn concept om te werken in verband met de verschijning van het groene Boek 6 , kwamen de concepten weer boven water. Dat was overigens geen verdienste van het Departement: Van Oven zélf moest De Jong er aan herinneren dat er nog materiaal lag voor een nieuwe drukproef. Zes jaar lang had zijn werk dus onaangeroerd gelegen, zes jaar lang had hij in onzekerheid verkeerd over het lot van zijn ontwerp. Een ander zou vermoedelijk voor de eer hebben bedankt opnieuw te worden ingeschakeld.

Tussen 1955 en 1961 is er dus zeer weinig gebeurd aan het Zevende Boek. ${ }^{40}$ Het werk aan de concepten voor Boek 6 O.M. hield dermate op, dat het Driemanschap zelfs geen poging deed enige lijn te brengen in de organisatie rond Boek 7. In feite was de inschakeling van het trio ook in dit opzicht vanaf het eerste begin een mislukking. Het volgende voorbeeld onderstreept dat nog eens.

Toen in november 1954 de Staatsdrukkerij het Driemanschap begon te bestoken met drukproeven van de door Kamphuisen voltooide titels, besloot men, gedwongen door tijdgebrek, de concepten in eerste instantie niet zelf te beoordelen, maar vooraf advies te vragen aan M.G. de Baat, een jurist die bij Unilever werkte en die in oktober 1954 was toegetreden tot de Staatscommissie. De Baat accepteerde en op 11 november 1954 ontving hij drukproeven van de vijf titels die Kamphuisen inmiddels had afgewerkt. De resterende twee (Bewaarneming en Aanneming van werk) zouden worden nagezonden zodra Kamphuisen de bewerking daarvan zou hebben voltooid, zo werd De Baat op 19 november medegedeeld.

39. Een maand later, op 3 mei 1956, schreef Franken aan Dorhout Mees: "Ik moet u berichten dat is gebleken dat de nagelaten concepten van prof. Meijers voor Boek 6 in nog zeer onvolkomen staat verkeerden, zodat het waarschijnlijk nog wel geruime tijd - om de gedachten te bepalen: ik schat in de loop van het volgende jaar - zal duren voordat het Driemanschap een ontwerp voor dit boek zal kunnen publiceren."

40. Als ik het goed heb gezien, zijn de wapenfeiten van het Driemanschap met betrekking tot Boek 7 tot de volgende drie beperkt gebleven: begin juni 1955 produceerde De Jong een aantal glossen op de titels Aanneming van werk en Borgtocht "... deze titels zijn natuurlijk nog lang niet aan de orde, maar ik laat de opmerkingen die ik bij doorlezing heb gemaakt, voor mijn eigen gemak vermenigvuldigen", terwijl Drion op 18 april 1956 en op 12 oktober 1956 een "Proeve van redactie voor titel $7.2^{\prime \prime}$ binnen het Driemanschap liet rondgaan. 
Een week later, op 25 november, was het inderdaad zover: Kamphuisen leverde de twee nog ontbrekende titels in. De Baat zou ze echter nooit onder ogen krijgen. Het Departement vergat eenvoudigweg de stukken op de bus te doen. ${ }^{41}$ Niet dat dat erg was overigens. Het Driemanschap heeft, verdiept als men was in de eigen problemen, nog geen regel uit de rapporten van De Baat gelezen. Pas in 1961, toen een nieuw begin werd gemaakt met het werk aan Boek 7 , kwamen zij voor het eerst ter spra$\mathrm{ke.}^{42}$

Het werk aan Boek 6 O.M. stond niet alleen de afwerking van de reeds gereedliggende ontwerpen in de weg. De nog niet voltooide titels deelden hetzelfde lot. Omdat de Driemannen als gevolg van tijdgebrek of gebrek aan eensgezindheid de beslissing over netelige vragen maar voor zich uitschoven, had het ook geen zin om informatie in te winnen of door te werken op basis van voorlopige concepten. Twee voorbeelden.

Star Busmann, die naar aanleiding van de oproep van Donker het Driemanschap op 21 maart 1955 berichtte dat hij met betrekking tot bepaalde punten overleg wenste voordat hij zich kon zetten aan de voltooiing van zijn concept, kreeg van de heren ten antwoord dat hij de zaak voorlopig maar moest laten rusten omdat zij geen kans zagen hem op korte termijn van advies te dienen. Hij zou verder nooit meer iets horen.

Iets dergelijks overkwam ook Dorhout Mees. Toen deze begin mei 1956 zover was dat hij de bewerking van de titels 7.17 en 18 wilde afsluiten en in verband daarmee antwoord wenste op de vraag hoe in het voorontwerp voor Boek 6 de natuurlijke verbintenis zou worden geregeld, schreef De Jong dat hij in de toelichting voorlopig maar niet te veel over dit onderwerp moest zeggen: het Driemanschap had de behandeling van dit "netelige" onderwerp na een voorlopige bespreking uitgesteld totdat men het gehele verbintenissenrecht zou hebben doorgewerkt. De Jong vond het in verband daarmee niet raadzaam Drion en Eggens reeds nu met deze zaak lastig te vallen. ${ }^{43}$ Kortom, Dorhout Mees moest zelf maar zien hoe hij de zaak oploste. Later zou dan blijken of zijn arbeid zinvol was geweest.

De werkwijze van het Driemanschap was niet alleen funest voor het tempo waarin de afwerking van Boek 7 zich voltrok. Doordat men steeds verder afweek van de concepten van Meijers ging ook langzaam maar zeker het verband met de overige delen van het ontwerp verloren. Het voorbereidende werk dat reeds was verricht verloor daardoor grotendeels zijn waarde.

41. De opmerking van De Jong - zie de Aanbiedingsbrief bij Boek 7, sub 3 (Parl. Gesch. Boek 7, p. 1) - als zou De Baat alle concepten van Kamphuisen hebben becommentarieerd, is dan ook onjuist.

42. Achteraf bekeken is het daarom enigszins lachwekkend dat het Driemanschap van De Baat wèl de toezegging verlangde dat hij uiterlijk op 1 februari 1955 met zijn werk gereed zou zijn.

43. Briefwisseling d.d. 15 en 31 mei 1956. Eerder, naar aanleiding van de oproep van Donker, had Dorhout Mees ook al zijn verbazing uitgesproken over de organisatie van het werk aan het nieuwe B.W. Uit zijn brief van 28 maart 1955: "Het is niet ondenkbaar dat ik vóor 1 Mei 1955 gereed kom. Maar hoe staat het dan met het overleg met het Driemanschap en het toetsen aan het nog vast te stellen Boek 6 ? Ik blijf het hoogst ondoelmatig achten deze beide handelingen niet te verrichten voordat ik mijn werk inzend. Zou ik dit toch moeten doen, dan zou ik over enige tijd met een voorstel tot wijziging moeten komen." 
Het kan niet anders, of dit moet voor ieder van de bewerkers een onaangename ervaring zijn geweest, een gegeven ook dat het enthousiasme voor het optreden van het Driemanschap bepaald niet bevorderde en zeker geen stimulans was om wetgevend werk ter hand te nemen. Toen Dorhout Mees na het overlijden van Bregstein in 1957 werd gevraagd om plaats te nemen in de Beneluxcommissie en tevens het verzoek kreeg de bewerking van de titel Koop op zich te nemen, de titel die wellicht meer dan enig andere aanrakingspunten met Boek 6 heeft $^{44}$, weigerde hij dan ook beleefd maar beslist. "Het lijkt mij in tegendeel rationeel", zo liet hij een verblufte Minister Beerman weten, "mij eerst zoveel mogelijk te oriënteren in de Beneluxcommissie. Voorts schijnt het mij zinloos, een voorlopig ontwerp te gaan opstellen, zolang ik niet ten minste over een voorlopig ontwerp voor Boek 6 kan beschikken. ${ }^{45}$

Omdat het Driemanschap zich bereid verklaarde de voorlopige concepten voor Boek 6 O.M. aan Dorhout Mees te sturen en de Minister toezegde medewerking te zullen verlenen aan een tijdelijke verlichting van diens onderwijstaak, accepteerde hij na enig aandringen toch de uitnodiging om zitting te nemen in de Benelux-commissie tot eenmaking van het recht. Ook dat werk zou hem echter op een teleurstelling komen te staan, want ofschoon hij regelmatig contact had met de Driemannen, kon hij niet verhinderen dat zij een geheel eigen koers gingen varen. Eind 1959 moest Dorhout Mees dan ook tot zijn spijt verklaren dat het ontwerp voor Boek 6 O.M. aan een verdere deelname van het Benelux-overleg in de weg stond. ${ }^{46}$ En dat, terwijl Bregstein nog in april 1957 het Driemanschap ervoor had gewaarschuwd niet te veel te veranderen in Boek 6: de voorlopige tekst van de Benelux-koop zou niet belangrijk verschillen van het concept van Meijers voor titel 7.1 en diens ontwerp voor Boek 6.47

\section{De herverkaveling}

Nadat begin januari 1961 duidelijk werd dat het Driemanschap met het zesde Boek zo ver gevorderd was dat de publicatie van het groene Boek in september 1961 mocht worden verwacht, besloot Minister Beerman dat de tijd was aangebroken om zich te beraden over de wijze waarop de afwerking van de overige delen van het OntwerpMeijers zou moeten worden georganiseerd. Voor Boek 7 viel de keuze op een bewerking van de onderscheidene titels door verschillende rechtsgeleerden, een besluit waarmee Beerman voortbouwde op de reeds door Donker ingeslagen weg.

Aan dit besluit lagen de volgende overwegingen ten grondslag. In de eerste plaats voelde het Departement er weinig voor om de samenwerking met het Driemanschap op dezelfde wijze voort te zetten. Alleen al voor het voltooien van het zesde Boek hadden de Driemannen 225 vergaderingen nodig gehad, hetgeen inhield dat gemiddeld nog minder dan één artikel per vergadering was behandeld. Voor de afwerking van

44. Zie A.S. Hartkamp, Titel 7.1 (koop en ruil) van het nieuwe Burgerlijk Wetboek, Ars Aequi 1990 , p. 295 e.v.

45. Brief van 24 oktober 1957.

46. Notulen van de 243 e vergadering van het Driemanschap van 28 oktober 1959. Deze opmerking was voor het Ministerie het sein de touwtjes wat strakker in handen te nemen. Het Driemanschap bracht bijgevolg een aantal aanpassingen aan, waardoor het Beneluxwerk weer kon worden hervat.

47. Notulen van de 151 e vergadering van het Driemanschap van 4 april 1957. 
het voorontwerp voor Boek 7, zou, in verband met de grotere omvang en het specialistische karakter van dit Boek, vermoedelijk eens zoveel tijd en overleg vereist zijn, hetgeen een zeker einde van de hercodificatiepoging zou betekenen. ${ }^{48}$

Daarbij kwam, dat De Jong, die grote moeite had met het tempo waarin de hercodificatie zich voortbewoog, er niets voor voelde de rest van zijn arbeidzame leven op te offeren aan het werk aan het nieuwe Burgerlijk Wetboek. Nadat hij zijn aandeel in Boek 6 in september 1957 min of meer had beëindigd, had hij dan ook te kennen gegeven als Drieman ontslag te willen nemen zodra Boek 6 gereed was. ${ }^{49}$ Daarmee behoorde een voortzetting van het Driemanschap ook tot de feitelijke onmogelijkheden. Minister Beerman zou tijdens de begrotingsbehandeling van 1962 dan ook verklaren dat het Driemanschap met het tot stand komen van Boek 6 een zodanige mijlpaal had bereikt, dat het zowel hem als het Driemanschap wenselijk leek, voor de rest van het Burgerlijk Wetboek een andere procedure te volgen. ${ }^{50}$

Een tweede factor die een rol speelde bij het besluit het Driemanschap te ontbinden, was de overweging dat het hoogst gewenst was dat Drion zich geheel zou kunnen concentreren op zijn functie van Regeringscommissaris. De totstandkoming van het voorontwerp voor Boek 6 had al veel te lijden gehad van zijn werk in het kader van de parlementaire behandeling van de Boeken 1 en 2 en Justitie wilde, als het even mogelijk was, een herhaling van die situatie voorkomen. Een voorwaarde daarvoor was wel dat De Jong bereid zou zijn om op te treden als coördinator voor Boek 7 om het contact te onderhouden met de verschillende bewerkers en te zorgen voor de uiteindelijke afwerking, een uitnodiging die hij na enig beraad aanvaardde. ${ }^{51}$

48. Zie ook de aanbiedingsbrief, Parl. Gesch. Boek 7, p. 1, waar De Jong schreef dat de te behandelen stof dermate omvangrijk was, dat bewerking door een commissie al te veel tijd zou hebben gevergd.

49. Aldus Belinfante in een nota over de positie van De Jong van 29 januari 1960.

50. Handelingen Tweede Kamer 1961-1962, p. 2142. Dat de houding tussen Ministerie en Driemanschap in de loop der jaren enigszins was bekoeld, kan wellicht ook worden afgeleid uit de ontvangst die het voorontwerp voor Boek 6 op het Departement kreeg. Van Ewijk schreef, kortaf: "Gisteren (7 november 1961) is de definitieve proef naar de vaste Commissie voor Justitie gezonden. De taak van het Driemanschap als college is voltooid, al zullen zijn leden nog wel betrokken worden bij de bewerking ten departemente van het regeringsontwerp van dit boek. U zoudt nu, naar het mij lijkt, twee dingen kunnen doen: een officiële bedankbrief aan de heren òf een laatste bijeenkomst met het college om de heren te bedanken. Wellicht verdient dit laatste de voorkeur."

51. Uit een verslag van een bespreking tussen Minister Beerman en het Driemanschap op 20 februari 1961: "Vervolgens brengt de Minister in bespreking het Zevende Boek. Hiervan zijn belangrijke gedeelten uitbesteed. Het lijkt gewenst ditzelfde te doen met de nog niet uitbestede gedeelten, met name met de belangrijke titel over de Koop. De Minister stelt zich voor, dat dan iemand zou moeten optreden als coördinator om het contact te onderhouden met de verschillende bewerkers en te zorgen voor de uiteindelijke afwerking. De heer De Jong stelt voor, dat de heer Drion ontheven zal worden van de voorbereidende werkzaamheden bij het Zevende Boek, opdat hij zich zo intensief mogelijk zal kunnen bezighouden met zijn taak als Regeringscommissaris. De heer Drion gaat daarmee akkoord. De Minister vraagt of de heer De Jong de coördinator zou willen zijn. De heer De Jong verzoekt dit nog in overweging te mogen nemen. Prof. De Grooth stelt voor dat één en ander door de leden van het Driemanschap nog onderling wordt besproken."

Een brief van Beerman aan de oud-medewerkers van Boek 7, gedateerd 14 november 1961, schept nog meer duidelijkheid: "Mede met het oog op het vele werk dat prof. Drion wacht als commissaris (..), heb ik mr. De Jong verzocht de coördinatie van de verdere bewerking der ontwerpen voor Boek 
Een derde overweging om de samenstelling van het voorontwerp voor Boek 7 niet toe te vertrouwen aan het Driemanschap, maar de stof te verdelen over een aantal juristen, was dat Minister Beerman het gewenst vond om alle universiteiten bij het werk aan het nieuwe Burgerlijk Wetboek te betrekken. De populariteit van de hercodificatiepoging was als gevolg van de problemen rond Boek 6 tot een onaanvaardbaar dieptepunt gedaald en door nu tal van vooraanstaande juristen in te schakelen hoopte Beerman weer iets van het oude enthousiasme terug te winnen.52 Dit gegeven verklaart ook waarom in sommige gevallen de keus viel op juristen zonder noemenswaardige praktijkervaring, hoewel het contractenrecht in het algemeen bij uitstek het terrein van practici is.

Tenslotte moest de Minister ermee rekening houden dat sinds het overlijden van Meijers tal van titels waren uitbesteed. Ook daarom besloot hij, althans wat betreft dit aspect van de zaak, vast te houden aan de door Donker uitgezette gedragslijn.

Het aanzoeken van de personen die in aanmerking zouden komen de bewerking van één of meer titels op zich te nemen, kostte enige moeite, maar eind december 1961 was het plaatje toch rond. Het zag er als volgt uit:

\section{Overeenkomsten strekkende tot overdracht van een goed of het genot daarvan:}

Titel 1 Koop en ruil

2 Verbruikleen

3 Schenking

4 Huur

5 Pacht

6 Bruikleen prof. T.J. Dorhout Mees, Utrecht

prof. S.N. van Opstall, Utrecht

prof. J.M. Polak, Wageningen

prof. Ph.A.N. Houwing

mr. P. de Haan, Delft

prof. S.N. van Opstall, Utrecht

II. Overeenkomsten tot het verrichten van arbeid:

7 Opdracht prof. W.C.L. van der Grinten, Nijmegen

8 Uitgeversovereenkomst

9 Bewaargeving

10 Vervoers- en expeditieovereenkomst

11 Arbeidsovereenkomst

prof. J.C. van Oven, Leiden

prof. S.N, van Opstall, Utrecht

Subcommissie Handelsrecht

prof. M.G. Levenbach, Amsterdam

51. $\rightarrow$

7 op zich te willen nemen. Hij heeft zich daartoe bereid verklaard en zal dus - in afwijking van de aanvankelijke opzet waarin deze taak aan het Driemanschap was toegedacht - de uiteindelijke verantwoordelijkheid voor deze ontwerpen tegenover de Minister van Justitie dragen."

52. Tijdens de begrotingsbehandeling van 1962 zei Beerman onder meer: "De heer De Jong heb ik bereid gevonden op te treden als coördinator voor Boek 7. De verschillende overeenkomsten, die in dat Boek zullen worden geregeld, zijn (..) uitbesteed bij vooraanstaande Nederlandse juristen. Men kan met recht zeggen, dat het nieuwe B.W. een nationaal wetboek zal zijn. Professoren en alumni van alle universiteiten zijn hierbij betrokken." (Handelingen Tweede Kamer 1961-1962, p. 2142). 
12 C.A.O.

13 Aanneming van werk

14 Vennootschap prof. G. de Grooth, Leiden

prof. W.C.L. van der Grinten

\section{Andere bijzondere overeenkomsten:}

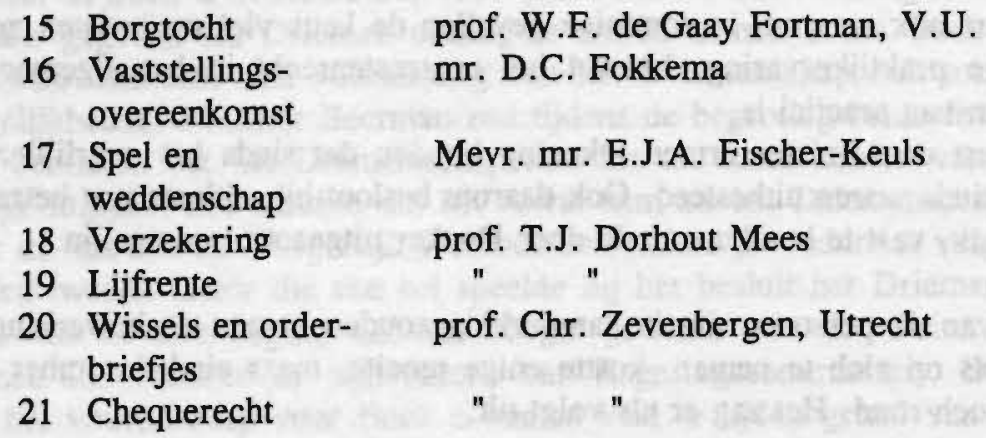

Zoals uit een vergelijking met de eerder gegeven lijst blijkt, werden alle de in 1954 gegeven opdrachten gehandhaafd, met uitzondering van de bewerking van de vaststellingsovereenkomst, die aan Star Busmann was opgedragen. De reden voor deze verandering was dat de Minister de door Star Busmann geleide subcommissie Rechtsvordering van de Staatscommissie wilde inschakelen voor de aanpassing van het Wetboek van Burgerlijke Rechtsvordering aan het vooruit in te voeren eerste Boek van het nieuwe B.W. Star Busmann vond deze cumulatie van taken echter wat al te bezwaarlijk en verkoos rechtsvordering boven de vaststellingsovereenkomst.

Nieuwe namen op de lijst waren die van Houwing, De Haan, Van Opstall, De Gaay Fortman, Van der Grinten, Polak, Fischer-Keuls, Fokkema en De Grooth. Bregstein was in 1957 overleden, Kamphuisen in augustus 1961.

Dat voor de Pacht De Haan boven Houwing werd verkozen, hing daarmee samen dat het Departement het van eminent belang achtte dat Houwing zelf de moeilijke titel Huur op zich zou nemen, terwijl het bij de Pacht voornamelijk zou aankomen op het losmaken van het privaatrecht uit de in 1958 herziene Pachtwet.

Voor de bewerking van de titels Verbruikleen, Bruikleen en Bewaargeving werd in eerste instantie gedacht aan prof. Gerbrandy jr, die echter voor de eer bedankte omdat het verbintenissenrecht niet tot zijn werkterrein als hoogleraar aan de V.U. behoorde. Als gevolg hiervan nam Van Opstall diens plaats in en werd De Gaay Fortman gevraagd de titel Borgtocht op zich te nemen, omdat hij én aan de V.U. verbonden was én in 1962 voor de NJV zou pre-adviseren over de borgtocht.

Van der Grinten dankte zijn uitverkiezing onder meer aan het feit dat hij in 1960 in Themis een zeer gedegen opstel over de titel Gemeenschap had gepubliceerd en vroeger met Meijers had gecorrespondeerd over het nieuwe Burgerlijk Wetboek, terwijl de keuze voor De Grooth is verklaard doordat deze in 1955 de NJV had voorgelicht over de aanneming van bouwwerken en daarbij ook al gebruik had gemaakt van de concepten van Meijers en Kamphuisen. Polak tenslotte, was kandidaat-notaris en goed bekend met het nieuwe Burgerlijk Wetboek, en Fokkema en Fischer-Keuls kregen ieder een titel toegewezen in verband met hun aandeel in het werk aan Boek 
6. Beide laatsten zouden bovendien De Jong assisteren bij zijn coördinatiewerk dat, in verband met zijn aanstaande benoeming tot vice-President bij de Hoge Raad, naar verwachting al zijn vrije tijd zou opvorderen.

Ofschoon De Jong voor zijn werk als coördinator wel aanstonds een vergoeding ontving, werd met de bewerkers van de voorontwerpen voor de verschillende titels niet over een honorarium gesproken. Minister Beerman dacht dit stukwerk te honoreren volgens een puntensysteem naar gelang de omvang en het soortelijk gewicht van de te bewerken titels. Omdat het werk aan Boek 7 echter veel trager zou verlopen dan oorspronkelijk was voorzien, zou het Ministerie pas in 1970 tot een eerste uitbetaling overgaan: een voorschot op het uiteindelijk te ontvangen bedrag. ${ }^{53}$ Franken zei daarover: "Je moest het een eer vinden om dit soort werk te doen. Je had je inkomsten uit andere bronnen. Het lag geheel in de stijl van de tijd om aan betalen niet te denken."

\section{Wijze van bewerking}

Nadat aldus in de herfst van 1961 het merendeel van de medewerkers bekend was, ontving ieder van hen een nota van De Jong, met daarin enkele punten die bij de voorbereiding van het groene Boek 7 in acht zouden moeten worden genomen. ${ }^{54} \mathrm{De}$ verleiding is groot om de gehele nota te citeren, maar ik moet met de volgende passages volstaan. De Jong schreef:

"Zodra één van de medewerkers een concept voor tekst en toelichting gereed heeft, zendt hij dit (liefst in duplo) aan mij toe. Na bestudering van dit concept zal ik dit mondeling met de ontwerper bespreken. Van het tweede concept, dat naar aanleiding van deze bespreking wordt samengesteld, wordt een drukproef gemaakt. Deze drukproef wordt aan het Departement van Justitie gezonden voor advies en wordt tevens ter kennis gebracht van de andere medewerkers. Na ontvangst van het rapport van het Departement wordt door de ontwerper in overleg met mij het definitieve ontwerp gereed gemaakt. Dit laatste kan eerst in een laat stadium geschieden omdat over de definitieve redactie pas kan worden beslist als van alle titels een drukproef aanwezig is. (...)

Ik overweeg nog om de Staatscommissie voor de burgerlijke wetgeving bij de arbeid aan het Zevende Boek in te schakelen, in dier voege dat de leden van de Staatscommissie die tot medewerking bereid zijn, één van de titels toegewezen krijgen om op betrekkelijk korte termijn over het eerste concept een rapport uit te brengen. Dit zal wel enige vertraging meebrengen, maar het geeft meer waarborg dat de problemen van alle kanten bekeken zijn. (...)

Het gevaar dreigt, dat er een zekere onevenwichtigheid zal ontstaan doordat niet alle medewerkers dezelfde opvatting zullen hebben over de vraag hoe uitvoerig de wet en de toelichting behoren te zijn. Hieromtrent zou ik willen opmerken, dat het in de bedoeling van Meijers lag om de regeling van de bijzondere contracten zo

53. Alleen Dorhout Mees, die immers al door Meijers was ingeschakeld, ontving een tussentijdse vergoeding.

54. Nota van 8 november 1961. 
beknopt mogelijk te houden, beknopter dus dan in het geldende B.W. Het lijkt mij gewenst deze gedachte als uitgangspunt te nemen. (...)

Ook voor de toelichting zou ik een grotere beknoptheid willen aanbevelen dan bij de samenstelling van het Zesde Boek is betracht. Op drie punten zou ik echter in dit verband de aandacht willen vestigen: 1e Het is noodzakelijk dat van alle bepalingen van het geldende B.W. wordt vermeld waarom zij wel of niet zijn overgenomen; wordt dit nagelaten, dan komen daarover vragen uit de Tweede Kamer; 2e Bij elk probleem moet de stand van de Nederlandse rechtspraak en litteratuur worden vermeld; $3 e$ In de toelichting op de vorige boeken is in ruime mate aandacht geschonken aan vreemd recht. In hoeverre dat ook bij de bijzondere overeenkomsten moet gebeuren, is niet in het algemeen te zeggen; in ieder geval lijkt het mij gewenst telkens te vermelden hoe de voornaamste wetboeken een probleem hebben opgelost."

Tot zover De Jong.

Eén van de meest opvallende punten aan dit stuk is dat de medewerkers volkomen vrij werden gelaten in hun "bewerking" van de concepten van Meijers. Gold in 1954 nog als richtlijn dat de teksten van Meijers in beginsel ongewijzigd moesten worden overgenomen, nu is daarvan geen spoor meer te ontdekken.

Ten dele hangt deze beleidswijziging uiteraard samen met de ingrijpende bewerking van de concepten voor het zesde Boek, die een aantal materiële en redactionele wijzigingen in de teksten van Meijers voor Boek 7 noodzakelijk maakte. Bovendien had de rechtsontwikkeling intussen niet stilgestaan. Daarnaast was het zo, dat na het overlijden van Meijers en Donker nu eenmaal op een ander tempo was overgeschakeld, terwijl ook de Kamer geleidelijk aan steeds meer werk was gaan maken van haar verslagen. Er was dus in dat opzicht zeker reden de concepten nog eens te bekijken en bijvoorbeeld de toelichting beter te documenteren. ${ }^{55}$ Toch verklaart dit nog niet dat de bewerkers geheel vrij waren naar eigen goeddunken te handelen. Werd deze verandering veroorzaakt doordat De Jong de kwaliteit van het door Meijers afgeleverde werk aanmerkelijk lager waardeerde dan zijn eigen prestaties, met andere woorden er niets voor voelde als slippendrager van Meijers te fungeren? Is dat het geweest? Het is niet onmogelijk. ${ }^{56}$

55. De Jong schreef in dit verband aan Van Oven: "De bedoeling van Minister Donker om het nieuwe B.W. in enkele jaren tot stand te brengen bracht mee, dat de toelichting zo kort mogelijk moest worden gehouden. In overeenstemming daarmee zijn in Uw concept geen verwijzingen opgenomen naar rechtspraak, literatuur en buitenlandse wetgeving. Sinds die tijd is op een ander tempo overgeschakeld en heeft de vaste Commissie blijk gegeven vrij diep op de materie te willen ingaan. Onder deze omstandigheden meen ik, dat de toelichting op Boek 7, zij het in mindere mate dan die van Boek 6, wel enigszins gedocumenteerd behoort te zijn."

56. Dat, zoals Fischer-Keuls in NJB 1974, p. 1409 e.v. stelt, deze koerswijziging een "noodzakelijke consequentie" zou zijn van het feit "dat het Meijers niet gegeven was zijn werk tot rijpheid te brengen, en dat dit ook zo zou zijn geweest als Meijers' concepten zich in een verdergevorderd stadium hadden bevonden", lijkt mij in elk geval niet juist. Wel is die uitlating illustratief voor de opstelling van De Jong - en daarvoor: het Driemanschap. Bovendien blijkt hier nog eens uit dat Drion c.s. er geen rekening mee wensten te houden dat de concepten naar de voorstelling van Meijers wél als definitief werden beschouwd, iets waar het merendeel van de medewerkers, blijkens 
Zeker is in elk geval dat De Jong zeer coulant was. Van der Grinten, die zich niet gelukkig voelde met Meijers' opzet voor de titel Opdracht en De Jong om raad vroeg, kreeg bijvoorbeeld te horen dat hij zich bepaald niet gebonden moest voelen aan de schema's van Meijers: "In het algemeen", zo schreef De Jong, "zijn de schema's die Meijers heeft ontworpen, zeer praktisch gebleken. Bij de bewerking van de Boeken 5 en 6 hebben wij dan ook op zeer ondergeschikte punten de verdeling in titels en afdelingen gewijzigd. Dit neemt niet weg, dat wij aan de opzet die Meijers voor de titel Opdracht heeft gemaakt, volstrekt niet gebonden zijn. Indien je bij de bewerking tot de conclusie komt dat het beter is een andere indeling te maken, dan moet je dat zeker doen." ${ }^{57}$

Een tweede opvallend detail van deze nota is, dat De Jong de methode die Meijers had toegepast bij het vorm geven van Boek 7 in feite nog eens te baat nam. Want hij zou inderdaad een aantal leden van de Staatscommissie inschakelen om over de opnieuw bewerkte concepten een rapportage en een tegenrapportage uit te laten brengen, gevolgd door een gezamenlijke vergadering met de ontwerper, coördinator en rapporteurs. ${ }^{58} \mathrm{Bij}$ mijn weten zijn, anders dan bij Meijers, echter nimmer deskundigen uit de praktijk ingeschakeld, met uitzondering van de verzekeringstitel, waarop J.W. Holleman een lijvig commentaar schreef. De Jong vertrouwde er kennelijk op dat de medewerkers zelf zo verstandig zouden zijn contact met de praktijk te zoeken, iets wat echter, als men de in het archief aanwezige nota's mag geloven, nauwelijks schijnt te zijn gebeurd..$^{59}$

56. $\rightarrow$

de in de BIJLAGE gepubliceerde resultaten van een vergelijking tussen de concepten van Meijers en het groene Boek wel oog voor had.

57. Brief van 28 november 1961.

58. In de aanbiedingsbrief bij het Groene Boek heeft De Jong een overzichtje gegeven van de mensen die optraden als rapporteur en tegen-rapporteur. Ik geef hier het lijstje, gerangschikt naar titel.

7.2 Ch.J.J.M Petit

7.3 Petit

7.4 P. de Haan

7.5 Ph.A.N. Houwing

7.6 Petit

7.7 L.J. Hijmans van den Bergh

7.8 W.G. Belinfante

7.9 Petit
7.13 A.F. Visser van ljzendoorn

7.14 P.H Smits

7.15 ?

7.16 Th. B. ten Kate

7.17 G.J. Wiarda

7.18 J.W.Holleman en J.A.L.M.

Loeff

7.19 ?

7.20 D.C.Fokkema

Over titel 7.1 is nimmer een rapport uitgebracht, doordat de Kooptitel het ontwerp voor de BeneluxKoop vrijwel op de voet volgde. Van de door Levenbach bewerkte titels zijn evenmin nota's van derden aangetroffen, hetgeen vermoedelijk daarmee samenhangt dat Levenbach pas in een laat stadium van zijn titels beviel.

59. Van Ewijk schreef op 13 oktober 1966 in zijn jaarlijkse overzicht van de stand van zaken met betrekking tot het nieuwe Burgerlijk Wetboek: "De meeste titels (van Boek 7) zijn, ook als ik dit niet hierboven heb vermeld, door een lid van de Staatscommissie gerecenseerd. (..) Ik merk nog op dat de bewerkers over het algemeen geen overleg (anders dan incidenteel) met het bedrijfsleven hebben gevoerd: soms is dit vroeger wel door Meijers gedaan. Inzake de Haagse uniforme internationale 
Een laatste opmerking die ik naar aanleiding van deze nota zou willen maken, heeft betrekking op de taak van De Jong zelf. In de aanbiedingsbrief bij het groene Boek benadrukte hij dat zijn aandeel in Boek 7 zeer beperkt was geweest en dat hij zich bepaald had tot het naar voren brengen van richtlijnen voor de wetgevingstechniek, het bemiddelen bij conflicten tussen ontwerper en rapporteurs, het bewaken van de inzendtermijnen en het wegstrijken van eventuele oneffenheden:

"Het ontwerp zal niet de indruk maken door één man te zijn geschreven. Ieder van de bewerkers heeft zijn eigen stijl en zijn eigen denkbeelden over de vraag of de toelichting alle denkbare problemen moet behandelen en een uitvoerige documentatie behoort te bevatten. De ondergetekende heeft er niet naar gestreefd ieder blijk van een persoonlijke aanpak weg te werken. Als zijn voornaamste taken heeft hij gezien: het plegen van overleg over de wenselijkheid van de voorgestelde bepalingen, het voorkomen van innerlijke tegenstrijdigheden, de zorg voor de aansluiting bij de laatste versies van de vorige boeken, en het verbeteren van oneffenheden in stijl, taal, spelling en interpunctie."

Er is mij dan ook slechts één geval bekend waarbij De Jong een concept volledig afkeurde, omdat het niet strookte met zijn denkbeelden. De ongelukkige was Fokke$\mathrm{ma}$, die in zijn concept voor de vaststellingsovereenkomst (titel 7.15) een combinatie had neergelegd van twee stelsels, enerzijds de zogenaamde dispositieve leer en anderzijds de constitutieve leer. De Jong was het daarmee echter niet eens en besliste dat Fokkema zijn ontwerp moest inrichten conform de constitutieve of declaratieve leer.

Het wrange van het geval is dat Regeringscommissaris Snijders inmiddels weer ten dele is teruggekeerd tot de door Fokkema voorgestane oplossing. Fokkema: "De Jong was er van overtuigd dat alleen de declaratieve leer goed was. Ik daarentegen was van mening dat beide mogelijkheden konden bestaan en naast elkaar moesten worden geduld. Daar was niet over eens te worden, zodat ik het ontwerp uiteindelijk maar heb ingericht volgens de wensen van De Jong. Snijders, die het later heeft bekeken, is weer geheel de andere kant uitgegaan en heeft nu gekozen voor de dispositieve leer. Zo kom je van het ene extreme in het andere extreme standpunt terecht. Ik ben daar een beetje treurig over."

\section{Oorzaken voor vertraging}

Eén van de redenen waarom De Jong zich bereid verklaarde het werk aan Boek 7 te coördineren, was, zoals reeds opgemerkt, de overweging dat hij op die wijze iets zou kunnen doen om de zware tak van Jan Drion, zijn vriend, te verlichten. De andere was dat hij ervan uitging dat de voltooiing van het voorontwerp voor Boek 7 maximaal drie jaar zou vergen. ${ }^{60}$ Het eind was dus in zicht.

\section{9. $\rightarrow$}

Koop is wel het bedrijfsleven geraadpleegd en Nederland had in Den Haag een veelzijdige delegatie, waarin ook Dorhout Mees."

60. Uit een nota van Van Ewijk van 15 september 1961: "Mr. De Jong rekent op maximaal drie jaar, maar acht het niet gewenst dit nu reeds aan de bewerkers mede te delen." 
Het liep echter allemaal anders dan De Jong zich had voorgesteld, want pas in november 1972 gingen de drukproeven voor de laatste maal naar de Staatsdrukkerij. Zelf was hij toen al niet meer actief betrokken bij het werk aan Boek 7. Zijn gezondheid, ondermijnd door twee langdurige perioden van ernstige ziekte, kon de inspanning van het wetgevende werk niet meer verdragen. De Jong zou snel na de officiële aanbieding van Boek 7 op 14 september 1974 komen te overlijden.

Eén van de zaken die het werk aan Boek 7 lange tijd parten heeft gespeeld, was dat niet elke bewerker er in slaagde zijn werk tijdig, dat wil zeggen binnen de door hem zelf opgegeven termijn, in eerste concept af te ronden. Met name Levenbach heeft het in dit opzicht bont gemaakt, en het is dan ook vooral aan zijn houding te wijten dat het groene Boek pas in 1973 van de persen rolde. De volgende voorbeelden spreken voor zich.

Uit een stencil, weergevende de stand van de werkzaamheden op 28 oktober 1963, blijkt dat van alle titels een eerste concept gereed was, met uitzondering van de titels $3,11,12,13$ en 15 . Bovendien was over de meeste titels reeds rapport uitgebracht.

De Jong, die dit overzicht twee dagen later in een gesprek met Minister Scholten nader toelichtte, wees er daarbij op dat met name de door Levenbach en De Gaay Fortman te bewerken titels hem zorgen baarden. De eerste had aanvankelijk 1 september als inleverdatum genoemd, maar naderhand bericht nog geen datum te kunnen noemen. Hij zou, volgens De Jong, nog in het onzekere verkeren over welke materiële vernieuwingen hij zou willen voorstellen. De arbeid van De Gaay Fortman had vermoedelijk vertraging ondervonden doordat hij in 1962-1963 rector-magnificus was geweest. De Jong hield hem daarom voor verontschuldigd. Onrustbarend was echter, dat hij verzoeken om bericht hoever hij gevorderd was, onbeantwoord liet.

De Minister besloot daarop Levenbach en De Gaay Fortman uit te nodigen voor een gesprek. ${ }^{61}$

Op 25 maart 1964 trok de Minister opnieuw aan de bel. Levenbach had de overeengekomen inleverdatum inmiddels al weer met ruim anderhalve maand overschreden met De Gaay Fortman was kennelijk een andere afspraak gemaakt - en bracht daarmee ook de publicatie van het zeerecht in Boek 8, dat volgens de prognose medio 1964 zou moeten verschijnen, in gevaar. Schadee was volgens de Minister met alle titels reeds ver gevorderd, op die over de bemanning na, aangezien hij meende daaraan niet te kunnen voortwerken zonder kennisneming van de concepten voor de titel Arbeidsovereenkomst in Boek 7.62

61. Dat het concept voor titel 3 (Schenking) nog niet ver was gevorderd, werd veroorzaakt doordat Polak zich in het voorjaar van 1963 in verband met andere werkzaamheden terugtrok. Wiersma, die blijkens zijn inaugurale rede (Schenking en hercodificatie, Groningen 1963) interesse had voor de schenkingsproblematiek en ook goed bevriend was met J. en H. Drion, zou per 1 mei van hetzelfde jaar deze taak op zich nemen.

Iets dergelijks gold ook voor de aanneming van werk, waar H. Drion in maart 1962 De Grooth opvolgde als ontwerper, aangezien de laatste in verband met zijn leeftijd en andere drukke bezigheden geen kans meer zag iets zelfstandig op te zetten.

62. Achteraf gezien was dat een farce, omdat in zowel het groene Boek 8 als in de vaststellings- en invoeringswet daarvan de bepalingen over de bemanning ontbraken. 
Drie weken later liet Levenbach de Minister weten dat hij, omdat hij eveneens "scherp peremptoir" stond met betrekking tot het afleveren van een rapport voor de arbeidsrechtcommissie van de EGKS, tot zijn spijt ook nu nog in het vage moest blijven over het tijdstip waarop zijn concepten waren te verwachten. Zelf rekende hij er echter op één en ander vóór de grote vakantie te kunnen afronden. ${ }^{63}$ Wéér drie weken later, op 7 mei 1964, kwam hij echter op deze toezegging terug en berichtte De Jong dat aan zijn ontwerpen nog belangrijke stukken zouden ontbreken, terwijl daardoor ook de compositie van de volgorde nog niet zou kunnen worden beslist. Hij durfde daarom geen vaste termijn meer te noemen.

De Jong raakte door deze handelwijze zozeer vertoornd, dat hij er begin oktober sterk bij de Minister op aandrong Levenbach van zijn taak te ontheffen. ${ }^{64}$ Alleen het feit dat er inmiddels ook bij enkele andere titels problemen waren gerezen, deed hem op dit verzoek terugkomen. ${ }^{65}$

Een jaar later was het opnieuw prijs. De Jong schreef in zijn jaarlijkse overzicht: "Levenbach (...) heeft nog steeds niets van de resultaten van zijn 'arbeid' laten zien. Aan de beloften die ik hem indertijd heb afgeperst, heeft hij zich niet gehouden en zijn latere beloften werden steeds vager. Enige tijd geleden ging het gerucht, dat Levenbach ernstig ziek was. Toen ik echter hoorde, dat hij weer een lezing gehouden heeft, heb ik hem een brief geschreven (..) waarop hij niet heeft geantwoord." 66

Minister Samkalden, die zich naar aanleiding van dit schrijven tot tweemaal toe persoonlijk met de zaak bemoeide, kreeg van Levenbach de verzekering dat hij vóór 1 april 1966 zijn werk zou inleveren. De overschrijding zou veroorzaakt worden doordat het werk voor 'Luxemburg' geen uitstel dulde en hij nog immer bezig was met een hergroepering van de artikelen. Die laatste mededeling was voor De Jong, die elk vertrouwen op een goede afloop reeds lang had verloren, teveel van het goede. Hij schreef de Minister:

"Ook als prof. Levenbach werkelijk op 1 April 1966 zijn concept zou inleveren, zal ik bij deze titel niet hetzelfde systeem kunnen toepassen als bij de andere. Daar prof. Levenbach mijn brieven niet pleegt te beantwoorden, zou het namelijk een onbegonnen werk zijn om overleg te plegen over de wijzigingen die ik nodig acht. Indien prof. Levenbach een ingrijpende verandering van het geldende recht beoogt zijn medeling over de hergroepering der artikelen wijst daarop -, lijkt het mij beter, dat ik het concept van prof. Levenbach ongewijzigd overneem onder vermelding, dat dit deel van het ontwerp niet onder mijn verantwoordelijkheid valt.

Dit lijkt mij ook de aangewezen methode voor het geval, dat het concept mij na 1 April bereikt."

63. Ook dit rapport, getiteld "Het recht van de vakorganisaties in Nederland" is niet tijdig gereed gekomen, want deze studie verscheen pas in 1966.

64. Als mogelijke vervangers van Levenbach werden genoemd: Valkhoff, Koopmans, Peters, Haakman, Royer en Schoordijk.

65. Een complicerende factor bijvoorbeeld was het overlijden van Jan Drion, waardoor Wiersma zijn werk aan de Schenkingstitel tijdelijk had moeten onderbreken in verband met zijn benoeming tot Regeringscommissaris voor Boek 4 . Bovendien was de afloop van erfrecht-debat van fundamenteel belang voor de definitie van de schenking.

66. Nota van F.J. de Jong van 9 augustus 1965. 
Levenbach zou op 11 augustus 1966, bijna twintig jaar nadat hij de opdracht uit handen van Meijers had ontvangen, het grootste deel van zijn concept voor de titels 11 en 12 inleveren. ${ }^{67}$ Het resultaat van zijn arbeid was al heel mager: het was louter een bewerking van het bestaande recht, een hergroepering van artikelen, een aanpassing aan de terminologie van de Boeken 3 en 6 . "Slechts in zoverre er min of meer een communis opinio over bestaat", zo schreef Levenbach in de inleidende opmerkingen bij titel 7.10, "zijn over punten met een duidelijke sociaal-politieke inslag nieuwe bepalingen in dit ontwerp opgenomen." Een regeling van de werkstaking of voorstellen tot herziening van het ontslagrecht waren in zijn ontwerp dan ook niet te vinden. Ook artikel 1637r B.W., dat volgens het besluit van de Ministerraad van 19 september 1952 zou mogen worden geschrapt, had Levenbach, zij het enigszins geamendeerd, behouden. ${ }^{68}$

Het zou onjuist zijn de beschuldigende vinger alleen naar Levenbach uit te steken. Er zijn ook andere medewerkers geweest die het geduld van De Jong soms zeer op de proef hebben gesteld. Zo schoot de afwerking van de titel Vennootschap niet op, omdat Hijmans van den Bergh, die belast was met het uitbrengen van een rapport, maar liefst vier jaar de tijd nam om het concept van Van der Grinten te bestuderen en pas in 1968 met zijn rapport gereed kwam. Het kwam toen min of meer als mosterd na de maaltijd, want De Jong had, nadat Hijmans in 1965 voor de zoveelste maal zijn woord had gebroken, wijselijk besloten Fischer-Keuls maar aan de bestudering van deze titel te zetten. ${ }^{69}$ Ook De Gaay Fortman had grote problemen zijn toezegging gestand te doen en produceerde eerst in oktober 1965 zijn eerste concept, terwijl Fokkema in eerste instantie wel op tijd gereed kwam, maar later zo in de ban raakte van alles te willen verbeteren, dat De Jong op een gegeven moment dreigde de toelichting zelf voor zijn rekening te nemen en op een later ogenblik deze titel zelfs blanco wenste te laten.

Het verschil is echter dat hun "stilzitten" nimmer dé factor was, waardoor de publicatie van het voorontwerp voor Boek 7 opnieuw met zoveel maanden moest worden uitgesteld. Er was altijd nog wel een ander probleem, dat alle andere overschaduwde.

67. Een ontwerp voor afdeling 7.10.6 (Bijzondere bepalingen voor handelsreizigers) zou later volgen. Deze afdeling werd in het groene Boek overigens blanco gelaten in verband met een reeds ingediend wetsontwerp ter aanpassing van het Wetboek van Koophandel betreffende de agentuurovereenkomst. 68. Andere vraagpunten die Meijers met betrekking tot Boek 7 had opgenomen hadden betrekking op de uitgave-overeenkomst, de bijzondere huurbescherming, het concurrentiebeding en de positie van de handelsreiziger. Het vraagpunt waarin artikel $1638 \mathrm{q}$ B.W. aan de orde werd gesteld, betrof de wenselijkheid van private straffen in de arbeidsovereenkomst en noemde naast dit artikel ook nog de artikelen $1639 \mathrm{r}$ en $\mathrm{t}$ B.W. De eerste twee punten sneuvelden in de vaste Commissie, die ze niet belangrijk genoeg vond, de laatste twee in de Ministerraad.

69. Als verzachtende omstandigheid kan wellicht gelden dat Hijmans in 1963 secretaris werd van de Utrechtse Senaat en kort daarop met het Overgangsrecht zou worden belast. Zijn rapport was evenwel nog geen halfje waard. 
Een tweede factor, die een belangrijke hinderpaal vormde voor een snelle afronding van het werk aan het Zevende Boek, had betrekking op de totstandkoming van de wellicht belangrijkste titel van Boek 7, de Koop.

Zoals ik hiervoor reeds heb aangestipt, was de Koop een van die onderwerpen waarmee de Benelux-studiecommissie voor de eenmaking van het recht zich bezighield. Dat betekende dat de bewerker van titel 7.1 in hoge mate afhankelijk was van het resultaat van de besprekingen in deze commissie. Voorts betekende het, dat het eigenlijke coördinatiewerk van De Jong eigenlijk pas kon plaats hebben als deze titel de pijler waarop een belangrijk deel van Boek 7 zou moeten rusten - gereed was. En indien men weet dat dit onderwerp al kort na 1948 nog door Meijers zelf op de agenda was geplaatst, dan is het duidelijk dat hierin een voorwerp van aanhoudende zorg lag. Een aantal momenten uit de historie van deze titel.

Begin 1963 was Dorhout Mees zover dat hij De Jong een eerste concept voor titel 7.1 kon aanbieden. De verdere afwerking, zo schreef hij aan De Jong, wachtte echter op de uitkomst van de Benelux-besprekingen. Anderhalf jaar en vele vergaderingen later was men, aldus een ontgoochelde Dorhout Mees, niettemin nog geen stap verder gekomen: "Na de vergadering van de Benelux-Commissie eind januari jl. dachten Nypels en ik dat wij nog slechts drie artikelen te behandelen hadden, waarover nog inlichtingen moesten ingewonnen worden, en verder bespreking van de toelichting en de Nederlandse vertaling. In de vergadering, die eind Mei jl. is gehouden, heeft men echter de tekst van de wet in behandeling genomen alsof het een volkomen nieuw ontwerp was en daar weer allerlei in veranderd. "70

Daar kwam nog bij dat de in april 1964 te Den Haag gehouden conferentie over de Internationale Koop tot een onverwacht succes had geleid. Nadat al sinds 1930 weinig succesrijke pogingen waren gedaan een eenvormig internationaal Kooprecht te ontwerpen, eindigde de Haagse Conferentie in de sluiting van tweetal verdragen, één betrekking hebbend op de internationale handelskoop, de ander op de totstandkoming van koopovereenkomsten. Het gevolg daarvan was dat de Benelux-Commissie, die tot dan toe de Internationale Koop niet erg au serieux had genomen, haar eigen arbeid opnieuw moest overwegen. Dorhout Mees schreef naar aanleiding van die ontwikkeling: "Als alles erg meeloopt - en de ervaring heeft mij geleerd dat dat nooit gebeurt zouden wij over een jaar klaar kunnen zijn, maar ik verwacht dat het wel een paar jaar zullen worden. Naar ik meen heeft het eerst daarna zin, een ontwerp voor de Koop voor het Nederlands B.W. vast te stellen."

Deze stagnatie was De Jong, die er op dat moment nog naar streefde het Groene Boek per ultimo 1965 te kunnen presenteren, uiteraard hoogst onwelkom. Hij deed Dorhout Mees dan ook de suggestie om in het groene Boek een voorlopige versie van de Koop op te nemen, in het Regeringsontwerp te vervangen door een definitieve, die dan zou kunnen worden ontleend aan de uiteindelijke Benelux-tekst. Dorhout Mees voelde echter weinig voor deze suggestie. Niet alleen zou daardoor, zo vreesde hij, de druk om de onderhandelingen te bespoedigen wegvallen, maar bovendien scheen het hem een bijzonder ondankbaar werk een toelichting op te stellen zolang de definitieve tekst van de Boeken 3 en 6 niet vast stond: "Ik zal het definitief totstandkomen van de

70. Brief van 17 juni 1964. 
Benelux-Koop echter zoveel mogelijk bespoedigen; hoe interessant het werk ook is, ik snak ernaar hiermede tenminste klaar te zijn. "71

Omdat De Jong op dat moment ook nog in grote onzekerheid verkeerde over het lot van de door Levenbach te bewerken titels, werd besloten de publicatiedatum van Boek 7 te verschuiven naar de zomer van 1967. En omdat de Minister er ook tegenoverde buitenwereld geen enkele twijfel over liet bestaan dat deze termijn onherroepelijk was, kon Dorhout Mees zijn mede-commissieleden onder druk houden en kon het Benelux-voorontwerp in januari 1967 eindelijk aan de Ministers van Justitie van de Benelux worden aangeboden.

Daarmee was de lijdensweg van deze titel overigens nog niet ten einde. Drie jaar later, op 19 oktober 1970, zou het op dit voorontwerp gebaseerde Ontwerp-Beneluxovereenkomst inzake Koop en ruil verschijnen, waardoor Dorhout Mees zijn concept voor titel 7.1 opnieuw moest omwerken. Bovendien bleek de inspanning om met een gezamenlijk ontwerp te komen uiteindelijk voor niets te zijn geweest: "De Belgen wilden niet ratificeren omdat ze uiteindelijk beseften dat de door hen zo geliefde regeling van de verborgen gebreken onder de tafel zou verdwijnen", aldus Dorhout Mees in een terugblik op deze bewogen periode.

De derde en laatste reden waarom het zevende groene Boek veel later dan voorzien werd gepubliceerd, was dat men op Justitie begin 1967 tot de conclusie kwam dat het bij nader inzien verstandiger zou zijn om met publicatie te wachten totdat het Gewijzigd Ontwerp voor Boek 3 (dat vrij wat verschillen met Meijers' ontwerp zou vertonen) gereed zou zijn. De verwachting was dat de M.v.A. en het G.O. tegen het eind van 1967 zouden verschijnen, zodat de publicatie van Boek 7, waaraan De Jong in de zomer van 1967 de laatste hand hoopte te leggen ${ }^{72}$, slechts met enige maanden zou worden vertraagd. ${ }^{73}$ Bovendien kon op deze wijze worden voorkomen dat het groene Boek voor wat betreft de afstemming op Boek 3, al enkele maanden na de publicatie weer zou zijn verouderd. ${ }^{74}$

71. Brief van 29 juni 1964.

72. Uit een nota van Van Ewijk van 13 oktober 1966: "Mr. de Jong handhaaft zijn verwachting dat het groene Boek in de zomer van 1967 definitief ter perse kan gaan (er zijn reeds veel drukproeven)." De Jong zelf zei er in Het Vaderland van 5 mei 1967 het volgende over: "Als ik van de zomer twee maanden vakantie heb neem ik alle titels achter elkaar door. Dan zal ik mij in de materie als geheel kunnen verdiepen, zal ik de titels waar nodig kunnen aanpassen aan elkaar, zal ik de terminologie van de twaalf samenstellers op elkaar kunnen afstemmen. Misschien zal ik dan eind van het jaar het groene boek van het Zevende Boek op tafel kunnen leggen."

73. Uit een brief van Van Ewijk aan De Jong van 5 april 1967: "Gisteren heb ik met Langemeijer en Snijders nog eens het perspectief van Boek 3 besproken. Snijders en ik neigen tot minder optimisme dan Langemeijer. Wij menen dat de M.v.A. en het G.O. niet ver voor het eind van dit kalenderjaar in zee zullen gaan.

Alle drie waren wij geneigd tot het standpunt dat het groene Boek 7 afgestemd moet zijn op het gewijzigd ontwerp Boek $3(\ldots)$ en dat het dus misschien de beste werkwijze zal zijn het, inmiddels overigens geacheveerde Boek 7 te laten liggen, totdat het vergeleken is met de wijzigingen in Boek 3 , voor zover deze ter zake dienende zullen zijn, hetgeen natuurlijk slechts op enkele punten het geval zal zijn."

74. Het was zeker niet de bedoeling om Boek 7 titel voor titel te gaan bezien - daarvoor zou ook de tijd hebben ontbroken - maar wel bestond de vrees dat in Boek 7 artikelen en vooral ook passages in 
Het Gewijzigd Ontwerp voor Boek 3 zou echter pas op 18 maart 1971 bij de Tweede Kamer worden ingediend. Daardoor kon het werk aan Boek 7, dat medio 1968 tot een voorlopig einde was gekomen, pas in 1971 worden hervat. Begrijpelijkerwijs voelde toen niemand er nog voor de concepten nog eens te herzien. In de eerste plaats zou het teveel ophouden Boek 7 O.M. geheel bij te werken en verder realiseerde men zich dat het nog geruime tijd zou duren alvorens de Kamer de gelegenheid zou hebben Boek 7 op de agenda te plaatsen. Een grondige bijwerking nu, zou ongetwijfeld tot dubbel werk leiden. De Vries, Hoofd van de Afdeling Wetgeving Privaatrecht, suggereerde zelfs geheel af te zien van een nieuwe codificatie van de bijzondere contracten, omdat het politiek geen haalbare zaak zou zijn van de vaste Commissie al te veel tijd te vragen voor het nieuwe B.W. ${ }^{75}$

Dit gegeven verklaart ook waarom de literatuur van de meeste titels slechts is bijgewerkt tot 1967. De toetsing bleef beperkt tot een afstemming op Boek 3 en een verwerking van actuele wetgeving. Om deze reden sneuvelde bijvoorbeeld afdeling 7.7.5, die door Van der Grinten was opgesteld voordat in juni 1967 de Beneluxmodelwet betreffende de agentuurovereenkomst tot stand werd gebracht. En een door het Departement opgestelde regeling van de aansprakelijkheid van de hotelhouder onderging eveneens de werking van de wet van de remmende voorsprong. Boek 7, ooit bedoeld als signaal voor de Kamer dat het Ministerie niet van opgeven wilde weten, werd zo een bekentenis van onmacht. ${ }^{76}$

74. $\rightarrow$

de Toelichting zouden voorkomen die een verkeerde indruk zouden geven van hetgeen geregeld was in de Boeken 3 en 6 en die de minister bij de behandeling van die boeken voor de voeten zouden kunnen worden gegooid. Bovendien konden op deze wijze mogelijke wijzigingen nog geruisloos worden aangebracht, die, wanneer Boek 7 eenmaal een groen Boek zou zijn, toelichting zouden behoeven.

75. Notulen van een beleidbespreking tussen de Minister en de Stafafdelingen Wetgeving NBW en Wetgeving Privaatrecht van 26 april 1971. De directe aanleiding voor het beleggen van deze bijeenkomst was de vraag of de vaste Commissie, die al bijna zes jaar worstelde met het algemeen deel van het nieuwe verbintenissenrecht, ooit uit deze materie zou kunnen komen. Zie verder hierboven, Hoofdstuk 7.

76. De wetgevingsoverzichten van Justitie spreken ook duidelijke taal voor wat betreft de moeizame bevalling van Boek 7 O.M.:

1966: "Vertrouwd wordt dat het voorontwerp voor Boek 7 médio 1967 en dat voor Boek 8 enige tijd daarna ter perse zal kunnen worden aangeboden."

1967: "Het voorontwerp van het Zevende Boek is zover gevorderd, dat het in 1968 wel zal kunnen verschijnen."

1968: "De Memorie van Antwoord voor Boek 3 hoopt ondergetekende in de eerste helft van 1969 in te zenden. De opstelling van het voorontwerp voor Boek 7 is zover gevorderd dat ik meen te mogen vertrouwen dat het spoedig na de verschijning van de Memorie van Antwoord op Boek 3 zal worden voltooid."

1969: "Boek 7 is ver gevorderd. De uiteindelijke tekst van het groene Boek zal echter niet kunnen worden vastgesteld voordat het bij de Memorie van Antwoord over Boek 3 behorende Gewijzigde Ontwerp van dat Boek gereed is." 


\section{Redactie- en afstemmingsproblemen}

De problemen met de Koop, de stagnatie bij bepaalde titels, de tegenslag bij de afwerking van het Gewijzigd Ontwerp Boek 3, het waren niet de enige problemen waarmee De Jong te kampen had. Een andere factor die aanvankelijk voor de nodige vertraging zorgde, was dat het merendeel van de medewerkers geen enkele wetgevende ervaring had en dat ieder van hen zo zijn eigen gedachten had over de vraag of een toelichting alle denkbare problemen moet behandelen. Daarnaast was het voor De Jong een belangrijke handicap dat de coördinatie pas achteraf, nadat de meeste titels in eerste of tweede concept gereed waren, kon worden verricht.

Vrijwel ieder eerste concept dat bij De Jong werd ingediend, leed aan het euvel van een te grote omslachtigheid. Het waren lijvige stukken, de beknoptheid en de gemakkelijke leesbaarheid die de concepten van Meijers hadden gekenmerkt, waren verdwenen. De betogen waren geleerd, soms enigszins deftig, zij gaven méér dan wat voor de praktijk nodig was. ${ }^{77}$ In die eerste concepten is dus, op aandringen van De Jong, het nodige geschrapt, al is het de vraag of het voldoende is geweest (zie hieronder).

Een ander punt is, dat sommige bewerkers soms regelrecht ingingen tegen de Boeken 3 en 6 , soms omdat zij zich van de overlapping niet bewust waren, soms ook omdat zij het met de in die boeken neergelegde oplossingen niet eens waren of streefden naar een verdergaande verfijning. In die zin was er dus weinig verschil met de werkwijze van het Driemanschap en gold ook hier het adagium: zoveel hoofden, zoveel zinnen.

Een voorbeeld. Het eerste ontwerp van Van Opstall voor titel 7.2 (Verbruikleen) week aanzienlijk af van de concepten van Meijers, hetgeen door hem als volgt werd gemotiveerd:

"In de eerste plaats meen ik dat de volgorde van de diverse bepalingen in genoemde ontwerpen nogal willekeurig is. Voorts acht ik op sommige punten een andere regeling dan die welke reeds was ontworpen gewenst. Tenslotte moest ik mijn ontwerpen aanzienlijk langer maken dan de bestaande, omdat bij het maken van de bestaande kennelijk werd uitgegaan van de onderstelling dat sommige punten in het Zesde Boek of andere Boeken algemeen zouden worden geregeld, terwijl mij niet is gebleken dat dit is geschied. Ik heb dus voor deze punten in mijn ontwerpen zelf een regeling moeten maken, die natuurlijk slechts geldt voor de daarin bepaalde onderwerpen, en dit heeft mij nog de meeste tijd gekost en is de oorzaak van het grootste deel van de verlenging die mijn ontwerpen ten opzichte van die van Kamphuisen vertonen. ${ }^{78}$

P.J. Swart, die namens het Departement deze titel aan een vluchtig onderzoek onderwierp, vond Van Opstalls werk echter bepaald geen verbetering en noemde het

77. Het tegenovergestelde kwam overigens ook voor. Het concept van Van der Grinten, ingediend in november 1962, bleek een schot in de roos en zou nauwelijks wijziging behoeven. En H. Drion had in zijn eerste concept slechts één noot opgenomen.

78. Brief van 2 januari 1963. 
concept uitvoerig, detaillistisch en meende bovendien dat het uitzonderlijke situaties regelde: "Het Ontwerp-Kamphuisen ( 5 artikelen) is veel beter dan dit (14 artikelen) en verdient beslist de voorkeur."

Gelukkig nam Van Opstall deze kritiek gunstig op - De Jong schreef: "Laten wij tekst en toelichting zo beknopt mogelijk houden en laten wij geen knopen doorhakken wanneer wij niet zeker weten, dat dit noodzakelijk is"79 - en leverde hij in juni 1964 een tweede concept af dat, op een aantal punten en komma's na, ongewijzigd in het groene Boek zou worden opgenomen.

Tenslotte het punt van de onderlinge afstemming. Omdat er geen sprake was van coördinatie tussen de bewerkers onderling - men wist van elkaars bestaan als bewerker nauwelijks af - zou De Jong na 1967, toen eindelijk de Kooptitel gereed kwam, zijn handen vol hebben aan het op elkaar afstemmen van de concepten. Dat er juist op dit punt nogal wat aan de concepten mankeerde, blijkt uit het volgende. Toen Houwing zijn concept voor de titel Huur aanbood, liet hij De Jong weten dat hij, in overeenstemming met de richtlijn, de resultaten van recente wetgeving zoveel mogelijk had geëerbiedigd; aangezien het hem niet bekend was hoe de Koop en de Pacht er uit zouden gaan zien, nam hij die dus maar ongewijzigd over...

Dat coördineren was een taak waar niet te licht over moet worden gedacht. Om een voorbeeld te noemen, bij het redigeren van de titel Verbruikleen zul je op z'n minst moeten beschikken over de bepalingen betreffende de Koop, Huur en Bewaargeving. Immers, verbruikleen verplicht, gelijk koop, tot eigendomsoverdracht en heeft tot gevolg dat, evenals bij huur of bewaargeving, een zaak in de macht van een ander wordt overgedragen en/of wordt teruggegeven. Bij Huurkoop moet je niet alleen kunnen beschikken over de Koop, maar bijvoorbeeld ook moeten weten hoe de algemene regeling van het eigendomsvoorbehoud er uitziet (Boek 3 ) in verband met het eigendomsvoorbehoud bij huurkoop. Het lijkt daarom niet onmogelijk dat dit werk nog tijdrovender is geweest dan het ontwerpen van de afzonderlijke titels. Veelzeggend is, dat De Jong zélf opmerkt dat de uiteindelijke redactie van "belangrijke stukken van de toelichting" niet afkomstig is van de individuele ontwerpers, maar dat zij werd geschreven door Fischer-Keuls, die hem met ingang van de zomer van 1967 voor dit werk terzijde zou staan en het uiteindelijk vrijwel geheel heeft overgenomen. ${ }^{80}$

79. In zijn brief aan Van Opstall, gedateerd 5 januari 1963, zette De Jong zijn visie op de bewerking van Meijers' concepten voor Boek 7 O.M. nog eens duidelijk uiteen: "Als algemene opmerking zou ik voorts nog willen zeggen, dat het geenszins de bedoeling van Meijers was, dat het nieuwe wetboek op elke vraag die men kan stellen, een antwoord geeft. Naar mijn persoonlijke mening is dat bij de samenstelling van Boek 6 niet altijd voldoende in het oog gehouden. Ik zou willen trachten bij Boek 7 niet in dezelfde fout te vervallen." Dan volgt het in de tekst aangehaalde citaat: "Laten wij tekst en toelichting zo beknopt mogelijk houden en geen knopen doorhakken wanneer wij niet zeker weten, dat dit noodzakelijk is."

80. Zie Parl. Gesch. Boek 7, p. 2, sub 7. Dit beeld wordt ook bevestigd door de vele nota's van de hand van mevrouw Fischer die ik in het archief heb aangetroffen. 


\section{De Jongs aandeel in Boek 7; besluit}

Met deze opmerking ben ik aangeland bij het aandeel van De Jong in Boek 7 . Hiervoor is reeds aangegeven dat zijn aandeel vermoedelijk niet erg groot is geweest. In de eerste plaats werd dat veroorzaakt doordat De Jong na zijn ziekte ${ }^{81}$ het grootste deel van zijn werk overdroeg aan mevrouw Fischer. Fischer: "Boek 7 stond onder supervisie van Frits de Jong. Ik stond hem bij, vrijwel alle correspondentie voor Boek 7 liep via mij. Mijn werk bestond vooral uit de coördinatie van de diverse titels onderling en in de afstemming op de Regeringsontwerpen van de Boeken 3 en 6. Ik deed het voorwerk en besprak dat met hem voorzover zijn gezondheid dat toeliet." Illustratief hiervoor is de volgende opmerking van De Jong aan Fischer bij een concept voor titel 7.8: "Ik ben er niet zeker van of je dit concept rechtstreeks naar de drukker wilt sturen. Neem mijn potloodaantekeningen alleen maar over als je het ermee eens bent." Ook H. Drion vertelde dat de gesprekken met De Jong verre van intensief waren geweest: "Het waren meer wensen die hij terloops te berde bracht, richtlijnen voor de wetgevingstechniek, zoals dat je in de toelichting voortdurend rekening diende te houden met de andere artikelen van het nieuwe Burgerlijk Wetboek."

Daarbij kwam, dat de organisatie in zoverre was gestroomlijnd, dat de rapporteurs De Jong het meeste werk uit handen namen, althans voorzover daarbij geen punten waren betrokken die uit een oogpunt van coördinatie van belang konden zijn. Wiersma kenschetste de rol van De Jong als die van een bemiddelaar, iemand die eigenlijk boven de partijen stond: "Hij legde het ontwerp aan de anderen voor en dan kwamen er opmerkingen en vragen over. Daar waren dan vragen of opmerkingen bij, waarvan ik vond dat het verstandige opmerkingen waren, dus waar het geen probleem was het ontwerp te veranderen."

Deze rol van bemiddelaar en scheidsman laat zich illustreren aan de hand van een conflict, gerezen tussen Dorhout Mees en Holleman, de rapporteur voor de verzekeringstitel. Holleman was van mening dat Dorhout Mees onvoldoende aandacht besteedde aan diens opmerkingen. De Jong schreef toen een kalmerend briefje aan Holleman en wees Dorhout Mees erop dat een goede vriendschap meer waard was dan het Burgerlijk Wetboek. Hij eindigde met de woorden: "Mocht het conflict echter blijven bestaan, dan zal ik mij op jou blijven verlaten en mij blijven bepalen tot opmerkingen van wetstechnische en taalkundige aard. (..) Je moet zelf beslissen wat je al of niet wilt overnemen." Smits, die het op een principieel punt niet eens was met Van der Grinten, kreeg van De Jong te horen: "Over de punten waarover gij van mening verschilt, wil ik eerst nog overleg plegen met mevr. Fischer-Keuls. Mijn ervaring is dat Van der Grinten in het geheel niet moeilijk is met het accepteren van wijzigingen. Blijft hij echter op zijn standpunt staan, dan acht ik het veiliger mij bij hem neer te leggen." 82

81. Op 3 december 1963, vrijwel onmiddellijk na zijn installatie als vice-president van de Hoge Raad, werd De Jong in het ziekenhuis opgenomen waar hij een zware hersenoperatie moest ondergaan. Volgens Fischer zou hij daarna nooit meer de oude zijn geworden, als gevolg van concentratieproblemen.

82. Vergelijk ook Dorhout Mees in: Acht civilisten in burger, Zwolle 1977, p. 90: "Hij (De Jong) heeft eigenlijk niet zo vreselijk veel in mijn ontwerp veranderd, was het er over het algemeen nogal 
Deze opmerking brengt mij bij de vraag of de organisatie van Boek 7 een gelukkige is geweest. Ik denk het niet. Het was, zeker bij de weinig strakke richtlijnen die De Jong hanteerde, buitengewoon moeilijk om ieder op één lijn te krijgen en er voor te zorgen dat ieder zijn concept tijdig indiende.

$\mathrm{Nu}$ zou kunnen worden tegengeworpen dat het gebeurde met Levenbach, Fokkema of Hijmans ook wel zeer uitzonderlijk is. Zelf ben ik daar echter niet zo van overtuigd. Het Driemanschap heeft zelf ook ettelijke tijdschema's gehanteerd - en overschreden. Daarenboven was het bepaald niet denkbeeldig dat een bewerker door gezondheidsproblemen of door een plotselinge opeenhoping van werk zijn taak niet kon voltooien. Het is daarom misschien niet onaardig een parallel trekken met het werk van de Staatscommissies voor het B.W. in het eind van de vorige eeuw. Ook daar werkten excellente juristen, ook daar lag de leiding in kundige handen, maar ook daar schoot het werk door coördinatieproblemen en verschillen in stijl niet op. Bovendien raakten door de lange duur de ontwerpen reeds tijdens het ontwerpen verouderd, en ontstond de noodzaak zich steeds opnieuw te buigen over een reeds aangenomen tekst.

Dat het van eminent belang is dat er bij een dergelijk omvangrijk project iemand is die het geheel kan overzien en zijn visie dwingend aan anderen kan opleggen, wordt in de bij dit hoofdstuk gevoegde bijlage aangetoond. Want per saldo zijn de verschillen tussen de concepten van Meijers en de tekst van het groene Zevende Boek, ondanks het gebrek aan leiding, helemaal niet zo groot. Het gaat om kleine nuances, die meestal voor de praktijk van weinig belang zijn. Die verschillen ontstaan doordat er iemand anders aan het werk is geweest, iemand met een andere opvatting ten aanzien van ontwerptechniek, taalgebruik en behandeling van de stof. Anders gezegd: als het ontwerp voor Boek 7 O.M. door nog weer anderen was geschreven, dan zou het er wéér anders uitzien. Waarschijnlijk niet beter of slechter, maar wél anders. Maar juist omdat de verschillen zo marginaal zijn, is het van het grootste belang dat deze neiging om de eigen persoonlijkheid te laten gelden, krachtig de kop wordt ingedrukt. Kamphuisen, die als eerste de titels van Meijers bewerkte, had die ervaring ook opgedaan. Over zijn ervaringen als ontwerper schreef hij aan Minister Donker:

"Het zij mij veroorloofd op te merken, dat de ervaring, die ik in de afgelopen maanden heb opgedaan, mij nog sterker dan tevoren heeft doen beseffen hoe juist Uw visie op de totstandkoming van het B.W. is. Natuurlijk had ik zonder enige moeite en zonder dat men mij traagheid zou kunnen verwijten de dubbele tijd kunnen besteden aan voorbereiding. Ik zou dan wellicht hier en daar nog weer iets geschaafd of veranderd hebben, maar ik betwijfel ten sterkste of het werk daardoor inderdaad veel beter geworden zou zijn. Natuurlijk realiseer ik mij volkomen, dat er gegronde aanmerkingen op mijn ontwerp zullen kunnen worden gemaakt en de critische blik van het Driemanschap en in laatste instantie van Uzelf is derhalve beslist nodig. Maar wat ik steeds sterker gevoel is, dat ook bij de beste voorbereiding er onvolkomenheden en onzekerheden zullen blijven bestaan. Dit is niet te voorkomen ook al zou men twintig jaar aan de voorbereiding werken en al zou

82.

mee eens, maar als hij iets voorstelde was het in de regel wel raak. Maar dat was dan voornamelijk een voorschrift, waaraan een bepaalde consequentie vast zat die ik niet had gezien; of dat een bepaling niet klopte met iets in het derde of zesde Boek, die hij zeer goed in zijn hoofd had." 
men een Memorie van Toelichting schrijven zo dik als alle Asser handboeken tezamen. Vandaar dat ik Uw opvattingen omtrent het tempo van het werk zo mogelijk nog hartelijker onderschrijf dan vroeger. ${ }^{83}$

83. Brief van 3 december 1954. 


\section{BULAGE}

Hiervoor is reeds aangegeven dat de bewerkers van het eerste uur, Kamphuisen en Van Oven, betrekkelijk weinig hebben veranderd in de concepten van Meijers, omdat een meer of minder ingrijpende omwerking niet tot hun opdracht behoorde, zij daartoe ook geen enkele aanleiding zagen en hun daarvoor bovendien de tijd zou hebben ontbroken.

De vraag is nu, in hoeverre de latere generatie medewerkers, die wél volledig vrij waren hun eigen opvattingen in het ontwerp neer te leggen en die daarnaast over een overvloed aan tijd beschikten, van deze concept-teksten zijn afgeweken. Alleen op die wijze kan de vraag worden beantwoord, of de lange voorbereidingsduur van Boek 7 O.M. gerechtvaardigd wordt door de resultaten, en, wat belangrijker is, of de concepten van Meijers inderdaad dermate voorlopig waren, dat publicatie in 1954 tot de onmogelijkheden behoorde.

Het resultaat van dit onderzoek treft de lezer hieronder aan. Daarbij is uitgegaan van de teksten van Meijers, zoals die door Kamphuisen en Van Oven in 1954 werden afgemaakt. Een bezwaar van deze werkwijze is weliswaar, dat slechts een aantal titels in de beoordeling wordt betrokken. Niettemin lijkt het mij, gelet op het feit dat de opgedane indrukken vrijwel steeds dezelfde zijn, onwaarschijnlijk dat de resultaten met betrekking tot de andere titels sterk zouden verschillen.

\section{a. Verbruikleen}

Titel 7.2 is één van die titels waar Kamphuisen, één kleine redactionele verbetering buiten beschouwing gelaten, zich heeft beperkt tot het toelichten van de door Meijers ontworpen bepalingen. Het concept van Meijers, opgesteld na de bespreking van 4 november 1953, zag er als volgt uit.

Artikel 1. Verbruikleen is een overeenkomst, waarbij de ene partij zich verbindt aan de andere partij een zekere hoeveelheid van naar de soort bepaalde roerende zaken in eigendom te leveren, waartegenover deze verplicht zaken van gelijke soort en hoedanigheid terug te geven.

Artikel 2. 1. Indien niet anders overeengekomen is, is hij, die een geldsom te leen ontvangt, verplicht daarvan de wettelijke rente te voldoen.

2. Indien een woekerrente bedongen is, wordt deze tot de wettelijke rente teruggebracht.

3. Een woekerrente is een rente, die hoger is dan de wet toestaat, of die, gelet op de omstandigheden van het geval, als onredelijk moet worden beschouwd.

Artikel 3. Is geen tijdstip voor de terugbetaling overeengekomen, dan is de schuldenaar verplicht het te leen ontvangene binnen zes weken na opzegging terug te geven.

Artikel 4. Indien is overeengekomen, dat het te leen ontvangene zal worden teruggegeven, wanneer de schuldenaar daartoe in staat zal zijn, zal de rechter, naar gelang der omstandigheden, de tijd van de teruggave bepalen.

Artikel 5. De bepalingen van deze titel vinden overeenkomstige toepassing telkens wanneer de schuldenaar van een geldsom een uitstel van betaling heeft bedongen. ${ }^{.4}$

84. In het concept van Kamphuisen was dit artikel enigszins gewijzigd en luidde: "De bepalingen van artikel 7.2.2 lid 1 en artikel 7.2.4 vinden overeenkomstige toepassing telkens wanneer de schuldenaar van een geldsom een uitstel van betaling heeft bedongen, echter met dien verstande, dat, indien de schuld rentedragend is, dezelfde rente verschuldigd blijft."

Kamphuisen vond, blijkens zijn toelichting aan het Driemanschap, met name de toepassingsverklaring van artikel 3 onjuist, omdat daaruit zou volgen dat in het geval van artikel 5 de crediteur toch na zes weken de schuld zou kunnen opvorderen, tenzij hij bij uitstel van betaling een bepaalde termijn zou hebben toegestaan. Bovendien was er zijns inziens niet de minste reden om bij uitstel van betaling plotseling de wettelijke rente te gaan berekenen, indien de oorspronkelijke schuld bijvoorbeeld $3 \%$ rente opbracht. Van Opstall zou deze toevoeging echter weer ongedaan maken. 
Een globale vergelijking met de tekst van het B.W. (artt. 1791-1810) leert het volgende.

In de eerste plaats valt het op, dat Meijers afstand deed van de gedachte dat de verbruikleen als een reęl contract zou moeten worden beschouwd, dat wil zeggen dat de overeenkomst tot verbruikleen eerst tot stand zou komen na afgifte van de zaak. "Deze opvatting is", zo schreef Kamphuisen in zijn inleiding bij deze titel, "een historisch overblijfsel uit het Romeinse recht, doch er zijn geen argumenten om haar te handhaven: integendeel, zowel uit dogmatische als uit practische overwegingen is het gewenst ook deze overeenkomsten als gewone consensuele contracten te behandelen. "ts

Een ander punt van verschil is dat Meijers de verbruikleen uitdrukkelijk beperkte tot de naar de soort bepaalde zaken (art. 7.2.1). Dat niet dezelfde zaken behoeven te worden teruggegeven, maar zaken van "gelijke soort en hoedanigheid", maakt dat verbruikleen van individueel bepaalde zaken niet mogelijk is. Uit hetzelfde artikel blijkt tevens dat verbruikleen eigendomsoverdracht impliceert; een bepaling als artikel 1792 B.W. werd daardoor overbodig, want door de eigendomsovergang gaan de lotgevallen van de geleende zaken de uitlener niet meer aan. Tenslotte regelt het artikel de verplichtingen van de lener: het "even zo veel" van art. 1791 B.W. werd geschrapt omdat het herhaaldelijk voorkomt, speciaal bij geldleningen, dat meer moet of minder mag worden teruggegeven. ${ }^{86}$

De stof, waaraan in het oude B.W. de artikelen 1802-1806 zijn gewijd, vinden we bij Meijers in artikel 7.2.2 samengevat. Indien niet anders is bedongen, zo volgt uit deze bepaling, dan is de geldlener de wettelijke rente verschuldigd. Ook is het artikel uitgebreid met een tweetal leden, gewijd aan de zogenaamde woekerrente.

In artikel 7.2.3 wordt een regel gegeven voor het geval omtrent het tijdstip van terugbetaling niets is overeengekomen. Artikel 1797 B.W. bepaalt dan dat de rechter "enig uitstel" kan geven, maar Meijers vond het kennelijk beter een vaste termijn in de wet op te nemen. Deze oplossing zou ook door Van Opstall worden overgenomen.

Vergelijkt men de tekst van het groene Boek met die van Meijers, dan valt al direkt één belangrijk verschil op. In plaats van één afdeling, koos Van Opstall voor een drietal: verbruikleen van geld, verbruikleen van roerende zaken en verbruikleen van andere goederen. In de toelichting wordt deze keuze gemotiveerd met het argument dat verbruikleen van geld verreweg het meest zou voorkomen en dat juist daar geen sprake zou zijn van een verbintenis tot het terugbetalen van zaken van een bepaalde soort en hoedanigheid, maar van een bepaald bedrag. ${ }^{87}$

Naar mijn indruk is het verschil in indelingen vooral van cosmetische aard. De tweede afdeling immers, is een vrij bloedeloos geheel, waarin alleen artikel 1 (definitie verbruikleen) een zeker nut heeft. Artikel 2 en 3 horen thuis in Boek 6 (zie art. 6:28 en 6:78), terwijl artikel 4 een verwijzingsregel is. Met betrekking afdeling 3 wordt in de toelichting gesteld: "De derde afdeling dient slechts om te doen uitkomen dat ook andere goederen dan die welke in de twee voorafgaande als voorwerp van verbruikleen zijn beschouwd, als zodanig kunnen dienen en dat, indien te dien aanzien een overeenkomst van verbruikleen is gesloten, daarop zoveel mogelijk de bepalingen van de tweede afdeling moeten worden toegepast. ${ }^{n 88} 89$

85. Het citaat vervolgt: "In werkelijkheid scheppen bewaargeving enz. evenzeer wederzijdse verplichtingen als de koopovereenkomst en trekt men hiervan de consequentie, dan vervallen tevens verschillende moeilijkheden, welke thans inherent zijn aan de z.g. voorovereenkomsten tot bewaargeving enz. Waar bovendien aan het handhaven van het reële karakter geen enkel voordeel verbonden is, laat het Ontwerp deze constructie varen."

Vergelijk ook art. 6.5.1.5 O.M., dat rechtstreeks aan Meijers was ontleend. Uit diens toelichting: "Dit artikel stelt buiten twijfel, dat de voorschriften betreffende overeenkomsten ook toepassing vinden, wanneer de uitvoering reeds geheel of gedeeltelijk met de toestemming plaats vindt. Deze bepaling is vooral van belang wanneer de toestemming in de uitvoering besloten ligt (..) Eggens spreekt hier van samenval van rechtsmomenten. Er bestaat tengevolge van het artikel geen enkele grond meer om de schenking metterdaad buiten het verbintenissenrecht te plaatsen of om de verbruikleenovereenkomst als een reëel contract te beschouwen, waaraan een niet door de verbruikleenregels beheerst consensueel contract kan voorafgaan."

86. Zie de toelichting bij artikel 7.2.1.1, p. 884 .

87. Toelichting Meijers, p. 883 , derde alinea.

88. Toelichting-Meijers, p. 884.

89. Ook lijkt de motivering die Van Opstall voor deze driedeling geeft niet geheel bevredigend. De vraag wat moet worden verstaan onder zaken van "gelijke soort en hoedanigheid" is immers aller- 
Een tweede verschil tussen het concept van Meijers en de tekst van Van Opstall, betreft de rente op verbruikleen van geld. Meijers (art. 7.2.2) koos voor de oplossing, dat, indien niet anders is bedongen, rente verschuldigd is. Van Opstall nam deze gedachte over, maar beperkte haar tot geldleningen in de uitoefening van beroep of bedrijf gesloten (art. 7.2.1.2). Aangezien het moeilijk voorstelbaar is dat een persoon of instantie, die er zijn beroep of bedrijf van maakt geld te lenen, zou verzuimen daarvoor een bepaald tarief in rekening te brengen, lijkt het nut van deze regel hoogst twijfelachtig. Bij dergelijke leningen is een rentevergoeding normaal. Anders daarentegen is het gesteld met leningen in de persoonlijke sfeer. Volgens de regeling van het ontwerp heeft iemand, die in goed vertrouwen geld uitleent en verzuimt een afspraak over de rente te maken, geen recht op vergoeding. Juist in die gevallen lijkt echter een wettelijke regel op z'n plaats, omdat het in de particuliere sfeer vaak voorkomt dat eventjes "iets voorgeschoten" wordt.

In Van Opstalls ontwerp ontbreken bovendien de twee leden inzake woekerrente. Het argument is dat er in het algemeen geen reden is degene die in geldnood zit te beschermen: "Vaak is een dergelijke lening de enige mogelijkheid om een in moeilijkheden geraakte onderneming in het leven te houden en de hoge rente wordt dan gerechtvaardigd door het grote risico dat de uitlener daarbij loopt. $\$ 0$ Daarnaast wijst de toelichting op de mogelijkheid het rentebeding te vernietigen op grond van bedrog, bedreiging, misbruik van omstandigheden of dwaling, terwijl in een noot wordt gewezen op de publiekrechtelijke regelingen op dit terrein, zoals de Geldschieterswet.

Wat echter schreef Kamphuisen? "Het tweede en derde lid handelen over woekerrente. Wat daaronder moet worden verstaan zegt het derde lid (als een voorbeeld van een wettelijke beperking der rente kan genoemd worden artikel 31 der Geldschieterswet), terwijl het tweede bepaalt, dat een dergelijke rente to de wettelijke wordt teruggebracht. Dat de wet een woekerrente niet kan erkennen behoeft wel geen toelichting, maar men zou zich kunnen afvragen of artikel 3.2.10 lid 4 niet voldoende middelen tegen woeker geeft. Daar immers wordt een rechtshandeling vernietigbaar verklaard, welke tot stand is gekomen door misbruik van omstandigheden, en dit misbruik wordt o.a. vermoed te bestaan in een geval van onevenredig grote benadeling. Intussen lijkt het gewenst bij woekerrente een speciale regeling te treffen. Vermietiging van de geldlening zal immers vaak een maatregel zijn, die de schuldenaar in een nog moeilijker positie brengt omdat hij dan de hoofdsom moet terugbetalen. Bovendien is het bewijs, dat de rente onredelijk hoog is vaak eenvoudiger te leveren dan het misbruik van omstandigheden en waar woeker een sociaal ongewenst verschijnsel is, moet de bestrijding zo krachtig mogelijk zijn."

Artikel 1798 B.W. (in het concept-Meijers artikel 4) nam Kamphuisen ongewijzigd over. Van Opstall schrapte haar omdat "er geen reden is om, indien een dergelijk beding gemaakt is, partijen daaraan niet te houden en de vrije beslissing van de rechter daarvoor in de plaats te stellen. ${ }^{91}$ Ook deze wijziging is weinig begrijpelijk. De vraag is, of de partij al dan niet tot teruggave in staat is. Het gaat niet, zoals in artikel 1797 B.W., om het verlenen van uitstel, maar om vaststelling van de tijd van teruggave. Door de rechter vrijheid van beoordeling te geven, komt de wet de uitlener tegemoet, voor wie het bewijs, dat de lener tot teruggave in staat is, dikwijls uiterst moeilijk zal zijn.

Een laatste punt van verschil tussen het werk van Meijers en de tekst van het groene Boek is dat in de concepten van Meijers een bepaling als artikel 7.1.2.4 (recht op onmiddellijke terugvordering hoofdsom bij niet-nakomen rente- of aflossingsverplichtingen) niet voorkwam. Van Opstall zelf gaf echter al aan dat het belang ervan marginaal is, omdat het een geregeld voorkomend beding is.

Uit deze eenvoudige vergelijking valt op te maken dat het concept van Meijers lang niet zo voorlopig was als dikwijls is gesuggereerd. Aan de grote lijnen, de opzet van de titel, de vernieuwingen ten opzichte van het B.W. enz., werd door Van Opstall eigenlijk niet getornd, ofschoon hij zich volstrekt niet gebonden voelde aan de teksten van Meijers.

\section{9. $\rightarrow$}

eerst een kwestie van de formulering van de overeenkomst en de bedoeling van partijen. Iemand die een bepaald bedrag aan geld (munten, bankbiljetten) leent, zal gewoonlijk aan zijn verplichtingen hebben voldaan indien hij hetzelfde bedrag per giro- of bankrekening overmaakt. Mocht er dan nog twijfel bestaan, dan kan de verkeersopvatting uitkomst bieden. $\mathrm{Er}$ is dus een grote mate van vrijheid ter bepaling van de vraag of een zaak die wordt teruggegeven, van gelijke soort is.

90. Toelichting-Meijers, p. 885

91. Toelichting-Meijers, p. 886. 
Verder is het twijfelachtig of Van Opstalls bijdrage aan deze overigens weinig belangrijke titel tot een werkelijke verbetering heeft geleid. Ook bij een bevestigend antwoord zou ik echter willen volhouden dat aard en omvang van de door hem verrichtte aanpassingen niet opwegen tegen de voorbereidingstijd van Boek 7. Dat is overigens geen verwijt aan Van Opstall: zoals opgemerkt steunt de tekst van het groene Boek vrijwel geheel op een concept dat hij in de zomer van 1964 inzond.

\section{b. Schenking}

De Schenking was één yan die weinige titels waarvan de tekst niet als een min of meer definitieve kon worden beschouwd, omdat verscheidene principiële vragen - bijvoorbeeld de kwestie of het vereiste van een notariële akce zou moeten worden gehandhaafd (artt. 1719 en 1720 B.W.) - door Meijers waren aangehouden ter nadere overweging. Kamphuisen was daardoor genoodzaakt enkele vrij belangrijke veranderingen in deze titel aan te brengen. Hij schrapte het vormvereiste, zette de titel op als een regeling van de formele schenking en bracht tenslotte nog een aantal kleine redactionele verbeteringen en verduidelijkingen aan.

Wiersma, de auteur van de schenkingstitel in het groene Boek, heeft deze principiële keuzen volledig geëerbiedigd en het concept van Kamphuisen vooral met betrekking tot de toelichting volledig omgewerkt. Dat wil echter niet zeggen dat het uiteindelijke resultaat niet ingrijpend zou verschillen van het door Kamphuisen afgeleverde werk. Er is wel degelijk verschil, maar de voornaamste reden daarvoor is dat Wiersma, veel meer dan Kamphuisen dat kon doen, in vergaande mate aansluiting heeft gezocht bij Boek 6 O.M. en het inmiddels vastgestelde Boek 4. Veel passages uit de Toelichting-Meijers grijpen, zo blijkt, rechtstreeks op deze boeken terug.

Omdat het, gelet op de omvang van de schenkingstitel niet mogelijk is alle veranderingen en verbeteringen de revue te laten passeren, wordt hier volstaan met het geven van enig cijfermateriaal. Uit een globale vergelijking blijkt dat de artikelen $1,4,8,7,9,10,11$ en 12 ook voorkwamen in de concepten van Kamphuisen, terwijl de artikelen 9 en 10 ongewijzigd door Wiersma werden overgenomen. De vijf resterende artikelen zijn dus volledig nieuw ontworpen, met deze aantekening, dat het opnemen van artikel 3 samenhing met een uitspraak van de Kamer over artikel 4.3.2.1. Kortom, zelfs in deze titel is nog betrekkelijk veel van het gedachtengoed van Meijers, en zeker van dat van Kamphuisen te herkennen. Vele wijzigingen ontlenen hun betekenis voornamelijk daaraan dat de ontwerper kennelijk prijs stelde op een meer verzorgde toelichting en minder ruimte wilde laten voor de fantasie van zijn lezers. Een kwestie van verschil in aanpak derhalve.

\section{c. Bruikleen}

De meest opvallende verandering die Van Opstall in de concepten van Meijers heeft aangebracht, is dat hij van de bruikleen weer een reël contract heeft gemaakt. Bij dit soort overeenkomsten zou het vrijwel altijd een vriendendienst betreffen ("om niet") die gratis wordt verricht, waarbij het niet gebruikelijk is "dat de uitlener reeds enige tijd voordat hij de zaak aan de lener afgeeft, zich bij overeenkomst daartoe juridisch verbindt: in de praktijk komt de overeenkomst vrijwel steeds eerst tot stand bij de afgifte van de zaak door de uitlener aan de bruiklener. ${ }^{\text {"92 }}$ Hiertegenover staat de mening van Kamphuisen, die deze opvatting een historisch overblijfsel uit het Romeinse recht noemde, omdat de preatoren nog niet zover waren om te erkennen dat een overeenkomst bij enkele wilsovereenstemming tot stand komt.

Ik geloof dat ook ditmaal het gelijk aan de zijde van Kamphuisen is. Er komen in het dagelijks leven tal van overeenkomsten tot stand, zonder dat partijen zich er volledig van bewust zijn wat de uitvoering daarvan met zich zal meebrengen of zonder dat zij daar tevoren reeds rekening mee hebben gehouden. Anderzijds is het opnieuw een illustratie dat de opvolgers van Meijers zich maar weinig gelegen lieten liggen aan zijn denkbeelden en dat men, ook op een dergelijk klein onderwerp, de stof opnieuw doordacht.

Een ander, zij het evenmin belangrijk verschil tussen het concept-Meijers en het Ontwerp-Meijers is de herintroductie van artikel 1786 B.W. (art. 9 O.M.), betreffende de hoofdelijke aansprakelijkheid van de bruikleners, een regel die wellicht ook uit afdeling 6.1.2 zou kunnen worden afgeleid. Een noviteit van Van Opstall is ook artikel 8, dat met zoveel woorden bepaalt dat de bruiklener gehouden is de zaak terug te geven in de staat waarin hij haar heeft ontvangen. Ook deze bepaling is tamelijk overbodig. Zij vloeit voort uit artikel 7.6.2 O.M. en komt, als ik het goed heb gezien, in het B.W. niet voor. Bovendien had de Hoge Raad in zijn arrest van 30 april 1937, NJ 1937, 900, op basis van artikel 1777 B.W. reeds hetzelfde aangenomen.

Tenslotte maak ik melding van de artikelen 2 lid 2, 3 lid 2 en 7 lid 2 O.M., de eerste twee een verbijzondering van de in lid 1 gegeven hoofdregel, de laatste beogend een regel te geven bij geschillen omtrent het tijdstip 
waarop de zaak in redelijkheid zou kunnen worden teruggegeven. Te verdedigen is een dergelijke bepaling zeker: het wekt alleen bevreemding dat Van Opstall haar bij titel 7.2 juist liet vallen.

Tot zover de materiële wijzigingen die Van Opstall in de concepten van Meijers en Kamphuisen heeft aangebracht. Aantal en omvang zijn dermate bescheiden dat kan worden gesteld dat titel 7.6 in feite niet het het werk van Van Opstall, maar dat van Meijers is. De andere vernieuwingen die 7.6 brengt, stammen in ieder geval geheel uit de koker van Meijers. ${ }^{93}$ Ik noem achtereenvolgens:

- de samensmelting van de artt. 1777-1779 B.W. tot én artikel (zie Toelichting-Meijers, p. 983, 984);

- de, in vergelijking met artikel 1780 B.W., sterk vereenvoudigde regeling van bruikleen na overlijden;

- het weglaten van de artikelen 1782-1784 B.W., artikelen waarvan volgens Kamphuisen zowel het praktisch nut als de redelijkheid twijfelachtig waren (zie Toelichting-Meijers, p. 984);

- de samenvoeging en vereenvoudiging van de artikelen 1785 en 1789 B.W.;

- de toevoeging van een regeling omtrent de vruchten (art. 7.6.2 lid 3 O.M);

- verduidelijking van de artikelen 1787 en 1788 B.W. inzake de teruggave van de in bruikleen gegeven zaak, indien noch een termijn, noch een gebruik van toepassing is.

Ilustratief voor de vergaande graad van voltooiing van Meijers' concept is dat Van Opstall geen enkel artikel heeft geschrapt, integendeel sommige zelfs letterlijk heeft overgenomen. Daarnaast heeft hij ook grote delen van de door Kamphuisen opgestelde toelichting in de toelichting van het Groene Boek verwerkt, zij het dat diens tekst daardoor wel aan bondigheid en helderheid zou inboeten." Samenvattend: verschillen in opvatting en smaak, wellicht ook van praktische kennis en persoonlijke ervaring, lijken hier de doorslag te hebben gegeven.

\section{d. Uitgeversovereenkomst}

Hiervoor kwam reeds ter sprake dat het concept van Van Oven voor de uitgeversovereenkomst (titel 7.8) vrijwel woordelijk gelijk was aan de nog door Meijers opgestelde teksten: in feite had Van Oven zich beperkt tot het toelichten en verwerken van de opmerkingen die in de vergadering van 1 februari 1952 waren gemaakt en waaraan Meijers nooit was toegekomen. Het tweede concept van Van Oven, opgesteld naar aanleiding van

93. Kamphuisens aandeel in deze titel was uitermate beperkt, behoudens het toelichten van de bepalingen. Hij had alleen de definitie van "Bruikleen" iets aangepast, "teneinde te voorkomen, dat deze overeenkomst als een reële zal worden geïnterpreteerd." Daarnaast werd door hem de eindredactie van artikel 7 opgesteld.

94. Men vergelijke bijvoorbeeld hun respectievelijke toelichtingen op artikel 7.6.2 leden 1 en 2:

Toelichting-Kamphuisen: Dit artikel regelt de verplichtingen van de bruiklener gedurende de tijd, dat hij de zaak onder zich heeft. Wat het tweede lid betreft lette men er op, dat het overeengekomene in casu voorgaat voor hetgeen uit de aard der geleende zaak voortvloeit. Heeft iemand b.v. een automobiel geleend met de afspraak, dat deze gebruikt zal worden ter opluistering van een etalage, dan mag de bruiklener er niet mede gaan rijden, hoezeer dit laatste gebruik uit de aard van een motorrijtuig voortvloeit.

Toelichting-Van Opstall: Dit artikel beoogt de bevoegdheid te begrenzen, die de bruiklener ten aanzien van de in bruikleen ontvangen zaak heeft. Deze bevoegdheid heeft niet als keerzijde een positieve verplichting van de uitlener om te zorgen dat de bruiklener het gebruik waartoe hij bevoegd is, ook zal kunnen maken. Zo al van enige verplichting van de uitlener te dezen aanzien na de uitgifte van de zaak sprake is, is dat hoogstens een verplichting tot niet doen, namelijk om niet gebruik te maken van een hem toekomende, bij voorbeeld uit zijn recht van eigendom van de zaak voortvloeiende, bevoegdheid om de zaak van de bruiklener terug te eisen, zolang deze haar ingevolge de overeenkomst mag gebruiken.

De omvang van de bevoegdheid tot gebruik van de bruiklener wordt in de eerste plaats omlijnd door hetgeen daaromtrent bij de overeenkomst is bepaald. Het gebruik waartoe de zaak naar haar aard bestemd is, komt voor die omlijning slechts subsidiair in aanmerking. Zo mag, als iemand een automobiel heeft uitgeleend met de bepaling dat deze de bruiklener slechts zal mogen dienen tot opluistering van zijn etalage, de bruiklener met dat voertuig niet gaan rijden, ofschoon dit in het algemeen het meest voor de hand liggende gebruik daarvan is. 
de besprekingen met de Adviescommissie voor het Auteursrecht, was ten opzichte van het eerste vrijwel ongewijzigd: slechts op één punt volgde Van Oven nu zijn eigen voorkeur.

Ook hier dringt zich de vraag op in hoeverte het spoedwerk, dat in de dagen van Donker nu eenmaal onvermijdelijk was, heeft geleid tot minder bruikbare teksten. Waarschijnlijk is de factor tijd in deze het minst belangrijk, want een vergelijking met de tekst van het groene Boek - die overigens voor een groot deel nog door Van Oven zelf is bezorgd - levert geen grote verschillen op. Weliswaar is de toelichting wat meer uitgedijd - in de conceptversie van 1955 waren geen verwijzingingen opgenomen naar rechtspraak, literatuur en buitenlandse wetgeving -, en zijn er artikelen van plaats veranderd of gesplitst, maar wezenlijk is dat allemaal niet. Bovendien is het de vraag of die aanvullingen wel zo zinvol zijn, want daardoor heeft de toelichting, althans naar mijn smaak, aanmerkelijk aan zeggingskracht ingeboet.

Een voorbeeld. Met betrekking tot artikel 7.8.7 lid 2 (het recht van de auteur om oplagecijfers te controleren) merkte Van Oven in 1954 op:

"Dit voorschrift dankt zijn onstaan aan het, naar het schijnt, bij enkele uitgevers voorkomende misbruik, van meer exemplaren te drukken dan waartoe hun de overeenkomst het recht gaf, zonder de auteur daarvan op de hoogte te stellen, waardoor deze zoals zich horen laat, zwaar benadeeld kan worden."

Wellicht is dit taalgebruik te joumalistiek van aard of onvoldoende verzorgd, maar omtrent de bedoeling van de ontwerper kan geen enkel misverstand bestaan. Dan de toelichting in het groene Boek. Zij zegt precies hetzelfde, maar - al is dat gedeeltelijk een kwestie van stijl - op een veel meer diplomatieke, versluierde wijze, waarbij, althans naar mijn mening, tal van overbodige details nader worden verklaard:

"De bepaling van de eerste zin van het tweede lid dient om te voorkomen dat meer exemplaren in het verkeer worden gebracht dan het oorspronkelijk voor de oplage vastgestelde aantal, zonder dat hiervoor twestemming van de wederpartij van de uitgever is verkregen. Aan deze kan echter niet het recht tot het doen controleren van de boekhouding van de uitgever worden toegekend zonder dat tevens waarborg bestaat dat degene die de controle verricht, de daarbij verkregen gegevens geheim houdt en aan zijn opdrachtgever slechts datgene mededeelt, wat rechtstreeks met zijn opdracht verband houdt. Daarom wordt in de tweede en derde zin van het tweede lid een zodanige verplichting op de deskundige gelegd en voorts bepaald dat de wederpartij er jegens de uitgever voor instaat dat de deskundige deze verplichting nakomt. De deskundige zal, bij schending van zijn geheimhoudingsplicht, zelf jegens de uitgever aansprakelijk zijn uit hoofde van een onrechtmatige daad, maar de aansprakelijkheid van de wederpartij biedt de uitgever een extra waarborg, ook al omdat zij ten gevolge heeft dat de wederpartij de door haar aangewezen deskundige op zijn geheimhoudingsplicht zal wijzen. "95

De wijzigingen die wél van belang zijn, concentreren zich op de artikelen 4,10 en 11 , die in de concepten van Meijers niet voorkwamen. Over het nut van deze aanvullingen durf ik geen oordeel uit te spreken, maar het lijkt mij onbetwistbaar dat het geringe aantal verbeteringen dat in deze twintig jaar werd aangebracht, de deugdelijkheid van Meijers' werk onderstreept. Bovendien is het zo, dat deze aanvullingen geen wijziging beoogden in de al gereedliggende teksten.

\section{e. Bewaameming}

De titel Bewaameming (de benaming is een vondst van Van Opstall) is één van die titels waarbij de voordelen die Meijers van hercodificatie verwachtte: eenvoud, overzichtelijkheid en rechtszekerheid, zeer duidelijk aan het licht treden.

Allereerst was het concept van Meijers voor deze titel veel korter dan de regeling van het B.W. van 1838 (titel 12 van Boek 3). De voornaamste reden daarvan was dat in deze titel alleen de sequestratie bij overeenkomst werd opgenomen, in tegenstelling tot de vier vormen die in het B.W. worden aangetroffen. Naast deze vereenvoudiging kon een verkorting worden bereikt door het weglaten van een aantal overbodige artikelen. Zo

95. Toelichting-Meijers, p. 1017. Een willekeurig gekozen ander voorbeeld: Bij de inieidende opmerkingen schreef Van Oven in 1954 ondermeer "Een afzonderlijk subjectief vermogensrecht, 'uitgeversrecht' geheten, dat men in buitenlandse wetgevingen wel vindt, kent het ontwerp niet. Daaraan bestaat geen behoefte. Ook is het gewenst de titel tot weinig voorschriften te beperken, geen regeling in bijzonderheden te geven, doch de uitwerking aan de praktijk en de rechtspraak over te laten". Dezelfde passage is in het groene Boek, de noten niet meegerekend, acht maal zo groot, zonder dat iets nieuws wordt gebracht (p. 1012-1013). 
schrapte Meijers bijvoorbeeld het onderscheid tussen vrijwillige bewaargeving en bewaargeving uit noodzaak (zie de artikelen 1735, 1740 en 1742 B.W.), de bijzondere bepalingen inzake de handelingsonbekwaamheid van de bewaarnemer of -gever (art. 1738 en 1739 B.W.), de bijzondere risicoregeling (artt. 1752 en 1753 B.W.) en de regel, vervat in de artikelen $1756,1760,1761$ en 1766 B.W.

Meijers beperkte zich niet tot vereenvoudiging alleen: hij wilde ook nieuw recht scheppen. Dat blijkt al uit zijn definitie van bewaargeving ("Door een overeenkomst van bewaargeving verbindt de bewaamemer zich jegens de bewaargever om een zaak, die deze hem toevertrouwt, te bewaren en terug te geven") waaruit een viertal vernieuwingen spreekt. In de toelichting op dit artikel schreef Kamphuisen: "In de eerste plaats is de overeenkomst als een consensuele geconstrueerd, terwijl het tot nu toe een reële was; (..) Vervolgens blijkt uit de woorden "een zaak", dat zowel roerende als onroerende zaken voorwerp van bewaargeving kunnen zijn, terwijl er tevens uit volgt, dat onlichamelijke zaken niet in bewaring kunnen worden gegeven. Er is weinig reden bewaargeving te beperken tot roerende zaken, want het is zeer wel denkbaar, dat iemand zijn huis aan een ander in bewaring wil geven en bezwaar daartegen bestaat niet; bewaargeving van onlichamelijke zaken laat zich echter moeilijk denken (..) Een belangrijke consequentie van de definitie is ook, dat het z.g. depositum irregulare buiten de overeenkomst van bewaargeving wordt gezet. (..) De woorden "en terug te geven" tenslotte leggen vast, dat niet alleen het bewaren, maar ook het teruggeven een hoofdverplichting van de bewaarnemer is; voor de aansprakelijkheid kan dit van belang zijn. ${ }^{n \%}$

Een andere noviteit die reeds in de concepten van Meijers was te vinden, is de aansprakelijkheidsregeling. Bepaalt het oude Burgerlijk Wetboek in artikel 1743 B.W. dat de bewaarnemer dezelfde zorg moet aanwenden die hij omtrent zijn eigen zaken aanwendt, in het concept van Meijers (art. 3) wordt de regel gegeven die in het algemeen geldt voor degene die verplicht is een bepaalde zaak af te geven: "De bewaarnemer moet bij het bewaren van de zaak de zorg van een goed bewaarnemer in acht nemen." Artikel 1749 B.W. kreeg ook al bij Meijers een soepelere formulering. Artikel 4 van zijn concept bepaalt dat de bewaarnemer de zaak niet zonder toestemming van de bewaargever op een andere wijze mag gebruiken, dan nodig is om deze in goede staat te houden. Daarmee codificeerde Meijers een regel die in de ons omringende landen reeds lang in de wet was te vinden.

Onderbewaarneming was bij Meijers strikt verboden. De codificatie van HR 16 maart 1951, NJ 1951, 676 (zie art. 7.9.1.4 O.M.) is dan ook van de hand van Kamphuisen, die het niet gewenst vond de onderbewaameming absoluut te verbieden. Het vierde lid van dit artikel, waarin de mogelijkheid wordt geopend dat de bewaamemer in verband met bijzondere omstandigheden de in bewaring genomen zaak tijdelijk elders opslaat, was wel een vondst van Meijers. Kamphuisen heeft deze bepaling letterlijk overgenomen en ook Van Opstall heeft er niets aan veranderd. Snijders daarentegen zou haar schrappen: "Indien uitdrukkelijk een bepaalde wijze van bewaring is afgesproken dient de bewaamemer daarvan in beginsel niet eenzijdig te kunnen afwijken. Dat uitleg van de overeenkomst tot een andere regel kan leiden en ook gewoonte en eisen van redelijkheid en billijkheid, bedoeld in artikel 6.5.3.1, een rol kunnen spelen, behoeft hier niet te worden bepaald. ${ }^{\text {"9? }}$

Tenslotte maakte Meijers van artikel 1761 B.W. een haalschuld, en vatte de artikelen $1761-1763$ B.W. in één lid samen. Daarnaast ontwierp hij nog een bepaling voor de situatie dat twee of meer personen gezamenlijk een zaak in bewaring geven. Deze bijzondere een regel zou in het R.O. niet worden overgenomen. ${ }^{98}$

Uit dit overzicht blijkt, dat Meijers titel 7.9 met een aantal nuttige aanvullingen heeft verrijkt, vernieuwingen die door zijn opvolgers vrijwel ongewijzigd zijn overgenomen. Hun bijdrage aan deze titel is dan ook, behoudens het toelichten van de artikelen, een beperkte geweest. Ik geef in het kort de meest in het oog springende verschillen tussen hun werk en dat van Meijers.

- Het concept van Meijers ging er nog van uit, dat de gratis bewaargeving de normale is. Deze voorstelling van zaken vond Kamphuisen echter niet meer in overeenstemming met de werkelijkheid, zodat hij Meijers' versie van ar. 1733 B.W. schrapte en bepaalde dat de bewaargeving slechts dan wordt geacht om niet te zijn aangegaan wanneer een uitdrukkelijke afspraak omtrent het bewaarloon ontbreekt en het gebruik of de billijkheid niet anders vorderen.

Van Opstall vond dit echter weer te ver gaan, en beperkte deze regel tot de beroeps- of bedrijfsmatige bewaarneming (art. 7.9.2 lid 1). Snijders zou het onderscheid professioneel/niet-professioneel overnemen, maar de verwijzing naar mogelijke afwijkingen op grond van overeenkomst, gebruik of billijkheid als zijnde

96. Zie ook de Toelichting-Meijers, p. 1023 e.v., waar Van Opstall soms vrijwel letterlijk de toelichting van Kamphuisen volgt.

97. Parl. Gesch. Boek 7, p. 398.

98. Zie Parl. Gesch. Boek 7, p. 414 e.v. 
overbodig schrappen. Dat aan de niet-professionele bewaarnemer in beginsel geen loon verschuldigd is, zou ook zonder uitdrukkelijke bepaling blijken. ${ }^{100}$.

- Volgens artikel 2 lid 2 concept-Meijers, diende de bewaargever de met de bewaameming verbonden kosten en de door de bewaarneming veroorzaakte schade te vergoeden. Kamphuisen was het daarmee slechts gedeeltelijk eens en bepaalde dat bij bewaargeving tegen loon de bewaarnemer zelf de kosten, als zijnde verdisconteerd in zijn loon, diende te dragen. Van Opstall nam zijn redactie vrijwel woordelijk over (art. 7.9 .2 lid 2). Regeringscommissaris Snijders koos uiteindelijk voor de meest genuanceerde oplossing: de bewaargever moet aan de bewaarnemer de aan de bewaring verbonden onkosten vergoeden, voor zover deze niet in het loon zijn begrepen.

- Meijers bepaalde in artikel 3 lid 2 dat bij bewaarneming om niet de bewaamemer voor geringe tekortkomingen niet aansprakelijk kon worden gesteld. Kamphuisen handhaafde daar de diligentia quam in suis van artikel 1743 B.W.: de bewaarnemer is slechts aansprakelijk indien hij niet dezelfde zorg heeft aangewend, die hij omtrent de bewaring van zijn eigen zaken pleegt toe te passen. Van Opstall vond geen van beide oplossingen aantrekkelijk en nam in zijn ontwerp de regel op (art. 7.9.3.) dat de bewaarnemer bij de bewaarneming de zorg van een goed bewaarnemer in acht dient te nemen, daarmee de consequentie trekkend dat de gedachte, dat de bewaarneming een vriendendienst is, niet meer past in deze tijd.

De volgende veranderingen stammen uit de koker van Van Opstall:

a. het uitschrijven van artikel 6.1.8.3 met betrekking tot de aansprakelijkheid van de bewaarnemer voor de onderbewaamemer (art. 7.9.1.4 lid 3).

b. de codificatie van artikel 1752 B.W, dat bepaalt dat de zaak in dezelfde toestand als waarin zij werd ontvangen moet worden teruggegeven (art. 7.1.9.6 lid 4).

c. het schrappen van artikel 1754 B.W., waarvan Meijers en Kamphuisen de toepasselijkheid hadden beperkt tot de bewaargeving om niet. Vermoedelijk vond Van Opstall het in dit artikel geregelde geval (de erfgenaam die de in bewaring gegeven zaak te goeder trouw doorverkoopt) dermate specieus, dat hij van codificatie afzag.

\section{f. Aanneming van werk}

De titel "aanneming van werk" was éen van die titels, waarbij Meijers er nog niet toe gekomen was de laatste tekst en de rapporten daarover onder loupe te nemen. Hoewel al dikwijls over deze titel was vergaderd, was er tot kort voor zijn overlijden nog sprake van een uitgebreide gedachtenwisseling tussen de ontwerper, de Raad voor het Bouwbedrijf en de Commissie tot Herziening van de Algemene Voorschriften voor de Bouwnijverheid. Kamphuisen was echter weinig onder de indruk van deze kritiek en schreef in de nota aan het Driemanschap dat hij, een kleine uitzondering daargelaten, alleen goede nota had genomen van de tekstuele opmerkingen.

Het concept van Meijers liet heel goed zien hoe verouderd dit deel van het B.W. eigenlijk is en bevatte voor meer dan de helft bepalingen op punten waarvoor het huidige B.W. geen regeling geeft. Ik vermeld de mogelijkheid van prijsverhoging en/of ontbinding op grond van buitengewone omstandigheden (arr. $5 ;$ art. 4 O.M.); prijsbepaling, indien de prijs niet in een bedrag was uitgedrukt (art. 6; art. 3 O.M.); herstel van gebreken vóor oplevering en/of recht op prijsvermindering (art. 8; artt. 8 en 9 O.M.); reclame- en verjaringstermijn terzake van gebreken (art. 9; art. 11 O.M).

Ook de regelingen die door Meijers wél werden overgenomen uit het B.W. waren op menig punt veranderd en aangevuld. Zo was artikel 1646 B.W., betreffende het meerwerk, zodanig verbeterd dat het vereiste van schriftelijke toestemming was vervallen, terwijl in de nieuwe redactie in vele gevallen zou kunnen worden aangenomen, dat toestemming, gegeven door de architect, mag worden beschouwd als toestemming vanwege de aanbesteder (vergelijk art. 7.12.5 O.M). Artikel 1643 B.W., betreffende de opneming, kreeg bij Meijers ook een sterk gewijzigde redactie, waarin de bevoegdheid tot opneming en haar consequenties duidelijk werden geregeld. Het artikel kwam erop neer dat wanneer men van de opneming geen gebruik maakt, het werk als goedgekeurd geldt.

Tenslotte noem ik artikel 12 van het concept-Meijers, dat een beperking bracht op de wel zeer rigide regel van artikel 1648 B.W., bepalende dat iedere overeenkomst van aanneming eindigt door de dood van de aannemer. Als oplossing koos Meijers voor de regel dat in een dergelijk geval de rechtsverkrijgenden van de aannemer recht hebben op een evenredig deel van de prijs, terwijl hij de bepaling ook uitbreidde tot die gevallen waarin onbekwaamheid buiten schuld leidde tot onmogelijkheid van nakoming.

100. Zie Parl. Gesch. Boek 7, p. 395 e.v. 
Kamphuisen veroorloofde zich ten opzichte van de concepten van Meijers slechts twee wijzigingen die inhoudelijk van belang zijn. Allereerst nam hij een regel op waarbij de aanbesteder tot op zekere hoogte het recht kreeg meer- of minderwerk te gelasten (vergelijk art. 7.12.5 O.M.). Daarnaast schrapte hij, na lang beraad, de risicoregeling van de artikelen 1641-1643 B.W. Kamphuisen schreef daarover: "Het lijkt mij onmogelijk een bevredigende regeling te ontwerpen omtrent het risico en omtrent de verplichtingen van partijen in geval van wanprestatie. De gevallen welke zich in de practijk kunnen voordoen, zijn zo verschillend, dat de voorgestelde oplossing in bepaalde gevallen ongetwijfeld tot onbillijkheden zou leiden. Bovendien komt het mij voor, dat de algemene regeling van het nieuwe B.W., speciaal afdeling 6.5.4, voldoende is om tot bevredigende oplossingen te komen." ${ }^{101}$

H. Drion, de bewerker van deze titel, heeft vrijwel elke bepaling heroverwogen en van een andere, meestal meer in bijzonderheden tredende redactie voorzien. Van alle titels die zijn onderzocht, is deze het meest drastisch gewijzigd. Gelet op de omvang van de wijzigingen, wordt volstaan met het opsommen van de belangrijkste verschillen.

- de herintroductie van de risicoregeling. Zie voor een motivering de toelichting bij de artikelen 7 en 10 , p. 1071-1073, 1075-1077;

- het schrappen van het bijzondere voorrecht van de werknemer, in dienst van de aanbesteder (art. 1650 B.W.) en het recht van terughouding (art. 1652 B.W.) in verband met de art. 3.10.3.13 en 14 G.O, die overigens beide inmiddels zijn vervallen;

- het niet overnemen van de bepalingen inzake opneming en de plicht tot oplevering in verband met de algemene regel van artikel 6.1.8.14;

- het laten vallen van art. 1640 B.W., bepalende dat kan worden overeengekomen dat de aannemer verplicht is de voor het werk benodigde materialen te leveren. Volgens de toelichting op p. 1066 valt dit reeds te lezen in de definitie van de aanneming van werk, terwijl op dit punt ook geen controverse zou bestaan die het geven van een regeling noodzakelijk zou maken. Op dat argument lijkt niets af te dingen.

Overziet men de door $\mathrm{H}$. Drion aangebrachte wijzigingen, dan kan ten aanzien van deze titel de conclusie niet anders zijn dat de tekst van het groene Boek wel een verbetering brengt ten opzichte van de teksten van Meijers, maar dat de aard en de omvang van de wijzigingen niet dusdanig is dat daarmee de tekst van Meijers is veroordeeld. Eerlijk gezegd zou mij dat ook wel enigszins verbazen. Het concept van Meijers was in nauw overleg met de praktijk opgesteld. Het zou na twintig jaar hoogstens op een paar punten verouderd kunnen zijn. Maar onvolledig of onbruikbaar? Nee.

101. Het citaat vervolgt: "Daar komt nog bij, dat ik vrees, dat in de door prof. Meijers ontworpen regeling de aanbesteder sterk geneigd zal zijn om, wanneer het werk gereed of bijna gereed is, onvolkomenheden te gaan zoeken teneinde de overeenkomst te kunnen ontbinden. Door een dergelijke ontbinding immers komt de aanbesteder financieel in een veel betere positie". H. Drion, de bewerker van titel 7.12, nam weer wél een risicoregeling op. Zie de artikelen 7.12.7 en 10 O.M. 
Hoofdstuk 9

BOEK 8: VERKEERSMIDDELEN EN VERVOER (1954-1992)

\section{Inleiding}

"Wat hebben wij aan een wettelijke regeling van regelend recht, zoals bijvoorbeeld het zeerecht heeft gegeven, die niet in samenwerking met vertegenwoordigers van de betrokken partijen is tot stand gekomen? Dat zeerecht is heel kundig gemaakt, maar heeft voor een belangrijk deel in de praktijk nooit gegolden, omdat het regelend recht vervangen is door de contracten, die door de grote ondernemers zelf zijn opgesteld. Een dergelijke mogelijkheid bestaat ook bij de voorgestelde regeling van standaardcontracten, maar daar is zij veel geringer. Wanneer men kan zeggen: gij hebt daaraan zelf medegewerkt, gij hebt dat zelf als de beste regeling beschouwd en voor zover wij daarvan zijn afgeweken, was dat in het algemeen belang, zal men zich wel tweemaal bedenken en niet te vlug een afwijkende regeling verkiezen."

Deze woorden, gesproken door Meijers tijdens de openbare behandeling van het $24 \mathrm{e}$ vraagpunt ("Moet meer dan thans de mogelijkheid geopend worden, dat voor bepaalde contracten de toepasselijke regels niet door de wet worden vastgesteld, maar door de Kroon of een andere overheidsinstantie onder medewerking of na raadpleging der belanghebbenden?"), zouden ook afkomstig kunnen zijn geweest van prof.mr. H. Schadee (1910), de hoofd- en eindredacteur van het groene Boek 8 en de gewezen Regeringscommissaris voor het nieuwe vervoersrecht. Doordat deze "patriarch van het zeerecht" ${ }^{1}$ de praktijk vanaf het eerste uur bij zijn werk wist te betrekken en zeer consequent en langdurig met belanghebbenden heeft overlegd en onderhandeld, slaagde hij er uiteindelijk in een tekst te bereiken waarin alle betrokkenen zich konden vinden, een resultaat dat voor de Tweede Kamer aanleiding was met een blanco verslag te komen.

In dit hoofdstuk zal een aantal aspecten uit de ontwikkeling van dit groene Boek en de daarop gebaseerde wetsontwerpen worden belicht. Daarbij zal, nog meer dan hiervoor het geval was, het accent liggen op de manier waarop het werk aan dit deel van het nieuwe wetboek werd georganiseerd. De kennis van het vervoersrecht van schrijver dezes is namelijk te gering om zich te wagen aan uitspraken over de inhoudelijke kwaliteiten van dit onderdeel van het nieuwe Burgerlijk Wetboek. Daarnaast ontbraken hem de tijd en de lust het meer dan 40.000 documenten tellende archief van Schadee nauwgezet te onderzoeken. ${ }^{2}$

1. Deze woorden zijn afkomstig van H. Cohen Jehoram, die Schadee van september 1962 tot augustus 1963 heeft geassisteerd bij diens werk aan het nieuwe zeerecht.

2. Zie de archiefinventaris nieuw Burgerlijk Wetboek van de Regeringscommissaris prof.mr. H. Schadee (1962 t/m 1988), Depot 256, Ministerie van Justitie. 


\section{Meijers' opzet voor Boek 8}

Volgens de "voorlopig door prof. Meijers ontworpen indeling van het nieuwe wetboek", overgelegd bij de behandeling van de Nota over het nieuwe Burgerlijk Wetboek $^{3}$, zou het achtste Boek (toen nog Boek 7) alleen het zee- en binnenvaartrecht bevatten. Zoals Meijers verklaarde naar aanleiding van een opmerking van de Minister van Verkeer en Waterstaat, die aandrong op een systematischer en meer onderling overeenstemmende behandeling van het vervoersrecht, was het "niet nodig en ook niet wenselijk" speciale regels omtrent het spoorweg- en het luchtvervoer in het Burgerlijk Wetboek op te nemen. Het spoorwegvervoer was in Nederland en ook daarbuiten altijd los van het Wetboek van Koophandel geweest, hetgeen vrijwel nooit tot moeilijkheden aanleiding had gegeven, terwijl het luchtrecht nagenoeg geheel onder invloed van internationale verdragen tot stand was gekomen en er, gelet op het uitputtende karakter daarvan, geen aanleiding bestond om in die historisch gegroeide situatie wijziging te brengen. ${ }^{4}$ Uit het slot van de "Algemene inleiding" tot de toelichting van de in 1954 door Meijers aangeboden voorontwerpen, bleek evenwel dat de ontwerper van zijn aanvankelijk voornemen was afgestapt: als inhoud van het achtste Boek werd mede het luchtrecht vermeld, met als argument dat dit recht in een modern wetboek niet zou mogen ontbreken. ${ }^{5}$

Een regeling voor de vervoers- en expeditieovereenkomst (ter vervanging van de nog op paard en wagen ${ }^{6}$ afgestemde regeling van de artt. 91 e.v. W.v.K.) was door Meijers geprojecteerd als titel 10 van Boek 7. Aanvankelijk was deze titel, die in het midden van de zestiger jaren naar Boek 8 zou worden overgebracht, gedacht als een algemene regeling voor alle vormen van vervoer (althans die ter zee, te land en over de binnenwateren), ten opzichte waarvan de in Boek 8 op te nemen regels als een nadere uitwerking waren te beschouwen. Dit denkbeeld, waaraan Meijers zelfs al ten dele vorm had gegeven, leidde echter tot sterk verzet van de "specialisten" in de subcommissie Handelsrecht ${ }^{7}$, die de noodzaak en de mogelijkheid van harmonisatie van het vervoersrecht in twijfel trokken en ook geen oog hadden voor de wenselijkheid beginselen van algemeen vervoersrecht op te stellen. ${ }^{8}$ Het gevolg daarvan was, dat Meijers er van afzag en de bewerking van deze titel aan de subcommissie delegeerde. ${ }^{9}$

3. Parl. Gesch. NBW, Algemeen Deel, p. 32-36.

4. Opmerkingen van Meijers, ontleend aan een notitie van W.G. Belinfante van 27 november 1952 met betrekking tot de derde reeks vraagpunten.

5. Zie ook Hugo van Kooten en Isette Reuder, Het zeerecht is het oudste recht, (interview met prof.mr. H. Schadee), Ars Aequi 1993, p. 9, "Wat is nou een Wetboek van Koophandel waar geen luchtrecht in staat?"

6. Zie K.F. Haak, Kroniek van het vervoer(s)recht, NJB 1986, p. 960 e.v.

7. Omstreeks 1954 hadden daarin zitting: R.P. Cleveringa, J.H. Beekhuis, T.J. Dorhout Mees, W.F. De Gaay Fortman, W.C.L. Van der Grinten, J.A.L.M. Loeff en H. Schadee. Het secretariaat werd gevoerd door W.J. Slagter.

8. Zie daarover Th.H.J. Dorrestein, Verkeersmiddelen en vervoer, NJB 1973, p. 1113 e.v.

9. Notulen van de subcommissie Handelsrecht van 30 april en 1 mei 1953 . Op 31 oktober 1953 ontving Meijers tekst en toelichting van het door de commissie opgestelde ontwerp, met daarbij de opdracht "om hiervan voor het nieuwe B.W. het gebruik te maken, hetwelk U.H.G. passend zal toeschijnen." 
Het opstellen van het voorontwerp van Boek 8, althans van belangrijke onderdelen daarvan, had Meijers uitbesteed aan de subcommissie Handelsrecht van de Staatscommissie. Die taak, die voor het grootste deel op de schouders van Cleveringa, Schadee en, in mindere mate, Beekhuis zou worden gelegd, bleef beperkt tot het aanpassen van het Tweede Boek van het Wetboek van Koophandel aan de op dat moment bekend zijnde ontwerpen voor het nieuwe Burgerlijk Wetboek. Het zee- en binnenvaartrecht waren namelijk betrekkelijk recent herzien (het zeerecht bij Wetten van 22 december 1924, Stb. 573 en 10 juni 1926, Stb. 171 en het binnenvaartrecht bij Wet van 24 juni 1939, Stb. 201), en werd daarom gerekend tot die wetgeving die, incidentele verbeteringen daargelaten, zoveel mogelijk onveranderd in het nieuwe wetboek zou moeten worden overgenomen.

Ook met betrekking tot het luchtrecht was er voor de subcommissie slechts een bescheiden rol weggelegd. De commissie had, volgens Cleveringa ${ }^{10}$, tot taak het luchtrecht te regelen op basis van de reeds bestaande of nog te sluiten internationale verdragen. Meijers was van mening dat een nationale regeling die van internationale gebruiken of afspraken zou afwijken, geen zin had. Een volledige beschrijving van het luchtrecht was dus niet aan de orde.

\section{Juni 1954; Boek 8 O.M. is vrijwel gereed}

Begin juni 1954 was de subcommissie nagenoeg gereed met haar werk, zo blijkt althans uit de notulen van een op 12 juni 1954 in aanwezigheid van Minister Donker gehouden vergadering. Volgens Cleveringa, die de Minister een kort overzicht gaf van de stand van zaken ten aanzien van Boek 8 , behoefde deze van de zijde van de subcommissie geen moeilijkheden te verwachten met betrekking tot zijn voornemen in september 1954 de resterende gedeelten van het Ontwerp-Meijers openbaar te maken. De regeling van het vervoer ter zee, waarbij aansluiting was gezocht bij het reeds uit 1924 daterende Brusselse Cognossementsverdrag (de zgn. Hague Rules) was gereed en kon, naar Cleveringa vertrouwde, ongewijzigd in het nieuwe Burgerlijk Wetboek worden opgenomen. Hetzelfde gold voor een ontwerp over de avarij-grosse - een onderdeel van het Wetboek van Koophandel dat nog uit 1838 stamde - dat was opgesteld door Schadee en inmiddels de goedkeuring van de subcommissie had verkregen. De commissie moest zich alleen nog buigen over een tweetal minder urgente kwesties, de één betrekking hebbend op de vraag of de regel van art. 356 lid 2 W.v.K. zou moeten worden uitgebreid tot het binnenvaartrecht, de ander verband houdend met de vraag of het mogelijk en ook wenselijk zou zijn het grootste deel van het Tweede Boek van het Wetboek van Koophandel niet in het Burgerlijk Wetboek over te nemen, maar de regeling over te laten aan bij Algemene Maatregelen van Bestuur vast te stellen standaardregelingen. Beide kwesties zouden volgens Cleveringa ruim binnen de de Minister gestelde termijn tot een oplossing kunnen worden gebracht.

Met betrekking tot het luchtrecht, waarin ongeveer dezelfde onderwerpen zouden moeten worden behandeld als in het zeerecht, had de commissie aanmerkelijk minder vorderingen gemaakt. Ook daarover behoefde de Minister zich echter geen al te grote zorgen te maken, want een deel van die onderwerpen, zoals de regeling van de vervoersovereenkomst, zou volgens Cleveringa vrij eenvoudig in aansluiting op reeds

10. Notulen van de 114 e vergadering van de subcommissie Handelsrecht van 12 juni 1954 . 
bestaande verdragen kunnen worden geregeld. En ten aanzien van de meer specifieke onderwerpen voorzag de voorzitter van de subcommissie Handelsrecht evenmin ernstige problemen. Een ontwerp met betrekking tot de internationale erkenning van zakelijke rechten op luchtvaartuigen, opgesteld door Schadee en Beekhuis, had reeds de goedkeuring van de subcommissie verworven, terwijl beide heren bezig waren met een ontwerp tot regeling van de aansprakelijkheid voor schade door vliegtuigen. Ook dit onderwerp zou spoedig gereed kunnen zijn, omdat men nauw aansluiting zocht bij het verdrag van Rome.

Wel zou de regeling van het luchtrecht (de 3e titel van het 8e Boek) voorlopig nog onvolledig moeten blijven, omdat ten aanzien van punten als de positie van de gezagvoerder, de hulp en berging alsmede de avarij-grosse, niet kon worden voortgebouwd op internationale afspraken. " Dat laatste was voor Minister Donker echter geen onoverkomelijk bezwaar: "Men zal moeten volstaan met een raamwerk, dat slechts gedeeltelijk wordt opgevuld."

\section{1954-1961: Een periode van stilstand}

Ofschoon de tekst voor het achtste groene Boek dus waarschijnlijk omstreeks september 1954 gereed kwam - een aanwijzing daarvoor is dat het merendeel van de door Cleveringa genoemde onderwerpen binnen een à twee jaar door middel van "voortreinen" tot wet zou worden verheven ${ }^{12}$-, bleef het ook rond dit Boek lange tijd stil. Het Driemanschap, dat formeel de verantwoordelijkheid droeg voor alle de door Meijers nagelaten concepten, en dus ook voor Boek 8, werd zo inbeslaggenomen door het werk aan het voorontwerp voor Boek 6 , dat men geen tijd had het concept voor Boek 8 te beoordelen. En omdat het Driemanschap, naarmate de bewerking van de teksten voor Boek 6 O.M. vorderde, steeds verder afweek van de door Meijers ingenomen standpunten, bestond er ook steeds steeds minder reden het voorontwerp voor Boek 8, dat immers geheel was afgestemd op de nog door Meijers opgestelde teksten, te publiceren; het zou dan uitsluitend als illustratiemateriaal voor een nieuw op te stellen ontwerp kunnen dienen.

De subcommissie Handelsrecht was vanzelfsprekend allesbehalve gelukkig met deze ontwikkeling, maar ook zij moest zich erbij neerleggen dat het tempo van de hercodificatie werd bepaald door het Driemanschap, dat niet harder kon werken dan het al deed. Een poging om Drion en de zijnen tot spoed aan te manen - begin 1958 herinnerde de subcommissie de Driemannen er aan dat het voorontwerp voor Boek 8 gereed lag en wachtte op publicatie van het verbintenissenrecht - liep dan ook op niets

11. Met betrekking tot de hulp of berging was weliswaar een verdrag gesloten (vergelijk I.H.Ph. Verschoor, Het verdrag van Brussel van 1938 betreffende hulp en berging van of door luchtvaartuigen op zee, Utrecht 1943), maar in 1954 was het door nog geen enkele Staat bekrachtigd.

12. Zie bijvoorbeeld de Wet van 15 augustus 1955, Stb. 1955, 398, waardoor de Hague-rules werden geïncorporeerd in het Wetboek van Koophandel, de Wet van 24 februari 1955, Stb. 1955, 71, houdende wijziging van art. 356 W.v.K. en de Wet van 6 maart 1957, Stb. 1957, 72, betreffende de internationale erkenning van rechten op luchtvaartuigen (Wet teboekgestelde Luchtvaartuigen).

Het advies met betrekking tot de standaardregelingen werd uitgebracht op 25 juni 1954. Omdat de meningen binnen de commissie sterk uiteenliepen, volgde op 17 december 1954 een tweede advies waarin één en ander unaniem werd ontraden. Het "verknippen" van het vervoersrecht zou esthetisch onaanvaardbaar zijn en de noodzaak met zich brengen de gehele stof opnieuw te doordenken. 
uit: de subcommissie kreeg ten antwoord dat de tijd die het Driemanschap nog nodig zou hebben voor het afwerken van het voorontwerp voor Boek 6 , zou kunnen worden besteed om een voorstel te doen tot regeling van het luchtrecht! ${ }^{13}$ Kortom, het werd september 1961, het tijdstip waarop het Driemanschap werd ontheven van zijn taak, voordat het vervoersrecht weer in beeld kwam.

\section{1961: Een nieuwe aanpak?}

Het behoeft geen betoog dat het Ministerie enigszins in z'n maag zat met het ontwerp van de subcommissie Handelsrecht. Weliswaar was het niet onmogelijk het binnen een relatief korte termijn - zeg een half jaar - aan te passen aan de inhoud van het nieuwe vermogensrecht, maar een dergelijke operatie zou én weinig aantrekkelijk én enigszins riskant zijn. Niemand kon immers nog voorspellen hoe het Gewijzigd Ontwerp voor Boek 3 er uit zou gaan zien en op welke punten het Regeringsontwerp voor Boek 6 zou afwijken van het door het Driemanschap afgeleverde produkt.

Bovendien was het ontwerp voor Boek 8 , met name ten aanzien van het zeerecht, tamelijk gedateerd: Molengraaffs codificatie, hoezeer ook een bewonderenswaardig stuk werk, was in veel opzichten naast de praktijk komen te staan en vormde met haar uitgebreide, over tal van paragrafen verdeelde regels van aanvullend recht een nogal log en onoverzichtelijk geheel ${ }^{14}$, hetgeen in het bijzonder bij de verwerking van internationale verdragen al dikwijls voor problemen had gezorgd. Dat het tot 1955 had geduurd alvorens de Hague Rules een plaats in het wetboek kregen, zegt in dit verband voldoende. ${ }^{15}$

Meijers wist dat natuurlijk ook wel ${ }^{16}$, maar had daar indertijd niet al te zwaar aan getild: de in eigen kring als alternatief voor de wettelijke regeling opgestelde voorschriften hadden nooit tot serieuze bezwaren aanleiding gegeven, zodat er geen dringende noodzaak was de gehele stof op korte termijn opnieuw onder het vergrootglas te nemen. Bovendien moest hij ermee rekening houden dat de werkkracht van de Kamer niet onbegrensd was: het tegelijkertijd herzien van het Burgerlijk Wetboek en van een groot deel van het Wetboek van Koophandel zou voor de volksvertegenwoordiging wel eens te veel van het goede kunnen zijn.

Dit laatste argument had echter eind 1961 iedere overtuigingskracht verloren. De hoop, dat het nieuwe wetboek er snel zou komen, was al lang vervlogen en Ministerie en Kamer waren na het overlijden van Meijers en Donker op een beduidend langzamer tempo overgeschakeld. Er was daarom veel voor te zeggen om de totstandkoming van het nieuwe Burgerlijk Wetboek aan te grijpen voor een algehele herziening van het zeerecht, mits men daarvoor iemand zou kunnen vinden die zich, eventueel met terzijdestelling van al zijn andere activiteiten, volledig aan deze taak zou kunnen wijden. Zo iemand moest niet alleen over voldoende wetenschappelijk prestige

13. Notulen van de 167 e vergadering van het Driemanschap van 3 januari 1958.

14. Zie de Handelingen van de NJV 1955, p. 584 e.v., waarin mr. J.A.L.M. Loeff, een autoriteit op het gebied van het zeerecht en tevens lid van de subcommissie Handelsrecht, illustreerde dat maar liefst acht verschillende wetten, titels of afdelingen moesten worden doorlopen om de inhoud van bijvoorbeeld een reischarter vast te stellen.

15. Vergelijk ook de "Inleidende opmerkingen" tot de toelichting van het Achtste groene Boek (eerste stuk), waarin uitgebreid wordt ingegaan op de feilen van het oude zee- (en binnenvaart-)recht.

16. Vergelijk het aan het begin van dit hoofdstuk opgenomen citaat. 
beschikken, maar ook een open oog en oor hebben voor de wensen van de praktijk. Want dat een opdracht aan een meerhoofdige, wetenschappelijk georiënteerde commissie geen garantie bood voor snel werk, daar was men inmiddels wel achter.

Geleid door deze overwegingen en na een positief advies van de subcommissie Handelsrecht besloot Minister Beerman op voorspraak van Cleveringa - dé autoriteit op het gebied van het zeerecht ${ }^{17}-, \mathrm{mr}$. H. Schadee, advocaat en dispacheur te Rotterdam, te belasten met de herziening van het zeerecht. ${ }^{18}$ Schadee, die door zijn lidmaatschap van de Staatscommissie al enige ervaring had op wetgevend terrein ${ }^{19}$, actief was in het Comité Maritime International en bovendien kon voortbouwen op het werk dat hij had verricht in het kader van een aan hem verleende opdracht tot het ontwerpen van een zeerecht voor Tunesië ${ }^{20}$, zou het ontwerp moeten voltooien in drie jaar tijds ${ }^{21}$, met inbegrip van een door de Minister noodzakelijk geacht overleg met de subcommissie Handelsrecht.

De benoeming van Schadee betekende dat ook een voorziening moest worden getroffen met betrekking tot het luchtrecht. De subcommissie Handelsrecht had de voorbereiding van haar werkzaamheden op het gebied van het luchtrecht tot dan toe namelijk steeds uitbesteed aan Schadee en Beekhuis, die met $z$ 'n tweeën de subcommissie luchtrecht vormden. Deze, in het verleden met succes toegepaste werkwijze, zou nu echter, zo meende men, in het gedrang kunnen komen door de opdracht aan Schadee.

Minister Beerman besloot daarom dat Beekhuis, die in 1952 lid was geworden van de Nederlandse afdeling van de ICAO (International Civil Aviation Organisation) en ook enige ervaring had met het zelfstandig opzetten van wetsontwerpen ${ }^{22}$, de bewerking van het luchtrecht alleen op zich zou moeten nemen, een taak die eenvoudiger

17. "Prof. Cleveringa zou ongetwijfeld zelf in aanmerking komen voor dit werk, ware het niet dat zijn huidige ambt (lid van de Raad van State) en zijn andere taken hem geen tijd en gelegenheid daartoe zouden laten", volgens Van Ewijk in een nota aan de Minister van 12 september 1961.

18. Schadee ontving zijn opdracht op 15 december 1961.

19. Schadee was, naast zijn werkzaamheden ten behoeve van de aanpassing van het Wetboek van Koophandel aan de Haque Rules, co-auteur van de Wet teboekgestelde Luchtvaartuigen. Daarnaast had hij van 1951 tot 1956 gewerkt aan de totstandkoming van de avarij grosse-regels voor de binnenvaart. (Zie "Recht door Zee", Zwolle 1980, p. XI).

20. Overigens was het resultaat nogal mager. Schadee: "Met dat ontwerp ben ik naar Tunis gereisd, op kosten van de Tunesische Regering natuurlijk, alwaar ik met grote eerbied werd ontvangen. De Tunesische Minister van Justitie zei toen echter tot mijn stomme verbazing: 'Tunesische wetten worden door Tunesiërs gemaakt, dus dat ontwerp van mijnheer Schadee leggen we in de la'. Het was een wonderlijke opdracht. Het had tot gevolg dat ik nog jaren daarna dozen met vijgen en dadels ontving." (Hugo van Kooten en Isette Reuder, a.w., Ars Aequi 1993, p. 11).

21. De termijn van drie jaar was zo gekozen dat de Boeken 7 en 8 gelijktijdig zouden kunnen verschijnen. De Jong, die met Cleveringa de inspirator was tot het verlenen van de opdracht aan Schadee, ging er op dat moment namelijk nog van uit dat de termijn, nodig voor de voltooiing van de ontwerpen voor de onder zijn leiding te bewerken titels van Boek 7, ten hoogste drie jaar zou bedragen. Bovendien vond men een langere termijn ongewenst omdat, zoals Van Ewijk schreef, "voorkomen moet worden dat de Kamer op enig moment zonder werk komt te zitten."

22. Tijdens de oorlogsjaren had Beekhuis met A.F. Schepel, de griffier van de Tweede Kamer en Paul Scholten gewerkt aan een wettelijke regeling voor de appartementseigendom, hetgeen resulteerde in een op 15 april 1947 aangeboden wetsvoorstel, houdende voorzieningen betreffende eigendom van appartementen, Bijl. Hand. Tweede Kamer, 1946-1947, 451. Zie ook hiervoor, Hoofdstuk 3. 
zou zijn dan die van Schadee, omdat de geldende luchtvaartwetgeving qua vorm betrekkelijk nauw aansloot bij de desbetreffende internationale verdragen.

Ook Beekhuis, die op 15 december zijn opdracht aanvaardde, zou het werk binnen drie jaren moeten voltooien, iets waartoe hij zich, zoals Van Ewijk schreef, ondanks zijn professoraat in Groningen en de voorziene bewerking van zijn deel uit de Asserserie "ten volle in staat achtte. ${ }^{23}$

Daarmee was de Minister er nog niet, want de subcommissie Handelsrecht had in haar advies met betrekking tot de voorgenomen benoeming van Schadee en Beekhuis erop gewezen dat zij met betrekking tot het binnenvaartrecht, dat evenals het zeerecht ver afstond van de praktijk en waarvan bovendien de essentiële dwingende aansprakelijkheidsbepalingen nooit in werking waren getreden, een analoge oplossing prefereerde.

Omdat het inderdaad weinig fraai zou zijn indien het Achtste Boek, naast twee gemoderniseerde titels ook nog een omvangrijk gedeelte "dood recht" zou bevat$t^{2} \mathrm{n}^{24}$, en het vermoedelijk ook vanuit een oogpunt van wetgevingsbeleid onwenselijk werd geacht dat de door belanghebbenden zelf opgestelde regeling van het vervoer te water ${ }^{25}$, in tegenstelling tot de regels met betrekking tot het vervoer over de weg ${ }^{26}$, aan praktisch elke overheidsinvloed ontrokken was, besloot Minister Beerman aan het verzoek van de Staatscommissie gehoor te geven.

Het bleek echter verre van eenvoudig iemand te vinden die thuis was in het binnenvaartrecht, in die kringen over het nodige gezag beschikte en bovendien ook nog bereid was zijn carrière tijdelijk aan het wetgevende werk ondergeschikt te maken. Men had de hoop op een geschikte kandidaat dan ook al bijna opgegeven, totdat Schadee het Ministerie attendeerde op mr. J. Swart, een bekend advocaat te Rotterdam, die zijn sporen in het binnenvaartrecht al ruimschoots had verdiend en volgens Schadee wel iets voelde voor de gedachte dit onderdeel van het burgerlijk recht te vereenvoudigen en aan te passen aan de wensen van de praktijk.

Swart had daar inderdaad wel oren naar en dientengevolge werd hem op 15 maart 1962, drie maanden nadat Schadee en Beekhuis hun opdracht hadden ontvangen, de bewerking van het binnenvaartrecht toevertrouwd. Ook hij verbond zich er toe zijn werk binnen drie jaar te voltooien, de gedachtenwisseling met de Staatscommissie en het - gezien de vele dwarsverbanden tussen het zee- en binnenvaartrecht - noodzakelijke overleg met Schadee daarbij inbegrepen.

\section{Nota van 31 oktober 1961.}

24. Aldus H. Schadee in zijn "Inleidende opmerkingen" tot de toelichting van het Achtste groene Boek, eerste stuk, p. 8.

25. Met medewerking van het Ministerie van Verkeer en Waterstaat werd in de behoefte aan standaardregelen voorzien door de in 1952 opgestelde en ingevoerde "Bevrachtingsvoorwaarden 1952" voor de wilde vaart, opgesteld door een commissie onder voorzitterschap van mr. J.A.L.M. Loeff. Voor de beurtvaart golden de Algemene Vervoercondities 1950, gewijzigd in september 1952, uitgegeven door de Stichting "vervoeradres" en opgesteld door een commissie onder voorzitterschap van prof.mr. L.J. Hijmans van den Bergh.

26. De Wet Autovervoer Goederen en de Wet Goederenvervoer Binnenscheepvaart, beide uit 1951, vormden het administratiefrechtelijk kader waarbinnen de belanghebbenden zelf tot het opstellen van standaardvoorwaarden konden komen. De taak van de overheid beperkte zich in feite tot goedkeuring van hetgeen door het bedrijfsleven zelf was tot stand gebracht. 
Tenslotte werd, wederom op advies van de Staatscommissie, besloten dat het trio Schadee-Beekhuis-Swart de bewerking van de door de subcommissie Handelsrecht opgestelde titel 7.10 (Vervoers- en expeditieovereenkomst) voor z'n rekening zou nemen, een beslissing die ook wel voor de hand lag gezien de nauwe samenhang tussen de daarin behandelde stof en Boek 8. Ook dat werk zou, gelet op de plannen van de coördinator van Boek 7, tegen het einde van 1964 gereed moeten zijn.

\section{Oktober 1964: Boek 8 voor tweederde gereed}

Schadee leverde zijn concept (tekst én toelichting) voor het zeerecht twee dagen voor het verstrijken van de termijn, op 29 december 1964 in, met uitzondering van de arbeidsovereenkomst ter zee, die door Levenbach zou worden ontworpen. Dat was een hele prestatie, omdat hij, door voortdurend overleg te voeren met de praktijk, kans had gezien het gehele bedrijfsleven, met al z'n tegenstrijdige belangen, achter zijn ontwerp te krijgen.

Een eerste concept voor titel 7.10 kwam op 23 oktober 1963 gereed. Dit ontwerp had echter nog geen definitief karakter, omdat Schadee en Beekhuis enerzijds en Swart anderzijds het op één of twee principiële punten niet eens konden worden en in afwachting van een beslissing door de Minister het werk aan deze titel hadden opgeschort.

Ook Beekhuis slaagde er in zijn werk tijdig af te ronden, al had hij, anders dan Schadee, nog geen overleg gevoerd met het bedrijfsleven. Dat zou echter, gelet op het overwegend internationale karakter van het luchtrecht, weinig meer dan een formaliteit zijn. Beekhuis zelf althans dacht aan één of twee vergaderingen wel genoeg te hebben. ${ }^{27}$

De opdracht aan mr. Swart bleek echter geen succes te zijn. Hoewel hij nog in oktober 1963 de Minister de verzekering had gegeven dat hij zijn concepten in 1964 zou inzenden, waarbij als streefdatum 1 oktober 1964 werd aanvaard, werd eind 1964 duidelijk dat die belofte van nul en generlei waarde was: pas na herhaald aandringen zond Swart zijn concepten in, die, ofschoon zij een redelijke omvang hadden, bij nadere bestudering uit weinig meer bleken te bestaan dan een serie blanco vellen, met daarboven het opschrift van de te ontwerpen titel of afdeling. De schaarse teksten die hij had ontworpen - voor in totaal twee afdelingen had Swart een door hem als "voorlopig" gekwalificeerde tekst opgesteld - weken bovendien sterk af van de vergelijkbare bepalingen van Schadee, terwijl iedere vorm van toelichting ontbrak. Met het overleg met de praktijk tenslotte, was slechts een aarzelend begin gemaakt. Kortom, in feite moest het werk aan het binnenvaartrecht nog beginnen.

27. Opmerking, ontleend aan een verslag van een bespreking met Minister Scholten op 4 februari 1965. 


\section{Wat nu?}

Hoewel dit slechte nieuws voor het Ministerie niet geheel onverwacht kwam Schadee, die zeer bevriend was met Van Ewijk had deze al meerdere malen laten weten er aan te twijfelen of Swart tijdig met een bruikbaar en goed bij de andere hoofdstukken aansluitend voorontwerp zou komen ${ }^{28}$ - stelde deze wanprestatie van Swart de Minister toch al direct voor een in feite onoplosbaar probleem. Immers, waar zou hij in dit stadium alsnog een advocaat, rechter of hoogleraar kunnen vinden die bereid zou zijn de failliete boedel van Swart over te nemen? Specialisten op het gebied van het binnenvaartrecht waren dun gezaaid en aan een uitbreiding van de taken van Schadee of Beekhuis, die, hoewel zij weinig of niets wisten van het binnenvaartrecht, tenminste vertrouwd waren met de overige delen van het $8 \mathrm{e}$ Boek, viel op dat moment nog niet te denken: Schadee was als gevolg van zijn vele andere werkzaamheden ${ }^{29}$ al een aantal malen aan de rand van een overspanning geweest en zou, volgens Van Ewijk ${ }^{30}$, ter vermijding van een onaangename verhouding tot Swart als medelid van de Rotterdamse balie, waarschijnlijk ook niet bereid zijn de bewerking van het binnenvaartrecht op zich te nemen. En Beekhuis had zijn handen inmiddels meer dan vol aan het opstellen van de Memorie van Antwoord voor Boek 5 , een taak die geen uitstel dulde en naar verwachting minimaal twee jaar in beslag zou nemen.

Omdat het ook niet mogelijk bleek iemand van het Departement in te schakelen een voorstel om Cohen Jehoram, die Schadee een jaar terzijde had gestaan bij de voorbereiding van het zeerecht, te belasten met de verdere bewerking van het binnenvaartrecht, werd door Minister Scholten afgewezen omdat de bezetting van de Stafafdeling Wetgeving Nieuw Burgerlijk Wetboek dan zou worden gereduceerd tot één man - en het tijdelijk opschorten van de bewerking van het binnenvaartrecht eveneens tot de onmogelijkheden behoorde ${ }^{31}$, bleef de Minister geen andere keus dan de opdracht aan Swart te continueren, met dien verstande dat Schadee, die voorbestemd was om te zijner tijd tot Regeringscommissaris voor Boek 8 te worden benoemd, als "waakhond" zou fungeren.

Dit betekende dat Swart en Schadee gezamenlijk het voorontwerp-binnenvaartrecht zouden voltooien, waarbij Swart zich met betrekking tot zaken als inhoud, vorm,

28. Schadee deed deze uitspraken omdat Swart, in tegenstelling tot Beekhuis, weinig of geen overleg met hem pleegde, ofschoon hij hem geregeld al zijn concepten toezond. (Aldus Van Ewijk in een nota van 1 oktober 1964).

29. In 1961 trad Schadee toe tot de advocaten- en dispacheursassociatie mrs. Nauta, Lambert, Schadee, Japikse en de Savornin Lohman, in 1963 werd hij te Leiden benoemd tot bijzonder hoogleraar in het vergelijkend zeerecht en van 1967 tot 1975 zou hij een leeropdracht in het vervoersrecht vernullen aan de Erasmus-Universiteit te Rotterdam. Daarnaast stond hij vanaf 1936 aan het hoofd van de "Vereenigde Dispacheurs" te Rotterdam. Tegenover Van Kooten en Reuder (Ars Aequi 1993, p. 10) verklaarde Schadee: "Ik heb altijd ontzettend veel arbitrages gedaan en die ben ik blijven doen. Ik heb perioden gehad dat ik meer dan 36 arbitrages tegelijkertijd in behandeling had."

30. Nota van 1 oktober 1964.

31. Bij de behandeling van de begroting voor 1964 (handelingen Tweede Kamer 1963-1964, p. 398) had Minister Scholten reeds aangekondigd dat het eerste concept voor het Achtste groene Boek z'n definitieve vorm begon te naderen. Het terugkomen op die uitspraak zou de kritiek op het werk aan het nieuwe Burgerlijk Wetboek ongetwijfeld nieuwe impulsen geven, vooral ook omdat de vorderingen met betrekking tot het voorontwerp voor Boek 7 eveneens teleurstellend waren. 
volgorde en terminologie zou moeten richten naar de aanwijzingen van Schadee, terwijl ingeval van meningsverschil de opvatting van de laatste zou prevaleren. Bovendien zou het ontwerp zich moeten schikken naar het reeds bestaande ontwerpzeerecht. ${ }^{32}$

\section{De opdracht aan Swart beëindigd}

Al snel bleek echter dat de samenwerking tussen Swart en Schadee veel te wensen overliet, hetgeen gelet op de eerdere verwikkelingen en de uitgesproken persoonlijkheid van beide heren, eigenlijk ook wel was te verwachten. ${ }^{33}$ Swart, die er vermoedelijk weinig voor voelde om aan de leiband van zijn jongere collega te lopen, schreef deze op 5 maart 1965 dat hun opvattingen over essentiële punten als de vraag of de praktijk vanaf het eerste begin bij het voorbereiden van het voorontwerp zou moeten worden betrokken en de vraag in hoeverre het binnenvaartrecht een afspiegeling zou moeten zijn van het zeerecht, te ver uiteen liepen om de samenwerking op vruchtbare wijze voort te zetten ${ }^{34}$, waarna Minister Scholten de opdracht aan Swart beëindigde.

Daarmee was de kans op een spoedige totstandkoming van het binnenvaartrecht voorgoed verkeken, want Schadee, die nu tot taak kreeg het uitermate onvolledige concept van Swart af te werken, was allesbehalve deskundig op het terrein van het binnenvaartrecht. "Ik wist," zo vertelde hij, "weinig van de binnenvaart af, dus ik heb me er erg in moeten inwerken."

\section{Boek 8 uitgebreid met hoofdstuk voor wegvervoer}

Was het besluit het binnenvaartrecht te herzien achteraf beschouwd dus niet zo'n goede stap, het weinig doordachte van die beslissing bleek eigenlijk nog duidelijker toen het Ministerie begin 1965 onder druk van een aantal vervoersorganisaties moest besluiten Boek 8 uit te breiden met een hoofdstuk voor het wegvervoersrecht. En het gevolg dáárvan was weer, dat het wegvervoersrecht eigenlijk steeds een stap achter zou lopen bij het zee- en binnenvaartrecht, en zo de ontwikkeling van die delen ernstig zou ophouden. Ter toelichting het volgende.

Zoals ik hiervoor schreef, was Meijers oorspronkelijk van plan in Boek 7 een algemene regeling voor alle vormen van vervoer op te stellen, die zonodig nog zou kunnen worden aangevuld met aanvullende bepalingen voor elk van deze vormen van vervoer afzonderlijk. Een dergelijke regeling was, aldus Meijers in zijn toelichting op dit voornemen, niet alleen noodzakelijk om te voorkomen dat de concurrentieverhoudingen tussen deze takken van vervoer verstoord zouden worden tengevolge van een niet gerechtvaardigd verschil in de op de verschillende vervoerstakken toepasselijke regels, maar zou, zeker als vraagpunt 24 bévestigend zou worden beantwoord, ook een nuttig instrument kunnen zijn bij het wijzigen en opstellen van de in

32. Aldus een instructie aan Swart van 17 december 1964.

33. Van Ewijk maakte de Minister op 15 januari 1965 deelgenoot van zijn sombere voorgevoelens: "De inschakeling van prof. Schadee bij het ontwerpen van het binnenvaartrecht is nog pas begonnen, zodat nog niet te zeggen valt of een goede samenwerking tussen hem en mr. Swart mag worden verwacht; optimistisch ben ik daarover niet."

34. Zie ook Van Kooten en Reuder, Interview met prof.mr. H. Schadee, Ars Aequi 1993, p. 8. 
deze vervoerstakken veel toegepaste standaardregelingen. "Vroeg of laat", zo besloot Meijers zijn toelichtende opmerkingen, "zal het inzicht veld winnen dat geheel gescheiden regelingen voor nauw-verwante onderwerpen ongewenst zijn en dat het nieuwe B.W. derhalve deze gedachte veeleer dan tegen te gaan, dient aan te moedigen"35.

De subcommissie Handelsrecht, tot wie deze woorden waren gericht, was het hiermee echter bepaald oneens, met als gevolg dat de door haar opgestelde titel over de vervoersovereenkomst (titel 7.10) slechts enkele algemene bepalingen kende, die zeker niet waren bedoeld als een algemene regeling voor het wegvervoer, ofschoon zij, gelet op het uitputtende karakter van de overige in Boek 8 op te nemen regels, wél voornamelijk op het wegvervoer van toepassing zouden zijn.

Nu was het op zich niet zo'n ernstige zaak dat in het nieuwe Burgerlijk Wetboek slechts een bescheiden plaats was ingeruimd voor het wegvervoer. De in het Wetboek van Koophandel opgenomen regels waren immers op sterven na dood en het vervoer over de weg ondervond ook geen schade van de regels die op het binnenvaartrecht van toepassing waren. Dat was, zoals reeds aangestipt, eveneens volledig "dood" recht. Het verschil in vervoersvoorwaarden dat er tussen beide vervoerstakken bestond, was louter het gevolg van een verschil in concurrentiekracht, de wet stond daar buiten.

Aan deze historisch gegroeide situatie kwam echter een abrupt einde toen Minister Beerman in 1961 uitsluitend het besluit nam het binnenvaartrecht aan te passen aan de eisen van de tijd. Immers, een nieuwe regeling voor het binnenvaartrecht, die toch voornamelijk door partijen zelf zou worden opgesteld, zou nadelig kunnen uitpakken voor het wegvervoer en mogelijk zelfs tot oneerlijke concurrentie aanleiding kunnen geven. Kortom, het besluit om uitsluitend het binnenvaartrecht te herzien, was, gelet op de verstrengeling van de binnenvaart en het wegvervoer en de grote economische belangen die daarbij op het spel stonden, erg onverstandig. ${ }^{36}$

Minister Scholten kon dus weinig anders doen dan ingaan op het verzoek van de Stichting Vervoeradres (een stichting waarin alle organisaties op het gebied van het goederenvervoer over de weg en de beurtvaart, alsmede de verladersorganisatie E.V.O. zijn vertegenwoordigd) om Boek 8 uit te breiden met een hoofdstuk over het wegvervoer. ${ }^{37}$

Ook met betrekking tot dit gedeelte van Boek 8 zou er het nodige van Schadee worden gevergd. Want hoewel het opstellen van het ontwerp voor het vervoer over de weg, bij gebreke van een geschikte (dat wil zeggen, onafhankelijke) praktijkjurist, voor het grootste deel zou worden verricht door $\mathrm{mr}$. H. Scheffer, een gepensioneerd

35. Notulen van de subcommissie Handelsrecht van 30 april en 1 mei 1953.

36. Eind 1963 was overigens al wel overwogen het wegvervoersrecht aan Boek 8 toe te voegen, maar Van Ewijk had toen gemeend de Minister een dergelijke stap te moeten ontraden omdat deze stof dan vermoedelijk zou moeten worden opgedragen aan Swart, ondanks de onzekerheid of hij tijdig en goed het binnenvaartrecht zou voltooien (Nota van Van Ewijk van 1 oktober 1964).

37. Een andere overweging daarbij was dat Nederland inmiddels was toegetreden tot de C.M.R. (Convention relative au contrat de transport international de marchandises par route, Genève 19 mei 1956, Trb. 1957, 84). Voor de bedrijfstak zélf speelde een rol dat er intern onenigheid was onstaan over de herziening van de Algemene Vervoercondities 1950. 
raadadviseur van Justitie ${ }^{38}$, zou er voor Schadee meer dan voldoende werk over blijven. Niet alleen zou hij er zorg voor moeten dragen dat de door Scheffer te ontwerpen regeling qua terminologie, systematiek en redactie zoveel mogelijk zou aansluiten bij de overige delen van Boek 8, maar bovendien zou het ontwerpen van de regeling voor het wegvervoer en het binnenvaartrecht zoveel mogelijk gelijk op moeten gaan, teneinde te bereiken dat beide partijen met het resultaat zouden kunnen instemmen. Want anders zou men in dezelfde situatie terecht komen als in 1952, toen de invoering van de na moeizaam onderhandelen tot stand gekomen aansprakelijkheidsregels voor de binnenvaart werd uitgesteld in afwachting van een regeling voor het wegvervoer, met het voorspelbare gevolg dat er helemaal niets gebeurde.

\section{Zee- en luchtrecht vervroegd publiceren?}

Toen begin 1965 eenmaal duidelijk was geworden dat de opzet om het binnenvaartrecht op korte termijn te ontwerpen, als mislukt kon worden beschouwd, rees vanzelfsprekend de vraag wat er met de concepten voor het zee- en luchtrecht moest gebeuren.

Omdat het, naar het zich liet aanzien, nog geruime tijd zou duren voordat Schadee een ontwerp voor het binnenvaartrecht aan het bedrijfsleven zou kunnen voorleggen en met de voorbereiding van het wegvervoersrecht zelfs nog een begin moest worden gemaakt, besloot Minister Scholten in overleg met Beekhuis en Schadee dat het groene Boek in twee afleveringen zou verschijnen. Dat in het voorontwerp voor het zeerecht de afdelingen gewijd aan het arbeidsrecht ter zee vermoedelijk "open" zouden moeten blijven, was voor de Minister van minder belang: "Ook al zou de regeling van de arbeidsovereenkomst ter zee bij de publicatie van het groene Boek nog ontbreken", zo valt in de notulen van die bijeenkomst te lezen, "is het van belang dat naar buiten blijkt, dat ook met het Achtste groene Boek voortgang is gemaakt." ${ }^{39}$

Aangezien de Minister geen tijd verloren wenste te laten gaan, werd besloten over de beide ontwerpen geen formeel advies aan de Staatscommissie te vragen, uit vrees dat dit zeer veel tijd zou kosten. In plaats daarvan zou Beekhuis, als voorzitter van de subcommissie Handelsrecht, aan elk harer leden een exemplaar toezenden, met het verzoek vóór 1 mei 1965 eventuele opmerkingen ter kennis van de ontwerpers te brengen. Mochten er opmerkingen van meer algemene aard binnenkomen, dan zou Beekhuis alsnog een vergadering met de subcommissie beleggen.

Ofschoon dit plan uitermate doeltreffend bleek - er kwamen van de leden van de subcommissie geen opmerkingen binnen die een vergadering noodzakelijk maakten werd al snel duidelijk dat aan het streven om het groene Boek in twee afleveringen te laten verschijnen, meer haken en ogen zaten dan men zich aanvankelijk had voorgesteld. Het voordeel van een publicatie in twee gedeelten - de omstandigheid dat er, althans voor wat betreft het zee- en luchtrecht, veel meer tijd zou zitten tussen het groene Boek en het Regeringsontwerp, iets wat met het oog op het verwerken van

38. Scheffer, ooit door Justitie "weggekocht" van Waterstaat, beschikte over een ruime kennis van het vervoersrecht, mede vanwege zijn werkzaamheden als vertegenwoordiger voor Nederland in de vergaderingen te Genève over de internationale regeling van het "inlandtransport."

39. Notulen van een bespreking met de Minister op 4 februari 1965. 
eventuele kritiek uiteraard hoogst welkom was - bleek bij nader inzien namelijk niet op te wegen tegen de nadelen die men ervan verwachtte.

In de eerste plaats bleek opnieuw dat onvoldoende rekening was gehouden met de verwevenheid van de verschillende in Boek 8 onder te brengen vervoerstakken, waardoor een publicatie in gedeelten de samenhang tussen de verschillende ontwerpen ongunstig zou kunnen beïnvloeden. Daardoor zou later dan toch weer harmonisatie nodig kunnen blijken en in het ergste geval zelfs een compleet herschrijven van bepaalde titels of afdelingen. Bovendien zou, zo vreesde men, een publicatie in twee afleveringen bij de binnenvaartrechtbelanghebbenden de vrees kunnen versterken dat het zeerecht teveel als model, ook voor het binnenvaartrecht, op de voorgrond zou worden geplaatst, hetgeen voor een vlot verloop van het overleg uiteraard weinig bevordelijk zou zijn. ${ }^{40}$

Een tweede factor die meespeelde bij de beslissing het zee- en luchtrecht niet afzonderlijk te publiceren, was dat de concepten van Beekhuis en Schadee bij nader inzien nogal wat tekortkomingen vertoonden. Want hoewel de beide ontwerpers regelmatig met elkaar hadden vergaderd, bleek, volgens Van Ewijk, de afstemming niet optimaal. ${ }^{41}$ Bovendien vertoonde het ontwerp van Schadee een aantal plaatsen die nadere studie en wellicht wijziging vereisten. Zo had de ontwerper van het zeerecht nog in het geheel geen rekening gehouden met de wijzigingen die in het Regeringsontwerp voor Boek 3 zouden worden aangebracht en dreigde ook de internationale rechtsontwikkeling roet in het eten te gooien. In het najaar van 1965 zou het Comité Maritime International namelijk bijeenkomen om te spreken over een ontwerpverdrag betreffende scheepshypotheken en schulden. Schadee was in zijn concept echter nog uitgegaan van een uit 1926 daterend verdrag, zodat het risico levensgroot was dat dit deel van zijn ontwerp al weer kort na de publicatie op de helling zou moeten. Ook daarom was afwachten geboden.

De derde en laatste factor die een rol speelde bij het besluit ernaar te streven de vier hoofdstukken van het groene Boek tóch gelijktijdig te publiceren, bestond er in dat het het Departement in feite aan mankracht ontbrak om de concepten voor het groene Boek te recenseren. Van Ewijk immers, had zijn handen op dat moment meer dan vol aan de invoeringswet voor Boek 1, het Mondeling Overleg over Boek 4 en de voorbereiding van de Memorie van Antwoord voor Boek 3, terwijl Cohen Jehoram, zijn enige medewerker, uiteraard niet kon worden belast met het toetsen van de concepten van Schadee, zijn vroegere leermeester. En na het vertrek van Scheffer was er eigenlijk niemand meer op Justitie die goed thuis was in het zee- en luchtrecht.

Er restte de Minister dan ook weinig anders dan het besluit om het zee- en luchtrecht afzonderlijk te publiceren voorlopig in de ijskast te zetten en de bestudering daarvan ten Departemente tot nader order te staken.

40. Aldus blijkt uit een memorandum van een bespreking tussen Schadee, Van Ewijk, Scheffer en Minister Samkalden op 31 augustus 1965.

41. Uit een nota van Van Ewijk van 13 oktober 1966: "Het luchtrecht is in eerste concept gereed en het zeerecht (in verband met het ontbreken van enige regels van I.P.R. en bepalingen over de arbeidsovereenkomst) grotendeels. Maar gebleken is dat er nog veel meer kan worden gedaan aan het vermijden van niet door specifieke eisen van de vervoerstak of bestaande verdragen geboden verschillen tussen de vier onderdelen. Er moet dus nog veel werk, ook aan het zee- en luchtrecht worden verzet." 


\section{1967: het binnenvaartrecht in eerste concept gereed}

Omdat Schadee zich vóór 1965 in feite voornamelijk met het zeerecht had beziggehouden - de belangstelling daarvoor was hem als het ware met de paplepel ingegoten, want sinds 1724 hadden acht generaties Schadee in rechte lijn het zee- en binnenvaartrecht beoefend - was hem er alles aan gelegen om de praktijk in een zo vroeg mogelijk stadium met zijn werk met betrekking tot het binnenvaartrecht te confronteren. Begin augustus 1965, dus drie maanden nadat Swart zijn congé had gekregen, had hij dan ook al een eerste schets voor het vervoersrecht (titel 8.10) klaar, bedoeld om te fungeren als discussiestuk.

Die confrontatie met de praktijk viel echter allesbehalve mee, in die zin dat er, tengevolge van het ontbreken van effectieve nationale en internationale regelgeving ${ }^{42}$, zeer veel tijd ging zitten in inventariseren van alle wensen en verlangens, het uitzoeken hoe iets in de praktijk precies werkte en het gladstrijken van de talrijke belangentegenstellingen. "Van alles wat ik oorspronkelijk op papier had gezet, is helemaal niets meer over", zo vertelde Schadee in een in 1967 gehouden vraaggesprek. "Als ik me heb teruggetrokken met een koffer vol nieuw-B.W. in mijn vakantiehuisje in Gorssel, en mijn vrouw vraagt 's avonds hoe het is gegaan, dan komt het voor dat ik opgewekt moet zeggen: ik heb alles verscheurd wat ik gisteren heb gedaan. "43

In feite fungeerde Schadee dan ook als arbiter. Hij moest het klimaat scheppen waarin partijen het gezamenlijk eens konden worden. ${ }^{44}$

Dit zoeken naar een tekst die neutraal genoeg was om iedereen per saldo gelijkelijk tevreden te stellen, was een proces van jaren. Het is enigszins vergelijkbaar met het samenstellen van een woordenboek in een taal die nog nooit werd opgetekend. Onverdroten tekende Schadee de klanken op, stelde hij de grammatica samen, bracht hij structuur en samenhang aan die voordien vrijwel ontbraken.

Daar kwam nog bij, dat het voor de ontwerper en zijn talrijke adviseurs - het eerste concept voor het zeerecht kwam bijvoorbeeld in een team van een man of veertien tot stand - niet altijd eenvoudig was het overleg te combineren met het dagelijkse werk. Zo moest Schadee het voornemen om zijn gesprekspartners voor het binnenvaartrecht eens per week voor een vergadering bijeen te roepen, al snel laten varen en overgaan tot één bijeenkomst in de twee weken. ${ }^{45}$ En dan ging het de meesten van hen waarschijnlijk nog te snel. Dorrestein, één van de adviseurs voor het zeerecht door Schadee heel toepasselijk aangeduid als de "zwoegers" - zou later althans verklaren dat hij en zijn collega's voortdurend het gevoel hadden gehad volledig in

42. Ook op internationaal gebied leidden én leiden de meeste regelingen met betrekking tot het binnenvaartrecht veelal een papieren bestaan. Zie K.F. Haak, a.w., p. 959.

43. "Vervoerslogica", Het Vaderland, 28 april 1965.

44. Over zijn overleg met de "maandagadviseurs", zo genoemd omdat de vergaderingen over het binnenvaartrecht altijd op de maandag plaatsvonden, vertelde Schadee: "Het ging allemaal even plezierig, er is nooit een kwaad woord gevallen. Ik volgde eigenlijk hun wensen, want u moet niet vergeten dat het transportrecht een kwestie van dubbeltjes is, dat wil zeggen van miljoenen tegenwoordig."

45. Aldus blijkt uit de notulen van een op 2 december 1965 gehouden bespreking over Boek 8 . 
het niet te verzinken bij het "moordend" werktempo van Schadee: "We just faded away. "46

De tijd die Schadee nu zou verliezen door het zeer intensieve overleg met het bedrijfsleven, zou later echter weer in één klap worden goedgemaakt, toen de Tweede Kamer het regeringsontwerp voetstoots aannam "gelet op het feit, dat bij de samenstelling van het betrokken ontwerp nauw overleg en uitvoerige samenspraak met de organisaties van alle betrokkenen heeft plaatsgevonden alsmede dat de kennis van de samensteller er borg voor staat, dat de ontworpen regelingen volledig doordacht en gericht zijn op een maximale praktische bruikbaarheid. ${ }^{47}$

Ondanks al deze zwarigheden slaagde Schadee er toch in het ontwerp voor het binnenvaartrecht op betrekkelijk korte termijn op te stellen. Medio 1967 was zijn ontwerp in eerste concept gereed, dat wil zeggen, voor alle de in Hoofdstuk III op te nemen titels was een eerste, voorlopige tekst voorhanden, terwijl het overleg met het bedrijfsleven al een eind op streek was. En daarmee werd de vraag of men er niet beter aan zou doen Boek 8 in verschillende afleveringen te laten verschijnen, opnieuw actueel.

\section{Splitsing publicatie Boek 8}

Op 18 juli 1967 concludeerde Minister Polak, na een uitvoerige gedachtenwisseling met Schadee, Scheffer en Van Ewijk - Beekhuis onbrak merkwaardig genoeg ter vergadering -, dat de tijd rijp was het groene Boek 8 in twee afleveringen te laten verschijnen:

I. zeerecht, binnenvaartrecht, algemene regels voor de vervoersovereenkomst, expeditie-overeenkomst, regels voor het gemengd vervoer;

II. de rest, zijnde het luchtrecht en het wegvervoer.

Alvorens ik nader in ga op de overwegingen die tot dit besluit hebben geleid, nog enige informatie over de vorderingen die met betrekking tot het lucht- en wegvervoersrecht waren gemaakt.

Zoals boven al werd aangegeven, was de bestudering van het luchtrecht, die zou worden gecombineerd met overleg met de praktijk, begin december 1965 door het Departement opgeschort. Sindsdien was er door Schadee, die in overleg met Beekhuis het concept moest inpassen in de rest van Boek 8, niet meer aan gewerkt, waardoor het concept qua opzet en terminologie vermoedelijk nog steeds niet in de pas liep met de andere ontwerpen. Een groot probleem was dat evenwel niet, want de nationale wet zou zich op de meeste punten toch moeten conformeren aan de internationale verdragen. Bovendien nam het luchtrecht ook destijds al een unieke positie in, in die zin dat het aantal raakvlakken met de andere takken van vervoer verhoudingsgewijs gering was.

46. Th. J. Dorrestein, Verkeersmiddelen en vervoer, NJB 1973, p. 1114.

47. Aldus de tekst van het Voorlopig Verslag van 29 oktober 1976 (zitting 1976-1977, nr 14049 , stuk nr 5). 
Anders lag het met het concept voor het wegvervoersrecht, dat, alle inspanningen van Scheffer ten spijt, nog ver verwijderd was van z'n definitieve vorm. Weliswaar had de ontwerper niet onbelangrijke vorderingen gemaakt met de voorbereiding van een wettelijke regeling en ten aanzien van enkele delen van zijn concept reeds de instemming van het bedrijfsleven verworven, maar desalniettemin was het overleg nog niet zo ver gevorderd dat binnen afzienbare termijn een volledig, afgerond ontwerp zou kunnen worden aangeboden.

Drie oorzaken waren daaraan debet.

In de eerste plaats waren de belanghebbenden het aanvankelijk op bijna ieder punt oneens gewees $\mathrm{t}^{48}$, zodat het plan om, alvorens met een ontwerp voor het vervoersrecht te komen, zich eerst te oriënteren bij het bedrijfsleven, al na een paar maanden moest worden opgegeven. Dat was een flinke tegenvaller, zeker indien een en ander wordt vergeleken met de soepele wijze waarop het overleg met de binnenvaart verliep. Schadee zei daar in 1966 over: "Het contact met het bedrijfsleven vindt op zeer bevredigende wijze plaats en levert minder moeilijkheden op dan aanvankelijk gevreesd werd. Er bestaat aan deze zijde een grote bereidheid tot medewerking. "49

Daarnaast worstelde Scheffer met het probleem dat er in vervoerskringen ernstig bezwaar tegen bestond om de C.M.R. (het verdrag met betrekking tot internationaal wegtransport) als model te gebruiken voor het nationale wegvervoersrecht. De C.M.R. zou onvoldoende recht doen aan de specifieke eisen van het binnenlands vervoer - er bestond onder meer bezwaar tegen de hoge aansprakelijkheidslimieten, de bewijslastregeling en de wijze waarop het document was geregeld - en bovendien zou het verdrag een aantal vragen onbeantwoord laten, waardoor een aanvullende regeling gewenst was. ${ }^{50}$ Omdat uiteraard moest worden voorkomen, dat deze regeling een dode letter zou blijven, was ook dit een materie waarop Scheffer z'n tanden stuk kon bijten.

Een laatste punt dat voor vertraging zorgde, was dat het ontwerp in verband met de geweldige toename van het aantal groepsreizen moest worden uitgebreid met een regeling voor het personenvervoer over de weg, een materie waarvoor niet kon worden teruggegrepen op nationaal recht en die bovendien nog werd gecompliceerd doordat er internationaal overleg over gaande was. Toen medio 1966 echter duidelijk werd dat van de internationale rechtsvorming niet teveel mocht worden verwacht ${ }^{51}$, werd besloten toch maar zelf een ontwerp op te stellen. Een ondankbaar werk, want het betekende dat Scheffer enerzijds rekening zou moeten houden met de in Neder-

48. De notulen van een op 31 augustus 1965 gehouden bespreking met Minister Samkalden vermelden: "Prof. Schadee en mr. Scheffer hebben een aantal vergaderingen bijgewoond van een juristencommissie, gevormd door de in de Stichting Vervoeradres verenigde beroepsorganisaties (...). Uit deze beraadslagingen is nog weinig positiefs te voorschijn gekomen; de belanghebbenden zijn het op de meeste punten nog oneens."

49. Memorandum van een bespreking met Minister Samkalden op 19 juli 1966.

50. Zie de Toelichting-Meijers, p. 1453 en Nicole M. van der Horst, De Wet Overeenkomst Wegvervoer, Ars Aequi 1984, p. 32 e.v.

51. De "Convention relative au contrat de transport international de voyageurs et de bagages par route", waarvoor al sinds het begin van de zestiger jaren voorbereidingen werden getroffen, zou pas op 1 maart 1973 gereed komen, te laat om als basis te kunnen dienen voor het groene Boek. 
land levende verlangens, maar er anderzijds voor zou moeten waken het internationale overleg niet teveel voor de voeten te lopen. ${ }^{52}$

Wat waren nu de overwegingen die ten grondslag lagen aan het besluit van Minister Polak om het zee-en binnenvaartrecht eerder te publiceren?

Een belangrijke overweging was uiteraard het gegeven dat de concepten voor het zee-en binnenvaartrecht ver gevorderd waren en dat het bedrijfsleven (althans voorzover door Schadee geraadpleegd) akkoord was gegaan met de ontwerp-teksten. Het afronden van het overleg, het verzorgen van de eindredactie, was, zo kan uit de toon van het verslag worden opgemaakt, nog slechts een kwestie van maanden, of hooguit een jaar misschien. ${ }^{53}$

Met betrekking tot het luchtrecht gold iets dergelijks. Het concept moest, de noodzaak tot een verdergaande afstemming daargelaten, alleen nog worden doorgesproken met enkele geïnteresseerde praktijkjuristen. Dat het luchtrecht internationaal nog in beweging was ${ }^{54}$ en bovendien buiten de geldende codificatie stond, deed de Minister echter besluiten het buiten Boek $8 \mathrm{I}$ te houden.

Een ander aspect dat tijdens deze gedachtenwisseling naar voren kwam, was de overweging dat voor het zeerecht een aantal nieuwe verdragen was opgesteld, of althans op korte termijn was te verwachten. Het zou uiteraard niet raadzaam zijn de aanpassing van de geldende wetgeving aan die verdragen langdurig uit te stellen: "Zoveel mogelijk dient te worden vermeden dat alsnog het Wetboek van Koophandel moet worden herzien voor de jaren die verstrijken voor de voltooiing en invoering van Boek 8, hetgeen dubbel werk, ten koste van de voortgang van Boek 8, zou betekenen, te meer omdat die aanpassing grotendeels door de heer Schadee zou moeten ontworpen."

Hetzelfde gold, maar dan in mindere mate, voor het binnenvaartrecht, dat in overeenstemming zou moeten worden gebracht met het uit 1965 daterende verdrag van Genève inzake de teboekstelling van binnenschepen (Trb. 1966, 228) met protocollen betreffende zakelijke rechten op binnenschepen, het beslag op en de gedwongen verkoop van binnenschepen. Schadee, die in zijn concept voor Boek 8 al volledig rekening had gehouden met dit verdrag, voelde er weinig voor deze titel uit zijn ontwerp te lichten en om te zetten in een wetsontwerp tot aanpassing van het Wetboek van Koophandel, ook omdat niet kon worden volstaan met het aanbrengen van een enkel artikeltje op Molengraaffs stramien. Ook daarom was een splitsing gewenst. ${ }^{55}$

52. Bovendien kwam bij deze materie ook een regeling met betrekking tot reisbureaus aan de orde, een onderwerp waarvoor in 1967 de eerste grondslagen nog moesten worden gelegd.

53. Tijdens de begrotingsbehandeling van 1968 (handelingen Tweede Kamer 1967-1968, p. 697) zou Minister Polak verklaren dat het eerste deel van het $8 \mathrm{e}$ groene Boek vermoedelijk eind 1968 of begin 1969 in de openbaarheid zou kunnen worden gebracht. Een jaar daarvoor (zie de Memorie van Toelichting bij de begroting van 1967) was reeds de hoop uitgesproken dat het voorontwerp voor Boek 7 medio 1967 en dat voor Boek 8 "enige tijd daarna" ter perse zou kunnen gaan.

54. Merkwaardig is, dat in 1967 nog niets erop wees dat op korte termijn een ingrijpende verdragswijziging kon worden verwacht. Ook anderszins is de gevolgde argumentatie weinig bevredigend: de ontwikkeling van Boek 2 is toch ook niet stilgezet toen de Europese Richtlijnen Nederland steeds vaker begonnen te bestoken?

55. Bovendien blonk de in het Wetboek van Koophandel neergelegde regeling niet uit in doorzichtig- 
De laatste en vermoedelijk véruit belangrijkste overweging had betrekking op het feit dat men door het vervroegd publiceren van Boek 8I, en wellicht ook het versneld invoeren daarvan - dat wil zeggen vóórdat de Boeken 3, 5 en 6 in werking zouden zijn getreden - hoopte te bereiken dat althans een deel van de kritiek op het werk aan het nieuwe Burgerlijk Wetboek zou worden weggenomen. Een misrekening, omdat het vervoersrecht voor het gros van de Nederlandse juristen een soort van "Geheimwissenschaft" is. Van Ewijk bracht dit punt als volgt onder woorden:

"Een zeer belangrijk aspect is het volgende, dat de gehele onderneming nieuw B.W. betreft. Wij worden voortdurend bedreigd met het verwijt dat deze onderneming pas na een flink aantal jaren reële vruchten zal afwerpen en intussen ertoe leidt dat aan bijwerking van onderdelen van ons geldende privaatrecht, ondanks de snelle evolutie van de maatschappelijke behoeften, weinig of niets wordt gedaan. Daargelaten of dit verwijt gerechtvaardigd dan wel weerlegbaar is, het is een ernstig gevaar. Geen beter antwoord dan de vervroegde invoering van stukken wetgeving die dankzij de onderneming ontstaan: nu Boek 1, straks Boek 2 en straks ook Boek 8I.

Hierbij komt dat aan Boek 8I weinig behoeft te worden gewerkt door de handvol juristen die met de Boeken 1-7 geoccupeerd zijn. In het werk van deze juristen behoeft dus door het nieuwe plan weinig of geen vertraging op te treden."

\section{Boek 8 O.M. (eerste stuk) gepubliceerd}

Het groene Boek 8 (eerste stuk) werd op 10 mei 1972 aangeboden aan Minister Van Agt. Dat was dus aanmerkelijk later dan voorzien, ook wanneer daarbij in aanmerking wordt genomen dat de Staatsdrukkerij bijna een jaar nodig had ${ }^{56}$ voordat het door Schadee afgeleverde werk - op Justitie ook wel bekend als het "Agt-ste Boek"van de persen rolde.

Een factor die vermoedelijk voor de nodige vertraging heeft gezorgd is dat Schadee het werk, verbonden aan de coördinatie en de afronding van de in dit deel op te nemen stukken, ernstig heeft onderschat. Natuurlijk, Schadee had bij het opstellen van de diverse concepten reeds terdege rekening gehouden met de inmiddels bereikte resultaten, maar de afstemming was niettemin minder optimaal dan hij oorspronkelijk had gehoopt. In de eerste plaats lag er een aantal jaren tussen zijn eerste werk en de concepten voor de andere delen van Boek 8. Bovendien was de stof te divers om in én oogopslag te kunnen worden overzien. In de woorden van Schadee: "Als je na het zeerecht een ander transportrecht gaat ontwerpen, dan ga je automatisch dezelfde terminologie gebruiken die je in het zeerecht hebt gebruikt. Het klopt dan wel eens niet. Door het ontwerpen van het wegvervoersrecht ben ik zeerechtelijk en binnenvaartrechtelijk andere ideeën gaan opdoen en dat moet je allemaal weer verwerken."

55. $\rightarrow$

heid. Molengraaff maakte graag gebruik van herhalingen of verwijzingen van de ene afdeling naar de andere, hetgeen dikwijls tot "refreinen" leidde. Aanpassing was daardoor een tijdrovende aangelegenheid.

56. Schadee had, blijkens een schrijven van 23 augustus 1971, zijn gehele ontwerp met toelichting reeds in december 1970 ingezonden aan het Departement. Toch zouden de eerste drukproeven pas in de loop van augustus 1971 gereedkomen. 
Eén en ander betekende dat het werk van vóór 1964 in feite nog eens dunnetjes moest worden overgedaan, dat het overleg met de praktijk moest worden heropend, en dat oude strijdpunten weer een kans kregen de kop op te steken. Daarbij hadden de uitkomsten van dat overleg uiteraard ook weer een zekere uitwerking op de concepten voor de binnenvaart en het wegvervoer. Met andere woorden, aan de concepten van Schadee, die in de zomer van 1967 ongetwijfeld een vrij definitief stadium hadden bereikt, is daarna mede om deze reden nog het nodige veranderd. Begin 1971 schreef hij dat ten aanzien van het zeerecht alle fasen van het overleg met belanghebbenden waren afgesloten, een mededeling die alleen verklaarbaar is indien wordt aangenomen dat Schadee het noodzakelijk heeft geoordeeld het overleg ná 1967 weer te heropenen.

Een tweede factor die mijns inziens voor het nodige oponthoud heeft gezorgd, is dat er door de voortdurende ontwikkelingen in het vervoersrecht nog nieuwe stukken zijn bijgekomen, waardoor inhoud en indeling van het concept-voorontwerp tussen 1967 en 1970 nog ingrijpend zijn gewijzigd. ${ }^{57}$ De inhoud van het te publiceren eerste stuk stond in 1967 eigenlijk zelfs in het geheel niet vast.

Hiervoor is er al op gewezen dat het opstellen van de bepalingen voor de reisovereenkomst (afdeling 8.2.6), volgens Schadee het moeilijkste onderdeel van Boek 8, omdat daar de belangen van de consument het duidelijkst op de voorgrond treden, in juli 1967 nog moest beginnen. Een ander voorbeeld vormt afdeling 8.2.2 (gemengd goederenvervoer), waarin enkele regels voor het zogenaamde gecombineerd vervoer (dat wil zeggen vervoer dat deels per schip, deels per auto en bijvoorbeeld deels per spoor geschiedt) worden gegeven. Weliswaar telde deze afdeling, waarvoor de basis eveneens pas in de loop van 1967 werd gelegd, in het voorontwerp slechts vier, nog geenszins als definitief aan te merken artikelen, maar het opstellen ervan noodzaakte wél tot opnieuw doornemen van de meeste andere bepalingen van het voorontwerp, teneinde de verschillende vervoersregimes zoveel mogelijk op elkaar af te stemmen. ${ }^{58}$ Bovendien had één en ander tot gevolg dat titel 7.10, die pas medio '67 werd overgeplaatst naar titel 2 van Boek 8, geheel opnieuw moest worden opgezet. Het lijkt daarom niet overdreven te stellen dat met het werk aan het eerste hoofdstuk, bevattende algemene bepalingen voor Vervoer in het algemeen, Zeerecht en Binnenvaartrecht, - hét hoofdstuk dus waarin alle lijnen van het vervoersrecht samenkomen -, in feite pas omstreeks 1967 een begin werd gemaakt.

Daar kwam bij dat Schadee in 1967 eenzijdig doof werd, zodat hij de internationale conferenties niet meer kon bijwonen en hij aangewezen was op wat Justitie aan infor-

\footnotetext{
57. Vergelijk ook handelingen Eerste Kamer 1978-1979, p. 568-573. Als één van de redenen voor de lange duur wees Regeringscommissaris Schadee erop dat "zeer intensief internationaal overleg" had plaatsgevonden, dat voorrang kreeg boven de voltooiing van Boek 8: "Terecht ging de toenmalige Minister van Justitie ervan uit, dat pogingen internationale regelingen te treffen, waarbij met Nederlandse wensen rekening werd gehouden, moesten prevaleren boven het opstellen van nationale regelingen, die dan toch weer zouden moeten aansluiten bij wat internationaal werd afgesproken. Beter was het dan bij het begin reeds invloed uit te oefenen."

58. Zie K.F. Haak, a.w., p. 956: "In dit circuit van compartimenten valt een zekere kentering in de richting van harmonisatie en integratie waar te nemen. Als belangrijkste oorzaak hiervan moet gewezen worden op de opkomst van de container, die niet alleen in sociaal en economisch opzicht spectaculaire ontwikkelingen in gang heeft gezet, maar ook de stoot heeft gegeven tot de ontwikkeling van regels voor het gecombineerd (multimodaal) vervoer en daarmee tot de noodzakelijke harmonisatie van de traditioneel gesegmenteerde vervoerregimes."
} 
matie inbracht. Dat leidde niet alleen tot tijdverlies, omdat zowel voorafgaand als na afloop van zo'n conferentie overleg met hem moest plaatsvinden, maar het werd daardoor ook moeilijker de internationale ontwikkelingen op het gebied van het vervoersrecht bij te houden, laat staan bij te sturen in een door Schadee gewenste richting. ${ }^{59}$

Een andere verklaring voor de lange duur is dat Schadee het zichzelf ook niet bepaald makkelijk heeft gemaakt. Schadee was een perfectionist in hart en nieren, iemand die, zoals hij in 1967 verklaarde, er bewust naar streefde een logisch gezien volkomen "foutloos" ontwerp af te leveren. ${ }^{60}$ En zo'n houding werkt nu eenmaal de neiging in de hand steeds weer nieuwe verbeteringen aan te brengen, de discussie over een tekst nooit als afgesloten te beschouwen.

Deze "nauwkeurigheidsmanie" - een onvriendelijke aanduiding, maar ik weet geen betere te bedenken - uitte zich bijvoorbeeld hierin, dat Schadee ieder onderdeel van zijn werk in grafieken vastlegde, elke titel steeds weer op ten minste vijftig punten doornam en in zijn kamer een groot wandbord had hangen waarop in wit, groen en rood werd aangegeven wat klaar was, wat onderhanden was en wat onderhanden genomen kon worden als daar even gelegenheid toe bestond. En men treft er ook de sporen van aan in de wijze waarop Schadee de praktijk bij zijn werk betrok, het overleg met de in totaal meer dan tachtig (!) adviseurs had georganiseerd. Want het geeft toch te denken dat Schadee, zoals hij in een brief aan Minister Polak uiteenzette ${ }^{61}$, maar liefst vijf jaar nodig had om het concept-binnenvaartrecht ( \pm 200 artikelen) driemaal door te spreken.

Over zijn stijl van wetgeving, door Haak niet ten onrechte als "mechanisch" betiteld $^{62}$, zei Schadee in 1988 :

59. Schadee: "Toen ik aan één oor doof geworden was, kon ik internationale conferenties niet meer bijwonen, want in die conferenties staat het lobbyen meestal centraal, terwijl in de officiële vergaderingen de speeches worden afgestoken. In Venetië, ik weet niet meer voor welk verdrag we er waren, was ik het met een Fransman helemaal niet eens. Wij hebben er de hele avond over gedebatteerd en we werden het niet eens. De volgende ochtend op de officiële vergadering hield de Fransman, die gelukkig een heel goede vriend van me was, een grote speech, waar ik niets van verstond, omdat hij aan mijn dove kant stond. Ik verstond geen woord, maar nam natuurlijk aan dat hij zijn standpunt van de vorige avond herhaalde. Ik ben daama tegen hem van leer getrokken als een losgelaten leeuw. Er waren gezichten die steeds verbaasder keken en eindelijk interrumpeerde de voorzitter: 'Hebt u misschien uw collega niet goed verstaan?', waarop mijn Franse collega zei: 'Ik heb er vannacht over gedacht en ik ben het helemaal met je eens geworden en heb dat net aan de vergadering uiteengezet'.

Het Comité Maritime was een grote république des bons amis. We hebben er veel glazen wijn op gedronken en we hebben er hartelijk om gelachen, maar ik heb tegen mezelf gezegd: 'Nooit meer naar internationale conferenties, want dan krijg je van zulke opmerkingen'. Het was toch heel vervelend."

60. Het Vaderland, 28 april 1967. Schadee zei daar: "Aan het eind wil ik alles naast elkaar stellen, alle oud tegen alle nieuw. Ik hoop dat het dan althans logisch gezien grotendeels 'foutloos' is". Schadee, Ars Aequi 1993, p. 10: "Ik heb emaar gestreefd zo volledig mogelijk te zijn."

61. Brief van 21 november 1968.

62. K.F. Haak, a.w., p. 962. Met betrekking tot de regeling van de zogenaamde "paardesprong" merkt Haak op: "Deze buitengewoon weerbarstige materie was in het Voorontwerp geregeld in niet minder dan 36 artikelen. Als bijlage in de Toelichting was een befaamd hamartologisch, d.w.z. Schadee-aans schema opgenomen (p. 1436 jo. 1437/8) aan de hand waarvan men kon berekenen op 
"Ik ben misschien hier en daar minder precies, hoewel ik tracht nauwkeurig te zijn: dat kunt u lezen in mijn boekje "Hamartologie". ${ }^{63}$ Dat is de kunst van het vermijden van fouten. Al die fouten heb ik getracht te elimineren. Het is hier en daar meer wiskunde dan recht. (..) De kunst is natuurlijk om te zorgen dat het wiskundig klopt, dat je geen lacunes hebt gelaten.

Als je die aanleg hebt, dan moet je dat gaan verdoezelen, want ik heb ontdekt dat het de mensen irriteert als je uiterst nauwkeurig bent. Ik heb eens in een artikel in het Juristenblad geschreven over electronische wetgeving, dat was voordat er computers kwamen. Dertien voorrechten kun je op miljoenen manieren rangschikken. De functie van 'dertien' is dat. Bij Boek 8 heb ik ook telkens bekeken hoeveel 'functies' er zijn en die heb ik getracht allemaal stuk voor stuk te behandelen. Dan weet je honderd procent zeker dat je niets bent vergeten."

Een vierde factor die vermoedelijk van invloed is geweest op de verlate publicatie van het eerste deel van Boek 8, is dat het ontwerp van Schadee gedeeltelijk herschreven moest worden om in samenhang met het geldende Burgerlijk Wetboek te kunnen functioneren. Op een aantal punten moest daardoor worden afgeweken van de Boeken 3 en 6 (en wellicht ook de reeds voltooide gedeelten van Boek 7) of, omgekeerd, voorlopig iets uit die Boeken worden "herhaald" dat later, bij de invoering van 3, 6 en 7 weer zou moeten worden geschrapt. Tegelijk moest er ook voor worden gewaakt dat het groene Boek 8 weer niet te ver zou afwijken van het nieuwe vermogensrecht, teneinde te voorkomen dat het bij de invoering van die Boeken ingrijpend zou moeten worden herzien. Het lijkt niet onwaarschijnlijk dat het zoeken naar een modus zodat Boek 8 (eerste stuk) à double usage kon dienen, toch ook de nodige moeilijkheden met zich heeft meegebracht. ${ }^{64}$

Als gevolg van al deze problemen kon dubbel werk - in 1967 één van de redenen om alle kaarten te zetten op de afwerking van het zee- en binnenvaartrecht - op den duur niet meer worden vermeden. Ik wijs er slechts op dat het Verdrag van Genève inzake teboekstelling van binnenschepen en zakelijke rechten daarop (1965) in 1974 bij wijze van "voortrein" in het Wetboek van Koophandel zou belanden. ${ }^{65}$ En in 1969 zou Schadee bijvoorbeeld worden belast met het opstellen van een ontwerp tot aanpassing van het Wetboek van Koophandel aan het Brusselse Protocol van 1968 op het Cognossementsverdrag (1924), ofschoon hij in zijn ontwerp al volledig met deze

62

welke van de zeven schakels van de keten der exploitatie-overeenkomsten dan wel op het gemene recht de aangevallene jegens de aanvaller een beroep kon doen."

63. H. Schadee, Hamartologie, Deventer 1967.

64. Naar de mening van J.A.L.M. Loeff (NJB 1973, p. 1085) sloot het voorontwerp voor Boek 8 (eerste stuk) overigens veel te weinig aan bij het recht in wording en zou Schadee er beter aan hebben gedaan de stof van Boek 8 te verspreiden over de Boeken 3, 6 en 7. Het is, maar dit terzijde, merkwaardig een dergelijk geluid te vernemen van iemand die zich in 1953 nog sterk keerde tegen deze gedachte. Zie over de 'betrekkelijke autonomie' van Boek 8 ook W.J. Oostwouder, Boek 8 BW: een vreemde eend in de bijt? in: BW-krant jaarboek 1992, Het Nieuw BW in functie, Arnhem 1992, p. 89-107.

65. Wet van 3 juli 1974, Stb. 388. 
aanvulling rekening had gehouden. ${ }^{66}$ Ook deze "klusjes tussendoor" zullen van invloed zijn geweest op de publicatiedatum van Boek 8.

\section{Boek 8 (eerste stuk) ook invoeren?}

Toen Boek $8 \mathrm{I}$ persklaar was en Schadee zijn handen voorlopig vrij had, rees vanzelfsprekend de vraag of na het verschijnen van dat deel snel verder moest worden gewerkt aan het opstellen van een Regeringsontwerp, danwel voorrang zou moeten worden gegeven aan het afwerken van Boek 8II. Daaraan had het werk namelijk sinds 1967 vrijwel stil gelegen doordat het Ministerie, dat er toen nog van uitging dat de ontwerpen voor het eerste stuk spoedig zouden verschijnen, Scheffer had vrijgemaakt voor het recenseren daarvan.

Schadee, die deze vraag op 26 januari 1972 in een brief aan de Minister voorlegde, was zelf van mening dat aan de invoering van 8I de voorkeur zou moeten worden gegeven boven het opnieuw ter hand nemen van het wegvervoersrecht en het luchtrecht. Boek $8 \mathrm{I}$ zou namelijk op een aantal punten aan een vrij sterk gevoelde behoefte voldoen. In volgorde van belangrijkheid waren dat: de expeditieovereenkomst, de reisovereenkomst, de zakenrechtelijke positie van het zeeschip en de rederij en avarijgrosse in de binnenvaart. Daarnaast wees Schadee erop "dat op dit ogenblik diegenen, die door de organisaties van het bedrijfsleven werden afgevaardigd mij te adviseren, zich op zeer vele en essentiële punten met mijn voorstellen hebben verenigd en dat een groot gedeelte van Boek $8 \mathrm{I}$ ook de instemming van deze organisaties zelf heeft. "67 Het was volgens Schadee, "op zijn minst twijfelachtig" of bij uitstel van invoering van de stof van Boek 81 tot de tijd die nog nodig zou zijn om 8II te publiceren en om te vormen tot Regeringsontwerp, die instemming nog zou bestaan.

De ambtelijke top voelde echter niet veel voor dit voorstel. Er zou weinig speciale urgentie bestaan om Boek $8 \mathrm{I}$ bij voorrang in te voeren en voor het geval dat Boek $8 \mathrm{I}$ afzonderlijk zou worden ingediend zou men aan de Kamer toch in ieder geval de toezegging moeten kunnen doen dat het Regeringsontwerp van 8II spoedig daarna zou volgen en dat de beide ontwerpen gelijktijdig in werking zouden treden (zulks mede om te voorkomen dat er een herhaling zou ontstaan van de situatie bij de invoering van het binnenvaartrecht in 1952). Bovendien zou de "buitenwereld" toch wel een jaar moeten worden gegeven om "scheepsraad" te houden over het groene Boek. Omdat uit de brief van Schadee kon worden afgeleid dat de publicatie van Boek $8 \mathrm{II}$ tegen het einde van 1973 kon worden tegemoetgezien, zou het volgen van de door het Departement voorgestane procedure slechts een half jaar extra kosten. De benoeming van Schadee tot Regeringscommissaris werd daarom nog enige tijd uitgesteld.

66. Dit ontwerp leidde tot de Wet van 11 maart 1981, Stb. 204.

67. Schadee had met betrekking tot het zeerecht volledige overeensternming met het bedrijfsleven bereikt. Met betrekking tot het binnenvaartrecht was hij tot een akkoord gekomen met zijn adviseurs. In verband met tijdgebrek had hij echter geen contact meer gezocht met de organisaties zelf: dat zou volgens Schadee minimaal twee tot drie jaar vergen en vermoedelijk weinig bijzonders opleveren. 


\section{Boek 8II gereed; Boek $8 \mathrm{I}$ ingediend bij Kamer}

Ook deze verwachting kwam niet uit. Het groene Boek 8II werd pas op 28 april 1976 aan de Minister aangeboden, terwijl met het drukken en uitgeven ervan nog een kleine zeven maanden zouden heengaan. Bovendien was het luchtrecht op het laatste moment nog uit de boot gevallen, hetgeen in de aanbiedingsbrief werd gemotiveerd met het argument dat het Verdrag van Warschau (1929) in 1975 was aangevuld met de zogenaamde protocollen van Montreal. ${ }^{68}$

De verklaring voor deze "tegenslag" - al kan men natuurlijk ook zeggen dat Schadee opnieuw té optimistisch was geweest - is mijns inziens vooral dat het verre van eenvoudig was alle belanghebbenden op één lijn te krijgen, zoals men reeds in de jaren 1965-1967 had ervaren. Illustratief is dat Schadee, die door de Stichting Vervoeradres in mei 1971 was benaderd om zijn diensten aan te bieden bij de broodnodige herziening van de A.V.C. (hetgeen resulteerde in de partiële herziening van 1972), kort daarna opnieuw zou worden gevraagd voor een bemiddelingspoging. Pas in 1976 zou dit overleg, dat voor de ontwikkeling van Boek 8II van levensbelang was, kunnen worden afgesloten. Daarvoor waren dan wel meer dan 200 (!) vergaderingen nodig geweest, verspreid over een tijdvak van vier jaar. Wordt daarbij in aanmerking genomen dat over de herziening van deze condities reeds sinds het midden van de jaren zestig overleg gaande was, dan kan men niet anders dan concluderen dat Schadee een engelengeduld moet hebben opgebracht. Instemming van alle belanghebbenden was zijns inziens essentieel voor het welslagen van zijn onderneming. ${ }^{69}$

Een tweede factor die mogelijkerwijs een rol heeft gespeeld - dit punt kwam ook in het in het kader van deze studie gehouden vraaggesprek met Schadee naar voren - is dat Schadee op 18 december 1971 van Unidroit de opdracht ontving tot het opstellen van een voorontwerp voor een verdrag inzake het vervoer van goederen over de binnenwateren, iets waaraan hij naar eigen zeggen absolute prioriteit moest verlenen boven al zijn andere werkzaamheden. Ook daardoor zal vertraging zijn ontstaan. Bovendien was Schadee op dat moment achter de schermen ook nog zeer betrokken bij het verdragenwerk en had hij bijvoorbeeld een actief deel in de voorbereidingen van het in 1973 te Genève tot stand gekomen verdrag betreffende de beperking van aansprakelijkheid van eigenaren van binnenschepen (CLN) en het in 1976 te Londen tot stand gekomen verdrag inzake beperking van aansprakelijkheid van maritieme vorderingen.

Tenslotte zal ook een rol hebben gespeeld, dat in de periode waarin het voorontwerp voor het vervoersrecht gestalte kreeg, voorbereidingen moesten worden getroffen voor het opstellen en indienen van het Regeringsontwerp voor Boek 8 (eerste stuk). Weliswaar spreekt het vanzelf dat het niet de taak van Schadee kon zijn te bezien of de Regering geen wijzigingen in zijn ontwerp zou moeten aanbrengen, maar als toekomstig Regeringscommissaris ${ }^{70}$ en als opsteller van het voorontwerp was het

68. Deze mededeling is in tegenspraak met het feit dat pas op 12 april 1976 door het Departement (onder toezicht van Beekhuis) een begin werd gemaakt met de bijwerking van het concept-luchtrecht. Sinds 1965 was er, zo is mij gebleken, nooit meer iets aan gebeurd.

69. Zie daarover ook H. Cohen Jehoram, Dupliek, NJB 1970, p. 1295.

70. Schadee werd bij K.B. van 23 april 1976, nr 76, met ingang van 1 mei 1976 aangewezen als Regeringscommissaris. 
uiteraard wél gewenst dat hij hierbij zoveel mogelijk werd betrokken. Dit werk nam ongeveer één jaar in beslag, ofschoon het Regeringsontwerp, dat op 14 september 1976 bij de Tweede Kamer werd ingediend, nauwelijks zou afwijken van het groene Boek.

Drie maanden later, op 16 december 1976, zou de Tweede Kamer Boek 8 (eerste stuk) met een simpele hamerslag aannemen.

\section{Intermezzo}

Hiervoor is erop gewezen dat het besluit van Minister Polak om Boek 8 vóór en los van de overige delen van het nieuwe Burgerlijk Wetboek in te voeren, door Van Agt, zijn opvolger, werd gerespecteerd. Aan dit besluit lagen de volgende overwegingen ten grondslag.

1. invoeren van de Boeken 3-8 gezamenlijk zou voor Departement, Kamer en rechtspraktijk een (te) grote belasting zijn;

2. de praktijk stemde volledig in met de inhoud van het nieuwe recht;

3. de internationale rechtsontwikkeling stond niet stil, met als gevolg dat het ontwerp steeds bijgewerkt zou moeten worden;

4. wachten op invoering van de Boeken 3-7 hield het risico in dat geen beroep meer zou kunnen worden gedaan op de persoon van Schadee, die in 1976 reeds de pensioengerechtigde leeftijd had overschreden.

Aan dit besluit kleefde echter één belangrijk nadeel: de indiening van Boek 8I zou het werk van de Kamercommissie, die op dat moment nog de handen vol had aan het uitbrengen van een Voorlopig Verslag over Boek 6, - het was juist door Snijders van de zandbank getrokken waar het al jaren had gelegen - niet mogen vertragen. Overleg was dus gewenst.

Dit overleg leidde ertoe dat de vaste Commissie uit eigen initiatief ${ }^{71}$ de toezegging deed geen verslag te zullen uitbrengen, in het vertrouwen dat na een jaar of vijf eventuele in de praktijk gebleken feilen bij een wijzigingswet zouden kunnen worden ondervangen. Het Departement op zijn beurt zou zich er toe moeten verplichten het Regeringsontwerp zoveel mogelijk te laten aansluiten bij het voorontwerp. Aan deze toezegging ging vooraf een mededeling in de pers, waarin de vaste Commissie haar voornemen bekend maakte, met het verzoek om reacties. Slechts door één deskundige - mr. J.A.L.M. Loeff - werden bezwaren gemaakt, doch na de daartoe gestelde termijn.

De literatuur bleek naderhand nogal verbaasd dat de Tweede Kamer, zonder ook maar iets van het Regeringsontwerp te kennen, zich met huid en haar overleverde aan de schepping van Schadee. Overeem ${ }^{72}$ noemde deze werkwijze een knieval voor de deskundigheid en energie van Schadee, maar zag haar tevens als een voorbeeld van

71. Aldus B.C. de Die in: Verslag Scheepsraad (Zwolle 1974), p. 2. Zie ook Parl. Gesch. Boek 8, p. 7-8.

72. R. Overeem, De reisovereenkomst, Deventer 1976, p. 75. 
parlementaire onmacht. Polak vroeg zich af of het allemaal wel zou lukken. ${ }^{73}$ Schadee zelf verklaarde: "Ik heb alle groeperingen op transportgebied altijd allemaal tot een gezamenlijke tekst kunnen brengen, vandaar dat de Kamer heeft gezegd: 'We kijken er niet naar. Schadee heeft met iedereen gesproken en als blijkt dat het niet goed is, dan kunnen we na een jaar of vijf verbeteringen aanbrengen. Maar om het nu beter te willen dan de hele praktijk, nee, dat heeft geen zin."

Het besluit van de Kamer lijkt zeer wel verdedigbaar. In de eerste plaats was daar natuurlijk de deskundigheid van Schadee. Boek 8 was zijn schepping, een kunstwerk dat de goedkeuring had van de "kenners" (het bedrijfsleven), iets waarop detailkritiek uit den boze was. Net zoals Meijers eertijds, had hij op alle punten volledige overeenstemming bereikt; het zou dwaasheid zijn daarin verbeteringen te willen aanbrengen.

In de tweede plaats was er de factor tijd. De Tweede Kamer had de buik meer dan vol van het werk aan het nieuwe Burgerlijk Wetboek - men denke aan de oproep van Jurgens om het bijltje er bij neer te leggen - en greep daarom elke mogelijkheid tot verlichting van haar werkzaamheden met beide handen aan. Fraai is anders, maar het is in elk geval beter dan het nodeloos vooruitschuiven van wetsontwerpen.

De derde factor die ter rechtvaardiging kan worden aangevoerd is dat de Kamer, nog meer dan bij de andere Boeken het geval was, onvoldoende deskundigheid bezat om Schadee tegenspel te kunnen bieden. Weliswaar had men - zoals later wel is gebeurd - een deskundige op het gebied van het vervoersrecht in de arm kunnen nemen om een Voorlopig Verslag op te stellen, maar daar was in 1973 nog geen enkele aanleiding voor. Het zwijgen over Boek 8 was, anders dan bij de andere Boeken, vrijwel algemeen, en de schaarse opmerkingen die over het voorontwerp werden gemaakt, waren niet van dien aard, dat er bijzondere aandacht aan zou moeten worden geschonken. ${ }^{74}$

Het besluit het Regeringsontwerp nagenoeg geheel te baseren op het groene Boek had echter één belangrijk nadeel. Het advies van de Raad van State zou namelijk enigszins in de lucht komen te hangen, omdat het voor het Departement wel vaststond dat, in verband met internationale ontwikkelingen, een aantal wijzigingen was te verwachten. Deze zouden pas bij de Memorie van Antwoord worden aangebracht, zodat het gevaar bestond dat een deel van de opmerkingen van de Raad hun doel zou voorbijschieten. Daarom werd in overleg met de Raad besloten dat het Departement (lees: Schadee) in overleg met de Raad (lees: Beekhuis) de wenselijk geachte wijzigingen reeds tijdens de voorbereiding van het advies van de Raad van State zou aanbrengen. Een ongebruikelijke, maar doeltreffende procedure, want op deze wijze won men niet alleen tijd, maar bovendien was het ook de enige methode om een diepgaand en zinrijk advies te verkrijgen.

$\mathrm{Bij}$ de voorbereiding van het wetsontwerp tot vaststelling van Boek 8 (tweede stuk) ging het er staatsrechtelijk gezien overigens nog vreemder aan toe. Schadee heeft toen

73. J.M. Polak, De wetgeving van het Departement van Justitie, NJB 1977, p. 2.

74. Behalve de frontale aanval van Loeff in NJB 1973, p. 1085 e.v., een artikel dat even bol stond van de diskwalificaties als leeg was aan argumenten, leverde alleen Dorrestein (NJB 1973, p. 1113 e.v.) substantiële kritiek. In "Scheepsraad", een bundel vrij korte pre-adviezen, kwam slechts hier en daar wat kritiek om de hoek kijken, en dan alleen nog op detailpunten. 
reeds vooruitlopend op de indiening van dit ontwerp contact gezocht met Beekhuis, teneinde het uitbrengen van een advies van de Raad nog meer te bespoedigen. Opmerkelijk is ook dat Beekhuis deze activiteit zelfs nog geruime tijd na zijn aftreden als Staatsraad in 1978 heeft vervuld. Kennelijk was er buiten hem ook niemand die zich geroepen voelde de discussie met Schadee aan te gaan. ${ }^{75}$

\section{Na 1976}

Ook na 1976 is Boek 8 geplaagd geweest door de nodige tegenslagen. De belangrijkste daarvan zal ik hier beschrijven.

Boek 8, eerste stuk, werd op 16 december 1976 door de Tweede Kamer aangenomen. Bij Wet van 28 maart 1979 (Stb. 1979, 245) ging de Eerste Kamer akkoord met de "zuurstok", een uitdrukking van Schadee die enig misnoegen verraadt over de kleur van de kaft waarin de vaststellingswet was gegoten. Anders dan de Tweede Kamer hadden de senatoren hun taak als medewetgever wél serieus genomen - kwade tongen beweren zelfs dat zij daarmee hun meerwaarde wilden aangeven - en elf vraagpunten geformuleerd. Eén hiervan - het negende vraagpunt met betrekking tot de huurkoop van binnenschepen - verdient in het bijzonder vermelding, omdat het een goede illustratie vormt hoe grillig het wetgevingsproces kan verlopen. Schadee zei daarover: "De Wet huurkoop binnenschepen heeft veel moeite gekost. C.H.F. Polak heeft destijds aan zijn mede-senatoren gevraagd of er nog onderwerpen waren die men graag geregeld zou willen zien, en of ik die dan eens wilde nagaan. De Eerste Kamer heeft toen gezegd: 'De scheepshuurkoop van binnenschepen, dat schijnt een moeilijk onderwerp te zijn'. Dus heb ik aan alle mensen die zich ermee bemoeiden, de hypotheekbanken enz. gevraagd: 'Hebben jullie wel eens moeilijkheden gehad met de huurkoop van binnenschepen?' De achtste zei, 'ja, dat moet hoognodig geregeld worden."

Dat was dus het zoveelste "klusje tussendoor". ${ }^{76}$

Boek 8, eerste stuk, was in 1979 overigens niet compleet. ${ }^{77}$ Zo ontbraken nog steeds de bepalingen met betrekking tot het arbeidsrecht (de titels 4.1, 4.3, 9.1 en 9.3),

75. Beekhuis zelf vertelde over deze periode: "Ik heb het lidmaatschap van de Raad na enige aarzeling aanvaard, want het was een functie waar ik aanvankelijk vreemd tegenover stond. Ik werd gewoonlijk benoemd als rapporteur over de ontwerpen voor het nieuwe Burgerlijk Wetboek die toen binnenkwamen, de Boeken 1,2 en 8 . Boek 8 betekende een geheel nieuw terrein voor de meeste leden van de Raad van State. Er is toen tegen mij gezegd dat het nuttig zou zijn indien ik het contact dat ik met Schadee had, zou kunnen voortzetten met betrekking tot de behandeling van zijn ontwerp door de Raad. Wij zouden dan de bedoelingen van Schadee leren kennen en hij kon tegelijk werken aan de Memorie van Antwoord. Justitie heeft zich met deze opzet verenigd. Ik heb toen regelmatig met Schadee vergaderd over Boek 8 en daarmee wel enig succes gehad, in die zin dat het groene Boek in verschillende opzichten afwijkt van het Regeringsontwerp. Na mijn aftreden als lid van de Raad van State heb ik Van Zeben bijgestaan bij de behandeling van het personenvervoer, dat ook met Schadee besproken werd." Zie ook: J.H. Beekhuis, Herinneringen aan mijn werk voor het nieuwe B.W., in: Goed en trouw, opstellen aangeboden aan W.C.L. van der Grinten, Zwolle 1984, p. 337; Interview (door J.M. van Dunné) in: Geschriften van Beekhuis, Zwolle 1989, p. 17.

76. Een en ander leidde tot de Wet van 27 juni 1985, Stb. 364.

77. Zie daarover: R. Cleton, Boek 8 van het nieuwe Burgerlijk Wetboek, Ars Aequi 1981, p. 246 e.v. 
moest nog een begin worden gemaakt met het opstellen van enige regels van I.P.R. en diende ook nog een oplossing te worden gevonden voor een aantal publiekrechtelijke kwesties, zoals de nationaliteit van schepen. Dit onderwerp, dat tot de competentie van Verkeer en Waterstaat behoorde, had overigens reeds de nodige voeten in aarde gehad. Al sinds het eind van de zestiger jaren was daarover overleg gaande.

Bovendien had de wet van de remmende voorsprong inmiddels z'n verwoestende werk gedaan. Artikel 8.5.1.1, regelende de redersaansprakelijkheid, werd nu door de praktijk als te streng ervaren (kennelijk was een nieuwe generatie adviseurs opgestaan) terwijl ook de internationale rechtsontwikkeling de verdere afwerking van Boek 8 zou blijven beheersen. Zo moesten de afdelingen over het personenvervoer ter zee (8.5.3) en over de binnenwateren (8.10.3) buiten de vaststellingswet worden gehouden in verband met het in 1974 tot stand gekomen Verdrag van Athene (met betrekking tot vervoer over zee) en het Geneefs Verdrag van 1976 dat het internationaal vervoer van passagiers over de binnenwateren regelt.

Anderzijds moest de wet nog worden aangevuld in verband met de kritiek die van consumentenzijde was uitgeoefend op afdeling 8.2.6 (reisovereenkomst), de totstandkoming van het Londens Verdrag inzake de beperking van maritieme vorderingen (1976) en de ratificatie van het Verdrag van Genève betreffende de beperking van aansprakelijkheid van binnenschepen (van belang voor resp. titel 8.7 en 8.12). Beide nieuw opgestelde titels zouden hun première overigens als voortrein beleven. Opnieuw dubbel werk dus. ${ }^{78}$

Het is begrijpelijk dat dit alles veel tijd kostte en de invoering van Boek 8 (eerste stuk) allerminst bespoedigde. Bovendien was Schadee genoodzaakt zijn krachten eerst te geven aan het opstellen van een voortrein voor titel 8.13, hetgeen leidde tot de Wet Overeenkomst Wegvervoer (Wet van 2 december 1982, Stb. 670). De herziene A.V.C. was namelijk geheel afgestemd op het nieuwe wegvervoersrecht, waardoor dit vóór alles moest worden ingevoerd. Bovendien noopte. dit tot het opstellen van een regeling inzake verjaring en verval.

Wordt daarbij in aanmerking genomen dat de invoering van Boek 8 alleen al verplichtte tot het doornemen van een vierhonderdtal wetten - in totaal goed voor zo'n zeveneneenhalve kilo papier - , dan mag het eigenlijk nog een wonder heten dat op 1 april 1991 Boek 8 nagenoeg in z'n geheel in werking is getreden. ${ }^{79}$ Een tijdwinst dus van negen maanden ten opzichte van de de invoering van de Boeken 3, 5 en 6 . Je moet er niet aan denken wat er zou zijn gebeurd als de invoering van die Boeken wat vlotter was verlopen.

\section{Samenvatting en conclusie}

Ofschoon het bovenstaande slechts een oppervlakkig beeld geeft van de geschiedenis van de totstandkoming van het achtste groene Boek en de daarop gebaseerde ontwer-

78. Een ander voorbeeld is de Wet van 11 maart 1981, Stb. 204, waardoor het Wetboek van Koophandel werd aangepast aan de wijzigingen en toevoegingen die de Hague Rules in 1968 hadden ondergaan. Het is haast overbodig te zeggen dat het groene Boek al van de nieuwe regels uitging. 79. Het commissariaat van Schadee zou bij K.B. van 18 november 1988, $\mathrm{nr} 50$, worden beëindigd. 
pen, is het mijns inziens niet onmogelijk er enige gevolgtrekkingen aan vast te knopen.

De eerste conclusie die ik zou willen trekken, is dat het werk aan Boek 8, na een flitsende start, gaandeweg in de versukkeling is geraakt. Het besluit Schadee het zeerecht te laten herzien was met het oog op de aan te trekken persoon alleszins gerechtvaardigd. Dat is naderhand ook wel gebleken. Hetzelfde gold ten aanzien van de codificatie van het luchtrecht, opgedragen aan Beekhuis. Ten aanzien van het binnenvaartrecht lag dat anders. Men had, toen eenmaal duidelijk werd dat er geen geschikte kandidaat voorhanden was, moeten volstaan met een herziening van het zeerecht.

Ernstiger evenwel was, dat het wegvervoersrecht aanvankelijk buiten de herziening werd gehouden, terwijl men op z'n klompen kon aanvoelen dat dit tot problemen zou leiden, de invoering van het "nieuwe binnenvaartrecht" indachtig. De gevolgen zijn bekend: doordat het wegvervoer er pas in 1965 bijkwam, moesten alle gereedliggende teksten opnieuw worden overwogen en was het tempo waarin de opstelling van het ontwerp voor het wegvervoer zich voltrok, bepalend voor de voortgang van de overige delen. Dat leidde er weer toe dat er nieuwe stukken bijkwamen, dat de internationale rechtsontwikkeling het voorontwerp op een gegeven moment links en rechts inhaalde, en dat Schadee het soms drukker had met reparatiewetgeving dan met het voorbereiden van de vaststelling en de invoering van Boek 8 .

Mijn tweede opmerking is, dat men er waarschijnlijk wijzer aan zou hebben gedaan de in Boek 8 op te nemen gedeelten één voor één te herzien. Een gescheiden behandeling zou vermoedelijk minstens zo snel zijn gegaan. Juist op dit terrein, waar de internationale rechtsontwikkeling de nationale dicteert, waar nieuwe vormen van vervoer als paddestoelen de grond uitschieten, is het gewenst het arbeidsveld overzichtelijk te houden. Het gevaar dat een ontwikkeling op één terrein ingrijpt op de andere delen, de ellende dat stagnatie hier leidt tot vertraging daar, het zijn bezwaren die door een gescheiden behandeling grotendeels zouden zijn voorkomen. Want zoveel is zeker: indien in 1965 besloten was voorrang te verlenen aan de afwerking van het zeerecht en het luchtrecht, dan hadden de daarop gebaseerde wetsontwerpen ruim vóór 1970 in het Staatsblad gestaan. En dan was het wegvervoersrecht en het binnenvaartrecht ook eerder klaar geweest omdat Schadee niet zou zijn vermoeid met de "klusjes tussendoor".

Mijn derde en laatste opmerking brengt mij bij de rol van Schadee. Zijn beschikbaarheid was, zo zou men kunnen zeggen, een conditio sine qua non voor het nemen van het besluit tot herziening van het zeerecht, zoals ook de opdracht aan Meijers dat was. De grote verdienste van Schadee is geweest, dat hij het geduld heeft willen opbrengen alle partijen op één lijn te krijgen. De moeilijkheden die hij daarbij moest overwinnen, moeten niet worden onderschat. ${ }^{80}$ Cohen Jehoram zei daarover: "Hij

80. Een en ander blijkt uit een brief van een adviseur van 2 december 1964, waarin deze zijn dank uitspreekt voor de voortreffelijke wijze waarop Schadee het overleg had geleid. Het schrijven aan de Minister, die de adviseurs ter afsluiting van het overleg een diner had aangeboden, begint zo: "Ik ben ervan overtuigd dat alle genodigden deze, als blijk van waardering bedoelde, geste op hoge prijs hebben gesteld en zich zullen herinneren als een zeer bijzondere afsluiting van de werkzaamheden. Bovendien was de uitnodiging een ware verrassing, aangezien het mogen meewerken aan dit stuk wetgeving op zichzelf reeds een eer en een genoegen was. Want een eer en genoegen is het, om zich te bezinnen op het toekomstige zeerecht met iemand als de Heer Schadee, die als rechtsgeleerde. 
heeft bereikt dat men het eens werd. Het was niet zo dat het uitgangspunt was dat iedereen dezelfde mening had, absoluut niet. ${ }^{n 1}$

Dat Schadee de praktijk vanaf het eerste moment bij zijn werk betrok, is overigens alleszins begrijpelijk. Schadee was alleen thuis in het zeerecht en moest ten aanzien van de andere delen dus wel overleg plegen. Bovendien is het zo, dat bij een zo dynamisch terrein als het vervoersrecht is, het geen enkele zin heeft een regeling op te stellen die niet in nauw overleg met de praktijk is ontwikkeld. Vandaar ook dat de schepping van Molengraaff is mislukt en dat Meijers door middel van het $24 \mathrm{e}$ vraagpunt het kader wilde scheppen waarbinnen de belangenorganisaties onder toezicht van de overheid zelf tot het scheppen van recht konden overgaan.

Betekent dit dat het werk en de aanpak van Schadee boven elke kritiek verheven zijn? Ik meen van niet. De coördinatie met Beekhuis mislukte, terwijl de samenwerking met Swart maar een kort leven was beschoren. Ook kan de vraag worden gesteld of hij met betrekking tot het binnenvaartrecht niet eerder aan de noodrem had kunnen trekken. Een ander punt van kritiek is, dat verzuimd is het zee- en binnenvaartrecht wetstechnisch samen te smelten. Boek 8 is gebouwd op herhalingen ${ }^{82}$, waarmee afbreuk wordt gedaan aan de codificatiegedachte. Ook lijkt de afstemming op de Boeken 3, 5 en 6 voor verbetering vatbaar. Te vrezen valt bovendien dat het werk van Schadee in verband met de stormachtige ontwikkelingen op het gebied van het vervoersrecht geen lang leven beschoren zal zijn, omdat Boek 8 op een aantal punten nogal gedetailleerd is. Ook heeft Schadee, zoals hijzelf heeft erkend, aanvankelijk niet altijd voldoende oog gehad voor de samenhang tussen de diverse vervoerstakken en heeft zijn allesoverheersende drang tot het reduceren van fouten hem parten gespeeld, waardoor de totstandkoming en invoering van Boek 8 aanmerkelijk langer heeft geduurd dan strict noodzakelijk was. Tenslotte is het voorstelbaar, dat het werk sneller zou zijn gegaan, indien de ontwerper tijdelijk één of twee taken zou hebben afgestoten.

Niettemin heeft Schadee een indrukwekkende prestatie geleverd. Als het om codificatie gaat, is tijdsduur immers een betrekkelijke zaak. Dat wordt bijvoorbeeld geillustreerd door de herziening van het zeerecht. In 1905 werd deze in de troonrede toegezegd en aan Molengraaff opgedragen. In 1907 was zijn ontwerp gereed, drie jaar later volgde het advies van de Raad van State, weer vier jaar later werd het ontwerp

\section{$80 . \rightarrow$}

rechter en zakenman in de onderhavige materie thuis is als geen ander, en tevens beschikt over de noodzakelijke humor. Wat dit betreft sloot het diner op perfecte wijze aan bij de werkvergaderingen. In een ander opzicht was het diner juist het tegenbeeld van die vergaderingen. In feite is sprake geweest van "legislative bargaining" in de beste zin van het woord. Elk der belangengroeperingen verscheen aan de tafel met een maximum aan wensen, en vertrok met minder in vervulling gegane wensen, dan hij gehoopt had. Zulks in absolute tegenstelling tot de tafel, waaromheen $U$ ons twee weken geleden deed samenkomen."

81. Vergelijk ook J.H. Beekhuis, Herinneringen aan mijn werk voor het nieuwe B.W., in: Goed en Trouw, Zwolle 1984, p. 339: "De gunstige wijze waarop de belanghebbenden bij het vervoersrecht op het werk van Schadee hebben gereageerd, (is) zeker een gevolg van de uiterst efficiënte wijze, waarop hij erin geslaagd is de vertegenwoordigers van die wereld bij het opstellen van zijn regelingen te betrekken."

82. Het boekje van H. Schadee, "Comparitie, Interne verwijzing in Boek 8 B.W., Zwolle 1991, is op dit beginsel gebaseerd. 
gepubliceerd. In 1920 werd een gewijzigd ontwerp ingediend, in 1924 kwam de wet in het Staatsblad. Drie jaar later trad zij in werking, na in de twee jaar daarvoor nog te zijn gewijzigd.

Deze herziening, die niet eens het gehele zeerecht omvatte, heeft dus tweeëntwintig jaar in beslag genomen. Zij omvatte echter nog slechts het zeerecht; eerst in 1934 trad een nieuwe regeling van het bergingsrecht in werking, in 1937 volgde een regeling van het arbeidsrecht. De nieuwe regeling van het binnenvaartrecht trad in 1952 in werking. De herziening van dit gedeelte heeft dus haast vijftig jaar gekost; het door haar bestreken gedeelte is slechts tweederde van het Achtste Boek. 


\section{Inleiding}

"In 1887 werd het grondwettelijk bezwaar tegen het regelen van onderwerpen bij afzonderlijke wet - zoo dit al ooit bestaan had - weggenomen; art. 150 (thans 151) der Grondwet laat deze regeling bij afzonderlijke wet ten aanzien van enkele onderwerpen uitdrukkelijk toe. Het woordje "enkele" is nog een laatste vermaning van den grondwetgever, dat deze regeling bij afzonderlijke wet uitzondering moet blijven. Een grondwettelijke rem, die niet scherp gesteld is, is geen rem. "1

Met deze woorden gaf Meijers in 1938 uiting aan zijn onvrede over het feit dat onderwerpen, ten aanzien waarvan het privaatrechtelijk karakter buiten kijf stond, na 1887 steeds vaker in afzonderlijke wetten zouden worden geregeld, en wel zonder dat daarvoor een deugdelijk motief bestond. Daarbij dacht hij in het bijzonder aan de wettelijke regelingen op het gebied van de industriële eigendom (het modellen-, merken- en octrooirecht), het auteursrecht en het recht op de handelsnaam, onderwerpen waarvoor hij later dan ook het negende Boek van zijn ontwerp zou bestemmen.

$\mathrm{Nu}$, meer dan vijftig jaar later, zijn Meijers' uitspraken nog steeds actueel. Want hoewel het huidige codificatieartikel (art. 107 Grondwet) een aanmerkelijk scherpere redactie heeft gekregen en de bevoegheid tot regeling in afzonderlijke wetten nog slechts voor "bepaalde" onderwerpen toelaat, de belangstelling voor codificatie sterk is toegenomen ${ }^{2}$ en de algehele herziening van het Burgerlijk Wetboek en het Wetboek van Koophandel bijna een feit is, staan de "rechten van de scheppende mens" nog steeds los van het Burgerlijk Wetboek.

Wat is er mis gegaan met het negende Boek?

\section{De inhoud van Boek 9}

Volgens de "voorlopig door prof. Meijers ontworpen indeling van het nieuwe Burgerlijk Wetboek", overgelegd bij het Mondeling Overleg over de Nota ${ }^{3}$, zou het negende Boek (toen nog Boek 8) als volgt zijn samengesteld:

Titel I. Auteursrecht.

Titel II. Octrooien.

Titel III. Recht op tekeningen en modellen van nijverheid.

Titel IV. Recht op merken.

1. E.M. Meijers, Wijzigingen en aanvullingen van het Burgerlijk Wetboek na 1838, in: Gedenkboek Burgerlijk Wetboek 1838-1938, Zwolle 1938, p. 38-39.

2. Ik wijs er slechts op dat er stemmen zijn opgegaan het Wetboek van Burgerlijke Rechtsvordering ingrijpend te herzien, dat er een discussie gaande is over de wenselijkheid van codificatie van het internationaal privaatrecht en dat gesproken wordt over een Algemene wet milieubeheer.

3. Parl. Gesch. NBW, Algemeen Deel, p. 35. 
Titel V. Het recht op de handelsnaam. ${ }^{4}$

Ter toelichting op het besluit de "rechten van de scheppende mens" in het Burgerlijk Wetboek op te nemen, schreef Meijers in diezelfde Nota:

\begin{abstract}
"Samenvoeging van het burgerlijk recht tot één wetboek wordt voorts nagestreefd door verschillende onderwerpen van burgerlijk recht, welke na 1838 in afzonderlijke wetten zijn geregeld, zoals de rechten van de scheppende mens en de coöperatieve vereniging, in het nieuwe wetboek op te nemen. De overzichtelijkheid van het recht, één der doeleinden van het codificatievoorschrift van artikel 157 van de grondwet, is hiermede gebaat. ${ }^{5}$
\end{abstract}

Het was echter niet alleen om redenen van systematiek en onderwijsbelang, dat Meijers het wenselijk vond de rechten van de scheppende mens in het Burgerlijk Wetboek op te nemen. In de aanbiedingsnota bij de eerste vier groene Boeken wees hij erop dat incorporatie ook noodzakelijk was om de samenhang tussen dit rechtsgebied en de overige delen van het burgerlijk recht te herstellen, waardoor overlappingen, tegenstrijdigheden en onduidelijkheden tot het verleden zouden gaan behoren en de regeling aan eenvoud zou winnen:

"Natuurlijk zal met een voortgaand specialisme in de rechtswetenschap de studie van deze rechten het bijzondere terrein van enkele juristen, die zich de daarvoor noodzakelijke bijzondere kennis hebben eigen gemaakt, blijven. Maar ook de regeling van deze rechten zou er slechts bij gewonnen hebben, wanneer men deze meer in verband met de algemene voorschriften van burgerlijk recht had gebracht men denke hier b.v. aan de overdracht en de bewaring van deze rechten - terwijl ook de redactie der artikelen allicht een weinig eenvoudiger zou zijn geworden." ${ }^{6}$

Een laatste argument dat een rol speelde bij de beslissing dit deel van het recht niet langer afzonderlijk te regelen, maar daarvoor in het Burgerlijk Wetboek een plaats in te ruimen, was de overweging dat op deze wijze als het ware in één beweging een aantal noodzakelijke verbeteringen en vernieuwingen kon worden aangebracht.

Het 26e vraagpunt bijvoorbeeld, dat een lans brak voor het wettelijk regelen van de bescherming van siermodellen, was door Meijers opgenomen omdat de Nederlandse wet aan tekeningen en modellen rechtstreekse bescherming onthield, ondanks het feit dat Nederland was toegetreden tot de Overeenkomst van 's-Gravenhage van 6 no-

4. Het kwekersrecht, destijds geregeld door het Kwekersbesluit 1941, was niet geprojecteerd als onderdeel van Boek 9. Meijers wilde daarover pas een beslissing nemen als de herziening van die regels een feit was. Zie de Memorie van Antwoord bij de vraagpunten 26-29 (zitting Tweede Kamer 1952-1953, nr 2846, stuk nr 25).

5. Parl. Gesch. NBW, Algemeen Deel, p. 8-9; Zie ook p. 31, 126 en 130. Meijers schrijft daar o.a. dat het nastreven van deelcodificaties nadelig is voor de ontwikkeling van het privaatrecht en onnodig specialisatie in de hand werkt: "Toegeven aan dit verlangen zou een uiteenrukken van het privaatrecht in verschillende losse stukken betekenen. (..) De alles bindende band, die het ganse privaatrecht bijeenhoudt en die tot algemeen toepasselijke voorschriften leidt, zou geheel teloor gaan. Vandaar dat het ontwerp tracht alle privaatrechtelijke regelingen zoveel mogelijk te omvatten."

6. Parl. Gesch. NBW, Algemeen Deel, p. 127. 
vember 1925 . Het $29 \mathrm{e}$ vraagpunt, waarin de wenselijkheid van een regeling van collectieve merken werd bepleit, was bedoeld ter uitvoering een door Nederland nimmer nagekomen verplichting tot bescherming van collectieve merken, voortvloeiend uit artikel 7 bis van het uit 1883 daterende Unieverdrag van Parijs. De Merkenwet van 1893 tenslotte, stond bekend als een weinig geslaagde regeling en deed op geen enkele wijze recht aan de sinds haar ontstaan sterk gewijzigde economische omstandigheden ${ }^{7}$, zodat ook aan deze materie een tweetal vraagpunten was gewijd.

Het opnemen van de rechten van de scheppende mens in het Burgerlijk Wetboek zou dus niet alleen de overzichtelijkheid en de toegankelijkheid van dit deel van het privaatrecht vergroten, maar zou bovendien tot gevolg hebben dat ook deze onderdelen van het burgerlijk recht op een moderner peil zouden worden gebracht.

\section{Wijze van bewerking}

Meijers ging bij het opstellen van de concepten voor het merken-, modellen-, en handelsnaamrecht op dezelfde wijze te werk als bij het ontwerpen van Boek 7. Hij legde zijn ontwerpen niet aan de voltallige subcommissie Burgerlijk Recht ter bespreking voor - dat zou vermoedelijk ook niet veel hebben opgeleverd - maar in plaats daarvan riep hij een bijzondere commissie in het leven. Deze commissie, die overigens niet altijd in dezelfde samenstelling bijeen kwam, bestond uit één of twee leden van de subcommissie Burgerlijk Recht (Bregstein, Belinfante en soms mevrouw Schönfeld-Polano) en een tweetal deskundigen uit de praktijk, te weten mr.ir. C.J. de Haan, de voorzitter van de Octrooiraad en prof.mr. G.H.C. Bodenhausen, hoogleraar aan de Universiteit van Utrecht en voorzitter van de Adviescommissie voor het Auteursrecht. Op deze wijze was de kwaliteit van het werk gewaarborgd en de instemming daarmee als het ware bij voorbaat verzekerd.

Met betrekking tot het auteurs- en het octrooirecht was de taak van Meijers beperkter. Voor wat het auteursrecht betreft kon hij namelijk gebruikmaken van een op 14 februari 1952 aan de Minister aangeboden ontwerp tot herziening van de Auteurswet. Dit ontwerp, dat was opgesteld door een commissie onder leiding van J. Alingh Prins, was er in de eerste plaats op gericht om de Auteurswet in overeenstemming te brengen met de op 26 juni 1948 tot stand gebrachte herziening van de Berner Conventie. Daarnaast bracht het ontwerp evenwel ook een aantal materiële wijzigingen die geen rechtstreeks verband hielden met de resultaten van de Brusselse Conferentie en die als tamelijk ingrijpend werden ervaren. ${ }^{8}$ Voor Meijers was er daarom geen reden zelf met bepaalde voorstellen te $k^{2} \operatorname{men}^{9}$, al betekende dat uiteraard niet dat hij zich geen enkele afwijking veroorloofde ten aanzien van het ontwerp van de commissie-Alingh Prins. Zo voegde hij in zijn ontwerp voor titel 9.1 aan artikel 25 van de Auteurswet een nieuw lid toe, waardoor de mogelijkheid om bij de overdracht van het auteursrecht afstand te doen van de in dat artikel genoemde hoogst persoon-

7. Zie het artikel van G.H.C. Bodenhausen in WPNR 4289 (1953) en de aldaar genoemde literatuur.

8. Vergelijk E.D. Hirsch Ballin, De herziening der Auteurswet, WPNR 4295-4299 (1953).

9. Om deze reden had Meijers ook afgezien van het stellen van vraagpunten omtrent het auteurs- (en octrooi-)recht. Zie de Nota bij de vraagpunten 26-29 (zitting Tweede Kamer 1952-1953, nr 2846, stuk nr 5). 
lijke rechten, sterk werd beperkt. Zou een dergelijke verbodsbepaling niet worden opgenomen, dan zou volgens Meijers iedere uitgever zich bij de overdracht van het auteursrecht de toestemming in het algemeen voor alle later aan te brengen wijzigingen doen geven, zonder dat daartegen zou kunnen worden opgekomen. ${ }^{10}$

Ook met betrekking tot het octrooirecht kon Meijers zich richten op een wetsontwerp dat zich in 1953 "in een vergevorderd stadium van voorbereiding bevond." ${ }^{11}$ Dit ontwerp, dat was opgesteld om de Nederlandse wetgeving in overeenstemming te brengen met de wijzigingen die te Londen op 2 juni 1934 waren aangebracht in het Unieverdrag tot bescherming van de industriële eigendom (Verdrag van Parijs), kende daarnaast enige andere wijzigingen van de wetgeving op het octrooirecht, zonder dat het kon worden aangemerkt als een voorstel tot een algehele herziening. Meijers had, volgens de Memorie van Antwoord bij de vragen ${ }^{12}$ 26-29, voortdurend contact onderhouden met de opstellers van dit wetsontwerp en kon er dus in beginsel mee volstaan de civielrechtelijke voorschriften van dit ontwerp op te nemen in zijn groene Boek.

\section{Kritiek}

Tegen het denkbeeld van Meijers om de rechten van de scheppende mens in het Burgerlijk Wetboek op te nemen, werd aanvankelijk enigszins vreemd aangekeken. En dat niet alleen door het Ministerie van Economische Zaken, dat, zoals ik reeds in het kader van mijn algemene bespreking van de vraagpuntenprocedure heb uiteengezet, vanaf het eerste ogenblik bezwaar maakte tegen het opnemen van de industriële eigendom in het Burgerlijk Wetboek. ${ }^{13}$

Zo bracht de vaste Commissie voor Justitie, die overigens met name bevreesd was dat Meijers te veel hooi op z'n vork zou nemen, tijdens het Mondeling Overleg over de Nota de vraag ter sprake of het wenselijk was de rechten van de scheppende mens een plaats te geven in het Burgerlijk Wetboek, een kwestie waaraan zij zonodig zelfs een vraagpunt zou willen wijden. Meijers wist de Commissie echter van het belang van het negende Boek te overtuigen door te benadrukken dat zulks de eenheid en de overzichtelijkheid van het gehele burgerlijke recht ten goede zou komen:

"Er zijn deskundigen, die het voortbestaan van afzonderlijke regelingen buiten een algemeen wetboek verdedigen. Dit standpunt ligt geheel op één lijn met het oordeel van deskundigen op ander gebied, die ieder voor de eigen materie een aantal onderwerpen buiten het Burgerlijk Wetboek wensen te zien gelaten.

Zou dit standpunt worden gevolgd, dan zouden b.v. ook het kinderrecht, het pachtrecht, het bouwrecht, het recht van de coöperatieve vereniging en het arbeidsrecht in afzonderlijke wetten blijven of worden geregeld. Men ziet dan alle

10. Van een beroep op de goede trouw verwachtte Meijers in dit verband niet veel: "In deze algemene overdracht zit niets wat in strijd met de goede trouw is en met een beroep op de goede trouw zouden dan niet meer dan enkele uitwassen te achterhalen zijn." (Opmerking aan de Adviescommissie voor het Auteursrecht bij artikel 26 ontwerp).

11. Zitting Tweede Kamer 1952-1953, nr 2846, stuk nr 25.

12. De Memorie van Antwoord werd door Minister Donker ingezonden op 12 augustus 1953 (zitting Tweede Kamer 1952-1953, nr 2846, stuk nr 25).

13. Zie hiervoor, Hoofdstuk 2. 
regelingen, die men zelf moet toepassen (..) als één geheel en men wil de eenheid daarvan bewaren zonder voldoende oog te hebben voor de eenheid en de overzichtelijkheid van het gehele burgerlijke recht. " 14

Een ander bezwaar dat tegen de onderbrenging van de rechten van de scheppende mens in het Burgerlijk Wetboek werd ingebracht was dat het hier een materie betrof die erg beweeglijk was en sterk werd beïnvloed door verdragen en plannen tot verdragen. Dit argument, dat buiten de Kamer alleen door Bodenhausen ${ }^{15}$ naar voren werd gebracht en al dadelijk sterk werd bekritiseerd omdat de internationale rechtsvorming, alle verdragen en plannen tot verdragen ten spijt, in een crisis verkeerde ${ }^{16}$, werd door Meijers (in een vergadering met diezelfde Bodenhausen) als volgt weerlegd:

"Wat tenslotte de aangevoerde stabiliteit van deze materie aangaat, op mij maakt dit argument hoegenaamd geen indruk; het voogdijrecht is eveneens instabiel, maar wordt niettemin in het B.W. geplaatst; en onderwerpen als koop, vertegenwoordiging, volmacht en in de toekomst waarschijnlijk nog vele andere, zullen eerlang internationaal worden geregeld, doch niemand zal bepleiten al deze onderwerpen nu ook maar buiten het B.W. te plaatsen. ${ }^{17}$

Het derde en laatste argument dat tegen het opnemen van de rechten van de scheppende mens in het Burgerlijk Wetboek werd aangevoerd, was dat op deze wijze het administratiefrechtelijk deel van de in Boek 9 op te nemen wettelijke regelingen zou

14. Parl. Gesch. NBW, Algemeen Deel, p. 31.

15. G.H.C. Bodenhausen, WPNR 4289 (1953).

16. Hirsch Ballin, de Amsterdamse ambtgenoot van Bodenhausen, schreef in een reactie op diens artikel: "Dat scheppingen van de menselijke geest niet plegen halt te houden bij landsgrenzen, zodat op dit gebied internationale regelingen in vergaande omvang bestaan of in wording zijn, heeft deze rechten niet labiel gemaakt, doch heeft in tegendeel tot consolidering geleid. De herziening van de Berner Conventie te Brussel in 1948 heeft dan ook proefondervindelijk bewezen, dat zij nagenoeg geen enkele wijziging van betekenis in de nationale Auteurswet 1912 medebrengt, ofschoon sedert de herziening te Rome in 1928 al weer een kwart eeuw is verstreken. "WPNR 4303 (1953).

17. Notulen van 25 juni 1953 van een bespreking over titel 9.2. Vergelijk ook het onderschrift van Meijers in WPNR 4313 (1953) naar aanleiding van een opmerking van Bodenhausen dat "het aanbeveling zou verdienen het merkenrecht voorlopig niet in het Burgerlijk Wetboek op te nemen gelet op een eventuele regeling in Beneluxverband": "Dat de Beneluxstudiecommissie van het recht ook de eenmaking van het recht in de Beneluxlanden reeds op haar agenda heeft geplaatst, is mij bekend, want zelf heb ik daartoe indertijd het initiatief genomen. Maar om, gezien dit feit, de opneming van het merkenrecht in het nieuwe Burgerlijk Wetboek uit te stellen - altijd weer de conclusie waartoe de heer Bodenhausen met zijn opmerkingen wil komen - is niet redelijk. Er zijn door dezelfde Commissie verschillende andere onderwerpen van burgerlijk recht in studie genomen, waarvan de bestudering reeds veel verder gevorderd is dan die van het merkenrecht, bijv. de regeling van de koopovereenkomst. Is dit een reden om de koop in het nieuwe Burgerlijk Wetboek niet te regelen? De ervaring heeft geleerd, dat hetgeen de genoemde Commissie in studie neemt, niet zo vlug een uniforme wet wordt (...). Mocht dit met enig deel van het burgerlijk recht in de toekomst voorspoediger lopen, welnu het ontwerp voor een nieuw Burgerlijk Wetboek is nog niet ingediend, noch rninder door het Parlement aangenomen; de uniforme regeling kan dan gemakkelijk worden ingelast." 
worden afgesplitst van de burgerrechtelijke bepalingen ${ }^{18}$, een bezwaar dat overigens in hoofdzaak het octrooirecht gold: bijna de helft van de artikelen van de Octrooiwet heeft namelijk een administratiefrechtelijk karakter.

Meijers tilde echter niet zo erg aan dit bezwaar. Al tijdens het Mondeling Overleg over de vraagpunten wees hij er bijvoorbeeld op dat het voor een uitgever een kleine moeite zou zijn de voor een bepaald onderwerp van belang zijnde regels te bundelen, zoals bijvoorbeeld ook ten aanzien van het kinderrecht en het arbeidsrecht het geval was. ${ }^{19}$ En in de "algemene inleiding" tot zijn ontwerp herinnerde hij er aan dat deze splitsing bij andere burgerrechtelijke onderwerpen zoals echtscheiding, voogdij en levensonderhoud nooit tot problemen aanleiding had gegeven. ${ }^{20}$ Tenslotte is het zo, dat Meijers de bepalingen die betrekking hebben op het ontstaan, bestaan of tenietgaan van een recht (van octrooi) als burgerrechtelijk beschouwde, zodat de veranderingen minder ingrijpend waren dan men op het eerste gezicht zou denken. Het volgende citaat uit de notulen van een vergadering met de bijzondere commissie, waarin Meijers de door hem aangebrachte splitsing verdedigde, maakt dat duidelijk:

"Ieder recht (bestaat) slechts voorzover de wetgever dit erkent; dit geldt evenzeer voor een "klassiek" recht als het eigendomsrecht, en in dit opzicht is er dus geen verschil tussen dit laatste recht en het octrooirecht. Dat aan het ontstaan van het octrooirecht een ingewikkelde verleningsprocedure door de Overheid voorafgaat, betekent geen essentieel verschil, nu de voorwaarden voor octrooiverlening zijn vastgelegd en de Staat tot verlening verplicht is wanneer aan deze is voldaan, en om dezelfde reden behoren deze voorwaarden voor verlening tot het burgerlijk recht; ook aan de huwelijkssluiting gaat een ingewikkelde procedure vooraf, en men denkt er toch niet aan daarom het huwelijksrecht, of althans de voorwaarden voor huwelijkssluiting, buiten het B.W. te plaatsen? Wel behoren zuiver formele bepalingen niet in het B.W., doch tot overbrenging van zulke bepalingen heeft spreker dan ook evenzeer op het gebied van de rechten van de scheppende mens als bijv. ter zake van het huwelijksrecht besloten. "21

18. Zie Bodenhausen, WPNR 4289 (1953). Daartegen: De Haan, Bijblad voor de Industriële Eigendom, 15 juni 1953, p. 66: "Deze splitsing zal waarschijnlijk door de direct belanghebbenden als een bezwaar worden gevoeld. (..) Gezien de grote belangen, verbonden aan de totstandkoming van het B.W. zullen de verschillende belanghebbende kringen zich de grootste zelfbeperking moeten opleggen, teneinde de toch al zo zware taak van prof. Meijers niet onnodig te verzwaren door het naar voren brengen van hun bijzondere belangen. Trouwens, een splitsing van de wet zal in feite geen ernstige bezwaren opleveren, wanneer het verband tussen het Burgerlijk Wetboek en de administratieve wetten voldoende gewaarborgd blijft."

19. Parl. Gesch. NBW, Algemeen Deel, p. 31.

20. Parl. Gesch. NBW, Algemeen Deel, p. 127.

21. Vergadering over het derde voorontwerp-octrooirecht op 25 juni 1953. Bodenhausen en Bregstein verklaarden zich geheel akkoord met deze uiteenzetting, zij het dat het de eerste om praktische redenen verstandiger leek het octrooirecht in een afzonderlijke wet op te nemen. Uit dezelfde vergadering bleek overigens dat Meijers ook weinig waardering kon opbrengen voor de dogmatische kant van de zaak: "... het dogmatische bezwaar (gaat) in ieder geval niet op t.a.v. andere rechten van de scheppende mens dan het octrooirecht, omdat daarbij geen verleningsprocedure plaats heeft, en het zou toch zeer onelegant zijn het octrooirecht (grotendeels) buiten het B.W., en de andere rechten in het B.W. te regelen; wil men nu ook de regeling van de andere rechten buiten het B.W. plaatsen, 


\section{De vraagpuntenprocedure}

De mondelinge behandeling van de vraagpunten bracht maar weinig nieuws. De vaste Commissie, die eigenlijk al tijdens het vooroverleg over de vraagpunten te kennen had gegeven de door Meijers aangesneden kwesties liever te willen schrappen omdat zij voor de wetsredactie van weinig belang waren, maakte zich er op een eenvoudige wijze van af. Alleen een drukproef van het hierboven aangehaalde artikel van Bodenhausen $^{22}$, waarin werd gesuggereerd dat de Minister de Kamer diverse malen op een verkeerd spoor had gezet en een bundel preadviezen van de Vereniging voor Handelsrecht, die pas aan de vooravond van de openbare behandeling verscheen, leidde ertoe dat een nader Mondeling Overleg moest worden ingelast.

Het artikel van Bodenhausen en de opmerkingen van de Vereniging voor Handelsrecht sorteerden echter weinig effect. Na een toelichting van de zijde van de Regering verklaarde de vaste Commissie zich in haar geheel akkoord met de voorlopige conclusies op de vraagpunten. Wel werd, naar aanleiding van de in de literatuur gevoerde discussie over het $26 \mathrm{e}$ vraagpunt, afgesproken dat de Minister op korte termijn een commissie in het leven zou roepen, die tot taak zou krijgen advies uit te brengen over de vraag "in hoeverre en op welke wijze bescherming van gebruiksmodellen mogelijk en gewenst is en in hoeverre daaraan behoefte blijkt te bestaan. ${ }^{23}$ Men meende namelijk dat Meijers de gebruiksmodellen en de siermodellen door elkaar had gehaald.

Tijdens de openbare behandeling voerden namens de Kamer slechts twee sprekers het woord: mevrouw Tendeloo, die zich beperkte tot het geven van enkele algemene beschouwingen over de beginselen die aan deze vraagpunten ten grondslag lagen, en Gerbrandy die, zij het in een vrij kleurloos betoog, vraagtekens plaatste bij de naamgeving van het negende Boek en terloops ook nog even de wenselijkheid van codificatie van dit stuk recht aanroerde. Dat laatste was, zoals Gerbrandy zelf opmerkte, eigenlijk alleen maar een verklaring, omdat hij zich geheel had aangesloten bij de conclusies op de vraagpunten. Kortom, de Kamer legde Meijers geen strobreed in de weg.

Aan de opmerkingen die Gerbrandy te berde bracht en het antwoord dat Meijers daarop gaf, heeft Cohen Jehoram reeds uitgebreid aandacht besteed. ${ }^{24}$ Desalniettemin is het niet onaardig de desbetreffende passages uit de "Handelingen" nog eens aan te halen, al was het maar omdat Meijers daar nog eens benadrukte dat hem er veel aan gelegen was de eenheid van het burgerlijk recht te herstellen, naar zijn mening één van de belangrijkste verworvenheden van de codificatie van 1838 .

21. $\rightarrow$

hetzij elegantia causa, hetzij om praktische redenen, dan geeft men daarmede blijk het met de dogmatiek tenslotte weer niet zo nauw te nemen, zodat ook aan het dogmatische bezwaar m.b.t. het octrooirecht, indien dit juist ware - quod non -, aldus weinig gewicht kan worden toegekend."

22. WPNR 4313 (1953).

23. Handelingen Tweede Kamer 1952-1953, p. 2880-2882 en 2914.

24. H. Cohen Jehoram, De codificatiegedachte en Boek 9 van het Nieuw Burgerlijk Wetboek, NJB 1983, p. 1212 e.v. 
De eerste opmerking van Gerbrandy richtte zich, zoals gezegd, tegen het opschrift van het negende Boek. Hiertegen had hij, als AR-politus, met name bezwaar omdat daarin geen recht zou worden gedaan aan de opvatting dat alleen God schept, en niet de mens:

"Bij kunstuitvoeringen b.v. wordt wel gesproken van een creatie en men kan zeggen, dat een bepaalde schrijver creatief is, maar ik vind eerlijk gezegd de term "scheppende mens" in de titulatuur: Rechten van de scheppende mens, arrogant." 25

De suggestie het negende Boek aan te duiden als Boek van de intellectuele of industriële eigendom, vond echter geen genade in de ogen van Meijers, omdat hij daarin nog iets proefde van het argument dat men vroeger tegen het auteursrecht in zijn algemeenheid placht aan te voeren:

"En waarom wens ik de andere namen, als die van industriële eigendom, persoonlijkheidsrechten, enz. niet te aanvaarden? Dat is hierom, omdat in al die namen wordt uitgedrukt een zeker grondbeginsel, dat bij die rechten gevolgd moet worden, of men moet het vergelijken met eigendom, of het is iets, dat aan de persoon gebonden is, beide onjuiste gedachten. Ook zitten wij altijd nog met de gedachte van een privilege. Juist hiertegen wenst men te reageren; er leeft nog altijd iets van de mening, dat deze rechten door de Staat worden geschapen en aan personen worden verleend, terwijl dit juist rechten zijn, waarvan men kan zeggen: het is natuurlijk een recht, waarop men aanspraak moet kunnen maken. (...) Het is geen privilege; het recht houdt verband met een uitvinding, een persoonlijk daad, die verricht is en waarvoor een zekere beloning gerechtvaardigd is." 26

Hoewel Meijers dus zijn redenen had om vast te houden aan de term "rechten van de scheppende mens" 27 , zou hij later toch besluiten de naam van Boek 9 te veranderen in "Rechten op de voortbrengselen van de geest". ${ }^{28}$ Gerbrandy was, zo leid ik af uit brieven die Meijers over deze kwestie ontving, bepaald niet de enige die zich aan de bewuste uitdrukking stoorde. En bij het op de spits drijven van deze kwestie was niemand gebaat, Meijers in het minst.

25. Handelingen Tweede Kamer 1952-1953, p. 2915

26. Handelingen Tweede Kamer 1952-1963, p. 2917-2918.

27. Vennoedelijk wenste hij een principieel geluid te laten horen tegen de gedachte dat een auteur zich voldoende beloond moet achten wanneer zijn werk wordt uitgegeven. Tegen deze gedachte had Meijers zelf ook meermalen strijd moeten leveren. Twee voorbeelden, ontleend aan Cohen Jehoram: - Meijers vroeg eens opslag voor zijn noten in het Weekblad van het Recht. Uitgeverij Belinfante weigerde, waarop Meijers samen met een aantal anderen de Nederlandse Jurisprudentie oprichtte. Binnen tien jaar was het "Weekblad" ter ziele. - Tjeenk Willink begon zijn auteurs steeds slechter te betalen. Dat was voor Meijers aanleiding de Universitaire Pers op te richten. Het fonds van Tjeenk Willink verliep in korte tijd.

28. In de aanbiedingsnota bij de eerste vier groene Boeken schreef Meijers: "Daar sommige Kamerleden aan de uitdrukking 'scheppende mens' aanstoot namen, is deze naam gewijzigd ..." Parl.

Gesch. NBW, Algemeen Deel, p. 134. 
Zijn tweede bezwaar bracht Gerbrandy als volgt onder woorden:

"... ik wil toch nog even mijn hart hierover uitstorten: waarom is men er zo buitengewoon op gesteld om dit stuk recht in de codificatie te hebben? Zeker, dit is - dat heb ik mijn studenten ook altijd geleerd - echt privaatrecht, maar het is wel een heel specifiek recht en men ervaart ook in de praktijk, dat alleen een bepaald slag juristen hiervan meer intensief op de hoogte is.

In de tweede plaats: het is zeer fluctuerend. Ieder, die de ontwikkeling van de Berner Conventie op de litteraire eigendom heeft gevolgd, ieder die meemaakt hoe er telkens weer stemmen opkomen voor bescherming van deze of die prestatie en die daarbij observeert, dat men internationaal op dit gebied moet samenwerken, stelt zich wel de vraag: is dat uitzonderlijk stuk privaatrecht wel zo uitermate geschikt om in de codificatie te worden opgenomen? Men verwijst dan naar een voorbeeld van een land, waarbij dit ook is geschied, zij het niet op dezelfde wijze als prof. Meijers het zich voorstelt te doen. ${ }^{29}$ Ik zou hierover gaarne nog iets van prof. Meijers horen. Ik begrijp, dat het kwaad ten volle is besloten en dat de Minister zich voorstelt het in de codificatie te brengen. De Minister heeft daarover op het ogenblik te zeggen, maar ik wil toch even nog naar voren brengen, dat dit mij inderdaad voorkomt te zijn niet bijzonder wenselijk. ${ }^{30}$

Meijers antwoordt dan, geheel in de lijn van zijn hierboven aangehaalde uitspraken:

"Ik heb reeds verklaard, dat, zolang men mij mijn oordeel vraagt over de samenstelling van het nieuwe Burgerlijk Wetboek, ik mij met hand en tand tegen deze mening zal verzetten. Het Burgerlijk Wetboek moet trachten te omvatten het ganse burgerlijk recht en wij moeten niet in een specialisme ondergaan. Als deze mening, deze richting, voet krijgt, moet men ook buiten het Burgerlijk wetboek het erfrecht plaatsen, want er zijn maar heel weinig juristen uit de praktijk, die iets van het erfrecht afweten, hetgeen misschien zelfs nog een voordeel oplevert, daar, juist omdat de advocaten in het algemeen zo weinig van het erfrecht afweten, er zo weinig over wordt geprocedeerd. Niemand denkt er echter over het erfrecht buiten het burgerlijk recht, buiten het Burgerlijk Wetboek, te gaan plaatsen.

Het kinderrecht, het pachtrecht, het zeerecht, zij alle zijn langzamerhand geworden het recht van specialisten, bovendien recht, vermengd met procesrecht, publiekrecht, enz.

Het is een principiële kwestie. Wil men de weg inslaan, dat men, omdat de specialisatie begint door te werken, dit alles buiten het burgerlijk recht gaat plaatsen? Als men die weg inslaat, dan eindigt men er mede, dat er geen Burgerlijk Wetboek meer is en men allemaal stukken op zich zelf heeft. Het nadeel van het plaatsen buiten het Burgerlijk Wetboek betreft niet alleen een kwestie van systematiek en onderwijsbelang. Het nadeel uit zich ook heel duidelijk in de wetten zelf. Uit de regeling van het octrooirecht blijkt bijvoorbeeld, dat men de kracht der

29. Gerbrandy doelde daarmee op de regeling in het Italiaanse B.W. (art. 2575-2594) waarin enkele hoofdlijnen van de rechten van de scheppende mens zijn verankerd, maar waarbij de verdere uitwerking van deze rechten aan bijzondere wetten is overgelaten.

30. Handelingen Tweede Kamer 1952-1953, p. 2915. 
inschrijving in registers daar ineens heel anders is gaan regelen dan die der overige registers. (...) Het pandrecht heeft ook weer een afzonderlijke regeling. Ik vraag nu: is dit gewenst? Waarom niet algemene gedachten in algemeen verband geregeld? Men zegt nu: dit recht is zo speciaal! Neen, Mijnheer de Voorzitter, het is helemaal niet speciaal; dit recht houdt ten nauwste verband met art. 1401 B.W., waarbij iemand, die een onrechtmatige daad heeft gepleegd, aansprakelijk wordt gesteld. (...) Wanneer u de regeling van deze onderwerpen afzonderlijk plaatst, dan brengt $\mathrm{u}$ mijns inziens een willekeurige scheiding in onderwerpen, die nauw samenhangen." ${ }^{31}$

En met die opmerking werd de algemene beraadslaging over dit punt gesloten.

\section{Stand van zaken ten tijde van Meijers' overlijden}

"Tijdens een bespreking met deskundigen betreffende de voortbrengselen van den geest is aan den Minister gebleken, dat ook het 9e Boek spoedig gereed zal zijn, al zullen het auteursrecht en het merkenrecht later nog gewijzigd moeten worden, zodat hier aanvankelijk enige open plekken moeten blijven."

Deze opmerking van Minister Donker, voorkomend in de notulen van de subcommissie Handelsrecht van 16 juni 1954, illustreert dat de Minister erop rekende het voorontwerp voor Boek 9 nog voor het einde van het jaar te kunnen publiceren. Dat die verwachting inderdaad niet ongegrond was, zal hieronder blijken.

Zoals ik hiervoor schreef, lag het in Meijers' bedoeling het ontwerp voor het auteursrecht (titel 9.1) op te stellen tegen de achtergrond van de voorstellen van de commissie-Alingh Prins. Meijers bracht dit plan ook inderdaad tot uitvoer en al op 12 mei 1952 werd zijn ontwerp voor het laatst in de commissie ad hoc besproken. Daarmee was het concept voor deze titel praktisch gereed, ware het niet dat na enige tijd duidelijk werd dat de voorstellen van de commissie-Alingh Prins niet door iedereen als een verbetering werden gezien. ${ }^{32}$ Het gevolg hiervan was dat Minister Donker zich op 17 april 1953 tot de in maart van dat jaar geïnstalleerde "Adviescommissie voor het Auteursrecht" wendde, met het verzoek advies uit te brengen over de vraag "of en in hoeverre het voorontwerp van wet der commissie-Alingh Prins in verband met de daaromtrent ingekomen opmerkingen dient te worden herzien". ${ }^{33}$

Begin augustus 1953 werd echter duidelijk dat het voorontwerp van de commissieAlingh Prins het Staatsblad nooit zou bereiken: het werk aan het nieuwe B.W. lag nog steeds op schema, hetgeen betekende dat het Ontwerp-Meijers voor het eind van het jaar mocht worden verwacht. Op 25 september werd de opdracht aan de adviescommissie dan ook in dier voege gewijzigd, dat zij op korte termijn advies zou moeten uitbrengen over het ontwerp van Meijers voor titel 9.1.

31. Handelingen Tweede Kamer 1952-1953, p. 2918.

32. Men zie de opmerkingen van Bodenhausen in WPNR 4289 (1953) en Hirsch Ballin in WPNR 4295-4299 (1953).

33. De adviescommissie, die op 12 maart 1953 werd geinstalleerd, was in het leven geroepen om de Minister van advies te dienen over het Voorontwerp-Verdrag van Rome d.d. 17 november 1951 betreffende de zgn. "droits voisins", t.w. de rechten van de uitvoerende kunstenaars, omroepinstellingen en fabrikanten van geluiddragers op de uitvoering van een werk. 
De commissie leverde vlot werk, want zes weken later, op 5 november 1953, was zij gereed met haar taak. Het negen pagina's tellende advies, dat vanwege de korte termijn waarin het moest worden opgesteld geen aandacht schonk aan de vraag of een nog verdergaande herziening van het auteursrecht gewenst was $^{34}$, bleek uitermate positief over de kwaliteit van het door Meijers afgeleverde werk. In feite beperkte het advies zich tot het voorstellen van enkele verduidelijkingen of aanvullingen, voornamelijk van taalkundige aard en werden verder enige opmerkingen gemaakt met betrekking tot de door Meijers voorgestelde rangschikking van de bepalingen.

Op 25 juni 1954, de dag van zijn overlijden, schreef Meijers een korte reactie waarin hij soms met slechts een paar zinnen aangaf waarom hij een bepaald voorstel al dan niet wenste te volgen, danwel de beslissing over een bepaald punt aan de commissie overliet. Daarmee was, althans wat Meijers betreft, het overleg over deze titel tot een eind gekomen. ${ }^{35}$

Het concept voor de titel 2 (Octrooien) had het in juni 1953 gebracht tot een derde versie, terwijl het overleg over deze titel - de laatste bespreking vond plaats op 25 juni 1953 - vermoedelijk als beëindigd kon worden beschouwd. Meijers had nog geen kans gezien de tijdens het overleg naar voren gebrachte opmerkingen te verwerken.

Voor de Handelsnaam had Meijers eveneens een concept gereed dat was doorgesproken met de bijzondere commissie ad hoc. Gegeven het feit dat dit concept nagenoeg geheel was gebaseerd op de slechts 11 artikelen tellende Handelsnaamwet, een wet die gedurende de dertig jaar van haar bestaan nog nooit stof tot kritiek had opgeleverd, neem ik aan dat ook dit concept als definitief kon worden aangemerkt.

Ook op het terrein van het merkenrecht was Meijers zo goed als gereed. Ook voor dit onderwerp had hij een concept opgesteld dat door de bijzondere commissie ad hoc aan alle kanten was bekeken (voor het laatst op 25 juni 1953). Wel zou - in verband

34. Met name Bodenhausen (zie WPNR 4289) had aangedrongen op een algehele herziening van het auteursrecht, omdat hij van oordeel was dat de voorstellen van de commissie-Alingh Prins niet ver genoeg gingen. Het nieuwe Burgerlijk Wetboek zou daardoor een wel bruikbaar, maar verouderd auteursrecht komen te bevatten. Meijers voelde echter niets voor die gedachte (zie ook Hirsch Ballin in WPNR 4310) omdat hij vreesde dat de vorming van een communis opinio te veel tijd zou vergen. Hij beperkte zich daarom tot een herziening van die punten waarover in de praktijk al lang en breed was gediscussieerd. (Nota aan de Ministerraad d.d. 13-11-1952).

35. Enkele voorbeelden van het commentaar van Meijers, waaruit onmiskenbaar blijkt dat hij de kunst van het wetgeven onder de knie had gekregen:

Art. 1 lid 2 ontwerp. Dat de overdracht van het auteursrecht bij akte moet geschieden, is reeds in art. 3.4.2.7 van het intussen gepubliceerde ontwerp te lezen; het was niet nodig dit hier nogmaals te herhalen.

Art.4 lid 2 Auteurswet. Mondelinge voordracht is een uitdrukking, die een wet ontsiert. In een voordracht ligt al besloten, dat die mondeling geschiedt. Wanneer in een vergadering wordt gedebatteerd, kan men niet zeggen dat daar voordrachten zijn gehouden, maar men kan hier wel van redevoeringen spreken (...).

Art. 16 Auteurswet. In de tekst staat reeds: bestemd voor het onderwijs of een ander wetenschappelijk doel, dan behoeft niet nog eens gezegd: voor zover door het doel gerechtvaardigd. (..) Waarom moeten alle moderne wetten door overlading onieesbaar gemaakt worden? 
met het feit dat het merkenrecht door de Beneluxstudiecommissie van het recht in studie was genomen - een aantal delen van deze titel pas gedurende de loop van de parlementaire behandeling in Boek 9 worden ingevoegd. Meijers wilde namelijk voorkomen dat de Belgen en de Luxemburgers het gevoel zouden krijgen voor een fait accompli te worden gesteld. ${ }^{36}$

Ten aanzien van het modellenrecht lag de situatie weer iets anders. Conform zijn toezegging aan de Kamer had Minister Donker in overleg met de Staatssecretaris van Economische Zaken begin november 1953 een speciale commissie ingesteld (de zgn. Commissie Modellenbescherming) die zou moeten onderzoeken in hoeverre bescherming van gebruiksmodellen wenselijk en mogelijk zou zijn. Deze commissie, waarin naast Meijers, De Haan en Bodenhausen een aantal vertegenwoordigers van Justitie en Economische Zaken zitting had ${ }^{37}$, kwam in zeer hoog tempo bijeen, te weten drie maal in november 1953, eenmaal in december 1953 en telkens eenmaal in resp. januari, februari en maart 1954.

Of de commissie toen vrijwel gereed was met haar werk valt niet met zekerheid te zeggen: van de zesde en zevende vergadering zijn geen notulen opgesteld. In ieder geval lag er een ontwerp-tekst van 4 februari en een ontwerp-toelichting, gedateerd 11 februari 1954, die beide een zodanige graad van voltooiing hadden bereikt, dat de commissie de ontwerpen na het overlijden van Meijers zonder daarin ook maar één wijziging aan te brengen aan de Minister aanbood. De veronderstelling lijkt daarom gewettigd dat ook dit deel van Boek 9 niet ver meer van zijn definitieve vorm was verwijderd. ${ }^{38}$

\section{7. $1954-1956$}

Hoewel na het overlijden van Meijers de meeste aandacht uitging naar het afwerken van de Boeken 5 en 6, werd er aanvankelijk ook in een straf tempo doorgewerkt aan Boek 9.

Zo werd het concept van Meijers voor de tekst van titel 2 (Octrooien) afgewerkt door De Haan die zijn ontwerp, inclusief een toelichtende nota voor het Driemanschap, op 22 oktober 1954 bij Minister Donker inleverde. Nadat het Driemanschap er zijn licht over had laten gaan - het commentaar van de Driemannen was gedateerd op 14 februari 1955 -, werden ontwerp en commentaar voorgelegd aan de Octrooiraad, die zich op 28 april 1955 akkoord verklaarde met het ontwerp. Vervolgens ontving

36. Zie het onderschrift van Meijers in WPNR 4313 (1953) en de volgende opmerking van Minister Donker, gemaakt tijdens de openbare behandeling van de vraagpunten 26-29: "Wanneer wij op een gegeven ogenblik tot het besluit komen, dat een gedeelte van het burgerlijk recht (...) in Beneluxverband één gemaakt kan worden, dan zullen natuurlijk de wettelijke regelingen, die wij hebben, en eventuele ontwerpen tot wijziging van het nationale recht, die onderweg zijn, hebben te wijken voor datgene, waaromtrent in het overleg tussen de drie landen overeenstemming is bereikt. Dit lijkt mij volkomen vanzelfsprekend." (Handelingen Tweede Kamer 1952-1953, p. 2920).

37. In alfabetische volgorde waren dat Belinfante, Van Dam, Davidson, Van Duyne, Eijssen, De Jong en Jurgens, alsmede De Vries, secretaris.

38. Een aanknopingspunt hiervoor vormt ook de uitspraak van Donker, gedaan tijdens het Mondeling Overleg over de Nota, dat "de ontwerpen betreffende de rechten van de scheppende mens vrijwel gereedliggen." (Parl. Gesch. NBW, Algemeen Deel, p. 31). 
De Haan uit handen van het Driemanschap op 22 juni 1955 de opdracht een toelichting bij deze titel te schrijven, waarna het ontwerp verdween in de archieven van het Ministerie, waar het nog steeds rust.

Nog vreemder verging het de door Meijers opgestelde tekst voor het auteursrecht. Toen het eind 1954 duidelijk werd dat de publicatie van de Boeken 5-9 nog wel even op zich zou laten wachten, besloot Minister Donker dat de Adviescommissie voor het Auteursrecht het inmiddels door haar voltooide concept van Meijers zou moeten omwerken tot een ontwerp tot wijziging van de Auteurswet. De Minister stond op het standpunt dat toetreding tot de te Brussel herziene Berner Conventie niet langer kon worden uitgesteld en was bovendien van mening dat het Ontwerp-Meijers ook los daarvan dusdanige verbeteringen bracht dat met uitstel van invoering van dit gedeelte van het nieuwe Burgerlijk Wetboek geen enkel doel gediend zou zijn.

De adviescommissie bood het resultaat van haar arbeid op 16 februari 1955 aan Minister Donker aan. Het civielrechtelijk gedeelte van dit wetsontwerp kwam, zoals de commissie in de Memorie van Toelichting schreef "practisch overeen met de wijzigingen, welke volgens het in belangrijke mate in overleg met prof. Meijers tot stand gekomen ontwerp voor titel 1 van Boek 9 van het nieuwe Burgerlijk Wetboek in het Auteursrecht zullen worden aangebracht." De systematiek van de Auteurswet had men nog wel behouden: "Echter worden in het ontwerp voor het nieuwe Burgerlijk Wetboek de bepalingen anders gerangschikt, waardoor een betere systematiek zal onstaan. De ondergetekenden hebben gemeend dat, zolang de huidige Auteurswet bestaat, het geen aanbeveling verdient ook reeds die verbeterde systematiek, welke tot een algehele vernummering der artikelen zou moeten leiden, over te nemen, zulks speciaal niet, omdat bij de invoering van het nieuwe Burgerlijk Wetboek de artikelen in ieder geval zullen worden vernummerd. Een tussentijdse extra-vernummering zou de wetsgebruikers nodeloze last bezorgen."

Een duidelijk bewijs dus voor de kwaliteit van het door Meijers afgeleverde werk. ${ }^{39}$ Ook deze voortrein werd echter - tezamen met het ontwerp voor titel 9.1 in de Ministeriële archieven bijgezet.

Aan de concepten voor het recht op de handelsnaam en het merkenrecht werd na het overlijden van Meijers niets meer gedaan. De bewerking van het eerste onderwerp zou door het Ministerie van Justitie geschieden, dat vanzelfsprekend weinig haast had met dit zeer kleine onderdeel van Boek 9. Het merkenrecht wachtte op de regeling in Beneluxverband, die, zoals de Memorie van Antwoord bij de Justitiebegroting voor 1955 verklaarde, "binnen korte tijd kan worden tegemoetgezien." Het werd uiteindelijk 1963.

Met betrekking tot het modellenrecht werd reeds opgemerkt dat de CommissieModellenbescherming het door Meijers opgestelde ontwerp ongewijzigd aan de Minister aanbood. Onvermeld bleef echter dat de commissie pas op 3 juli 1956 tot deze stap besloot, vermoedelijk een gevolg van de dood van Meijers, waardoor de druk om tot een bepaald compromis te komen wegviel. Daardoor kregen oude twistpunten weer de kans de kop op te steken.

Wat was het geval? Reeds toen Meijers het modellenrecht behandelde, bleek dat de verantwoordelijke ambtenaren van Economische Zaken bezwaar maakten tegen het

39. Vergelijk ook H.C. Cohen Jehoram, Schrap één onzalig woordje uit de Auteurswet 1912, NJB 1992, p. 1542 e.v. 
opnemen van deze materie in het Burgerlijk Wetboek: het modellenrecht zou tot de competentie van het Ministerie van Economische Zaken behoren. Meijers had uiteraard, mede gezien zijn statuur, weinig moeite gehad dit bezwaar te weerleggen, maar voor zijn opvolgers lag dat anders. Na zijn overlijden was er geen werkelijke leider meer, was ook de drang weggevallen om snel met een aanvaardbaar resultaat te komen. Toen dan ook begin 1956 bekend werd dat één van de Benelux-groepen van de A.I.P.P.I. (Association Internationale pour la Protection de la Propriéte Industrièlle) een ontwerp voor een eenvormige modellenwet had opgesteld, zagen de vertegenwoordigers van Economische Zaken hun kans schoon en deden zij het voorstel het werk aan titel 9.4 op te schorten. Daaraan was - alweer een aanwijzing dat de echte "spirit" ontbrak - sinds het overlijden van Meijers niets meer gedaan. ${ }^{40}$

Ofschoon een meerderheid van de commissie erop wees dat een Beneluxontwerp niet binnen afzienbare tijd was te verwachten en tevens werd benadrukt dat de positie die Nederland in het overleg zou kunnen innemen versterkt zou worden indien men op een eigen, moderne regeling zou kunnen wijzen, bleek de minderheid niet te overtuigen. Het gevolg hiervan was dat er uiteindelijk een compromis ter tafel kwam dat de instemming van beide partijen verwierf, maar dat tevens een dermate tweeslachtig karakter had, dat er eigenlijk niet mee te werken viel. Men kwam overeen dat de voorlopige ontwerpen van Meijers zouden worden aangeboden met de kanttekening dat daaromtrent nog geen overleg was gevoerd met de Benelux-partners. Tegelijkertijd werd besloten stappen te ondernemen om de Benelux-subcommissie te bewegen zo snel mogelijk te beginnen met het opstellen van een ontwerp voor een eenvormige Modellenwet. Daarmee was de kans op een spoedig resultaat verkeken: het ontwerp van Meijers werd op deze wijze als het ware buiten de discussie geplaatst, met als gevolg dat men weer van voor af aan moest beginnen. ${ }^{41}$

Wellicht zou men hiertegen kunnen opmerken: Als het dan zo duidelijk is dat het werk aan dit deel van Boek 9 op grond van oneigenlijke motieven op de lange baan werd geschoven, waarom greep de Minister dan niet in? Het antwoord op deze vraag is simpel. In de vergadering van de Commissie-Modellenbescherming werd tevens afgesproken dat in de brief die de ontwerpen zou vergezellen, de verwachting zou worden uitgesproken dat het Benelux-ontwerp wel in de loop van 1957 gereed zou kunnen zijn. De Minister kon dus gerust zijn.

Dat daarmee onjuiste informatie werd gegeven - Davidson, die voor Nederland zitting had in de A.I.I.P.I, wees erop dat die schatting hem wel zeer optimistisch voorkwam en ook De Jong tekende protest aan tegen de gewraakte zinsnede - scheen het merendeel van de commissieleden niet te deren. ${ }^{42}$

40. Formeel gezien was de langdurige stagnatie te wijten aan het feit dat de secretaris, $\mathrm{mr}$. L. de Vries, iemand die het denkbeeld van een nieuw Burgerlijk Wetboek ook niet erg pousseerde, overbelast was met andere werkzaamheden. Voorzitter Bodenhausen besloot daarom "ten einde raad" de vergadering dan maar zelf bijeen te roepen. Dat hij daar meer dan twee jaar mee wachtte, duidt echter niet op een overmaat aan besluitvaardigheid, terwijl het feit dat geen van de andere leden actie ondernam evenmin als een teken van een voortvarendheid kan worden gezien.

41. De Benelux Eenvormige wet inzake tekeningen of modellen zou pas in 1966 tot stand komen. Inwerkingtreding volgde op 1 januari 1974.

42. Verslag van de achtste vergadering van de Commissie-Modellenbescherming, gehouden op 3 juli 1956. Het eindverslag van de commissie zou pas in 1958 in druk verschijnen. 


\section{Na 1956}

Na 1956 heeft, althans in het kader van het werk aan het nieuwe Burgerlijk Wetboek, het werk aan het negende Boek stilgelegen. Ofschoon het boek wel regelmatig in de kolommen van de begroting werd opgevoerd als dat deel van het Burgerlijk Wetboek dat ook als laatste zou verschijnen, bleef het lange tijd rustig rond de rechten van de scheppende mens: tot 1963, het jaar waarin Beerman plaats moest maken voor Scholten, was er zelfs geen plaats voor ingeruimd op de interne overzichtsnota's.

Eén en ander hield en houdt vermoedelijk verband met het feit dat de gebreken van het Burgerlijk Wetboek het sterkst werden gevoeld op het terrein van het vermogensrecht, het rechtsgebied ook waar de schijnwerpers van de juridische pers voortdurend op waren gericht. Dit maakte dat de achtereenvolgende Ministers er waarschijnlijk alles aan was gelegen juist dit deel van het nieuwe Burgerlijk Wetboek het Staatsblad binnen te loodsen. Daardoor bleef er voor de andere delen van het ontwerp geen tijd over.

Voor Boek $9 \mathrm{kwam}$ daar bovendien nog bij dat de in dit Boek op te nemen wetgeving altijd buiten de codificatie was gebleven, zodat ook daarin geen stimulans was gelegen het werk aan dit deel van het Ontwerp-Meijers ter hand te nemen. ${ }^{43}$

In dit licht is het dan ook begrijpelijk dat er slechts twee momenten zijn aan te wijzen waarop binnen de muren van het Departement een enigszins principiële discussie heeft plaatsgevonden over de toekomst van het negende Boek, momenten die bovendien in het teken staan van het hierboven opgemerkte. Dat gebeurde in het najaar van 1965, toen in opdracht van Minister Samkalden een uitgebreide nota werd opgesteld over Boek 9, omdat hij niet tevreden was met de informatie die tot dan toe was verstrekt. ${ }^{44}$ lets dergelijks was het geval in het voorjaar van 1971 , toen een bijzondere vergadering van de Stafafdelingen Wetgeving werd belegd teneinde enkele problemen rond de totstandkoming van het nieuwe Burgerlijk Wetboek te bespreken.

\section{De nota}

Allereerst enkele passages uit de aan Minister Samkalden voorgelegde nota, die althans naar mijn mening - sterk is geschreven vanuit de gedachte dat van alle Boeken van het nieuwe Burgerlijk Wetboek het Negende het minst belangrijke is. Sommige argumenten zijn alleen te billijken indien men op het standpunt staat dat hercodificatie van het algemeen deel van het verbintenissenrecht en het zakenrecht het meest nodig is. Bovendien wordt een aantal belangrijke gezichtspunten geheel buiten beschouwing gelaten. Zo worden bijvoorbeeld uitsluitend bezwaren aangevoerd tegen het opnieuw ter hand nemen van het werk aan het negende Boek.

43. Dat dit argument vreemd is, neemt niet weg dat het gebruikt werd om de voorrang van het zeeen binnenvaartrecht boven het luchtrecht te rechtvaardigen. Zie daarover ook A.S. Hartkamp (interview) Ars Aequi 1991, p. 1114-1115.

44. Sinds 1963 werd de opschorting van de werkzaamheden met betrekking tot Boek 9 gemotiveerd met de opmerking dat in Beneluxverband werd gewerkt aan Eenvormige wetten op het terrein van het merken- en modellenrecht. Dat hetzelfde, maar dan in nog breder verband, gold voor het zee-en binnenvaartrecht, waaraan wel stevig werd doorgewerkt, deed er kennelijk niet toe. 
De nota ${ }^{45}$ begint met de constatering dat het denkbeeld van een negende Boek, althans voorzover het de industriële eigendom zou bevatten, in het verleden op weinig waardering kon rekenen:

"Reeds toen Meijers de industriële eigendom behandelde, o.a. met de voorzitter van de Octrooiraad (mr.ir. C.J. de Haan) en prof. Bodenhausen, bleek dat er zowel door deze heren als door het Ministerie van Economische Zaken bezwaar werd gemaakt tegen het opnemen van deze materie (...) in het Burgerlijk Wetboek. Men verwachtte daarvan grote moeilijkheden, enerzijds van wetstechnische aard, anderzijds in verband met de omstandigheid dat dit gedeelte van het recht erg beweeglijk is en voor een belangrijk deel gevormd wordt in internationaal verband."

Nadat de schrijver erop heeft gewezen dat Meijers hier bepaald anders over dacht, vervolgt hij:

"De zaak is nooit definitief met Economische Zaken uitgevochten. Het enkele feit dat in diverse stukken welke de Ministerraad zijn gepasseerd, het verschijnen van het 9de Boek als vaststaand wordt aangemerkt, kan, naar het mij voorkomt, Economische Zaken niet beletten om hun verzet tegen een negende Boek, althans één dat de industriële eigendom zal bevatten, vol te houden.

Tenslotte kan de Ministerraad altijd op een eerder genomen besluit terugkomen. Evenmin uitgemaakt is de zaak m.i. doordat de Tweede Kamer bij de vraagpuntenprocedure zich ermede heeft verenigd dat er een negende Boek zou komen dat ook de industriële eigendom zou bevatten. Speciaal door de intussen opgekomen ontwikkeling in internationaal verband zal men zeker niet kunnen zeggen, dat de denkbeelden van de Tweede Kamer in 1953 de zaak voorgoed zouden hebben beslist."

Die "ontwikkeling in internationaal verband" blijkt betrekking te hebben op het feit dat de Eenvormige Beneluxwet op de warenmerken inmiddels de Merkenwet 1893 had vervangen en dat een uniforme Benelux Modellenwet en een Europees Octrooirecht op komst waren, een voorspelling die voor wat betreft het octrooirecht overigens wel zeer voorbarig was: het Verdrag over het Gemeenschapsoctrooi kwam pas op 15 december 1975 (Trb. 1976, 103) tot stand en zal, als ik goed ben ingelicht, wel nooit in werking treden.

Deze tendens tot rechtsunificatie zou, aldus de nota, de opneming van deze onderwerpen in het Burgerlijk Wetboek bijzonder bemoeilijken:

45. Deze nota, gedateerd 27 september 1965, werd opgesteld door W.G. Belinfante, die zijn informatie grotendeels had ontleend aan mededelingen van mr. L. de Vries: "Mr. de Vries zelf is er van overtuigd, dat het niet mogelijk is de industriële eigendom in Boek 9 van het nieuwe B.W. op te nemen. $\mathrm{Na}$ zijn terugkomst zal hij U nader en beter kunnen inlichten." 
"De beide genoemde Benelux-wetten zijn uniforme wetten. Zij bevatten, naast burgerlijk recht, ook procesrechtelijke, strafrechtelijke en administratiefrechtelijke bepalingen. (...) Spreiding van verschillende bepalingen over verschillende wetboeken zal, dunkt mij, niet geoorloofd zijn. Zelfs opneming van deze uniforme wetten met proces-, straf- en administratiefrechtelijke bepalingen erbij in Boek 9 van het nieuwe B.W. levert bezwaren op. Enerzijds behouden dan de artikelen niet dezelfde nummers als zij in de uniforme wetten hebben, anderzijds ontsiert men het Burgerlijk Wetboek met bepalingen die daarin naar hun aard niet thuishoren."

Hoe men erover oordeelt dat op deze wijze een groot deel van het burgerlijk recht buiten het Burgerlijk Wetboek blijft staan, wordt niet vermeld.

Tenslotte is er, "de volgende, wellicht grootste moeilijkheid", het feit dat de industriële eigendom onder EZ ressorteert:

"Justitie is van de desbetreffende wetten tweede ondertekenaar. Komen deze onderwerpen in het B.W., dan zal uiteraard Justitie het eerst verantwoordelijke ministerie zijn. (..) Ofschoon dit nog niet zou betekenen dat nu ook de Octrooiraad en het Merkenbureau onder Justitie zouden komen te ressorteren, is het toch wel duidelijk dat Economische Zaken de positie die zij met betrekking tot de industriële eigendom inneemt, niet zal willen prijsgeven. Aan de andere kant zal Justitie moeilijk er in kunnen toestemmen, dat voor deze onderdelen Economische Zaken het eerst verantwoordelijke ministerie zal zijn. (En dan is het) de vraag (..) of er alsdan voldoende reden bestaat om een "romp" 9de Boek te maken. In ieder geval zou de titel "rechten op voortbrengselen van de geest" wel wat weids zijn en ook niet helemaal correct, als dit boek voorlopig niets anders zou bevatten dan het auteursrecht en de handelsnaam."

Het argument, dat het wetstechnisch bezwaren zou opleveren het formele recht van het materiële te scheiden, lijkt in tegenspraak met het feit dat Meijers de bedoelde splitsing reeds in zijn ontwerp had aangebracht en wordt bijvoorbeeld ook niet gestaafd door de ervaringen die zijn opgedaan met het pachtrecht. In de inleidende opmerkingen (p. 956) bij titel 7.5 merkt De Haan op: "De hierbedoelde splitsing (tussen materieel en formeel recht) laat zich zelfs zonder moeite verwezenlijken, temeer nu ook in de tegenwoordige Pachtwet reeds het materiële pachtrecht, waaraan uitsluitend het eerste hoofstuk is gewijd, duidelijk is afgescheiden van de rest van de stof, die over de hoofdstukken II-IV is verdeeld." In feite zou men daar kunnen spreken van een omgekeerd precedent: de Staatscommissie 1919 en het ontwerp-1929 hadden de regeling van deze bijzondere overeenkomst gedacht als een nieuwe titel van het Derde Boek van het Burgerlijk Wetboek, want vóór 1937 was de Pacht gewoon in het Burgerlijk Wetboek geregeld.

En wat de oppositie tegen dit denkbeeld betreft: inderdaad, De Haan en Bodenhausen waren geen voorstander van deze gedachte - het in paragraaf 4 opgenomen citaat van Meijers richtte zich bijvoorbeeld tegen een opmerking van De Haan - en zij hebben dan ook een aantal malen geprobeerd Meijers van deze gedachte af te 
brengen. Maar dit neemt niet weg dat zij zijn oordeel respecteerden en loyaal meewerkten ${ }^{46}$, naar buiten toe het denkbeeld zelfs verdedigden en na het overlijden van Meijers het werk in zijn geest afrondden. ${ }^{47}$

Met dat verzet viel het dus nogal mee.

Een dergelijke relativering ook op z'n plaats wanneer het gaat om het andere inhoudelijke bezwaar, het argument dat de meeste van de in Boek 9 op te nemen onderwerpen ten gevolge van internationale invloeden regelmatig aan verandering onderhevig waren (en zijn).

Hier valt tegen in te brengen dat de internationale regelingen veelal een beperkt terrein bestrijken, dat zij soms niet verder gaan dan het voorschrijven van een bepaald minimum, waarboven de gebonden Staten de vrijheid hebben zelf een regeling te treffen. Bovendien is de weg naar een verdrag $\operatorname{lang}^{48}$ en is het allesbehalve zeker of succes zal worden geboekt, zodat het onverstandig is al te zeer te vertrouwen op de internationale rechtsvorming.

Waar dat toe kan leiden illustreert de Auteurswet 1912, die pas in 1985 (Wet van 30 mei 1985, Stb. 307) een aanpassing van betekenis onderging. Wie deze wet bekijkt wordt onmiddellijk getroffen door de verschillende wijzen van nummering die in de loop der jaren zijn toegepast, het ontsierende taalgebruik en de gebrekkige systematiek. Bedenkelijker nog is dat de Auteurswet een aantal bepalingen kent die in 1912 wellicht reden van bestaan hadden, maar die nu als een antiek overblijfsel uit een reeds lang vervlogen tijd moeten worden aangemerkt. Ik wijs op artikel 7, een artikel dat de Adviescommissie voor het Auteursrecht aanvankelijk wilde handhaven, maar door Meijers met de volgende motivering werd geschrapt:

"Dat de hoogst persoonlijke rechten ook op de werkgever moeten overgaan, zou ik als een terugtred in de ontwikkeling van het mensdom beschouwen: degeen, die in dienst is, wordt slechts als een werktuig in handen van de werkgever aangemerkt, zodat ook zelfs hoogst persoonlijke rechten op deze moeten overgaan. Ik beschouw dit als een miskenning van de persoonlijkheid, waarop slechts uitgevers en andere ondernemers aansturen. Dat er buitenlandse wetten zijn die dit doen maakt op mij even weinig indruk als dat men verklaart: de meerderheid der mensheid is thans

46. Zie het onderschrift van Meijers in WPNR 4313, waarin hij met zoveel woorden te kennen gaf dat de kritiek van Bodenhausen op het denkbeeld van een Negende Boek nauwelijks serieus te nemen was "omdat reeds in details door mij regelingen zijn voorbereid, voortdurend in aangename samenwerking met (...) mr. G.H.C. Bodenhausen."

47. De Adviescommissie voor het Auteursrecht bood het door haar voltooide concept voor titel 9.1 aan met de opmerking dat de commissie het ontwerp had voltooid "in de gedachte, dat het slechts past van de tekst van de inmiddels overleden ontwerper af te wijken, indien bij nader mondeling overleg overeenstemming te verwachten zou zijn geweest, of indien de tekst der te Brussel herziene Berner Conventie of andere klemmende redenen afwijking van het inzicht van prof. Meijers (zou) rechtvaardigen." En dan te bedenken dat Bodenhausen in WPNR 4313 (1953) nog strijdbaar had geschreven dat met betrekking tot het auteursrecht niet de Minister (lees: Meijers) maar "veeleer de (..) Adviescommissie voor het Auteursrecht bevoegd (was) een mening uit te spreken."

48. Ter illustratie: De Berner Conventie werd in 1967 te Stockholm herzien. De daar opgestelde akte was echter van een dermate laag niveau, dat bekrachtiging uitbleef en in 1971 een nieuwe overlegronde volgde. Deze leidde tot de Akte van Parijs (Trb. 1972, 157), hetgeen uiteindelijk pas in 1985 resulteerde in een aanpassing van de Auteurswet 1912. 
communistisch, dus niemand anders dan de Staat dient een auteursrecht te hebben". 4950

Tenslotte dient te worden bedacht dat het een voordeel is om over moderne wetgeving te kunnen beschikken, omdat daarvan een voorbeeldfunctie uitgaat ${ }^{51}$ en deze meestal ook eenvoudiger te wijzigen is dan een wet van enkele tientallen jaren oud. Juist het argument dat het zo uitermate moeilijk was het Wetboek van Koophandel aan de te passen aan de bestaande verdragen op het gebied van het zee- en binnenvaartrecht, gaf de doorslag om Boek 8 in te voeren vóór de rest van het nieuwe Burgerlijk Wetboek.

\section{De discussie in 1971}

In 1971 verkeerde het werk aan het nieuwe Burgerlijk Wetboek in een impasse, hetgeen vooral werd veroorzaakt doordat de Kamer de wetgevingsproductie van het Departement, vrucht van de achterstand die in de jaren vijftig en zestig was opgelopen, niet meer kon bijhouden. Het Regeringsontwerp voor Boek 6 wachtte al bijna 7 jaar op een Voorlopig Verslag, het Gewijzigd Ontwerp voor Boek 3 was op 18 maart 1971 ingediend, het erfrecht zou de Kamer als "voortrein" aandoen en de Memorie van Antwoord voor Boek 5 werd in de loop van 1972 verwacht.

In vergelijking tot de situatie van 1965 waren de rollen dus precies omgedraaid. Was het in $1965 \mathrm{zo}$, dat het Departement over onvoldoende mankracht beschikte om het gehele Burgerlijk Wetboek gelijk aan te vatten, in 1971 was het de Kamer die met dit probleem te kampen had. Het resultaat was echter hetzelfde, beperking van de stof was noodzaak. Opnieuw viel daarom het besluit ${ }^{52}$ het werk aan Boek 9 voorlopig niet ter hand te nemen, teneinde de Kamer niet verder onder druk te zetten. In zoverre was er dus géén verschil met de situatie in het midden van de jaren zestig.

Frappant is echter, dat de in het verleden aangevoerde argumenten voor het stopzetten van het werk aan de concepten voor Boek 9 ditmaal vrijwel geheel buiten beschouwing bleven, een aanwijzing ook dat men de overtuigingskracht daarvan niet erg groot vond. Het argument, dat de internationale rechtsontwikkeling alan de totstandkoming van Boek 9 in de weg zou staan, werd nu door Belinfante en Van Ewijk van geen betekenis geacht, terwijl Regeringscommissaris Snijders zelfs niet de moeite nam dit door De Vries naar voren gebrachte argument in zijn beschouwingen te betrekken. ${ }^{53}$ En de stelling, dat een scheiding tussen formele en materiële bepalin-

49. Ontleend aan het antwoord van Meijers naar aanleiding van de opmerkingen van de Adviescommissie voor het Auteursrecht over het concept voor titel 9.1 .

50. Voor de actuele stand van zaken betreffende artikel 7 Auteurswet verwijs ik naar de speech van Staatssecretaris Kosto d.d. 21 november 1991 ter opening van het symposium van de Stichting Auteursrechtmanifestaties, getiteld, "HET WERKGEVERSAUTEURSRECHT, kan de werkgever het maken?"

51. Zie daarover Minister Hirsch Ballin, Nieuw BW bevat mogelijk veel exportartikelen, Nederlandse Staatscourant, 24 januari 1992.

52. Vergadering van 26 april 1971. Zie ook hiervoor, Hoofdstuk 7.

53. De opmerking van Regeringscommissaris Snijders, gemaakt tijdens de UCV naar aanleiding van de Stofkamoperatie (handelingen Tweede Kamer 1983-1984, nr 18113, UCV 82, p. 82-83), dat Boek 
gen wetstechnisch moeilijk te verwezenlijken zou zijn, is in de notulen van deze bespreking zelfs niet terug te vinden. Integendeel, tot twee maal toe werd door iemand, van wie men het waarschijnlijk het minst zou verwachten, Belinfante, benadrukt dat een codificatie van dit deel van het recht ertoe zou kunnen leiden dat "een onsamenhangend tot een samenhangend en daardoor ook minder omvangrijk geheel zou kunnen worden gemaakt."

In feite speelde alleen het protocollaire bezwaar nog een rol, maar Van Ewijk, die dit punt ter sprake bracht, gaf als zijn mening te kennen dat men er toch niet aan zou kunnen ontkomen - alle bezwaren van Economische Zaken ten spijt - de verschillende wetten op het gebied van de intellectuele en industriële eigendom samen te voegen, een opmerking waarop niemand van de aanwezigen reageerde.

\section{En nu...?}

De conclusie van dit verhaal is een tamelijk voor de hand liggende. Boek 9, of althans de gedachte daarachter, is ten gronde gegaan aan het feit dat een herziening van het Wetboek van Koophandel en Burgerlijk Wetboek ineens, een beetje teveel van het goede was. Want hoewel de concepten voor de rechten van de scheppende mens geschikt waren om zonder al te veel aanpassingen in het Staatsblad te worden gepubliceerd, had het Departement noch de mankracht noch de interesse om het werk van Meijers c.s. af te ronden.

$\mathrm{Nu}$ het werk aan de Boeken 3-8 op een oor na is gevild en de bezwaren van het voortmodderen van partiële herzieningen inmiddels wel voldoende zijn gebleken ${ }^{54}$, dringt zich de vraag op of het werk aan Boek 9 alsnog ter hand moet worden genomen. Zakelijk gezien is er geen enkele reden waarom men Boek 9, zo mogelijk aangevuld met het kwekersrecht en de wet op de naburige rechten, niet zou doorzetten. Of het er van komt is een tweede..$^{55} 56$

53. $\rightarrow$

9. gelet op de internationale rechtsontwikkeling "er zeker voorlopig niet komt", betekent niet dat hij inmiddels van gedachten zou zijn veranderd. Elk ander antwoord zou, gelet op het prominente verlangen van de Kamer nu eindelijk eens van het werk aan de hercodificatie te worden verlost, vermoedelijk een nieuwe aanleiding zijn geweest het nieuwe B.W. een stok tussen de benen te steken. In zoverre is dus sprake van een opmerkelijke continuïteit in de argumentatie - ook in het recht zijn er paradoxen te over. Zie ook C.J.J.C. van Nispen, Pleidooi voor Boek 9, in: Het Nieuw BW in functie, BW-krant jaarboek 1992, Amhem 1992, p. 112.

54. Vergelijk ook de in NJB 1984, op p. 15-16 gevoerde discussie tussen De Vries en Cohen Jehoram; zie ook F.W. Grosheide en A.S. Hartkamp, Auteursrecht en Nieuw Burgerlijk Wetboekeen inleiding -, Informatierecht/AMI, 15e jaargang nummer 10, 1991, p. 211, en C.J.J.C. van Nispen, Pleidooi voor Boek 9, in: Het Nieuw B.W. in functie, BW-krant jaarboek 1992, Arnhem 1992, p. 109-118. J.J. Brinkhof, Codificatie van het recht van de intellectuele eigendom, NJB 194. p. 771-779. Anders: B.C. de Die, NTBR 1992, p. 81; Ch. Gielen, Volghende het rechte oordeel van redene, Zwolle 1994, p. 2.

55. Meijers gaf in 1938 de volgende verklaring voor het feit dat de rechten van de scheppende mens buiten het Burgerlijk Wetboek werden gehouden: "Bij al deze onderwerpen schijnt de wetgever niet geweten te hebben of zij in een Burgerlijk Wetboek of een Wetboek van Koophandel thuishoorden en daarom ze maar in een afzonderlijke wet gelaten te hebben. Misschien ook vindt de wetgever het veel eenvoudiger om nieuwe onderwerpen maar in een bijzondere wet te laten in plaats van ze in de oude wetboeken een plaats toe te delen, waar zij onwennig moeten aandoen." (E.M. Meijers, Wijzigingen 
Dan is er alleen nog het protocollaire bezwaar. Cohen Jehoram heeft ooit voorgesteld deze kwestie uit de wereld te helpen door de Minister van Economische Zaken met betrekking tot de rechten van de industriële eigendom het eerste ondertekenaarschap aan te bieden. Een zinrijke gedachte. Nodig is dat evenwel niet. Meijers had uiteraard geen enkele behoefte de vruchten van zijn arbeid onnodig in gevaar te brengen. Daarom bestookte hij de Staatssecretaris van Economische Zaken net zolang met argumenten, totdat deze aan Minister Donker liet weten dat hij, zij het "schoorvoetend", kon "instemmen met het voornemen van prof. Meijers het recht van de industriële eigendom in het nieuw Burgerlijk Wetboek op te nemen." ${ }^{57}$

55.

en aanvullingen van het Burgerlijk Wetboek na 1838, in: Gedenkboek Burgerlijk Wetboek 18381938, Zwolle 1938, p. 39).

56. Inmiddels lijkt de eerste aanzet te zijn gegeven. In de Justitiebegroting voor 1994, zitting Tweede Kamer 1993-1994, nr 23400, stuk $\mathrm{nr} 2$, p. 20, staat vermeld: "Voorts is in studie de vraag of er aanleiding bestaat om alsnog een Boek 9 betreffende de voortbrengselen van de geest tot stand te brengen."

57. Brief van de Staatsecretaris van Economische Zaken d.d. 7 september 1953. Dit gegeven verklaart ook dat vertegenwoordigers van Economische Zaken daadwerkelijk hebben meegewerkt aan het opstellen en beoordelen van de concepten voor Boek 9: men denke daarbij aan de werkzaamheden in de Commissie-Modellenbescherming en aan de activiteiten in Beneluxverband. 


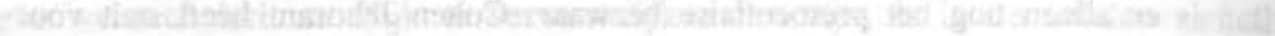

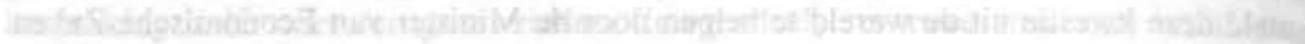

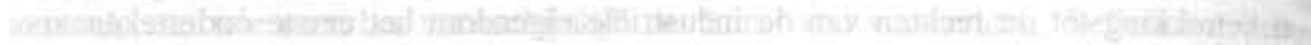

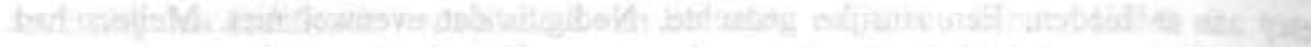

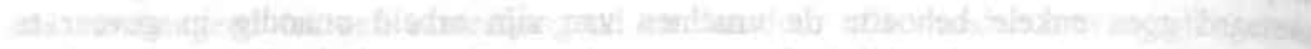

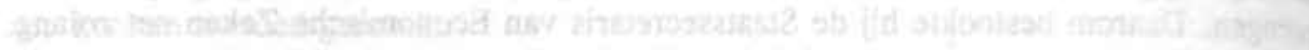

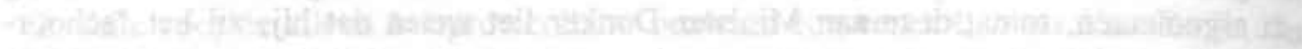

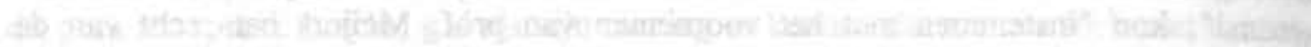

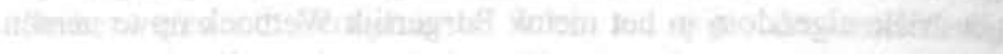

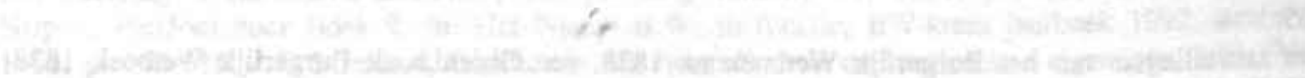

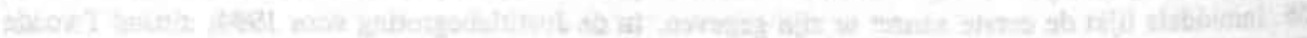

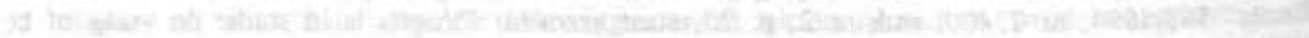

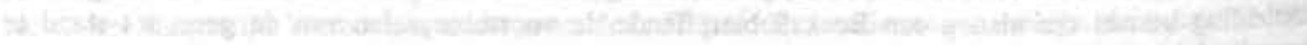

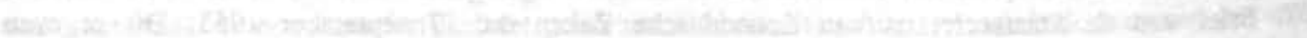

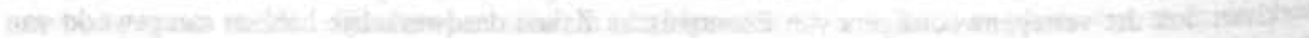

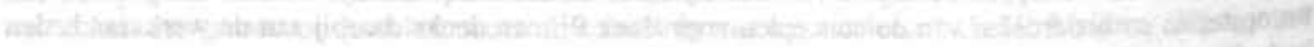

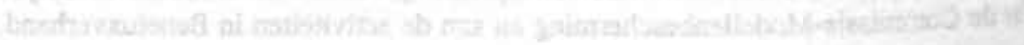


Hoofdstuk 11

INVOERINGSPERIKELEN (1980-1992)

"Er zijn dan ook onder ons twee soorten van gevoelens omtrent de invoering van nieuwe wetgevingen, welke lijnregt tegen elkander overstaan. Sommigen namelijk, en hiertoe behooren vooral de oudere Regtsgeleerden, willen van volstrekt niets nieuws weten. (..) Anderen daarentegen, en onder dezen vooral de jongere beoefenaren des regts, verheugen zich door eene nieuwe wetgeving den voorrang vernietigd te zien, welke eene langere beoefening en ondervinding natuurlijk te voren aan ouderen geven moest. Alles willen zij nieuw hebben, om oudere kennis nutteloos te kunnen verklaren, en zelfs in dat geen, wat het nieuwe met de oudere regten gemeen heeft, zoeken zij onvermoeid naar nieuwigheden (..)."

\section{Inleiding}

Nadat de Boeken 3, 5 en 6 op 20 april 1977 met algemene stemmen door de Tweede Kamer waren aangenomen, leek niets aan een spoedige invoering meer in de weg te staan. Op 29 november 1979, ter gelegenheid van de officiële aanbieding van Schoordijks boek "Het verbintenissenrecht naar het nieuwe B.W.", liet Minister De Ruiter dan ook weten dat hij ernaar streefde de invoering van de Boeken 3-6, alsmede van enkele titels van Boek 7, in 1984 te doen plaatsvinden. Juridisch Nederland diende er ernstig rekening mee te houden dat het oude B.W. het 150-jarig bestaan in 1988 niet zou halen, zo kon uit de toespraak van de Minister worden opgemaakt. ${ }^{2}$ Neleman: "Bij de aanbieding van het boek van Schoordijk heb ik voor Minister De Ruiter een toespraakje voorbereid en daarin tot uitdrukking gebracht dat de invoering in 1984 te verwachten viel. De Minister had namelijk ervaren dat zoveel mensen zeiden 'het zal mijn tijd wel duren.' We hadden daar ook goede aanwijzingen voor, omdat er met de Kamer afspraken over waren gemaakt. Die datum was bepaald niet uit de lucht gegrepen."

Teneinde de Tweede Kamer zoveel mogelijk te ontzien en de tijdsruimte tussen vaststelling en invoering zo kort mogelijk te doen zijn - de gang van zaken met betrekking tot de invoering van de Boeken 1 en 2 had uitgewezen dat het ook wel zonder vaststellingswetten had gekund - was de invoering beperkt tot de Boeken 3-6. Boek 7 (Bijzondere overeenkomsten) was door het Departement bewust terzijde gelegd, een vijftal aan de Boeken 3-6 verwante titels buiten beschouwing gelaten. ${ }^{3}$

1. Joan Melchior Kemper, geciteerd bij H. Cohen Jehoram, Over codificatie van vó́r Portalis tot na Meijers, Deventer 1970.

2. De Ruiters rede werd gepubliceerd in de Staatscourant van 4 december 1979. Zie ook NJB 1979 , p. 1007, alsmede de toelichting bij de Justitiebegroting voor 1981, Parl. Gesch. Voortgang, p. 5: "Met kracht wordt gewerkt aan de voltooiing van het grote werk. Daarbij wordt ernaar gestreefd althans de Boeken 3-6 in 1984 in te voeren, hetgeen betekent, dat de daartoe nodige ontwerpen in het komende parlementaire jaar voor een belangrijk deel gereed moeten worden gemaakt."

3. Het betrof de titels 1 (Koop en ruil), 3 (Schenking), 7 (Opdracht), 9 (Bewaarneming), 14 (Borgtocht) en 15 (Vaststellingsovereenkomst), waarvan de vaststelling en invoering telkens in een apart wetsontwerp waren geregeld. 
Dat hierdoor een deel van de bovenverdieping van het B.W. voorlopig nog oud zou blijven, met alle extra werk die dat voor het Departement met zich mee zou brengen, werd op de koop toegenomen. Begin september 1975, toen de eerste voorbereidingen werden getroffen voor de invoeringswetten, had De Die opgemerkt:

"De Tweede Kamer is reeds zeer zwaar belast met wetgevingswerk. Voor het nieuwe B.W. kan slechts een bescheiden plaats worden verlangd. Deze wordt vermoedelijk ruimschoots gevuld door de reeds aanhangige ontwerpen, straks nog te vermeerderen met invoeringswetten. Grote delen van de ontwerpen zijn politiek niet erg interessant. Het zal derhalve toch al stuurmanskunst vergen dit brok de Kamers door te loodsen (..). Voegt men bij het bovengenoemde nu nog een ontwerp tot vaststelling van Boek 7, dan wordt de Tweede Kamer wel onder het nieuwe B.W. bedolven. (..) Ik ben doodsbang dat we aldus de nu zichtbaar groeiende plant van het nieuwe B.W. zouden gaan verstikken: 'qui trop embrasse, mal étrient.'"4

Niettemin zou de invoeringswetgeving ook zonder Boek 7 een bijzonder omvangrijk geheel blijken te zijn. De al in 1971 in de Memorie van Antwoord bij afdeling 3.1.2 toegezegde Kadasterwet, de partiële herziening van het wetboek van Burgerlijke Rechtsvordering, waartoe in 1973 het voortouw was genomen en de regeling van de Algemene Voorwaarden, in de begroting van 1975 in het vooruitzicht gestelds, zouden een flink stuk aan het dossier toevoegen. Daar tussendoor liepen nog verschillende voortreinen van Boek 8.

\section{Verhuizen kost bedstro ${ }^{6}$}

Om de invoering van het nieuwe vermogensrecht zo goed mogelijk te laten verlopen, werd door Justitie begin 1980 contact opgenomen met vertegenwoordigers van een aantal juridische beroepsgroepen. Dit contact zou na twee bijeenkomsten uitmonden in de oprichting van de zogenaamde "Stuurgroep Begeleiding Invoering NBW". ${ }^{7}$ De

4. Nota van 2 september 1975. In gelijke zin oordeelden Van Ewijk ("Het perspectief is uiterst somber"), Neleman en Snijders. Alleen Herrmann meende dat invoering van de belangrijkste delen van Boek 7 voor de Kamer "de pil enigszins zou kunnen vergulden".

5. Zie zitting Tweede Kamer 1974-1975, nr 13100, stuk nr 2, p. 7.

6. Trema 1980, p. 1-2. F.C. de Vries schreef daar: "Het belang van een goede rechtspleging na invoering van het nieuwe burgerlijk recht vergt (..) gezamenlijke inspanningen van rechters en advocaten, zodat zij te zijner tijd in staat zullen zijn geschillen op basis van gedegen inzicht in het dan geldende recht tot oplossing te brengen. Het is duidelijk dat het op de weg van het bestuur van onze vereniging ligt hier het voortouw te nemen opdat op korte termijn een adequate instructie van de rechterlijke macht van de grond komt. Anderzijds is evenzeer duidelijk dat de rechterlijke macht niet in staat zal zijn deze instructie in eigen beheer te verzorgen. De Minister van Justitie die het project met zoveel voortvarendheid voortstuwt, zal het mogelijk moeten maken dat de rechterlijke macht én de advocatuur wetenschappelijk begeleid worden op hun pad naar het nieuwe recht."

7. Zie zitting Tweede Kamer 1980-1981, nr 16400, stuk nr 1, p. 4; handelingen Tweede Kamer $1980-1981$, p. $1108,1115,1307-1308$. 
eerste bijeenkomst, op 18 februari 1980 , had een inventariserend karakter. ${ }^{8}$ Uit het verslag blijkt dat de komst van het nieuwe B.W. door iedereen als een gegeven werd beschouwd; de belangrijkste wens uit de vergadering was een royale financiële steun bij de begeleiding van de invoering. Wél werd van de zijde van de NVVR gewezen op de onderbezetting van de rechterlijke macht, een verband dat echter buiten de orde werd verklaard. Een verzoek om studieverlof of een tijdelijke uitbreiding van het rechterlijk apparaat werd aanvankelijk eveneens afgewezen, wegens het ontbreken van elke financiële ruimte.

Op 10 juni 1980 vond een tweede bijeenkomst plaats, waarin alle mogelijkheden van begeleiding (cursussen, literatuurvoorziening, televisiecursussen, etc.) onder de loep werden genomen. De slotsom van deze bespreking was dat, gelet op de diversiteit van de doelgroep, het van de grond brengen van een beknopte, inleidende en praktijkgerichte cursus, te ontwerpen door de Stafafdeling NBW, de meeste prioriteit had. De gedachten gingen daarbij uit naar een opzet, waar binnen een bestek van ongeveer tien bijeenkomsten van \pm twee uur aan de hand van standaardarresten en speciaal daartoe ontworpen casusposities de nieuwe systematiek en de belangrijkste materiële vernieuwingen van de Boeken 3,5 en 6 konden worden aangeboden. Daarbij zou een relatief zwaar accent op de voorbereiding en zelfstudie moeten worden gelegd. De taak van het Departement bleef, naast het verstrekken van een aanloopsubsidie van fl 60.000 ,- aan de SSR en een eenmalige docententraining, verder beperkt tot het geven van morele steun en advies. ${ }^{9}$

Wel werd ditmaal een uitzondering gemaakt voor de rechterlijke macht, die voor een periode van ongeveer vier jaar drie jonge rechters mocht aantrekken, die voor $3 / 5$ waren vrijgesteld voor het opzetten en geven van onderwijs in het nieuwe Burgerlijk Wetboek. De reden voor deze voorkeursbehandeling was dat binnen de NVVR reeds in april 1979 het initiatief was genomen tot het opzetten van een tamelijk ambitieus opgezette cursus-NBW, en dat - gelet op eerdere uitlatingen - deze voorziening ook als harde voorwaarde voor invoering werd gezien. Dit initiatief werd gemotiveerd vanuit de bijzondere verantwoordelijkheid van het Ministerie voor de rechterlijke macht. ${ }^{10}$

8. Afgevaardigd waren leden van de Nederlandse Vereniging voor Rechtspraak, de Stichting Studiecentrum Rechtspleging, de Koninklijke Notariële Broederschap, de Nederlandse Orde van Advocaten, de Nederlandse Vereniging van Gerechtsdeurwaarders, de Nederlandse Vereniging voor Rechtskundige Adviseurs en de Commissie Cöordinatie Juridische PAO. Later (vergelijk zitting Tweede Kamer 1980-1981, nr 16400, stuk nr 18), zouden ook vertegenwoordigers van de Bureaus voor Rechtshulp en van het Nederlands Genootschap voor Bedrijfsjuristen worden uitgenodigd.

9. Zie zitting Eerste Kamer 1981-1982, nr 17100, stuk nr 34 c; Advocatenblad 1983, p. 232. Initiatieven op het gebied van de literatuurvoorziening bleken naar het oordeel van de vergadering niet noodzakelijk. Diverse uitgevers hadden zich al met voortvarendheid op deze markt geworpen de Parlementaire Geschiedenis Boeken 3, 5 en 6, alsmede de 60-delige reeks Monografieën NBW waren in een vergevorderd stadium van voorbereiding. Bovendien werd reeds beschikt over het compendium van Hartkamp (1977) en het breed opgezette commentaar van Schoordijk; AsserHartkamp I zou in 1984 verschijnen. Tenslotte zou het NJB in 1981 het initiatief nemen tot een artikelenreeks over het nieuwe B.W.

10. Zie daarover R. Herrmann in Trema 1981, p. 82 e.v. De Minister zou overigens pas op 22 januari 1981 in een brief aan de NVVR van dit voornemen doen blijken, kennelijk om scheve ogen te vermijden. 
In september 1982 werd het sein gegeven tot het grootscheepse NBW/PAO-project, met het doel ruim 5000 geïnteresseerden, dat wil zeggen ongeveer de helft van de totale doelgroep, vóór 1984 met de hoofdlijnen van het nieuwe vermogensrecht vertrouwd te maken. De organisatie en de uitvoering waren toevertrouwd aan het Centrum NBW, ondergebracht bij het Bureau van de Juridische Faculteit van de Rijksuniversiteit Utrecht. ${ }^{\text {II }}$ Het cursusmateriaal kreeg van coördinator R.S. Meijer het volgende motto mee, ontleend aan Assers commentaar op het B.W.: "Thans laat het zich aanzien, dat de reeds voor lang aangevangene, dikwijls herziene en gewijzigde, telkens door omstandigheden vertraagde, en eindelijk voltooide Nederlandsche Wetboeken binnenkort in werking zullen worden gebragt." De redactie van het Advocatenblad schreef: "Wij hebben ons tot dusverre zelf bedrogen met de gedachte: het zal mijn tijd wel duren. Dat mogen wij nu wel uit ons hoofd zetten, want het wordt menens." 12

Er moest weer gestudeerd worden. Verspreid over het gehele land zouden elke drie maanden zestien tot achttien NBW/PAO-cursussen worden gehouden, met vijfendertig deelnemers per cursus, verdeeld over tien bijeenkomsten van twee uur. De rechterlijke macht (SSR) wees vanaf begin 1983 in zes bijeenkomsten van vijf uur meer dan zeshonderd rechters en raio's op de continuïteit tussen het oude en het nieuwe recht, de Broederschap van Notarissen zette een meerjarenplan op voor de begeleiding van haar ruim duizend leden, eveneens te starten in het voorjaar van 1983. Verder waren er bijzondere cursussen voor het griffiepersoneel $(500)$, de belastingdienst $(300)$, voor enkele zeer grote advocatenkantoren (200), verzekerings- en andere bedrijfsjuristen (750), alsmede talloze bijzondere PAO-cursussen van Universiteiten en commerciële organisaties. ${ }^{13}$

Tenslotte zouden vrijwel alle faculteiten met ingang van de cursus 1982-1983 het nieuwe B.W. op hun programma zetten. Een uitzondering vormde Nijmegen, waar Van der Grinten met emeritaat ging en Rotterdam, waar men een jaar achteraan kwam. ${ }^{14}$

\section{Problemen}

Het jaar 1984 zou niet worden gehaald. Op 29 mei 1982, enkele maanden na de beëdiging, viel het tweede Kabinet-Van Agt. Het gevolg hiervan was dat vervroegde verkiezingen moesten worden uitgeschreven. Dat betekende dat de leden van de vaste Commissie eind juni het werk aan de invoeringswetgeving opschortten om op verkiezingstoernee te gaan. En omdat men in juni 1982 reeds voorzag dat de samenstelling van de Commissie na de verkiezingen tot aan het nieuwe Kabinet een voorlopige zou zijn - enige leden van de commissie stonden aan de marge van de verkiesbaarheid -, betekende dit dat pas op 4 november, toen het nieuwe Kabinet werd geïnstalleerd, de draad weer kon worden opgepakt. De NBW-karavaan had een vertraging opgelopen

11. Zie Trema 1982, p. 72 e.v.; Advocatenblad 1982, p. 27 en p. 32.

12. Advocatenblad 1982, p. 89.

13. Zie voor nadere gegevens zitting Tweede Kamer 1982-1983, nr 17600, stuk nr 11, p. 14 e.v.

14. Zie H.C.F. Schoordijk, Een antwoord aan Van Dunné, NJB 1984, p. 678. 
van vijf maanden, voldoende om het tijdschema, dat toch al niet ruim was bemeten, aardig in de war te laten lopen. ${ }^{15}$

Een nog grotere tegenslag was, dat de nieuwe vaste Commissie niet bij voorbaat bereid bleek de behandeling van de invoeringswetgeving, waarbij met uitzondering van Boek 4 vrijwel geen actuele politieke belangen waren betrokken, volgens schema af te werken. Integendeel, op 16 december 1982 wendde de Commissie zich tot de nieuw aangetreden Minister mr. F. Korthals Altes, met de vraag of hij voornemens was "de lijn voort te zetten, zoals die destijds uw voorganger, Minister De Ruiter, voor ogen stond." Als dat het geval zou zijn, dan zou de Commissie "het op prijs stellen tevens van $u$ te vernemen of $u$ daarbij thans wellicht ook denkt aan prioriteitstellingen bij de afwikkeling van dit programma en zo ja, welke deze dan zijn." Verder werd de Minister medegedeeld dat de Commissie zijn antwoord in publieke discussie zou geven en dat zij het voornemen had daarover een hoorzitting te beleggen met de Nederlandse Vereniging voor Rechtspraak, de Nederlandse Orde van Advocaten en de Koninklijke Notariële Broederschap. ${ }^{16}$

De boodschap was duidelijk: de Commissie voelde er weinig voor het hoge tempo, waarmee haar voorganger was begonnen, voort te zetten. Zelfs de mogelijkheid het bijltje erbij neer te leggen werd uitdrukkelijk opengehouden. ${ }^{17}$ Een herhaling dreigde van de situatie in 1973. De omstandigheid dat het Departement tijdens de afwezigheid van de Kamer het aantal bij de vaste Commissie ingediende delen van de Invoeringswet-NBW van drie had opgevoerd tot zes, terwijl nog zeven delen in aantocht waren, zal daaraan ongetwijfeld debet zijn geweest. ${ }^{18}$

15. Tot juni 1982 was het tempo zeer bevredigend geweest. Minister De Ruiter zou dan ook in de begroting voor 1983 (zie Parl. Gesch. Voortgang, p. 8) nog de verwachting uitspreken dat de Tweede Kamer erin zou slagen de eerste zes delen van de invoeringswet medio 1983 plenair af te doen: "De hoop dat de Tweede Kamer in de loop van het zittingsjaar het overgrote deel, zo niet het geheel van de opgesomde ontwerpen zal hebben behandeld, is niet ongegrond." Overigens is het de vraag of het Departement zélf in staat zou zijn de streefdatum 1984-1985 te halen. Eind 1982 lagen nog zeven delen van de invoeringswetgeving op de ontwerptafel, waaronder de complexe materie van het overgangsrecht. Zie daarover M. Reinsma, Regelmaat 1988, p. 144.

16. Zie Parl. Gesch. Voortgang, p. 9.

17. Zie A. Kosto, Advocatenblad 1985, p. 459. Tijdens zijn redevoering ter gelegenheid van de jaarvergadering van de Nederlandse Orde van Advocaten, liet de Voorzitter van de vaste Commissie voor Justitie doorschemeren dat er in 1982 binnen de Commissie twijfels bestonden over de wenselijkheid van een geheel nieuw B.W. Eerst nadat duidelijk werd dat aan de oproep tot een "Brede Wetenschappelijke Discussie" (zie hieronder) geen enkel gehoor werd gegeven, "trok de vaste Commissie van haar kant de conclusie dat met het werk aan het NBW moest worden voortgegaan."

18. Eind december 1982 hadden de volgende delen het Departement verlaten: Eerste gedeelte (januari 1981): wijziging Wetboek van Burgerlijke Rechtsvordering, Wet op de Rechterlijke Organisatie, en de Faillissementswet (16593); Tweede gedeelte (juli 1981): invoeging afdeling 6.5.2a (algemene voorwaarden) (16981); Derde gedeelte (oktober 1981): wijziging van Boek 4 (17141); Vierde gedeelte (juli 1982): wijziging van Boek 3, behoudens titel 3.11, alsmede de Kadasterwet (17496); Vijfde gedeelte (september 1982): wijziging van titel 3.11 en de Boeken 5 en 6 (17541); Zesde gedeelte (december 1982): aanpassing van de Boeken 1 en 2 (17725).

Nog zouden volgen: Zevende gedeelte (mei 1983): aanpassing van de Boeken 3 en 5 B.W. en enige andere wetten (17896); Achtste gedeelte (juli 1985): aanpassing van de Wet op de Bedrijfsorganisatie en andere wetten (19077); Negende gedeelte (mei 1986): aanpassing van de Postwet 1954 en andere wetten (19527); Tiende gedeelte (maart 1988): aanpassing van de Wet voorkeursrecht 
Een andere moeilijkheid was, dat als gevolg van de slechte economische situatie in 1981 en 1982 door Justitie een aantal bezuinigingsmaatregelen was getroffen, waarbij de rechterlijke macht, die al jaren met onderbezetting had te kampen, niet was ontzien. Bij de Rechtbanken gold begin 1983 een onderbezettingspercentage van 16 procent (absoluut 79), bij de Hoven 32 procent (absoluut 69) ${ }^{19}$ Dit betekende, dat er binnen deze kring met toenemende bezorgdheid werd gekeken naar het nieuwe B.W., alleen al gelet op de noodzaak tot omscholing. J.H.B.M. Saelman, kantonrechter te Amsterdam, schatte in Trema dat de invoering van het nieuwe B.W. neer zou komen op een netto-investering van vier maanden capaciteitsverlies over twee jaar: "De bestaande achterstanden en knelpunten zijn bekend. De cursus in de geschetste opzet vormt eens te meer een nieuwe zware belasting zonder een spoor van verlichting elders. " ${ }^{\text {20 }}$

Wel moet ik hier onmiddellijk aan toevoegen, dat deze reactie wel enigszins voorbarig was. Saelman, wiens bezorgdheid ongetwijfeld in brede kring werd gedeeld, sprak zijn beduchtheid over het vele werk, verbonden aan het volgen van de SSR-cursus, uit vóórdat deze cursussen goed en wel van start waren gegaan. Bovendien zouden de cursussen in de meeste gevallen voor ten minste de helft van de cursusduur buiten de normale werktijd plaatsvinden. ${ }^{21}$ Tenslotte zou het eerste deel van de cursus, waartegen zijn bedenkingen waren gericht, voor driekwart gedeelte zijn gewijd aan het opfrissen van jurisprudentie, juist omdat er in het nieuwe B.W. zoveel recente jurisprudentie was verwerkt. ${ }^{22}$ Pas in de tweede en de derde fase van de cursus zouden de systematiek en terminologie van het nieuwe B.W., respectievelijk capita selecta en overgangsrecht aan de orde komen. Een zekere mate van koudwatervrees kwam er dus ook wel bij. Neleman: "Wat vele practici missen, met name rechters, is dat zij nieuwe rechtspraak bijhouden en voor zichzelf in een systeem plaatsen. Dan wordt het heel moeilijk een systeem te beheersen dat uitgaat van die rechtspraak - het nieuwe B.W." Ten Kate, lange tijd voorzitter van de SSR: "Ik kan

18. $\rightarrow$

gemeenten en andere wetten (20503); Elfde gedeelte (mei 1985): Aanvulling van de Overgangswet nieuw Burgerlijk Wetboek (18998); Twaalfde gedeelte (mei 1986): Voorbereiding Invoeringswet Boeken 3, 5 en 6 (19528); Dertiende gedeelte (december 1989): Bezemwet (21418).

19. De NVVR noemde in haar schrijven aan de Tweede Kamer van 28 februari 1983 (zie Trema 1983, p. 147 e.v.) t.a.v. de Rechtbanken ten onrechte een cijfer van 21 procent.

20. Trema 1982, p. 120. In Trema 1983, p. 25 (De NBW-trein dendert voort) berekende D.J. Buijs dat als gevolg van de cursuslast (op jaarbasis) vijfentwintig rechters niet beschikbaar zouden zijn voor rechterlijk werk.

21. Aldus blijkt uit antwoorden van de Minister op vragen van de vaste Commissie, zitting Tweede Kamer 1982-1983, nr 17600, stuk nr 11, p. 15.

22. Illustratief is de volgende passage uit een advies van de werkgroep invoering Nieuw B.W., ingesteld door de NVVR, geciteerd in Trema 1981, p. 83: "De belangrijkste moeilijkheid voor de praktijk zal in eerste instantie vermoedelijk de systematiek van het nieuwe vermogensrecht zijn, die ten opzichte van de huidige systematiek ingrijpend gewijzigd is. Ten dele geldt dit ook voor de terminologie. Wat de materieelrechtelijke oplossingen betreft bevat het nieuwe B.W. vanzelfsprekend op détailpunten een groot aantal wijzigingen ten opzichte van het huidige recht. Wanneer men evenwel de détails buiten beschouwing laat, kan geconstateerd worden dat het nieuwe B.W. weliswaar in een groot aantal gevallen nieuwe wegen inslaat, maar dat er daarnaast op een groot aantal gebieden veeleer sprake is van aansluiting bij de huidige stand van rechtspraak en literatuur. Op deze gebieden zal de schok van invoering niet groot hoeven te zijn, mits men op de hoogte is van met name recente ontwikkelingen in de rechtspraak." 
mij niet helemaal aan de indruk onttrekken, dat veel mensen door het kennisnemen van het nieuwe B.W. ontdekken dat ze ook het huidige recht niet kennen. Die factor speelt ontegenzeglijk een grote rol bij de bezwaren tegen het nieuwe B.W." ${ }^{23}$

Tenslotte deed Minister Korthals Altes nog een duit in het zakje, door vier weken na zijn aantreden in een vraaggesprek met het Nederlands Juristenblad te verklaren dat hij aarzelingen had of het werk aan het nieuwe B.W. moest worden doorgezet. In antwoord op de vraag of het in het kader van de overbelasting van de rechterlijke macht niet wenselijk zou zijn de invoering van het nieuwe B.W. "voor onbepaalde tijd uit te stellen", verklaarde de Minister: "Het is een onderwerp dat zo verstrekkend van aard is, dat ik niet daarover binnen vier weken een uitspraak doe. Maar, zoals gezegd, we moeten zelfs daar naar kijken, al durf ik bepaald geen uitspraak te doen dat in de vaste wil, die tot nog toe in elk kamerdebat tot uiting is gekomen, om door te gaan met de invoering van het NBW, een wijziging is gekomen. (..) Misschien hebben wij behoefte aan wat ik weleens noem: niet een BMD, maar een BWD, een Brede Wetenschappelijke Discussie. ${ }^{24}$

Ter motivering van zijn uitspraak verwees de Minister naar een opmerking van de Deken van de Orde van Advocaten, mr. P.C. van den Hoek, die zich in zijn jaarrede van 24 september 1982 had afgevraagd "of de invoering van een geheel nieuw Burgerlijk Wetboek werkelijk nog verantwoord is in een tijd, waarin het rechterlijk apparaat het werk niet aankan. (...) Het gaat mij niet om de vraag, of deze hercodificatie nodig of zinvol is, maar om de praktische gevolgen van de invoering in een tijd, waarin goede rechtspraak en rechtshulp uit de financiële lengte of breedte moeten komen." ${ }^{25}$ Een mager argument, omdat in de Stuurgroep Begeleiding Invoering NBW, waarin zowel de NVVR als de Orde van Advocaten waren vertegenwoordigd, nooit bezwaren tegen de invoering waren geuit, laat staan verzet was aangekondigd. Bovendien was het door Van den Hoek gelegde verband duidelijk enigszins retorisch, omdat de rechtshulp nu eenmaal niet kan worden gefinancierd uit het laten rusten van het nieuwe B.W. Het had er dus enigszins de schijn van dat de nieuwe Deken zélf weinig voelde voor een nieuw Burgerlijk Wetboek, maar het niet aandurfde de Orde, die altijd actief had meegewerkt, die zwaai te laten maken en daarom zijn toevlucht zocht bij de rechterlijke macht. ${ }^{26}$ Snijders: "Als de advocaten in 1983 met concrete

23. Zie ook H.C.F. Schoordijk, NJB 1984, p. 677 e.v.: "De praktijk heeft het Nieuw B.W. voor zich uitgeschoven, niet uit afkeer, maar omdat - ik druk mij zwak uit - aan de education permanente nog wel wat ontbreekt. De boekenkast van de jurist - ook die van de rechter - is doorgaans slecht gevuld. Dit feit en niet het Nieuw B.W. voert tot overbelasting." Vergelijk ook F.B. Bakels, NJB 1984, p. 1284 en J.H. Saelman, Trema 1982, p. 119.

24. J.F. Bruinsma, N. Huls, Interview met de nieuwe Minister van Justitie, mr. F. Korthals Altes, NJB 1983, p. 5.

25. Advocatenblad 1982, p. 456.

26. H. Drion, Rechtsgeleerd Magazijn Themis 1983, p. 117 , sprak in dit verband over de "waaghalzerij van het jongetje dat, bibberend in zijn zwembroekje, het waagt ter discussie te stellen of het wel zo verantwoord is die koude zee in te lopen." Ook de redactie van het Advocatenblad (1983, p. 242) zou zich tegen Van den Hoek keren: "Er circuleren geruchten over uitstel van de invoering van het NBW. Wij zouden het erg betreuren, indien tot een dergelijk uitstel wordt besloten." Zie ook A.S. Hartkamp, die hierover in NJB 1984, p. 786 een "leerzaam gedicht" schreef: "De Minister dirigeert zelf een duet van meesters Van den Haak en van den Hoek, de laatste zingt vals, de eerste mooi, maar zacht." 
bezwaren waren gekomen, dan had ik die punten nog verwerkt. Die bezwaren waren er niet, zodat dit de enige manier was om het nieuwe B.W. nog te stoppen."

Opmerkelijk was ook dat de Minister zijn uitspraak naar buiten bracht zonder daarover kennelijk vooraf met de werkers aan het nieuwe B.W. van gedachten te hebben gewisseld. Daardoor kon het ook gebeuren dat de Minister op 16 december 1982 nog een uitgebreide nota van Meijer ontving, met als kop "Argumenten voor het aanhouden van de geplande invoeringsdatum van de Boeken 3-6 Nieuw B.W. in 1984/1985." De eerste zin luidde: "Gevolggevend aan een verzoek van Uw voorganger doe ik U bij deze enige notities toekomen die bij voorkomende gelegenheid benut kunnen worden in een gedachtenwisseling over het streven de invoering van de Boeken 3-6 conform de eerder aangekondigde planning te laten verlopen." Ook leidde deze communicatiestoornis ertoe dat de Stafafdeling - tot verbazing van de Minister ${ }^{27}$ - een persbericht liet uitgaan dat onverminderd werd gestreefd naar invoering van de Boeken 3-6 in 1984/85. De Die zei daarover: "Korthals Altes twijfelde aanvankelijk of hij het nieuwe B.W. zou doorzetten. Hij vond dat eerst een Brede Wetenschappelijke Discussie gevoerd moest worden. Dat kwam allemaal nogal onverwacht. Ik had toen net naar aanleiding van vragen uit de pers een bericht doen uitgaan met de mededeling 'business as usual'. - Geheel in onschuld overigens!"28

Het lijkt dus niet onaannemelijk dat de Minister zich, naar een woord van $\mathrm{H}$. Drion, "nog even lekker wilde wikkelen in de warme wol van een Brede Wetenschappelijke Discussie"29 en zelf moeilijkheden wenste, in plaats van erger te voorkomen. Er was eind 1982 binnen de praktijk wel sprake van enige onrust, die zich een paar maanden later zou verbreden door de weerstand tegen de als erg detaillistisch ervaren cursussen $^{30}$, maar erg gestructureerd was het allemaal niet. ${ }^{31}$ Hartkamp zei daarover: "Korthals Altes is een politicus. Ik weet niet wat hij allemaal heeft gedacht. Hij kwam natuurlijk uit een sector van de praktijk, uit een groot advocatenkantoor, waar men helemaal niet geporteerd was voor die nieuwe wet, dus misschien moest hij zelf ook nog aan de gedachte wennen." ${ }^{32}$

27. Zie Trema 1983, p. 27 e.v.

28. Geciteerd bij Ed Florijn en Isette Reuder, Om het in ambtelijke termen uit te drukken, NTBR 1992 , p. 80.

29. Rechtsgeleerd Magazijn Themis 1983, p. 117.

30. Zie Van Hasselt, Een kameel is een paard ontworpen door een commissie, NJB 1983, p. 1052; Pinckaers, NJB 1984, p. 268.

31. Later, in een interview in Trema 1983, p. 27 e.v., verdedigde Korthals Altes zijn geruchtmakende uitspraak onder andere met het argument dat hij de beslissing om door te gaan niet uit handen had willen geven aan de Kamer, die immers had aangegeven het antwoord van de Minister door te sturen naar de beroepsorganisaties. Opvallend is echier, dat het interview met het NJB op 2 december 1982 werd afgenomen, twee weken voordat de vaste Commissie haar brief schreef. Bovendien was Meijer toen nog zeer optimistisch over de houding van de Kamer: "Van politieke druk ten gunste voor uitstel (of afstel) is in het Parlement niet gebleken, integendeel."

In 1990 (interview door J.E. te Loo, Fiat Justitia, maart 1990) verklaarde Korthals Altes, inmiddels Minister af: "Ik was bepaald geen voorstander van het NBW toen ik Minister werd. Hieruit kan men afleiden dat als men tijdig van de gelegenheid gebruik had gemaakt met mij bepaald wel te praten zou zijn geweest."

32. Vergelijk ook A. Kosto, Advocatenblad 1985, p. 461: "Met het tegenwoordige Kabinet trad een Minister aan die uit de advocatuur stamde. Daar het vermoeden bestond dat hij niet zonder meer 


\section{Notitie invoering nieuw B.W.}

Op 17 januari 1983 verscheen een uitgebreide notitie van Minister Korthals Altes, waarin hij de vaste Commissie voor Justitie mededeelde voornemens te zijn de lijn van zijn voorganger ten aanzien van de invoering door te trekken en te streven naar invoering in 1985: "Uitgangspunt blijft het streven naar invoering van de Boeken 3-6 binnen enige jaren. ${ }^{133}$ Daarnaast kondigde de Minister een gesprek aan met enkele beroepsorganisaties, een punt waar hij ook moeilijk omheen kon nu hij in het vraaggesprek met het NJB het voornemen tot het voeren van een nadere discussie reeds had geuit.

Deze notitie was qua inhoud grotendeels gebaseerd op een eerdere, voorlopige (interne) nota van Snijders, alsmede op de nota-Meijer van 16 december 1982. De notitie begon met de constatering dat de streefdatum 1984/1985 bij diverse gelegenheden, zoals de vaststelling van de Boeken 3, 5 en 6, de begrotingsbehandeling en het overleg met de beroepsgroepen, als volstrekt serieus was gepresenteerd. Daarbij werd vastgesteld dat noch in de politiek, noch in wetenschappelijke kring, noch bij de beroepsgroepen ooit sprake was geweest van een krachtige oppositie tegen het nieuwe B.W., maar integendeel steeds waardevolle steun was ondervonden.

Op dit door Regering en Parlement gewekte vertrouwen was volgens de Minister door velen voortgebouwd: door de anticiperende interpretatie die sinds 1980 een ware hausse beleefde, cursussen, faculteiten, uitgevers en redacties. Het nu nog principieel ter discussie stellen van de invoering - daaronder begrepen uitstel - zou dit vertrouwen ernstig beschamen, tot een voor de rechtspraktijk onwenselijke onzekerheid leiden en onherstelbare schade tot gevolg hebben. Daarbij werd er onder andere op gewezen dat het oude vermogensrecht achterhaald was door jurisprudentie en doctrine, hetgeen belemmerend werkte op de verdere uitbouw door bijzondere wetgeving en rechtspraak; dat het lot van tal van moderniseringen, praktische vereenvoudigingen en verduidelijkingen verbonden was met de integrale invoering; dat partiële herzieningen en rechterlijke rechtsvorming geen reële alternatieven konden of zouden vormen.

Letterlijk schreef Snijders: "Het project ontleent zijn kwaliteiten voor een belangrijk deel aan het systematisch steeds weer verwerken van het weerwerk dat is geleverd door zowel literatuur en rechtspraak als door de praktijk die in vele stadia opnieuw bij het opstellen van de ontwerpen betrokken is geweest, grotendeels via de drie beroepsorganisaties. Dit is bij de voortgang van het werk steeds bijgehouden, zodat na invoering de verdere rechtsontwikkeling daarbij zonder onnodige onder-

\footnotetext{
32. $\rightarrow$

voorstander was van de nieuwe codificatie besloot de vaste Commissie de Minister uit te nodigen om zijn beleidsvoornemens ter zake van het NBW kenbaar te maken."

Bedacht moet echter worden dat de vaste Commissie een dergelijke redengeving ook wel bijzonder van pas kwam. Zij zou tenslotte ook niet schromen (zie hieronder) haar wens om uitstel of afstel voor rekening van de beroepsgroepen te brengen.

33. Parl. Gesch. Voortgang, p. 10. De notitie van de Minister is tevens afgedrukt in Advocatenblad 1983, p. 92 e.v. en in Trema 1983, p. 64 e.v. De term Brede Wetenschappelijke Discussie - een wel zeer ongelukkige verwijzing naar de BMD, een miljoenenverslindende inspraakronde over kernenergie -, bleef ditmaal achterwege.
} 
breking kan aanknopen. Het werk stopzetten zou ertoe leiden dat wel een onderbreking ontstaat. De draad zal dan later moeilijk meer kunnen worden opgenomen."

$\mathrm{Na}$ aldus de argumenten tegen het stopzetten van de hercodificatie te hebben geschetst, ging de notitie in op enkele algemene bezwaren die de laatste tijd de kop hadden opgestoken. Genoemd werden de bij de rechterlijke macht levende bezorgdheid over toename van de werklast door bijscholing en de vrees voor de onzekerheden die door de vele vage en open normen, alsmede door toevoeging van enkele discretionaire bevoegdheden in het leven zouden worden geroepen.

Met betrekking tot het eerste punt wees de Minister erop dat men zich het nieuwe recht toch eens eigen diende te maken en dat de principiële wijzigingen die het nieuwe B.W. bracht, enerzijds beperkt in aantal waren en anderzijds duidelijk herkenbaar. Gebrek aan kennis en onzekerheid, zou, bij een redelijke en tijdige inspanning om de weg in het nieuwe systeem te vinden, niet méér zijn te vrezen dan bij continuering van het oude en gebrekkige B.W. Ook zou veel van de bezorgdheid zijn ingegeven door de wens zich de materie in korte tijd geheel eigen te maken, een onrealistisch verlangen: "Waaraan de beoefenaar van de rechtspraktijk behoefte heeft, is een redelijke basiskennis en een trefzekere zoektechniek. De betere systematiek en de aansluiting aan de recente rechtsontwikkeling van het NBW waarborgen dat men daarin al snel beter zijn weg zal kunnen vinden dan in het geldend recht."

Met betrekking tot het tweede punt stelde de Minister dat het enkele feit dat de rechter vaker als benaderbare instantie expliciet in de wet wordt genoemd, en dat hem vaker expliciet discretionaire bevoegdheden zijn toegekend, geenszins impliceerde dat in vergelijkbare gevallen thans minder geprocedeerd zou worden: "De onzekerheid die in een aantal gevallen door de invoering zal ontstaan is (..) slechts één van de factoren die partijen tot een procedure - soms ook juist tot een schikking - kunnen brengen." Daarnaast werd benadrukt dat veel van de zogenaamde vage normen en maatstaven van het nieuwe B.W. onder het oude B.W. geheel ongeregeld waren. ${ }^{34}$

Tenslotte ging de notitie in op de vraag in welke mate de invoering van het nieuwe B.W. de rechter zou "raken". Volgens de Minister zou slechts dertig procent van het aantal zaken dat voor de Rechtbank werd gebracht "NBW-gevoelig" zijn en zou het leeuwedeel van deze zaken in beslag worden genomen door wanprestatieclaims, dat wil zeggen geschillen waarbij de rechtsvraag zelden tot problemen aanleiding geeft. Bovendien zou het nieuwe B.W. op dit punt weinig verrassingen in petto hebben. Vrees voor een "drastische toename" van de werklast van de rechter zou daarom niet reëel zijn. Orde-voorzitter Van den Hoek kreeg ook nog een veeg uit de pan: "Voor wat betreft het kostenaspect is de voorstelling van zaken als zou de invoering van het nieuwe B.W. ten koste gaan van andere prioriteiten, zoals bijvoorbeeld de financiering van de rechtshulp, niet juist. (..) Voor het Departement zijn althans de meeste kosten gemaakt. Afgezien van enkele naar manuren omgerekende en overigens toch al

34. Vergelijk ook A.S. Hartkamp, Open normen (in het bijzonder de redelijkheid en de billijkheid in het nieuw B.W.), WPNR 5559-5560 (1981); W.C.L. van der Grinten, Verbintenissenrecht volgens het NBW, NJB 1983, p. 1234. Met betrekking tot de toegenomen vermelding van de rechter als conflict-oplosser zij erop gewezen dat het nieuwe B.W. slechts drie werkelijk nieuwe bevoegdheden kende, bedoeld voor marginale gevallen; - terugdringing van de vernietiging via alternatieve sancties - imprévision - matigingsrecht. 
vast bezette personeelsplaatsen, gaat het om bedragen van enkele tonnen verspreid over verscheidene jaren. Al bij al bedragen die niet alleen in het niet vallen bij de (gedeeltelijke) afschrijving van de publieke en private investeringen uit het verre en het recente verleden, maar die ook uit een bezuinigingsoogpunt niet opwegen tegen de na verloop van een eventueel uitstel onvermijdelijke extra uitgaven." Voor andere overheidsinstellingen, de particuliere rechtspraktijk en het bedrijfsleven zou het niet anders liggen.

Aan het eind van de notitie schonk de Minister aandacht aan de vraag of alternatieven in de sfeer van enig uitstel of een sterke fasering soulaas zouden kunnen brengen. Uitstel zou zijns inziens het gevaar oproepen dat het project niet alleen op onderdelen opnieuw ter discussie zou komen te staan, maar ook als zodanig. Er zou zich namelijk geen geschikter moment aandienen voor de invoering, in de zin dat de genoemde kosten of inspanningen dan kleiner of gemakkelijker op te brengen zouden zijn. Ditzelfde gold ook voor de werkers aan het nieuwe B.W. zelf: "Bijwerking kan (..) op den duur een te zware opgave blijken, waarbij ook een rol zal spelen dat de daardoor thans beschikbare werkkracht en deskundigheid moeilijk te vervangen zal zijn." Uitstel - met alle onzekerheid en beschaamd vertrouwen - zou derhalve moeilijk anders kunnen worden uitgelegd dan als een aanloop tot afstel.

Letterlijk schreef Snijders: "Ik heb sinds september 1976 zowel volaan in de Hoge Raad als in de wetgeving meegedraaid. Dat is niet lang meer vol te houden en er kan zeker geen extra belasting meer bij, hetzij op het gebied van de wetgeving zelf, hetzij op dat van de begeleiding daarvan."

Over de mogelijkheid tot fasering was de Minister nog somberder: "Het alternatief van een sterke fasering draagt allereerst dezelfde risico's met zich mee als dat van uitstel. Bovendien - nog daargelaten hoe men zich zo'n verdeling voorstelt - moet men beseffen dat fasering per saldo een enorme toeneming van de invoeringspijn teweeg brengt. Alleen al het aantal tijdelijke interne aanpassingen en overgangsrechtelijke problemen zal buitensporig toenemen, waarbij fouten moeilijk vermijdbaar zullen blijken te zijn en in elk geval een chaotisch beeld zal ontstaan. Het aanpassingsproces van de maatschappij - de betrokken beroepsgroepen, het bedrijfsleven en overige justiciabelen - zal daardoor extra bemoeilijkt worden en de onzekerheid over wat geldend recht is, toenemen."

Letterlijk schreef Snijders: "Waar de hoofdweg het begeeft is er behoefte aan omwegen. Zou men deze omweg volgen, dan wordt het gevaar van ernstige vertragingen stellig groter en blijft boven het werk bovendien steeds de dreiging hangen van onvoltooid te blijven steken, nadat men enige aantrekkelijke stukken (consumentenkoop, algemene voorwaarden) eruit heeft gehaald. Eén van de argumenten om het verbintenissenrecht te codificeren is de toenemende moeilijkheid om nieuwe regels in de wetgeving in te passen, als de algemene regels verouderd zijn, zodat aanvullingen niet meer vanuit de hoofdregel kunnen worden geformuleerd en uitgelegd. (..) Ik moge nog eens met klem wijzen op het over Boek 6 opgemerkte. Deze kans verzuimen betekent voorgoed een verlaging van de kwaliteit van verdere wetgeving op elk gebied waar op het algemeen deel van het verbintenissenrecht gesteund moet worden." 


\section{Reacties en stellingname}

De schriftelijke reacties van de beroepsgroepen ${ }^{35}$ op de notitie van de Minister waren veelbelovend. Er bleek eigenlijk uit dat iedereen zich allang bij de komst van het nieuwe B.W. had neergelegd. Zo schreven de notarissen dat ingestemd kon worden met het voornemen van de Minister om vast te houden aan spoedige invoering (1985), omdat "de argumenten, welke hercodificatie en invoering van een nieuw Burgerlijk Wetboek wenselijk en nodig maken, nog steeds gelden." ${ }^{36}$ Ook de Consumentenbond bleek een warm voorstander van een snelle en integrale invoering: "Wij juichen het toe dat de Minister van Justitie onverkort wenst vast te houden aan het voorgenomen invoeringsprogramma (..)." ${ }^{37}$ Ter argumentatie werd onder andere gewezen op de maatschappelijke behoefte aan een nieuw Burgerlijk Wetboek, de reeds in het werk gedane investeringen en de nadelige psychologische effecten die het loslaten van het tijdschema tot gevolg zou hebben: "Indien in dit stadium besloten zou worden het steeds gehanteerde tijdschema los te laten, zou dat naar onze mening zeer demotiverend werken en de invoeringsoperatie alleen maar moeilijker maken. ${ }^{.38}$

Tenslotte liet ook de NVVR zich bepaald positief uit over het nieuwe B.W.: "Het nieuwe B.W. als factor van op vernieuwing gerichte rechtsontwikkeling vertegenwoordigt een groot algemeen belang (..). Er is onloochenbaar een effectieve wisselwerking tussen rechtspraak, rechtswetenschappelijke literatuur en het nieuwe B.W." In dit licht bezien zou "afstel of niet planmatig doordacht en verantwoord uitstel" naar de mening van de NVVR "onwenselijke gevolgen" hebben. ${ }^{39}$

Wel werd in het vervolg van de brief van de NVVR de vrees uitgesproken dat de invoering van het nieuwe B.W. een tijdelijke extra werkbelasting tot gevolg zou hebben, hetgeen in verband met de reeds bestaande achterstanden bij de rechterlijke macht niet verantwoord zou zijn. Gewezen werd onder andere op de procesaanzuigende bijwerking van nieuwe wetsteksten, de toename van nieuwe vage normen en discretionaire bevoegdheden en de tijdelijke, maar intensieve werklastvermeerdering als gevolg van NBW-cursussen. Scheltema zei daar in 1987 over: "Ik erger me er soms aan dat bijvoorbeeld de rechterlijke macht denkt, dat als het nieuwe B.W. op 1 januari wordt ingevoerd, plotseling allerlei onderdelen uit het hoofd moeten worden geleerd. Dat is sterk overdreven. Ik denk dat er op 1 januari uberhaupt niet veel gebeurt, dat men eerst nog een tijdje bezig is met het afhandelen van oude procedures en dat dan langzamerhand ook procedures over het nieuwe recht komen. " $\mathrm{H}$. Drion:

35. De Orde was er niet in geslaagd tijdig haar standpunt kenbaar te maken.

36. Parl. Gesch. Voortgang, p. 245.

37. Parl. Gesch. Voortgang, p. 248.

38. Het citaat vervolgt: "Al diegenen, die zich jarenlang hebben ingespannen voor de realisering van het nieuw B.W. en de velen, die al actief of passief aan de bijscholingsprogramma's hebben deelgenomen, zouden het gevoel krijgen, dat hun moeite vergeefs is geweest. De indruk, dat het allemaal zo'n vaart niet zal lopen, zou de animo tot verdere investeringen in het nieuwe recht doen vergaan. De invoering in een later stadium zou daardoor alleen maar moeilijker worden."

39. Parl. Gesch. Voortgang, p. 255. Daarbij wees zij er op dat door de anticiperende rechtspraak enerzijds de praktijk gedurende een ongewisse periode te doen zou krijgen met twee wetboeken ("Dit veroorzaakt problemen voor het sociaal-economisch verkeer en de daarbij een rol spelende rechtspraktijk"), anderzijds dat die anticiperende rechtspraak wellicht haar gezag zou verliezen en de rechter nieuwe wegen zou gaan bewandelen die noch met het oude, noch met nieuwe recht sporen. 
"De weerstand tegen de cursussen, tegen de systematiek, het lijkt me allemaal wat overdreven. De rechter stuit in iedere zaak voortdurend op wetten, algemene maatregelen van bestuur, op beschikkingen die hij voor het eerst ziet, en waar hij niet nerveus van wordt. Maar hier heeft hij kennelijk het gevoel dat hij het uit het hoofd moet leren."

De NVVR schuwde niet om, evenals in 1980 het geval was geweest, het nieuwe B.W. als hefboom te gebruiken om de achterstanden bij de rechterlijke macht weg te werken ${ }^{40}$ Men greep de kans, door Minister en Kamer geboden, met beide handen aan: "De Vereniging gaat (...) ervan uit dat een extra-belasting van de rechterlijke macht onafwendbaar is. De Vereniging acht het niet meer dan redelijk en ook niet meer dan getuigen van behoorlijk bestuur dat een op die extra belasting - drastisch of minder drastisch - toegesneden voorzieningenpakket tijdelijk wordt geschapen en gewaarborgd. Daarbij valt in de eerste plaats te denken aan het thans op peil brengen, overeenkomstig de bestaande normen, van de bezetting van de rechterlijke macht."

\section{De Hoorzitting van de vaste Commissie}

Op 3 maart 1983 hield de vaste Commissie voor Justitie naar aanleiding van de ingekomen reacties een hoorzitting over het nieuwe B.W. Uitgenodigd waren vertegenwoordigers van de NVVR, de Nederlandse Orde van Advocaten, de Koninklijke Notariële Broederschap en de Consumentenbond. Van de bijna veertig leden van de vaste Commissie waren er slechts acht aanwezig: Kosto, Tripels, Wessel-Tuinstra, Haas-Berger, Buikema, Van der Burg, Schutte, Salomons en griffier Kerkhofs.

Het beeld dat uit deze hoorzitting ${ }^{41}$ naar voren $\mathrm{kwam}$, stemde in grote lijnen overeen met de schriftelijke ingenomen standpunten. De NVVR ${ }^{42}$ liet zich, evenals in haar brief, positief uit over het nieuwe B.W. Wel zou, met het oog op de voorbereiding van de rechterlijke macht, een "planmatig en doordacht uitstel" wenselijk zijn, doch ten hoogste van 1 à 2 jaar (dus 1986 of 1987). Gefaseerde invoering werd uitdrukkelijk afgewezen. Daarnaast vestigde de Vereniging de aandacht op de overbelasting van de rechterlijke macht, die in verband met de invoering van het nieuwe B.W. zou toenemen. Zij pleitte daarom, behalve voor uitbreiding van het aantal rechters, voor wettelijke maatregelen, zoals bijvoorbeeld de unusrechtspraak, alsmede verbetering van de infrastructuur (technische hulpmiddelen) en voor uitbreiding van

40. Van enig overstatement was zij niet wars. Bij het berekenen van het tekort aan rechters werd bijvoorbeeld uitgegaan van de "thans geldende normen", ondanks dat deze normen reeds lang ter discussie stonden en het allang geen geheim meer was dat onderbezetting en achterstanden mede bepaald werden door lokale factoren, zoals mismanagement. In 1981 waren de achterstanden bij de Rechtbanken het hoogst in Amsterdam, Den Haag en Rotterdam, bijna 40 \% van het totaal. Bij de Hoven namen Amsterdam en Den Haag $60 \%$ van de achterstand voor hun rekening. Zie verder F.P. van Tulder en A.C. Spapens, Doelmatig rechtspreken, Den Haag 1990, p. 57 e.v.

De cursuscommissie NBW zou later tegen het bepleiten van deze koppeling krachtig bij het bestuur zou protesteren.

41. Van de hoorzitting werd geen verslag gemaakt. De informatie is ontleend aan een korte notitie van mevr. Van der Horst (Stafafdeling NBW) die ter vergadering aanwezig was. Met betrekking tot het standpunt van de Orde van Advocaten is daarnaast geput uit de brief van 29 maart 1983, waarin de Orde haar visie op de invoering kenbaar maakte. Zie Parl. Gesch. Voortgang, p. 248 e.v.

42. De NVVR werd vertegenwoordigd door H.F. van den Haak, J.H.B.M. Saelman, W.E. Haak en mevr. M.P.K. Ruts-Houtman. 
het middenkader. De "koppeling" werd niet meer aangeroerd. Kennelijk voelde de NVVR ook wel dat het niet aanging het thema achterstanden over de rug van het nieuwe B.W. te behandelen.

Ook de Broederschap, vertegenwoordigd door notaris H.M. Sasse en mevr. H.M. van Ittersum-Meijer, hield vast aan haar standpunt en was tegenstander van temporisering. Eén citaat: "In verband met de anticipatie moet ieder verder uitstel van invoering worden voorkomen. Ook het notariaat anticipeert bij het opstellen van contracten op het nieuwe B.W. De aankomende juristen zijn primair gericht op het nieuwe B.W. De invoeringsfase moet zo kort mogelijk gehouden worden. ${ }^{\text {n43 }}$

De vertegenwoordiging van de Orde $e^{44}$ was, zoals kon worden verwacht, aanmerkelijk kritischer. Na te hebben opgemerkt dat de Orde de komst van het nieuwe B.W. steeds als een politiek gegeven had beschouwd en daaraan loyaal had meegewerkt, bracht de Deken in een "terzijde" naar voren, dat men zich in toenemende mate afvroeg of zulk perfectionisme werkelijk nodig was, of al de open normen wenselijk waren, of het veelvuldig rechterlijk ingrijpen vanuit een oogpunt van rechtszekerheid wel wenselijk was. Deze geluiden, "hoe ernstig te nemen ook", waren echter (nog) geen reden om thans van "ongerustheid en zorg" te reppen. Nieuwe omstandigheden, die tot een heroverweging van dit standpunt hadden geleid, waren de overbelasting van de rechterlijke macht en de omvang en de ernst van de bezuinigingen. Dit zou betekenen dat de invoering van het nieuwe B.W. een "slechte zaak" zou zijn, indien de rechterlijke macht onvoldoende bewerktuigd zou zijn voor haar nieuwe taak. Uitstel zou volgens de Orde slechts gerechtvaardigd zijn ter voorziening in die "randvoorwaarde". De vervulling daarvan zou echter niet ten koste mogen gaan van gevangeniswezen en rechtshulp.

De Consumentenbond ${ }^{45}$ tenslotte, bleek een groot voorstander van invoering in 1985, niet slechts omwille van de belangrijke vernieuwingen op het terrein van het consumentenrecht. Enkele citaten. "De Consumentenbond houdt onverkort vast aan invoering van het nieuwe B.W. in 1985. (..) Op gezag van het Compendium van Hartkamp wordt tegengesproken dat het nieuwe B.W. teveel open normen zou bevatten. (..) De overbelasting van de rechterlijke macht is niet te wijten aan het nieuwe B.W., maar aan het gebrek aan efficiëncy. (..) Het bijscholingsprobleem is geen acuut probleem; men wist al jaren geleden dat men tezijnertijd het nieuwe B.W. moest gaan bestuderen. (..) Het consumentenrecht zal niet leiden tot een grotere toeloop op de rechter, daar het veel dwingend recht bevat."

Bij de hoorzitting bleek uit vragen en opmerkingen van de Kamerleden ook enigszins welk standpunt door hen werd ingenomen. Duidelijk werd dat het eigenlijke probleem bij de vaste Commissie lag, die terugschrok voor de grote stapel inhoudelijk zware ontwerpen die inmiddels gereed lag. Tripels (VVD) vond bijvoorbeeld dat de Commissie hard moest doorwerken, maar beter niet gebonden kon zijn aan een vaste termijn. Van der Burg (CDA) gaf als zijn mening te kennen dat de streefdatum 1985 illusoir was en dat eerder gedacht zou moeten worden aan 1987 of zelfs 1990. De

43. Vergelijk ook WPNR 5652 (1983).

44. Afgevaardigd waren P.C. van den Hoek, G.A. Stuyling de Lange, J.G. de Vries Robbé en J.R. Glasz.

45. De Consumentenbond werd vertegenwoordigd door mevr. E. Dil-Stork en T. Recter. 
gedachten van Schutte (GPV) en Wessel-Tuinstra (D '66) leken in dezelfde richting te gaan.

Ook bleek - zoals door Snijders reeds voorzien - uit verschillende, regelmatig terugkerende vragen dat, nu de praktijk van langdurig uitstel niet wilde weten, bij een aantal Kamerleden een voorkeur bestond voor fasering dan wel de mogelijkheid alleen bepaalde voor de consument belangrijke onderwerpen in te voeren en de rest bij het oude te laten. Zo werd aan de Consumentenbond de vraag gesteld of de door hem wenselijk geachte onderdelen van het nieuwe B.W. niet tijdelijk of blijvend zouden moeten worden losgekoppeld van het nieuwe B.W. en als voortrein of losse trein konden worden ingevoerd. Salomons (PvdA) wees er daarbij op dat door het beslag dat het nieuwe B.W. op de werktijd van de Kamer legde, andere voor de consument belangrijke wetsontwerpen bleven liggen. Haas-Berger (PvdA) stelde voor de consumentenkoop en de algemene voorwaarden uit het nieuwe B.W. te lichten en in te voeren, en het B.W. voor het overige te repareren, daarmee illustrerend dat met de Kamer eigenlijk geen afspraken zijn te maken. Eerder, tijdens de behandeling van de Boeken 3, 5 en 6 in 1977 stelde zij vast: "Ik hoop dat nu met de vaststelling van deze drie Boeken die discussie - namelijk over de wenselijkheid van de invoering - tot het verleden behoort. ${ }^{46}$

Deze "leading questions" om een eventueel uitstel of afstel voor rekening van de beroepsgroepen te brengen, hadden echter geen enkel succes, zodat er voor de Commissie weinig anders opzat dan het werk voort te zetten. Hartkamp vatte het resultaat van de besprekingen voor de Minister als volgt samen: "Intussen lijkt het, gezien het voorgaande, onaannemelijk dat de vaste Commissie het werk niet zal willen voortzetten. Wel vindt men kennelijk het huidige tempo te hoog. (..) Te verwachten valt, dat het - ook zonder een toezegging uwerzijds - wel tot een uitstel van één of twee jaar zal komen, nu wij voor het tempo afhankelijk zijn van de vaste Commissie en niet aannemelijk is dat deze haar standpunt, dat 1985 niet langer reëel is, zal prijs geven. "47

\section{Korthals Altes reageert; de operatie-Stofkam aangekondigd}

Het beeld dat uit de hoorzitting naar voren was gekomen, was voor het nieuwe B.W. dus al met al buitengewoon hoopgevend. Bovendien had het het grote voordeel dat de Minister in één klap van zijn koudwatervrees was verlost. Toen Korthals Altes begreep dat de vaste Commissie alleen maar erop uit was geweest hem voor haar karretje te spannen $^{48}$, besloot de Minister dat het tijd was de rollen om te draaien. Vanaf dat moment zou hij er alles aan doen om het invoerings-K.B. op zijn naam te krijgen.

Duidelijk was, dat de Minister met de Broederschap en met de Consumentenbond voorshands weinig gesprekstof had en dat het zwaartepunt bij de vaste Commissie en

46. Parl. Gesch. Boek 3, p. 19.

47. Nota van 15 maart 1983.

48. Vergelijk mevrouw Salomons, die in antwoord op een bitse opmerking van Minister Korthals Altes, dat de invoeringspijn alleen kon worden voorkomen door het nieuwe B.W. niet in te voeren, antwoordde: "Wij hebben u daar het vorige jaar toe pogen uit te lokken, maar u wilde dat niet." (Parl. Gesch. Voortgang, p. 50). 
de rechterlijke macht lag. De bezwaren van de Orde werden niet au serieux genomen. Op het Ministerie was namelijk bekend dat de adviescommissies de Algemene Raad wél positief hadden geadviseerd over de invoering van het nieuwe B.W., terwijl ook in het Advocatenblad aanmerkelijk gunstiger over het nieuwe B.W. werd geschreven dan de Deken in zijn "terzijde" had willen doen voorkomen. Bij het ontbreken van elk gespecificeerd bewijsaanbod leken zijn inhoudelijke opmerkingen - door Meijer omschreven als "nauwelijks gemotiveerde weerzin" - dan ook vooral door drempelvrees te zijn ingegeven. ${ }^{49}$ Tekenend is, dat Van den Hoek tijdens de hoorzitting verklaarde dat hij nog geen kennis had genomen van het nieuwe B.W.

Omdat op het Ministerie wel werd ingezien dat het niet verstandig was de bezorgdheid van de NVVR weg te nemen ${ }^{50}$, concentreerde men zich allereerst op de vraag in hoeverre de feitelijke stellingen van de Vereniging juist waren. Dit leidde ertoe dat begin april een nota van Meijer verscheen, waarin op basis van door het W.O.D.C en HDORR verstrekt cijfermateriaal werd nagegaan welk aandeel van de rechterlijke werkzaamheden door het nieuwe vermogenrecht zouden worden geraakt.

Uit deze nota bleek dat slechts maximaal dertig procent van de aantallen civiele zaken "NBW-gevoelig" zou zijn, zoals in de notitie aan de vaste Commissie reeds was verondersteld. Bovendien zouden van deze restgroep de wanprestatie- en onrechtmatige daad-claims vrijwel alle ruimte opeisen. Meijer wees er daarbij nog op, dat een zeer aanzienlijk deel van deze zaken "zuiver" feitelijke kwesties zou behelzen, met daarnaast een vrij grote groep van gevallen waarin slechts geprocedeerd wordt om een executoriale titel te verkrijgen. Gecorrigeerd naar de bewerkelijkheid van deze zaken, zou slechts maximaal 15 tot 20 procent van de werktijd in deze "handelszaken" zitten, inclusief de faillissementen en onderwerpen die niet door de Boeken 36 werden geraakt. Een flinke opsteker voor het Departement, want daarmee leken de pessimistische opmerkingen van de NVVR over de invoeringspijn volledig te zijn gelogenstraft. ${ }^{51}$

In de tweede plaats werd de Minister in overweging gegeven toezeggingen te doen op het punt van de personele en materiële bewerktuiging van de rechterlijk macht, zodat voor haar de mogelijkheid zou worden geopend de bestaande achterstanden vóór

49. De brief met suggesties tot vereenvoudiging etc. die de Orde op 13 april 1983 (zie Advocatenblad 1983 , p. 231) aan de vaste Commissie zou sturen, was aanmerkelijk positiever van toon. Zo werd met betrekking tot de open normen opgemerkt dat er "alle aanleiding" bestond de verwachting van G.J. Wiarda te onderschrijven dat "de rechter tegenover de nieuwe bepalingen voorshands waarschijnlijk wat minder vrijmoedig (zal) staan dan tegenover de oude" en werd beklemtoond dat de wetgever "veel energie en vernunft" had gestoken "in het op een zo afgewogen wijze als mogelijk is vastleggen en formuleren van hetgeen thans als recht wordt ervaren (..)." De omstandigheid dat deze reactie in hoofdzaak steunde op een advies van die leden van de Orde, die meegewerkt hadden aan onderdelen van het nieuwe B.W. (mrs. Sillevis Smitt en Schepel), is daarbij zonder twijfel van betekenis geweest.

50. Hartkamp tekende op 15 maart 1983 aan: "Die bezorgdheid is immers maar al te begrijpelijk en berust op een - naar onze mening te pessimistische - inschatting die nu eenmaal moeilijk feitelijk weersproken kan worden door er een meer optimistische voorspelling tegenover te stellen."

51. Vergelijk ook de uiteenzetting van Minister Korthals Altes in zijn brief aan de vaste Commissie van 17 januari 1983, Parl. Gesch. Voortgang, p. 14.; R.S. Meijer, Een gerechtvaardigde verrijking, in: Fait accompli, Zwolle 1983, p. 30 e.v. 
de inwerkingtreding weg te werken. ${ }^{52}$ Een andere verlichting van de problemen zou volgens de Stafafdeling kunnen bestaan in het verlenen van het door de NVVR gevraagde uitstel, nu het toch wel zeker was dat de Tweede Kamer de behandeling van de invoeringswetten niet voor 1985 zou willen afronden. Tenslotte werd een nadere toetsing overwogen van het corpus der Boeken 3-6, alsmede van de overige invoeringswetten, op werklastverzwarende aspecten, een weg die Regeringscommissaris Snijders begin januari zelf al had gesuggereerd. Deze laatste maatregel zou bekendheid krijgen onder de naam "Stofkam-Operatie."

De gesprekken die de Minister op 26 en 27 april 1983 met de NVVR, Orde, Consumentenbond en het Genootschap voor Bedrijfjuristen zou voeren, leverden geen verrassingen meer op. ${ }^{53}$

\section{Mondeling Overleg}

De vaste Commissie voor Justitie voerde op 4 mei 1983 een Mondeling Overleg met Minister van Justitie Korthals Altes over de invoering van het nieuwe B.W., zulks naar aanleiding van de brief van de Commissie over dat onderwerp van december 1982 , het antwoord van de Minister van januari 1983 en het overleg van de Commissie met de beroepsgroepen. ${ }^{54}$ Daarbij constateerde de Minister dat, gelet op de achterstand die inmiddels was opgelopen, de invoeringsdatum van 1 januari 1985 niet meer te verwezenlijken was. In plaats daarvan zou moeten worden gestreefd naar invoering per juli of september 1986.

Voorts deed de Minister de toezegging dat enkele bepalingen, die de werklast van de praktijk in het bijzonder zouden raken, op de mogelijkheid van vereenvoudiging zouden worden bezien. Bovendien zou het overgangsrecht zodanig worden aangepast, dat het aantal gevallen waarop het nieuwe recht na de invoering terstond zou moeten worden toegepast, zou verminderen en de invoering geleidelijker zou verlopen. De Minister verklaarde dat daarbij nauw overleg zou worden gevoerd met de beroepsorganisaties. Tenslotte stelde hij voor Boek 4 te ontkoppelen, alsmede enige titels van Boek 7 na de Boeken 3, 5 en 6 in te voeren, teneinde de belasting van het Parlement te verminderen. De Kamer kreeg dus ruim een jaar extra om de invoeringswetgeving te behandelen en wist zich bovendien verlost van het lastige en controversiële erfrecht-ontwerp, dat politiek het grootste probleem van de invoeringswet betekende.

De voorstellen van de Minister vonden een gunstig onthaal. Algemeen werd geconstateerd dat er geen weg terug meer was. Bij vier van de vijf woordvoerders van de in de vaste Commissie vertegenwoordigde politieke partijen bleek bereidheid bestaan mee te werken aan de vaststelling van een tijdschema, uitgaande van invoering per 1 juli 1986. Het doorslaggevende argument was het volop in uitvoering zijn van cursussen en academische studieprogramma's, een argument dat door de Minister met

52. In concreto leidde dit ertoe dat medio 1983 met de NVVR een overeenkomst werd gesloten die erin voorzag dat de onderbezetting in 1986 zou zijn opgeheven door onder meer een enkele jaren volgehouden serie extra benoemingen.

53. Zie voor een verslag daarvan Parl. Gesch. Voortgang, p. 16.

54. Parl. Gesch. Voortgang, p. 16-25. 
kracht was uitgespeeld. ${ }^{55}$ Slechts één spreker, Van der Burg, pleitte ervoor als invoeringsdatum 1 januari 1987 vast te houden, omdat het nog onbekend was wat de Stofkam-Operatie uiteindelijk aan vereenvoudigingen zou opleveren en omdat door althans één van de faculteiten was opgemerkt dat invoering per 1 januari 1987 geen wezenlijke problemen zou opleveren.

Het leek er dus op, dat de NBW-trein, die de Minister zelf min of meer had helpen ontsporen, uiteindelijk toch behouden aan zou komen. Hartkamp schreef na afloop van de vergadering: "Over de invoering van de Boeken 3-6 is pas Mondeling Overleg met de Tweede Kamer gevoerd. Er waren twee problemen: de Kamercommissie voor Justitie kan het werk niet aan en de rechterlijke macht, die reeds zwaar overbezet is, vreest verdere achterstanden door invoering van het nieuwe B.W. Niettemin is tot invoering medio 1986 besloten. Aan het eerste probleem wordt tegemoetgekomen door Boek 4 (erfrecht) los te koppelen en de andere Boeken in te voeren. Het tweede probleem is in feite onoplosbaar, maar om een gebaar te maken is toegezegd dat enige bepalingen in de Boeken 3,5 en 6 , die de werklast van de praktijk in het bijzonder raken, nog eens zullen worden bezien. ${ }^{\text {} 56}$

Op 29 september 1983 verscheen de "Nota voortgang van de invoeringswet Boeken 36 nieuw B.W. " 57 , waarin volgens de redactie van het NJB "het resultaat was neergelegd van de schizofrene arbeid die Regeringscommissaris Snijders en de juristen van de afdeling NBW van het Ministerie van Justitie in de afgelopen mooie zomermaanden hebben moeten verrichten: afbreken van stukken Nieuw BW die in de voorafgaande jaren moeizaam waren opgebouwd." 58 De belangrijkste wijzigingen die werden voorgesteld betroffen de loskoppeling van Boek 4 (alsmede enkele titels van Boek 7), het vervallen van het terugkooprecht in Boek 3 (artt. 3.4.2.3a en 3b) en het uitstel van de invoering van de aansprakelijkheid voor gevaarlijke stoffen in Boek 6 . Daarnaast werd titel 3.6 (Bewind) teruggenomen, die veel weerstand opriep vanwege zijn gecompliceerdheid ${ }^{59}$, een gevolg van het streven alle bewindsvormen in een beperkt aantal formele bepalingen vast te leggen. ${ }^{60}$

55. Aan de vooravond van het Mondeling Overleg hadden ook enkele hoogleraren zich tot de vaste Commissie gewend en met klem om spoedige invoering verzocht.

56. Brief van 8 juni 1983.

57. Parl. Gesch. Voortgang, p. 25-32.

58. NJB 1983, p. 1209.

59. Vergelijk H. Stein, Advocatenblad 1982, p. 551 e.v.: "Het wettelijk systeem van titel 3.6 is hoogst ongelukkig. "; H.C.F. Schoordijk, WPNR 5630 (1982).

60. Volgens J.M. Van Dunné (NJB 1984, p. 1287) zou er een causaal verband bestaan tussen de afslankingsvoorstellen en de kritische ontvangst van het nieuwe B.W. in de postdoctorale cursussen. Voor deze stelling biedt het NBW-archief geen aanknopingspunt. Wel is het aannemelijk dat de NBW-cursussen het enthousiasme voor het nieuwe B.W. aanvankelijk niet zeer hebben vergroot, vanwege hun overwegend detaillistische karakter. Zie bijvoorbeeld NJB 1983, p. 1052; 1984, p. 268; Rechtsgeleerd Magazijn Themis, 1983, p. 177; Trema 1989, p. 30. Hartkamp: "De fout van die cursussen is geweest dat zij eigenlijk alleen maar moeilijke problemen aan de orde stelden. Ik heb zelf ook een onderdeel gemaakt, over pand en hypotheek, en dat heb ik meer simpel gehouden en daar heb ik nooit veel bezwaar over gehoord. Maar veel onderdelen van de cursus bestonden gewoon uit lastige vragen." Neleman: "Het was de bedoeling, althans dat was de opzet van de cursus, dat je er zoveel mogelijk problemen in stopte. Dat leidde ertoe, psychologisch misschien niet handig, dat je 
Het had overigens maar weinig gescheeld, of er zou nog meer zijn geschrapt. In juni 1983 stelde de zogenaamde Commissie deregulering in verband met de economische ontwikkeling (Commissie-Van der Grinten) onder andere voor om de regeling van de consumentenkoop (titel 7.1) tot aanvullend recht te maken en het wetsontwerp inzake de Algemene Voorwaarden in te trekken. Minister Korthals Altes stond echter (ondanks zijn functie als voortrekker van de-regulering) bepaald niet onsympathiek tegenover deze ontwerpen, zodat er door de Regering uiteindelijk alleen op details concessies zouden worden gedaan. ${ }^{61}$ Snijders licht toe: "Van der Grintens visie op de algemene voorwaarden is een hele specifieke, die hij al eerder met grote klem had geuit in de SER, zonder resultaat. Via deze economische de-reguleringscommissie hebben we dezelfde kritiek weer teruggekregen." Hartkamp zei daarover in 1986: "Uit juridische kringen is er heel weinig kritiek op de Algemene Voorwaarden gekomen. Iedere jurist zal toegeven dat er op het ogenblik teveel macht is aan de kant van de opstellers van de voorwaarden. Dat is een evidentie. Die adviezen waren niet serieus te nemen, vooral als je ziet dat ook de Hoge Raad zelf weer vooruitloopt op het wetsontwerp, wel wetende dat het helemaal niet zeker of het wordt aangenomen in de Eerste Kamer ${ }^{62}$ Er zaten in die commissie alleen leden uit het bedrijfsleven en een paar hoge ambtenaren, die daar ook toe gerekend konden worden, zoals Rutten."

En daarmee leek niets meer aan een spoedige invoering in de weg te staan. De vereenvoudigingsvoorstellen werden gunstig ontvange ${ }^{63}$, de door Korthals Altes geëntameerde Brede Wetenschappelijke Discussie was, zoals de Minister later niet ten onrechte zou constateren, zonder gevolg gebleven. Snijders: "Die discussie heeft bestaan uit weinig principiële kritiek. De wetenschappelijke wereld is nadrukkelijk verzocht een mening te geven - zowel van de kant van de Minister als van de kant van de politiek. Ze zijn niet spontaan met opmerkingen gekomen, men is aangespoord een mening te geven, wat er eigenlijk op duidt dat men zich allang bij het nieuwe B.W. had neergelegd. Dat leert ook de verdere geschiedenis. Ook het congres van het dispuut Joannes van der Linden, herfst 1983, gaf gelegenheid om met kritiek te komen, om een vuist te maken, maar dat is niet gebeurd."

Het NJB schreef naar aanleiding van de congresbundel: "Die inhoud toont (..) duidelijk aan dat de daadwerkelijke invoering op een termijn van enkele jaren van althans een groot deel van het nieuwe vermogensrecht nu toch echt als fait accompli,

60. $\rightarrow$

casus verzon die gecompliceerd waren en waarin nogal wat moeilijkheden waren verwerkt. (..) Daardoor heeft men wellicht het idee gekregen dat het nieuwe B.W. vreselijk moeilijk was."

61. Zie Parl. Gesch. Boek 6 (invoering), p. 1462-1463; Verg. ook F. Bruinsma en N. Huls, De Commissie van Wijzen, Kwartaalbericht Nieuw BW, 1988, p. 118.

62. Zie HR 25 april 1986, NJ 1986, 714 (Van der Meer/gemeente Smilde) en HR 16 januari 1987, NJ 1987, 263 (Hooyen/De Tilburgsche Hypotheekbank).

63. Vergelijk het commentaar van de NVVR bij brief van 3 februari 1884, afgedrukt in Trema 1984, p. 72 e.v. Enkele citaten: "De Vereniging staat in beginsel positief tegen invoering van het Nieuw B.W., zij het dat daarover binnen de rechterlijke macht wel verschillend wordt gedacht. (..) De door de Minister in zijn nota aangekondigde voornemens tot afgeslankte invoering van het Nieuw B.W. (worden) in beginsel positief gewaardeerd. Terzijde zij nog aangetekend dat het waardering verdient dat het nieuwe wetboek vele nog omstreden punten op een heldere en doordachte manier regelt. (..) Gaarne blijven wij in goed overleg met uw commissie bereid verdere bijdragen te leveren aan de totstandkoming van het voor de rechtspraktijk zo belangrijke Nieuwe Burgerlijk Wetboek." 
als voldongen feit, door iedereen aanvaard zal moeten worden. ${ }^{64}$ Het woord was aan de Kamer.

\section{Opnieuw tegenslag}

Hiervoor werd aangegeven, dat op de vierde mei bij de meeste sprekers bereidheid bestond mee te werken aan een tijdschema, uitgaande van invoering per 1 juli 1986. Een jaar later was er van die bereidheid echter weinig meer te werken, een gedreven pleidooi van Schoordijk $\mathrm{k}^{65}$ ten spijt. Tijdens de uitgebreide commissievergadering van 4 april 1984 was de toonzetting al duidelijk in mineur ${ }^{66}$, terwijl de vaste Commissie op 10 mei liet weten dat "de behandeling van de invoeringswetgeving door de Tweede Kamer niet in de huidige zittingsperiode voltooid kan worden bij de gedegen wijze van behandeling die de commissie ook voor deze invoeringswetgeving zal blijven nastreven. ${ }^{n 77}$ Dat betekende dat de behandeling van de ter tafel liggende invoeringswetgeving pas omstreeks begin 1988 zou kunnen worden afgerond. Een ultieme poging van Minister Korthals Altes om de Kamer op andere gedachten te brengen, kon daarin geen verandering brengen. ${ }^{68}$ De studieboeken konden worden opgeborgen, de cursussen gestaakt. De invoering van de Boeken 3, 5 en 6 zou, na de behandeling door de Eerste Kamer, op z'n vroegst in de loop van 1989 kunnen worden gerealiseerd. ${ }^{69}$

Waarom sloeg de stemming van de Kamer zo plotseling om? Een deel van het antwoord op deze vraag wordt eigenlijk al door de vaste Commissie zelf gegeven. In de brief van de Commissie van 10 mei wordt immers opgemerkt dat men de gedegen

64. NJB 1983, p. 1209.

65. H.C.F. Schoordijk, Naar een spoedige invoering van het Nieuw B.W., NJB 1984, p. 161-166. Daartegen J.M. van Dunné, Naar een spoedige invoering van het nieuw B.W.? Liever snel recht dan goed recht? NJB 1984, p. 669-676, met een naschrift van Schoordijk, p. 676-678. (Zie ook NJB 1984 , p. 1282 e.v.). Een uiterste poging van Verburgh (NJB 1984, p. 741-743) om dan voorlopig alleen maar Boek 6 in te voeren. kwam te laat, evenals een bijdrage van W. van den Bergh en B. Groefsema in Ars Aequi 1984, p. 383-391.

66. Het verslag van deze hoorzitting is opgenomen in Parl. Gesch. Voortgang, p. 34-59.

67. Zie Parl. Gesch. Voortgang, p. 60-62.

68. In een brief aan de vaste Commissie van 6 juni 1984 (opgenomen in Parl. Gesch. Voortgang, p. 62-64) benadrukte de Minister dat de behandeling van het Burgerlijk Wetboek niet mocht worden vertraagd. Hij wees daarbij op de vele moeite en kosten, die de juridische wereld reeds had geïnvesteerd om zich op het nieuwe recht voor te bereiden. Dat van uitstel schadelijke effecten moesten worden gevreesd zag de Minister bevestigd in gesprekken die hij had gevoerd met vertegenwoordigers van de rechterlijke macht en de universitaire wereld. (Zie verder Advocatenblad 1984, p. 422423).

69. Dat de animo voor de NBW-cursussen sterk daalde toen duidelijkheid was verkregen over het nieuwe tijdschema, blijkt uit het volgende schema, gebaseerd op de cycli PAO-cursussen. Ook de omstandigheid, dat de Stofkam-operatie tot belangrijke wijzigingen in de reeds vastgestelde teksten leidde, zodat de moeizaam verworven kennis op die punten weer werd achterhaald, zal daaraan debet zijn geweest. (Vergelijk NJB 1987, p. 476.)

$\begin{array}{llllllll}9-1982 & 1-1983 & 4-1983 & 9-1983 & 1-1984 & 4-1984 & 9-1984 & 2-1985 \\ 560 & 560 & 660 & 700 & 485 & 245 & 290 & 35\end{array}$


behandeling, die vóór 1982 werd toegepast, ook nu wil blijven volgen. Er is slechts dit verschil dat de Commissie daarvoor nu tweemaal zoveel tijd denkt nodig te hebben. Met andere woorden, de produktiviteit van de Commissie met betrekking tot de behandeling van wetsontwerpen betreffende het nieuwe B.W. zou worden gehalveerd, vermoedelijk omdat men aan andere wetsontwerpen een hogere prioriteit wenste te geven. Een bekend geluid.

Een ander deel van het antwoord zou ik willen zoeken in de veronderstelling dat de vaste Commissie, toen zij eenmaal het tijdschema uitgewerkt voor zich had liggen, tot de ontdekking kwam dat het niet bijster aantrekkelijk was om op de voorstellen van Minister Korthals Altes in te gaan. Eén van de consequenties daarvan was namelijk dat de Commissie, als gevolg van de vertraging opgelopen na 1982, ongeveer elke twee maanden een Voorlopig Verslag moest produceren, wilde zij voor het einde van de parlementaire periode gereed zijn. En omdat er in het schema geen enkele rek zat, was het dus "slikken of stikken". Dan is de gedachte aan uitstel niet zo verwonderlijk, zeker wanneer je daarmee bij de buitenwereld de indruk hoopt weg te nemen dat je elk voorstel dat van de Regering komt, voetstoots accepteert. Dat in de de invoeringswetten op bepaalde punten (voordeelverrekening bij schadevergoeding, terugkooprecht) werd teruggekomen op de reeds vastgestelde wetstekst, zal die gedachte nog hebben bevorderd; men had in 1980 te kennen gegeven dat het zo goed was; waarom dan nog veranderen? ${ }^{70}$ Daarbij kwam dat de Stofkam-operatie in de literatuur inmiddels al weer het nodige stof had doen opwaaien, zodat de kans op een nieuw "informatie-infarct" niet denkbeeldig was. ${ }^{71}$

Tenslotte lijkt het niet uitgesloten, dat de verhouding tussen de Minister en althans een deel van de vaste Commissie kort voordat het Mondeling Overleg zou plaatsvinden zodanig was vertroebeld, dat er op het punt van het nieuwe B.W. geen zinnig gesprek meer mogelijk was. ${ }^{72}$ De aanleiding voor deze verwijdering had waarschijnlijk betrekking op de wijze waarop Hartkamp het Voorlopig Verslag inzake de Algemene Voorwaarden, waarvan de vaste Commissie veel werk had gemaakt, had beantwoord. Begin februari 1984 beklaagde Van der Burg zich bij de Minister dat 3/4 deel van zijn vragen in het Voorlopig Verslag (later teruggebracht tot de helft) niet

70. Dat mogelijk als gevolg van deze houding bij sommige Kamerleden irritatie is ontstaan, blijkt wellicht uit de discussie inzake de problematiek van afgebroken onderhandelingen (Parl. Gesch Boek 6 (invoering), p. 1438 e.v.). Nadat deze materie buiten de vaststellingswet was gehouden, werd, naar aanleiding van een vage opmerking van de vaste Commissie, bij de invoeringswet tóch een regeling voorgesteld. Commissielid Van der Burg vond dat wat al te voortvarend: "Soms ziet men (..) dat de inkt van een arrest van de Hoge Raad nog niet droog is, of de ontwerper staat al klaar met een wetstekst." Later zou Van der Burg dit argument aangrijpen om de positie van Regeringscommissaris Snijders ter discussie te stellen. Uit het NRC Handelsblad van 18 september 1986: "In het CDA is de gedachte opgekomen dat we van de Regeringscommissaris afmoeten. Het NBW moet rechtstreeks door de Minister worden behandeld. De Minister heeft met andere woorden te weinig greep op het project, en Snijders zou te hard van stapel lopen bij het opnemen van jurisprudentie."

71. De oprichting van het tijdschrift Kwartaalbericht NBW in 1984, waarin - de voorlichtende doelstelling van het blad ten spijt - tal van wetenschappelijke medewerkers de kans geboden werd hun NBW-ei te leggen, kwam vanuit dit oogpunt bezien op een weinig gelukkig moment.

72. Tekenend is dat vaste Commissie op 10 mei nog de indruk wekte dat de vraag of de rechterlijke macht wel voldoende bewerktuigd was, haar voornaamste aanleiding tot twijfel was. Uit de brief die Korthals Altes op 6 juni aan de Kamer stuurde, bleek dat representanten van diezelfde rechterlijke macht tegen verder uitstel gekant waren. Toch zou de Kamer geen duimbreed wijken. 
zou zijn beantwoord. ${ }^{73}$ Volgens Hartkamp ${ }^{74}$ zou er zakelijk gezien niet veel aan de hand zijn: "Toen ik gisteren mr. Van der Burg opbelde met het verzoek mij uit te leggen wat er zijns inziens mis is, verwees hij mij wegens tijdgebrek naar de bijzonder griffier, mr. De Vries Lentsch-Kostense. In een gesprek dat ik vanmorgen met haar voerde zei ze mij dat ze mr. Van der Burg reeds had verteld dat er slechts één vraag niet beantwoord is."

Verder zou Van der Burg gepikeerd zijn door de wijze waarop sommige vragen waren beantwoord. Hartkamp: "Waarin schuilt (de verdere) onmin van mr. Van der Burg? De bijzonder griffier kon dit niet met zekerheid zeggen, maar zij noemde mij een aantal passages waarin weliswaar een (soms uitvoerige) beantwoording te vinden is, die echter volgens haar niet volledig recht doet aan de vragen van de commissie. Soms berust dit eenvoudig op een misverstand, waartoe ook de haars inziens onduidelijke geformuleerde vraag makkelijk aanleiding kon geven." Hartkamp noemt dan als voorbeeld de vraag "wat zich verzet tegen het handhaven van de regel van het tweede lid van art. 6.5.1.3.", welke regel inhoudt dat een beding in algemene voorwaarden vernietigbaar is indien de gebruiker bij het sluiten van de overeenkomst begreep of moest begrijpen dat de wederpartij deze overeenkomst niet zou hebben aangegaan indien hij het beding had gekend. ${ }^{75}$ Hartkamp: "In de Memorie van Antwoord ${ }^{76}$ is die vraag uitvoerig beantwoord vanuit de veronderstelling dat de Commissie bedoelde te vragen: waarom art. 6.5.2A.2 lid 2 sub a in plaats van het oorspronkelijke art. 6.5.1.3 lid 2. De commissie bedoelde echter: waarom niet 6.5.1.3. lid 2 gehandhaafd naast art. 6.5.2A.2 lid 2 sub a. Wie zou daar nu op komen? Een zodanige cumulatie van toetsingsgronden, die nog nooit door iemand is verdedigd, zou toch wel teveel van het goede of het kwade zijn. ${ }^{177}$

Hartkamp sloot zijn nota als volgt af: "Mr. Van der Burg is niet alleen een drukbezet, maar ook een heetgebakerd man. Hij had het tegen mij over een mogelijke strafexpeditie in de vorm van een nader Voorlopig Verslag. Na het gesprek met de bijzonder griffier schijnt hij weer bekoeld."

Niettemin zou Van der Burg, onder afkeuring van al wat Commissielid heette, toch tot een "strafexpeditie" overgaan. Op 1 oktober 1984, toen het Eindverslag al was gepasseerd, zouden hij en VVD-Kamerlid Korthals zich zonder behoorlijke grond distantiëren van het wetsontwerp en zo de behandeling enkele maanden ophouden. ${ }^{78}$ Is

73. Vergelijk Parl. Gesch. Boek 6 (invoering), p. 1463: "De Commissie moest constateren dat de wijze waarop de Minister en de Staatssecretaris in de onderhavige memorie sommige van haar opmerkingen hebben beantwoord, de voortgang van de werkzaamheden in het kader van de invoeringswetgeving niet bevorder."

74. Nota van 16 februari 1984 aan Minister Korthals Altes.

75. Zie Parl. Gesch. Boek 6 (invoering), p. 1583.

76. Zie Parl Gesch. Boek 6 (invoering), p. 1585.

77. Zie ook Parl. Gesch. Boek 6 (invoering), p. 1590 en 1594 e.v.) waar dit misverstand wordt rechtgezet.

78. Zie Parl. Gesch. Boek 6 (invoering), p. 1466 e.v. Het argument van Van der Burg was dat hij de noodzaak van een wettelijke regeling betwijfelde, gelet op de dereguleringsvoorstellen van de Commissie-Van der Grinten van 27 juni 1983. Een merkwaardige motivering, want de Regering had het standpunt van Van der Grinten, compleet met reactie, in de M.v.A. vermeld. Bovendien had de CDA-fractie zich geconformeerd aan het Eindverslag, waarin het centrale stuk van deze titel werd akkoord bevonden. 
het irreëel te veronderstellen, dat de voorkeur voor een langzamer behandeling in mei 1984 door dezelfde motieven werd ingegeven?

\section{Een zuur werk}

Niemand zal wel willen betwisten, dat datgene wat er uiteindelijk op 10 mei 1984 gebeurde, aan de Stofkam-Operatie een zekere nutteloosheid verleende. Een zekere troost zou misschien kunnen worden gevonden in de overweging, dat althans de rechterlijke macht er de voordelen van trok. Ook dat is echter maar zeer de vraag. Snijders, die in $z^{\prime} n$ eentje de halsbrekende operatie ${ }^{79}$ in drie maanden uitvoerde, schreef in een toelichting op zijn voorstellen, dat de wens het Parlement te ontlasten "verreweg" het belangrijkste motief was geweest. Hij voegde eraan toe: "te bedenken valt dat dit, vanuit een oogpunt van termijnoverschrijding, ook wel erg vitaal is geweest. (..) Het gaat hier om een reeks detailbepalingen die inderdaad niet heel veel verschil zullen maken in vergelijking met de nu eenmaal niet op te lossen moeilijkheden die men vreest van het enkele feit dat er zoveel tegelijk verandert. Bepaalde regels die in het bijzonder voor de werklast van belang zijn, kan men niet aanwijzen, tenzij met een verwijzing naar algemene normen. ${ }^{80}$ Een zuur werk dus.

Hartkamp vult aan: "Volgens mij is het rendement van de Stofkam-Operatie nihil geweest. Het stelt allemaal niets voor. Die invoeringskosten zijn er, je moet je inwerken, je moet nieuwe contracten maken. Het is een normaal maatschappelijk risico dat wetten af en toe vernieuwd worden."

Een interessante vraag is, of het Ministerie deze problemen niet had kunnen voorkomen. Dat het Ministerie al ver voordat de definitieve teksten vaststonden, begon met het opzetten van cursussen, is mijns inziens allesbehalve verstandig geweest. Daardoor kon de praktijk zich niet werkelijk instellen op de nieuwe wetgeving, hetgeen irritaties in de hand werkte. Bovendien kwamen er daardoor ook weer nieuwe vragen los, die uiteraard door de Kamer moesten worden meegenomen - voor 99,9 procent

79. Men bedenke dat door de gehele invoeringswetgeving heen tal van bepalingen waren waarin aanpassingen of formules voorkwamen die op de ontkoppelde gedeelten betrekking hadden. Bovendien kon Snijders niet al te stellig zijn in zijn voorstellen tot schrapping, omdat de kans groot was dat een aantal van de dereguleringsvoorstellen weerstanden zou oproepen, en het dus niet verstandig was bij voorbaat de pas naar de weg terug af te snijden. Ten Kate zei daarover: "Wat van hem gevergd wordt is niet gering. Als hij een tekst heeft bedacht, volgt het toetsen van die tekst aan de praktijk. Hij hoort veel mensen, werkt dat netjes uit en geeft er een toelichting bij, legt iedereen uit waarom die tekst zo moet luiden. Dan komt er een nieuwe Regering met het voorstel te dereguleren: 'Meneer Snijders, wilt u even wat eenvoudiger regels vaststellen?' Hij moet dan een nieuwe regel geven en uitleggen waarom die regel beter is en eenvoudiger, terwijl hij net heeft verteld waarom die regel in zijn laatste versie zo goed was. Dat is natuurlijk een beetje mishandeling van een mens."

80. Nota van 7 juli 1983. 
van de juristen was het nieuwe B.W. vóór 1980 nog een gesloten boek. ${ }^{81}$ Dat het er zo weinig zijn geweest, zegt overigens wel iets over de kwaliteit van Snijders' werk.

Een tweede fout is mogelijk geweest, dat het Departement teveel aan de invoeringswetgeving heeft gekoppeld. Het gelijktijdig meenemen van de Boeken 1 en 2, hoezeer ook een technisch aangelegenheid, was niet nodig geweest. Wellicht zou het ook beter zijn geweest om de herziening van Rechtsvordering buiten de invoeringswetgeving te houden. Weliswaar had deze samenvoeging voor Ministerie en praktijk grote voordelen, omdat op deze wijze éen samenhangend stuk recht in werking kon treden en uitlegmoeilijkheden tegen de achtergrond van oud en nieuw recht werden vermeden, maar voor de Kamer was het waarschijnlijk de druppel die de emmer deed overlopen. ${ }^{82}$

Anderzijds dient te worden bedacht, dat de aanvankelijke aarzelingen van Minister Korthals Altes ook tot de nodige beeldvertekening hebben geleid. Zijn optreden, gecombineerd met het feit dat te zelfder tijd binnen de vaste Commissie een wisseling van de wacht plaatsvond en niet meer op de vlotte medewerking van haar voorzitter, $\mathrm{mr}$. Roethof kon worden vertrouwd, was in zekere zin onvoorzienbaar en daarom ook onvermijdbaar. Als het project in de jaren zestig met wat meer voortvarendheid ter hand was genomen, waren deze geluiden, die voornamelijk aan een soort oververmoeidheid waren te wijten, niet voorgekomen. Iets dergelijks geldt ook voor het optreden van Van der Burg en misschien ook Korthals. Omdat het nieuwe B.W. na 1965 uit een oogpunt van politiek niet meer interessant was, kregen de schaarse fractiespecialisten het alleen voor het zeggen.

\section{Een onzedelijk voorstel ${ }^{83}$}

De Stofkam-Operatie was niet de laatste hindernis die bij de voltooiing van het nieuwe B.W. moest worden genomen. Op 11 juli 1986 werd in de Staatscourant $\mathrm{nr}$ 131 het zogenaamde Regeerakkoord afgedrukt, waarin werd bepaald dat er binnen drie maanden een Commissie van Wijzen zou moeten komen om te adviseren over de voortzetting van de invoering van de Boeken 3, 5 en 6 van het nieuwe Burgerlijk Wetboek. Opnieuw dreigde de politiek een spaak in het wiel te steken. ${ }^{84}$

81. Ook de publicatie van de Parlementaire Geschiedenis Boeken 3, 5 en 6 in 1981 lijkt een niet te onderschatten invloed te hebben gehad op de rechtsgeleerde kritiek. Het is althans frappant dat het aantal bijdragen over het nieuwe B.W. na 1981 verdrievoudigde. Vergelijk ook de discussie in NJB 1970, p. 1037 e.v., waaruit blijkt dat de uitgave van de zogenaamde wetgevingsbijlagen in 1970 moest worden gestaakt, omdat er van de 3400 abonnees op het NJB nog geen 250 waren die zich hierop wensten te abonneren.

82. Hiertegen pleit weer dat de gevolgen van een gefaseerde aanpak in Belgiẽ bij de invoering van het Gerechtelijk Wetboek niet erg gunstig zijn geweest. Algemeen werd geklaagd over de chaotische gevolgen.

83. Naar Van der Burg, die tijdens de UCV van 1984 het voorstel van de vaste Commissie om Minister Korthals Altes tot stopzetting uit te lokken, betitelde als een "bijna onzedelijk voorstel." Zie Parl. Gesch. Voortgang, p. 50.

84. Zie H.C.F. Schoordijk, Een onverwachte zinsnede in het regeerakkoord, NJB 1986, p. 882 e.v.; P.J.J. van Buuren en J.M.Polak, De politiek en het Nieuw Burgerlijk Wetboek, NJB 1986, p. 1234;

H. Franken, Het allerlaatste peremptoir, Rechtsgeleerd Magazijn Themis 1987, p. 161-164. 
Het initiatief tot de bewuste passage - omhooggevallen door gebrek aan gewich ${ }^{85}$ was genomen door Van der Burg en Korthals en in zoverre dus weinig opzienbarend: ook na 1984 had Van der Burg aan iedereen die het horen wilde, verkondigd dat 1994 een realistischer datum voor invoering was dan 1989/1990. De twee motiveerden hun stap met de volgende argumenten. In de eerste plaats zouden er bij grote groepen praktijkjuristen nog steeds grote bezwaren bestaan tegen de invoering van het nieuwe B.W. Dat die geluiden sinds 1984 in de pers niet meer werden vernomen - de NBWcursussen lagen inmiddels al weer bijna twee jaar stil - deed daaraan niets af. Om aan alle onzekerheid een einde te maken, zou het daarom nuttig zijn een commissie van niet direct bij het nieuwe B.W. betrokken praktijkdeskundigen te laten oordelen. Korthals: "Er is een soort angst - ik begrijp het nog steeds niet - om openlijk te zeggen dat je tegen het nieuw BW bent. ${ }^{186}$

In de tweede plaats werden de perikelen rond de behandeling van het wetsontwerp Algemene Voorwaarden opnieuw van stal gehaald. Beide Kamerleden voelden zich overvleugeld door raadadviseur Hartkamp en Regeringscommissaris Snijders. In de woorden van Van der Burg: "In het CDA is de gedachte opgekomen dat we van de Regeringscommissaris afmoeten. Het NBW moet rechtstreeks door de Minister worden behandeld." ${ }^{87}$ En: "Er moet een eind komen aan het taboe dat het NBW overal boven staat en dat de Tweede Kamer zomaar overal 'ja' op moet zeggen. " ${ }^{88}$

Tenslotte zou het werk aan het nieuwe B.W. tot gevolg hebben dat Nederland nog tot ver in jaren negentig verstoken zou blijven van consument-vriendelijke wetgeving. Van der Burg: "Er is niets verloren als het NBW niet volgens plan wordt ingevoerd en alleen het huidige wetboek wordt aangevuld met maatschappelijk relevante wetgeving inzake consumentenbescherming en aansprakelijkheid. " 89

Over het eerste argument kan ik kort zijn. Het advies van de Commissie van Wijzen liet er geen twijfel over bestaan dat er binnen de beroepsgroepen geen zwaarwegende principiële bezwaren bestonden tegen de invoering van de Boeken 3, 5 en 6 . In zekere zin was dat antwoord ook wel te verwachten, omdat de Commissie zich voör haar standpuntbepaling baseerde op de officiële standpunten van Snijders' gesprekspartners uit 1983/1984 en geen navraag deed bij de "achterban". De uitslag van zo'n

85. Van der Burg: "In alle ernst, een spreekbeurt in Vianen levert politiek meer op dan het hele Nieuw B.W." Ontleend aan F. Bruinsma en N. Huls, De Commissie van Wijzen, Kwartaalbericht NBW 1988, p. 117 e.v.

86. Geciteerd bij F. Bruinsma en N. Huls, De Commissie van Wijzen, Kwartaalbericht Nieuw BW, 1988 , p. 117.

87. NRC Handelsblad van 18 september 1986.

88. In het radio-programma "Op de rand van het recht" van 9 december 1986, gewijd aan de problematiek van de voordeelsverrekening bij sommenverzekering (art. 6.1.9.11a) zei Van der Burg het als volgt: "Er wordt wel eens gedaan, alsof het Nieuw Burgerlijk Wetboek een zuiver technische materie is, binnenskamers, waar alleen hooggeleerden en andere geleerden zich over kunnen buigen, waar eigenlijk de Kamer zelf zich verre van zou moeten houden. Ik heb mij daar al die jaren dat ik met het nieuwe Burgerlijk Wetboek bezig ben tegen verzet (..)."

89. Deze uitspraak lijkt niet vrij van adders. Bij afwijzing van het nieuwe B.W. had het wetsvoorstel algemene voorwaarden moeten worden aangepast (en in feite flink worden omgewerkt) aan het oude B.W. Dat had het CDA en de VVD alsnog de kans gegeven het voorstel uit te kleden. Waarschijnlijk was het dan zeker niet vóorr 1992 in werking getreden. 
enquête zou natuurlijk ook al te voorspelbaar zijn geweest. ${ }^{90}{ }^{91}$ Het tweede argument, dat de Kamer teveel aan de leiband van het Ministerie zou lopen, vraagt wat meer uitdieping. Het argument is niet nieuw. Jurgens kwam in 1973 met een soortgelijke opmerking. Wel is er dit verschil, dat Van der Burg zich persoonlijk tegen de Regeringscommissaris en Hartkamp keerde, met name ten aanzien van de gang van zaken rond de Algemene voorwaarden. ${ }^{92}$ Naar mijn stellige indruk ligt hier, afgezien van het reeds boven opgemerkte, inderdaad een belangrijke verklaring voor het ontstaan van de Commissie van Wijzen.

Het is voor een Kamerlid ongetwijfeld weinig aantrekkelijk zich te verdiepen in het nieuwe vermogensrecht. Wie zich intensief bezighoudt met het nieuwe B.W. - en dat is de enige manier die vruchten afwerpt - beweegt zich al snel aan de marge van de verkiesbaarheid. Mevrouw Salomons, die daar zelf volgens sommigen het slachtoffer van werd, zei het als volgt: "Actieve participatie aan het NBW-wetgevingswerk door parlementariërs kost je je kop: vandaar ook de neiging tot vooruitschuiven. ${ }^{193}$ Dat leidt ertoe dat de wens om een politiek punt te scoren groter is dan bij een normaal wetsontwerp. De deskundige alomtegenwoordigheid van Departement en Regeringscommissaris is daarvoor echter te groot. Voor een redelijk denkend Kamerlid zal dat nooit een bezwaar zijn. Anderen hebben daar misschien wat meer moeite mee. In elk geval blijft het ongelooflijk, dat één of twee Kamerleden de invoeringsoperatie met enkele jaren konden uitstellen, door gebruik te maken van een argument dat twee jaar eerder door alle beroepsorganisaties was afgewezen.

Het derde argument is een illustratie van de stelling dat de Kamer zich wel met wetgeving op het terrein van het privaatrecht wil bezighouden, maar alleen voorzover het onderwerpen betreft die in de publieke belangstelling staan, of, zoals Van der Burg het uitdrukte "maatschappelijk relevant" zijn. Het is het motief dat ertoe heeft geleid dat de wetgever het centrale deel van het vermogensrecht, dat voor de praktijk van levensbelang is, maar door de politiek al snel wordt aangezien voor technische juristerij, tot 1947 links heeft laten liggen. Het is ook één van de oorzaken die ertoe heeft geleid dat het B.W. in 1947 dermate verouderd was, dat het in zijn geheel

90. Een voorbeeld is de enquete van het Nederlands Genootschap van Bedrijfsjuristen in 1986, waaruit bleek dat slechts twintig procent van de leden voorstander was van invoering (NBG Ledenbulletin 3/5, december 1986). Het Genootschap zelf was echter al vanaf 1980 actief bij de NBW-stuurgroep betrokken. Bovendien had de Commissie, ingesteld door de Nederlandse Maatschappij voor Nijverheid en Handel, in 1976 positief over het nieuwe vermogensrecht geadviseerd.

Om dezelfde reden werd medio 1985 door Justitie een enquête naar werkbelasting onder leden van de rechterlijk macht afgewezen (zie Fibbe en Hangelbroek, NJB 1986, p. 1422 e.v.).

91. Vergelijk ook H. Cohen Jehoram, Juristen, tijdschriften en uitgevers in Nederland, NJB 1970, p. 1037 e.v.

92. Overigens zou Van der Burg deze uitspraak later noch willen ontkennen noch bevestigen. In antwoord op vragen van Schutte (GPV) of het waar was dat voor de CDA-fractie de politieke prioriteit van het nieuwe B.W. nul was, en men met het voorstel kwam de Regeringscommissaris naar huis te sturen, antwoordde Van der Burg: "De Commissie van Wijzen (..) zal volgens ons aangeven hoe groot het maatschappelijk draagvlak is voor de invoering van de Boeken 3,5 en 6 van het nieuwe Burgerlijk Wetboek." Over de positie Snijders liet hij zich niet uit: "Het is allereerst aan het kabinet om, na advisering door de Commissie van Wijzen en aan de hand van de door de Minister van Justitie gehanteerde uitgangspunten als globalisering van wetgeving, te bepalen hoe voortgegaan moet worden met de Boeken 3, 5 en 6." (Parl. Gesch. Voortgang, p. 78-79).

93. Uitspraak tijdens NBW-forum studenten-dispuut Tobias Asser, Leiden, 15 oktober 1986. 
moest worden herzien. Als een nieuw B.W. nodig was, dan was het nodig als "brood", niet zozeer vanwege de "krenten".

De noodzaak van de hercodificatie is paradoxaal genoeg in belangrijke mate bepaald doordat de politiek er niet in geïnteresseerd is. Een paradox, maar ook een beetje een contradictie. ${ }^{94}$

\section{Een meesterzet}

In zijn toespraak bij de installatie van de Commissie van Wijzen ${ }^{95}$ (Voluit: Commissie advisering invoering van de Boeken 3, 5 en 6 van het nieuwe Burgerlijk Wetboek) wond Minister Korthals Altes er geen doekjes om dat hij die installatie liever niet had gedaan: "Het is immers in een door anderen dan mijzelf opgesteld regeerakkoord dat ik wel als fundament voor mijn handelen heb aanvaard - dat de wenselijkheid van het uit te brengen advies is neergelegd." Volgens de Minister zou invoering in 1989 of 1990 een alleszins gerechtvaardigde stap zijn geweest. Van den Haak, de voorzitter van de Commissie, was zo mogelijk nog duidelijker. In zijn antwoord aan de Minister liet hij doorschemeren dat hij eigenlijk niet begreep waaraan de Commissie haar bestaan had te danken: "Uitsluitend naar de letter en op zichzelf beschouwd biedt de opdracht plaats voor beschouwingen niet alleen over alle modaliteiten van invoering (..) maar ook over de invoering als zodanig." En: "Er zou al veel gewonnen zijn, als wij erin zouden kunnen slagen thans op korte termijn te bereiken dat de herdenking van 150 jaar Burgerlijk Wetboek op 1 oktober 1988 geen gerede aanleiding meer kan vormen om weer eens te gaan speculeren over de invoering van het NBW." Snijders: "Ik ken natuurlijk een aantal leden van de Commissie en die vraag is mij ook regelmatig gesteld."

94. Dat de Tweede Kamer in de jaren ' 80 een vertragende factor is geweest in het wetgevingsproces blijkt ook doordat het haar gemiddeld zo'n 22 maanden kostte om met een Voorlopig Verslag over een deel van de invoeringswet te komen, terwijl de Regering voor het beantwoorden daarvan gemiddeld 4,5 maand nodig had. Wordt daarbij in aanmerking genomen dat over de delen VIII, IX en $\mathrm{X}$ (aanpassingswetgeving) in wezen met een blanco verslag kon worden volstaan, dan kom je op 29 maanden, d.w.z. tweeëneenhalf jaar.

95. De Commissie werd ingesteld bij besluit van 12 september 1986. Zitting daarin hadden: $\mathrm{mr}$. H.F. van den Haak (voorzitter), president van de rechtbank te Haariem; mevr. mr. S. Boekman, raadsheer in de Hoge Raad; prof.mr. C.J.M. Brunner, hoogleraar burgerlijk recht aan de RU Groningen; prof.mr. P. Clausing, hoogleraar burgerlijk recht aan de Universiteit van Amsterdam; mr. P.C. van den Hoek, advocaat en procureur te Amsterdam; prof.mr. J.M.M. Maeijer, hoogleraar handels- en burgerlijk recht aan de Katholieke Universiteit Nijmegen; mr. G. Mannourij, vicepresident van de rechtbank te Zwolle; prof.mr. F.H.J. Mijnssen, raadsheer in de Hoge Raad en buitengewoon hoogleraar in het burgerlijk recht aan de Vrije Universiteit te Amsterdam; prof.mr. M.J.G.C. Raaijmakers, juridisch adviseur van Philips en buitengewoon hoogleraar in het burgerlijk recht aan de Katholieke Universiteit van Brabant; mr. A.H.M. Santen, notaris te Amsterdam; mr. J.L.M. Urlings, vice-president van het gerechtshof te 's-Hertogenbosch; mr. F.B. Bakels (secretaris), rechter in de rechtbank te Haarlem.

96. Beide toespraken zijn gepubliceerd in Staatscourant $\mathrm{nr} 181$ van 19 september 1986. De samenstelling van de Commissie is vermeld in Staatscourant nr 178 van 16 september 1986 . Zie ook Parl. Gesch. Voortgang, p. 261-270. 
De Commissie was er al na zes vergaderingen uit. Het eenstemmige advies luidde dat het nieuwe B.W. onverkort en zo spoedig mogelijk diende te worden ingevoerd, met als motto "Der Worte sind genug gewechselt, laszt mich auch endlich die Inkraftsetzung sehen." ${ }^{\text {97 }}$ Fijntjes werd daaraan toegevoegd, dat naar de mening van de Commissie de oppositie tegen het nieuwe B.W. alleen bij sommige leden van de Regeringspartijen bestond en niet viel terug te voeren op bezwaren van de praktijk. Wolffensperger (D'66) zou later dan ook ironisch verklaren dat de passage in het regeerakkoord een "meesterzet" was van degenen die het nieuwe B.W. zo snel mogelijk ingevoerd wilden zien, een kwalificatie die door Van der Burg "in dankbaarheid" werd aanvaard..$^{98}$

Wel stelde de Commissie enige belangrijke randvoorwaarden ten aanzien van de invoering. Om de invoering zo ongestoord mogelijk te laten verlopen, zou de wetgever terughoudendheid moeten betrachten bij het telkens opnieuw ter discussie stellen van al vastgestelde wetsteksten. In de tweede plaats zou de definitieve nummering zo spoedig mogelijk moeten worden vastgesteld. Ten derde zou een vaste datum voor de invoering moeten worden vastgesteld. Tenslotte zou de praktijk gelegenheid moeten worden gegeven zich de inhoud van het nieuwe recht eigen te maken, contracten aan te passen, etc. De invoeringsdatum zou daarom 24 maanden moeten liggen na de datum waarop het laatste gedeelte van de invoeringswetgeving in het Staatsblad is gepubliceerd.

De vraag kan worden gesteld, of deze Commissie wel tot een ander oordeel had kunnen komen. Te bedenken valt, dat zij werd samengesteld onder verantwoordelijkheid van Minister Korthals Altes, die zich na 1984 had ontpopt als een voorvechter van het nieuwe B.W. In die zin was de instelling van de Commissie een merkwaardige procedure, ofschoon het Regeerakkoord zelf deze weg voorschreef.

Intussen meen ik, dat op het besluit van de Minister weinig was af te dingen. Van de Commissie maakten namelijk tevens mensen deel uit, waarvan bekend was dat zij kritisch stonden tegenover het nieuwe B.W., zoals Brunner, Van den Hoek en Raaijmaakers. Het standpunt van Voorzitter Van den Haak was bij niemand bekend althans vóór de installatievergadering. Alleen secretaris Bakels had zich eerder, overigens op zakelijke gronden, in een polemiek met Van Dunné positief uitgelaten over de kwaliteiten van het nieuwe B.W..$^{99}$

Ook uit de rede van Van den Haak bij de aanbieding van het rapport blijkt niet van enige vooringenomenheid: "De Commissie is geenszins blind geweest voor wat zij kon traceren als bezwaren van de praktijk. 't NBW was voor de Commissie niet op voorhand sacrosanct. Het is juist realisme op dit punt dat in de door de Commissie gemaakte afweging van praktisch-bestuurlijke aard een belangrijke rol heeft gespeeld."

Tenslotte is het zo dat de Commissie eenparig tot een positief oordeel kwam, ook al heeft dat wellicht de nodige voeten in aarde gehad. ${ }^{100}$ Vermoedelijk is zij daarom

97. Rapport en aanbevelingen werden uitgebracht op 13 januari 1987. Het rapport is opgenomen in Parl. Gesch. Voortgang, p. 275-290.

98. Parl. Gesch. Voortgang, p. 85. Niettemin zou Van der Burg ook na het positief uitgevallen advies bezwaren blijven houden. Zie Parl. Gesch. Boek 6 (invoering), p. 1295, 1313 en 1417.

99. Zie NJB 1984, p. 1282 e.v.

100. Zie daarover, overigens in tegenovergestelde zin, Bakels en Raaijmakers, in: Kwartaalbericht NBW 1988, p. 120. 
niet voor niets door haar geestelijke vaders een "Commissie van Wijzen" genoemd: Anno 1987 waren verstandige mensen vóór een nieuw B.W. Hartkamp: "Het positieve eindoordeel verbaasde mij niet. Niet zozeer vanwege de samenstelling van die Commissie, maar meer omdat ik in het algemeen het gevoel had dat het werk, in het toen bereikte stadium, niet meer kon worden gestopt. ${ }^{101}$

\section{Tenslotte}

Nadat de Commissie van Wijzen haar unaniem oordeel over de invoering van de Boeken 3, 5 en 6 had uitgesproken en de Tweede Kamer dat advies had overgenomen, leek eindelijk niets meer aan een spoedige invoering van dit deel van het nieuwe B.W. in de weg te staan. Wel ontstond er in de Tweede Kamer nog enig rumoer omtrent de exacte invoeringsdatum - dit in verband met de in het advies aanbevolen overgangstermijn van twee jaar na beëindiging van de parlementaire behandeling -, maar Minister Korthals maakte aan alle twijfels een eind door te stellen dat men, hoe men ook rekende, altijd uit zou komen op circa 1 januari 1992. Sindsdien was deze datum een eigen leven gaan leiden.

In deze geoliede machine dreigde op het laatste moment nog enig zand te worden gestrooid door een actie van Van Dunné, Stein en Luijten, sprekend namens een door hen opgerichte "Werkgroep invoeringsproblemen Nieuw B.W." 102 Op 15 februari 1989 wendden zij zich tot de vaste Commissie voor Justitie, nadat de eerste contacten met Van der Burg waren gelegd. Uit een schrijven dat ter voorbereiding van deze bespreking werd opgesteld, bleek dat bij de werkgroep de zorg over de belasting van de rechterlijke macht centraal stond: "De invoering van het N.B.W. (zal) een uitbreiding van de rechterlijke macht en van de administratie vereisen, ten aanzien waarvan het allerminst aannemelijk is, dat deze bij invoering van het wetboek beschikbaar zal zijn. Voorkomen dient te worden dat door de invoering van het N.B.W. een aantal regelingen van kracht worden, die zonder een passende opvang in rechterlijke macht en administratie tot een ontwrichting van het rechtsverkeer zullen moeten leiden. " 103

De ideeën van de werkgroep vonden bij de vaste Commissie een onverwacht gunstig onthaal. Een citaat uit het verslag dat van deze bespreking werd gemaakt:

101. Kluwer Cahier, februari 1991 , p. 1.

102. De samenstelling van deze werkgroep was als volgt: jhr.mr. H.P. van Beresteyn, oud-advocaat, kantonrechter te Rotterdam; prof.mr. Gr. van der Burght, hoogleraar notarieel recht, VU Amsterdam; prof.mr. J.L.P. Cahen, hoogleraar privaatrecht, Universiteit van Amsterdam; prof.mr. J.M. van Dunné, hoogleraar privaatrecht, Erasmus Universiteit Rotterdam; prof.mr. J.H.A. Lokin, hoogleraar rechtsgeschiedenis, R.U. Groningen; prof.mr. E.E.A. Luijten, oud-hoogleraar notarieel recht, K.U. Nijmegen; mr. H.C.G.L. Polak, oud-advocaat en -kantonrechter, lid van de Raad van State; mr. R.A. Salomons, bedrijfsjurist Delta Lloyd, Amsterdam; prof.mr. P.A. Stein, hoogleraar privaatrecht, Universiteit van Amsterdam; prof.mr. C.Ae. Uniken Venema, oud-bedrijfsjurist Philips NV, hoogleraar Anglo-Amerikaans recht R.U. Groningen; mr. A.D. Mijs, President Rechtbank Dordrecht; mr. J.A. van de Ven, advocaat Dutilh c.s. Rotterdam; mr. H.C. Wesseling, oudbedrijfsjurist Unilever NV, Rotterdam; prof.mr. W.J. Zwalve, hoogleraar inleiding, R.U. Groningen.

103. Brief van 1 februari 1989. Als voorbeelden van deze regelingen werden genoemd "de methodiek van het NBW, waarin wordt afgezien van vaste regels en veeleer de oplossing wordt gezocht in ruime rechterlijke bevoegdheden" en de regeling van de inschrijving van registergoederen, die tot grotere werkbelasting bij het hypotheekkantoor zou leiden. 
"Nadat de doelstellingen van de groep waren toegelicht, waarbij vooral de zorg over het kostenaspect benadrukt is, stelde voorzitter Kosto (PvdA) dat deze problematiek zeker onder de aandacht van de kabinetsformateur gebracht dient te worden ten behoeve van de financiële paragraaf in het regeerakkoord. De heer Kosto verzocht de groep om bezwaren te formuleren, inclusief inhoudelijke bezwaren met betrekking tot de wetstekst (..) Ten aanzien van dit laatste punt kreeg Kosto met nadruk bijval van enkele andere commissieleden, waarbij men zich distantieerde van het standpunt van de Minister dat aan de tekst niet meer getornd kan worden." Dat de vaste Commissie zich had vastgelegd op de datum van 1 januari 1992 en op de aanbeveling van de Commissie van Wijzen, dat de wetgever "er wijs aan zou doen terughoudendheid te betrachten bij het telkens opnieuw ter discussie stellen van reeds vastgestelde wetsteksten", waren Kosto c.s. kennelijk alweer vergeten. ${ }^{104}$

Op 27 september 1989 verscheen het rapport "Kosten en tekortkomingen van het Nieuw Burgerlijk Wetboek" (Boeken 3, 5 en 6). ${ }^{105}$ Het rapport bestond uit vier delen: een kostenberekening van de invoering van het nieuwe B.W., een overzicht van de knelpunten in het nieuwe recht (twee delen) en tenslotte problemen van overgangsrecht. Het eerste deel werd geschreven door Van Dunné in samenwerking met drs. R. Teijl (econoom aan de EUR), het tweede deel, waarin een groot aantal bepalingen werd verzameld waaruit een toename van de werkbelasting van de rechterlijke macht zou kunnen worden afgeleid, was het resultaat van eigen onderzoek, een oproep in de vakpers die reacties opleverde ${ }^{106}$ en een literatuur-onderzoek. Voor het derde deel werden uitsluitend de handboeken van Schoordijk, gewijd aan de Boeken 3 (1986) en 6 (1979), bestudeerd. Het deel dat betrekking had op het overgangsrecht bestond uit de vermelding van twee (gedateerde) brieven van de NVVR, alsmede een verdwaald opstel van Van Dunné over de taal van het nieuwe B.W.

De strekking van het rapport loog er niet om: het nieuwe B.W. zou een slordig, dogmatiserend en tekortschietend produkt zijn, waarvan de invoering gigantische kosten zou veroorzaken, zowel bij de overheid als bij het bedrijfsleven. Voor de overheid zou gedacht moeten worden aan een bedrag van 1,4 miljard over vijf jaar, voor het bedrijfsleven lag dit cijfer zelfs op 6,5 miljard. De Kamer werd daarom geadviseerd zich nog eens goed achter de oren te krabben of invoering wel gewenst was in een tijd, waarin de rechterlijke macht "een stortvloed van nieuwe wetgeving" op haar af ziet komen en ingrijpende reorganisatiemaatregelen in het verschiet liggen: "De conclusie lijkt onontkoombaar, dat wij te maken hebben met een moeilijk toegankelijk, onhanteerbaar, niet op de praktijk gericht Nieuw Burgerlijk Wetboek, dat bij invoering enorme kosten veroorzaakt, bij de overheid en het bedrijfsleven. (..) Geen prettig vooruitzicht voor een rechterlijke macht die toch al naar het woord van

104. Vergelijk ook de uitspraak van Kosto van 11 november 1986, dat "het bepaald niet gewenst (is), dat straks weer wijzen van buiten op het Binnenhof worden ingezet." (Handelingen Tweede Kamer 1986-1987, p. 1209).

105. Het rapport (met bijlagen) is verschenen in de serie rechtsvinding, Amhem 1990, deel 7. Een samenvatting is opgenomen in NJB 1989, p. 1258 e.v.; Parl. Gesch Voortgang, p. 297-301.

106. Veel succes lijkt die oproep niet te hebben gehad, omdat tien van de tweeëndertig "qua redactie onjuiste bepalingen" reeds in februari 1989, toen de Commissie aan het werk toog, bij haar bekend waren. 
Leijten, als 'een elftal met acht man moet spelen' (NJB 1987, p. 454). Het parlement is, ook nu, aan het woord."

Helaas hadden de hoogleraren hun zaak ernstig geschaad door een tomeloze overschatting van de kosten, zo bleek uit reacties uit de literatuur ${ }^{107}$ en van het Departement. ${ }^{108} \mathrm{De}$ in het rapport voorkomende schattingen waren meestal uit de lucht gegrepen, ook waar betere, controleerbare cijfers voorhanden waren. Zo werd bijvoorbeeld voor de bijscholing van juristen een kostenpost van 500 miljoen opgevoerd, terwijl bijvoorbeeld de eerste cyclus PAO-cursussen in 1983/1985 niet meer meer vergde dan 2 á 3 miljoen, de bijdrage van de cursisten daaronder begrepen. ${ }^{109}$ Fantasierijk was ook de "uiterst behoudende schatting" van de kosten van de openbare registers, veroorzaakt door een toename van het aantal schadeclaims. Volgens het rapport zou, als gevolg van een verdubbeling van het aantal inschrijvingshandelingen, als gevolg van verschrijvingen op jaarbasis in minstens 60.000 gevallen een schadeclaim kunnen worden ingesteld, hetgeen zou leiden tot een schadepost van 200 miljoen gulden. Onderzoek van het Ministerie bracht echter aan het licht dat "thans" gemiddeld slechts één schadeclaim per jaar werd ingediend.

Ook deden de gevolgen van het feit dat de Rotterdamse faculteit pas in een laat stadium was overgeschakeld op het nieuwe B.W. zich op een navrante wijze voelen: het merendeel van de tekstuele opmerkingen was ontleend aan de deels verouderde commentaren van Schoordijk, zodat veel kritische opmerkingen zich richtten tegen niet meer bestaande teksten. Verder had ongeveer een derde van de in eigen beheer verzamelde kritische aantekeningen betrekking op kwesties waarover reeds lang en breed was gediscussieerd en waarvoor door de stellers van het rapport geen nieuwe argumenten werden aangedragen. Het leek er daardoor verdacht veel op, dat men of al die jaren had zitten slapen, óf dat er sprake was achterhoedegevechten. ${ }^{110}$

Het meest fundamentele gebrek was echter dat was nagelaten de voordelen van invoering van het nieuwe B.W. te berekenen, of althans ten minste een raming was gemaakt van de kosten die zouden ontstaan bij niet-invoering. "Neem nooit een

107. Zie Mokkende profesoren, Advocatenblad 1989, p. 595 e.v.; Het dourzettingsvermogen van prof. Van Dunné, NJB 1989, p. 1271; Tegen beter weten in, Ars Aequi 1989, p. 972; en E.H. Hondius, Rechtseconomie en Privaatrecht: enige kanttekeningen, in: Rechtseconomie en recht, Zwolle 1991, p. 95-105. Anders; NWB: fiat, Trema 1989, p. 333-334; B.J.A.W.V.M. Pinckaers, NJB 1989, p. 1516 e.v.

108. Het commentaar van Justitie is afgedrukt in Parl. Gesch. Voortgang, p. 301-313.

109. Van Dunné c.s. schatten de lastenverhoging als gevolg van een toename van de werklast van de rechterlijke macht op 18 miljoen, waarbij de toename van de werklast (toevloed nieuwe zaken én grotere complexiteit) werd geschat op 20 procent. De Commissie-Van Schendel kwam amper anderhalf jaar later (Recht vooruit, nr 2, februari 1991, p. 8) voor de invoeringsfase 1992-1994 uit op een cijfer van ruim 35 formatieplaatsen, dat wil zeggen een bedrag in de orde van grootte van 3,2 miljoen.

110. Vergelijk in dit verband de volgende passage uit de Justitiebegroting voor 1993, zitting Tweede Kamer 1993-1994, nr 23400, stuk nr 2, p. 20: "Na het verschijnen van verslagen in 1990 en 1991 met prognoses omtrent de consequenties van de invoering van het nieuwe vermogensrecht voor de werklast van de rechterlijke macht heeft de commissie-Van Schendel bezien of zich sinds de invoering moeilijkheden hebben voorgedaan. Daarbij is gebleken dat de invoering van het nieuwe vermogensrecht tot nu toe niet tot moeilijkheden aanleiding heeft gegeven. In verband daarmee is er op dit moment onvoldoende reden het toegezegde derde verslag uit te brengen." 
tekstverwerker, want die is veel duurder dan een ouderwetse schrijfmachine", schreef De Die in een commentaar op het rapport.

Het brandje was snel geblust. Reeds op 18 oktober lag het weerwoord van de Minister bij de vaste Commissie, met als conclusie dat het financiële gedeelte van het rapport elke indicatieve waarde miste, terwijl de tekstuele opmerkingen grotendeels "oude koeien" zouden zijn. Minister Korthals schreef boven het concept: "Al zijn de critici nog zo snel, het NBW achterhaalt hen wel." ${ }^{111}$

Wel zou, als gevolg van deze perikelen, de Eerste Kamer de behandeling van het zevende gedeelte van de Invoeringswet een week ophouden en pas op 28 december 1989 tot stemming overgaan. Daardoor kwam de afkondiging van het inwerkingtredings-KB op het laatste moment nog in enig gevaar. ${ }^{112}$ Door het ontwerp-KB echter gelijktijdig met het ontwerp-gedeelte aan de Koningin voor te leggen, kon ook dit gevaar worden bezworen. Bij Besluit van 20 februari 1990, Staatsblad 1990, nr 90, werd bepaald dat de Boeken 3, 5 en 6 met ingang van 1 januari 1992 in werking zouden treden.

Anders dan in het begin van de tachtiger jaren zou de juristenwereld weinig reden tot klagen hebben over de begeleiding bij de invoering. En masse stortte zij zich op de cursussen, aangeboden door de PAO-instellingen van de verschillende juridische faculteiten, alsmede het cursusaanbod van de commerciële uitgevers. In één week werd de cursist wegwijs gemaakt in de beginselen van het nieuwe vermogensrecht, en werden 150 jaren van achterstand overbrugd. ${ }^{113}$

Eindelijk vond dan op 21 januari 1992 in de Haagse Ridderzaal in aanwezigheid van Koningin Beatrix de officiële viering van de invoering van het nieuwe Burgerlijk Wetboek plaats. ${ }^{114}$ Het doel was bereikt, de moeiten en offers vergeten.

111. Van Dunné c.s. publiceerden op 8 november nog een weerwoord, waarin zij trachtten aan te tonen dat de kritiek van de Minister ten aanzien van het kostenaspect voor het grootste gedeelte misplaatst was. Zie Parl. Gesch. Voortgang, p. 313-314.

112. Eerder had Staatsraad H.C.G.L. Polak, voormalig lid van de actiegroep-Van Dunné, nog een poging gedaan Regering en Parlement te bewegen van invoering af te zien. Daartoe bracht hij op 9 november 1989 - een unicum sinds de openbaarmaking van de adviezen van de Raad van State in 1970 - een afzonderlijk advies uit bij het sluitstuk van de invoeringswet, de zogenaamde Bezemwet. (Zie Parl. Gesch. Voortgang, p. 116-118.)

113. Een week blokken in een conferentieoord op de Veluwe kostte bij Kluwer fl 3085,- exclusief BTW, bij Euroforum voor drie dagen zonder kost en inwoning fl 2.750,- exclusief BTW. Bij de universiteiten werd voor vijf bijeenkomsten een bedrag van fl 1.095,- gevraagd, voor een weekje met het nieuwe B.W. naar de zon (bestemming Barcelona, de Algarve en Costa del Sol, inclusief vliegreis) werd door de Maastrichtse PAO fl $3.250,--$ in rekening gebracht. Door middel van een eenmalige subsidie van Justitie aan de Orde van Advocaten (zie Advocatenblad 1990, p. 485) waren de kosten voor de minder draagkrachtigen onder de advocaten zelfs nihil.

114. De op deze bijeenkornst gehouden toespraken zijn opgenomen in Trema 1992, p. 51-69. Zie ook NJB 1992, p. 296-297; Kroniek van het vermogensrecht over het jaar 1993, Utrecht 1993, p. 1 e.v. 
Hoofdstuk 12

CONCLUSIE

Het traditionele beeld van de geschiedenis van de hercodificatie van het Nederlandse burgerlijk recht is, dat tussen 1838 en 1938 door slechts weinigen de noodzaak van een algehele herziening werd bepleit. Hieraan wordt vervolgens de conclusie vastgeknoopt dat Meijers, die in 1947 opdracht kreeg tot het maken van een nieuw Burgerlijk Wetboek, min of meer alleen stond in zijn streven naar hercodificatie en dat die opdracht alleen is te verklaren vanuit de naoorlogse vernieuwingsdrang.

Een ander beeld, dat eveneens stevig in ons denken is verankerd, is dat een hercodificatie van deze omvang noodzakelijkerwijs veel tijd kost. De opzet van Minister Van Maarseveen om door de inschakeling van Meijers in een beperkt aantal jaren een geheel nieuwe codificatie tot stand te brengen, zou daarom reeds bij voorbaat tot mislukken zijn gedoemd. Samengevat komen beide beelden hierop neer, dat codificatie van grote delen van het recht reeds in 1947 een achterhaald idee was, een verspilling van tijd en kennis. De moeizame totstandkoming van het nieuwe Burgerlijk Wetboek wordt gezien als een bevestiging van deze opvatting.

Dit boek bevestigt dit beeld niet. Natuurlijk, Meijers was inderdaad een eenling in die zin dat hij vermoedelijk de enige was die het avontuur aandurfde. Maar dat betekent nog niet dat de wenselijkheid daarvan door vrijwel iedereen in twijfel werd getrokken. En ook heeft het allemaal lang geduurd, althans veel langer dan men zich in 1947 had voorgesteld. Het had echter veel sneller gekund.

Hoe zit het dan wel? De gedachte dat alleen Meijers voorstander van hercodificatie was en dat het waarschijnlijk een toevallige samenloop van omstandigheden was die Minister Van Maarseveen het besluit tot herziening in de pen gaf, vindt in elk geval geen steun in de geschiedenis van de hercodificatie en lijkt vooral te zijn gevoed door de onlustgevoelens die ontstonden na 1954, toen Meijers was overleden en een nieuwe codificatie ver weg leek. Pas vanaf dat moment zijn tegenstanders van de hercodificatie zich bijvoorbeeld gaan beroepen op Scholtens bekende uitspraak uit 1938, "Ons B.W. is een rustig bezit", daarmee de suggestie wekkend dat Scholten, als vertolker van de algemene mening, de wenselijkheid van een algehele herziening principieel afwees. Hierboven is echter vastgesteld, dat Scholten meende dat de politieke drang, niet de juridische wenselijkheid voor hercodificatie afwezig was. Eén en ander bevestigt de stelling van $\mathrm{H}$. Drion, dat de zogenaamde controverse LeidenAmsterdam pas na de oorlog is ontstaan, en dan voornamelijk in de verbeelding van sommige Amsterdammers. ${ }^{\prime}$

Vanaf het eerste begin is stormgelopen tegen het Burgerlijk Wetboek van 1838. Aanvankelijk ging het daarbij om het herstellen van in het verleden gemaakte fouten. Later begreep men dat elke wet regelmatig aanpassing nodig heeft, enerzijds om de rechtsontwikkeling vast te leggen, anderzijds om deze waar nodig tẽ sturen. De politiek wilde echter in de eerste decennia na de invoering van een herziening, hoe onbetekenend ook, niet weten. Alleen in de schaarse gevallen dat een sterk sprekende

1. Zie hierover N.H.M. Roos, De Nederlandse privaatrechtsleer in dramatisch perspectief, Groningen 1987, p. 31-36. 
sociale nood in het geding was of met een enkele wijziging kon worden volstaan, bleek het parlement bereid haar grondwettelijke taak van medewetgever ernstig te nemen.

Het jaar 1870 vormde in zeker opzicht een keerpunt. In dat jaar werd de Nederlandse Juristen-Vereniging opgericht, om de wetgever te overtuigen van de noodzaak van een algehele herziening van de burgerlijke wetgeving. Niettemin zou zij al snel ervaren dat alleen een vuist maken niet voldoende is. Alleen als je een Minister hebt, die bereid is zich voor de volle honderd procent in te zetten, is er een kans dat een voorstel tot een technische herziening uiteindelijk vruchten zal afwerpen. Voorbeelden daarvan zijn de Ministers Van Hall, De Vries en Modderman, die, anders dan hun tijdgenoten, wel kans zagen privaatrechtelijke wetgeving tot stand te brengen of althans daartoe een aanzet te geven. Daarbuiten was het echter armoe troef.

Omstreeks 1910 was de aandacht van Regering en Kamer voor de burgerlijke wetgeving op een dieptepunt aangeland en was de desintegratie van de codificatie nabij. Pogingen van verschillende Staatscommissies om het Burgerlijk Wetboek en het Wetboek van Koophandel te herzien waren doodgelopen, de partiële herziening was na 1879 zo goed als in de ban gedaan. Weinig verwonderlijk dus dat de Nederlandse Juristen-Vereniging, die in 1912 de kwestie van de herziening van de wetboeken opnieuw op haar agenda plaatste, ditmaal haar hoop vestigde op rechtsvorming door de rechter. Deze oproep was wel succesrijk. In 1913 zag de Nederlandse Jurisprudentie het licht, in 1919 wees de Hoge Raad het arrest Lindenbaum/Cohen, waarmee dit college het buitenwettelijk recht als rechtsbron erkende en op één lijn plaatste met het geschreven recht. Dat het daarna snel is gegaan, blijkt doordat in 1931 het Algemeen Deel zou verschijnen, waarin Scholten de veranderde betekenis van de rechter ten opzichte van de wet een theoretisch fundament probeerde te geven.

Het is juist omstreeks die tijd dat Meijers erop wijst dat de mogelijkheden van jurisprudentiële rechtsvorming niet moeten worden overschat en dat wetgever en rechter beiden een taak hebben bij de rechtsvorming. Evenals een wetstekst, die niet meer beantwoordt aan de behoeften van het dagelijks leven, verstarrend kan werken, kan een jurisprudentiële regel een rechtvaardige oplossing in de weg staan. Bovendien geldt ten aanzien van deze laatste categorie het bezwaar dat $z 0^{\prime} n$ regel slechts is gegeven voor een bepaald geval en dat de onderliggende algemene regel soms moeilijk is te ontdekken, tot schade van de rechtszekerheid en de rechtsontwikkeling. Tenslotte vormt een oude wetstekst niet zelden een beletsel om nieuwe regels tot ontwikkeling te laten komen.

Meijers' herhaalde pleidooien, waarvan de juistheid overigens niet werd ontkend, lieten de wetgever echter onaangedaan. Daarmee werd zijn stelling, dat de politiek niet in het vermogensrecht is geînteresseerd, andermaal onderschreven. Het moet daarom vermoedelijk vooral aan de persoon van Minister Van Maarseveen worden toegeschreven, dat in 1947 eindelijk het besluit viel een nieuw Burgerlijk Wetboek te ontwerpen. ${ }^{2}$

2. Csaba Varga, Codification as a Socio-Historical Phenomenon, Budapest 1991, p. 256 e.v., spreekt in dit verband over het subjectieve moment. Voorwaarde voor codificatie is niet alleen dat de wet niet langer zijn dienende functie kan vervullen, maar ook dat deze behoefte zichtbaar gemaakt wordt als een situatie die een wettelijk ingrijpen vereist. De plaats die de wet in de samenleving inneemt, de 
Uit deze schets van honderd jaar hercodificatiegedachte blijkt allereerst, dat Meijers' standpunten met betrekking tot de wenselijkheid van herziening kunnen worden beschouwd als het (voorlopig) eindpunt van een historische ontwikkeling. Een herziening was onontkoombaar, indien men de codificatiegedachte in ere wenste te houden.

In de tweede plaats blijkt, dat één van de belangrijkste motieven van Meijers voor hercodificatie een rechtspolitiek argument was, namelijk het herstel van de taakverdeling tussen wetgever en rechter. De wet moest weer tot rechtsbron worden, enerzijds door het codificeren, het toegankelijk maken van belangrijke jurisprudentie, anderzijds door nieuwe gedachten in de wet op te nemen, de rechtsontwikkeling een impuls te geven. Een rationele opbouw van de wet kwam daar nog bij.

In de derde plaats kan worden gesteld, dat de ongelukkige geschiedenis van de pogingen tot herziening in zoverre nuttig is geweest, doordat Meijers er lering uit trok voor zijn onderneming door de in het verleden gemaakte fouten zoveel mogelijk te vermijden. Voorbeelden daarvan zijn dat hij bij K.B. benoemd wilde worden om zijn opdracht onafhankelijk te maken van Ministerswisselingen, aan de ruime mate van inspraak die hij zou bieden, aan de wijze waarop hij de Tweede Kamer zou betrekken bij de hercodificatie, en aan het feit dat de Staatscommissie-Limburg slechts een adviserende stem kreeg, zodat hij het overzicht, het belangrijkste motief om slechts één man het werk te gunnen, kon behouden en voor vertraging gevrijwaard bleef.

Dit onderzoek toont verder aan dat een hercodificatie niet noodzakelijkerwijs lang behoeft te duren. Afgaande op de rijpheid van Meijers' concepten enerzijds en hun aansluiting bij het geldende recht anderzijds, kan de stelling worden verdedigd dat het nieuwe B.W. vóór 1960 in het Staatsblad zou hebben gestaan indien Meijers er in geslaagd zou zijn het ontwerp tijdig af te leveren.

Dat dit niet het geval is geweest, kan aan verschillende oorzaken worden toegeschreven. Een eerste belangrijk punt is, dat na 1954 het aantal mensen dat bij het werk aan de hercodificatie betrokken was, steeds verder uitdijdde, totdat Regeringscommissaris Snijders in het begin van de jaren zeventig het min of meer alleen voor het zeggen kreeg.

Het aantal mensen dat aan een dergelijk project werkt en verantwoordelijkheid draagt voor de voortgang, dient zo klein mogelijk te zijn. Een eenmansopdracht verdient verre de voorkeur boven een twee- of driemanschap. Anders bestaat het gevaar dat men voor grote en vaak onoplosbare coördinatieproblemen komt te staan, zoals bijvoorbeeld ten aanzien van de groene Boeken 6 en 7 het geval is geweest. Ook bestaat het risico dat veelvuldig compromissen moeten worden gesloten, tot nadeel van de zeggingskracht van een tekst en de acceptatie daarvan door wetenschap en praktijk. Het groene Boek 6 draagt hiervan de sporen, evenals de Memorie van Antwoord en het Gewijzigd Ontwerp Boek 3, vooral in vergelijking met de latere tekst van Boek 6, die eenmanswerk was.

Hiermee hangt samen dat het werk aan het nieuwe B.W. lange tijd een krachtige leider heeft moeten ontberen, iemand die besluitvaardig is en de wensen van de

2. $\rightarrow$

traditie, de ervaringen met wetshervorming en de persoon van de initiatiefnemer zijn daarbij van doorslaggevend belang. 
praktijk aanvoelt. Meijers had dat, Snijders ook. Zowel in de periode-Meijers als in de periode-Snijders zien we een krachtige, de facto eenhoofdige leiding samengaan met een grote mate van openheid naar buiten. Juist bij een commissoriale werkwijze zal de neiging bestaan om de externe contacten te beperken, vooral indien de interne verhoudingen onder druk staan, zoals gedurende de periode van het Driemanschap het geval was. Hetzelfde geldt met betrekking tot Boek 4, in de periode 1954-1974. Direct overleg met de notarissen zou vele pagina's witte stukken hebben bespaard.

Gebrek aan belangstelling van de verantwoordelijke bewindslieden is een andere belangrijke verklaring. Daardoor kregen hobbyisme en perfectionisme teveel kansen. Een dergelijk omvangrijk project dient noodzakelijkerwijs snel te verlopen. Te lang studeren betekent dat de problemen toenemen en dat er van de aanvankelijke opzet niets terecht komt. Bovendien staat de maatschappelijke ontwikkeling niet stil. De gang van zaken rond het nieuwe erfrecht, waarin als gevolg van de opkomst van het OVB-testament geleidelijk een steeds zwaarder accent is komen te liggen op de versterking van de positie van de langstlevende, is daarvan een voorbeeld. Een andere illustratie hiervan levert de herziening van het vervoersrecht op. Te veel gelegenheid bieden om de ontwerpen van alle kanten te bekijken, brengt ook de Kamer meer dan goed is in de verleiding een eigen merk, zo niet aan het wetboek, dan toch aan een aantal artikelen te geven. Bij een technisch onderwerp als de herziening van het vermogensrecht dient de discussie tussen literatuur en Departement vooral niet via de Kamer te verlopen. Het betreft een onderwerp ten aanzien waarvan zij niet voldoende is gekwalificeerd. Als gevolg daarvan heeft de Kamer sinds het midden van de jaren zestig voornamelijk als doorgeefluik gefunctioneerd, waardoor de onvrede toenam en de betrokkenheid daalde. Als de Kamer zelf niet in staat is te bedenken wat er tegen of voor een bepaald wetsontwerp is, dan moet zij zich er verre van houden.

Meer algemeen kan worden geconstateerd dat het punt dat niet getornd moet worden aan vastgestelde teksten principieel te weinig aandacht heeft gekregen. Het streven naar kwaliteit houdt weliswaar het codificatie-ideaal levend en geeft de wetenschap vleugels, maar het is tegelijk een utopie. ${ }^{3}$ De ervaring wijst uit dat ook wetten, die een voorbereidingstijd van een jaar of vier, vijf hebben gekend, nog gebreken vertonen. Je kunt dan nog wel meer tijd spenderen om het aantal fouten te verminderen, maar uit een oogpunt van voortgang van de werkzaamheden is dat niet produktief. Bovendien irriteert een dergelijke opstelling de Kamer, zoals blijkt uit de perikelen rond de invoeringswetgeving. Feit is ook dat de verschillen tussen het werk van Meijers en dat van zijn opvolgers niet opzienbarend zijn en maatschappelijk gezien wellicht grotendeels irrelevant. Alleen foutieve regels zijn lastig, omdat de rechter daar niet mee uit de voeten kan.

Tenslotte zou het voor het draagvlak van het project beter zijn geweest indien er buiten de kring van de ontwerpers wat meer mensen bij betrokken waren geweest. In dat verband is het jammer dat de Staatscommissie voor de Burgerlijke Wetgeving is opgeheven. Dat Meijers alle groten van het burgerlijk recht om zich heen wist te verzamelen, betekende dat de kritiek daar kwam waar zij hoorde te komen, hetgeen een belangrijke arbeidsbesparing opleverde. In de latere jaren daarentegen kwam de kritiek soms als mosterd na de maaltijd, doordat zij op het verkeerde moment werd gemobiliseerd. 


\section{SUMMARY}

This book is a study of the development of the idea of recodification in the Netherlands since 1838 and, more particularly, of the origins and elaboration of the new Civil Code, on which professor E.M. Meijers began work in 1947. In the Netherlands the origins of the Civil Code of 1838 have been studied intensively, but a comprehensive account of the efforts to rejuvenate the existing legislation in the field of private law has been lacking up to now. Many lawyers are to a certain extent acquainted with the latest developments in codification; however, their knowledge is rather fragmentary and not always accurate.

The research strategy adopted in this study primarily regards the investigation and analysis of legal periodicals and of parliamentary debates about the budget in the nineteenth and early twentieth century, which have hardly been explored before. With regard to the origins of the new Civil Code extensive use has been made of the archives of the Ministry of Justice, as well as of a large number of interviews with people who worked on the recodification or were otherwise involved with it.

After an account of the aims, methods and design of this study in the first chapter, a sketch of the history of the recodification of Dutch private law between 1838 and 1938 is given in chapter 2 . In the next chapters the origins and development of the new Civil Code are described.

Chapter 3 deals extensively with Meijers' role in the recodification process, describing his working methods and attitude towards the project, his chairmanship of the Royal Commission for the Legislation of Private Law, his relation with the Ministry of Justice and its successive ministers. The role of the Lower House is also investigated, especially in respect to the debate about the outlines and politically sensitive aspects of the new Code.

In chapter 4 this description and analysis has been continued with regard to the Triumvirate which succeeded Meijers in 1954. Mention is made of the gradually expanding organization of the project, differences in the views about the project, the diminishing authority of the drafters, as well as the personal relations between them. Attention has also been paid to the question in which respect the texts of Books 5 and 6 of the new Civil Code, drafted by the Triumvirate, can be considered a continuation of Meijers' work. This chapter ends with the dissolution of the Triumvirate in 1961.

Chapter 5 focuses on Meijers' most important successor, professor J. Drion, who worked with O. van Ewijk of the Ministry of Justice on the memorandum of reply of the new law of inheritance from 1961 to 1964 . Attention has also been paid to the three government commissioners who worked on the project after Drion's untimely death in 1964: professor K. Wiersma for Book 4 (law of inheritance), professor J.H. Beekhuis for Book 5 (property law) and professor G.E. Langemeijer for Books 3 and 6 (the general part of the law of obligations).

Chapter 6 describes the troubled history of the new law of inheritance. Emphasis has been placed on the role of the notarial profession as a lobby group and on the influence of its most prominent spokesmen, in relation to the role and authority of the drafters. An important aspect of this story is the debate about the legal position of the surviving spouse in the case of inheritance by testament, which problem the States- 
General have been reluctant to solve for more than fifty years, due to a lack of knowledge and interest.

Chapter 7 reports on the development of Books 3, 5 and 6 after 1964. For the analysis of the legislative process of Book 3 special attention has been paid to the history of Chapter 3.1.1 (General provisions), focusing on the attitudes of the drafters about and the organization of the project. With regard to Book 5 the account centred on the relation of the government commissioner with the Ministry of Justice, especially in respect to the lack of supervision. The study of Book 6 compares the work of government commissioner W. Snijders with the work of the Triumvirate with respect to the use of comparative law, the handling of criticism and the discussion with practicing lawyers. Separate attention has been paid to the legislative process after 1976, when the Lower House had to decide about these Books.

Chapter 8 offers a sketch of the development of the first draft of Book 7 (Special contracts), dealing with Meijers' aims with this Book, the role of the Triumvirate and the contributions of the people who have been assigned with the task to complete this part of the Code since 1961. The chapter concludes with a global comparison of a couple of titels in Meijers' draft with the bill as it was finally sent to the Lower House.

In chapter 9 the development of the new law of transport together with the law on the means of transportation has been described, arguing that the link between these fields of law affected the legislative project. The role of government commissioner $\mathrm{H}$. Schadee has also been highlighted, as well as the importance of his ongoing discussion with practicing jurists.

Chapter 10 deals with the law of intellectual property. Although it was planned to be laid down in Book 9 of the new Civil Code, a draft has never been published.

Finally, chapter 11 shows the difficulties which accompanied the implementation of Books 3, 5 and 6 of the new Civil Code from 1980 to 1992. Special attention has been given to the role of the standing parliamentary committee for Justice, which longed to get rid of the matter, the hesitance of the practicing lawyers to get acquainted with the multitude of imminent changes, the steadily growing influence of legal science, as well as the relative importance of the fact that a long succession of governments and parties had supported the drafting of the new Code, or at least had not opposed it.

From this study can be concluded that the old Civil Code has faced a stiff opposition from the beginning. Originally the criticism focused especially on the language and system of the Code, later the fact that the legislator did not keep pace with developments in society was considered more important.

Politicians did not want to hear of revision in the first decades after the adoption of the Civil Code, except for a small number of cases in which a pressing social need had to be countered. This situation was caused by the time-consuming parliamentary procedures and the frequent changes of government, which resulted in the fact that only bills that could be passed within one parliamentary year stood a chance to be taken into consideration. Only in the rare case that a minister was determined to try his utmost, a revision of the Civil Code could be brought about.

In the first decade of this century the interest of government and Parliament in legislation in the field of private law was at its lowest. Attempts of a number of Royal 
Commissions to instigate a general revision fell on deaf ears. A partial revision was almost out of the question since 1879 , as the respective Royal Commissions were all officially set up to prepare a general revision.

This disintegration of the idea of codification led to a shift of attention to judicial lawmaking, similar to earlier developments in France. In 1913 a start was made with systematically publishing and annotating case law; in 1919 the Dutch Supreme Court handed down its opinion in the case Lindenbaum/Cohen, which recognized judgemade law as a source of law on the same level as statutory rules. For a time the shift of attention diminished the urgency of recodification, but it did not make it unnecessary, as judicial law-making has its drawbacks, especially if it has to develop in connection with an existing code.

E.M. Meijers, professor of private law in Leyden, was one of the first people to draw attention to this fact, but his repeated pleas for a general revision were not heeded by the legislator. At last in 1947 a decision was made to draft a new Civil Code, probably due to the influence of the Minister of Justice, J.H. van Maarseveen, who was personally interested in the project. This shows that, though many people argued for the necessity of recodification for a long time, the actual decision depended on factors like the person of the Minister of Justice, experiences with earlier attempts at revision, the role of tradition and the availability of alternative ways of law-making.

Another conclusion which can be drawn of this study is that a recodification does not necessarily have to take a long time. Considering the maturity of Meijers' drafts at the time of his death and their close affiliation with the law of the day, it can be argued that the new Civil Code could have been published in the Bulletin of Acts and Degrees before 1960 if Meijers had been able to finish his work in time. That 1960 proved to be too early, is due to a number of causes. In the first place the number of people working on the project increased steadily, until the early 1970's when government commissioner Snijders became almost the sole figure in charge of the recodification. An arrangement like a triumvirate or a number of government commissioners creates large and often unsurmountable coordination problems, as the drafting of Books 6 and 7 shows. Another drawback is that compromises abound, which impair the expressiveness of the text and diminish its chances to be approved by the community of academic and practicing lawyers. Traces of this can be found in the original bill for Book 6, as well as the memorandum of reply and the memorandum of amendment of Book 3, especially when compared with the revised bill for Book 6 , which was prepared by one man.

In the second place it is necessary for a project like the new Civil Code that it is headed by a strong leader with an open mind towards the wishes and ideas of practicing lawyers. Meijers and Snijders were leaders in this sense. However, when the project is prepared in a commission, the tendency will be to limit external contacts, especially when the personal relations between the members of the commission are strained. This had been the case with the Triumvirate, as well as with the people who worked on the law of inheritance (Book 4) from 1954 to 1974. Direct contact with the notarial profession would have prevented a large amount of parliamentary debate.

A third explanation for the long time spent on the new Civil Code is the lack of interest of the responsible ministers. Because of that the drafters indulged too much in their specialistic interests and perfectionistic attitude. Preparing the codification too 
thoroughly leads to an increase of problems and the separation of the project with its original aims. Besides, the developments in society do not come to a halt in the mean time. The work on the new law of inheritance and on the revision of the law of transport illustrates this point.

It can also be argued that the abundant opportunities to consider the drafts can tempt Parliament to leave its mark to a larger degree than desirable on at least a couple of articles in the Code. Ideally speaking, the discussion between the Ministry of Justice and the legal community about a technical subject like the revision of property law should not be conducted in such a way that Parliament acts as a transmitter between the two. This happened to be the case, however, and because of a lack of interest and expertise Members of Parliament became increasingly dissatisfied with the project.

A general comment can be that the temptation of perfectionism worked out negatively. Perfect law does not exist, although striving for quality keeps the idea of codification alive and inspires legal science. This study shows that Meijers' work is only in minor respects different from the work of his successors; in terms of social impact the differences are almost irrelevant. Another general lesson can be that it would have been better for the support of the project if more people had been involved with it. Meijers was able to discuss his plans with the leading writers on private law, so that any criticism reached him in an early stage. His handling of criticism led in its turn to a certain commitment of these writers to the project and fewer criticism afterwards. The criticism in later years, however, came too often at the wrong moment, when changes were more difficult to make. 


\section{REGISTER}

Adviescommissie voor het Auteursrecht 453, 515, 516, 522-523,

Binnenvaartrecht

- karakter B.W. 489

- opzet Meijers 485

- voortgang 490-491, 499

B.W.-club

- en het Driemanschap 182, 188, 216

- samenstelling 167

- werkwijze 167-168, 170-171, 183

Brede Wetenschappelijke Discussie 541, 543

Codificatie

- betrokkenheid juristen bij - B.W. 12, 17, 18-21, 21-23

- definitie - 9

- invloed Code Civil op - B.W. 15-17, 21, 25

Codificatiegedachte

- definitie 9, 10

Commissie-Van der Grinten 553-556

Commissie Modellenbescherming 164, 524, 525-527

Commissie van Wijzen

- aanleiding 558

- achtergronden 559-561

- advies 562-563

- instelling 561

- samenstelling 561

Cursussen NBW 538, 551, 554, 566

Driemanschap

- en de rol van de Ministers 223-231

- medewerkers 179

Enquête

- eerste - Meijers ETZ 159

- inzake overdracht onroerend goed 110

- inzake kettingbeding 235 
- tweede - Meijers ETZ 159

- wenselijkheid herziening BW 92-94

Herziening

minister en - 59-60

partiële - aanvaard 33-36, 51-53

richtlijnen bij de - 93, 95

roep om algehele $-11,27,29-31,36,41$

roep om partiële - 30-31, 42, 48-49

standpunt literatuur m.b.t. - 36-37, 64, 67, 70

standpunt politiek m.b.t. - 58-63, 68-69

standpunt rechterlijke macht m.b.t. - 69-70

Invoeringsperikelen

achtergronden van de - in 1982 538-543

algemene voorwaarden en - 553, 555-557, 559, 560

Langstlevende echtgenoot

- en de ouderlijke boedelverdeling 347-349, 356-357

- en de rol van de traditie 349-350

- en de problematiek van hertrouwen 351-353

- en het vruchtgebruik 355-356

- en de praktijk van het erfrecht 357-358

- in de geschiedenis 346-347

Legisme $39-41,65$

Luchtrecht

- afstel 499, 505

- eerste concepten 485-486

- opzet Meijers 484

- voortgang 490

Nederlandse Juristenvereniging

- ontstaan 48

- vergadering $187048-51$

- vergadering 1912 67-70

Nota algemeen Beleid NBW 407-409

Nota voortgang NBW 413-415

Notitie Invoering nieuw B.W. 543-545

Onderzoek

- afbakening 2

- doelstelling 1-2 
- methode - archiefonderzoek 2-3

- vraaggesprekken 3-4

- detailstudies 4-5

- literatuuronderzoek 5-6

Oorzaken voor vertraging Boek 5 en 6 O.M.

- gezagsvacuum 187, 216-220

- moeilijkheidsgraad stof 222-223

- onderlinge verhoudingen 220-222

- overbelasting Drion 197, 201, 241

- perfectionisme 186-187, 208-212

- revisie concepten Meijers 185, 187, 205-206

- tempo 212-216

Oorzaken voor vertraging

- Boek 3 G.O. 470-473, 478-487

- Boek 5 G.O. 500-502

- Boek 6 G.O. (zie voorlopig verslag Boek 6)

Opbouw boek 6-7

Opdrachtverlening Driemanschap

- achtergronden 177-179

- benoeming 177

- benoeming De Grooth 222

- einde 455

- ontslagname Eggens 221

- richtlijnen 183-184

- voorwaarden bij - 179

Opdrachtverlening Meijers

- aanleiding 91-92

- achtergronden 96-105

- benoeming 96

- procedure bij - 92-93

- voorwaarden bij - 93

Oppositie-Jurgens 411-413, 415-416

Opvolging Drion 288, 298

- Beekhuis 290, 385, 389

- Langemeijer 290, 361, 371, 381-382

- Schadee 487-488, 506, 509

- Wiersma 290

Organisatie van het werk (na 1961)

- beantwoorden Voorlopig Verslag Boek 4, 266, 269, 272-274 
- coördinatie werkzaamheden Nieuw Burgerlijk Wetboek 278-279

- ongewijzigd indienen Boek $6265,280,290-291$

- oprichting Stafafdeling NBW 295-296

- uitbesteden Boek 7265

- werkverlichting/overbelasting Drion 279

Overlijden Drion 285-288

Overlijden Meijers 175

Praktijkoverleg en

- Boek 3 373-374, 383

- Boek 5 393, 396

- Boek 6 422-425

- Boek 7 442-443, 461-462

- Boek 8 483, 496-497, 502, 505, 511

Publicatie

- Ontwerp-Meijers (eerste stuk) 164-170

- Ontwerp-Meijers (tweede stuk) 173, 183

- Ontwerp-Meijers Boek 6195

Rechtsvergelijking

- bij Meijers 111-114

- bij het Driemanschap 232-234

- bij Snijders 421-422

Rapport I Commissie Erfrecht

- inhoud 269-271

- standpunt t.a.v. verzorgingsrecht 1 . echtgenoot 271

Rapport II Commissie Erfrecht

- inhoud 282

- standpunt t.a.v. verzorgingsrecht l. echtgenoot 284-285

Secretarissen Meijers

- Drion 107, 111, 114

- Franken 108, 111, 165

- Polak, J.M. 165

Staatscommissie tot herziening B.W. (Stc. Modderman)

- instelling 54

- resultaten 56-59

- werkwijze 55-56

Staatscommissie voor de burgerlijke wetgeving (voor 1940)

- instelling 73-75

- onderlinge verhoudingen 119-124 
- resultaten 77-81

- takomschrijving 75-77

Staatscommissie voor de burgerlijke wetgeving (na 1940)

- samenstelling 114

- subcommissie handelsrecht $115,116,120,440,444,461,484-485$

- taakopvatting 116

- werkwijze 116-119

Staatsrechtelijke problemen van wetgeving

- afdelingenonderzoek 43-46, 50

- recht van amendement 46

- sluiting brengt stuiting 46-48

Stofkamoperatie

- aanleiding 551

- achtergronden 549-554

- inhoud 551-552

- rendement 557

\section{Vergelijking}

- concept-Meijers/ontwerp-Meijers Boek 5 245-253

- concept-Meijers/ontwerp-Meijers Boek 6 258-264

- concept-Meijers/ontwerp Meijers Boek 7 476-481

- Regeringsontwerp-Gewijzigd Ontwerp Boek 3 432-433

- Regeringsontwerp-Gewijzigd Ontwerp Boek 5 434-435

Vervoers- en expeditieovereenkomst $120,484,490$

Voorlopig Verslag Boek 6

- voorbereiding 397-399

- voortgang $399-400,406-410$

- vraagpunten 400-404, 408-409, 414-415, 437, 439

Voortrein Boek 4

- advies van de Raad van State over - 325-326

- inhoud 315-316

- kritiek jaarvergadering KNB 321-323

- literatuurkritiek 318-321

- totstandkoming 316-318

- voorlopig verslag over - 323-324

Vruchtgebruikontwerp (eerste versie)

- advies van de Raad van State over - 327-328

- inhoud 326-328

- kritiek jaarvergadering KNB 1982 330-333

- literatuurkritiek 328-330 
- ontkoppeling - 333-334

- totstandkoming 325-326

Vruchtgebruikontwerp (tweede versie)

- kritiek jaarvergadering KNB 1992 342-344

- literatuurkritiek 339-342

- totstandkoming 336-337

Vraagpuntenprocedure

- aanleiding 124-125

- betekenis 162-164

- interdepartementaal overleg over de - 143-148

- opzet 134-137, 147-148

- persconferentie 162

- procedure 153-156

- raadpleging Hoge Raad in het kader van - 140

- raadpleging SER in het kader van - 144

- selectie vraagpunten 148-151

- tijdschema 140-142

- verzet Ministerraad 131-134

- voortgang 151,160

Wegvervoersrecht

- Boek 8 uitgebreid met - 492-494

Wet of rechter

- na $191281-85,88$

- omstreeks 1900 64-67

- voor $187037-39$

Wetsontwerp 120863 (zie voortrein)

Wetsontwerp 17141 (zie vruchtgebruikontwerp)

Werkgroep invoeringsproblemen Nieuw B.W.

- aanleiding 563

- advies 564-718

- reacties 565-560

- samenstelling 563

Werkwijze Driemanschap

- eerste concepten 254-257

- effecten lange duur 235-244

- inschakeling Staatscommissie 182, 190-191, 234

- overleg met de praktijk 234-235

- positie medewerkers $182,188,194,189-199,218-219$

- procedure 180-181

- rechtsvergelijking 212-216, 232-234

- vergadertempo 179, 181, 199, 204-205, 217 
- voorwerk 182

- werkverdeling 192-195

Werkwijze Meijers

- eerste concepten 106-108

- inschakeling Staatscommissie 114-117

- overleg met de praktijk 110

- positie secretarissen 110, 112

- redigeren tekst en toelichting 109-111

- rechtsvergelijking 112-114

- voorwerk 108-109

Wisfull thinking 230-231

Zeerecht

- eerste concepten 485

- karakter B.W. 485, 487

- opzet Meijers 485

- voortgang 490 


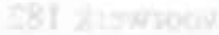

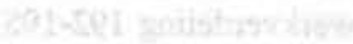

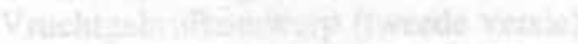

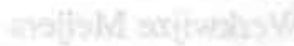

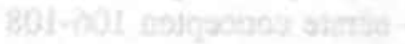

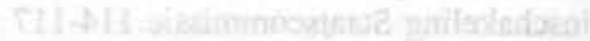

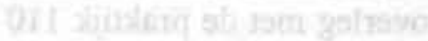

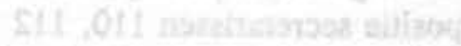

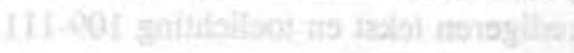

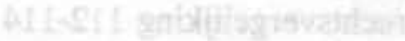

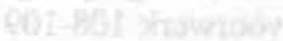

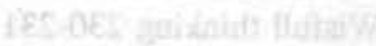

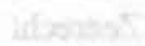

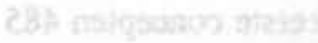

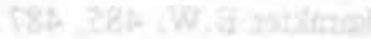

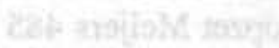

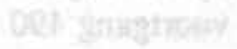




\section{CURRICULUM VITAE}

Erik Florijn werd op 29 september 1961 in Zoetermeer geboren. Nadat hij in 1980 aan de Rijksscholengemeenschap te Gouda zijn diploma Atheneum A behaalde, studeerde hij Nederlands recht aan de Faculteit der Rechtsgeleerdheid van de Rijksuniversiteit Utrecht, alwaar hij op 22 juli 1985 afstudeerde. $\mathrm{Na}$ een jaar te hebben gewerkt als medewerker Onderwijs en Welzijn te Binnenmaas, begon hij op 15 mei 1986 als wetenschappelijk assistent bij de vakgroep Metajuridica van de Faculteit der Rechtsgeleerdheid van de Rijksuniversiteit Limburg met een vooronderzoek naar het ontstaan en de ontwikkeling van het nieuwe Burgerlijk Wetboek, dat na twee en een half jaar uitmondde in promotieonderzoek. Sinds 1 april 1994 is hij verbonden aan de Afdeling Bestuursrechtspraak van de Raad van State. 


\section{Burgerlijk Wetboek}

Op 25 april 1947 ontving de Leidse hoogleraar Eduard Maurits Meijers (1880-1954) bij Koninklijk Besluit de opdracht een "nieuw burgerlijk wetboek" te ontwerpen.

Een van de belangrijkste overwegingen om Meijers de opdracht te verlenen, was de verwachting dat hij het grote werk binnen een jaar of tien zou kunnen volbrengen.

Het is anders gelopen. De totstandkoming van het nieuwe Burgerlijk Wetboek is een werk van zeer lange adem geweest en heeft generaties juristen in de ban gehouden. Pas met de inwerkingtreding van de Boeken 3, 5 en 6 op 1 januari 1992 is de herziening van het uit 1838 stammende Burgerlijk Wetboek nagenoeg voltooid.

In dit boek wordt de totstandkoming van het nieuwe Burgerlijk Wetboek beschreven en worden de oorzaken van voortgang en vertraging vastgesteld. Daarbij is gebruik gemaakt van de archieven van het Ministerie van Justitie en van in het kader van dit onderzoek gehouden gesprekken met (oud-)medewerkers aan het nieuwe Burgerlijk Wetboek.

Aangezien de hercodificatie van het privaatrecht de grootste en langdurigste wetgevingsoperatie in de Nederlandse rechtsgeschiedenis is geweest, waaraan een groot deel van de privaatrechtselite van deze eeuw heeft deelgenomen, is een verrassende en boeiende kijk op het wetgevingsproces entstaan. Ingegaan wordt op de organisatie van het werk, de rol van de politiek, de betekenis van de wetenschappelijke kritiek en de invloed van belangengroepen.

Daarnaast wordt de geschiedenis van de hercodificatie, die de auteur overigens al in 1840, twee jaar na de invoering van het oude Burgerlijk Wetboek laat beginnen, in een rieuw en breder perspectief geplaatst.

\section{Universitaire Pers Maastricht}

